UNIVERSIDADE DE SÃO PAULO

INSTITUTO DE GEOCIEENCIAS

\title{
CONTRIBUIÇÃO AO ESTUDO DAS ROCHAS GRANITÓIDES E MINERALIZAÇÕES ASSOCIADAS DA SUITE INTRUSIVA VELHO GUILHERME, PROVÍNCIA ESTANIFERA DO SUL DO PARÁ
}

VOLUME 1

Nilson Pinto Teixeira

Orientador: Prof. Dr. Jorge Silva Bettencourt

TESE DE DOUTORAMENTO

Programa de Pós-Graduação em Recursos Minerais e Hidrogeologia 


$$
\begin{aligned}
& \text { UNIVERSIDADE DE SÃO PAULO } \\
& \text { INSTITUTO DE GEOCIENCIAS }
\end{aligned}
$$

\title{
CONTIIBUIÇÃO AO ESTUDO DAS ROCHAS GRAMITÓIDES E MINERALIZAÇÕES ASSOCIADAS DA SUITE INTRUSIVA VELHO GUILHERME, PROVÍNCIA ESTANÍFERA DO SUL DO PARÁ
}

\author{
NILSON PINTO TEIXEIRA
}

Orientador: Prof. Dr. Jorge Silva Bettencourt

\author{
TESE DE DOUTORAMENTO
}

\section{COMISSÃO JULGADORA}

Nome

Presidente: Prof. Dr. Jorge Silva Bettencourt

Examinadores: Prof. Dr. Lauro Valentim Stoll Nardi

Prof. Dr. Nilson Francisquini Botelho

Prof. Dr. Roberto Dall'Agnol

Prof. Dr. Silvio Roberto Farias Vlach
Assinatura

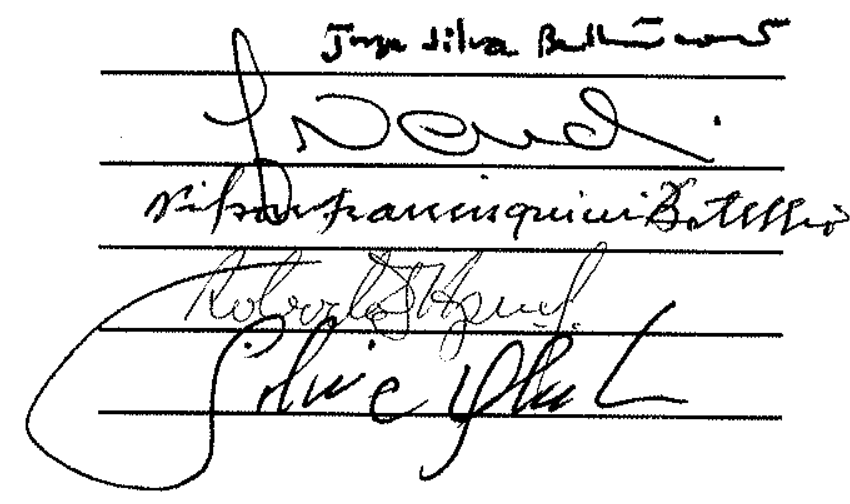

SÃO PAULO

1999 

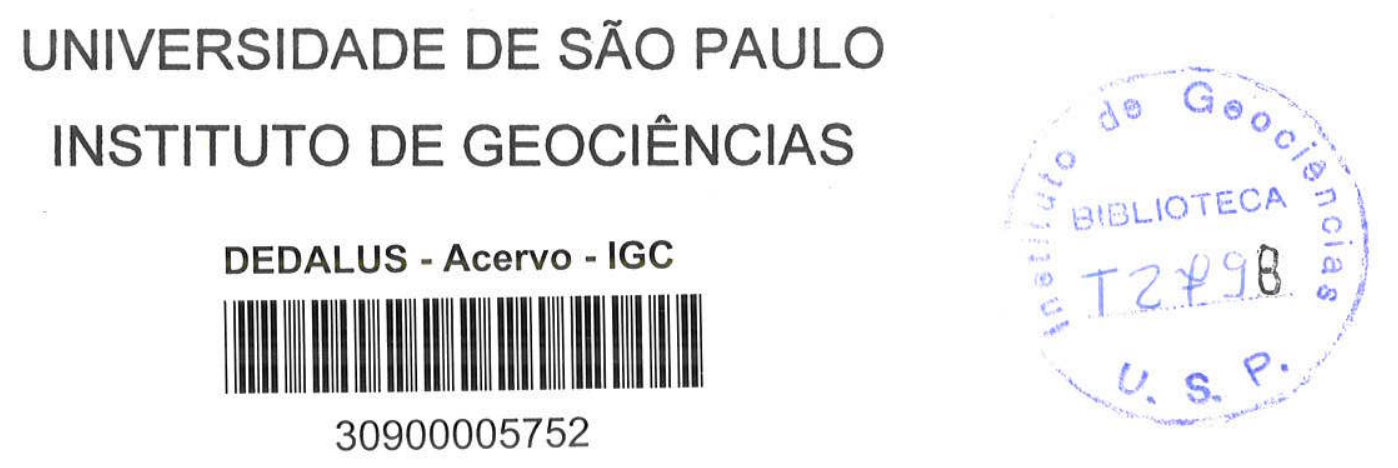

\author{
CONTRIBUIÇÃO AO ESTUDO DAS ROCHAS \\ GRANITÓIDES E MINERALIZAÇÕES ASSOCIADAS DA \\ SUITE INTRUSIVA VELHO GUILHERME, PROVÍNCIA \\ ESTANÍFERA DO SUL DO PARÁ \\ Volume 1
}

Nilson Pinto Teixeira

Orientador: Prof. Dr. Jorge Silva Bettencourt

TESE DE DOUTORAMENTO
Programa de Pós-Graduação em Recursos Minerais e Hidrogeologia

São Paulo

1999 


\section{SUMÁRIO}

VOLUME 1

AGRADECIMENTOS.

DEDICATÓRIA

RESUMO iv

ABSTRACT.

LISTA DE FIGURAS

$\mathrm{x}$

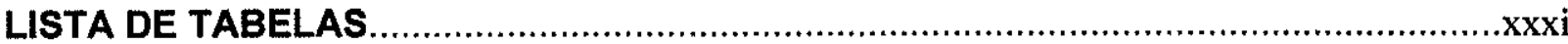

LISTA DE QUADROS xxxiv

\section{CAPÍTULO 1}

1-INTRODUÇÃO 1

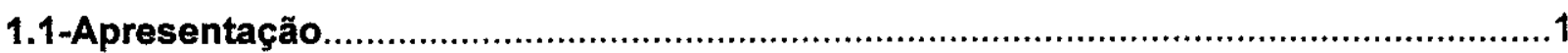

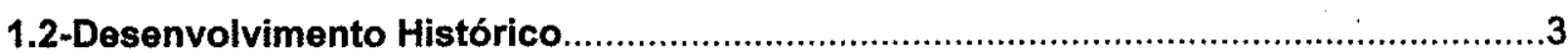

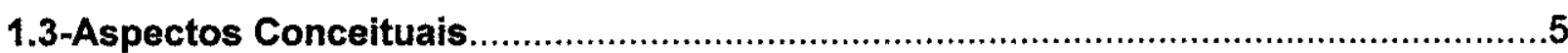

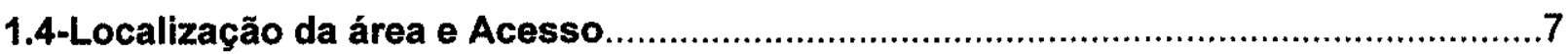

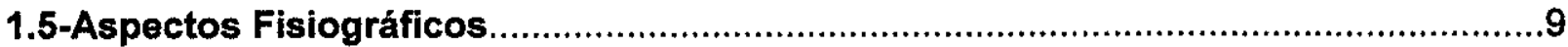

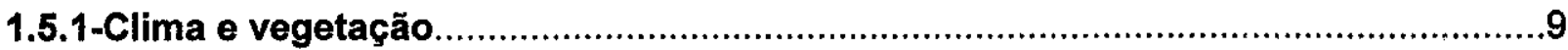

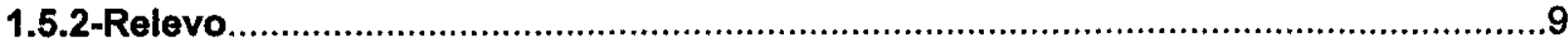

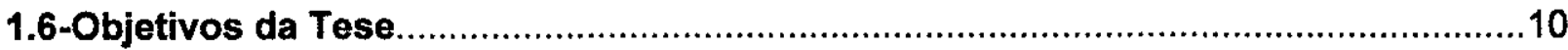

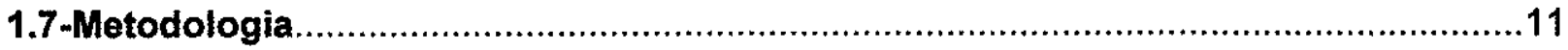

1.7.1-Elaboração de Mapas e Coleta de Amostras.......................................................11

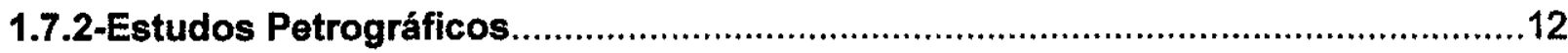

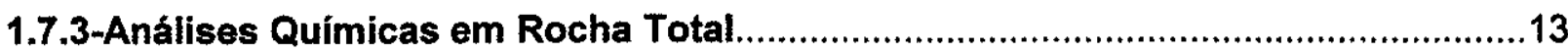

1.7.4-Análises químicas em fases minerais..............................................................14

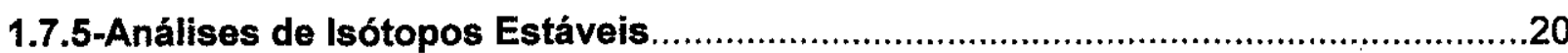

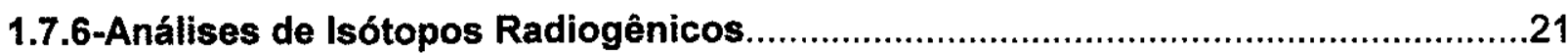

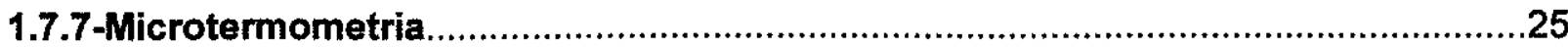

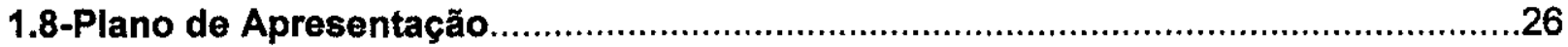

\section{CAPITULOO 2}

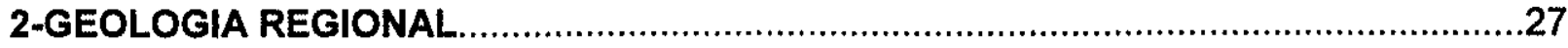

2.1-Litoestratigrafia, Aspectos Estruturais e Geocronologia......................................28

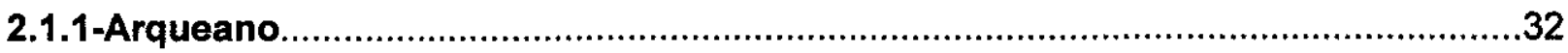

2.1.1.1-Terreno Granito-Greenstone do Sul do Pará.......................................................35 


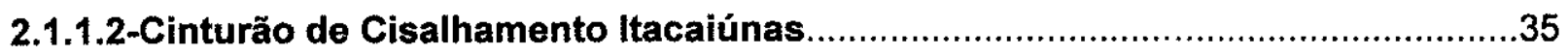

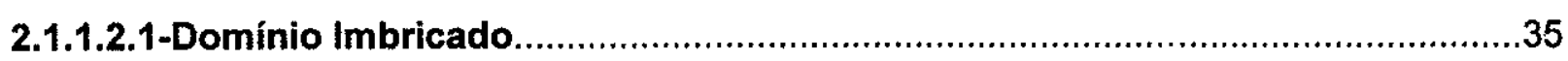

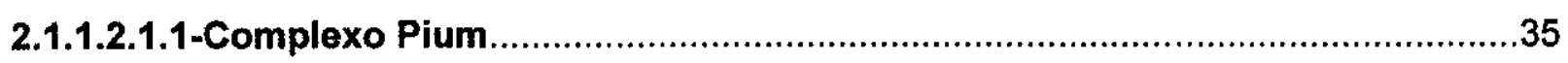

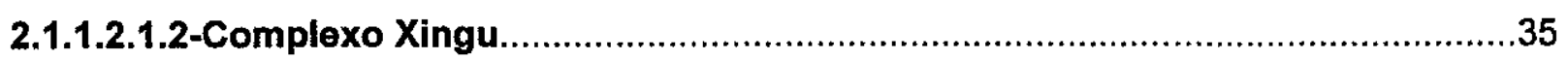

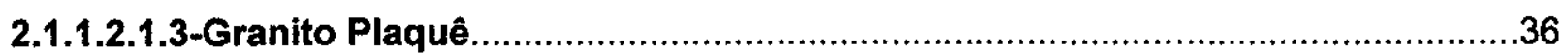

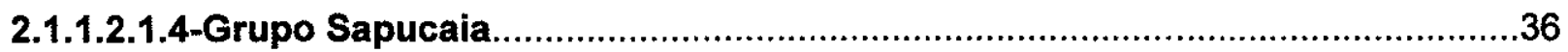

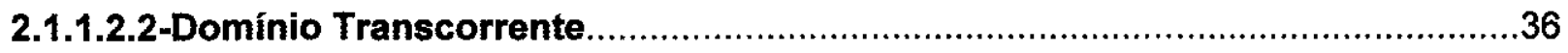

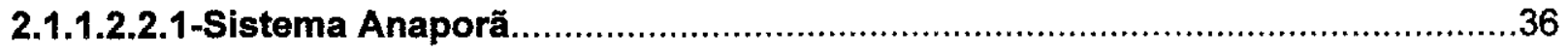

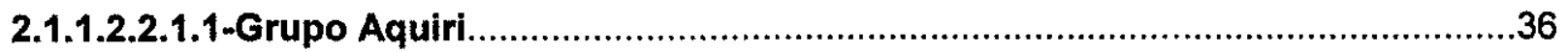

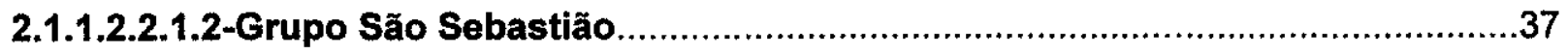

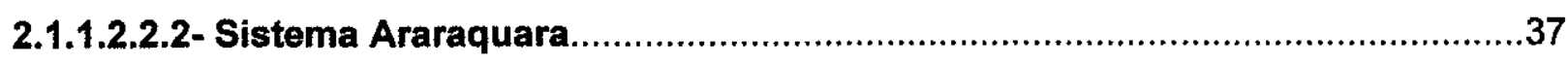

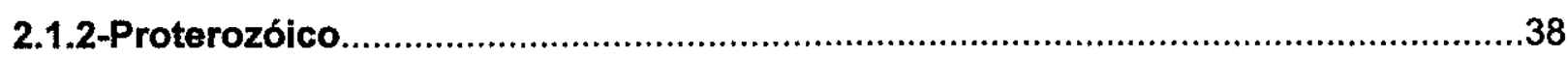

2.1.2.1-Intrusões Ácidas e Máficas-Ultramáficas...................................................38

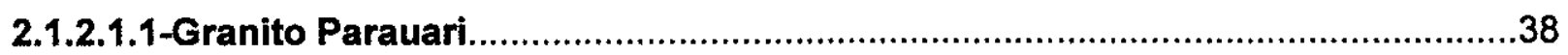

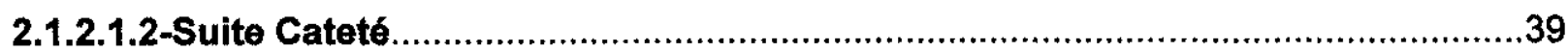

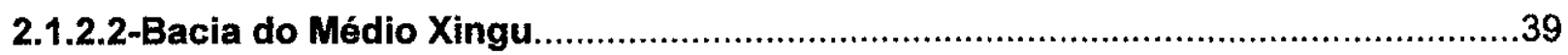

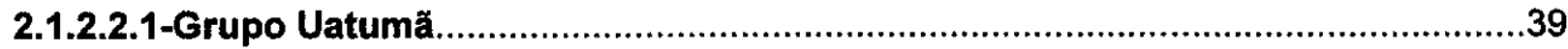

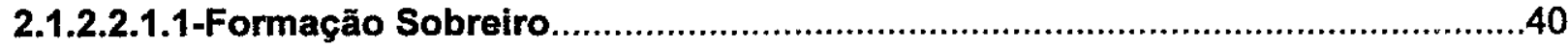

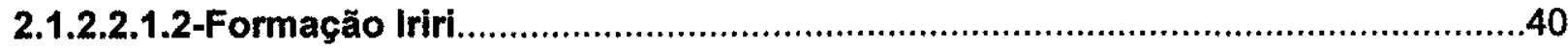

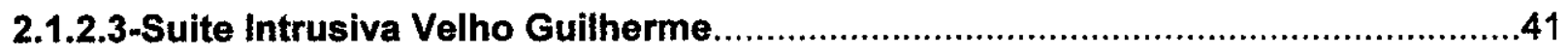

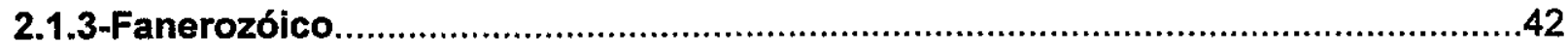

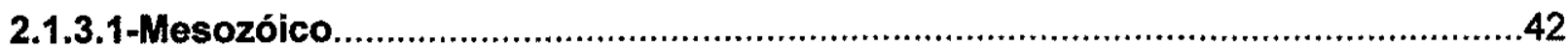

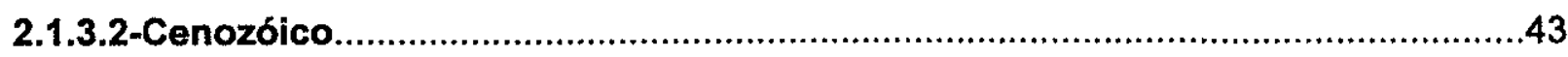

CAPÍTULO 3

3-MACIÇO GRANITÓIDE ANTÔNIO VICENTE....................................................44

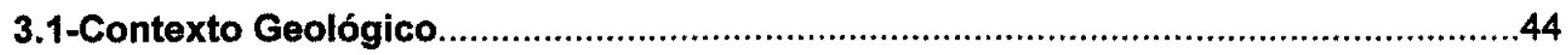

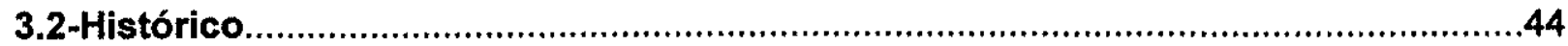

3.3-Aspectos Fotogeológicos e de Campo..........................................................46

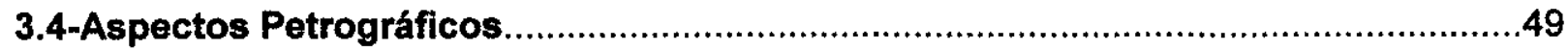

3.4.1-Facies granitóides das porções centro-sudoeste e sudoeste do maciço.............50

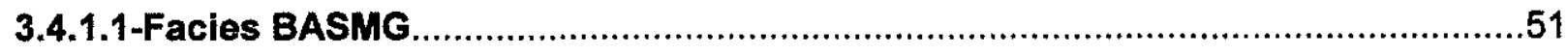

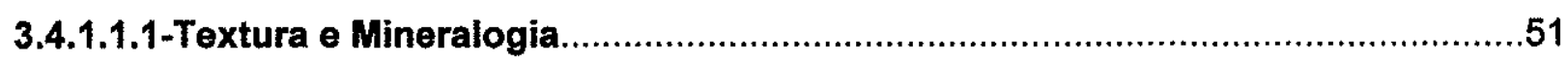

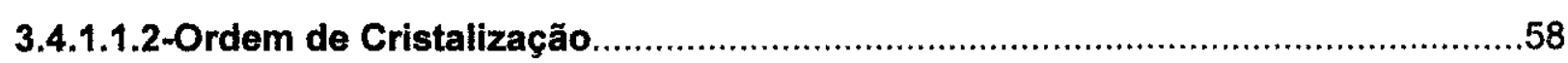

3.4.1.1.2.1-Ordem de Cristalização Magmática..........................................................59

3.4.1.1.2.2-Ordem de Cristalização Tardi a Pós-magmática.....................................61 
3.4.1.2-Facies BASAFG e ABSG. .63

3.4.1.2.1-Textura e Mineralogia. .63

3.4.1.3-Facies BSGCI. .64

3.4.1.3.1-Textura e Mineralogia. .64

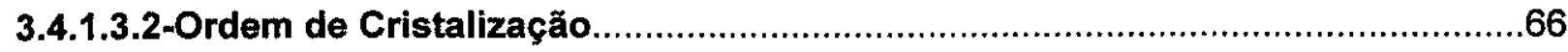

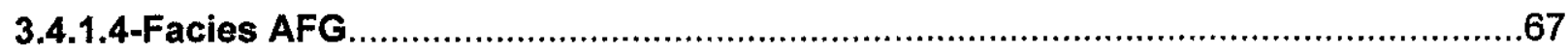

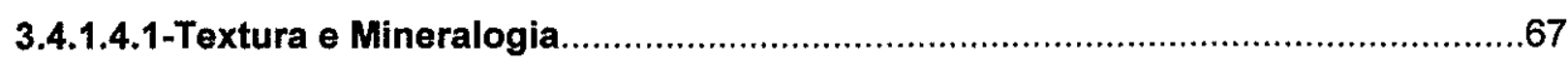

3.4.1.4.2-Ordem de Cristalização................................................................................67

3.4.2-Facies granitóides das porções sudeste, centro-norte e noroeste do maciçio....69

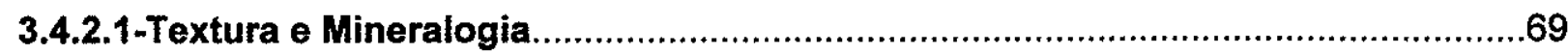

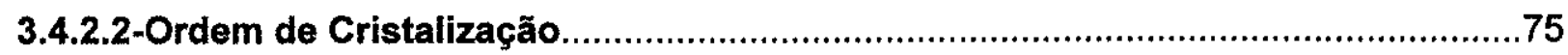

3.4.3-Facies granitóide da porção nordeste do maciço ..................................................80

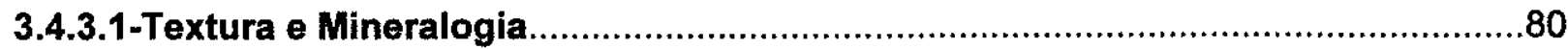

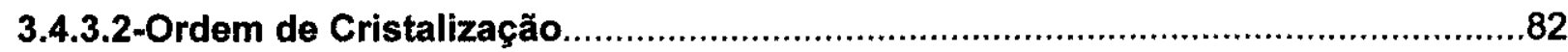

3.4.4-Facies granitóides de ocorrência localizada no maciço......................................84

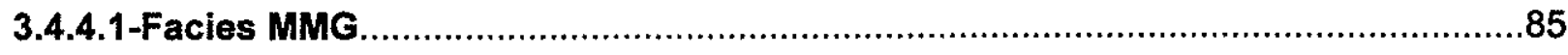

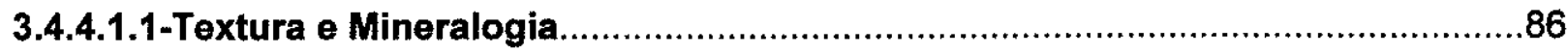

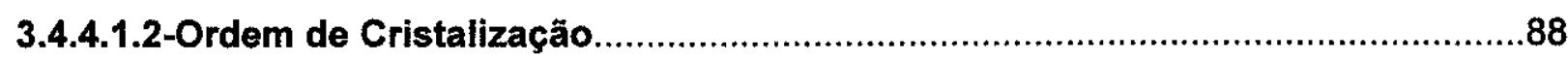

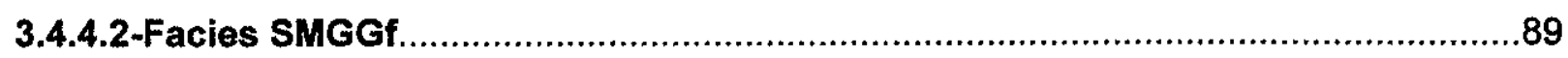

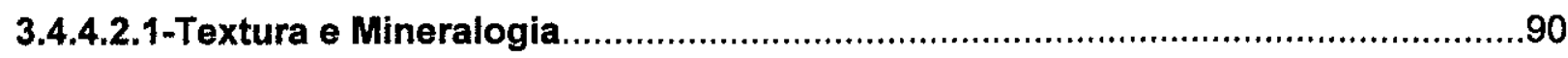

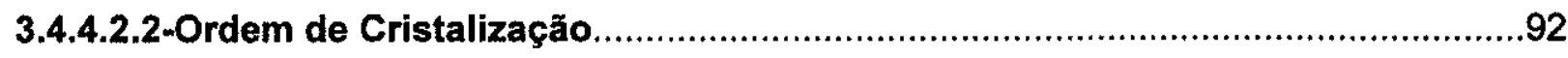

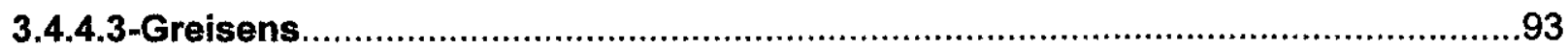

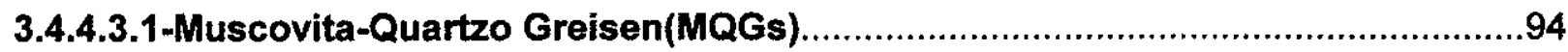

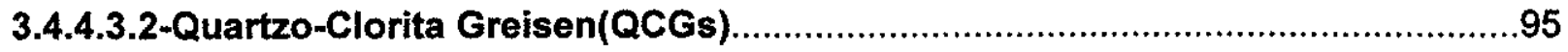

3.4.4.3.3-Clorita-"Siderofilita"-"Muscovita"-Quartzo Greisen(CSMQGs).....................95

3.4.5-Discussão e Considerações Finais .......................................................................99

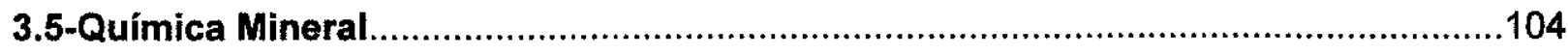

3.5.1-Análises através de Microssonda Eletrônica..................................................104

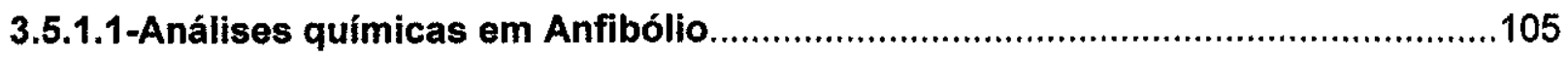

3.5.1.2-Análises químicas em Biotita..................................................................110

3.5.1.2.1-Composição química..........................................................................110

3.5.1.2.2-Classificação e Representação gráfica...................................................113

3.5.1.2.3-Condições de Cristalização..................................................................114

3.5.1.3-Análises químicas em Clorita ..........................................................117

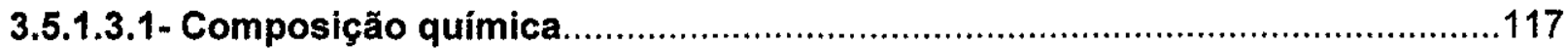

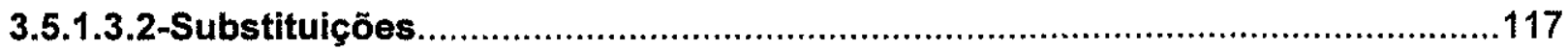

3.5.1.3.3-Classificação e Representação Gráfica.....................................................124 
3.5.1.3.4-Condições de Cristalização ............................................................ 125

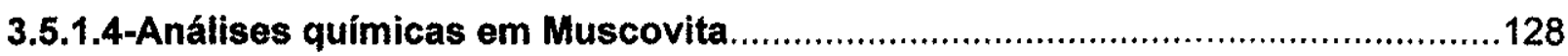

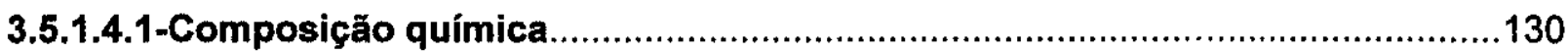

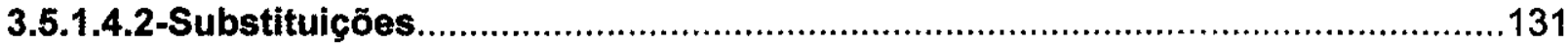

3.5.1.4.3-Classificação e Representação Gráfica....................................................133

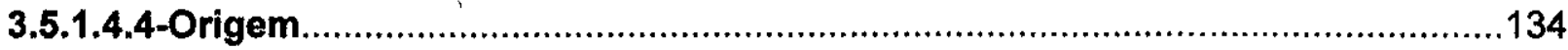

3.5.1.5-Análises químicas em Feldspato potássico.............................................135

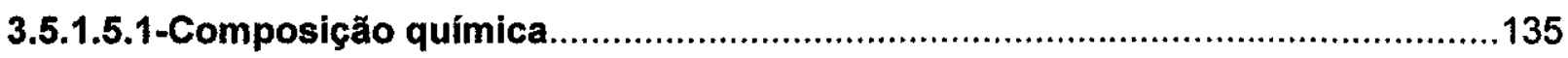

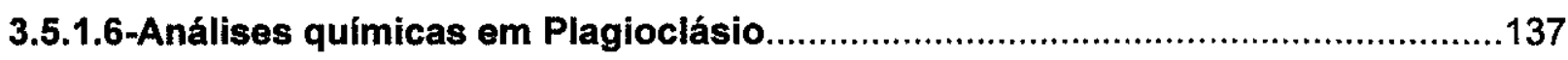

3.5.1.6.1 -Composição química....................................................................... 137

3.5.2-Análises através de Microscopia Eletrônica.....................................................140

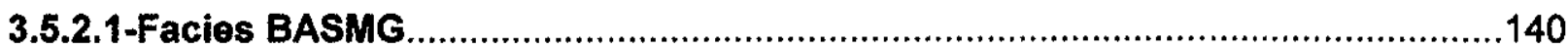

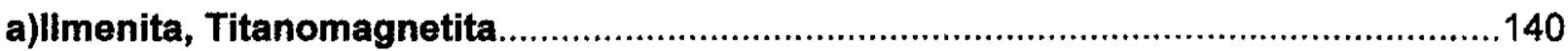

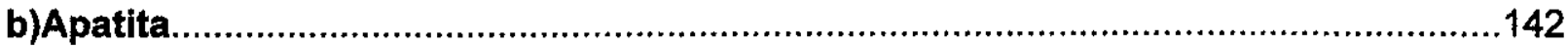

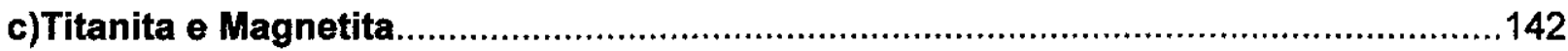

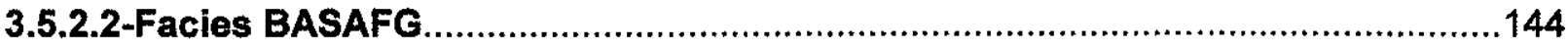

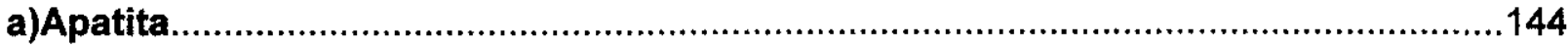

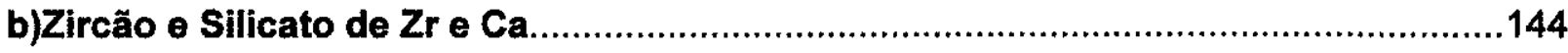

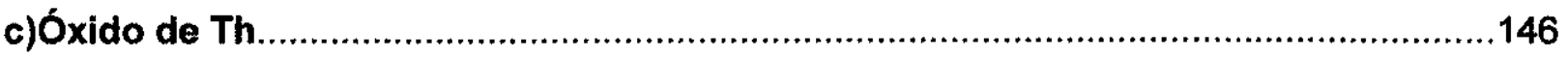

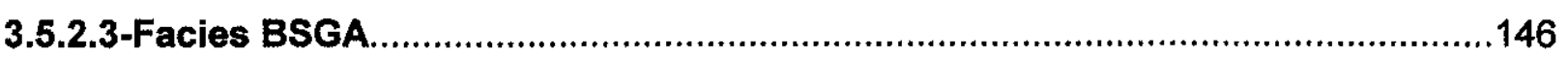

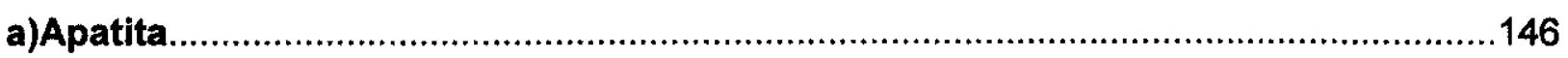

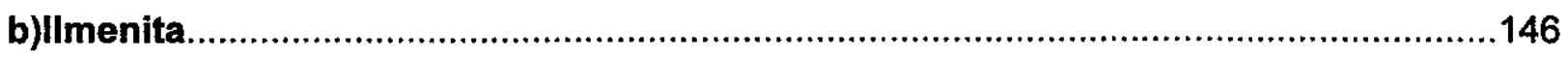

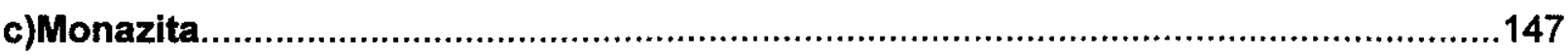

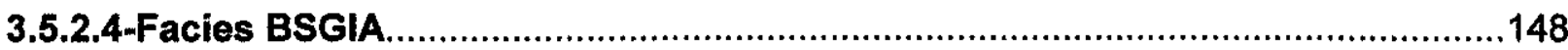

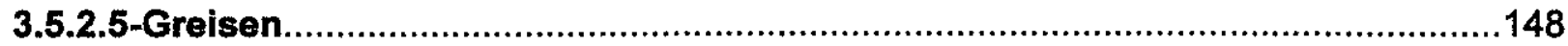

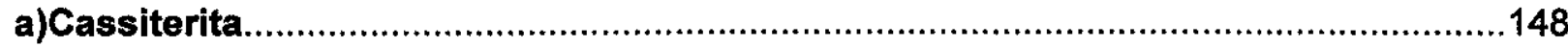

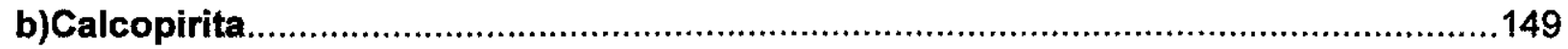

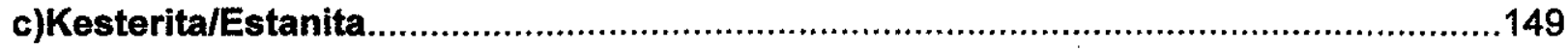

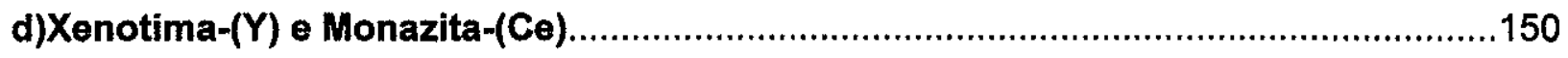

3.5.3-Conclusões e Considerações Finais...........................................................151

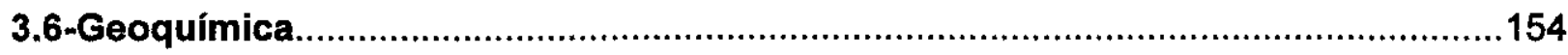

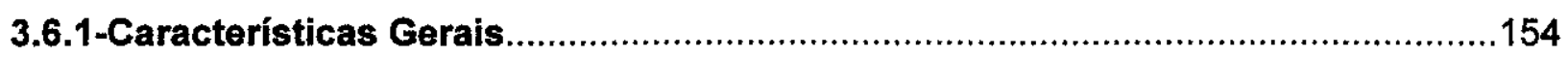

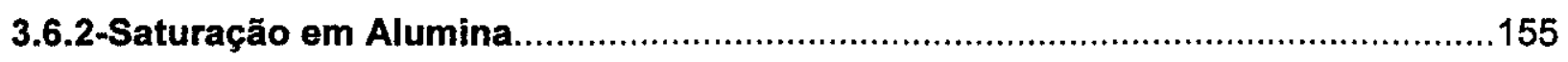

3.6.3-Afinidade Tectonomagmática e Tipologia........................................................156

3.6.4-Outras Feições Geoquímicas........................................................................160

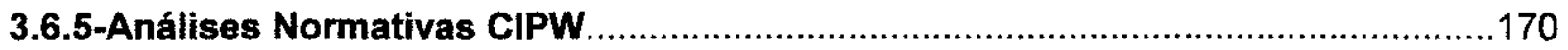

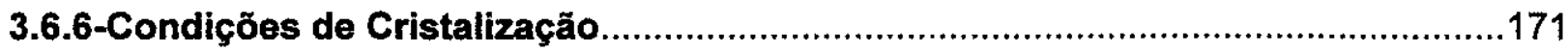


3.6.6.1-Posicionamento Crustal 171

3.6.6.2-Condições de $\mathrm{fO}_{2}, \mathrm{~T} \in \mathrm{P}$ .172

3.6.7-Conclusões e Considerações Finais. 179

CAPÍTULO 4

4-MACIÇO GRANITÓIDE VELHO GUILHERME. .183

4.1-Contexto Geológico 183

4.2-Histórico 183

4.3-Aspectos de Campo e de Amostragem. 185

4.4-Aspectos Petrográficos 185

4.4.1-Facies BSGEm. 190

4.4.1.1-Textura e Mineralogia. 191

4.4.1.2-Ordem de Cristalização Magmática. 193

4.4.2-Facies SGH. 194

4.4.2.1-Textura e Mineralogia. .194

4.4.2.2-Ordem de Cristalização. 198

4.4.3-Facies MSG. 198

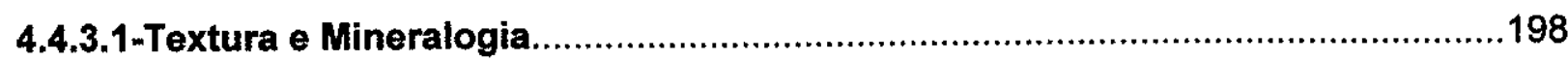

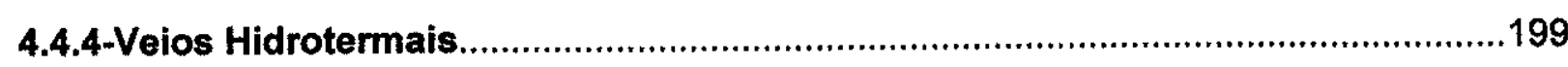

4.4.5-Discussão e Considerações Finais............................................................200

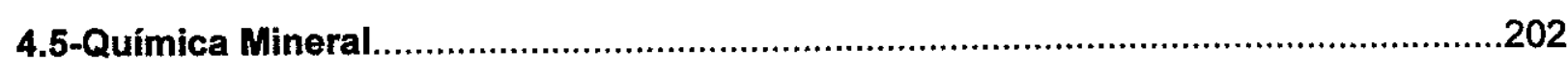

4.5.1-Análises através de Microssonda Eletrônica.............................................202

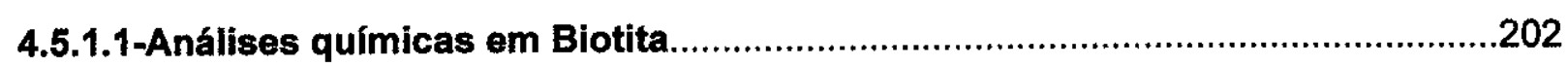

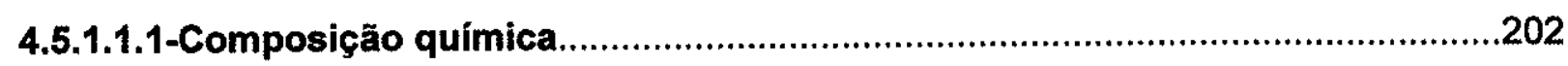

4.5.1.1.2-Classificação e Representação gráfica....................................................204

4.5.1.1.3-Condições de Cristalização..........................................................................206

4.5.1.2-Análises químicas em Plagioclásio.........................................................208

4.5.1.2.1-Composição química e representação gráfica............................................208

4.5.1.3-Análise química em Feldspato potássico...................................................210

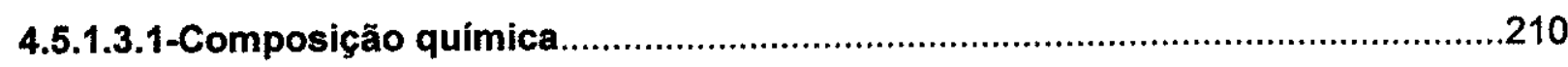

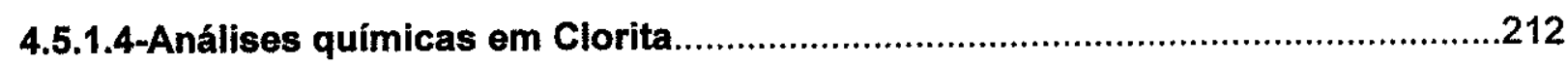

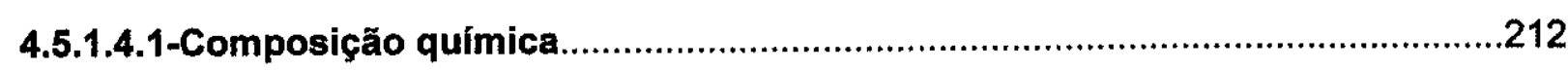

4.5.1.4.2-Classificação e representação gráfica......................................................216

4.5.1.4.3-Condições de Cristalização.......................................................................217

4.5.1.5-Análises químicas em Muscovita............................................................217

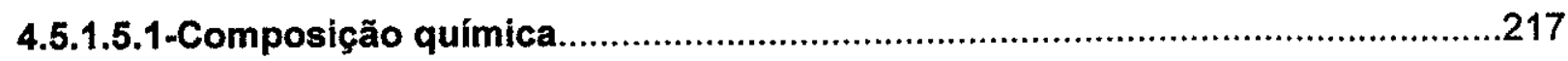

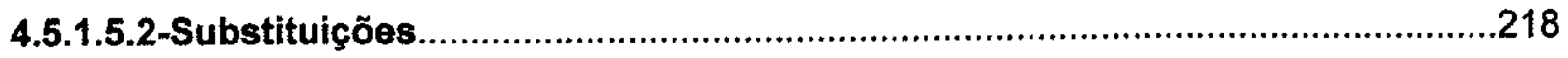

4.5.1.5.3-Clssificação e Representação Gráfica......................................................220 


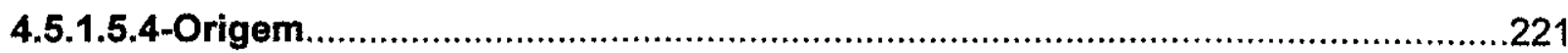

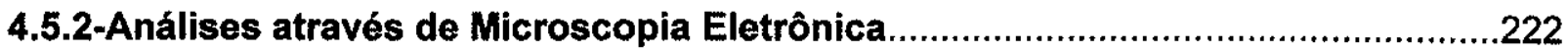

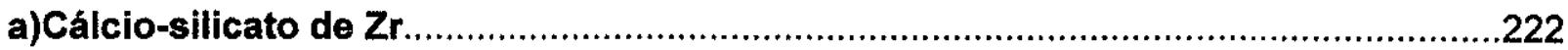

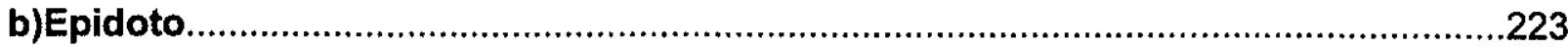

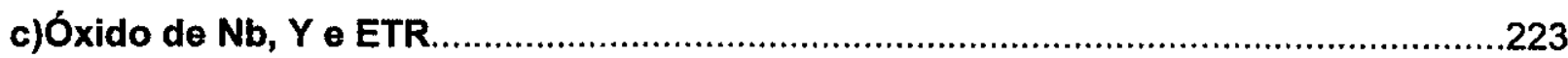

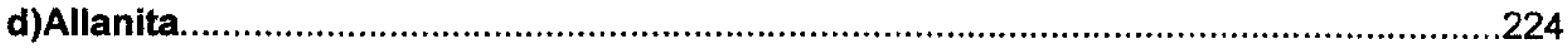

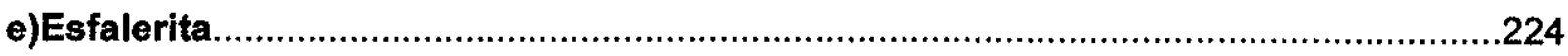

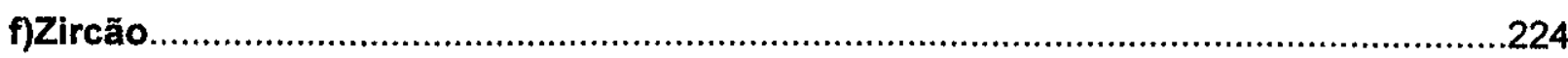

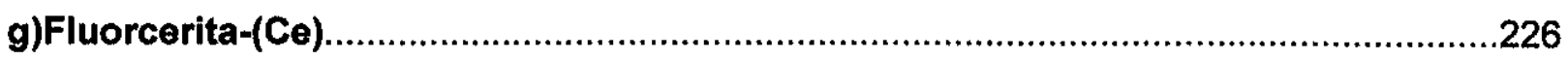

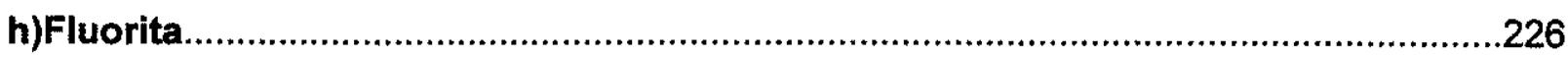

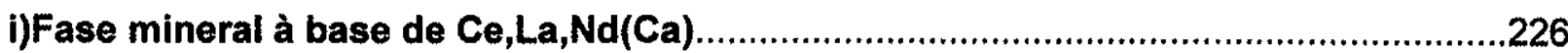

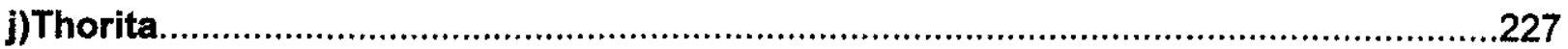

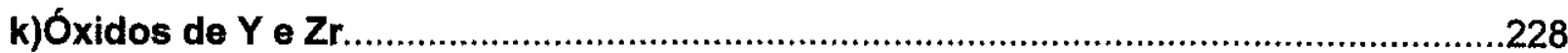

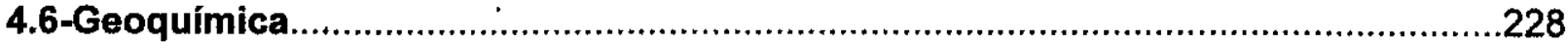

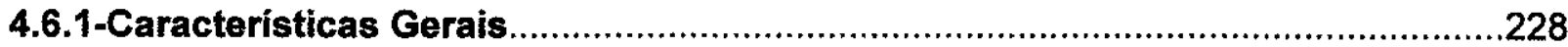

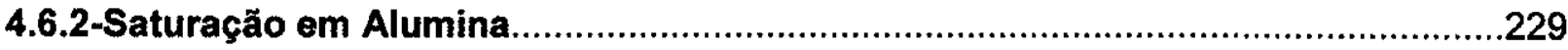

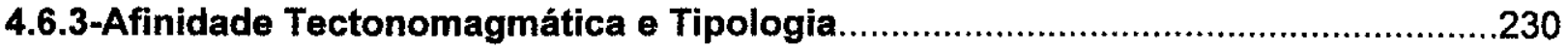

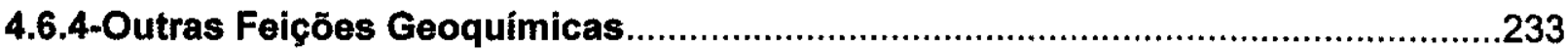

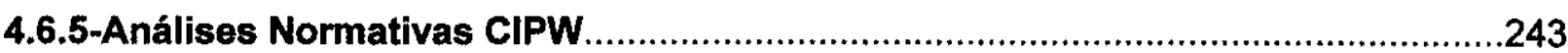

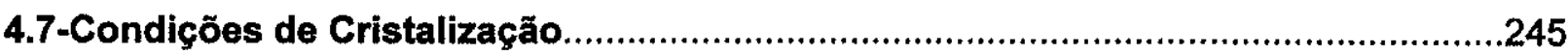

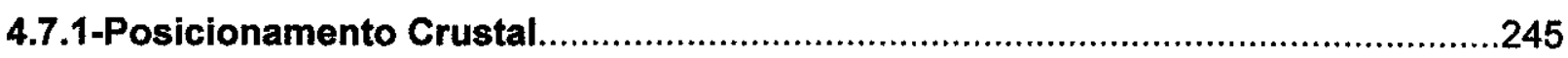

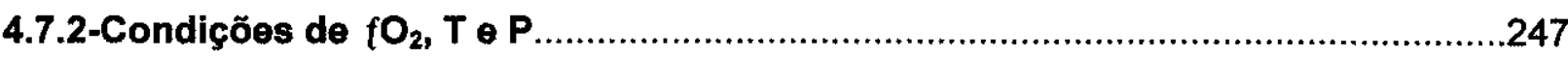

4.8-Conclusões e Considerações Finais.................................................................248

\section{CAPÍTULO 5}

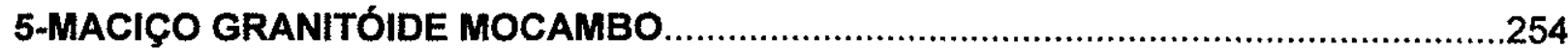

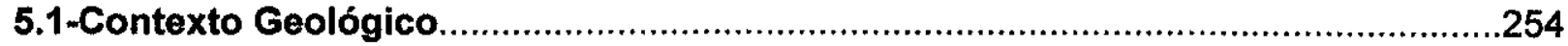

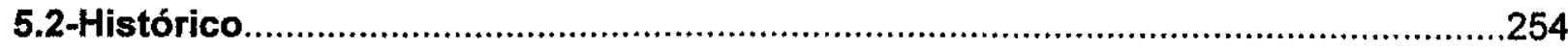

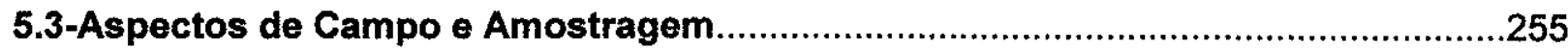

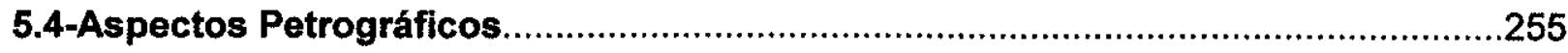

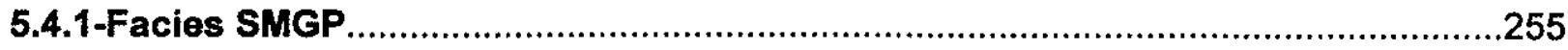

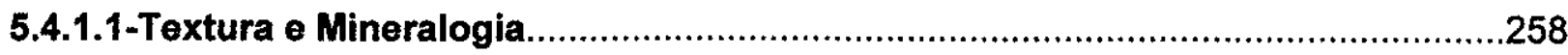

5.4.1.2-Ordem de Cristalização.............................................................................262

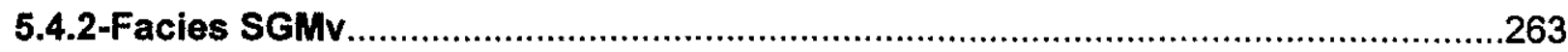

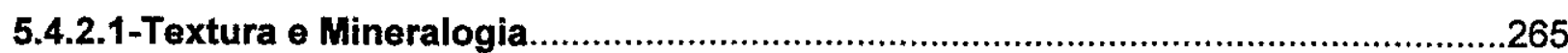

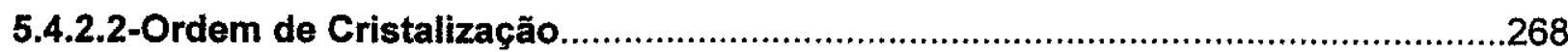

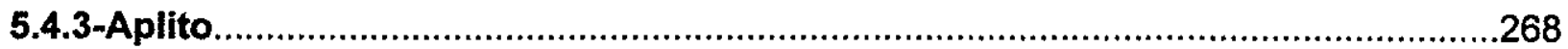


5.4.3.1-Textura e Mineralogia. 269

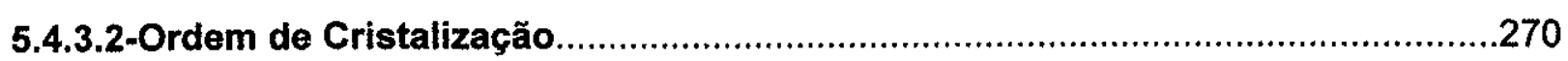

5.4.4-Siderofilita-Clorita-Muscovita-Quartzo Greisen...........................................271

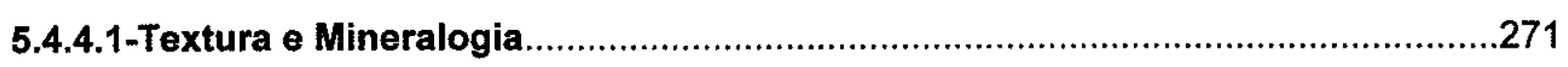

5.4.5-Discussão e Considerações Finais................................................................273

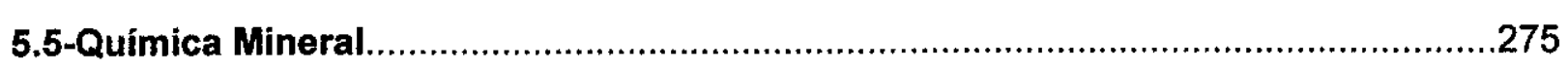

5.5.1-Análises químicas através de Microssonda Eletrônica.....................................275

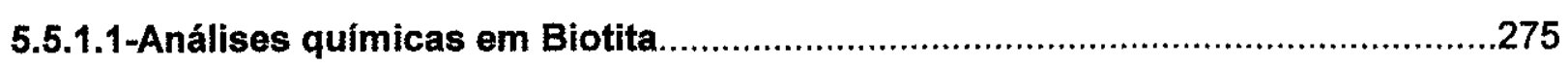

5.5.1.1.1-Classificação e Representação Gráfica.......................................................278

5.5.1.2-Análises químicas em Feldspato potássico............................................279

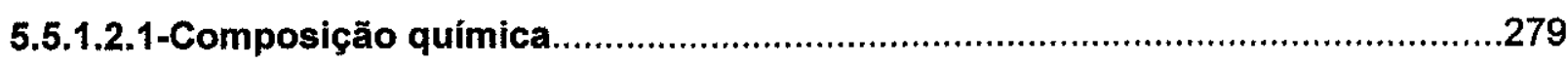

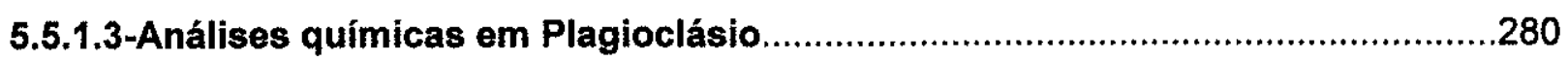

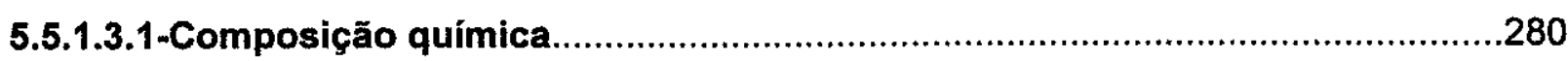

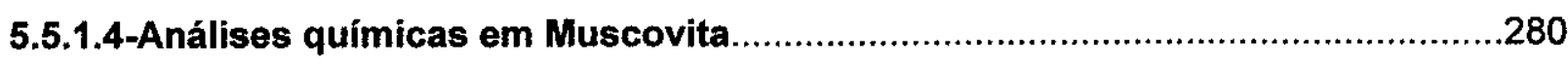

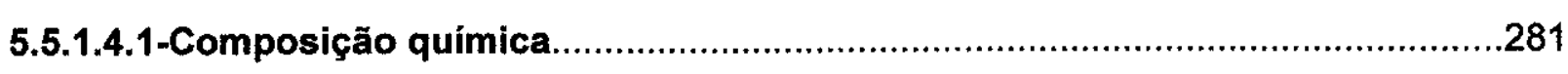

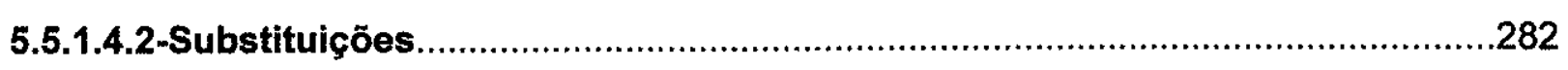

5.5.1.4.3-Classificação e Representação Gráfica.......................................................283

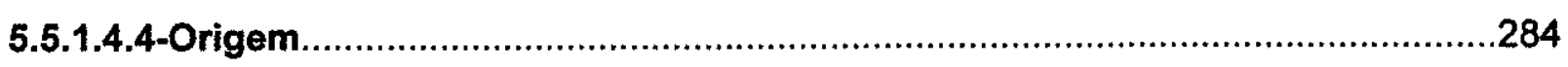

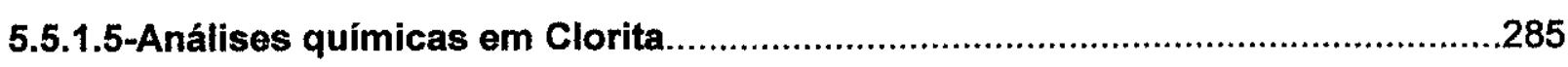

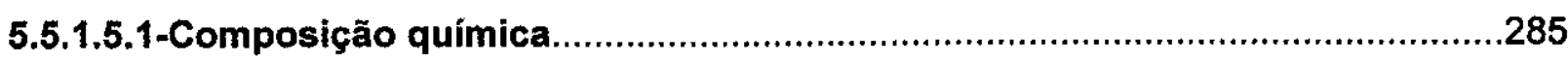

5.5.1.5.2-Classificação e Representação Gráfica.................................................28

5.5.1.5.3-Condições de Cristalização......................................................................289

5.5.2-Análises químicas através de Microscopia Eletrônica.....................................290

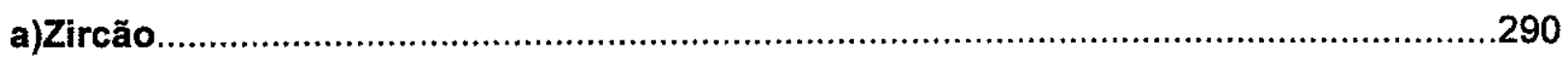

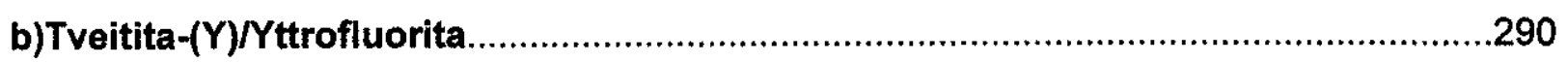

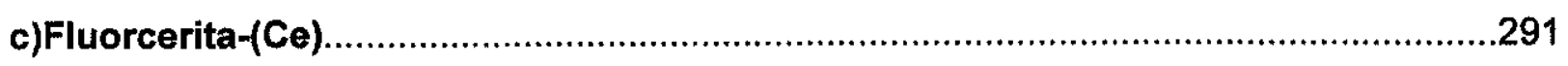

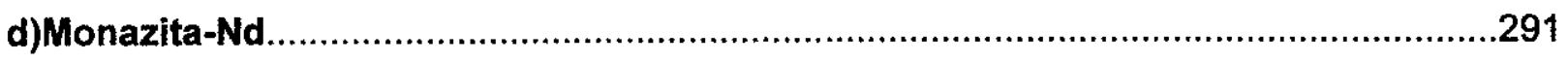

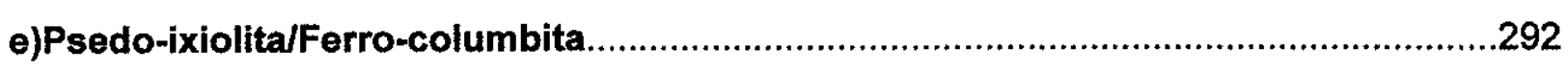

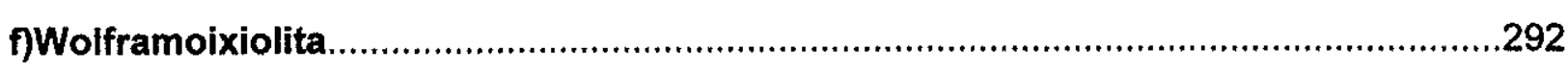

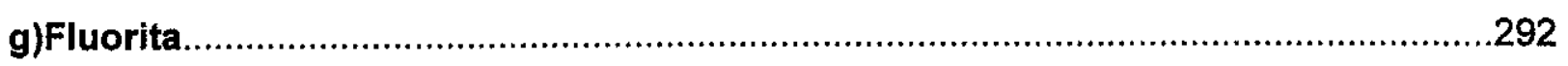

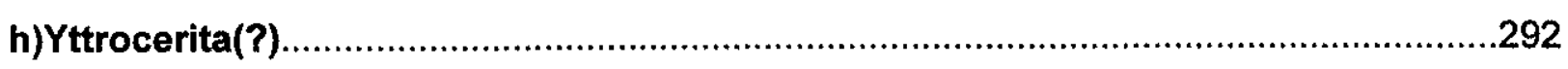

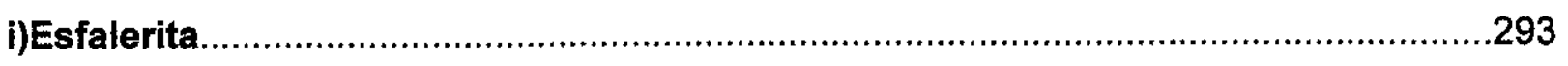

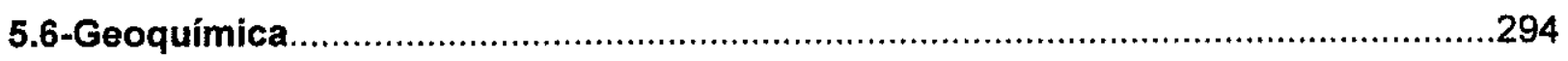

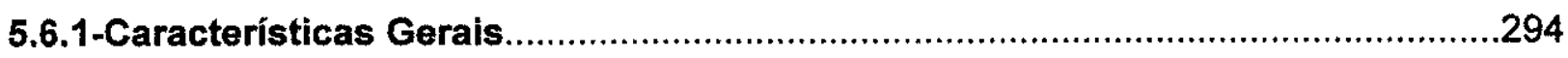

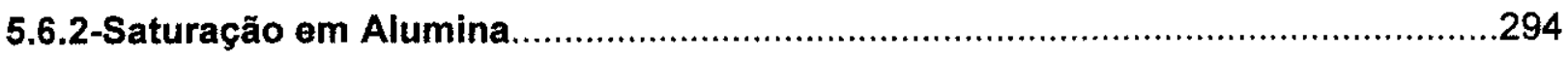

5.6.3-Afinidade Tectonomagmática e Tipologia.................................................295

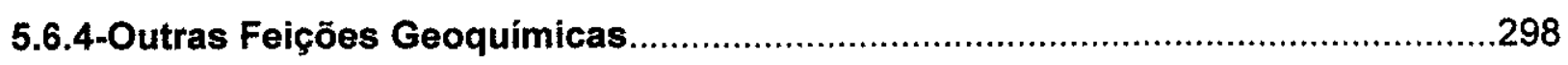


5.6.5-Análises Normativas CIPW 308

5.7-Condições de Cristalização .309

5.7.1-Posicionamento Crustal 309

5.7.2-Condições de $\mathrm{fO}_{2}, \mathrm{~T} \in \mathrm{P}$ .311

5.8-Conclusões e Considerações Finais. .313

\section{CAPITULO 6}

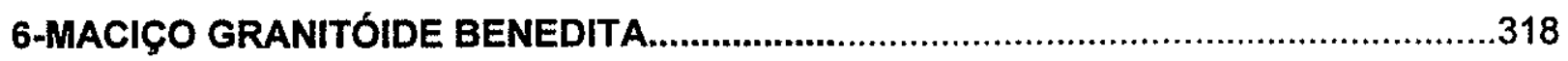

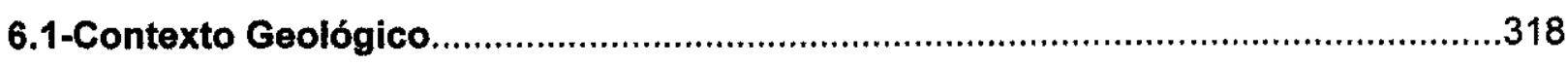

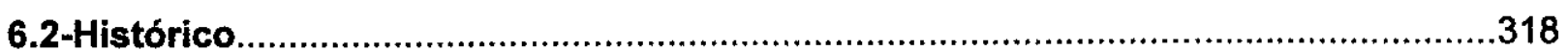

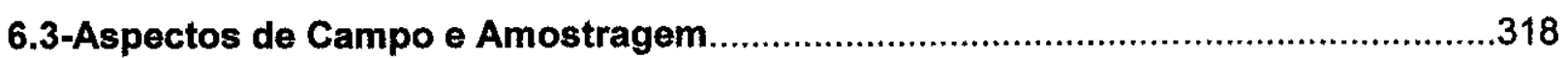

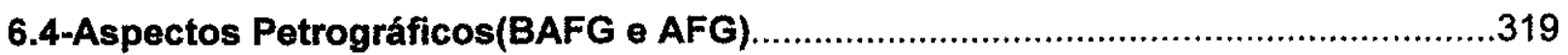

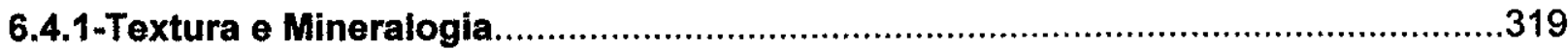

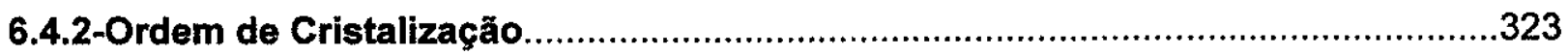

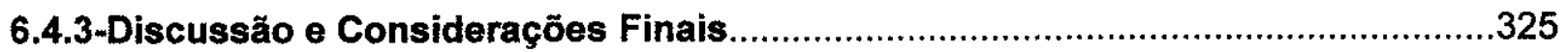

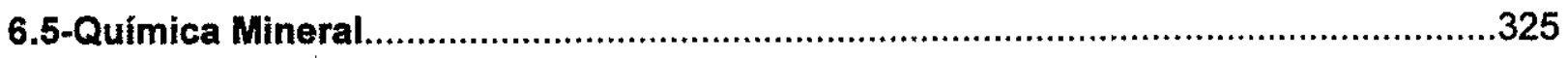

6.5.1-Análises químicas através de Microssonda Eletrônica..................................326

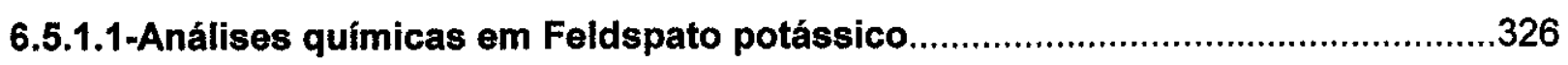

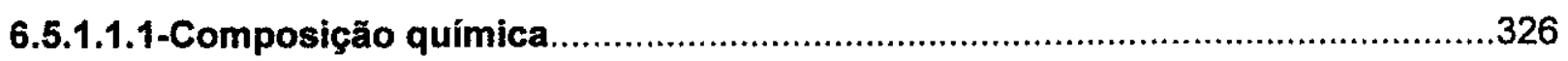

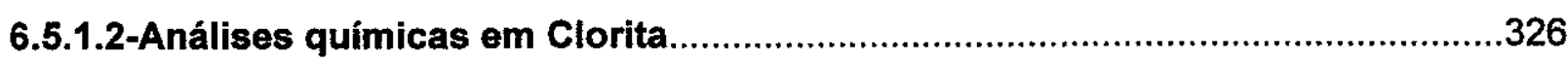

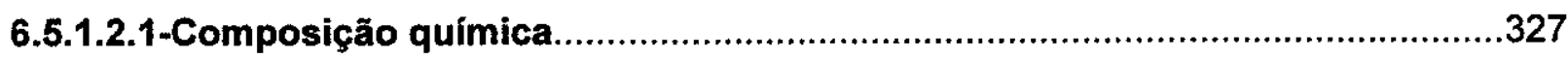

6.5.1.2.2-Classificação e Representação Gráfica ....................................................330

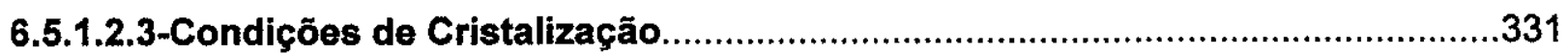

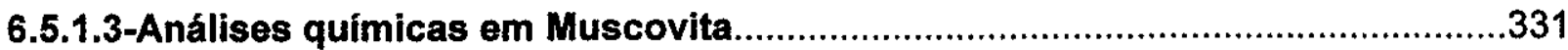

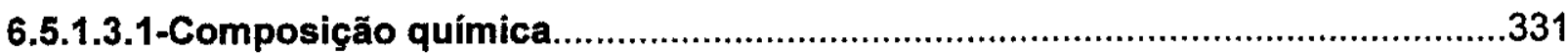

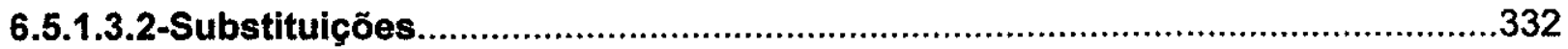

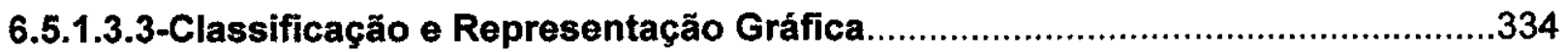

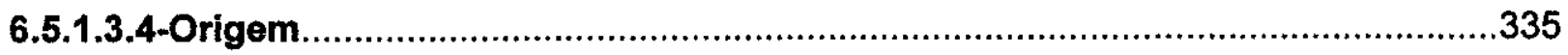

6.5.2-Análises químicas através de Microscopia Eletrônica...................................336

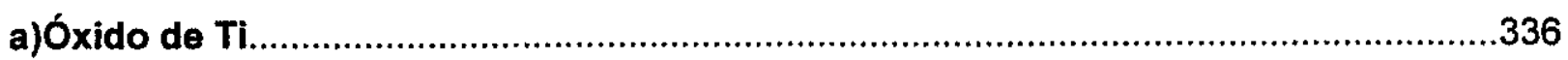

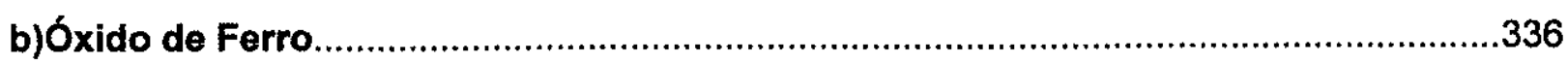

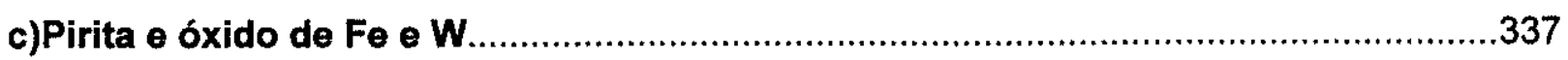

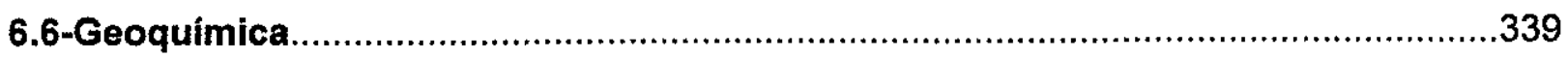

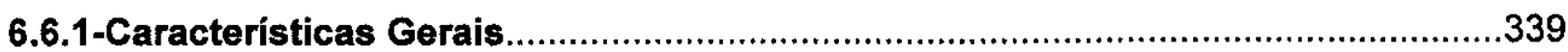

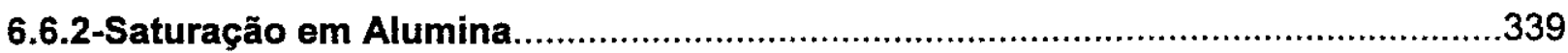

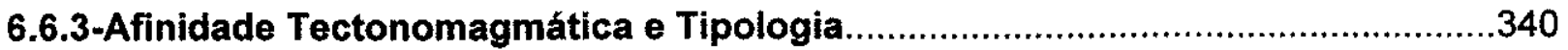

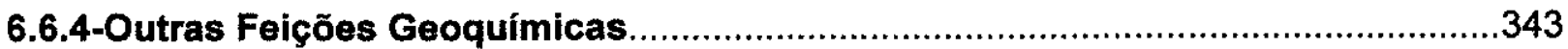


6.6.5-Análise Normativas CIPW. .351

6.7-Condições de Cristalização .353

6.8-Conclusões e Considerações Finais. .354

\section{CAPÍTULO 7}

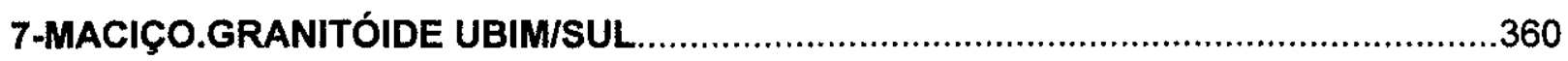

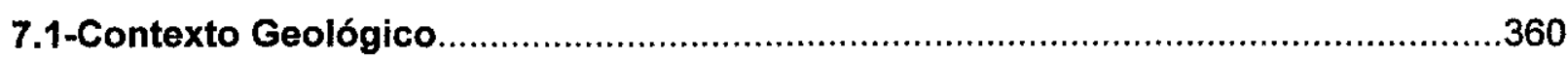

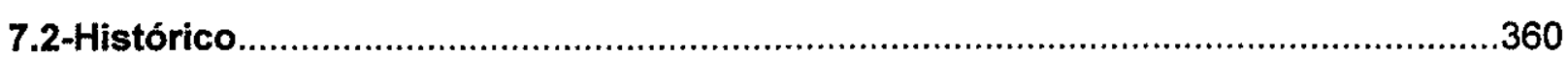

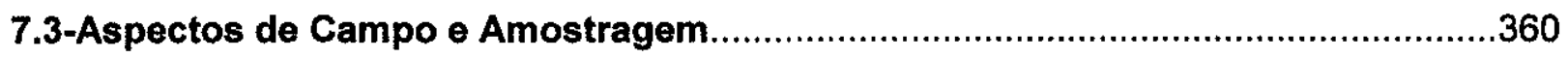

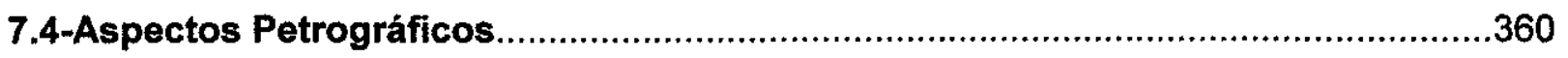

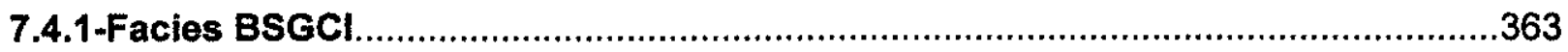

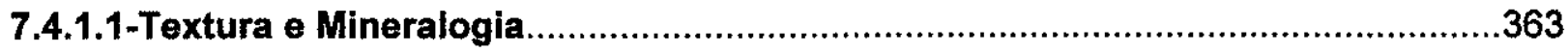

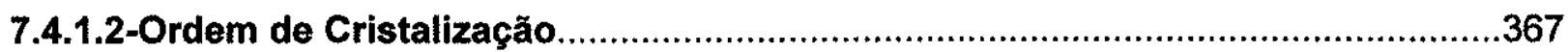

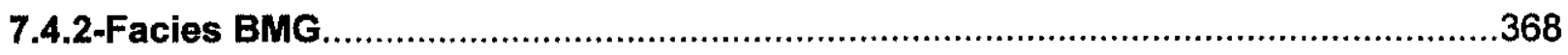

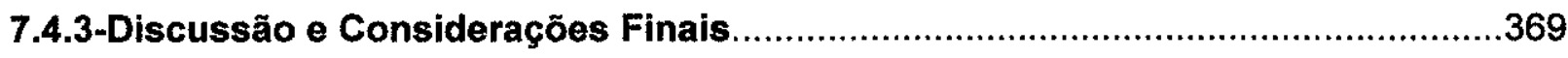

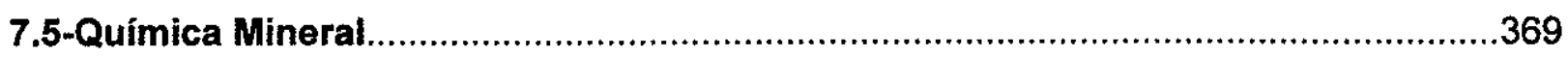

7.5.1-Análises através de Microssonda Eletrônica..................................................370

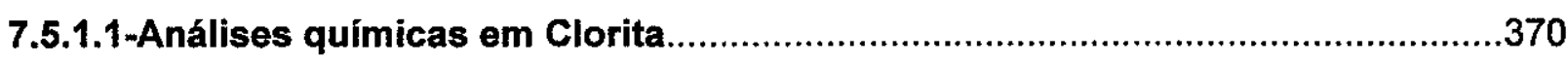

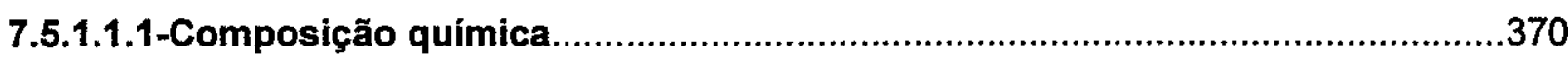

7.5.1.1.2-Classificação e Representação Gráfica ....................................................373

7.5.1.1.3-Condições de Cristalização.......................................................................373

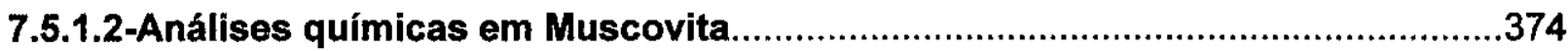

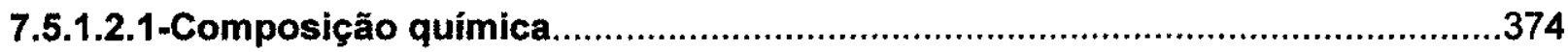

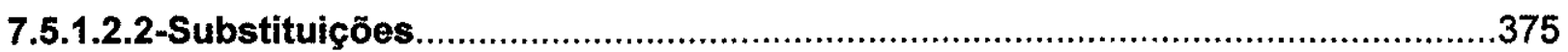

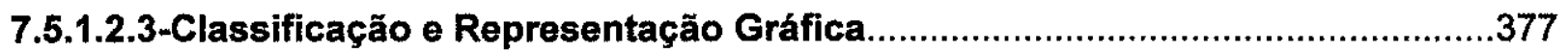

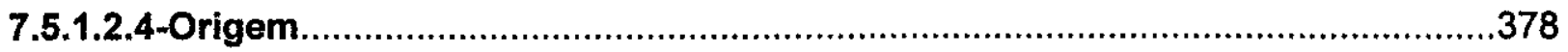

7.5.1.3-Análises químicas em Feldspato potássico...........................................379

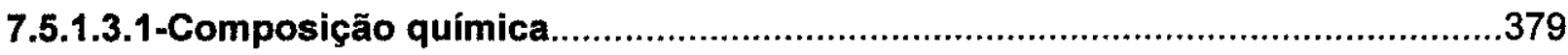

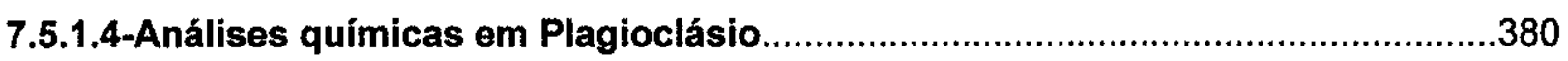

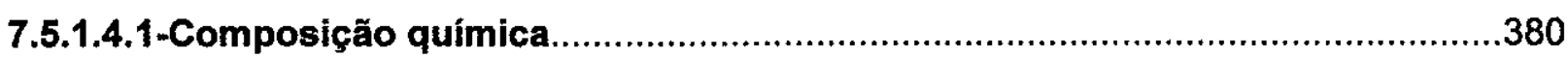

7.5.2-Análises químicas através de Microscopia Eletrônica....................................380

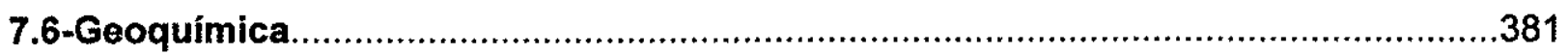

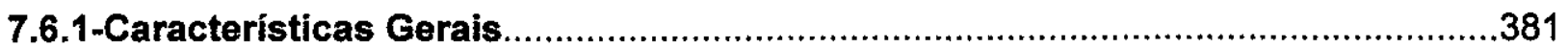

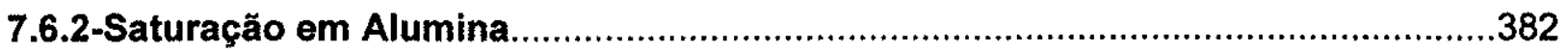

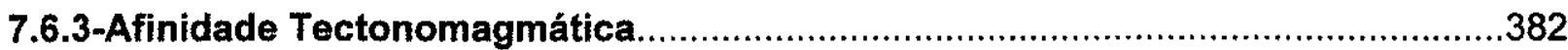

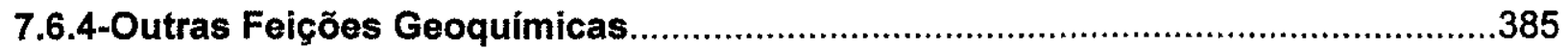

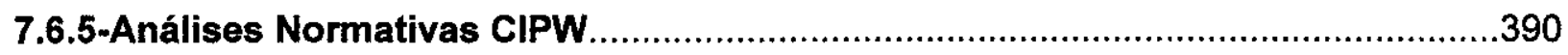


7.7-Condições de Cristalização 392

7.8-Conclusões e Considerações Finais. .392

\section{CAPÍTULO 8}

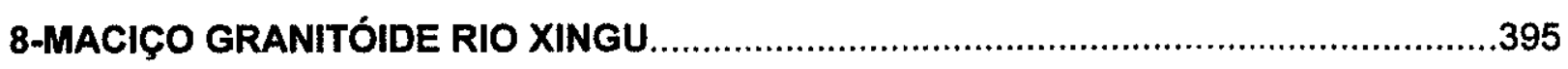

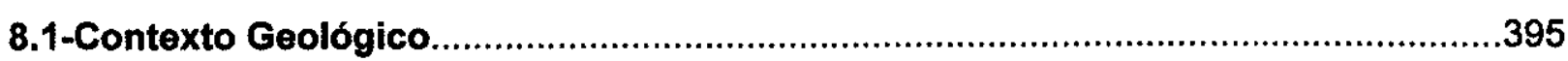

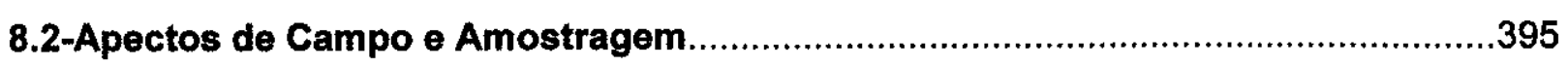

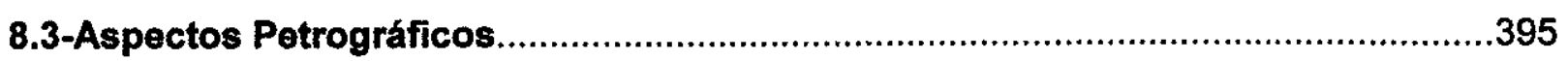

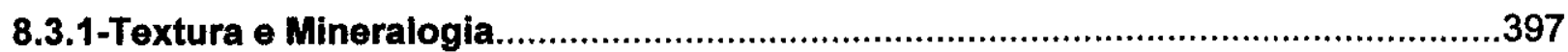

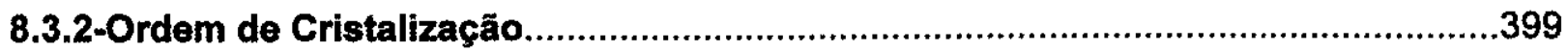

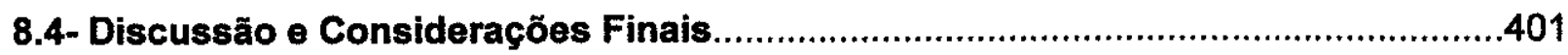

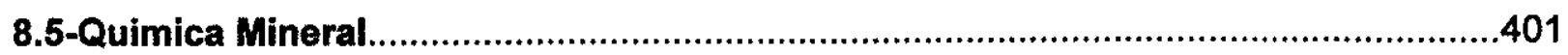

8.5.1-Análises químicas através de Microssonda Eletrônica....................................401

8.5.1.1-Análises químicas em Feldspato potássico..............................................401

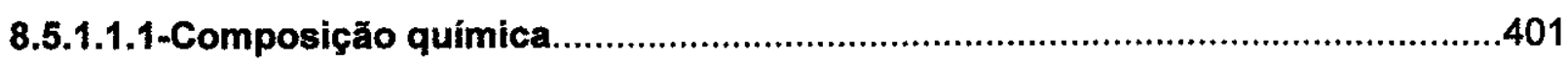

8.5.1.2-Análises químicas em Plagioclásio.........................................................403

8.5.2-Análises químicas através de Microscopia Eletrônica........................................404

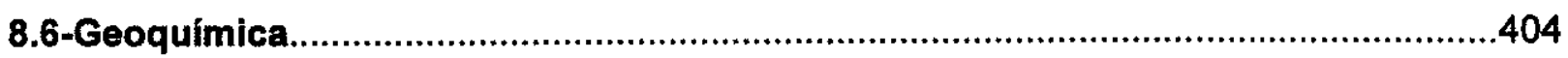

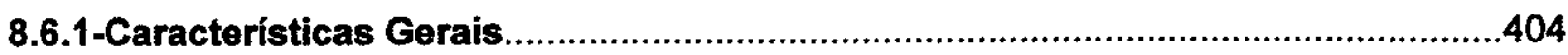

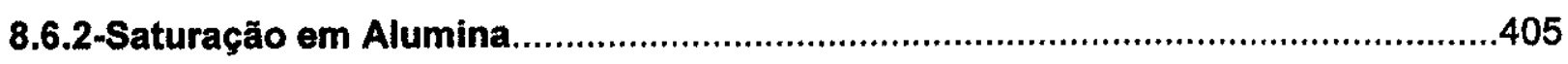

8.6.3-Afinidade Tectonomagmática e Tipologia....................................................405

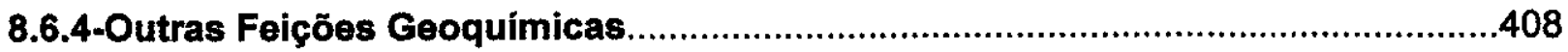

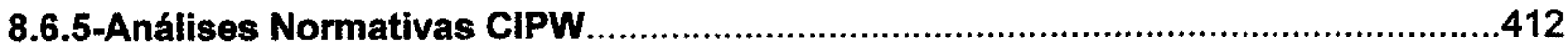

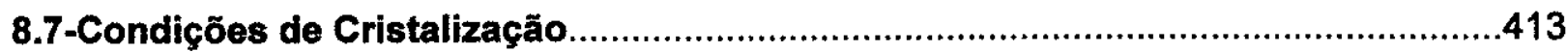

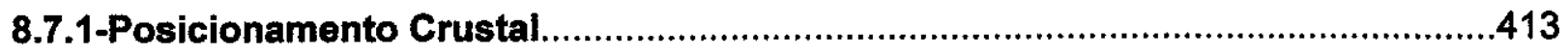

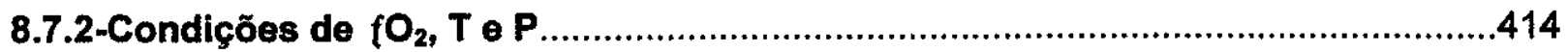

8.8-Conclusões e Considerações Finais.................................................................415

\section{CAPÍTULO 9}

9-ESTUDO DE ISÓTOPOS DE OXIGÊNIO............................................................419

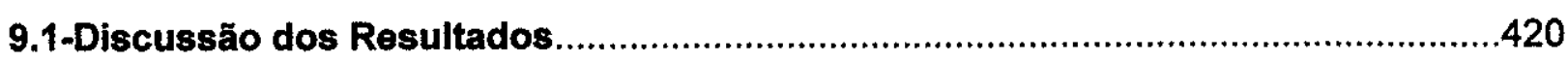

\section{CAPÍTULO 10}

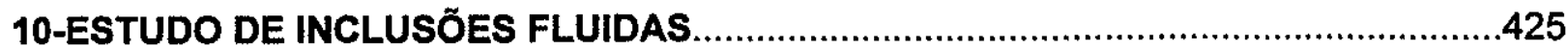

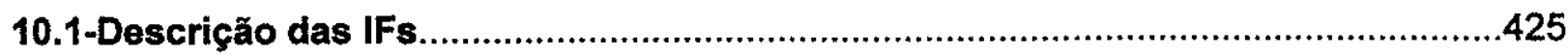

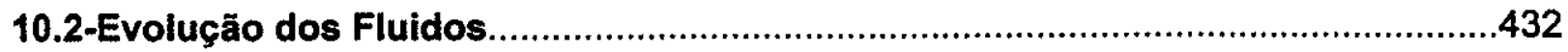

10.3-Controle dos Fluidos sobre as mineralizações de Sn ....................................434 
CAPITULO 11

11-GEOCRONOLOGIA E GEOQUÍMICA ISOTÓPICA ............................................447

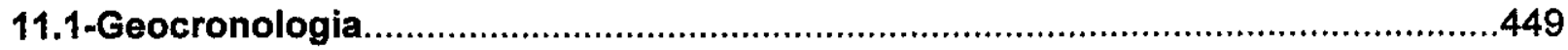

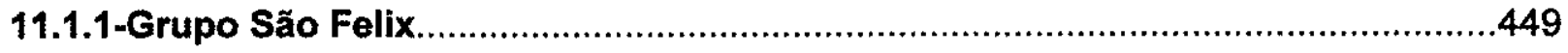

11.1.2-Suite Intrusiva Velho Guilherme ........................................................450

a)Maciço granitóide Antônio Vicente .................................................................450

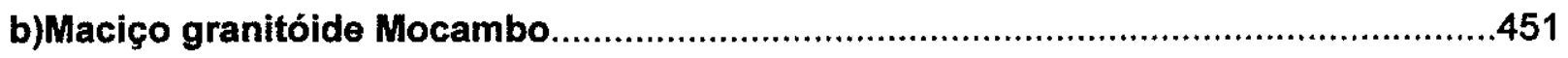

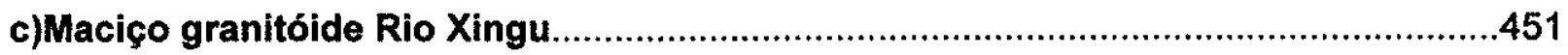

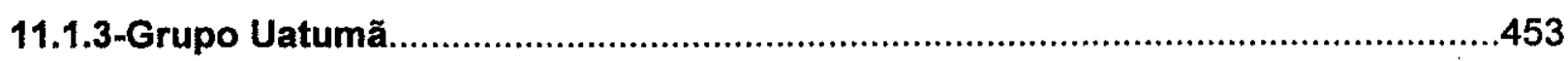

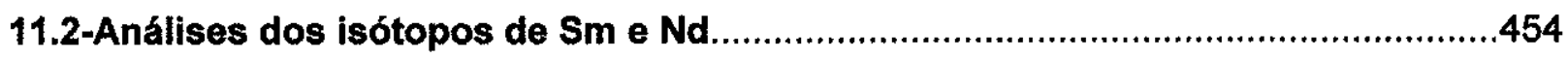

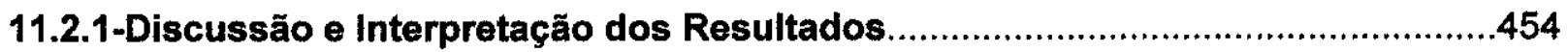

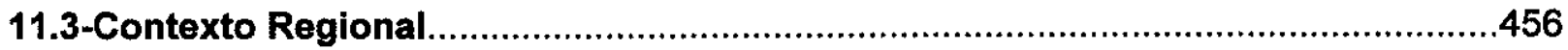

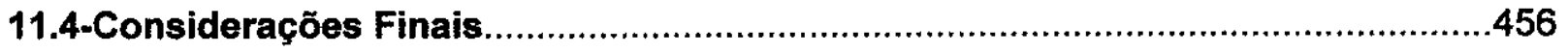

\section{CÁPITULO 12}

12- QUADRO COMPARATIVO ENTRE OS GRANITÓIDES DOS MACIÇOS DA SUITE..462

\section{CAPÍTULO 13}

13-DISCUSSÃO E CONCLUSÕES FINAIS .465

REFERÊNCIAS BIBLIOGRÁFICAS

VOLUME 2

ANEXOS

PRANCHAS 


\section{AGRADECIMENTOS}

$O$ autor desta tese agradece às pessoas e instituições, abaixo relacionadas, pelo apoio recebido durante a execução deste trabalho, sem o qual não teria sido possível a sua realização:

* ao Prof. Dr. Jorge Silva Bettencourt pela orientação acadêmica e profissional e pelo apoio dados durante toda a execução deste trabalho;

* à CAPES, Fundação Coordenação de Aperfeiçoamento de Pessoal de Nível Superior, pela concessão da Bolsa de estudos;

* à FAPESP, Fundação de Apoio a Pesquisa do Estado de São Paulo, pelo apoio financeiro concedido para a realização de grande parte deste trabalho(Projeto $n^{0}$ 96/3942-0);

* à Universidade Federal do Pará, através do Departamento de Geologia, do Centro de Geociências, pelo apoio financeiro concedido para as duas primeiras viagens de campo realizadas na fase inicial deste trabalho;

* ao Departamento de Geologia pela concessão de meu afastamento, pelo periodo de quatro anos, sem prejuízos financeiros;

* ao Prof. Dr. Roberto Dall'Agnol pela orientação durante a primeira fase deste trabalho e pela oportunidade concedida, com vistas ao estudo das rochas granitóides ora investigadas;

* ao Prof. Dr. Cândido Augusto Veloso Moura e seus colaboradores Prof. Dr. Thomas Scheller e Geóloga Cintia Gaia. pela execução das análises isotópicas $\mathrm{Pb}-\mathrm{Pb}$ (em rocha total) e $\mathrm{Pb}-\mathrm{Pb}$ em zirções(por evaporação de $\mathrm{Pb}$ ) no Laboratório de Geoquímica Isotópica do Centro de Geociências da Universidade Federal do Pará;

* à Profa. Dra. Rosa Maria Bello pelo apoio e orientação dispensados durante o estudo de inclusões Fluidas;

*ao Profs. Drs. Silvio Vlach e Excelso.Ruberti e ao técnico Marcos Mansueto pelo apoio e orientação dados durante a realização das análises químicas em fase minerais realizadas no Laboratório de Microssonda Eletrônica do Departamento de Mineralogia e Petrologia do Instituto de Geociências da Universidade de São Paulo;

* ao Prof. Dr. Colombo C.G. Tassinari pelo empenho dispensado durante a execução das análises isotópicas Sm-Nd no Centro de Geocronologia do Instituto de Geociências da Universidade de São Paulo, bem como ao Prof Dr. Key Sato e às técnicas Liliane Petronilho, Ivone Sonaki e Hélen Sonaki;

* ao Prof. Dr. Roberto Vizeu Lima Pinheiro por ter aceito me substituir como docente da disciplina Fotogeologia durante o periodo de meu afastamento;

* à Profa. Dra. Ana Maria Góes por ter sido minha fiadora junto ao Departamento de Pessoal da Universidade Federal do Pará devido meu afastamento; 
* ao Prof. Dr. lan McReath pela leitura da parte de geoquímica relativa aos granitóides do maciço Antônio Vicente;

* ao Prof. Dr. Wilson Teixeira pela leitura da parte de geocronologia e geoquímica isotópica ;

* à Geóloga Sandra.Garcia Gabas pelo apoio e orientação concedidos durante a execução das análises químicas semi-quantitativas em fase minerais, através de Microscopia Eletrônica de Varredura, no Laboratório de Caracterização Mineral da Faculdade de Engenharia de Minas da Escola Politécnica da Universidade de São Paulo;

* à Taboca Mineração S/A nas pessoas dos Geólogos Tadeu Veiga, Germano.José Reabe, Hildo Coelho, Carlos Augusto Sena e Evandro Cintra pela hospedagem e poio concedidos durante grande parte dos trabalho de campo na área de ocorrência do maciço granitóide Antônio Vicente, bem como aos técnicos Quegenaldo e Seabra;

* à CPRM, nas pessoas dos Geólogos Edésio Buenano Macambira e Xafi Jorge João, pelo apio nos trabalhos de campo e pela concessão de relatório interno e mapas relativos à gelogia da Folha SB-22-Y-B(Folha São Felix do Xingu);

* à Mineração São Francisco de Assis(Projeto Mocambo), na pessoa de Sr. Adalberto Maia, pelo apoio dado durante os trabalhos de campo referente ao maciço Mocambo;

* ao aos Professores do Instituta de Geociências/USP, especialmente, aqueles lotados no Departamento de Geologia Econômica, por terem me acolhido para desenvolver este trabalho;

* à Colega Irena Sparrenberger pela ajuda na confeç̧ão dos Abstract;

* aos Geólogos Pedro Carlos Pocciottti e Rita Parisi Conde pelo apoio dado na solução dos problemas com os nossos microcomputadores, bem como à Marcinha;

* ao motorista William Neves pelo apio dispensado durante os trabalhos de campo;

* ao Geólogo Cláudio Lamarão e ao técnico Lopes do Centro de Geociências da Universidade Federal do Pará, pelo apoio dado durante a separações de zircões;

* à técnica Aninha pela confecção das seções polidas utilizadas nas análises em microssonda eletrônica;

* à técnica Almerinda pela confecção das seções polidas utilizadas em microscopia ótica(luz refletida);

* ao Laboratório de Análises químicas do Departamento de Mineralogia e Petrologia do IGUSP e aos químicos Sandra, Ricardo e Marinês pela realização das análises químicas de FeO em biotita;

* aos colegas Tarcísio, Sônia, Jamile, Lena, Caetano, João Moreschi, Lilian, Venerando, Almani, Ana, Kátia, Jaquelini, Alexandre(Bruce), Alexandre, Carbeny, Tony, Gilberto, André, agrô, Cláudio, Anizia, Marcelo, Bolivar, Marta, Afonso, Valdecir, Washington, Bruno, Túlio, Albano, Marco Aurélio, Marco Antônio, Régis, Panza, Priscila, Braz, Vera, Ana Lúcia, 
Shimada, Murilo, Sara, Rolando, Rey, Hugo, Lis, André, Célia, João, Mário, Roberto, Douglas e Chico Bill, entre tantos outros, pela amizade e companheirismo;

* ao pessoal de apoio Ademir(Belém), Seu Eduardo(Belém), Ana Paula, Magali, Carina, Silvio, Serginho, Brenda, Érica, Maristela, Maria Aparecida, Lúcia, Vitor, Seu Walter, Seu José(xerox), e a todos que de alguma forma contribuíram para a realização deste trabalho. 
DEDICATÓRIA

Ao meu filho Leopoldo, meus pais Wilson e Sebastiana, meus irmãos Durval, Luiz, Catarina, Rita e Miton e à minha Companheira Kate. 


\section{RESUMO}

Os maciços granitóides Mesoproterozóicos Antônio Vicente, Velho Guilherme, Mocambo, Benedita, Ubim/Sul e RioXingu, da Suite Intrusiva Velho Guilherme, ora estudados, pertencentes à Provincia Estanifera do Sul do Pará(PESP), encontram-se alojados em rochas arqueanas, tanto do Terreno Granito-Greeenstone do Sul do Pará(TGGSP) quanto em seqủências do embasamento arqueano retrabalhado, constitutivas do Cinturão de Cisalhamento Itacaiúnas. São anorogênicos, possuem composições sieno a monzograniticas, com termos álcali-feldspato graníticos subordinados e mostram-se afetados, em diferentes graus, por alterações tardi a pós-magmáticas. Apresentam natureza subalcalina, são peraluminosos a metaluminosos, de paleoambiência intra-placas e assemelham-se aos granitóides tipo-A, do sub-grupo- $A_{2}$.

A cristalização fracionada foi, ao que tudo indica, o principal processo petrogenético que governou a evolução dos granitóides da suite. Os diferenciados mais evoluidos e hospedeiros de mineralizações de $\mathrm{Sn}$ mostram um grau extremo de diferenciação(SiO $\mathrm{S}_{2}$ $>75 \%$ ) e são produtos de fracionamento magmático e da interação com fluidos tardi a pósmagmáticos ricos em voláteis $(F, C l)$. Esses fluidos foram responsáveis pela extração de $\mathrm{Sn}^{+2}$, a partir das fases minerais primárias, especialmente, da biotita, incorporando-o às soluções residuais onde, ao que tudo indica, oxidou-se, passando para a forma $\mathrm{Sn}^{+4}$ e depositando-se como cassiterita( \pm kersterita/estanita).

Dados petrográficos, de química mineral (anfibólio, biotita, clorita) e geoquimicos, demonstraram que os granitóides dessa suite evoluíram, em grande parte, sob condições magmáticas de baixa $f \mathrm{O}_{2}\left(\cong 10^{-18}\right)$, as quais estenderam-se para o estágio de alterações tardi a pós-magmáticas. Indicam, ainda, que os mesmos foram colocados em níveis crustais rasos, a temperaturas e pressōes variáveis entre 690 e $890^{\circ} \mathrm{C}$ e 0,8 e 4,0 kbar, respectivamente.

Os valores de $\delta 18^{\circ}(+8$ a $+9 \%$ referentes a quartzo 1 dos referidos maciços sugerem que os granitóides do maciço Mocambo derivaram de uma fonte provavelmente distinta daquela dos granitóides dos dois outros maciços ora comentados.

Dados isotópicos $\mathrm{Pb}-\mathrm{Pb}($ valores de $\mu 1)$ e $\mathrm{Sm}-\mathrm{Nd}[\varepsilon \mathrm{Nd}(\mathrm{t})]$ indicam uma fonte crustal para os magmas geradores dos granitóides estudados, bem como demonstram que os protólitos dos mesmos evoluíram em estágio único e diferenciaram-se diretamente do manto entre 3,2 Ga e 3,0 Ga, conforme é indicado pelas suas idades modelo( $T_{D M}$ ) a saber: 1) 3,2 Ga-maciço granitóide Antônio Vicente; 2) 3,0 Ga- maciço granitóide Rio Xingu; 3) 3,0 Gamaciço granitóide Mocambo. Os valores fortemente negativos de $\varepsilon \mathrm{Nd}(\mathrm{t})$, respectivamente, 11,939(rocha total)/-12,20(zircão); -8,08(zircáo) ;-11,87(rocha total)/-12,36(zircão), pressupõem o envolvimento de uma crosta predominantemente Arqueana, ou mesmo uma 
provável mistura de uma componente de material derivado do manto com componentes de material crustal Arqueano em 3,2 Ga(maciço granitóide Antônio Vicente) e 3,0 Ga(maciços granitóides Rio Xingu e Mocambo).

Deve-se ressaltar, entretanto, que os valores de $\varepsilon \mathrm{Nd}(\mathrm{t}=1862 \pm 32 \mathrm{Ma})$ igual a $-8,08$, idade modelo $\left(T_{D M}\right)$ de $3,0 \mathrm{Ga}$ e $\delta^{18} \mathrm{O}=+8,8$ a $+9,0 \%$ dos granitóides do maciço Mocambo, são diferentes daqueles relativos aos maciços António Vicente, Velho Guilherme e Rio Xingu. Conjectura-se, assim, que: a) os granitóides do maciço Mocambo evoluíram a partir de um protólito de idade $\left(T_{D M}\right)$ mais jovem do que aquele dos granitóides do maciço Antônio Vicente; b) o protólito dos granitóides do maciço Mocambo tinha características isotópicas $\left[\left(\delta^{18} \mathrm{O}\right.\right.$ e $\left.\varepsilon \mathrm{Nd}(\mathrm{t})\right]$ distintas daquelas dos protólitos dos granitóides dos maciços Antônio Vicente, Velho Guilherme e Rio Xingu.

A relação Th/Ta referente aos granitóides dos maciços Velho Guilherme, Benedita e Rio Xingu sugere uma fonte dominantemente de crosta continental superior. Adicionalmente, a razão inicial ${ }^{87} \mathrm{Sr} /{ }^{86} \mathrm{Sr}=0,708 \pm 0,048$ obtida em granitóides do maciço Velho Gulherme indica um baixo grau de contaminação por crosta mais antiga. Em relação aos granitóides do maciço Ubim/Sul, a razão Th/Ta sugere uma fonte magmática localizada em um segmento crustal um pouco mais profundo do que a crosta superior. Os protólitos dos granitóides do maciço Mocambo resultaram de uma mistura de material de crosta profunda e crosta continental superior. $O$ amplo espalhamento composicional observado em relação aos granitóides do maciço Antônio Vicente parece representar uma mistura de material do manto com componentes de crosta profunda e crosta continental e talvez, até, uma contribuição adicional de sedimentos.

Apesar disso, os granitóides estudados não desenvolveram concentrações econômicas de metais(classe mundial). Mesmo os depósitos de cassiterita, explotados, eram fracos e tornaram-se inviáveis economicamente. Embora reconheça-se que os granitóides sejam diferenciados extremamente silicosos e evoluidos, os processos de diferenciação magmática, estado de oxidação, a cristalização fracionada e outros fatores, não foram suficientes para gerar concentrações econômicas de elementos litófilos, como era de se esperar. Do mesmo modo, na liberação de voláteis, o fracionamento líquido-liquido ou, enfim, a carga fluidal atuante no estágio de alterações tardi a pós-magmáticas não propiciou a formação de depósitos importantes

Em razão do que foi comentado acima, acredita-se que granitóides da Suite Intrusiva Velho Guilherme evoluíram a partir da fusão de diferentes segmentos crustais, com participação e mistura de material mantélico, de composições particulares e empobrecidos em elementos produtores de calor(U, Th, Rb e K). Talvez a mistura de uma componente de material mantélico empobrecido em elementos litófilos com componentes crustais de crosta 
inferior e de crosta continental superior, também, empobrecidos, tenha sido o fator determinante para gerar granitóides com essas características geoquímicas.

"Underplating" de magma básico tem sido sugerido, hipoteticamente, como sendo a fonte para a fusão parcial de rochas granulíticas máficas na base da crosta inferior. Neste trabalho não se descarta a hipótese da participação de sistemas do tipo "hot-spot" como fonte de calor para a fusão parcial dos protólitos dos granitóides estudados nem tampouco o modelo de plumas do manto. Os granitóides em pauta podem ainda estar relacionado à atividade magmática distal associada tanto à evolução da orogenia Maroni-itacaiúnas, quanto à orogenia Tapajós-Ventuári.

O conjunto de dados comentados neste trabalho permite estabelecer que nas áreas de ocorrência dos maciços granitóides, ora estudados, são remotas as possibilidades da existência de importantes depósitos de elementos litófilos(por exemplo estanho), com perspectivas de explotação econômica. Pode representar uma exceção a isso, a área de abrangência do maciço granitóide Mocambo, já que na mesma, ainda, existe uma reserva estocada(comunicação verbal). Entretanto, sua explotação dependerá sempre dos rumos futuros do mercado internacional, hoje extremamente desfavorável. 


\section{ABSTRACT}

The Antônio Vicente, Velho Guilherme, Mocambo, Benedita, Ubim/Sul e Rio Xingu Mesoproterozoic granitoid massifs of the Velho Guilherme Intrusive Suite belong to the Provincia Estanifera do Sul do Pará(PESP). The massifs are hosted by the Archean GraniteGreenstone Terrane of south Pará(TGGSP) and by Archean basement rocks, reworked to variable degrees, which are part of the Itacaiunas Shear Belt. They are described as anorogenic, syeno to monzogranitic in composition, with small amounts of alkali-feldspar granite, and are affected by late to postmagmatic alterations. Geochemically, these granites are subalkaline, peraluminous to metaluminous and plot in the fields of A-type granites $\left(A_{2}\right.$ subgroup) and within-plate granites.

Fractional crystallization apparently was the main petrogenetic process which governed the evolution of the granites. The most fractionated members host tin mineralization, are extremely evolved, enriched in silica $\left(\mathrm{SiO}_{2}>75 \%\right)$ and are products of magmatic fractionation and interaction with $(F, C l)$ enriched fluids. These fluids, enriched in mobile volatile components, were responsible for $\mathrm{Sn}^{2+}$ extraction from primary mineral phases, specially biotite. $\mathrm{Sn}^{2+}$ was incorporated to complex flows of fluid solutions, where it was apparently oxidized as $\mathrm{Sn}^{4+}$ resulting in the formation of cassiterite( \pm kesterite/stannite).

Petrographic, mineral chemistry and geochemical data indicate that the granitoids of this suite evolved mainly under low $\mathrm{fO}_{2}\left(\cong 10^{-18}\right)$ magmatic conditions, which extended to the late to postmagmatic alteration stage, were emplaced at high crustal levels and crystallized at high- $\mathrm{T}\left(690\right.$ to $\left.890^{\circ} \mathrm{C}\right)$ at confining pressures variable from 0,8 to $4,0 \mathrm{kbar}$.

The quartzo $1 \delta^{18} \mathrm{O}$ values of the Antônio Vicente, Vetho Guilherme and Mocambo massifs suggest that diferent lithospheric type(sources) were involved in the genesis of the massifs.

The current $\mathrm{Pb}-\mathrm{Pb}(\mu 1$ between $8,9 \pm 0,14$ and $9,9 \pm 0,60)$ and $\mathrm{Sm}-\mathrm{Nd}[\mathrm{eNd}(\mathrm{t}=1,8 \mathrm{Ga}))]$ isotopic data suggest a crustal source for the granitoids, which are, also, the result of onestage $\mathrm{Pb}$-isotopic evolution. They still demonstrate that the protolithes were differentiated directly from the mantle between $3,2-3,0 \mathrm{Ga}$. The strongly negative $\varepsilon N d(t)$ values, respectivelly, -11,93(whole rock)/-12,20(zircon); -8,08(zircon); $-11,87$ (whole rock)/12,36(zircon), can be more consistently interpreted as a result of, a predominantly Archean crust, or more preciselly, mixing between a mantle material and Archean crustal material components, during the time interval 3,2 to $3,0 \mathrm{Ga}$.

The Mocambo massif yield $\varepsilon N d(t)=-8,08, T_{D M}$ model-age $(3,0 \mathrm{Ga})$ and $\delta^{18} \mathrm{O}$ values $(+8,8$ to $+9,0 \%$ which are quiet different from those of the other massifs. This gives the evidence of derivation from a younger source. 
The Th/Ta ratios from the Velho Guilherme, Benedita and Rio Xingu granitoids suggest an upper continental crust source. Similarly, the initial ${ }^{87} \mathrm{Sr}^{86} \mathrm{Sr}_{(1}$, ratio from the Velho Guilherme of $0,708 \pm 0,048$ indicates low degree of contamination by an older depleted crustal component such as the Archean gneiss. In relation to the Ubim/Sul granitoids, the magmatic source as indicated by these elements, is linked to a deeper crustal segment below the upper crust. The ultimate source material for the Mocambo massif granitoids seems to be a mixture of lower crust and upper continental crust material components. The variable Th/Ta ratios 3, 31 to 38,98 observed in Antônio Vicente massif are the reflection of a mixture of mantle material with lower continental crust material components, though possible amounts of metassedimentary rock contribuitions might be considered.

Underplating of basic magma has been suggested, hypothetically, as necessary driven mechanism for granulitic rock partial melting of the lower crust. However, it is not discarded the hot-spots and mantle plume evolution models as appropiate mechanisms for the Archean crustal material partial melting and generation of the granitoid's protolith.. The anorogenic magmatism which generated the granitoids can be still related to the distal magmatic activity associated either to Maroni-ltacaiúnas or to the Tapajós-Ventuari orogenesis.

Moreover the Velho Guilherme Intrusive Suite granitoids have evolved from melting of different crustal segments mixed, sometimes, with mantle material of particular compositions and improverished in radioactive heat production elements $(\mathrm{U}, \mathrm{Th}, \mathrm{Rb}$ and $\mathrm{K})$.

Apart from their tin-specialized nature, none world-class tin deposit was generated by the studied granitoids. Even the mined cassiterite pay-streaks and the majority of the alluvial deposits were of poor grade and turn out to be economically unfeasible. The magmatic fractionation processes, redox conditions, crystal fractionation, efficiency of metal extraction, etc., were not enough for the concentration of lithophile elements at the expected economic levels. Seemingly the volatile liberation, the liquid-liquid fractionation and the processes leading to fluid release during the late to postmagmatic alteration stage precluded the genesis of any important rare-metal deposit. Exception to this, is the Mocambo massif, where significant resources were measured(oral comunication - Mineração São Francisco de Assis- 1995). However, for the moment, the present tin-metal prices don't favor a payable mining operation. 


\section{LISTA DE FIGURAS E FOTOMICROGRAFIAS}

$\mathrm{Pg}$

Figura 1.1- Mapa do Pará mostrando a localização geográfica da Área de ocorrência dos maciços granitóides estudados.

Figura 2.1- Mapa tectônico do Craton Amazônico(Tassinari, 1996)

Figura 2.2- Mapa tectônico regional da Folha SB-22-Y-B(Folha São Felix do Xingu).....

Figura 2.3- Mapa geológico da Folha SB-22-Y-B(Folha São Felix do Xingu).

Figura 3.1- Mapa geológico da área de ocorrência do maciço granitóide Antônio Vicente

Figura 3.2- Diagramas triangulares Q-A-P e Q-(A+P)-M'(Streckeise, 1976). a) composições modais gerais; b) composições médias

Figura 3.3- Fluxograma mostrando esquematicamente a ordem de cristalização das principais fases minerais magmáticas e tardi a pós-magmáticas constitutivas da facies BASMG do maciço granitóide Antônio Vicente.

Figura 3.4- Fluxograma mostrando esquematicamente a ordem de cristalização das principais fases minerais magmáticas e tardi a pós-magmáticas constitutivas da facies AFG do maciço granitóide Antônio Vicente.

Figura 3.5- Fluxograma mostrando esquematicamente a ordem de cristalização das principais fases minerais magmáticas e tardi a pós-magmáticas constitutivas da facies BSG, BSGA e BSGIA do maciço granitóide Antônio Vicente.

Figura 3.6- Fluxograma mostrando esquematicamente a ordem de cristalização das principais fases minerais magmáticas e tardi a pós-magmáticas constitutivas da facies BMG do maciço granitóide Antônio Vicente.

Figura 3.7- Fluxograma mostrando esquematicamente a ordem de cristalização das principais fases minerais magmáticas e tardi a pós-magmáticas constitutivas da facies MMG do maciço granitóide Antônio Vicente.

Figura 3.8- Fluxograma mostrando esquematicamente a ordem de cristalização das principais fases minerais magmáticas e tardi a pós-magmáticas constitutivas da facies SMGGf do maciço granitóide Antônio Vicente.

Figura 3.9- Diagrama triangular quartzo-(fluorita+topázio)-micas(Kühne et al., 1972. In: Stemprok, 1987), mostrando a distrubuição composicional dos greisens associados aos maciços granitóides Antônio Vicente e Mocambo.

Figura 3.10- Mapa simplificado do maciço granitóide Antônio Vicente mostrando as principais áreas de ocorrência dos depósitos aluvionares de cassiterita e topázio.

Figura 3.11. Diagrama de classificação dos anfibólios $\mathrm{Na} \times(\mathrm{Ca}+\mathrm{Na})$ mostrando a 
distribuição composicional dos tipos presentes em granitóides do maciço granitóide Antônio Vicente, com base nas recomendações da IMA e conforme Leake(1978), Hawthorne(1981) e Leake et al.(1997): a) Facies BASMG; b) Facies BASAFG. As linhas tracejadas são os limites apresentados por Leake(1978)

Figura 3.12a. Diagrama de classificação dos anfibólios $\mathrm{TSi} \times \mathrm{Mg} /\left(\mathrm{Mg}+\mathrm{Fe}^{2+}\right)$ mostrando a distribuição composicional dos tipos presentes em granitóides do maciço granitóide Antônio Vicente, com base nas recomendações da IMA e conformr Leake(1978) e Hawthorne(1981. A linha tracejada representa o limite proposto por Hawthorne(1981). Simbologias de acordo com a Figura $3.11 \mathrm{a}, \mathrm{b}$

Figura 3.12b. Diagrama de classificação dos anfibólios $\mathrm{Si} \times \mathrm{Mg} /\left(\mathrm{Mg}+\mathrm{Fe}^{2+}\right)$ mostrando a distribuição composicional dos tipos presentes em granitóides do maciço granitóide Antônio Vicente, com base nas recomendações da IMA e conforme Leake et al.(1997). Simbologias de acordo com a Figura $3.11 a, b$

Figura 3.13- Diagramas de correlações entre cátions dos anfibílios das facies BASMG e BASAFG do maciço granitóide Antônio Vicente: a) $\left(\mathrm{Fe}^{3+}+\mathrm{Al}^{\mathrm{IV}}\right) \times\left(\mathrm{Mg}+\mathrm{Si}+\mathrm{Fe}^{2+}\right)$; b) $\mathrm{Al}^{\mathrm{NV}} \times$ $(\mathrm{Na}+\mathrm{K}) ;$ c) $\left(\mathrm{Na}+\mathrm{Fe}^{3+}\right) \times\left(\mathrm{Ca}+\mathrm{Mg}+\mathrm{Fe}^{2+}\right) ;$ d) $\mathrm{Al}^{\mathrm{N}} \times\left(\mathrm{Mg}+\mathrm{Si}+\mathrm{Fe}^{2+}\right) ;$ e) $\mathrm{Fe}^{3+} \times$ $\left(\mathrm{Ti}+\mathrm{Fe}^{2+}\right)$

Figura 3.14.- Diagrama triangular $(\mathrm{FeO})-\mathrm{Mg}-\mathrm{Al}_{2} \mathrm{O}_{3}$ baseado em Nockolds(1947) mostrando as composições de biotitas em diferentes associações minerais. Campos: 1= biotita associada à muscovita+topázio+fluorita+etc.; 2 = biotita não acompanhada por outras fases máficas; 3 = biotita associada à hornblenda, piroxênio e/ou olivina. As análises constantes no diagrama são da amostra SL-9B-DT da facies BSG do maciço granitóide Antônio Vicente.

Figura 3.15.- Diagrama triangular $(\mathrm{FeO}+\mathrm{MnO})-\left(10 \times \mathrm{TiO}_{2}\right)-\mathrm{MgO}$ de Nachit(1994. In: Borges , 1997) mostrando a distribuição composicional da biotita da amostra SL-9B-DT, da facies BSG do maciço granitóide Antônio Vicente. $A=$ campo das micas magmáticas; $\mathbf{B}=$ campo das micas magmáticas reequilibradas.

Figura 3.16- Diagrama triangular $\mathrm{FeO}_{\mathrm{T}}-\mathrm{MgO}-\mathrm{Al}_{2} \mathrm{O}_{3}$ mostrando a projeção composicional da biotita da amostra SL-9B-DT, da facies BSG do maciço granitóide Antônio Vicente. As linhas cheias delimitam o campo composicional de biotitas de rochas ígneas conforme(Nockolds, 1947) e a linha tracejada separa biotitas magmáticas de biotitas metamórfico-metassomáticas, conforme Gokhale(1968).

Figura 3.17.- Diagrama Mg - Al(total) de Nachit et al.(1985) mostrando a distribuição composicional da biotita da amostra SL-9B-DT, da facies BSG do maciço granitóide Antônio Vicente.

Figura 3.18.- Diagrama triangular $\mathrm{R}^{3+}-\mathrm{Mg}-\mathrm{R}^{2+}$ de Foster(1960b), mostrando a relação entre 
$\left(\mathrm{Al}^{\mathrm{V}}, \mathrm{Fe}^{3+}, \mathrm{Ti}\right), \mathrm{Mg}$ e $\mathrm{Fe}^{2+}\left(\mathrm{Mn}^{2+}\right)$ em micas trioctaédricas e a posição ocupada no diagrama por análises de biotita da amostra SL-9B-DT, da facies BSG do maciço granitóide Antônio Vicente.

Figura 3.19.- Diagrama $\mathrm{Al}^{\mathrm{Vl}}$ versus $\mathrm{Mg} /\left(\mathrm{Mg}+\mathrm{Fe}^{2+}\right)$ de Guidotti(1984) mostrando a distribuição composicional da biotita da amostra SL-9B-DT, da facies BSG do maciço granitóide Antônio Vicente. $A=$ annita; $F=$ flogopita; $F A=$ flogopita aluminosa; $A A=$ annita aluminosa; $\mathrm{S}=$ siderofilita; $\mathrm{E}=\mathrm{K}_{2}\left(\mathrm{Mg}_{4} \mathrm{Al}_{2}\right)\left(\mathrm{Al}_{4} \mathrm{Si}_{4} \mathrm{O}_{20}\right)(\mathrm{OH})_{4}$

Figura 3.20.- Projeção da composição da biotita da amostra SL-9B-DT, da facies BSG do maciço granitóide Antônio Vicente, no diagrama $(\mathrm{Mg}-\mathrm{Li})$ versus $\left(\mathrm{Fe}_{\mathrm{T}}+\mathrm{Mn}+\mathrm{Ti}-\mathrm{Al}^{\mathrm{V} l}\right)$ de Tischendorf et al.(1997). Lp=lepidomelana; Febt=ferro-biotita; Mgbt=magnésio biotita; $\mathrm{Sd}=$ =siderofilita; $\mathrm{Fg}=$ =flogopita; Plt=protolitionita.

Figura 3.21- Representação composicional da biotita da facies BSG do maciço granitóide Antônio Vicente no diagrama triangular $\mathrm{Fe}^{2+}-\mathrm{Fe}^{3+}-\mathrm{Mg}$ de Wones \& Eugster(1965). Círculos vermelhos correspondem as análises onde os conteúdos de FeO foram calculados por via úmida; círculos azuis representam as análises onde os conteúdos de FeO estimados a partir da equação de Bruiyn et al.(1983; In: Solansaari(1995).

Figura 3.22- Representação composicional da biotita da facies BSG do maciço granitóide Antônio Vicente no diagrama $\mathrm{T}$ - $\log \mathrm{fO}_{2}$ para pressão total de $2 \mathrm{~Kb}$ segundo Wones \& Eugster(1965). I = curva tampão $\mathrm{Fe}_{3} \mathrm{O}_{4}-\mathrm{Fe}_{2} \mathrm{O}_{3} ; \mathrm{II}$ = curva tampão $\mathrm{Ni}-\mathrm{NiO}$; III = curva tampão $\mathrm{Fe}_{2} \mathrm{SiO}_{4}-\mathrm{SiO}_{2}-\mathrm{Fe}_{3} \mathrm{O}_{4}$. Os números pequenos do interior do diagrama representam as relações $\mathrm{Fe}^{2+}-\mathrm{Fe}^{3+}-\mathrm{Mg}$ da Figura 24. Simbologias de acordo com a Figura 3.21.....

Figura 3.23.- Diagrama $\mathrm{Al}^{\mathrm{V}}$ versus $\mathrm{Al}^{\mathrm{N}}$ mostrando a distribuição composicional das cloritas estudadas. a) facies BASMG, BASAFG e BSG. b) Clorita-siderofilita-muscovita-quartzo greisen. Maciço granitóide Antônio Vicente.

Figura 3.24.- Diagrama $\mathrm{Al}^{\mathrm{IV}}$ versus a razão $\mathrm{Fe} /(\mathrm{Fe}+\mathrm{Mg})$ mostrando a distribuição composicional das cloritas pertencentes às facies granitóides BASMG, BASAFG e BSG(a) e do clorita-siderofilita-muscovita-quartzo greisen(b). Maciço granitóide Antônio Vicente...... Figura 3.25 - Diagramas $\mathrm{Al}^{\mathrm{Vl}}$ vs. $\mathrm{Fe} /(\mathrm{Fe}+\mathrm{Mg})$ mostrando a distribuição composicional das cloritas pertencentes às facies granitóides BASMG, BASAFG e BSG(a) e do cloritasiderofilita-muscovita-quartzo greisen(b). Maciço granitóide Antônio Vicente

Figura 3.26.- Diagrama $\mathrm{Al}^{\mathrm{V} l}$ versus os cátions bivalentes $\left(\mathrm{Fe}^{2+}+\mathrm{Mg}^{2+}\right)$ mostrando a distribuição[composicional das cloritas estudadas. a) facies granitóides BASMG, BASAFG e BSG. b) clorita-siderofilita-muscovita-quartzo greisen. Maciço granitóide Antônio Vicente..

Figura 3.27.- Diagrama $\mathrm{Al}^{\mathrm{VI}}$ versus $\mathrm{Fe}^{2+}$ mostrando a distribuição composicional das cloritas pertencentes às facies granitóides BASMG, BASAFG e BSG(a) e ao clorita-siderofilitamuscovita-quartzo greisen(b). Maciço granitóide Antônio Vicente. 
Figura 3.28.- Diagrama $\mathrm{Al}^{\mathrm{lV}}$ versus os cátions bivalentes $\left(\mathrm{Fe}^{2+}+\mathrm{Mg}^{2+}\right)$ mostrando a distribuição composicional das cloritas pertencentes às facies granitóides BASMG, BASAFG e BSG(a) e ao clorita-siderofilita-muscovita-quartzo greisen(b) Maciço granitóide Antônio Vicente.

Figura 3.29.- Diagrama $\mathrm{Si}+\mathrm{Al}^{\mathrm{V}}$ versus os cátions bivalentes $\left(\mathrm{Fe}^{2+}+\mathrm{Mg}^{2+}\right)$ mostrando a distribuição composicional das cloritas pertencentes às facies granitóides BASMG, BASAFG e BSG(a) e ao clorita-siderofilita-muscovita-quartzo greisen(b). Maciço granitóide Antônio Vicente.

Figura 3.30.- Diagrama Si versus $\mathrm{Fe}($ total $) /\left(\mathrm{Fe}^{2+}+\mathrm{Mg}\right)$ mostrando a classificação das cloritas estudadas de acordo a proposição de Hey(1954). L=leuchtenbergita, variedade da

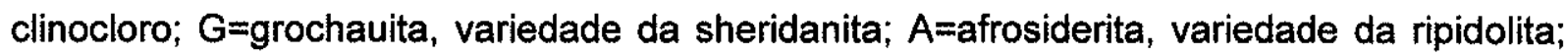
$B=$ bavalita, variedade da dafnita.

Figura 3.31- Representação composicional catiônicada da muscovita do clorita-siderofilitamuscovita-quartzo greisen associado ao maciço granitóide Antônio Vicente. a) $\mathrm{Si}-\mathrm{Al}_{\mathrm{T}}$; b) $\left.\mathrm{Mg}-\mathrm{Al}_{T} ; \mathrm{c}\right) \mathrm{Ti}-\mathrm{Al} \mathrm{I}_{T}$; d) XFe-Al $;$ e) $\mathrm{K}-\mathrm{Na}$ ).

Figura 3.32- Representação composicional da muscovita do clorita-siderofilita-muscovitaquartzo greisen associado ao maciço granitóide Antônio Vicente no diagrama $\mathrm{Al}^{\mathrm{IV}}$ versus [(Al $\left.\left.{ }^{\mathrm{V} l}-2\right)+2 \mathrm{Ti}\right]$ de Cathelineau(1982), modificado de Dias(1987). In: Simões(1992).

Figura 3.33- Representação composicional da muscovita do clorita-siderofilita-muscovitaquartzo greisen associado ao maciço granitóide Antônio Vicente no diagrama $\mathrm{Mg}-(\mathrm{Si}-6+\mathrm{Ti})$, modificado de Dias(1987). In: Simões(1992).

Figura 3.34- Representação gráfica das percentagens das moléculas paragoníticas e celadoníticas presentes na muscovita do clorita-siderofilita-muscovita-quartzo greisen associado ao maciço granitóide Antônio Vicente, de acordo com Simões(1992). \% mol. paragonita $=100 \times \mathrm{Na} /(\mathrm{Na}+\mathrm{K}) ; \%$ mol. celadonita $=100 \times(\mathrm{Si}-6) / 2$.

Figura 3.35- Diagrama (Mg-Li) vs. [(Fe $\left.\left.+\mathrm{Mn}+\mathrm{Ti}^{\mathrm{i}}\right)-\mathrm{Al}^{\mathrm{V}}\right]$ de Tischendorf et al.(1997) mostrando a distribuição composicional da muscovita do clorita-siderofilita-muscovita-quartzo greisen associado a facies granitóide BSG do maciço granitóide Antônio Vicente.

Figura 3.36- Distribuição composicional da muscovita do clorita-siderofilita-muscovitaquartzo greisen associado ao maciço granitóide Antônio Vicente no diagrama triangular $\mathrm{Mg}$-Ti-Na de Miller et al.(1981). $\mathrm{P}=$ campo composicional das muscovitas primárias; $\mathrm{S}=$ campo composicional das muscovitas secundárias.

Figura 3.37- Diagrama triangular Ab-Q-An mostrando a distribuição composicional dos feldspatos potássicos(microclina pertítica) das facies granitóides BASMG, BASAFG e BSG do maciço granitóide Antônio Vicente.

Figura 3.38- Diagrama Na-K mostrando a distribuição composicional das análises de 
feldspato potássico(microclina pertítica) das facies granitóides BASMG, BASAFG e BSG do maciço granitóide Antônio Vicente.

Figura 3.39- Diagrama Na-Ca mostrando a distribuição composicional das análises de feldspato potássico(microclina pertítica) das facies granitóides BASMG, BASAFG e BSG do maciço granitóide Antônio Vicente.

Figura 3.40- Diagrama triangular Ab-Q-An mostrando a distribuição composicional dos plagioclásios das facies granitóides BASMG, BASAFG e BSG do maciço granitóide Antônio Vicente.

Figura 3.41- Diagrama Ab-An mostrando a distribuição composicional das análises de plagioclásios das facies granitóides BASMG, BASAFG e BSG do maciço granitóide Antônio Vicente.

Figura 3.42- Diagrama Na-Ca mostrando a distribuição composicional das análises de plagiociásios das facies granitóides BASMG, BASAFG e BSG do maciço granitóide Antônio Vicente.

Figura 3.43 (a) relacionamento microtextural envolvendo as variedades de IImenita(ilm1, ilm2 e ilm3) e titanomagnetita; (b) detalhe do relacionamento existente entre ilm 2 e ilm3 e titanomagnetita; (c) detalhe de uma inclusão de ilm1 em cristal de anfibólio; (d) detalhe do intimo relacionamente microtextural desenvolvido ente magnetita e titanita. Facies granitóide BASMG. Maciço granitóide Antônio Vicente.

Figura 3.44- (a) aspecto microtextural do zircão; (b) detalhe do relacionamento microtextural entre armstrongita/catapleita e a thorianita. Facies granitóide BASAFG. Maciço granitóide Antônio Vicente.

Figura 3.45- (a) Aspecto microtextural mostrando o relacionamento entre monazita, óxido de $\mathrm{Ce}, \mathrm{La}, \mathrm{Nd}$ e Ca e bodenita, intimamente associados à cloritização da biotita; (b) Detalhe da monazita apresentada na Figura $3.45 a$.

Figura 3.46- (a) aspecto do relacionamento desenvolvido entre calcopirita e kesterita; (b) Detalhe da monazita e xenotima. Clorita-siderofilita-muscovita-quartzo greisen associado ao maciço granitóide Antônio Vicente.

Figura 3.47. Diagrama binário A/CNK versus A/NK(Maniar\& Piccoli, 1989) mostrando a distribuição das facies granitóides do MGAV, com baseado nos indices de Shand(ISA)........

Figura 3.48. Diagramas discriminantes de paleoambiência tectônica de Pearce et al.(1984) mostrando a distribuição das amostras dos granitóides do MGAV (a) Y-Nb; (b) [Nb+Y]-Rb; (c) Yb-Ta. Simbologia de acordo com a Figura 3.47.

Figura 3.49 - Diagrama $\mathrm{Zr}+\mathrm{Nb}+\mathrm{Ce}+\mathrm{Y}$ vs. $\left(\mathrm{K}_{2} \mathrm{O}+\mathrm{Na}_{2} \mathrm{O}\right) / \mathrm{CaO}$ de Whalen et al.(1987) mostrando a distribuição composicional das amostras das principais facies granitóides do maciço granitóide Antônio Vicente. 
Figura 3.50- Diagrama $\mathrm{Zr}+\mathrm{Nb}+\mathrm{Ce}+\mathrm{Y}$ vs. (FeOT/MgO) de Whalen et al.(1987) exibindo as análises das principais facies granitóides do maciço granitóide Antônio Vicente.

Figura 3.51- 10.000Ga vs. $\left(\mathrm{K}_{2} \mathrm{O}+\mathrm{Na}_{2} \mathrm{O}\right) / \mathrm{Al}_{2} \mathrm{O}_{3}$ de Whalen et al.(1987) exibindo as análises das principais facies granitóides do maciço granitóide Antônio Vicente

Figura 3.52- Diagramas triangulares $\mathrm{Y}-\mathrm{Nb}-\mathrm{Ce}(\mathrm{a})$ e $\mathrm{Y}-\mathrm{Nb}-3 \mathrm{Ga}$ (b) de Eby(1992) mostrando a distribuição composicional das principais facies granitóides do maciço granitóide Antônio Vicente.

Figura 3.53- Diagramas retangulares $\mathrm{SiO}_{2}$ vs. $\mathrm{FeO}^{*} /\left(\mathrm{FeO}^{*}+\mathrm{MgO}\right)(\mathrm{a})$ e $\mathrm{CaO}$ vs. $\mathrm{Na} 2 \mathrm{O}(\mathrm{b})$ mostrando a distribuição composicional das principais facies granitóides do maciço granitóide Antônio Vicente.

Figura 3.54- Distribuição composicional das amostras das principais facies granitóides do maciço granitóide Antônio Vicente nos diagramas (a) Rb-K; (b) Rb-Sr; (c) Rb-Ba; (d) Rb-Zr; (e) Th-U; f) Rb-Ba-Sr(El-Bouseily \& Sokkary, 1975). Simbologia de acordo com a Figura $3.54 b$.

Figura 3.55. Distribuição composicional das amostras das principais facies granitóides do maciço granitóide Antônio Vicente e dos greisens a ele associados nos diagramas (a) $\mathrm{F}-\mathrm{Cl}$; (b) F-Sn; (c) Cl-Sn; (d) $\mathrm{Na}_{2} \mathrm{O}-\mathrm{Sn}$; e) $\mathrm{Sn}-\mathrm{Rb} / \mathrm{Sr}$; f) $\mathrm{Sn}-\mathrm{TiO}_{2}$. Simbologia de (a) e (b) acordo com as Figuras $3.55 \mathrm{c}, \mathrm{d}, \mathrm{e}, \mathrm{f}$. O losango indica a composição média da crosta conforme Taylor \& McLennan, 1985)

Figura 3.56- Padrões de ETR Padrão de distribuição dos ETR para os granitóides do maciço granitóide Antônio Vicente.

Figura 3.57- Diagrama normativo Q-Ab-Or mostrando a distribuição composicional das principais facies granitóides do maciço granitóide Antônio Vicente. As linhas tracejadas indicam a distribuição de freqüência das razões Q-Ab-Or de 1190 rochas graníticas de Winkler \& Von Plaren(1961). As projeções das linhas cotéticas isobáricas P-E'5 de 2, 5 e $7 \mathrm{kbar}$ foram compiladas de Winkler(1977). M é o máximo de freqüência , A representa a posição e temperatura do ponto de mínimo sem $F($ Tuttle \& Bowen, 1958). 1\%F, 2\%F e $4 \% \mathrm{~F}$ representam as posições e temperaturas dos pontos de mínimo com $F$ adicionado e excesse de água a $1 \mathrm{kbar}$ (Manning, 1981).

Figura 3.58- Diagrama normativo Ab-An-Or mostrando a distribuição composicional das pricipais facies granitóides e greisens associados ao maciço Antônio Vicente..

Figura 3.59- Diagrama $\mathrm{Fe} /(\mathrm{Fe}+\mathrm{Mg}$ ) vs. Alv (compilado a partir de Anderson \& Smith, 1995, modificado de Leake, 1978) mostrando a distibuição composicional dos anfibólios das facies BASMG e BASAFG do maciço granitóide Antônio Vicente. As linhas vermelhas limitam os campos de diferentes $\mathrm{fO}_{2}$.

Figura 3.60- Diagrama Ti vs. AIT(compilado a partir de Turner et al., 1992, constuido a 
partir de Johnson \& Rutherford, 1989) mostrando a distibuição composicional dos anfibólios das facies BASMG e BASAFG do maciço granitóide Antônio Vicente

Figura 3.61- Diagrama P-T(compilado a partir de Brown \& Fyfe, 1970) mostrando a estimativa da temperatura de cristalização dos anfibólios das facies BASMG e BASAFG do maciço granitóide Antônio Vicente, determinada a partir da pressão estimada através do barômetro de Johnson \& Rutherford(1989). As linhas vermelhas representam o começo da fusão reconhecida em granito seco e as linhas azuis correspondem ao começo da fusão reconhecida em misturas dioritícas resultantes da decomposição das várias fases hidratadas indicadas. Também são indicadas a curva do"solidus" saturada em água determinada para dois tipos minerais quartzo-feldspáticos juntamente com os possiveis gradientes geotermais e a curva do limite de equilibrio entre cianita e sillimanita. A principal produção de liquidos graníticos naturais mais provável corresponde à área em rosa acinzentada. $20^{\circ} \mathrm{C}$ e $30^{\circ} \mathrm{C} / \mathrm{Km}$ correspondem às linhas azuis superior e inferior, respectivamente.

Figura 3.62- Diagrama P-T(compilado a partir de Brown \& Fyfe, 1970) mostrando a estimativa da temperatura de cristalização da biotita da facies BSG do maciço granitóide Antônio Vicente, determinada a partir da temperatura estimada através do termômetro de Wones \& Eugster(1965). As linhas vermelhas e azuis, bem como as outras informações correspondem ao que foi apresentado na Figura 3.61

Figura 4.1- Mapa geológico da área de ocorrência do maciço granitóide Velho Guilherme....

Figura 4.2- Diagramas triangulares $Q-A-P(a)$ e $Q-(A+P)-M^{\prime}(b)$ de Streckeisen(1976) mostrando a distribuição composicional modal das facies granitóides do maciço granitóide Velho Guilherme

Figura 4.3- Fluxograma mostrando um esboço esquemático da seqüência de cristalização magmática e tardi a pós-magmática das fases minerais presentes nos granitóides do. maciço Velho Guilherme.

Figura 4.4.- Diagrama triangular $\left(\mathrm{FeO}_{\mathrm{T}}\right)-\mathrm{MgO}-\mathrm{Al}_{2} \mathrm{O}_{3}$ baseado em Nockolds(1947)mostrando as composições da biotita em diferentes associações minerais. Campos: 1= biotita associada à muscovita+topázio+fluorita+etc.; 2 = biotita não acompanhada por outras fases máficas; 3 = biotita associada à hornblenda, piroxênio e/ou olivina.

Figura 4.5.- Diagrama triangular $(\mathrm{FeO}+\mathrm{MnO})-\left(10 \times \mathrm{TiO}_{2}\right)-\mathrm{MgO}$ de Nachit(1994. In: Borges - 1997) mostrando a distribuição composicional da biotita da amostra NN-VG-63A, da facies BSGEm do maciço granitóide Velho Guilherme. $A$ = campo das micas magmáticas; $\mathbf{B}=$ campo das micas magmáticas reequilibradas.

Figura 4.6.- Diagrama triangular $\mathrm{FeO}_{\mathrm{T}}-\mathrm{MgO}-\mathrm{Al}_{2} \mathrm{O}_{3}$ mostrando a projeção composicional da biotita da amostra NN-VG-63A, da facies BSGEm do maciço granitóide Velho 
Guilherme. As linhas cheias delimitam o campo composicional de biotita de rochas ígneas conforme(Nockolds, 1947) e a linha tracejada separa biotita magmáticas de biotita metamórfico-metassomáticas, conforme Gokhale(1968).

Figura 4.7- Diagrama triangular $\mathrm{R}^{3+}-\mathrm{Mg}-\mathrm{R}^{2+}$ de Foster(1960b), mostrando a relação entre $\left(\mathrm{Al}^{\mathrm{V}}, \mathrm{Fe}^{3+}, \mathrm{Ti}\right), \mathrm{Mg}$ e $\mathrm{Fe}^{2+}\left(\mathrm{Mn}^{2+}\right)$ em micas trioctaédicas e a posição ocupada no diagrama pelas análises da biotita da amostra NN-VG-63A, da facies BSGEm do maciço granitóide Velho Guilherme.

Figura 4.8 - Diagrama $\mathrm{Al}^{\mathrm{V} /}$ versus $\mathrm{Mg} /\left(\mathrm{Mg}+\mathrm{Fe}^{2+}\right)$ de Guidotti(1984) mostrando a distribuição composicional da biotita da amostra NN-VG-63A, da facies BSGEm do maciço granitóide Velho Guilherme. $A=$ annita; $F=$ flogopita; $F A=$ flogopita aluminosa; $A A=$ annita aluminosa; $\mathrm{S}=$ siderofilita; $\mathrm{E}=\mathrm{K}_{2}\left(\mathrm{Mg}_{4} \mathrm{Al}_{2}\right)\left(\mathrm{Al}_{4} \mathrm{Si}_{4} \mathrm{O}_{20}\right)(\mathrm{OH})_{4}$.

Figura 4.9.- Projeção da composição da biotita da amostra NN-VG-63A, da facies BSGEm do maciço granitóide Velho Guilherme, no diagrama $(\mathrm{Mg}-\mathrm{Li})$ vs. $\left(\mathrm{Fe}_{\mathrm{T}}+\mathrm{Mn}+\mathrm{Ti}-\mathrm{Al}^{\mathrm{V}}\right)$, de Tischendorf et al.(1997). Lp=lepidomelana; Febt=ferro-biotita; Mgbt=magnésio biotita; $\mathrm{Sd}=$ siderofilita; Fg=flogopita; PIt=protolitionita

Figura 4.10 - Representação composicional da biotita da amostra NN-VG-63A, da facies BSGEm do maciço granitóide Velho Guilherme no diagrama triangular $\mathrm{Fe}^{2+}-\mathrm{Fe}^{3+}-\mathrm{Mg}$ de Wones \& Eugster(1965)

Figura 4.11- Representação composicional da biotita da amostra NN-VG-63A, da facies BSGEm do maciço granitóide Velho Guilherme no diagrama $\mathrm{T}^{0} \mathrm{C}-\log \mathrm{fO}_{2}$ para pressão total de 2070b segundo Wones \& Eugster(1965). I = curva tampão $\mathrm{Fe}_{3} \mathrm{O}_{4}-\mathrm{Fe}_{2} \mathrm{O}_{3} ; \mathrm{II}=$ curva tampão Ni-NiO; III = curva tampão $\mathrm{Fe}_{2} \mathrm{SiO}_{4}-\mathrm{SiO}_{2}-\mathrm{Fe}_{3} \mathrm{O}_{4}$. Os números pequenos do interior do diagrama representam as relações $\mathrm{Fe}^{2+}-\mathrm{Fe}^{3+}-\mathrm{Mg}$ da Figura 4.10.

Figura 4.12- Diagrama triangular Ab-Or-An mostrando a distribuição composicional dos plagioclásio das facies BSGEm, SGH e MSG pertencentes ao maciço granitóide Velho Guiulherme.

Figura 4.13- Diagrama $\mathrm{Ca}$ - $\mathrm{Na}$ mostrando a disribuição composicional dos plagioclásios estudados.

Figura 4.14- Diagrama An-Ab mostrando a participação dessas duas moléculas nos plagioclásio estudados.

Figura 4.15- Diagrama triangular Ab-Or-An mostrando a distribuição composicional do feldspato potássico das facies BSGEm, SGH e MSG pertencentes ao maciço granitóide Velho Guiulherme

Figura 4.16- Diagrama K-Na mostrando a distribuição composicional do feldspato potássico das facies BSGEm, SGH e MSG pertencentes ao maciço granitóide Velho Guiulherme........ Figura 4.17- Diagrama $\mathrm{Al}^{\mathrm{VI}}$ versus $\mathrm{Al}^{\mathrm{lv}}$ mostrando a distribuição composicional da clorita da 
facies SGH do maciço granitóide Velho Guilherme.

Figura 4.18.- Diagrama $\mathrm{Al}^{\mathrm{Vl}}$ versus os cátions bivalentes $\left(\mathrm{Fe}^{2+}+\mathrm{Mg}^{2+}\right)$ mostrando a distribuição composicional da clorita pertencente à facies granitóide SGH do maciço granitóide Velho Guilherme.

Figura 4.19- Diagrama $\mathrm{Al}^{\mathrm{V} /}$ versus $\mathrm{Fe}^{2+}$ mostrando a distribuição composicional da clorita pertencente à facies granitóide SGH do maciço Velho Guilherme.

Figura 4.20- Diagrama $\mathrm{Al}^{\mathrm{iV}}$ versus os cátions bivalentes $\left(\mathrm{Fe}^{2+}+\mathrm{Mg}^{2+}\right)$ mostrando a distribuição composicional da clorita pertencente à facies granitóide SGH do maciço granitóide Velho Guilherme.

Figura 4.21- Diagrama $\mathrm{Al}^{\mathrm{IV}}$ versus a razão $\mathrm{Fe}^{2+} /\left(\mathrm{Fe}^{2+}+\mathrm{Mg}\right)$ mostrando a distribuição composicional da clorita pertencente às facies granitóide SGH do maciço granitóide Velho Guilherme.

Figura 4.22- Diagrama $\mathrm{Al}^{\mathrm{Vl}}$ versus a razão $\mathrm{Fe}^{2+} /\left(\mathrm{Fe}^{2+}+\mathrm{Mg}\right)$ mostrando a distribuição composicional da clorita pertencente às facies granitóide SGH do maciço granitóide Velho Guilherme

Figura 4.23.- Diagrama $\mathrm{Si}+\mathrm{Al}^{\mathrm{VI}}$ versus os cátions bivalentes $\left(\mathrm{Fe}^{2+}+\mathrm{Mg}^{2+}\right)$ mostrando a distribuição composicional da clorita pertencente à facies granitóide $\mathrm{SGH}$, do maciço granitóide Velho Guilherme

Figura 4.24 - Diagrama $\mathrm{Al}^{\mathrm{IV}}$ vs. $\mathrm{Fe}_{2+}$ mostrando a distribuição composicional da clorita da facies granitóide $S G H$, do maciço granitóide Velho Guilherme

Figura 4.25 - Diagrama $\mathrm{Fe}^{2+}$ vs. $\mathrm{Mg}^{2+}$ mostrando a distribuição composicional da clorita da facies granitóide $\mathrm{SGH}$, do maciço granitóide Velho Guilherme.

Figura 4.26.- Diagrama Si versus $\mathrm{Al}^{\mathrm{V}}$ mostrando a distribuição composicional da clorita pertencente à facies granitóide SGH, do maciço granitóide Velho Guilherme.

Figura 4.27.- Diagrama Si versus $\mathrm{Fe}($ total $) /\left(\mathrm{Fe}^{2+}+\mathrm{Mg}\right)$ mostrando a classificação da clorita estudada de acordo com Hey(1954). L=leuchtenbergita, variedade da clinocloro;

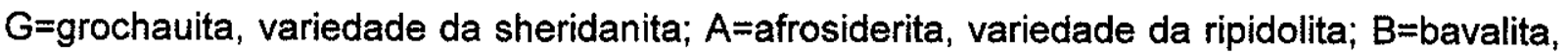
variedade da daphinita

Figura 4.28- Representação composicional catiônica da muscovita da amostra NN-VG-77N da facies SGH do maciço granitóide Velho Guilherme nos diagramas: a) Si-Al $;$; b) $M g-A l_{T}$; c) Ti-Al ; d) XFe-Al ; e) $\mathrm{K}-\mathrm{Na}$ )

Figura 4.29- Representação composicional da muscovita da amostra NN-VG-77N da facies SGH do maciço granitóide Velho Guilherme no diagrama $A I^{\mathrm{lv}}$ versus $\left[\left(\mathrm{Al}^{\mathrm{V}}-2\right)+2 \mathrm{Ti}\right]$ de Cathelineau(1982), modificado de Dias(1987). In: Simões(1992).

Figura 4.30- Representação composicional da muscovita da amostra NN-VG-77N da facies SGH do maciço granitóide Velho Guilherme no diagrama Mg-(Si-6+Ti), modificado de 
Figura 4.31- Representação gráfica das percentagens das moléculas paragoníticas e celadoníticas presentes na muscovita da amostra NN-VG-77N da facies SGH do maciço granitóide Velho Guilherme, de acordo com Simões(1992). \% mol. paragonita= $100 \times \mathrm{Na} /(\mathrm{Na}+\mathrm{K}) ; \%$ mol. celadonita $=100 \times(\mathrm{Si}-6) / 2$.

Figura 4.32. Diagrama $(\mathrm{Mg}-\mathrm{Li})$ vs. $\left(\mathrm{Fe}_{T}+\mathrm{Mn}+\mathrm{Ti}-\mathrm{Al} \mathrm{l}^{\mathrm{Vl}}\right)$ de Tischendorf et al.(1997) mostrando a distribuição composicional da muscovita da amostra NN-VG-77N, da facies SGH do maciço granitóide Velho Guilherme

Figura 4.33- Distribuição composicional da muscovita da amostra NN-VG-77N, da facies SGH do maciço granitóide Velho Guilherme no diagrama triangular Mg-Ti-Na de Miller et al.(1981). $P=c a m p o$ composicional da muscovita primária; $S=$ campo composicional da muscovita secundária.

Figura 4.34- (a) aspecto microtextural do óxido de $\mathrm{Nb}-\mathrm{Y}$-Ce-ETR[ceriopirocloro$(\mathrm{Ce}) /$ fergusonita-beta(Y)/Fergusonita( $\mathrm{Y}$; (b) aspecto microtextural da allanita. Amostra NNVG-77N, da facies SGH. Maciço granitóide Velho Guilherme.

Figura 4.35- Aspecto microtextal de um cristal irregularmente zonado mostrando porções correspondentes à fluorcerita, fluorcerita alterada, Fluorita com ETR e fluorita pura.

Figura 4.36. Aspecto microtextural de uma fase mineral óxido à base de $\mathrm{Y}$ e $\mathrm{Zr}$, presente na amostra NN-VG-35A, da facies SGH do maciço granitóide Velho Guilherme.

Figura 4.37. Diagrama binário A/CNK versus NKIA(Maniar\& Piccoli, 1989) mostrando a distribuição das facies granitóides do MGVG, com base nos índices de Shand(ISA)...

Figura 4.38. Diagramas discriminantes de paleoambiência tectônica de Pearce et al.(1984) mostrando a distribuição das amostras dos granitóides do MGVG (a) $\mathrm{Y}-\mathrm{Nb}$; (b) [Nb+Y]-Rb; (c) Yb-Ta.

Figura 4.39- Diagrama $\mathrm{Zr}+\mathrm{Nb}+\mathrm{Ce}+\mathrm{Y}$ vs. $\left(\mathrm{K}_{2} \mathrm{O}+\mathrm{Na}_{2} \mathrm{O}\right) / \mathrm{CaO}$ de Whalen et al.(1987) mostrando a distribuição composicional das amostras das principais facies granitóides do maciço granitóide Velho Guilherme.

Figura 4.40- Diagrama $\mathrm{Zr}+\mathrm{Nb}+\mathrm{Ce}+\mathrm{Y}$ vs. (FeOT/MgO) de Whalen et al.(1987) exibindo as análises das principais facies granitóides do maciço granitóide Velho Guilherme.

Figura 4.41- Diagrama $10000 \mathrm{Ga} / \mathrm{Al}$ v.s. $\left(\mathrm{K}_{2} \mathrm{O}+\mathrm{Na}_{2} \mathrm{O}\right) / \mathrm{Al}_{2} \mathrm{O}_{3}$ de Whalen et al.(1987) mostrando a tipologia e o grau de alcalinidade/índice agpaítico das principais facies granitóides do maciço Velho Guilherme.

Figura 4.42- Diagramas triangulares $\mathrm{Y}-\mathrm{Nb}-\mathrm{Ce}(\mathrm{a})$ e $\mathrm{Y}-\mathrm{Nb}-3 \mathrm{Ga}(\mathrm{b})$ de Eby(1992) mostrando a distribuição composicional das principais facies granitóides do maciço granitóide Velho Guilherme.

Figura 4.43. Diagramas retangulares $\mathrm{SiO}_{2}$ vs. $\mathrm{FeO}^{*} /\left(\mathrm{FeO}^{*}+\mathrm{MgO}\right)(\mathrm{a})$ e $\mathrm{CaO}$ vs. $\mathrm{Na}_{2} \mathrm{O}(\mathrm{b})$ 
mostrando a distribuição composicional das principais facies granitóides do maciço granitóide Velho Guilherme.

Figura 4.44-. Diagrama $\mathrm{Sr}-\mathrm{Na}_{2} \mathrm{O}$ mostrando a distribuição composicional das amostras das principais facies granitóides do maciço granitóide Velho Guilherme.

Figura 4.45- Distribuição composicional das principais facies granitóides do maciço Velho Guilherme nos diagramas (a) Rb-K; (b) Rb-Sr; (c) Rb-Ba-Sr(El Bouseily \& El Sokkary, 1975); (d) $\mathrm{Rb}-\mathrm{Zr}$; (e) Th-U. Os campos 1 a 5 do diagrama Rb-Ba-Sr correspondem a diorito, granodiorita, e quartzo diorito, granito anômalo, granito normal e granito extremamente diferenciado.

Figura 4.46-. Distribuição composicional das amostras das principais facies granitóides do maciço granitóide Velho Guilherme e do veio hidrotermal a ele associados nos diagramas

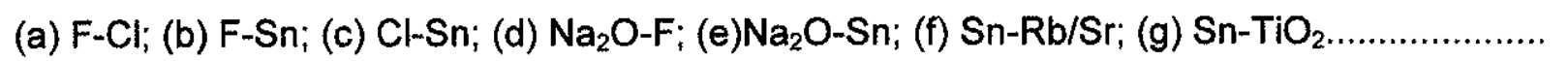

Figura 4.47. Padrão de distribuição dos ETR para os granitóides do maciço Velho Guilherme.

Figura 4.48a -Diagrama normativo Q-Ab-Or mostrando a distribuição composicional das principais facies granitóides do maciço granitóide Velho Guilherme. A curva envoltório de todos os pontos corresponde ao campo de freqüência das razões Q-Ab-Or de 1190 rochas graniticas de Winkler \& Von Plaren(1961). As projeções das linhas cotéticas isobáricas PE'5 de 2, 5 e $7 \mathrm{kbar}$ foram compiladas de Winkler(1977). M é o máximo de freqủência , A representa a posição e temperatura do ponto de minimo sem $F$ (Tuttle \& Bowen, 1958). $1 \% \mathrm{~F}, 2 \% \mathrm{~F}$ e $4 \% \mathrm{~F}$ representam as posições e temperaturas dos pontos de mínimo com $\mathrm{F}$ adicionado e excesse de água a $1 \mathrm{kbar}$ (Manning, 1981).

Figura 4.48b- Diagrama normativo Ab-An-Or mostrando a distibuição composicional das principais facies petrográficas do maciço granitóide Velho Guilherme.

Figura 5.1- Mapa geológico da área de ocorrência do maciço granitóide Mocambo.

Figura 5.2. Diagramas triangulares Q-A-P e Q-(A+P)M' de Streckeisen(1976) mostrando a distribuição composicional modal geral dos ganitóides e greisen do maciço granitóide Mocambo(a) e suas composições médias(b).

Figura 5.3- Fluxograma mostrando um esboço esquemático da seqüência de cristalização magmática e tardi a pós-magmática das fases minerais da facies SMGP do maciço granitóide Mocambo.

Figura 5.4.- Diagrama triangular $\mathrm{Mg}-\mathrm{R}^{2+}-\mathrm{R}^{3+}$ de Forster(1960b), mostrando a relação entre $\mathrm{Mg}, \mathrm{Fe}^{2+}\left(\mathrm{Mn}^{2+}\right)$ e $\left(\mathrm{Al}^{\mathrm{V}}, \mathrm{Fe}^{3+}, \mathrm{Ti}^{4+}\right)$ em micas trioctaédricas e a posição ocupada no diagrama pelas análises de biotita da amostra NN-GM-24, da facies SGMv do maciço granitóide Mocambo 
Figura 5.5.- Diagrama $\mathrm{Al}^{\mathrm{VI}}$ versus $\mathrm{Mg} /\left(\mathrm{Mg}+\mathrm{Fe}^{2+}\right)$ de Guidotti(1984) mostrando a distribuição composicional da biotita da amostra NN-GM-24, da facies SGMv do maciço granitóide Mocambo. $A=$ annita; $B=f l o g o p i t a ; A F=$ flogopita aluminosa; $A A=$ annita aluminosa; $\mathrm{S}=$ siderofilita; $\mathrm{E}=\mathrm{K}_{2}\left(\mathrm{Mg}_{4} \mathrm{Al}_{2}\right)\left(\mathrm{Al}_{4} \mathrm{Si}_{4} \mathrm{O}_{20}(\mathrm{OH})_{4}\right.$

Figura 5.6.- Diagrama triangular $\mathrm{Mg}-\left(\mathrm{Feo}+\mathrm{Fe}_{2} \mathrm{O}_{3}\right)-\mathrm{Al}_{2} \mathrm{O}_{3}$ baseado em Nockolds(1947) mostrando as composições de biotitas em diferentes associações minerais. Campos: $1=$ biotita associada à muscovita+topázio+fluorita+etc.; II = biotita não acompanhada por outras fases máficas; III = biotita associada à hornblenda, piroxênio e/ou olivina. As análises constantes no diagrama são da amostra NN-GM-24 da facies SGMv do maciço granitóide Mocambo

Figura 5.7.- Diagrama triangular $(\mathrm{FeO}+\mathrm{MnO})$ - $\left(10 \times \mathrm{TiO}_{2}\right)$ - $\mathrm{MgO}$ de Nachit(1994) mostrando a distribuição composicional da biotita da amostra NN-GM-24, da facies SGMv do maciço granitóide Mocambo. $\mathbf{A}=$ campo das micas magmáticas; $\mathbf{B}=$ campo das micas magmáticas reequilibradas.

Figura 5.8.- Diagrama triangular $\mathrm{FeO}_{\mathrm{T}}-\mathrm{MgO}-\mathrm{Al}_{2} \mathrm{O}_{3}$ mostrando a projeção composicional da biotita da amostra NN-GM-24, da facies SGMv do maciço granitóide Mocambo. As linhas cheias delimitam o campo composicional de biotitas de rochas igneas conforme(Nockolds, 1947) e a linha tracejada separa biotitas magmáticas de biotitas metamórfico-metassomáticas, conforme Gokhale(1968).

Figura 5.9- Diagrama Mg-Li vs. Fe $+\mathrm{Mn}+\mathrm{Ti}_{\mathrm{A}} \mathrm{Al} \mathrm{l}^{\mathrm{Vl}}$ de Tischendorf et al.(1997) mostrando a distribuição composicional da biotita da amostra NN-GM-24, da facies SGMv do maciço granitóide Mocambo.

Figura 5.10- Distribuição composicional do feldspato potássico da amostra NN-GM-56A do maciço granitóide Mocambo no diagrama triangular Ab-Or-An.

Figura 5.11- Distribuição composicional do plagioclásio da amostra NN-GM-56A do maciço granitóide Mocambo no diagrama triangular Ab-Or-Na.

Figura 5.12- Representação composicional catiônica das muscovitas das facies SGMv e SMGP e do SCMQGs do maciço granitóide Mocambo nos diagramas Si-AlT(a); Mg-Al $I_{\mathrm{T}}(\mathrm{b})$ $\mathrm{Ti}-\mathrm{Al} \mathrm{I}_{\mathrm{T}}(\mathrm{c}) ; \mathrm{XFe}-\mathrm{Al} \mathrm{I}_{\mathrm{T}}(\mathrm{d}) ; \mathrm{K}-\mathrm{Na}(\mathrm{e})$.

Figura 5.13- Representação composicional da muscovita das facies SMGP e SGMv e do SCMQGs do maciço granitóide Mocambo no diagrama $\mathrm{Al}^{\mathrm{IV}}$ versus $\left[\left(\mathrm{Al}^{\mathrm{VI}}-2\right)+2 \mathrm{Ti}\right]$ de Cathelineau(1982), modificado de Dias(1987). In: Simões(1992).

Figura 5.14- Representação composicional das muscovitas das facies SMGP e SGMv e do SCMQGs do maciço granitóide Mocambo no diagrama Mg-(Si-6+Ti), modificado de Dias(1987). In: Simões(1992).....

Figura 5.15- Representação gráfica das percentagens das moléculas paragoníticas e 
celadoníticas presentes nas muscovitas das facies SMGP e SGMV e do SCMQGs do maciço granitóide Mocambo, de acordo com Simões(1992). \% mol. paragonita= $100 \times \mathrm{Na} /(\mathrm{Na}+\mathrm{K}) ; \% \mathrm{~mol}$. celadonita $=100 \times(\mathrm{Si}-6) / 2$

Figura 5.16- Distribuição composicional das muscovitas das facies SMGP e SGMv e do SCMQGs do maciço granitóide Mocambo no diagrama [(FeT+Mn+Ti)-(Mg-Li)], de classificação composicional e nomenclatura de micas trioctaédricas e dioctaédricas de Tischendorf et al.(1997).

Figura 5.17- Distribuição composicional das muscovitas das facies SMGP e SGMv do maciço granitóide Mocambo no diagrama triangular Mg-Ti-Na de Miller et al.(1981). $\mathrm{P}=$ campo composicional das muscovitas primárias; $\mathrm{S}=$ campo composicional das muscovitas secundárias.

Figura 5.18- Diagrama catiônicos mostrando a distribuição composicional da clorita da facies SGMv e do SCMQGs do maciço granitóide Mocambo. (a) $\mathrm{Al}^{\mathrm{lv}}$ versus $\mathrm{Al}^{\mathrm{VI}}$; (b) $\left(\mathrm{Fe}^{2+}\right.$ $+\mathrm{Mg}^{2+}$ ) versus $\mathrm{Al}^{\mathrm{VI}}$; (c) $\mathrm{Fe}^{2+}$ versus $\mathrm{Al}^{\mathrm{VI}}$; (d) $\left(\mathrm{Fe}^{2+}+\mathrm{Mg}^{2+}\right.$ ) versus $\mathrm{Al}^{\mathrm{lV}} ;$ (e) $\mathrm{Fe}^{2+} /\left(\mathrm{Fe}^{2+}+\mathrm{Mg}^{2+}\right)$

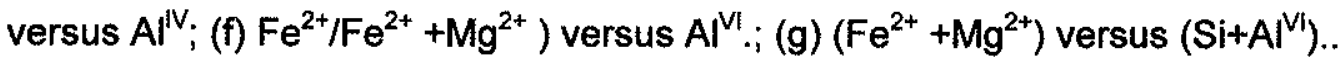

Figura 5.19- Diagrama Si $\times \mathrm{Fe}_{(\text {total) }} /\left(\mathrm{Fe}^{2+}+\mathrm{Mg}^{2+}\right)$ de Hey(1954) mostrando a distribuição composicional da clorita do SGMv e SCMQGs do maciço granitóide Mocambo.

Figura 5.20. (a) aspecto microtextural da tveitita-(Y)/yttrofluorita, fluocerita-(Ce) e monazita presente na amostra NN-GM-56A, da facies SMGP; (b) aspecto microtextural mostrando o relacionamente entre a pseudoixiolita/ferrocolumbita e a wolframixiolita da amostra NNGM-56A(facies SMGP); (c) aspecto microtextural evidenciando a relação entre fluorita, tveitita/yttrofluorita e ytrocerita presentes na amostra NN-GM-24, da facies SGMv.

Figura 5.21- Diagrama binário A/CNK versus NKJA(Maniar\& Piccoli, 1989) mostrando a distribuição das facies granitóides do MGM, com baseado nos indices de Shand(ISA).

Figura 5.22- Diagramas discriminantes de paleoambiência tectônica de Pearce et al.(1984) mostrando a distribuição das amostras dos granitóides do MGM (a) Y-Nb; (b) [Nb+Y]-Rb; (c) $\mathrm{Yb}-\mathrm{Ta}$

Figura 5.23- Diagrama $\mathrm{Zr}+\mathrm{Nb}+\mathrm{Ce}+\mathrm{Y}$ vs. $\left(\mathrm{K}_{2} \mathrm{O}+\mathrm{Na}_{2} \mathrm{O}\right) / \mathrm{CaO}$ de Whalen et al.(1987) mostrando a distribuição composicional das amostras das principais facies granitóides do maciço granitóide Mocambo.

Figura 5.24- Diagrama $\mathrm{Zr}+\mathrm{Nb}+\mathrm{Ce}+\mathrm{Y}$ contra ( $\mathrm{Fe}$ (total)/MgO) de Whalen et al.(1987) mostrando a distribuição composicional das amostras das principais facies granitóides do maciço Mocambo.

Figura 5.25- Diagrama $10.000 \mathrm{Ga}$ vs. $\left(\mathrm{K} 2 \mathrm{O}+\mathrm{Na}_{2} \mathrm{O}\right) / \mathrm{Al}_{2} \mathrm{O}_{3}$ de Whalen et al.(1987), modificado por Rämö \& Haapala(1995) mostrando a tipologia e o grau da alcalinidade/índice agpaitico das principais facies granitóides do maciço granitóide 
Mocambo

Figura 5.26 Diagramas triangulares $\mathrm{Y}-\mathrm{Nb}-\mathrm{Ce}(\mathrm{a})$ e $\mathrm{Y}-\mathrm{Nb}-3 \mathrm{Ga}(\mathrm{b})$ de Eby(1992) mostrando a distribuição composicional das principais facies granitóides do maciço granitóide Mocambo.

Figura 5.27. Diagramas retangulares mostrando a distribuição composicional das principais facies granitóides do maciço Mocambo: (a) $\mathrm{SiO}_{2}$ vs. $\mathrm{FeO}^{*} /\left(\mathrm{FeO}^{*}+\mathrm{MgO}\right.$ ); (b) $\mathrm{CaO}$ vs. $\mathrm{Na}_{2} \mathrm{O}$...

Figura 5.28- Diagrama $\mathrm{Sr}-\mathrm{Na}_{2} \mathrm{O}$ mostrando a distribuição composicional das amostras das principais facies granitóides do maciço granitóide Mocambo

Figura 5.29- Distribuição composicional das amostras das principais facies granitóides do maciço granitóide Mocambo nos diagramas (a) Rb-K; (b) Rb-Sr; (c) Rb-Ba-Sr(El-Bouseily \& Sokkary, 1975); (d) $\mathrm{Rb}-\mathrm{Zr}$; (e) Zr-Hf; (f) Th-U. Os campos 1 a 5 do diagrama Rb-Ba-Sr correspondem a dioritos, granodioritos e quartzo dioritos, granitos anômalos, granitos normais e granitos extremamente diferenciados.

Figura 5.30- Distribuição composicional das amostras das principais facies granitóides do maciço granitóide Mocambo e de um corpo de SCMQGs a ele associado nos diagramas (a) $\mathrm{F}-\mathrm{Sn}$; (b) $\mathrm{Na}_{2} \mathrm{O}-\mathrm{F}$

Figura 5.31- Diagramas $\mathrm{Sn}_{-} \mathrm{TiO}_{2}(\mathrm{a})$ e $\mathrm{Sn}-(\mathrm{Rb} / \mathrm{Sr})$, compilados a partir de Lehmann \& Mahawat(1989), mostrando a distribuição dos granitóides do maciço Mocambo e do SCMQGs a ele associado

Figura 5.32- Padrão de distribuição dos elementos terras raras normalizados para condritos(Sun, 1982) do maciço granitóide Mocambo.

Figura 5.33a- Diagrama normativo Q-Ab-Or mostrando a distribuição composicional das principais facies granitóides do maciço granitóide Mocambo. A curva envoltório dos pontos corresponde à distribuição de freqüência das razões $Q-A b-O r$ de 1190 rochas graníticas de Winkler \& Von Plaren(1961). As projeções das linhas cotéticas isobáricas P-E'5 de 2, 5 e $7 \mathrm{kbar}$ foram compiladas de Winkler(1977). M é o máximo de freqüência , A representa a posição e temperatura do ponto de mínimo sem $\mathrm{F}$ (Tuttle \& Bowen, 1958). 1\%F, 2\%F e $4 \% \mathrm{~F}$ representam as posiçōes e temperaturas dos pontos de mínimo com $\mathrm{F}$ adicionado $\mathrm{e}$ excesse de água a $1 \mathrm{kbar}($ Manning, 1981)

Figura 5.33b- Diagrama normativo Ab-An-Or mostrando a distibuição composicional das principais facies petrográficas do maciço granitóide Mocambo.

Figura 6.1- Mapa geológico da área de ocorrência do maciço granitóide Benedita.

Figura 6.2- Diagramas triangularers $Q-A-P$ e $Q-(A+P)-M^{\prime}$ de Streckeisen(1976) mosttrando a distribuição composicional modal geral dos ganitóides do maciço granitóide Benedita(a) e suas composições modais médias(b).

Figura 6.3- Fluxograma mostrando um esboço esquemático da seqüência de cristalização magmática e tardi a pós-magmática das fases minerais das facies BAFG e AFG do maciço 
granitóide Benedita. esf= esfalerita; allan= allanita.

Figura 6.4- Distribuição composicional do feldspato potássico da amostra NE-B-09 do maciço granitóide Benedita no diagrama triangular Ab-Or-An.

Figura 6.5- Diagramas catiônicos mostrando a distribuição composicional da clorita da facies BAFG do maciço granitóide Benedita. (a) $\mathrm{Al}^{\mathrm{Vl}}$ versus $\mathrm{Al}^{\mathrm{IV}}$; (b) $\left(\mathrm{Fe}^{2+}+\mathrm{Mg}^{2+}\right)-\mathrm{Al}^{\mathrm{Vl}}$; (c) $\mathrm{Al}^{\mathrm{VI}}-\mathrm{Fe} 2+$; (d) $\mathrm{Al}^{\mathrm{IV}}-\left(\mathrm{Fe}^{2+}+\mathrm{Mg}^{2+}\right)$; (e) $\mathrm{Al}^{\mathrm{lV}}-\mathrm{Fe} /(\mathrm{Fe}+\mathrm{Mg}) ;(\mathrm{f}) \mathrm{AlVl}-\mathrm{Fe} /(\mathrm{Fe}+\mathrm{Mg}) ;(\mathrm{g}) \mathrm{Si}+\mathrm{Al}^{\mathrm{VI}}$ $\left(\mathrm{Fe}^{2+}+\mathrm{Mg}^{2+}\right) ;(\mathrm{h}) \mathrm{Si}-\mathrm{Al}^{\mathrm{V}}$

Figura 6.6- Diagrama Si versus $\mathrm{Fe}($ total $) /\left(\mathrm{Fe}^{2+}+\mathrm{Mg}^{2+}\right)$ mostrando a representação gráfica e a classificação da clorita estudada(círculos vermelhos) de acordo com Hey(1954).

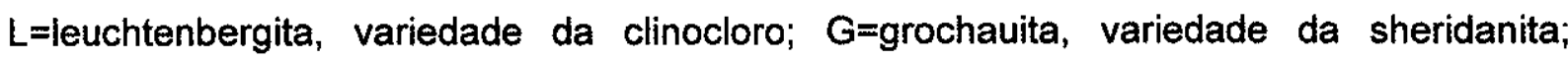
$A=$ afrosiderita, variedade da ripidolita; $B=$ bavalita, variedade da dafnita.

Figura 6.7- Representação composicional catiônica da muscovita da facies BAFG do maciço granitóide Benedita. a) (Si-Al ; b) Mg-Alt; c) Ti-AlT; d) XFe-AlT; e) $\mathrm{K}-\mathrm{Na}$ ).

Figura 6.8- Representação composicional da muscovita da facies BAFG do maciço granitóide Benedita no diagrama $A l^{\mathrm{lv}}$ versus [(Al $\left.\left.\mathrm{V}^{\mathrm{V}}-2\right)+2 \mathrm{Ti}\right]$ de Cathelineau(1982), modificado de Dias(1987). In: Simões(1992).

Figura 6.9- Representação composicional da muscovita da facies BAFG do maciço granitóide Benedita no diagrama Mg-(Si-6+Ti), modificado de Dias(1987). In: Simões(1992)

Figura 6.10a- Representação gráfica das percentagens das moléculas paragoníticas e celadoníticas presentes na muscovita da facies BAFG do maciço granitóide Benedita, de acordo com Simões(1992). \% mol. paragonita $=100 \times \mathrm{Na} /(\mathrm{Na}+\mathrm{K}) ; \%$ mol. celadonita $=100 \times(\mathrm{Si}-$ 6) $/ 2$

Figura 6.10b- Distribuição composicional da muscovita da facies BAFG do maciço granitóide Benedita no diagrama $\left[\left(\mathrm{Fe}_{\mathrm{T}}+\mathrm{Mn}+\mathrm{Ti}+\mathrm{Al} \mathrm{V}^{\mathrm{V}}\right)-(\mathrm{Mg}-\mathrm{Li})\right]$, de classificação composicional e nomenclatura de micas trioctaédrica e dioctaédrica apresentado por Tischendorf et al.(1997).

Figura 6.11- Distribuição composicional da muscovita da facies BAFG do maciço granitóide Benedita no diagrama triangular Mg-Ti-Na de Miller et al.(1981). $\mathrm{P}=$ campo composicional da muscovita primária; $S=$ campo composicional da muscovita secundária

Figura 6.12- Detalhe de um cristal de pirita sendo parcialmente substituido por óxido de $\mathrm{Fe}$ e $W$, presente na amostra NE-B-09, da facies BAFG do maciço granitóide Benedita.

Figura 6.13- Diagrama binário AVCNK versus NKIA(Maniar\& Piccoli, 1989) mostrando a distribuição das facies granitóides do MGB, com base nos índices de Shand(ISA).

Figura 6.14- Diagramas discriminantes de paleoambiência tectônica conforme Pearce et al.(1984) mostrando a distribuição das amostras dos granitóides do MGB: (a) Y-Nb; (b) $[\mathrm{Nb}+\mathrm{Y}]-\mathrm{Rb} ;(\mathrm{c}) \mathrm{Yb}-\mathrm{Ta}$. 
Figura 6.15- Diagrama $\mathrm{Zr}+\mathrm{Nb}+\mathrm{Ce}+\mathrm{Y}$ vs. $\left(\mathrm{K}_{2} \mathrm{O}+\mathrm{Na}_{2} \mathrm{O}\right) / \mathrm{CaO}$ de Whalen et al.(1987a) mostrando a distribuição composicional das amostras das principais facies granitóides do maciço granitóide Benedita.

Figura 6.16- Diagrama $\mathrm{Zr}+\mathrm{Nb}+\mathrm{Ce}+\mathrm{Y}$ vs. $(\mathrm{FeO} / \mathrm{MgO})$ de Whalen et al.(1987a) exibindo as análises das principais facies granitóides do maciço granitóide Benedita.

Figura 6.17- Diagrama $10.000 \mathrm{Ga}$ vs. $\left(\mathrm{K}_{2} \mathrm{O}+\mathrm{Na}_{2} \mathrm{O}\right) / \mathrm{Al}_{2} \mathrm{O}_{3}$ de Whalen et al.(1987a), modificado por Rämö \& Haapala(1995) mostrando a tipologia e o grau da alcalinidade(índice agpaítico) das principais facies granitóides do maciço granitóide Benedita.

Figura 6.18- Diagramas triangulares $\mathrm{Y}-\mathrm{Nb}-\mathrm{Ce}(\mathrm{a})$ e $\mathrm{Y}-\mathrm{Nb}-3 \mathrm{Ga}(\mathrm{b})$ de $\mathrm{Eby}(1992)$ mostrando a distribuição composicional das principais facies granitóides do maciço granitóide Benedita.

Figura 6.19- Diagramas retangulares $\mathrm{SiO}_{2}$ vs. $\mathrm{FeO}^{*} /\left(\mathrm{FeO}^{*}+\mathrm{MgO}\right)(\mathrm{a})$ e $\mathrm{CaO}$ vs. $\mathrm{Na}_{2} \mathrm{O}(\mathrm{b})$ mostrando a distribuição composicional das principais facies granitóides do maciço granitóide Benedita.

Figura 6.20- Diagrama $\mathrm{Sr}-\mathrm{Na}_{2} \mathrm{O}$ mostrando a distribuição composicional das amostras das principais facies granitóides do maciço granitóide Benedita.

Figura 6.21- Distribuição composicional das amostras das principais facies granitóides do maciço granitóide Benedita nos diagramas (a) Rb-K; (b) Rb-Sr; c) Rb-Ba; (d) Rb-Ba-Sr(ElBouseily \& Sokkary, 1975); (e) $\mathrm{Rb}-\mathrm{Zr}$; (f) Th-U. Os campos 1 a 5 do diagrama Rb-Ba-Sr correspondem, respectivamente, a dioritos, granodioritos e quartzo dioritos, granitos anômalos, granitos normais e granitos extremamente diferenciados.

Figura 6.22- Distribuição composicional das amostras das principais facies granitóides do maciço granitóide Benedita nos diagramas (a) F-Cl; (b) $\mathrm{F}-\mathrm{Sn}$; (c) $\mathrm{Sn}-\mathrm{Na}_{2} \mathrm{O}$; (d) $\mathrm{Na}_{2} \mathrm{O}-\mathrm{F}$; (e) $\mathrm{Sn}-\mathrm{Rb} / \mathrm{Sr} ; \mathrm{Sn}-\mathrm{TiO}_{2}$.

Figura 6.23- Padrão de distribuição dos ETR dos granitóides do maciço Benedita.

Figura 6.24a- Diagrama normativo Q-Ab-Or mostrando a distribuição composicional das principais facies granitóides do maciço granitóide Benedita. A curva envoltório dos pontos corresponde ao campo de freqüência das razões $Q-A b-O r$ de 1190 rochas graníticas de Winkler \& Von Plaren(1961). As projeções das linhas cotéticas isobáricas P-E'5 de 2, 5 e $7 \mathrm{kbar}$ foram compiladas de Winkler(1977). $M=$ máximo de freqüência , $A=a$ posição e temperatura do ponto de mínimo sem $F($ Tuttle \& Bowen, 1958). 1\%F, 2\%F e $4 \% F$ representam as posições e temperaturas dos pontos de mínimo com $F$ adicionado e excesso de água a $1 \mathrm{kbar}($ Manning, 1981)

Figura 6.24b- Diagrama normativo Ab-An-Or mostrando a distibuição composicional das principais facies petrográficas do maciço granitóide Benedita. 
Figura 7.1- Diagramas triangulares $Q-A-P$ e $Q-(A+P)-M^{\prime}(S t r e k e i s e n, 1976)$ mostrando a distribuição composicional modal geral(a) e valores médios $(b)$ das facies granitóides do maciço granitóide Ubim/Sul.

Figura 7.2- Fluxograma mostrando um esboço esquemático da seqüência de cristalização magmática e tardi a pós-magmática das fases minerais da facies $\mathrm{BSGCl}$ do maciço granitóideUbim/Sul. Esf= esfalerita; allan= allanita......

Figura 7.3- Diagramas catiônicos mostrando a distribuição composicional da clorita da facies $B M G$ do maciço granitóide Ubim/Sul. a) $\mathrm{Al}^{\mathrm{IV}}$ vs. $\mathrm{Al}^{\mathrm{VI}}$; b) $\mathrm{Al}^{\mathrm{Vl}}$ vs. $\left(\mathrm{Fe}^{2+}+\mathrm{Mg}^{2+}\right)$; c) $\mathrm{Al}^{\mathrm{VI}}$ vs. $\mathrm{Fe}^{2+}$; d) $\mathrm{Al}^{\mathrm{l} V}$ vs. $\left.\left(\mathrm{Fe}^{2+}+\mathrm{Mg}^{2+}\right) ; \mathrm{e}\right) \mathrm{Al}^{\mathrm{lV}}$ vs. $\mathrm{Fe} /(\mathrm{Fe}+\mathrm{Mg}) ;$ f) $\mathrm{Al}^{\mathrm{Vl}}$ vs. $\left.\mathrm{Fe} /(\mathrm{Fe}+\mathrm{Mg}) ; \mathrm{g}\right) \mathrm{Si}+\mathrm{Al}^{\mathrm{V}}$ vs $\left.\left(\mathrm{Fe}^{2+}+\mathrm{Mg}^{2+}\right) ; \mathrm{h}\right)$ Si vs. $\mathrm{Al}^{\mathrm{V}}$.

Figura 7.4.- Diagrama Si versus $\mathrm{Fe}($ total $) /\left(\mathrm{Fe}^{2+}+\mathrm{Mg}\right)$ mostrando a classificação da clorita estudada de acordo a proposição de Hey(1954). L=leuchtenbergita, variedade da clinocloro; $G=$ grochauita, variedade da sheridanita; $A=$ afrosiderita, variedade da ripidolita; $B=$ bavalita, variedade da dafnita. Simbologia de acordo com a Figura 7.3.

Figura 7.5- Representação composicional catiônica da muscovita da facies BMG do maciço granitóide Ubim/Sul. a) Si-AIT; b) Mg-AlT; c) Ti-AlT; d) Xfe-AlT; e) K-Na

Figura 7.6- Representação composicional da muscovita da facies BMG do maciço granitóide Ubim/Sul no diagrama $\mathrm{Al}^{\mathrm{lV}}$ versus $\left[\left(\mathrm{Al}^{\mathrm{VI}}-2\right)+2 \mathrm{Ti}\right]$ de Cathelineau(1982), modificado de Dias(1987). In: Simões(1992).

Figura 7.7- Representação composicional da muscovita da facies BMG do maciço granitóide Ubim/Sul no diagrama Mg-(Si-6+Ti), modificado de Dias(1987). In: Simões(1992).

Figura 7.8- Representação gráfica das percentagens das moléculas paragoníticas e celadoníticas presentes na muscovita da facies BMG do maciço granitóide Ubim/Sul, de acordo com Simões(1992). \% mol. paragonita $=100 \times \mathrm{Na} /(\mathrm{Na}+\mathrm{K}) ; \%$ mol. celadonita= $100 \times($ Si-6) $/ 2$.

Figura 7.9- Distribuição composicional da muscovita da facies BMG do maciço granitóide Ubim/Sul no diagrama $[(F e T+M n+T i)-(M g-L i)]$, de classificação composicional e nomenclatura de micas trioctaédricas e dioctaédricas apresentado por Tischendorf et al.(1997)

Figura 7.10- Distribuição composicional da muscovita da facies BMG do maciço granitóide Ubim/Sul no diagrama triangular Mg-Ti-Na de Miller et al.(1981). $\mathrm{P}=$ campo composicional da muscovita primária; $S=$ campo composiocional da muscovita secundária.

Figura 7.11- Distribuição composicional do feldspato potássico da amostra NE-B-32 do maciço granitóide Ubim/Sul no diagrama triangular A-Or-An.

Figura 7.12- Distribuição composicional do plagiociásio da amostra NE-B-32 do maciço 
granitóide Ubim/Sul no diagrama triangular A-Or-An.....

Figura 7.13- Diagrama binário A/CNK versus NK/A(Maniar\& Piccoli, 1989) mostrando a distribuição das facies granitóides do MGUS, com base nos índices de Shand(ISA)

Figura 7.14- Diagramas discriminantes de paleoambiência tectônica de Pearce et al.(1984) mostrando a distribuição das amostras dos granitóides do MGUS. (a) $\mathrm{Y}-\mathrm{Nb}$; (b) [Nb+Y]-Rb; (c) $\mathrm{Yb}-\mathrm{Ta}$.

Figura 7.15- Diagramas disciminantes mostrando a tipologia e o grau da alcalinidade(ndice agpaítico) das principais facies granitóides do maciço granitóide Ubim/Sul. a) $\mathrm{Zr}+\mathrm{Nb}+\mathrm{Ce}+\mathrm{Y}$ vs. $\left(\mathrm{K}_{2} \mathrm{O}+\mathrm{Na}_{2} \mathrm{O}\right) / \mathrm{CaO}($ Whalen et al., 1987); b) $\mathrm{Zr}+\mathrm{Nb}+\mathrm{Ce}+\mathrm{Y}$ vs. (FeOT/MgO) de Whalen et al.(1987) ; c) $10.000 \mathrm{Ga}$ vs. $\left(\mathrm{K}_{2} \mathrm{O}+\mathrm{Na}_{2} \mathrm{O}\right) / \mathrm{Al}_{2} \mathrm{O}_{3}$ (Whalen et al., 1987; modificado por Rämö \& Haapala, 1995).

Figura 7.16 Diagramas triangulares $\mathrm{Y}-\mathrm{Nb}-\mathrm{Ce}(\mathrm{a})$ e $\mathrm{Y}-\mathrm{Nb}-3 \mathrm{Ga}(\mathrm{b})$ de Eby(1992) mostrando a distribuição composicional das principais facies granitóides do maciço granitóide Ubim/Sul..

Figura 7.17- Distribuição composicional das amostras das principais facies granitóides do maciço granitóide Ubim/Sul nos diagramas (a) Rb-K; (b) Rb-Sr; (c) Rb-Ba-Sr(El-Bouseily \& Sokkary, 1975); (d) $\mathrm{Rb}-\mathrm{Zr}$; (e) Th-U. Os campos 1 a 5 do diagrama $\mathrm{Rb}-\mathrm{Ba}-\mathrm{Sr}$ correspondem, respectivamente, a dioritos, granodioritos e quartzo dioritos, granitos anômalos, granitos normais e granitos extremamente diferenciados.

Figura 7.18. Padrão de distribuição dos ETR para os granitóides do maciço Ubim/Sul.

Figura 7.19a- Diagrama normativo Q-Ab-Or mostrando a distribuição composicional das principais facies granitóides do maciço granitóide Ubim/Sul. A curva envoltório dos postos composicionais corresponde ao campo de freqüência das razões Q-Ab-Or de 1190 rochas graniticas de Winkler \& Von Plaren(1961). As projeções das linhas cotéticas isobáricas P. E'5 de 2, 5 e 7kbar foram compiladas de Winkler(1977). $M=$ é o máximo de freqüência das rochas graniticas, $A=$ a posição e temperatura do ponto de mínimo sem $F(T u t t l e ~ \&$ Bowen, 1958). $1 \% \mathrm{~F}, 2 \% \mathrm{~F}$ e $4 \% \mathrm{~F}$ representam as posições e temperaturas dos pontos de mínimo com $\mathrm{F}$ adicionado e excesse de água a $1 \mathrm{kbar}($ Manning, 1981)

Figura 7.19b- Diagrama normativo Ab-An-Or mostrando a distibuição composicional das principais facies petrográficas do maciço granitóide Ubim/Sul.

Figura 8.1- Diagramas ternários Q-A-P e Q-(A+P)-M'(Streckeisen, 1976) mostrando a distribuição composicional modal do granitóide do maciço Rio Xingu

Figura 8.2. Fluxograma mostrando um esboço esquemático da seqüência de cristalização magmática e tardi a pós-magmática das fases minerais associadas à facies SAFGP do maciço granitóide Rio Xingu. esf= esfalerita

Figura 8.3- Distribuição composicional do feldspato potássico da amostra NN-AV-40 do maciço granitóide Rio Xingu no diagrama triangular A-Or-An 
Figura 8.4- Diagrama Na-K mostrando a distribuição composicional do feldspato potássico da facies SAFGP do maciço granitóide Rio Xingu.

Figura 8.5- Distribuição composicional do plagioclásio da amostra NN-AV-40 do maciço granitóide Rio Xingu no diagrama triangular A-Or-An.

Figura 8.6- Diagrama Na-K mostrado a distrubuição composicional do plagioclásio da facies SAFGP do maciço granitóide Rio Xingu.

Figura 8.7- Diagrama binário A/CNK versus NKJA(Maniar\& Piccoli, 1989) mostrando a distribuição das facies granitóides do MGRX, com baseado nos índices de Shand(ISA).......

Figura 8.8- Diagramas discriminantes de paleoambiência tectônica de Pearce et al.(1984) mostrando a distribuição das amostras dos granitóides do MGRX (a) $\mathrm{Y}-\mathrm{Nb}$; (b) $[\mathrm{Nb}+\mathrm{Y}]-\mathrm{Rb}$; (c) $\mathrm{Yb}-\mathrm{Ta}$

Figura 8.9- Diagrama $\mathrm{Zr}+\mathrm{Nb}+\mathrm{Ce}+\mathrm{Y}$ vs. $\left(\mathrm{K}_{2} \mathrm{O}+\mathrm{Na}_{2} \mathrm{O}\right) / \mathrm{CaO}$ de Whalen et al.(1987) mostrando a distribuição composicional das amostras das principais facies granitóides do MGRX

Figura 8.10- Diagrama $\mathrm{Zr}+\mathrm{Nb}+\mathrm{Ce}+\mathrm{Y}$ vs. $\mathrm{FeO} / \mathrm{MgO}$ de Whalen et al.(1987) mostrando a distribuição composicional das amostras das principais facies granitóides do MGRX.

Figura 8.11- Diagrama $10.000 \mathrm{Ga} / \mathrm{Al}$ vs. $\left(\mathrm{K}_{2} \mathrm{O}+\mathrm{Na}_{2} \mathrm{O}\right) / \mathrm{Al}_{2} \mathrm{O}_{3}$ de Whaten et al.(1987) mostrando a distribuiçăo composicional das amostras das principais facies granitóides do MGRX.

Figura 8.12- Diagramas triangulares $\mathrm{Y}-\mathrm{Nb}-\mathrm{Ce}(\mathrm{a})$ e $\mathrm{Y}-\mathrm{Nb}-3 \mathrm{Ga}(\mathrm{b})$ de Eby(1992) mostrando a distribuição composicional da facies granitóides SAFGP do maciço granitóide Rio Xingu...... 408 Figura 8.13- Distribuição composicional das amostras da facies SAFGP do maciço granitóide Rio Xingu. (a) Rb-K; (b) Rb-Sr; (c)Rb-Ba; (d) Rb-Zr; (e) Th-U; f) Rb-Ba-Sr(ElBouseily \& Sokkary, 1975). Os campos 1 a 5 do diagrama $\mathrm{Rb}-\mathrm{Ba}-\mathrm{Sr}$ correspondem a dioritos, granodioritos e quartzo dioritos, granitos anômalos, granitos normais e granitos extremamente diferenciados.

Figura 8.14. Padrão de distribuição dos ETR para os granitóides do maciço Rio Xingu

Figura 8.15- a) Diagrama normativo Q-Ab-Or mostrando a distribuição composicional das principais facies granitóides do maciço granitóide Rio Xingu. A curva envoltório dos pontos composicionais corresponde ao campo de distribuição de freqüência das razões $Q-A b-O r$ de 1190 rochas graníticas de Winkler \& Von Plaren(1961). As projeções das linhas cotéticas isobáricas P-E'5 de 2, 5 e 7kbar foram compiladas de Winkler(1977). $M=0$ máximo de frequêencia,$A=$ a posição e temperatura do ponto de mínimo sem $F$ (Tuttle \& Bowen, 1958). 1\%F, 2\%F e 4\%F representam as posições e temperaturas dos pontos de mínimo com $F$ adicionado e excesse de água a $1 \mathrm{kbar}($ Manning, 1981); b) Diagrama normativo Ab-An-Or mostrando a distibuição composicional das principais facies 
petrográficas do maciço granitóide Rio Xingu.

Figura 9.1- Esquema comparativo mostrando as características isotópicas em termos de $\delta^{18} \mathrm{O}$ obtidos em grãos de quartzo de granitóides e de greisen dos maciço Antônio Vicente, Velho Guilherme e Mocambo.

Figura 9.2- Diagrama retangular $\delta^{18} \mathrm{O}$ v.s $\varepsilon N d$ mostrando as assinaturas isotópicas dos granitóides dos maciços Antônio Vicente e Mocambo.

Fotomicrografia 10.1- Aspecto das IFs bifásicas observadas em grãos de quartzo 1 da amostra SL-7C-DT(BSG). LN(1000X).

Fotomicrografia 10.2- Aspecto das IFs trifásicas(em baixo à esquerda) presentes na amostra SL-7C-DT(BSG), LN(1000X).....

Fotomicrografia 10.3(a, b)- Aspecto geral das dimensões das IFs estudadas. Amostra SL2A-DT(BSGIA). LN(1000X).

Figura 10.1- Histogramas de freqüência mostrando os intervalos de variação das TE(a), $\mathrm{Tfg}(\mathrm{b})$ e Th(total)(c) das Ifs do Grupo 1 presentes em grão de quartzo 1 das amostras IE02(BASMG), SL-7C-DT(BSG) e NN-AV-IN-5(CSMQGs) do maciço granitóide Antônio Vicente.

Figura 10.2- Histogramas de freqüência mostrando os intervalos de variação das TE(a), $\mathrm{Tfg}(\mathrm{b})$ e Th(total)(c) das IFs do Grupo 2 presentes em grãos de quartzo1 das amostras IE02(BASMG) e SL-7C-DT(BSG) do maciço granitóide Antônio Vicente.

Figura 10.3- Histogramas de freqüência mostrando os intervalos de variação das TE(a), $\operatorname{Tfg}(\mathrm{b})$ e Th(total)(c) das Ifs do Grupo 3 presentes em grão de quartzo 1 das amostras IE02(BASMG) e SL-7C-DT(BSG) do maciço granitóide Antônio Vicente.

Figura 10.4- Histogramas de freqüência mostrando os intervalos de variação das TE(a), Tfg(b) e Th(total)(c) das lfs do Grupo 4 presentes em grão de quartzo 1 das amostras IE02(BASMG), SL-7C-DT(BSG) e SL-2A-DT(BSGIA) do maciço granitóide Antônio Vicente....

Figura 10.5- Histogramas de freqüência mostrando os intervalos de variação das TE(a), $\operatorname{Tfg}(\mathrm{b})$ e Th(total)(c) das Ifs do Grupo 5 presentes em grão de quartzo 1 da amostra SL-2ADT(BSGIA) do maciço granitóide Antônio Vicente.

Figura 10.6- Histogramas de freqüência mostrando os intervalos de variação das TE(a), $\operatorname{Tfg}(\mathrm{b})$ e Th(total)(c) das Ifs do Grupo 6 presentes em grão de quartzo 1 da amostra SL-2ADT(BSGIA) do maciço granitóide Antônio Vicente.

Figura 10.7- Histogramas de freqüência mostrando os intervalos de variação das TE(a), $\operatorname{Tfg}(b)$ e Th(total)(c) das lfs do Grupo 7 presentes em grão de quartzo 1 da amostra SL-2ADT(BSGIA) do maciço granitóide Antônio Vicente.

Figura 10.8- Histogramas de freqüência mostrando os intervalos de variação das TE(a), $\operatorname{Tfg}(b)$ e Th(total)(c) das Ifs do Grupo 8 presentes em grão de quartzo 1 da amostra NN- 
AV-IN-5(CSMQGs) do maciço granitóide Antônio Vicente.

Figura 10.9- Diagramas Th contra Tfg mostrando a distribuição de todos os grupos de IFs caracterizados . (a) Grupo 1;(b) Grupo 2; c) Grupo 3; d) Grupo 4; e) Grupo 5; f) Grupo 6; g) Grupo 7; h) Grupo 8c).

Fotomicrografia 10.4- Aspecto das inclusões estudadas mostrando a relação de volume entre a fase de vapor(gás) e a líquida. Amostra IE-02(BASMG). LN.

Figura 11.1- Diagrama isocrônico ${ }^{206} \mathrm{~Pb} /{ }^{204} \mathrm{~Pb}$ vs. ${ }^{207} \mathrm{~Pb} /{ }^{204} \mathrm{~Pb}$ mostrando a distribuição dos pontos experimentais e a idade de cristalização dos granitóide do maciço Antônio Vicente... 457 Figura 11.2- Diagrama isocrônico ${ }^{206} \mathrm{~Pb} /{ }^{204} \mathrm{~Pb}$ vs. ${ }^{207} \mathrm{~Pb} /{ }^{204} \mathrm{~Pb}$ mostrando a distribuição dos pontos experimentais e a idade de cristalização dos granitóides do maciço Rio Xingu.......... 458 Figura 11.3- Diagrama isocrônico ${ }^{206} \mathrm{~Pb} /{ }^{204} \mathrm{~Pb}$ vs. ${ }^{207} \mathrm{~Pb} /{ }^{204} \mathrm{~Pb}$ mostrando a distribuição dos pontos experimentais e a idade de cristalização das rochas vulcânicas do Grupo Uatumã.... 458 Figura 11.4- Diagrama de variação do $\varepsilon N d$ em função do tempo geológico, mostrando os intervalos de tempo de diferenciação manto-crosta dos protólitos crustais dos granitóides dos maciços Antônio Vicente e Rio Xingu e da vulcânica andesiticas do Grupo Uatumã(a). (b) dos granitóides do maciço Mocambo, das vulcânicas rioliticas do Grupo Uatumã, do granodiorito Rio Maria e da metavulcânica máfica do grupo Tucumã.

Figura 13.1- Diagramas $\mathrm{Sn}-\mathrm{TiO}_{2}(\mathrm{a})$ e $\mathrm{Sn}-\mathrm{Rb} / \mathrm{Sr}(\mathrm{b})$ compilado a partir de Lehmann \& Mahawat(1989) mostrando a distribuição composicional dos granitóides dos maciços da Suite Intrusiva Velho Guilherme, Província Estanifera do Sul do Pará.

Figura 13.2- Diagrama Th-Ta baseada em Hoffman(1988) mostrando a distribuição composicional dos granitóides dos maciços da Suite Intrusiva Velho Guilherme, Província Estanifera do Sul do Pará.

Figura 13.3- Diagrama $\mathrm{Sr}-\mathrm{Rb} / \mathrm{Sr}$ compilado a partir de Lehmann \& Mahawat(1989) mostrando a distribuição composicional dos granitóides dos maciços da Suite Intrusiva Velho Guilherme, Província Estanífera do Sul do Pará. 


\section{LISTA DE TABELAS}

Tabela 3.1-Composições modais da facies granitóide biotita-anfibólio sieno a monzogranito(BASMG) do maciço granitóide Antônio Vicente.

Tabela 3.2- Composições modais do anfibólio-biotita sienogranito(ABSG) e do biotitaanfibólio sieno a álcali-feldspato granito(BASAFG) do maciço granitóide Antônio Vicente.

Tabela 3.3- Composições modais do biotita sienogranito com clorita(BSGCl) do maciço granitóide Antônio Vicente.

Tabela 3.4- Composições modais do álcali-feldspato granito(AFG) do maciço granitóide Antônio Vicente.

Tabela 3.5- Composições modais do biotita sienogranito pouco transformado(BSG). Maciço granitóide Antônio Vicente.

Tabela 3.6- Composições modais do biotita sienogranito alterado(BSGA). Maciço granitóide Antônio Vicente.

Tabela 3.7- Composições modais do biotita sienogranito intensamente alterado(BSGIA). Maciço granitóide Antônio Vicente.

Tabela 3.8- Composições modais do biotita monzogranito(BMG). Maciço granitóide Antônio Vicente.

Tabela 3.9- Composições modais do micromonzogranito(MMG) e do sieno a monzogranito granofírico(SMGGf). Maciço granitóide António Vicente.

Tabela 3. 10- Composições modais dos muscovita-quartzo greisen(MQGs), quartzoclorita greisen(QCGs) e clorita- "siderofilita"- "muscovita"-quartzo graisen(CSMQGs). Maciço granitóide Antônio Vicente.

Tabela 3.11- Principais características petrográficas das facies granitóides e de greisens associados ao maciço granitóide Antônio Vicente

Tabela 3.12- Estimativas da temperatura de cristalização da clorita $\left(\mathrm{Cl}_{2}\right)$ das facies granitóides BASMG, BASAFG e BSG e do clorita-"siderofilita"-"muscovita"-quartzo greisen do maciço granitóide Antônio Vicente

Tabela 3.19- Conteúdos médios de $\mathrm{F}, \mathrm{Cl}$ e $\mathrm{SiO}_{2}$ (em rocha total) nas principais facies granitóides do maciço granitóide Antônio Vicente.

Tabela 3.20- Conteúdos médios de $\mathrm{F}$ e $\mathrm{Cl}$ em anfibólios das facies BASMG e BASAFG e em biotita da facies BSG(diferenciados magmáticos) do maciço granitóide Antônio Vicente.

Tabela 3.21- Dados de ETR referentes às principais facies granitóides do maciço 
granitóide Antônio Vicente

Tabela 4.1- Composições modais da facies biotita sienogranito equigranular médio(BSGEm). Maciço granitóide Velho Guilherme.

Tabela 4.2- Composições modais das facies sienogranito heterogranular(SGH) e microsienogranito(MSG). Maciço granitóide Velho Guilherme.

Tabela 4.3- Principais características petrográficas das facies granitóides do maciço Velho Guilherme.

Tabela 4.4- Dados de ETR referentes às principais facies granitóides e veio hidrotermal associados ao maciço Velho Guilherme.

Tabela 5.1- Composições modais do sienogranito a monzogranito porfirítico(SMGP). Maciço granitóide Mocambo.

Tabela 5.2-Composições modais do sienogranito com muscovita(SGMv) e da rocha aplítica(AAFG). Maciço granitóide Mocambo.

Tabela 5.3- Composição modal do "siderofilita"clorita-muscovita-quartzo greisen(SCMQGs). Maciço granitóide Mocambo.

Tabela 5.4- Principais características petrográficas dos granitóides e greisen associados ao maciço granitóide Mocambo

Tabela 5.6- Dados de ETR referentes às principais facies granitóides e greisen associados ao maciço granitóide Mocambo

Tabela 6.1- Composições modais das facies granitóides AFG e BAFG do maciço granitóide Benedita.

Tabela 6.2-Principais características petrográficas das facies granitóides associadas ao maciço granitóide Benedita.

Tabela 6.4- Principais características dos ETR nos granitóides do maciço Benedita.....

Tabela 7.1- Composições modais da facies granitóide BSGCl do maciço Ubim/Sul....... 362

Tabela 7.2-Composições modais da facies BMG do maciço granitóide Ubim.Sul..........

Tabela 7.3- Principais características petrográficas dos granitóides do maciço Ubim/Sul.

Tabela 7.5- Principais características dos ETR nos granitóides do maciço Ubim/Sul.....

Tabela 8.1- Composições modais do Sieno a álcali-feldspato granito porfirítico(SAFGP) do maciço granitóide Rio Xingu.

Tabela 8.2-Principais características petrográficas da facies granitóide SAFGP do maciço granitóide Rio Xingu.

Tabela 8.4- Principais características dos ETR nos granitóides do maciço Rio Xingu....

Tabela 9.1- Caracteristicas isotópicas de granitóides e greisen dos maciços Antônio Vicente, Velho Guilherme e Mocambo, em termos de $\delta^{18} \mathrm{O}$. 
Tabela 10.1- Principais características petrográficas das facies granitóides e de greisens do maciço granitóide Antônio Vicente estudados através de microtermometria..

Tabela 10.2- Resultados microtermométricos obtidos através do estudo de inclusões fluidas em granitóides e greisen do maciço granitóide Antônio Vicente.

Tabela 10.3- Evolução dos sistemas salinos segundo o "trend" BASMG(facies menos evoluida) ao CSMQGs(greisen) do maciço granitóide Antônio Vicente..

Tabela 11.1- Idades radiométricas $\mathrm{Pb}-\mathrm{Pb}$ (em rocha total), $\mathrm{Pb}-\mathrm{Pb}$ (em zircões por evaporação de $\mathrm{Pb}$ ) e U-Pb(em zições) e características isotópicas $\mathrm{Sm}-\mathrm{Nd}$ de rochas granitóides da Suite Intrusiva Velho Guilherme, Grupo Uatumã, Grupo São Félix, Granodiorita Rio Maria e Grupo Tucumã, ocorrentes na Folha São Féelix do Xingu SB-22-Y-B. 


\section{LISTA DE QUADROS}

Quadro 1.1- Resumo esquemático do arranjo lito-estratigráfico mais recente propsto para a Folha São Felix do Xingu, de acordo com CPRM/DNPM(1991) e, adicionalmente, dados produzidos neste trabalho

Quadro 12.1- Quadro Comparativo mostrando as principais características dos maciços da Suite Intrusiva Velho Guilherme. 


\section{1- INTRODUÇÃO}

\section{1-Apresentação}

O magmatismo anorogênico Proterozóico do Craton Amazônico é um dos mais expressivos do mundo. Ele encerra um grande volume de rochas granitóides e vulcânicas máficas, intermediárias e félsicas, com subordinados tipos plutônicos máficos(Dall'Agnol et al., 1987; Bettencourt \& Dall'Agnol, 1987; Issler \& Lima, 1987; Bettencourt et al., 1991; Teixeira et al., 1998; Dall'Agnol et al., 1999). Em termos gerais, esse magmatismo se assemelha, em diversos aspectos(idades, característica geoquímicas e evolução magmática), àqueles ocorrentes em outras regiōes do mundo tais como na Província Proterozóica Norte Americana e no Escudo Fenoscandiano(Anderson \& Brender, 1989; Emslie, 1991; Haapala \& Rämö, 1990; Rämö \& Haapala, 1995).

Particularmente, no que se refere às rochas granitóides do PaleoproterozóicoMesoproterozóico, vários estudos têm sido realizados(Abreu \& Ramos, 1974; Dall'Agnol, 1980; Horbe et al., 1985; Bettencourt \& Dall'Agnol, 1987; Dall'Agnol et al., 1988; Horbe et al., 1991; Teixeira \& Dall'Agnol, 1991;Magalhães,1991; Teixeira \& Andrade, 1992; Dall'Agnol et al., 1993b; Teixeira et al., 1994; Teixeira et al., 1998; Dall'Agnol et al., 1999). Dentre elas, ocorre um grande volume de granitóides, com características subalcalinas e alcalinas, que apresentam diversas semelhanças com os granitóides do tipo "A"(Loiselle \& Wones, 1979; Collins et al., 1982; Pitcher, 1983; Cobbing, 1990; Eby, 1990; Eby, 1992; Turner et al., 1992; entre outros) e detém expressivas mineralizações de estanho e outros metais raros(Dall'Agnol, 1980; Horbe et al., 1985; Dall'Agnol et al., 1986, Bettencourt \& Dall'Agnol, 1987, Daoud, 1988; Teixeira e Dall'Agnol, 1990, Horbe et al., 1991; Faraco et al.,1991; Dall'Agnol et al., 1993b; Teixeira \& Dall'Agnol, 1994; Bettencourt et al., 1995; Borges, 1997; Dall'Agnol et al., 1999).

Os corpos granitóides estaniferos da Suite Intrusiva Velho Guilherme, ocorrentes na região sul-sudeste do Estado do Pará, objetos desse estudo, embora já tenham sido investigados com diferentes enfoques por diversos autores(Abreu \& Ramos, 1974; Silva et al., 1974; Dall'Agnol, 1980, 1982a; Dall'Agnol et al., 1984; Dall'Agnol et al., 1993b; Dall'Agnol et al., 1999; Sá, 1985; Magalhães, 1991; CPRM/DNPM, 1991;; Faraco et al, 1991; Lafon et al., 1991; Teixeira \& Dall'Agnol, 1991; Teixeira \& Andrade, 1992; Teixeira et al., 1994; Teixeira et al., 1998; Lafon et al., 1995), ainda não mereceram, até à redação desta tese, um estudo mais detalhado a respeito da caracterização petrográfica de cada corpo, que 
permitisse estabelecer uma organização faciológica, interna, para os mesmos, bem como não foram compreendidos com clareza as relações temporais e petrogenéticas existentes entre as facies granitóides que constituem cada maciço nem, tampouco, foram caracterizados os processos geradores das mineralizações.

Além disso, não foram efetuadas comparações mais pormenorizadas entre os vários corpos da suite, seja do ponto de vista petrográfico, geoquímico, petrológico e geocronológicos ou das suas evoluções magmáticas e do potencial metalogenético. Ademais, não foram realizados estudos visando caracterizar as idades e o(s) tipo(s) de protólito(s) dos magmas granitóides da suite e suas áreas fontes, nem tampouco se procurou verificar as relações de contemporaneidade e de afinidades petrogenéticas entre 0 plutonismo Velho guilherme e o vulcanismo Uatumã, ambos geograficamente associados.

O propósito deste trabalho é estudar seis maciços granitóides portadores de mineralizações de cassiterita, pertencentes à Suite Intrusiva Velho Guilherme(CPRM/DNPM, 1991), da Província Estanífera do sul do Pará(Abreu \& Ramos, 1974), que ocorrem na região sul- sudeste do Estado do Pará. São eles os maciços granitóides Antônio Vicente(MGAV), Velho Guitherme(MGVG), Mocambo(MGM), Benedita(MGB), Ubim/Sul(MGU/S) e Rio Xingu(MGRX).

E digno de nota que os depósitos económicos de cassiterita que foram explotados por garimpeiros(década de 1970) e por empresas de mineração(por toda a década de 1980 e início dos anos 90 ) se restringiram àqueles de natureza secundária, os quais se encontravam distibuidos na principal rede de drenagem do interior dos maciços granitóides(depósitos aluvionares). Ocorrências primárias ainda existem, embora em baixas concentrações, associadas às facies mais evoluídas e mais intensamente afetadas por alterações tardi a pós-magmáticas, bem como a corpos de greisens. É provável que depósitos primários econômicos, tenham existido. Entretanto, presume-se que os processos erosivos e os agentes superficiais de transporte atuantes ao longo do tempo, os tenham desmontado, carreando-os para os vales de drenagem, onde finalmente eles foram concentrados. Em outras palavras, o nível atual de erosão deixa crer que os depósitos primários de metais raros associados a zonas apicais ou cúpolas foram arrasados e a cassiterita e minerais associados foram transportados para as áreas aluvionares do interior e das adjacências dos corpos granitóides. Outros bens minerais, tais como topázio e fluorita, embora sejam observados diretamente no campo, tanto em áreas aluvionares, quanto "in situ" nos blocos de rocha(forma primária), até o momento, somente o topázio aluvionar foi explotado por pequenos garimpeiros de forma artesanal, para sobrevivência. Minerais do grupo da columbita-tantalita, são referidos genericamente na literatura(Abreu \& Ramos, 
1974; Faraco et al., 1991) e através de informações verbais de garimpeiros e moradores da região, mas não há noticias de explotação desse tipo de bem mineral.

\section{2- Desenvolvimento Histórico}

Os depósitos minerais relacionados às rochas granitóides podem incluir diferentes combinações de elementos tais como $\mathrm{Sn}, \mathrm{W}, \mathrm{U}, \mathrm{Th}, \mathrm{Mo}, \mathrm{Cu}, \mathrm{Nb}, \mathrm{Ta}, \mathrm{Be}, \mathrm{Li}, \mathrm{ETR}, \mathrm{Sb}, \mathrm{As}$, $\mathrm{Ag}, \mathrm{Au}, \mathrm{Pb}$ e $\mathrm{Zn}$ (em ordem decrescente de associação; Strong, 1988). Eles tem sido, provavelmente, mais estudados ao longo do tempo do que os depósitos de outros tipos de metais. Os depósitos hercinianos europeus vem sendo explotados desde os primeiros dias da Idade do Bronze, passando pela ascensão e queda do Império Romano(Ex: o distrito Cornwall-Inglaterra é uma importante fonte de estanho desde o tempo dos Fenícios; Strong, 1988). De acordo com Scherba(1970), as descrições mais antigas sobre os depósitos relacionados aos greisens, bem como sobre a origem dos mesmos, datam de Agrícola(1546), Leman(1753), Lomonov(1757), Hetton(1788), Leonard(1832), Eli de Bomon(1847) e Dobre(1841).

Das décadas de 60 e 70, são memoráveis os trabalhos que foram desenvolvidos pelos geólogos da antiga União Soviética. Dentre os mais conhecidos destacam-se aqueles de Serebryakova(1961) Beus(1964), Beus \& Zalashkova(1964), Beus \& Sitnin(1968), Tauson et al.(1968), Shcherba(1970), Kovalenko et al.(1970), Stemprok(1977), Tischendorf(1977), Stemprok(1978), Kovalenko(1978) e Varlamoff(1978). Esses trabalhos são considerados clássicos e nortearam a grande maioria dos estudos sobre granitóides a metais raros desenvolvidos por pesquisadores de outras regiōes do mundo.

De modo geral, são trabalhos que discutem a importância dos processos metassomáticos, pós-magmáticos de alta temperatura, desenvolvidos em rochas granitóides ácidas a ultra-ácidas, como processos formadores de depósitos de elementos raros(Sn, W, $\mathrm{Li}, \mathrm{Ta}, \mathrm{Mo}, \mathrm{Rb}, \mathrm{Zr}, \mathrm{Be}, \mathrm{Nb}$, etc.). Descrevem uma série de feições petrográficas(microclinização, albitização e greisenização) e geoquímicas(faixas de variação do conteúdos de elementos) relacionadas a esses processos. Estabelecem limites nos teores de elementos tais como $\mathrm{Sn}, \mathrm{W}, \mathrm{Li}, \mathrm{Nb}$, comparando os valores determinados para granitóides especializados e granitóides normais. Discutem a origem dos granitóides a metais raros, apresentam esquemas e descrições detalhadas dos diversos tipos de depósitos e indicam os vários ambientes geológicos para formação dos dos mesmos.

A participação efetiva dos geólogos ocidentais(muito incipiente nas décadas de $60 \mathrm{e}$ início da década de 70), no que se refere a esse tema, toma vulto a partir dos trabalhos de Holland(1972), Silitoe(1974), El-Bouseily \& El-Sokkary(1975), Haapalla(1977), Taylor(1978), Burnham \& Ohmoto(1980), Olade(1980), Dall'Agnol(1980), Bettencourt et al.(1981), 
Pollard(1983), Pollard et al.(1983), Bowden \& Kinnaird(1984), Bowden et al.(1984), Botelho \& Marini(1984), Kinnaird(1985), Taylor \& Pollard(1988), entre outros. Todos esses autores ressaltaram(nas entre linhas) a necessidade dos estudos petrográficos sistemáticos e refinados. Mostraram a importância da caracterização das paragêneses minerais formadas pelos processos de alterações tardi a pós-magmáticas, desenvolvidos em altas temperaturas e que são controlados por fissuras e/ou por microfissuras ou, ainda, se desenvolvem de forma pervasiva, preferencialmente nas regiões apicais dos complexos granitóides. Ademais, baseando-se em estudos petrográficos, estabeleceram uma ordem cronológica de desenvolvimento dos processos tardi a pós-magmáticos, mostrando que os mesmos íniciam-se com uma fase de feldspatização potássica(microclinização), seguida de uma fase essencialmente sódica(albitização) e chegando ao climax com uma fase de greisenização. Afora as questões relativas aos aspectos petrográficos, caracterizaram uma série de feições geoquímicas peculiares de granitóides especializados a metais raros, distinguindo-os daqueles considerados normais.

Nos últimos anos, centenas de trabalhos enfocando esse tema foram publicados. Dentre eles destacam-se aqueles de Cerny \& Mintzer(1988), Strong(1988), Rossi et al.(1988), Pollard(1988, 1989a e b, 1995a e 1995b), Charoy \& Pollard(1989), Frank(1990), Cuney \& Raimbault(1991), Horbe et al.(1991), Plimer \& Kleeman(1991), Schwart(1992), Haapalla(1995), Yin et al.(1995), Suwimouprecha et al.(1995), Pollard et al.(1995, Hämö \& Haapalla(1995), Daoud(1988), Teixeira \& Andrade(1992), Leite Junior(1992), Marini et al.(1992), Botelho et al.(1993), Dall'Agnol et al.(1993b), Dall'Agnol et al.(1994), Melo(1995), Costi et al.(1995), Borges et al.(1996), Costi et al.(1996), Borges(1997), Lenharo(1998), Dall'Agnol et al.(1999).

Paralelamente a esses trabalhos, diversos outros envolvendo estudos experimentais tem sido realizados(Kovalenko, 1978; Durisova, 1978; Manning, 1981, 1982; Pichavant, 1981, 1987; Manning \& Henderson, 1984; Candela, 1989a, 1989b, 1992;Manning \& Hill, 1990; Taylor \& Wall, 1992; Zhang et al., 1994; Baker \& Vaillancourt, 1995; Linnen et al., 1995; Linnen et al, 1996).

Além desses, outros trabalhos abordando aspectos relacionados à origem das rochas granitóides, à tipologia e ambiência tectônica dos granitóides, bem como à fonte dos metais foram realizados. Dentre eles destacam-se aqueles de Chappell \& White(1974), Hutchinson \& Chakraborty(1979), Loiselle \& Wones(1979), Takahashi et al.(1980), Ishihara(1981), Collins et al.(1982), Chappell \& White(1982), Pitcher(1983), Kovalenko \& Kovalenko(1984), Pearce et al.(1984), Batchelor \& Bowden(1985), Lehmann(1987), Whalen et al.(1987), Cobbin(1990), Eby(1990), Creaser et al.(1991), Eby(1992), Haapala \& 
Rämö(1992), Turner et al., 1992, Botelho et al.(1993), Sanson et al.,(1995), Blevin \& Chappell(1995), Teixeira et al.(1998), Dal'Agnol et al.(1999).

\section{3- Aspectos Conceituais}

Os aspectos conceituais relativos à definição, nomenclatura e classificação das rochas granitóides são discutidos por Chappell \& White(1974), Streckeisen(1976), Ernst(1976), Taylor(1979), Le Maitre(1989), Didier(1991), White(1992) e Pitcher(1995), entre outros. Assim, prefere-se enfocar aqui apenas alguns dos principais conceitos relacionados aos termos que são de uso mais corrente quando se trata de granitóides hospedeiros de depósitos minerais.

1)Especialização Geoquímica: esse termo foi utilizado por Beus \& Sitnin(1968) para agrupar uma série de peculiaridades, relacionadas especificamente à composição química de complexos rochosos. Tais peculiaridades poderiam ser utilizadas como parâmetros indicadores da similaridade ou diferença entre os mesmos, indicando domínios genéticos ou de possível potencial metálico entre tipos de rochas ou entre suites similares.

Atualmente, embora se reconheça o conceito de especialização geoquímica, conforme definido por Beus \& Sitnin(1968), não é mais aceita pela maioria dos estudiosos a idéia praticamente estática de que essa seria unicamente determinada pela composição do material magmático primário. Diversos outros fatores podem determinar a especialização geoquímica de um complexo magmático tais como: a) composição da área fonte e/ou do protólito; b) contaminação por material enriquecido; c) remobilização e enriquecimento através de processos metassomáticos e hidrotermais; d) interação com as rochas encaixantes; etc. É com esse sentido que esse termo será utilizado nesse trabaho.

2) Greisenização/Greisen: Scherba(1970) discutiu os processos de greisenização, definindo-o como uma complicada transformação pós-magmática de alta temperatura, desenvolvida nas rochas graniticas sob o patrocínio de soluções residuais ácidas a ultraácidas, ricas em sílica e constituintes voláteis. Esses processos seriam típicos de magmas félsicos colocados em niveis moderadamente rasos a rasos de profundidade $(1,5$ a $4,4 \mathrm{Km})$, cujos produtos são expressos por rochas granitóides greisenizadas, greisens e minérios de $\mathrm{W}, \mathrm{Sn}, \mathrm{Be}, \mathrm{Mo}, \mathrm{As}, \mathrm{Bi}, \mathrm{Zr}, \mathrm{Ta}, \mathrm{Nb}, \mathrm{ETR}$ e de outos elementos raros.

Definiu os greisens como rochas metassomáticas constituídas essencialmente por quartzo e micas, portando freqüentemente topázio, fluorita, turmalina, feldspato e minerais metálicos, formadas a partir de granitos ou de outras rochas, pela ação de soluções pneumatoliticas-hidrotermais, de alta temperatura e com elevados teores de $\mathrm{F}, \mathrm{Cl}$ e água, cuja fonte é atribuida aos granitos. 
Stemprok(1987) reviu essas definições. Considerou que a greisenização é um processo metassomático característico, que acompanha a origem de alguns granitos metalogeneticamente especializados. Ela se relaciona às alterações pós-magmáticas, as quais comumente mudam a composição mineralógica dos granitos em vários estágios seqüenciais, após a colocação dos mesmos. Alterações metassomáticas potássicas e sódicas(feldspatizações) precedem a greisenização, mas podem, também, seguí-la. Nas suas definições os seguintes aspectos são, geralmente, enfatizados: a) greisenização é um processo metassomático cuja a origem está relacionada a granitóides leucocráticos de alta sílica(70-74\% de $\left.\mathrm{SiO}_{2}\right)$; b). Ela atua sobre rochas sólidas, sem uma participação importante de reações na porção líquida do corpo granitico; c) no seu curso ocorrem mudanças mineralógicas caracterizadas pela decomposição da biotita e dos feldspatos, bem como remobilização de sílica e alumina na rocha. Ou seja, a greisenização é definida como um processo metassomático pós-magmático, relacionado a granitos, no curso do qual a biotita e os feldspatos tornam-se instáveis. Eles são substituídos por agregados complexos de micas, quartzo, topázio, fluorita e turmalina, com aporte considerável de alguns elementos tais como estanho, tungstênio, molibdênio ou berilio. É com esse sentido que esse termo será utilizado nesse trabalho.

3) Granitos Especializados: esse termo é devido a Tischendorf(1977). Ele foi empregado para designar rochas granitóides distintas, com ampla ocorrência no mundo, semelhantes petrográfica e geoquimicamente, com posições geotectônicas equivalentes e de ocorrência em ambientes estruturais similares. Elas seriam formadas em condições especiais, cuja principal característica seria a de estarem associadas geneticamente e espacialmente a depósitos metálicos de elementos raros(Sn, Li, Rb, Cs, Be, Nb, Ta, W, Zr, Hf, Y, ETR). Correlacionou a especialização desses granitóides ao tipo de depósitos que os mesmos hospedam(Ex: granitos especializados em estanho ou granitos estaníferos; granitos especializados em wolfrâmio ou granitos wolframiferos; etc.). Ressaltou a inexistência de qualquer relação direta entre a acumulação de elementos raros e as rochas magmáticas silicosas(mais ou menos especializadas), havendo, entretanto, uma coerência genética entre os depósitos e os complexos intrusivos especializados geologicamente, petrograficamente e geoquimicamente, como um todo. E com esse sentido que esse termo será utilizado neste trabalho.

4) Alterações tardi a pós-magmáticas: os processos relacionados aos estágios tardios de formação de minerais, decorrentes das interações entre os fluidos residuais tardios ricos em voláteis e rochas tem sido referidos na literatura, por vários autores, através de terminologias diversas tais como alteração metassomática, alteração deutérica, alteração tardi a pós-magmática, etc. Com o objetivo de uniformizar o uso dessa terminologia será 
adotada nesse trabalho o sentido utilizado por Dall'Agnoll(1980), Pollard(1983), Botelho(1984), ou seja, alterações(transformações) tardi a pós-magmáticas.

\section{4-Localização da Área e Acesso}

A área de ocorrência dos maciços granitóides, objetos de estudo, localiza-se na região sul-sudeste do Estado do Pará, a oeste da cidade de Xinguara, em região circunvizinha aos municípios de Tucumã e São Felix do Xingu(Folha SB-22-Y-B-São Felix do Xingu). Está compreendida entre os paralelos $600^{\prime} 00^{\prime \prime}$ e $700^{\prime} 00^{\prime \prime}$ de latitude sul e os meridianos $5100^{\prime} 00^{\prime \prime}$ e 52 30' $00^{\prime \prime}$ de longitude oeste, perfazendo um total de aproximadamente $18.481,51 \mathrm{Km} 2$ (Figura 1.1).

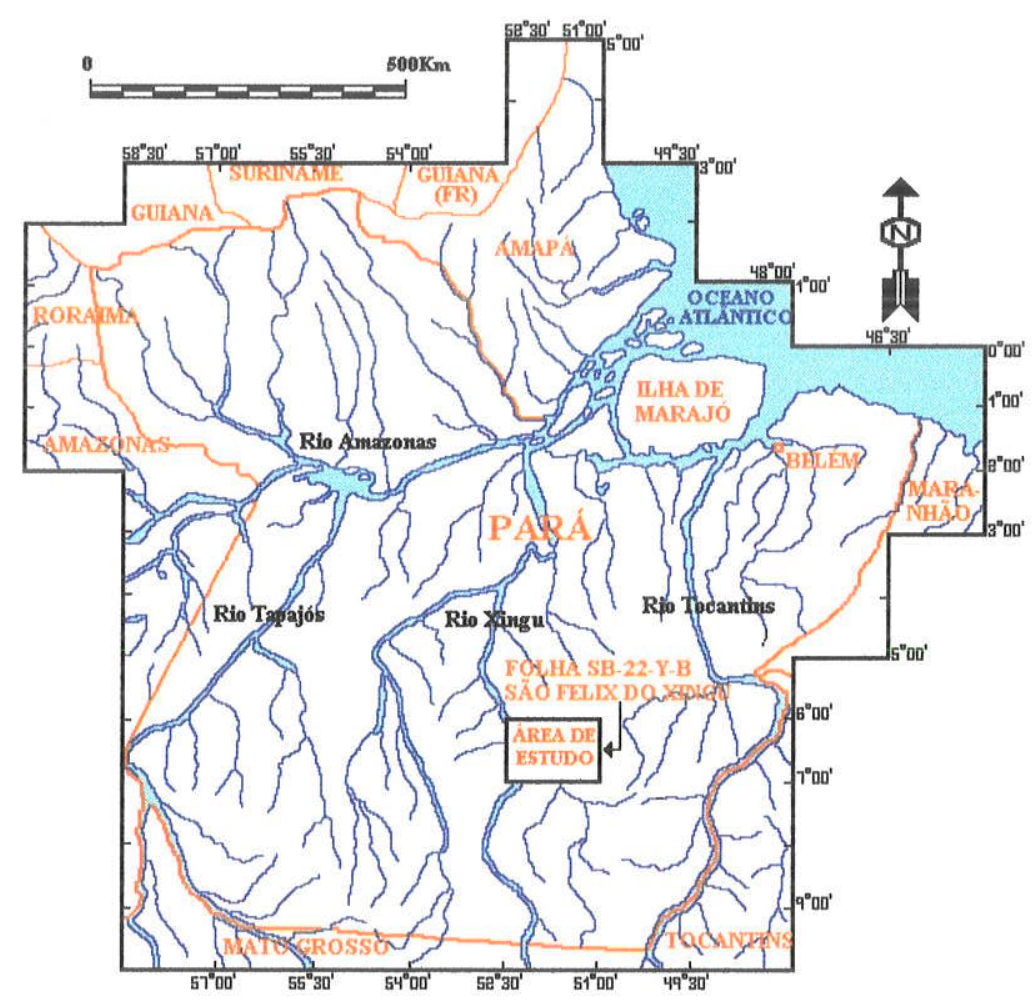

Figura 1.1- Mapa geográfico do Estado do Pará mostrando a localização da área de ocorrência dos maciços granitóides estudados.

As principais vias de acesso terrestres que servem a região são as Rodovias PA150(Belém-Marabá-Xinguara) e PA-279(Xinguara-Tucumã-São Felix do Xingu), sendo que esta última atravessa a área no sentido leste-oeste. Existem, ainda, no interior da área, estradas vicinais que conduzem aos pequenos povoados e vilas da região e à sedes de fazendas, permitindo, assim, a utilização de veículos como meio de transporte no interior da mesma. 
Além disso, o acesso à área pode ser realizado por via aérea e fluvial. No primeiro caso, o acesso pode ser realizado utilizando-se aviões de pequeno porte, uma vez que os aeroportos são, geralmente, improvisados(aeroportos de fazendas e/ou de pequenas cidades da região).

Por via fluvial, pode-se atingir a área através do rio Xingu, partindo-se da cidade de Altamira. Entretanto, trata-se de um rio bastante encachoeirado, no qual só é possível a navegação em embarcações de pequeno porte e em algumas épocas do ano.

Cabe esclarecer que a área em questão dista da capital do Estado do Pará(Belém) aproximadamente $1.300 \mathrm{~km}$, por via terrestre(PA-150 + PA-279), e o acesso se desenvolve em condições sempre precárias, com as estradas em péssimas condições de tráfego(atoleiros, dezenas de pontes de madeira, quatro travessias de balsas por possantes rios da região, etc). Além disso, a área é palco de intensos conflitos sociais envolvendo fazendeiros, posseiros e garimpeiros, bem como representa uma das regiões mais endêmicas do Estado do Pará, representada, principalmente, por malária, epatite e lechimaniose.

Ademais, o acesso à área é freqüentemente dificultado tanto por problemas de ordem climática(períodos de chuvas acompanhados de enchentes), quanto por aqueles de cunho sócio-econômico a saber: a) destruição de pontes por madeireiros que atuam na região, como forma de protesto frente ao descaso do governo; b) descaso do governo no que diz respeito a construção de obras de incentivo ao desenvolvimento da região(ausência de energia elétrica, pavimentação e manutenção das estradas e ações de saneamento básico, escolas, etc).

Adicionalmente, a esses problemas, as empresas de mineração que atuavam na região de ocorrência dos maciços granitóides da Suite Intrusiva Velho Guilherme(Mineração Taboca S/A, do Grupo Paranapanema, na área de ocorrência do maciço granitóide Antônio Vicente; Mineração São Francisco de Assis Ltda.; na área de ocorrência do maciço granitóide Mocambo) tinham suas atividades voltadas principalmente, para a explotação de cassiterita. Com a brusca queda do preço desse bem no mercado(nacional e internacional) no inicio da década de 90 , tais empresas interromperam suas atividades e foram desativadas. Assim, as condições de infra-estrutura, para o desenvolvimento de trabalhos de pesquisas geológicas na região, que já eram precárias, tornaram-se insuportáveis, acarretando sérios problemas para o estudo desses maciços granitóides. Isso se refletiu nos trabalhos de campo desenvolvidos para o estudo dos granitóides objetos de estudo nesse trabalho. 


\section{5- Aspectos Fisiográficos}

\subsection{1 - Clima e vegetação}

A região sul-sudeste do Estado do Pará se caracteriza por apresentar um clima tropical de monção, definido, principalmente, por um período seco, no inverno(dias relativamente mais curtos) e um período úmido bem acentuado e tipicamente marcado por chuvas torrenciais, no verão(dias longos). O período de chuvas se inicia no mês de Setembro, atinge o clímax em meados de Dezembro a Março, encerrando-se em Maio. Constitui um período seco o restante do ano. A precipitação pluviométrica anual situa-se em torno dos $1.650 \mathrm{~mm}$.

Segundo Nimer(1989), a temperatura máxima absoluta do ano situa-se em torno dos $42{ }^{\circ} \mathrm{C}$, a mínima entre $8^{\circ} \mathrm{C}$ e $12{ }^{\circ} \mathrm{C}$ e a média das mínimas no mês de Julho varia entre 14 ${ }^{\circ} \mathrm{C}$ e $16^{\circ} \mathrm{C}$.

De acordo com Veloso et al.(1974) e observações de campo, a região sul-sudeste do Estado do Pará encerra diversos tipos de vegetação, entre os quais a floresta e uma mancha de mistura cerrado/floresta tem grande predominância e ampla distribuição.

A floresta densa ocorre preferencialmente nas zonas montanhosas, caracterizando uma cobertura arbórea uniforme de árvores de pequeno porte e grupos de castanheiras. Nas áreas de vales são predominantes os cipoais, os quais, dependendo da largura dos vales, podem se estender até as meias encostas. Nas regiões aplainadas é predominante o desenvolvimento da floresta aberta e do cerrado.

\subsection{2- Relevo}

De modo geral, o relevo da região pode ser dividido em quatro domínios: 1) relêvo colinoso formado de estreitas faixas alinhadas, de topos angulosos e perfis simétricos, bem como por serras em cristas com perfis em questas(Ex: Grupos Tucumã e São Felix do Xingu, unidades litoestratigráficas do Cinturão de Cisalhamento Itacaiúnas); 2) relêvo arrasado com colinas suaves(Ex: Granodiorito Rio Maria, unidade constitutiva do Terreno Granito-Greenstone do Sul do Pará); 3) relevo colinoso de topos arredondados, correspondente às áreas de ocorrência dos granitóides objeto de estudo;4) relevo de platôs(Ex: áreas de ocorrência das unidades metassedimentares correspondentes ao Grupo São Sebastião e as rochas sedimentares da Formação Triunfo).

Essas características geomorfológicas foram enquadradas por Veloso et al.(1974) como pertencentes à unidade morfo-estrutural e morfo-climática do Planalto Dissecado do Sul do Pará.

São maciços residuais de topos aplainados e conjuntos de cristas e picos interpenetrados por faixas de terrenos rebaixados. As altitudes variam geralmente entre 500 
e 600 metros, embora possam ocorrer trechos mais elevados. É uma unidade de relevo intensamente dissecada por vales encaixados, geralmente controlados por alinhamentos estruturais estabelecidos em unidades arqueanas e proterozóicas.

\section{6- Objetivos da Tese}

Levando-se em conta os dados já existentes sobre os granitóides da Suite Intrusiva Velho Guilherme, bem como aqueles que foram produzidos neste trabalho através da utilização de diversas técnicas de investigação(ver mais adiante), pode-se atingir o objetivos a saber:

1-Caracterização do quadro geodinâmico regional com vistas ao posicionamento espacial dos corpos granitóides da Suite Intrusiva Velho Guilherme;

2-Definição, quando possivel, da estruturação interna de cada maciço e a tipologia;

3-Caracterização da natureza da especialização dos granitóides, bem como dos tipos de mineralizações associadas(cassiterita, fluorita, topázio, etc);

4-Caracterização de feições petrográficas, geoquímicas e radiogênicas diagnósticas de granitóides especializados a metais raros;

5-Caracterização da relação entre o magmatismo plutônico dos granitóides estudados e o magmatismo vulcânico intermediário e félsico do Grupo Uatumã, baseada em dados isotópicos(principalmente $\mathrm{Sm}-\mathrm{Nd}$ e $\mathrm{Pb}-\mathrm{Pb}$ ) e geoquímicos(principalmente elementos traços e elementos terras raras), buscando caracterizar as características da área fonte e a idade modelo de seus protólitos, bem como a natureza dos magmas progenitores dos mesmos, com vistas a estabelecer relações de cogeneticadade ou não entre ambos;

6-Caracterização a tipologia das fases micáceas e de minerais acessórios associadas às mineralizações de cassiterita;

7-Estimar as condições de colocação dos magmas granitóides com base em dados petrográficos, qúimicos de rocha total e de química mineral;

8-Determinação das idades radiométricas dos granitóides do maciços granitóides Antônio Vicente, Mocambo e Rio Xingu, dos vulcanitos andesíticos e riolíticos do Grupo Uatumã e de rochas metavulcânicas máficas do Grupo São Felix através do método $\mathrm{Pb}-\mathrm{Pb}$ 
em zircões por evaporação e $\mathrm{Pb}-\mathrm{Pb}$ em rocha total e em feldspatos, com vistas a posicionálos temporalmente no quadro evolutivo regional do Craton Amazônico;

9-Com base em dados petrográficos, químicos de rocha total e de fases minerais, avaliar o papel desempenhado pelos hologênios, especialmente $\mathrm{F}, \mathrm{Cl}$, bem como de outros voláteis associados como agentes transportadores, deposicionais e concentradores de metais raros, especialmente, do estanho.

10-Caracterização dos processos magmáticos e tardi a pós-magmáticos com vistas à modelagem genética dos magmas granitóides e das mineralizações associadas; as quais podem contribuir para a elaboração de modelos prospectivos em outras regiões, bem como permitem compará-los com granitóides de outras províncias;

\section{7- Metodologia}

\subsection{1- Elaboração de Mapas e Coleta de Amostras}

Foram confeccionados mapas temáticos preliminares(drenagem, relevo, litoestrutural, fotolitológico e base logística), utilizando-se para isso fotografias aéreas verticais convencionais, em papel preto e branco, nas escalas de 1:45.000 e 1:50.000, mosaicos de Radar(1:100.000) e imagens de satélite(Landsat-TM), em papel preto e branco, na escala 1:100.000. Para isso, foram aplicados os princípios recomendados por Soares e Fiori(1976), bem como foram utilizados materiais fornecidos por professores do Instituto Nacional de Pesquisas Espaciais(INPE) de São José dos Campos(São Paulo) e pelo Dr. Mário Ivan Lima(IBGE), durante os cursos realizados no Curso de Pós-graduação do Núcleo de Ciências Geofisicas e Geológicas da Universidade Federal do Pará. Além disso, foram utilizados mapas geológicos já existentes(Sá, 1985; Teixeira \& Dall'Agnol, 1991; CPRM/DNPM, 1991).

A partir dessas bases preliminares pode-se, então, desenvolver as diversas etapas de campo. Essas consistiram da realização de perfis contínuos e coleta de amostras para fins diversos(estudos petrográficos, análises químicas, etc), tomada de medidas estruturais e descrições de afloramentos. Os aspectos texturais e estruturais, bem como outros de interesse para o trabalho foram fotografados com vistas a ilustrar as observações de campo.

Após as etapas de campo foram realizados trabalhos de escritório e laboratoriais. Esses culminaram com a confecção das versões finais dos mapas geológicos da área de ocorrência de cada maciço granitóide, bem como dos respectivos mapas de amostragem.

Esses mapas representam versões melhoradas e daquelas mais antigas existentes na literatura acerca dos maciços granitóides Antônio Vicente, Velho Guilherme e 
Após as etapas de campo foram realizados trabalhos de escritório e laboratoriais. Esses culminaram com a confecção das versões finais dos mapas geológicos da área de ocorrência de cada maciço granitóide, bem como dos respectivos mapas de amostragem.

Esses mapas representam versões melhoradas e daquelas mais antigas existentes na literatura acerca dos maciços granitóides Antônio Vicente, Velho Guilherme e Mocambo(Abreu \& Ramos, 1974; Dall'Agnol, 1980). No que se refere aos granitóides Benedita e Ubim/Sul, face às dificeis condições de acesso e à inexistência de qualquer tipo de infra-estrutura para a realização dos trabalhos de campo, foram considerados os mapas elaborados por Teixeira \& Andrade(1992). O granitóide Rio Xingu, por sua vez, devido ao seu ineditismo, a sua reduzida dimensão, homogeneidade petrográfica e à falta de fotografias aéreas em escala adequada para representá-lo em mapa, não foi apresentado em mapa específico.

Os mapas de localização geográfica da área estudada(Figura 1.1) e o de contextualização tectônica(Figura 2.1) foram extraidos da literatura(DNPM e Tassinari, 1996, respectivamente). Os mapas geotectônico(Figura 2.2) e geológico regional(Figura 2.3) foram concedidos pela Superintendência Regional da CPRM de Belém e constam em CPRM/DNPM(1991) e em Faraco et al.(1991).

As versões finais dos mapas foram preparadas através do Software CorelDraw 8.

\subsection{2- Estudos Petrográficos}

O estudo de lâminas delgadas consistiu de descrições mineralógicas detalhadas, análises texturais(conforme Alling, 1932 e 1938; Serebryakova, 1961; Beus \& Zalashkova; 1964; Fisher, 1971; Smith, 1974; Phillips, 1974; Bard, 1980; Williams et al., 1982; Mackenzie et al., 1982; Smith \& Brown, 1988, Richardson, 1988, Schwartz, 1992) e modais de acordo com Chayes(1956) e Jung \& Brousse(1959).

As descricões mineralógicas $e$ as análises texturais envolveram : 1) 0 reconhecimento das fases minerais, suas relações de contato, forma, dimensão(conforme Williams et al.(1982), presença de inclusões, intercrescimentos( exsolução e substituição), estruturas(se deformadas ou não), bem como suas relações de equilíbrio com outras fases presentes; 2) caracterização de paragêneses(magmáticas e tardi a pós-magmáticas); 3) estado de equilibrio(se alteradas ou não); 4) ordem de cristalização magmática e cronologia de formação das paragêneses tardi a pós-magmáticas.

As análises modais envolveram a contagem de pontos, em média de 1.500 pontos por amostra. Foram, ainda, realizadas em algumas amostras, a nivel de tira teima e de confirmação dos resultados, análises modais por colorimetria. Entretanto, sabia-se de antemão, que esse tipo de análise permitiria apenas a contagem dos constituintes 
De qualquer modo, os resultados modais, entre outras coisas, permitiram nomear e caracterizar melhor as diversas facies granitóides estudadas. Para tal foram seguidas as recomendações de Streckeisen(1976) e Le Maitre(1989). Deve-se ressaltar, contudo, que a separação do plagioclásio primário(de composição albita-oligoclásio) da albita tardi a pósmagmática ocorreu de modo muito claro e o conteúdo modal dessa última foi adicionado ao do feldspatato potássico para os cálculos dos valores " $A$ " dos diagramas Q-A-P e Q-(A+P)M'(Streckeisen, 1976). Näo foi possivel, durante a contagem de pontos, separar de modo preciso o feldspato potássico primário daquele formado no estágio tardi a pósmagmático(ver mais adiante) $e$, por isso, seus conteúdos não foram apresentados separadamente. Assim, os dados modais quando recalculados para $100 \%$, afim de serem lançados nos referidos diagramas, envolveram, para os cálculos dos valores de " $A$ ", a somatória dos conteúdos modais de feldspato potássico primário+feldspato potássico tardi a pós-magmático+albita tardi a pós-magmática. Em razão disso, as composições finais dos granitóides estudados, observadas nos referidos diagramas, não refletem suas composições magmáticas originais, mas, sobretudo, as composições modificadas pelas alterações tardi a pós-magmáticas.

Para determinação ótica da composição do plagioclásio utilizou-se, quando possível, o método.da seção paralela à $\mathrm{g}^{1}(010)$, conforme as recomendações de Roubaut(1963).

No que se refere às rochas encaixantes, não foram abordadas com o mesmo grau de aprofundamento dispensado aos granitóides, uma vez que não representam o objeto central desse trabalho. Foram realizadas apenas observações superficiais em amostras selecionadas de rochas andesíticas e rioliticas do grupo Uatumã(área de ocorrência do maciço granitóide Mocambo), de metavulcânicas máficas dos Grupos Tucumã(área de ocorrência do maciço granitóide Velho Guilherme) e São Felix(área de ocorrência do maciço granitóide Mocambo), visando caracterizar paragêneses minerais indicativas das condições de metamorfismo de contato, as quais foram comparadadas com aquelas caracterizadas por Dall'Agnol(1980) em rochas encaixantes dos maciços granitóides Antônio Vicente e Velho Guilherme.

\subsection{3- Análises Químicas em Rocha Total}

Após os estudos petrográficos, foram selecionadas 69 amostras para análises químicas em rocha total, envolvendo elementos maiores $\left(\mathrm{SiO}_{2}, \mathrm{TiO}_{2}, \mathrm{Al} 2 \mathrm{O}_{3}, \mathrm{Fe}_{2} \mathrm{O}_{3}, \mathrm{FeO}\right.$, $\mathrm{MnO}, \mathrm{MgO}, \mathrm{CaO}, \mathrm{Na}_{2} \mathrm{O}, \mathrm{K}_{2} \mathrm{O}, \mathrm{P}_{2} \mathrm{O}_{5}$ e PF, em percentagem), elementos traços( $\mathrm{Rb}, \mathrm{Sr}, \mathrm{Zr}$, $\mathrm{Nb}, \mathrm{Y}, \mathrm{Hf}, \mathrm{Ta}, \mathrm{Mo}, \mathrm{Au}, \mathrm{Ba}, \mathrm{Be}, \mathrm{Co}, \mathrm{Cr}, \mathrm{Cu}, \mathrm{Ga}, \mathrm{Ni}, \mathrm{Sc}, \mathrm{Th}, \mathrm{U}, \mathrm{V}, \mathrm{Zn}, \mathrm{Cl}, \mathrm{F}, \mathrm{Li}, \mathrm{Sn}$ e W, em ppm) e elementos terras raras(La, Ce, Pr, Nd, Sm, Eu, Gd, Tb, Dy, Ho, Er, Tm, Yb e Lu, em ppm). Os corpos granitóides e os, greissens foram analisados para o total dos elementos 
listados acima da seguinte forma: granitóides Antônio Vicente(24 amostras), Mocambo(06 amostras), Velho Guilherme(11 amostras), Benedita(06 amostras), Ubim/Sul(06 amostras) e Rio Xingu(02 amostras); greisens(04 amostras).

As análises químicas para os elementos maiores, elementos traços, exceto o Li e ETR(apenas para o maciço granitóide Antônio Vicente) foram realizadas no ACTLABS(Activation Laboratories Ltd, Ancaster, Ontário-Canadá). As análises para os elementos maiores foram realizadas através do método fusion-ICP(Inductively Coupled Plasma Emission), enquanto que os elementos traços(exceto $\mathrm{F} \mathrm{e} \mathrm{Cl}$ ) foram dosados através do método fusion-ICP/MS(Inductively Coupled Plasma-Mass Spectrometry). O F foi analisado pelo método SIE(Selective lon Electrode) e $\mathrm{Cl}$ pelo método INAA(Instrumental Neutron Activation Analysis). As análises para o Li e ETR(maciço granitóide Antônio Vicente) foram realizadas no Service D'analyses des Roches et Mineraux du Centre de Recherches Petrographiques et Geochimiques(Nancy-France). O método de análise utilizado foi AA(Atomic Absorption).

No que se refere às rochas granitóides da Suite Intrusiva Velho Guilherme, os dados químicos de rocha total aliados aos estudos petrográficos permitiram separar e classificar, com maior segurança, os diversos grupos de granitóides constitutivos de cada um dos maciços estudados, bem como possibilitaram compará-los(correlação intra e intergranitóides). Propiciaram, ainda, compará-los com granitóides de outras provincias nacionais e de outras regiões do mundo.

\subsection{4- Análises químicas em fases minerais}

Essas análises foram realizadas através de microssonda eletrônica do Departamento de Mineralogia e Petrologia do Instituto de Geociências da Universidade de São Paulo e de microscópio eletrónico de varredura(MEV) do laboratório de caracterização mineral da Faculdade de Engenharia de Minas da Escola Politécnica da Universidade de São Paulo.

As análises por microssonda foram realizadas em um equipamento marca JEOL, modelo.JXA, 8600, com cinco espectrêmetros, com EDS(Energy Dispersive System; para análises qualitativas) e WDS(Wavelenght Dispersive System; para análises quantitativas), tendo sido utilizado o sistema de análises automatizado Tracor-Northern(Norran Instruments 1990). Elas foram feitas em WDS e ocorreram de acordo com a rotina do laboratório, obedecendo as seguintes condições analíticas:

1-Voltagem de Aceleração: $15 \mathrm{KEV}$;

2-Feixe da Corrente: $20.10 \pm 0.10$; 
3-Diâmetro do Feixe:

a) $5 \mu \mathrm{m}$ (para as fases máficas anfibólio, minerais opacos e micas)

b) $10 \mu \mathrm{m}$ (para as fases feldspáticas sódicas)

c) $5 \mu \mathrm{m}$ (para as fases feldspáticas potássicas)

4- Desvio Padrão analítico máximo para os elementos maiores analisados em percentagem:

\begin{tabular}{|l|c|c|c|c|}
\hline Fases Minerais analisadas & Anfibólio & Minerais Opacos & Fases Micáceas & Feldspatos \\
\hline Elementos Analisados & & & & \\
\hline $\mathrm{Si}$ & 0,60 & 25,50 & 0,70 & 0,50 \\
\hline $\mathrm{Cl}$ & 3,80 & 25,50 & 25,50 & \\
\hline $\mathrm{F}$ & 25,50 & 25,50 & 25,50 & \\
\hline $\mathrm{Al}$ & 1,00 & 25,50 & 1,00 & 0,80 \\
\hline $\mathrm{K}$ & 2,50 & 25,50 & 5,20 & 17,30 \\
\hline $\mathrm{Na}$ & 3,40 & 25,50 & 25,50 & 18,90 \\
\hline $\mathrm{Ca}$ & 1,00 & 25,50 & 5,60 & 25,50 \\
\hline $\mathrm{Mg}$ & 1,00 & 25,50 & 1,00 & \\
\hline $\mathrm{Fe}$ & 1,00 & 1,00 & 1,00 & 25,50 \\
\hline $\mathrm{Ti}$ & 5,70 & 1,00 & 10,40 & \\
\hline $\mathrm{Mn}$ & 8,10 & 2,30 & 12,20 & 25,50 \\
\hline $\mathrm{Ba}$ & 25,50 & 25,50 & 25,50 & 2,50 \\
\hline $\mathrm{Sr}$ & & & & \\
\hline
\end{tabular}

As correções quantitativas ZAF para efeitos de matriz(Z: No. Atômico; A: Absorção; F: Fluorescência) foram executadas através do Programa PRZ(Noran Instruments 1990). 
Abaixo são apresentadas as fases minerais e elementos analisados, bem como os tipos de cristais e os padrões utilizados e o tempo de contagem.

\begin{tabular}{|l|c|c|c|}
\hline $\begin{array}{l}\text { FasesMinerais(Anfibólio+Mi } \\
\text {-cas+Minerais Opacos) } \\
\text { Elementos Analisados }\end{array}$ & Cristais & $\begin{array}{c}\text { Tempo Máximo de } \\
\text { Contagem (em segundos) }\end{array}$ & Padrões \\
\hline $\mathrm{Si}$ & TAP & 05 & Wollastonita \\
\hline $\mathrm{Ti}$ & LIF & 30 & Rutilo \\
\hline $\mathrm{F}$ & TAP & 10 & Bafluoreto \\
\hline $\mathrm{Al}$ & TAP & 8 & Corindon \\
\hline $\mathrm{Fe}$ & LIF & 14 & Hematita \\
\hline $\mathrm{Ba}$ & LIF & 40 & Basint \\
\hline $\mathrm{Cl}$ & PET & 10 & Tugtupita \\
\hline $\mathrm{Mn}$ & LIF & 40 & Rodonita \\
\hline $\mathrm{Ma}$ & TAP & 20 & Periclásio \\
\hline $\mathrm{Ca}$ & PET & 20 & Wollastonita \\
\hline $\mathrm{Na}$ & TAP & 10 & Andesina \\
\hline $\mathrm{K}$ & PET & 10 & OR2ST5 \\
\hline
\end{tabular}

\begin{tabular}{|l|c|c|c|}
\hline $\begin{array}{l}\text { FasesMinerais(Feldspatos) } \\
\text { E Elementos Analisados }\end{array}$ & Cristais & $\begin{array}{c}\text { Tempo de Contagem (em } \\
\text { segundos) }\end{array}$ & Padrões \\
\hline $\mathrm{Si}$ & TAP & 05 & Microclina \\
\hline $\mathrm{Sr}$ & PET & 50 & Srsint \\
\hline $\mathrm{Alr}$ & TAP & 05 & Corindon \\
\hline $\mathrm{Ba}$ & PET & 50 & Basint \\
\hline $\mathrm{Fe}$ & LIF & 50 & Hematita \\
\hline $\mathrm{Ca}$ & PET & 40 & Wollastonit \\
\hline $\mathrm{Na}$ & TAP & 10 & Andesina \\
\hline $\mathrm{K}$ & PET & 10 & Microclina \\
\hline
\end{tabular}

O estudo envolveu um total de 134 análises e foram dosados os óxidos $\mathrm{SiO}_{2}, \mathrm{TiO}_{2}$, $\mathrm{Al}_{2} \mathrm{O}_{3}, \mathrm{FeO}, \mathrm{MnO}, \mathrm{MgO}, \mathrm{CaO}, \mathrm{Na}_{2} \mathrm{O}, \mathrm{K} 2 \mathrm{O}, \mathrm{BaO}$ mais $\mathrm{F}$ e $\mathrm{Cl}$ (fases máficas) e $\mathrm{SiO}_{2}, \mathrm{Al}_{2} \mathrm{O}_{3}$ $\mathrm{FeO}, \mathrm{CaO}, \mathrm{SrO}, \mathrm{BaO}, \mathrm{Na}_{2} \mathrm{O}$ e $\mathrm{K}_{2} \mathrm{O}$ (feldspatos). Elas foram consideradas, em geral, muito boas, excetuando-se a isso, aquelas realizadas para plagioclásio rico em $\mathrm{Na}$ (albita), cujos valores da somatória dos álcalis(cátions na fórmula estrutural), na maioria dos casos, fecharam abaixo do satisfatório $(<3,80 \%)$. O material foi preparado na forma de secões delgadas polidas, circulares, as quais passaram por um processo de metalização à base de 
carbono. O conjunto das análises compreendeu amostras de granitóides e de greisen e foram assim discriminadas:

1) Maciço granitóide Antônio Vicente: 15 de anfibólio, 04 de biotita, 13 de clorita, 05 de minerais opacos, 15 de plagioclásio e 12 de feldspato potássico pertítico.

2) Maciço granitóide Mocambo: 04 de biotita, 10 de mica branca, 04 de plagioclásio e 02 de feldspato pertítico.

3) Maciço granitóide Benedita: 04 de clorita, 05 de feldspato pertítico e 03 de minerais opacos.

4) Maciço granitóide Ubim/Sul: 04 de clorita, 14 de mica branca, 08 de plagioclásio e 11 de feldspato pertítico.

O tratamento de dados visando os cálculos para determinação das fórmulas estruturais, classificação e nomenclaturas das fases minerais estudadas obdeceram as seguintes condições:

\section{1-Anfibólio}

Para os cálculos das fórmulas estruturais dessa fase mineral foi utilizado o método noticiado por Richard \& Clarke(1990), que encontra-se no "software" Minpet 2.02- Mineral and Petrological data Processing System(Richard, 1988-1995). A classificação dos mesmos obdeceu as recomendações da "International Mineralogical Association"(IMA), as quais constam em Leake(1978), Hawthorne(1981) e Leake et al.(1997).

Em razão das análises não fornecerem os conteúdos de $\mathrm{Fe}_{2} \mathrm{O}_{3}$, todos cátions foram recalculados com base em 23 átomos de oxigénio, conforme as recomendações de Leake(1978) e Hawthorne(1981). Posteriormente, o total dos cátions foi ajustado para $5+8=13$, pela variação $\mathrm{Fe}^{2+} / \mathrm{Fe}^{3+}$, excluindo-se $\mathrm{Ca}+\mathrm{Na}+\mathrm{K}($ Leake, 1978). Assim o método utilizado foi 13-CNK(Richard \& Clarke, 1990).

Para a classificação e nomenclatura, foram utilizados inicialmente os parâmetros $(\mathrm{Na}+\mathrm{K})_{\mathrm{B}}, \mathrm{Ti}, \mathrm{Fe}^{3+}$ e $\mathrm{Al}^{\mathrm{IV}}$, conforme as recomendaões de Leake(1978) e de Hawthorne(1981), em conformidade com a IMA e, posterioemente, foram aplicadas as recomendaçóes de Leake et al.(1997).

\section{2- Biotita}

Em relação à essa fase mineral, os cálculos das fórmulas estruturais foram realizados através do método de Deer et al.(1966) e tiveram por base 24 oxigênios e 2(OH), com os ânions $(\mathrm{O}, \mathrm{F}, \mathrm{Cl})$ fixos. As análises realizadas não forneceram os conteúdos de $\mathrm{H}_{2} \mathrm{O} e$ os conteúdos de $\mathrm{Li}$, não foram dosados diretamente na microssonda. Os teores de $\mathrm{H}_{2} \mathrm{O}$ foram calculados automaticamente por Minpete 2.02. Para a biotita da facies granitóide BSG 
do maciço Antônio Vicente os conteúdos FeO foram calculados inicialmente através de análises químicas, por via úmida(método de Wilson), em grãos de biotita separados no separador magnético Frantz. Os teores de $\mathrm{Fe}_{2} \mathrm{O}_{3}$ foram calculados a partir da relação dos conteúdos de ferro total, $\mathrm{FeO}_{\text {(total) }}$ fornecidos pela microssonda eletrônica, e aqueles de $\mathrm{FeO}$ onde $\% \mathrm{FeO}_{\mathrm{T}}=\% \mathrm{FeO}+0,8998 \mathrm{x} \% \mathrm{Fe} 2 \mathrm{O} 3$ (conforme Ragland, 1989, pg 36; Abdel-Rahman, 1994, pgs 527 e 529 ). Sabe-se, entretanto, que os conteúdos de FeO, calculados por via úmida, podem ser enganosos ou não representativos, visto que análises de minerais separados podem refletir mais de uma geraçăo, da fase em questão, na amostra analisada, ou podem corresponder a cristais zonados, muito comuns em granitóides diferenciados e em rochas aplíticas associados(Fonteilles, 1987; Monier et al., 1987; 1995; Cottsmann et al. 1994; Charoy et al., 1995. In: Tischendorf et al., 1997). Intercrescimentos, sobrecrescimentos e inclusões de outros minerais são outros fatores, mas não acarretam grandes problemas para o método da microssonda, embora possam afetar seriamente os resultados das análises em minerais separados(Tischendorf et al., 1997). No que se refere à biotita analisada por via úmida, as observações acima citadas não são descartadas, embora pareçam, pelo menos em parte, pouco prováveis, visto que na facies BSG(hospedeira) não foram observadas, através de microscopia ótica, outras gerações de biotita. Entretanto, o mesmo não pode ser dito em relação a presença ou não de intercrescimentos, sobrecrescimentos e inclusões nos cristais constituvos do concentrado analisado. Para a biotita dos granitóides dos demais maciços, os cálculos dos conteúdos de FeO foram realizados através da equação de Bruyn et al.(1983; In: Salonsaari, 1995, pg. 94), onde $\mathrm{FeO}=\left[-10,7325+0,0705^{*} \mathrm{SiO}_{2}+0,4598^{*} \mathrm{TiO}_{2}+0,3067^{*} \mathrm{Al}_{2} \mathrm{O}_{3}+0,8433^{*} \mathrm{FeO}^{\text {(total) }}+\right.$ $0,288^{*} \mathrm{MnO}-0,0581^{*} \mathrm{MgO}-0,0765^{*} \mathrm{CaO}-1,1295^{*} \mathrm{Na}_{2} \mathrm{O}+0,4172^{*} \mathrm{~K}_{2} \mathrm{O}$. A partir dos conteúdos de $\mathrm{FeO}$, calculados, e dos teores de $\mathrm{FeO}$ (total), obtidos através da microssonda eletrônica, pode-se calcular também os teores de $\mathrm{Fe}_{2} \mathrm{O}_{3}$. De posse desses resultados, foram recalculadas as fórmulas estruturais correspondentes a cada análise

Os cálculos das quantidades de aluminios tetredral( $\left.\mathrm{Al}^{\mathrm{IV}}\right)$ e octaedral(AI $\left.{ }^{\mathrm{V}}\right)$ foram feitos através do método apresentado por Deer et al.(1966; pgs 545-546), visto que quando calculados através do Minpet 2.02(cópia utilizada neste vtrabalnho), os valores são arredondados, perdendo-se com isso, a verdadeira relação entre essas duas quantidades.

Sendo o lítio um componente essencial em micas, especialmente naquelas de rochas granitóides diferenciadas, de pegmatitos e de aplitos(Tischendorf et al.(1997) e como seu conteúdo não é fornecida nas análises através de microssonda eletrônica, estimou-se os teores do mesmo, na biotita estudada, a partir da equação sugerida por Tindle \& Webb(1990), ligeiramente modificada e recomendada por Tischendorf et al.(1997). 
Obdeceu-se, para isso, as características composicionais da biotita em questão, onde $\mathrm{Li}_{2} \mathrm{O}=\left(0,289 x \% \mathrm{SiO}_{2}\right)-9,658$ para biotitas com $\mathrm{SiO}_{2}>34 \%$ e $\mathrm{MgO}<6 \%$.

\section{3- Clorita}

Para essa fase, os cálculos das fórmulas estruturais tomaram por base 14 oxigênios(meia fórmula), 6 grupos $(\mathrm{OH})$ e ânions $(\mathrm{O}+\mathrm{F}+\mathrm{Cl})$ fixos e foram realizados através do software Minpet 2.02(Richard, 1995). Os conteúdos de $\mathrm{H}_{2} \mathrm{O}, \mathrm{Fe}^{2+}$ e de $\mathrm{Fe}^{3+}$ foram calculados automaticamente através do Minpet 2.02. Os cálculos das quantidades de alumínios tetredral $\left(A I^{V}\right)$ e octaedral $\left(A l^{V I}\right)$ foram feitos através do método de Deer et al.(1966; pgs 545-546), já que quando elas são através do Minpet 2.02(cópia utilizada neste trabalho), os valores são arredondados, do mesmo modo que em relação a biotita.

\section{4-Muscovita}

Os cálculos das fórmulas estruturais dessa fase micácea tiveram por base 22 oxigênios e $2(\mathrm{OH})$, com os ânions $(\mathrm{O}, \mathrm{F}, \mathrm{Cl})$ fixos. As análises realizadas não forneceram os conteúdos de $\mathrm{H}_{2} \mathrm{O}$ e os conteúdos de $\mathrm{Li}$, não são dosados em microssonda eletrônica. $\mathrm{Os}$ teores de $\mathrm{Fe}^{2+}, \mathrm{Fe}^{3+}$ e de $\mathrm{H}_{2} \mathrm{O}$ foram calculados automaticamente pelo software Minpete 2.02. Os cálculos das quantidades de aluminios tetredral( $\left(\mathrm{Il}^{\mathrm{IV}}\right)$ e octaedral(AI $\left.{ }^{\mathrm{VI}}\right)$ foram feitos através do método de Deer et al.(1966; pgs 545-546), pelas mesmas razões apresentadas em relação à biotita e à clorita. Os conteúdos de $\mathrm{Li}_{2} \mathrm{O}$ foram estimados a partir da equação $\mathrm{Li}_{2} \mathrm{O}=0,3935^{\star} \mathrm{F}^{1,326}$, recomendada por Tischendorf et al.(1997), para micas dioctaédricas com $F=0,01$ a 8,00 , visto que como se sabe não se pode obtê-los através de análises por microssonda elewtrO6nica e não foi possivel realizar análises por via úmida.

\section{5- Feldspato potássico o Plagioclásio}

Os cálculos das fórmulas estruturais para essas duas fases foram efetuados através do software Minpet versão 2.02(Richard, 1995) e tiveram por base 32 oxigênios com os ânions $(\mathrm{O}+\mathrm{F}+\mathrm{Cl})$ fixos. Posteriormente, foram calculados os totais dos sítios $\mathrm{X}=\mathrm{Si}+\mathrm{Al} e$ $\mathrm{Z}=\mathrm{Ti}+\mathrm{Fe}^{2+}+\mathrm{Mg}+\mathrm{Ca}+\mathrm{Na}+\mathrm{K}$, bem como as proporções dos membros ternários finais $\mathrm{Ab}-\mathrm{Or}-$ $A n$, onde $A b=100 . \mathrm{Na} /(\mathrm{Ca}+\mathrm{Na}+\mathrm{K})$, Or $=100 \cdot \mathrm{K} /(\mathrm{Ca}+\mathrm{Na}+\mathrm{K})$ e $\mathrm{An}=100 \cdot \mathrm{Ca} /(\mathrm{Ca}+\mathrm{Na}+\mathrm{K})$, conforme recomendações de Deer et al.(1966).

As microanálises por fluorescência de raios-X através de MEV(Microscópio Eletrônico de Varredura, "back scattering"-BSD-eletron retroespalhados)foram realizadas em aparelho marca LEICA, modelo $S-440$ (Stereoscan-440), equipado com EDS(Energy 
Dispersive System; para análises qualitativas e semi-quantitativas). As microanálises foram pontuais e ocorreram em condições de $20 \mathrm{kvolts}$ e "fit index" inferior a 5.

Para elas foram envolvidas, essencialmente a caracterização semi-quantitativa(EDS) das as fases minerais acessórias, incluindo os minerais opacos em amostras de granitóides e de greisen, as quais foram assim discriminadas:

1) Maciço granitóide Antônio Vicente: 22 em fases minerais de granitóides e 13 em amostras de greisen.

2) Maciço granitóide Velho Guilherme: 28 análises em fases minerais de granitóides.

3) Maciço granitóide Mocambo: 22 análises em fases minerais de granitóides e 05 em fases minerais de greisen.

4) Maciço granitóide Benedita: 08 análises em fases minerais de granitóide.

5) Maciço granitóide Ubim/Sul: 02 análises em fases minerais de granitóide.

6) Maciço granitóide Rio Xingu: 03 análises em fases minerais de granitóide

Os resultados mostram-se apresentados sob a forma de anexos(ver mais adiante).

Almejou-se com isso caracterizar com maior precisão as fases minerais estudadas; compreender as condições de cristalização das fases minerais e dos granitóides hospedeiros, considerando-se para isso as fases minerais anfibólio, biotita, as fases óxidos( ilmenita e magnetida((fases primárias do estágio magmático) ) e clorita(fase secundária do estyágio de alterações tardi a pós-magmáticas). E apartir disso, pode-se estimar se intervalos de temperatura sob as quais os granitóides estudados cristalizaram, bem como em que condições de $\mathrm{fO}_{2}$ os mesmos evoluíra(se oxidantes ou redutoras), através da estimativa dos valores do $\left(\log \mathrm{fO}_{2}\right)$, (conforme parâmetros estabelecidos por Wones \& Eugster,1995). Adicionalmente, os dados de química mineral foram utilizados para determinação de geobarômetros(anfibólio) e geotermômetros(biotita e clorita), conforme pode será visto ao longo do texto

\subsection{5- Análises de Isótopos Estáveis}

Nos últimos anos um grande número de análises de isótopos de oxigênio tem sido realizadas em granitóides de todo o mundo(Taylor, 1978). No Brasil, face à grande carência de laboratórios especializados, a utilização desse tipo de método de investigação científica no estudo de rochas granitóides e silicatos é muito incipiente.

O estudo de isótopos de Oxigênio em granitóides tem fornecido importantes informações acerca da origem dessas rochas, bem como no que se refere às condições de formação e aos processos que afetaram os corpos granitóides após a sua colocação(Silvermam, 1951; Garlick, 1966; Taylor Jr., 1968; O'Neil et al., 1977; Taylor Jr, 1978; Hoefs, 1980; Rollinson, 1993; entre outros). 
De modo mais restrito, o estudo das razões ${ }^{18} \mathrm{O} /{ }^{16} \mathrm{O}$ é de grande utilidade para o entendimento dos três pricipais fenômenos relacionados às rochas plutônicas a saber: 1) quimismo e troca isotópica entre os plutons e as rochas encaixantes; 2 ) interações entre os plutons e fluidos de origens diversas; 3 ) processos de anatexia ou de assimilação de rochas sedimentares e metassedimentares durante a evolução e ascensão dos magmas.

Além disso, o estudo das razões ${ }^{18} \mathrm{O} /{ }^{16} \mathrm{O}$ em rocha total e em fases minerais tem sido usado para discriminar os principais tipos de protólitos de rochas granitóides(O'Neil, 1977; Cheang et al., 1986; entre outros), bem como determinar temperaturas de cristalização de magmas(O'Neil, 1977).

No que se refere aos granitóides da Suite Intrusiva Velho Guilherme, objetos de estudo, as principais razões que nos levaram a incluir as análises de isótopos de Oxigênio foram: 1) o interesse em caracterizar o tipo de protólitos dos referidos granitóides; 2) estudar as prováveis mudanças ocorridas durante os estágios magmático e tardi a pós-magmático. Considerou-se, para essas análises a fase mineral quartzo 1(ver Aspectos Petrográficos). Assim foram separados mecanicamente grãos de quartzo 1 oriundos dos termos menos evoluídos e mais evoluídos(extremos magmáticos) e das facies menos transformadas e mais transformadas(extremos tardi a pós-magmáticos) pertencentes aos maciço granitóide Antônio Vicente e de clorita-siderofilita-muscovita-quartzo greisen associado a este maciço, bem como grãos de quartzo 1 dos maciços Velho Guilherme e Mocambo.

As análises foram desenvolvidas no Geochron Laboratories Krueger Enterprises(Cambridge/Massachusetts-USA).

\subsection{6- Análises de Isótopos Radiogênicos}

Os estudos de isótopos radiogênicos envolveram análises pelos métodos $\mathrm{Pb}-\mathrm{Pb}$ em rocha total e em minerais(feldspato potássico e zircão). Essas análises compuseram diagramas isocrónicos utilizando-se para tal as razões ${ }^{206} \mathrm{~Pb} /{ }^{204} \mathrm{~Pb}$ vs. ${ }^{207} \mathrm{~Pb} /{ }^{204} \mathrm{~Pb}$. As idades obtidas foram relacionadas aos resultados originados através de análises isotópicas $\mathrm{Sm}-\mathrm{Nd}$, envolvendo idades modelo(TDM), valores de $\varepsilon N d(0)$ e de $\varepsilon N d(t)$, conforme De Paolo(1988).

As análises envolveram amostras dos granitóides dos maciços Antônio Vicente, Mocambo e Rio Xingu(Suite Intrusiva Velho Guilherme), de rochas metavulcânicas máficas dos Grupos Tucumã e São Felix, de rochas granitóides correlacionadas ao Granodiorito Rio Maria e de rochas vulcânicas andesíticas e riolíticas do Grupo Uatumã.

Elas foram realizadas no Laboratório de Geologia Isotópica(Pará-Iso) do Centro de Geociências da Universidade Federal do Pará( $\mathrm{Pb}-\mathrm{Pb}$ em rocha total, em feldspatos e em zircões por evaporação de $\mathrm{Pb}$ ) e no Centro de Pesquisas Geocronológicas(CPGeo) do 
Instituto de Geociências da Universidade de São Paulo(Sm-Nd). Segue-se uma síntese sobre o procedimento das análises:

1- Análises isotópicas pelo método $\mathrm{Pb}-\mathrm{Pb}$ em rochas e feldspatos

1.1- Siute Intrusiva Velho Guilherme

1.1.1- Maciço granitóide Antônio Vicente

Nesse maciço foram analisadas sete amostras de rochas e duas de feldspato potássico. Inicialmente foi construído um diagrama isocrônico com as sete amostras de rochas e duas frações de feldspato potássico. Uma das amostras de rocha não alinhou no diagrama e foi retirada devido corresponder a uma variedade de granitóide intensamente afetada por alterações tardi a pós-magmáticas(BSGIA). O novo diagrama construído, ainda, um alto valor de $M S W D(18,90)$, evidenciado um certo desalinhamento dos pontos experimentais referentes a duas amostras(facies BASAFG e BMG; ver itam Aspectos Petrográficos). Embora as duas amostras não indicassem quaisquer problemas geológicos, foi construido um terceiro diagrama isocrônico, sem essas duas amostras. Nele, foi obtido um baixo valor de $M S W D(4,47)$, indicativo de um maior alinhamento dos pontos experimentais, e uma idade similar aquela obtida no diagrama anterior. Assim, esse resultado foi considerado como a idade da intrusão do corpo granitóide como um todo.

\subsection{2- Maciço granitóide Rio Xingu}

Desse maciço foram analisadas quatro amostras de rochas. O diagrama construído indicou valor de MSWD igual a 0,06 evidenciando um excelente alinhamento dos pontos experimentais. A idade obtida foi interpretada como aquela de intrusão desse corpo.

\section{2- Grupo Uatumã}

Neste grupo foram analisadas oito amostras, sendo seis de amostras de rochas vulcânicas andesíticas, pertencentes à Formação Sobreiro e duas de rochas rioliticas da Formação Iriri. Em relação às amostras da Formação Sobreiro, foi inicialmente construído um diagrama isocrônico com valor de MSWD igual a 22,80, indicando um desalinhamento dos pontos experimentais e ,por conseguinte, pouca credibilidade para a idade obtida. Posteriormente, foram adicionadas ao diagrama isocrônico as duas amostras da Formação Iriri. O resultado obtido não melhorou, visto que o valor de MSWD obtido $(19,11)$ evidenciou um desalinhamento dos pontos experimentais. Tentativamente, foram retiradas do diagrama duas amostras da Formação Sobreiro, que mostravam-se muito desalinhadas, $e$, tentativamente, um novo diagrama isocrônico, para o Grupo Uatumã(Formações Sobreiro e Iriri) foi confeccionado. Nele, obteve-se um valor de MSWD igual a 5,95, indicando um bom 
alinhamento dos pontos experimentais. A idade obtida foi interpretada como sendo a idade do vulcanismo Uatumão na área estudada.

2- Análises istópicas em zircões pelo método de evaporação de $\mathrm{Pb}$

Conforme informações fornecidas pelo Pará-Isso(Prof. Dr. Cândido A. V. Moura), o método de dataçăo de monocristais de zircão por evaporação de $\mathrm{Pb}(\mathrm{Pb}-\mathrm{Pb}$ em zircão) permite determinar a idade aparente ${ }^{207} \mathrm{~Pb} /{ }^{206} \mathrm{~Pb}$ de um cristal de zircão em um espectrômetro de massa de termo-ionozação(Krober, 1986, 1987). As análises isotópicas foram realizadas em um espectrômetro marca FINNIGAN, modêlo MAT 262 e obedeceram a rotina do referido laboratório para esse tipo de análise.

\section{1- Procedimentos analíticos}

2.1.1- Suite Intrusiva Velho Guilherme

\subsubsection{1-Maciço granitóide Antônio Vicente}

Desse maciço foram analisados dez cristais de zircão da amostra IE-05(facies BASMG). Entretanto, em oito deles não foram obtidos sinais de $\mathrm{Pb}$ suficiente para as análises espectrométricas. Assim, apenas dois cristais foram analisados plenamente. $O$ primeiro, de número 6 , corresponde a um grão translúcido, de coloração castanha, forma prismática bipiramidal, fraturado e portadior de inclusões inclores, com relação $C: L$ de aproximadamente $3: 1$. O segundo, de número 8 , eqüivale a um cristal translúcido, rosa pálido, prismático bipiramidal, hospedeiro de inclusões arredondadas, com relação $C: L$ de aproximadamente $3: 1$.

No primeiro cristal a idade foi calculada a partir de 88 razões ${ }^{207} \mathrm{~Pb} /{ }^{206} \mathrm{~Pb}$, enquanto que no segundo a idade foi obtida com base na média de 18 razões ${ }^{207} \mathrm{~Pb} /{ }^{206} \mathrm{~Pb}$. As duas idades foram obtidas nas etapas de avaporação correspondentes às temperaturas de $1.500^{\circ} \mathrm{C}$ (grão 6) e $1.550^{\circ} \mathrm{C}$ (grão 8). A partir delas foi calculada a idade aparente ${ }^{207} \mathrm{~Pb} /{ }^{206} \mathrm{~Pb}$ média. As incertezas das análises foram de $2 \sigma$.

\subsubsection{2- Maciço granitóide Mocambo}

De acordo com o relatório de análises fornecido pelo Pará-Isso, nesse maciço foram analisados tentativamente seis cristais de zircão metamítico da amostra NN-GM-56(facies SMGP), uma vez que não foram obtidos grãos de outra natureza. Segundo o Prof Dr. Cândido A. V. Moura(responsável por essas análises no Pará-lsso) cristais metamíticos devem ser evitados pois podem falsear os resultados, uma vez que a metamitização destrói a estrutura cristalina do zircão, permitindo mais facilmente a abertura do sistema U-Pb no mineral $\mathrm{e} o$ conseqüente ingresso de $\mathrm{Pb}$ comum(contaminação). Por isso, procura-se 
sempre selecionar cristais não metamíticos e, preferencialmente, transparentes e sem inclusões ou fraturas. No entanto, quando zircões com essas caracteristicas não estão presentes, não resta outra alternativa a não ser analisar tentativamente, os cristais disponiveis. Em razão disso, por falta de opção de escolha, quatro cristais foram selecionados por serem os mais adequados para as análises como pode ser observado a segui:

Zircão 1: cristal opaco, acinzentado, prismático, metamítico, com relação C:L igual a 3:1.

Zircão 2: cristal opaco, cinza esverdeado, prismático, metamítico, quebrado em uma extremidade.

Zircão 3: cristal opaco, esbranquiçado com leve sobreton lilás, metamítico, com sobrecrescimento semelhante a uma geminação e com relação C:L igual a 3:1.

Zircão 5: cristal opaco, esverdeado, prismático, metamítico, com relação C:L de 2:1.

Assim, os quatro zircões analisados forneceram dados que permitiram calcular a idade aparente ${ }^{207} \mathrm{~Pb} /{ }^{206} \mathrm{~Pb}$. As idades obtidas nas primeiras etapas de evaporação dos zircões 3 e 5 foram eliminadas dos cálculos por apresentarem uma presença significativa de $\mathrm{Pb}$ de contaminação, traduzida pela razão $206 \mathrm{~Pb} / 204 \mathrm{~Pb}$ inferior a 2.500 .

\subsubsection{3- Maciço granitóide Rio Xingu}

Nesse maciço foram analisados seis grãos de zircões da amostra NN-AV43(facies SAFGP) e todos foram utilizados no cálculo da idade aparente $207 \mathrm{~Pb} / 206 \mathrm{~Pb}$. Os cristais analisados são muito similares como pode ser observado a seguir:

Zircão 1: cristal transparente, rosa claro, prismático bipiramidal e euédrico(relação $C: L=2: 1$ ). Zircão 2: cristal transparente, rosa claro, prismático, com relação C:L aproximadamente 2:1. Zircão 3: cristal transparente, prismático bipiramidal, portando inclusão incolor(relação C:L aproximadamente $2: 1$ ).

Zircão 4: cristal transparente, rosa claro, prismático bipiramidal, com relação $C: L$ aproximadamente $2: 1$.

Zircão 5: cristal transparente, rosa claro, prismático, portando inclusões incolores e exibindo fraturas, com relação $C: L=2: 1$.

Zircão 6: cristal transparente, rosa claro, prismático, hospedando inclusões incolores(relação $C: L=2: 1)$.

\subsection{2- Grupo São Felix}


$\mathrm{Na}$ amostra NN-GM-14 desse grupo correspondente a uma rocha metavulcânica máfica fora analisados oito cristais de zircões, sendo que em apenas seis grãos foi possivel determinar as idades aparentes:

Zircão 1: cristal subédrico, translúcido, rosado. Relação $C: L=2: 1$.

Zircão 2: cristal subarredondado, levemente translúcido, rosado. Relação C:L=2:1.

Zircão 3: cristal transparente, subédrico superficie de aspecto rugoso. Realação $C: L=2,50: 1$. Zircão 6: cristal transparente, subédrico. Relação $C: L=1: 1$.

Zircão 7: cristal transparente, subarredondado. Relação $C: L=1,500: 1$.

Zircão 8: cristal transparente e quebrado.

As idades aparentes 207Pb/206Pb fornecidas pelos zirções de números 6 e 7 não foram consideradas porque os valores das razões $206 \mathrm{~Pb} / 204 \mathrm{~Pb}$, obtidas nas diferentes etapas de avaporação situaram-se abaixo do limite de 2.500 aceito no laboratório.

As análises realizadas através do métrodo $\mathrm{Sm}-\mathrm{Nd}$ obdeceram os principios analíticos da rotina do CPGeo-IG/USP(Sato et al., 1995; Sato 1998).

Apartir dos dados obtidos buscou-se: a) posicionar temporalmente as unidades estudadas em termos de suas idades de colocação; 2) caracterizar as idades de seus protólitos e a natureza das áreas fontes dos mesmos, através da determinação das idades TDM e dos parâmetros $\mathbf{E N d}$, bem como caracterizar as prováveis áreas fontes(mantélica, crustal ou mistura de ambas) dos granitóides e das demais unidadses estudadas ; 3) verificar as possiveis afinidades entre o plutonismo Vetho Guilherme e o vulcanismo Uatumã; 4) caracterizar regionalmente possiveis candidatos a protólitos dos granitóides e vulcanitos referidos acima.

\subsection{7- Microtermometria}

No que diz respeito aos granitóides da Suite Velho Guilherme, o estudo das IFs foi realizado mediante a análise de seções delgadas polidas nas duas faces opostas(bi-polidas) de 10 amostras selecionadas entre as facies granitóides relativamente menos evoluidas e menos afetadas por alterações tardi a pós-magmáticas, entre aquelas mais evoluídas e mais afetadas por essas alterações e entre amostras de greisen(no sentido Stemprok, 1987), pertencentes ao maciço granitóide Antônio Vicente. A fase mineral selecionada, a partir dos estudos petrográficos, foi o quartzo 1 (ver Aspectos Petrográficos), visto que essa fase mineral é a que melhor se prestou para as análises em função da sua dimensão, transparência e das características de suas inclusões fluidas(ver mais adiante). Para esses estudos foram seguidos os principios estabelecidos, Roedder(1984). 
Os estudos foram realizados no Laboratório de Microtermometria do Departamento de Mineralogia e Petrologia do Instituto de Geocências da Universidade de São Paulo, sob a supervisão da Prof. Dr. Rosa Maria da S. Bello e consistiram de duas etapas.

$\mathrm{Na}$ primeira foi realizado o reconhecimento petrográfico, mapeamento, descrição e classificação dos diversos grupos de IFs, bem como foram confeccionados desenhos esquemáticos e fotomicrografias das mesmas.

A segunda etapa consistiu de observações e tomada de medidas microtermométricas em platina de resfriamento/aquecimento em aparelho de marca Chaimeca, desenvolvido pela "Societé Chaimeca" de Nancy/França(Poty et al., 1976) e, assim determinar as temperaturas do ponto eutético(TE), da fusão do gelo(Tfg) e de homogeneização da fase de vapor(Th). A finalidade da leitura dessas medidas foi determinar as características físico-químicas dos sistemas aquossalinos estudados(temperatura de aprisionamento das IFs, densidade das fases aquosas, salinidade dos sistemas e tipos de sistemas salinos)

\section{8- Plano de Apresentação}

Os estudos desenvolvidos, os resultados obtidos, os problemas ocorridos e as conclusões alcançadas serão apresentadas a seguir, iniciando-se pela geologia regional envolvendo aspectos lito-estratigráficos, estruturais e geocronológicos da área de ocorrência dos maciços granitóides da Suite Intrusiva Velho Guilherme, Provincia Estanífera do Sul da Pará, seguindo-se de capítulos envolvendo individualmente cada maciço e abordando aspectos da contextualização geológica, trabalho de fotointerpretação e de amostragem, aspectos petrográficos, de química mineral e quimica de rocha total, estudo de isótopos estáveis $\left({ }^{18} \mathrm{O} /{ }^{16} \mathrm{O} \mathrm{em}\right.$ grãos de quartzo 1), estudo de inclusões fluidas, datações radiométricas $\mathrm{e}$ isótopos radiogênicos. Finalmente, far-se-á a integração, análise e interpretação de todos os dados obtidos, que culminará com a elaboração de um modelo evolutivo para os granitóides da Suite Intrusiva Velho Guilherme. Como fechamento, será apresentado um capítulo de conclusões e recomendações. Seguir-se-ão a esse último capitulo as referências bibliográficas, os anexos e as pranchas. 


\section{CAPÍTULO 2}

\section{2- GEOLOGIA REGIONAL.}

Em termos regionais, a área da Folha SB-22-Y-B(São Felix do Xingu), portadora dos granitóides em estudo, situa-se tectonicamente no contexto do Craton Amazônico(Almeida, 1978), mais especificamente, no Bloco Araguacema(Hasui et al.,1984). Abrange porções arqueanas representadas por unidades do Terreno Granito-Greenstone do Sul do Pará(Araújo et al., 1988) ou Terreno Granito-Greenstone de Rio Maria(Costa et al., 1995) e do Cinturão de Cisalhamento Itacaiúnas(Araújo et al., 1988), bem como abriga conjuntos intrusivos máficos-ultramáficos e ácidos, paleoproterozóicos e mesozóicos e uma área significativa da Bacia do Médio Xingu de idade Proterozóica(CPRM/DNPM, 1991). Diversos modelos de compartimentação e evolução do Craton Amazônico tem sido propostos dentre os quais destacam-se os de Amaral(1974), Almeida et al.(1981), Cordani \& Brito Neves(1982), Teixeira et al.(1989) e Tassinari(1996). Sínteses recentes sobre os diversos modelos geotectônicos propostos para a compartimentação do Craton Amazônico constam em Santos(1996), Borges(1997), Pinheiro(1997) e Lenharo(1998). Neste trabalho, é adotado o modelo mobilista de acresção continental, cuja versão mais atualizada(Tassinari, 1996) mostra-se representada pela Figura 2.1.

Geograficamente, situa-se na regiăo sul-sudeste do Estado do Pará, na aba oestesudoeste da Serra dos Carajás, abrangendo áreas dos Municípios de São Felix do Xingu e Tucumã.

Estudos geológicos nessa região vem se desenvolvendo por mais de duas décadas e, ao longo desse tempo, diversas propostas de cartas geológicas foram apresentadas, bem como uma série de arranjos lito-estratigráficos e modelos de evolução tectónica-estrutural tem sido idealizados(Silva et al., 1974; Hirata et al., 1982; DOCEGEO, 1988; Araújo et al., 1988; CPRM/DNPM, 1991; Costa et al, 1995; Pinheiro, 1997).

Neste trabalho será adotado, embora com reservas, o mapa geológico regional, na escala 1:250.000, elaborado pelo convênio CPRM/DNPM, relativo ao "Projeto Especial Mapas de Recursos Minerais do Solo e de Vegetação para a Area do Programa Grande Carajás/Sub-Programa Mapas Metalogenéticos e de Previsão de Recursos Minerais", desenvolvido no período entre 1986 e 1991(Faraco et el., 1991; Macambira \& Vale no Prelo), que corresponde à Folha SB-22-Y-B(Folha São Felix do Xingu), Figura 3.

A utilização deve-se ao fato do mesmo representar o trabalho de mapeamento geológico mais recente realizado na área de ocorrência dos granitóides em estudo. Em 
relação aos aspectos estratigráfico e tecto̊nica-estruturais, serão assumidas, em parte, as proposiçðes de CPRM/DNPM(1991) e, adicionalmente, as de Costa et al.(1995). Essa última por representar a tentativa mais atualizada de integração das informações geológicas e geocronológicas da regiáo de abrangência do Programa Grande Carajás. Ela teve por base os trabalhos realizados pela CPRM(Araújo \& Maia, 1991; Araújo et al., 1988; Araújo et al., 1992; Araújo et al., 1994; Faraco et al., 1991; Costa et al., 1992; Costa et al., 1993; Costa et al., 1994; Macambira \& Vale, no prelo; Macambira et al., 1994), por pesquisadores do Centro de Geociências da Universidade Federal do Pará(Gastal et al., 1987; Gonçalez et al., 1988; Macambira \& Lancelot, 1991a e 1991b; Macambira \& Lancelot, 1992; Macambira \& Lafon, 1994; Macambira et al., 1990; Macambira et al., 1991, Macambira et al., 1993; Lafon \& Macambira, 1990; Lafon et al., 1991; Lafon et al., 1994; Lafon et al., 1995), bem como por outros trabalhos realizados na regiåo(Olszewski et al., 1989; Machado et al., 1991; Pimentel \& Machado, 1994).

Embora a carta geológica acima referida dé um idéia bastante razoável acerca da distribuição geral das unidades litológicas que constituem a área da folha, bem como sobre o arranjo estratigráfico das mesmas, essa tentativa apresenta uma série de imperfeiçóes, as quais são impostas por: 1) dificuldades de acesso às diversas áreas da folha; 2) auséncia, muitas vezes, de bons afloramentos envolvendo as várias unidades lito-estratigráficas que constituem a geologia da folha; 3 ) falta de visualização, diretamente no campo, das relações de contato entre elas; 4) insuficiência de dados petrográficos, estruturais, químicos e isotópicos acerca de grande parte das unidades da folha. Uma das relevâncias deste trabalho é dirimir, pelo menos em parte, essas imperfeições.

\section{1-Litoestratigrafia, Aspectos Estruturais e Geocronologia}

A realidade geológia de Fotha SB-22-Y-B e fruto da atuaçăo de diversos processos termo-tectónicos desenvolvidos no Aqueano e no Proterozóico, os quais mostram-se testemunhados em unidades lito-estratigráficas e evidenciados por elementos estruturais pertencentes ao Terreno Granito-Greenstone do sul do Pará ou de Rio Maria, ao Cinturão de Cisalhamento Itacaiúnas e à Bacia do Médio Xingu(Figura 2.2). Além disso, estão presentes Intrusões Ácidas e Máfico-Ultramáficas Proterozóicas, Intrusões Máficas Mesozóicas e Coberturas Sedimentares Cenozóicas(CPRM/DNPM, 1991; Costa et al., 1995). O Quadro 2.1 sumariza o arranjo lito-estratigráfico mais recente proposto para a Folha São Felix do Xingu, de acordo com CPRM/DNPM(1991) e, adicionalmente, são apresentados dados produzidos por Teixeira et al.(1998) e neste trabalho. 
Figura 2.1- Mapa tectônico do Craton Amazônico(Tassinari, 1996) mostrando a localizaçăo da área de ocorrência dos maciços granitóides da Suite Intrusiva Velho Guilherme, Folha SB-22-Y-B(São Felix do Xingu). Região sul-sudeste do Estado do Pará. 


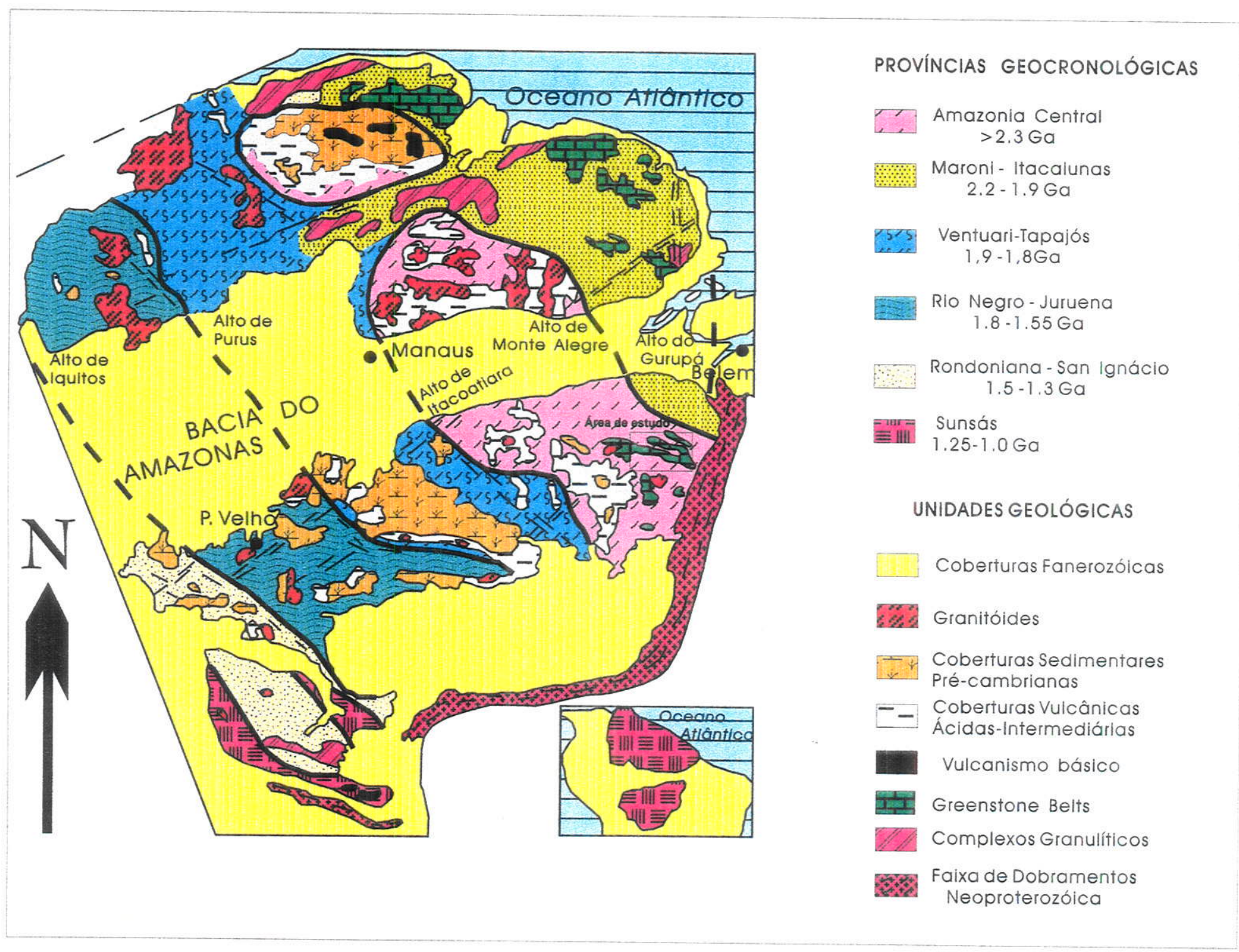


Quadro 1. Resumo esquemático do arranjo lito-estratigráfico mais recente proposto para a Folha São Felix do Xingu, de acordo com CPRM/DNPM(1991) e, adicionalmente, dados produzidos neste trabalho. (1)Silva et al.(1974); (2) Amaral(1974); (3) Basei(1975); (4) Lafon et al.(1991); (5) Cunha et al.(1991); (6) CPRM/DNPM(1991); (7) Machado et al.(1991); (8) Macambira \& Lancelot(1991ª); (9) Macambira \& Lancelot(1992); (10) Rodrigues et al.(1992); (11) Machado(1994); (12) Lafon et al.(1995); (13) Teixeira et al.(1998).

\begin{tabular}{|c|c|c|c|c|}
\hline ERAS & PERIOODOS & UNIDADES & LITOLOGIAS & IDADES(Ma)/MÉTODOS \\
\hline \multirow[t]{3}{*}{ FANEROZÓICO } & \multirow[t]{2}{*}{ Cenozóico } & $\begin{array}{l}\text { Quaternário } \\
\text { Colúvio-Aluvionar }\end{array}$ & $\begin{array}{l}\text { Sedimentos Inconsoilidados, predominantemente areno- } \\
\text { argilisos }\end{array}$ & \\
\hline & & Terciário Laterítico & $\begin{array}{l}\text { Oxidos-Hidroxidos de Fe e Al, argilo minerais e minerais } \\
\text { resistatos }\end{array}$ & \\
\hline & Mesozóico & Diabásio Cururu & Diques de Diabásio & $\mathrm{K} / \mathrm{Ar}=120-1809 \mathrm{roch}$ total $(1)$ \\
\hline \multirow{7}{*}{ PROTEROZÓICO } & \multirow{7}{*}{ Mesoproterozóico } & Formação Triunfo & $\begin{array}{l}\text { Quartzo-arenitos e arenitos arcoseanos com intercalaç̧̃es } \\
\text { de niveis de siltitos e conglomerados. }\end{array}$ & Sem dataçð̄es \\
\hline & & \multirow{6}{*}{ Suite Intrusiva Velho Guilherme } & $\begin{array}{l}\text { Macico Granitbide Mocambo: sieno a monzogranito } \\
\text { porfiŕtico; sienogranito com muscovita. }\end{array}$ & $\begin{array}{l}\begin{array}{l}\mathrm{Pb}-\mathrm{Pb}=1.862 \pm 32(\text { zircóes por evaporaçẵo } \\
\text { de } \mathrm{Pb})(13)\end{array}\end{array}$ \\
\hline & & & $\begin{array}{l}\text { Maciço Granitbide Vetho Guilherme: biofita sienogranito } \\
\text { equigranular médio; sienogranito heterogranular, } \\
\text { microssienogranito. }\end{array}$ & $\begin{array}{l}\mathrm{Rb} / \mathrm{Sr}=1.653 \pm 28 \text { (rocha total)(4) } \\
\mathrm{RJ}=0,7082 \pm 0,0236 \\
\mathrm{MSWD}=1,71\end{array}$ \\
\hline & & & & $\begin{array}{l}\mathrm{Pb}-\mathrm{Pb}=1.874 \pm 30 \text { (rocha total } \mathrm{e} \\
\text { feldspato)(12) } \\
\mu 1=8,9 \pm 0,14 \text { (simples) } \\
M S W D=1,53\end{array}$ \\
\hline & & & $\begin{array}{l}\text { Maciço Granitóide Antônio Vicente: biotita sienogranito, } \\
\text { biotita monzogranito, anfibólio-biotita sienogranito, } \\
\text { biotitata-anfibolifo ólcali-feldspato granito, biotita } \\
\text { sienogranito com clorita; alcali-feldspato granito. }\end{array}$ & $\begin{array}{l}\mathrm{Pb}-\mathrm{Pb}=1.1896 \pm 9(\text { rocha total } \mathrm{e} \\
\text { feldspato)(13) } \\
\mathrm{MSWD}=4,47 \\
\mu 1=9,2 \pm 0,06 \text { (simples) } \\
\mu 2=12,0,16 \text { (Stacey \& Kramers) } \\
\mathrm{Pb}-\mathrm{Pb}=1.867 \pm 4 \text { (zirçes por evaporaço } \\
\text { de Pb)(13) }\end{array}$ \\
\hline & & & $\begin{array}{l}\text { Maciço granitbide Rio Xingu: sieno a álcali-feldspato } \\
\text { granito. }\end{array}$ & $\begin{array}{l}\mathrm{Pb}-\mathrm{Pb}=1,906 \pm 29 \text { (rocha total) }(13) \\
\mathrm{MSWD}=0,06 \\
\mu 1=9,3 \pm 0,11 \text { (simples) } \\
\mu 2=12,6 \pm 0,32 \text { (Stacey \& Kramers) } \\
\mathrm{Pb}-\mathrm{Pb}=1.866 \pm 3 \text { (zircōes açăo dePb)(13) }\end{array}$ \\
\hline & & & $\begin{array}{l}\text { Macicos granitidides Benedita, Ubim/Sul, Ubim/Norte, } \\
\text { Serra ds Queimada e Bom Jardim: bioutita -álcali-feldspato } \\
\text { granito; alcali-feldspato granto; biotita sienogranito com } \\
\text { clorita; biotita monzogranito; granitos indiferenciados. } \\
\end{array}$ & Sem dataçōes \\
\hline
\end{tabular}




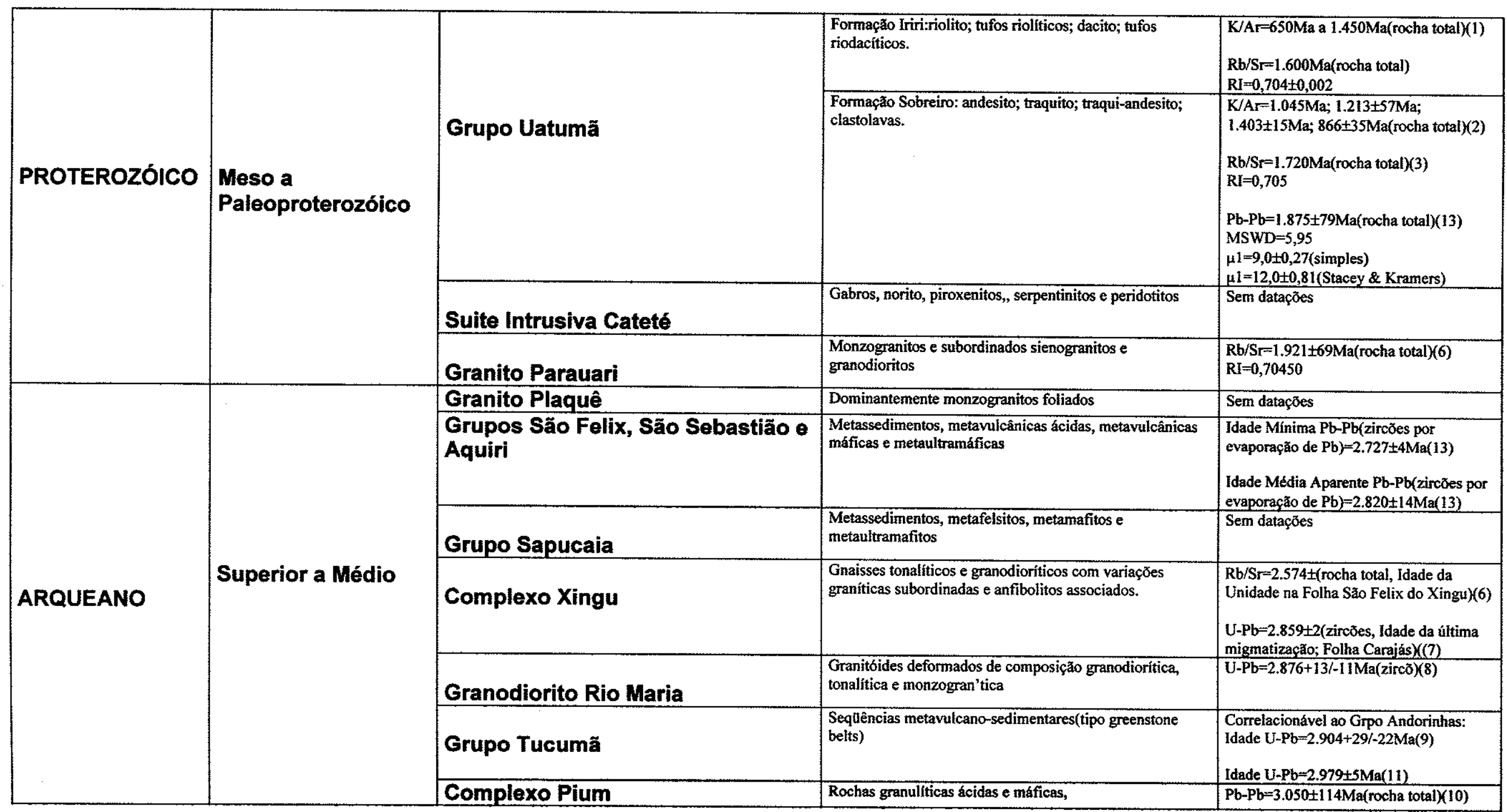




\subsection{1-Aqueano}

\subsubsection{1-Terreno Granito Greenstone do Sul do Pará}

O Terreno Granito-Greenstone do Sul do Pará(CPRM/DNPM, 1991) ou Terreno Granito-Greenstone de Rio Maria(TGGRM; Costa et al., 1995), de Idade Arqueana(Figuras 2.2 e 2.3) abriga, na área da Folha São Felix do Xingu, seqüências metavulcanosedimentares(tipo "greenstone belts") pertencentes ao Grupo Tucumã(CPRM/DNPM, 1991) e um conjunto de rochas granitóides deformadas, de composição variável desde granodiorítica/tonalítica a monzogranítica, correlacionáveis ao Granodiorito Rio Maria(Medeiros, 1987). De acordo com CPRM/DNPM(1991), o Grupo Tucumã está representado pelas Formações Igarapé do Cuca(metavulcânicas máficas), Igarapé da Abelha(metassedimentos e meta-vulcânicas ácidas e máficas) e lgarapé da Pista(metassedimentos).

As relações de contato entre as unidades do Grupo Tucumã e o Granodiorito Rio Maria são discordantes. Os granitóides mostram natureza intrusiva em relação às supracrustais. A estruturação interna é caracterizada por zonas de cisalhamento oblíquas, formadas em condições de facies xisto verde, com componente direcional dextral, orientadas preferencialmente na direção NW-SE, com mergulhos fortes para NE e com lineação de estiramento disposta predominantemente na direção NE-SW e mergulho para NE. Essas zonas são marcantes no domínio do Grupo Tucumã e fracamente desenvolvidas no Granodiorito Rio Maria(Figura 2.3).

Datações radiométricas àcerca das rochas do Grupo Tucumã inexistem. Entretanto, elas foram correlacionadas às do Grupo Andorinhas(DOCEGEO, 1988), expostas na Folha Pau D'Arco, a sudeste da Folha São Felix do Xingu. Macambira \& Lancelot(1992) dataram pelo método U-Pb as rochas metariodacíticas do Grupo Andorinhas, e obtiveram uma idade de 2.904+29/-22 Ma. Utilizando o mesmo método, Macambira \& Lancelot(1991a) e Macambira(1992), obtiveram para os granitóides do Granodiorito Rio Maria uma idade de 2.876+13/-11 Ma. Posteriormente, Pimentel \& Machado(1994) dataram zircões de rochas vulcånicas félsicas pertencentes ao Grupo Andorinhas, obtendo uma idade de $2.979 \pm 5 \mathrm{Ma}$.

De acordo com Costa et al.(1995) esses dados geocronológicos estão em perfeita consonância com as observações de campo, possibilitando, portanto, uma correlação entre os dois grupos. Entretanto, observa-se que os dados apresentados pelo referido autor não eleminam, de forma inequivoca, as incertezas existentes àcerca da ldade das rochas do Grupo Tucumã, ficando para o futuro esse esclarecimento. Além disso, associações litológicas muito semelhantes, àquelas descritas como pertencentes ao Grupo Tucumã, ocorrentes na mesma folha, foram atribuidas aos Grupos Aquiri, São Sebastião e São Felix(ver mais adiante). 
Figura 2.2-. Mapa Tectónico regional da Folha SB-22-Y-B(Folha Såo Felix do Xingu), mostrando os três grandes compartimentos geotectônicos $(A, B$ e $C)$ do Arqueano/Mesoproterozóico, seus Domínios e Sistemas Estruturais e Intrusões Ácidas e Máfico-Ultramáficas Proterozóicas. Dentre essas últimas são apresentados os Corpos Granitóides da Suite Intrusiva Velho Guilherme(1- Maciço Granitóide António Vicente; 2- Granitóide Benedita; 3- Granitóide Ubim/Sul; 4- Granitóide Rio Xingu; 5Granitóide Mocambo; 6- Maciço Granitóide Velho Guilherme. Fonte:CPRM/DNPM(1991). Regiăo Sudeste do Pará. 

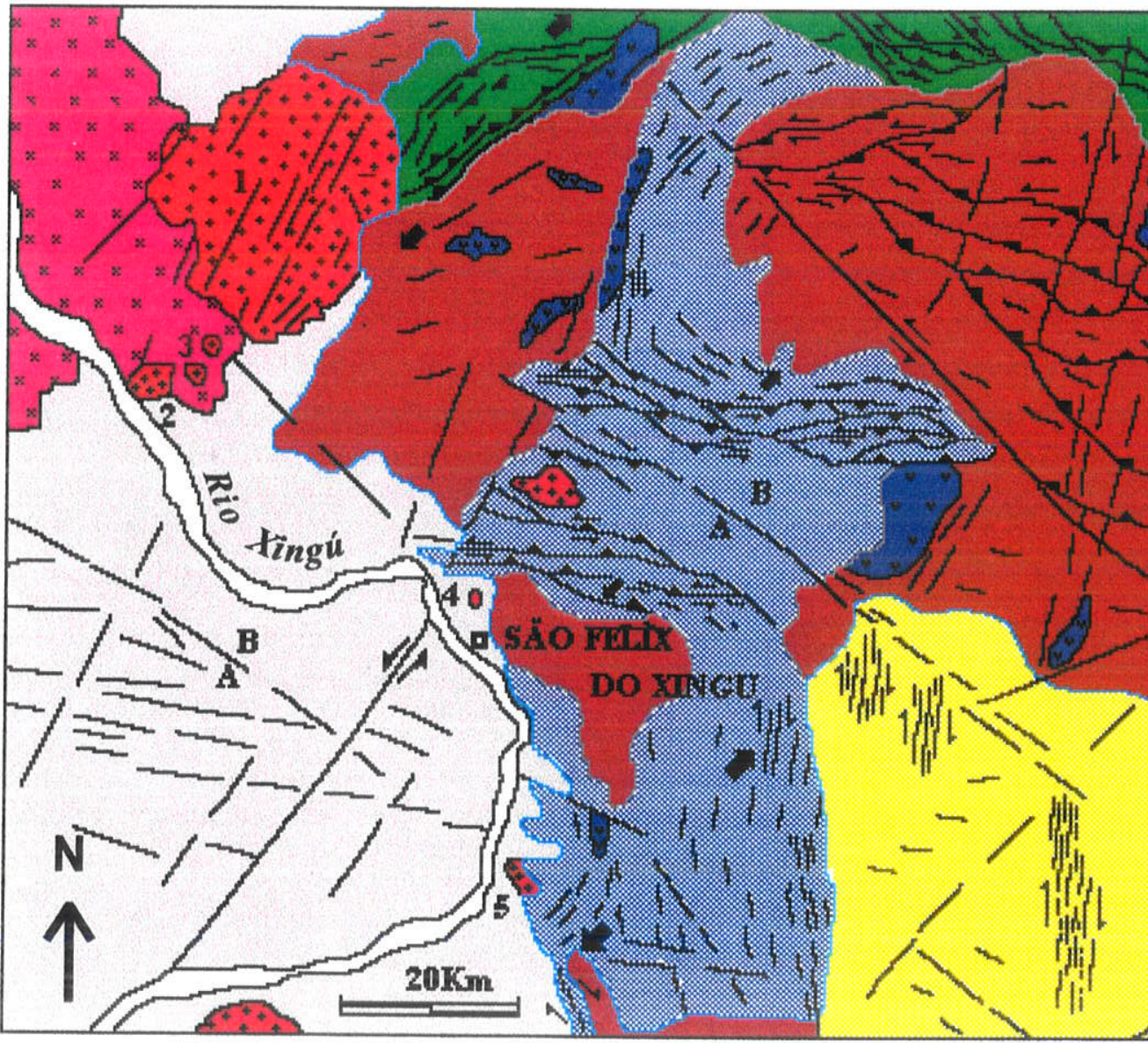

\section{A - TERRENO GRANITO-GREENSTONE DO SUL DO PARÁ} (REGIME DIRECIONAL)

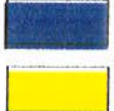

Hemiflores positivas (Grupo Tucumã)

Granitóides (Granodiorito Rio Maria)

\section{B - CINTURÃO DE CISALHAMENTO ITACAIÚNAS}

(REGIME COMPRESSIVO OBLIQUO)

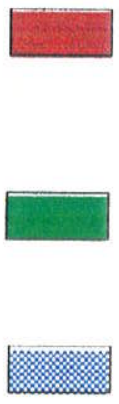

DOMINIO IMBRICADO

Complexo Pium

Complexo Xingú

Granito Plaqué

Grupo Sapucaia

DOMÍNIO Transcorrente

Sistema Anaporã

Grupo Aquiri

Grupo São Sebastião

SISTEMA ARARAQUARA

Grupo São Félix

\section{INTRUSÕES PALEOPROTEROZÓICAS}

* Composição Ácida

Composição Máfica-ultramáfica

\section{C - BACIA DO MÉDIO XINGU}

Grupo Uatumã

Formação Sobreiro

Formação Iriri

\section{CONVENCOÖES}

Limites entre undidades geotectônicas

Limites entre sistemas

1) Fraturas indiscriminadas

B/A Falha normal

Falha transcorrente

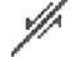

Zona de cisalhamento com cavalgamento obliquo sinistral

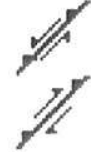

Zona de cisalhamento com cavalgamento oblíquo dextral

_ Zona de cisalhamento direcional dextral

픈 discreta

Z- Zona de cisallhamento direcional sinistral discreta

그는 Zona de cisalhamento direcional dextral

$\cong \quad$ Zona de cisalhamento direcional sinistral

7 Lineaçáo de estiramento

- Sentido do transporte de massas rochosas nos diferentes sistemas estruturais

SUITE INTRUSIVA VELHO GUILHERIME

* Maciços Granitóides:

1- Antonio Vicente; 2- Benedita; 3 - Ubim/Sul;

4- Rio Xingú; 5- Mocambo; 6- Velho Guilherme. 
Figura 2.3 Mapa geológico da Folha SB-22-Y-B(São Felix do Xingu) mostrando as principais unidades lito-estratigráficas ocorrentes na região(adaptada de Faraco et al., 1991). 


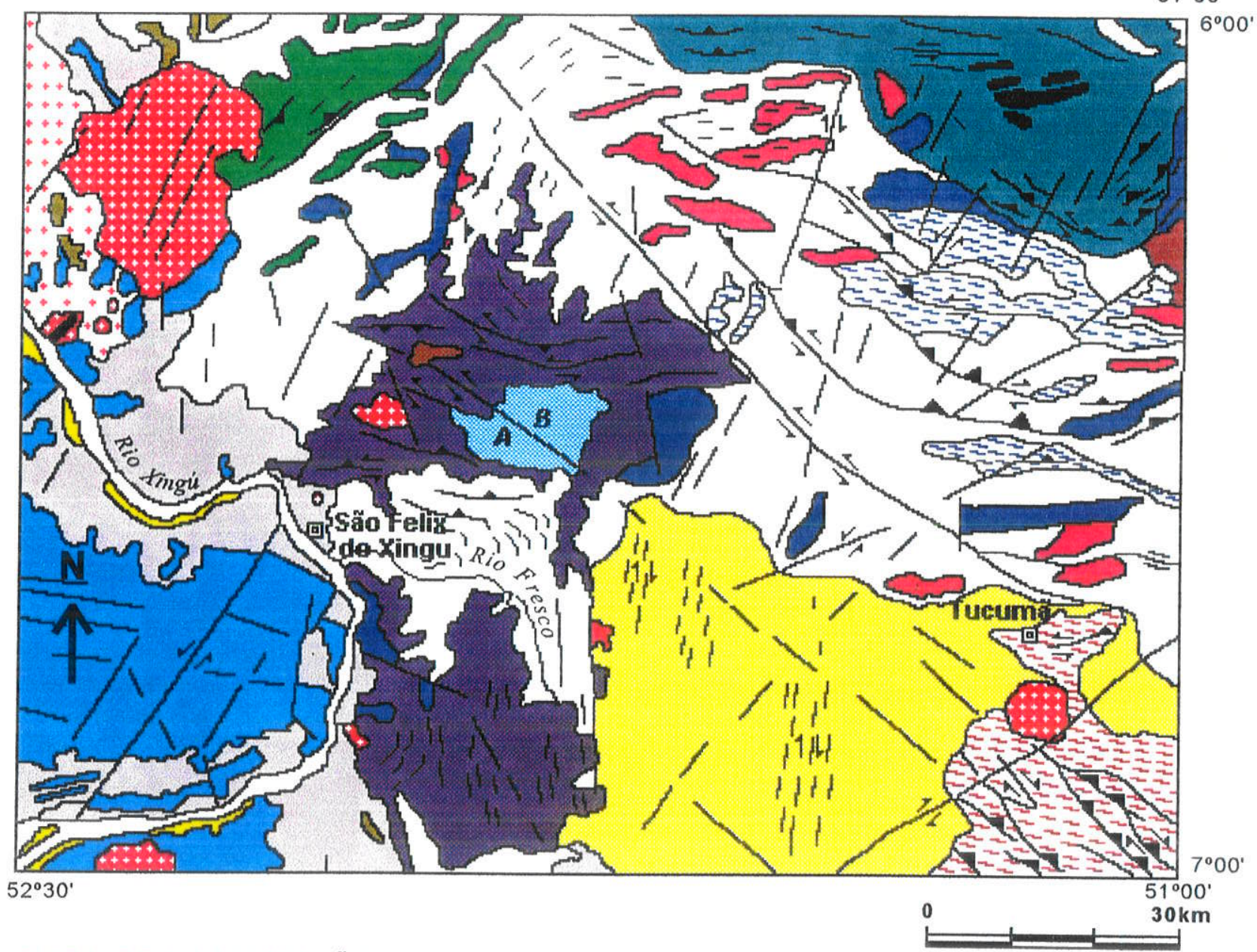

\section{MAPA DE LOCALIZAÇÃO}

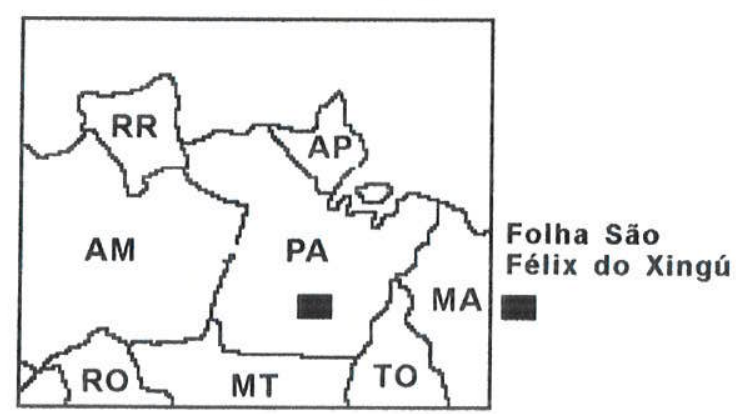

\section{CONVENÇÕES}

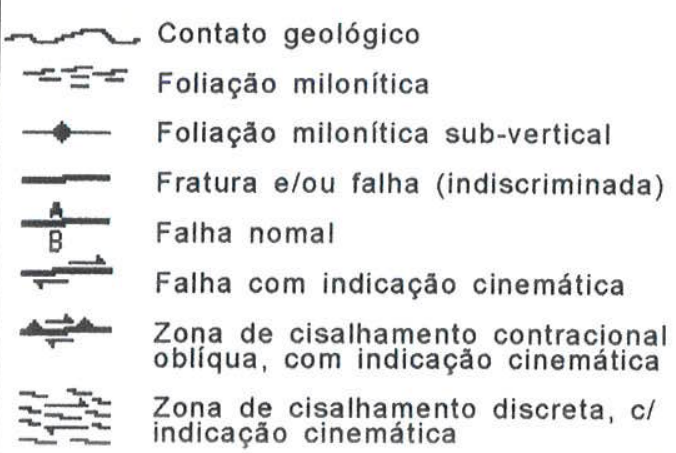

\section{CENOZÓICO}

Quaternário

Terciário MESOZÓICO

Diabásio Cururu MESO A PALEOPROTEROZÓICO

F+: Suite intrusiva Velho Guilherme Formação Triunfo

Grupo Uatumã: Formação Iriri

Grupo Uatumã: Formação Sobreiro Suíte Intrusiva Cateté Granito Parauari

\section{ARQUEANO SUPERIOR A MÉDIO}

Granito Plaquê

Grupo São Félix

Grupo São Sebastião

Grupo Aquiri

E-Z Grupo Sapucaia

Complexo Xingú

Granodiorito Rio Maria

Grupo Tacumã

Complexo Pium 


\subsubsection{2-Cinturão de Cisalhamento Itacaiúnas}

Representa o compartimento geotectônico de maior expressão em área de distribuição na folha. Está constituído por rochas de Idade Arqueana, intensamente deformadas, lenticularizadas, cujas feições estruturais induziram CPRM/DNPM(1991) e Costa et al.(1995) a agrupá-las em dois domínios a saber: 1) Domínio Imbricado; 2) Domínio Transcorrente(Figura 2.2).

\subsubsection{1-Domínio Imbricado}

Este domínio é constituído por rochas granulíticas pertencentes ao Complexo Pium(Araújo et al., 1988), por gnaisses do Complexo Xingu(Silva et al., 1974) e pelo Granito Plaquê(Araújo et al., 1988), bem como por seqüências metavulcano-sedimentares do Grupo Sapucaia(Figura 2.3 e 2.4).

\subsubsection{1- Complexo Pium}

O Complexo Pium(unidade mais antiga aflorante na folha) é formado por granulitos máficos e félsicos(kinzigitos, periclasitos e granoblastitos). De acordo com Costa et al.(1995) representa frações de crosta inferior que foram lançadas ao nível de crosta superior através da componente de cavalgamento de zonas de cisalhamento obliquas. Essas lascas alternam-se com faixas de gnaisses do Complexo Xingu. Datações radiométricas pelo método $\mathrm{Pb}-\mathrm{Pb}$ em rocha total, realizadas por Rodrigues et al.(1992), indicaram uma idade de $3.050 \pm 57$ Ma para essa unidade.

\subsection{2- Complexo Xingu}

O Complexo Xingu, por sua vez, está amplamente distribuído na área da folha. Consiste de gnaisses de composição granodiorítica a tonalítica, que mostram-se migmatizados em diferentes graus e exibem estruturas estromatiticas freqüentes. Estudos geocronológicos utilizando o método $\mathrm{Rb}-\mathrm{Sr}$ em rocha total indicaram uma idade mínima para essa unidade igual a $2.574 \pm 34 \mathrm{Ma}(\mathrm{CPRM} / \mathrm{DNPM}, 1991)$.Entretanto, datações radiométricas realizadas por Machado et al.(1991) através do método $\mathrm{Pb}-\mathrm{Pb}$, em rocha total forneceram uma idade de $2.859 \pm 2 \mathrm{Ma}$, a qual foi considerada como a idade do último evento de migmatização. Neste trabalho, foram realizadas diversas tentativas de datações de zircões(por evaporação de $\mathrm{Pb}$ ), de rochas gnáissicas, finamente bandadas, aflorantes na porção sul-sudeste do maciço granitóide Antônio Vicente. Todas as tentativas foram frustradas, visto que um amplo espectro de idades foi obtido, não permitindo estabelecer uma idade inequívoca para as rochas do Complexo Xingu na região. 


\subsection{3- Granito Plaquê}

O Granito Plaquê representa corpos granitóides estratóides de natureza sincolisional, de composição granítica e com trama planar penetrativa. Do mesmo modo que as rochas do Complexo Pium, forma corpos lenticularizados dispostos preferencialmente na diração $E-W$, os quais alternam-se com faixas do Complexo Xingu. Até o momento, não foram realizados estudos geocronológicos nas rochas dessa unidade.

\subsection{4- Grupo Sapucaia}

O Grupo Sapucaia está representado por seqüências metassedimentares comprendendo xistos, quartzitos e formações ferríferas, dispostas sob a forma de faixas orientadas na direção E-W, que encontram-se alternadas com faixas do Complexo Xingu(Costa et al., 1995). Datações geocronológicas acerca dessa unidade inexistem. Entretanto, DOCEGEO(1988), do mesmo modo como fez para o Grupo Tucumã, correlacionou as rochas desse grupo com aquelas do Grupo Andorinhas.

\subsubsection{2-Dimínio Transcorrente}

Conforme CPRM/DNPM(1991) este domínio compreende os sistemas Anaporã(ENEWSW) e Araraquara(N-S), Figura 2.3.

\subsubsection{1- Sistema Anaporã}

Este sistema Anaporã está representado pelos Grupos Aquiri(Soares et al., 1988) e São Sebastião( CPRM/DNPM, 1991; Macambira \& Vale, no prelo).

\subsection{1- Grupo Aquiri}

Este grupo(Figura 2.3) está constituído por uma seqüéncia metavulcano-sedimentar que abriga rochas metavulcânicas ácidas e máficas, metassedimentos, arenitos a arcóseos. Embora não tenha sido objeto de estudos geocronológicos, foi correlacionado ao Grupo Grão Pará(Silva et al., 1974). Nesse grupo as datações radiométricas realizadas em rochas metavulcânicas félsicas, pelo método U-Pb em zircões, revelaram idade igual a $2.758 \pm 39$ $\mathrm{Ma}($ Wirth et al., 1986) e pelo método $\mathrm{Rb}-\mathrm{Sr}$ (rocha total) em basaltos, uma idade de $2.687 \pm 54$ Ma(Gibbs et al., 1986). Foi considerado de idade Arqueana superior(CPRM/DNPM, 1991) e, tentativamente, foi correlacionado aos demais conjuntos supracrustais associados aos sistemas transcorrentes relacionados à evolução do Cinturão de Cisalhamento Itacaiúnas, tomando-se como exemplo os Grupos São Felix, São Sebastião e Grão Pará.

Costa et al.(1995) admitem que houve diacronismo no desenvolvimento dessas unidades, assumindo a idéia de estarem ligadas a um mesmo evento, apesar de estarem relacionadas a sistemas transcorrentes independentes. De qualquer modo, isso é 
considerado apenas como uma hipótese, visto que os dados existentes são insuficientes e qualquer conclusão, a esse respeito, é muito prematura.

\subsection{2- Grupo São Sebastião}

Este grupo representa uma seqüência metavulcano-sedimentar contituída por xistos, filitos e quartzitos, com intercalações de anfibolitos e formações ferriferas. As unidades litológicas desse grupo distribuem-se segundo faixas alongadas, lenticularizadas, dispostas, preferencialmente, na direção NE-SW. Faz contato com o Complexo Xingu através de zonas de cisalhamento dúctil de baixo ângulo, enquanto que com as rochas máfico-ultramáficas da Suite Cateté e com o maciço granitóide Antônio Vicente, da Suite Intrusiva Velho Guilherme, é discordante. Foi correlacionado por Silva et al.(1974) e Schobbenhaus et al.(1981) ao Grupo Grão Pará. CPRM/DNPM(1991), baseando-se na compartimentação e na evolução tectônica-estrutural do Cinturão de Cisalhamento Itacaiúnas interpretaram que as diferentes bacias, situadas ao longo dos sistemas transcorrentes Anaporã e Araraquara, foram formadas sincronicamente, mas com evoluções lito-estruturais distintas. Por essa razão, os autores supracitados consideraram cada grupo(Aquiri, São Sebastião e São Felix) como uma entidade geológica particular.

\subsection{2- Sistema Araraquara}

Este sistema, por sua vez, envolve seqüências metavulcano-sedimentares, com termos metavulcânicos félsicos e máficos, com intercalações de meta-ultramáficas, metaarenitos, meta-arcóseos, meta-grauvacas, filitos, xistos, quartzitos e formações ferriferas, pretencentes ao Grupo São Felix(CPRM/DNPM, 1991).

Mostra-se ora encoberto ora cortado por unidades do Grupo Uatumã(Bacia do Médio Xingu), bem como apresenta-se seccionado, discordantemente, por corpos máficosultramáficos da Suite Cateté, por granitóides da Suite Intrusiva Velho Guilherme(ver mais adiante), bem como por diques do Diabásio Cururu.

Em termos estruturais, mostra-se seccionado internamente por zonas de cisalhamento de caráter cavalgante obliquas, as quais formam duas estruturas divergentes, separadas por um alto estrutural constituído por gnaisses do Complexo Xingu. Ao longo de todo o sistema predomina uma componente de cisalhamento dextral, com a lineação de estiramento dispondo-se preferencialmente na direção NE-SW e mergulhando ora para NE, ora para SW.

Todo o conjunto se encontra seccionado por zonas de cisalhamento com movimentação cavalgante obliqua, que imprimem a orientação regional do sistema como um todo e que configuram, internamente, estruturas do tipo duplexe compressivo(Figura 2.3). 
Em relação à idade desse grupo, Silva et al.(1974) posicionaram essas rochas no Précambriano Médio a Superior e Schobbenhaus et al.(1981)assumiram uma idade Arqueana. CPRM/DNPM(1991), apesar da inexistência, na época, de estudos radiométricos nessa unidade, admitiram uma correlação crono-lito-estrutural com as rochas dos Grupos São Sebastião, Aquiri e Grão Pará. Nesse trabalho, essa hipótese toma vulto. Datações radiométricas realizadas em zircões(por evaporação de $\mathrm{Pb}$ ) de rochas metavulcânicas máficas do Grupo São Felix acusaram uma idade mínima aparente igual a $2.727 \pm 4 \mathrm{Ma}$. Entretanto, análises de alguns zircões, revelaram uma idade média aparente igual a $2.820 \pm 14 \mathrm{Ma}$. Considerando que essa última idade é mais velha do que aquelas obtidas nos demais cristais de zircão dessa rocha, pode-se interpretá-la com aquela de um cristal herdado do protólito da mesma, ou ainda como a idade de um cristal que foi assimilado a partir das rochas encaixantes da câmara magmática. De qualquer modo, decidir qual das duas idades representa a idade do vulcanismo é uma tarefa difícil. A idade de $2.727 \pm 4 \mathrm{Ma}$. representa, ao que tudo indica, a idade mínima para o evento vulcânico, mas, o fato de existirem cristais de zircão fornecendo idade ${ }^{207} \mathrm{~Pb} /{ }^{206} \mathrm{~Pb}$ igual a $2.820 \pm 14 \mathrm{Ma}$ sugere que esse evento magmático pode ser cerca de 100 milhões de anos mais velho.

\subsection{2-Proterozóico}

O regime essencialmente compressivo do Arqueano passou a um regime predominantemente distensivo, no Proterozóico(CPRM/DNPM, 1991; Costa et al., 1995). Esse novo regime afetou as diversas unidades lito-estruturais que constituem a Folha São Felix do Xingu, possibilitando à implantação da Bacia do Médio Xingu(Figura 2.2).

Conforme Costa et al.(1995), o ápice do estiramento crustal, propiciou a implantação e/ou a reativação de antigas estruturas planares que, adicionalmente ao adelgaçamento da crosta, facilitaram o "emplacement" de: 1) corpos magmáticos máficos-ultramáficos, representados pelos complexos magmáticos da Suite Cateté; 2) dos corpos ígneos expressos pelo Granito Parauari e; 3 ) dos granitóides da Suite Intrusiva Velho Guilherme. Além disso, possibilitaram a ascensão do vulcanismo ácido-intermediário representado pelo Grupo Uatumã e deposição dos sedimentos da Formação Triunfo.

\subsubsection{1-Intrusões Ácidas e Máficas-Ultramáficas}

\subsubsection{1- Granito Parauari}

O Granito Parauari(Santos et al., 1975), está representado por um conjunto de granitóides de composição monzogranítica a sienogranítica, com granodioritos subordinados. Esses granitóides são cortados discordantemente pelos corpos intrusivos máfico-ultramáficos da Suite Cateté, pelo maciço granitóide Antônio Vicente(Suite Intrusiva 
Velho Guilherme) e por extensos diques de diabásio Mesozóicos(Diabásio Cururu). Mostrase parcialmente encoberto por unidades vuicánicas do Grupo Uatumã e por sedimentos da Formação Triunfo(CPRM/DNPM, 1991). São granitóides metaluminosos, de afiliação cálcioalcalina, de aspecto isotrópico(ausência de estruturas planares ou lineares de natureza tectogênica), de textura hipidiomórfica eqüigranular, localmente, com tendência porfirítica, sem evidências de metamorfismo regional.

Datações radiométricas pelo método $\mathrm{Rb}-\mathrm{Sr}$, em rocha total, realizadas por Macambira et al.(1992), revelaram uma idade de $1.902 \pm 39 \mathrm{Ma}$, razão inicial de $0,704 \pm 5$ e um MSWD igual a 2,69 para esse granitóide. Essa idade é interpretada por esses autores como sendo a idade de cristalização do Granito Parauari.

\subsubsection{2- Suite Cateté}

A Suite Intrusiva Cateté consiste de inúmeros corpos máficos-ultramáficos, representados por gabros, noritos, piroxenitos, serpentinitos e peridotitos não deformados e não metamorfisados. De um modo geral, esses corpos encontram-se encaixados, discordantemente em rochas pertencentes ao Complexo Xingu e ao Granito Plaquê, bem como em litotipos diversos dos Grupos São Felix , Aquiri e São Sebastião(CPRM/DNPM, 1991). Datações radiométricas em rochas dessa unidade são inexistentes. Entretanto, os autores acima citados, pelo fato das rochas dessa unidade não apresentarem evidéncias de deformação dúctil e de metamorfismo, bem como ocorrerem, por vezes, discordantemente, à estruturação regional, admitiram uma idade Paleoproterozóica para as mesmas, e aceitaram a hipótese de que elas possam ser correlacionadas às ultramáficas do tipo Rio Vermelho(Araújo et al., 1991). De qualquer modo, até o momento, as dúvidas permanecem em relação ao posicionamento estratigráfico dessa unidade.

\subsubsection{2-Bacia do Médio Xingu}

A Bacia do Médio Xingu(Figura 2.2) está representada na área por unidades do Grupo Uatumã(Caputo et al., 1972) e da Formação Triunfo(Brasil, 1972).

\subsubsection{1- Grupo Uatumã}

De acordo com CPRM/DNPM(1991) esse grupo mostra-se constituido por um conjunto de rochas vulcânicas, com subordinadas e raras intercalações de tufos e rochas sedimentares, as quais foram reunidas nas Formações Sobreiro(IDESP, 1970) e Iriri(BRASIL, 1972). 


\subsection{1-Formação Sobreiro}

A Formação Sobreiro, porção inferior do grupo, representa um amplo vulcanismo fissural, de composição intermediária, que compreende predominantemente andesitos e, subordinadamente, traquitos e traqui-andesitos(CPRM/DNPM, 1991).

Datações radiométricas realizadas em rochas atribuídas a essa unidade são raras e confusas. Amaral(1974) datou através do método K-Ar, em rocha total, andesitos aflorantes ao longo dos rios Xingu e Fresco e obteve idades de $1.045 \mathrm{Ma}, 1.213 \pm 57 \mathrm{Ma}, 1.403 \pm 15 \mathrm{Ma}$ e $866 \pm 35 \mathrm{Ma}$. Basei(1978) realizou datações pelo método $\mathrm{Rb} / \mathrm{Sr}$ (rocha total) em andesitos ocorrentes na Folha SA-22-V-C e obteve uma idade de 1.720 , com razão inicial igual a 0,708 .

Recentemente, Teixeira et al.(1998) realizaram datações radiométricas através do método $\mathrm{Pb}-\mathrm{Pb}$ (rocha total) em uma combinação de amostras de rochas vulcânicas andesíticas da Formação Sobreiro e riolíticas da Formação Iriri, aflorantes na área de ocorrência do maciço granitóide Mocambo. A idade de $1.875 \pm 79 \mathrm{Ma}(\mathrm{MSWD}=5,95)$, obtida para essa unidade, foi interpretada pelos referidos autores como sendo a idade desse vulcanismo na região e o fato de superpor, nos limites dos erros, às idades obtidas, pelos mesmos autores, para os granitóides da Suite Intrusiva Velho Guilherme(ver mais adiante),sugere uma contemporaneidade entre os eventos plutónicos dessa suite e as vulcânicas do Grupo Uatumã.

\subsection{2- Formação Iriri}

A Formação Iriri(topo), representa os termos ácidos do grupo e está constituida, dominantemente, por riolitos e tufos riolíticos com subordinados dacitos e riodacitos.

Essas unidades ocorrem tanto como derrames, quanto como extensos diques preenchendo grandes fraturas relacionadas ao amplo estiramento crustal ocorrido na região, na interface Paleoproterozóico/Mesoproterozóico.

Datações geocronológicas, utilizando o métodos KIAr em rocha total, realizadas por Silva et al.(1974) acusaram idades variando entre $650 \mathrm{Ma}$ e $1450 \mathrm{Ma}$. Os mesmos autores realizaram, ainda datações através do método $\mathrm{Rb} / \mathrm{Sr}$ (rocha total) e obtiveram uma idade 1.600Ma. Posteriormente, Cunha et al.(1981) realizaram análises geocronológicas em rochas dessa unidade através do método $\mathrm{Rb} / \mathrm{Sr}$ em rocha total e obtiveram uma idade de $1.856 \pm 29 \mathrm{Ma}$, com razão inicial igual a $0,704 \pm 0,002$. Os trabalhos de campo realizados por CPRM/DNPM(1991) revelaram que as rochas do Grupo Uatumã encontram-se sobrepostas ao Granito Parauari(idade $\mathrm{Rb} / \mathrm{Sr}=1.902 \pm 39 \mathrm{Ma}$ )

A Formação Triunfo(Silva et al., 1974) mostra-se assentada em franca discordância angular nas rochas gnássicas do Complexo Xingu, nas unidades metavulcano-sedimentares 
do Grupo São Felix, no Granito Parauari e nas rochas das Formações Sobreiro e Iriri. É constituída por rochas sedimentares detríticas tais como quartzo-arenitos e arenitos arcoseanos com intercalações de niveis de siltitos e congiomerados.

Em termos geocronológicos, não existem, até o momento, datações radiométricas nessa unidade, bem como não foram observados e/ou descritos registros de fósseis. Entretanto, suas relações com as unidades do Grupo Uatumã permitem estabelecer uma idade mais jovem para a mesma em relação a esse grupo.

\subsubsection{3- Suite Intrusiva Velho Guilherme}

Esta unidade está representada na área da Folha São Felix do Xingu por diversos corpos intrusivos ácidos, de formas e dimensões variáveis, desde pequenos "stocks" arredondados até grandes batólitos amebóides.

Os corpos granitóides separadamente são conhecidos na literatura como Antônio Vicente, Velho Guilherme, Mocambo, Benedita, Ubim/norte, Ubim/sul, Serra da Queimada e Bom Jardim. Além desses, existem outros sem designação formal até o momento.

São rochas peraluminosas a metaluminosas, de composição álcali-feldspato granítica, sienogranítica e, mais subordinadamente, monzogranítica, que mostram-se afetadas por alterações tardi a pós-magmáticas em diferentes intensidades. Elas, quase sempre, hospedam mineralizações de cassiterita(principalmente), fluorita, topázio, columbita-tantalita e molibdenita(Abreu \& Ramos, 1974; Faraco et al., 1991). Apresentam natureza anorogênica, exibem caracteríticas geoquímicas de granitóides tipo-A(conforme definido por Loiselle \& Wones, 1979; Collins et al., 1982) e de ambiência intraplacas (conforme a proposição de Pearce et al., 1984).

Os primeiros dados geocronológicos àcerca desses granitóides foram sempre muito problemáticos, devido: 1) ao desconhecimento da estruturação interna dos corpos, da organização das facies e da caracterização tipológica no interior de cada maciço; 2) à inexistência de amostragem sistemática e amarradas aos tipos litológicos, decorrente, principalmente, das dificuldades de acesso, impostas pelas próprias características da região onde ocorrem. Entretanto, dados geocronológicos obtidos mais recentemente por Lafon et al.(1991), através do método $\mathrm{Rb}-\mathrm{Sr}$, em rocha total, em amostras do maciço granitóide Velho Guilherme, forneceram uma idade de $1.653+28 \mathrm{Ma}$, com razão inicial de $0,708 \pm 0,048$, a qual foi interpretada pelos mesmos autores como sendo a idade de colocação do corpo. Posteriormente, Lafon et al.(1995) realizaram, no mesmo granitóide, datações pelo médtodo $\mathrm{Pb}-\mathrm{Pb}$, em rocha total e em duas frações de feldspato, e obtiveram uma idade igual a $1.874 \pm 30 \mathrm{Ma}$. Essa foi comparada às idades obtidas, pelo mesmo método, por Machado et al.(1991) em outros corpos granitóides da Província Mineral de Carajás, aflorantes em áreas vizinhas próximas ao Granitóide Velho Guilherme, levando 
Lafon et al.(1995) a considerarem essa idade como sendo aquela de colocação do referido corpo. Além disso, face à grande similaridade das idades obtidas por Machado et al.(1991), Rodrigues et al.(1992), Avelar et al.(1994) e Lafon et al.(1995) relativas a vários granitóides anorogênicos da província, há uma tendência, entre os memos, de considerarem que o plutonismo anorogênico da Amazônia Oriental está restrito a um pequeno período, situandose entre 1,87 e 1,88 Ga.

Teixeira et al.(1998) realizaram datações radiométricas através do método $\mathrm{Pb}-\mathrm{Pb}$ em rocha total em granitóides dos maciços Antônio Vicente e Rio Xingu, obtendo, respectivamente, as idades $1896 \pm 9 \mathrm{Ma}$ e $1906 \pm 29 \mathrm{Ma}$. Adicionalmente, os mesmos autores realizaram datações pelo método $\mathrm{Pb}-\mathrm{Pb}$ em zircões(por evaporação de $\mathrm{Pb}$ ), de granitóides dos maciços Antônio Vicente, Mocambo e Rio Xingu e obtiveram, respectivamente, as idades $1867 \pm 4 \mathrm{Ma}$., $1862 \pm 32 \mathrm{Ma}$ e $1866 \pm 3 \mathrm{Ma}$. Uma discussão detalhada àcerca desses dados será realizada mais adiante.

\subsection{3-Fanerozóico}

O Fanerozóico está representado na Folha São Felix por unidades lito-estratigráficas do Mesozóico e do Cenozóico.

\subsubsection{1-Mesozóico}

O Mesozóico se faz presente através de uma retomada dos movimentos distensivos, que reativaram antigas zonas de fraqueza da crosta e propiciaram a ascensão de magmas máficos, os quais foram alojados em amplas fissuras sob a forma de diques de dimensões quilométricas. Esse evento magmático vem sendo reconhecido e descrito desde o trabalho de Oliveira(1928) e foi designado originalmente como "Dolerito Cururu" por Silva et al.(1974). Entretanto, ao longo do tempo, recebeu outras denominaçōes. Assim, CPRM/DNPM(1991) com o intuito de uniformizar a nomenclatura, propos designar esse evento magmático de Diabásio Cururu.

O Diabásio Cururu representa um enxame de diques essencialmente diabásicos de natureza anorogênica e de colocaçào subvulcânia, com ampla distribuição na região. Os diques mostram-se distribuídos de modo errático na Folha São Felix do Xingu e tem orientação preferencial NW-SE e NE-SW.

Em termos geocronológicos, não foram realizadas, até o momento, datações radiométricas no Diabásio Cururu, na área da folha. Entretanto, existe uma certa harmonia em atribuir uma idade Mesozóica a esse magmatismo fissural máfico, ocorrente na região(Issler et al., 1974, CPRM/DNPM, 1991, entre outros). 


\subsubsection{2-Cenozóico}

O Cenozóico, por sua vez, mostra-se representado por coberturas relacionadas às condições climáticas do Terciário e por depósitos sedimentares Quaternário. 


\section{CAPÍTULO 3}

\section{3.- MACIÇO GRANITÓIDE ANTÔNIO VICENTE(MGAV)}

\section{1- Contexto Geológico}

O MGAV aflora na região sul-sudeste do Estado do Pará, na extremidade oeste da Serra dos Carajás, a aproximadamente $50 \mathrm{~km}$ a noroeste da Cidade de São Félix do Xingu (Figura 2.3). Apresenta uma forma amebóide e ocupa uma área eqüivalente a $600 \mathrm{~km}^{2}$. E intrusivo a norte em rochas do Complexo Xingu, do Grupo São Sebastião e da Formação Sobreiro(Grupo Uatumã), a nordeste em rochas do Grupo São Sebastião, a este em rochas do Complexo Xingu, a sudeste e sul em rochas das Formações Sobreiro e Iriri(Grupo Uatumã) e a oeste e noroeste no Granito Parauari (Figura 3.1).

\section{2- Histórico}

Ele foi referido inicialmente na literatura por Silva et al. (1974) que o incluíram entre os "granitos tipo Serra dos Carajás", em função, sobretudo, da sua forma, de suas dimensões batolíticas e da ausência, aparente, de mineralizações estaniferas associadas. Com a descoberta, por geólogos da DOCEGEO, no final da década de 70, de importantes mineralizações de cassiterita, associadas ao mesmo, passou a ser considerado como do tipo Velho Guilherme (Hirata et al., 1982). Finalmente, mais recentemente, CPRM/DNPM(1991) o enquadram juntamente com outros maciços da região na Suite Intrusiva Velho Guilherme.

Todos os trabalhos referidos acima envolveram principalmente aspectos referentes ao arranjo estratigráfico das diversas unidades aflorantes na região e, dentre elas, o maciço granitóide Antônio Vicente. O primeiro estudo visando uma melhor caracterização petrográfica dos granitóides do maciço, bem como sua evolução magmática foi realizado por Dall'Agnol (1980). Dall'Agnol (1982a) realizou um estudo comparativo entre alguns maciços granitóides pós-Ciclo Transamazónico da Amazônia Oriental ( Antônio Vicente, Velho Guilherme, Mocambo, Serra dos Carajás e Jamon). Ele mostrou que, sob o ponto de vista petrográfico e de suas evoluções petrológicas, os maciços granitóides Antônio Vicente(MGAV), Velho Guilherme(MGVG) e Mocambo(MGM), apresentavam muitas similaridades, sugerindo estarem relacionados a um mesmo evento magmático regional.

Dall'Agnol et al. (1984) apresentaram para esses mesmos maciços novos dados geocronológicos e uma discussão sobre o comportamento de alguns elementos traços (Rb, 
$\mathrm{Sr}, \mathrm{Zr}, \mathrm{Y}, \mathrm{Ba}$ ). Tais autores observaram que os leucogranitos dominantes nos maciços Antônio Vicente, Velho Guilherme e Mocambo, apresentavam notáveis semelhanças no comportamento daqueles elementos. Concluíram que se tratava de granitóides extremamente evoluídos, com evolução magmática semelhante, cujos processos de alterações tardi a pós-magmáticas que os afetaram eram similares e que os mesmos hospedavam importantes mineralizações de estanho. No que se refere à geocronologia, foi frustada a tentativa de obtenção de uma isócrona $\mathrm{Rb} / \mathrm{Sr}$ para o MGAV. Entretanto, os autores mencionados, assumiram que esses maciços eram contemporâneos.

Dall'Agnol et al. (1986) fizeram uma reavaliação dos dados existentes sobre os granitóides da região e concluiram pela impossibilidade, naquele momento, de uma separação objetiva entre as Suites Serra dos Carajás e Velho Guilherme. Adotaram, por isso a designação genérica de granitos anorogênicos. Esse mesmo critério foi adotado por DOCEGEO (1988).

Dall'Agnol et al. (1988) estudaram o comportamento da susceptibilidade magnética (SM) em diversos maciços granitóides da Amazônia, inclusive o MGAV. Concluíram que no mesmo predominam valores de susceptibilidade magnética baixos. Sugeriram, ainda, que os baixos valores de SM encontrados sistematicamente nas facies mais evoluídas dos granitos estaníferos, podem ser um guia no estágio de reconhecimento da prospecção de cassiterita.

Magalhães(1991), realizou estudos detalhados de susceptibilidade magnética(SM) no MGAV, observando que as facies petrográficas mais evoluídas e mais afetadas por transformações tardi a pós-magmáticas exibem valores de SM mais baixos do que aqueles determinados para as facies menos evoluídas e menos afetadas por esses processos.

Teixeira \& Dall'Agnol(1991) elaboraram um mapa detalhado do MGAV com base em trabalhos de campo e em estudos de fotointerpretação e petrográficos minuciosos. Definiram quatro grandes domínios faciológicos no interior do maciço. Realizaram, ainda, um estudo preliminar sobre as alterações(transformações) tardi a pós-magmáticas que afetaram parcialmente alguns granitóides do maciço e ressaltaram a necessidade de estudos petrográficos mais refinados.

Teixeira et al.(1994), caracterizaram em algumas facies do MGAV(BSG, BSGA e BSGIA) diversas feições elou assinaturas geoquímicas diagnósticas da sua especialização(sentido de Tischendorf, 1977), principalmente, em estanho.

Teixeira et al.(1998) obtiveram através dos métodos $\mathrm{Pb}-\mathrm{Pb}$ em rocha total $e \mathrm{em}$ feldspato potássico e $\mathrm{Pb}-\mathrm{Pb}$ em zircões(por evaporação de $\mathrm{Pb}$ ) as idades de $1896 \pm 9 \mathrm{Ma}$. e $1867 \pm 4 \mathrm{Ma}$, respectivamente, para maciço Antônio Vicente e interpretaram essas idades como aquelas de cristalização do maciço como um todo(ver mais adiante). 


\section{3.- Aspectos Fotogeológicos e de Campo}

Os trabalhos de fotointerpretação permitiram delimitar melhor o contorno do maciço. Seus contatos com as encaixantes são, ora bem definidos e abruptos, truncando o "trend" estrutural regional e evidenciando discordância litologico-estrutural, ora controlados por fraturas e/ou por falhas de natureza duvidosa, caracterizadas pela presença de alinhamentos retilineos de relevo e de drenagem. Esses são mais marcantes nas porções noroeste, norte, nordeste e sul (Figura 3.1).

No contexto do maciço, foram separadas com base nas caracteristicas dos elementos texturais de relevo e, subordinadamente, de drenagem diversas zonas fotolitológicas(Soares \& Fiori, 1976), as quais foram confrontadas com a distribuição das diversas variedades petrográficas no interior do maciço. Constatou-se uma boa concordância entre os principais padrões realçados na fotointerpretação e os domínios das principais facies petrográficas.

Deve ser ressaltado, no entanto, que essa concordância não foi sempre perfeita $e$ que a fotointerpretação foi obviamente confrontada com os dados petrográficos e de campo para os indispensáveis ajustes. Além disso, são freqüentes as ocorrências de variações petrográficas locais em cada facies, as quais não são representáveis na escala do mapeamento adotada. É óbvio também que sendo o relevo do corpo, na maioria das vezes, pouco pronunciado e as amostras disponiveis coletadas, em grande parte, ao longo de grotas e igarapés, não se pode ambicionar uma visão clara da arquitetura do corpo. Não foram igualmente estabelecidos as relaçőes de contato entre as diversas facies, não sendo, portanto, conhecida a ordem relativa de colocação entre as mesmas, pois os afloramentos são, via de regra, em forma de blocos e há ausência de grandes exposições sob a forma de pedreiras ou de cortes de estradas.

Além disso, só se teve acesso a amostras de um único furo de sondagem, realizado em uma porção de granitóide intensamente afetada por alterações tardi a pósmagmáticas e em um corpo de greisen. Mesmo assim, o furo foi incompleto, só sendo possível caracterizar a ordem de amostragem e organizar os tipos graças às de informações verbais prestadas pelo Geólogo Germano José Raabe(Gerente de produção), que permanecia na área da mina São Raimundo, já desativada.

Foram distinguidos no no interior do MGAV quatro domínios petrográficos principais(Figura 3.1). As áreas correspondentes a cada um dos domínios devem ser entendidas como áreas de predominância de um determinado tipo faciológico de granitóide , uma vez que outras variedades não mapeáveis na escala adotada podem ocorrer localmente(ver adiante). 
O primeiro domínio(1) corresponde à porção centro-sudeste do corpo e nele foram caracterizados, dominantemente, biotita-anfibólio sienogranito com biotita-anfibólio monzogranito subordinado(BASMG), pouco afetados por alterações tardi a pós-magmáticas.

O segundo(2), ocupando toda a porção sudoeste do maciço, e sendo constituído por anfibólio-biotita sienogranito(ABSG), biotita-anfibólio sienogranito a álcali-feldspato granito(BASAFG), biotita sienogranito com clorita(BSGCl) e álcali-feldspato granito(AFG).

O terceiro(3), por sua vez, se estende desde a porção sudeste do maciço até à sua região central, e se espalha para norte e noroeste. Ele corresponde a biotita sienogranito com biotita monzogranito subordinado(BSG, BSGA e BSGIA). Essas variedades de granitos mostram-se afetados por alterações tardi a pós-magmáticas em diferentes graus que se tornam muito expressivas nas facies BSGA e BSGIA(ver adiante).

O quarto(4) e último, ocupa a porção nordeste do maciço e nele aflora biotita monzogranito(BMG) sem alterações importantes, com biotita sienogranito subordinado.

Localmente, foram caracterizadas facies granitóides não mapeáveis na escala de mapeamento adotada no trabalho. Essas facies correspondem a micromonzogranito(MMG) e a sienogranito e monzogranito granofírico(SMGGf).

Associados ao biotita sienogranito e suas variedades alteradas(BSG, BSGA e BSGIA) foram identificados, localmente, zonas e corpos de greisens(Prancha 1; Foto a), zonas hidrotermalizadas(Prancha 1; Foto $\mathrm{b}$ ) e veios de fluorita(Prancha 1; Foto $\mathrm{c}$ ). Dentre os greisens foram distinguidos diferentes tipos a saber: 1) muscovita+quartzo greisen; 2) clorita+quartzo greisen; 3) clorita+"siderofilita"+muscovita+quartzo greisen. Nas zonas hidrotermalizadas é comum o desenvolvimento de vênulas enriquecidas em clorita, que imprimem às mesmas uma coloração verde escura. Essas vênulas são, geralmente, de ordem milimétrica a centimétrica. Os veios de fluorita são de espessura milimétrica e centimétrica.

Apesar das limitações assinaladas anteriormente, a ausência de estruturas marcantes no interior do corpo, o seu caráter francamente discordante em relação às encaixantes e a natureza das mesmas, demonstraram que a colocação do corpo granitóide como um todo se deu a profundidades rasas (ver mais adiante). Além disso, a relação cristais-líquido não deveria ser muito elevada quando da colocação (Pitcher, 1979). Tais aspectos tem sido verificados sistematicamente em outros granitos anorogênicos ou póstectônicos da Amazônia (Dall'Agnol et al., 1987; Gastral, 1987; Gonçalez et al., 1988;; Daoud, 1988, entre outros). 
Figura 3.1 - Mapa geológico da área de ocorrência do maciço granitóide Antônio Vicente. 


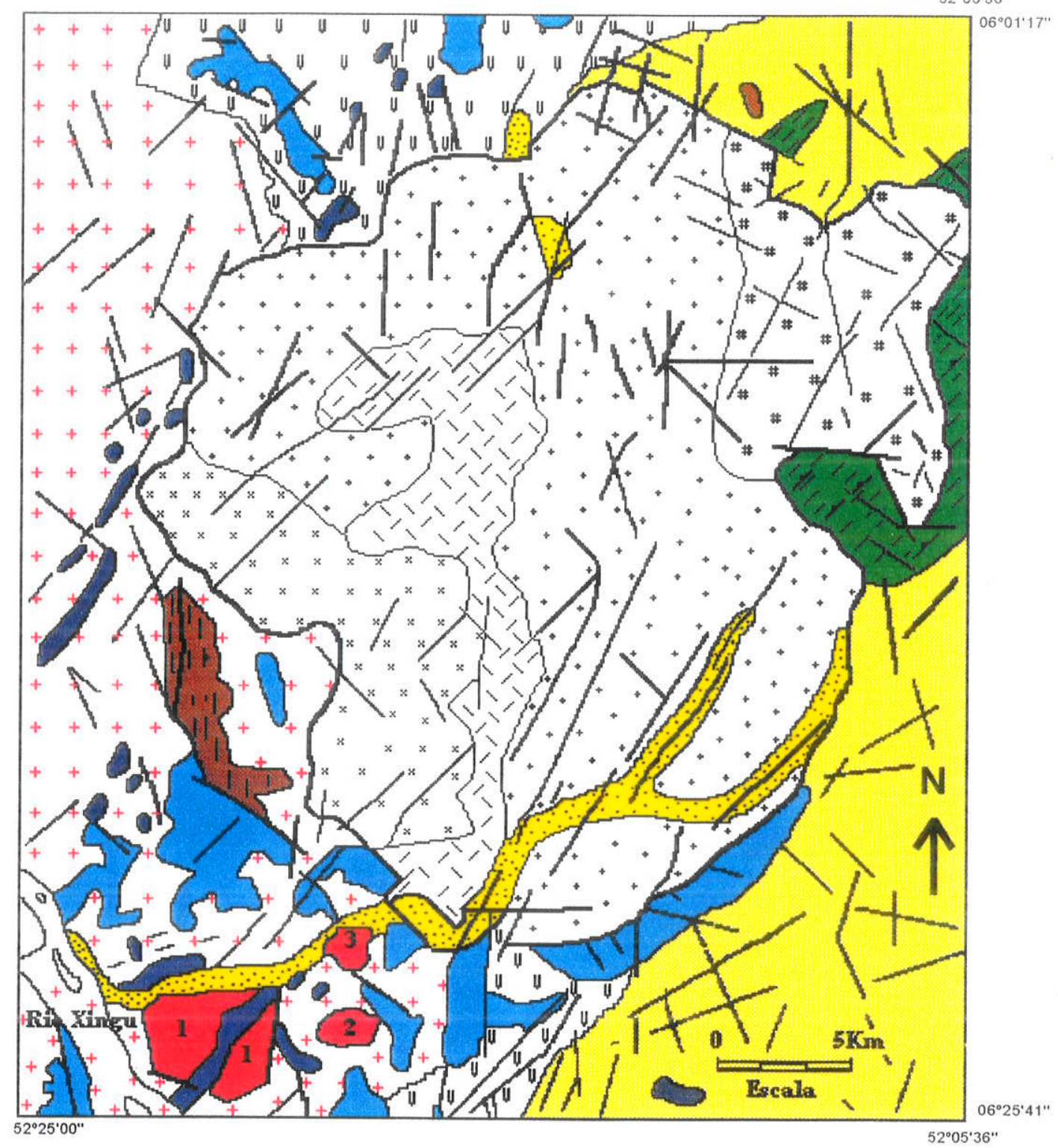

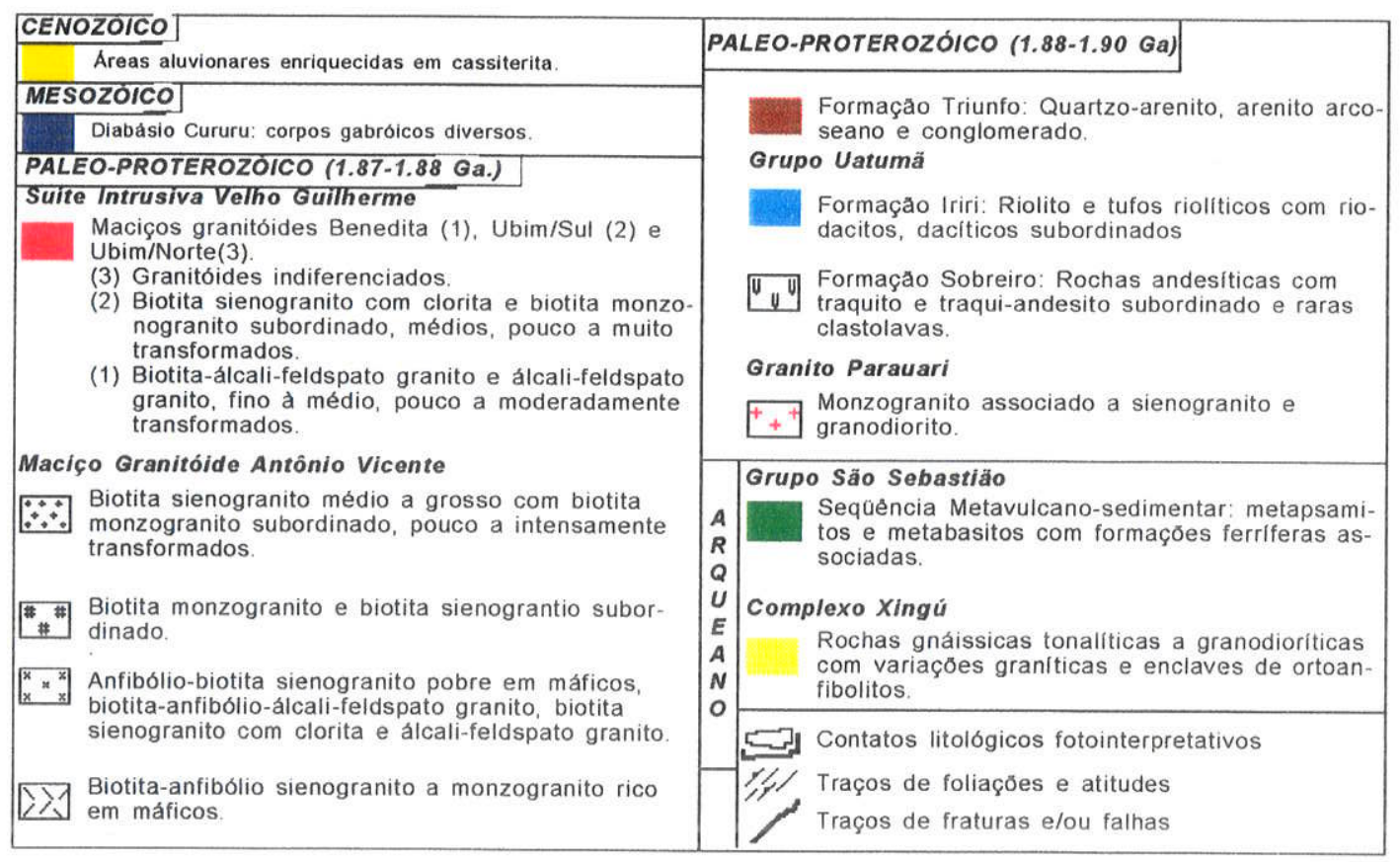




\section{4-Aspectos Petrográficos}

Dall'Agnol (1980) limitou seu estudo a amostras provenientes da porção sudeste do maciço, onde foram distinguidos quatro facies granitóides: a) biotita-anfibólio granitóide grosso (GG); b) microgranito $(M G)$ c) leucogranito equigranular médio ( $G M)$; d) leucogranito heterogranular médio a fino $(\mathrm{GH})$. O mapeamento geológico concomitante à explotação de cassiterita, levado a efeito pela Taboca Mineração S/A durante a última metade da década de 80 , propiciou uma série de informações adicionais acerca desse maciço, que foi amostrado de modo mais abrangente e sistemático(Anexo 1).

De um total de quase três centenas de amostras, 61 representativas de cada variedade de granitóides e 06 amostras de greisens foram selecionadas para a realização de análises modais. Utilizou-se um contador de pontos eletrônico de marca Swift para as análises, sendo computado em média 1.500 pontos por amostra. Foi feito apenas uma contagem por amostra, independente de sua granulação e os resultados obtidos não são, portanto, rigorosos do ponto de vista estatístico(Chayes, 1956). Considera-se, apesar dos valores isolados de cada amostra não serem perfeitamente exatos, que o conjunto de dados é representativo das composições modais atuais das rochas do maciço(modificadas por alterações tardi a pós-magmáticas). Adotou-se para a classificação e nomenclatura dessas rochas, as recomendações de Steckeisen, (1976) e Le Maitre(1989).

Os diagramas $Q-A-P$ e Q-(A+P)-M' correspondentes são apresentados na Figura 3.2a. Constata-se que não existe uma grande variação nas composições, que são tipicamente graníticas e subsolvus( conforme classificação deTuttle \& Bowen, 1958), com uma única amostra situando-se no campo dos granodioritos. Todos os campos dos granitos são ocupados, porém há uma notável concentração naquele dos sienogranitos(campo 3a; Streckeisen, 1976). Isso se reflete claramente nas composições médias de cada variedade (Figura 3.2b). No diagrama $Q-(A+P)-M$ ' percebe-se o caráter leucocrático a hololeucocrático da totalidade das amostras estudadas, havendo apenas cinco amostras com $M^{\prime}>10 \%$ e um número muito elevado de amostras com $\mathrm{M}^{\prime}<5 \%$. Isso demonstra o caráter extremamente silicoso e evoluído dos magmas geradores dos granitóides do maciço.

A distribuição das amostras é muito similar àquela observada em relação a outros maciços granitóides anorogênicos da Amazônia Oriental (Dall'Agnol, 1980; Gonçalvez et al., 1988; Gastal, 1987; Rios, 1991, entre outros). Ela não coincide, entretanto, com aquelas das diferentes fases granitóides de Lameyre e Bowden (1982) e Bowden et al. (1984), aproximando-se, porém em grande parte, do campo dos granitóides crustais desses autores. Cabe destacar, no entanto, que os referidos autores incluem nesse grupo granitóides essencialmente peraluminosos, geralmente a duas micas, derivados de magmas oriundos de fusões crustais de metassedimentos, ao passo que as características 
petrográficas dos granitóides do maciço Antônio Vicente, bem como a natureza do seu protólito(ver mais adiante) divergem dos granitóides mencionados.

Considerando que as fases minerais associadas ao estágio de alterações tardi a pós-magmáticas são muito expressivas em determinadas variedades e em função de seu interesse petrogenético e metalogenético, procurou-se quantificar nas análises modais a contribuição dos minerais formados nesse estágio. Assumiu-se as associações microclina $\left(\mathrm{Fk}_{2}\right)$, sericita \pm muscovita $\left(\mathrm{Mv}_{1}\right) \pm \operatorname{clorita}\left(\mathrm{Cl}_{1}\right) \pm$ fluorita $\left(\left.F\right|_{1}\right) \pm$ epidoto $\left(\mathrm{Ep}_{1}\right) \pm$ topázio $\left(\mathrm{Top}_{1}\right)$, albita, clorita $\left(\mathrm{Cl}_{2}\right) \pm$ minerais opacos $\left(\mathrm{Mop}_{2}\right) \pm$ muscovita $\left(\mathrm{Mv}_{2}\right) \pm$ esfalerita \pm fluorita $\left(\mathrm{Fl}_{2}\right) \pm$ epidoto $\left(E \mathrm{p}_{2}\right)$, topázio $\left(\mathrm{Top}_{2}\right)$ e argilo-minerais como as mais representativas desse estágio e indicou-se as contribuições das mesmas nos granitóides estudados. Nas amostras mais intensamente alteradas observa-se percentagens modais expressivas de microclina $\left(\mathrm{Fk}_{2}\right)$, albita, sericita, muscovita e fluorita, bem como a presença de cassiterita. Essas associações minerais mostram-se intimamente associadas aos processos de alterações e dos feldspatos e da biotita ocorridos no estágio de alterações tardi a pósmagmáticas, os quais, culminaram com a greisenização de porções dos granitóides do maciço, especialmente, da facies BSG(BSGA e BSGIA).

\subsection{1-Facies granitóides das porçöes centro-sudoeste e sudoeste do maciço}

Nessas porções do MGAV (Figura 3.1). predominam: 1) biotita-anfibólio sienogranito a monzogranito (BASMG), rico em máficos $(M>5 \%) ; 2)$ anfibólio-biotita sienogranito (ABSG), relativamente pobre em máficos $(\mathrm{M}<3 \%)$, com biotita-anfíbólio sienogranito a álcali-feldspato granito subordinado( BASAFG); 3) biotita sienogranito com clorita (BSGCl) e; 4) álcali-feldspato granito (AFG).

As composições modais absolutas e médias desses granitóides encontram-se nas Tabelas 3.1 a 3.4 .

Em que pesem as suas diferenças mineralógicas quantitativas, essas rochas exibem uma grande afinidade textural, tanto no que se refere ao arranjo dos seus minerais, quanto em relação às características individuais de cada fase mineral. Esse fato aliado à distribuição geográfica dos diversos tipos de granitóides desse domínio, à importância das transformações tardi a pós-magmáticas discutidas anteriormente e à ausência de mineralizações importantes de estanho nessa região do maciço permitiram tratá-las de maneira conjunta.

$\mathrm{Na}$ análise e interpretação dos diagramas Q-A-P e' Q-(A+P)-M'(Figuras $6 a$ e $6 b)$ e das Tabelas 3.1 a 3.4 observa-se um pequeno "trend" de diferenciação magmática, traduzido pela presença dos biotita-anfibólio monzogranito e biotita-anfibólio sienogranitos rico em máficos $\left(M^{\prime}>5 \%\right)$, que representaria o termo menos evoluído e de maior área de 
ocorrência. Os estágios intermediários da evolução seriam representados pelo anfibóliobiotita sienogranito pobre em máficos, biotita-anfibólio-álcali-feldspato granito e biotita sienogranito com clorita, ao passo que do magma granítico residual resultaria o álcalifeldspato granito.

\subsubsection{1- Facies BASMG}

\subsubsection{1- Textura e Mineralogia}

O BASMG assemelha-se à variedade GG de Dall'Agnol (1980) e apresenta uma textura hipidiomórfica heterogranular média a grossa e coloração variável desde cinza ou cinza escura até rosa-acinzentada(Prancha 2; Fotos a e b). As composições modais de amostras isoladas são bastante variadas, provavelmente em função da menor precisão das análises em amostras mais grossas(Tabela 3.1). Ressalta-se, no entanto, que: 1) a sua composição média incide no campo dos monzogranitos; 2) os seus teores de quartzo costumam ser inferiores aos das demais variedades, ocorrendo o inverso com os valores de M'(Figura 3.2a).

E constituído essencialmente por quartzo, feldspato potássico e plagioclásio, ocorrendo como minerais varietais anfibólio e biotita. Como minerais acessórios ocorrem minerais opacos $\left(\mathrm{MOP}_{1,2 \theta_{3}}\right)$ e apatita(mais freqüentes), titanita(Tit $\left.{ }_{1 \theta_{2}}\right)$, allanita e zircão.

As fases minerais secundárias relacionadas a processos de alterações tardi a pósmagmáticas(no sentido de Dall'Agnol, 1980; Pollard, 1983; Botelho, 1984) estão representadas por microclina pertítica $\left(\mathrm{Fk}_{2}\right)$, sericita $\pm \operatorname{muscovita}\left(\mathrm{Mv}_{1}\right) \pm \operatorname{clorita}\left(\mathrm{Cl}_{1}\right) \pm$ fluorita $\left(F I_{1}\right)$, epidoto $\left(E p_{1}\right)$, carbonato, clorita $\left(\mathrm{Cl}_{2}\right)$, fluorita $\left(\mathrm{FI}_{2}\right),\left(E \mathrm{p}_{2}\right)$, minerais opacos $\left(\mathrm{MOP}_{3}\right)$, Muscovita $\left(\mathrm{Mv}_{2}\right)$, albita e argilo minerais. Essas fases não mostram-se desenvolvidas de modo muito intenso nessas rochas e foram reunidas em dois conjuntos principais a saber:

1) fases associadas a um primeiro evento metassomático, de naturaza potássica, evidenciado pela substuição parcial(descalcificação) do $\mathrm{Pl}_{1}$, por sericita \pm muscovita( $\left(\mathrm{MV}_{1}\right) \pm$ clorita $\left(\mathrm{Cl}_{1}\right) \pm$ fluorita $\left(\mathrm{Fl}_{1}\right)$, epidoto $\left(\mathrm{Ep}_{1}\right) \pm$ carbonato, que marca 0 inicio do estágio de transformações tardi a pós-magmáticas. $E$, adicionalmente, pela microclinização $\left(F k_{2}\right)$ do plagioclásio primário $\left(\mathrm{PI}_{1}\right)$, de composição albita-oligoclásio a andesina.

2) fases associadas a um evento subseqüente de metassmatismo sódico traduzido, principalmente pela albitização dos feldspatos potássicos $\left(F k_{1}\right.$ e $\left.F k_{2}\right)$ e, muito subordinadamente, do plagioclásio primário $\left(\mathrm{Pl}_{1}\right)$, bem como pela substituição parcial da biotita, produzindo clorita $\left(\mathrm{Cl}_{2}\right)+$ fluorita $\left(\mathrm{FI}_{2}\right)+$ minerais opacos $\left(\mathrm{MOP}_{3}\right) \pm$ epidoto $\left(\mathrm{Ep}_{2}\right) \pm$ quartzo(Qtz 3$) \pm$ "muscovita" $\left(\mathrm{Mv}_{2}\right)$. 
3) os argilo-minerais tem sido associados às fases finais desse estágio(Kinnaird et al., 1985a; Kinnaird et al., 1985b; kinnaird, 1985; Pollard \& Taylor, 1986; Strong, 1988). Entretanto, nesse granitóide, o posicionamento temporal desses minerais é dividoso, visto, às vezes, parece permear todos produtos resultantes dos eventos metassomáticos acima referidos. Isso é válido para todos os granitóides dos diversos maciços estudados.

O anfibólio é sempre abundante nessa variedade e predomina sobre a biotita. Certos minerais acessórios -opacos e apatita- apresentam conteúdos pouco variáveis e alcançam teores algo significativos. Epidoto $\left(E p_{1}+E p_{2}\right)$, sericita \pm muscovita $\left(M_{1}+M_{1} v_{2}\right)$, albita e clorita $\left(\mathrm{Cl}_{1}+\mathrm{Cl}_{2}\right)$, principais produtos secundários, são poucos abundantes, exceto a clorita que em um única amostra alcança o teor de $7 \%$ (Tabela3.1). O plagioclásio é relativamente enriquecido em anortita quando comparado ao encontrado na maioria das amostras das outras variedades de granitóides do corpo.

Texturas atribuídas a processos de exsolução e/ou de substituição(Alling, 1932 e 1938; Fisher, 1971; Smith, 1974; Richardson, 1988; Smith \& Brown, 1988), associadas às fases feldspáticas, foram caracterizadas e estão representadas por "strings perthites", "film perthites", "band perthites", "vein perthites", "patch perthites", "swapped rims", "albite rims", "myrmekite rims" e "poikilitic albite".

O quartzo ocorre em, pelo menos, seis tipos, os quais diferem entre si, tanto pela morfologia e textura, quanto pela origem. Assim tem-se:

a) Quartzo 1(Qtz 1$)$ : apresenta-se, em geral, como cristais subédricos a anédricos, de granulação média a grossa. Desenvolve, entre si e com outras fases minerais, contatos irregulares e, às vezes, suturados, embora, localmente, ocorram contatos retos. Mostra-se, geralmente, fraturado e, por vezes, exibe forte extinção ondulante. Localmente, pode exibir inclusões de minerais opacos e apatita.

b) Quartzo 2(Qtz $)$ : é, geralmente, subédrico, apresenta granulação fina a média e desenvolve, com as outras fases minerais, contatos mais regulares do que o quartzo $1 \mathrm{e}$ mostra, por vezes, faces bem formadas. Exibe, às vezes, inclusões de minerais opacos e de feldspato potássico $1\left(\mathrm{Fk}_{1}\right)$ e, localmente, ocorre como inclusões em grãos de feldspato potássico 2( $\left.\mathrm{Fk}_{2}\right)$.

c) Quartzo 3(Qtz $)$ : ocorre, predominantemente, como cristais anédricos, via de regra, em íntima associação com anfibólio, biotita, minerais opacos $\left(\mathrm{MOP}_{2}\right)$, titanita(Tit $\left.{ }_{2}\right)$ e, às vezes, allanita.

d) Quartzo 4(Qtz $)_{4}$ : assemelha-se muito ao tipo 3, mas ocorre preferencialmente, em ítima associação com a biotita, juntamente com clorita $\left(\mathrm{Cl}_{2}\right)$, minerais opacos $\left(\mathrm{MOP}_{3}\right)$, epidoto $\left(\mathrm{Ep}_{2}\right)$ e fluorita $\left(F l_{2}\right)$. 
e) Quartzo 5(Qtz 5$)$ : tem aspecto de "vermes", formando intercrescimentos mirmequíticos em bordas albíticas("myrmekites rims"), geralmente, associadas ora a cristais de plagioclásio $1\left(\mathrm{PI}_{1}\right)$, ora ao plagioclásio $2\left(\mathrm{Pl}_{2}\right)$.
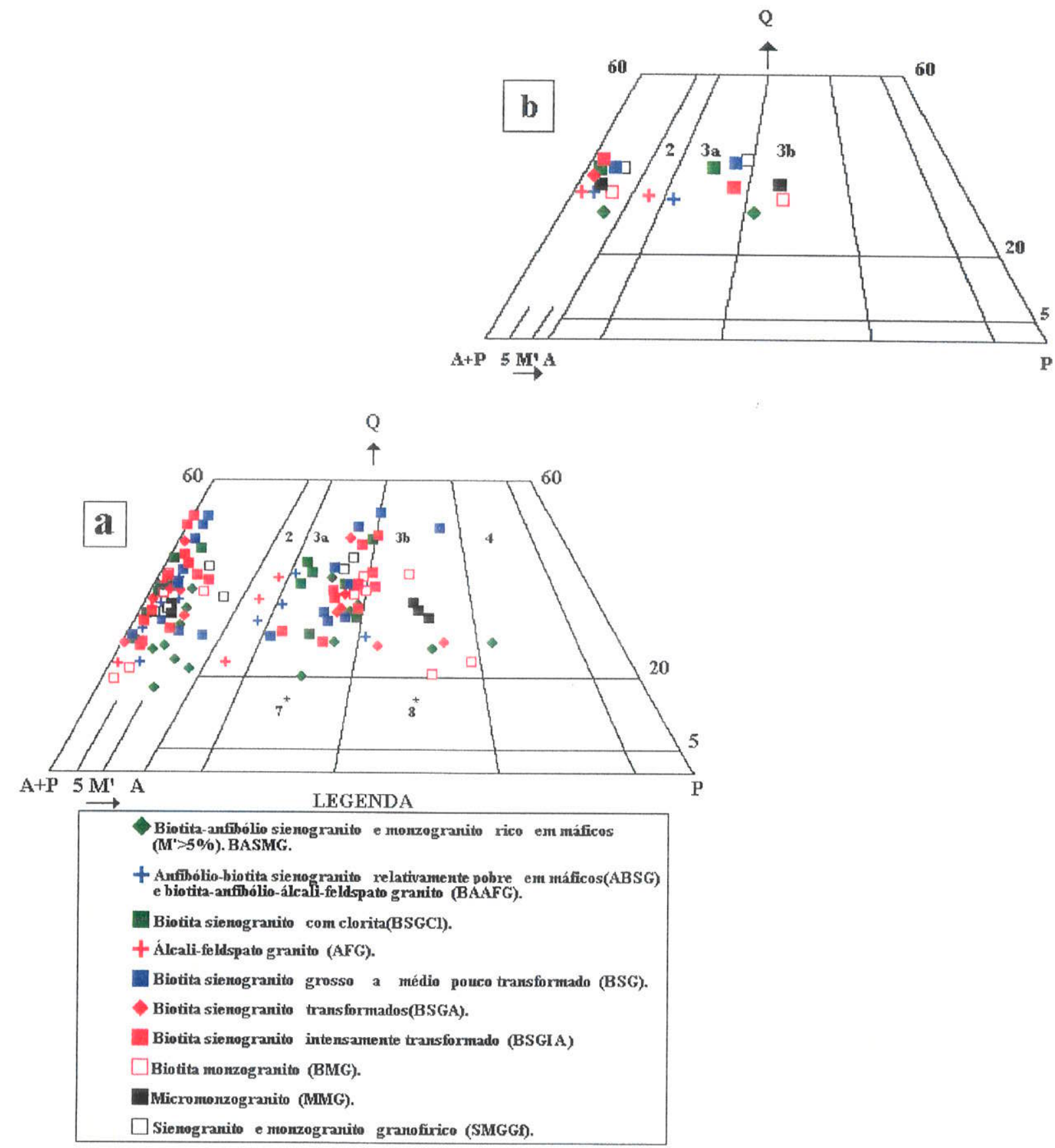

Figura 3.2. a) diagramas triangulares $Q-A-P$ e $Q-(A+P)-M$ '(Streckeisen, 1976), mostrando as distribuições composicionais modais gerais dos granitóides que constituem o Maciço Granitóide Antônio Vicente; b) os mesmos diagramas apresentando as médias dessas composições (Teixeira \& Dall'Agnol, 1991, modificado). 
Tabela 3.1- Composições modais da facies granitóide biotita-anfibólio sieno a monzogranito(BASMG). Maciço granitóide Antônio Vicente. Tr=Traço; Nd= Năo detectado; $\mathrm{Nc}=$ Não contado.

\begin{tabular}{|c|c|c|c|c|c|c|c|c|c|}
\hline \multirow{2}{*}{$\frac{\text { VARIEDADE }}{\text { AMOSTRAS }}$} & \multicolumn{9}{|c|}{ BASMG } \\
\hline & 01-GFe & 03-Gfe & $\mathrm{IE}-02$ & IE-04 & IE-05 & $\mathrm{N}-\mathrm{S}-5$ & $\mathrm{~N}-\mathrm{S}-6$ & $\mathrm{~N}-\mathrm{S}-3$ & \\
\hline & 1 & 2 & 3 & 4 & 5 & 6 & 7 & 8 & \\
\hline \multicolumn{10}{|l|}{$\begin{array}{l}\text { MINERAIS } \\
\text { PRIMÁRIOS }(\%)\end{array}$} \\
\hline QUARTZO & 22 & 25 & 30 & 38 & 18 & 27 & 32 & 24 & \\
\hline PLAGIOCLASIO & 28 & 17 & 19 & 13 & 17 & 24 & 20 & 44 & \\
\hline FELDSPATO $\left(\mathrm{Fk}_{1}\right)$ & 34 & 47 & 41 & 41 & 53 & 40 & 38 & 20 & \\
\hline ANFIBOLIO & 13 & 06 & 03 & 04 & 08 & 02 & 04 & 03 & \\
\hline BIOTITA & 01 & 01 & 06 & 04 & $\mathrm{Tr}$ & 02 & $\mathrm{Tr}$ & $\mathrm{Tr}$ & \\
\hline ZIRCÁO & $\mathrm{Tr}$ & Tr & $\mathrm{Tr}$ & $\mathrm{Tr}$ & $\mathrm{Tr}$ & $\mathrm{Tr}$ & 01 & 01 & \\
\hline MINERAIS OPACOS & 01 & $\operatorname{Tr}$ & $\mathrm{Tr}$ & $\operatorname{Tr}$ & $\mathrm{Tr}$ & $\mathrm{Tr}$ & 01 & 01 & \\
\hline APATITA & 01 & $\operatorname{Tr}$ & 01 & $\operatorname{Tr}$ & $\mathrm{Tr}$ & $\mathrm{Tr}$ & $\mathrm{Tr}$ & $\mathrm{Tr}$ & \\
\hline ALLANITA & $\mathrm{Tr}$ & $\mathrm{Tr}$ & $\mathrm{Tr}$ & $\mathrm{Tr}$ & $\operatorname{Tr}$ & $\mathrm{Tr}$ & $\mathrm{Tr}$ & $\mathrm{Tr}$ & \\
\hline TITANITA & $\mathrm{Tr}$ & $\mathrm{Tr}$ & $\mathrm{Tr}$ & $\mathrm{Tr}$ & $\mathrm{Tr}$ & $\mathrm{Tr}$ & $\mathrm{Tr}$ & $\mathrm{Tr}$ & \\
\hline \multicolumn{10}{|l|}{$\begin{array}{l}\text { MINERAIS } \\
\text { SECUNDÁRIOS(\%) }\end{array}$} \\
\hline SERICITA+MUSCOVITA & $\mathrm{Tr}$ & $\mathrm{Tr}$ & $\mathrm{Tr}$ & $\mathrm{Tr}$ & $\mathrm{Tr}$ & $\mathrm{Tr}$ & $\mathrm{Tr}$ & $\mathrm{Tr}$ & \\
\hline FELDSPATO $\left(\mathrm{Fk}_{2}\right)$ & $\mathrm{NC}$ & $\mathrm{NC}$ & Nc & Nc & $\mathrm{Nc}$ & NC & $\mathrm{NC}$ & Nc & \\
\hline CLORITA & $\mathrm{Tr}$ & $\mathrm{Tr}$ & $\mathrm{Tr}$ & $\mathrm{Tr}$ & $\mathrm{Tr}$ & $\mathrm{Tr}$ & $\mathrm{Tr}$ & 07 & \\
\hline EPIDOTO & $\operatorname{Tr}$ & $\mathrm{Tr}$ & $\mathrm{Tr}$ & $\operatorname{Tr}$ & 01 & $\mathrm{Tr}$ & 01 & 01 & \\
\hline CARBONATO & $\mathrm{Nd}$ & No & $\mathrm{Na}$ & $\mathrm{Nd}$ & Nd & Nd & $\mathrm{Nd}$ & $\mathrm{Tr}$ & \\
\hline ALBITA & $\mathrm{Tr}$ & $\mathrm{Tr}$ & $\mathrm{Tt}$ & $\mathrm{Tr}$ & 01 & 03 & 02 & 01 & \\
\hline FLUORITA & $\mathrm{Tr}$ & Nd & Nd & Nd & $\mathrm{Nd}$ & Nd & $\mathrm{Nd}$ & $\operatorname{Tr}$ & \\
\hline MINERAIS OPACOS & $\mathrm{Tr}$ & $\mathrm{Tr}$ & $\mathrm{Tr}$ & $T r$ & Tr & $\mathrm{Tr}$ & $\mathrm{Tr}$ & $\mathrm{Tr}$ & \\
\hline QUARTZO & $\mathrm{Tr}$ & $\mathrm{Tr}$ & $\mathrm{Tr}$ & $\mathrm{Tr}$ & $\mathrm{Tr}$ & Tr & $\mathrm{Tr}$ & $\mathrm{Tr}$ & \\
\hline ARGILO-MINERAIS & Nc & Nc & $\mathrm{Nc}$ & Nc & $\mathrm{NC}$ & $\mathrm{Nc}$ & Nc & $\mathrm{NC}$ & \\
\hline $\begin{array}{l}\text { COMPOSICÁOO DO } \\
\text { PLAGIOCLÁSIO }\end{array}$ & An26 & An22 & An27 & - & $\operatorname{An} 22$ & $\begin{array}{c}\text { An8- } \\
12\end{array}$ & $\begin{array}{c}\text { An13- } \\
15\end{array}$ & - & \\
\hline & & & & & & & & & MÉDIAS \\
\hline $\mathbf{Q}$ & 26 & 28 & 34 & 41 & 20 & 29 & 35 & 27 & 30 \\
\hline A & 34 & 51 & 45 & 45 & 61 & 45 & 43 & 23 & 43 \\
\hline $\mathrm{P}$ & 40 & 21 & 21 & 14 & 19 & 26 & 22 & 50 & 27 \\
\hline $\mathbf{Q}$ & 22 & 26 & 31 & 38 & 18 & 27 & 34 & 24 & 28 \\
\hline$A+P$ & 63 & 67 & 60 & 54 & 71 & 65 & 61 & 64 & 63 \\
\hline$M^{\prime \prime}$ & 15 & 07 & 09 & 08 & 11 & 08 & 05 & 12 & 09 \\
\hline NÚMERO DE PONTOS & 1500 & 1500 & 1500 & 1500 & 1200 & 1300 & 1500 & 1500 & \\
\hline
\end{tabular}

O feldspato potássico apresenta-se em, pelo menos, duas gerações a saber:

a) Feldspato potássico 1(Fk $)_{1}$ : corresponde aos grãos, geralmente, subédricos a euédricos, de granulação fina a média, que, algumas vezes, mostram-se substituídos parcialmente pela biotita(Prancha 2; Foto c).

b) Feldspato potássico 2( $\left.\mathrm{Fk}_{2}\right)$ : ocorre, geralmente, como megacristais anédricos a subédricos, formados pela substituição do plagioclásio 1 (microclinização). Representa o tipo mais comum. As evidências dessa substituição mostram-se traduzidas pelo desenvolvimento de"manchas" de feldspato potássico nas regiões dos planos de maclas(Prancha 2; Foto d) e de clivagem e nas bordas dos cristais de plagioclásio $\left(\mathrm{Pl}_{1}\right)$, bem como pela presença de "fantasmas" de plagioclásio 1 no interior dos megacristais de feldspato potássico 2(Prancha 2; Foto e). Desenvolve contatos irregulares, por vezes, interpenetrantes, principaimente entre si e com o plagioclásio. E, invariavelmente, 
pertítico(mesopertitas), se caracterizando pelo desenvolvimento de intercrescimentos de exsolução("strings perthites"; Prancha 2; Foto f) e de substituição(como por exemplo "films"e "chess-board perrthites"(Prancha 3; Foto a). Geralmente, as maclas são ausentes ou estão mascaradas por texturas de intercrescimentos. Entretanto, localmente, são observados os tipos xadrez(albita-periclina), característico da microclina(Prancha 3; Foto b) e Carisbad. A luz natural, mostra aspecto "sujo", ao que tudo indica, decorrente de alteraçòes tardi a pós-magmáticas para argilo-minerais. Algumas vezes, pode exibir inclusões de $Q t z_{2}$ e $Q t z_{5}$ (Prancha 3; Foto c), de $\mathrm{Pl}_{1}$ e $\mathrm{Pl}_{2}$ (Prancha 3; Foto d), de anfibólio(Prancha 3; Foto e), minerais opacos, apatita e, muito subordinadamente, de zircão. Na grande maioria das vezes, os grãos exibem bordas irregulares $e$, localmente, entre eles podem se desenvolver bordas albíticas("swapped rims"; Prancha 3; Foto f). Muito raramente, nos contatos entre feldspato potássico e plagioclásio, podem ser observados intercrescimentos mirmequiticos. Algumas vezes, mostra-se fraturado e essas fraturas podem estar preenchidas por óxido e/ou hidróxido de ferro.

Sobre a distinção do tipo de feldspato potássico(se ortoclásio ou microclina), utilizou-se como critério inicial a caracterização com base no tipo de macla. Nesse sentido, foi identificado, embora localmente, o maclamento albita-periclina ou xadrez, característico da microclina(Smith, 1974; Brown \& Parsons, 1994). Adicionalmente, comparou-se as texturas de intercrescimentos pertiticos, aqui definidas, com diversos exemplos existentes na literatura(Alling, 1932 e 1938; Smith, 1974, Brown \& Smith, 1988, Richardson, 1988). O resultado obtido indica que, pelo menos em parte, se trata de microclina pertítica. De qualquer modo, para que essa dúvida seja sanada definitivamente necessita-se de estudos através de raios- $X$, afim de que se possa caracterizar a triclinicidade da mesma.

No que se refere ao plagioclásio, foram distingüidos, pelo menos dois tipos, com base na morfologia, textura, origem e coposição.

O primeiro $\left(\mathrm{Pl}_{1}\right)$, forma, em geral, cristais subédricos, de dimensões média a grossa, embora possam ocorrer grãos, relativamente, mais finos, principalmente quando ocorre formando agregados, juntamente com anfibólio, minerais opacos(MOP $\left.P_{1}\right)$ e apatita(Prancha 4; Foto a). Esses agregados se assemalham muito com estruturas cumuláticas. Entre si e com outras fases minerais, desenvolve contatos irregulares, interpenetrantes e, às vezes, retos(principalmente com quartzo e anfibólio). Mostra, por vezes, bordas corroídas, algumas vezes, albitizadas("albite rims"). Nessas bordas, podem se desenvolver intercrescimentos mirmequíticos("myrmekite rims"). Internamente, os grãos costumam ser zonados(zoneamento normal; Smith, 1974), embora, por vezes, esse zoneamento mostrese mascarado pelo desenvolvimento de sericita \pm muscovita $\left(\mathrm{Mv}_{1}\right) \pm \operatorname{clorita}\left(\mathrm{Cl}_{1}\right) \pm$ fluorita $\left(\mathrm{Fl}_{1}\right)$ \pm epidoto(Ep1) \pm carbonato(Prancha 4; Foto b), decorrente, da descalcificação das porções 
mais internas e mais cálcicas dos cristais(Smith, 1974; Dall'Agnol, 1980). Podem ocorrer, em menor escala, cristais zonados irregularmente("patch zones"). Além disso, apresenta-se, quase sempre, parcialmente substituído por $\mathrm{Fk}_{2}$. As maclas são, geralmente visiveis e os tipos dominantes são regidos pelas leis da albita e da albita-Carlsbad. Localmente, cristais de plagioclásio mostram-se deformados, exibindo ora maclas arqueadas, ora descontínuas ("glade twnning"). Em grãos, relativamente, mais grossos, ocorrem, algumas vezes, inclusões de anfibólio, minerais opacos e apatita. Em termos composicionais(determinação ótica), varia de albita a oligoclásio cálcico $\left(A n_{27-8}\right)$ a andesina sódica, embora sejam mais comuns as composições de oligoclásio cálcio $\left(\mathrm{An}_{20}\right)$. Essas composições correspondem, principalmente, às zonas mais internas dos grãos, passiveis de determinação ótica, uma vez que essas composições tornam-se mais sódicas no sentido das bordas, até atingirem $\mathrm{An}_{0}$ nas "albite rims" Estudos realizados em microssonda eletrônica revelaram uma composição em torno de $\mathrm{An}_{32}$ (andesina sódica; ver mais adiante).

O plagioclásio $2\left(\mathrm{Pl}_{2}\right)$, por sua vez, corresponde aos cristais, geralmente, subédricos, por vezes, com bordas corroídas e às vezes mirmequíticas("myrmekite rims"), de granulação fina a média, muito pouco alterados, freqüentemente límpidos, com maclas nítidas e que costumam ocorrer, quase que exclusivamente, como inclusões no feldspato potássico 2(Prancha 4; Foto c). Apresenta composição albítica e se assemelha muito à "poikilitic albite"(Fisher, 1971)e representa, ao que tudo indica, um primeiro evento de metassomatismo sódico(albitização 1) ocorrido no estágio magmático . Localmente, mostra-se levemente substituido por $\mathrm{Fk}_{2} e$, algumas vezes, exibe minúsculas inclusões, orientadas, preferencialmente, de apatita(Prancha 4; Foto d).

O anfibólio é, geralmente, abundante nessa variedade de granitóide e predomina sobre a biotita, exceto na amostra IE-02(Tabela 3.1). Ocorre, quase sempre, como cristais subédricos e anédricos, finos a médios. Desenvolve entre si e com outras fases minerais, contatos irregulares, retos $\mathrm{e}$ interpenetrantes(principalmente com a biotita). Forma, freqüentemente agregados, juntamente com plagioclásio, minerais opacos e apatita, os quais lembram texturas cumuláticas. Por vezes, exibem textura poiquilitica, cujas inclusões mais comuns são de minerais opacos e apatita(Prancha 4; Foto e). Apresenta pleocroismo fraco a moderado, variando de verde escuro/verde-oliva $(Z$ e $Y)$ a castanho claro/castanhoesverdeado $(X)$ ou verde-azulado/verde claro( $Z$ e $Y)$ a verde-amarelado claro ou castanho pálido-esverdeado $(X)$. Possui elongação positiva, ângulo de extinção entre $6^{\circ}$ e $28,5^{\circ}$ e valor médio igual a $14,5^{\circ}$, sinal ótico negativo e ângulo $2 \mathrm{~V}$ moderado a baixo. Mostra-se, por vezes, em desequilíbrio, alterando-se para biotita, em intima associação com minerais opacos $\left(\mathrm{MOP}_{2}\right)$, titanita(Tit $\left.{ }_{2}\right)$, allanita e quartzo 3(Pranch 4; Foto f). Localmente, ocorre como 
inclusões em cristais de $\mathrm{Pl}_{1}$ (Prancha 5, Foto a) e $\mathrm{Fk}_{2}$, juntamente com minerais opacos e apatita.

Estudos realizados através de microscopia ótica e de microssonda eletrônica indicaram tratar-se de alumíniohastingsita a alumíniohastingsita a alumínio-ferroedenita(ver mais adiante). Essas composições concordam com aquelas determinadas para os anfibólios, desse mesma facies granitoide, por Dall'Agnol(1980).

A biotita, por sua vez, ocorre em lamelas anédricas a subédricas, geralmente, associadas ao anfibólio, embora ocorra, também de forma intersticial(Prancha 5; Foto b) ou mesmo substituindo o feldspato potássico(Fk1); Prancha 2, Foto c). Isso evidencia um segundo evento metassomático ocorrido no estágio magmático(microclinização 1). Exibe pleocroísmo moderado, variando de castanho escuro $(Z$ e $Y)$ a castanho claro(X), castanho escuro-avermelhado $(Z$ e $Y)$ a castanho claro-amarelado $(X)$. Eventualmente, exibe textura poiquilítica, caracterizada pela presença de inclusões de apatita, minerais opacos $\left(\mathrm{MOP}_{1}\right)$, quartzo $\left(\mathrm{Qtz} \mathrm{z}_{2}\right)$, plagioclásio1 e feldspato potássico1. Apresenta-se, algumas vezes, parcialmente cloritizada $\left(\mathrm{Cl}_{2}\right)$ e quando mais intensamente transformada, apresenta ao longo de seus planos de clivagem, o desenvolvimento de epidoto $\left(E p_{2}\right)$, quartzo 4 e "muscovita( $\left(\mathrm{Mv}_{2}\right)$ " e, subordinadamente, de minerais opacos 3(Prancha 5; Foto c).

Os minerais acessórios- apatita, minerais opacos $\left(\mathrm{MOP}_{1 \mathrm{e} 2}\right)$, titanita( $\left(\mathrm{Tit}_{1 \mathrm{e}} 2\right)$, allanita e zircão- associam-se, preferencialmente, às fases máficas. A apatita costuma ocorrer como finos grãos euédricos a subédricos, ora em cristais alongados ora como formas prismáticas hexagonais(Prancha 5; Foto d).

Os minerais opacos ocorrem em, pelo menos, três tipos, que envolvem aspectos morfológicos, texturais e genéticos a saber: 1) corresponde à uma fase primária(MOP $\left.{ }_{1}\right)$ e apresenta-se cristais, geralmente, subédricos, formando agregados com a apatita e inclusos no anfibólio, plagioclásio 1 e quartzo 1, principalmente. Representa uma fase primária(Mop1); 2) cristais anédricos a subédricos associados ao desequilíbrio do anfibólio

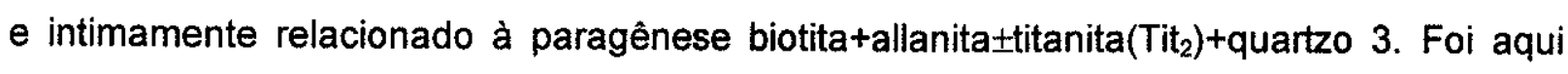
considerado como $\left.\mathrm{MOP}_{2} ; 3\right)$ grãos anédricos associados à cloritização da biotita $\left(\mathrm{Cl}_{2}\right)$. Eles ocorrem juntamente com quartzo $4+$ epidoto $\left(E p_{2}\right)+$ fluorita $\left(F I_{2}\right)+$ "muscovita( $\left(\mathrm{Mv}_{2}\right)^{\prime} \mathrm{e}$ dispõem-se, preferencialmente, ao longo dos planos de clivagem da mesma. Adotou-se a designação de $\mathrm{MOP}_{3}$.

A titanita é, de modo geral, pouco freqüente e ocorre como grãos subédricos a anédricos, ora em seu hábito característico(losangular ;Prancha 5; Foto e), ora como cristais prismáticos alongados $\left(\mathrm{Tit}_{1}\right)$ ). Além disso, ocorre, ainda, em íntima associação com as fases atribuídas à alteração do anfibólio para biotita(Tit $\left.{ }_{2}\right)$ ). A allanita e o zircão são, ainda, menos freqüentes. 
Os produtos de alterações tardi a pós-magmáticas mostram-se relacionados, principalmente, à desestabilização das fases feldspáticas e da biotita.

Associados à alteração do plagioclásio1, o par sericita \pm muscovita $\left(\mathrm{Mv}_{\uparrow}\right)$ e 0 feldspato potássico 2, representam os principais produtos de alteraçăo nessas rochas, que, de um modo geral, mostram-se pouco alteradas. As micas ocorrem em agregados complexos de finíssimas lamelas, os quais mostram-se distribuidos, preferenciaimente, nas zonas mais centrais dos cristais de plagioclásio1(zoneamento normal; Smith, 1974), geralmente acompanhadas de clorita $\left(\mathrm{Cl}_{1}\right)$ e fluorita $\left(\mathrm{Fl}_{1}\right)$, epidoto $\left(\mathrm{Ep_{1 }}\right)$ e, às vezes, carbonato. Além disso, ocorrem, subordinadamente, como "patch zones" em cristais zonados irregularmente. Epidoto $\left(\mathrm{Ep}_{2}\right)$ e fluorita $\left(\mathrm{Fl}_{2} ; \mathrm{Prancha} 5\right.$; Foto f) ocorrem, ainda, como finos grãos associada à biotita. Os argilo-minerais estão restritos a alteração do feldspato potássico, ocorrendo como nuvens superpostas ao mesmo, impondo-lhes um aspecto "sujo".

A albita tardia, embora pouco expresiva nessa variedade de granitóides, costuma ocorrer segundo, pelo menos, seis variedades distintas. Excetuam-se a isso, as albitas pertíticas. Os tipos reconhecidos mostram-se, preferencialmente, associados ao feldspato potássico 2( $\left.\mathrm{Fk}_{2}\right)$ e ao plagioclásio $\left(\mathrm{Pl}_{1}\right.$ e $\left.\mathrm{Pl}_{2}\right)$ e foram classificados como: 1) bordas albíticas desenvolvidas entre grãos de feldspato potássico 2("swapped rims"; Prancha 6; Foto a); 2) bordas albíticas associadas ao plagioclásio 1("albite rims"; Prancha 6; Foto b); 3) agrupamentos de albitas com formas de "dedos" e "mãos" que se dispõem como "invasores" dos cristais de feldspato potássico, a partir de uma borda ou do contato entre dois grãos da mesma espécie(Prancha 6; Foto c); 4) franjas albíticas intergranulares desenvolvidas entre dois cristais de feldspato potássico, mas com eixos óticos invertidos em relação ao cristal adjacente("coroas trocadas"; Prancha 6; Foto d); 5) "chess-board albite"(Prancha 6; Foto e); 6) bordas albíticas com intercrescimentos de quartzo, associadas ao plagioclásio("myrmekites rims"; Prancha 6; Foto f).

\subsubsection{2- Odem de Cristalização}

É do conhecimento básico em geologia que as rochas ígneas são formadas a partir da cristalização de um magma e que durante e após a sua colocação diversos estágios de formação mineral podem ser reconhecidos(Brown \& Parsons, 1994). No que se refere às rochas granitóides em questão(facies BASMG), apesar da superposição dos processos de alterações tardi a pós-magmáticas àqueles de natureza magmática, os estudos petrográficos permitiram reconhecer, pelo menos em parte, registros, ainda que parciais, de dois estágios de formação mineral: 1) Estágio de cristalização 
magmática(ECM); 2) Estágio de alteração tardi a pós-magmáticas(EATPM). A Figura 3.3 sumariza a ordem de formação mineral nesses estágios.

\subsection{1- Ordem de Cristalização Magmática}

O exame pormenorizado de lâminas delgadas possibilitou estabelecer o panorama abaixo para a seqüência de cristalização das fases minerais constitutivas dessa facies granitóide.

1- Nucleação e crescimento de fases minerais acessórias, representadas, principalmente, por minerais opacos, apatita, titanita( $\left.\mathrm{Tit}_{1}\right)$ e zircão. Isto é sustentado pela presença sistemática dessas fases como inclusões nas fases minerais essenciais(quartzo 1 e plagioclásio 1) e varietais(anfibólio e biotita)(Prancha 7; Foto a).

2- O prosseguimento desse estágio é marcado pelo aparecimento, quase concomitante, de anfibólio e plagioclásio 1(albita-oligoclásio a andesina). Isso se justifica pela ocorrência dessas fases formando agregados semalhantes a cumulatos, juntamente com apatita e minerais opacos, principalmente, bem como por hospedarem inclusões dessas duas fases precoces(Prancha 4;Foto a). Além, disso, plagioclásio 1 e anfibólio(Prancha 7; Foto b), podem ocorrer como inclusões em cristais de quartzo 1 e 2 , feldspato potássico 2(Prancha 3 ; Foto e) e, subordinadamente, em lamelas de biotita(Prancha 2; Foto $\mathrm{c}$ ).

3- Embora, em grande parte, mascarados pelas paragêneses minerais relacionadas ao estágio de alterações tardi a pós-magmáticas, sobrepostas ao evento tipicamente magmático, a seqüência de cristalização prosseguiu com o aparecimento de quartzo 1 , feldspato potássico 1 e quartzo 2. Isso pode, em parte, ser justificado pela presença, lado a lado, de quartzo 1 e feldspato potássico 1, quartzo 1 e anfibólio, quartzo 1 e plagioclásio 1 , quartzo 2 e plagioclásio 1, quartzo 1 e quartzo 2, feldspato potássico 1 e quartzo 2 e quartzo 2 e anfibólio. A relação plagiociásio 1 e feldspato potássico 1 é sempre muito confusa, visto que o primeiro encontra-se, geralmente, sendo substituído, em diferentes intensidades, por feldspato potássico 2. Isso caracteriza um segundo evento de metassomatismo potássico (microclinização 2). Entretanto, como essa facies granitóide representa o termo menos evoluído e menos transformado do maciço, bem como não são noticiadas mineralizações a ela associadas, acredita-se tratar-se de um processo de metassomatismo potássico inicial, que marca o fim do estágio magmático e o início do estágio de alterações tardi a pósmagmáticas. Isso pode ser corroborado pelo desenvolvimente, embora localizado, de "myrmekita rims"(Phillips, 1974) em cristais de plagioclásio 1, os quais mostram-se parcialmente substituidos por $\mathrm{Fk}_{2}$, evidenciando um estágio transicional de substituição. 
Esse fato é muito comum em micrloclina granitos(Riederer, $1965 \mathrm{In}$ : Smith, 1974 e pode significar o fim do estágio magmático(Riederer, 1965 In: Smith, 1974).

Além disso, inclusões de plagioclásio $2\left(\mathrm{Pl}_{2}\right)$, de composição albítica(ver descrição acima), em megacristais de $\mathrm{Fk}_{2}$ podem ser observadas com freqüencia nas rochas estudadas. Essas inclusões se assemelham muito ao que Fisher(1971) designou de "poikilitic albite" em oposição ao termo "cleavelandite" de Laves \& Soldatos(1963 In: Smith, 1974). Acerca dessas inclusões, Fisher(1971), considerou que as mesmas seriam uma fase primária, decorrente da substituição da microclina por albita(metassomatismo sódico), produzindo "chess-board albite", que se cristalizariam mais ou menos em contemporaneidade com a microclina hospedeira ou um pouco antes. E seriam incorporadas acidentalmente pelo feldspato potássico hospedeiro.

No que se refere aos granitóides estudados, a hipótese de que esses cristais de albita teriam se cristalizados um pouco antes do hospedeiro $\left(\mathrm{Fk}_{2}\right)$, ou pelo menos uma parte dele, parece mais coerente, visto que os mesmos mostram-se plenamente formados a ao contato com 0 hospedeiro desenvolvem, algumas vezes, uma franja mirmequitica("myrmekite rims"), ao que tudo indica, reflexo de reações de troca entre os dois devido à incorporação(Prancha 4; Foto c). Outra evidência disso, é a orientação preferencial de grupos de inclusões de albita, freqüentemente em nítida discordância com a orientação ótica dos cristais de microclina pertítica hospedeiros $\left(\mathrm{Fk}_{2}\right)$. As bordas albíticas observadas em algumas dessas inclusões podem ser explicadas do mesmo modo que aquelas descritas em cristais de plagioclásio $1\left(\mathrm{Pl}_{1}\right)$, sem necessariamente representarem uma outra geração de mirmequitas. Assim o seu desenvolvimento estaria associado a reações locais de troca entre as inciusões de albita $\left(\mathrm{Pl}_{2}\right)$ e o feldspato potássico hospedeiro( $\left.\mathrm{Fk}_{2}\right)$.

4- Associada às reações do anfibólio com o líquido magmático, ao que tudo indica, em condições "subsolidus", ocorre o aparecimento da biotita, juntamente com minerais opacos $\left(\mathrm{MOP}_{2}\right)+$ allanita+titanita(Tit $\left.{ }_{2}\right)+$ quartzo3..

5- Ainda no estágio magmático, foram caracterizadas, nesses granitóides uma série de texturas de intercrescimentos, envolvendo, preferencialmente, o grupo dos feldspatos. Esses são representadas por pertitas, atribuídas, principalmente, a processos de exsolução, onde destaca-se o tipo "string perthites"(Alling, 1938; Smith, 1974). Outros tipos de pertitas ocorrem, estando, entretanto associados ao estágio de alterações tardi a pós-magmáticas. São relacionados à substituição ocorrida, ao que tudo indica, em condições subsolidus( Alling, 1938; Smith, 1974; Blasi \& Blasi, 1994). Dentre eles destacam-se: "film perthites", "band perthites", "vein perthites", "patch perthites" e "chess-board albite"(Alling, 1932, 1938; Smith, 1974; Smith \& Brown, 1988). Esses vários tipos ocorrem combinados, formando pertitas compostas(Alling, 1938; Smith, 1974), embora um tipo ou outro possa ter origem 
distinta e ter sua formação associada a momentos(tempos) diferentes. Além disso, é comum a gradação de um tipo a outro, principalmente quando se trata dos tipos "film", "band", "vein" e "patch perthites"(Prancha 7; Fotos $c, d, e, f)$.

\subsection{2- Ordem de Cristalização Tardi a Pós-magmática}

Diversos autores tem estabelecido uma ordem cronológica de formação de fases minerais nesse estágio. Dentre eles destacam-se Serebryakova(1961), Beus(1964), Beus \& Zalashkova(1964) Scherba(1970), Ginzburg(1970), Haapala(1977), Pollard(1983), Pollard et al.(1983), Kinnaird(1985), Kinnaird et al.(1985b), Pollard \& Taylor(1986), Taylor \& Pollard(1988), Strong(1988), Richardson(1988), Witt(1988), Pollard(1989a) e Pollard(1989b), entre outros.

Nesse trabalho, o estudo de seções delgadas permitiu elaborar o seguinte quadro em relação a essa questão:

1) Os primeiros indicios da formação de minerais neste estágio mostram-se registrado através de diversas fases minerais originadas durante um segundo evento autometassomático, de natureza potássica, que afetou, especialmente, o plagioclásio1 $\left(\mathrm{Pl}_{1}\right)$, de composição albita-oligoclásio a andesina. No que se refere ao plagioclásio, observou-se dois instantes de substituição do mesmo: 1) substituição parcial, em diferentes graus, por sericita \pm muscovita $\left(\mathrm{Mv}_{1}\right) \pm \operatorname{clorita}\left(\mathrm{Cl}_{1}\right) \pm$ fluorita $\left(\mathrm{Fl}_{1}\right) \pm$ carbonato; 2) substituição por microclina pertítica $\left(F_{2}\right)$. Essa separação no tempo deve-se ao fato de terem sido observados "esqueletos" e "fantasmas" de $\mathrm{Pl}_{1}$, com relíctos de sericita \pm muscovita( $\mathrm{Mv}_{1}$; Prancha 2; Foto e), no interior de cristais grossos $(>5 \mathrm{~mm})$ de $\mathrm{Fk}_{2}$.

2) Seguindo-se a esse evento, foi caracterizado um segundo episódio autometassomático, dessa feita, de natureza sódica(albitização 2), traduzido, principalmente, pela albitização do feldspato potássico2 e, em menor escala, do plagioclásio1. e, ao que tudo indica, pela substituição da biotita por clorita $\left(\mathrm{Cl}_{2}\right) \pm$ minerais $\operatorname{opacos}\left(\mathrm{MOP}_{3}\right) \pm$ epidoto $\left(\mathrm{Ep}_{2}\right) \pm$ fluorita $\left(\mathrm{Fl}_{2}\right) \pm$ quartzo 4 . No que se refere à albitização, é um processo francamente posterior à microclinização do $\mathrm{Pl}_{1}$, visto que as feições de substituição são muito claras, especialmente, em relação ao $\mathrm{Fk}_{2}$ (Conforme visto anteriormente). No caso da biotita, é difícil estabelecer o momento exato dessa alteração. Entretanto, a presença de fluorita $\left(\mathrm{Fl}_{2}\right)$ na associação mostra uma tendência dessa alteração estar relacionada a esse segundo evento. Isso decorre do fato desse mineral se tornar, relativamente, mais bem desenvolvido e mais abundante durante a albitização. Além disso, em amostras onde a biotita tem conteúdos, relativamente mais expressivos(Tabela 3.1) e encontra-se mais preservada, a presença de albita é inexpressiva, o mesmo ocorrendo com a fluorita 2. 
Os argilo-minerais ocorrem amplamente substituindo tanto o feldspato potássico 1 , quanto o $\mathrm{Fk}_{2}$, sendo portanto, dificil posicionar sua ordem de formação ao longo do tempo em relação a esse granitóide. Entretanto, alguns autores atribuem a formação dos argilominerais a um evento de alteração argilica, ocorrente no final do estágio de alteração tardi a pós-magmática ou nas porções mais superiores das cúpolas dos plutons ganitóides(Silitoe et al., 1975; Kinnaird et al.,1985b; Pollard \& Taylor, 1986; Strong, 1988; Pollard, 1989b; entre outros).

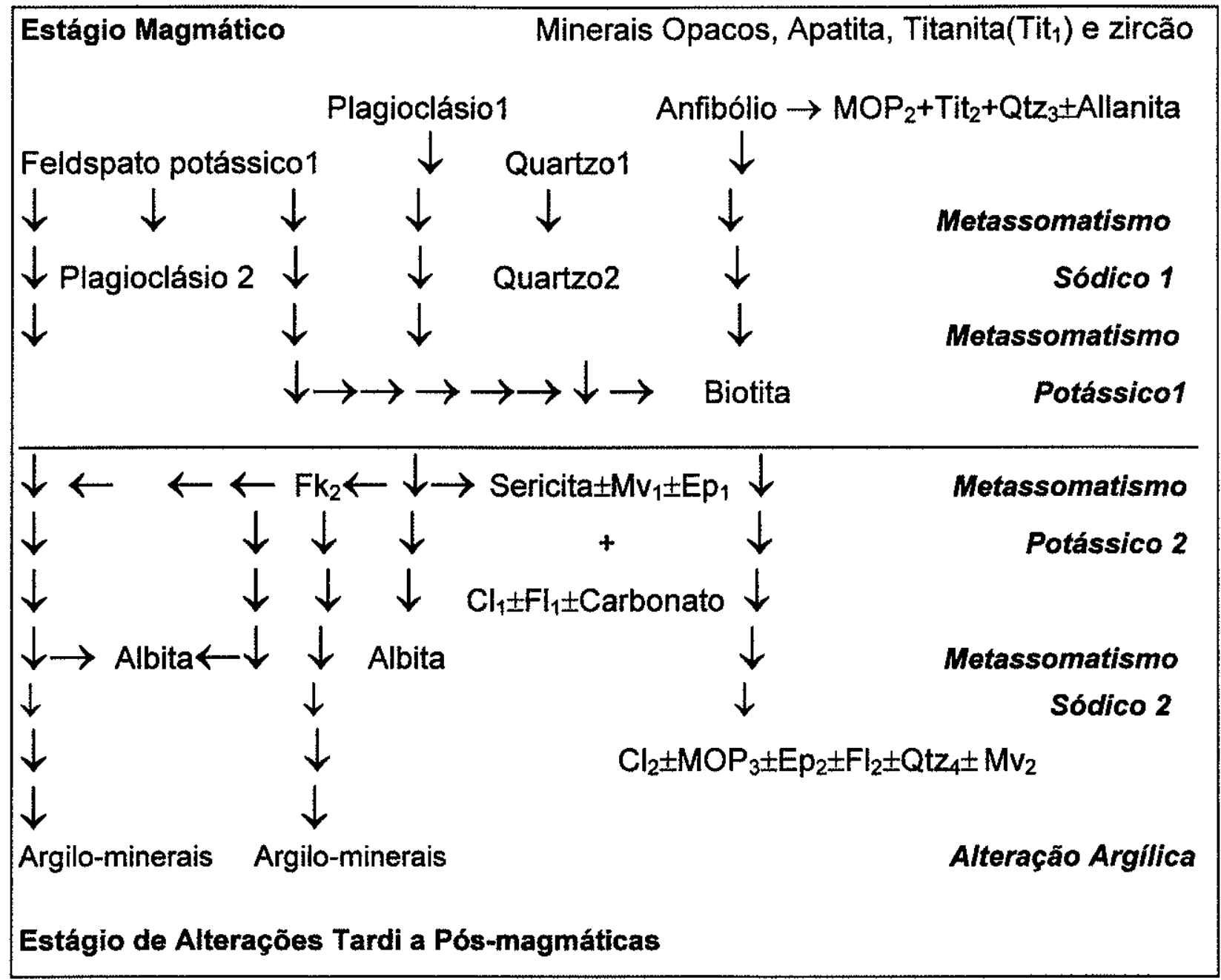

Figura 3.3. Fluxograma mostrando as ordens de cristalizaçőes magmática e tardi a pós-magmática das fases minerais da facies BASMG. Maciço granitóide António Vicente. 


\subsubsection{2- Facies BASAFG e ABSG}

\subsubsection{1- Textura e Mineralogia}

Esses granitóides representam uma variação composicional do BASMG. Comparativamente a ele, esses guardam uma série de semelhanças texturais e mineralógicas com o mesmo, mas diferem por serem relativamente mais enriquecidos em feldspato potássico e empobrecidos em plagioclásio, anfibólio e biotita. Além disso, zircão, allanita e epidoto são, em média, mais freqüentes nessas variedades de granitóides, enquanto que titanita e apatita são raros ou ausentes(Tabelas 3.1 e 3.2). Ademais, análises químicas através de microssonda eletrônica revelaram uma composição entre hastingsita e a da ferro-edenita(ver mais adiante).

Tabela 3.2- Composições modais do anfibólio-biotita sienogranito(ABSG) e do biotita-anfibólio sieno a ákali feldspato granito(BASAFG). Maciço granitóide Antônio Vicente. Ir= traço: Nd= Não detectado: $N c=$ Não contado.

\begin{tabular}{|c|c|c|c|c|c|c|c|}
\hline \multirow{2}{*}{$\frac{\text { VARIEDADE }}{\text { AMOSTRAS }}$} & \multicolumn{4}{|c|}{ ABSG } & \multicolumn{3}{|c|}{ BASAFG } \\
\hline & MUT-21 & $1 \mathrm{G}-\mathrm{SN}-12$ & MUT-20 & & MUT-24A & $1 G-S N=11$ & \\
\hline & 9 & 10 & 11 & & 12 & 13 & \\
\hline $\begin{array}{l}\text { MINERAIS } \\
\text { PRIMÁRIOS }(\%)\end{array}$ & & & & & & & \\
\hline QUARTZO & 34 & 20 & 39 & & 34 & 30 & \\
\hline PLAGIOCLÁSIO & 08 & 10 & 06 & & 12 & 05 & \\
\hline FELDSPATO $\left(\right.$ Fk $\left._{1}\right)$ & 52 & 53 & 48 & & 45 & 56 & \\
\hline ANFIBÓLIO & $\mathrm{Tr}$ & 01 & $\mathrm{Tr}$ & & 02 & 02 & \\
\hline BIOTITA & $\mathrm{Tr}$ & 03 & 03 & & 01 & 01 & \\
\hline ZIRCĀO & Ir & $\mathrm{Ir}$ & Ir & & ir & $\mathrm{Ir}_{\mathrm{r}}$ & \\
\hline MINERAIS OPACOS & $\mathrm{Tr}$ & $\mathrm{Tr}$ & $\mathrm{Ir}$ & & Ir & $\mathrm{Ir}$ & \\
\hline APATITA & $\mathrm{Nd}$ & $\mathrm{Nd}$ & Nd & & $\mathrm{Ir}$ & $\mathrm{Tr}$ & \\
\hline ALLANITA & 02 & 02 & $\mathrm{Nd}$ & & Nd & $\mathrm{Nd}$ & \\
\hline $\begin{array}{l}\text { MINERAIS } \\
\text { SECUNDÁRIOS }(\%)\end{array}$ & & & & & & & \\
\hline SERICITA \pm MUSCOVITA & $\mathrm{Tr}$ & Ir & $\mathrm{Tr}$ & & 01 & $\operatorname{Tr}$ & \\
\hline FELDSPATO $\left(\mathrm{Fk}_{2}\right.$ ) & NC & $\mathrm{NC}$ & $\mathrm{Nc}$ & & $\mathrm{NC}$ & $\mathrm{Nc}$ & \\
\hline CLORITA & Ir & $\mathrm{Ir}$ & $\mathrm{Tr}$ & & Ir & $\mathrm{Tr}$ & \\
\hline EPIDOTO & $\pi$ & $\mathrm{Tr}$ & OI & & 01 & $\mathrm{Ir}$ & \\
\hline AlLBITA & 03 & 09 & 02 & & 04 & 06 & \\
\hline FLUORITA & Nd & 01 & Ir & & Ir & $\mathrm{Ir}$ & \\
\hline QUARTZO & $\operatorname{Tr}$ & Ir & $\operatorname{Tr}$ & & $\mathrm{Tr}$ & $\mathrm{Ir}$ & \\
\hline MINERAIS OPACOS & $\mathrm{Tr}$ & $\mathrm{Ir}$ & $\mathrm{Tr}$ & & $\mathrm{Tr}$ & $\operatorname{Tr}$ & \\
\hline ARGILO-MINERAIS & NC & NC & NC & NC & NC & $\mathrm{NC}$ & \\
\hline $\begin{array}{l}\text { COMPOSIČÃO DO } \\
\text { PLAGIOCLÁSIO }\end{array}$ & An4-11 & An11-17 & - & MÉDIAS & $\operatorname{An} 23$ & An28 & MÉDIAS \\
\hline$Q$ & 35 & 22 & 41 & 33 & 36 & 31 & 34 \\
\hline A & 57 & 67 & 52 & 59 & 52 & 64 & 58 \\
\hline$P$ & 08 & 11 & 07 & 08 & 12 & 05 & 08 \\
\hline$Q$ & 36 & 23 & 40 & 33 & 35 & 30 & 33 \\
\hline$A+P$ & 61 & 72 & 56 & 63 & 61 & 67 & 64 \\
\hline$M^{\prime}$ & 03 & 05 & 04 & 04 & 04 & 03 & 03 \\
\hline NÚMERO DE PONTOS & 1400 & 1500 & 1500 & & 1500 & 1500 & \\
\hline
\end{tabular}

Feições ligadas ao metassomatismo potássico mostram-se expressivas, embora costumem ser mais comuns as substituições do plagioclásio $1\left(\mathrm{PI}_{1}\right)$ por feldspato potássico 2 (microclinização). O desenvolvimento de sericitat/-muscovita( $\left(\mathrm{Mv}_{1}\right)$ é pouco pronunciado. A albitização é pouco expressiva, sendo traduzida, principalmente, por "swapped rims" e "albite rims", bem como por albitas intergranulares desenvolvidas, preferencialmente, nos 
contatos entre grãos de feldspato potássico $\left(\mathrm{Fk}_{2}\right)$. Além disso, ocorrem, ainda, fluorita $\left(\mathrm{Fl}_{2}\right)$, ligada principalmente à biotita) e argili-minerais(intimamente associados ao feldspato potássico $\left(\mathrm{Fk}_{1}\right.$ e $\left.\mathrm{Fk}_{2}\right)$.

Intercrescimentos pertíticos(mesopertitas) são texturas muito comuns, sendo relativamente mais freqüentes aqueles tipo "films perthites"

Em termos composicionais, ocupam os campos dos álcali-feldspato granitos e sienogranitos e mostram natureza holo-leucocrática(Figuras 3.2 a e $3.2 \mathrm{~b}$ )

Embora sejam muito semelhantes entre si, mostram algumas diferenças a saber: 1) No BASAFG o anfibólio é relativamente mais abundante e está melhor preservado, estando apenas levemente alterado para biotita(+allanita+minerais opacos 2), enquanto que no ABSG torna-se raro, uma vez que foi quase que totalmente substituído pela biotita; 2) Na facies ABSG a cloritização é relativamente intensa, afetando tanto a biotita, quanto o feldspato potássico; 3) As feições de albitização do feldspato potássico("swapped rims", chess-board albite" e albitas intergranulares) são mais pronunciadas nos ABSG.

Em relação à ordem de cristalização das fases minerais primárias e tardi a pósmagmáticas, não foge ao que foi estabelecido para a facies BASMG.

\subsubsection{3-Facies $\mathrm{BSGCl}$}

\subsubsection{1-Textura e Mineralogia}

Esse granitóide é tipicamente desprovido de anfibólio(Tabela 3.3). A biotita mostra-se freqüentemente cloritizada em diferentes intensidades e constitui o principal máfico primário.

Composicionalmente, ocupa o campo dos sienogranitos e mostram natureza hololeucocrática(Figuras 3.a e 3b).

Consiste essencialmente de quartzo, feldspato potássico e plagioclásio, sendo varietal a biotita. Os minerais acessórios são pouco abundantes, sendo mais comum o zircão. Localmente, minerais opacos e apatita podem alcançar teores expressivos. A clorita $\left(\mathrm{Cl}_{2}\right)$ ) é o principal produto secundário. Feições ligadas ao metassomatismo potássico mostram desenvolvimento moderado e estão associadas, principalmente, à substituição do plagioclásio por feldspato potássico, bem como pelo desenvolvomento de sericita \pm muscovita $\left(\mathrm{MV}_{1}\right) \pm$ fluorita $\left(\mathrm{Fl}_{1}\right) \pm$ clorita $\left(\mathrm{Cl}_{1}\right)$. A albitização é pouco desenvolvida e está representada por "chess-board albite" relacionada à substituição do feldspato potássico $\left(\mathrm{Fk}_{2}\right)$ por albita, pelo desenvolvimento de agrupamentos de albita no contato entre cristais de feldspato potássico $\left(\mathrm{Fk}_{2}\right)$, e por "swapped rims" e "albite rims".

intercrescimentos pertíticos são texturas comuns e predominam os tipos "film", "veins" e "patch pertites", embora ocorra, subordinadamente, o tipo "string pertite". Além 
disso, localmente, são observados intercrescimentos granofíricos, especialmente aqueles tipo insular, conforme Smith \& Brown(1988);Prancha 8; Foto a, deste trabalho), o que demonstra condições de cristalização em nivel crustal raso.

Tabela 3.3- Composições modais do biotita sienogranito com clorita(BSGCl). Maciço granitóide Antônio Vicente. Trm traços; NC= Não contado.

\begin{tabular}{|c|c|c|c|c|c|c|c|c|}
\hline \multirow{2}{*}{\begin{tabular}{|l} 
VARIEDADE \\
AMOSTRAS
\end{tabular}} & \multicolumn{8}{|c|}{$\mathrm{BSGCI}$} \\
\hline & AM-03-MUT & $\mathrm{N}-\mathrm{S}-4$ & $\mathrm{~N}-\mathrm{S}-2 \mathrm{~A}$ & IG-SN-1 & $N-S-1 B$ & SN-6 & $\mathrm{SN}-4$ & \\
\hline & 14 & 15 & 16 & 17 & 18 & 19 & 20 & \\
\hline \multicolumn{9}{|c|}{ MINERAIS PRIMÁRIOS[\%] } \\
\hline QUARTZO & 46 & 38 & 33 & 43 & 28 & 38 & 40 & \\
\hline PLAGIOCLÁSIO & 17 & 17 & 21 & 08 & 16 & 09 & 10 & \\
\hline K-FELDSPATO & 30 & 42 & 43 & 47 & 53 & 51 & 47 & \\
\hline BIOTITA & 05 & 01 & 02 & $\mathrm{Ir}$ & $\mathrm{Ir}$ & Ir & 02 & \\
\hline ZIRCÃO & $\mathrm{Tr}$ & $\mathrm{Tr}$ & $\mathrm{Tr}$ & $\pi r$ & Tr & Ir & $\mathrm{Ir}$ & \\
\hline MINERAIS OPACOS & $\mathrm{Tr}$ & $\pi$ & $\mathrm{Ir}$ & $\mathrm{Tr}$ & $\operatorname{Ir}$ & $\mathrm{Ir}$ & $\mathrm{mr}$ & \\
\hline APATITA & $\operatorname{Tr}$ & $\operatorname{Tr}$ & $\mathrm{fr}$ & $\mathrm{Tr}$ & Ir & Ir & $\mathrm{Ir}$ & \\
\hline \multicolumn{9}{|l|}{$\begin{array}{l}\text { MINERAIS } \\
\text { SECUNDÁRIOS }(\%)\end{array}$} \\
\hline SERICITA \pm -MUSCOVITA & $\mathrm{Tr}$ & Tr & Ir & $\operatorname{Tr}$ & Ir & Ir & $\mathrm{Ir}$ & \\
\hline K-FELDSPATO & $\mathrm{NC}$ & Nc & NC & $\mathrm{NC}$ & NC & NC & $\mathrm{NC}$ & \\
\hline CLORITA & $\mathrm{Tr}$ & 01 & Ir & 01 & 01 & 01 & 01 & \\
\hline EPIDOTO & Ir & $T r$ & Ir & $\mathrm{Tr}$ & Ir & $\mathrm{Tr}$ & $\mathrm{Ir}$ & \\
\hline ALBITA & 02 & 01 & 01 & $\mathrm{Tr}$ & 01 & Tr & Ir & \\
\hline FLUORITA & $\mathrm{Tr}$ & $\mathrm{Ir}$ & Ir & $\mathrm{Tr}$ & $\mathrm{Ir}$ & Ir & $\mathrm{Tr}$ & \\
\hline MINERAIS OPACOS & Tr & Ir & Ir & $\mathrm{Tr}$ & Ir & Ir & $\mathrm{Tr}$ & \\
\hline QUARTZO & $\mathrm{Tr}$ & $\mathrm{Ir}$ & Tr & $\mathrm{Tr}$ & $\overline{T r}$ & Ir & $\pi$ & \\
\hline ARGILO-MINERAIS & $\mathrm{NC}$ & Nc & $\mathrm{NC}$ & NC & $\mathrm{NC}$ & NC & $\mathrm{NC}$ & \\
\hline $\begin{array}{l}\text { COMPOSIČÃO DO } \\
\text { PLACIOCLÁSIO }\end{array}$ & - & - & - & - & - & - & - & MÉDIAS \\
\hline$Q$ & 48 & 39 & 34 & 44 & 29 & 39 & 41 & 39 \\
\hline $\mathrm{A}$ & 34 & 44 & 44 & 48 & 55 & 52 & 49 & 47 \\
\hline$P$ & 18 & 17 & 22 & 08 & 16 & 09 & 10 & 14 \\
\hline$Q$ & 46 & 38 & 33 & 44 & 28 & 38 & 40 & 38 \\
\hline$A+P$ & 49 & 60 & 65 & 55 & 70 & 61 & 57 & 60 \\
\hline$M^{\prime}$ & 05 & 02 & 02 & 01 & 02 & 01 & 03 & 02 \\
\hline NÚMERO DE PONTOS & 1200 & 1500 & 1300 & 1200 & 1400 & 1200 & 1500 & \\
\hline
\end{tabular}

O quartzo ocorre em, pelo menos, cinco variedades definidas de acordo com a morfologia, aspecto textural e origem. Os cinco tipos correspondem mais ou menos àqueles definidos na facies BASMG e suas variações(BAAFG e ABSG), exceto no que se refere ao tipo 4(quartzo intercrescido com plagioclásio formando intercrescimentos mirmequíticos). Nesses granitóides, o quartzo 4 corresponde àquele associado aos intercrescimentos granofíricos.

Feldspato potássico e plagioclásio mostram características texturais semelhantes com aqueles decritos nos BASMG, embora, nesta facies, esse último, seja composicionalmente mais sódico.

A biotita forma cristais anédricos a subédricos e, geralmente, ocorre em agregados juntamente com minerais opacos $\left(\mathrm{MOP}_{2}\right)$ e quartzo 3 , embora possa ocorrer, também, de forma intersticial. Apresenta pleocroísmo moderado a forte, variando de castanho escuro- 
avermelhado ( $Z$ e $Y)$ a castanho pálido(X) ou palha. Exibe, por vezes, inclusões de apatita, zircão e minerais opacos(Mop 1). Mostra-se, quase sempre, parcialmente cloritizada, sendo, ainda, substituida por minerais opacos $\left(\mathrm{MOP}_{2}\right)$, epidoto e $\mathrm{Qtz}$ (geralmente fusiforme), os quais mostram-se dispostos preferencialmente ao longo dos planos de clivagem da mesma(Prancha 8; Foto b).

A clorita ocorre tal qual nas facies granitóides apresentadas anteriormente. Forma lamelas anédricas, tem pleocroismo fraco, variando de verde claro $(Z$ e $Y)$ a verde pálido $(X)$ $e$, às vezes, exibe cor de interferência anômala(violácea), especialmente, quando associadas à cloritização da biotita $\left(\mathrm{Cl}_{2}\right)$.

Dentre os minerais acessórios, o zircão é relativamente o mais freqüente, ocorrendo como minúsculos grãos euédricos a subédricos, intimamente associados à biotita ou como inclusões na mesma. Nesse último caso, pode desenvolver nítidos halos pleocróicos(Prancha 8; Foto c).

Os minerais opacos apresentam-se em dois tipos bem definidos. primeiro(MOP$\left.)_{1}\right)$ é caracrizado por cristais, geralmente, subédricos associados à biotita, zircão e apatita. $\mathrm{O}$ segundo $\left(\mathrm{MOP}_{2}\right)$ consiste de gãos anédricos dispostos paralelamente aos planos de clivagem da biotita e/ou clorita.

A apatita é menos freqüente, embora, localmente, possa alcançar teores relativamente expressivos. Forma gãos, geralmente, subédricos a euédricos, via de regra, associados à biotita, zircão e minerais opacos.

\subsubsection{2- Ordem de Cristalização}

A ordem de cristalização das fases minerais desse granitóide difere um pouco daquela estabelecida para os granitóides vistos anteriormente. A ausência do anfibólio decorre, muito provavelmente, de reações deste com o líquido magmático em condições subsolidus, produzindo biotita + minerais opacos $\left(\mathrm{MOP}_{2}\right)+$ epidoto + quartzo3. 0 desaparecimento do anfibólio, ocorreu, ao que tudo indica, quando todas as fases essenciais(quartzo 1 e 2+feldspato potássico 1+plagioclásio 1 e 2) estavam formadas. Isso é justificado pela presença de inclusões dessas fases em cristais de biotita, bem como pela cristalização intersticial da mesma. Ressaltadas essas observações, a ordem de cristalização segue mais ou menos os mesmos caminhos descritos no caso dos granitóides descritos anteriormente(Figura 3.3), sendo, portanto, desnecessário repetí-los aqui. 


\subsubsection{4- Facies AFG}

\subsubsection{1- Textura e Mineralogia}

Esse granitóide representa a facies mais diferenciada e evoluída na âmbito desse domínio do maciço. É muito pobre em máficos(biotita) e em plagioclásio e muito rica em quartzo e feldspato potássico(microclina pertítica), conforme pode ser observado na Tabela 3.4. Ele representa o líquido magmáticos mais evoluido na evolução dos granitóides do maciço Antônio Vicente como um todo, ou mesmo, em relação aos granitóides dessa região do maciço. $\mathrm{Na}$ Prancha 8 , Foto d são mostradas as características texturais microscópico dessa facies granitóide.

Localmente, apresenta textura de preenchimento, representada por microfraturas preenchidas por veios de quartzo.

As alterações tardi a pós-magmáticas são traduzidas pelo desenvolvimento de sericita \pm Muscovita $\left(\mathrm{Mv}_{1}\right) \pm$ clorita $\left(\mathrm{Cl}_{1}\right) \pm$ epidoto $\left(\mathrm{Ep}_{1}\right)$ e de Feldspato potássico $2\left(\mathrm{FK}_{2}\right)$, associados à substituição parcial do plagioclásio1, de albitas intergranulares nos contatos entre cristais de feldspato potássico( $\mathrm{Fk}_{2}$; "coroas trocadas"; Prancha 8, Foto f) e por bordas albíticas tipo "swapped rims", bem como por "chess-board albite" decorrentes da substituição do feldspato potássico $\left(\mathrm{Fk}_{2}\right)$. Além disso, as lemelas de biotita mostram-se, quase sempre, cloritizadas $\left(\mathrm{Cl}_{2}\right)$, ocorrendo, ainda, como sub-produtos dessa alteração epidoto $\left(E \mathrm{p}_{2}\right) \pm$ minerais opacos $\left(\mathrm{MOP}_{2}\right) \pm$ quartzo 3 e os cristais de feldspato potássico(Fk e $\mathrm{Fk}_{2}$ ) mostram-se, invariavelmente, alterados para argilo-minerais. No conjunto, esses produtos tardi a pós-magmáticos não se mostram muito expressivos nesse granitóide. Intercrescimentos pertíticos são características comuns dos feldspato potássicos e mostram representados por pertitas compostas(Alling, 1938), sendo mais freqüentes os tipos "films", os quais gradam, por vezes, para "veins" e "bands perthites"(Prancha 8, Foto e)

\subsubsection{2- Ordem de Cristalização}

No que se refere à seqüência de cristalização, o exame de lâminas delgadas permitiu estabelecer o seguinte quadro:

1) As fases minerais precoces, representadas por minerais opacos, zircão e apatita, ao que tudo indica, foram as primeiras a separar do líquido magmático gerador desse granitóide. Isso se justifica pela presença de inclusões das mesmas nas fases essenciais e, mais raramente, na biotita biotita.

2) Dentre as três fases essenciais, o plagioclásio 1 iniciou sua cristalização um pouco antes do feldspato potássico $\left(F k_{1}\right)$ e do quartzo1 $\left(Q t z_{1}\right)$. Essas fases hospedam, mesmo que localmente, inclusões de $\mathrm{PI}_{1}$. 
3) $\mathrm{O}$ quartzo 1 e o $\mathrm{Fk}_{1}$ ocorrem lado a lado e desenvolvem, por vezes, contatos interpenetrantes. Isso é indicativo de uma deposição conjunta. Além disso, não foram observadas relações de inclusões entre essas fases.

4) A biotita, quase sempre cloritizada, parece uma fases tardia em relação às demais fases primárias, visto que ocorre de forma intersticial em relação ao $\mathrm{Qtz}_{1}$ e ao $\mathrm{Fk}_{1}$.

5) As demais fases são claramente tardi a pós-magmáticas.

A Figura 3.4 mostra um esboço da seqüência de cristalização das fases minerais magmáticas e tardi a pós-magmáticas dessa facies. Tabela 3.4- Composições modais do álcali-feldspato granito(AFG). Maciço
granitóide Antönio Vicente. Tr= Traço; NC= Não contado.

\begin{tabular}{|c|c|c|c|c|}
\hline \multirow{2}{*}{\begin{tabular}{|l|} 
VARIEDADE \\
AMOSTRAS \\
\end{tabular}} & \multicolumn{4}{|c|}{ AFG } \\
\hline & $\mathrm{N}-\mathrm{S}-5 \mathrm{~A}$ & MUT-23 & $1 G-S N-10$ & \\
\hline & 21 & 22 & 23 & \\
\hline $\begin{array}{l}\text { MINERAIS } \\
\text { PRIMÁRIOS(\%) }\end{array}$ & & & & \\
\hline QUARTZO & 24 & 35 & 40 & \\
\hline PLAGIOCLÁSIO & 03 & 03 & 05 & \\
\hline FELDSPATO(Fk 1$)$ & 68 & 52 & 42 & \\
\hline BIOTIIA & 01 & ir & $\mathrm{Tr}$ & \\
\hline ZIRC ÃO & $\operatorname{Tr}$ & $\pi r$ & Ir & \\
\hline MINERAIS OPACOS & $\mathrm{Tr}$ & 01 & 01 & \\
\hline APATITA & Ir & Ir & Ir & \\
\hline $\begin{array}{l}\text { MINERAIS } \\
\text { SECUNDÁRIOS(\%) }\end{array}$ & & & & \\
\hline SERICIIA \pm MUSCOVITA & Ir & $\operatorname{Tr}$ & Tr & \\
\hline K-FELDSPATO $\left(\mathrm{Fk}_{2}\right)$ & & & & \\
\hline CLORITA & 01 & Tr & $\operatorname{Tr}$ & \\
\hline EPIDOTO & Ir & 02 & Tr & \\
\hline ALBITA & 03 & 07 & 12 & \\
\hline MINERAIS OPACOS & $\mathrm{Ir}$ & $\mathrm{Tr}$ & $\mathrm{Tr}$ & \\
\hline QUARTZO & Tr & Ir & $\pi$ & \\
\hline ARGILO-MINERAIS & $\mathrm{Nc}$ & $\mathrm{NC}$ & NC & \\
\hline $\begin{array}{l}\text { COMPOSIÇÃO DO } \\
\text { PLAGIOCLÁSIO }\end{array}$ & - & - & - & MÉDIAS \\
\hline$Q$ & 24 & 36 & 41 & 34 \\
\hline A & 73 & 61 & 55 & 63 \\
\hline $\mathrm{P}$ & 03 & 03 & 04 & 03 \\
\hline$Q$ & 24 & 35 & 40 & 33 \\
\hline$A+P$ & 75 & 63 & 59 & 66 \\
\hline$M^{\prime}$ & 01 & 02 & 01 & 01 \\
\hline NÚMERO DE PONTOS & 1500 & 1400 & 1500 & \\
\hline
\end{tabular}




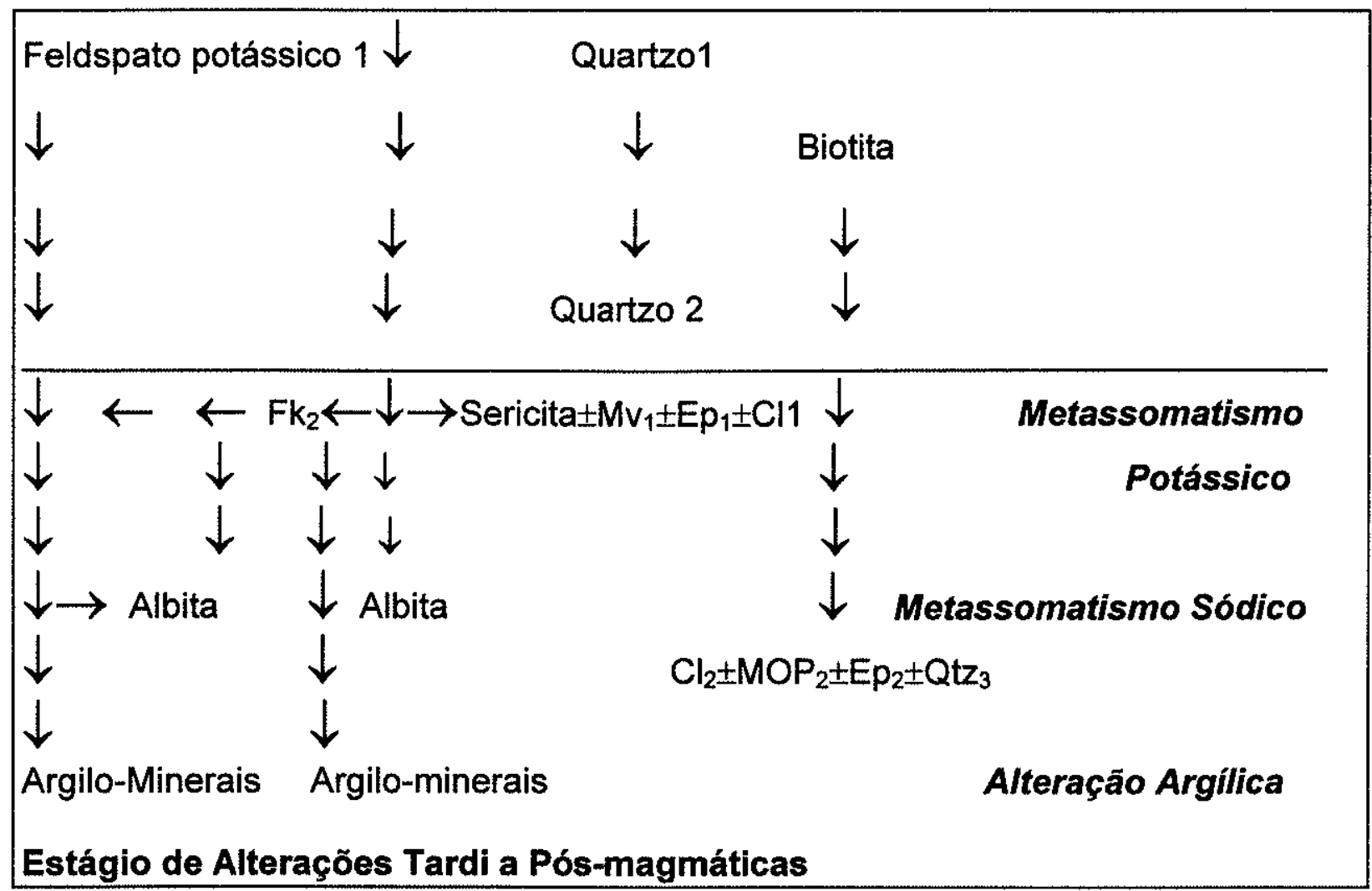

Figura 3.4. Fluxograma mostrando as seqüências de cristalizações magmática e tardi a pósmagmática das fases minerais da facies AFG. Maçço granitóide António Vicente.

\subsection{2- Facies granitóides das porções sudeste, centro-norte e noroeste do maciço}

Nessas porções do maciço predominam, amplamente, biotita sienogranitos(BSG) com biotita monzogranitos subordinados (Figura 3.1), os quais mostram-se afetados, em diferentes intensidades por alteraçōes tardi a pós-magmáticas. As variedades mais intensamente alteradas foram designadas de biotita sieno ganitos alterados(BSGA) e biotita sienogranitos intensamente alterados(BSGIA).

\subsubsection{1- Textura e Mineralogia}

São rochas de granulação grossa com variações para tipos equigranular médio e heterogranular fino a médio, os quais exibem coloração variável, predominando as cores rosa e cinza, mas ocorrendo, ainda, tipos rosa-acinzentado e vermelho tijolo(Prancha 9; Fotos a, b, c, d, e, f). Esses granitóides apresentam-se, muitas vezes, afetados por alterações tardi a pós-magmáticas, de natureza pervasiva(Richardson, 1988; Witt, 1988; Taylor \& Pollard, 1988) que, por vezes, tornam-se expressivas. Esses vários tipos ocorrem intimamente associados no campo, não tendo sido possível observar as relações de contato entre os mesmos que pudessem indicar facies distintas. Considerando que há notáveis semeihanças petrográficas entre essas rochas, apesar dos contrastes de granulação e de 
coloração, tudo indica, que essas variações traduzem essencialmente os efeitos das alterações tardi a pós-magmáticas que afetaram esses granitóides em diferentes intensidades. Nas variedades onde predomina a coloração rosa observa-se que a microclinização prevalece sobre a albitização, ocorrendo o inverso nas variedades de tonalidades cinza. Feições com características semelhantes a essas foram descritas em granitóides análogos da região sudeste do Pará(Gonçalez et al., 1988) e de outras regiões da Amazônia(Bettencourt \& Dall'Agnol, 1987).

As composições modais desses granitóides encontram-se nas Tabelas 3.5, 3.6 e 3.7. Com base na importância das paragêneses minerais tardi a pós-magmáticas -sericita \pm muscovita $\left(\mathrm{Mv}_{1}\right) \pm \operatorname{clorita}\left(\mathrm{Cl}_{1}\right) \pm$ fluorita $\left(\mathrm{Fl}_{1}\right) \pm \operatorname{epidoto}\left(E p_{1}\right) \pm$ topázio $\left(\mathrm{Top}_{1}\right)$, microclina pertítica $\left(\mathrm{Fk}_{2}\right)$, albita, fluorita $\left(\mathrm{Fl}_{2}\right)$, clorita $\left(\mathrm{Cl}_{2}\right)$, Epidoto $\left(E \mathrm{p}_{2}\right)$, allanita, topázio $\left(\mathrm{Top}_{2}\right)$, Muscovita $\left(\mathrm{Mv}_{2}\right)$, minerais opacos $\left(\mathrm{MOP}_{2}\right)$, e argilo-minerais- aqui assumidas, e no grau de desenvolvimento das mesmas nesses granitóides foram caracterizadas três variedades petrográficas: 1) biotita sienogranitos pouco alterados[BSG; sericita \pm muscovita( $\left.\mathrm{Mv}_{1}\right) \pm$ clorita $\left(\mathrm{Cl}_{1}\right) \pm$ fluorita $\left(\mathrm{Fl}_{1}\right) \pm$ epidoto $\left(E p_{1}\right) \pm$ topázio $\left(\mathrm{Top}_{1}\right)$, microclina pertítica $\left(\mathrm{Fk}_{2}\right)$, albita, fluorita $\left(\mathrm{Fl}_{2}\right)$, clorita $\left(\mathrm{Cl}_{2}\right)$, Epidoto $\left(\mathrm{Ep}_{2}\right)$, allanita, topázio(Top $)_{2}$, Muscovita $\left(\mathrm{Mv}_{2}\right)$ e minerais $\operatorname{opacos}\left(\mathrm{MOP}_{2}\right) \leq 3 \%$, em média]; 2) biotita sienigranitos alterados[BSGA; $3 \%<$ sericita \pm muscovita $\left(\mathrm{Mv}_{1}\right) \pm \operatorname{clorita}\left(\mathrm{Cl}_{1}\right) \pm$ fluorita $\left(\mathrm{Fl}_{1}\right) \pm$ epidoto $\left(\mathrm{Ep}_{1}\right) \pm$ topázio(Top $\left.)_{1}\right)$, microclina pertítica $\left(\mathrm{Fk}_{2}\right)$, albita, fluorita $\left(\mathrm{Fl}_{2}\right)$, clorita $\left(\mathrm{Cl}_{2}\right)$, Epidoto $\left(\mathrm{Ep}_{2}\right)$, allanita, topázio(Top $\mathrm{To}_{2}$, Muscovita $\left(\mathrm{Mv}_{2}\right)$ e minerais opacos $\left(\mathrm{MOP}_{2}\right)>6 \%$, em média]; 3) biotita sienogranitos intensamente alterados[BSGIA; sericita $\pm \operatorname{muscovita}\left(\mathrm{Mv}_{1}\right) \pm \operatorname{clorita}\left(\mathrm{Cl}_{1}\right) \pm$ fluorita( $\left(\mathrm{Fl}_{1}\right) \pm$ epidoto $\left(E p_{1}\right) \pm$ topázio $\left(\mathrm{Top}_{1}\right)$, microclina pertítica $\left(\mathrm{Fk}_{2}\right)$, albita, fluorita $\left(\mathrm{FI}_{2}\right)$, clorita $\left(\mathrm{Cl}_{2}\right)$, Epidoto $\left(\mathrm{Ep}_{2}\right)$, allanita, topázio $\left(\mathrm{Top}_{2}\right)$, Muscovita $\left(\mathrm{Mv}_{2}\right)$ e minerais opacos $\left(\mathrm{MOP} \mathrm{P}_{2}\right)>6 \%$, em média]. O topázio, embora ocorra sempre em baixas quantidades, é mais freqüente nessa última variedade. Os argilo-minerais não foram quantificados devido formarem nuvens sobre os grãos de feldspato potássico, dando-lhes um aspecto "sujo", só observado à luz natural.

As composições modais de cada uma das variedades de granitóides dessa porção do maciço(Tabelas 3.5, 3.6 e 3.7) e a distribuição dessas composições nos diagramas Q-A$P$ e $Q-(A+P)-M^{\prime}$ (Figura 3.2a, 3.2b) mostram uma ampla predominância dos termos sienograníticos sobre os monzogranitos. No conjunto, são dominantes os granitóides hololeucocráticos $\left(M^{\prime}<5 \%\right)$, embora ocorram, subordinadamente, rochas leucocráticas $\left(M^{\prime}>5 \%\right)$. No diagrama $Q-(A+P)-M$ ', embora não se observe claramente um "trend" de variação em termos dos constituintes máficos, nota-se que os conteúdos desses minerais são, de modo geral, mais elevados no BSG do que nos BSGA e BSGIA. Nesses dois últimos os conteúdos de máficos se eqüivalem. Em relação aos constituintes essenciais, as três variedades mostram uma grande homogeneidade composicional. 
Em amostras de mão desses granitóides, o feldspato potássico pode exibir tanto uma coloração cinza clara ou esbranquiçada, quanto rosa. O plagioclásio, por sua vez, pode ser esverdeado ou cinza esbranquiçado(Prancha 9; Fotos $a, b$ ).

Consistem essencialmente de quartzo, feldspato potássico e plagioclásio. A biotita é o varietal, não sendo, porém, muito abundante. Como minerais acessórios primários ocorrem zircão, minerais opacos e apatita. Os dois primeiros são mais abundantes e, relativamente, mais freqüentes, embora seus teores nunca alcancem 1\%(Tabelas 5, 6 e 7). As fases minerais formadas no estágio de alteraçōes tardi a pós-magmáticas, determinadas através de microscopia ótica, estão representadas por sericita \pm muscovita $\left(\mathrm{Mv}_{1}\right) \pm \operatorname{clorita}\left(\mathrm{Cl}_{1}\right)$ \pm fluorita $\left(F I_{1}\right) \pm$ epidoto $\left(E p_{1}\right) \pm$ topázio $\left(T_{o p} p_{1}\right.$, microclina pertítica $\left(F k_{2}\right)$, albita, fluorita $\left(F I_{2}\right)$, clorita $\left(\mathrm{Cl}_{2}\right)$, Epidoto $\left(\mathrm{Ep}_{2}\right)$, allanita, topázio(Top $\left.{ }_{2}\right)$, Muscovita $\left(\mathrm{Mv}_{2}\right)$, minerais opacos $\left(\mathrm{MOP}_{2}\right)$, monazita e argilo-minerais . A cassiterita está associada a esse estágio e ocorre, preferencialmente, na variedade BSGIA.

Texturas de intercrescimentos intimamente relacionadas aos feldspatos são abundantes e estão representadas por microclina pertítica, a qual forma, preferencialmente, mesopertitas(Smith, 1974). Os tipos de pertitas caracterizados são atrubídos tanto a processos de exsolução("string perthites"), quanto de substituição("film", "band", "vein" e "patch perthites"). Esses tipos foram assim definidos com base nos princípios estabelecidos por Alling(1932 e 1938), Smith(1974) Smith \& Brown(1988). Os diversos tipos ocorrem associados, constituindo pertitas compostas(Alling, 1938) e, por vezes, mostram gradações de um tipo a outro, principalmente, aqueles formados por substituição(Prancha 10; Foto a).

Intercrescimentos granofíricos e mirmequíticos são observados, localmente em algumas amostras, sendo que os primeiros são, relativamente, mais abundantes, predominando o tipo insular, enquanto que os últimos são muito raros e mostram-se representados por mirmequitas tipo "bulbous" (conforme Smith \& Brown, 1988; Prancha 10, Foto $b, c$, deste trabalho).

O quartzo ocorre em, pelo menos, quatro tipo morfológicos a saber:

1) o quartzo 1 é o tipo mais comum. Se apresenta como grãos grossos, predominantemente anédricos, os quais desenvolvem, freqüentemente, bordas corroidas e contatos irregulares a interpenetrantes. Localmente, pode desenvolver contatos retos. Mostra-se, algumas vezes, deformado, fraturado e com forte extinção ondulante. Ocasionalmente, exibe inclusões, as quais mostram-se representadas por feldspato potássico $1\left(\mathrm{Fk}_{1}\right)$ e plagioclásio $1\left(\mathrm{Pl}_{1}\right)$.

2) o quartzo 2, por sua vez, corresponde aos cristais de granulação média e contornos subédricos a euédricos. Costuma desenvolver contatos retos a irregulares e, às vezes, pode apresentar-se incluso no feldspato potássico $2\left(\mathrm{Fk}_{2}\right)$. 
3) o quartzo 3 apresenta-se intimamente associado à cloritização da biotita. Forma cristais, geralmente, fusiformes, dispostos paralelamente aos planos de clivagem da mesma. Freqüentemente está acompanhado de minerais opacos $\left(\mathrm{MOP}_{2}\right)$, epidoto $\left(E \mathrm{p}_{2}\right)$ e allanita.

4) o quartzo 4 integra os intercrescimentos mirmequíticos do tipo "mirmekite rims"(Phillips, 1974) e granofíricos.

O feldspato potássico é mais freqüente sob a forma de fenocristais anédricos a subédricos $\left(\mathrm{Fk}_{2}\right)$, de granulação grossa, formados a partir da substituição do plagioclásio 1. Entretanto, cristais subédricos, de granulação fina a média $\left(\mathrm{Fk}_{1}\right)$ são observados localmente. O $\mathrm{Fk}_{2}$ desenvolve contatos retos, irregulares e interpenetrantes. Mostra-se, em geral, parcialmente albitizado("chess-board perthites") e transformado para argilo-minerais. Apresenta, às vezes, bordas albiticas("swapped rims"), bem como no contato entre seus grãos ocorrem, freqüentemente, agrupamentos de albita dispostos em bandas paralelas a sub-paralelas, entre si, e com sinal ótico invertido em relação ao cristal adjascente("coroas trocadas"; Prancha 10; Foto d). Localmente, em contato com plagioclásio, ocorre albita intergranulare. Além disso, agregados de albita formando figuras tipo "dedos" e "mãos" e dispostos como que invadindo cristais de feldspato potássico $2\left(\mathrm{Fk}_{2}\right)$ costumam ocorrer, preferencialmente, nas variedades mais intensamente transformadas(BSGIA; Prancha 10; Foto e ).

No que se refere ao plagioclásio, o tipo $1\left(\mathrm{Pl}_{1}\right)$ é o mais comum. Apresenta-se em cristais, geralmente, subédricos, embora ocorram, subordinadamente, grãos euédricos. Exibe, às vezes, bordas corroídas, principalmente, ao contato com feldspato potássico( $\left.\mathrm{Fk}_{2}\right)$. Desenvolve contatos irregulares e interpenetrantes e, muito locaimente, retos. Mostra-se alterado em diferentes graus para: 1) sericita \pm muscovita $\left(\mathrm{Mv}_{1}\right) \pm \operatorname{clorita}\left(\mathrm{Cl}_{1}\right) \pm$ flurita( $\left(\mathrm{Fl}_{1}\right) \pm$ epidoto $\left(E p_{1}\right) \pm$ topázio $\left.\left(T o p_{1}\right) ; 2\right)$ microclina pertítica $\left(F k_{2}\right)$. O primeiro conjunto dessas alterações tende a se desenvolver mais intensamente nas porções centrais dos cristais com zoneamento normal(Smith, 1974), descalcificando-as(Prancha 10; Foto f). Desenvolve-se, ainda, na forma de zonas irregulares ("patch zones"). Essas zonas preferenciais de desenvolvimento dessas alterações refletem, ao que tudo indica, porções relativamente mais cálcicas dos cristais(Dall'Agnol, 1980; Daoud, 1988; Teixeira \& Andrade, 1992). No BSG o epidoto consome o Ca do plagioclásio, ao passo que nos BSGA e BSGIA dá-se a formação preferencial de fluorita. O topázio substitui a albita ou, associado à fluorita, ao plagioclásio, relativamente, mais pobre em cálcio(Dall'Agnol, 1980). As maclas não costumam ser muito nítidas, uma vez que encontram-se, por vezes, mascaradas pelas fases minerais de alteração. Entretanto, onde é possivel observá-las, são governadas pelas leis da albita e albita-Carlsbad. Localmente, elas encontram-se deformadas, arqueadas ou mostram-se mecanicamente descontinuas("glade twinning"). Às vezes, cristais de 
plagioclásio 1 apresentam texturas tipo "synneusis"(Vance, 1969; Smith, 1974; Dall'Agnol, 1980). Ao contato com feldspato potássico ocorrem, localmente, bordas albiticas("albite rims" e intercrescimentos mirmequíticos do tipo "myrmekite rims"; Phillips, 1974). Em termos composicionais(determinação ótica), é variável desde An0(nas bordas) até An17(nas porções mais centrais), embora sejam mais comuns as composições albita-oligoclásio sódico(An9-17). O tipo 2 é pouco freqüente e apresenta características semelhantes àquelas descritas, em relação a esse mesmo tipo, presentes nas variedades granitóides vistas anteriormente.

A biotita ocorre em lamelas anédricas a subédricas, de dimensões variáveis, desde finas até grossas Apresenta-se ora formando agregados, ora de forma intersticial. Mostrase, por vezes, parcialmente cloritizada $\left(\mathrm{Cl}_{2}\right)$ e, associados a essa alteração, ocorrem, ainda, epidoto $\left(E \mathrm{p}_{2}\right)$, allanita, quartzo 3, minerais opacos $\left(\mathrm{MOP}_{2}\right)$ e fluorita $\left(\mathrm{Fl}_{2}\right.$; Prancha 11, Foto a). Exibe pleocroismo moderado a forte, variando desde castanho escuro-avermelhado $(\mathrm{Z}$ e $\mathrm{Y})$ a castanho claro-amarelado(X), castanho escuro-esverdeado $(Z$ e $Y)$ a castanho pálido ou palha $(X)$. Localmente, apresenta evidências de deformação traduzidas por moderada extinção ondulante e pelo desenvolvimento de "kink-bands". As vezes exibe inclusões de minerais opacos $\left(\mathrm{Mop}_{1}\right)$, zircão e apatita. Ao contato com o zircão desenvolve nítidos halos pleocróicos.

Dentre os acessórios, o zircão é o mais comum. Ocorre como minúsculos grãos, geralmente, subédricos a euédricos, por vezes, associados à biotita. Os minerais opacos são algo freqüentes e ocorrem em, pelo menos, duas variedades. A primeira(MOP 1$)$, consiste de grãos subédricos a euédricos finos, às vezes, de hábito hexagonal, que ocorrem ora íntimamente associados à biotita, ora como inclusões nessa. A outra variedade $\left(\mathrm{MOP}_{2}\right)$, mostra-se ligada à cloritização da biotita. Forma grãos alongados, dispostos paralelamente aos planos de clivagem da mesma, especialmente, quando essa está cloritizada. A apatita é menos freqüente. Apresenta-se como finos cristais subédricos a euédricos, associados à biotita e minerais opacos $\left(\mathrm{MOP}_{1}\right)$, formando agregados ou como inclusões na primeira. $A$ monazita é rara e mostra afinidades com as fases máficas. Forma cristais muito finos, de contornos subédricos a euédricos.

No que se refere aos produtos de alterações tardi a pós-magmáticas, o par sericita \pm muscovita $\left(\mathrm{Mv}_{1}\right)$ ocorre como finas lamelas, ligadas, preferencialmente, à alteração do plagioclásio. Os argilo-minerais, por seu turno, formam nuvens amarronzadas( à luz natural), íntimamente associadas aos feldspatos potássicos, dando-lhe um aspecto "sujo". A fluorita ocorre, ora como cristais anédricos a subédricos, de granulação variável, desde finos até grossos, tanto na modalidade incolor, quanto lilás. Os cristais mais grossos $\left(\mathrm{Fl}_{2}\right)$ mostram-se, geralmente, associados à biotita(Prancha 11; Foto a), enquanto que os tipos 
mais finos costumam estar intimamente associados à alteração do plagiociásio( $\left(\mathrm{Fl}_{1}\right)$. Ocorre, ainda, localizadamente, formando vênulas, prenenchendo fraturas, especialmente, no plagioclásio. $O$ topázio é, relativamente, mais freqüente nas variedades mais transformadas desses granitóides(BSGA e BSGIA). Assim como a fluorita, se apresenta como grãos anédricos a subédricos, de granulacão variável desde fina até grossa. As variedades finas costumam estar ligadas à alteração do plagioclásio(Top 1 ), enquanto que os tipos grossos $\left(\mathrm{Top}_{2}\right.$ ) ocorrem, preferencialmente, dispersos na rocha. Algumas vezes o Top encontrar-se envolto por auréolas de muscovita 2(Prancha 11; Foto b). A allanita, embora não muito freqüente, pode alcançar, em algumas amostras, teores relativamente expressivos. Costuma ocorrer, preferencialmente, associada à biotita cloritizada como produto dessa alteração, juntamente com epidoto( $\left.E p_{2}\right)$, minerais opacos $\left(M O P_{2}\right)$, fluorita $\left(F l_{2}\right)$ e quartzo 3. Forma gãos, geralmente, anédricos, dispostos, preferencialmente, ao longo dos planos de clivagem da biotita cloritizada. A monazita é pouco freqüente. Ocorre como minúsculos grãos, geralmente, euédricos, os quais mostram-se ora associados às fases máficas, ora encontram-se disseminados na rocha.

A albita(albitização) pode assumir formas variadas de acordo com o modo de ocorrência e a fase mineral a qual encontra-se associada. Assim tem-se:

1) albita tipo "swapped rims": ocorre como bordas nos contatos entre dois ou mais grãos de feldspato potássico $\left(\mathrm{Fk}_{2}\right)$.

2) albita tipo "albite rims": se apresenta como bordas no cristais de plagioclásio $\left(\mathrm{Pl}_{1}\right.$ e $\left.\mathrm{Pl}_{2}\right)$.

3) albita como "coroas trocadas": costuma ocorrer, preferencialmente, como franjas no contato entre dois ou mais cristais de feldspato. Essas franjas mostram-se dispostas em, pelo menos, duas gerações, ambas com sinais óticos invertidos em relação ao cristal adjacente("coroas trocadas"; Prancha 10; Foto d).

4) albita formando agrupamentos semelhantes a "dedos"e/ou "mãos": Esse tipo se dispõe como que invadindo o cristal de feldspato potássico( $\left.F k_{2}\right)$ hospedeiro(Prancha 10; Foto e).

5) albita tipo "chess-board albite": formam texturas semelhantes a um tabuleiro de xadrez e se desenvolvem a partir da substuição do feldspato potássico(Prancha 11; Foto c).

6) albita intergranular desenvolvida no contato entre cristais de plagioclásio $\left(\mathrm{Pl}_{1}\right)$ e de feldspato potássico $\left(\mathrm{Fk}_{2}\right)$.

A cassiterita é pouco abundante, mas pode assumir teores, relativamente, importantes nas amostras mais intensamente alteradas(Tabela 3.7). Mostra-se intimamente associada à muscovita $\left(\mathrm{Mv}_{2}\right)+$ clorita oxidada $\left(\mathrm{Cl}_{2}\right)$ e à fluorita $\left(\mathrm{Fl}_{2}\right)$. Apresenta-se como finos grãos anédricos a subédricos, de coloração castanha-avermelhada(à luz natural, Prancha 11; Foto $d, e)$ ), exibe cor de interferência alta, caracterizada pela mistura de azul- 
esverdeado intenso, vermelho $e$ amarelo $e$, às vezes, mostra-se caracteristicamente maclada(Prancha 11; Foto f).

\subsubsection{2- Ordem de Cristalização}

Os estudos petrográficos voltados para o entendimento da ordem de cristalização das fases minerais tipicamente magmáticas cristalizadas ao longo da história de solidificação desses granitóides, baseou-se fundamentalmente nas relações texturais entre fases minerais e permitiu estabelecer a seguinte seqüência:

1- As fases minerais acessórias representadas, principalmente, por zircão e minerais opacos e apatita são precoces em relação ao quartzo, feldspato potássico e plagioclásio. Isso é justificado pela presença dessas fases menores como inclusões nesses minerais. Embora isso seja mais freqüente em relação à biotita.

2- A biotita, principal varietal, parece ter iniciado sua cristalização um pouco antes do plagioclásio $\left(\mathrm{Pl}_{1}\right)$ e feldspato potássico $\left(\mathrm{Fk}_{1}\right)$, visto que, localmente, em algumas amostras, ocorre como inclusão nesses minerais e no quartzo 1. Entretanto, deve ter tido seu curso de cristalização prolongado, uma vez que pode ser observada, também, de forma intersticial em relação a esses minerais.

3- No diz respeito aos minerais assenciais, as evidências texturais demonstram que o plagioclásio $\left(\mathrm{Pl}_{1}\right)$ e o feldspato potássico $\left(\mathrm{Fk}_{1}\right)$ iniciaram a cristalizar, pelo menos em parte, antes do quartzo 1. As evidências disso são traduzidas pela presença, com certa freqüência, de inclusões de $\mathrm{Pl}_{1}$ e $\mathrm{Fk}_{1}$ nesses ultimo, não tendo sido observada o inverso. Entretanto, no que se refere ao $\mathrm{Fk}_{1}$, pode-se notar que a cristalização do mesmo se prolongou além da de quartzo e plagioclásio, visto que ele pode ocorrer na forma intersticial.

4- A substituição do $\mathrm{Pl}_{1}$ por sericita $\pm \operatorname{muscovita}\left(\mathrm{Mv}_{1}\right) \pm \operatorname{clorita}\left(\mathrm{Cl}_{1}\right) \pm$ fluorita( $\left(\mathrm{Fl}_{1}\right) \pm$ epidoto $\left(E p_{1}\right) \pm$ topázio $\left(\operatorname{Top}_{1}\right)$ parece marcar o início do estágio de alterações tardi a pósmagmáticas. A Figura 3.5 sintetiza a seqüência de cristalização acima apresentada e extende para o estágio de alterações tardi a pós-magmáticas. 


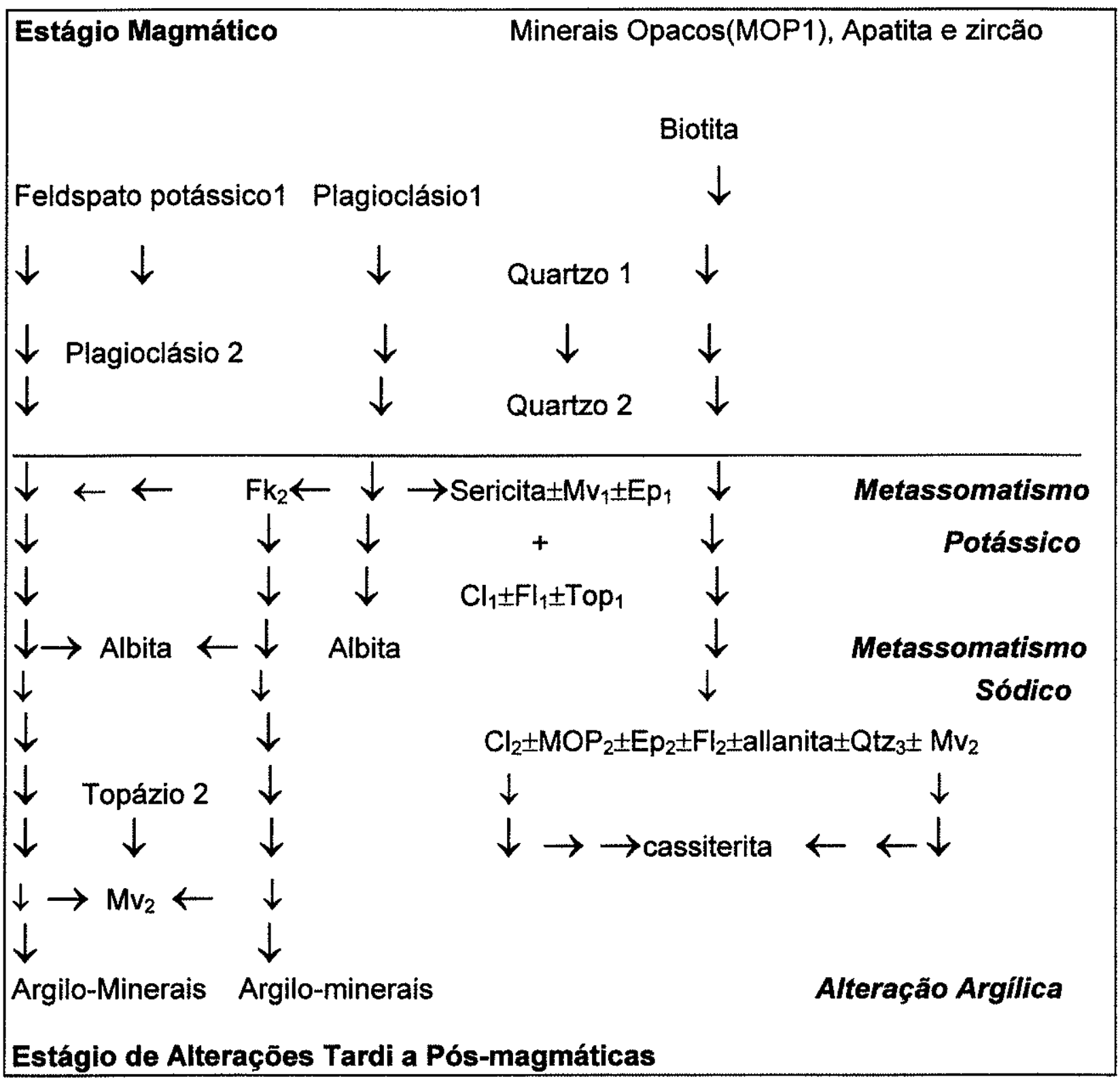

Figura 3.5. Fluxograma mostrando as ordens de cristalizaçőes magmática e tardi a pós-magmática das fases minerais das facies BSG, BSGA e BSGIA. Maciço granitóide Antônio Vicente. 
Tabela 3.5- Composições modais do biotita sienogranito pouco transformado(BSG). Maciço granitóide Antônio Vicente. $\mathrm{Tr}=t r a c ̧ o, ~ N d=$ não detectado.

\begin{tabular}{|c|c|c|c|c|c|c|c|c|c|c|c|}
\hline VARIEDADES & \multicolumn{11}{|c|}{ BSG } \\
\hline \multirow[t]{2}{*}{ AMOSTRAS } & SL-3A-DT & SL-6A-DT & SL-6C-DT & SL-2-DT & SL-7C-DT & SL-8-DT & SL-9B-DT & NR-AV-11 & NR-AV-23 & NE-B-71 & \\
\hline & 24 & 25 & 26 & 27 & 28 & 29 & 30 & 31 & 32 & 33 & \\
\hline $\begin{array}{l}\text { MINERAIS } \\
\text { PRIMÁRIOS(\%) }\end{array}$ & & & & & & & & & & & \\
\hline QUARTZO & 40 & 48 & 37 & 48 & 51 & 28 & 29 & 21 & 31 & 32 & \\
\hline PLAGIOCLÁSIO & 14 & 29 & 17 & 14 & 16 & 09 & 18 & 20 & 17 & 22 & \\
\hline K-FELDSPATO & 37 & 21 & 37 & 24 & 28 & 60 & 39 & 43 & 43 & 40 & \\
\hline BIOTITA & 03 & 01 & 03 & $\mathrm{Tr}$ & $\mathrm{Tr}$ & 01 & 10 & 12 & $\mathrm{Tr}$ & 02 & \\
\hline CLORITA & 01 & 02 & 02 & 02 & 03 & $\mathrm{Tr}$ & 04 & 03 & 04 & $\mathrm{Tr}$ & \\
\hline ZIRCÁO & $\mathrm{Tr}$ & $\mathrm{Tr}$ & $\mathrm{Tr}$ & $\mathrm{Tr}$ & $\mathrm{Tr}$ & $\mathrm{Tr}$ & $\mathrm{Tr}$ & $\mathrm{Tr}$ & $\mathrm{Tr}$ & $\mathrm{Tr}$ & \\
\hline $\begin{array}{l}\text { MINERAIS } \\
\text { OPACOS }\end{array}$ & $\mathrm{Tr}$ & $\mathrm{Tr}$ & $\mathrm{Tr}$ & $\mathrm{Tr}$ & $\mathrm{Tr}$ & $\mathrm{Tr}$ & $\mathrm{Tr}$ & $\mathrm{Tr}$ & $\mathrm{Tr}$ & $\mathrm{Tr}$ & \\
\hline APATITA & Nd & Nd & Tr & $\mathrm{Tr}$ & $\mathrm{Tr}$ & $\mathrm{Tr}$ & $\mathrm{Tr}$ & $\mathrm{Tr}$ & $\mathrm{Tr}$ & $\mathrm{Tr}$ & \\
\hline ALLANITA & $\mathrm{Tr}$ & Nd & $\mathrm{Nd}$ & $\mathrm{Tr}$ & Nd & Tr & $\mathrm{Tr}$ & $\mathrm{Tr}$ & Nd & Nd & \\
\hline MONAZITA & $\mathrm{Tr}$ & Nd & $\mathrm{Nd}$ & $\mathrm{Tr}$ & $\mathrm{Tr}$ & Nd & $\mathrm{Nd}$ & Nd & $\mathrm{Nd}$ & $\mathrm{Nd}$ & \\
\hline $\begin{array}{l}\text { MINERAIS } \\
\text { SECUNDÁRIOS }\end{array}$ & & & & & & & & & & & \\
\hline EPIDOTO & $\mathrm{Tr}$ & $\mathrm{Tr}$ & 01 & $\mathrm{Tr}$ & $\mathrm{Tr}$ & $\mathrm{Tr}$ & $\mathrm{Tr}$ & $\mathrm{Tr}$ & $\mathrm{Tr}$ & $T r$ & \\
\hline ALBITA & 05 & 01 & 04 & 05 & 01 & 02 & 01 & 01 & 04 & 03 & \\
\hline $\begin{array}{l}\text { SERICITA+/- } \\
\text { MUSCOVITA }\end{array}$ & $\mathrm{Tr}$ & $\mathrm{Tr}$ & $\mathrm{Tr}$ & $\mathrm{Tr}$ & $\mathrm{Tr}$ & $\mathrm{Tr}$ & $\mathrm{Tr}$ & $\operatorname{Tr}$ & $\mathrm{Tr}$ & $\mathrm{Tr}$ & \\
\hline FLUORITA & $T r$ & $\mathrm{Tr}$ & $\mathrm{Tr}$ & Tr & $\operatorname{Tr}$ & $\mathrm{Tr}$ & $\mathrm{Tr}$ & $\mathrm{Tr}$ & $\mathrm{Tr}$ & $\mathrm{Tr}$ & \\
\hline TOPAZIO & Nd & Nd & $\mathrm{Nd}$ & $\mathrm{Nd}$ & Nd & $\mathrm{Tr}$ & Nd & Nd & Nd & No & \\
\hline $\begin{array}{l}\text { COMPOSIÇÄO DO } \\
\text { PLAGIOCLÁSIO }\end{array}$ & - & - & An7 & An12-17 & An2 & - & - & - & - & - & MEDIAS \\
\hline Q & 42 & 50 & 39 & 50 & 53 & 29 & 33 & 32 & 33 & 34 & 40 \\
\hline $\mathrm{A}$ & 44 & 21 & 43 & 36 & 30 & 62 & 46 & 50 & 50 & 44 & 43 \\
\hline $\mathrm{P}$ & 14 & 29 & 18 & 14 & 17 & 09 & 21 & 18 & 17 & 22 & 17 \\
\hline $\mathbf{Q}$ & 42 & 48 & 38 & 51 & 52 & 29 & 29 & 30 & 32 & 33 & 38 \\
\hline$A+P$ & 54 & 49 & 57 & 46 & 45 & 70 & 57 & 61 & 63 & 65 & 57 \\
\hline$M^{\prime}$ & 04 & 03 & 05 & 03 & 03 & 01 & 14 & 09 & 05 & 02 & 05 \\
\hline $\begin{array}{l}\text { NUMERO DE } \\
\text { PONTOS }\end{array}$ & 1500 & 1500 & 1500 & 1500 & 1500 & 1500 & 1500 & 1500 & 1500 & 1500 & \\
\hline
\end{tabular}


Tabela 3.6- Composições modais do biotita sienogranito alterado(BSGA). Maciço granitóide Antônio Vicente. Tr=traço; $\mathrm{Nd}=$ não detectado; $\mathrm{Nc}=$ não contado.

\begin{tabular}{|c|c|c|c|c|c|c|}
\hline VARIEDADE & & & & SGA & & \\
\hline AMOSTRAS & SL-1B-DT & SL-4-DT & SL-5-DT & $\mathrm{NE}-\mathrm{B}-47$ & $\mathrm{NE}+\mathrm{B}-82$ & \\
\hline & 34 & 35 & 36 & 37 & 38 & \\
\hline $\begin{array}{l}\text { MINERAIS } \\
\text { PRIMARIOS }(\%)\end{array}$ & & & & & & \\
\hline QUARTZO & 35 & 26 & 33 & 46 & 33 & \\
\hline PLAGIOCLÁSIO & 17 & 41 & 19 & 14 & 19 & \\
\hline K-FELDSPATO & 37 & 25 & 38 & 35 & 41 & \\
\hline BIOTITA & $\mathrm{Tr}$ & $\mathrm{Tr}$ & $\operatorname{Tr}$ & $\mathrm{Tr}$ & Tr & \\
\hline CLORITA & 04 & 01 & 02 & 01 & 02 & \\
\hline ZIRCAO & $\mathrm{Tr}$ & $\mathrm{Tr}$ & $\operatorname{Tr}$ & $\mathrm{Tr}$ & $\mathrm{Tr}$ & \\
\hline MINERAIS OPACOS & $\mathrm{Tr}$ & $\mathrm{Tr}$ & $\mathrm{Tr}$ & $\operatorname{Tr}$ & $\mathrm{Tr}$ & \\
\hline APATITA & $\operatorname{Tr}$ & $\mathrm{Nd}$ & Nd & $\mathrm{Tr}$ & $\operatorname{Tr}$ & \\
\hline MONAZITA & $\mathrm{Nd}$ & $\mathrm{Nd}$ & $\operatorname{Tr}$ & $\mathrm{Nd}$ & Nd & \\
\hline $\begin{array}{l}\text { MINERAIS } \\
\text { SECUNDARIOS }\end{array}$ & & & & & & \\
\hline EPIDOTO & $\mathrm{Tr}$ & $\mathrm{Tr}$ & $\mathrm{Tr}$ & $\mathrm{Tr}$ & $\mathrm{Tr}$ & \\
\hline ALBITA & 07 & 06 & 07 & 02 & 03 & \\
\hline $\begin{array}{l}\text { SERICITA+/- } \\
\text { MUSCOVITA }\end{array}$ & $\mathrm{Tr}$ & 03 & $\mathrm{Tr}$ & 02 & 01 & \\
\hline FLUORITA & Tr & $\mathrm{Tr}$ & $\mathrm{Tr}$ & $\mathrm{Tr}$ & 01 & \\
\hline $\begin{array}{l}\text { COMPOSICCAOO DO } \\
\text { PLAGIOCLASIO }\end{array}$ & An2 & Ang & - & - & - & MÉDIAS \\
\hline $\mathbf{Q}$ & 37 & 27 & 34 & 34 & 48 & 36 \\
\hline A & 45 & 31 & 47 & 46 & 38 & 41 \\
\hline$P$ & 18 & 42 & 19 & 20 & 14 & 23 \\
\hline $\mathbf{Q}$ & 38 & 28 & 36 & 35 & 48 & 37 \\
\hline $\bar{A}+\mathrm{P}$ & 58 & 72 & 61 & 63 & 51 & 61 \\
\hline $\mathbf{M}^{\prime}$ & 04 & 0 & 03 & 02 & 01 & 02 \\
\hline $\begin{array}{l}\text { NUMERO DE } \\
\text { PONTOS }\end{array}$ & & & & & & \\
\hline
\end{tabular}


Tabela 3.7- Composiçōes modaisdo biotita sienogranito intensamente alterado(BSGIA). Maciço granitóide Antônio Vicente. Tr= Traço,; Nd=nåo determinado.

\begin{tabular}{|c|c|c|c|c|c|c|c|c|c|c|c|c|}
\hline VARIEDADE & \multicolumn{12}{|c|}{ BSGIA } \\
\hline AMOSTRAS & SL-2A-DT & NE-B-60 & NE-B-63 & NE-B-75 & NE-B-75B(B)A & NR-AV-43 & NR-AV-48 & NE-B-83 & NE-B-83A & NE-B-83! & NE-B-83K & \\
\hline & 39 & 40 & 41 & 42 & 43 & 44 & 45 & 46 & 47 & 48 & 49 & \\
\hline $\begin{array}{l}\text { MINERAIS } \\
\text { PRIMARIOS(\%) }\end{array}$ & & & & & & & & & & & & \\
\hline QUARTZO & 40 & 38 & 25 & 27 & 29 & 34 & 40 & 35 & 37 & 44 & 43 & \\
\hline PLAGIOCLASIO & 21 & 15 & 28 & 18 & 10 & 16 & 19 & 21 & 18 & 16 & 14 & \\
\hline K-FELDSPATO & 26 & 38 & 36 & 46 & 49 & 36 & 29 & 29 & 36 & 23 & 28 & \\
\hline BIOTITA & $\operatorname{Tr}$ & 02 & 02 & $\mathrm{Tr}$ & $\mathrm{Tr}$ & 01 & $\mathrm{Tr}$ & $\mathrm{Tr}$ & 01 & $\mathrm{Tr}$ & $\mathrm{Tr}$ & \\
\hline CLORITA & 03 & 01 & 02 & 03 & 01 & 04 & 04 & 01 & 01 & $\mathrm{Tr}$ & $\mathrm{Tr}$ & \\
\hline ZIRCAO & $\mathrm{Tr}$ & $\mathrm{Tr}$ & $\mathrm{Tr}$ & $\mathrm{Tr}$ & $\operatorname{Tr}$ & $\mathrm{Tr}$ & $\mathrm{Tr}$ & $\mathrm{Tr}$ & $\mathrm{Tr}$ & $\mathrm{Tr}$ & $\mathrm{Tr}$ & \\
\hline $\begin{array}{l}\text { MINERAIS } \\
\text { OPACOS }\end{array}$ & $\operatorname{Tr}$ & $\mathrm{Tr}$ & $\mathrm{Tr}$ & $\mathrm{Tr}$ & $\mathrm{Tr}$ & $\mathrm{Tr}$ & $\mathrm{Tr}$ & $\mathrm{Tr}$ & $\mathrm{Tr}$ & $\overline{T r}$ & $\mathrm{Tr}$ & \\
\hline APATITA & $\mathrm{Tr}$ & $\mathrm{Tr}$ & $\mathrm{Tr}$ & $\mathrm{Tr}$ & $\mathrm{Tr}$ & $\overline{T r}$ & $\operatorname{Tr}$ & $\mathrm{Tr}$ & $\mathrm{Tr}$ & $\overline{\mathrm{Tr}}$ & $\mathrm{Tr}$ & \\
\hline $\begin{array}{l}\text { MINERAIS } \\
\text { SECUNDARIOS( } \\
\text { \%) }\end{array}$ & & & & & & & & & & & & \\
\hline EPIDOTO & $\mathrm{Tr}$ & $\mathrm{Tr}$ & $\mathrm{Tr}$ & $\mathrm{Tr}$ & $\mathrm{Tr}$ & $\mathrm{Tr}$ & $\mathrm{Tr}$ & $\mathrm{Tr}$ & $\mathrm{Tr}$ & $\mathrm{Tr}$ & $\mathrm{Tr}$ & \\
\hline ALBITA & 09 & 07 & 04 & 05 & 08 & 08 & 06 & 05 & 03 & 06 & 06 & \\
\hline $\begin{array}{l}\text { SERICITA+/- } \\
\text { MUSCOVITA }\end{array}$ & 01 & 01 & 02 & 01 & 03 & $\mathrm{Tr}$ & 01 & 07 & 05 & $\mathrm{Tr}$ & $\mathrm{Tr}$ & \\
\hline FLUORITA & $\mathrm{Tr}$ & $T r$ & Tr & $\mathrm{Tr}$ & $\mathrm{Tr}$ & $\mathrm{Tr}$ & 01 & 01 & $\mathrm{Tr}$ & 01 & $\mathrm{Tr}$ & \\
\hline TOPAZIO & $\mathrm{Nd}$ & $\mathrm{Tr}$ & $\mathrm{Tr}$ & $\mathrm{Nd}$ & $\mathrm{Nd}$ & $\operatorname{Tr}$ & $\mathrm{Tr}$ & $\mathrm{Tr}$ & $\mathrm{Tr}$ & Nd & $\mathrm{Tr}$ & \\
\hline CASSITERITA & $\mathrm{Tr}$ & Tr & $\mathrm{Tr}$ & $\mathrm{Tr}$ & $\mathrm{Tr}$ & $\mathrm{Tr}$ & $\mathrm{Tr}$ & $\mathrm{Tr}$ & $\mathrm{Tr}$ & $\mathrm{Tr}$ & $\mathrm{Tr}$ & \\
\hline $\begin{array}{l}\text { COMPOSICAO } \\
\text { DO } \\
\text { PLAGIOCLÁSIO } \\
\end{array}$ & An0-9 & And & An12 & - & 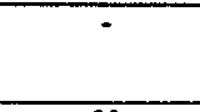 & An7-9 & $\operatorname{An} 3-9$ & An4 & An4 & - & $\because$ & MEDIAS \\
\hline $\bar{Q}$ & 42 & 38 & 27 & 28 & 30 & 37 & 42 & 39 & 39 & 49 & 47 & 38 \\
\hline $\mathrm{A}$ & 37 & 46 & 43 & 53 & 60 & 46 & 37 & 38 & 42 & 33 & 37 & 43 \\
\hline$P$ & 21 & 16 & 30 & 19 & 10 & 17 & 21 & 23 & 19 & 19 & 16 & 19 \\
\hline $\mathbf{Q}$ & 45 & 40 & 27 & 28 & 32 & 37 & 43 & 41 & 40 & 53 & 51 & 40 \\
\hline$A+P$ & 52 & 57 & 69 & 68 & 66 & 57 & 53 & 58 & 59 & 47 & 49 & 58 \\
\hline$M^{\prime}$ & 03 & 03 & 04 & 04 & 02 & 06 & 04 & 01 & 01 & 0 & 0 & 02 \\
\hline $\begin{array}{l}\text { NUMMERO DE } \\
\text { PONTOS }\end{array}$ & 1500 & 1500 & 1400 & 1500 & 1300 & 1500 & 1500 & 1500 & 1300 & 1200 & 1500 & \\
\hline
\end{tabular}




\subsection{3 - Facies granitóide da porção nordeste do maciço}

Nessa porçăo do maciço(Figura 3.1) afloram, dominantemente, biotita monzogranito(BMG), com biotita sienogranito subordinado. Esses granitóides, embora guardem muitas semelhanças com os BSGs, descritos anteriormente, diferem dos mesmos, tanto pelo seu caráter francamente monzogranítico, quanto pela distribuição geográfica. Ademais, são rochas pouco afetadas por alterações tardi a pós-magmáticas. Os dados químicos, também, ratificam a diferença(ver mais adiante).

Ressalta-se, entretanto, que existem muitas semelhanças texturais e mineralógicas entre o BMG e os BSGs, o que denota uma provável transição entre eles. Em razão disso, serão enfocados, apenas, os aspectos mais característicos do BMG, afim de que sejam evitadas repetições.

\subsubsection{1- Textura e Mineralogia}

As composições modais desses granitóides encontram-se na Tabela 3.8 e a distribuição dessas composições podem ser visualizadas na Figura 3.2(a, b). Na análise do diagrama Q-A-P, observa-se que das seis amostras selecionadas para as análises modais, três são tipicamente de composição monzogranítica, duas situam-se no limite entre os campos das composições sienograníticas e monzograníticas e uma ocupa o campo dos sienogranitos, embora muito próximo ao limite com o campo dos monzogranitos. Além disso, seus conteúdos modais médios, ocupam o campo das composições monzograníticas.

No diagrama $Q-(A+P)-M^{\prime}$, nota-se que a ampla maioria das amostras ocupa uma área próxima à aresta $Q-(A+P)$, excetuando-se a isso a amostra de número 53(Tabela 3.8) devido apresentar, dentre todas, os mais altos conteúdos de biotita(4\%) e clorita(5\%). Comparativamente ao BSG e suas variações(BSGA e BSGIA), vistos anteriormente, mostra conteúdos modais de plagioclásio mais elevados, mais baixos de quartzo e de feldspato potássico(microclina pertítica), bem como apresenta-se menos afetados por alterações tardi a pós-magmáticas.

De um modo geral, é uma rocha que exibe textura hipidiomórfica equigranular a heterogranular, incluindo tipos de granulação fina a média, média e grossa(Prancha 12; Fotos a, b), tipos equigranulares médios e porfiríticos. Apresenta coloração variável, podendo ser rosa, rosa-esbranquiçada e rosa-acinzentada. Apesar da variação de granulação desse granitóide, não se observa mudanças drásticas na cor dos feldspatos. Eles são sistematicamente rosa(feldspato potássico) e cinza-esbranquiçado(plagioclásio).

Consiste essencialmente de quartzo, feldspato potássico e plagioclásio, sendo varietal a biotita. Como minerais acessórios ocorrem zircăo, minerais opacos $\left(\mathrm{MOP}_{1}\right)$, 
apatita e, muito subordinadamente, monazita. $\mathrm{A}$ clorita $\left(\mathrm{Cl}_{2}\right)$ associada à biotita, é o principal máfico secundário, formado no estágio de alterações tardi a pós-magmáticas.

Os produtos dessas aiterações podem ser agrupados em, pelo menos, dois tipos principais de associações minerais. O primeiro está representado por feições, não muito intensas, ligadas à substituição parcial do plagioclásio $1\left(\mathrm{PI}_{1}\right)$, traduzidas por sericita \pm muscovita $\left(\mathrm{Mv}_{1}\right) \pm \operatorname{clorita}\left(\mathrm{Cl}_{1}\right) \pm$ fluorita $\left(\mathrm{Fl}_{1}\right) \pm$ epidoto $\left(E \mathrm{p}_{1}\right)$, bem como pela microclinização do mesmo $\left(\mathrm{Fk}_{2}\right)$. Essas associações evidenciam em evento metassomático de natureza potássica. O segundo, embora muito pouco expressivos, está representado pelo desenvolvimento de albita(albitização) em formas diversificadas, relacionada a um evento de metassomatismo sódico, ocorrido após o metassomatismo potássico, bem como pela substituição parcial da biotita por clorita $\left(\mathrm{Cl}_{2}\right) \pm$ minerais opacos $\left(M O P_{2}\right) \pm$ epidoto $\left(\mathrm{Ep}_{2}\right) \pm$ allanita \pm quartzo $_{3}$. Esse evento afetou tanto o plagioclásio, quanto ao feldspato potássico 2. Além disso, outra feição ligada à substituição do feldspato potássico está representada por argilo-minerais, os quais, embora sem muitas evidências, são atribuídos à alteração argílica(Pollard \& Taylor, 1986; Witt, 1988; entre outros).

Texturas de intercrescimentos formadas, ao que tudo indica, em condições "subsolidus", decorrentes de processos de exsolução e de substituição estão representadas por intercrescimentos pertíticos.

As pertitas são muito comuns, constituem mesopertitas compostas e estão representadas pelos tipos "string", "films", "band" e "vein" perthites"(Alling, 1932, 1938; Smith, 1974). Intercrescimentos granofíricos são localizados e mostram-se relacionados às variedades porfiríticas.

- quartzo, plagioclásio e feldspato potássico apresentam características microtexturais semelhantes àquelas descritas àcerca dessas mesmas fases minerais que constituem a facies BSG e suas variações(BSGA e BSGIA). Por isso, não serão repetidas aqui. Apesar disso, o plagioclásio mostra-se muito menos afetado por transformações tardi a pós-magmáticas e apresenta composição variável entre $A n_{9}$ e $A n_{26}$ (determinação ótica), embora sejam mais freqüentes as composiçōes entre $A n_{9}$ e $A n_{13}, 0$ que, de certa forma, não foge muito do intervalo composicional deternimado para o plagioclásio constitutivo do BSG. A biotita alcança teores relativamente significativos em algumas amostras(Tabela 3.8), o mesmo ocorrendo com a clorita $\left(\mathrm{Cl}_{2}\right)$ a ela associada.

Os minerais acessórios a saber, zircão, minerais opacos e apatita são, relativamente, mais abundantes do que na facies BSG.

As fases minerais representativas do estágio de alteração tardi a pós-magmática mostram-se associadas aos feldspatos e à biotita. $O$ conjunto, constituído de sericita \pm muscovita $\left(\mathrm{Mv}_{1}\right) \pm \operatorname{clorita}\left(\mathrm{Cl}_{1}\right) \pm$ fluorita $\left(\mathrm{Fl}_{1}\right) \pm$ epidoto $\left(\mathrm{Ep}_{1}\right)$, está intimamente associado ao 
plagioclásio e se desenvolve, preferencialmente, de modo mais intenso, nas porções centrais dos cristaisl(cristais com zoneamento normal, Smith)1974), embora possam ocorrer em zonas irregulares("patch zones"). Esse fato evidencia que essas zonas eram, relativamente, mais cálcicas e agora encontram-se descalcificadas(Dall'Agnol, 1980, entre outros) Os produtos de alterações, relacionados à biotita, não diferem daquilo que foi observado na facies BSG. A albita, embora pouco expressiva, não varia muito, quanto forma e modo de ocorrência, a exemplo do que foi apresentado em relação à facies BSG. A fluorita ocorre, ainda, em algumas amostras, ora como cristais independentes, de granulação média a grossa, ora associados à biotita. Allanita e monazita são pouco freqüentes. Os argilo-minerais mostram-se, invariavelmente, associado ao feldspato potássico. Ocorrem sob a forma de nuvens, as quais dão aos grãos hospedeiros um aspecto "sujo", quando observados à luz natural.

\subsubsection{2- Ordem de Cristalização}

Os estudos petrográficos com vistas ao estabelecimento da ordem de separação das fases minerais primárias a partir do líquido magmático, permitiram estabelecer a seguinte seqüência:

1) Zircão, apatita e minerais opacos(MOP 1$)$ são fases precoces em relação às fases essenciais(quartzo, plagioclásio e feldspato potássico) e biotita, uma vez que ocorrem como inclusões em gãos dessas fases maiores;

2) inclusões de plagioclásio $\left(P l_{1}\right)$ em cristais de quartzo(Qtz $)_{1}$ e de feldspato potássico( $\left.F_{k_{1}}\right)$ são indicações de que o $\mathrm{Pl}_{1}$ iniciou a sua separação, a partir do líquido magmático, pelo menos em parte, um pouco antes do início da cristalização do $Q t z_{1}$ e do $\mathrm{Fk}_{1 ;}$

3) quartzo 1 e feldspato potássico $\left(\mathrm{Fk}_{1}\right)$ desenvolvem, às vezes, contatos interpenetrantes e, por vezes, ocorrem lado a lado. Isso evidencia que essas fases minerais passaram a se separar do líquido magmmático mais ou menos no mesmo intervalo de temperatura e pressão. Entretanto, a ocorrência localizada de $\mathrm{Fk}_{1}$ intersticial leva a se crer que o mesmo teve prolongada a sua cristalização além da do quartzo 1;

4) a biotita é uma fase posterior, pelo menos em parte, às fases assenciais, uma vez que ocorre de forma intersticial em relação às mesmas;

5) as fases minerais restantes são atribuídas ao estágio de alterações tardi a pósmagmáticas. A Figura 3.6 sintetiza as observações acima discutidas e apresenta uma extensão em relação às fases minerais atribuídas ao estágio de alterações tardi a pósmagmáticas. 
Tabela 3.8- Composiçסes modais do biotita monzogranitos(BMG). Maciço granitóide Antônio Vicente. Tr= Traço; Nd= Nåo detectado; $\mathrm{Nc}=\mathrm{N}$ ào contado

\begin{tabular}{|c|c|c|c|c|c|c|c|}
\hline VARIEDADE & & & & BMG & & & \\
\hline AMOSTRAS & GAM-CS-15 & GAM-CS-38 & GAM-CS-54 & GAM-CS-33 & GAM-CS-55A & GR-01 & \\
\hline & 50 & 51 & 52 & 53 & 54 & 55 & \\
\hline $\begin{array}{l}\text { MINERAIS } \\
\text { PRIMÁRIOS(\%) }\end{array}$ & & & & & & & \\
\hline QUARTZO & 37 & 23 & 37 & 38 & 40 & 21 & \\
\hline PLAGIOCLÁSIO & 21 & 46 & 18 & 26 & 20 & 41 & \\
\hline FELLSPATO $\left(\mathrm{Fk}_{1}\right)$ & 39 & 26 & 39 & 35 & 37 & 35 & \\
\hline BIOTITA & 02 & 01 & 03 & 04 & 03 & 02 & \\
\hline ZIRCAO & $\mathrm{Tr}$ & Ir & $\mathrm{Tr}$ & $\mathrm{Tr}$ & $\mathrm{Tr}$ & $\mathrm{Tr}$ & \\
\hline MINERAIS OPACOS & Tr & $\operatorname{Tr}$ & $\operatorname{Tr}$ & $\mathrm{Tr}$ & $\mathrm{Tr}$ & $\operatorname{Tr}$ & \\
\hline APATITA & $\mathrm{Tr}$ & $\mathrm{Tr}$ & $\mathrm{Tr}$ & $\mathrm{Tr}$ & $\mathrm{Tr}$ & $\mathrm{Tr}$ & \\
\hline $\begin{array}{l}\text { MNERAIS } \\
\text { SECUNDARIOS(\%) }\end{array}$ & & & & & & & \\
\hline $\begin{array}{l}\text { SERICITAIMUSCOVIT } \\
\text { A }\end{array}$ & $\overline{\mathrm{Tr}}$ & $\mathrm{Tr}$ & $\mathrm{Tr}$ & $\mathrm{Tr}$ & $\operatorname{Tr}$ & Tr & \\
\hline FELDSPATO $\left(\mathrm{Fk}_{2}\right)$ & $\overline{N c}$ & Nc & Nc & Nc & Nc & $\overline{N c}$ & \\
\hline CLORITA & 01 & 03 & $\mathrm{Tr}$ & 05 & $\mathrm{Tr}$ & $\mathrm{Tr}$ & \\
\hline ALLANITA & Nd & Nd & Tr & $T r$ & $\operatorname{Tr}$ & $\mathrm{Tr}$ & \\
\hline EPIDOTO & $\mathrm{Tr}$ & $\mathrm{Tr}$ & Tr & $\mathrm{Tr}$ & $\mathrm{Tr}$ & $\mathrm{Tr}$ & \\
\hline ALBITA & $\operatorname{Tr}$ & 01 & 02 & 02 & $\mathrm{Tr}$ & $\mathrm{Tr}$ & \\
\hline FLUORITA & $\mathrm{Tr}$ & $\mathrm{Tr}$ & $\mathrm{Tr}$ & $\mathrm{Tr}$ & $\mathrm{Tr}$ & $T r$ & \\
\hline MONAZITA & $\mathrm{Tr}$ & $\mathrm{Nd}$ & Nd & Nd & Nd & $\mathrm{Nd}$ & \\
\hline MINERAIS OPACOS & $\operatorname{Tr}$ & $\mathrm{Tr}$ & $\mathrm{Tr}$ & $\mathrm{Tr}$ & $\mathrm{Tr}$ & $\mathrm{Tr}$ & \\
\hline QUARTZO & $\mathrm{Tr}$ & $\mathrm{Tr}$ & $\mathrm{Tr}$ & $\operatorname{Tr}$ & $\operatorname{Tr}$ & $\mathrm{Tr}$ & \\
\hline ARGILO-MINERAIS & Nc & $\mathrm{Nc}$ & Nc & Nc & Nc & $\mathrm{Nc}$ & \\
\hline $\begin{array}{l}\text { COMPOSIÇÁO DO } \\
\text { PLAGIOCLASIO }\end{array}$ & An9-13 & An9-26 & An12 & - & An12 & - & MEDIA \\
\hline$Q$ & 38 & 24 & 38 & 42 & 42 & 22 & 34 \\
\hline $\bar{A}$ & 40 & 28 & 43 & 30 & 38 & 36 & 36 \\
\hline $\mathrm{P}$ & 22 & 48 & 19 & 28 & 20 & 42 & 30 \\
\hline 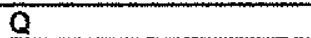 & 37 & 23 & 37 & 38 & 41 & 21 & 33 \\
\hline$A+P$ & 60 & 73 & 60 & 53 & 57 & 77 & 63 \\
\hline $\mathrm{M}^{\prime}$ & 03 & 04 & 03 & 09 & 02 & 02 & 04 \\
\hline $\begin{array}{l}\text { NUNERO DE } \\
\text { PONTOS }\end{array}$ & 1500 & 1500 & 1500 & 1500 & 1500 & 1500 & \\
\hline
\end{tabular}




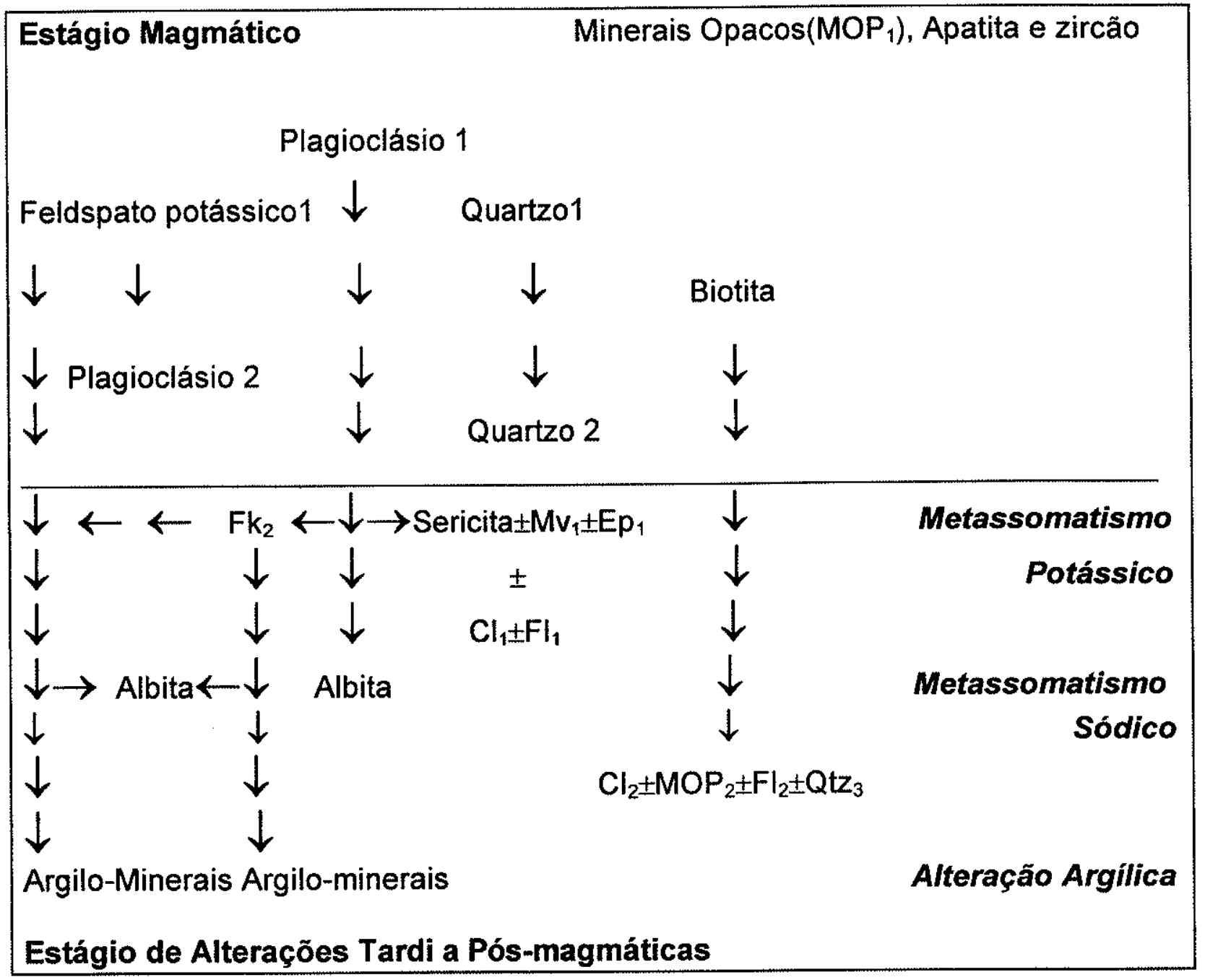

Figura 3.6. Fluxograma esquemático mostrando as ordens de cristalizações magmática e tardi a pós-magmática das fases minerais da facies BMG do maciço granitóide Antônio Vicente.

\subsection{4- Facies granitóides de ocorrência localizada no maciço}

Além das facies granitóides vistas acima, afloram, localmente, no contexto do MGAV, duas variedades de granitóides e corpos de greisens não representáveis, em mapa, na escala de trabalho adotada. Os granitóides estão representados por micromonzogranitos(MMG) e sieno e monzogranitos granofíricos(SMGGf). Os greisens mostram-se representados por mica-quartzo greisens conforme a classificação proposta por Scherba(1970) ou por mica greisen rico em quartzo e mica greisen pobre em quartzo, de acordo com a classificação proposta por Kühne et al.(1972; in: Stemprok, 1987). 


\subsubsection{1- Facies MMG}

Esse granitóide forma, ao que tudo indica, veios, diques, ou mesmo, pequenos "stocks". De acordo com informaçõrs verbais fornecidas por geólogos da Taboca Mineração S/A e com Sá(1985) esse granitóide corta a variedade BSG. Seus afloramentos ocorrem, preferencialmente, nas porções NE, E, SE, central e $S$ do maciço(Anexo 1). Suas composições modais encontram-se na Tabela 9 e a distribuição composicional modal de amostras representativas dessa facies pode ser visualizada na Figura 3.2(a, b).

Tabela 3.9 - Composiçōes modais do micromonzogranito(MMG) e do sienogranito a monzogranito granofírico(SMGGi). Maciço granitóide Antônio Vicente. Tr= Traço; Nd= Não detectado: NC= Não contado.

\begin{tabular}{|c|c|c|c|c|c|c|c|c|}
\hline \multirow{2}{*}{$\begin{array}{l}\text { VARIEDADES } \\
\text { AMOSTRAS }\end{array}$} & \multicolumn{4}{|c|}{ MMG } & \multicolumn{4}{|c|}{ SMGGf } \\
\hline & SL-IA-DI & NR-AV-36A & SL-2C-DT & & $I G-B \cup-3 A$ & NR-AV-8 & NE-B-50 & \\
\hline & 56 & 57 & 58 & & 59 & 60 & 61 & \\
\hline \multicolumn{9}{|l|}{ MINERAIS PRIMÁRIOS $(\%)$} \\
\hline QUARTO & 34 & 33 & 30 & & 36 & 34 & 41 & \\
\hline PLAGIOCLÁSIO & 21 & 29 & 34 & & 13 & 24 & 15 & \\
\hline FELDSPATO $\left(\mathrm{Fk}_{1}\right)$ & 30 & 28 & 24 & & 37 & 35 & 36 & \\
\hline BIOTITA & $01 \mathrm{r}$ & $\mathrm{Tr}$ & $\mathrm{Tr}$ & & $\mathrm{Tr}$ & Ir & 01 & \\
\hline ZIRCÃO & $\pi r$ & Ir & $\mathrm{Tr}$ & & $\mathrm{Tr}$ & $\mathrm{Tr}$ & $\mathrm{Tr}$ & \\
\hline MINERAIS OPACOS & $\mathrm{Tr}$ & $\mathrm{Tr}$ & $\mathrm{Tr}$ & & $\mathrm{Tr}$ & $\mathrm{Tr}$ & Ir & \\
\hline APATITA & Ir & Ir & Ir & & $\pi r$ & Ir & $\mathrm{Ir}$ & \\
\hline \multicolumn{9}{|l|}{$\begin{array}{l}\text { MINERAIS } \\
\text { SECUNDÁRIOS(\%) }\end{array}$} \\
\hline SERICIIA \pm MUSCOVITA & $\operatorname{Tr}$ & $\pi$ & $\bar{\pi}$ & & Ir & Tr & 02 & \\
\hline FELDSPATO $\left(\mathrm{Fk}_{2}\right)$ & $\mathrm{NC}$ & $\mathrm{Nc}$ & $\mathrm{Nc}$ & & NC & $\mathrm{Nc}$ & Nc & \\
\hline CLORITA & 06 & 06 & 05 & & 07 & 05 & 03 & \\
\hline ALLANITA & $\mathrm{Nd}$ & $\mathrm{Nd}$ & Nd & & 07 & $\mathrm{Ir}$ & Ir & \\
\hline EPIDOTO & 01 & $\mathrm{Tr}$ & $\mathrm{Tr}$ & & $\operatorname{Tr}$ & Ir & It & \\
\hline ALBITA & 07 & 04 & 06 & & If & 01 & 02 & \\
\hline FLUORITA & $\mathrm{Tr}$ & $\mathrm{Tr}$ & $\mathrm{Tr}$ & & Ir & $\pi$ & Ir & \\
\hline TOPAZIO & $\pi$ & Nd & Nd & & $\mathrm{Nd}$ & Nd & $\mathrm{Nd}$ & \\
\hline ESFALERITA & Nd & Nd & Nd & & $\mathrm{Tr}$ & Tr & Ir & \\
\hline MINERAIS OPACOS & $\mathrm{Tr}$ & $\mathrm{Tr}$ & Tr & & $\mathrm{Tr}$ & $\mathrm{Tr}$ & $\mathrm{Tr}$ & \\
\hline QUARTZO & $\mathrm{Tr}$ & $\operatorname{Tr}$ & Ir & & Tr & $\mathrm{Tr}$ & $\mathrm{Tr}$ & \\
\hline ARGILO-MINERAIS & NC & NC & Nc & & $\mathrm{Nc}$ & $\mathrm{NC}$ & NC & \\
\hline $\begin{array}{l}\text { COMPOSIC̨ÃO DO } \\
\text { PLAGIOCLÁSIO }\end{array}$ & An8-14 & - & An6-8 & MÉDIAS & Anl5 & - & Anl2 & MÉDIAS \\
\hline$Q$ & 38 & 35 & 32 & 35 & 42 & 36 & 44 & 41 \\
\hline $\mathrm{A}$ & 40 & 34 & 32 & 35 & 43 & 39 & 40 & 41 \\
\hline$P$ & 22 & $3 !$ & 36 & 30 & 15 & 25 & 16 & 18 \\
\hline$Q$ & 35 & 33 & 33 & & 36 & 34 & 43 & \\
\hline$A+P$ & 60 & 61 & 64 & & 50 & 61 & 53 & \\
\hline$M^{\prime}$ & 05 & 06 & $\mathbf{0 3}$ & & 14 & 05 & 04 & \\
\hline NÚMERO DE PONTOS & 1400 & 1500 & 1300 & & 1500 & 1500 & 1500 & \\
\hline
\end{tabular}

No diagrama Q-A-P, as amostras desse grupo granitóide ocupam perfeitamente 0 campo dos monzogranitos, enquanto que no diagrama $Q-(A+P)-M^{\prime}$ situam-se um pouco afastadas da aresta $Q-(A+P)$, uma vez que seus teores em máficos são, em geral, relativamente elevados, principalmente, devido aos conteúdos de clorita(Tabela 3.9). Embora essas rochas apresentem teores algo expressivos de albita modal, no conjunto, os produtos das alterações tardi a pós-magmáticas não são muito significativos. Além disso, 
deve ser ressaltado que face à grande dificuldade de separação entre as duas variedades de feldspato potássico, durante a contagem de pontos(análises modais), para o cálculo dos valores de "A" dos diagramas Q-A-P e Q-(A+P)-M'(Streckeisen, 1976), foi considerado o total dos feldspatos potássicos $\left(\mathrm{Fk}_{1}+\mathrm{Fk}_{2}\right)+$ albita. Assim a distribuição das amostras nesses diagramas não reflete a composição magmática original desse granitóide, mas sim uma composição modal modificada pelos processos de alterações tardi a pós-magmáticas que afetaram o mesmo, após sua colocação. Entretanto, como esses processos não foram muito intensos, a composição modal atual não deve se distanciar muito da composição magmática original desse granitóide.

\subsubsection{1- Textura e Mineralogia}

Esse granitóide apresenta, em geral, uma textura heterogranular a equigranular fina, com ocorrência localizada de textura porfiritica. Mostra coloração rosa-acinzentada a creme(Prancha 12; Fotos $\mathrm{c}, \mathrm{d})$ ).

Consiste essencialmente de quartzo, feldspato potássico e plagioclásio, sendo varietal a biotita, que mostra-se, geralmente, cloritizada em diferentes graus. Como minerais acessórios ocorrem zircão(mais freqüente), minerais opacos, apatita e allanita. Os produtos de alterações tardi a pós-magmáticas estão representados pela associação sericita $\pm \operatorname{muscovita}\left(\mathrm{MV}_{1}\right) \pm \operatorname{clorita}\left(\mathrm{Cl}_{1}\right) \pm$ fluorita $\left(\mathrm{Fl}_{1}\right) \pm \operatorname{epidoto}\left(\mathrm{Ep}_{1}\right) \pm$ topázio(Top1) e feldspato potássico2, intimamente associados, especialmente, à substituição do PI1, pela albitização dos feldspatos, bem como pela associação clorita( $\left(\mathrm{Cl}_{2}\right) \pm$ minerais opacos $\left(\mathrm{MOP}_{2}\right) \pm$ allanita \pm epidoto $\left(E \mathrm{p}_{2}\right) \pm$ quartzo3, associados à cloritização da biotita e por argilo-minerais relacionados à alteração argílica dos feldspatos potássicos.

Texturas de intercrescimentos mostram-se representadas, principalmente, por tipos atribuídos à substituição, ocorrida em condições "subsolidus". São pertitas compostas(Alling, 1938; Smith, 1974), que, geralmente, gradam de um tipo a outro. Dentre eles se destacam "film", "band" e "vein perthites", embora ocorram, subordinadamente "patch perthites". Além desses, ocorrem, localmente, intercrescimentos mirmequíticos do tipo "myrmekite rims"(Phillips, 1974)

O quartzo ocorre em, pelo menos, quatro tipos morfológicos a saber:

1) quartzo 1: ocorre, geralmente, como fenocristais ou como grãos, relativamente, mais grossos que os demais tipos. Tem contornos anédricos e mostra-se, por vezes, fraturado e exibe forte extinção ondulante.

2) quartzo 2: é o tipo mais comum. Costuma se apresentar como grãos anédricos a subédricos e, raramente, euédricos, de dimensões fina a média. 
3) quartzo 3: ocorre intimamente associado à biotita cloritizada. Forma gãos anédricos, alongados e com aspecto fusiforme, que se dispõem paralelamente aos planos de clivagem das fases micáceas.

4) quartzo 4: refere-se àquele que integra os intercrescimentos mirmequíticos.

O feldspato potássico $\left(\mathrm{Fk}_{1}\right)$ é, via de regra, pertítico, embora não tão rico em pertitas como nas demais variedades de granitóides vistos anteriormente. Excetuam-se a isso, os cristais de microclina pertítica( $\left(\mathrm{Fk}_{2}\right)$, que ocorrem como fenocristais, uma vez que eles não diferem em nada daqueles descritos nos granitóides supracitados. $O$ tipo mais comum( $\left.F k_{1}\right)$ forma gãos finos a médios, de contornos anédricos a subédricos, por vezes, de bordas corroídas. Desenvolve com outras fases minerais contatos, geralmente, irregulares e interpenetrantes, embora ocorram, subordinadamente, contatos retos. Mostrase, em geral, parcialmente alterado para argilo-minerais e, às vezes, hospeda inclusões, principalmente, de plagioclásio. Nos contatos entre si e, algumas vezes, com o plagioclásio pode-se desenvolver fases albiticas do tipo "swapped rims"(Smith, 1974). Os fenocristais $\left(F_{k}\right)$ são, geralmente, subédricos e, por vezes, exibem bordas corroídas. Mostram-se, relativamente, mais alterados para argilo-minerais $e$, algumas vezes, encontram-se parcialmente substituídos por albita("chess-board albite"; Smith, 1974). Costuma ser, geralmente, mais enriquecido em pertitas e, localmente, mostra-se substituíndo o plagioclásio(microclinização). Este fato é aqui atribuído a um primeiro epsódio de metassomatismo potássico, que afetou, em diferentes graus, os diversos tipos de granitóides estudados. Eventualmente, exibe maclas, principalmente do tipo Carisbad.

O plagioclásio, por sua vez, ocorre em duas modalidades, podendo se apresentar tanto como grãos finos(mais comuns), quanto como fenocristais(raros). Exceto no que se refere à granulação, as duas variedades mostram caracteríticas texturais idénticas. Formam cristais anédricos a subédricos, geralmente, zonados(zoneamento normal) e costumam estar, parcialmente, alterados a sericita \pm muscovita $\left(\mathrm{Mv}_{1}\right) \pm \operatorname{clorita}\left(\mathrm{Cl}_{1}\right) \pm$ fluorita $\left(\left.F\right|_{1}\right) \pm$ epidoto $\left(E p_{1}\right) \pm$ topázio(Top $p_{1}$. Essa paragênese é mais acentuada nas porções centrais dos gãos e constitue mais uma evidência de um primeiro evento de metassomatismo potássico que reinou, com diferentes intensidades, sobre as diversas facies granitóides estudadas, conforme referido anteriormente. Cristais geminados dos tipos albita e albita-Carlsbad são comuns. Bordas albíticas tipo "albite rims" são freqüentes e formam, as vezes, mirmequitas("myrmekite rims"). Em termos composicionais(determinação ótica), o plagioclásio apresenta teores de anortita variáveis desde $A n_{6}$ até $A n_{14}$, sendo, entretanto, mais comuns aquelas composições em torno de $A n_{8}$. 
A biotita ocorre como lamelas anédricas a subédricas, embora ocorram, localmente, cristais finos e anédricos. Apresenta pleocroismo forte, variando desde castanho-esverdeado escuro $(Z$ e $Y)$ a castanho-esverdeado pálido(X), castanho escuro( $Z$ e $Y)$ a castanho pálido $(X)$ e castanho-avermelhado(Ze $Y)$ a castanho-amarelado ou palha(X). Exibe, localmente, evidências de deformaçào traduzidas pela presença de "kink-bands" e por forte extinção ondulante. Costuma hospedar inclusões, sendo as mais comuns de zircão, com as quais desenvolve nítidos halos pleocróicos, embora àquelas de apatita e de minerais opacos possam ocorrer de modo subordinado. Encontra-se, quase sempre, parcialmente transformada para clorita $\left(\mathrm{Cl}_{2}\right)$, a qual mostra-se, por vezes, associada a epidoto $\left(\mathrm{Ep}_{2}\right)+$ quartzo $\left(\mathrm{Qtz} z_{3}\right)+$ minerais opacos $\left(\mathrm{MOP}_{2}\right)+$ allanita e, às vezes, fluorita $\left(\mathrm{Fl}_{2}\right)$

Quanto aos minerais acessórios, o zircão é o mais comum, ocorrendo como finos grãos subédricos a euédricos, geralmente, inclusos na biotita. A apatita, por sua vez, forma finos cristais prismáticos(seções longitudinais), ora alongados, ora com hábito poligonal hexagonal(seções basais), via de regra, associados às fases máficas. Os minerais opacos ocorrem em duas modalidades. A primeira(MOP $)_{1}$, ao que tudo indica, representa uma fase primária e costuma ocorrer como grãos anédricos, às vezes, subédricos, geralmente, associados e/ou inclusos na biotita. $A$ segunda( $\left(\mathrm{MOP}_{2}\right)$, mostra-se intimamente associada à biotita cloritizada $\left(\mathrm{Cl}_{2}\right)$ e forma grãos anédricos, dispostos, preferencialmente ao longo dos planos de clivagem da mesma.

As fases minerais tardi a pós-magmáticas resultam da alteração do plagioclásio[sericita $\pm \operatorname{muscovita(Mv1)} \pm \operatorname{clorita}\left(\mathrm{Cl}_{1}\right) \pm \operatorname{fluorita}\left(\mathrm{Fl}_{1}\right) \pm \operatorname{epidoto}\left(\mathrm{Ep}_{1}\right) \pm$ topázio $\left(\mathrm{Top}_{1}\right)$, microclina pertítica $\left(\mathrm{Fk}_{2}\right)$ e albita], da biotita[clorita $\left(\mathrm{Cl}_{2}\right) \pm$ minerais $\operatorname{opacos}\left(\mathrm{MOP}_{2}\right) \pm$ quartzo(Qtz 3$) \pm$ allanita \pm fluorita $\left.\left(\mathrm{FI}_{2}\right)\right]$ e do feldspato potássico(argilominerais).

\subsubsection{2- Ordem de cristalização}

O estudo de seções delgadas objetivando caracterizar a seqüência de cristalização dos constituintes minerais formados no estágio magmático permitiu sumariar o seguinte:

1) As fases minerais primárias expressas por zircão, minerais opacos $\left(M O P_{1}\right)$ e apatita precederam, na seqüência de cristalização, as fases maiores representadas por quartzo, plagioclásio e feldspato potássico e biotita. Isso é demonstrado através da ocorrências de inclusões, das primeiras nessas últimas.

2) Quartzo, plagiociásio e feldspato potássico, ao que tudo indica, devem ter iniciada a cristalizar dentro de um mesmo intervalo de temperatura e pressão, haja vista que ocorrem lado a lado e não são observadas relações de inclusões de uma fase em relação a outra. 
3) A biotita, por sua vez, parece ter se separado do líquido magmático um pouco após as fases essenciais, uma vez que, algumas vezes, ocorre de forma intersticial em relação as mesmas.

As demais fases formaram-se no estágio de alterações tardi a pós-magmáticas às expensas dos feldspatos e da biotita. A Figura 3.7 ilustra resumidamente a seqüencia acima estabelecida.

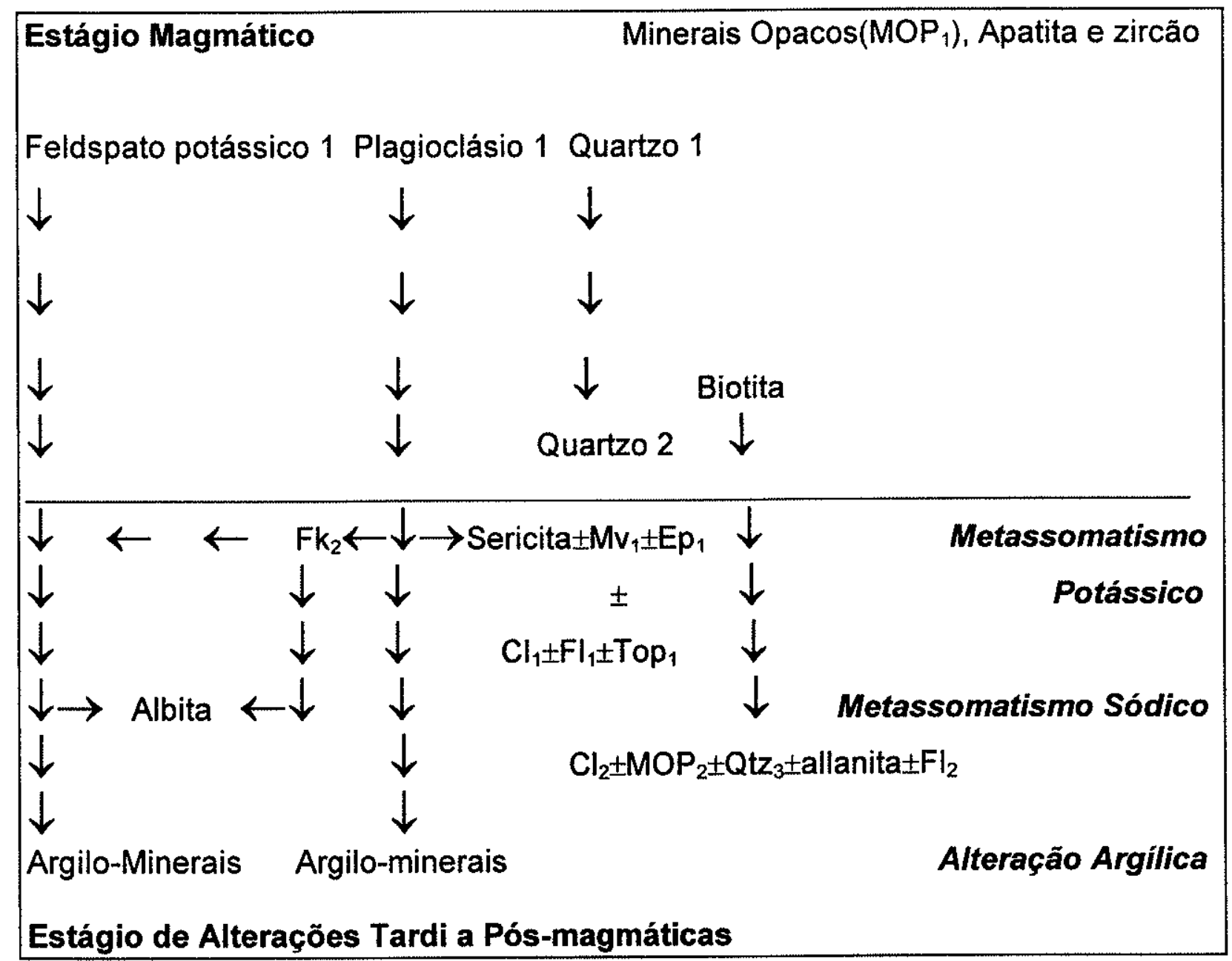

Figura 3.7. Fluxograma esquemático da seqüência de cristalização magmática e tardi a pós-magmática das fases minerais da facies MMG. Maciço granitóide Antônio Vicente.

\section{4.4.2- Facies SMGGf}

Essa variedade de granitóide tem distribuição aleatória no interior do maciço, foi amostrada nas porções S, central, N, e SW do mesmo(Anexo 1).

Em termos modais(Tabela 3.9 e Figura 3.2), varia de sienogranito a monzogranito, é pobre em biotita, com conteúdos, quase sempre, inferiores a $1 \%$ e possui teores relativamente elevados de clorita( $3 \%$ a $7 \%)$. Em amostras localizadas a allanita pode 
ocorrer em conteúdos algo expressivos $(7 \%)$. Em relação às paragêneses tardi a pósmagmáticas, elas são muito incipientes.

\subsubsection{1- Textura e Mineralogia}

De modo geral, apresenta textura hipidiomórfica heterogranular, fina a média e exibe coloração rosa a rosa-acinzentada(Prancha 12; Fotos e). Apresenta abundantes intercrescimentos granofíricos, os quais mostram-se representados pelos tipos insular, cuneiformes, vermicular e "radiating fringe" (conforme Smith \& Brown, 1988; Prancha 12, foto $f$, deste trabaiho). Guarda muita semelhança textural e mineralógica com o micromonzogranito.

Consiste essencialmente de quartzo, feldspato potássico(microclina pertítica) e plagioclásio, sendo varietal a biotita. Como minerais acessórios ocorrem zircão e minerais opacos $\left(\mathrm{MOP}_{1}\right)$. A clorita $\left(\mathrm{Cl}_{2}\right)$ representa o principal produto do estágio de alterações tardi a pós-magmáticas e mostra-se intimamente associada à biotita, embora ocorram, ainda, minerais opacos $\left(M O P_{2}\right) \pm$ epidoto $\left(E p_{1}\right) \pm$ esfalerita \pm quartzo 2. As outras fases minerais ligadas a esse estágio mostram-se representadas por sericita \pm muscovita( $\left.\mathrm{Mv}_{1}\right) \pm$ clorita $\left(\mathrm{Cl}_{1}\right) \pm$ fluorita $\left(\mathrm{Fl}_{1}\right)$ e $\mathrm{Fk}_{2}$, decorrentes da substituição parcial do plagioclásio1 $\left(\mathrm{Pl}_{1}\right)$ e argilo-minerais, relacionados à alteração dos feldspatos potássicos.

O quartzo ocorre em, pelo menos, três variedades a saber:

1) quartzo 1: forma cristais, geralmente, subédricos a euédricos, de granulação, dominantemente, média, os quais apresentam-se, via de regra, envoltos por franjas granofíricas e que encontram-se inseridos em uma matriz, também, granofírica fina(Prancha 12, Foto f).

2) quartzo 2: ocorre intimamente associado à biotita cloritizada e clorita $\left(\mathrm{Cl}_{2}\right)$. Forma grãos alongados e fusiformes, que se dispõem, preferencialmente, ao longo dos planos de clivagem das mesmas. Mostra-se, geralmente, associado aos minerais \pm clorita $\left(\mathrm{Cl}_{2}\right)$ \pm 0 acos $\left(\mathrm{MOP}_{2}\right) \pm$ epidoto $\left(\mathrm{Ep}_{1}\right) \pm$ esfaleritatallanita.

3) quartzo 3: constitui os intercrescimentos granofíricos, juntamente com o feldspato potássico( $\left.\mathrm{Fk}_{2}\right)$, e pode assumir formas diversas, sendo mais comuns os tipos insular, radial e vermicular, ocorrendo, subordinadamente, o tipo cuneiforme. Essas designações foram aqui assumidas de acordo com Smith \& Brown(1988).

O feldspato potássico, por sua vez, é essencialmente pertítico e raramente apresenta-se maclado, mas quando essas são evidentes, mostram-se governadas pelas leis de Carlsbad. Ocorre em, pelo menos duas variedades. O primeiro tipo $\left(\mathrm{Fk}_{1}\right)$, está representado por cristais, geralmente, euédricos a subédricos, de granulação, dominantemente, média, os quais encontram-se, por vezes, envoltos por uma franja 
granofírica, à semelhança do que ocorre com o quartzo tipo 1. Mostra-se imerso em uma matriz essencialmente granofírica, mais fina. Costuma estar, parcialmente, alterado para argilo-minerais, os quais o recobrem como uma nuvem, dando-the um aspecto "sujo", quando observados à luz naturtal. Localmente, mostra-se substituindo o plagioclásio 1 e as evidências a esse respeito são expressas pela presença de relíctos ou "fantasmas" de $\mathrm{Pl}_{1}$ no interior do mesmo. O outro tipo $\left(\mathrm{Fk}_{2}\right)$, forma intercrescimentos granofíricos com o $\mathrm{Qtz}{ }_{3}$.

O plagioclásio( $\left(\mathrm{Pl}_{1}\right)$ ocorre, geralmente, como cristais anédricos a subédricos, de granulação média, imersos na matriz granofírica. Apresenta-se, apenas, levemente alterado para sericita \pm muscovita $\left(\mathrm{Mv}_{1}\right) \pm \mathrm{clorita}\left(\mathrm{Cl}_{1}\right) \pm$ fluorita $\left(\mathrm{Fl}_{1}\right)$, exibe maclas nítidas, sendo mais comum aquelas regidas pelas leis da albita. Grãos zonados são pouco abundantes. Em termos composicionais, situa-se entre $A n_{12}$ e $A n_{15}$ (determinação ótica).

A biotita forma lamelas, predominantemente, anédricas, embora possam ocorrer, subordinadamente, grãos subédricos. Mostra-se, quase sempre, cloritizada em diferentes graus. Exibe pleocroismo moderado, variando de castanho escuro $(\mathrm{Z}$ e $\mathrm{Y})$ a castanho claroesverdeado $(X)$. Algumas vezes hospeda inclusões de zircão e ao contato com o mesmo desenvolve nítidos halos pleocróicos. Associados à cloritização ocorrem, ainda, minerais opacos2, esfalerita, allanita, quartzo 2 e, mais raramente, epidoto1.

Dentre os minerais acessórios, o zircão é o mais freqüente, embora nunca seja abundante. Ocorre como finos grãos subédricos a euédricos, geralmente, associados às fases máficas, em especial, à biotita e à biotita cloritizada. A allanita é pouco freqüente, mas em amostra localizada assume teores, relativamente, importantes(Tabela 3.9). Ocorre como cristais anédricos a subédricos, intersticiais e, geralmente, associadois à clorita $\left(\mathrm{Cl}_{2}\right)$. Os minerais opacos ocorrem ora como cristais subédricos, associados à biotita(forma primária; $\mathrm{MOP}_{1}$ ), ora como cristais anédricos, intimamente ligados à cloritização da biotita(MOP ${ }_{2}$, os quais mostram-se dispostos, preferencialmente, ao longo dos planos de clivagem da mesma.

A clorita $\left(\mathrm{Cl}_{2}\right)$ apresenta-se, na maioria dos casos, como lamelas anédricas formadas às expensas da biotita, as quais ocorrem entremeadas com a mesma. Exibe pleocroísmo fraco, variando de verde abacate $(Z$ e $Y)$ a "palha" $(X)$.

No que se refere às paragêneses tipicamente tardi a pós-magmáticas, sericita \pm muscovita $\left(\mathrm{Mv}_{1}\right) \pm$ clorita $\left(\mathrm{Cl}_{1}\right) \pm$ fluorita $\left(\mathrm{Fl}_{1}\right)$, ocorrem intimamente associadas à alteração do plagioclásio e costumam se concentrar nas porções centrais dos cristais "hospedeiros"(cristais com zoneamento normal),embora possam formar aglomerados em forma de "patch zones"( cristais zonados irregularmente). Em relação ao feldspato potássico2(microclina pertítica), as evidências de substituição são traduzidas pela presença de "fantasmas" ou relíctos de plagioclásio1 no interior dos cristais de $\mathrm{Fk}_{2}$, bem como pela 
ocorrência de "patch"(manchas) de $\mathrm{Fk}_{2}$ desenvolvidas ora nas bordas dos grãos de $\mathrm{Pl}_{1}$, ora nas zonas de clivagem do mesmo. Feições semelhantes a essas săo descritas por Serebryakova(1961), Beus \& Zalashkova(1964) e Witt(1988). Além dessas fases, ocorrem outras gerações associadas à substituição da biotita. Elas estão representadas por clorita $\left(\mathrm{Cl}_{2}\right) \pm$ minerais opacos $\left(\mathrm{MOP}_{2}\right) \pm$ quartzo $\left(\mathrm{Qtz} \mathrm{z}_{2}\right) \pm$ esfaleritatallanita \pm epidoto $\left(E p_{1}\right)$. Os argilo-minerais estão ligados preferencialmente aos feldspatos potássicos e, embora de difícil posicionamento temporal, paracem estar relacionados a um processo de alteração argíica ocorrido no final do estágio de alteraçōes tardi a pós-magmáticas. Eles apresentamse sob a forma de nuvens superpostas aos cristais de $\mathrm{Fk}_{1}$ e $\mathrm{Fk}_{2}$, atribuindo-lhes um aspecto "sujo", quando observados à luz natural.

\subsubsection{2- Ordem de cristalização}

As observações petrográficas com vistas à caracterizar a ordem de cristalização magmática das fases minerais constitutivas desse granitóide indicaram o seguinte sequiência:

1) As fases minerais acessórias representadas por zircão apatita e minerais opacos(MOP 1$)$ são precoces em relação às fases essenciais e à biotita. Isso é sustentado pelo fato desses minerais ocorrerem com inclusões nessas fases maiores.

2) Quartzo, plagioclásio e feldspato potássico ocorrem lado a lado, não tendo sido observadas relações de inclusões entre os mesmos. Além disso, o elevado conteúdo de fases intercrescidas(intercrescimentos granofíricos), dificultou a observação das relações entre eles. Assim, ao que tudo indica, quartzo, plagioclásio e feldspato potássico iniciaram a cristalizar dentro de intervalos de temperatura e pressão mais ou menos eqüivalentes.

3) A biotita, principal máfico primário, é posterior, pelo menos em parte, visto que ocorre, algumas vezes, de forma intersticial em relação às fases essenciais.

4) As demais fases estão asociadas ao estágio de alteração tardi a pós-magmática.

A Figura 3.8 mostra um esboçado resumido acerca da ordem cronológica de cristalização mineral acima apresentada, onde está, também incluída, a seqüência aproximada de formação das fases minerais relacionadas ao estágio de alterações tardi a pós-magmáticas. 


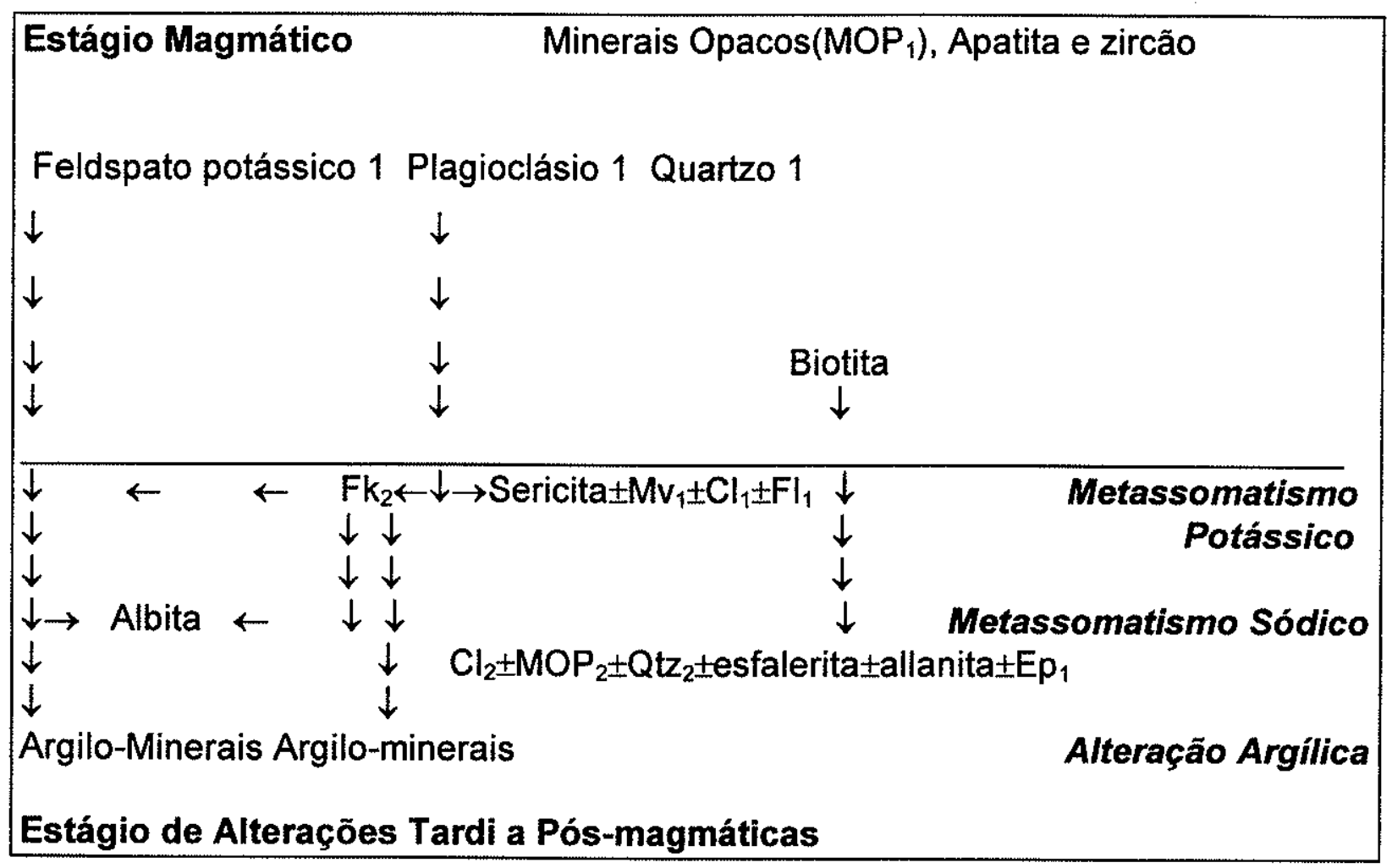

Figura 3.8. Fluxograma esquemático da seqüência de cristalização magmática e tardi a pós-magmática das fases minerais da facies SMGGf. Maciço granitóide Antônio Vicente.

\subsubsection{3-Geisens}

Os greisens formam tanto corpos tabulares, ao que tudo indica, alojados em fraturas e/ou falhas das facies BSG, quanto podem se apresentar como zonas sob a forma de "manchas", formadas a partir da intensa alteração prevasiva(Taylor \& Pollard, 1988) de porções dessa facies granitóide. Nesse último caso, parecem representar um estágio avançado das variedades BSGA e BSGIA. Eles foram amostrados em superfície(Prancha 1; Foto a) e através de um furo de sondagem(Prancha 13; Fotos $a, b$ ).

As ocorrências em superficie apresentam-se intensamente intemperizadas, fato que dificultou a caracterização da existência ou não de uma estruturação interna. Mesmo assim, pode-se caracterizar duas variedades de greisens, tomando-se por base a textura e a mineralogia: 1) "muscovita-quartzo greisen; 2) quartzo-clorita greisen.

No que se refere às ocorrências em sub-superfície, pode-se identificar, pelo menos, dois tipos texturais, integrantes, ao que tudo indica, de uma zona alterada, pelo menos em parte, pervasivamente. No sentido do granitóide intensamente alterado para a zona de greisen "sensu stricto"(Sherba, 1970; Stemprok, 1987), ocorrem duas variedades texturais a saber: 1) clorita-"siderofilita"-"muscovita"-quartzo greisen médio a 
grosso(CSMQGG; Prancha 13; Foto a); 2) clorita-"siderofilita"-"muscovita"-quartzo greisen fino(CSMQGF; Prancha 13; Foto b).

Todos os tipos acima caracterizados foram classificados como mica-quartzo greisens conforme a proposição de Sherba(1970) ou, ainda, como mica greisens ricos em quartzo e mica greisens pobres em quartzo, de acordo com a classificação proposta por Kühne et al.(1972; in: Stemprok, 1987). A Figura 3.9 mostra a distribuição das amostras no diagrama quartzo-fluorita+topázio-mica(conforme proposição de Kühne et al. , 1972 .In: Stemprok, 1987) e a Tabela 3.10 mostra a composições modais desses greisens.

\subsubsection{1- Muscovita-Quartzo Greisen(MQGs)}

Em amostra de mão, essa variedade se apresenta como um agregado ou mistura de massas minerais verdes e esbranquiçadas, que, texturalmente, lembra a facies granitóide da qual se originou, resguardando-se, entretanto, os efeitos da greisenização. Ao microscópio, apresenta textura hipidiomórfica heterogranular e granulação amplamente variável, desde tipos finos até grossos. Constitui-se essenciaimente de quartzo e muscovita(mica branca), os quais se apresentam em proporções mais ou menos eqüivalentes, embora o quartzo ocorra em conteúdo levemente superior. Como fases minerais menores ocorrem zircão, minerais opacos, allanita, esfalerita, rutilo e cassiterita.

O quartzo apresenta-se como cristais, geralmente, anédricos, por vezes, com bordas corroídas, embora ocorram, subordinadamente, grãos subédricos e, mais raramente, euédricos. Possui dimensões variáveis, desde finas até grossas, embora sejam mais comuns as dimensões média a grossa. Desenvolve contatos irregulares, suturados e, às vezes, retos. Mostra evidências de deformação, estando, por vezes, fraturado e exibindo forte extinção ondulante. Apresenta, ainda, subgrãos de deformação, os quais são mais nitidos nos cristais mais grossos.

A muscovita(mica branca) forma lamelas anédricas, subédricas e, mais raramente, euédricas, finas, dispostas em agregados. Exibe relevo ondulante fraco e apresenta cores de interferências altas, destacando-se o amarelo, o vermelho e o azul intenso cintilante(ver mais adiante).

A allanita é algo freqüente, embora nunca seja abundante. Apresenta-se como grãos anédricos de granulação fina, por vezes, bastante alterados, os quais mostram-se, por vezes, associados à muscovita. Algumas vezes, encontra-se disposta, preferencialmente, ao longo dos planos de clivagem da mesma.

O zircão é menos freqüente e apresenta-se ora como grãos arredondados, anédricos, ora com hábito prismático, euédricos, por vezes zonados, embora possam ocorrer subordinados cristais subédricos. Os minerais opacos costumam ocorrer como 
grãos finos e anédricos, em geral, em íntima associação com a muscovita. A esfalerita, por sua vez, ocorre como grãos, via de regra, anédricos, quase sempre, associados à muscovita, os quais, dispõem-se, por vezes, paralelamente ao logo dos planos de clivagem da mesma. A cassiterita e o rutilo ocorrem em teores muitíssimos reduzidos e apresentamse como finíssimos gãos anédricos disseminados na rocha.

\subsubsection{2- Quartzo-Clorita Greisen(QCGs)}

Em amostra de mão, esse tipo, se caracteriza por uma textura muito fina, com tendéncia afanítica, exibe aspecto maciço e apresenta uma coloração verde oliva escuro. Ao microscópio, mostra textura hipidiomórfica heterogranular fina(Prancha 13; Foto c). Consiste essencialmente de clorita(mais abundante) e quartzo(Tabela 3.10) e, muito subordinadamente, sericita+muscovita. Como fases minerais menores ocorrem esfalerita, allanita, zircão e minerais opacos.

O quartzo, ocorre como finos grãos anédricos, embora ocorram, localmente, cristais de dimensões médias. Desenvolve contatos irregulares, apresenta evidências de deformação, traduzidas por fraturas e uma moderada extinção ondulante e, por vezes, mostra-se, parcialmente, encoberto por finas lemelas de sericita \pm muscovita.

A clorita costuma ocorrer como finas lamelas anédricas, embora posam ocorrer cristais médios e subédricos. Forma, em geral, agregados, os quais mostram-se, por vezes, envolvendo grãos de quartzo. Às vezes, pode formar agregados, nos quais as lamelas individuais apresentam-se dispostas de forma radial. Apresenta pleocroismo fraco, variando de verde "abacate" $(Z$ e $Y)$ a verde claro-amarelado $(X)$ e apresenta-se, parcialmente oxidada.

A esfalerita é relativamente a mais abundante. Costuma ocorrer como grãos anédricos, finos a médios em intima associação com a clorita oxidada ou superpondo-se ao quartzo. A allanita ocorre como grãos finos a médios, anédricos a subédricos, por vezes, oxidados, os quais mostram-se ora dispersos na rocha, ora associados à clorita. $O$ zircão é algo freqüente. Apresenta-se, quase sempre, como finos grãos subédricos a euédricos, que mostram-se, por vezes, zonados e encontram-se dispersos na rocha. Algumas vezes, ocorre envolto por franjas de óxido/hidróxido de ferro. O minerais opacos costumam se apresentar como finos grãos anédricos associados à clorita e à esfalerita.

\subsubsection{3- Clorita-"Siderofilita"-"Muscovita"-Quarto Greisens(CSMQGs)}

Essa variedade refere-se tanto aos termos de granulação média a grossa(Prancha 13; Foto d), quanto àquela de granulação fina(Prancha 13; Foto e). Devido à grande 
semelhança composicional e mineralógica serão abordados conjuntamente, afim de que sejam evitadas repetições.

O termo fino corresponde à porção, aparentemente, mais afastada do granito $e$, ao que tudo indica está relacionado a fraturas desenvolvidas no termo médio a grosso. Exibe estrutura laminar, milimétrica, e coloração negra(Prancha 13; Foto f). A estrutura laminar, embora muito nítida em amostras de mão(Prancha 14; Foto a), não é nítida ao microscópio. Deve, contudo, corresponder a uma laminação de fluxo de material, visto que, mesmo ao microscópio, não foram observadas quaisquer evidências de estruturas de natureza tectógena. Sua nitidez, na escala mesoscópica, deve-se, provavelmente, a um leve efeito de intemperismo. Essa variedade passa bruscamente para o tipo de granulação média a grossa, isotrópico, de coloração cinza escura, situado na zona mais próxima ao granito. Esse termo passa gradativamente, para a variedade de granitóide intensamente alterada(BSGIA), de coloração rosa, conforme pode ser observado na Foto $f$ da Prancha 13. Nesse caso, corresponde a manchas ou zonas de greisens originadas por alteração pervasiva do granitóide progenitor(facies BSG)

Em ambas as variedades, não foram observadas diferenças mineralógicas marcantes, exceto pelo maior enriquecimento em cassiterita na variedade de granulação média a grossa. Esse fato é, ainda, mais acentuado, próximo à passagem para a variedade fina.

De modo geral, essas duas variedades texturais de greisens consistem essencialmente de quartzo, "muscovita", "siderofilita", clorita e restos de biotita. Como fases minerais menores ocorrem zircão, minerais opacos, cassiterita, fluorita, monazita e topázio.

$\mathrm{O}$ quartzo ocorre em, pelo menos, duas modalidades texturais e morfológicas. A primeira( $\left(\mathrm{Qt}_{1}\right)$ corresponde a cristais médios a grossos, geralmente, anédricos, por vezes, com bordas corroídas. Desenvolve, muitas vezes, contatos irregulares e interpenetrantes e mostra evidências de deformação, as quais são traduzidas por uma forte extinção ondulante, pela presença de fraturas e por subgrãos de deformação. É morfologicamente e texturalmente muito semelhante ao quartzo tipo 1 descrito nos granitóides, aos quais esses geisens estão associados(BSG, BSGA e BSGIA). O segundo tipo(Qtz $z_{2}$ ) forma grãos finos, geralmente anédricos, mostra-se intimamente associado às fases micáceas e, em muitas amostras, apresenta-se orientado, preferencialmente, definindo, ao que tudo indica, uma linearidade de fluxo(Prancha 14; Foto b), decorrente de um evento de silicificação relacionado à geisenização(Stemprok, 1987).

A "muscovita" ocorre como finas lamelas anédricas, formando agregados complexos, juntamente com clorita e siderofilita, bem como com restos de biotita oxidada, minerais opacos e quartzo 2. Apresenta relevo ondulante e exibe cor de interferência alta, 
caracterizada por uma mistura de cores, dentre as quais destacam-se o azul intenso, o amarelo e o vermelho, embora ocorram, localmente, lamelas com tonalidades cinza. A "siderofilita", difere da muscovita devido apresentar pleocroíosmo fraco, variando de marrom claro pálido $(\mathrm{Z}$ e $\mathrm{Y})$ a incolor $(\mathrm{X})$. Análises químicas obtidas através de microssonda eletrônica revelaram que se trata de variedades de fengita, as quais variam de Li-Al micas a Mg-Al micas(ver mais adiante).

A clorita forma lamelas anédricas, de granulação fina e exibe pleocroísmo fraco, variando de verde oliva(Z e $Y)$ a verde claro pálido $(X)$. Mostra-se, quase sempre, parcialmente alterada para "siderofilita" e muscovita, podendo, ainda, se encontrar oxidada.

A biotita ocorre como restos, ao que tudo indica, da biotita primária. Apresenta-se como lamelas cloritizadas e oxidadas, de granulação fina, média e grossa. Exibe pleocroísmo moderado, variando de castanho escuro-avermelhado $(Z$ e $Y)$ a castanhoamarelado $(X)$ e apresenta cor de interferência caracteristicamente baixa.

O zircão é pouco abundante e ocorre como finos cristais subédricos a euédricos, por vezes, zonados, associados, preferencialmente, às fases micáceas, tanto como inclusões, quanto ao lado delas.

Os minerais opacos costumam ocorrer em, pelo menos, duas modalidades morfológicas. O primeiro tipo ocorre como grãos médios a grossos, subédricos, dispersos na rocha. O segundo tipo, forma cristais finos e anédricos, os quais mostram-se intimamente associados à alteração das fases micáceas, dispondo-s/e ao longo dos planos de clivagem das mesmas.

A fluorita é abundante em algumas amostras. Ocorre como cristais anédricos a subédricos, médios a grossos, disseminados na rocha. Pode ocorrer, ainda, formando vênulas e veios de dimensões milimétricas(Prancha 14; Foto $\mathrm{c}$ ).

A cassiterita, por sua vez, pode alcançar conteúdos algo significativos em algumas amostras, especialmente, naquelas representativas das variedades médias a grossas, nas porções próximas à passagem para o tipo fino(Prancha 14; Fotos d, e). Apresenta-se como grãos finos anédricos a subédricos, por vezes, formando agregados. Mostra-se associada, preferencialmente, aos agrupamentos de clorita oxidada. Os cristais costumam apresentar coloração castanho- avermelhada ou caramelada $e$, às vezes, mostram-se caracteristicamente maclados(Prancha 14; Foto f). 
Tabela 3.10- Composiçőes modais dos muscovita-quartzo greisen(MQGs), quartzo-clorita greisen(QCGs) e clorita'siderofilita"-"muscovita"-quartzo greisen(CSMQGs). Maciço granitóide Antônio Vicente. $\mathrm{Tr}=$ traço; Nd= Năo detectado; $\mathrm{Nc}=$ Năo contado.

\begin{tabular}{|l|c|c|c|c|c|c|}
\hline VARIEDADES & MQGs & QCGs & \multicolumn{3}{|c|}{ CSMQGs } \\
\hline AMOSTRAS & NR-AV-38A & $\begin{array}{c}\text { NR-AV- } \\
26 \mathrm{~B}\end{array}$ & NN-AV-IN-6 & NN-AV-41 & NN-AV-TOP-3 & NN-AV-TOP-7 \\
\hline MINERALOGIA(\%) & 62 & 63 & 64 & 65 & 66 & 67 \\
\hline QUARTZO & 51 & 48 & 56 & 59 & 62 & 60 \\
\hline MUSCOVITA & 48 & 0 & 17 & 13 & 17 & 17 \\
\hline SIDEROFILITA & $\mathrm{Nd}$ & $\mathrm{Nd}$ & 17 & 12 & 15 & 16 \\
\hline CLORITA & 0 & 49 & 9 & 12 & $\mathrm{O}$ & $\mathrm{Tr}$ \\
\hline BIOTITA & $\mathrm{Nd}$ & $\mathrm{Nd}$ & $\mathrm{Tr}$ & $\mathrm{Tr}$ & $\mathrm{Tr}$ & $\mathrm{Tr}$ \\
\hline ZIRCÁO & $\mathrm{Tr}$ & $\mathrm{Tr}$ & $\mathrm{Tr}$ & $\mathrm{Tr}$ & $\mathrm{Tr}$ & $\mathrm{Tr}$ \\
\hline ALLANITA & $\mathrm{Tr}$ & $\mathrm{Tr}$ & $\mathrm{Nd}$ & $\mathrm{Nd}$ & $\mathrm{Nd}$ & $\mathrm{Nd}$ \\
\hline MONAZITA & $\mathrm{Nd}$ & $\mathrm{Nd}$ & $\mathrm{Tr}$ & $\mathrm{Tr}$ & $\mathrm{Tr}$ & $\mathrm{Tr}$ \\
\hline MINERAIS OPACOS & $\mathrm{Nd}$ & 02 & $\mathrm{Tr}$ & $\mathrm{Tr}$ & $\mathrm{Tr}$ & $\mathrm{Tr}$ \\
\hline RUTILO & $\mathrm{Tr}$ & $\mathrm{Nd}$ & $\mathrm{Nd}$ & $\mathrm{Nd}$ & $\mathrm{Nd}$ & $\mathrm{Nd}$ \\
\hline FLUORITA & $\mathrm{Nd}$ & $\mathrm{Nd}$ & $\mathrm{Tr}$ & $\mathrm{Tr}$ & $\mathrm{Tr}$ & 01 \\
\hline TOPAZIO & $\mathrm{Nd}$ & $\mathrm{Nd}$ & $\mathrm{Tr}$ & $\mathrm{Tr}$ & $\mathrm{Tr}$ & $\mathrm{Tr}$ \\
\hline CASSITERITA & $\mathrm{Tr}$ & $\mathrm{Nd}$ & $\mathrm{Tr}$ & 01 & $\mathrm{Tr}$ & $\mathrm{Tr}$ \\
\hline Q & 100 & 100 & 100 & 100 & 100 & 100 \\
\hline A & 0 & 0 & 0 & 0 & 0 & 0 \\
\hline P & 0 & 0 & 0 & 0 & 0 & 0 \\
\hline NÚMERO DE & 1500 & 1500 & 1500 & 1000 & 1370 & 1100 \\
\hline PONTOS & & & & & & 0 \\
\hline
\end{tabular}

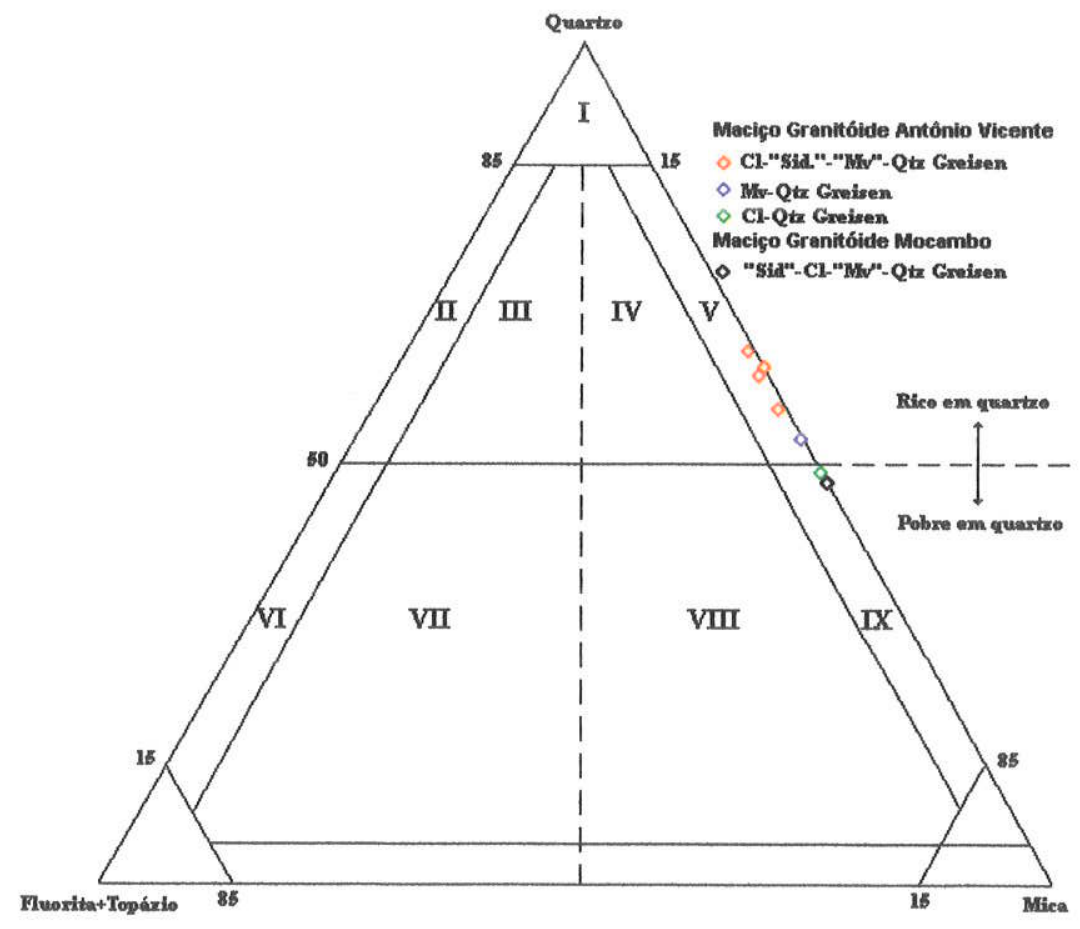

Figura 3.9. Diagrama triangular quartzo-fluorita+topázio-mica(Kühne et al., 1972. In: Stemprok, 1987) mostrando a distribuição das variedades dos greisens associados à facies BSG, BSGA e BSGIA do maciço granitóide Antônio Vicente e do greisen associado ao maciço granitóide Mocambo. 


\subsection{5 - Discussão e Considerações Finais}

Os trabalhos de fotointerpretação e de campo, bem como os estudos petrográficos, realizados no âmbito do maciço granitóide Antônio Vicente, revelaram a existência de diversas facies petrográficas representadas, principalmente, por granitóides a biotita e anfibólio, de composições monzogranítica, sienogranítica e álcali-feldspato granítica, granitóides a biotita, dominantemente monzogranítico e granitóides a biotita sieno a monzogranítico, heterogranulares e, às vezes, equigranulares, de granulação média a grossa e coloração variável, ocorrendo tipos rosa, rosa-acinzentados, cinza e vermelho tijolo. Além desses, ocorrem, localmente, tipos granitóides finos traduzidos por micromonzogranito e sieno a monzogranito granofírico, bem como zonas e corpos de mica greisens, veios hidrotermais, a base de clorita, e veios de fluorita.

Os granitóides mostram-se afetados, em diferentes intensidades, por alterações tardi a pós-magmáticas, dominantemente, pervasiva(Taylor \& Pollard, 1988), embora, localmente, possam apresentar caracteríticas de alteração fissural. Elas se desenvolveram através de dois episódios autometassomáticos principais, os quais mostram-se, por vezes, superpostos. As evidências petrográficas mostraram que o primeiro episódio é dominantemente potássico, enquanto o evento subseqüente mostra natureza sódica. Os estágios finais dessas alterações estão representados por argilização e silicificação, culminando com greisenização. As facies granitóides mais intensamante alterados e os greisens hospedam mineralização de cassiterita, fluorita e, subordinadamente, topázio, etc.

A ausência de estruturas marcantes no interior do corpo, o seu caráter francamente discordante em relação às estruturas das suas encaixantes e a natureza das mesmas, bem como a presença de intercrescimentos gráficos e granofíricos em grande parte dos granitóides do maciço, demonstram que a colocação do corpo granitóide, como um todo, se deu em nível crustal raso. Além disso, a relação cristais-líquido não deveria ser muito elevada quando da colocação (Pitcher, 1979). Tais aspectos tem sido verificados sistematicamente em outros granitos anorogênicos ou pós-tectônicos da Amazônia (Dall'Agnol et al., 1987; Gastral, 1987; Gonçalez et al., 1988;; Daoude, 1988, entre outros).

A Figura 3.10 mostra os principais pontos de ocorrência das facies granitóides mais intensamente afetadas por alterações tardi a pós- 
magmáticas(BSGA e BSGIA) e de greisens, no interior do maciço granitóide Antônio Vicente(Teixeira \& Dall'Agnol, 1991). Foram, também, indicadas, nessa figura, as áreas dos principais depósitos aluvionares de cassiterita, onde se desenvolveram, entre os anos de 1980 e 1990, os trabalhos de lavra realizados pela Taboca Mineração S/A e de potencial econômico comprovado. A presença de topázio foi destacada por ser um mineral restrito às facies mais intensamente alteradas. $O$ exame dessa figura evidencia claramente a estreita relação entre as áreas ricas em mineralizações de cassiterita e topázio e aquelas onde ocorrem as facies granitóides mais intensamente afetadas por alteraçōes tardi a pós-magmáticas. Observa-se, ainda, a ausência de mineralizações nas porções nordeste e sudoeste do maciço. Isso evidencia a íntima relação entre as mineralizações de cassiterita e topázio e os diferenciados mais evoluidos do maciço, ou seja, o BSG, BSGA e BSGIA. Entretanto, é importante ressaltar que as facies álicali-feldspato graníticas e sienograníticas, ocorrentes nas porções sudoeste e centro-sudoeste do maciço, também originadas de magmas muito evoluídos e silicosos, não se encontram muito afetados por alterações tardi a pós-magmáticos e a elas não são registradas notícias de mineralizaçōes associadas, nem tampouco, foram observados indícios das mesmas durante os estudos petrográficos realizados neste trabalho. Isso indica que as soluções tardias ricas em voláteis(agentes das alterações tardi a pósmagmáticas) desempenharam um papel fundamental na remobilização, transporte e deposição da cassiterita, topázio e fluorita, entre outras fases, e sem elas não haveria condições de gerar depósitos importantes(Teixeira \& Dall'Agnol, 1991).

A Tabela 3.11 sintetiza as principais caracteristicas petrográficas acerca dos granitóides e dos greisens associados desse maciço, obtidas através de microscopia ótica. 


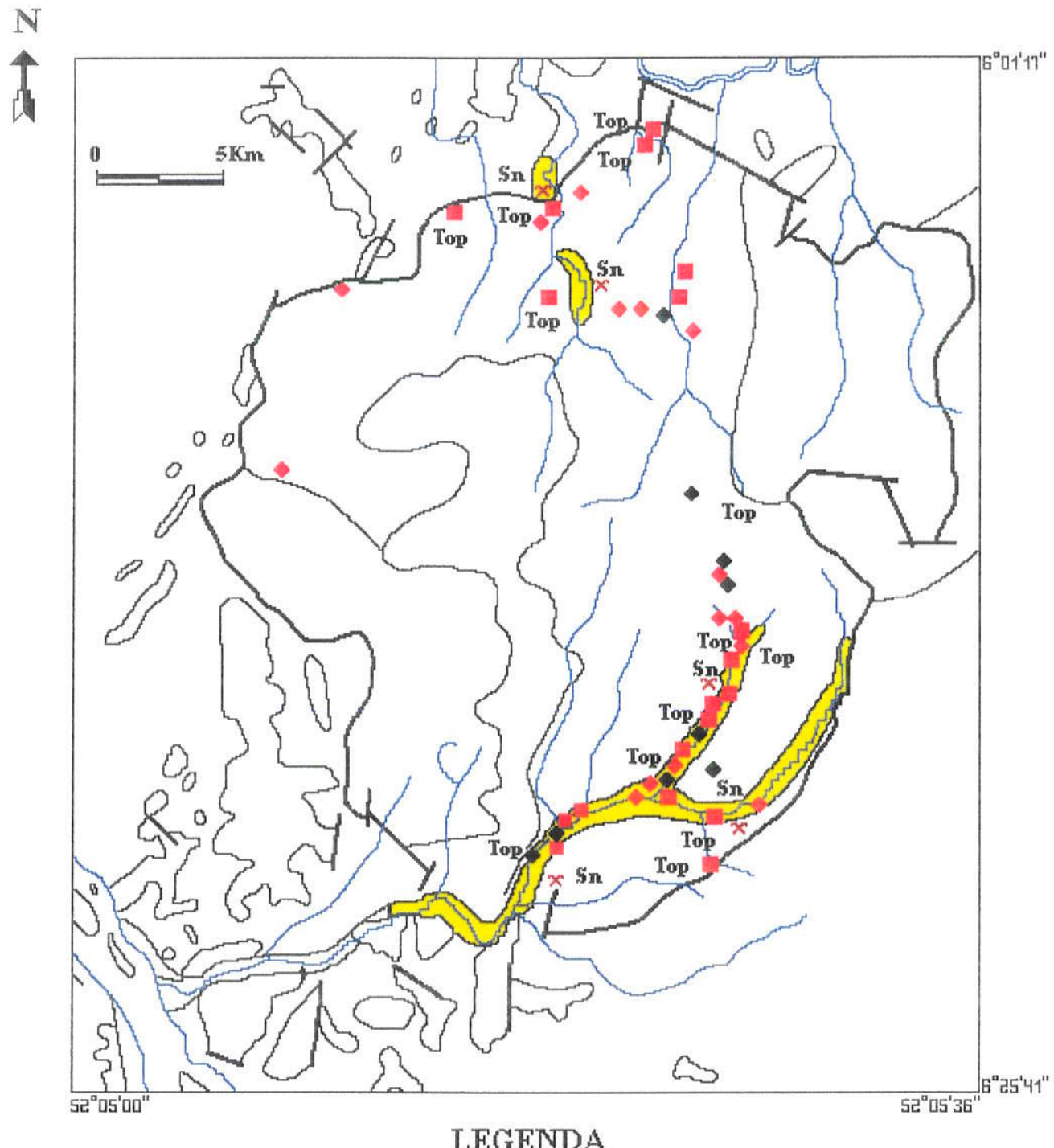

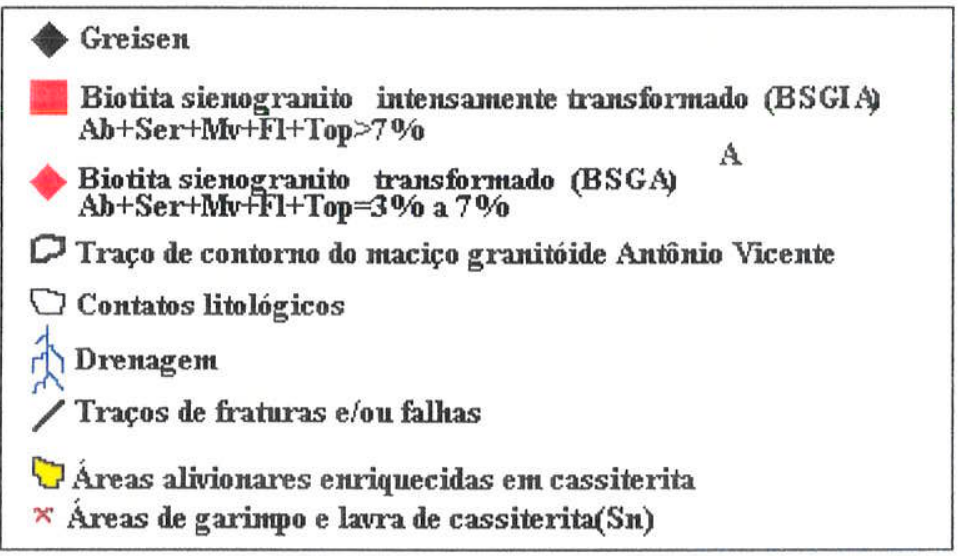

Figura 3.10- Mapa de amostragem resumindo os principais pontos de ocorrência das facies granitóides mais intensamente afetadas por alterações tardi a pós-magmáticas(BSGA e BSGIA) e de greisens no interior do maciço granitóide Antônio Vicente. São indicadas também as áreas aluvionares enriquecidas em cassterita e topázio(Teixeira \& Dall'Agnol, 1991) 
Tabela 3.11- Principais caracteristicas petrográficas das facies granitóides e de greisens associados ao maciço granitóide Antônio Vicente.

\begin{tabular}{|c|c|c|c|c|c|}
\hline $\begin{array}{l}\text { Facies } \\
\text { Granitólde }\end{array}$ & Minerais Essenciais & Winerals Varletais & $\begin{array}{l}\text { Minerais Acessórios } \\
\text { Primários }\end{array}$ & Minerais Secundários & $\begin{array}{l}\text { Mineralizaçōes/Mo } \\
\text { do de Ocorrência }\end{array}$ \\
\hline BASMG & $\begin{array}{l}\text { "quarzo, "plagiociásio(Ab-Olg a And), } \\
\text { "feldspato potássico(microclina pertítica) }\end{array}$ & $\begin{array}{l}\text { "aluminiohastingsítica a } \\
\text { ferro-edenita } \\
\text { " biotita }\end{array}$ & $\begin{array}{l}\text { "minerais opacos } \\
\text { "Apatita } \\
\text { " titanita } \\
\text { "zircäo } \\
\text { "allanita } \\
\end{array}$ & $\begin{array}{l}\text { sericita, muscovita, clorita, epidoto, fluorita, } \\
\text { carbonato, feldspato potássico(microclina } \\
\text { pertlitica), albita, minerais opacos, quartzo, } \\
\text { argilo-minerais }\end{array}$ & Ausentes \\
\hline ABSG & $\begin{array}{l}\text { "quartzo, "plagioclásio(Ab-Olg), "feldspato } \\
\text { potássico(microclina pertítica) }\end{array}$ & $\begin{array}{l}\text { "homblenda } \\
\text { "biotita }\end{array}$ & $\begin{array}{l}\text { "minerais opacos } \\
\text { "Apatita } \\
\text { "Zircão } \\
\text { "allanita }\end{array}$ & $\begin{array}{l}\text { sericita, muscovita, clorita, epidoto, fluorita, } \\
\text { feldspato potássico(microclina pertítica), } \\
\text { albita, minerais opacos, quartzo, argilo. } \\
\text { minerais }\end{array}$ & Ausentes \\
\hline BASAFG & $\begin{array}{l}\text { "quartzo, "plagioclásio(Ab-Olg), *feldspato } \\
\text { potássico(microcina pertítica) }\end{array}$ & $\begin{array}{l}\text { * hastingsita a ferro } \\
\text { edenitica } \\
\text { " biotita }\end{array}$ & $\begin{array}{l}\text { "minerais opacos } \\
\text { "Apatita } \\
\text { "zircåo }\end{array}$ & $\begin{array}{l}\text { sericita, muscovita, clorita, epidoto, fluorita, } \\
\text { feldspato potássico(microclina pertitica), } \\
\text { albita, minerais opacos, quartzo, argilo- } \\
\text { minerais }\end{array}$ & Ausentes \\
\hline BSGCI & $\begin{array}{l}\text { *quartzo, " plagioclásio(Ab-olg), " feldspato } \\
\text { potássico(microclina pertítica) }\end{array}$ & " biolita & $\begin{array}{l}\text { "minerais opacos } \\
\text { "Apatita } \\
\text { "zircão }\end{array}$ & $\begin{array}{l}\text { sericita, muscovita, clorita, epidoto, fluorita, } \\
\text { feldspato potássico(microclina pertitica), } \\
\text { albita, minerais opacos, quartzo, argilo- } \\
\text { minerais }\end{array}$ & Ausentes \\
\hline$\overline{A F G}$ & $\begin{array}{l}\text { "quartzo, "plagioclásio(Ab), „feldspato } \\
\text { potássico(microclina pertitica) }\end{array}$ & * biotita $\leq 1 \%$ & $\begin{array}{l}\text { "minerais opacos } \\
\text { *Apatita } \\
\text { *zircăo }\end{array}$ & $\begin{array}{l}\text { sericita, muscovita, clorita, epidoto, feldspato } \\
\text { potássico(microclina pertítica), albita, } \\
\text { minerais opacos, quartzo, argilo-minerais }\end{array}$ & Ausentes \\
\hline$\overline{B S G}$ & $\begin{array}{l}\text { "quartzo, "plagioclésio(Ab-Olig), "feldspato } \\
\text { potéssico(microclina pertítica) }\end{array}$ & * biotita & $\begin{array}{l}\text { "minerais opacos } \\
\text { *Apatita } \\
\text { "zircăo }\end{array}$ & $\begin{array}{l}\text { sericita, muscovita, clorita, epidoło, fluorita, } \\
\text { feldspato potássico(microclina perítica), } \\
\text { albita, topázio, allanita, monazita, minerais } \\
\text { opacos, quartzo, argilo-minerais }\end{array}$ & Ausentes \\
\hline BSGA & $\begin{array}{l}\text { "quartzo, "plagioclásio(Ab-Olig), "feldspato } \\
\text { potássico(microclina pertítica) }\end{array}$ & * biotita & $\begin{array}{l}\text { "minerais opacos } \\
\text { "Apatita } \\
\text { "zircso }\end{array}$ & $\begin{array}{l}\text { sericita, muscovita, clorita, epidoto, fluorita, } \\
\text { feidspato potássico(microclina pertítica), } \\
\text { albita, monazita, minerais opacos, quartzo, } \\
\text { argilo-minerais }\end{array}$ & Ausentes \\
\hline
\end{tabular}




\section{Continuação da Tabela 3.11.}

\begin{tabular}{|c|c|c|c|c|c|}
\hline BSGIA & $\begin{array}{l}\text { "quartzo, "plagiocísio(Ab-Olig), tfeldspato } \\
\text { potéssico(microclina pertitica) }\end{array}$ & * biotita & $\begin{array}{l}\text { "minerais opacos } \\
\text { "Apatita } \\
\text { "zircăo }\end{array}$ & $\begin{array}{l}\text { sericita, muscovita, clorita, epidoto, fluorita, } \\
\text { feldspato potássico(microclina pertítica), } \\
\text { albita, topázio, cassiterita, minerais coacos, } \\
\text { quartzo, argilo-minerais }\end{array}$ & $\begin{array}{l}\text { Cassiterita, Fluorita } \\
\text { e Topázio: } \\
\text { disseminados } \\
\text { Fluoría: veios }\end{array}$ \\
\hline BMG & $\begin{array}{l}\text { "quartzo, "plagioclésio(Ab-Olig), "feldspato } \\
\text { potássico(microclina pertitica) }\end{array}$ & " biotita & $\begin{array}{l}\text { "minerais opacos } \\
\text { "Apatita } \\
\text { "zircão }\end{array}$ & $\begin{array}{l}\text { sericita, muscovita, clorita, epidoto, fluorita, } \\
\text { feldspato potéssico(microclina pertitica), } \\
\text { albita, allanita, monazita, minerais opacos, } \\
\text { quartzo, argilo-minerais }\end{array}$ & Ausentes \\
\hline MMG & $\begin{array}{l}\text { "quartzo, "plagioclásio(Ab-Olig), "feldspato } \\
\text { potássico(microclina pertitica) }\end{array}$ & * biotita & $\begin{array}{l}\text { *minerais opacos } \\
\text { "Apatita } \\
\text { "zirḉo }\end{array}$ & $\begin{array}{l}\text { sericita, muscovita, clorita, epidoto, fluorita, } \\
\text { fełdspato potássico(microclina pertítica), } \\
\text { albita, topázio, minerais opacos, quartzo, } \\
\text { argilo-minerais }\end{array}$ & Ausentes \\
\hline SMGGf & $\begin{array}{l}\text { "quartzo, "plagioclásio(Ab-Olig), "feldspato } \\
\text { potássico(microclina pertítica) }\end{array}$ & " biotita $\leq 1 \%$ & $\begin{array}{l}\text { "minerais opacos } \\
\text { "Apatita } \\
\text { "zircåo }\end{array}$ & $\begin{array}{l}\text { sericita, muscovita, ciorita, epidoto, fluorita, } \\
\text { feldspato potássico(microclina pertítica), } \\
\text { albita, allanita, minerais opacos, quartzo, } \\
\text { argilo-minerais }\end{array}$ & Ausentes \\
\hline MQGs & quarzo e muscovita & & $\begin{array}{l}\text { zircăo, minerais opacoa, } \\
\text { rutilo }\end{array}$ & allanita, quartzo & $\begin{array}{l}\text { Cassiterita: } \\
\text { disseminada }\end{array}$ \\
\hline QCGs & clorita e quartzo & & zircăo e minerais opacos & allanita, esfalerita & Ausentes \\
\hline CSMQGs & quarzo, muscovita, siderofilita e clorita & & $\begin{array}{l}\text { biotita, zircåo, minerais } \\
\text { opacos }\end{array}$ & monazita, fluorita, topázio, cassiterita & $\begin{array}{l}\text { cassiterita, fluorita e } \\
\text { topázio: } \\
\text { disseminados }\end{array}$ \\
\hline
\end{tabular}




\section{5- Química Mineral}

No âmbito do maciço granitóide Antônio Vicente foram realizadas através de microssonda eletrônica um total de 70 análises pontuais quantitativas(WDS), assim discriminadas: 15 de anfibólio, 04 de biotita, 13 de clorita, 06 de muscovita, 05 de minerais opacos, 15 de plagioclásio e 12 de feldspato potássico pertítico. Foram realizadas, ainda, análises semi-quantitativas(EDS) através de microscopia eletrônica de varredura(MEV), as quais envolveram essencialmente a caracterização de fases minerais acessórias, incluindo os minerais opacos, em amostras de granitóides(22 análises) e de greisen(13 em amostras).

\subsection{1- Análises através de Microssonda Eletrônica}

\subsubsection{1- Análises químicas em Anfibólio}

Essas análises envolveram essencialmente os anfibólios presentes nas facies granitóides BASMG e BASAFG. Em ambos os casos foram analisadas porções do centro dos cristais, bem com entre o centro e a borda e das bordas. As análises químicas e suas respectivas fórmulas estruturais são apresentadas no Anexo 2

Tomando-se por base os parâmetros das fórmulas estruturais $(\mathrm{Ca}+\mathrm{Na})_{B}$ e $\mathrm{Na}_{\mathrm{B}}$, recomendados por Leake(1978) e Leake et al.(1997), calculou-se os mesmos para os anfibólios estudados, obtendo-se os seguintes valores: 1) de acordo com Leake(1978) $(\mathrm{Ca}+\mathrm{Na}) \mathrm{B}>1,67$ e $\mathrm{NaB}<0,67$, com $\mathrm{CaB}>1,34 ; 2)$ de acordo com Leake et al.(1997) $(\mathrm{Ca}+\mathrm{Na}) \mathrm{B}>1,00$ e $\mathrm{NaB}<0,50$, com $\mathrm{CaB}>1,50$. Concluiu-se, portanto, que em relação aos quatro principais grupos de anfibólios, se trata de anfibólios cálcicos, conforme é ilustrado pela Figura $3.11 \mathrm{a}, \mathrm{b}$.

Utilizou-se em seguida o diagrama $\mathrm{Mg} /\left(\mathrm{Mg}+\mathrm{Fe}^{2+}\right)$ versus TSi(Figura 3c, pg 1033 , Leake, 1978; Figura 2, pg 5, Howthorne, 1981), com vistas à classificação dos mesmos. Nele(Figura 3.12a) observa-se que, entre as amostras da facies BASMG, não há uma grande variação composicional. Dentre as 11 amostras estudadas, 07 situam-se no campo correspondente a hornblenda hastingsítica magnesiana(análises $1 \mathrm{C} 1,2 \mathrm{C} 1,3 \mathrm{C} 1,4 \mathrm{C} 2,5 \mathrm{C} 2$, $9 \mathrm{C} 3$ e 18C5), 01 no limite entre esse campo e aquele da hornblenda ferro-edenítica(análise 19C5), 01 no campo da hastingsita magnesiana(análise 6C2) e 02 no campo da hornblenda hastingsítica(análises $10 \mathrm{C} 3$ e 11C3).

No que se refere às amostras da facies BASAFG, o total das análises ocupa a mesma posição no diagrama. Elas incidem na linha limitrofe entre os campos da hornblenda ferro-edenítica e da hornblenda hastingsítica, em posição nitidamente diferente daquelas ocupadas pelas análises das amostras da facies BASMG. 
Posteriormente, foram aplicadas as recomendações de Leake et al.(1997). Embora esses autores tenham apresentado uma série de modificações àcerca da nomenclatura e classificação dos anfibólios, foram mantidas muitas das recomendações de Leake(1978) e Hawthorne(1981). Em função disso, as amostras foram lançadas no diagrama $\left(\mathrm{Mg} /\left(\mathrm{Mg}+\mathrm{Fe}^{2+}\right)\right.$ versus Si(Figura $\left.3.12 \mathrm{~b}\right)$. Aquelas pertencentes à facies BASMG incidiram, em sua ampla maioria, no campo da hastingsita, com uma única amostra "plotando"em cima da linha divisória entre os campos da hastingsita e da ferro-edenita. Devido apresentarem $\mathrm{Al}^{\mathrm{IV}}>1,00$, foram nominados de alumíniohastingsita(10 amostras) e alumíniohastingsita a alumínio-ferro-edenita(01 amostra). Em relação às amostras da facies BASAFG, todas incidiram em cima da linha limítrofe entre os campos da hastingsita e da ferro-edenita. Apesar da grande semelhança entre os dois grupos de anfibólios estudados, eles se distinguem claramente, nos dois diagramas(Figuras 3.12a, 3.12b). Isso decorre do fato das amostras da facies BASAFG apresentarem, de um modo geral, teores, relativamente, mais elavados de $\mathrm{Si}$, em relação à ampla maioria das amostras da última facies BASMG(exceto em relação à análise 19C5) e, principalmente, devido possuírem conteúdos muito mais baixos de $\mathrm{Mg}$ e teores mais elevados de $\mathrm{Fe}^{2+} \mathrm{e}$, conseqüentemente, apresentarem razões $\mathrm{Mg} /\left(\mathrm{Mg}+\mathrm{Fe}^{2+}\right)$, muito mais baixas do que aquelas da facies BASMG.
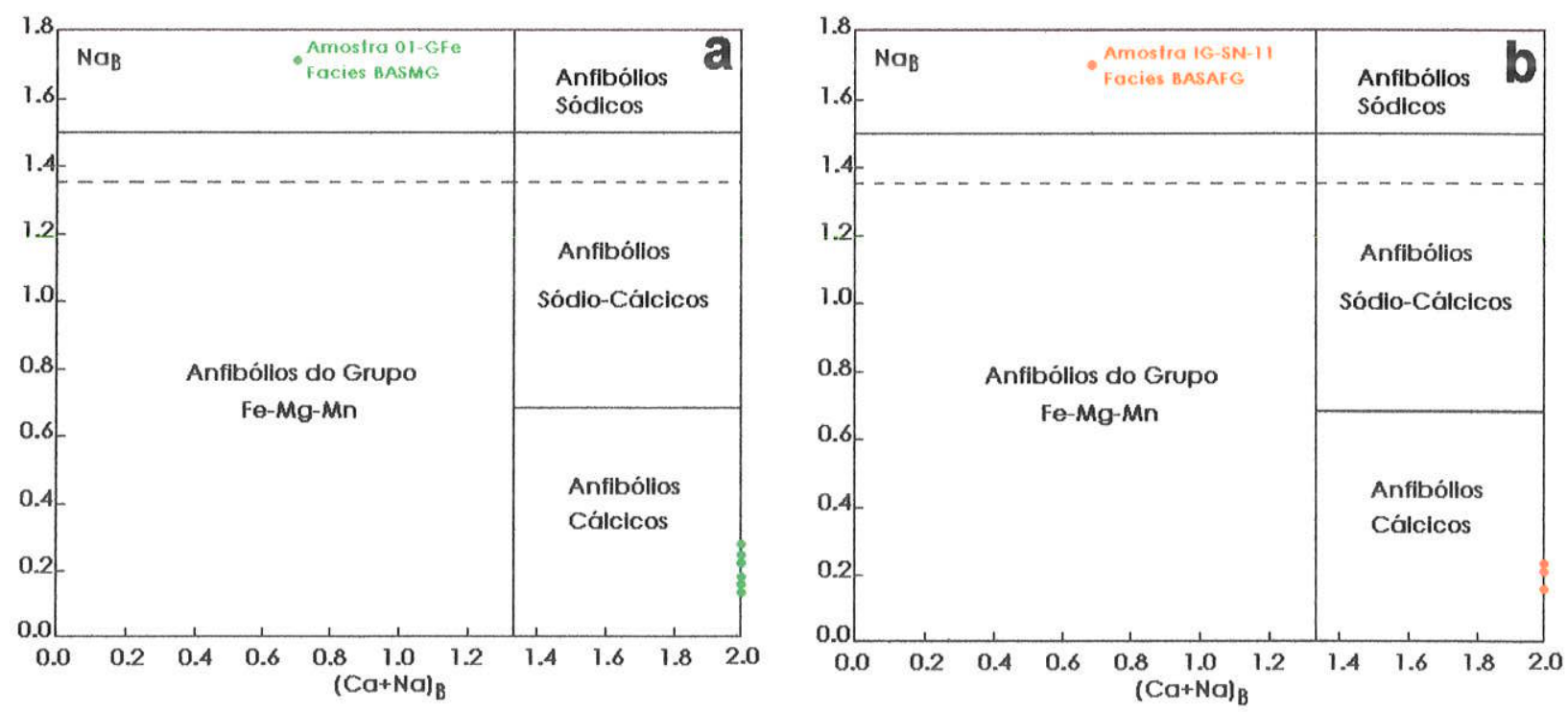

Figura 3.11. Diagrama de classificação dos anfibólios $\mathrm{Na} \times(\mathrm{Ca}+\mathrm{Na})$ mostrando a distribuição composicional dos tipos presentes em granitóides do maciço granitóide Antônio Vicente, com base nas recomendações da IMA e conforme Leake(1978), Hawthorne(1981) e Leake et al.(1997): a) Facies BASMG; b) Facies BASAFG. As linhas tracejadas são os limites apresentados por Leake(1978). 


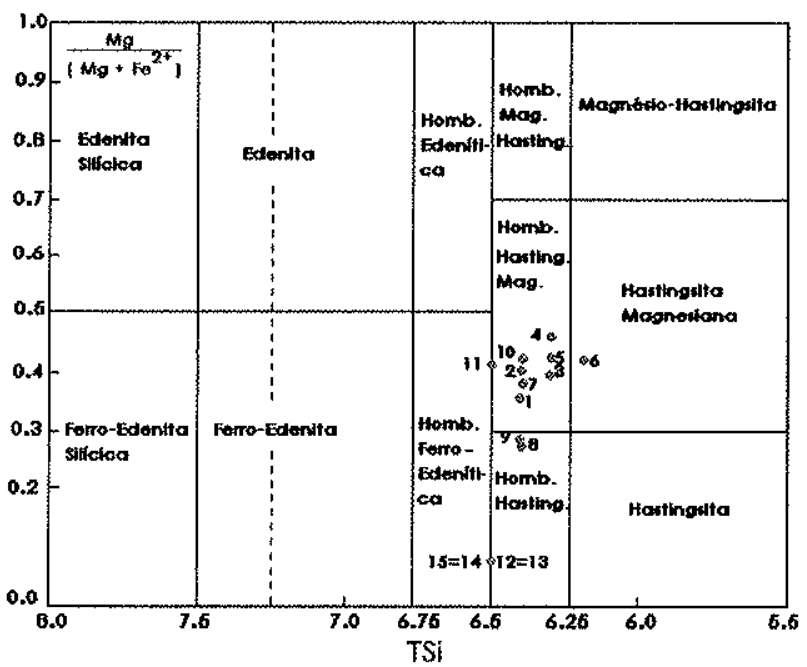

Figura 3.12a. Diagrama de classificação dos anfibólios TSi $X \mathrm{Mg} /\left(\mathrm{Mg}+\mathrm{Fe}^{2+}\right)$ mostrando a distribuição composicional dos tipos presentes em granitóides do maciço granitóide Antônio Vicente, com base nas recomendações da IMA e conforme Leake(1978) e Hawthorne(1981. A linha tracejada representa o limite proposto por Hawthorne(1981). Simbologias de acordo com a Figura $3.11 \mathrm{a}, \mathrm{b}$.

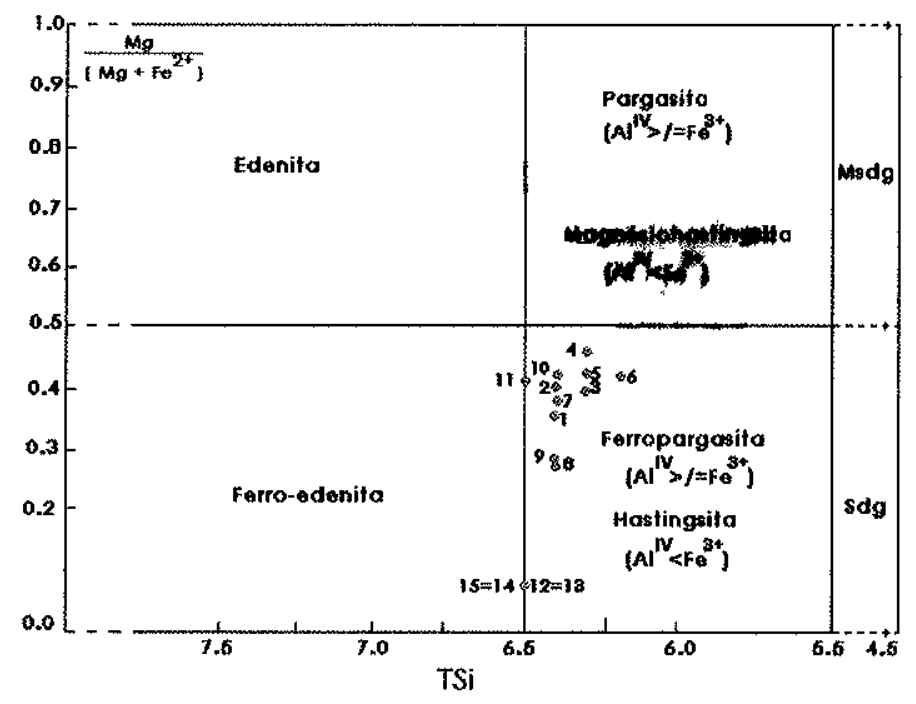

Figura 3.12b. Diagrama de classificação dos anfibólios $\mathrm{Si} \times \mathrm{Mg} /\left(\mathrm{Mg}+\mathrm{Fe}^{2+}\right)$ mostrando a distribuição composicional dos tipos presentes em granitóides do maciço granitóide Antônio Vicente, com base nas recomendações da IMA e conforme Leake et al.(1997). Simbologias de acordo com a Figura $3.11 \mathrm{a}, \mathrm{b}$.

Essa distinção, bastante nítida, entre as composições dos anfibólios das duas facies estudadas, é coerente com as observações petrográficas, visto que a facies BASAFG 
representa uma variação faciológica mais evoluída em relação à facies BASMG, no âmbito do maciço. A variação composicional do anfibólio entre as duas facies está ligada, por sua vez, à mudanças composicionais ocorridas durante a diferenciação magmática desses granitóides.

Além das diferenças composicionais marcantes observadas entre os anfibólios das duas facies granitóides estudadas, observa-se, também, que os grãos analisados apresentam pequenas variações químicas, as quais ocorrem tanto a nível interno de um mesmo cristal(variação intragrãos), quanto entre os grãos individualmente(variação intergrãos). Na Figura 3.13a nota-se uma nítida correlação negativa entre $\left(\mathrm{Fe}^{3+}+\mathrm{Al}^{\mathrm{N}}\right)$ e $\left(\mathrm{Mg}+\mathrm{Si}+\mathrm{Fe}^{2+}\right)$ em relação às amostras das facies BASMG e BASAFG. Os valores de $\left(\mathrm{Fe}^{3+}+\mathrm{Al}^{\mathrm{N}}\right)$ decrescem no sentido do BASMG para o BASAFG, ocorrendo o inverso no que se refere aos valores $\mathrm{de}\left(\mathrm{Mg}+\mathrm{Si}+\mathrm{Fe}^{2+}\right)$.

Czamanske \& Wones(1973) realizaram um estudo detalhado nas fases minerais biotita, anfibólio e piroxênio de unidades monzoníticas, granodioríticas e graníticas de Finnmarka(Noruega). As variações composicionais observadas nos anfibólios presentes nos monzonitos e granodioritos foram consideradas atipicas, tendo sido interpretadas, pelos referidos autores, como sendo reflexo de cristalização sob condições progressivamente oxidantes, onde a média das razões $\mathrm{Fe}^{2+} / \mathrm{Fe}^{2+}+\mathrm{Mg}$ dos anfibólios analisados mudou de 0,58 no monzonito para 0,29 no granodiorito. Nos anfibólios estudados neste trabalho, essa razão aumenta de 0,61 na facies BASMG para 0,91 na facies BASAFG, contrastando com o que foi observado por Czamanske \& Wones(1973). Assim. a variação composicional observada entre os anfibólios das facies BASMG e BASAFG reflete, ao que tudo indica, uma redução nas condições de oxidação, durante a differenciação magmática, no sentido da facies menos evoluída(BASMG) para aquela mais diferenciada e, relativamente, mais silícica(BASAFG). Adicionalmente, aumentam, no mesmo sentido, os conteúdos médios de $\mathrm{TiO}_{2}, \mathrm{Na}_{2} \mathrm{O}$ e de $\mathrm{MnO}$ e decrescem, embora muito levemente, os teores médios de $\mathrm{Al}_{2} \mathrm{O}_{3} \mathrm{e}$ de $\mathrm{K}_{2} \mathrm{O}$.

No que se refere às análises realizadas em cristais individuais de anfibólio da facies BASMG, nota-se, em relação ao grão 1, uma leve correlação negativa entre $\left(\mathrm{Fe}^{3+}+\mathrm{Al}^{\mathrm{IV}}\right)$ e $\left(\mathrm{Mg}+\mathrm{Si}+\mathrm{Fe}^{2+}\right)$ no sentido da análise 3 (centro) para a análise 2(região entre o centro e a borda), que passa para uma correlação positiva no sentido da análise 2 para a análise 1 (borda). A correlação negativa observada entre as análises 3 e 2 deve refletir reações de substituição, as quais podem ser ilustradas pela reação $2 b$ ( substituição Tschermakitica) apresentada por Czamanske \& Wones(1973, pg. 360). O mesmo é válido em relação às análises 4 contra 5 , do grão 2, 9 contra 7 e 8 do grão 3 e 10 contra 11 do grão 4 .

$\mathrm{Na}$ Figura $3.13 \mathrm{~b}$, também é clara a distinção composicional entre o grupo de anfibólios da facies BASMG e aquele $s$ da facies BASAFG, em relação aos parâmetros $\mathrm{Al}^{\mathrm{N}}$ 
versus (NA+K). Observa-se uma correlação negativa entre os mesmos, com o decréscimo dos conteúdos de $\mathrm{Al}^{\mathrm{N}}$ no sentido do BASMG para o BASAFG. Os valores de $(\mathrm{Na}+\mathrm{K})$, embora varie internamente em cada grupo de anfibólios, são mais ou menos equivalentes nos dois conjuntos como um todo, situando-se entre 0,50 e 0,54 .

$\mathrm{Na}$ Figura 3.13c, nota-se uma perfeita correlação negativa entre $\left(\mathrm{Na}+\mathrm{Fe}^{3+}\right)$ e $\left(\mathrm{Ca}+\mathrm{Mg}+\mathrm{Fe}^{2+}\right)$, onde os valores de $\left(\mathrm{Na}+\mathrm{Fe}^{3+}\right)$ decrescem acentuadamente no sentido da facies BASMG para a facies BASAFG, ocorrendo 0 inverso com os valores de $\left(\mathrm{Ca}+\mathrm{Mg}+\mathrm{Fe}^{2+}\right)$. Como os valores de $\mathrm{Na}$ são mais ou menos eqüivalentes nos dois grupos de anfibólios, a diminuição nos valores de $\mathrm{Fe}^{3+}$ e o aumento de $\mathrm{Fe}^{2+}$ no sentido da facies BASMG para a facies BASAFG, pode ser explicada por uma mudança nas condições de oxidação, as quais tornaram-se, ao que tudo indica, mais reduzidas durante a diferenciação magmática desses granitóides, conforme visto anteriormente.

Considerando os gãos individuais de cada facies, observa-se em relação ao BASMG uma correlação negativa entre : 1) a análise 3(centro) contra a 2(entre a borda e o centro) e entre essa última e a 1 (borda), do grão $1 ; 2$ ) a análise 4 (centro) contra a 5 (entre a borda e o centro) e entre a 6 (centro) e a 5 (entre a borda e o centro), do grão $2 ; 3$ ) a análise 9 (centro) contra a 8 (entre a borda e o centro) e entre a 7 (entre a borda e o centro) contra a 8 (entre a borda e o centro)., do grão 3 ; 4) a análise 10(entre a borda e o centro) contra a 11(borda).

Em relação à facies BASAFG, nota-se uma correlação negativa entre a análise 12 (centro) contra a 13(entre a borda e o centro) e entre 12(centro) a 14(borda), do grăo 1.

Essas variações podem ser ilustradas pela substituição tipo 3(Riebeckítica) de Czamanske \& Wones(1973).

Como conclusão, pode-se dizer que nos anfibólios estudados ocorreram, pelo menos, dois tipos de substituições paralelas(emparalhadas), as quais são ilustradas pelas substituições Tschermakítica e Riebeckítica.

No diagrama $\mathrm{Al}^{\mathrm{N}} \times \mathrm{Mg} /\left(\mathrm{Fe}^{3+}+\mathrm{Mg}\right)($ Figura 3.13d) observa-se uma leve correlação positiva, onde tanto $\mathrm{Al}^{\mathrm{N}}$, quanto $\mathrm{Mg} /\left(\mathrm{Fe}^{3+}+\mathrm{Mg}\right)$ diminuem no sentido da facies BASMG para a facies BASAFG, caracterizando dois grupos muito distintos de anfibólios. Este fato confirma as observações apresentadas acima, e mostra que as variações composicionais exibidas pelos dois grupos de anfibólios estão ligadas, em grande parte, à redução nas condições de oxidação durante a evolução magmática dos granitóides em tela, no sentido da facies BASMG para o BASAFG.

$\mathrm{Na}$ análise do diagrama $\mathrm{Fe}^{3+}$ versus $\left(\mathrm{Ti}+\mathrm{Fe}^{2+}\right)$ (Figura 3.13e), nota-se uma clara corrrelação negativa entre $\mathrm{Fe}^{3+}$ e $\left(\mathrm{Ti}+\mathrm{Fe}^{2+}\right)$, onde $\mathrm{Fe}^{3+}$ decresce no sentido da facies BASMG para a facies BASAFG, ocorrendo o inverso com $\left(\mathrm{Ti}+\mathrm{Fe}^{2+}\right.$ ). Isso demonstra uma redução nas condições de oxidação no sentido do BASMG para o BASAFG e confirma as observações anteriores. Além disso, os conteúdos médios de $\mathrm{TiO}_{2}($ Anexo 2$)$ aumentam de 
$1,79 \%$ no BASMG para $1,87 \%$ no BASAFG, evidenciando condições menos oxidantes no mesmo sentido. Esse enriquecimento relativo de $\mathrm{Fe}^{2+}$ e $\mathrm{Ti}$ no sentido da facies mais evoluída(BASAFG) é uma forte indicação da existência de condições menos oxidantes durante a cristalização dos anfibólios dessa facies em relação aos anfibólios da facies BASMG.
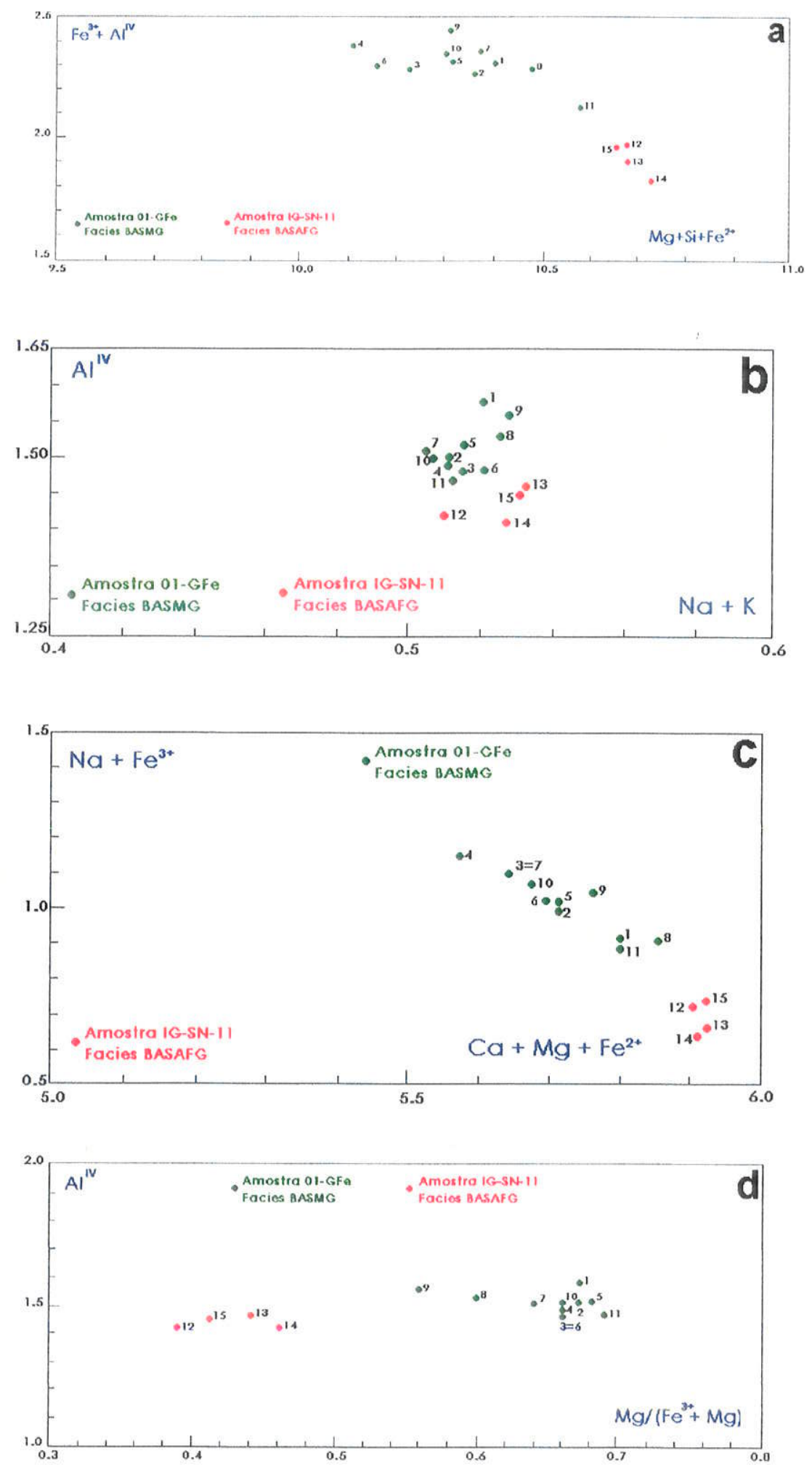


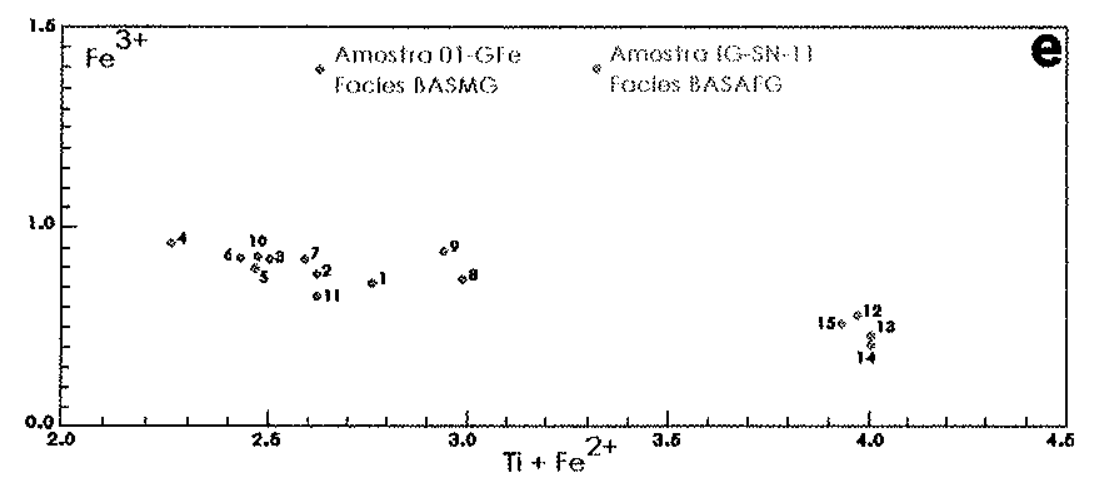

Figura 3.13- Diagramas de correlaçóes entre cátions dos anfibilios das facies BASMG e BASAFG do maciço granitóide Antônio Vicente: a) $\left(\mathrm{Fe}^{3+}+\mathrm{Al}^{\mathrm{IV}}\right) \times\left(\mathrm{Mg}+\mathrm{Si}+\mathrm{Fe}^{2+}\right) ;$ b) $\mathrm{Al}^{\mathrm{IV}} \times$ $(\mathrm{Na}+\mathrm{K}) ; \mathrm{c})\left(\mathrm{Na}+\mathrm{Fe}^{3+}\right) \times\left(\mathrm{Ca}+\mathrm{Mg}+\mathrm{Fe}^{2+}\right) ;$ d) $\left.\mathrm{Al}^{\mathrm{N}} \times\left(\mathrm{Mg}+\mathrm{Si}+\mathrm{Fe}^{2+}\right) ; \mathrm{e}\right) \mathrm{Fe}^{3+} \times\left(\mathrm{Ti}+\mathrm{Fe}^{2+}\right)$.

\subsubsection{2- Análises químicas em Biotita}

Em relação a essa fase mineral, foram realizadas quatro análises pontuais em um único grão da amostra(SL-9B-DT), pertencente à facies BSG. Os Anexos 3 e 3.1 mostram as análises realizadas na biotitas estudada, bem como suas fórmulas estruturais.

\subsubsection{1- Composição química, origem e natureza}

As análises da biotita estudada mostram que o cristal investigado, pelo menos na área analisada, não exibe variações importantes, sendo sua química praticamente constante(Anexos 3 e 3.1). Os valores de XFe são iguais a 0,85 .

Nockolds(1947), realizou um estudo comparativo entre a composição química de biotitas de diversos tipos rochas igneas, em diferentes associações paragenéticas, estabelecendo, estatísticamente, com base nos seus conteúdos de $\mathrm{MgO}$, ferro total(como $\mathrm{FeO}$ ) e $\mathrm{Al}_{2} \mathrm{O}_{3}$, três áreas composicionais, preferenciais, de associações: 1) campo da biotita associada com muscovita, topázio, etc; 2) campo da biotita não acompanhada por outros minerais máficos; 3 ) campo da biotita associada com hornblenda, piroxênio ou olivina.

Em relação as análises da biotita estudada, quando lançadas no diagrama apresentado por Nockolds(1947; Figura 3.14 deste trabalho), observa-se que as mesmas incidem no campo "II", referentes às biotitas não acompanhadas de outros minerais máficos. Isso é coerente com as observações realizadas através de microscopia ótica, uma vez que a facies hospedeira da biotita estudada(facies BSG), é desprovida de outra fase máfica importante, sendo a biotita seu principal máfico primário. No diagrama triangular (FeO+MnO) $-10 \times \mathrm{TiO}_{2}-\mathrm{MgO}$ de Nachit(1994. In: Borges, 1997), Figura 3.15, nota-se que os quatro pontos analisados incidem no campo das biotitas magmáticas(campo "A"). $O$ mesmo 
ocorre em relação ao diagrama $\mathrm{MgO}$ - $\mathrm{FeO}_{\mathrm{T}}-\mathrm{Al}_{2} \mathrm{O}_{3}$ de Gokhale(1968), apresentado na Figura 3.16. Nesse diagrama as quatro análises incidem no campo das biotitas magmáticas.

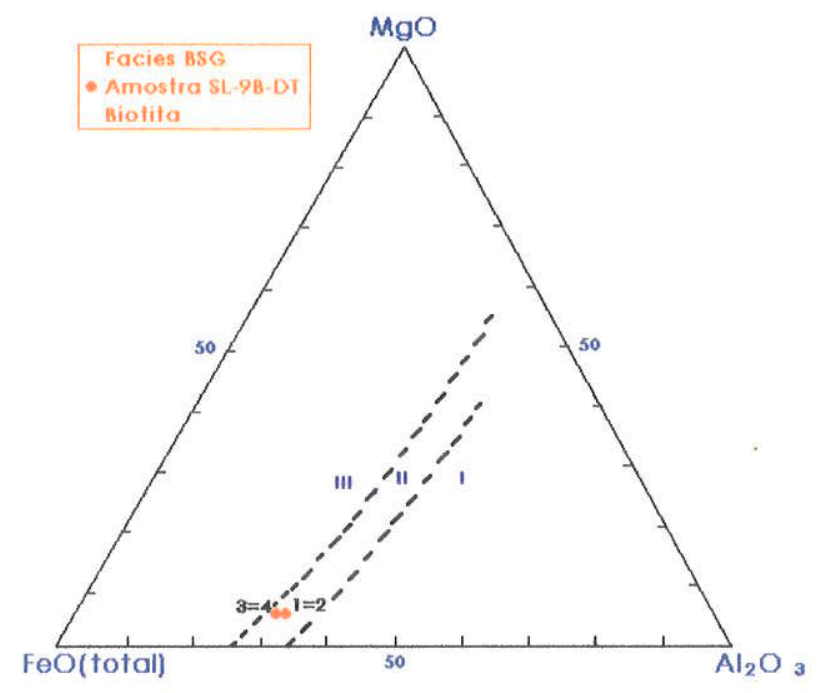

Figura 3.14.- Diagrama triangular $(\mathrm{FeO})-\mathrm{Mg}_{\mathrm{T}} \mathrm{Al}_{2} \mathrm{O}_{3}$ baseado em Nockolds(1947) mostrando as composições de biotitas em diferentes associações minerais. Campos: 1= biotita associada à muscovita+topázio+fluorita+etc.; $2=$ biotita não acompanhada por outras fases máficas; 3 = biotita associada à hornblenda, piroxênio e/ou olivina. As análises constantes no diagrama são da amostra SL-9B-DT da facies BSG do maciço granitóide Antônio Vicente.

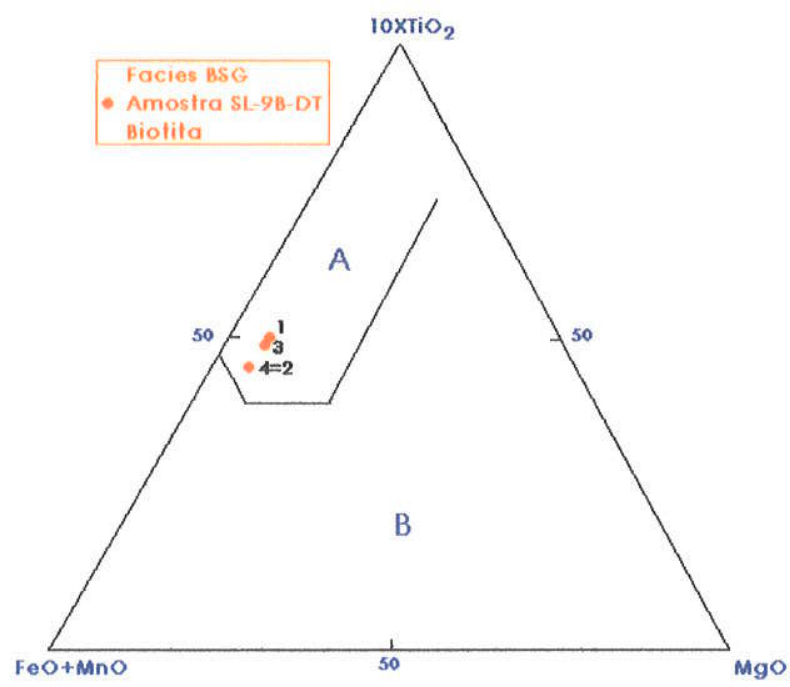

Figura 3.15.- Diagrama triangular $(\mathrm{FeO}+\mathrm{MnO})-\left(10 \times \mathrm{TiO}_{2}\right)-\mathrm{MgO}$ de Nachit(1994. In: Borges, 1997) mostrando a distribuição composicional da biotita da amostra SL-9B-DT, da facies BSG do maciço granitóide Antônio Vicente. $\mathbf{A}=$ campo das micas magmáticas; $\mathbf{B}=$ campo das micas magmáticas reequilibradas. 


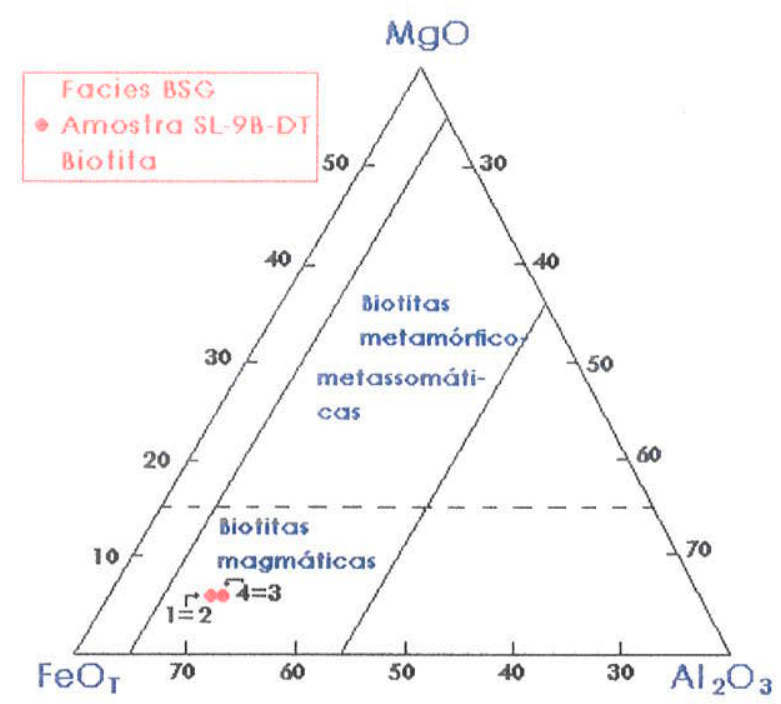

Figura 3.16- Diagrama triangular $\mathrm{FeO}_{\mathrm{T}}-\mathrm{MgO}-\mathrm{Al}_{2} \mathrm{O}_{3}$ mostrando a projeção composicional da biotita da amostra SL-9B-DT, da facies BSG do maciço granitóide Antônio Vicente. As linhas cheias delimitam o campo composicional de biotitas de rochas ígneas conforme(Nockolds, 1947) e a linha tracejada separa biotitas magmáticas de biotitas metamórfico-metassomáticas, conforme Gokhale(1968).

No diagrama $M g-\mathrm{Al}_{\mathrm{T}}$ (Figura 3.17), que expressa a relação entre o quimismo das biotitas e as séries magmáticas de rochas granitóides, apresentado por Nachit et al.(1985), as análises das biotitas estudadas situam-se perfeitamente no campo dos granitóides das séries subalcalinas. Isso é, também, concordante com o quimismo de rocha total da facies BSG(ver mais adiante).

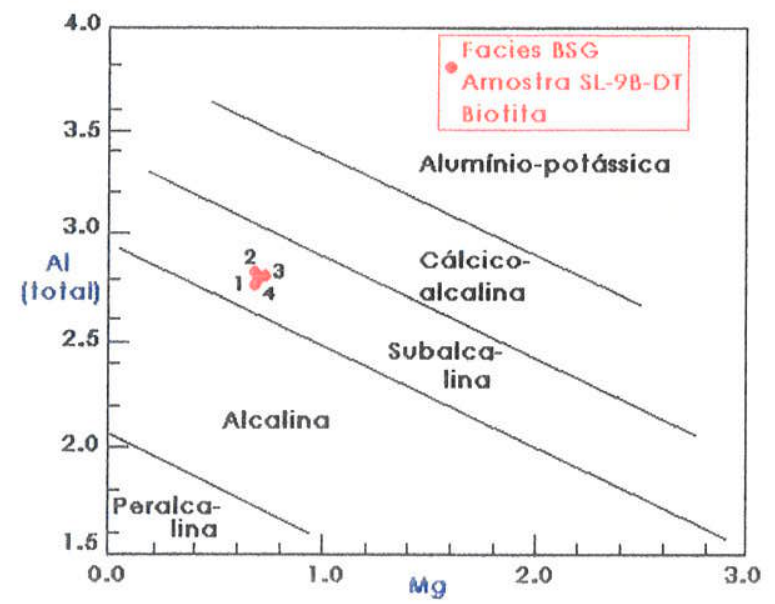

Figura 3.17.- Diagrama Mg - Al(total) de Nachit et al.(1985) mostrando a distribuição composicional da biotita da amostra SL-9B-DT, da facies BSG do maciço granitóide Antônio Vicente. 


\subsection{Classificação e Representação Gráfica}

A classificação mais comum aplicada às micas trioctaédricas é devida à Foster(1960b), que se baseou no sítio de ocupação octaédrica.

Para efeito de classificação da biotita estudada, utilizou-se inicialmente diagrama triangular $\mathrm{R}^{3+}\left(\mathrm{Al}^{3+}, \mathrm{Fe}^{3+}+\mathrm{Ti}^{4+}\right)-\mathrm{Mg}-\mathrm{R}^{2+}\left(\mathrm{Fe}^{2+}+\mathrm{Mn}^{2+}\right)$ de dessa autora, Figura 21 deste trabalho. Nele, observa-se que as composições da biotita analisada caem entre o campo das micas trioctaédricas do tipo siderofilitas e lepidomelanas de pegmatitos e a área de concentração das biotitas ferrosas, embora muito próximo do primeiro.

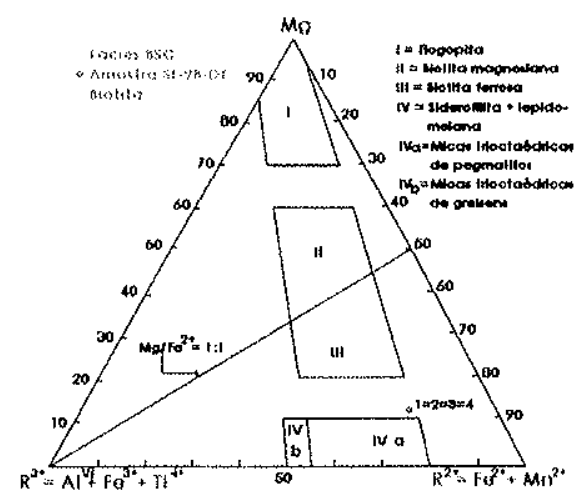

Figura 3.18.- Diagrama triangular $\mathrm{R}^{3+}-\mathrm{Mg}-\mathrm{R}^{2+}$ de Foster(1960)), mostrando a relação entre (Al" $\left.\mathrm{Fe}^{3+}, \mathrm{Ti}\right), \mathrm{Mg}$ e $\mathrm{Fe}^{2+}\left(\mathrm{Mn}^{2+}\right)$ em micas trioctaédricas e a posição ocupada no diagrama por análises de biotita da amostra SL-9B-DT, da facies BSG do maciço granitóide Antônio Vicente.

Em seguida, utilizou-se o diagrama $\mathrm{Al}^{\mathrm{V} l}$ versus $\mathrm{Mg} /\left(\mathrm{Mg}+\mathrm{Fe}^{2+}\right)$ de Guidotti(1984), Figura 22 deste trabalho. Nesse nota-se que as composições da biotita incidem na região composicional das annitas(entre annita e annita aluminosa), tendendo a uma composição mais annítica aluminosa.

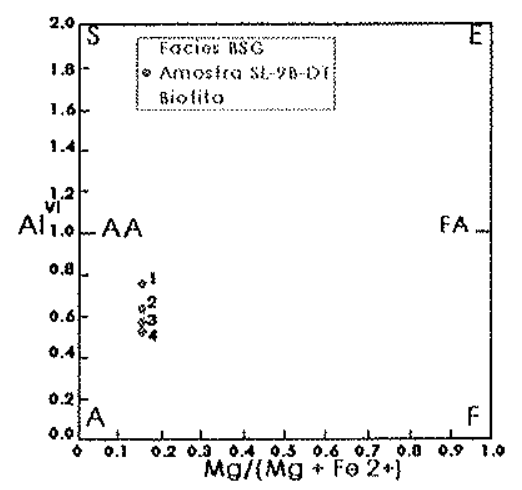

Figura 3.19.- Diagrama $\mathrm{Al}^{\mathrm{l}}$ versus $\mathrm{Mg} /\left(\mathrm{Mg}+\mathrm{Fe}^{2+}\right)$ de Guidotti(1984) mostrando a distribuiçåo composicional da biotita da amostra SL-9B-DT, da facies BSG do maciço granitóide Antônio Vicente. $A=$ annita; $F=$ flogopita; $F A=$ flogopita aluminosa; $A A=$ annita aluminosa; $S=$ siderofilita; $E=$ $\mathrm{K}_{2}\left(\mathrm{Mg}_{4} \mathrm{Al}_{2}\right)\left(\mathrm{Al}_{4} \mathrm{Si}_{4} \mathrm{O}_{20}\right)(\mathrm{OH})_{4}$. 
Finalmente, utilizou-se o diagrama $\left(\mathrm{Fe}_{\mathrm{T}}+\mathrm{Mn}+\mathrm{Ti}-\mathrm{Al}^{\mathrm{V}}\right)$ versus $\mathrm{Mg}-\mathrm{Li}$ apresentado por Tischendorf et al.(1997). De acordo com esses autores, o Li é um componente essencial nas micas de rochas granitóides diferenciadas, pegmatitos e aplitos e a falta de determinação dos conteúdos desse elemento nessas rochas gera a perda de importantes informações petrogenéticas, bem como leva a erros sistemáticos nos cálculos das fórmulas estruturais das micas trioctédricas e dioctaédricas formadas nesses ambientes.

Como a mica estudada pertence a esse tipo de ambiente, calculou-se os canteúdos de Li a partir da equação sugerida por Tindle \& Webb(1990), modificada ligeiramente e recomendada por Tischendorf et al.(1997). De posse dos resultados, utilizou-se o diagrama acima referido(Figura 3.20). Nele, observa-se que três análises da biotita estudada "plotam" inteiramente no campo composicional da lepidomelana e uma no campo da siderofilita, com todas as análises situando-se no quadrante das Mg-Fe micas( quadrante " I" )

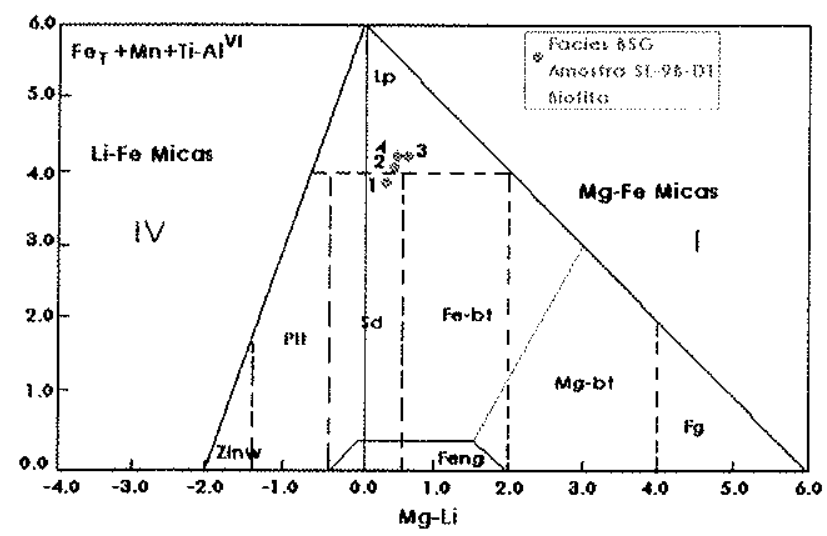

Figura 3.20.- Projeção da composição da biotita da amostra SL-9B-DT, da facies BSG do maciço granitóide Antônio Vicente, no diagrama (Mg-Li) versus $\left(\mathrm{Fe}_{\mathrm{T}}+\mathrm{Mn}+\mathrm{Ti}-\mathrm{Al}{ }^{\mathrm{VI}}\right.$ ) de Tischendorf et al.(1997). Lp=lepidomelana; Febt=ferro-biotita; Mgbt=magnésio biotita; Sd=siderofilita; Fg=flogopita; PIt=protolitionita.

\subsubsection{3- Condições de Cristalização}

Com base no quimismo da biotita e no trabalhos experimentais desenvolvidos por Wones \& Eugster(1965), Rutherford(1973) e Hewitt \& Wones(1975), pode-se determinar alguns parâmetros que atuam e influenciam as condições físico-químicas de cristalização dessa mica, tais como o $\log \mathrm{fO}_{2}$ e a temperatura de cristalização aproximada da mesma.

Em relação à biotita estudada, a aplicação do seu quimismo ao trabalho experimental apresentado por Wones \& Eugster(1965), deve ser encarada com reserva, visto que as análises realizadas não dosaram, diretamente na microssonda eletrônica, os conteúdos de $\mathrm{Fe}^{2+}$ e $\mathrm{Fe}^{3+}$ (conforme visto anteriormente). Em vista disso, os cálculos da temperatura de cristalização, da biotita aqui estudada, bem como aqueles do $\log$ da $\mathrm{fO}_{2}$, estimados com 
base no estudo experimental de Wones \& Eugster(1965), devem ser vistos apenas como estimativas de referência.

Os minerais opacos foram caracterizados, em parte, através análises semiquantitativas(EDS) por microscopia eletrônica de varredura, em amostras das variedades mais alteradas(BSGA e BSGIA) da facies BSG. O óxido analisado foi principalmente ilmenita(dominante). Tal paragênese difere daquela definida e utilizada no trabalho experimental desenvolvido por Wones \& Eugster(1965), uma vez que esses autores utilizaram apenas magnetita na pargênese com a biotita.

No diagrama $\mathrm{Fe}^{2+}-\mathrm{Fe}^{3+}-\mathrm{Mg}$ (Wones \& Eugster, 1965; Figura 3.21 deste trabalho) nota-se que a composição da biotita estudada situa-se abaixo da curva "buffer" (tampão) $\mathrm{Fe}_{2} \mathrm{SiO}_{4}-\mathrm{SiO}_{2}-\mathrm{Fe}_{3} \mathrm{O}_{4}$ (faialita-quartzo-magnetita). Isso evidencia que a biotita em questão cristalizou em baixas condiçōes de fugacidade de oxigênio. Esses dados quando transportados para o diagrama $T\left({ }^{\circ} \mathrm{C}\right)$ versus $\log \mathrm{fO}_{2}$ a $2 \mathrm{~Kb}$, de Wones \& Eugster(1965), Figura 3.22 deste trabalho, indicam condiçōes de cristalização em ambiente com $\log \mathrm{fO}_{2}$ muito baixo, de aproximadamente $-18,5$ e temperatura variando entre $808,3^{\circ} \mathrm{C}$ e $825^{\circ} \mathrm{C}$.

Os os valores obtidos para o $\log \mathrm{fO}_{2}$ são compativeis com o esperado, sendo coerente com as observações apresentadas acima, visto que a biotita estudada mostra-se enriquecida em $\mathrm{Fe}^{2+}$ em detrimento ao $\mathrm{Fe}^{3+}$, cujos teores variam entre 0,0427 e 0,261 (Anexo 3). Além disso, de acordo com Middelaar \& Keith(1990), as altas razões $\mathrm{Fe}^{2+} / \mathrm{Fe}^{3+}$ e a ausência de magnetita e titanita em granitos do Sistema Can Tung, indicaram condições redutoras nos fluidos magmáticos e hidrotermais do referido sistema. Considerando essas observações e extrapolando-as para a biotita, aqui estudada, nota-se que há uma concordância com esses autores, visto que a biotita em questão possui elevadas razões $\mathrm{Fe}^{2+} / \mathrm{Fe}^{3+}$. Esse fato permite, então concluir que a mesma cristalizou em condições magmáticas redutoras.

Em relação à temperatura, o valor parece um pouco elevado, considerando que a biotita estudada cristalizou tardiamente em relação aos minerais essenciais plagioclásio, quartzo e feldspato potássico, embora essa temperatura esteja dentro dos limites de estabilidade de uma biotita magmática(Brown \& Fyfe, 1970).

Objetivando melhorar esses resultados calculou-se os conteúdos de FeO(óxido de ferro ferroso) através da equação de Bruiyn et al.(1983; In: Salonsaari, 1995, pg. 94). A partir dos conteúdos de FeO, calculados, e dos teores de $\mathrm{FeO}$ (total), obtidos através da microssonda eletrónica, pode-se calcular também os teores de $\mathrm{Fe}_{2} \mathrm{O}_{3}$. De posse desses resultados, foram recalculadas as fómulas estruturais correspondentes a cada análise(Anexo 3.1). Assim, foram recalculadas as proporções $\mathrm{Fe}^{2+}+\mathrm{Fe}^{3+}+\mathrm{Mg}=100 \%$. Os resultados obtidos foram lançados nos diagramas de Wones \& Eugster(1965), Figuras 3.21 e 3.22, deste trabalho. 
$\mathrm{Na}$ Figura 3.21, as análises plotaram entre as curvas tampão $\mathrm{Ni}-\mathrm{NiO}$ e $\mathrm{Fe}_{3} \mathrm{O}_{4}-\mathrm{Fe}_{2} \mathrm{O}_{3}$, embora muito próximas da primeira, indicando reduzidas condições de fugacidade de oxigênio. Na Figura 3.22 observa-se que o $\log \mathrm{fO}_{2}$ situa-se em torno de $-16,80$ e a temperatura de cristalização da biotita entre $695,8^{\circ} \mathrm{C}$ e $710,4^{\circ} \mathrm{C}$. Esses resultados são mais realistas e estão mais de acordo com as observações petrográficas, em relação as estimativas apresentadas anteriormente.

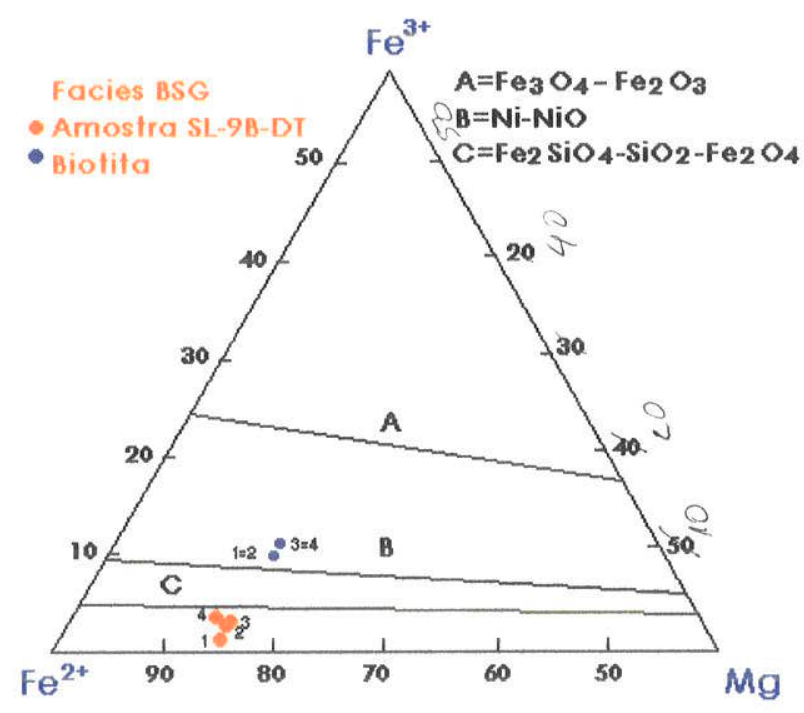

Figura 3.21- Representação composicional da biotita da facies BSG do maciço granitóide Antônio Vicente no diagrama triangular $\mathrm{Fe}^{2+}-\mathrm{Fe}^{3+}-\mathrm{Mg}$ de Wones \& Eugster(1965). Círculos vermelhos correspondem as análises onde os conteúdos de $\mathrm{FeO}$ foram calculados por via úmida; círculos azuis representam as análises onde os conteúdos de $\mathrm{FeO}$ estimados a partir da equação de Bruiyn et al.(1983; In: Solansaari(1995).

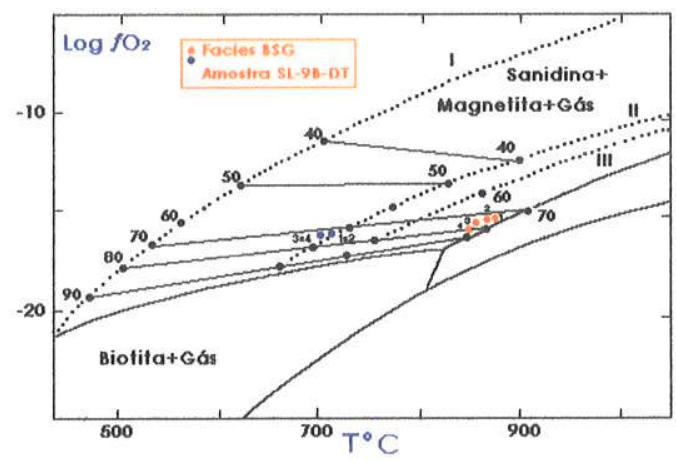

Figura 3.22- Representação composicional da biotita da facies BSG do maciço granitóide Antônio Vicente no diagrama $\mathrm{T}$ - $\log f \mathrm{O}_{2}$ para pressão total de $2 \mathrm{~Kb}$ segundo Wones \& Eugster(1965). I = curva tampão $\mathrm{Fe}_{3} \mathrm{O}_{4}-\mathrm{Fe}_{2} \mathrm{O}_{3} ; \boldsymbol{I I}=$ curva tampão $\mathrm{Ni}-\mathrm{NiO}$; III = curva tampão $\mathrm{Fe}_{2} \mathrm{SiO}_{4}-\mathrm{SiO}_{2}-\mathrm{Fe}_{3} \mathrm{O}_{4}$. Os números pequenos do interior do diagrama representam as relações $\mathrm{Fe}^{2+}-\mathrm{Fe}^{3+}-\mathrm{Mg}$ da Figura 24 . Simbologias de acordo com a Figura 3.21. 


\subsubsection{3 - Análises químicas em Clorita}

As cloritas constituem um grupo de minerais com estrutura em camadas, que sob vários aspectos, se assemelham às micas e cujas principais ocorrências correspondem a produtos de alteração hidrotermal de rochas eruptivas, em xistos cloríticos e em sedimentos argilosos juntamente com minerais argilosos(Deer et al., 1966). Nos granitóides estudados elas mostram-se relacionadas ao estágio de alterações tardi a pós-magmáticas e ocorrem associadas tanto à alteração do plagioclásio primário(designada como clorita1), quanto à biotita(designada como clorita2). Os grãos analisados correspondem à clorita $2\left(\mathrm{Cl}_{2}\right)$ e dizem respeito às facies granitóides BASMG, BASAFG e BSG.

Neste contexto, foram realizadas um total de 13 análises pontuais assim discrimminadas: 03 análises em dois grãos de clorita da facies BASMG(amostra 01-Gfe), 07 análises em três grãos da facies BASAFG(amostra IG-SN-11) e 03 análises em u.m grão da facies BSG(amostra SL-9B-DT).

Adicionalmente, foram realizadas, ainda, quatro análises pontuais em um grão de clorita da amostra NN-AV-IN-10 de clorita-siderofilita-muscovita-quartzo greisen. Os resultados analíticos obtidos, bem como as fórmulas estruturais encontram-se no Anexo 4

\subsubsection{1- Composição química}

As cloritas analisadas nesse trabalho mostram, em relação às facies granitóides e greisen estudados, uma nítida variação composicional. Os teores médios de Si são mais elevados na facies BASAFG $(2,50-2,97 \%)$, decrescendo no sentido das facies BASMG $(2,44$ $-2,51 \%)$ e BSG $(2,23-2,27 \%)$ e do greisen(1,96 - 2,38), sendo porém mais baixos neste último. FeO(total) e MnO aumentam no sentido da facies BASMG para BSG, O FeOT decresce no sentido dessa última para o greisen, enquanto que o MnO aumenta. Os conteúdos de $\mathrm{CaO}$ e $\mathrm{TiO}_{2}$ decrescem no sentido do BASMG para o BSG e deste para o greisen. Os conteúdos de $\mathrm{Al}_{2} \mathrm{O}_{3}$ e de $\mathrm{MgO}$ săo mais elevado nas facies $\mathrm{BASMG}$, decrescem nas amostras da facies BASAFG e voltam crescer no sentido da facies BSG. No greisen o $\mathrm{Al}_{2} \mathrm{O}_{3}$ assume os mais elevados valores, enquanto que o $\mathrm{MgO}$ torna-se inexpressivo. $\mathrm{F} \mathrm{e} \mathrm{Cl}$ estão quase sempre presentes na grande maioria das amostras, com o $F$ assumindo os mais altos valores na clorita da facies BASMG $(0,07-0,35 \%)$ e os mais baixos nas cloritas da facies BSG $(0,00-0,11 \%)$ e do greisen $(0,00-0,01)$, ocorrendo o mesmo com o $\mathrm{Cl}$.

\subsubsection{2- Substituições}

Cathelineau(1988) utilizou um modelo matemático algébrico para calcular a contribuição de cada um dos membros finais teóricos de soluções sólidas de minerais de argila, cristalizados em condições desconhecidas. As substituições apresentadas por esse autor foram dadas sob uma forma similar àquelas propostas por autores como Bragg(1937), 
Bragg \& Claringbull(1965) Thompson \& Tompson(1976 e Tompson et al.(1982), todos citados em Cathelineau(1988). Segundo Cathelineau(1988), de acordo com tais autores, uma solução sólida pode ser escrita por uma composição de referência e por vetores de substituição. Esses vetores expressam relaçōes algébricas que descrevem a adição ou a subtração de um membro final para um mineral de referência. Estas relações algébricas são dependentes da massa e do balanço de carga no mineral. Como exemplo dessas relações algébricas, Cathelineau(1988) apresentou:

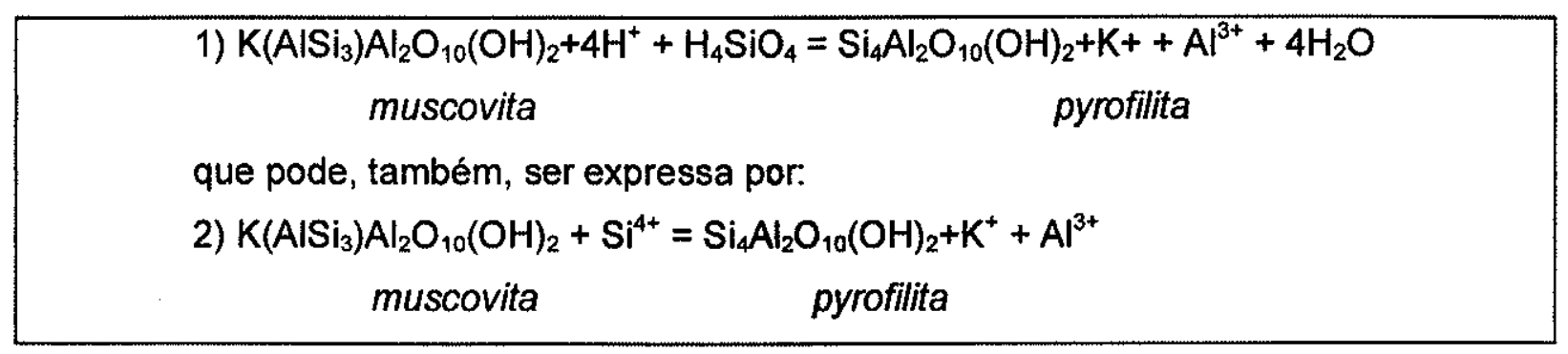

No espaço vetorial, muscovita e pyrofilita são representados por dois pontos com as seguintes coordenadas:

\begin{tabular}{|l|c|c|}
\hline & $\mathrm{Mu}$ & $\mathrm{Pyr}$ \\
\hline $\mathrm{K}$ & 1 & 0 \\
\hline $\mathrm{Ca}$ & 0 & 0 \\
\hline $\mathrm{Na}$ & 0 & 0 \\
\hline $\mathrm{Si}(\mathrm{IV})$ & 3 & 4 \\
\hline $\mathrm{Al}(\mathrm{IV})$ & 1 & 0 \\
\hline $\mathrm{Al}(\mathrm{VI})$ & 2 & 2 \\
\hline $\mathrm{R}^{2+}$ & 0 & 0 \\
\hline
\end{tabular}

As principais correlações entre as variáveis químicas em cloritas e illitas expressas por vetores de substituição fornecidos por Cathelineau(1988) são:

\begin{tabular}{|c|c|}
\hline Illitas & Cloritas \\
\hline $\begin{array}{l}\text { Origem: mineral de referência } \\
\text { Muscovita }\end{array}$ & Talco - 3 brucita \\
\hline $\begin{array}{l}\text { Vetores de Substituição } \\
\mathrm{I}_{-1}\left(\mathrm{Si}_{+1} \mathrm{Al}_{-1}\right)_{\mathrm{IV}} \\
\mathrm{K}_{-1} \mathrm{Na}_{+1} \\
\mathrm{~K}_{-1} \mathrm{Ca}_{+1 / 2} \\
\left(\mathrm{Si}_{+1} \mathrm{Al}_{-1}\right)_{\mathrm{IV}}\left(\mathrm{Al}_{-1} \mathrm{R}_{+1}^{2+}\right)_{\mathrm{V}} \\
\mathrm{FeMg}_{-1}\end{array}$ & 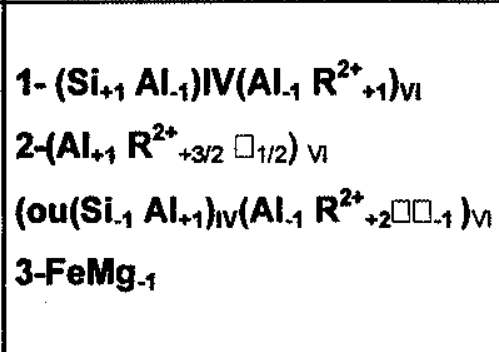 \\
\hline
\end{tabular}


$\mathrm{Na}$ análise do diagrama $\mathrm{Al}^{\mathrm{IV}}$ vs. $\mathrm{Al}^{\mathrm{VI}}$, Figura 3.23(a,b) deste trabalho, observa-se que o $\mathrm{Al}^{\mathrm{IV}}$ varia amplamente, tanto de forma global(de 1,023 na clorita da facies BASAFG a 1,770 na da facies BSG até 2,03 no greisen), quanto internamente em cada facies(na facies BASMG de 1,422 a 1,557; na facies BASAFG entre 1,023 e 1,491; na facies BSG de 1,724 a 1,770; e no greisen entre 1,61 e 2,03). Do mesmo modo que o $\mathrm{Al}^{\mathrm{lv}}$, 。 $\mathrm{Al}^{\mathrm{VI}}$ varia, para o conjunto das análises, de 0,0 na facies BASMG até 0,849 no greisen, bem como mostra variações dentro dos grupos de análises de cada facies(facies BASMG de 0,0 a 0,036; facies BASAFG entre 0,163 e 0,242; facies BSG de 0,077 a 0,137; e de 0,323 a 0,849 no greisen). Em relação a todas as análises, é configurada uma correlação negativa entre $\mathrm{Al}^{\mathrm{IV}} \mathrm{e}$ $\mathrm{Al}^{\mathrm{VI}}$. Internamente a cada facies, essa correlação negativa mantem-se em relação à facies BASAFG e greisen, mas torna-se positiva no âmbito das facies BASMG e BSG.
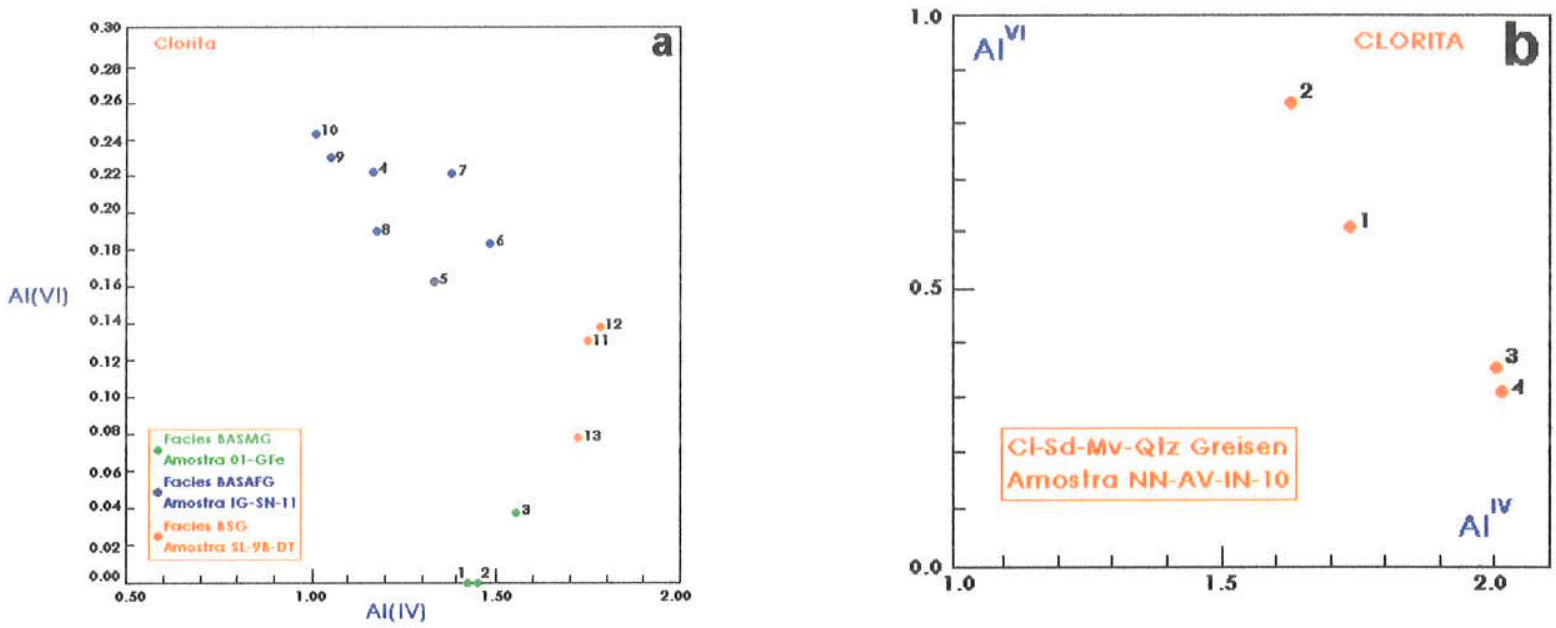

Figura 3.23.- Diagrama $\mathrm{Al}^{\mathrm{V}}$ versus $\mathrm{Al}^{\mathrm{l}}$ mostrando a distribuição composicional das cloritas estudadas. a) facies BASMG, BASAFG e BSG. b) Clorita-siderofilita-muscovita-quartzo greisen. Maciço granitóide Antônio Vicente.

No diagrama $\mathrm{Al}^{\mathrm{IV}}$ vs. a razão $\mathrm{Fe} /(\mathrm{Fe}+\mathrm{Mg})$, Figura 3.24(a,b), nota-se, para o conjunto das análises, que o aumento de $\mathrm{Al}^{\mathrm{IV}}$ é acompanhado por uma diminuição na razão $\mathrm{Fe} / \mathrm{Fe}+\mathrm{Mg}$. Em outras palavras, $\mathrm{Al}^{\mathrm{IV}}$ e a razão $\mathrm{Fe} /(\mathrm{Fe}+\mathrm{Mg})$ desenvolvem uma correlação levemente negativa. Essa característica química é contrastante com as observações de diversos autores tais como Hey(1954), Foster(1962), Cathelineau \& Nieva(1985), Kranidiotis \& MacLean(1987), Cathelineau(1987) e Zang \& Fyfe(1995). Por outro lado, se assemelha muito com as observações a esse respeito apresentadas por Borges(1997). Em relação as análises por grupos de amostras de cada facies granitóides, observa-se que as quantidades de $\mathrm{Al}^{\mathrm{IV}}$ diminuem no sentido da clorita da facies BASMG para a da facies BASAFG, ocorrendo o inverso com a razão $\mathrm{Fe} /(\mathrm{Fe}+\mathrm{Mg})$. 

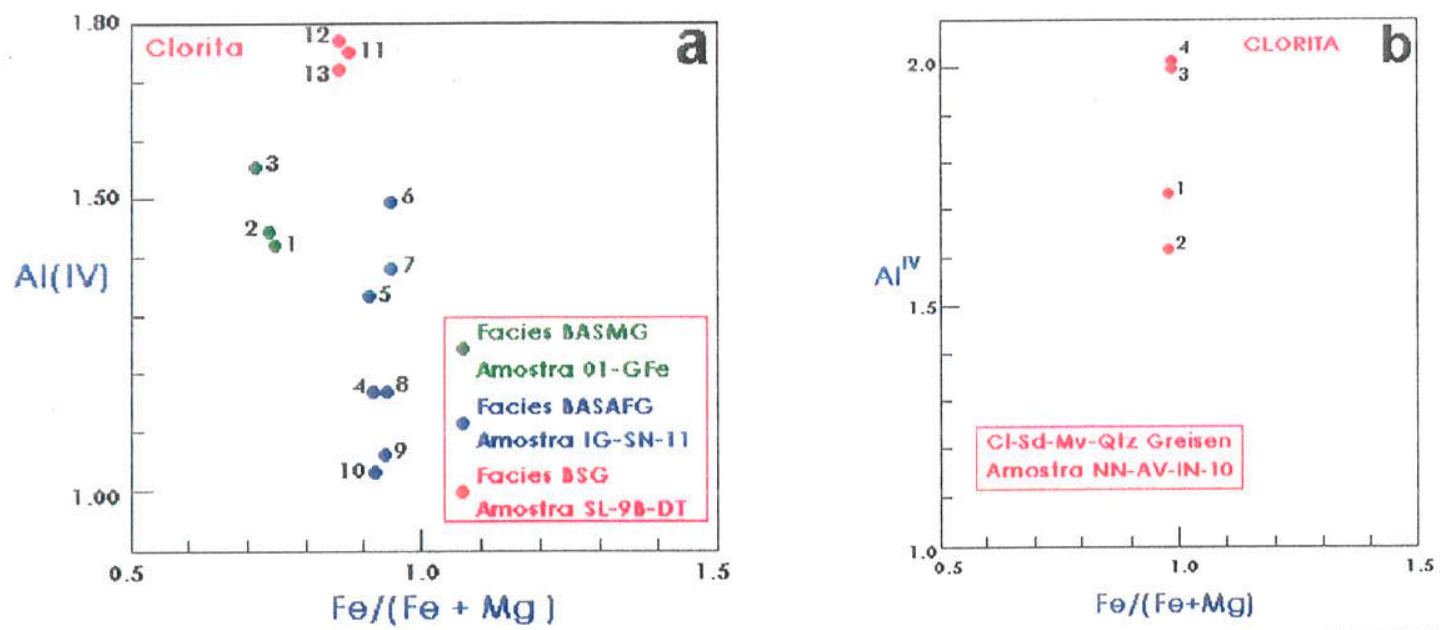

Figura 3.24.- Diagrama $\mathrm{Al}^{\mathrm{IV}}$ versus a razão $\mathrm{Fe} /(\mathrm{Fe}+\mathrm{Mg})$ mostrando a distribuição composicional das cloritas pertencentes às facies granitóides BASMG, BASAFG e BSG(a) e do clorita-siderofilitamuscovita-quartzo greisen(b). Maciço granitóide Antônio Vicente.

Na Figura 3.25(a,b) existe uma correlação levemente positiva entre $\mathrm{Al}^{\mathrm{V} /}$ e a razão $\mathrm{Fe} /(\mathrm{Fe}+\mathrm{Mg})$, quando considerado o conjunto de todas as análises.

Quando as variações composicionais das cloritas estudadas são analisadas em separado, por conjuntos individuais de análises, observa-se, na Figura 3.24(a, b), que na clorita da facies BASMG há uma leve correlação negativa entre $\mathrm{Al}^{\mathrm{IV}}$ e a razão $\mathrm{Fe} /(\mathrm{Fe}+\mathrm{Mg})$. No contexto das facies BASAFG, BSG e no greisen, esta correlação torna-se ligeiramente positiva. Embora os valores de $\mathrm{Al}^{\mathrm{IV}}$ variem claramente em todos os grupos, individualmente, as razões $\mathrm{Fe} /(\mathrm{Fe}+\mathrm{Mg})$ são muito pouco variáveis, sendo mais ou menos constante em cada grupo.
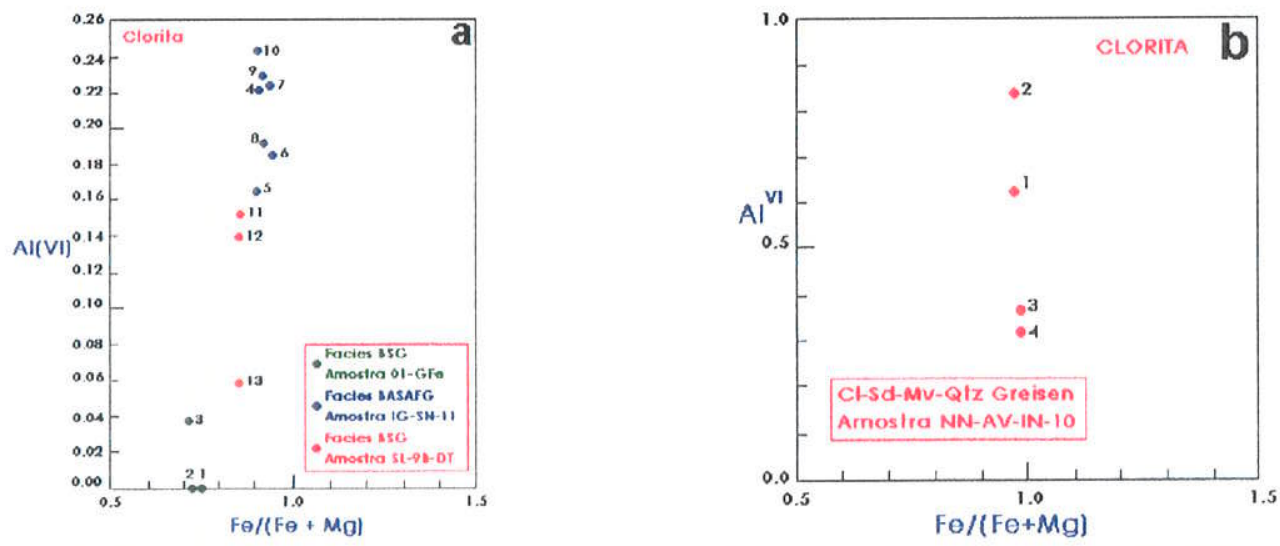

Figura 3.25 - Diagramas $\mathrm{Al}^{\mathrm{V}}$ vs. $\mathrm{Fe} /(\mathrm{Fe}+\mathrm{Mg})$ mostrando a distribuição composicional das cloritas pertencentes às facies granitóides BASMG, BASAFG e BSG(a) e do clorita-siderofilita-muscovitaquartzo greisen(b). Maciço granitóide Antônio Vicente. 
No primeiro caso, a correlação negativa entre $\mathrm{Al} \mathrm{I}^{\mathrm{IV}}$ e a razão $\mathrm{Fe} /(\mathrm{Fe}+\mathrm{Mg})$, na clorita da facies BASMG, é devida, principalmente, ao aumento de $\mathrm{Fe}^{2+}$ e de $\mathrm{Mg}^{2+}$ no sítio octaédrico, considerando o sentido da análise de número 1 para a de número 3 , com as razões $\mathrm{Fe} /(\mathrm{Fe}+\mathrm{Mg}$ ) variando de 0,746 a 0,715, no mesmo sentido(Anexo 4). Nesse mesmo sentido, o $\mathrm{Al}^{\mathrm{IV}}$ aumenta de 1,422 na análise 1 para 1,557 na análise 3 .

No segundo caso, o $\mathrm{Al}^{\mathrm{lV}}$ da clorita das facies BASAFG, BSG e do greisen, é pobremente correlacionado com a razão $\mathrm{Fe} /(\mathrm{Fe}+\mathrm{Mg})$.

Na Figura 3.25(a, b) nota-se que a variação composicional da clorita, por cada facies em separado, fica por conta, quase que exclusivamente, das quantidades de $\mathrm{Al}^{\mathrm{V} !}$, visto que as razões $\mathrm{Fe} /(\mathrm{Fe}+\mathrm{Mg})$ variam muito pouco. Isso evidencia que as substituições ocorridas nos sítios octaédricos $\left(\mathrm{R}^{2+}\right.$ por $\left.1 \mathrm{~A} \mathrm{l}^{3+}\right)$, da clorita das facies granitóides estudadas e do greisen, foram contrabalanceadas pelas substituições de $\mathrm{Si}^{4+}$ por $\mathrm{Al}^{3+}$ nos sítios tetraédricos. Isso é coerente com o que foi observado em relação ao segundo caso referente à Figura 3.24 .

$\mathrm{A}$ análise da Figura 3.26(a, b) revela uma correlação negativa entre o $\mathrm{Al}^{\mathrm{V}}$ e os cátions bivalentes $\left(\mathrm{Fe}^{2+}+\mathrm{Mg}^{2+}\right)$, quando considerado o conjunto de todas as análises. Essa correlação se mantem quando se trata da clorita pertencente às facies BASAFG, BSG e do greisen. No caso da clorita da facies BASMG, existe uma correlação positiva. O mesmo é observado no diagrama $\mathrm{Al}^{\mathrm{VI}}$ vs. $\mathrm{Fe}^{2+}$, Figura $3.27 \mathrm{a}, \mathrm{b}$ ) deste trabalho.
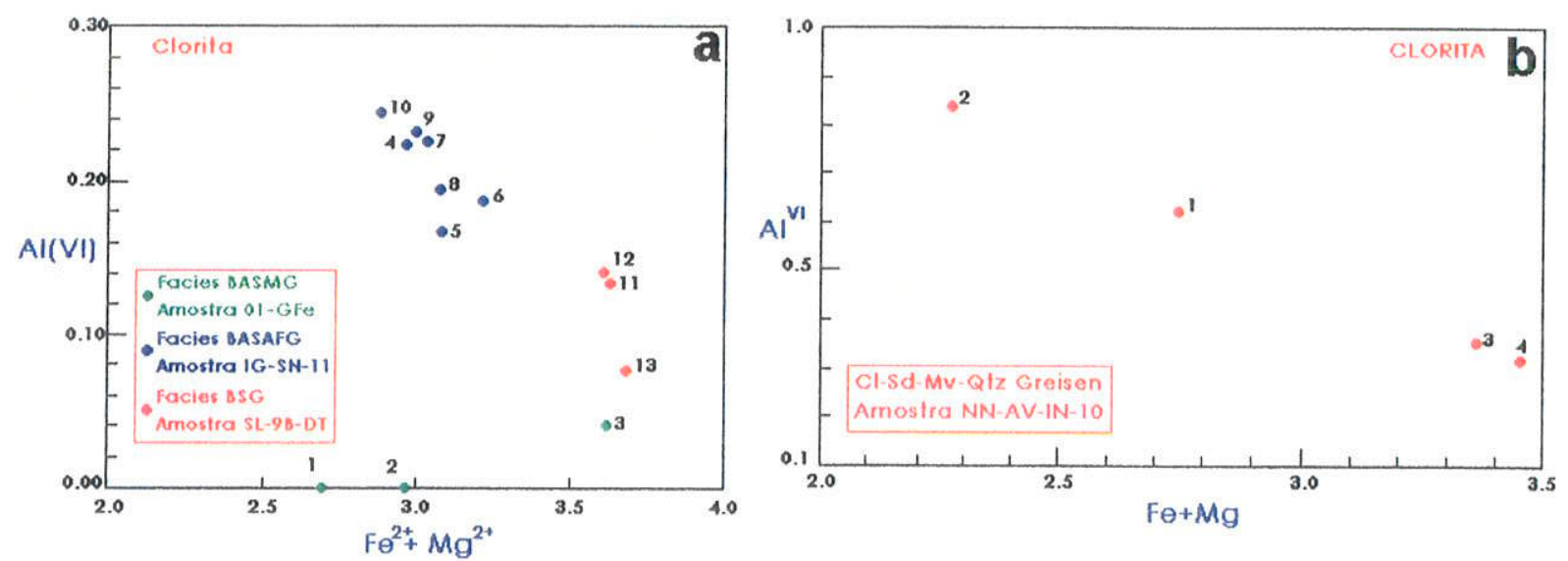

Figura 3.26.- Diagrama $\mathrm{Al}^{\mathrm{V}}$ versus os cátions bivalentes $\left(\mathrm{Fe}^{2+}+\mathrm{Mg}^{2+}\right)$ mostrando a distribuição composicional das cloritas estudadas. a) facies granitóides BASMG, BASAFG e BSG. b) cloritasiderofilita-muscovita-quartzo greisen. Maciço granitóide Antônio Vicente. 

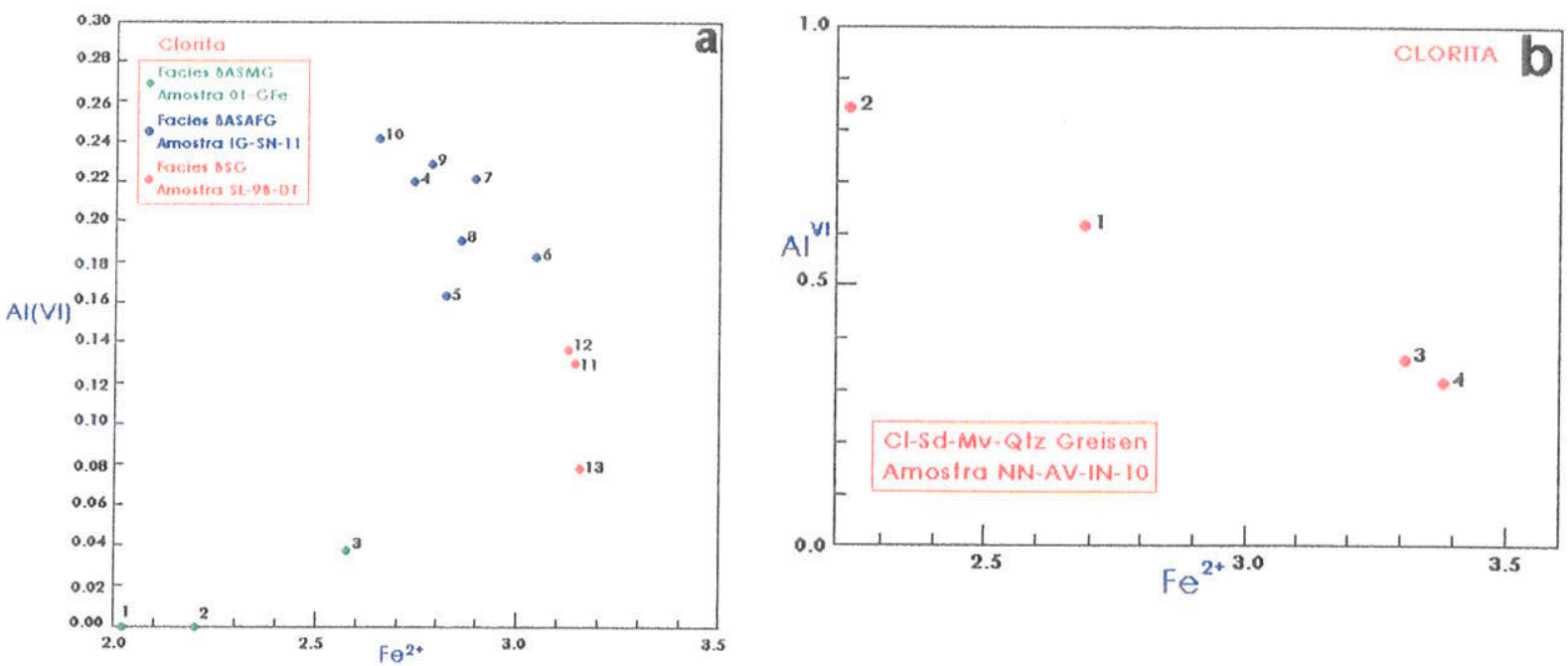

Figura 3.27.- Diagrama $\mathrm{Al}^{\mathrm{V}}$ versus $\mathrm{Fe}^{2+}$ mostrando a distribuição composicional das cloritas pertencentes às facies granitóides BASMG, BASAFG e BSG(a) e ao clorita-siderofilita-muscovitaquartzo greisen(b). Maciço granitóide Antônio Vicente.

A Figura 3.28(a, b) mostra, para o conjunto de todas as análises, uma correlação positiva entre $\mathrm{Al}^{\mathrm{lV}}$ e os cátions bivalentes $\left(\mathrm{Fe}^{2+}+\mathrm{Mg}^{2+}\right)$. No caso das composições em separado por facies, nota-se que naquelas pertencentes às facies BASMG e BASAFG, a correlação positiva observada, em relação ao conjunto de todas as amostras, se mantém. Excetuam-se a isso, as cloritas da facies BSG e do greisen, que mostram uma correlação negativa.
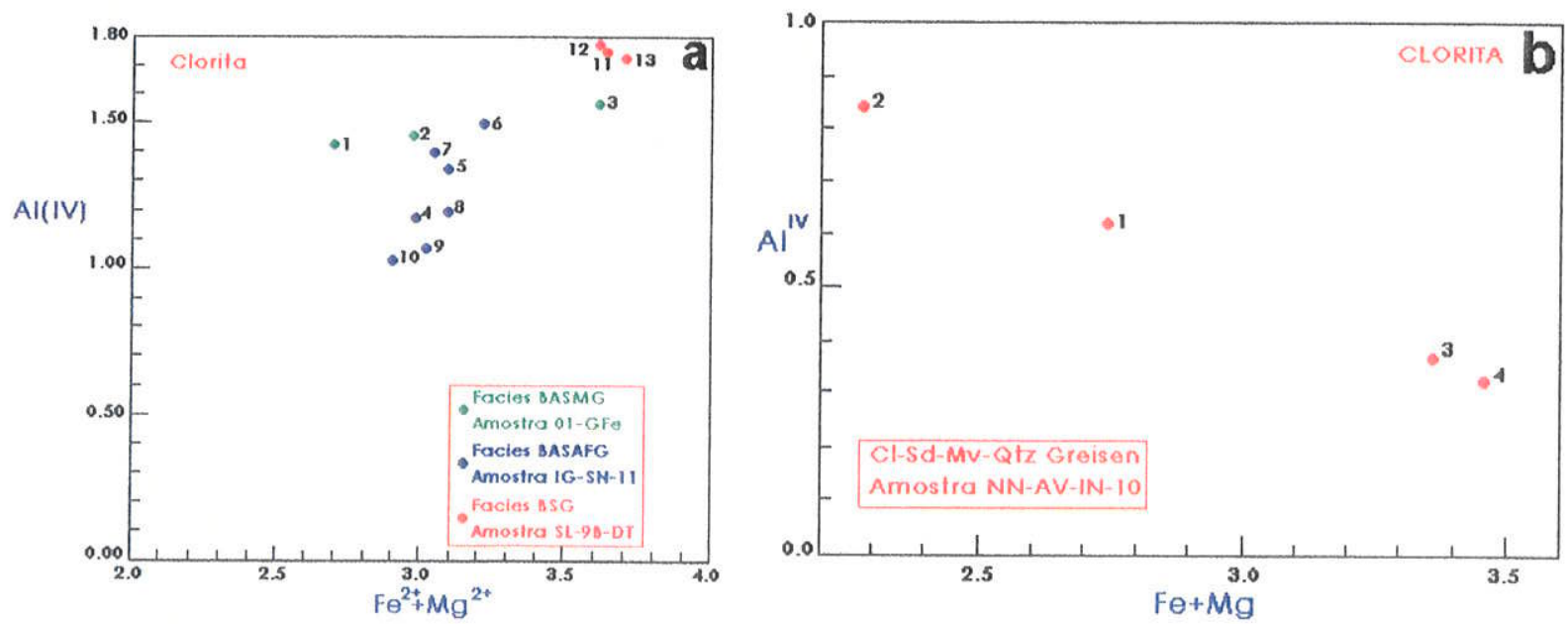

Figura 3.28.- Diagrama $\mathrm{Al}^{\mathrm{IV}}$ versus os cátions bivalentes $\left(\mathrm{Fe}^{2+}+\mathrm{Mg}^{2+}\right)$ mostrando a distribuição composicional das cloritas pertencentes às facies granitóides BASMG, BASAFG e BSG(a) e ao cloritasiderofilita-muscovita-quartzo greisen(b) Maciço granitóide Antônio Vicente. 


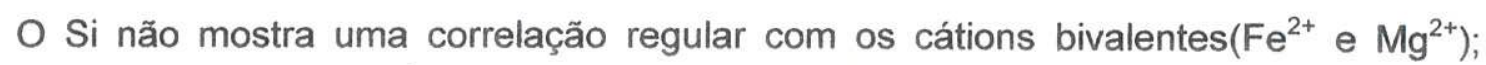
Anexo 4). Entretanto, na Figura 3.29(a, b) observa-se uma nítida correlação negativa entre $\mathrm{Si}+\mathrm{Al}^{\mathrm{VI}}$ e os cátion bivalentes $\left(\mathrm{Fe}^{2+}+\mathrm{Mg}^{2+}\right)$, tanto em relação ao conjunto de todas as análises, quanto em relação às análises em separado por facies.
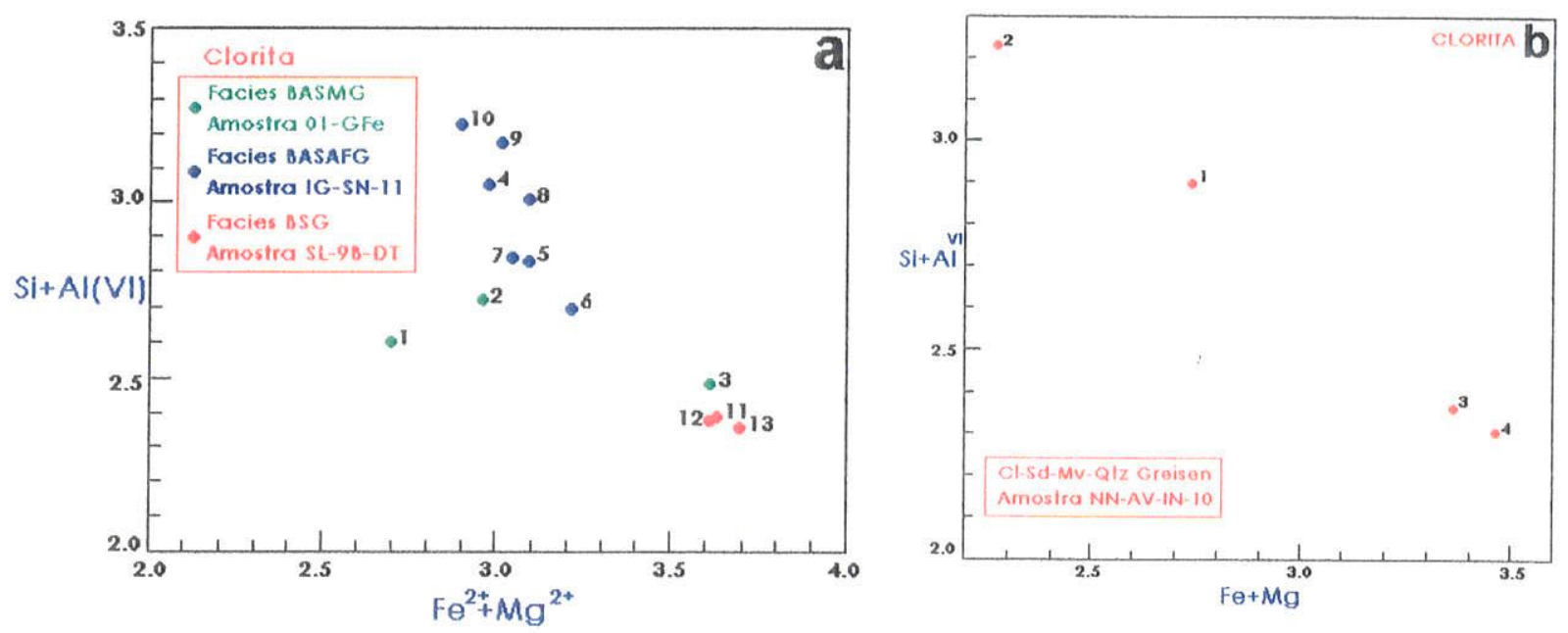

Figura 3.29.- Diagrama $\mathrm{Si+Al} \mathrm{l}^{\mathrm{N}}$ versus os cátions bivalentes $\left(\mathrm{Fe}^{2+}+\mathrm{Mg}^{2+}\right)$ mostrando a distribuição composicional das cloritas pertencentes às facies granitóides BASMG, BASAFG e BSG(a) e ao cloritasiderofilita-muscovita-quartzo greisen(b). Maciço granitóide Antônio Vicente.

Por fim, nas cloritas estudadas, em função dos dados acima apresentados, prevaleceram os mecanismos de substituições mais coerentes com aqueles estabelecidos pela equação $2\left[\left(\mathrm{Al}_{+1} \mathrm{R}^{2+}{ }_{+3 / 2} \square_{1 / 2}\right)_{\mathrm{VI}}\right.$ ou $\left.\left(\mathrm{Si}_{-1} \mathrm{Al}_{+1}\right)_{\mathrm{IV}}\left(\mathrm{Al}_{-1} \mathrm{R}^{2+}{ }_{+2} \square_{-1}\right)_{\mathrm{VI}}\right]$ fornecida por Cathelineau(1988; pg. 478).

Ademais, conforme visto anteriormente, as quantidades de ferro férrico, das cloritas estudadas(não medidas através da microssonda), devem ser muito reduzidas. Na fórmula estrutural calculada através do Minpet 2.02(na base de 14 oxigênios), os valores de $\mathrm{Fe}^{3+}$ são invariavelmente iguais a 0,00 . Entretanto, sabe-se, de antemão, que o referido software (cópia utilizada neste trabalho) arredonda os conteúdos de diversas variáveis e, dentre elas, o ferro férrico. Assim, os supostos baixos valores de $\mathrm{Fe}^{3+}$ aliados a muito provável ausência de magnetita nas facies granitóides em questão, indicam baixas condições de $\mathfrak{f O}_{2}$ durante a cristalização das cloritas estudadas e, ao que tudo indica, abaixo do buffer quartzo-fayalitamagnetita(QFM).

Uma hipótese semelhante à acima apresentada, foi formulada por Kranidiotis \& McLean(1987; pg. 1901), em estudo realizado em cloritas do depósito hidrotermal de sulfetos maciços, vulcanogênicos, de Phelps Dodge(Matagami, Quebec). 


\subsubsection{3-Classificação e Representação Gráfica}

Hey(1954) apresentou um modelo de classificação revisada para as cloritas. De acordo com esse autor as cloritas podem ser classificadas inicialmente em dois grupos composicionais: 1) cloritas da série normal, năo oxidadas ou ortocloritas; 2) cloritas oxidadas. A principal diferença entre as cloritas desses grupos tem por base os conteúdos de $\mathrm{Fe}_{2} \mathrm{O}_{3}$. As ortocloritas apresentam teores inferiores a $4 \%$, enquanto que as cloritas oxidadas possuem esses teores superiores a $4 \%$. No que se refere às cloritas estudadas neste trabalho, foram enquadradas no grupo das cloritas não oxidadas, visto que todos os grão analisados possuem conteúdos de $\mathrm{Fe}_{2} \mathrm{O}_{3}$ extremamente baixos e iguais a zero, sendo portanto, cloritas enriquecidas em FeO(Anexo 4). Além disso, Hey(op. cit.) elaborou um diagrama classificatório para as cloritas considerando as variáveis $\mathrm{Si}$ vs. $\mathrm{Fe}($ total) $/(\mathrm{Fe}+\mathrm{Mg}$ ). Deve-se ressaltar, porém, que essa classificação é baseada apenas na alocação de pontos, sendo, também, os limites entre os diversos tipos de clorita, arbitrários. Ademais, de acordo com Cathelineau \& Nieva(1985) ela não fornece nenhuma indicação sobre a origem da mesma, ném tampouco implica em uma definição estrutural.

Os dados químicos das cloritas estudadas nesse trabalho foram lançados no diagrama proposto por Hey(1954; Figura 3.30 deste trabalho) e obteve-se os seguintes resultados: 1) a clorita da facies BASMG incidiu na linha limitrofe entre os campos da pseudothuringita e da ripidolita, próximo ao campo da variedade afrosiderita, variedade da ripidolita; 2) a clorita da facies BASAFG "plotou" : duas análises no campo da brunsvigita; duas na linha limítrofe entre os campos da brunsvigita e da afrosiderita; uma no campo da afrosiderita; uma na linha divisória entre os campos da afrosiderita e da pseudothuringita; e uma no campo da bavalita,variedade da dafnita; 3) a clorita da facies BSG "plotou" plenamente no campo da pseudothuringita. No que se refere a clorita do greisen, duas amostras incidiram no campo composicional da pseudothuringita, a semelhança das amostras da facies BSG, e duas não foram plotadas devido possuírem valores de $\mathrm{Si}$ inferiores a 2(Anexo 4). Essa correspondência composicional entre a clorita da facies BSG e do greisen revela uma coerência tipológica, visto que o corpo de greisen ao qual a clorita aqui estudada pertence mostra-se associado a essa facies granitóide, bem como representa uma variedade dessa facies que foi mais intensamente afetada por por alteraçøes tardi a pós-magmáticas pervasiva, que culminou com greisenização(ver Aspectos Petrográficos deste capitulo). 


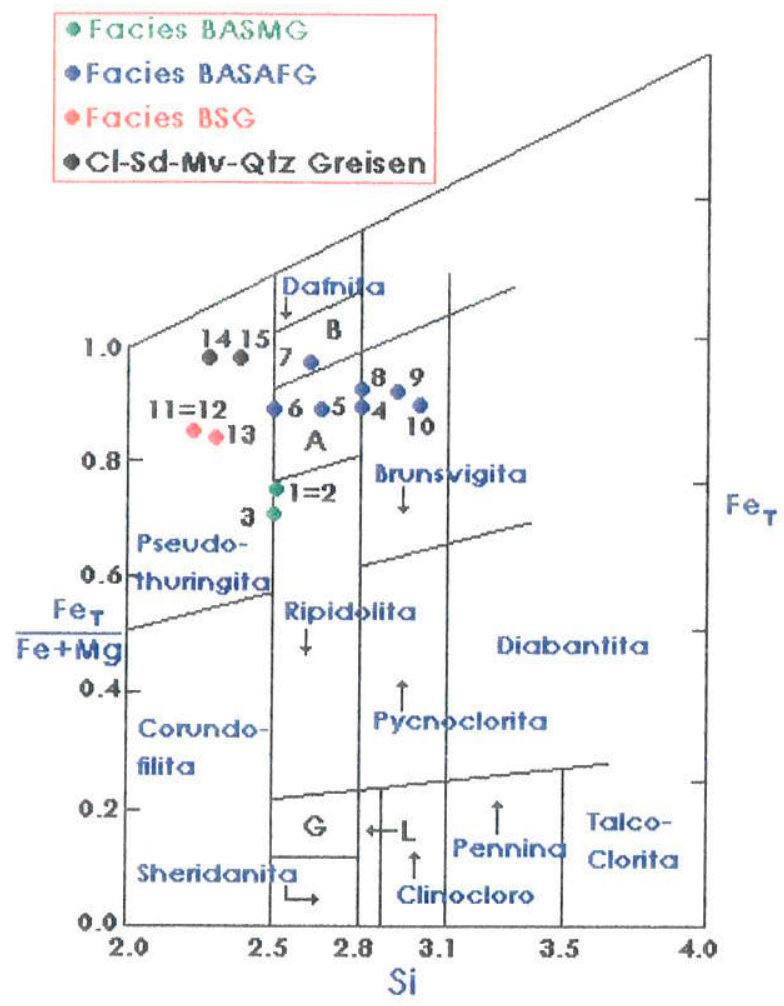

Figura 3.30.- Diagrama Si versus $\mathrm{Fe}($ total $) /\left(\mathrm{Fe}^{2+}+\mathrm{Mg}\right)$ mostrando a classificação das cloritas estudadas de acordo a proposição de Hey(1954). L=leuchtenbergita, variedade da clinocloro; $\mathrm{G}=$ grochauita, variedade da sheridanita; $A=$ afrosiderita, variedade da ripidolita; $B=b a v a l i t a$, variedade da dafnita.

\subsubsection{4- Condições de Cristalização}

De acordo com Cathelineau \& Nieva(1985) e Cathelineau(1988) há uma intima relação entre a variação composicional das cloritas e a temperatura de cristalização. Nos estudos realizados por tais autores em cloritas ocorrentes no campo geotermal de Azufres(México), foi observado que o conteúdo de $\mathrm{Al}^{\mathrm{IV}}$ no sítio tetraedral de cloritas e o conteúdo de $\mathrm{K}$ e a ocupância total intercamadas de illitas aumentam com a temperatura. Essas variações químicas são relacionadas, principalmente, ao marcante decréscimo na fração molar dos membros finais ricos em $\mathrm{Si}^{\mathrm{iV}}$ (caolinita para clorita e pirofilita para illita), o qual torna-se desprezivel a aproximadamente $300^{\circ} \mathrm{C}$. Outras mudanças químicas, tais como a variação nos conteúdos de $\mathrm{Fe}$ e de $\mathrm{Mg}$ são parcialmente influenciadas pela temperatura, sendo, contudo, fortemente dependentes do ambiente geológico e, conseqüentemente, da composição das soluções envolvidas. Essas observações foram referendadas por Zang \& Fyfe(1995), em estudo realizado em clorita de rochas alteradas do depósito de ouro do Igarapé Bahia, na Serra dos Carajás, bem como por Borges(1997), em estudo realizado em clorita presente em corpos de greisens associados ao granitóide Água Boa, na Mina Pitinga, no Estado do Amazonas. 
Cathelineau \& Nieva(1985) e Cathelineau(1988) estabeleceram um modelo geotermométrico para clorita e illita, baseado nas variações dos sitios de ocupância da estrutura cristalina dessas fases minerais, principalmente $\mathrm{Al}^{\mathrm{IV}}$ e a ocupáncia $\left(6-\mathrm{Al}^{\mathrm{N}}-(\mathrm{Mg}+\right.$ $\left.\mathrm{Fe}^{2+}\right)=\mathrm{VAC}$, como dependentes da temperatura e propuseram a seguinte equação para o cálculo da estimativa da temperatura de cristalização da clorita como uma função do conteúdo de $\mathrm{Al}^{\mathrm{N}}$ : $\mathrm{T}^{0} \mathrm{C}=321,9772\left(\mathrm{Al}^{\mathrm{N}}\right)-61,9229$. Essa equação representa uma reta de regressão com $r=0,64$.

A clorita enfocada neste trabalho, conforme foi visto anteriormente, apresenta composições nitidamente variáveis, tanto entre as facies granitóides estudadas, quanto no âmbito interno de cada facies. À composição da mesma foi aplicada a equação de Cathelineau(1988), obtendo-se as seguintes resultados: 1) a clorita da facies BASAFG possui os mais baixos teores de $\mathrm{Al}^{\mathrm{N}}$ na fórmula estrutural, variando ente 1,023 e 1,491, os quais correspondem a um intervalo de temperatura de cristalização entre $267,46^{\circ} \mathrm{C}$ e $418,15^{\circ} \mathrm{C}$; 2) a clorita da facies BASMG mostra valores de $\mathrm{Al}^{\mathrm{N}}$ intermediários, situando-se entre 1,422 e 1,557 , que eqüivale a um intervalo de temperatura de cristalização entre $395,93^{\circ} \mathrm{C}$ e $439,40^{\circ} \mathrm{C}$; 3) a clorita da facies BSG possui os mais altos conteúdos de $\mathrm{Al}^{\mathrm{N}}$, dentre as facies granitóides estudadas, os quais variam entre 1,724 e 1,770 e correspondem a temperatura de cristalização entre $493,17^{\circ} \mathrm{C}$ e $\left.507,98^{\circ} \mathrm{C} ; 4\right)$ a clorita do greisen, cujos valores de $\mathrm{Al}^{\mathrm{N}}$ são, em geral, mais elevados do que aqueles dos granitóides, visto que varia entre 1,617 e 2,033 , apresenta uma temperatura de cristalização estimada variando de $458,71^{\circ} \mathrm{C}$ a $592,66^{\circ} \mathrm{C}$.

Zang \& Fyfe(1995) revisaram o termómetro elaborado por Cathelineau \& Nieva(1985) e Cathelineau(1988). Reajustaram a equação elaborada pelos mesmos e calcularam as temperaturas de cristalização das cloritas, por eles estudadas, através da equação $T^{0} \mathrm{C}=$ $106,2\left(\mathrm{Al} \mathrm{I}^{\mathrm{N}}\right)+17,5$. Além disso, observaram que devido o $\mathrm{Al}^{\mathrm{N}}$ também variar com a razão $\mathrm{Fe} /(\mathrm{Fe}+\mathrm{Mg})$, que implicaria em temperaturas muito mais altas para cloritas com altas razőes $\mathrm{Fe} /(\mathrm{Fe}+\mathrm{Mg})$, propuseram realizar correções de acordo com o relação entre $\mathrm{Al}^{\mathrm{N}}$ e a razão $\mathrm{Fe} /(\mathrm{Fe}+\mathrm{Mg})$, conforme fora sugerido por Cathelineau \& Nieva(1985) e Kranidiotis \& Maclean(1987). Assim, a correção realizada consistiu em recalcular os valores de $\mathrm{Al}^{\mathrm{N}}$ através da equação $\mathrm{Al}^{\mathrm{N}}{ }_{\text {(corrigido) }}=\mathrm{Al}^{\mathrm{N}}$ medido $-0,88[\mathrm{Fe} /(\mathrm{Fe}+\mathrm{Mg})-0,34]$.

Em razão disso, procurou-se, neste trabalho, realizar algumas experiências com o intúito de melhor estimar as temperaturas de cristalização das cloritas estudadas(Tabela 3.12). Assim foram consideradas as seguintes tentativas:

1) Considerando tão somente os reajustes realizados por Zang \& Fyfe(op. cit.) na equação original de Cathelineau(1988), sem contudo, corrigir os valores de $\mathrm{Al}^{\mathrm{N}}$, obteve-se as seguintes temperaturas: a) 277,61 a $280,50^{\circ} \mathrm{C}$ (para a clorita da facies BASMG); b) 296,02 a 
$299,57^{\circ} \mathrm{C}$ (para a clorita da facies BASAFG); c) 290,88 a $291,81^{\circ} \mathrm{C}$ (para a clorita da facies BSG); d) $189,23^{\circ} \mathrm{C}$ a $233,40^{\circ} \mathrm{C}$ (para a clorita do greisen).

2) Considerando os reajustes realizados por Zang \& Fyfe(op. cit) na equação original de Cathelineau(1988), mas incluindo a correção do $\mathrm{Al}^{\mathrm{l}}$, conforme a equação de correção apresentada por esses autores(ver acima). As temperaturas obtidas para as cloritas estudadas foram: a) $130,98^{\circ} \mathrm{C}$ a $147,81^{\circ} \mathrm{C}$ (para a facies BASMG); b) $72,41^{\circ} \mathrm{C}$ a $118,92^{\circ} \mathrm{C}$ (para a facies BASAFG); c) $152,27^{\circ} \mathrm{C}$ a $156,62^{\circ} \mathrm{C}$ (para a facies BSG); d) $130,39^{\circ} \mathrm{C}$ a $173,59^{\circ} \mathrm{C}$ (para o greisen).

3) Considerando a equação original de Cathelineau(1988), mas assumindo a correção dos valores de $\mathrm{Al}^{\mathrm{l}}$, conforme Zang \& Fyfe(op. cit.). As temperaturas de cristalização estimadas para a clorita foram: a) para a facies BASMG entre $280,98^{\circ} \mathrm{C}$ e $333,14^{\circ} \mathrm{C}$; b) para a facies BASAFG de $104,54^{\circ} \mathrm{C}$ a $245,56^{\circ} \mathrm{C}$; c) para a facies BSG entre $346,67^{\circ} \mathrm{C}$ e $359,87^{\circ} \mathrm{C}$; d) para o greisen de $280,33^{\circ} \mathrm{C}$ a $411,32^{\circ} \mathrm{C}$.

Os dados apresentados acima, aliados aos estudos petrográficos revelam que as temperaturas estimadas a partir da equação de Cathelineau(1988), sem realizar quaisquer reajustes ou correções nas quantidades de $\mathrm{Al}^{\mathrm{v}}$, parecem um tanto elevadas, especialmente, aquelas referentes à clorita da facies BSG e do greisen(temperaturas 1; Tabela 3.12). Entretanto, quando comparadas com dados existentes na literatuta, obtidos através de estudos de química mineral e de inclusões fluidas em fases minerais de depósitos hidrotermais associadas a rochas granitóides, pegmatitos e a corpos de greisens, bem como através da interpretação do equilibrio de fases( Scherba, 1970; Haapala, 1977; Haapala \& Kinnnunen,1979; Durisova, 1978, Charoy, 1979 e Naumov \& Ivanova, 1980, In: Stemprok, 1987; Kinnaird, 1985; Kinnaird et al., 1985a; Cathelineau, 1986; Thomas \& Sponer, 1985 e 1988, In: Strong, 1988; Witt, 1988, In: Taylor \& Pollard, 1988; Pollard et al.,1989; Borges, 1997), elas parecem coerentes, visto que situam-se dentro dos limites das temperaturas reinantes nos ambientes hidrotermais estudados pelos autores supracitados.

As temperaturas obtidas a partir da equação de Zang \& Fyfe(op. cit), sem considerar as correções das quantidades de $\mathrm{Al}^{\mathrm{l}}$ (temperaturas 2; Tabela 3.12), conforme recomendado pelos referidos autores, parecem, também, compativeis com aquelas das condições ambientais de cristalização das cloritas estudadas, nesse trabalho, visto que não destoam claramente das temperaturas obtidas em fases minerais de depósitos hidrotermais, publicadas na literatura.

Quando nos cálculos da temperatura, é utilizada a equação de Zang \& Fyfe(op. cit.), mas considerando as correções dos valores de $\mathrm{Al}^{\mathrm{lv}}$, as temperaturas obtidas(temperaturas 
3; Tabela 3.12) tornam-se muito baixas e parecem pouco realistas e, portanto, incompativeis com aquelas das condições de cristalização da clorita 2, visto que são temperaturas incoerentes com as condições do estágio tardi a pós-magmático em que se formaram, onde, geralmente, as temperaturas devem ser mais elevadas.

Uma combinação da equação da Cathelineau(1988) com a equação de Zang \& Fyfe(op. cit.), para as correções das quantidades de $\mathrm{Al}^{\mathrm{IV}}$, também, fornece estimativas de temperaturas coerentes com aquelas obtidas para cloritas formadas em ambientes hidrotermais(Cathelineau \& Nieva, 1985; Kranidiotis \& Maclean,1987; Cathelineau, 1988; Zang \& Fyfe, 1995). Uma vantagem desta estimativa(temperaturas 4; Tabela 3.12) sobre aquela que considera a equação de Zang \& Fyfe(1995) e a não correção das quantidades de $\mathrm{Al}^{\mathrm{IV}}$ (temperaturas 2, Tabela 3.12) é que ela representa a ampla variação dos teores de $A I^{\mathrm{IV}}$ apresentada pela clorita da facies BASAFG, enquanto a última mascara esse variação.

De acordo com Cathelineau \& Nieva(1985), variações nas quantidades de $\mathrm{Al}^{\mathrm{N}} \mathrm{com}$ a temperatura a razões $\mathrm{Fe} /(\mathrm{Fe}+\mathrm{Mg})$ constantes, podem propiciar um bom geotermômetro. Essa acertiva é referendada por Zang \& Fyfe(op. cit.). De fato, as cloritas estudadas neste trabalho, conforme é observado na Figura 3.24, apresentam essas características, ou seja, mostram uma ampla variação nas quantidades de $\mathrm{Al}^{\mathrm{IV}}$ e apresentam, por outro lado, razões $\mathrm{Fe} /(\mathrm{Fe}+\mathrm{Mg})$, praticamente constantes. Assim , as temperaturas obtidas através da equação de Cathelineau(1988) devem ser consideradas aquelas mais realistas $e$, portanto, mais coerentes com as condições mínimas de cristalização das cloritas estudadas.

Tabela 3.12.- Estimativas da temperatura de cristalizaçăo da clorita( $\left.\mathrm{Ch}_{2}\right)$ das facies granitóides BASMG, BASAFG e BSG e do clorita-siderofilita-muscovita-quartzo greisen do maciço granitóide Antônio Vicente.

\begin{tabular}{|l|c|c|c|c|}
\hline FACIES GRANITOIDES & BASMG & BASAFG & BSG & $\begin{array}{c}\text { Cl-Sd-Mv-Qtz } \\
\text { Greisen }\end{array}$ \\
\hline FASEMINERAL & CLORITA & CLORITA & CLORITA & CLORITA \\
\hline TEMPERATURAS('C) & & & & \\
\hline 1 & $395,93-439,40$ & $267,46-418,15$ & $493,17-607,98$ & $458,71-592,66$ \\
\hline 2 & $277,61-280,50$ & $296,02-299,57$ & $290,88-291,81$ & $189,23-233,40$ \\
\hline 3 & $130,60-147,81$ & $72,41-118,92$ & $152,27-156,62$ & $130,39-172,59$ \\
\hline 4 & $280,98-333,14$ & $104,54-245,56$ & $346,67-359,87$ & $280,33-411,32$ \\
\hline
\end{tabular}

1- De acordo com o geotermómetro elaborado por Cathelineau \& Nieva(1985) e Cathelineau(1988)

2- Conforme as observaços de Zang \& Fyfe(1995), embora sem recaicular Al(IV).

3. Conforme as observaçoes de Zang \& Fyfe(1995), recalculando Al(IV).

4- De acordo com o geotermómetro elaborado por Cathelineau \& Nieva(1985) e Cathelineau(1988), mas recalculando Al(IV) conforme recomendações de Zang \& Fyfe(1995).

\subsubsection{4-Análises químicas em Muscovita}

No que se refere a essa fase mineral, foram realizadas um total de seis análises pontuais em dois grãos distintos da amostra NN-AV-IN-10, de clorita-siderofilita-muscovitaquartzo greisen, as quais foram assim discriminadas. Em ambos grãos a muscovita 
analisada refere-se à muscovita $2\left(\mathrm{Mv}_{2}\right)$, conforme visto no item aspectos petrográficos deste capitulo.

A muscovita pertence ao grupo das micas dioctaédricas(Foster, 1960a; Howthorne \& Cerny, 1982). O grupo ao qual ela pertence é composto por três membros finais(Harrison, 1990):

1) Muscovita("stricto sensu") $\mathrm{KAl}_{2}\left(\mathrm{Si}_{3} \mathrm{Al}\right) \mathrm{O}_{10}(\mathrm{OH})_{2}$

2) Celadonita $\mathrm{K}\left(\mathrm{Al} \mathrm{R} \mathrm{R}^{2+, 3+, 4+}\right) \mathrm{Si}_{4} \mathrm{O}_{10}(\mathrm{OH})_{2} \quad[\mathrm{R}=\mathrm{Mg}, \mathrm{Fe}, \mathrm{Mn}, \ldots]$

3) Paragonita $\mathrm{NaAl}_{2}\left(\mathrm{Si}_{3} \mathrm{Al}\right) \mathrm{O}_{10}(\mathrm{OH})_{2}$

Conforme o autor supracitado, entre os membros finais muscovita e celadonita ocorre uma solução sólida contínua, a qual é, por vezes, referida como o grupo da fengita, embora esse termo deva ser idealmente restrito a composições que contenham entre $40 \%$ e $90 \%$ da molécula da molécula celadonita. A muscovita e a paragonita não formam uma série contínua. As muscovitas são consideradas inclusas, em termos de seus membros extremos muscovita("stricto sensu"), celadonita e paragonita. As variações composicionais neste grupo são denominadas de substituições "do tipo Tschermak" e estão representadas por:
a) $\left(\mathrm{R}^{2+}\right)^{\mathrm{VI}}+\mathrm{Si}^{\mathrm{V}}=\mathrm{Al}^{\mathrm{IV}}+\mathrm{Al} \mathrm{I}^{\mathrm{VI}}$
b) $\left(\mathrm{R}^{2+}\right)^{\mathrm{V}}+\mathrm{Si}^{\mathrm{N}}=\left(\mathrm{Fe}^{3+}\right)^{\mathrm{V}}+\mathrm{Al}^{\mathrm{VI}}$
c) $3\left(\mathrm{R}^{3+}\right)^{\mathrm{V}}+\mathrm{Si}^{\mathrm{V}}=\mathrm{Ti}^{\mathrm{VI}}+2 \mathrm{Al} \mathrm{V}^{\mathrm{V}}$

Adicionalmente a essas, Harrison(1990) apresenta para a variação composicional das fengitas as seguintes substituições: $2 \mathrm{Al}^{\mathrm{N}}+\mathrm{Si}^{\mathrm{N}}=2 \mathrm{Al} \mathrm{l}^{\mathrm{V}}+2\left(\mathrm{R}^{2+}\right)^{\mathrm{VI}}$.

No caso das micas brancas naturais, sem lítio, Monier \& Robert(1986b) descrevem como sendo uma solução sólida entre o membro extremo muscovita $\mathrm{K}\left(\mathrm{Al}_{2} \square\right)\left(\mathrm{Si}_{3}\right.$ Al) $\mathrm{O}_{10}(\mathrm{OH})_{2}$, onde $\square$ representa a vacância no sítio octaedral, e o membro final celadonita $\mathrm{K}\left(\mathrm{Al} \mathrm{M} \mathrm{M}^{2+} \square\right) \mathrm{Si}_{4} \mathrm{O}_{10}(\mathrm{OH})_{2}$, onde $\mathrm{M}^{2+}=\mathrm{Mg}^{2+}, \mathrm{Fe}^{2+}$, a qual é considerada como série fengítica. De acordo com esses autores os mecanismos de substituição que caracterizam essa série podem ser descritos como:

$\mathrm{Al}^{\mathrm{V}}, \mathrm{Al}^{\mathrm{N}} \rightarrow\left(\mathrm{M}^{2+}\right), \mathrm{Si}^{\mathrm{V}} \quad(1)$
$\left(\mathrm{M}^{2+}\right), \mathrm{Si}^{\mathrm{N}} \leftarrow \mathrm{Al}^{\mathrm{Vi}}, \mathrm{Al}^{\mathrm{V}}$

Assim, se $x$ é a quantidade de substituições, de acordo com a equação (1) , 0 membro final muscovita tem $x=0$ e o membro final A-celadonita possui $x=1$. $E$ a pureza do caráter octaedral é mantida. 
Além disso, segunto esses autores, embora a possibilidade de solução sólida entre micas dioctaedrais e trioctaedrais tenha sido pouco considera, o seguinte mecanismo de substituição é envolvido:

$$
\begin{aligned}
& 2 / 3 \mathrm{Al} V \mathrm{VI}, 1 / 3 \square \rightarrow\left(\mathrm{M}^{2+}\right)^{\mathrm{VI}} \\
& \left(\mathrm{M}^{2+}\right)^{\mathrm{VI}} \leftarrow 2 / 3 \mathrm{Al}^{\mathrm{VI}}, 1 / 3 \square
\end{aligned}
$$

Se y é a quantidade de substituições de acordo com a equação (2), o membro final muscovita tem $\mathbf{y}=0$ e o membro extremo biotita(flogopita com $\mathrm{M}^{2+}=\mathrm{Mg}$ e a annita com $\mathrm{M}^{2+}$

$=\mathrm{Fe}^{2+}$ ) tem $\mathbf{y}=3$, com a fórmula $\mathrm{KM}^{2+}{ }_{3}\left(\mathrm{Si}_{3} \mathrm{Al}\right) \mathrm{O}_{10}(\mathrm{OH})_{2}$. Nessas séries o número de vacâncias nos sítios octaedrais é variável.

Monier \& Robert(1986b) ressaltaram, ainda, que muitas soluções sólidas de muscovitas naturais são combinações das substituições (1) e (2) e podem ser descritas pelos dois parâmetros $x$ e $y$. Desta forma, a fórmula geral da muscovita é $K\left(\mathrm{Al}_{2-x-2 y / 3} \mathrm{M}^{2+}{ }_{x+y}\right.$ $\left.\square_{1-y / 3}\right)^{I V}\left(\mathrm{Si}_{3+x} A I_{1-x}\right)^{I V} O_{10}(O H)_{2}$.

\subsubsection{1- Composição química}

Os resultados analíticos obtidos para essa mica, bem como suas respectivas fórmulas estruturais encontram-se no Anexo 5.

Com base no Anexo 5 e na Figura 3.31 observa-se que a mesma ostenta conteúdos extremamente baixos de $\mathrm{Ti}, \mathrm{Mg}, \mathrm{Na}$, e Li e possui teores, relativamente, elevados de $\mathrm{Si}, \mathrm{Al}_{\mathrm{T}}$, F e K. Os valores de XFe são pouco variáveis e oscilam entre 0,96 e 0,99.
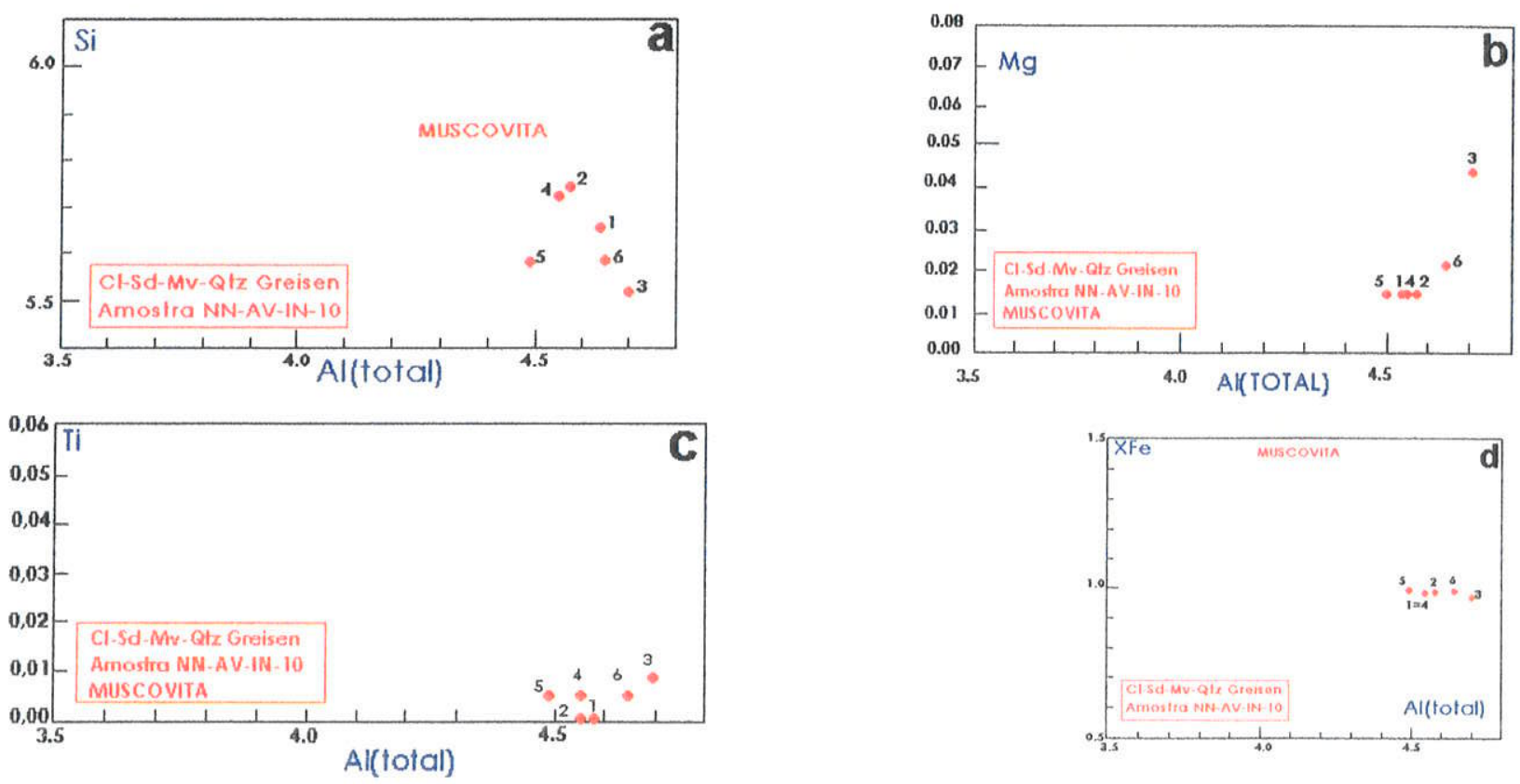


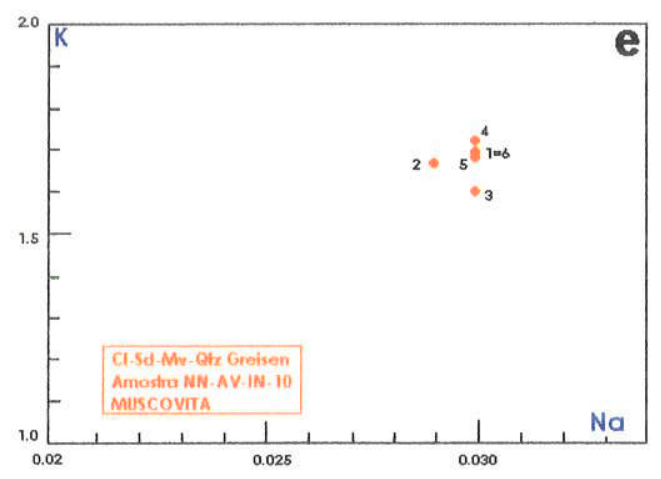

Figura 3.31- Representação composicional catiônicada da muscovita do clorita-siderofilitamuscovita-quartzo greisen associado ao maciço granitóide Antônio Vicente. a) $\mathrm{Si}_{-} \mathrm{Al}_{T} ; \mathrm{b}$ ) $\left.\mathrm{Mg}-\mathrm{Al}_{T} ; \mathrm{C}\right) \mathrm{Ti}_{\mathrm{i}} \mathrm{Al} \mathrm{I}_{\mathrm{T}}$; d) XFe-Al $\mathrm{X}_{\mathrm{T}}$; e) $\mathrm{K}-\mathrm{Na}$ )

\subsubsection{2- Substituições}

As Figuras 3.32(Cathelineau, 1982, modificada de Dias, 1987. In: Simões, 1992) e 3.33(modificada de Dias, 1987. In: Simões, 1992) apresentam a substituição fengítica e permitem avaliar as proporções de $\mathrm{Fe}^{3+}$ e $\mathrm{Fe}^{2+}$ presentes nas muscovitas. De acordo com Simões(1992), o diagrama retangular [(Al $\left.\left.\mathrm{I}^{\mathrm{V}}-2\right)+2 \mathrm{Ti}\right]$ vs. $A l^{\mathrm{IV}}$ evidencia a correlação entre $A l^{\mathrm{lv}}$ e $\mathrm{Al}^{\mathrm{VI}}$, esperada em uma substituição fengítica e indica a proporção de $\mathrm{Fe}^{3+}$ presente em função da substituição $\mathrm{Al}^{3+} \rightarrow \mathrm{Fe}^{3+}\left(\mathrm{Fe}^{3+} \rightarrow \mathrm{Al}^{3+}\right)$ inerente à própria substituição fengítica(fengitas que se afastam da correlação). Ainda segundo esse autor, o diagrama (Si$6+\mathrm{Ti}$ ) contra $\mathrm{Mg}$ tem o propósito de avaliar a proporção de $\mathrm{Fe}^{2+}$ associado ao $\mathrm{Mg}$ que entra na posição octaédrica para compensar o excesso de carga provocado pela substituição fengítica(se todo o excesso de carga é compensado pelo $\mathrm{Mg}$, então $\mathrm{Fe}^{2+}=0$ e todo o ferro estará no estado trivalente).

Em relação à muscovita estudada, as Figuras 3.32 e 3.33 mostram um baixo grau de substituição fengítica. Observa-se ainda, um grau relativamente alto da substituição $\mathrm{Al}^{\mathrm{VI}}$ por $\mathrm{Fe}^{3+}\left(\mathrm{Fe}^{3+} \rightarrow \mathrm{Al}^{\mathrm{Vl}}\right)$ para a muscovita em questão. Dessa forma, o excesso de carga provocado pela substituição fengítica é compensado pela entrada dos íons divalentes $\mathrm{Mg}$ e $\mathrm{Fe}^{2+}$. Na muscovita estudada, observa-se que apenas o $\mathrm{Mg}$ contribuiu, embora muito pouco, para essa substituição, visto que, de acordo com as Figuras 3.32 e 3.33 , o ferro estrutural está essencialmente no estado trivalente.

Os graus de substituições fengítica e paragoníticas podem ser avaliados a partir do diagrama $\%$ da molécula celadonítica(\%mol Cel.) vs. $\%$ da molécula paragonítica(\%mol Parag.; Figura 3.34 deste trabalho). Nele, nota-se que a substituição paragonítica é muito reduzida, enquanto que a substituição fengítica, dada pela \% molécula celadonítica, é ausente, uma vez que os valores dessa variável são todos negativos na muscovita estudada. 


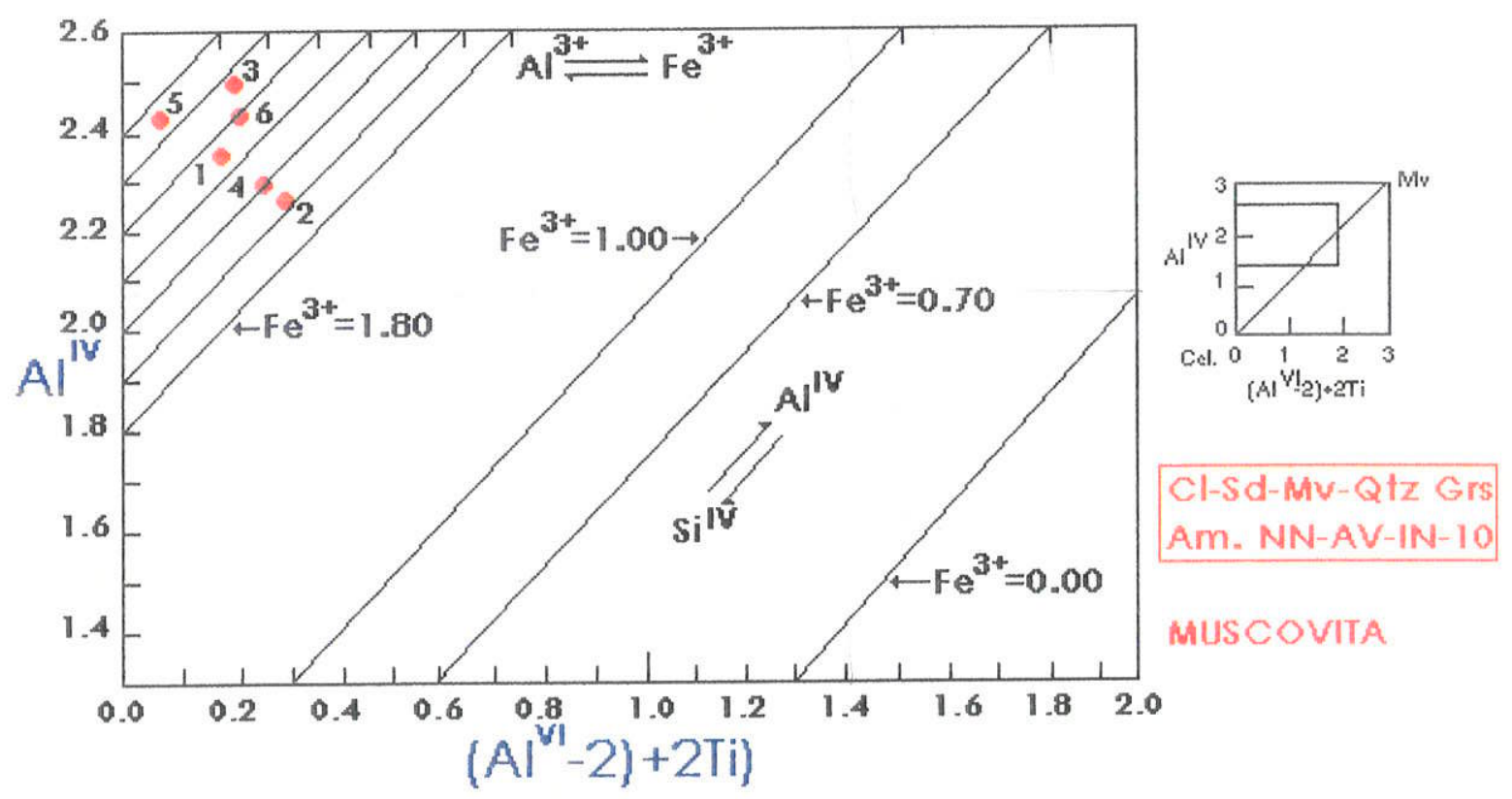

Figura 3.32- Representação composicional da muscovita do clorita-siderofilita-muscovita-quartzo greisen associado ao maciço granitóide Antônio Vicente no diagrama $\mathrm{Al}^{\mathrm{V}}$ versus $\left[\left(\mathrm{Al}^{\mathrm{V}}-2\right)+2 \mathrm{Ti}\right]$ de Cathelineau(1982), modificado de Dias(1987). In: Simões(1992).

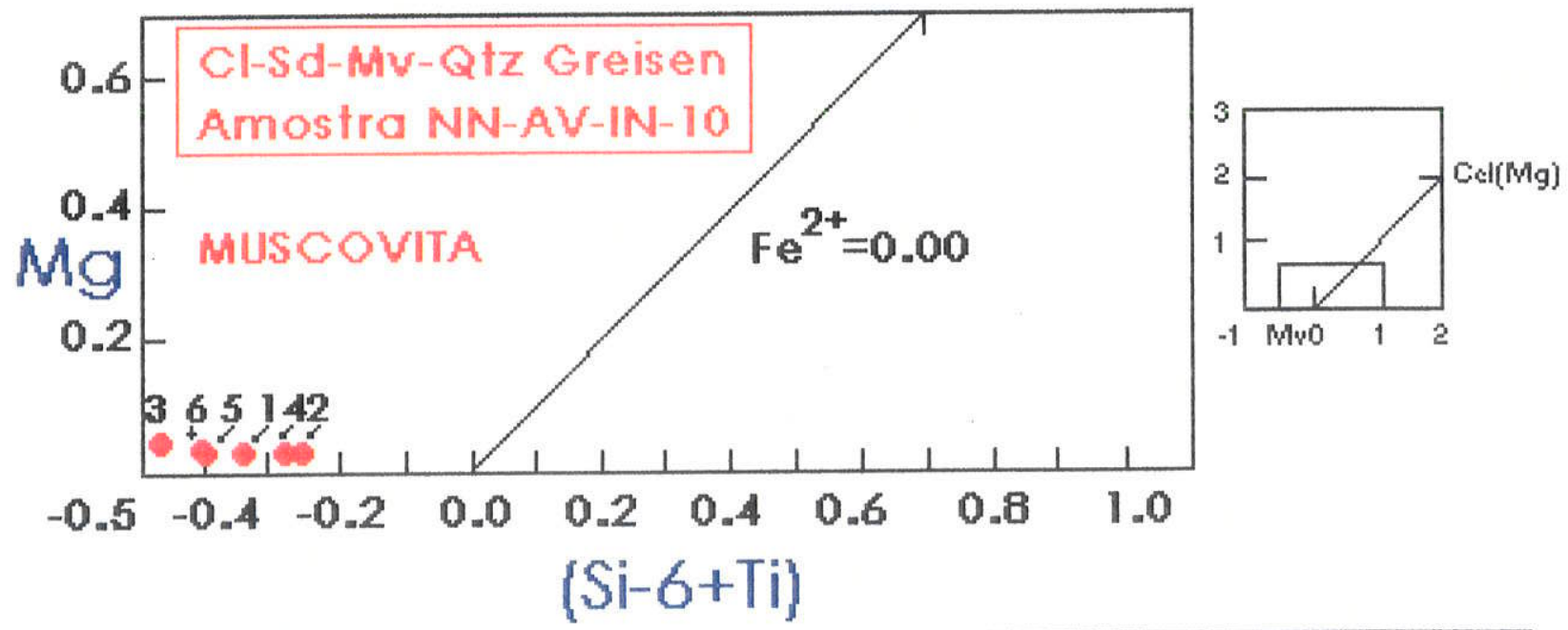

Figura 3.33- Representação composicional da muscovita do clorita-siderofilita-muscovita-quartzo greisen associado ao maciço granitóide Antônio Vicente no diagrama Mg-(Si-6+Ti), modificado de Dias(1987). In: Simões(1992). 


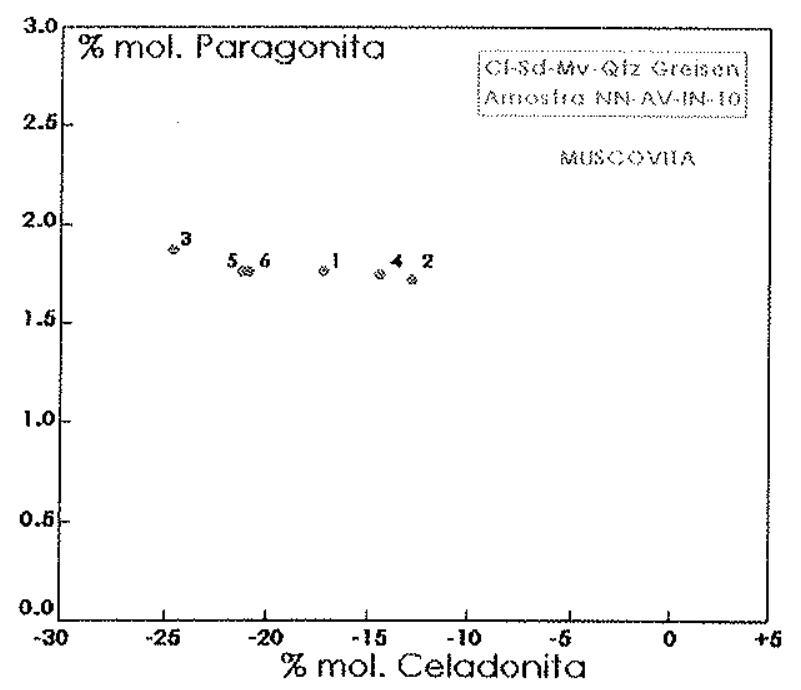

Figura 3.34- Representação gráfica das percentagens das moléculas paragoníticas e celadoníticas presentes na muscovita do clorita-siderofilita-muscovita-quartzo greisen associado ao maciço granitóide Antônio Vicente, de acordo com Simð̋es(1992). \% mol. paragonita= 100xNa/(Na+K); \%mol. celadonita $=100 \times(\mathrm{Si}-6) / 2$.

\subsubsection{3- Classificação e Representação Gráfica}

Tischendorf et al.(1997) introduziram na literatura geológica um novo diagrama bidimensional para classificação e representação gráfica de micas. O diagrama foi baseado na abundância absoluta dos cátions na camada tetraedral e propicia um meio simples para classificar as micas em termos de suas composições e da ocupância do sitio octaedral, bem como permite que seja observado, ao mesmo tempo, o relacionamento completo entre variedades de micas com ou sem litio e entre micas trioctaédricas e dioctaédricas.

Assim, as composições da muscovita estudada quando lançadas no diagrama Mg-Li vs. $\left[\left(\mathrm{Fe}_{\mathrm{T}}+\mathrm{Mn}+\mathrm{Ti}\right)-\mathrm{Al}^{\mathrm{V}}\right]$ de Tischendorf et al.(1997), Figura 3.35 deste trabalho, incidem no campo da fengita, com três análises "plotando" no quadrante das Li-Al micas, duas na área composicional corrrespondete às Mg-Al micas e uma em cima da linha limitrofe entre esses dois quadrantes.

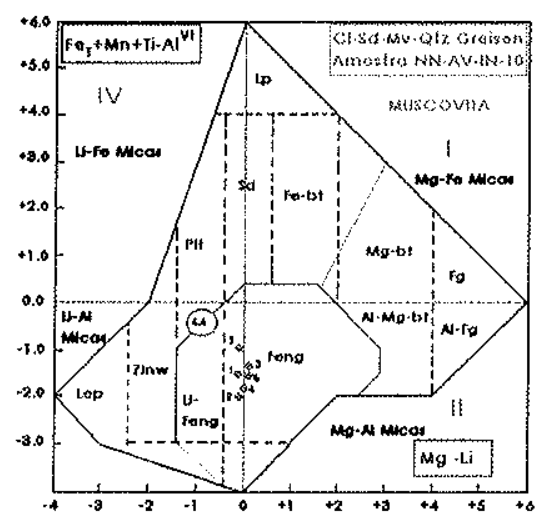

Figura 3.35- Diagrama $(\mathrm{Mg}-\mathrm{Li})$ vs. $\left[\left(\mathrm{Fe}_{\mathrm{T}}+\mathrm{Mn}+\mathrm{Ti}\right)-\left.\mathrm{Al}\right|^{\mathrm{v} /}\right] \mathrm{de}$ Tischendorf et al.(1997) mostrando a distribuição composicional da muscovita do clorita-siderofilitamuscovita-quartzo greisen associado a facies granitóide BSG do maciço granitóide Antônio Vicente. 


\subsubsection{4- Origem}

Diversos autores tem discutido a origem primária(magmática) ou secundária(tardi a pós-magmática, metassomática, etc.) de muscovitas em rochas granitóides(Syritso et al., 1970; Miller et al., 1981; Speer, 1984; Monier et al., 1984; Fonteilles, 1987; Monier et al., 1987; Simões, 1992, entre outros).

Os estudos petrográficos realizados em seções delgadas de amostras de cloritasiderofilita-muscovita-quartzo greisen mostraram que, texturalmente, trata-se de micas brancas secundárias formadas, às expensas da clorita $\left(\mathrm{Cl}_{2}\right)$ e dos feldspatos, no estágio de greisenização.

Os dados químicos quando lançados no diagrama triangular $\mathrm{Mg}-\mathrm{Ti}-\mathrm{Na}$ de Miller et al.(1981), Figura 3.36 deste trabalho, mostram que a composição da muscovita aqui estudada incide, preferencialmente, no campo das muscovitas primárias. Comparativamente às muscovitas estudadas por Miller et al.(1981), Monier et al.(1984) e Simões(1992), essa muscovita, em termos do seu quimismo, apresenta muitas afinidas com as muscovitas secundárias, visto que possui conteúdos muito reduzidos de $\mathrm{Ti}$ e $\mathrm{Na}$, bem como seus teores de $\mathrm{Al}, \mathrm{Mg}$ e Si são compatíveis com as mesmas. Isso é corroborado, também, pelo fato de que certas análises de muscovitas, texturamente secundárias, apresentadas por Miller et al.(1981; Figura 2b, pg 28), incidirem no campo das muscovitas primárias, se suporpondo as mesmas. Essa superposição de análises de muscovitas de diferentes origens ocorre em função dos limites entre os campos correspondentes a muscovitas primárias e secundárias ser definido estatisticamente, adimitindo, portanto, imperfeições, as quais podem perfeitamente corresponder a um "plot" fora do seu verdadeiro campo composicional, como é o caso aqui apresentado.

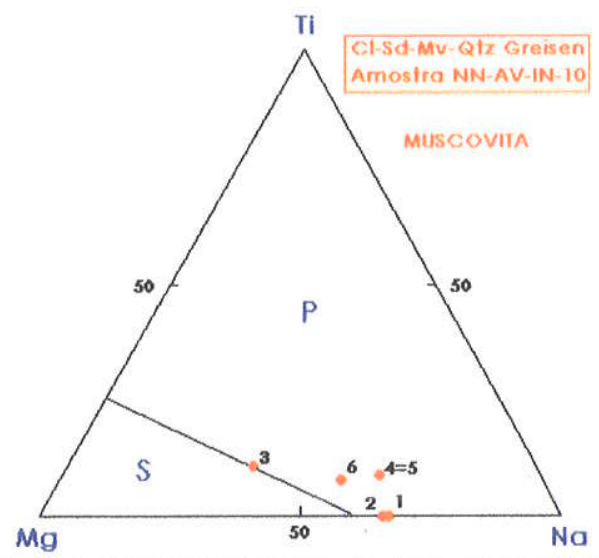

Figura 3.36- Distribuição composicional da muscovita do clorita-siderofilita-muscovita-quartzo greisen associado ao maciço granitóide Antônio Vicente no diagrama triangular Mg-Ti-Na de Miller et al.(1981). $P=$ campo composicional das muscovitas primárias; $S=$ campo composicional das muscovitas secundárias. 


\subsubsection{Análises químicas em Feldspato potássico}

Para essa fase mineral foram realizadas um total de 12 análises assim discriminadas: 03 análises em um grão da amostra 01-Gfe(facies BASMG), 06 amostras em um grão da amostra IG-SN-11(facies BASAFG) e 03 análises de um grão da amostra SL9B-DT(facies BSG). Todos os grãos analisados correspondem ao feldspato potássico 2(microclina pertítica 2). As análises, as fórmulas estruturais e as proporções Ab-Or-An encontram-se no Anexo 6.

\subsubsection{1- Composição química}

$\mathrm{Na}$ análise do diagrama Ab-Or-An(Figura 3.37), observa-se que há uma ampla variação composicional do feldspato potássico, tanto em relação a cada facies individualmente, quanto no que se refere às facies entre si. Nota-se que na facies BASMG as composições são mais potássicas, onde a molécula ortoclásio varia entre $72 \%$ e $97 \%$, com composição média igual a $86,33 \%$. As análises referentes à facies BASAFG ocupam, na sua grande maioria, uma posição intermediária, com os valores variando entre $1,0 \% \mathrm{e}$ $67,19 \%$, e média de $38,83 \%$. As análises da facies BSG formam, na sua quase totalidade, o extremo mais empobrecido na molécula potássica, embora o valor médio seja superior aquele das análises da facies BASAFG. Isso decorre do fato de uma análise da facies BSG possuir valor de Or extremamente atto e igual a $97 \%$ (análise número 12), interferindo fortemente no cálculo da média, visto que as outras análises da facies exibem valores entre $2 \%$ ne $21 \%$ (análises 11 e 10, respectivamente). Adicionalmente a isso, duas análises da facies BASAFG possuem valores de Or muito baixos, entre $1 \%$ e $6 \%$ (análises 7 e 9 , respectivamente). Essas análises correspondem às fases albíticas de substituição do feldspato pertitico(ver aspectos petrográficos). No que se refere à molécula An, as análises, de um modo geral, mostram teores extremamente baixos(até $6 \%$ ) a inexistentes. É necessário ressaltar que as quantidades da fração anortita se fazem presentes e tendem a aumentar nas amostras mais ricas em Ab, ou seja, nas análises mais ricas em em sódio, fato que é coerente com o que é apresentado por Deer et al.(1966).

Esse trend composicional mostrando um empobrecimento na molécula ortoclásio no sentido da facies BASMG para a facies BSG evidencia, ao que tudo indica, relaçóes de troca entre $\mathrm{Na}$ e $\mathrm{K}$ em função dos processos de substituição, que culminaram com a formação das pertitas de substituiçäo(tais como "films", "veins" e "bands perthites"),ocorridos durante o estágio de alteraçōes tardi a pós-magmáticas, tornando mais ricos em sódio os feldspatos potássico das facies mais enriquecidas em feldspato potássico. Em outras palavras, esse trend reflete o sentido da facies menos microclinizada(BASMG) para aquela mais afetada pelo evento metassomático de natureza sódica(albitização), que propiciou as formação das microclinas pertíticas de substituição do plagioclásio 
primário $\left(\mathrm{PI}_{1}\right)$. Ou melhor, há uma clara correlação negativa entre $\mathrm{Na}$ e K(Figura 3.38) paralelamente ao trend de albitização tardi a pós-magmática.

De acordo com Deer et al.(1966), a molécula de anortita tem, geralmente, teores razoavelmente baixos de sanidina, a qual tem, de um modo característico, menos do que $1 \%$ de $\mathrm{CaO}$. No ortoclásio, contudo, a quantidade de $\mathrm{CaO}$ tende a aumentar à medida que a razão $\mathrm{Na} / \mathrm{K}$ cresce aproximando-se da composição da albita. No caso das feldspatos estudados, essa acertiva é válida, visto que os teores de anortita aumentam até $6 \%$ nas análises onde as razões $\mathrm{Na} / \mathrm{K}$ são maiores(Anexo 6). A Figura 3.39 ilustra nitidamente o aumento de Ca paralelamente ao crescimento das quantidades de $\mathrm{Na}$, caracterizando uma correlação positiva entre esses dois cátions.

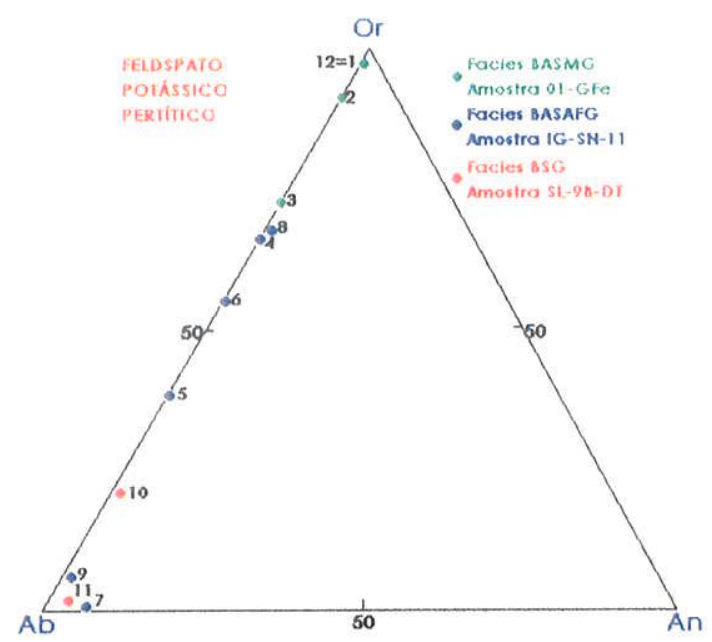

Figura 3.37 Diagrama triangular Ab-Q-An mostrando a distribuição composicional dos feldspatos potássicos(microclina pertítica) das facies granitóides BASMG, BASAFG e BSG do maciço granitóide Antônio Vicente.

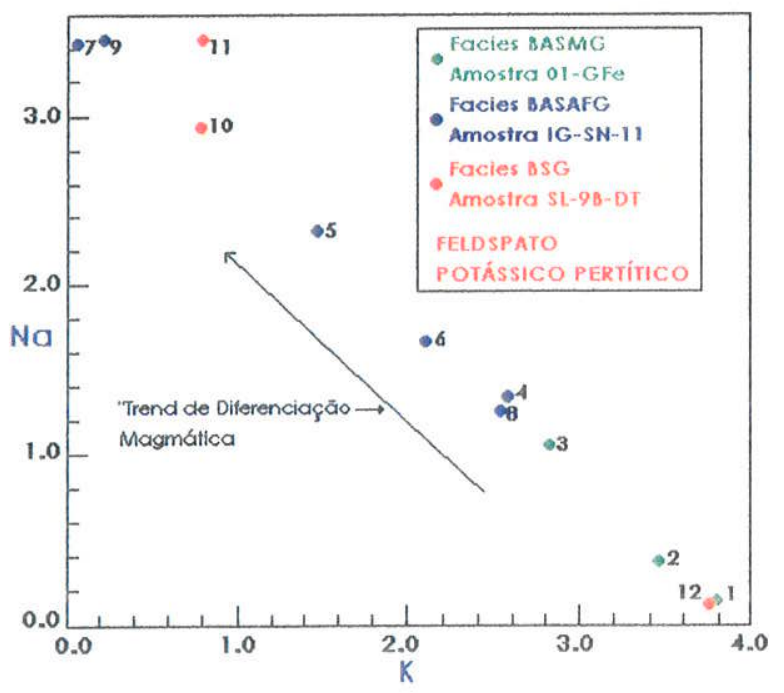

Figura 3.38- Diagrama Na-K mostrando a distribuição composicional das análises de feldspato potássico(microclina pertítica) das facies granitóides BASMG, BASAFG e BSG do maciço granitóide Antônio Vicente. 


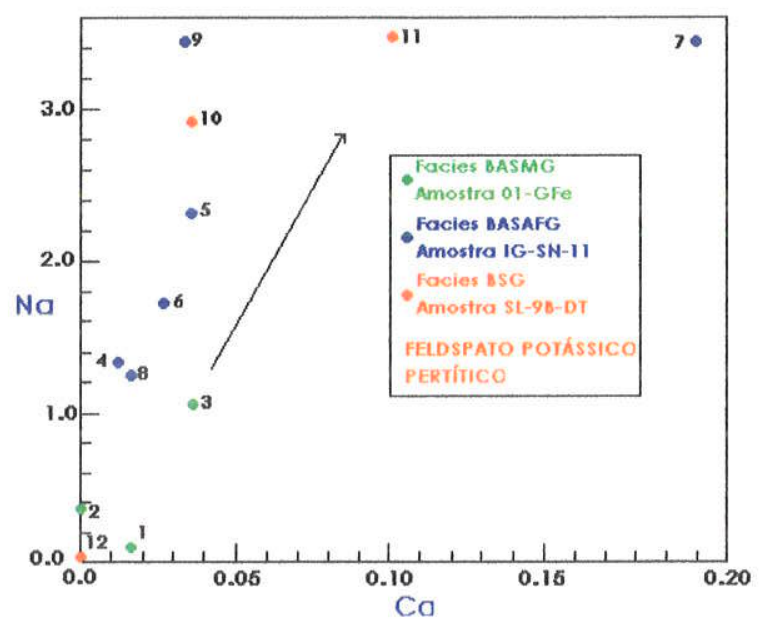

Figura 3.39- Diagrama Na-Ca mostrando a distribuição composicional das análises de feldspato potássico(microclina pertítica) das facies granitóides BASMG, BASAFG e BSG do maciço granitóide Antônio Vicente.

Em relação às condições de cristalização, não foi possível determiná-las visto que a ampla maioria dos cristais encontra-se invariavelmente alterados(albitizados e/ou argilizados), não sendo, portanto recomendada a utilização dos diversos geotermômetros existentes na literatura(Haselton et al., 1983; Brown \& Parsons, 1985; Elkins \& Grove, 1990; Nekvasil, 1994; entre outros). O mesmo é válido para o plagioclásio.

\subsubsection{6- Análises químicas em Plagioclásio}

O estudo de plagioclásio envolveu um total de 15 análises pontuais em grãos de amostras representativas de granitóides, as quais foram assim discriminadas: 1) 04 análises da amostra 01-GFe da facies BASMG. As análises de números 1 e 2 correspondem à porção central do cristal e as análises 3 e 4 à porção entre o centro e a borda do mesmo gão; 2) 02 análises da amostra IG-SN-11 da facies BASAFG, sendo ambas da boda de um mesmo cristal; 3) 09 análises da amostra SL-9B-DT da facies BSG. As análises 7, 8, 9 e 11 referem-se à região central de um mesmo grão e as análises 10, 12 e 15 são oriundas da região de borda de três grãos distintos. As de números 13 e 14 foram realizadas em uma zona levemente microclinizada de um grão amostra SL-9B-DTR da facies BSG. Os resultados analíticos, as fórmulas estruturais calculadas, bem como outros dados encontram-se no Anexo 7.

\subsubsection{1- Composição química}

Em termos composicionais, as análises mostram no conjunto um ampla espectro de variação, especialmente entre a facies BASMG e as facies BASAFG e BSG(Figura 42). A facies $B A S M G$ mostra composições essencialmente andesina, variando entre $\mathrm{An}_{31-32}$, na porções compreendida entre o centro e a borda e $\mathrm{An}_{36-37}$ na região central do cristal estudado. Embora mais precisas, essas composições são coerentes com aquelas determinadas oticamente. As análises referentes à facies BASAFG situam-se no campo 
correspondente à albita, apresentando composição $A n_{2}$, evidenciando um maior empobrecimento de anortita no sentido das bordas do cristal. Esse fato pode refletir uma composição mais sódica do plagioclásio dessa facies em função do seu caráter sieno a álcali feldspato granítico, demonstrando, portanto, uma natureza mais evoluída da mesma em relação à facies BASMG. O que, também, é acompanhado pela composição do plagioclásio. De qualquer modo, como as análises não foram realizadas em todas as porções do cristal, mas apenas nas bordas, essa conclusão fica limitada. No que diz respeito às análises da facies BSG, observa-se uma nítida variação composicional das mesmas, entre $\mathrm{An}_{1-3}$ (bordas) e $\mathrm{An}_{9-12}$ (no centro), evidenciando um zoneamento normal do cristal estudado. As análises 13 e 14 fogem do campo composicional da série dos plagioclásio talvez devido a uma leve microclinização(entrada de $\mathrm{K}$ no lugar do $\mathrm{Na}$ ) na zona analisada. De modo geral, essas composições são mais ou menos coerentes com aquelas determinadas através de microscopia ótica. E o trend composicional, geral, desenvolvido pelas três facies é concordante com aquele demontrado pelos estudos petrográficos.

$A$ análise do diagrama $A b$ contra An(Figura 3.41) mostra um trend de distribuição composicional coerente com o observado acima e ilustra perfeitamente o trend de diferenciação magmática esperado, visto que a facies BASMG tem sido considerada como aquela, relativamente, menos evoluída no âmbito do maciço, enquanto que as facies BASAFG e BSG, representam os termos intermediários e mais evoluídos, respectivamente. Essa conclusão é reforçada quando se observa a Figura 3.42.

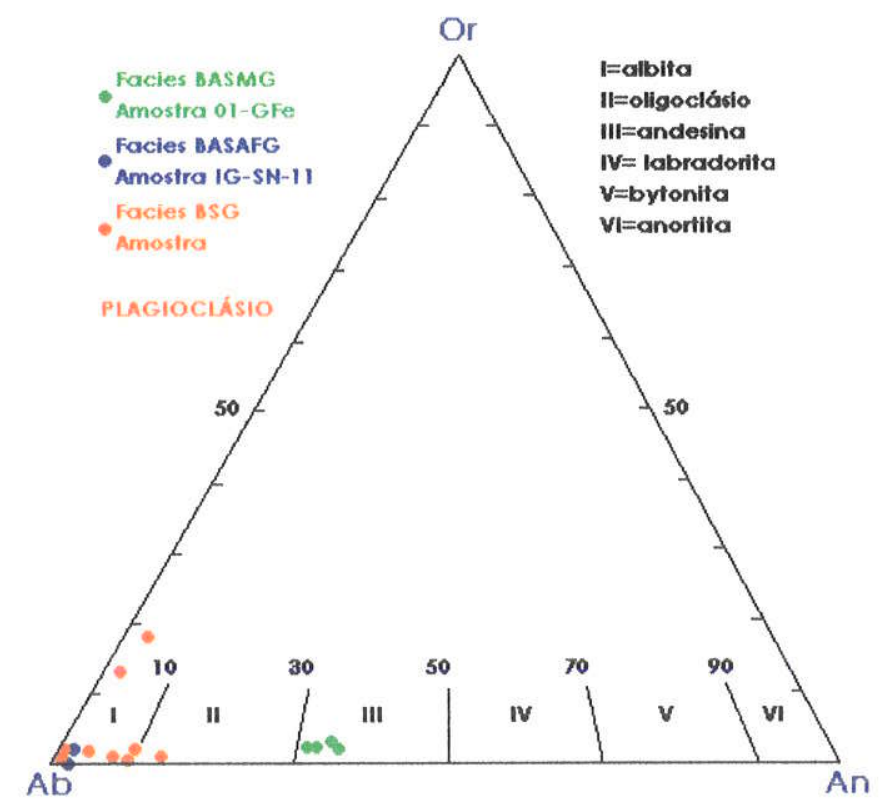

Figura 3.40 Diagrama triangular Ab-Q-An mostrando a distribuição composicional dos plagioclásios das facies granitóides BASMG, BASAFG e BSG do maciço granitóide Antônio Vicente. 


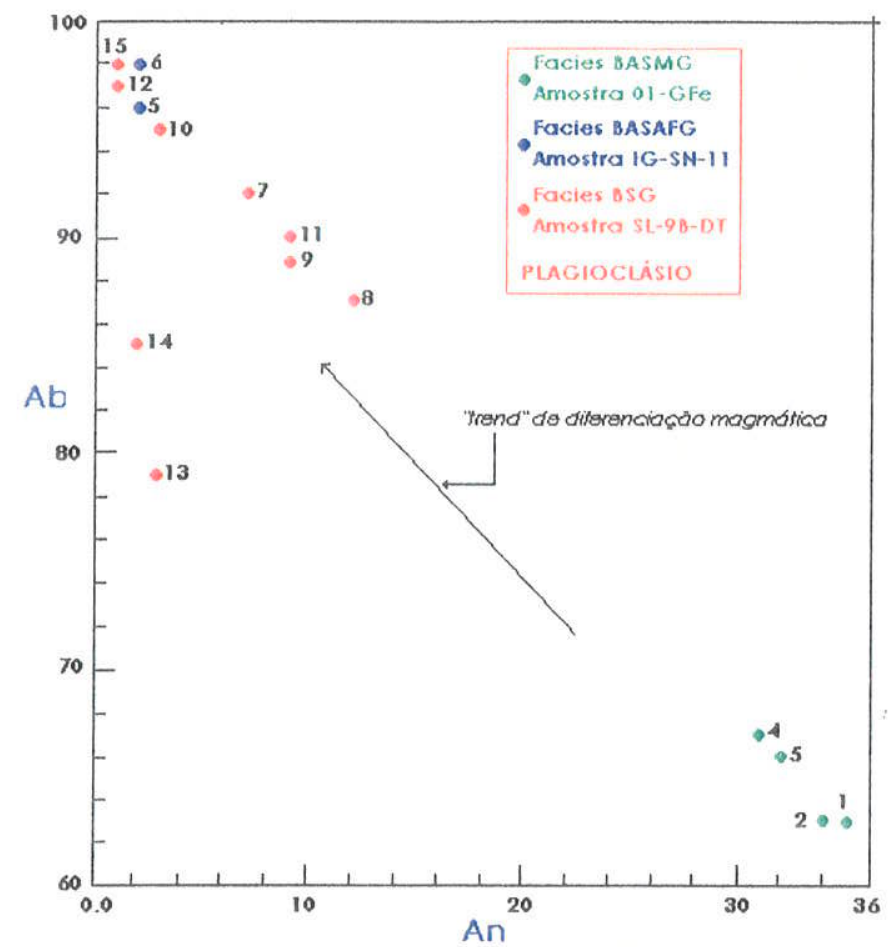

Figura 3.41 Diagrama Ab-An mostrando a distribuição composicional das análises de plagioclásios das facies granitóides BASMG, BASAFG e BSG do maciço granitóide Antônio Vicente.

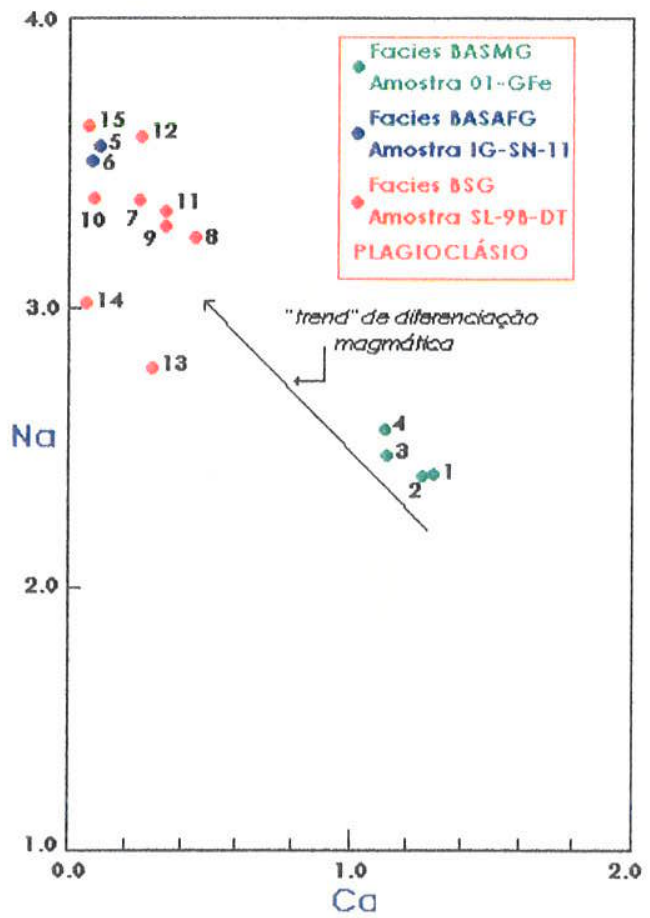

Figura 3.42 Diagrama Na-Ca mostrando a distribuição composicional das análises de plagioclásios das facies granitóides BASMG, BASAFG e BSG do maciço granitóide Antônio Vicente. 


\subsection{2- Análises através de Microscopia Eletrónica.}

No âmbito deste maciço foram realizadas um total de 28 análises semiquantitativas(EDS), com o objetivo de caracterizar fases minerais menores de dificil caracterização através de microscopia ótica ou mesmo através de microssonda eletrônica em virtudo de suas diminutas dimensões, sendo, portanto análises complementares. Elas análises mostram-se discriminadas da seguinte maneira: 1) 08 análises na facies BASMG, amostra 01-GFe, envoivendo 03 análises de ilmenita, 01 de titanomagnetita, 01 de apatita, 01 de titanita e 01 de óxido de ferro(magnetita); 2) 04 análises na facies BASAFG, amostra IG-SN-11, envolvendo 01 análise de apatita, 01 de zircão, 01 de silicato de $\mathrm{Zr}$ (com $\mathrm{Ca}, \mathrm{Y}$, Nd e La em ordem decrescente de abundância) e 01de óxido de Th(com Ca, Ag, Y, Ce, La, Cd, Nd, Bi e Dy em ordem decrescente de abundância); 3) 05 análises na facies BSGA, amostra NN-AV-BA-04, envolvendo 01 análise de ilmenita, 01 de apatita, 01 de monazita, 01 de óxido de $\mathrm{Ce}, \mathrm{La}, \mathrm{Nd}$ e $\mathrm{Ca}$ e 01 de Silicato de $\mathrm{Fe}, \mathrm{Ce}, \mathrm{Nd}, \mathrm{Ca}$ e Bi; 4) 02 análises na facies BSGIA, amostra NE-B-75, envolvendo 01 análise de silicato de Th com $\mathrm{Y}, \mathrm{Ag}, \mathrm{Fe}, \mathrm{Cd}, \mathrm{Bi}, \mathrm{Yb}$ e Sn(em ordem decrescente de abundância) e 01 de zircão; 5) 09 análises no $\mathrm{Cl}$-Sid-MvQtz greisen médio a grosso, amostra NN-AN-IN-10, envolvendo 04 análises de cassiterita, 01 de calcopirita, 01 de kesterita, 02 de xenotima e 01 de monazita. Os Anexos 8, 9, 10, 11 e 12 mostram os resultados analíticos obtidos.

\subsubsection{1- Facies BASMG}

\section{a) IImenita, Titanomagnetita}

São fases acessórias e correpondem à grande parte dos minerais opacos descritos genericamente nos aspectos petrográficos, desse capítulo. Ocorrem tanto como fases primárias $\left(\mathrm{MOP}_{1}\right.$ e $\left.M O P_{2}\right)$ associados à apatita e ao zircão e à desestabilização do anfibólio em favor da biotita, quanto como fases secundárias $\left(M O P_{3}\right)$, intimamente associadas à alteração dessa última e da clorita. A Figura $3.43(a, b)$ mostra uma inclusão de ilmenita+titanomagnetita em anfibólio, bem como a intima relação entre essas duas fases. Observa-se que a ilmenita ocorre segundo, pelo menos, três tipos distintos. A primeira(ilmenita 1), apresenta-se como grão independente, de forma irregular, com contatos retos a lobados com o anfibólio hospedeiro(Figura 3.43a). Encontra-se separado do cristal de titanomagnetita por uma massa intersticial composta, ao que tudo indica, de anfibólio. No seu interior observa-se uma inclusão de apatita. A segunda(ilmenita 2) apresenta-se como intercrescimentos de forma lamelar em planos existentes no interior da titanomagnetita, os quais mostram-se dispostos segundo duas direções principais(Figura $3.43 a$ e b). As lamelas são pouco numerosas e formam uma rede de baixa densidade no cristal hospedeira. O terceira tipo(ilmenita 3) forma manchas ou "petchs" irregulares na titanomagnetita(Figura 3.43a e b). 
A titanomagnetita apresenta-se como um grão bastante fraturado e, conforme visto acima, abriga intercrescimentos de ilmenita tipo "trellis" e tipo grânulos.

Na Figura 3.43c observa-se um cristal independente de ilmenita(ilmenita 1), com contomos subédicos, incluso em anfibólio.

De acordo com as terminologias sugeridas por Buddington \& Lindsley(1964; pg 322 a 323), os intercrecimentos representados pelas ilmenitas 2 e 3(deste trabalho) correspondem aos tipos 2(intercrescimentos tipo "trellis") e 4(grânulos de ilmenita na titanomagnetita), respectivamente, daqueles autores, embora, os grânulos de ilmenita 3 sejam irregulares e angulosos e não arredondados como o termo pode sugerir. Assim, optou-se pela terminologia "ilmenita composta", conforme sugestão de Haggerty(1991, pg.132).

No Anexo 8 observa-se que, embora os três tipos não apresentem grandes variações composicionais, a llmenita 1 é relatvamente mais empobrecida em $\mathrm{Fe}$ (análises por MEV) do que aquelas dos tipos 2 (mais attos conteúdos) e 3 . Os teores de Ti são equivalentes, enquanto que aqueles de Mn caem levemente no sentido da ilmenita 1 para a 3.

Em relação a origem, a do tipo 1, pelas suas características microtexturais, parece ter cristalizado concomitantemente com a titanomagnetita. Isso é evidenciado pelo fato de se encontrarem lado a lado e exibirem dimensöes semelhantes, bem como pela presença uma fina massa de anfibólio entre os dois grãos, decorrente, ao tudo indica, do preenchimento desse interstício existente entre ambos, durante a cristalização do anfibólio hospedeiro. Essa hipótese dependeria, porém da composição geral do magma da qual essas fases cristalizaram(Buddington \& Lindsley, 1964; pg 322). Esses autores, baseandose em estudos de outros pesquisadores sobre o relacionamento microtextural de titanomagnetita e ilmenita de algumas bandas ricas em minerais óxidos da intrusão Skaegaard, mostraram que grãos independentes de ilmenita, foram produzidos a partir da desmistura de uma única fase de solução sólida inicial e que outros óxidos, oriundos de hortonolito -ferrogabbro, foram, em parte, originados a partir da desmistura de uma única fase e, em parte, a partir de coprecipitação. As evidéncias microtexturais àcerca do relacionamento entre 0 grão de ilmenita 1 e o de titanomagnetita(Figura $3.43 a$ e b) indicam que esta última hipótese é a mais plausivel, ou seja, os cristais de ilmenita 1 e de titanomagnetita se precipitaram simultaneamente, logo após que da apatita ter iniciado sua história de cristalização e antes do inicio da cristalização do anfibólio.

Em relação a origem do grão da Figura $3.43 \mathrm{c}$, a mesma hipótese é válida, mudando apenas o momento de sua precipitação. Em outras palavras, foi um grão que se pecipitou sem a companhia da titanomagnetita. O momento pode ter sido um pouco antes da cristalização do anfibólio. Magalhães(1991) estudou grãos independentes de ilmenita associada às facies portadoras de anfibólio e biotita e concluiu que os mesmos teriam sido gerados diretamente a partir do líquido magmático. Essa hipótese é concordante com a 
primeira apresentada acima e está em conformidade com Buddington \& Lindsley(1964). Em relação à ilmenita em grãos isolados pertencente às facies a biotita(não estudada neste trabalho), Magalhães(op. cit.), atribuiu sua origem a processos de transformação dos minerais ferro-magnesianos.

Quanto a ilmenita tipo 2(ilmenita tipo "trellis"), de acordo com Haggerty(1991) é um tipo que resulta claramente de exsolução-oxidação. Schwartz(1931) estabeleceu uma série de critérios para a caracterização de texturas de exsolução. Segundo esse autor, os intercrescimentos consistem de diminutas inclusões de uma determinada fase mineral, as quais mostram-se, geralmente distribuídos segundo direções cristalográficas do cristal hospedeiro(solvente) e suas orientações variam com a orientação do mesmo. Conforme Edwards(1954), as inclusões podem ter formas lamelares, de placas, de folhas ou de barras. A ilmenita aqui estudada se enquadra perfeitamente nesses critérios e, por conseguinte, corresponde a uma ilmenita formada por exsolução-oxidação.

A ilmenita 3(ilmenita composta), por sua vez, pode representar tanto uma fase primária gerada a partir do líquido magmático, quanto pode ser produto de exsoluçãooxidação conforme postulado por Haggerty(1991). Entretanto, se considerada a primeira hipótese(origem primária), essa ilmenita poderia ser correlacionada a ilmenita tipo 1. Nesse caso, representaria uma geração precoce de minerais opacos 1 , que foi englobada pela titanomagnetita e não exsolvida pela mesma. Entretanto, são apenas especulações, visto que, o momento, não existem evidéncias conclusivas à esse respeito.

\section{b) Apatita}

A apatita ocorre segundo grão arredondados inclusos na ilmenita 1 (grão independente), bem como ao contato com a ilmenita 3. Quimicamente, apresenta composição semelhante aquelas apresentadas por Deer et el.(1966; pg 534) e Botelho(1992), no que diz respeito aos conteúdos aos elementos maiores. Em relação aos elementos menores, mostra-se empobrecida em ETR e contem cerca de 1,2\% de $\mathrm{Y}$. $O$ não fornecimento das quantidades de $\mathrm{F}, \mathrm{Cl}, \mathrm{H}_{2} \mathrm{O}$ e $\mathrm{C}$ pelo MEV não permitiu classificá-la em relação os membros extremos da série isomórfica(fluor-apatita, clorapatita, hidroxiapatita e carbonato apatita; Deer et al., 1966, pg. 531).

\section{c) Titanita e Magnetita}

A Figura $3.43 \mathrm{~d}$ mostra a íntima relação da magnetita com a titanita no interior de um cristal de anfibólio. Verifica-se que a magnetita se encontra intensamente fragmentada e preenchida por uma massa intersticial constituida essencilmente por titanita. As relações microtexturais entre essas duas fases e o grão de anfibólio hospedeiro permitem, estabelecer, pelo menos, duas hipótese de interpretação: 1) que as mesmas representam 
produtos da reação parcial do anfibólio com o líquido magmático e na consequente formação de biotita(conforme visto no item Aspectos Petrográficos deste capítulo), já que o anfibólio, nesta área, mostra-se parcialmente alterado(biotitizado); 2) que a magnetita é uma fase precoce em relação ao anfibólio, enquanto que a massa intersticial, correspondente quimicamente a titanita, seja um produto local da desestabilização do anfibólio em pról da biotita. Isso é reforçado pela aspecto do cristal de magnetita, bem como pela presença de cristais euédricos a subédricos de apatita proximos à magnetita, indicando que apatita e magnetita se precipitaram dentro de um mesmo intervalo de temperatura, antes do anfibólio ter iniciado sua história de cristalização. Embora não se descarte a primeira hipótese, a segunda parece mais plausivel. Os resultados análíticos obtidos para essas duas fases encontram-se no Anexo 8.
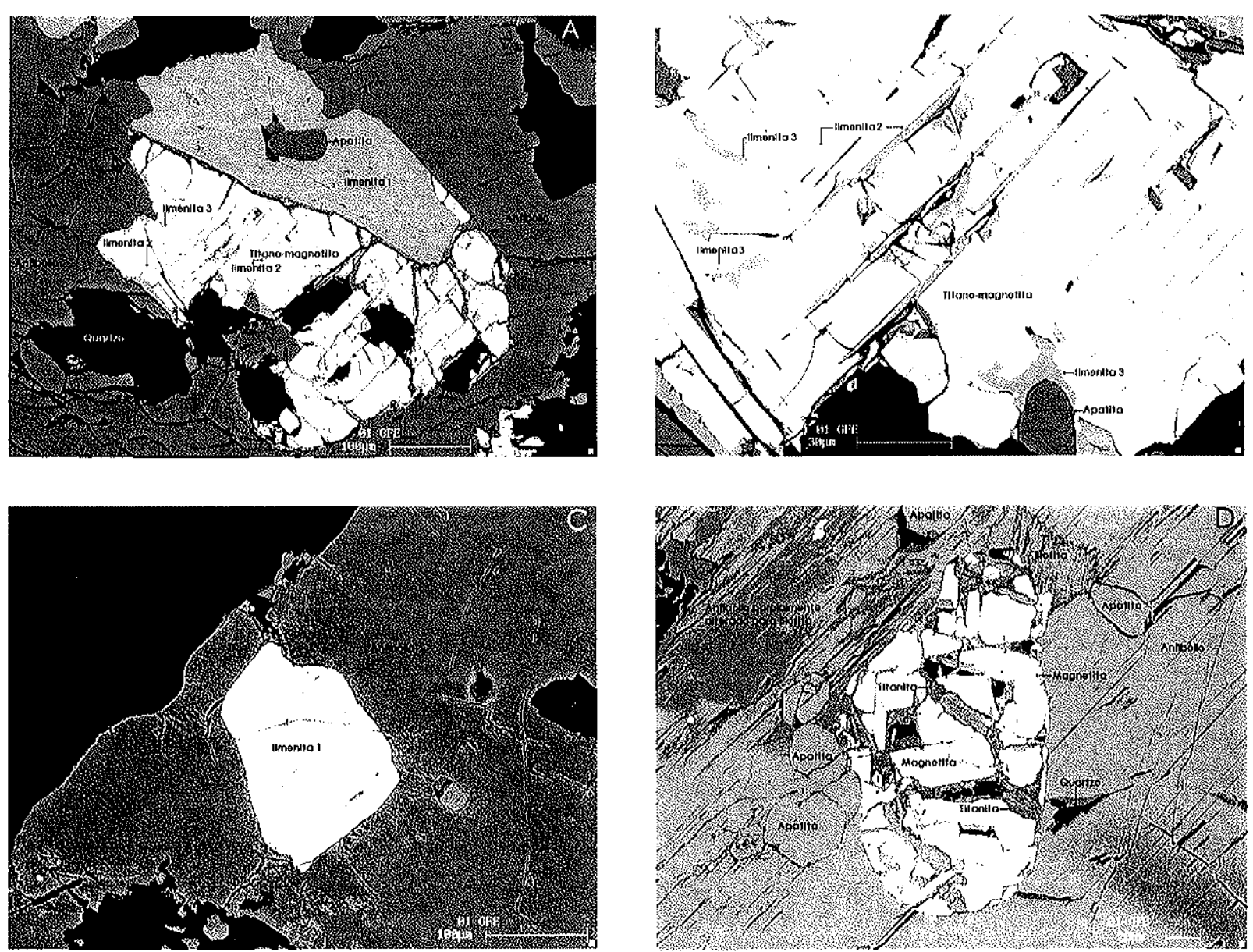

Figura 3.43. (a) relacionamento microtextural envolvendo as variedades de llmenita(ilm1, ilm2 e ilm3) e titanomagnetita; (b) detalhe do relacionamento existente entre ilm 2 e ilm3 e titanomagnetita; (c) detalhe de uma inclusão de ilm1 em cristal de anfibólio; (d) detalhe do intimo relacionamente microtextural desenvolvido ente magnetita e titanita. Facies granitóide BASMG. Maciço granitóide Antônio Vicente. 


\subsubsection{2- Facies BASAFG}

Nessa variedade de granitóide as análises semi-quantitativas(EDS) por microscopia eletrônica de varredura revelaram, na amostra IG-SN-11, a presença de apatita e zircão( já observados através de microscopia ótica) e de óxido de Th(Figura 3.44). Todas essas fases correspondem a minerais primários, visto que ocorrem como inclusões na biotita e e não foram observadas evidências microtexturais que apontassem para uma origem secundária. O Anexo 9 mostra os resultados analíticos obtidos em relação a essas fases minerais.

\section{a) Apatita}

No que se refere a apatita não foram confeccionadas imagens. Assim, serão abordadas aqui apenas suas principais características quimicas. $O$ grão analisado apresenta composição levemente diferente daquele apresentado anteriormente, pertencente a facies BASMG. Ele é relativamente mais pobre em $\mathrm{P}$ e $\mathrm{Ca}$ e, mostra conteúdos mais altos de silício. Apresenta teores mais elevados de ETR(Dy, Ce, La e Nd) e de Y. As considerações realizadas acima em relação a impossibilidade de classificação da apatita da facies BASMG, dentro dos quatro componentes extremos da série isomórfica, são válidas aqui.

\section{b) Zircão e Silicato de Zr e Ca}

Foi realizada apenas uma análise em zircão. O grão estudado(Figura 3.44a)mostra forma subédrica a euédica e apresenta-se nitidamente zonado. Quimicamente, é muito pobre em ETR e em Y. Além do zircão, foi realizada, ainda, uma análise em uma fase silicátca rica em $\mathrm{Zr}$, com Ca presente (Figura 3.44b). O grão estudado encontra-se parcialmente incluso em um grão de óxido de Th(ver mais adiante), mostra-se fraturado e apresenta-se nítidamente fraturado. É, texturaimente, muito semelhante ao zircão.

$\mathrm{Na}$ análise do Anexo 9 , observa-se que o zircão não apresenta nenhuma feição importante. E extremamente pobre em $\mathrm{Y}, \mathrm{Nb}$ e $\mathrm{Sn}$. Em relação às terras raras, possui baixos conteúdos de $\mathrm{Yb}$ e $\mathrm{Nd}$.

O cálcio-silicato de $\mathrm{Zr}$, por sua vez, comparativamente ao zircão, mostra mais baixos teores de $\mathrm{Si}$ e de $\mathrm{Zr}$ e é exaurido em $\mathrm{Sn}, \mathrm{Nb}$ e $\mathrm{Yb}$. Por outro lado, apresenta teores relativamente mais elevados de $\mathrm{Y}, \mathrm{Ce}, \mathrm{La}$ e $\mathrm{Nd}$, bem como contém cerca de $2,4 \%$ de $\mathrm{Ca}$. $\mathrm{A}$ presença desse elemento e de Al impedem classificá-lo como zircão. A ausência Fe e os relativamente baixos teores de Al não permitem enquadrá-lo no grupo do epidoto, embora o teor de Ca seja coerente com aquela da allanita(por exemplo). Assim, com base em aspectos texturais e nos principais tipos de estruturas dos minerais de ETR, Th, U, Zr e Hf, apresentados por Ewing \& Chakoumakos(1982; pg. 244), chegou-se a conclusão de que pode se tratar: 1 ) de um cristal de armstrongita( $\left.\mathrm{CaZrSi} \mathrm{O}_{15} .2,5 \mathrm{H}_{2} \mathrm{O}\right)$, filossilicato de cálcio e 
zircônio, ocorrente em pegmatitos graníticos alcalinos do maciço "KhanBogdinskii(Mongólia), caracterizado e definido porr Vladykin et al.(1974) e apresentado por Fleischer(1974)). De acordo com esse autor, essa designação foi uma homenagem a Neil A. Armstrong(primeiro homem a pisar na superfície da Lua). É um mineral de cor marrom, brilho vítreo e muito frágil(quebradiço). Não é atacado por $\mathrm{HCl}$ ou $\mathrm{HNO}_{3}$, embora seja dissolvido por HF(Fleischer, op. cit.). Pelo menos uma dessas características pode ser observada na Figura $3.44 \mathrm{~b}$ e diz respeito a natureza quebradiça do cristal analisado; 2) de um silicato designado de cálcio-catapleita $\left(\mathrm{CaZrSi}_{3} \mathrm{O}_{9} \cdot 2 \mathrm{H}_{2} \mathrm{O}\right)$, caracterizado e definido por Portinov(1964) e apresentado por Fleischer(op. cit.; pg. 1153). Ele foi definido em pegmatitos sieníticos do maciço alcalino de Burpala, do norte de Baikal, em cavidades entre cristais de microclina, associado com pirofanita, pirocloro, titanolavenita, loparita, kupletskita, apatita rica em ETR e hiortdalita. Suas principais cartacterísticas óticas são a coloração amarelo pálido a creme e brilho vítreo a opaco(Fleischer, op. cit.). Devido a reduzida dimensão do cristal, aqui estudado, não foi possivel observá-lo, claramente, através de microscopia ótica. Entretanto, em relação associação paragenética da catapleita, apresentada acima, sabe-se que a apatita rica em ETR é uma fase presente na amostra aqui estudada, embora ela seja uma fase claramente primária, enquanto que aquela da paragênese descrita acima por Fleischer(op. cit.), ao que tudo indica, é de origem secundária(visto que ocorre preenchendo cavidades). Para esclarecer essa dúvida necessita-se de dados de raios- $X$ sobre a estrutura cristalina da mesma, não disponiveis no momento.
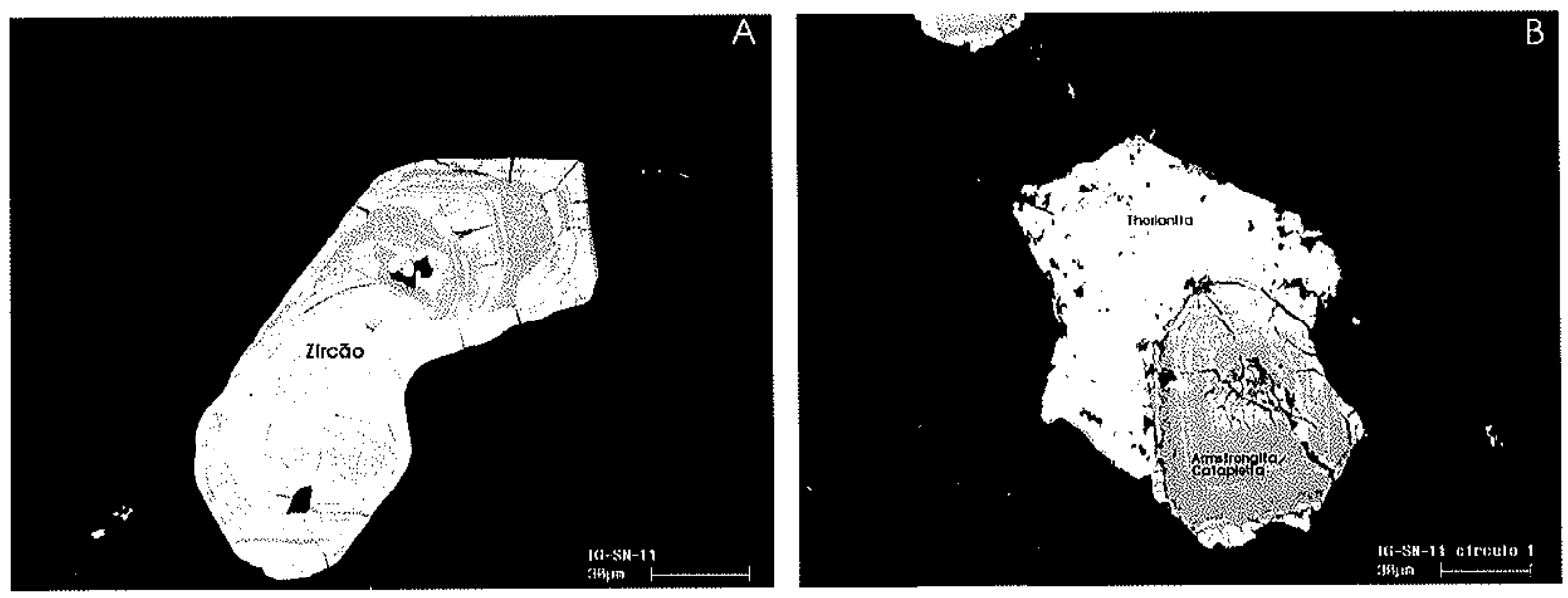

Figura 3.44- (a) aspecto microtextural do zircão; (b) detalho do relacionamento microtextural entre armstrongita/catapleita e a thorita. Facies granitóide BASAFG. Maciço granotóide Antônio Vicente.

\section{c) Óxido de Th}




\section{c) Óxido de Th}

Esse mineral apresenta-se sob a forma subédrica a euédrica e hospeda, além armstrongita/cálcio-catapleita, diminutos cristais não caracterizados neste trabalho(Figura $3.44 b)$. Isso evidencia uma cristalização tardia em relação as mesmas, e ao que tudo indica, secundária. Quimicamente, em termos dos elementos maiores, exceto ○ $\mathrm{Ca}$, é muito semelhante a thorianita(ver Ewing \& Chakoumakos, 1982; pg. 241) Exibe teores relativamente elevados de $\mathrm{Ca}, \mathrm{Ag}, \mathrm{Y}, \mathrm{Ce}$ e mais modestos de $\mathrm{Si}, \mathrm{La}, \mathrm{Cd}, \mathrm{Nd}, \mathrm{Bi}$ e $\mathrm{Dy}$, bem como baixíssimas quantidades de $\mathrm{Sn}$.

\subsubsection{3- Facies BSGA}

No âmbito dessa facies foram caracterizadas na amostra NN-AV-BA-04 as fases apatita, ilmenita, monazita, óxido de $\mathrm{Ce}, \mathrm{La}, \mathrm{Nd}$ e $\mathrm{Ca}$ (em ordem decrescente de abundáncia) e bodenita(silicato de $\mathrm{Fe}, \mathrm{Ca}$ e ETR).

\section{a) Apatita}

Embora não se disponha de imagem dessa apatita, as observações na imagem do vídeo acoplado ao MEV mostraram que ela se apresenta sob a forma de grãos euédricos a subédricos, ora prismáticos e alongados, ora como polígonos aproximadamente hexagonais. Eles ocorrem tanto como inclusões na ilmenita e biotita, quanto em contato com a primeira. Essas características microtexturais indicam que a mesma corresponde a uma fase primária. A análise do Anexo 10 mostra que, comparativamente a apatita das facies BASMG e BASAFG, ela possui teores relativamente mais elevados de $\mathrm{Y}, \mathrm{Yb}, \mathrm{Dy}, \mathrm{Ce}$, La do que a aquela da facies BASMG e de $\mathrm{P}, \mathrm{Ca}, \mathrm{Yb}$ e Dy do que aquela da facies BASAFG. Por outro lado, mostra-se, relativamente, mais empobrecida em $\mathrm{P}, \mathrm{Nb}, \mathrm{Nd}$ e $\mathrm{Ca}$ em relação a apatita da facies BASMG e em y, $\mathrm{Nb}, \mathrm{Ce}$, La e Nd do que aquela da facies BASAFG. De qualquer modo, observa-se que, no geral, ela tem afinidades quimicas tanto com a apatita da facies BASMG, quanto com a apatita da facies BASAFG.

\section{b) Ilmenita}

Do mesmo modo que a apatita, não foram obtidas imagens da ilmenita. Observações realizadas através de microscopia ótica adicionadas as análises EDS(em MEV) mostraram que ela é a fase óxido dominante. Ela ocorre como grãos anédricos, os quais mostram-se, geralmente, inclusos e/ou em contato com a biotita. As vezes, hospeda inclusões de apatita. O tipo mais comum corresponde a ilmenita em grãos independente, não associados a titanomagnetita e corresponde ao tipo 1, estudado na facies BASMG.

No Anexo 10, verifica-se que a ilmenita, aqui estudada, mostra teores mais baixos de $\mathrm{Fe}$ e $\mathrm{Ti}$, relativamente àquelas ocorrentes na facies BASMG, sendo, contudo, mais 
enriquecida em Mn. Uma diferença característica da ilmenita 1, ocorrente nas facies BASMG e BSGA, em relação aquelas dos tipos 2 e 3("trellis" e em granulos, respectivamente), ocorrentes na facies BASMG, são mais baixos conteúdos de Fe e os mais altos de Mn.

\section{c) Monazita}

É uma fase pouco abundante. O grão analisado mostra-se intimamente associado a cloritização da biotita(Figura 3.45 a, b). Apresenta forma anédrica e, em microscopia ótica, exibe cores de interferência altas, traduzidas pela mistura de azul cintilante, rosa, amarelo e vermelho. Localmente, mostra-se parcialmente substituída por óxido de $\mathrm{Ce}, \mathrm{La}, \mathrm{Nd}$ e Ca e por bodenita(aluminossilicato de Fe, $\mathrm{Ca}$ e ETR). Suas relações microtexturais com a biotita cloritizada evidenciam claramente que a mesma é uma fase secundária, formada, ao que tudo indica, às expensas dessa mica. É importante ressaltar que nas observações realizadas através de microscopia ótica, a biotita hospedeira da monazita em questão, exibe, nas regiões não afetadas por cloritização, coloração marrom avermelhada e cores de interferência altas, lembrando muito, nesses propriedades óticas, a siderofilita estudada no ambito do maciço granitóide Mocambo.

Em relação ao seu quimismo, mostra-se enriquecida em Ce e La e apresenta quantidades apreciáveis de Th, Nd e Y(Anexo 10). Essas características químicas, especialmente, a presença de Th, permitem classificá-la como monazita-Ce(La, Ce, $\mathrm{Nd}$, Th) $\mathrm{PO}_{4}$, conforme Jones et al.(1996; pg. 354).
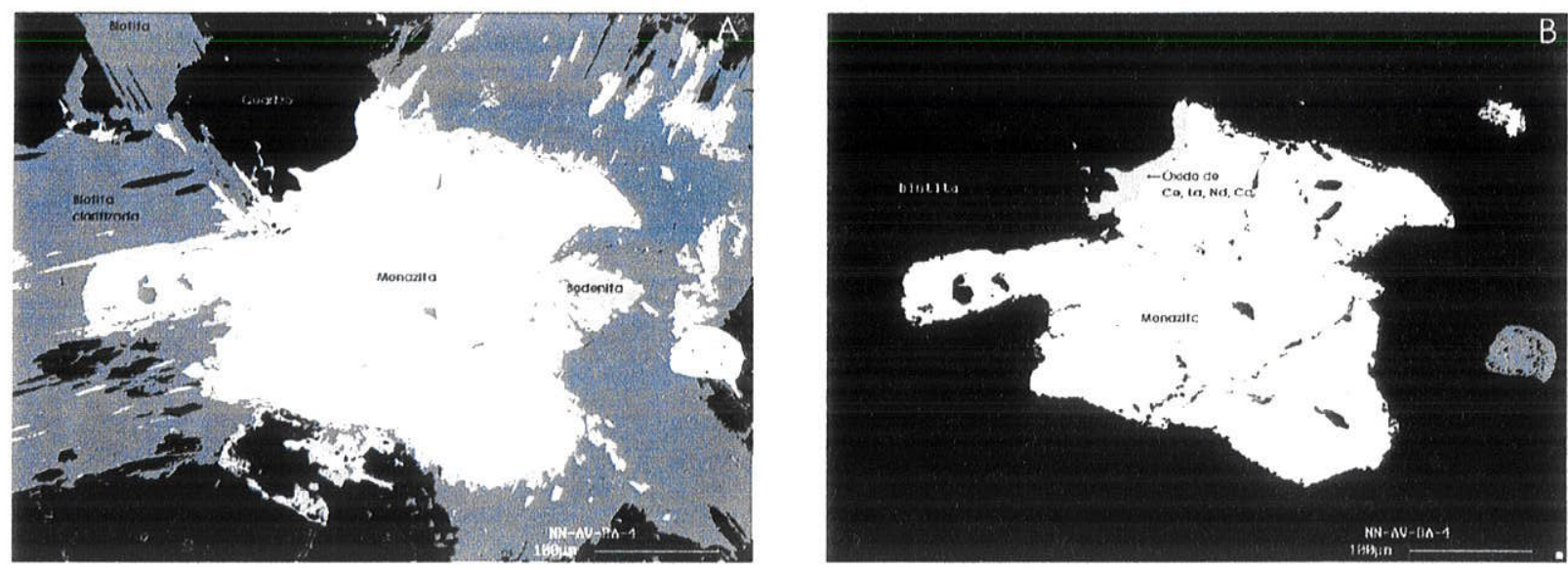

Figura 3.45. (a) Aspecto microtextural mostrando o relacionamente entre monazita, óxido de Ce, La, $\mathrm{Nd}$ e Ca e bodenita, intimante associados a cloritização da biotita; (b) Detalhe da monazita apresentada na Figura 5.43a. 


\subsubsection{4- Facies BSGIA}

As fases minerais caracterizadas nesta facies foram zircão e thorita, pertencentes a amostra NE-B-75. Essas duas fases apresentam-se como diminutos grãos subédricos, os quais mostram-se inclusos em clorita $\left(\mathrm{Cl}_{2}\right)$, com a qual desenvolvem nitidos halos pleocróicos. Suas relações microtexturais com a clorita, bem como suas formas levam a se crer que são fases primárias, que foram, ao que tudo indica, capturadas pela biotita primária, da qual foi gerada a clorita, no estágio de alterações tardi a pós-magmáticas, que afetaram essa facies granitóide de modo intenso.

No Anexo 11 nota-se estabelecer que o zircão $\left(\mathrm{ZrSiO}_{4}\right)$ é uma fase impura, caracterizada pela presença de quantidades algo expressivas de $Y$, bem como por conteúdos mais modestos de $\mathrm{Ag}, \mathrm{P}, \mathrm{Yb}, \mathrm{Cd}, \mathrm{Al}, \mathrm{Fe}, \mathrm{Sn}, \mathrm{Nb}, \mathrm{Bi}$, Dy e $\mathrm{Ce}$.

Do mesmo modo que o zircão, observa-se no Anexo 10 que a thorita(ThSiO4) é também uma fase impura, visto que hospeda quantidades relativamente importantes de $Y$, $\mathrm{Ag}, \mathrm{Fe}$ e $\mathrm{Cd}$ e pequenos teores de $\mathrm{Bi}, \mathrm{Y}, \mathrm{Sn}$, Dy e $\mathrm{P}$.

Resguardado-se as devidas proporçōes dos elementos presentes no zircão e na thorita, nota-se que, exceto pela presença de $\mathrm{Zr}$ e Ce no primeiro e de Th no segundo, as composiçőes de ambos são muito semelhantes. De acordo com Ewing \& Chakoumakos(1982; pg. 239), elementos tais como $\mathrm{Zr}$ e $\mathrm{Th}$, ocorrentes em pegmatitos graníticos, não ocorrem com freqüência em estruturas nas quais eles são componentes principais, mas podem ocorrer, por substituiçőes isomórficas, como componentes menores ou maiores em outras estruturas. Por essa razão, é válida a hipótese de que a thorita seja uma fase em que o Th substituiu isomorficamente o zr na estrutura do zircão. Essa substituição poderia ter ocorrido tanto no estágio magmático, quanto a thorita poderia representar uma fase tardia. Entretanto, no momento, não se dispõem de dados conclusivos à esse respeito, como por exemplo informações sobre a estrutura cristalina através de difração de raios-X.

\subsubsection{5- Greisen}

Foi analisada através de MEV a amostra NN-AV-IN-10(clorita-siderofilita-muscovitaquartzo greise médio a grosso). As fases estudadas foram cassiterita, calcopirita, kesterita/estanita, xenotima e monazita.

\section{a) Cassiterita}

Foram realizadas quatro análises de cassiterita, as quais envolveram quatro cristais distintos. Não foram confeccionadas imagens dos grãos analisados, mas uma descrição sobre as propriedades óticas desse mineral constam no item Aspectos Petrográficos desse capítulo. Os resultados análíticos encontram-se no Anexo 12 
O Anexo 12, revela que os grão analisados não exibem variações composicionais importantes. Os conteúdos de Sn situam-se entre $78,596 \%$ e $79,174 \%$, observa-se a presença de pequenos teores de $\mathrm{Fe}$ em todos os grãos e nota-se a presença de quantidades ínfimas de $\mathrm{Nb}$ nos grãos 1 e 2 e de Ta no grão 3 . Essas características evidenciam um grau elevado de homogeneidade composicional dos grãos estudados. Embora, virtualmente todas as cassiteritas sejam micro-não homogéneas e contenham inclusões de vários outros minerais, é verdade também, que cassiteritas de granitos a metais raros e pegmatitos são as mais puras e os seus conteúdos de microinclusões são mais baixos(Foord, 1982). De acordo com Voronina et al.(1978. In: Foord, 1982), parece que isso é devido não tanto quanto a ausência de desmisturas mecânicas de outros minerais, quanto ao seu maior tamanho. É provável então, que a relativa pureza dos grãos estudados deva-se, principalmente, ao tamanho dos cristais que são, de fato, muito finos.

Comparativamente a cassiteritas de outras regiões, mostra-se relativamente mais enriquecida em $\mathrm{Sn}$ do que as cassiteritas associadas ao granito Mangabeira, Goiás(Botelho, 1992; pg 308) e ao maciço Oriente Novo, Rondônia(Leite Jr., 1992) e apresenta teores equivalentes aquelas das diferentes bandas de cassiterita ocorrentes em veios de quartzo da Mina Elúvio-Barranco Superior, Rondônia(Leite Jr., 1992).

\section{b) Calcopirita}

O grão estudado ocorre intimamente associada a clorita $\left(\mathrm{Cl}_{2}\right)+$ siderofilita+ muscovita $\left(\mathrm{Mv}_{2}\right)+$ quartzo tardio, fases secundárias associadas ao estágio de alteraçōes tardi a pós-magmáticas que culminaram com greisenização. A calcopirita, devido estar ausente nas facies granitóides estudadas e restringir sua ocorrência aos greisens, representa um produto secundário. Apresenta forma anédrica, exibe bordas corroídas e, por vezes, substituídas por kesterita/estanita(Figura 3.46a) e mostra-se intensamente fraturada.

$\mathrm{Na}$ análise do Anexo 12, observa-se que, composicionalmente, contém quantidades apreciáveis de $\mathrm{Fe} \mathrm{e} \mathrm{Cu}(30,792 \%$ e $33,894 \%$, respectivamente) e baixíssimos conteúdos de Zne As.

\section{c) Kesterita/Estanita}

Esta fase mineral mostra-se restrita as bordas de substituição da calcopirita(Figura 3.46a) e, ao que tudo indica, representa uma fase secundária. A observação do Anexo 12, revela que se trata de um sulfeto de $\mathrm{Zn}, \mathrm{Cu}$ e $\mathrm{Sn}$, com quantidades apreciáveis de $\mathrm{Fe}$, podendo representar tanto kesterita, quanto estanita. De acordo com Hall et al.(1978) kesterita e estanita são estruturalmente distintas. Conforme esses autores, a principal diferença estrutural é que na estanita os átomos de $\mathrm{Fe}$ e $\mathrm{Zn}$ participam das camadas $\mathrm{Z}=0$ e 
$\mathrm{Z}=1 / 2$ do metal, juntos com o $\mathrm{Sn}$, enquanto que na kesterita essa camadas são ocupadas pelos átomos de Cu e Sn.

No caso do sulfeto estudado, não se dispõem de dados acerca da estrutura cristalina do mesmo. Entretanto, de acordo com Foord(1982), a presença de Fe em quantidades apreciáveis é uma feição freqüente na kesterita. Isso é coerente em relação ao sulfeto estudado, embora esse dado não permita concluir de forma inequívoca sobre essa questão e a dúvida permanece.

\section{d) Xenotima-(Y) e Monazita-(Ce)}

Os grão analisados ocorrem como minúsculos cristais subédricos a euédricos, intimamente associados a clorita( $(\mathrm{Cl} 2)+$ siderofilita+quartzo tardio(Figura $3.46 \mathrm{~b}$ ). Os grãos de xenotima apresentam-se internamente zonados e exibem, invariavelmente, bordas de substituição.

Quimicamente, observa-se uma ligeira variação composicional entre as diferentes zonas(zonas de tonalidades cinza e branca; Figura 3.46b; Anexo 12). As porções cinza correspondem composicionalmente a típica xenotima-Y(de acordo Jones et al., 1996), visto que são constituídas essencialmente de $P, O$ e $Y$, embora hospedem infimas quantidades de $\mathrm{Al}, \mathrm{Fe}, \mathrm{Ag}, \mathrm{Nb}, \mathrm{Sn}$ e $\mathrm{Cd}$. As zonas brancas, embora não fujam dessa designação, mostram-se algo enriquecidas em $\mathrm{Yb}$ e Dy e relativamente empobrecidas em $\mathrm{P}, \mathrm{O}$ e $\mathrm{Y}$. Uma comparação do quimismo da xenotima, aqui estuda, com o quimismo da xenotima, oriunda de pegmatitos da Península de Kola, fornecida por Belolipetskii \& Voloshin(1996; pg. 322), revela que as zonas cinzas da xenotima, aqui estudada, são muito mais enriquecida em $Y$ e mostra-se exaurida em ETR. As zonas de brancas, são também mais enriquecidas em $Y, Y b$ e Dy, quando comparada à análise 2, daqueles autores, embora apresente-se muito mais empobrecida em $\mathrm{Yb}$ em relação a análise 1dos mesmos. A monazita, por sua vez, apresenta-se como um grão subédrico, sem variações composicionais internas aparentes(Figura 3.46b). Quimicamente, mostra teores elevados de Ce e La e quantidades mais modestas de $\mathrm{Nd}$, Th e $\mathrm{Y}$. De acordo com Jones et al.(1996) essa composição corresponde a monazita-Ce. Além desses componentes maiores, hospeda reduzidas quantidades de $\mathrm{Bi}, \mathrm{Nb}, \mathrm{Si}, \mathrm{Al}, \mathrm{Yb}, \mathrm{Fe}, \mathrm{Dy}$ e $\mathrm{Sn}$ (em ordem decrescente de abundância relativa). Comparativamente à monazita estudada na facies BSGA, exibe conteúdos mais elevados de $\mathrm{P}, \mathrm{Ce}$, La e Nd e mais baixos de $\mathrm{Y}$, Th e $\mathrm{O}$.

Em relação a origem da xenotima e monazita, suas relações microtexturais com as outras fases presentes na amostra analisada e a forma subédrica do grão de xenotima, não fornecem dados conclusivos à esse respeito. Entretanto, considerando-se que essas fases não foram detectadas em amostras de facies granitóides pouco efetadas por alteraçőes tardi a pós-magmáticas, pressupõem-se que as mesmas tenham suas origens relacionadas ao 
estágio de alterações tardi a pós-magmáticas que culminaram com a greisenização. Isso é reforçado pelas características da monazita associada a facies BSGA, cujas relações microtexturais indicam claramente uma origem tardia.

Na Península do Kola, Rússia, minerais de Y e ETR, tais como xenotima e monazita, ocorrem associados a complexos rochosos do Arqueano Superior-Estágio Kola(2.800-3.000 Ma) e mostram-se relacionadas a granitos alterados metassomaticamente((Belkov, 1979. In: Belolipetskii \& Voloshin, 1996), com a xenotima ocorrendo, ainda, em pegmatitos contendo micas e metais raros, onde processos de albitização e silicificação foram importantes(Kalita, 1961. In: Belolipetskii \& Voloshin, 1996). A monazita ocorre, também, em complexos do Proterozóico Inferior-Estágio Kareliano(1.700-2.400 Ma), da mesma península, onde mostrase relacionada a produtos finais de intrusões graníticas peralcalinas(silexitos; Belkov et al., 1988. In: Belolipetskii \& Voloshin, 1996) e a metassomatitos apograníticos do PaleozóicoEstágio Caledoniano-Herciniano, onde mostra-se associada a pegmatitos alcalinos e em veios hidrotermais(Semenov, 1972; Khomyakov, 1990. In: Belolipetskii \& Voloshin, 1996).

Considerando os dados apresentados acima, bem como os vários ambientes de ocorrências desses fosfatos(de Y e ETR), nos já bem estudados depósitos da Península do Kola(Rússia), observa-se que uma origem secundária para as mesmas é a mais coerente.
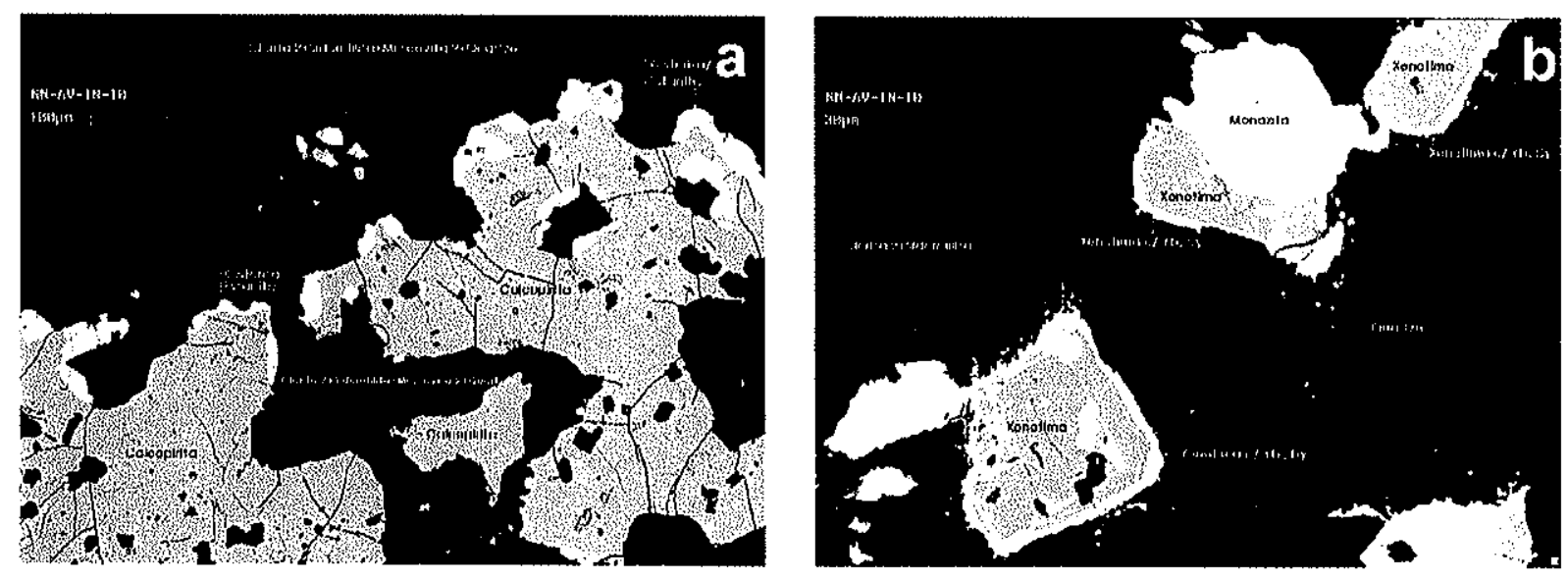

Figura 3.46- (a) aspecto e relacionamento desenvolvido entre calcopirita e kesterita; (b) Detalhe da monazita e xenotima. Clorita-siderofilita-muscovita-quartzo greisen associado ao maciço granitóide Antônio Vicente.

\subsection{3- Conclusões e Considerações finais}

Os trabalhos de fotointerpretação e de amostragem aliados aos estudos petrográficos e às análises realizadas através de microssonda eletrônica e de microscopia ótica de varredura, conduziram às seguintes conclusões àcerca dos granitóides do maciço granitóide Antônio Vicente, bem como dos corpos de greisen a ele associados: 
1) O maciço granitóide Antônio Vicente é constituído por diversas facies petrográficas representadas, principalmente, por granitóides a biotita e anfibólio, de composiçőes monzogranítica, sienogranítica e álcali-feldspato granítica, granitóide a biotita, dominantemente monzogranítico e granitóides a biotita sieno a monzograníticos. Eles são, de um modo geral, heterogranulares e, às vezes, equigranulares, de granulação média a grossa e coloração variável, incluindo tipos rosa, rosa-acinzentados, cinza e vermelho tijolo. Localmente, ocorrem tipos granitóides finos traduzidos por micromonzogranito e sieno a monzogranito granofírico, bem como zonas e corpos de mica greisens, veios hidrotermais(à base de clorita) e veios de fluorita;

2) suas composições modais demonstram que se trata de granitóides leucocráticos a hololeucocráticos que evoluíram a partir de magmas muito diferenciados e silicosos;

3) de um modo geral, eles mostram-se afetados, em diferentes intensidades, por alterações tardi a pós-magmáticas, dominantemente, pervasiva, embora, localmente, possam apresentar características de alteraçăo fissural. Elas se desenvolveram segundo dois episódios autometassomáticos principais, os quais apresentam, por vezes, superpostos. As evidências petrográficas mostraram que o primeiro episódio é dominantemente potássico, enquanto o evento subseqüente mostra natureza sódica. Os estágios finais dessas alterações estão representados por argilização e silicificaçăo, culminando com greisenização. As facies granitóides mais intensamente alterados e os greisens hospedam mineralização de cassiterita, fluorita e, subordinadamente, topázio, bem como outras fases minerais menores;

4) a ausência de estruturas, de natureza tectogênica, marcantes no interior do corpo, o seu caráter francamente discordante em relação aos "trends" estruturais regionais das suas encaixantes, bem como a presença de intercrescimentos gráficos e granofíricos em grande parte dos granitóides do maciço, evidenciam que a colocação dos corpos granitóides se deu em nivel crustal alto, com a relação cristais-liquido não tendo sido muito elevada quando da colocação;

5) os estudos de química mineral mostraram que os anfibólios das facies BASMG e BASAFG pertencem ao grupo dos anfibólios cálcicos. com as amostras da facies BASMG correspondendo, dominantemente, à hastingsita. No que diz respeito às amostras da facies BASAFG, todas as amostras "plotaram" em cima da linha limítrofe entre os campos da hastingsita e da ferro-edenita. Devido todas as amostras apresentarem $\mathrm{Al}^{\mathrm{N}}>1,00$, foram designados de aluminiohastingsita a alumínio-ferro-edenita; 
6) apesar da grande semelhança entre os dois grupos de anfibólios estudados, aquele pertencente a facies BASMG se distinguiu claramente daquele da facies BASAFG, devido as, relativamente, mais elevadas quantidades de Si no anfibólio da primeira, em relação à ampla maioria das amostras desta última facies e, principalmente, devido o anfibólio da facies BASAFG possuir conteúdos muito mais baixos de $\mathrm{Mg}$ e teores mais elevados de $\mathrm{Fe}^{2+}$ $e$, conseqüentemente, apresentarem razőes $\mathrm{Mg} /\left(\mathrm{Mg}+\mathrm{Fe}^{2+}\right)$, muito mais baixas do que aquelas da facies BASMG;

7) a distinção, bastante nítida, entre as composições dos anfibólios das facie granitóides estudadas, é coerente com as observaçżes petrográficas, visto que a facies BASAFG representa uma variação faciológica mais evoluída em relação à facies BASMG, no âmbito do maciço. A variação composicional do anfibólio entre as duas facies está ligada, por sua vez, à mudanças composicionais ocorridas durante a diferenciação magmática que gerou esses granitóides;

8) a variação composicional observada entre os anfibólios das referidas facies reflete, ao que tudo indica, uma redução nas condições de oxidação(ou na fugacidade de oxigênio), durante a diferenciação magmática, no sentido da facies menos evoluída(BASMG) para aquela mais diferenciada e, relativamente, mais silícica(BASAFG);

9) as análises de biotita da facies BSG mostraram que o cristal investigado, pelo menos na área analisada, năo exibe variações importantes, sendo seu químismo praticamente constante, com $\mathrm{Xfe}=0,85$. Elas confirmaram que se trata de biotita não acompanhada de outros minerais máficos, fato coerente com as observações realizadas através de microscopia ótica;

10) no que diz respeito à classificação e nomenclatura, as análises mostraram que se trata de uma biotita annítica-aluminosa;

11) tomando-se por base trabalhos experimentais relativos à biotita, estimou-se um valor do Log $f \mathrm{O}_{2}$ em torno de $-16,80$, com as temperaturas mínimas de cristalização oscilando entre $695,8^{\circ} \mathrm{C}$ e $710,4^{\circ} \mathrm{C}$;

12) análises químicas em cloritas tardi a pós-magmáticas referentes as facies granitóides BASMG, BASAFG, BSG e ao CSMQGs revelaram que se trata de cloritas não oxidadas, de composiçōes amplamente variadas que correspondem à: 1) clorita da facies BASMG incidiu na linha limítrofe entre os campos da pseudothuringita e da ripidolita, próximo ao campo da 
afrosiderita, variedade da ripidolita; 2) a clorita da facies BASAFG "plotou" : duas análises no campo da brunsvigita; duas na linha limítrofe entre os campos da brunsvigita e da afrosiderita; uma no campo da afrosiderita; uma na linha divisória entre os campos da afrosiderita e da pseudothuringita; e uma no campo da bavalita,variedade da dafnita; 3) a clorita da facies BSG "plotou" plenamente no campo da pseudothuringita. No que se refere a clorita do greisen, duas amostras incidiram no campo composicional da pseudothuringita, a semelhança das amostras da facies BSG;

13) a correspondéncia composicional entre a clorita da facies BSG e do greisen revela uma coerência tipológica, visto que o corpo de greisen ao qual a clorita estudada pertence mostra-se associado a esta facies granitóide, bem como representa uma variedade, dessa mesma facies, que foi mais intensamente afetada por por alterações tardi a pós-magmáticas pervasiva, culminando com a greisenização da mesma.

14) a aplicação de um geotermômetro adequado permitiu estimar as seguintes temperaturas mínimas de cristalização para as cloritas estudadas: 1) $267,46^{\circ} \mathrm{C}$ a $418,15^{\circ} \mathrm{C}$ (facies BASAFG); 2) $395,93^{\circ} \mathrm{C}$ a $439,40^{\circ} \mathrm{C}$ (facies BASMG); 3) $493,17^{\circ} \mathrm{C}$ a $507,98^{\circ} \mathrm{C}$ (facies BSG); 4) $458,71^{\circ} \mathrm{C}$ a $592,66^{\circ} \mathrm{C}$ (greisen);

15) análises químicas de muscovita secundária do CSMQGs revelaram tratar-se de muscovita fengítica, corrrespondente às Mg-Al micas;

16) análises químicas através de MEV em amostras de granitóides e de greisen indicaram a presença de uma série de fases minerais menores hospedeiras de diversos metais raros e de ETR. Dentre elas destacam-se: monazita-(Ce), óxido de $\mathrm{Ce}, \mathrm{Nd}$ e $\mathrm{Ca}$, bodenita, cassiterita, calcopirita, kesterita/estanita e xenotima-(Y)

\section{6- Geoquímica}

Os dados químicos apresentados nas Tabelas 3.13 a 3.18(Anexo 13) referem-se às principais facies petrográficas caracterizadas no maciço e aos corpos de greisens associados ao mesmo.

\subsection{1-Características Gerais}

No âmbito deste maciço observa-se que a facies granitóide mais evoluída e diferenciada(BSG) e suas variedades mais fortemente afetadas por alterações tardi a pósmagmáticas e hospedeiras de mineralizações de estanho(BSGA e BSGIA) possuem os mais altos teores de $\mathrm{SiO}_{2}$, geralmente superiores a $75 \%$. De um modo geral, os granitóides mais 
diferenciados, em relação às facies menos evoluídas do maciço, possuem conteúdos de $\mathrm{TiO}_{2}, \mathrm{CaO}, \mathrm{MgO}, \mathrm{Sr}, \mathrm{Ba}, \mathrm{Cl}, \mathrm{B}, \mathrm{Ta}, \mathrm{Ga}, \mathrm{Hf}$ e ETRP sempre muito baixos, enquanto aqueles de $\mathrm{Rb}, \mathrm{Zr}, \mathrm{Y}, \mathrm{F}, \mathrm{Li}, \mathrm{U}, \mathrm{Nb}$ e ETRL são sistematicamente altos. Como uma consequência as razões $\mathrm{FeO} /(\mathrm{FeO}+\mathrm{MgO}), \mathrm{Rb} / \mathrm{Sr}, \mathrm{Rb} / \mathrm{Ba}$, e $\mathrm{F} / \mathrm{Cl}$ são invariavelmente altas, especialmente nas facies granitóides BSG, BSGA e BSGIA, enquanto as razões K/Rb são muito baixas se comparadas com aquelas dos granitos considerados normais(Shaw, 1968). Além disso, uma feição característica nos granitóides desse maciço são os relativamente baixos conteúdos de $\mathrm{Ga}$, o que, de certa forma, contraria a definição geoquímica original dos granitóides TipoA(Loiselle \& Wones, 1979; Collins et al., 1982; Whalen et al., 1987).

\subsection{2- Saturação em Alumina(ISA)}

De modo geral, as rochas do maciço são dominantemente peraluminosos, embora algumas amostras incidam no campo dos granitóides metaluminosos(Figura 3.47). Essas amostras correspondem às facies BASMG e BSG e suas variações(BSGA e BSGIA). No caso das amostras da facies BASMG, uma hipótese plausivel para explicar seu posicionamento no domínio das rochas metaluminosas refere-se a presença de anfibólio na mesma, o qual, conforme visto no ítem Química Mineral (deste capitulo), pertencente ao grupo dos anfibólio cálcicos. No que se refere às amostras da facies BSG e suas variações, a incidência de algumas amostras no campo das rochas metaluminosas pode ser explicada pela presença maior de fluorita nas mesmas em relação as demais amostras do grupo.
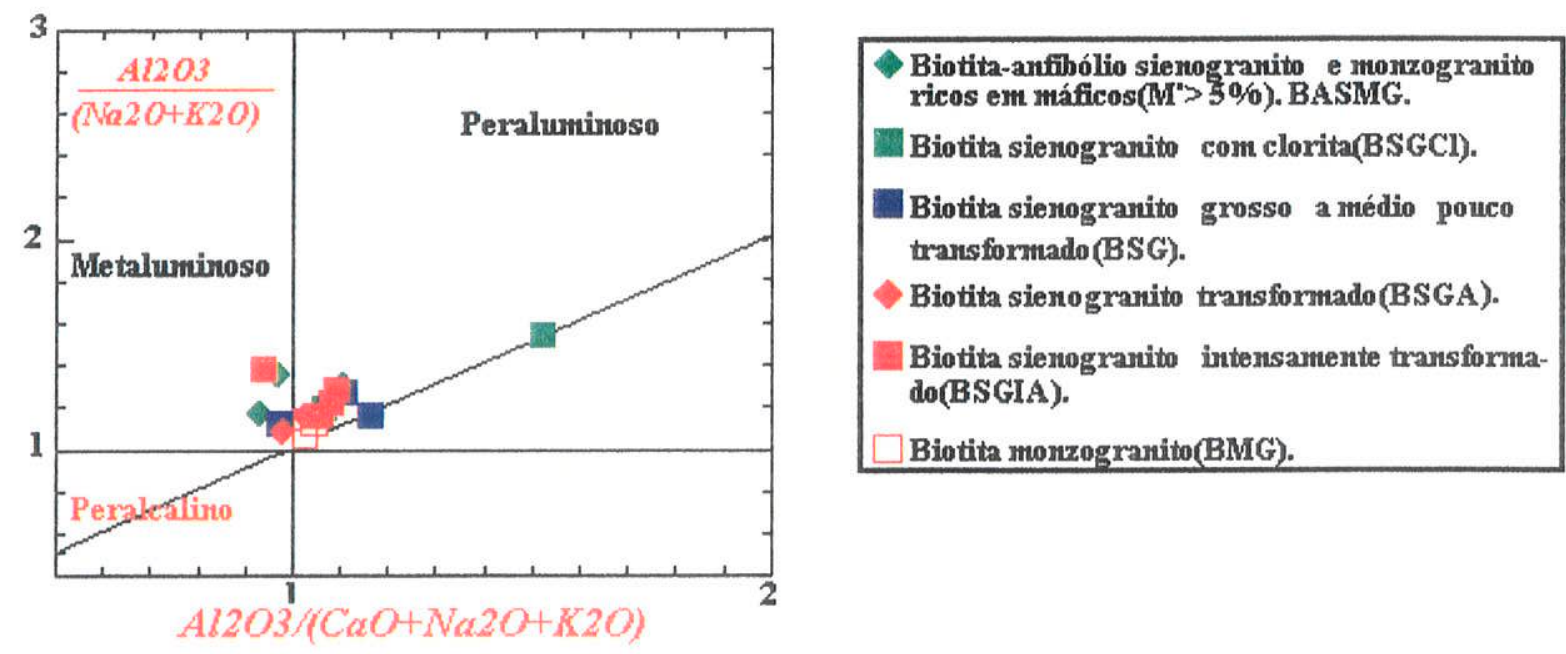

Figura 3.47. Diagrama binário A/CNK versus A/NK(Maniar\& Piccoli, 1989) mostrando a distribuição das facies granitóides do MGAV, com baseado nos índices de Shand(ISA). 


\subsection{3 - Afinidade Tectonomagmática e Tipologia}

Baseando-se em dados químicos referentes a elementos maiores e traços, diversos autores tem apresentado sugestões para caracterizar a tipologia de granitóides e suas relações com o ambiente tectônico onde os mesmos foram colocados(Chappell \& White, 1974; Loiselle \& Wones, 1979, Collins et al., 1982; Pitcher, 1983; Pearce et al., 1984; Whalen et al., 1987; Cobbing, 1990; Eby, 1990 e 1992; Förster at al., 1997; entre outros).

Nos diagramas clássicos $\mathrm{Y}-\mathrm{Nb}$ e $(\mathrm{Y}+\mathrm{Nb})-\mathrm{Rb}$ de Pearce et al.(1984), Figura 3.48a, b deste trabalho, observa-se que as amostras dos granitóides "plotam", em sua grande maioria, no campo dos granitóides intra-placas. Entretanto, em ambos os diagramas, algumas amostras incidem fora desse campo. No que se refere ao diagrama $\mathrm{Y}-\mathrm{Nb}$, os relativamente mais baixos conteúdos de $Y$, especialmente, nas amostras das facies BMG parecem ser a principal razão para a fuga das mesmas do domínio dos granitóides intraplacas para o campo dos granitóides de arcos vulcânicos. No que diz respeito ao diagrama $(\mathrm{Nb}+\mathrm{Y})-\mathrm{Rb}$, volta a se repetir o fato. Ou seja, devido aos conteúdos relativamente mais baixos de $\mathrm{Y}$ e de $\mathrm{Nb}$ nas amostras da facies BMG, estas "plotam" fora do campo das rochas de ambiência intra-placas, no âmbito dos granitóides sin-colisionais. Uma razão para explicar, pelo menos em parte, os baixos conteúdos, especialmente de $Y$, nas amostras desta facies granitóidespode ser atribuida à ausência de fases minerais portadoras de concentrações importantes desse elemento nas mesmas(ver ítem Aspectos Petrográficos deste capítulo).

Förster et al.(1997), baseados em um grande quantidade de dados químicos novos obtidos a partir de diversos granitóides oriundos de várias regiões do mundo, realizaram uma avaliação do diagrama discriminante $(\mathrm{Nb}+\mathrm{Y})-\mathrm{Rb}$ para inferir ambientes tectônicos de rochas igneas silícicas, de Pearce et al.,1984). Tais autores concluíram que este método de discriminação de ambientes tectônicos para rochas ígneas silicicas não é por si só decisivo. Ele serve, porém, como uma ferramenta que juntamente com outras(tais como datações e avaliaçőes geológicas) auxiliam na descrição da origem das rochas ígneas. Isoladamente, não é um método decisivo, devendo, portanto, ser acompanhado por outros tipos de informações geológicas que possam auxiliar na caracterização da paleoambiência tectônica, nas quais as rochas, objetos de investagação, foram formadas. Sem isso, um prognóstico baseado apenas em análises químicas "plotadas" no diagrama, será de pequeno valor. Esses autores mostraram que a correlação da geoquímica e a posição tectônica existe, mas que ambiguidades e classificaçōes errôneas ocorrem, a saber: 1) orogenias complexas ou polifásicas podem misturar rochas fontes de diferentes proveniências tectônicas. Isso é comum em arcos continentais e em ambientes colisionais, os quais podem estar estreitamente associados no tempo e no espaço com regimes extensionais; 2) a diferenciação ígnea pode produzir trends composicionais que cruzam os limites dos campos, 
especialmente, os limites entre os campos dos granitóides de arcos vulcânicos(VAG) e o dos granitóides intra-placas(WPG).

No diagrama Yb-Ta de Pearce et al.(1984), Figura 3.48c deste trabalho, as análises incidem, na sua grande maioria, no campo composicional correspondente aos granitos intraplacas, embora três amostras plotem no campo dos granitos de arcos vulcânicos(uma amostra da facies BSGCI) e nos campos dos granitos de cadeias oceânicas(uma amostra da facies BASMG e uma amostra da facies BSGIA), confirmando o que já foi observado acima, em relação aos outros dois diagramas de Pearce et al.(1984), e reforçando as observações de Förster et al.(1997).

Desse modo, talvez a hipótese de diferenciação ígnea e, adicionalmente, a atuação dos processos de alterações tardi a pós-magmáticas, que afetaram as rochas do maciço, em diferentes graus de intensidade, sejam os fatores mais prováveis para explicar esse comportamento composicional de algumas amostras dos granitóides estudados. De qualquer modo, no momento, qualquer conclusão a esse respeito é prematura.
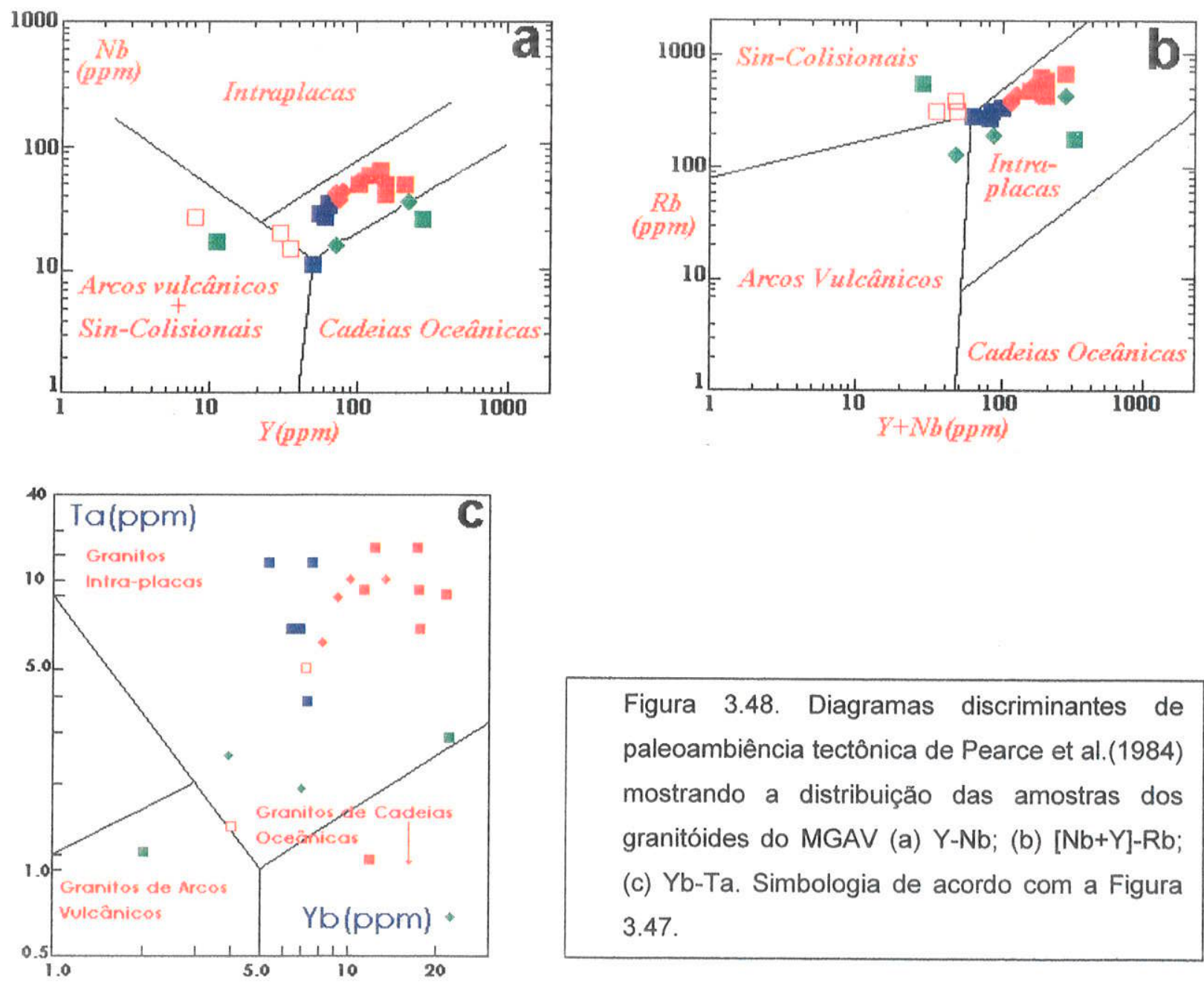

Figura 3.48. Diagramas discriminantes de paleoambiência tectônica de Pearce et al.(1984) mostrando a distribuição das amostras dos granitóides do MGAV (a) $\mathrm{Y}-\mathrm{Nb}$; (b) [Nb+Y]-Rb; (c) Yb-Ta. Simbologia de acordo com a Figura 3.47 . 
De acordo com Whalen et al.(1987), granitóides tipo-I, altamente fracionados, podem ser distiguidos de granitóides tipo-A utilizando-se o parâmetro de discriminação $\mathrm{Zr}+\mathrm{Nd}+\mathrm{Ce}+\mathrm{Y}$, visto que, de acordo com esse autor, para um dado grau de fracionamento, os granitos tipo-A comportam conteúdos muito mais altos desses elementos incompatíveis do que aqueles do tipo-I.

Assim, no que diz respeito aos granitóides em estudo, os dados químicos referentes a esses elementos foram lançados nos diagrama $\mathrm{Zr}+\mathrm{Nb}+\mathrm{Ce}+\mathrm{Y}$ vs. $\left(\mathrm{K}_{2} \mathrm{O}+\mathrm{Na}_{2} \mathrm{O}\right) / \mathrm{CaO}$, de Whalen et al.(1987), Figura 3.49, deste trabalho. Nele observa-se que a totalidade das amostras ocupa o campo dos granitóides tipo-A. No diagrama $\mathrm{Zr}+\mathrm{Nb}+\mathrm{Ce}+\mathrm{Y}$ vs. $\left(\mathrm{Fe}_{\mathrm{T}} / \mathrm{MgO}\right)$, dos mesmos autores, Figura 4.50 deste trabalho, que expressa o grau de fracionamento, nota-se que a ampla maioria das amostras "plota" no campo dos granitóides tipo-A. Excetua-se a isso uma única amostra pertencente a facies BMG, que incide no campo dos granitos félsicos fracionados, em razão dos seus relativamente mais reduzidos conteúdos desses elementos incompatíveis, especialmente de Y(Tabela 3.17, Anexo 13). Observa-se, ainda, um nítido trend de diferenciação/fracionamento entre as principais facies granitóides do maciço, traduzido pelas mais baixas razões $\mathrm{Fe}_{\mathrm{T}} / \mathrm{MgO}$, na facies menos evoluída e menos afetada por alterações tardi a pós-magmáticas(BASMG), que grada para valores intermediários nas facies BMG BSGCl, BSG e BSGA e atinge os valores mais elevados na variedade BSGIA, a qual representa o termo mais evoluído/diferenciado e mais intensamente afetado por alterações tardi a pós-magmáticas no âmbito do maciço.

$\mathrm{O}$ diagrama $10.000 \mathrm{Ga} / \mathrm{Al}$ vs. $\left(\mathrm{K}_{2} \mathrm{O}+\mathrm{Na}_{2} \mathrm{O}\right) / \mathrm{Al}_{2} \mathrm{O}_{3}$ de Whalen et al.(1987), modificado por Rämö \& Haapala(1995), que exprime o grau de alcalinidade ou índice agpaítico, Figura 3.51 deste trabalho, mostra que a quase totalidade das amostras dos granitóides estudados incide na área composicional correspondente aos granitos tipo-A, de natureza subalcalina. As quatro amostras referentes as facies BASMG, BMG, BSGA e BSGIA, que fogem dessa característica justificam seu posicionamento fora do campo dos granitos tipo-A devido, principalmente, aos seus muito reduzidos conteúdos de Ga(Tabelas 3.14 a 3.17, Anexo 13).

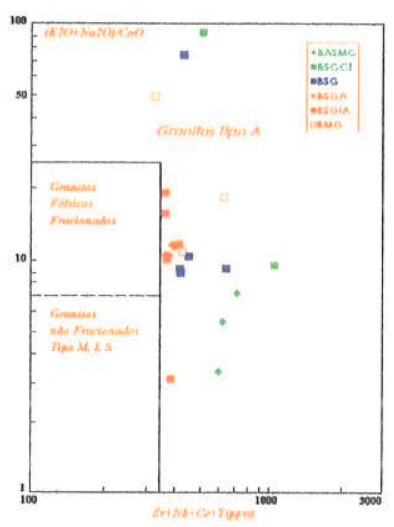

Figura 3.49 - Diagrama $\mathrm{Zr}+\mathrm{Nb}+\mathrm{Ce}+\mathrm{Y}$ vs. $\left(\mathrm{K}_{2} \mathrm{O}+\mathrm{Na}_{2} \mathrm{O}\right) / \mathrm{CaO}$ de Whalen et al.(1987) mostrando a distribuição composicional das amostras das principais facies granitóides do maciço granitóide Antônio Vicente. 


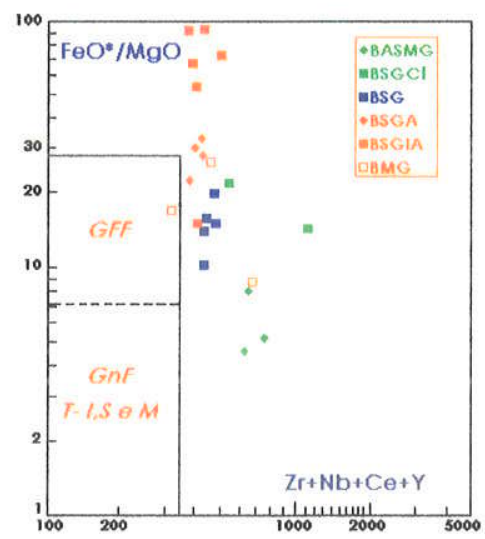

Figura 3.50- Diagrama $\mathrm{Zr}+\mathrm{Nb}+\mathrm{Ce}+\mathrm{Y}$ vs.
(FeOT/MgO) de Whalen et al.(1987) exibindo as
análises das principais facies granitóides do maciço
granitóide Antônio Vicente.

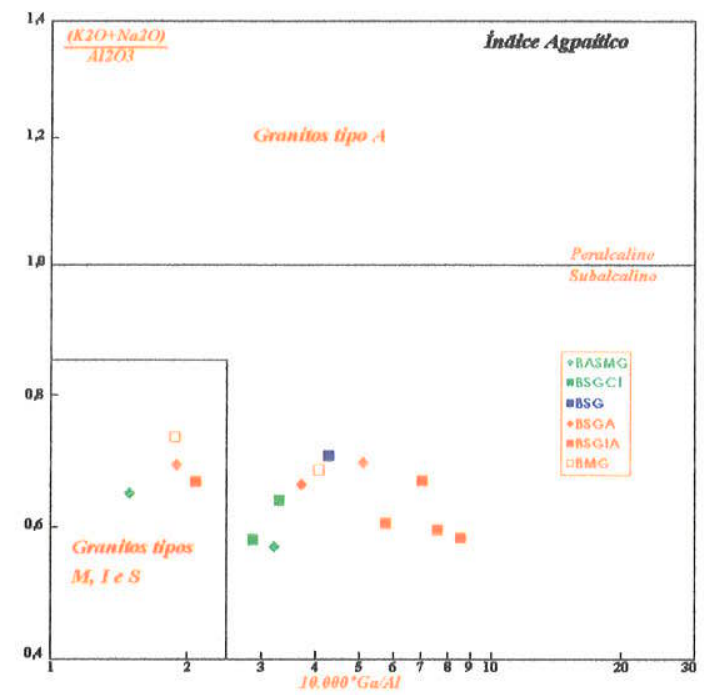

Figura 3.51- $10.000 \mathrm{Ga}$ vs. $\left(\mathrm{K}_{2} \mathrm{O}+\mathrm{Na}_{2} \mathrm{O}\right) / \mathrm{Al}_{2} \mathrm{O}_{3}$ de Whalen et al.(1987) exibindo as análises das principais facies granitóides do maciço granitóide Antônio Vicente.

Eby(1992), baseado em dados químicos apresentados por Eby(1990), subdividiu os granitos tipo-A em dois grupos. O primeiro grupo foi designado como tipo- $A_{1}$ e apresenta certas similaridades com os basaltos de ilhas oceânicas, enquanto que o segundo grupo, tipo- $A_{2}$, foi assim definido por guardar certas semelhanças químicas com a média da crosta e com basaltos de arcos de ilha.

Com base na subdivisão apresentada por Eby(1992), os dados químicos dos granitóides aqui estudados foram lançados nos diagramas triangulares discriminantes $\mathrm{Y}-\mathrm{Nb}$ Ce e Y-Nb-3Ga, Figura 3.52a, b. Em ambos os diagramas as amostras incidem preferencialmente no campo correspondente aos granitóides tipo- $A_{2}$. Excetuam-se a isso, duas amostras pertencentes as facies BSGCl e BMG. No diagrama $\mathrm{Y}-\mathrm{Nb}-\mathrm{Ce}$ as duas amostras em questão incidem plenamente na área composicional correspondente aos granitóide tipo- $A_{1}$, devido principalmente aos seus reduzidos conteúdos de $\mathrm{Y}$ e $\mathrm{Nb}$ e relativamente elevados de $\mathrm{Ce}$. No diagrama $\mathrm{Y}-\mathrm{Nb}-3 \mathrm{Ga}$ observa-se que a amostra da facies 
BSGCl plota no campo dos granitos tipo-A $A_{1}$ em função, principalmente, de seu teor algo elevados de $\mathrm{Ga}$ e, subordinadamente, do conteúdo de $\mathrm{Nb}$. No que se refere a amostra da facies BMG, a razão de plotar no campo dos granitos tipo-A1 deve-se ao seu elevado conteúdo de $\mathrm{Nb}$ e da desprezível quantidade de $\mathrm{Ga}$.
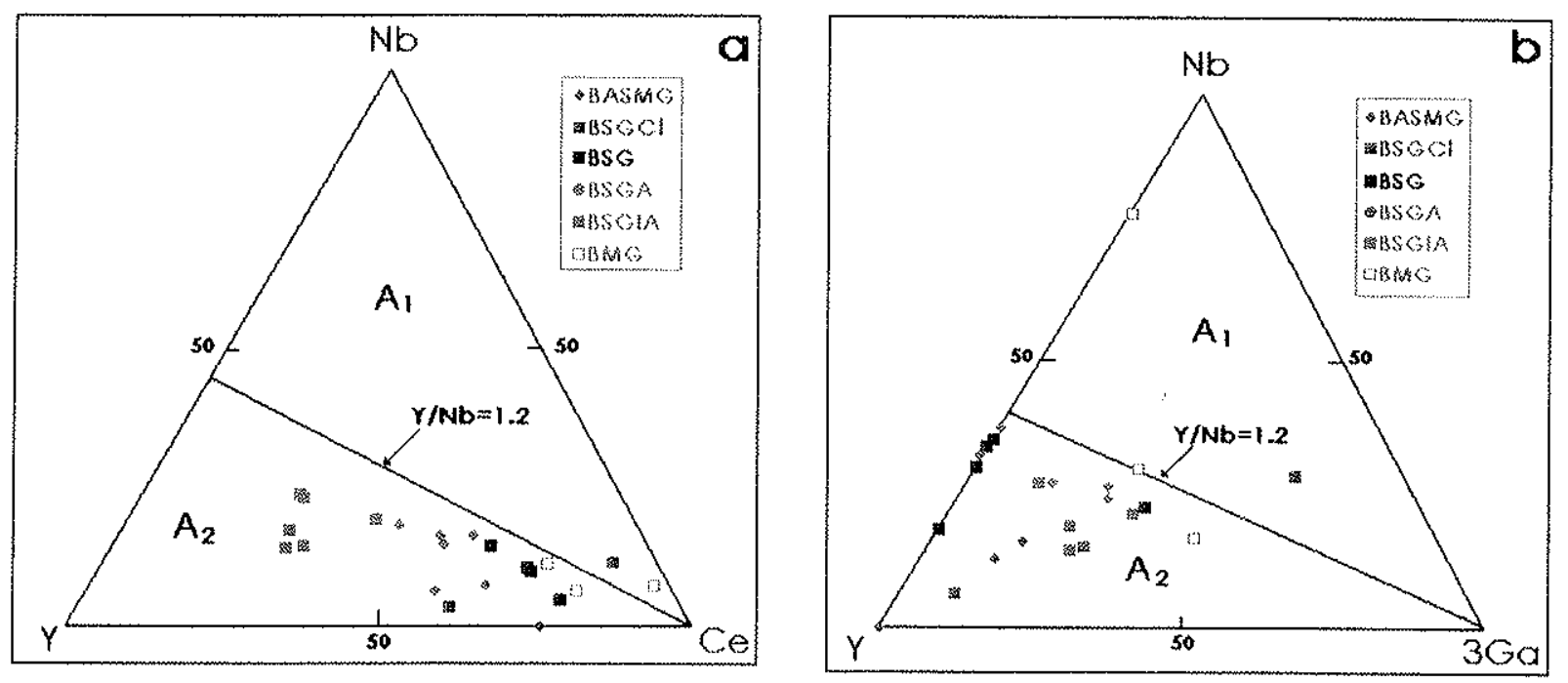

Figura 3.52 Diagramas triangulares $\mathrm{Y}-\mathrm{Nb}-\mathrm{Ce}(\mathrm{a})$ e $\mathrm{Y}-\mathrm{Nb}-3 \mathrm{Ga}(\mathrm{b})$ de $\mathrm{Eby}(1992)$ mostrando a distribuição composicional das principais facies granitóides do maciço granitóide Antônio Vicente.

\subsection{4- Outras Feições Geoquímicas}

A análise do diagrama $\mathrm{SiO}_{2}$ vs. $\mathrm{FeO}^{*} /\left(\mathrm{FeO}^{*}+\mathrm{MgO}\right)$, Figura 3.53, revela uma correlação positiva entre essas duas variáveis durante o estágio magmático, o qual mostrase representado pelas facies BASMG, BSGCI, BMG e BSG. Essa correlação positiva passa a ser negativa no estágio de alteraçőes tardi a pós-magmáticas, que por sua vez, encontrase representado pelas facies $B S G A, B S G I A$ e greisens, visto que os conteúdos de $\mathrm{SiO}_{2}$ decrescem sistematicamente no sentido da facies BSG(facies magmática mais evoluida e diferenciada), para as facies BSGA, BSGIA e Greisen, respectivamente. Nota-se, ainda, um nítido trend de enriquecimento de ferro no estágio magmático, no sentido da facies $B A S M G$ (menos evoluída) para a facies BSG(mais evoluida), o qual é suavisado no estágio de alterações tardi a pós-magmáticas, no sentido da facies BSGA para o CSMQGs. 


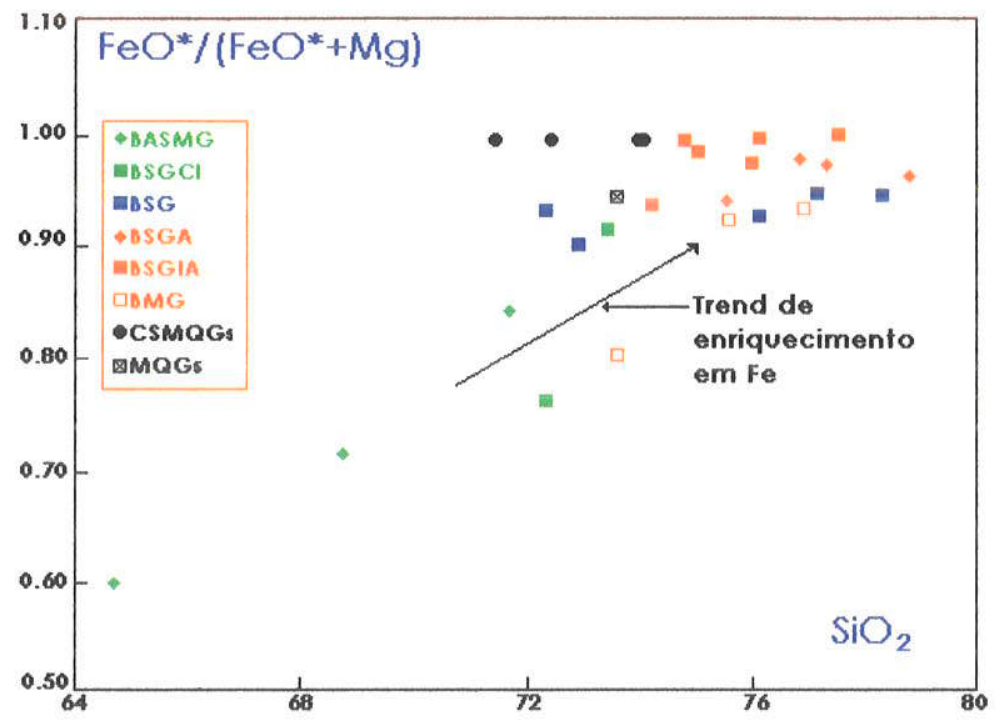

Figura 3.53. Diagramas retangulares $\mathrm{SiO}_{2}$ vs. $\mathrm{FeO}^{*} /\left(\mathrm{FeO}^{*}+\mathrm{MgO}\right)(\mathrm{a})$ e $\mathrm{CaO}$ vs. $\mathrm{Na} 2 \mathrm{O}$ (b) mostrando a distribuição composicional das principais facies granitóides do maciço granitóide Antônio Vicente.

As razões $\mathrm{K} / \mathrm{Rb}$ entre de 300 a 150 são consideradas normais para granitos (Shaw, 1968). Entretanto, em muitos dos complexos graníticos, as fases mais evoluídas apresentam razões $\mathrm{K} / \mathrm{Rb}$ mais baixas do que 150. Nos granitóides estudados(exceto os greisens), as razões $\mathrm{K} / \mathrm{Rb}$ da totalidade das amostras situa-se entre 50 e 300. Entretanto, as razões $\mathrm{K} / \mathrm{Rb}$ da grande maioria das amostras situa-se abaixo de 300 e acima de 50/Figura 3.54a). São excessões a isso três amostras de CSMQGs e uma de MQGs, cujas razões são inferiores a 50 e superiores a 20. Os teores de K, para a ampla maioria das amostras, variam muito pouco entre os granitóides, independentemente, da intensidade das alterações tardi a pós-magmáticas, enquanto que os teores de $\mathrm{Rb}$ aumentam claramente no sentido da facies BASMG para a BSG(estágio magmático) e desta para as variedades mais intensamente afetadas por tais alterações(BSGA e BSGIA) e do CSMQGs, conforme mostrado na Figura3.54a.

$\mathrm{Na}$ Figura 3.54b e c observa-se que $\mathrm{Sr}$ e $\mathrm{Ba}$ comportaram-se como elementos compatíveis durante a evolução magmática dos granitóides, sendo empobrecidos no líquido magmático mais tardio, representado pela facies BSG. Em contraste, o Rb é incompatível e suas concentrações são significativamente mais altas nas facies magmáticas mais evoluídas(BSGCl e BSG), bem como nas variedades mais intensamente afetadas por alterações tardi a pós-magmáticas(BSGA e BSGIA) e nos greisens(MQGs e CSMQGs), indicando que os processos de alterações tardi a pós-magmáticos, de natureza prevasiva, que reinaram sobre porções desses granitóides reforçam a essa tendência. Portanto, as 
facies granitóides especializados em $\mathrm{Sn}$ são extremamente exauridas em $\mathrm{Sr}$ e $\mathrm{Ba}$ e enriquecidos em $\mathrm{Rb}$.

O Zr, embora apresente-se em concentrações geralmente altas nos granitóides estudados(Tabelas 3.13 a 3.18, Anexo 13), comportou-se como elemento compatível durante a diferenciação magmática. No diagrama Rb-Zr(Figura 3.54d) nota-se que seus teores decrescem sistematicamente no sentido da facies menos evoluída(BASMG) para a mais diferenciada(BSG), enquanto que os de $\mathrm{Rb}$ aumentam no mesmo sentido, estabelecendo-se uma correlação negativa entre esses dois elementos. No estágio de alterações tardi a pós-magmáticas, seus conteúdos se tornam ainda mais reduzidos, decrescendo no sentido da facies relativamente menos alterada(BSGA) para a mais intensamente alterada(BSGIA) e CSMQGs, enquanto os de $\mathrm{Rb}$ atingem seus valores mais significativas(Figura 3.54d).

$\mathrm{U}$ e Th comportaram-se como elementos incompativeis, estabelecendo uma correlação positiva durante o estágio magmático, visto que suas concentrações crescem no sentido da facies menos evoluída(BASMG) para a mais diferenciada(BSG), conforme pode ser observado na Figura 3.54e. No estágio de alterações tardi a pós-magmáticas, os conteúdos $U$ tendem a aumentar no sentido da variedade relativamente menos alterada(BSGA) para a mais intensamente alterada(BSGIA), enquanto que os de Th decrescem no mesmo sentido. Entretanto, a partir da facies BSGIA esse comportamento muda com a greisenização. As concentrações de $U$ decrescem bruscamente no sentido da facies BSGIA para o CSMQGs, enquanto que as de Th tendem a aumentar(Figura 58e).

No diagrama triangular Rb-Ba-Sr (Figura 3.54f), os granitóides mais intensamente transformados(BSGIA) do maciço situam-se no campo dos granitóides extremamente diferenciados (EI Bouseily \& El Sokkary, 1975), enquanto os granitos contendo anfibólio(BASMG) incidem no campo dos granitos normais e os BSG na transição entre esses campos. Observa-se, ainda, os valores extremamente baixos de $\mathrm{Sr}$, um nítido "trend" de enriquecimento de $\mathrm{Rb}$ no sentido dos BASMG para os BSG(estágio magmático) e, desses, para os BSGA e BSGIA(estágio tardi a pós-magmático), ocorrendo o inverso em relação ao $\mathrm{Ba}$.
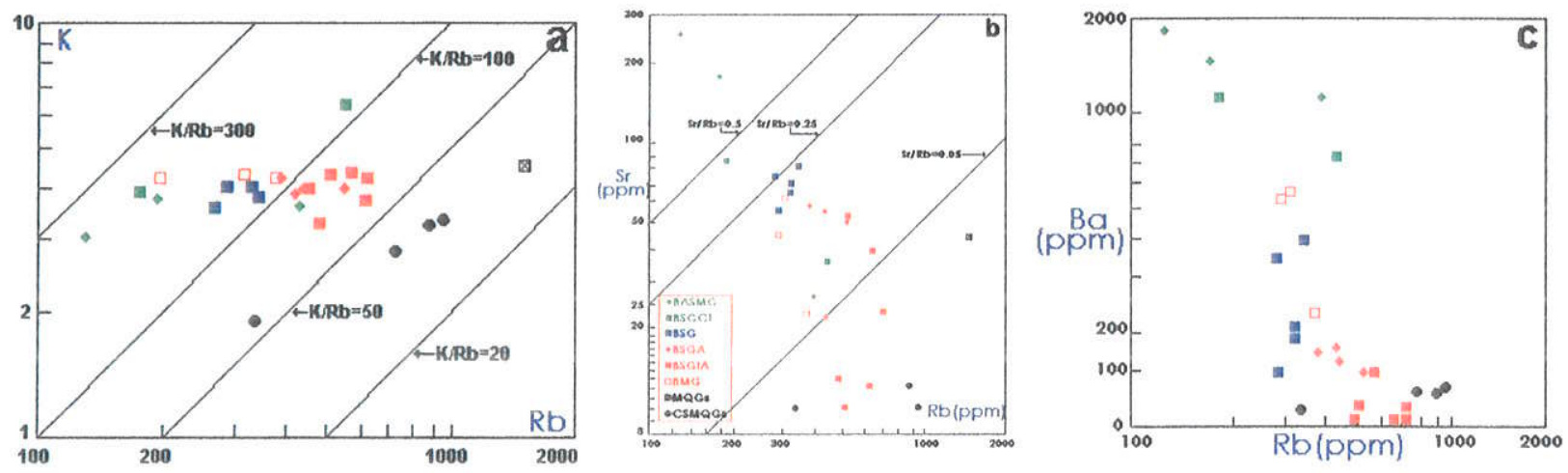

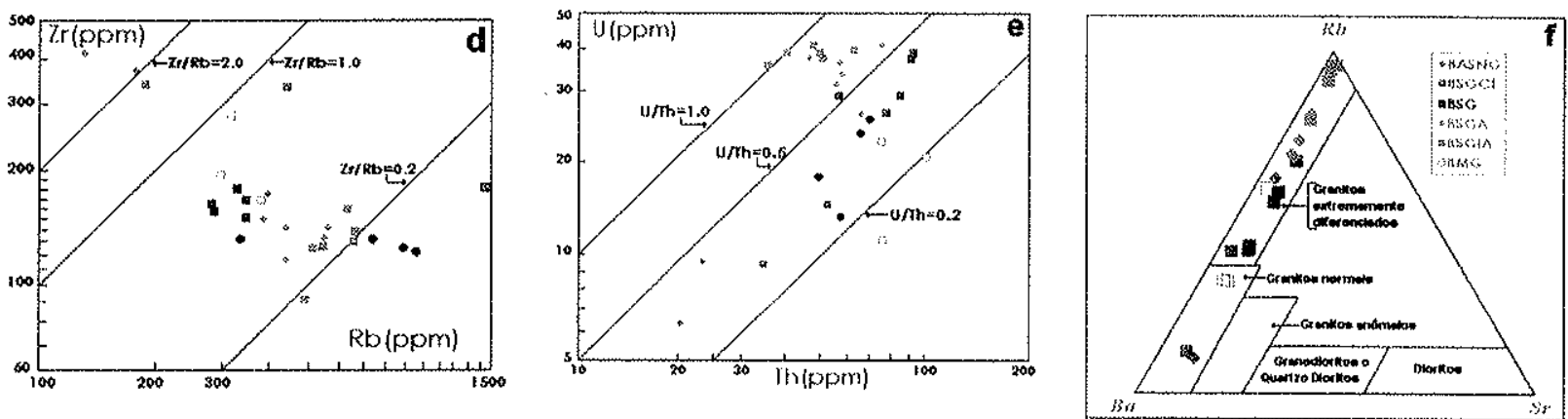

Figura 3.54- Distribuição composicional das amostras das principais facies granitóides do maciço granitóide Antônio Vicente nos diagramas (a) Rb-K; (b) Rb-Sr; (c) Rb-Ba; (d) Rb-Zr; (e) Th-U; f) RbBa-Sr(El-Bouseily \& Sokkary, 1975). Simbologia de acordo com a Figura 3.54b.

Considerando a importåncia dos fluidos tardios nos processoṣ de alterações tardi a pós-magmáticos $e$, por conseguinte, suas influências no transporte, deposição e concentração das mineralizações, especialmente de estanho, torna-se relevante analisar o papel do $\mathrm{F}$ e dos $\mathrm{Cl}$ nesses granitóides, bem como o comportamento de outros elementos relacionados aos mesmos.

De acordo com Bailey(1977), o conteúdo médio de F em granitóides é de cerca de $800 \mathrm{ppm}$, embora os valores absolutos possam estar limitados entre dezenas de "ppm" e vários "porcentos". Conforme esse autor esta ampla variação pode ocorrer tanto a nível de um mesmo granitóide, quanto entre diferentes tipos de granitóides.

Nas facies granitóides consideradas como diferenciados magmáticos os conteúdos desse elemento variam largamente, desde valores médios iguais a $745 \mathrm{ppm}$ (facies BSGCl) até $2.580 \mathrm{ppm}$ (facies BSG). Esses valores tornam-se ainda mais elevados nas variedades granitóides mais intensamente afetados por alteraçōes tardi a pós-magmáticas, onde atingem teores médios entre $3.675 \mathrm{ppm}$ (variedade BSGA) e 6.566,70ppm(variedade BSGIA). As quantidades mais expressivas são encontradas no clorita-siderofilita-muscovita-quartzo greisen, onde o conteúdo de $F$ alcança um valor médio igual a 1,49\%(Tabelas 3.13 a 3.18 , Anexo 13), embora em algumas amostras possa atingir até $2,2 \%$ (Tabela 3.18, Anexo 13).

No que se refere às fases minerais primárias maiores de granitóides, Bailey(1977) postula que $30 \%$ a $90 \%$ do $\mathrm{F}$ estão, geralmente, contidos na biotita, com quantidades subordinadas na hornblenda, muscovita, quartzo e em minerais acessórios. Entretanto, o referido autor considera que ocasionalmente minerais acessórios tais como apatita, titanita, fluorita, microlita, pirocloro, topázio, turmalina, fluorita, bastnasita, ambligonita, espodumênio, criolita, etc, possam contribuir com mais de $50 \%$ de $F$, notadamente quando presentes em granitóides ricos em $F$ e em zonas de "roof" de origem metassomáticas(apogranitos). 
Em relação aos granitos estudados, dados de química mineral obtidos através de microssonda eletrônica, revelaram que em termos dos principais minerais máficos(varietais), o anfibólio(alumínio-ferrohastingsita a edenita) pertencente às facies BASMG e BASAFG mostra-se, relativamente, mais enriquecido em $F$ do que a biotita da facies BSG(diferenciados magmáticos). Entretanto, tanto o anfibólio, quanto a biotita annítica hospedam reduzidas quantidades de F. Assim, embora se reconheça que as principais fontes primárias de $F$ possam corresponder ao anfibólio e à biotita, os dados petrográficos(microscopia ótica), aliados aos dados de microssonda eletrônica e de microscopia eletrônica, bem como os dados químicos de rocha total, indicam que o $\mathrm{F}$ possa ter sido extraído das referidas fases(anfibólio e biotita), passando a se concentrar nas soluções tardi a pós-magmáticas.

No estágio de alterações tardi a pós-magmáticas, o F dessas soluções formou minerais próprios, representados, principalmente por fluorita(dominante) e topázio, bem como é constituinte das fases micáceas associadas a esse estágio tais como micas brancas("muscovita"), siderofilita e clorita. Isso é evidenciado pelos teores, relativamente, mais elevados de $F$ nas variedades(diferenciados) mais intensamente alteradas(BSGA e BSGIA), bem como nos greisens, especialmente no clorita-siderofilita-muscovita-quartzo greisen, doque nas facies magmáticas menos evoluidas e menos afetadas por alterações tardi a pós-magmáticas. A presença da paragênese fluorita + topázio + muscovita + clorita + siderofilita e a sua relação com conteúdos importantes de $F$, na facie granitóide mais diferenciada(BSG) e nas suas variações(BSGA e BSGIA) reforça a hipótese de que os granitóides do maciço foram colocados em nivel crustal raso, entre $1 \mathrm{Km}$ e $5 \mathrm{Km}$ (Bailey, 1977). Além disso, com base neste autor, parece razoável imaginar que as soluções contendo $F$ foram separadas e removidas, de modo mais expressivo, a partir da cristalização da facies BSG, nesse nivel mais alto de colocação.

No que se refere ao comportamento do $\mathrm{F} \mathrm{e} \mathrm{Cl}$ durante a evolução magmática que produziu os granitóides do maciço, observa-se, a partir dos dados químicos(médias) obtidos em rocha total(Tabela 3.19), que o mais elevado conteúdo de $F$ está no diferenciado magmático mais tardio(facies BSG) e os mais reduzidos nos diferenciados magmáticos, relativamente, mais precoces(facies BASMG e BSGCl), enquanto que com o $\mathrm{Cl}$ ocorre 0 inverso. De acordo com Fuge(1977) $\circ \mathrm{Cl}$ por possuir uma baixa solubilidade na fusão silicática é concentrado nos minerais formados precocemente, enquanto que of por possuir forte afinidade com a fusão se enriquece nos minerais formados tardiamente. Em relação aos granitóides estudados, esse comportamento do $\mathrm{F}$ e do $\mathrm{Cl}$ é confirmado a partir de dados de química mineral(conteúdos médios), obtidos a partir de micossonda eletrônica, em anfibólios das facies BASMG e BASAFG. Na Tabela 3.20 nota-se que os conteúdos de $\mathrm{Cl}$ nos anfibólios são sempre mais altos do que aqueles de $F$. Esse fato confirma as 
observações de Fuge(op. cit.), visto que o anfibólio, juntamente com o plagioclásio( $\left(\mathrm{f}_{1}\right)$, representam as fases primárias maiores, mais precoces na ordem de cristalização mineral, no âmbito das facies ganitóides em que o anfibólio foi analisado(ver ítem Aspectos Petrográficos). Entretanto, isso não é coerente com o que é observado em relação aos dados de química mineral obtidos através de micossonda eletrônica em biotita(Tabela 3.20). Sendo ela uma fase tardia relativamente às fases essenciais maiores, era de se esperar que a mesma possuisse conteúdos mais elevados de $\mathrm{F}$ do que os de $\mathrm{Cl}$, o que não é observado. Uma hipótese para explicar esse fato está relacionada, ao que tudo indica, à preferência do $F$ pelos fluidos tardi a pós-magmáticos, uma vez seus conteúdos mostram-se aumentados nas variedades granitóides mais intensamente afetadas por alterações tardi a pósmagmáticas. Nesse caso, a fluorita e, subordinadamente o topázio, representam os pincipais hospedeiros de F e não a biotita. Além disso, a facies granitóide BSG, portadora da biotita analisada, abriga pequenas quantidades de fluorita 2 , que por sua vez, mostra-se intimamente associada à alteração parcial da biotita(cloritização). Em razão disso, ela pode estar algo "defluorizada" e, por conseguinte, exaurida de F.

Tabela 3.19 Conteúdos médios de $\mathrm{F}, \mathrm{Cl}$ e $\mathrm{SiO}_{2}$ (em rocha total) nas principais facies granitóides do maciço granitóide Antônio Vicente.

\begin{tabular}{|l|c|c|c|c|}
\hline Facies Granitóides & Flúor(ppm) & Cloro(ppm) & $\mathrm{SiO}_{2}(\%)$ & $\begin{array}{c}\text { Estágios } \\
\text { Evolutivos }\end{array}$ \\
\hline BASMG(3) & 896,67 & 692,33 & 68,38 & Magmático \\
\hline BSGCl(2) & 745,00 & 178,00 & 72,90 & \\
\hline BMG(3) & 1063,33 & 446,00 & 75,41 & \\
\hline BSG(5) & 2580,00 & 361,00 & 76,34 & Tardi a Pós- \\
\hline BSGA(4) & 3675,00 & 100,50 & 77,12 & magmático \\
\hline BSGIA(6) & 6556,70 & 52,17 & 75,06 & \\
\hline CSMQGs(4) & 14950,00 & 0,00 & 72,97 & \\
\hline
\end{tabular}

Tabela 3.20 Conteúdos médios de $\mathrm{F} \mathrm{e} \mathrm{Cl}$ em anfibólios das facies BASMG e BASAFG e em biotita da facies BSG(diferenciados magmáticos) do maciço granitóide Antônio Vicente.

\begin{tabular}{|l|l|c|c|}
\hline Fase Mineral & \multicolumn{1}{|c|}{ Anfibólio } & Flúor(\%) & Cloro(\%) \\
\hline Facies Granitóide & BASMG(11) & 0,3464 & 0,8954 \\
\cline { 2 - 4 } & BASAFG(4) & 0,1775 & 0,6200 \\
\hline Fase Mineral & Biotita & & \\
\hline Facies Granitóide & BSG & 0,0375 & 0,4025 \\
\hline
\end{tabular}


As Tabelas 3.13 a 3.18 (Anexo 13) e a Figura 3.55a mostram uma correlação negativa entre $\mathrm{F}$ e $\mathrm{Cl}$, com o Flúor aumentando no sentido da facies BASMG para a BSG(estágio magmático) e, dessa para a BSGA e BSGIA(estágio tardi a pós-magmático). As razões $\mathrm{F} / \mathrm{Cl}$ aumentam no mesmo sentido. Nos greisens $\circ \mathrm{Cl}$ não foi detectado em nenhuma das amostras analisadas.

A Figura $3.55 \mathrm{~b}$ mostra uma correlação negativa entre $F$ e $\mathrm{Sn}$ no estágio magmático(sentido BASMG para os BSG), com o $F$ aumentando e o Sn decrescendo. No estágio tardi a pós-magmático essa correlação passa a ser positiva com $\mathrm{F}$ e $\mathrm{Sn}$ aumentando sistematicamente no sentido da facies BSG para para as variedades BSGA e BSGIA e dessa última para o CSMQGs. Além disso, as amostras com teores mais elevados de flúor apresentam, também, teores mais elevados de estanho(variedade BSGIA e CSMQGs), o que é reforçado pela presença de cassiterita nas amostras dessas duas variedades(Tabelas 3.16 e 3.18, Anexo 13 ; Prancha 11,Foto D, E e F).

Por outro lado, na Figura $3.55 \mathrm{c}$ observa-se que tanto $\mathrm{Cl}$ quanto $\mathrm{Sn}$ decrescem no estágio magmático, no sentida da facies BASMG(menos evoluída) para a mais evoluida e diferenciada(BSG). No estágio de alterações tardi a pós-magmáticas os conteúdos de $\mathrm{Cl}$ diminuem no sentido da facies BSG para as variedades BSGA e BSGIA, enquanto que os de $S n$ aumentam no mesmo sentido.

No diagrama $\mathrm{Na}_{2} \mathrm{O}-\mathrm{Sn}$ (Figura $3.55 \mathrm{~d}$ ) observa-se que no estágio magmático as quantidades de $\mathrm{Sn}$ decrescem claramente no sentido da facies menos evoluída(BASMG) para a mais diferenciada(BSG). No estágio de alterações tardi a pós-magmáticas, os conteúdos de $\mathrm{Sn}$ crescem vertiginosamente no sendido da facies BSG para as suas variedades BSGA e BSGIA. No CSMQGs os teores de $\mathrm{Sn}$ são equivalentes aqueles dessa última variedade. $\mathrm{O} \mathrm{Na}_{2} \mathrm{O}$ exibe teores praticamente constantes(em torno de $3 \%$ ) em ambos os estágios, exceto no CSMQGs onde os teores desse óxido são bastante reduzidos $(<0.10 \%)$. Isso evidencia que durante os estágios magmáticos e de alterações tardi a pós-magmáticas(até o evento metassomático de albitização) não houve um aporte de $\mathrm{Na}$ de fora do sistema, que se comportou como um ambiente fechado em relação as encaixantes do maciço(ver mais adiante).

$\mathrm{Na}$ Figura 3.55e nota-se que o $\mathrm{Sn}$ e a razão $\mathrm{Rb} / \mathrm{Sr}$ (índice de diferenciação) desenvolvem uma correlação negativa no estágio magmático, caracterizada pelo descréscimo dos teores de $\mathrm{Sn}$ e um aumento paralelo das razões $\mathrm{Rb} / \mathrm{Sr}$, devido o aumento relativo de $\mathrm{Rb}$ e diminuição do $\mathrm{Sr}$. No estágio de alterações tardi a pós-magmáticas a correlação entre essas duas variáveis se torna nitidamente positiva, uma vez que tanto $\mathrm{Sn}$, quanto $\mathrm{Rb}$ aumentam drasticamente nesse estágio, especialmente em relação à variedade BSGIA e ao CSMQGs, enquanto o $\mathrm{Sr}$ assume baixíssimas quantidades. Esse feição 
demonstra um enriquecimento do $\mathrm{Sn}$ a partir da interação da facies BSG com fluidos tardios(Lehmann \& Mahawat, 1989).

No diagrama $\mathrm{Sn}-\mathrm{TiO}_{2}$ verifica-se, no estágio magmático, que as quantidades de $\mathrm{Sn}$ e $\mathrm{TiO}_{2}$ diminuem no sentido da facies BASMG(menos evoluída) para facies BSG(mais evoluida), caracterizando uma correlação positiva. No estágio de alterações tardi a pósmagmáticas, essa correlaçăo positiva torna-se negativa, sendo definida pelo aumento das concentrações de estanho no sentido da da facies BSG para as suas variedades mais intensamente afetadas por alterações tardi a pós-magmáticas, mas torna-se novamente positiva a partir da variedade BAGIA em direção ao CSMQGs, uma vez que tanto os conteúdos de $\mathrm{Sn}$, quanto as de $\mathrm{TiO}_{2}$ aumentam.

Os dados apresentados reforçam a hipótese de que os fluidos tardi a pósmagmáticos enriquecidos em voláteis, especialmente $F$, estão relacionado diretamente com as mineralizaçōes de cassiterita, visto que a presença da mesma está restrita à variedade mais intensamente afetada por alterações tardi a pós-magmáticas e aos greisens(CSMQGs e MQGs), não parecendo verdadeiro no que diz respeito ao $\mathrm{Cl}$.

Considerando que as variedades granitóides mais transformadas e evoluídas e os greisens são os termos hospedeiros das mineralizações de cassiterita e que a fluorita e o topázio são mais freqüentes e abundantes nessas rochas, presume-se que o flúor desempenhou um papel fundamental na evolução e gênese dos depósitos de cassiterita, uma vez que as concentrações de F são, também, engrandecidas nessas rochas.
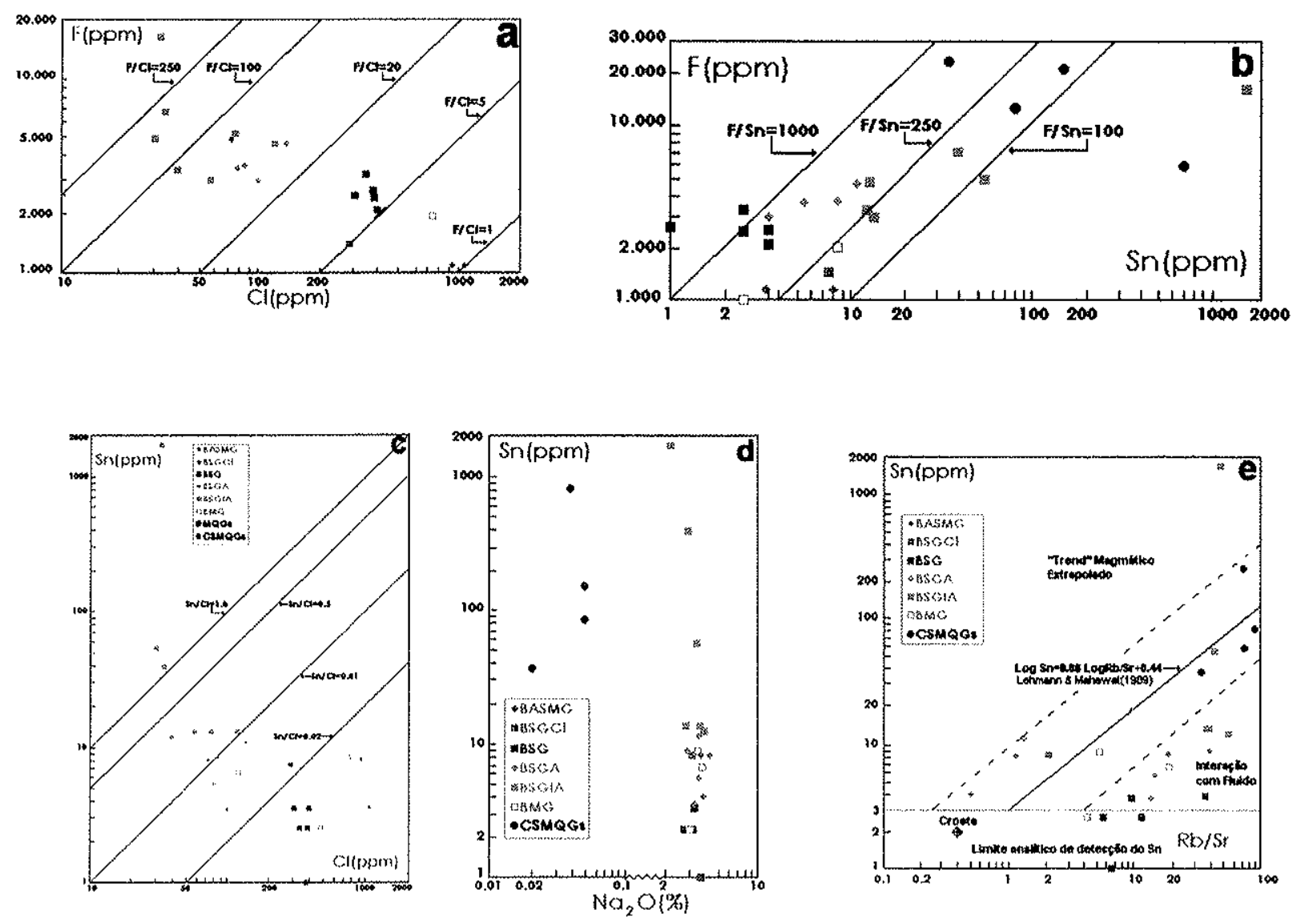


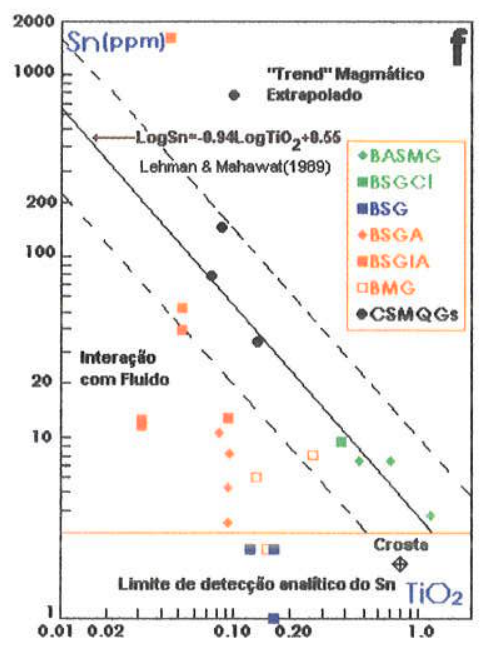

Figura 3.55. Distribuição composicional das amostras das principais facies granitóides do maciço granitóide Antônio Vicente e dos greisens a ele associados nos diagramas (a) F-Cl; (b) F-Sn; (c) $\mathrm{Cl}-\mathrm{Sn}$; (d) $\mathrm{Na}_{2} \mathrm{O}-\mathrm{Sn}$; e) $\mathrm{Sn}-\mathrm{Rb} / \mathrm{Sr}$; f) $\mathrm{Sn}-\mathrm{TiO}_{2}$. Simbologia de (a) e (b) acordo com as Figuras $3.55 \mathrm{c}, \mathrm{d}, \mathrm{e}, \mathrm{f}$. O losango indica a composição média da crosta conforme Taylor \& McLennan, 1985).

No que se refere às concentrações dos ETR, bem como seus padrões de distribuição normalizados para condritos(Figura 3.5660), observa-se um típico padrão "gaivota", onde os conteúdos médios dos ETRL(Tabela 3.21) são mais enriquecidas nos diferenciados magmáticos, relativamente, menos evoluídos(facies BASMG e BSGCl, onde $\Sigma E T R L=460,26 p p m$ e $777,55 p p m$, respectivamente) e mais empobrecidas no diferenciado magmático mais evoluídos(facies BSG, onde $\sum=374,59 \mathrm{ppm}$ ), bem como nas suas variedades mais afetadas por alterações tardi a pós-magmáticas(facies BSGA e BSGIA, onde $\Sigma=258,59 \mathrm{ppm}$ e $170,55 \mathrm{ppm}$, respectivamente) e no CSMQGs(onde $\Sigma=195,04 \mathrm{ppm}$ ). Esse comportamento dos ETRL nos granitóides estudados é compatível com a evolução de magmas félsicos, onde as concentrações dos ETRL decrescem drasticamente durante a diferenciação de tais magmas(Miller \& Mittlefheld, 1982). Além disso, a presença de apreciáveis fases de vapor podem levar a uma exaustão dos ETRL(Miller\& Mittlefheld, 1982). Isso pode explicar a razão das baixas concentrações de ETRL nas variedades mais intensamente afetadas por alterações tardi a pós-magmáticas(facies BSGA e BSGIA) e no CSMQGs.

Em relação aos ETRP(Figura 3.56; Tabela 3.21), observa-se uma distribuição regular. Nos diferenciados magmáticos, as maiores concentrações médias relativas são encontradas nas variedades BASMG e BSGCl(onde $\sum=59,41 \mathrm{ppm}$ e $\sum=92,48 \mathrm{ppm}$, respectivamente), enquanto que as menores mostram-se contidas na facies BMG e BSG(onde $\sum=30,42 \mathrm{ppm}$ e $\sum=45,51 \mathrm{ppm}$, respectivamente) e no CSMQGs(onde $\Sigma=41,67 \mathrm{ppm}$ ). As razões para esse comportamento dos ETRP podem ser explicadas pela presença das fases anfibólio, apatita, zircão e titanita(facies BASMG) e apatita(facies BSGCI), as quais ocorrem como traços ou estão ausentes nas demais variedades de granitóides. Como exceção a isso, são os mais elevados conteúdos médios de ETRP na variedade $\mathrm{BSGIA}$ (onde $\Sigma=74,80 \mathrm{ppm}$ ), em relação a todas as demais facies granitóides do maciço. Entretanto, a presença de Thorita e zircão enriquecidos em ETRP, especialmente 
em Yb e Dy, nessa variedade de granitóide, pode explicar esses elevados conteúdos de ETRP(ver ítem Química Mineral deste capítulo).

As razões $(\mathrm{La} / \mathrm{Yb})_{\mathrm{N}}$, nos diferenciados magmáticos(Tabela 3.21), crescem no sentido da facies BASMG de 7,91 para 16,71 na facies BMG, com a facies BSGCl ocupando uma posição intermediária(14,69), mas decrescem no sentido da facies $B S G(9,67)$, sendo essa queda mais pronunciada nas variedades $B S G A$ e $\operatorname{BSGIA}(4,04$ e 1,26, respectivamente), com o CSMQGs possuindo valores intermediárioos entre essas duas últimas variedades.

$\mathrm{Em}$ relação ao $\mathrm{Eu}$, as mais acentuadas anomalias negativas mostram-se representadas no diferenciado mais evoluído(facies BSG), as quais tornam-se, ainda, mais pronunciadas nas suas variedades mais alteradas(Facies BSGA e BSGIA), enquanto que as menores anomalias negativas são encontradas nas facies BASMG e BSGCl. Isso demonstra a importância dos feldspatos no fracionamento desse elemento que se comportou como elemento compativel durante a diferenciação/fracionamento que produziu os granitóides do maciço, visto que esses minerais tem maior afinidade pelo $\mathrm{Eu}^{2+}$ do que por outros ETR trivalentes(Miller \& Mittlefheld, 1982). As razões $\left(E u_{N} / E u^{*}\right)$ são todas eqüivalentes e aproximadamente iguais a 13,70 , tanto nos diferenciados magmáticos, quanto nas variedades granitóides tardi a pós-magmáticas e no CSMQGs(Tabela 3.21).

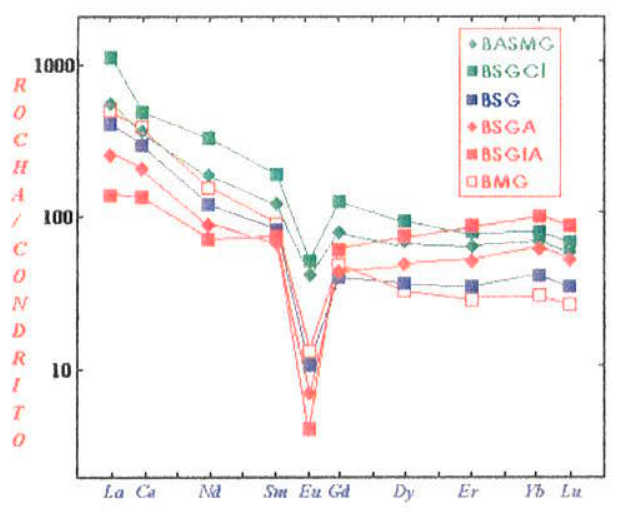

Figura 3.56.- Padrões de ETR Padrão de distribuição dos ETR para os granitóides do maciço granitóide Antônio Vicente

Tabela 3.21. Dados de ETR referentes às principais facies granitóides do maciço granitóide Antônio Vicente.

\begin{tabular}{|l|c|c|c|c|c|c|c|}
\hline $\begin{array}{l}\text { Facies } \\
\text { Granitóides }\end{array}$ & BASMG & BSGCI & BMG & BSG & BSGA & BSGIA & CSMQGs \\
\hline$($ La/Yb) & 7,91 & 14,69 & 16,71 & 9,67 & 4,04 & 1,26 & 3,45 \\
\hline$\left(\mathrm{Eu}_{N} / \mathrm{Eu}^{*}\right)$ & 13,74 & 13,70 & 13,70 & 13,69 & 13,70 & 13,70 & 13,69 \\
\hline$\sum E T R L$ & 460,26 & 777,55 & 454,88 & 374,59 & 259,59 & 170,55 & 195,04 \\
\hline$\sum E T R P$ & 59,41 & 92,48 & 30,42 & 45,51 & 47,44 & 74,80 & 41,67 \\
\hline$\sum E T R$ & 519,67 & 870,03 & 485,30 & 420,10 & 306,03 & 245,37 & 236,71 \\
\hline
\end{tabular}




\subsection{5- Análises Normativas CIPW}

As análises normativas CIPW referentes aos granitóides e greisens desse maciço(Tabelas 3.22 a 3.27, Anexo 14) foram calculadas através do software Minpet versão 2.02(Richard, 1988-1995), a partir de análises químicas de rocha total. A análise integrada das mesmas permite estabelecer que:

1) Os diferenciados magmáticos representados pelas facies BASMG e BSG são de um modo geral subsaturados em $\mathrm{Al}_{2} \mathrm{O}_{3}$. São excessões a isso uma amostra de cada uma dessas facies, que exibem córidon normativo, embora em baixas quantidades.

2) Os diferenciados magmáticos correspondentes às facies BSGCl e BMG mostram-se invariavelmente saturados em alumina, embora no geral apresentem baixo córidon normativo.

3) As variedades granitóides da facies BSG mais intensamente afetadas por alterações radi a pós-magmáticas(BSGA e BSGIA) e os greisens são sistematicamente saturados em $\mathrm{Al}_{2} \mathrm{O}_{3}$ e os mais elevados conteúdos de córindon normativo săo encontrados no MQGs e CQGs $(9,18 \%$ e $9,28 \%)$.

4) Os conteúdos de anortita decrescem no sentido da facies BASMG para os demais granitóides, mas crescem no CSMQGs. Os de albita tendem a crescer no sentido do BASMG para os outros granitóides, mas decrescem drasticamente nos greisens. Em razão disso, as razões Ab/An crescem no sentido da facies BASMG para os outros granitóides, mas decrescem no sentido do CQGs e CSMQGs.

5) Os conteúdos de $\mathrm{Hy}$, Mgt e de Ilm tendem a decrescer a partir da facies BASMG em direção às demais variedades de granitóides e de greisens, sendo excessão os mais elevados conteúdos de Mgt apresentado pelo CQGs(8,78\%).

No diagrama Q-Ab-Or(Figura 3.57) nota-se que as composições normativas dos granitóides desse maciço incidem dentro do campo de $86 \%$ de freqüência das razões normativas Q-Ab-Or de 1190 rochas graníticas de Winkler e Von Platen(1961). Percebe-se, também, que as composições de uma boa parte dos granitóides afasta-se um pouco do campo de máxima freqüência(ponto $M$ ). Enquanto uma parte se desloca no sentido do vértice do quartzo(silicificação), especialmente, aquelas correspondentes às variedades mais afetadas por alterações tardi a pós-magmáticas, outra tende aos vértice do Or(microclinização). Uma excessão a isso são as composições do BASMG. Uma amostra "plota" no campo de máxima freqüência e duas fogem um pouco no sentido do vértice da albita. Além disso, uma amostra da facies BSGCl foge totalmente para próximo da aresta QOr(silicificação+microclinização).

Embora esses granitóides mostrem-se afetados por albitização, em diferentes graus, seu efeito não se reflete nas suas composições normativas globais. Isso demonstra que os processos de alteração se deram segundo um sistema fechado, fato que não permitiu um 
aporte de $\mathrm{Na}$ ao mesmo. Isso é reforçado pelas quantidades de $\mathrm{F}$ no magma gerador dos granitóides desse maciço, que mostram-se na ampla maioria das amostras muito baixas. Elas situando-se abaixo da posição de temperatura do ponto de mínimo correspondente a $1 \%$ de $F$ adicionado(Manning, 1981) e em torno do ponto de minimo sem adição de $F(T u t t l e$ \& Bowen, 1958), Figura 3.57 deste trabalho. $O$ que demonstra que o $F$ foi remobilizado e enriquecido no estágio de alterações tardi a pós-magmáticas. Isso é evidenciado pela presença de quantidades expressivas desse elemento nos diferenciados mais evoluídos e mais afetados por alteraçőes tardi a pós-magmáticas e que se reflete em quantidades algo elevadas de fluorita, às vezes de topázio, e, subordinadamente, de outras fases menores portadoras de $\mathrm{F}$ nos mesmos(ver ítem "química mineral" deste capítulo).

Ainda em relação a esse diagrama, observa-se que a quase totalidade das composições situa-se entre as projeções das linhas cotéticas de $\mathrm{P}_{\mathrm{H} 2 \mathrm{O}}$ de $2 \mathrm{kbar}$ e de $5 \mathrm{kbar}$ de Winkler(1977), especialmente, as composições das facies mais evoluidas e afetadas por alterações tardi a pós-magmáticas. As composições dos diferenciados magmáticos correspondentes às facies BASMG, BMG e BSG situam-se preferencialmente em torno da projeção da linha cotética de $\mathrm{P}_{\mathrm{H} 2 \mathrm{O}}$ de $7 \mathrm{kbar}$.

No diagrama Ab-An-Or(Figura 3.58), a ampla maioria das amostras dos granitóides "plota" próximo à aresta Ab-Or, em posição intermediária entre esses dois vértices, com apenas uma amostra da facies BASMG e uma outra da facies BSGIA se afastando um pouco dessa aresta em direção ao vértice $A n$, devido aos seus maiores conteúdos de anortita normativa em relação às demais análises. Uma amostra das facies $\mathrm{BSGCl}$, que em razão de possuir conteúdo de An normativo muito baixo, incide na aresta $A b-O r$, próximo ao vértide do Or. O mesmo ocorre com a análise do MQGs. O CQGs, por sua vez, "plota" próximo ao vértice da $A b$, enquanto que as composições normativas do CSMQGs se distribuem muito próximo da aresta An-Or, com uma amostra ocupando uma posição intermediária e as demais tendendo claramente para o vértice do Or.

\subsection{6- Condições de Cristalização}

\subsubsection{1- Posicionamento Crustal}

Dall'Agnol(1980) apoiado em dados de campo referentes às relações de contato dos granitóides desse maciço com rochas vulcânicas andesiticas e riolíticas, não metamorfisadas(Grupo Uatumã), bem como nas suas similaridades texturais e químicas com os "younger granites" da Nigéria(granitos de alto nível) e suas analogias com granitos de epizona concluiu que os granitos desse maciço cristalizaram em nivel superior da crosta.

Neste trabalho, as considerações de Dall'Ágnol(op. cit.) são reforçadas, também, por dados de campo, bem como por estudos petrográficos, geoquímicos e isotópicos a saber: 
1) No campo os granitóides desse maciço ocorrem lado a lado, no mesmo nivel de erosão, com rochas vulcânicas intermediárias da Formação Sobreiro e félsicas da Formação Iriri(Grupo Uatumã). Embora os contatos entre os granitóides e as rochas vulcånicas não tenham sido observados diretamente no campo, o fato de ocorrerem associadas indica um posicionamento no mesmo nível crustal, em condições sub-vulcânicas a vulcânicas.

2) Os estudos petrográficos realizados através de microscopia ótica revelaram a presença de abundantes intercrescimentos granofíricos, especialmente em facies granitóides de ocorrências localizadas no interior do maciço(facies MMG e SMGGf). Essas texturas são geralmente desenvolvidas em rochas igneas félsicas colocadas próximo à superficie do crosta(Moorhouse, 1959, pg. 270; Smith, 1974, pg. 582; Bard, 1986, p.111) e, por conseguinte, em condições de baixas pressões, a partir de uma cristalização rápida de um granito eutético ternário, com quantidades semelhantes de quartzo, feldspato potássico e plagioclásio(Smith, 1974, pg. 582).

3) A presença da paragênese fluorita+sericita+muscovita+topázio, em diferentes proporções nesses granitóides, bem como sua relação com importantes conteúdos de $F$, indicam um posicionamente dos mesmos em nível crustal raso, entre $1 \mathrm{~km}$ a $5 \mathrm{~km}$ (Bailey, 1977).

4) Datações radiométricas em uma combinação de amostras de andesitos e riolitos do Grupo Uatumã, realizadas através do método $\mathrm{Pb}-\mathrm{Pb}$ em rocha total(Teixeira et al., 1998), indicaram uma idade de $1.875 \pm 79 \mathrm{Ma}$ para esse grupo. Datações através do mesmo método, bem como por evaporação de $\mathrm{Pb}$ em zircões dos granitóides do maciço Antônio Vicente forneceram idades de $1.896 \pm 9 \mathrm{Ma}$ e de $1.867 \pm 4$, respectivamente. Essas idades foram interpretadas como aquelas de cristalização das unidades acima referidas e indicam uma contemporaneidade entre os eventos vulcánicos e plutônicos. Essa associação reforça a hipótese de posicionamento em nivel crustal raso dos granitóides, em razão de suas estreitas relações com as rochas vulcânicas no tempo e no espaço.

\subsubsection{2- Condições de $\mathrm{fO}_{2}, \mathrm{~T} \in \mathrm{P}$}

Análises químicas em grãos de anfibólios, de composições dominantemente hastingsítica $e$, subordinadamente, ferro-edenítica(aluminiohastingsita e alumíniohastingsita a aluminio-ferro-edenita.conforme a classificação apresentada por Leake et al, 1997), presentes nas facies à biotita e anfibólio mostraram um nítido "trend" de redução nas condições de fugacidade de oxigênio durante a diferenciação magmática no sentido da facies menos evoluída(BASMG) para aquela mais diferenciada $e$, relativamente, mais silicica(BASAFG), conforme discutido no item "química mineral" deste capítulo. A Figura 
3.59, deste trabalho(compilada de Anderson \& Smith, 1995) ilustra perfeitamente esse "trend". Nela observa-se que o anfibólio da facies BASMG iniciou sua cristalização em condições intermediárias de $\mathrm{fO}_{2}$ e evoluiu para condições de $\mathrm{fO}_{2}$ baixas, enquanto que 0 anfibólio da facies BASAFG cristalizou em condições de fugacidade de oxigênio muito baixas.

Estudos petrográficos realizados através de microscopia ótica, aliados à caracterização mineral através de microscopia eletrônica de varredura, revelaram a presença de ilmenita e de titano-magnetita como fases óxidos de $\mathrm{Fe}-\mathrm{Ti}$ dominantes nos granitóides desse maciço, em especial, na facies BASMG. Essas fases são indicativas de que esse granitóide cristalizou sob condições de baixa fugacidade de oxigênio, sendo, por conseguinte, um granitóide reduzido, a semelhança daqueles da série ilmenita(conforme a classificação de Ishihara, 1977), ainda que tenha hornblenda relativamente pobre em $\mathrm{Fe}^{2+}$, com as razões $\mathrm{Fe}^{2+} /\left(\mathrm{Fe}^{2+}+\mathrm{Mg}\right)$ situando-se entre 0,53 e 0,71 e sendo bem mais baixas do que aquelas de $\mathrm{FeO}_{\mathrm{T}} /\left(\mathrm{FeO}_{\mathrm{T}}+\mathrm{MgO}\right)$ de rocha total, cujos valores estão compreendidos entre 0,83 e 0,89 .

Em razão do que foi apresentado acima, o "trend" de redução nas condições de oxidação observado em relação ao anfibólio corresponde, na realidade, a um "trend" de aumento nas condições de redução que imperaram durante a cristalização fracionada no sentido da facies BASMG para a facies BASAFG.

Adicionalmente, análises químicas em grãos de biotita de composição annítica ocorrentes na facies BSG- considerada o diferenciado magmático mais evoluído- indicaram que a mesma cristalizou sob condições de baixa $\mathrm{fO}_{2}\left(\cong 10^{-16,80}\right)$. Considerando que a biotita é uma fase primária tardia em relação ao anfibólio e às fases essenciais- quartzo, plagioclásio e feldspato potássico- em todas as facies granitóides do maciço, pode-se concluir que condições redutoras reinaram por todo o estágio de evolução magmática dos granitóides desse maciço.

Além disso, o intervalo de temperatura estimado para a biotita em questão deve estar próximo daquele que marca o final de estágio magmático, uma vez que a mesma corresponde a última fase mineral primária, dessa facies granitóide, a iniciar sua história de cristalização. Isso é mais ou menos confirmado pela temperatura mínima estimada(ver ítem Química Mineral, deste capítulo) para a cristalização da clorita dessa mesma facies $\left(493,17^{\circ} \mathrm{C}-507,98^{\circ} \mathrm{C}\right)$, visto que ela representa uma das primeiras fases secundárias a iniciar sua cristalização no estágio de alterações tardi a pós-magmáticas. Assim, o intervalo de temperatura estimado para a cristalização dos cristais da biotita estudada, deve corresponder ao intervalo de temperaturas mínimas de cristalização dos granitóides desse maciço, cuja formação é atribuída ao estágio magmático. 
Em relação às condições de pressão, diversos autores tem apresentado vários barômetros, baseados no conteúdo de Al em anfibólios(hornblenda), aplicados à rochas granitóides(Ghen \& Stont, 1981; Thompson et al., 1982; Powell \& Evans, 1983; Ganguly \& Saxena, 1984; Peters et al., 1985; Hammarstron \& Zen, 1986; Hollister et al. 1987; Johnson \& Rutherford, 1988; Johnson \& Rutherford, 1989a; Rutter et al., 1989; Schmidt, 1992; Anderson \& Smith, 1995; entre outros). Entretanto, uma grande parte deles tem se voltado ora para auréolas de plutons calci-alcalinos, ora para plutons calci-alcalinos metaluminosos. Alguns tem se baseado em parâmetros mineralógicos de rochas graníticas peraluminosas a duas micas e outros para rochas vulcânicas. Até recentemente, nenhum barômetro foi elaborado para rochas graníticas subalcalinas, especialmente aquelas de colocação subvulcânica.

Em razão disso, foi utilizado neste trabalho, apenas com o objetivo de se estimar condições de pressão de referência, o barômetro elaborado por Johnson e Rutherford(1989a), uma vez que o mesmo pode ser aplicado para deduzir as pressões de eqüilibrio de rochas vulcânicas e plutônicas. No caso de rochas plutônicas, as pressões deduzidas correspondem à profundidade da intrusão. O barômetro de Anderson \& Smith(1995) não pode ser aplica devido o anfibólio dos granitóides estudados neste trabalho não preencherem os requisitos exigidos pelo barômetro desses autores. As razöes $\mathrm{Fe}_{(\text {total) }}$ $/\left(\mathrm{Fe}_{(\text {total) }}+\mathrm{Mg}\right)$ nos granitóides estudados variam entre 0,76 e 0,85(facies BASMG) e de 0,95 a 0,96(facies BASAFG), enquanto a aplicação do referido barômetro exige razões entre 0,40 e 0,65 . Do mesmo modo, a ampla maioria dos grãos analisados apresenta razões $\mathrm{Fe}^{3+}$ $/\left(\mathrm{Fe}^{3+}+\mathrm{Fe}^{2+}\right.$ ) oscilando entre 0,27 e 0,36 (facies BASMG) e de 0,10 a 0,13(facies BASAFG), enquanto a razão exigida dever ser aproximadamente 0,25 .

Assim, considerando-se o barômetro de Johnson \& Rutherford(1989a), as análises dos anfibólios, foram lançadas no diagrama $\mathrm{Ti}$ vs. $\mathrm{Al}_{(\text {total), }}$ compilado a partir de Turner et al.(1992), Figura 3.60 deste trabalho. Nela observa-se que a pressão estimada para o anfibólio da facies BASMG situa-se entre aproximadamente 2,8 e $4 \mathrm{kbar}$, enquanto que para o anfibólio da facies BASAFG ela varia de aproximadamente 2,7 até 3,5kbar. Isso signica dizer que as pressões estimadas correspondem à profundidade de colocação dos granitóides em questão.

No que se refere à temperatura de cristalização, utilizou-se para estimativa o trabalho experimental de Brown \& Fyfe(1970), realizado a partir de granito seco(dry granite) contendo biotita e muscovita, ou hornblenda, como fases portadoras de $\mathrm{OH}$. Assim, as pressões estimadas foram lançadas no diagrama P-T(Figura 2; pg.314, desses autores), Figura. 3.61 deste trabalho. Nele observa-se que o intervalo de pressão estimado para o anfibólio da facies BASMG corresponde a um intervalo de temperatura situado entre $871,1^{\circ} \mathrm{C}$ e $881,6^{\circ} \mathrm{C}$. 
Para as pressões estimadas em relação à facies BASAFG, obteve-se temperaturas variando de $867,1^{\circ} \mathrm{C}$ a $876,3^{\circ} \mathrm{C}$.

Essas condições de $\mathrm{T}$ e $\mathrm{P}$ estimadas para a cristalização dos anfibólios desses granitóides, embora não pareçam muito distantes daquelas em que os mesmos cristalizaram, servem, no momento, apenas como estimativas de referências. Isso decorre, principalmente, das razões a saber: 1) da não existência, até o momento, de calibrações de barômetros para rochas granitóides de colocação subvulcánica, de natureza peraluminosas e caráter subalcalino, ocorrentes em ambientes intraplacas e com características semelhentes àquelas dos granitóides tipo-A; do sub-grupo $A_{2} ; 2$ ) do fato de que mesmo os barômetros, baseados em parâmetros inerentes ao anfibólio(hornblenda), fartamente apresentados na literatura, ainda serem considerados como de "status" preliminar, até que todas as reações envolvidas na paragênese onde o mesmo esteja inserido sejam estabelecidas e experimentalmente calibradas, usando a composição de todos os minerais, a semelhança do que foi desenvolvido para as rochas metamórficas, e não somente a composição da hornblenda(conforme sugerido por Anderson \& Smith, 1995, pg. 557), além de outros parâmetros termodinâmicos tais como a temperatura e a $\mathrm{fO}_{2}$.

Ainda em relação às condições de cristalização dos granitóides desse maciço, análises químicas em biotita da facies BSG, revelaram, a partir da aplicação do termômetro de Wones \& Eugster(1965), temperatura de cristalização oscilando entre $695,80^{\circ} \mathrm{C}$ e $710,00^{\circ} \mathrm{C}$. Do mesmo modo que em relação ao anfibólio, utilizou-se o trabalho experimental de Brown \& Fyfe(1970) para estimar o intervalo de pressão correspondente a esse intervalo. $\mathrm{Na}$ Figura 3.62, nota-se que as pressões estimadas situam-se entre aproximadamente $0.8 \mathrm{kbar}$ e 1.10kbar. Esse resultado é compativel com aquele de referência obtido em relação ao anfibólio, uma vez que a biotita estudada encontra-se hospedada na facies granitóides que, dentre os principais diferenciados magmáticos do maciço, representa a facies mais tardia e evoluída no âmbito do mesmo. De acordo com dados de campo, essa facies forma a ampla maioria dos morros que realçam a topografia do maciço e, ao que tudo indica, parace ter sido colocada nas porções mais superiores do edifício granitóide onde as pressões eram, supostamente mais reduzidas, enquanto que as facies a biotita e anfibólio ocorrem nas regiöes mais arrasadas do mesmo, aflorando, preferencialmente, nas vales de drenagem. Isso leva a supor que os mesmos foram colocados em posições mais baixas, onde as pressões e temperaturas deveriam ser mais elevadas, especialmente no momento de suas colocações. De qualquer modo são valores de referências que devem ser melhorados e testados no futuro através de mais análises, especialmente em grãos de biotita das facies a biotita e anfibólio, não disponiveis no momento, bem como a partir de outros dados complementares. 


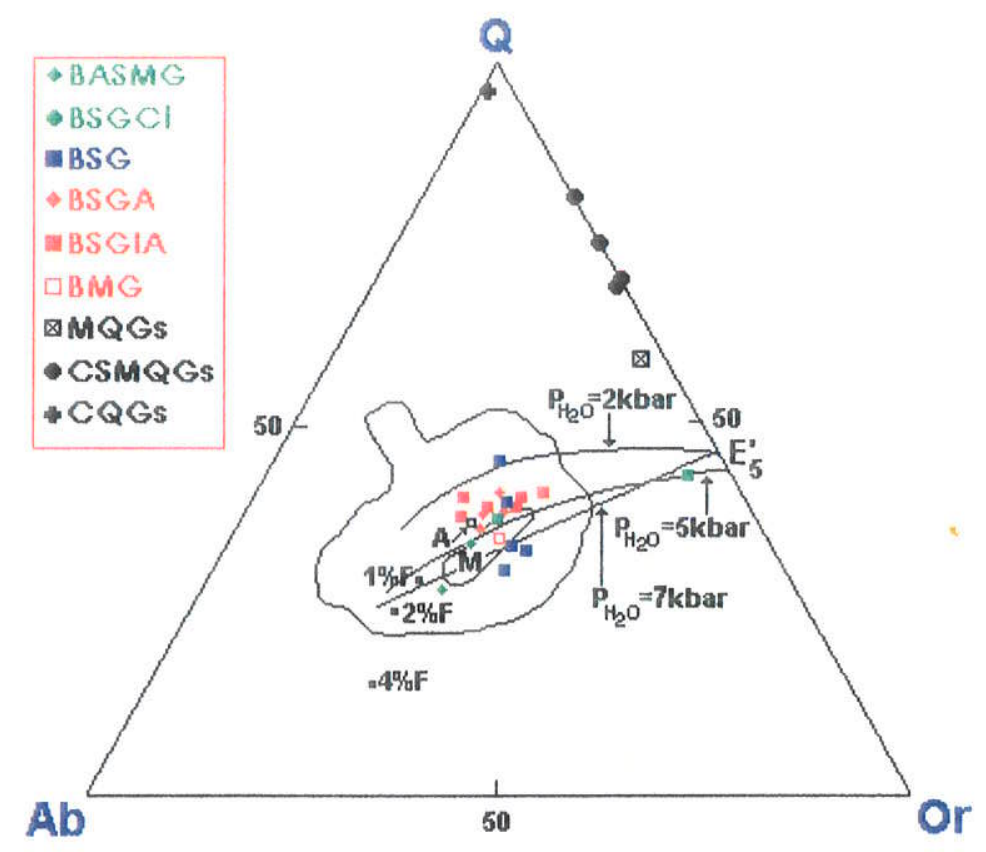

Figura 3.57- Diagrama normativo Q-Ab-Or mostrando a distribuição composicional das principais facies granitóides do maciço granitóide Antônio Vicente. As linhas tracejadas indicam a distribuição de freqüência das razões Q-Ab-Or de 1190 rochas graníticas de Winkler \& Von Plaren(1961). As projeções das linhas cotéticas isobáricas P-E'5 de 2, 5 e 7kbar foram compiladas de Winkler(1977). M é o máximo de freqüência , A representa a posição e temperatura do ponto de mínimo sem $F$ (Tuttle \& Bowen, 1958). $1 \% \mathrm{~F}, 2 \% \mathrm{~F} \mathrm{e} 4 \% \mathrm{~F}$ representam as posições e temperaturas dos pontos de mínimo com $\mathrm{F}$ adicionado e excesse de água a $1 \mathrm{kbar}($ Manning, 1981).

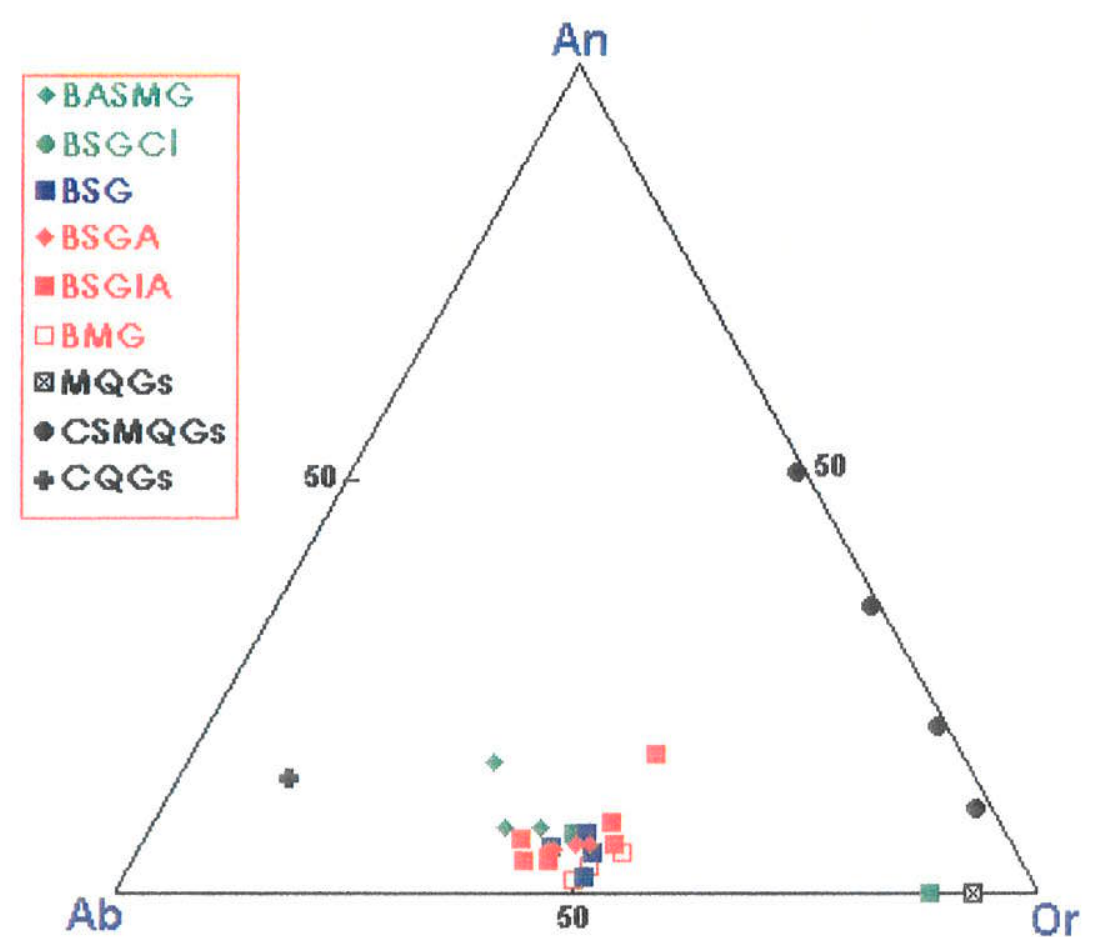

Figura 3.58- Diagrama normativo Ab-An-Or mostrando a distribuição composicional das pricipais facies granitóides e greisens associados ao maciço Antônio Vicente. 


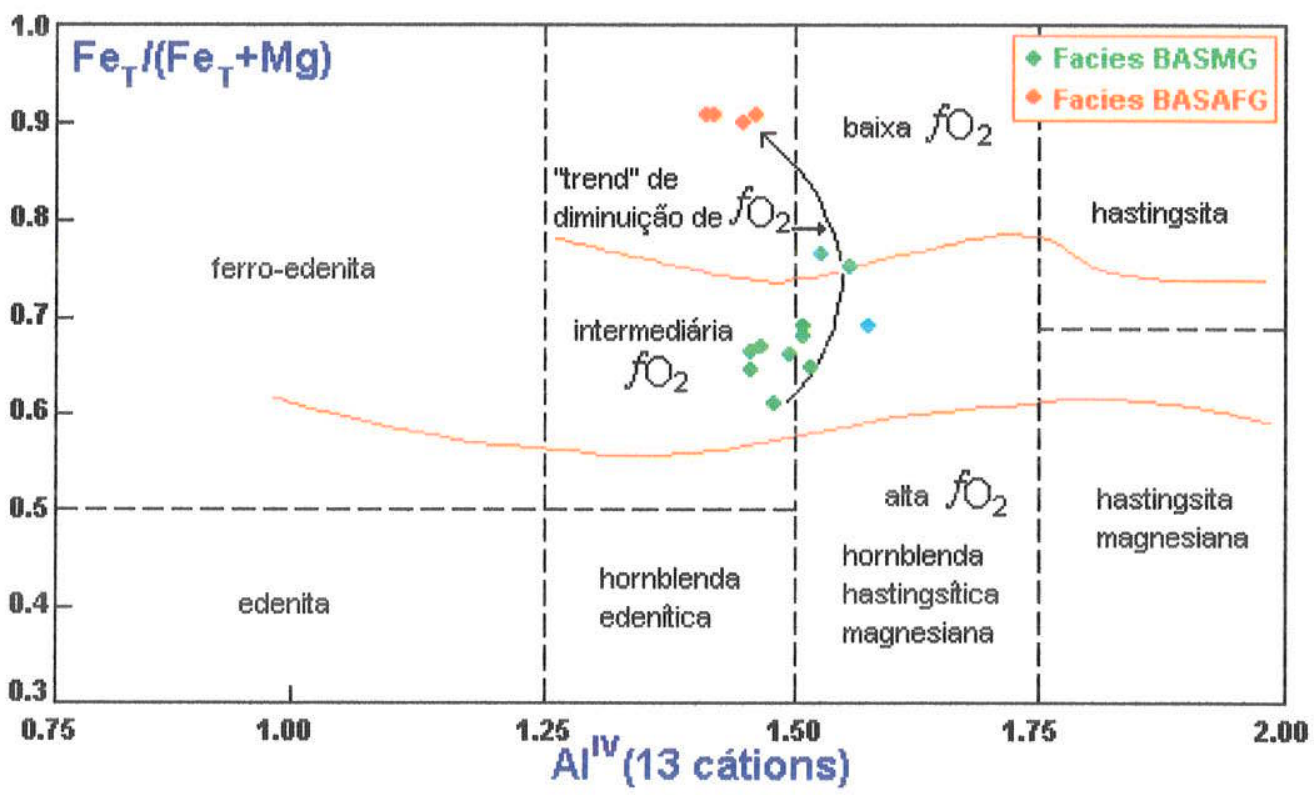

Figura 3.59- Diagrama Fe/(Fe+Mg) vs. $\mathrm{Al}^{\mathrm{IV}}$ (compilado a partir de Anderson \& Smith, 1995, modificado de Leake, 1978) mostrando a distibuição composicional dos anfibólios das facies BASMG e BASAFG do maciço granitóide Antônio Vicente. As linhas vermelhas limitam os campos de diferentes $\mathrm{fO}_{2}$.

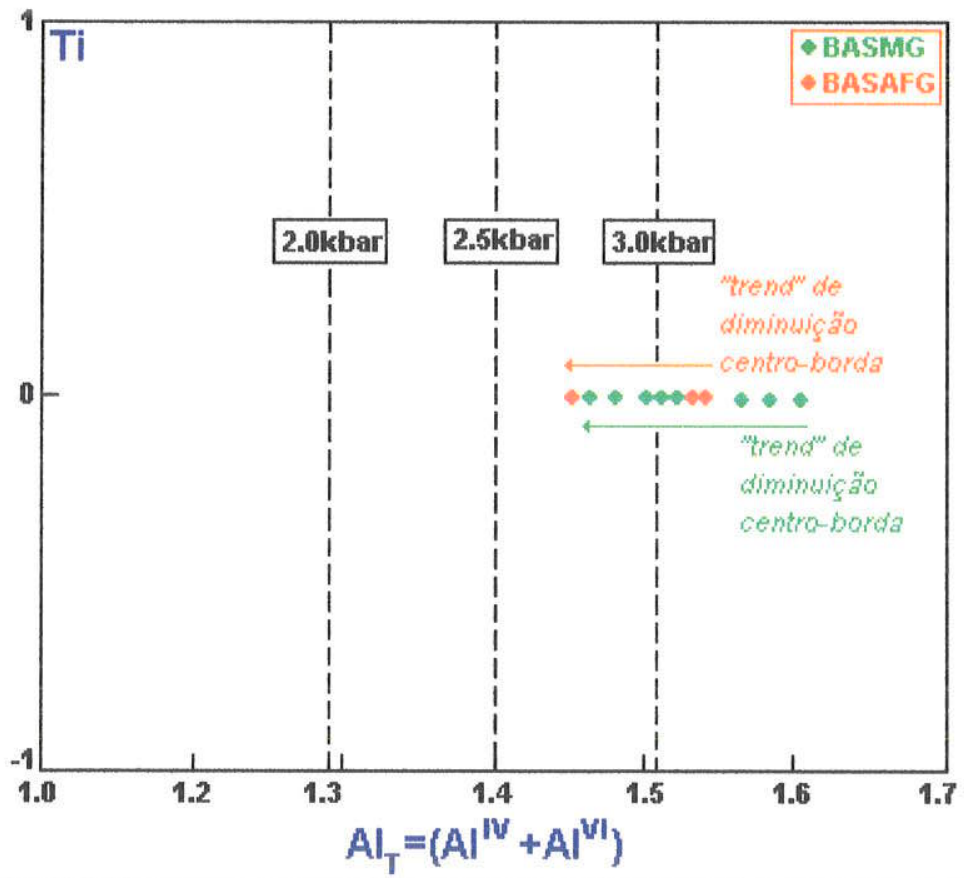

Figura 3.60- Diagrama Ti vs. AIT(compilado a partir de Turner et al., 1992, constuído a partir de Johnson \& Rutherford, 1989a) mostrando a distibuição composicional dos anfibólios das facies BASMG e BASAFG do maciço granitóide Antônio Vicente. 


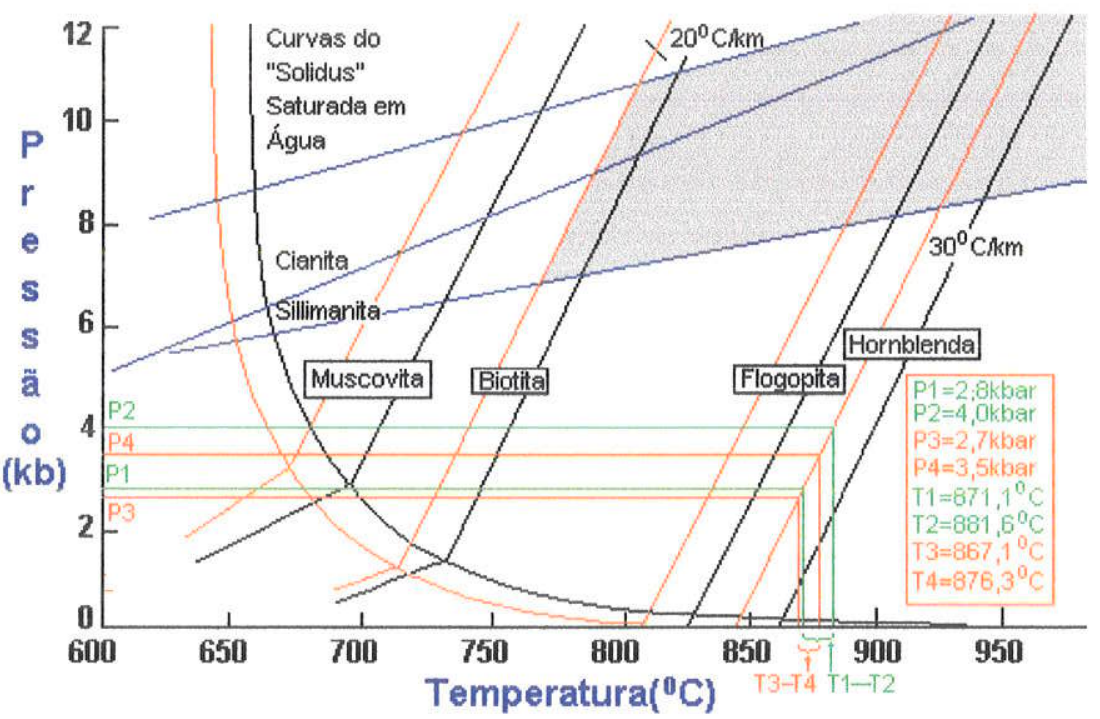

Figura 3.61- Diagrama P-T(compilado a partir de Brown \& Fyfe, 1970) mostrando a estimativa da temperatura de cristalização dos anfibólios das facies BASMG e BASAFG do maciço granitóide Antônio Vicente, determinada a partir da pressão estimada através do barômetro de Johnson \& Rutherford(1989a). As linhas vermelhas representam o começo da fusão reconhecida em granito seco e as linhas azuis correspondem ao começo da fusão reconhecida em misturas dioritícas resultantes da decomposição das várias fases hidratadas indicadas. Também são indicadas a curva do"solidus" saturada em água determinada para dois tipos minerais quartzo-feldspáticos juntamente com os possíveis gradientes geotermais e a curva do limite de equilíbrio entre cianita e sillimanita. A principal produção de líquidos graníticos naturais mais provável corresponde à área em rosa acinzentada. $20^{\circ} \mathrm{C}$ e $30^{\circ} \mathrm{C} / \mathrm{Km}$ correspondem às linhas azuis superior e inferior, respectivamente.

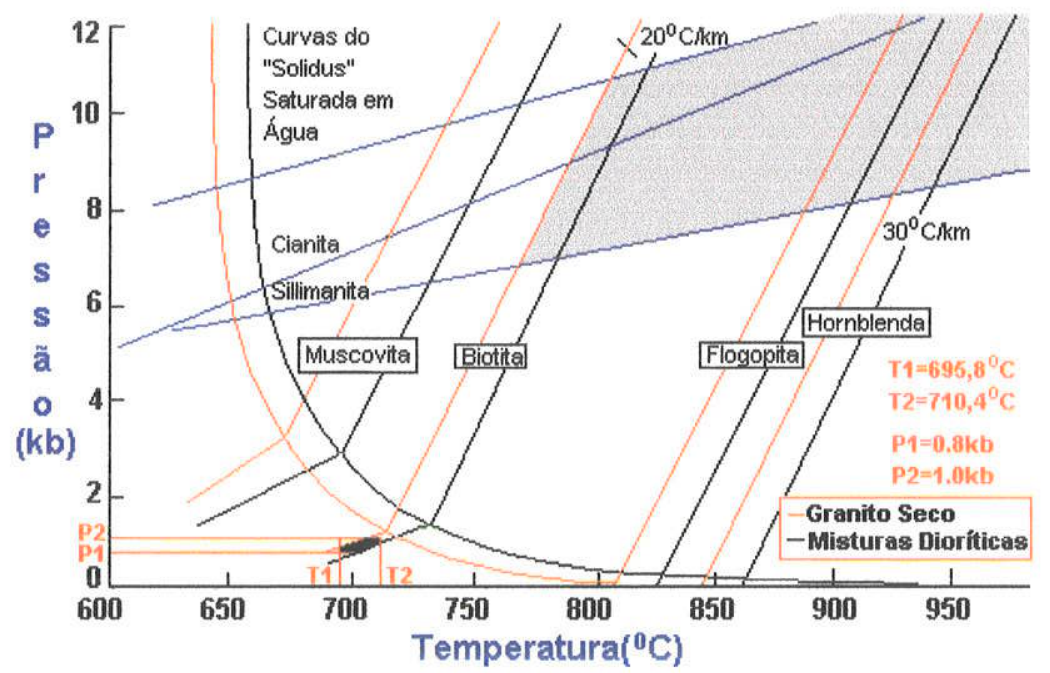

Figura 3.62- Diagrama P-T(compilado a partir de Brown \& Fyfe, 1970) mostrando a estimativa da temperatura de cristalização da biotita da facies BSG do maciço granitóide Antônio Vicente, determinada a partir da temperatura estimada através do termômetro de Wones \& Eugster(1965). As linhas vermelhas e azuis, bem como as outras informações correspondem ao que foi apresentado na Figura 3.61. 


\subsection{7- Conclusões e Considerações Finais}

Os dados químicos apresentados neste capítulo referentes ao maciço granitóide Antônio Vicente permitiram estabelecer as seguintes conclusões:

1)Os granitóides são peraluminosos a metaluminosos, de natureza subalcalina, correspondem composicionalmente aos granitos do sub-grupo $A_{2}$ e mostram caracteristicas de ambiência Intra-placas.

2) A facies granitóide mais evoluída e diferenciada(BSG) e suas variedades mais fortemente afetadas por alterações tardi a pós-magmáticas e hospedeiras de mineralizações de estanho(BSGA e BSGIA) possuem os mais altos teores de $\mathrm{SiO}_{2}$, geralmente superiores a $75 \%$.

3) Os granitóides mais diferenciados, em relação às facies menos evoluídas do maciço, possuem conteúdos de $\mathrm{TiO}_{2} \mathrm{CaO}, \mathrm{MgO}, \mathrm{Sr}, \mathrm{Ba}, \mathrm{Cl}, \mathrm{B}, \mathrm{Ta}, \mathrm{Ga}$, Hf e ETRP sempre muito baixos, enquanto aqueles de $\mathrm{Rb}, \mathrm{Zr}, \mathrm{Y}, \mathrm{F}, \mathrm{Li}, \mathrm{U}, \mathrm{Nb}$ e ETRL são sistematicamente altos.

3) As razões $\mathrm{FeO} /(\mathrm{FeO}+\mathrm{MgO}), \mathrm{Rb} / \mathrm{Sr}, \mathrm{Rb} / \mathrm{Ba}$, e $\mathrm{F} / \mathrm{Cl}$ são invariavelmente altas, especialmente nas facies granitóides BSG e suas variedades mais intensamente afetadas por alterações tardi a pós-magmáticas e portadoras de mineralizações de Sn(BSGA e BSGIA), enquanto as razões K/Rb são muito baixas se comparadas com aquelas dos granitos considerados normais.

4) Uma feição característica nos granitóides desse maciço são os relativamente baixos conteúdos $\mathrm{Ga}$, o que contraria uma das características geoquímicas dos granitos Tipo-A. A hipotese mais plausivel para explicar os baixos valores de Ga nesses granitóides refere-se à estreita relação desse elemento com o Al(Taylor, 1965), que, também se apresenta em teores relativamente baixos se comparados com aqueles da média dos granitos apresentada por Le Maitre(1976).

5) As razões médias Th/U são variáveis, situam-se entre 1,14 e 4,40, evidenciando a que se trata de granitos HHP.

6) Nos diferenciados magmáticos desse maciço os conteúdos de $F$ variam largamente, desde valores médios iguais a 745ppm(facies $B S G C l$ ) até 2.580ppm(facies BSG). Esses valores tornam-se ainda mais elevados nas variedades granitoides mais intensamente afetados por alterações tardi a pós-magmáticas, onde atingem teores médios entre $3.675 \mathrm{ppm}$ (variedade BSGA) e 6.566,70ppm(variedade BSGIA). As quantidades mais expressivas são encontradas no clorita-siderofilita-muscovita-quartzo greisen, onde o conteúdo de F alcança um valor médio igual a 1,49\%, embora em algumas amostras possa atingir até $2,2 \%$.

7) A presença da paragênese fluorita+topázio+muscovita+clorita+siderofilita e a sua relação com conteúdos importantes de $F$, na facie granitóide mais diferenciada(BSG) e nas suas 
variações(BSGA e BSGIA) é indicativa de que os granitóides do maciço foram colocados em nível crustal raso, entre $1 \mathrm{Km}$ e $5 \mathrm{Km}$. Além disso, parece razoável imaginar que as soluções contendo $F$ foram separadas e removidas, de modo mais expressivo, a partir da cristalização da facies BSG, nesse nível mais alto de colocação.

8) As amostras com teores mais elevados de flúor apresentam, também, teores mais elevados de estanho(variedade BSGIA e CSMQGs), o que é reforçado pela presença de cassiterita nas amostras dessas duas variedades.

9) Tanto $\mathrm{Cl}$ quanto $\mathrm{Sn}$ decrescem no estágio magmático, no sentida da facies BASMG(menos evoluida) para a mais evoluida e diferenciada(BSG). No estágio de alterações tardi a pós-magmáticas os conteúdos de $\mathrm{Cl}$ diminuem no sentido da facies BSG para as variedades BSGA e BSGIA, enquanto que os de Sn aumentam no mesmo sentido.

11) Considerando que as facies mais transformadas e evoluidas e os greisens são os termos hospedeiros das mineralizações de cassiterita e que a fluorita e o topázio são mais freqüentes e abundadntes nessas rochas(exceto o topázio que não foi detectado nos greisens), presume-se que o fiúor desempenhou um papel fundamental na evolução e gênese dos depósitos de cassiterita. Isso reforça a hipótese de que os fluidos tardi a pósmagmáticos enriquecidos em voláteis, especialmente em $F$, estão relacionado diretamente com as mineralizações de cassiterita, nesse maciço, não parecendo verdadeiro no que diz respeito ao $\mathrm{Cl}$.

12) No que se refere às concentraçōes dos ETR, os granitóides do maciço mostram que conteúdos médios dos ETRL são mais enriquecidas nos diferenciados magmáticos, relativamente, menos evoluidos(facies BASMG e BSGCl, onde $\Sigma E T R L=460,26 \mathrm{ppm}$ e $777,55 \mathrm{ppm}$, respectivamente) e mais empobrecidas no diferenciado magmático mais evoluidos(facies $B S G$, onde $\Sigma=374,59 \mathrm{ppm}$ ), bem como nas suas variedades mais afetadas por alterações tardi a pós-magmáticas(facies BSGA e BSGIA, onde $\Sigma=258,59 \mathrm{ppm}$ e $170,55 \mathrm{ppm}$, respectivamente) e no CSMQGs(onde $\Sigma=195,04 \mathrm{ppm}$ ).

13) Esse comportamento dos ETRL nos granitóides estudados é compativel com a evolução de magmas félsicos, onde as concentrações dos ETRL decrescem drasticamente durante a diferenciação de tais magmas.

14) A presença de apreciáveis fases de vapor nos resíduos magmáticos mais tardios(diferenciado BSG) e nos fluidos tardi a pós-magmáticos podem ter levado a uma exaustão, por lixiviação, dos ETRL. Isso pode explicar, pelo menos em parte, a razão das baixas concentraçōes de ETRL nas variedades mais intensamente afetadas por alterações tardi a pós-magmáticas(facies BSGA e BSGIA) e no CSMQGs.

15) Em relação aos ETRP, verifica-se que nos diferenciados magmáticos, as maiores concentrações médias relativas são encontradas nas variedades BASMG e BSGCl(onde 
$\Sigma=59,41 \mathrm{ppm}$ e $\Sigma=92,48 \mathrm{ppm}$, respectivamente), enquanto que as menores mostram-se contidas na facies BMG e $B S G$ (onde $\Sigma=30,42 \mathrm{ppm}$ e $\Sigma=45,51 \mathrm{ppm}$, respectivamente) e no CSMQGs(onde $\sum=41,67 \mathrm{ppm}$ ).

16 As razões para esse comportamento dos ETRP podem ser explicadas pela presença das fases anfibólio, apatita, zircão e titanita(facies BASMG) e apatita(facies BSGCl), as quais ocorrem como traços ou estão ausentes nas demais variedades de granitóides. Como exceção a isso, são os mais elevados conteúdos médios de ETRP na variedade BSGIA(onde $\Sigma=74,80 \mathrm{ppm}$ ), em relação a todas as demais facies granitóides do maciço. Entretanto, a presença de Thorita e zircão(analisados através deMEV) enriquecidos em ETRP, especialmente em Yb e Dy, nessa variedade de granitóide, pode explicar esses elevados conteúdos de ETRP.

17) As razões $(L a / Y b)_{N}$, nos diferenciados magmáticos, crescem no sentido da facies $\operatorname{BASMG}(7,91)$ para facies $\mathrm{BMG}(16,71)$, com a facies $\mathrm{BSGCl}$ ocupando uma posição intermediária(14,69), mas decresce no sentido da facies $B S G(9,67)$, sendo essa queda mais pronunciada nas variedades BSGA e BSGIA(4,04 e 1,26, respectivamente), com o CSMQGs possuindo valores intermediários entre essas duas últimas variedades.

18) As mais acentuadas anomalias negativas do Eu mostram-se representadas no diferenciado mais evoluido(facies BSG), as quais tornam-se, ainda, mais pronunciadas nas suas variedades mais alteradas(Facies BSGA e BSGIA), enquanto que as menores anomalias negativas são encontradas nas facies BASMG e $\mathrm{BSGCl}$. Isso demonstra a importância dos feldspatos no fracionamento desse elemento que se comportou como elemento compatível durante a diferenciação/fracionamento que produziu os granitóides do maciço, visto que esses minerais tem maior afinidade pelo $\mathrm{Eu}^{2+}$ do que por outros ETR trivalentes.

19) As razões $\left(E u_{N} / E u^{*}\right)$ são todas eqüivalentes e aproximadamente iguais a 13,70 , tanto nos diferenciados magmáticos, quanto nas variedades granitóides tardi a pós-magmáticas $\Theta$ no CSMQGs.

20) Os diferenciados magmáticos representados pelas facies BASMG e BSG são de um modo geral subsaturados em $\mathrm{Al}_{2} \mathrm{O}_{3}$.

21) Os diferenciados magmáticos correspondentes às facies $B S G C l$ e BMG mostram-se invariavelmente saturados em alumina, embora no geral apresentem baixo córidon normativo.

22) As variedades granitóides da facies BSG mais intensamente afetadas por alterações tardi a pós-magmáticas(BSGA e BSGIA) e os greisens são sistematicamente saturados em $\mathrm{Al}_{2} \mathrm{O}_{3}$ 
23) Embora esses granitóides mostrem-se afetados por albitização, em diferentes graus, seu efeito não se reflete nas suas composições normativas globais. Isso demonstra que os processos de alteração se deram segundo um sistema fechado, fato que não permitiu um aporte de $\mathrm{Na}$ ao mesmo.

24) As quantidades de $F$ no magma gerador dos granitóides desse maciço mostram-se na ampla maioria das amostras muito baixas. Elas situando-se abaixo da posição de temperatura do ponto de mínimo correspondente a $1 \%$ de $\mathrm{F}$ e em torno do ponto de mínimo sem adição de $F$. Isso demonstra que o F foi remobilizado e enriquecido no estágio de alterações tardi a pós-magmáticas, cuja evidência é traduzida pela presença de quantidades expressivas desse elemento nos diferenciados mais evoluidos $e$ mais afetados por alterações tardi a pós-magmáticas e que se reflete em quantidades algo elevadas de fluorita, às vezes de topázio, e, subordinadamente, de outras fases menores portadoras de F nos mesmos.

25) Em relação à pressão reinante durante a cristalização, a quase totalidade das composições situa-se entre as projeções das linhas cotéticas de $\mathrm{P}_{\mathrm{H} 2 \mathrm{O}}$ de $2 \mathrm{kbar}$ e de $5 \mathrm{kbar}$, especialmente, as composições das facies mais evoluídas e afetadas por alterações tardi a pós-magmáticas. As composições dos diferenciados magmáticos correspondentes às facies BASMG, BMG e BSG situam-se preferencialmente em torno da projeção da linha cotética de $P_{\mathrm{H} 2 \mathrm{O}}$ de $7 \mathrm{kbar}$. 


\section{CAPÍTULO 4}

\section{4- MACIÇO GRANITÓIDE VELHO GUILHERME(MGVG)}

\section{1- Contexto Geológico}

Esse maciço aflora no âmbito do Terreno Granito-Greenstone do Sul do Pará(CPRM/DNPM, 1991) ou Terreno Granito-Greenstone de Rio Maria(Costa et al., 1995), imediatamente a sul da cidade de Tucumã(Figura 4.1). Apresenta uma forma grosseiramente circular e possui área de exposição de aproximadamente $80 \mathrm{Km}^{2}$. Mostra-se encaixado, discordantemente, em unidades do Grupo Tucumã(CPRM/DNPM, op. cit.) e em granitóides do Granodiorito Rio Maria(Medeiros, 1987). No contexto do Grupo Tucumã, é intrusivo a norte, nordeste, leste, sudeste e a oeste em rochas metavulcano-sedimentares da Formação Igarapé do Cuca e a sul e sudoeste em metassedimentos miloníticos da Formação Igarapé Abelha. No que se refere ao Granodiorito Rio Maria, faz contato discordante a noroeste com granitóides protomiloniticos e miloníticos, de composição, dominantemente, sienogranítica a monzogranitica.

\section{2- Histórico}

Foi referido, inicialmente, na literatura por Abreu \& Ramos(1974) como Serra Velho Guilherme, a qual foi interpretada como sendo de natureza granítica, tendo sido comparada com aquelas de Rondónia, mais conhecidas na época, devido suas mineralizações de estanho.

O termo Velho Guilherme foi utilizado por Silva et al.(1974) para designar um conjunto de mais de duas dezenas de corpos granitóides, circulares, de ambiência cratônica, colocados em condições sub-vulcânicas, que hospedavam mineralizações de cassiterita e topázio e se localizavam, principalmente, nas Folhas SB-22-Y-C e SC-22-X-A. A partir de então tais granitóides passaram a ser conhecidos na literatura como do "Tipo Velho Guilherme". Entretanto, ao longo do tempo, esse conjunto de granitóides sofreu algumas modificações(Hirata et al., 1982; Docegeo, 1988).

CPRM/DNPM(op. cit.), baseando-se na emenda introduzida ao "Código de Nomenclatura Estratigráfica" por Shol(1977), adotaram a terminologia "Suite Intrusiva Velho Guilherme" para designar o conjunto de maciços granitóides, situados na Folha SB-22-Y$B$ (Folha São Felix do Xingu), não metamorfisados e de idade Mesoproterozóica. A razão disso, deveu-se a uma série de semelhanças existentes entre os mesmos, tais como a idade, mineralogia, aspecto textural, quimismo, metalogenia, evolução petrológica e 
condicionamento estrutural. Como um maciço individual pertencente a esse conjunto, está incluido o maciço granitóide Velho Guilherme, que empresta o nome à suite.

O primeiro estudo dirigido para a caracterização dos diferentes maciços granitóides da porção sul da Amazónia Oriental foi realizado por Dall'Agnol(1980). Esse autor buscou caracterizar petrográfica e geoquimicamente, bem como compreender a evolução petrológica e magmática dos granitóides dos maciços Antônio Vicente, Central de Carajás, Mocambo e Jamon. Procurou, ainda, compreender os processos de alteração tardi a pósmagmática que afetaram tais granitóides em diferentes graus. Além disso, buscou reunir uma série de elementos que possibilitassem a definição de diferentes gerações de granitóides e suas tipologias.

Dall'Agnol(1982a) realizou um estudo comparativo entre alguns maciços granitóides pós-Ciclo Transamazônico da Amazônia Oriental estudados por Dall'Agnol(1980). Mostrou que, sob o ponto de vista petrográfico e de suas evoluções petrológicas, os maciços Antônio Vicente, Velho Guilherme e Mocambo, apresentavam muitas similaridades, sugerindo estarem relacionados a um mesmo evento magmático regional.

Dall'Agnol et al.(1984) apresentaram novos dados geocronológicos para esses mesmos maciços e estudaram o comportamente de alguns elementos traços $(\mathrm{Rb}, \mathrm{Sr}, \mathrm{Zr}, \mathrm{Y}$ e $\mathrm{Ba}$ ). No que se refere aos dados geocronológicos, para o maciço granitóide Jamon, obtiveram uma idade, pelo método $\mathrm{Rb}-\mathrm{Sr}$ em rocha total, de $1.601 \pm 21 \mathrm{Ma}$, com uma razão inicial igual a $0,712+/-0,0017$, enquanto que para o maciço António vicente, a tentativa de datação foi frustrada, visto que não obtiveram uma isócrona. Em relação aos elementos traços, esses autores mostraram que os leucogranitos dominantes nos maciços Antônio Vicente, Velho Guilherme e Mocambo, apresentavam notáveis semelhanças no comportamento daqueles elementos e concluiram tratar-se de granitos extremamente fracionados e com evoluções petrológicas e processos de alteração tardi a pós-magmatica similares, indicando pertencerem a um mesmo evento magmático.

Dall'Agnol et al.(1986) apresentaram uma sintese do conhecimento sobre as rochas granitóides da porção sul da Amazónio Oriental. Esses autores concluíram que as "suites de granitos pós-tectônicos e/ou anorogênicos" deveriam ser encaradas com muitas reservas e que a caracterização das mesmas ressentia-se de um alto grau de subjetividade. Ressaltaram a necessidade de mapeamentos geológicos mais detathados e estudos petrológicos e geocronológicos, voltados para cada maciço, como forma de se chegar a uma definição mais correta e segura a respeito das várias suites.

CPRM/DNPM(op. cit.), realizaram estudos geocronológicos, baseados no método $\mathrm{Rb}-\mathrm{Sr}$, em rocha total, em amostras do maciço granitóide Velho Guilherme, as quais forneceram uma idade de $1.653 \pm 14 \mathrm{Ma}$, com razão inicial de $0,70823 \pm 0,02361$, interpretada por Lafon et al.(1991) como sendo a idade de colocação do corpo. Posteriormente, Lafon et 
al.(1995), realizaram, no mesmo granitóide, datações pelo médtodo $\mathrm{Pb}-\mathrm{Pb}$, em rocha total e em duas frações de feldspato, e obtiveram uma idade igual a $1.874 \pm 30 \mathrm{Ma}$. Essa foi comparada às idades obtidas, pelo mesmo método, por Machado et al.(1991) em outros corpos granitóides da Província Mineral de Carajás aflorantes em áreas vizinhas próximas ao Granitóide Velho Guilherme, e levaram Lafon et al.(1995) a considerarem essa idade como aquela de colocação do referido corpo, abandonando a idéia inicial de Lafon et al.(1991).

Dall'Agnol et al.(1993b) caracterizaram uma série de feições diagnósticas da especialização para estanho de alguns maciços granitóides da Amazônia Oriental e, dentre eles, o maciço granitóide Velho Guilherme. A definição de tais feições foi baseada, damentalmente, em aspectos petrográficos, assinaturas geoquímicas, susceptibilidade magnética, relação $U$ e Th e na produção de calor.

Souza \& Marques(1994) apresentaram uma sintese sobre aspectos litogeoquímicos e metalogenéticos acerca do "granito Velho Guilherme". Esses autores consideraram, com base em dados químicos(elementos maiores, alguns elementos traços- $\mathrm{Rb}, \mathrm{Y}, \mathrm{F}$ e $\mathrm{Cl}-\mathrm{e}$ elementos terras raras), que esse granitóide é favorecido a conter mineralizações de estanho e outros metais associados $(\mathrm{W}, \mathrm{Nb}, \mathrm{Ta}, \mathrm{U})$.Além disso, devido seu enriquecimento em elementos terras raras pesados e uma forte anomalia negativa do Eu, esses autores atribuíram uma derivação crustal para o mesmo.

\section{3- Aspectos de Campo e Amostragem}

Os trabalhos de campo envolveram tão somente a descrição e coleta de amostras das porções centro-norte e noroeste do corpo(Anexo 15), uma vez que as limitações naturais impostas pela própria realidade da região, bem como pela falta de infra-estrutura, impossibilitaram o acesso às outras áreas do maciço. Esse fato, impediu a realização de uma amostragem sistemática, mais abrangente e mais representativa do mesmo. De qualquer modo, a coleta realizada, envolveu porções do maciço não visitadas anteriormente e, de certa forma, complementou os estudos petrográficos e químicos efetuado por Dall'Agnol(1980) e por CPRM/DNPM(op. cit.). Os afloramentos visitados apresentam-se sob a forma de blocos e lagedos.

\section{4- Aspectos Petrográficos}

Os estudos petrográficos permitiram caracterizar, pelo menos, três variedades granitóides no maciço, a saber: 1) biotita sienogranito equigranular médio(BSGEm); 2) sienogranito heterogranular(SGH); 3) micro-sienogranito(MSG). Essa distinção baseou-se, fundamentalmente, na textura, na granulação e no conteúdo de biotita dessas rochas. 
Adicionalmente, durante os trabalhos de campo, pode-se observar que o BSGEm é seccionado pelo SGH(Prancha 15; Foto a) e, esse último, é cortado pelo MSG e por veios hidrotermais à base de quartzo e epidoto. Entretanto, em mapa, não foi possivel representar, separadamente, cada uma dessas variedades granitóides, uma vez que as limitações impostas pela amostragem impediu caracterizar zonas preferencias de ocorrencia das mesmas ou áreas de predominância de uma variedade em relação às outras.

As Tabelas 4.1 e 4.2 , mostram as composições modais desses granitóides, e a Figura 4.2(a,b) apresenta a distribuição dessas composições nos diagramas Q-A-P e Q$(A+P)-M^{\prime}($ Streckeisen, 1976).

No diagrama Q-A-P nota-se que esses granitóides são essencialmente sienograniticos e caracteristicamente subsolvus(Tuttle \& Bowen, 1958) . No diagrama Q$(A+P)-M^{\prime}$, eles incidem sobre e muito próximos à aresta $Q-(A+P)$ e possuem valores de $M^{\prime}$ sempre inferiores a $5 \%$, embora o BSGEm seja, relativamente, mais enriquecido em máficos do que as outras duas variedades.

Essas características demonstram que esses granitóides são rochas de natureza holo-leucocrática, que se originaram a partir de líquidos muito diferenciados e evoluidos, extremamente silicosos. Denotam, ainda, que os mesmos são muito semelhantes àqueles constitutivos do maciço granitóide Antônio Vicente, em especial, a facies BSG e suas variações(BSGA e BSGIA).

Ademais, as características petrográficas desses granitóides correspondem, quase que perfeitamente, com àquelas, desse mesmo maciço, apresentadas por Dall'Agnol(1980), evidenciando que o maciço Velho Guilherme, como um todo, parece representar, em termos petrográficos, um corpo, composicionalmente, pouco variável, embora ocorram pequenas variações texturais e no conteúdo de biotita. Isso é, principalmente válido para as porções noroeste, nordeste, leste e sudeste do maciço. Infelizmente, não foi possível estabelecer uma comparação, em termos composicionais modais, entre essa amostragem do maciço $e$ àquela realizada por CPRM/DNPM(op. cit.). A classificação desses autores foi realizada de modo genérico para todos os granitóides do maciço e não envolveu contagem de pontos. Baseou-se, apenas, em observações macroscópicas. Como os granitóides desse maciço são, preferencialmente, de coloração rosa -tanto aqueles aqui apresentados, quanto aqueles estudados por Dall'Agnol(1980) e descritos por CPRM/DNPM(1991) - acredita-se que para a a classificação realizada por CPRM/DNPM(op. cit.), os autores deixaram-se levar pela crença de uma ampla predominância do feldspato potássico(rosa) sobre o plagioclásio. Apenas isso justifica que os mesmos tenham classificado esses granitóides como álcalifeldspato granitos. 
Figura 4.1. Mapa geológico da área de ocorréncia do maciço granitóide Velho Guilherme. 


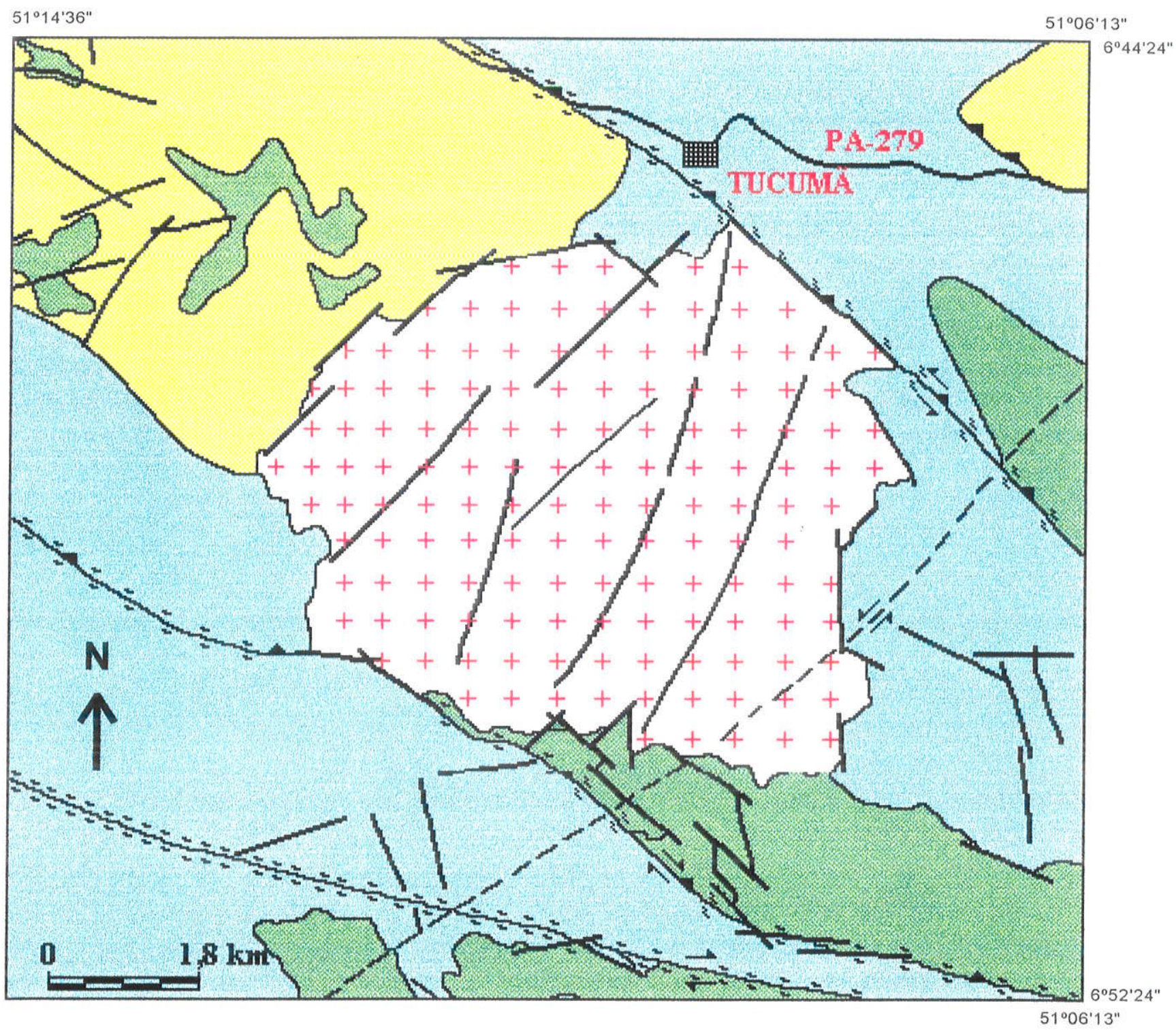

SUITE INTRUSIVA VELHO GUILHERME

++ Maciço granitóide Velho Guilherme: Biotita sienogranito equigranular médio, sienogranito heterogranular e micro-sienogranito.

\section{GRANODIORITO RIO MARIA}

Granodiorito com subordinados tonalito e monzogranito.

\section{GRUPO TUCUMÃ}

Formação Igarapé Abelha: Filito, mica xisto, metarenito, formaçöes ferriferas e metarcóseos.

Formação Igarapé do Cuca: Actinolita xisto ortoderivado com subordinados antofilitacordierita xisto, metasserpentinito, talco xisto, filito e biotita xisto.

Zona de cisalhamento dúctil com cavalgamento obliquo dextral.

Zona de cisalhamento dúctil com cavalgamento obliquo sinsitral.

Falha transcorrente rúptil

Traços fotointerpretativos de fraturas e/ou falhas. 
Tabela 4.1- Composiçóes modais da facies biotita sienogranito equigranular médio(BSGEm). Maciço granitóide Velho Guilherme. Tr= traço; $\mathrm{Nd}=$ não detectado; $\mathrm{Nc=năo} \mathrm{contado.}$

\begin{tabular}{|c|c|c|c|c|c|c|c|c|c|}
\hline \multirow{2}{*}{\begin{tabular}{|l} 
VARIEDADES \\
AMOSTRAS \\
\end{tabular}} & \multicolumn{9}{|c|}{ ESGEm } \\
\hline & $\begin{array}{c}\text { NN-VG- } \\
31 \\
\end{array}$ & $\begin{array}{c}N-V G- \\
32 A\end{array}$ & $\begin{array}{c}\text { NN-VG- } \\
63 \\
\end{array}$ & $\begin{array}{c}N-V G- \\
63 A \\
\end{array}$ & $\begin{array}{l}\text { NN- } \\
\text { VG-68 }\end{array}$ & $\begin{array}{c}\text { NN-VG- } \\
36 \\
\end{array}$ & $\begin{array}{l}\text { NN.VG- } \\
37 \\
\end{array}$ & $\begin{array}{c}\text { NN-VG- } \\
70 \\
\end{array}$ & $\begin{array}{l}\text { NN-VG- } \\
71 \\
\end{array}$ \\
\hline & 1 & 2 & 3 & 4 & 5 & 6 & 7 & 8 & 9 \\
\hline \multicolumn{10}{|l|}{$\begin{array}{l}\text { MINERAIS } \\
\text { PRIMARIOS(\%) }\end{array}$} \\
\hline QUARTZO & 36 & 36 & 39 & 36 & 34 & 40 & 37 & 34 & 26 \\
\hline PLAGIOCLASIO & 18 & 19 & 12 & 18 & 22 & 14 & 16 & 15 & 20 \\
\hline KFELDSPATO & 30 & 27 & 25 & 26 & 28 & 27 & 33 & 27 & 32 \\
\hline BIOTITA & 01 & 01 & 03 & 02 & 01 & 03 & 01 & 02 & $\mathrm{Tr}$ \\
\hline ZIRCAO & $\mathrm{Tr}$ & $\mathrm{Tr}$ & $\operatorname{Tr}$ & $T r$ & $\mathrm{Tr}$ & $\mathrm{Tr}$ & $\mathrm{Tr}$ & $T r$ & $\mathrm{Tr}$ \\
\hline MINERAIS OPACOS & $\mathrm{Tr}$ & $T r$ & $\operatorname{Tr}$ & $\mathrm{Tr}$ & $\mathrm{Tr}$ & $\mathrm{Tr}$ & 01 & Tr & $\mathrm{Tr}$ \\
\hline RUTILO & $\mathrm{Tr}$ & $\mathrm{Tr}$ & $\operatorname{Tr}$ & $\mathrm{Tr}$ & $\mathrm{Tr}$ & $\mathrm{Tr}$ & $\mathrm{Tr}$ & $\mathrm{Tr}$ & $\mathrm{Tr}$ \\
\hline \multicolumn{10}{|l|}{$\begin{array}{l}\text { MINERAIS } \\
\text { SECUNDÁRIOS(\%) }\end{array}$} \\
\hline $\begin{array}{l}\text { SERICITA+/- } \\
\text { MUSCOVITA }\end{array}$ & 03 & 03 & 02 & 02 & 01 & 02 & 01 & 03 & 01 \\
\hline K-FELDSPATO & Ne & Nc & Ne & Nc & $\mathrm{Nc}$ & Nc & $\mathrm{Ne}$ & Nc & NC \\
\hline CLORITA & $\operatorname{Tr}$ & $\mathrm{Tr}$ & 01 & 01 & $\mathrm{Tr}$ & 01 & $\mathrm{Tr}$ & 01 & $\mathrm{Tr}$ \\
\hline ALBITA & 11 & 13 & 17 & 15 & 13 & 12 & 11 & 18 & 19 \\
\hline MUSCOVITA & $\mathrm{Tr}$ & $T r$ & $T r$ & $\mathrm{Tr}$ & $\mathrm{Tr}$ & $\mathrm{Tr}$ & $\mathrm{Tr}$ & $\mathrm{Tr}$ & $\mathrm{Tr}$ \\
\hline FLUORITA & $\mathrm{Tr}$ & $\operatorname{Tr}$ & $\mathrm{Tr}$ & $\mathrm{Tr}$ & 01 & $\mathrm{Tr}$ & $\mathrm{Tr}$ & $\mathrm{Tr}$ & $\mathrm{Tr}$ \\
\hline TOPAZIO & Nd & Nd & Nd & Nd & $\mathrm{Tr}$ & $\mathrm{Nd}$ & Nd & $\mathrm{Tr}$ & Nd \\
\hline ALLANITA & $\mathrm{Tr}$ & $\mathrm{Tr}$ & $\mathrm{Nd}$ & Nd & $\mathrm{Nd}$ & $\mathrm{Tr}$ & $\mathrm{Tr}$ & $\mathrm{Tr}$ & $\mathrm{Tr}$ \\
\hline QUARTZO & Tr & Tr & $\mathrm{Tr}$ & $\mathrm{Tr}$ & $\mathrm{Tr}$ & $\mathrm{Tr}$ & $\mathrm{Tr}$ & $\mathrm{Tr}$ & $\mathrm{Tr}$ \\
\hline MINERAIS OPACOS & $\operatorname{Tr}$ & $\mathrm{Tr}$ & $\mathrm{Tr}$ & Tr & $\mathrm{Tr}$ & $\mathrm{Tr}$ & $\mathrm{Tr}$ & $\mathrm{Tr}$ & $\mathrm{Tr}$ \\
\hline ARGILO-MINERAIS & $\mathrm{Nc}$ & Nc & Nc & $\mathrm{NC}$ & $\mathrm{Nc}$ & Nc & $\mathrm{Nc}$ & Nc & $\mathrm{Nc}$ \\
\hline \multicolumn{10}{|l|}{$\begin{array}{l}\text { COMPOSIÇAOO DO } \\
\text { PLAGIOCLÁSIO }\end{array}$} \\
\hline$Q$ & 38 & 38 & 42 & 38 & 35 & 43 & 38 & 36 & 27 \\
\hline$A$ & 43 & 42 & 45 & 43 & 42 & 42 & 45 & 47 & 53 \\
\hline $\mathrm{P}$ & 19 & 20 & 13 & 19 & 23 & 15 & 17 & 17 & 20 \\
\hline$Q$ & 38 & 38 & 40 & 37 & 35 & 41 & 37 & 35 & 26 \\
\hline$A+P$ & 61 & 61 & 56 & 60 & 64 & 56 & 61 & 62 & 72 \\
\hline $\mathrm{M}^{\prime}$ & 01 & 01 & 04 & 03 & 01 & 03 & 02 & 03 & 02 \\
\hline $\begin{array}{l}\text { NUMERO DE } \\
\text { PONTOS }\end{array}$ & 1419 & 1518 & 1596 & 1509 & 1164 & 1470 & 1419 & 1302 & 1281 \\
\hline
\end{tabular}


Tabela 4.2.. Composições modais da facies sienogranito heterogranular(SGH). Maciço granitóide Velho Guilherme. Rel. $A b=$ relativamente abundante; $T r=$ traço; $N d=$ não detectado; $N c=$ não contado.

\begin{tabular}{|c|c|c|c|c|c|c|c|c|c|c|}
\hline VARIEDADES & & & & & SGH & & & & & MSG \\
\hline AMOSTRAS & $\begin{array}{c}\text { NN-VG- } \\
33\end{array}$ & $\begin{array}{c}\text { NN-VG- } \\
35 \mathrm{~A}\end{array}$ & $\begin{array}{c}\text { NN-VG- } \\
35 B\end{array}$ & \begin{tabular}{|c|} 
NN-VG- \\
75
\end{tabular} & $\begin{array}{c}\text { NN-VG- } \\
77 N\end{array}$ & $\begin{array}{c}\text { NN-VG- } \\
77 \mathrm{D}\end{array}$ & $\begin{array}{c}\text { NN-VG- } \\
34 A\end{array}$ & $\begin{array}{c}\text { NN-VG- } \\
77\end{array}$ & $\begin{array}{c}\text { NN-VG- } \\
77 \mathrm{C}\end{array}$ & $\begin{array}{c}\text { NN-VG- } \\
77 A\end{array}$ \\
\hline & 10 & 11 & 12 & 13 & 14 & 15 & 16 & 17 & 18 & 18 \\
\hline $\begin{array}{l}\text { MINERAIS } \\
\text { PRIMÁRIOS }\end{array}$ & & & & & & & & & & \\
\hline QUARTZO & 39 & 41 & 35 & 29 & $\overline{35}$ & 26 & 39 & 35 & 39 & 36 \\
\hline PLAGIOCLÁSIO & 17 & 14 & $\overline{12}$ & 16 & 14 & 17 & 18 & 14 & 13 & 14 \\
\hline K-FELDSPATO & 28 & 31 & 31 & 36 & 32 & 35 & 22 & 29 & 15 & 31 \\
\hline BIOTITA & Tr & $\operatorname{Tr}$ & $\mathrm{Tr}$ & $\mathrm{Tr}$ & Tr & $\mathrm{Tr}$ & $\operatorname{Tr}$ & 01 & Nd & Tr \\
\hline ZIRCÁO & Tr & $\operatorname{Tr}$ & $\mathrm{Tr}$ & Tr & $\operatorname{Tr}$ & $\operatorname{Tr}$ & Tr & $\operatorname{Tr}$ & Tr & $\operatorname{Tr}$ \\
\hline MINERAIS OPACOS & $\mathrm{Tr}$ & $\overline{T r}$ & $\mathrm{Tr}$ & $\mathrm{Tr}$ & Tr & $\mathrm{Tr}$ & $\mathrm{Tr}$ & $\mathrm{Tr}$ & $\mathrm{Tr}$ & $\operatorname{Tr}$ \\
\hline RUTILO & $\operatorname{Tr}$ & $\overline{T r}$ & $\mathrm{Tr}$ & $\operatorname{Tr}$ & Tr & $\operatorname{Tr}$ & $\mathrm{Tr}$ & Tr & $\operatorname{Tr}$ & $\operatorname{Tr}$ \\
\hline $\begin{array}{l}\text { MINERAIS } \\
\text { SECUNDÁRIOS }\end{array}$ & & & & & & & & & & \\
\hline $\begin{array}{l}\text { SERICITAt } \\
\text { MUSCOVITA }\end{array}$ & 04 & 02 & 01 & 03 & 02 & 03 & 01 & 01 & 12 & Tr \\
\hline K-FELDSPATO & Nc & Nc & NC & NC & Nc & Nc & NC & $\mathrm{NC}$ & NC & NC \\
\hline CLORITA & $\operatorname{Tr}$ & $\mathrm{Tr}$ & $\overline{T r}$ & Tr & Tr & Tr & 02 & $\mathrm{Tr}$ & Tr & $\mathrm{Tr}$ \\
\hline ALBITA & 08 & 11 & 16 & 15 & 13 & 18 & 15 & 17 & 15 & 16 \\
\hline MUSCOVITA & Tr & 01 & $\mathrm{Tr}$ & Tr & 01 & 01 & 03 & Tr & Tr & $\operatorname{Tr}$ \\
\hline EPIDOTO & $\overline{T r}$ & Tr & $\mathrm{Tr}$ & Tr & Tr & $\operatorname{Tr}$ & $\operatorname{Tr}$ & $\operatorname{Tr}$ & $\operatorname{Tr}$ & Tr \\
\hline ALLANITA & $\mathrm{Tr}$ & Tr & 02 & Nd & 03 & Nd & $\mathrm{Nd}$ & Nd & 03 & 02 \\
\hline FLUORITA & $\operatorname{Tr}$ & $\overline{T r}$ & 01 & 01 & Tr & $\mathrm{Tr}$ & $\mathrm{Tr}$ & 01 & 01 & Tr \\
\hline ESFALERITA & Tr & $\mathrm{Tr}$ & $\operatorname{Tr}$ & Tr & Tr & $\operatorname{Tr}$ & $\mathrm{Tr}$ & $\operatorname{Tr}$ & $\mathrm{Tr}$ & $\mathrm{Nd}$ \\
\hline CARBONATO & Nd & Nd & $\mathrm{Nd}$ & Nd & Nd & Nd & Nd & $\mathrm{Nd}$ & $\mathrm{Nd}$ & $\operatorname{Tr}$ \\
\hline MINERAIS OPACOS & $\mathrm{Tr}$ & $\mathrm{Tr}$ & $\mathrm{Tr}$ & Tr & $\mathrm{Tr}$ & $\operatorname{Tr}$ & Tr & $\operatorname{Tr}$ & $\operatorname{Tr}$ & Tr \\
\hline QUARTZO & $\mathrm{Tr}$ & $\mathrm{Tr}$ & $\mathrm{Tr}$ & Tr & $\operatorname{Tr}$ & Tr & Tr & $\overline{T r}$ & Tr & $\operatorname{Tr}$ \\
\hline ARGILO-MINERAIS & NC & Nc & NC & Nc & Nc & $\mathrm{Nc}$ & Nc & Nc & Nc & $\mathrm{Nc}$ \\
\hline $\begin{array}{l}\text { COMPOSIÇÁO DO } \\
\text { PLAGIOCLÁSIO }\end{array}$ & $=$ & $\overline{A n_{12}}$ & - & $=$ & $=$ & - & $\mathrm{An}_{7}$ & - & - & - \\
\hline $\bar{Q}$ & 43 & 42 & 37 & 30 & 37 & 27 & 42 & 37 & 48 & 37 \\
\hline A & 39 & 43 & 50 & 53 & 48 & 55 & 39 & 48 & 36 & 48 \\
\hline$P$ & 18 & 15 & 13 & 17 & 15 & 18 & 19 & 15 & 16 & 15 \\
\hline $\mathrm{Q}$ & 42 & 42 & 37 & 30 & 37 & 27 & 46 & 36 & 49 & 37 \\
\hline$A+P$ & 57 & 57 & 63 & 70 & 62 & 73 & 53 & 63 & 51 & 63 \\
\hline $\mathrm{M}^{\prime}$ & 01 & 01 & 0 & 0 & 01 & 0 & 01 & 01 & 0 & 0 \\
\hline $\begin{array}{l}\text { NUMERO DE } \\
\text { PONTOS }\end{array}$ & 1491 & 1425 & 1551 & 1359 & 1545 & 897 & 1425 & 1680 & 1848 & 1323 \\
\hline
\end{tabular}



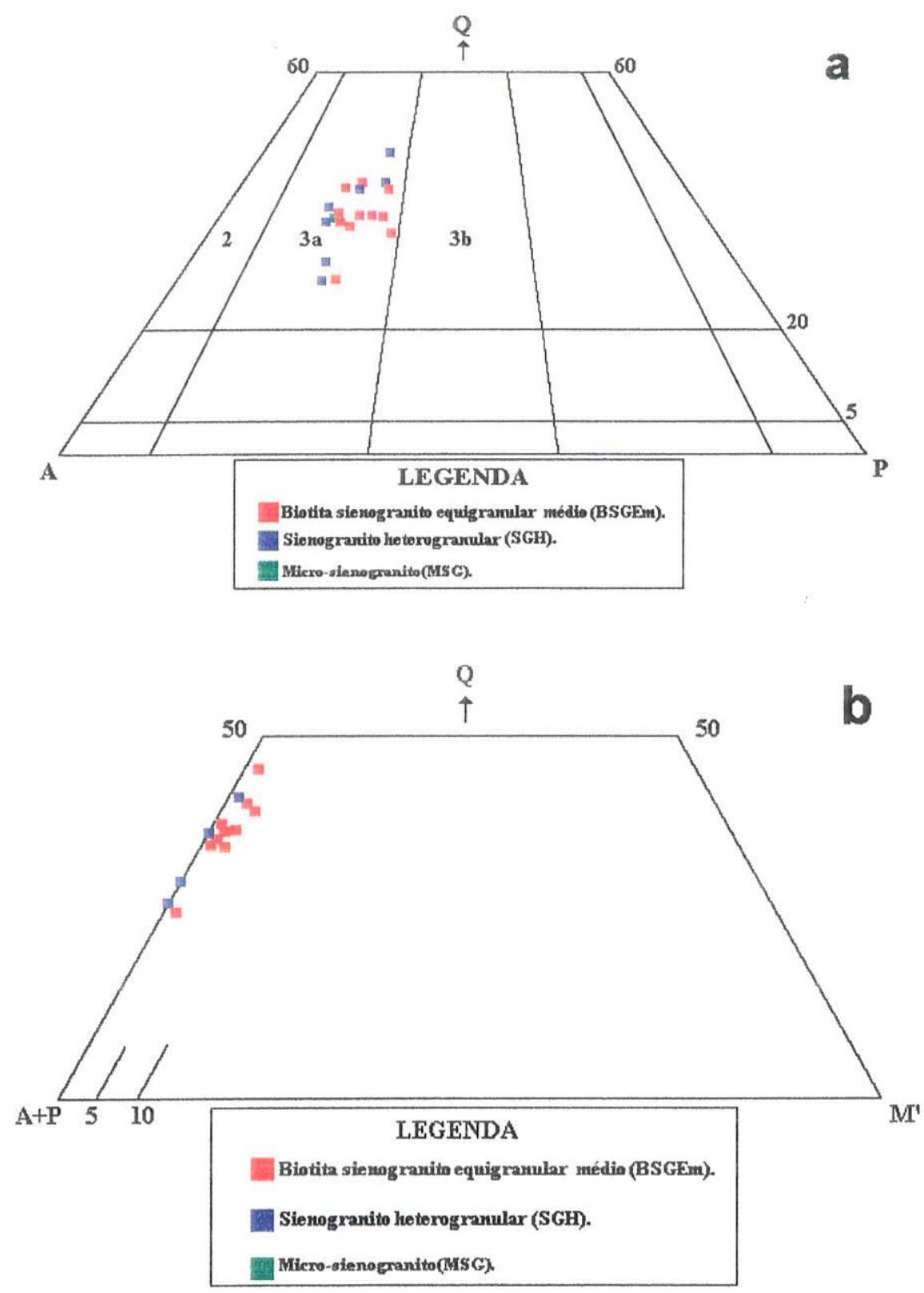

Figura 4.2. Diagramas triangulares $Q-A-P(a)$ e $Q-(A+P)-M^{\prime}(b)$ de Streckeisen(1976) mostrando a distribuição composicional modal das facies granitóides do maciço granitóide Velho Guilherme.

\subsection{1- Facies BSGEm}

Essa variedade parece constituir o tipo dominante, em área de abrangência, no interior do maciço $e$, ao que tudo indica, representa a facies mais velha do corpo. Entretanto, essa hipótese não deve ser considerada como definitiva, visto que devido aos problemas de amostragem, não se pode obter informações seguras a esse respeito. De qualquer modo, é válido lembrar que em alguns complexos intrusivos multifásicos(Daoud, 1988) ou constituídos de vários pulsos magmáticos(Janasi, 1992) é possivel estabelecer a ordem cronológica de injeção de diversas facies granitóides na edificação dos maciços. É 
verdadeiro, também, que em outros maciços a várias facies, não é possivel estabelecer a ordem de colocação das mesmas, visto que elas se interpenetram.

\subsubsection{1- Textura e Mineralogia}

Essa facies apresenta textura hipidiomórfica equigranular média, tem aspecto isotrópico e possui coloração rosa-acinzentada(Prancha 15; Fotos b, c). Consiste essencialmente de quartzo, feldspato potássico $\left(\mathrm{Fk}_{1}\right)$ e plagioclásio $\left(\mathrm{Pl}_{1}\right)$, sendo varietal a biotita. Como minerais acessórios ocorrem zircão e minerais opacos(MOP 1 ).

São produtos secundários, formados no estágio de alterações tardi a pósmagmáticas sericita \pm muscovita $\left(\mathrm{Mv}_{1}\right) \pm$ clorita $\left(\mathrm{Cl}_{1}\right) \pm F l u o r i t a\left(\mathrm{Fl}_{1}\right) \pm$ topázio $\left(\mathrm{Top}_{1}\right)$ e $\mathrm{Fk}_{2}$, os quais mostram-se associados a um evento metassomático, de natureza potássica, ocorrido no início desse estágio, e que propiciou, preferencialmente, a substituicão parcial do plagioclásio primário $\left(\left.P\right|_{1}\right)$. Associados a um evento de metassomático de natureza sódica, subseqüente, ocorrem albita, relacionada à substituição parcial dos feldspatos potássicos $\left(\mathrm{Fk}_{1}\right.$ e $\left.\mathrm{Fk}_{2}\right)$ e clorita $\left(\mathrm{Cl}_{2}\right) \pm$ minerais opacos $\left(\mathrm{MOP}_{2}\right) \pm$ esfalerita \pm muscovita $\left(\mathrm{Mv}_{2}\right) \pm$ quartzo $3 \pm$ fluorita $\left(\mathrm{Fl}_{2}\right) \pm$ allanita, relacionados a alteração parcial da biotita, muscovita 2(3 ?) vinculada a alteração do topázio2(metassomatismo potássico 2 ?) argilo-minerais, associados a um evento de alteração argílica de posicionamento temporal duvidoso.

O quartzo ocorre em, pelo menos quatro variedades $\left(Q t z_{1}, Q t z_{2}, Q t z_{3}\right.$ e $\left.Q t z_{4}\right)$. As três primeiras correspondem aos tipos 1, 2 e 3 caracterizados nos granitóides do maciço Antônio Vicente, especialmente, na variedades BSG, BSGA e BSGIA, enquanto que o Qtz4 está associado à um evento de silicificação tardia, ocorrido, ao que tudo indica, no curso da greisenização. As caracteristicas dos tipos 1, 2 e 3 não serão apresentadas aqui, afim de se evitar repetições, o que tornaria o texto, ainda, mais longo e cansativo.

O feldspato potássico $\left(\mathrm{Fk}_{1}\right)$ e o plgioclásio $\left(\mathrm{Pl}_{1}\right.$ e $\left.\mathrm{Pl}_{2}\right)$ guardam muitas semelhanças morfológicas e texturais com essas mesmas fases minerais descritas nos granitóides do MGAV. Entretanto, em relação ao feldspato potássico, algumas diferenças foram observadas: 1) os grãos tardios de feldspato potássico $\left(F k_{2}\right)$ não costumam se apresentar como fenocristais grossos, sendo, preferencialmente, médios; 2) Os cristais de $\mathrm{Fk}_{1}$ são, geralmente, menos pertíticos e desenvolvem, mais freqüentemente, "string perthites", por vezes, em gradação para "film perthites"(Alling, 1938; Smith, 1974), sendo, portanto, típicas pertitas compostas(Alling, 1938). Além disso, o plagioclásio1 apresenta composição variando entre $\mathrm{An}_{6}$ e $\mathrm{An} \mathrm{n}_{9}$ (determinação ótica).

A biotita ocorre como lamelas anédricas a subédricas, geralmente, de granulação fina e encontra-se, quase sempre, parcialmente substituída por clorita $\left(\mathrm{Cl}_{2}\right) \pm$ minerais opacos $\left(\mathrm{MOP}_{2}\right) \pm$ esfalerita \pm quartzo $\left(\mathrm{Qtz}_{3}\right) \pm$ fluorita $\left(\mathrm{FI}_{2}\right) \pm$ muscovita $\left(\mathrm{Mv}_{2}\right) \pm$ allanita. Essas 
fases costumam ocorrer dispondo-se, preferencialmente, ao longo dos planos de clivagem da mesma(Prancha 15; Fotos d, e). Exibe pleocroísmo moderado, que varia de castanho escuro-avermelhado $(Z$ e $Y)$ a castanho pálido-amarelado $(X)$. As vezes, hospeda inclusões de zircão, com as quais desenvolve nítidos halos pleocróicos.

Dentre os minerais acessórios, o zircão é o mais freqüente, embora nunca seja abundante. Ocorre como finos grãos subédricos a euédricos, os quais mostram-se associados às fases máficas. Locaimente, ocorre como inclusões em cristais de quartzo $\left(Q t z_{1}\right)$. Os minerais opacos apresentam-se na versáo primária(MOP 1$)$ e secundária(MOP$)$. $O M O P_{1}$, é pouco freqüente, forma cristais forma grăos subédricos e costuma estar associado às fases micáceas, enquanto $\circ \mathrm{MOP}_{2}$ mostra-se intimamente associado á cloritização da biotita(conforme visto acima).

Com relação às fases minerais associadas ao estágio de alterações tardi a pósmagmáticas, a albita representa a fase mais abundante, podendo alcançar até $19 \%$ de composição modal. Assume formas variadas tais como "swapped rims", "albite rims" e "chess-board albite". Além disso, nas zonas de contato entre cristais de feldspato potássico ou entre grãos de feldspato potássico e plagioclásio, podem ocorrer agrupamentos de cristais de albita formando franjas, geralmente, duplas ou emparelhadas, as quais apresentam sinal ótico invertido em relação ao cristal de feldspato adjacente("coroas trocadas"). Pode ocorrer, ainda, como agregados sob a forma de "dedos" ou "mãos" (Dall'Agnol, 1980; Teixeira\& Dall'Agnol, 1991; Teixeira \& Andrade, 1992; Borges, 1997). Essas feições caracterizam um evento de metassomatismo sódico(albitização) que afetou esse granitóide e que sucedeu um outro de natureza potássica, evidenciado, principalmente, pela sericitização \pm muscivitização $\left(\mathrm{Mv}_{1}\right)$ e microclinização do plagioclásio primário $\left(\mathrm{Pl}_{\uparrow}\right)$.

As fases sericitatmuscovita $\left(\mathrm{Mv}_{1}\right)$, juntamente com clorita $\left(\mathrm{Cl}_{1}\right)$, fluorita $\left(\mathrm{Fl}_{1}\right)$, topázio1 e argilo-minerais é freqüente, mas não costumam ser abundantes. Ocorrem como finas lamelas e minúsculos cristais $\left(\mathrm{FI}_{1}\right)$, vinculados, intimamente, à descalcificação do plagioclágio primário $\left(\mathrm{Pl}_{1}\right)$, de composição albita-oligoclásio $\mathrm{e}$, subordinadamente, do plagioclásio primário, de composição albita $\left(\mathrm{Pl}_{2}\right)$. Esta alteração tende a ser mais intensa nas porções centrais dos cristais, evidenciando um zoneamento normal dos mesmos(Smith, 1974, Dall'Agnol, 1980; Teixeira \& Dall'Agnol, 1991), embora, se desenvolva, subordinadamente, sob a forma de "patch zones". Em alguns locais, cristais de plagioclásio primário $\left(\mathrm{Pl}_{1}\right)$, alterados, mostram-se substituidos, parcialmente, por feldspato potásico( $\left.\mathrm{Fk}_{2}\right)$. Eles ocorrem como relíctos ou fantasmas no interior dos grãos de $\mathrm{Fk}_{2}$. Isso demonstra que o início do estágio de atterações tardi a pós-magmáticas é marcado pela substituição parcial do plagioclásios primário, que é traduzida pela associação paragenética sericita \pm muscovita $\left(\mathrm{Mv}_{1}\right) \pm$ clorita $\left(\mathrm{Cl}_{1}\right) \pm$ fluorita $\left(\mathrm{Fl}_{1}\right) \pm$ topázio(Top $\left.{ }_{1}\right)$. Essas fases de alteração estão associadas a um evento metassomático, de natureza potássica, que culminou com a 
substituição(microclinização), parcial ou total, do plagiociásio primário por feldspato potássico( $\left(\mathrm{Fk}_{2}\right)$.

A fluorita $\left(\mathrm{FI}_{2}\right)$ é freqüente, porém pouco abundante. Apresenta-se como finos a médios cristais, associados às fases máficas, em especial, a biotita, mas ocorre, também, de forma independente, dispersa na rocha. Apresenta-ser tanto na coloração lilás, quanto incolor(Prancha 15; Fotos e, f).

O topázio(Top 2 ) é pouco freqüente nessa variedade de granitóide. Ocorre, muito localmente, sob a forma de grãos anédricos, arredondados, em geral, envoltos por uma auréola de muscovita( $\left(\mathrm{Mv}_{2}\right.$; Prancha 16; Foto a).

A allanita, está ausente em algumas amostras, mas mostra-se abundante em outras. Nesse caso, costuma formar agregados de cristais(Prancha 15; Foto $f$ ), por vezes, subédricos e associados às fases máficas.

Os argilo-minerais mostram-se associados aos feldspatos potássicos. Apresentam-se como nuvens, as quais atribuem, aos mesmos um aspecto "sujo".

A muscovita $\left(\mathrm{Mv}_{2}\right)$, dissociada da paragênese sericita \pm muscovita $\left(\mathrm{Mv}_{1}\right) \pm \operatorname{clorita}\left(\mathrm{Cl}_{1}\right) \pm$ fluorita $\left(F l_{1}\right) \pm$ topázio(Top $\left.{ }_{1}\right)$ e do contexto da alteração da biotita, forma lamelas, geralmente, anédricas a subédricas e mostra-se associada à alteração tardia da clorita $\left(\mathrm{Cl}_{2}\right)$, dos plgioclásios $\left(\mathrm{Pl}_{1}\right.$ e $\left.\mathrm{Pl}_{2}\right)$, dos feldspatos potássicos $\left(\mathrm{Fk}_{1}\right.$ e $\left.\mathrm{Fk}_{2}\right)$ e do topázio2. Exibe cores de interferências altas, sendo predominante um azul intenso(Prancha 16; Foto b), embora possa apresentar, subordinadamente, tons amarelados e avermelhados. A luz natural, é incolor e exibe relevo ondulante fraco. Ao que tudo indica, representa o mais evidente produto de um segundo evento de metassomatismo potássico que afetou esse granitóide.

\subsubsection{2- Ordem de Cristalização Magmática}

Os estudos petrográficos desenvolvidos para o entendimento da ordem de separação das fases minerais primárias, a partir do liquido magmático, permitiu estabelecer que:

1) O zircão e os minerais opacos $\left(\mathrm{MOP}_{1}\right)$ representam, ao que tudo indica, fases precoces em relação às demais, visto que ocorrem como inclusões, principalmente, em cristais de quartzo(Qtz $\left.{ }_{1}\right)$, plagioclásio $\left(\mathrm{Pl}_{1}\right)$ e biotita, especialmente nas duas primeiras.

2) Em relação ao quartzo( $Q t z_{1}$ e $\left.Q t z_{2}\right)$, plagioclásio $\left(P_{1}\right)$ e feldspato potássico( $\left.F k_{1}\right)$, parecem ter iniciado suas separações a partir do liquido magmático dentro de um mesmo intervalo de temperatura e pressão, com o plagioclásio $\left(\mathrm{Pl}_{1}\right)$ tendo se separado um pouco antes. Isso é justificado pela ocorrência, embora muito localmente, de inclusões desse mineral em cristais das outras duas fases essenciais. Quartzo(Qtz $z_{1}$ e $\left.Q t z_{2}\right)$ e feldspato potássico $\left(\mathrm{Fk}_{1}\right)$ não mostram relações de inclusões, ocorrendo lado a lado, embora, algumas vezes o feldspato potássico $\left(\mathrm{Fk}_{1}\right)$ ocorra de forma intersticial. Esse fato, indica, muito 
provavelmente, que o feldspato potássico( $\left.\mathrm{Fk}_{1}\right)$ teve a sua cristalização prolongada em relação ao quartzo(Qtz $z_{1}$ e $\left.Q t z_{2}\right)$.

3) A biotita é, ao que parece, posterior ao quartzo( $Q t z_{1}$ e $\left.Q t z_{2}\right)$, visto que inclusões dessa fase mineral podem ser observadas em lamelas de biotita. Além disso, a biotita apresenta-se, por vezes, de forma intersticial em relacão às fases essenciais.

4) O plagioclásio 2 ocorre como inclusões nos grãos de $\mathrm{Fk}_{2} \mathrm{e}$, ao que tudo indica, representa o que Fisher(1971) designou de "poikilitic albite". Essa feição de acordo com Riederer(1965; In: Smith, 1974) evidencia uma transição na substituição do plagioclásio primário por feldspato potássico tardio, ou seja de $\mathrm{Pl}_{1}$ por $\mathrm{Fk}_{2}$ e marca o final do estágio magmático, seguindo-se, então aquele de alteraçōes tardi a pós-magmáticas.

5) As demais fases estão relacionadas a este estágio.

A Figura 4.3 mostra um fluxograma sumariando a seqüência de cristalização magmática e tardi a pós-magmática das fases minerais constituintes deste facies granitóides.

\subsection{2- Facies SGH}

Essa variedade de granitóide, embora guarde grandes afinidades com o BSGEm, mostra algumas diferenças a saber: 1) apresenta menor conteúdo, relativo, de biotita; 2) a biotita costuma estar, quase sempre, mais intensamente alterada ; 3) mostra-se mais intensamente afetada por alteraçōes tardi a pós-magmáticas.

\subsubsection{1-Textura e Mineralogia}

Esse granitóide exibe textura hipidiomórfica heterogranular, média. Subordinadamente ocorrem variações para termos finos a médios e grossos. Apresenta coloração rosa a rosa-esbranquiçada(Prancha 16; Fotos c, d).

Consiste essencialmente de quartzo, feldspato potássico e plagioclásio, sendo o principal varietal a biotita(restos). Como minerais acessórios ocorrem zircão, minerais $\operatorname{opacos}\left(\mathrm{MOP}_{1}\right)$ e rutilo.

As fases minerais tardias, atribuídas ao estágio de alterações tardi a pósmagmáticas, mostram-se representadas por sericita $\pm \operatorname{muscovita}\left(\mathrm{Mv}_{1}\right) \pm \operatorname{clorita}\left(\mathrm{Cl}_{1}\right) \pm$ fluorita $\left(\mathrm{Fl}_{1}\right) \pm$ epidoto $\left(\mathrm{Ep}_{1}\right)$ e feldspato potássico $2\left(\mathrm{Fk}_{2}\right)$, albita, clorita $\left(\mathrm{Cl}_{2}\right) \pm$ muscovita $\left(\mathrm{Mv}_{2}\right) \pm$ epidoto2 $\left(\mathrm{Ep}_{2}\right) \pm$ minerais opacos $\left(\mathrm{MOP}_{2}\right) \pm$ fluorita $\left(\mathrm{Fl}_{2}\right) \pm$ quartzo3 $\left(\mathrm{Qtz}_{3}\right) \pm$ esfalerita \pm allanita, argilo-minerais.

Texturas de intercrescimentos, associadas a processos de exsolução e de substituição, ocorridos tanto em condições magmáticas, quanto no estágio de alterações tardi a pós-magmáticas, mostram-se traduzidas por intercrescimentos pertiticos 
compostos(Alling, 1938; Smith, 1974, Smith \& Brown, 1988), sendo mais comuns os tipos "string", "film", "band", "vein" e "patch perthites".

O quartzo ocorre em, pelo menos, quatro variedades, com base na textura e morfologia, a saber:

1) Quartzo 1(Qtz $)_{1}$ : corresponde aos grãos, geralmente, anédricos, médios a grossos, com freqüentes bordas corroidas, por vezes, fraturados e com forte extinção ondulante. Pode hospedar, algumas vezes, finos grão de plagioclasio $\left(\mathrm{Pl}_{1}\right)$.

2) Quartzo 2(Qtz $)$ : forma grãos, na maioria das vezes, subédricos, embora ocorram, subordinadamente, cristais euédricos, de granulação média que mostram-se dispersos na rocha.

3) Quartzo 3(Qtz $\left.z_{3}\right)$ : está representado por grãos anédricos, intimamente associados à alteração da biotita(cloritização) e que ocorrem juntamente com clorita $\left(\mathrm{Cl}_{2}\right)$,muscovita2( $\left(\mathrm{Mv}_{2}\right)$, opacos $\left(M O P_{2}\right)$, epidoto $\left(E p_{2}\right)$, fluorita, allanita e esfalerita, dispondo-se, preferencialmente, ao longo dos planos de clivagem da mesma.

4) Quartzo 4(Qtz $)$ : diz respeito ao quartzo intercrescido com o feldspato potássico, compondo os intercrescimentos granofíricos, os quais são pouco freqüentes e tem ocorrência localizada.

O feldspato potássico, por sua vez, ocorre em dois tipos, os quais foram distingüidos pela granulação e morfologia. Esses tipos correspondem àqueles que foram reconhecidos $e$ descritos nas variedades de granitóides do MGAV e na facies BSGEm. O tipo 1(Fk $\left.{ }_{1}\right)$, ocorre como cristais, geralmente, subédricos, finos a médios, os quais fazem contatos com quartzo 1 e 2(Qtz $z_{1}$ e $\left.Q t z_{2}\right)$ e plagioclásio $1\left(P l_{1}\right)$. Localmente, apresenta-se na forma intersticial. $E$ pertítico, apresenta-se, invariavelmente, alterado para argilo-minarais e costuma se encontrar, parcialmente, albitizado("swapped rims"; Prancha 16, Foto e) e muscovitizado $\left(\mathrm{Mv}_{2}\right)$. Além disso, nas regiões de contato entre dois ou mais grãos de $\mathrm{Fk}_{1}$, ocorrem franjas albíticas compostas, as quais exibem sinal ótico invertido em relação ao cristal de $\mathrm{Fk}_{1}$ adjacente("coroas trocadas"; Prancha 16; Foto e). Às vezes, esses agrupamentos albíticos, associados à substituição do $\mathrm{Fk}_{1}$, formam arranjos semelhantes a "dedos" e "mãos", os quais se dispõem como que invadindo o cristal de Fk ${ }_{1}$ hospedeiro. Feiçōes semelhantes a essas foram descritas por Dall'Agnol(1980), Teixeira \& Dall'Agnol(1991), Teixeira \& Andrade(1992) e Borges(1997). Localmente, exibe inclusões de plagioclásio $\left(\mathrm{Pl}_{1}\right)$. O tipo 2( $\left.\mathrm{Fk}_{2}\right)$ se diferencia do $\mathrm{Fk}_{1}$ por ser apresentar como cristais médios a grossos e se mostrar substituindo o plagioclásio $\left(\mathrm{PI}_{\uparrow}\right)$. Além disso, mostra-se, eventualmente, hospedando inclusões de quartzo $2\left(\mathrm{Qtz}_{2}\right)$ e plagioclásio $\left(\mathrm{Pl}_{1}\right.$ e $\left.\mathrm{Pl}_{2}\right)$. Entretanto, em termos texturais, os dois tipos guardam muitas semelhanças entre si, visto que ambos são pertíticos. 
O plagioclásio ocorre em, pelo menos, duas modalidades, com base em aspectos morfológicos e na composição. O tipo $1\left(\mathrm{Pl}_{1}\right)$, forma cristais anédricos a subédricos, de granulação média, embora ocorram, às vezes, grãos finos. Desenvolve contatos entre si e com quartzo( $Q t z_{1}$ e $\left.Q t z_{2}\right)$ e feldspato potássico( $\left.F k_{1}\right)$ retos , irregulares e interpenetrantes. Costuma estar, parciaimente, alterado para sericita $\pm \operatorname{muscovita}\left(\mathrm{Mv}_{1}\right) \pm \operatorname{clorita}\left(\mathrm{Cl}_{1}\right) \pm$ fluorita $\left(F l_{1}\right) \pm$ epidoto( $\left.E p_{1}\right)$ e essa associação paragenética tende a ser mais expressiva nas porções mais centrais dos cristais, evidenciando que essas regiōes eram, relativamente, mais cálcicas, e que foram descalcificadas devido à interação dos cristais com fluidos tardios. Ocorre, ainda, como "patch zones" em grãos zonados irregularmente. As vezes, no contato com feldspato potássico, ocorrem franjas albíticas("albite rims"). As maclas são nítidas e mostram-se governadas pelas leis da albita $\theta$ albita-Carlsbad. Em termos composicionais, varia entre $A n_{7}$ e $A n_{12}$ (determinação ótica).

O tipo $2\left(\mathrm{Pl}_{2}\right)$ é muito pouco freqüete e diferencia-se do $\mathrm{Pl}_{1}$ por se apresentar como grãos pouco afetados por alterações. Mostra-se, quase sempre, límpido e com maclas bastante nitidas, as quais encontram-se regidas pelas leis da albita e albita-Carlsbad. Pelo seu aspecto e relevo, deve se tratar de um plagioclásio de composição albita.

A biotita é pouco abundante e ocorre como restos. Forma lamelas anédricas, finas a médias, as quais encontram-se, quase que completamente, substituida por clorita $\left(\mathrm{Cl}_{2}\right) \pm$ minerais opacos $\left(\mathrm{MOP}_{2}\right) \pm$ epidoto $\left(\mathrm{Ep}_{2}\right) \pm$ allanita \pm esfalerita \pm quartzo(Qtz $)($ Prancha 16; Foto f). Exibe pleocroismo moderado, variando de castanho escuro-avermelhado $(\mathrm{Z}$ e $\mathrm{Y}$ ) até castanho pálido-amarelado(X).

No que se refere às fases minerais acessórias, o zircão é a mais freqüente, embora nunca seja abundante. Forma minúsculos grãos subédricos a euédricos, associados às fases micáceas, embora ocorra, às vezes, como inclusões no quartzo $\left(Q t z_{\uparrow}\right)$ e no plagioclásio $\left(\mathrm{Pl}_{1}\right)$. Os minerais opacos $\left(\mathrm{MOP}_{1}\right)$, afora os tipos associados à alteração da biotita(MOP$)$, são muito raros e, quando presentes, apresentam-se como cristais subédricos, geralmente, finos, os quais costumam ocorrer como inclusões na biotita.

Em relação às fases minerais associadas ao estágio de alteração tardi a pósmagmática, o cunjunto sericita \pm muscovita $\left(\mathrm{Mv}_{1}\right) \pm \operatorname{clorita}\left(\mathrm{Cl}_{1}\right) \pm$ fluorita $\left(\mathrm{Fl}_{1}\right) \pm$ epidoto1 $\left(\mathrm{Ep}_{1}\right)$ e o feldspato potássico $\left(F_{2}\right)$ mostram-se associados à substituição parcial dos plagioclásios $\left(\mathrm{Pl}_{1}\right.$ e $\left.\mathrm{Pl}_{2}\right)$, embora sejam mais intensamente desenvolvidos em relação ao $\mathrm{Pl}_{1}$. Os primeiros tendem a se desenvolver nas porções mais centrais dos cristais com zoneamento normal, embora ocorram de modo menos expressivo em zonas irregulares ou "patch zones". A ocorrência preferencial nas zonas mais internas dos cristais está, também, associada à descalcifacação dos mesmos, nessas regiões, que outrora foram relativamente mais cálcicas. A substituição do plagioclásio, especiaimente, o $\mathrm{Pl}_{1}$ por $\mathrm{Fk}_{2}$ (microclinização) 
ocorre em diferentes graus de intensidade, podendo ser parcial ou total. Isso é evidenciado pela presença de manchas de microclina nas zonas de bordas dos cristais de $\mathrm{Pl}_{1}$, bem como no interior dos mesmos, a partir dos planos de clivagem. Às vezes, são observados "fantasmas" ou relíctos de plagioclásio no interior dos grãos de $\mathrm{Fk}_{2}$.

A albitização é marcante e chega a alcançar até $18 \%$ modal(Tabela 4.2). É traduzida por diversas formas de agrupamentos e franjas albíticas, os quais mostram-se representados por:

1) "swapped rims" : refere-se a albita desenvolvida, preferencialmente, como franjas ou bordas no feldspato potássico, principalmente em relação ao $\mathrm{Fk}_{2}$ (Prancha 16; Foto e).

2)"albite rims": consiste de franjas ou bordas no plagioclásio $\left(\mathrm{Pl}_{4}\right)$.

3) "Coroas trocadas"; são agrupamentos de finos cristais de albita que ocorrem, preferencialmente, no contato entre dois ou mais grãos de feldspato potássico, especialmente de $\mathrm{Fk}_{2}$, dispondo-se em franjas, aproximadamente paralelas entre si e com eixos óticos invertidos em relação ao cristal de feldspato potássico adjacente(Prancha 16; Foto $\theta$ ).

4) "chess-board albite": é pouco freqüente, ocorrendo, localmente, em algumas amostras.

5) agrupamentos albíticos tipo "dedos"ou "mäos": se refere aos agrupamentos de cristais dispostos de modo semelhante a "dedos" e/ou "mãos", os quais mostram-se como se estivessem invadindo os cristais de feldspato potássico hospedeiro.

A clorita apresenta-se como lamelas anédricas, finas a médias e exibe pleocroismo moderado, o qual oscila entre verde oliva( $Z$ e $Y$ ) e verde claro(X). A allanita é uma fase secundária cujos conteúdos são muito variáveis. Em algumas amostras pode atingir até $3 \%$ modal da rocha, em outras é muito pouco abundante, podendo estar ausente. Costuma ocorrer como cristais subédricos, finos, zonados, os quais exibem cores de interferência variáveis, desde tonalidades amareladas a avermelhadas até tons cinza-azulada. $O$ epidoto pode, algumas vezes, se confundir com a allanita. Entretanto, na maioria das vezes, ocorre segundo gãos fusiformes, dispostos, preferencialmente, ao longo dos planos de clivagem da biotita cloritizada. A esfalerita e os minerais opacos $\left(\mathrm{MOP}_{2}\right)$ são pouco freqüentes. Ocorrem, na maioria das vezes, como grãos anédricos e, do mesmo modo que o epidoto, dispõem-se ao longo dos planos de clivagem das fases micáceas.

A fluorita, além de ocorrer como finos grãos associados à descalcificação do plagioclásio $\left(P \mathrm{Pl}_{1}\right)$, juntamente com sericita \pm muscovita $\left(\mathrm{Mv}_{1}\right) \pm \operatorname{clorita}\left(\mathrm{Cl}_{1}\right) \pm$ epidoto $\left(E \mathrm{p}_{1}\right)$, ocorre, ainda, como cristais mais grossos, ora intimamente associados à biotita cloritizada, ora disseminados na rocha. Em ambos os casos, forma cristais anédricos, algumas vezes, levemente substituídos por carbonatos e apresenta-se nas modalidades lilás e incolor. 
Os argilo-minerais mostram-se, preferencialmente, associados ao feldspato potássico( $F_{k_{1}}$ e $\mathrm{Fk}_{2}$ ), ocorrendo sob a forma de "nuvens" superpostas aos mesmos, dandothes um aspecto "sujo".

\subsubsection{2- Ordem de Cristalização}

Com relação à ordem de separação das fases minerais primárias a partir do líquido magmático, esse granitóide guarda grande semeihança com a facies BSGEm, sendo, por essa razão, desnecessário repetir esses aspectos, aqui. O mesmo é válido para fases minearais associadas ao estágio de alterações tardi a pós-magmáticas.

\subsection{3-Facies MSG}

Ao que tudo indica, representa a facies de menor área de abrangência no maciço. Ocorre muito localmente, sob a forma de diques, seccionando a facies SGH.

\subsubsection{1- Textura e Mineralogia}

Apresenta textura hipidiomórfica, heterogranular fina(Prancha 17; Fotos a, b), podendo, locaimente, tender a uma textura porfiritica fina. Consiste essencialmente de quartzo, feldspato potássico e plagioclásio, sendo muito pobre em máficos, o que lhe confere um aspecto alasquítico. Entretanto, restos de biotita cloritizada e/ou oxidada e de clorita, podem ser observados localmente. Como minerais acessórios predominam opacos $\left(M O P_{1}\right)$, rutilo e zircão.

Em relação às fases minerais relacionadas ao estágio de alterações tardi a pósmagmáticas, a albita é a mais abundante, ocorrendo, muito subordinadamente, sericita \pm muscovita $\left(\mathrm{Mv}_{1}\right)+$ clorita $\left(\mathrm{Cl}_{1}\right)+$ fluorita $\left(\mathrm{Fl}_{1}\right)$, feldspato potássico 2, albita, clorita $\left(\mathrm{Cl}_{2}\right)+$ allanita+ epidoto+minerais opacos $\left(\mathrm{MOP}_{2}\right)$, fluorita $\left(\mathrm{Fl}_{2}\right)$, carbonatos, argilo-minerais e muscovita( $\left(\mathrm{Mv}_{2}\right)$.

Texturas de intercrescimentos são observadas, tanto aquelas relacionadas a processos de exsolução, quanto de substituição, sendo os tipos mais comuns as pertitas tipo "film", "band"e "vein"(Alling, 1932 e 1938; Smith, 1974).

Exceto pela granulação, mostra características mineralógicas magmáticas e tardi a pós-magmáticas muito semelhantes ao que foi exposto em relação à facies SGH, diferido apenas no que diz respeito à ausência de esfalerita e à presença de carbonato. O mesmo é válido para a ordem de cristalização, cujo esboço segue o que foi apresentado em relação à facies BSGEm(Figura 4.3) 


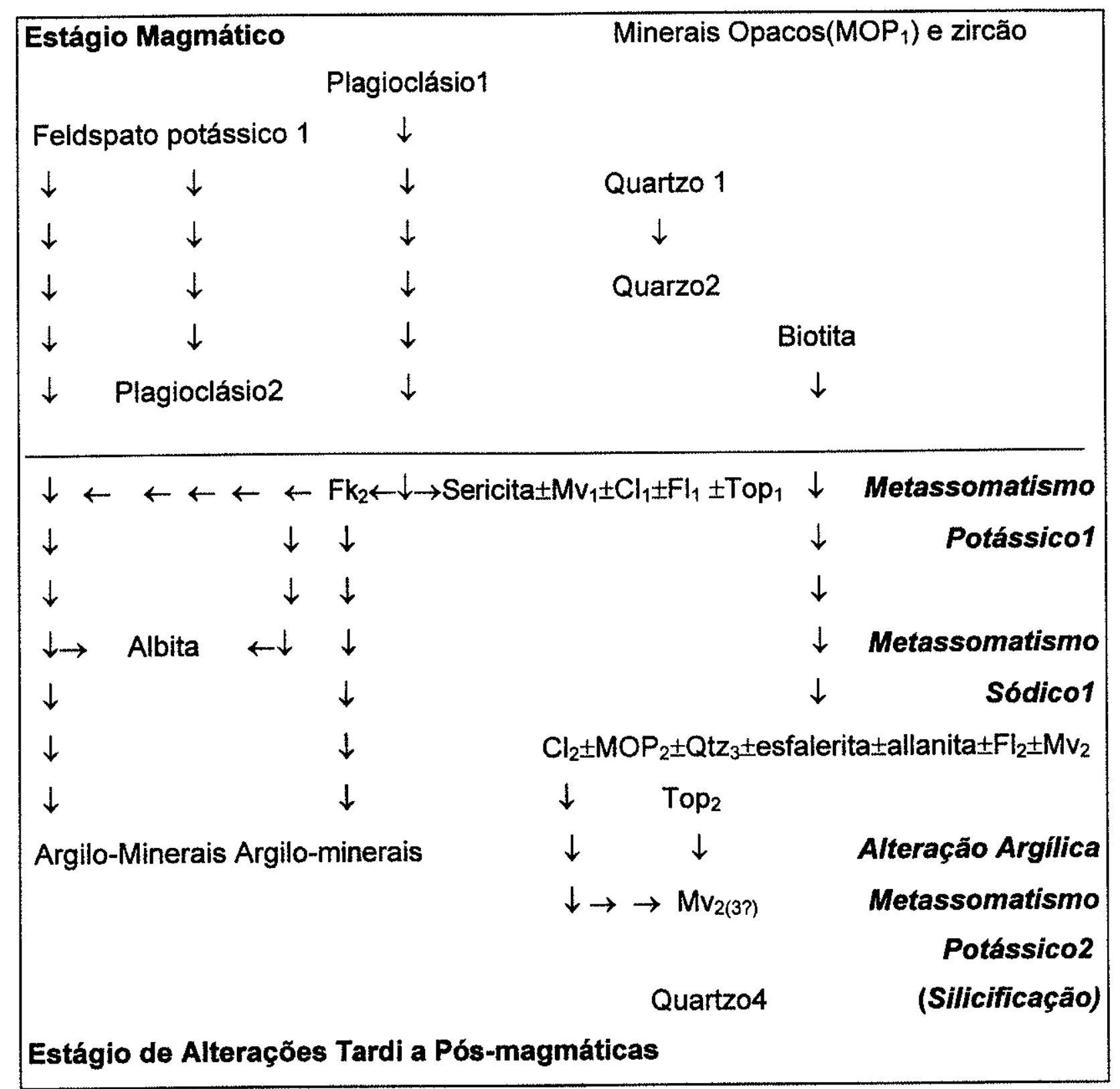

Figura 4.3- Fluxograma mostrando um esboço esquemático da sequ̇éncia de cristalização magmática e tardi a pós-magmática das fases minerais presentes nos granitóides do. maciço Velho Guilherme.

\subsection{4- Veios Hidrotermais}

$\mathrm{Na}$ área de ocorrência desses veios, observa-se que os mesmos estão encaixados no SGH. Apresentam forma tabular, espessura centimétrica e coloração verde a verdeesbranquiçada(Prancha 17; Foto c, d, e, f). Consistem essencialmente de quartzo e epidoto, sendo a clorita uma fase muito subordinada além de restos de biotita.

O quartzo apresenta-se como grãos anédricos a subédricos, de dimensões variáveis desde grãos fino até grossos. Os cristais mais grossos, constituem níveis ou faixas irregulares, entremeados com niveis contendo epidoto e quartzo de dimensöes finas. Nos 
níveis a grãos mais finos, o quartzo desenvolve contatos retos a irregulares e, às vezes, poligonizados. Localmente, esses niveis, podem apresentar epidoto intersticial.

O epidoto forma agregados de cristais anédricos a subédricos, embora ocorram, subordinadamente, cristais euédricos e zonados. Apresenta-se intimamente associado à substituição parcial ou total da biotita cloritizada e à clorita. Exibe cores de interferência variáveis desde altas(azul, amarelo e vermelho) até baixas(cinza-azulado).

A biotita e a clorita ocorrem como restos de lamelas anédricas, as quais foram, quase que inteiramente substituidas por epidoto.

\subsection{5- Discussões e Cosiderações Finais}

Os trabalhos de fotointerpretação e de campo, aliados aos estudos petrográficos, mostraram a existência de, pelo menos, três facies granitóides no interior desse maciço. A separação entre elas não ficou evidente, em mapa, devido à pequena dimensão do corpo frente à escala de trabalho adotada. São granitóides sienograniticos, com variações texturais desde tipos equigranulares médios, de coloração rosa, algo enriquecidos em biotita, os quais mostram-se seccionados por granitóides heterogranulares médios a grossos, também, rosa , relativamente, mais pobres em biotita, que por sua vez, mostram-se cortados por microgranitos e veios hidrotermais ricos em quartzo e epidoto.

De modo geral, esses granitóides mostram-se afetados, de forma intensa, por alterações tardi a pós-magmáticas, as quais decorreram de um episódio metassomático inicial, de natureza potássica, seguido de um evento metassomático sódico que, por sua vez, foi superposto por um segundo evento potássico, seguido de silicificação. Mineralizações importantes de cassiterita não são noticiadas e tampouco foram observadas no âmbito desse maciço. Entretanto, pequenas ocorrências de cassiterita e topázio, esplotadas por garimpeiros, são registradas por antigos moradores da região, sem contudo representarem um atrativo para empresas mineradoras que atuaram nas circunvizinhanças, tais como nas áreas de ocorrência dos maciços granitóides Antônio Vicente e Mocambo.

Neste trabalho, apenas fluorita e topázio, em concentrações muito baixas, foram observados através de microscopia ótica. A Tabela 4.3 mostra as principais características petrográficas das facies granitóides desse maciço. 
Tabela 4.3- Principais caracteristicas petrográficas das facies granitóides do maciço granitóide Velho Guilherme.

\begin{tabular}{|c|c|c|c|c|c|}
\hline $\begin{array}{l}\text { Facies } \\
\text { Granitoides }\end{array}$ & Minerais essenciais & Minerais Variotais & Minerais Acessortos Primários & Mlnerais secundários & $\begin{array}{c}\text { Mineralizaçoes/ } \\
\text { Modo de } \\
\text { ocorréncla }\end{array}$ \\
\hline BSGEm & $\begin{array}{l}\text { "quartzo } \\
\text { "plagioclásio(Ana-9) } \\
\text { "feldspato potássico }\end{array}$ & "biotita & $\begin{array}{l}\text { "zircăo } \\
\text { " minerais opacos }\end{array}$ & $\begin{array}{l}\text { sericita, muscovita, clorita, fluorita, topázio, } \\
\text { feldspato potássico(microclina pertltica), } \\
\text { albita, minerais opacos, esfalerita, allanita, } \\
\text { argilo-minarais }\end{array}$ & Ausentes \\
\hline$\overline{\text { SGH }}$ & $\begin{array}{l}\text { *quartzo } \\
\text { "plagioclásio( }\left(A n_{7-12}\right) \\
\text { *feldspato potássico }\end{array}$ & "biotita & $\begin{array}{l}\text { * zirço } \\
\text { * minerais opacos } \\
\text { * rutilo }\end{array}$ & $\begin{array}{l}\text { sericita, muscovita, clorita, epidoto, fluorita, } \\
\text { feldspato potássico(microclina pertítica), } \\
\text { albita, minerais opacos, esfalerita, allanita, } \\
\text { argilo-minarais. }\end{array}$ & Ausentes \\
\hline MSG & $\begin{array}{l}\text { "quartzo } \\
\text { "plagioclásio } \\
\text { *feldspato potássico }\end{array}$ & "biotitas $1 \%$ & $\begin{array}{l}\text { - zircāo } \\
\text { "minerais opacos } \\
\text { "rutilo }\end{array}$ & $\begin{array}{l}\text { sericita, muscovita, clorita, epidoto, fluorita, } \\
\text { feldspato potássico(microclina pertitica), } \\
\text { albita, minerais opacos, carbonato, allanita, } \\
\text { argilo-minarais. }\end{array}$ & Ausentes \\
\hline
\end{tabular}




\section{5- Química Mineral}

\subsection{1- Análises através de Microssonda Eletrônica}

No âmbito deste maciço foram realizadas um total de 27 análises pontuais assim discriminadas: 1) facies BSGEm $=06$ de biotita, 02 de plagioclásio e 02 de feldspato potássico pertítico; 2) facies $\mathrm{SGH}=02$ de plagioclásio, 02 de feldspato potássico pertítico, 02 de albita pertítica, 02 de clorita e 04 de muscovita; 3) facies MSG = 02 de plagioclásio e 03 de feldspato potássico pertítico.

\subsubsection{1- Análises químicas em Biotita}

As análises de biotita foram realizadas em dois grãos distintos. No grão 1 foram tomadas medidas em áreas do centro do cristal, entre o centro e a borda e na borda, enquanto que no grão 2 a única análise realizada se restringiu à borda. Os dados analíticos obtidos e as fórmulas estruturais encontram-se no Anexo 16.

\subsubsection{1-Composição química}

De um modo geral, os grãos estudados não mostram variações importantes. Os valores de XFe são iguais a 0,99 em todas as análises.

Sua composição quando "plotada" no diagrama de Nockolds(1947; Figura 4.4 deste trabalho), incide no campo " $\mathbf{P}$, correspondente às biotitas associadas à muscovita+topázio+fluorita+ etc. Isso é conflitante com o que foi observado nos estudos petrográficos(microscopia ótica), já que a facies granitóide hospedeira da biotita em questão(facies BSGEm), embora contenha traços de muscovita e de fluorita, sabe-se que essas fases são claramente secundárias, mostram-se associadas ao estágio de alterações tardi a pós-magmáticas e decorrem tanto da alteração do plagioclásio, quanto da biotita. Sendo assim, não representam uma associação tal qual é aquela concebida para diagrama de Nockolds(op. cit.). Em relação ao topázio, está ausente nesta facies. Em outras palavras, a facies granitóide BSGEm é desprovida de outra fase máfica importante, sendo a biotita seu principal máfico primário. Em razão disso, era de se esperar que a composição da mesma incidisse no campo "Il" do referido diagrama.

No diagrama triangular ( $\mathrm{FeO}+\mathrm{MnO}$ )-10xTiO $-\mathrm{MgO}$ de Nachit(1994. In: Borges, 1997), Figura 4.5, nota-se que as seis análises caem no campo correspondente às micas magmáticas reequilibradas(campo "B" ). No diagrama $\mathrm{MgO}-\mathrm{FeO}_{\mathrm{T}}-\mathrm{Al}_{2} \mathrm{O}_{3}$ de Gokhale(1968), apresentado na Figura 4.6, as análises "plotam" inteiramente no campo correspondente à mica magmática, confirmando a natureza primária da biotita estudada. 


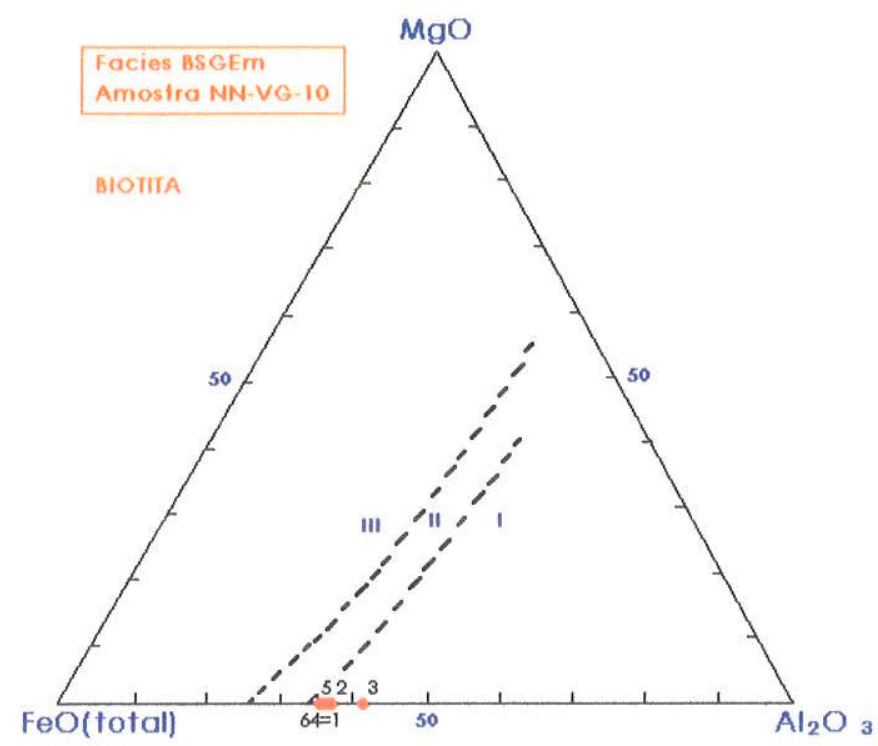

Figura 4.4.- Diagrama triangular $\left(\mathrm{FeO}_{\mathrm{T}}\right)-\mathrm{MgO}-\mathrm{Al}_{2} \mathrm{O}_{3}$ baseado em Nockolds(1947)mostrando as composições da biotita em diferentes associações minerais. Campos: 1= biotita associada à muscovita+topázio+fluorita+etc.; $2=$ biotita não acompanhada por outras fases máficas; 3 = biotita associada à hornblenda, piroxênio e/ou olivina.

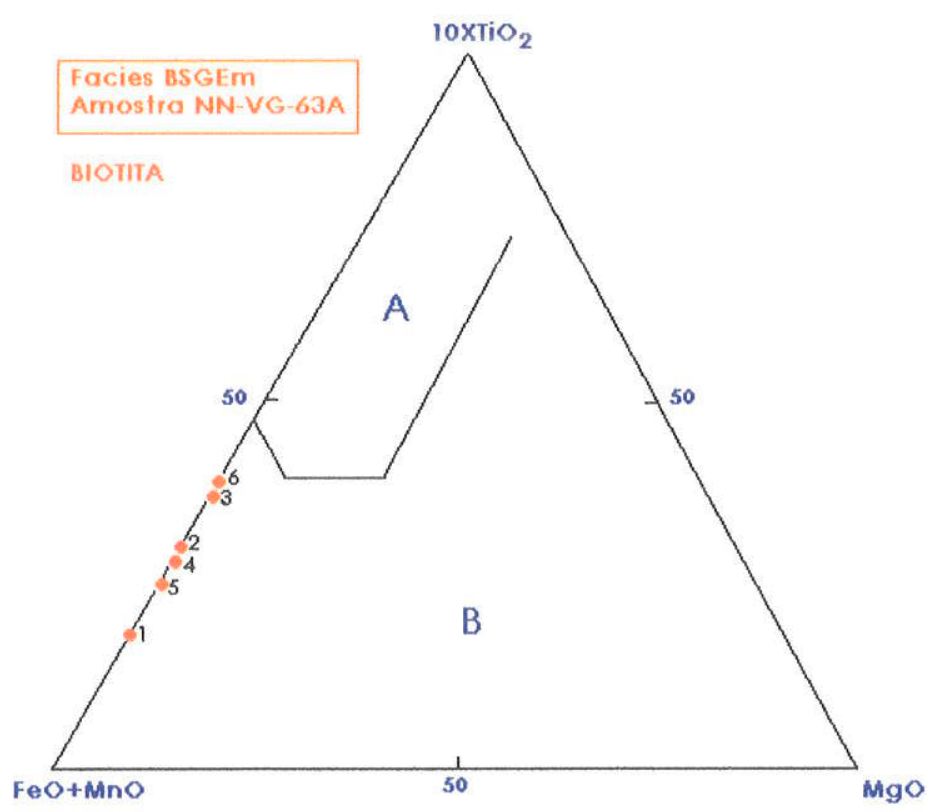

Figura 4.5.- Diagrama triangular $(\mathrm{FeO}+\mathrm{MnO})-\left(10 \times \mathrm{TiO}_{2}\right)-\mathrm{MgO}$ de Nachit(1994. In: Borges , 1997) mostrando a distribuição composicional da biotita da amostra NN-VG-63A, da facies BSGEm do maciço granitóide Velho Guilherme. $\mathbf{A}=$ campo das micas magmáticas; $\mathbf{B}=$ campo das micas magmáticas reequilibradas. 


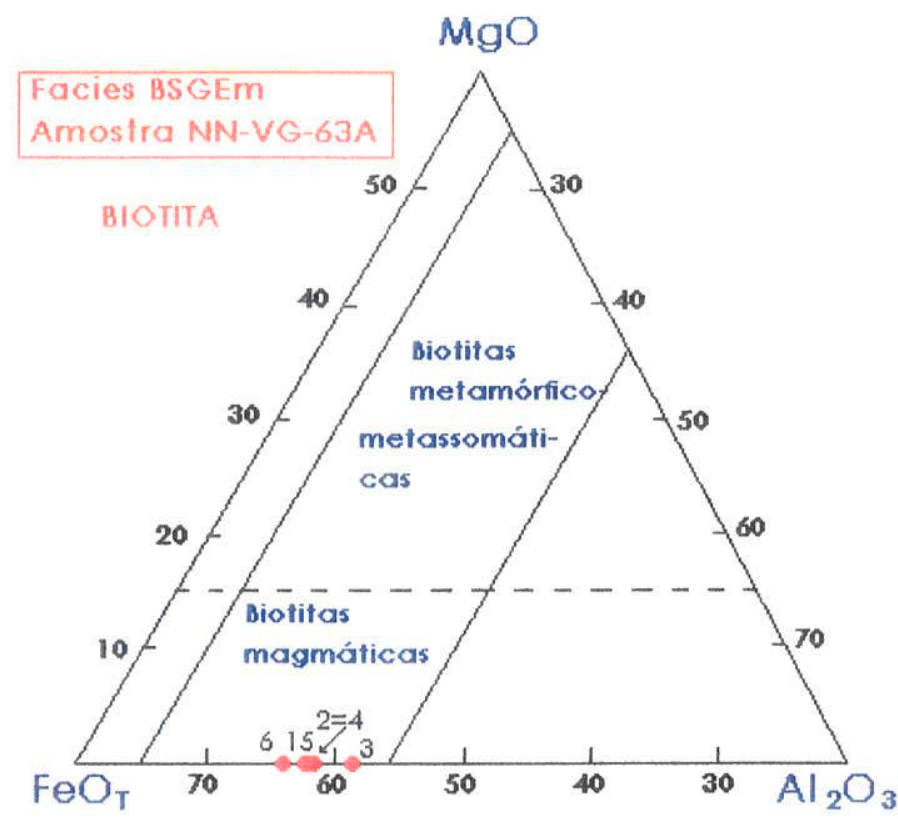

Figura 4.6.- Diagrama triangular $\mathrm{FeO}_{\mathrm{T}}-\mathrm{MgO}-\mathrm{Al}_{2} \mathrm{O}_{3}$ mostrando a projeção composicional da biotita da amostra NN-VG-63A, da facies BSGEm do maciço granitóide Velho Guilherme. As linhas cheias delimitam o campo composicional de biotita de rochas ígneas conforme(Nockolds, 1947) e a linha tracejada separa biotita magmáticas de biotita metamórfico-metassomáticas, conforme Gokhale(1968).

\subsubsection{2- Classificação e Representação gráfica}

Para efeito de classificação da biotita estudada, foi utilizado inicialmente o diagrama triangular $\mathrm{R}^{3+}\left(\mathrm{Al}^{3+}, \mathrm{Fe}^{3+}+\mathrm{Ti}^{4+}\right)-\mathrm{Mg}-\mathrm{R}^{2+}\left(\mathrm{Fe}^{2+}+\mathrm{Mn}^{2+}\right)$ de dessa autora, Figura 4.7. Nele, observa-se que as composições da biotita analisada caem inteiramente no campo das micas trioctaédricas do tipo siderofilita e lepidomelana de pegmatitos.

Em seqüência, as análises foram "plotadas" no diagrama $\mathrm{Al}^{\mathrm{Vl}} \mathrm{vs}$. $\mathrm{Mg} /\left(\mathrm{Mg}+\mathrm{Fe}^{2+}\right)$ de Guidotti(1984), Figura 4.8. Nesse diagrama verifica-se que as mesmas incidem na região composicional compreendida entre a annita aluminosa e a siderofilita, tendendo a uma composição mais annítica aluminosa, especialmente, a análise número 6(Anexo 16), correspondente ao grão 2 .

Finalmente, as análises foram lançadas sobre o diagrama $\left(\mathrm{Fe}_{\mathrm{T}}+\mathrm{Mn}+\mathrm{Ti}-\mathrm{Al}{ }^{\mathrm{VI}}\right)$ vs. $\mathrm{Mg}-\mathrm{Li}$, apresentado por Tischendorf et al.(1997), Figura 4.9, deste trabalho. Nota-se que cinco análises "plotam" inteiramente no campo composicional da siderofilita, e uma incide sobre a linha limítrofe entre este campo e o da protolitionita, todas no quadrante IV, correspondente às Li-Fe micas. 


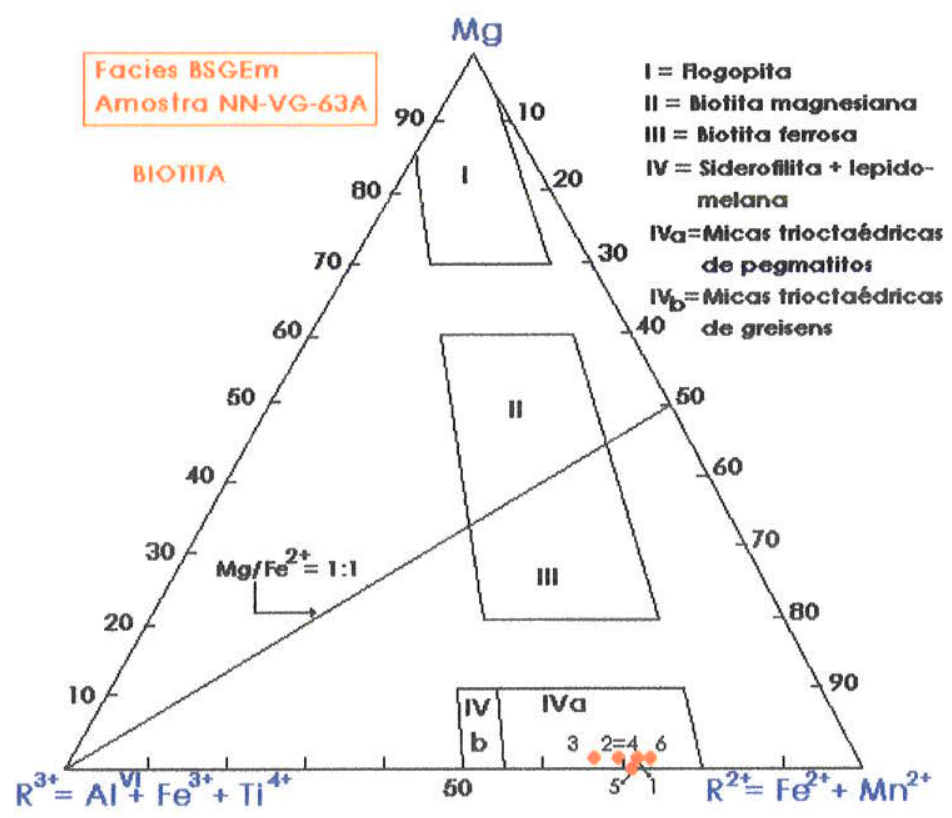

Figura 4.7- Diagrama triangular $\mathrm{R}^{3+}-\mathrm{Mg}-\mathrm{R}^{2+}$ de Foster(1960b), mostrando a relação entre $\left(\mathrm{Al}^{\mathrm{V}}, \mathrm{Fe}^{3+}\right.$, $\mathrm{Ti}), \mathrm{Mg}$ e $\mathrm{Fe}^{2+}\left(\mathrm{Mn}^{2+}\right)$ em micas trioctaédricas e a posição ocupada no diagrama pelas análises da biotita da amostra NN-VG-63A, da facies BSGEm do maciço granitóide Velho Guilherme.

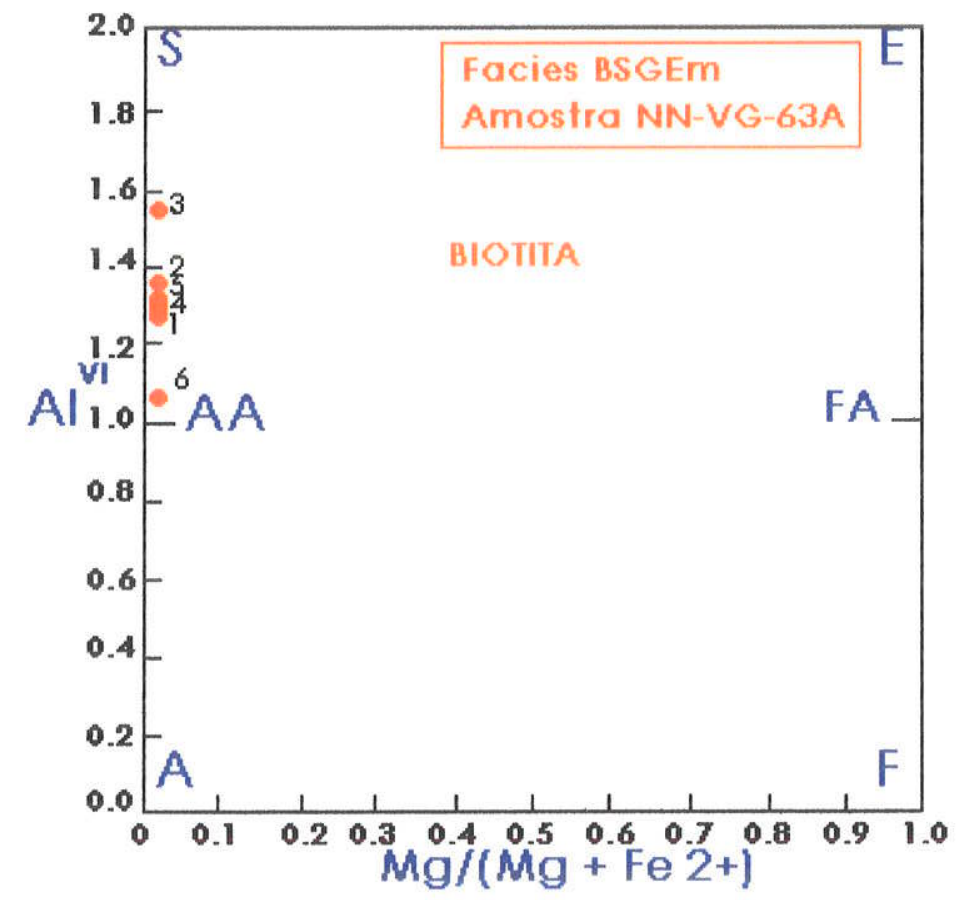

Figura 4.8- Diagrama $\mathrm{Al}^{\mathrm{N}}$ versus $\mathrm{Mg} /\left(\mathrm{Mg}+\mathrm{Fe}^{2+}\right)$ de Guidotti(1984) mostrando a distribuição composicional da biotita da amostra NN-VG-63A, da facies BSGEm do maciço granitóide Velho Guilherme. $A=$ annita; $F=$ flogopita; $F A=$ flogopita aluminosa; $A A=$ annita aluminosa; $S=$ siderofilita; $E=$ $\mathrm{K}_{2}\left(\mathrm{Mg}_{4} \mathrm{Al}_{2}\right)\left(\mathrm{Al}_{4} \mathrm{Si}_{4} \mathrm{O}_{20}\right)(\mathrm{OH})_{4}$. 


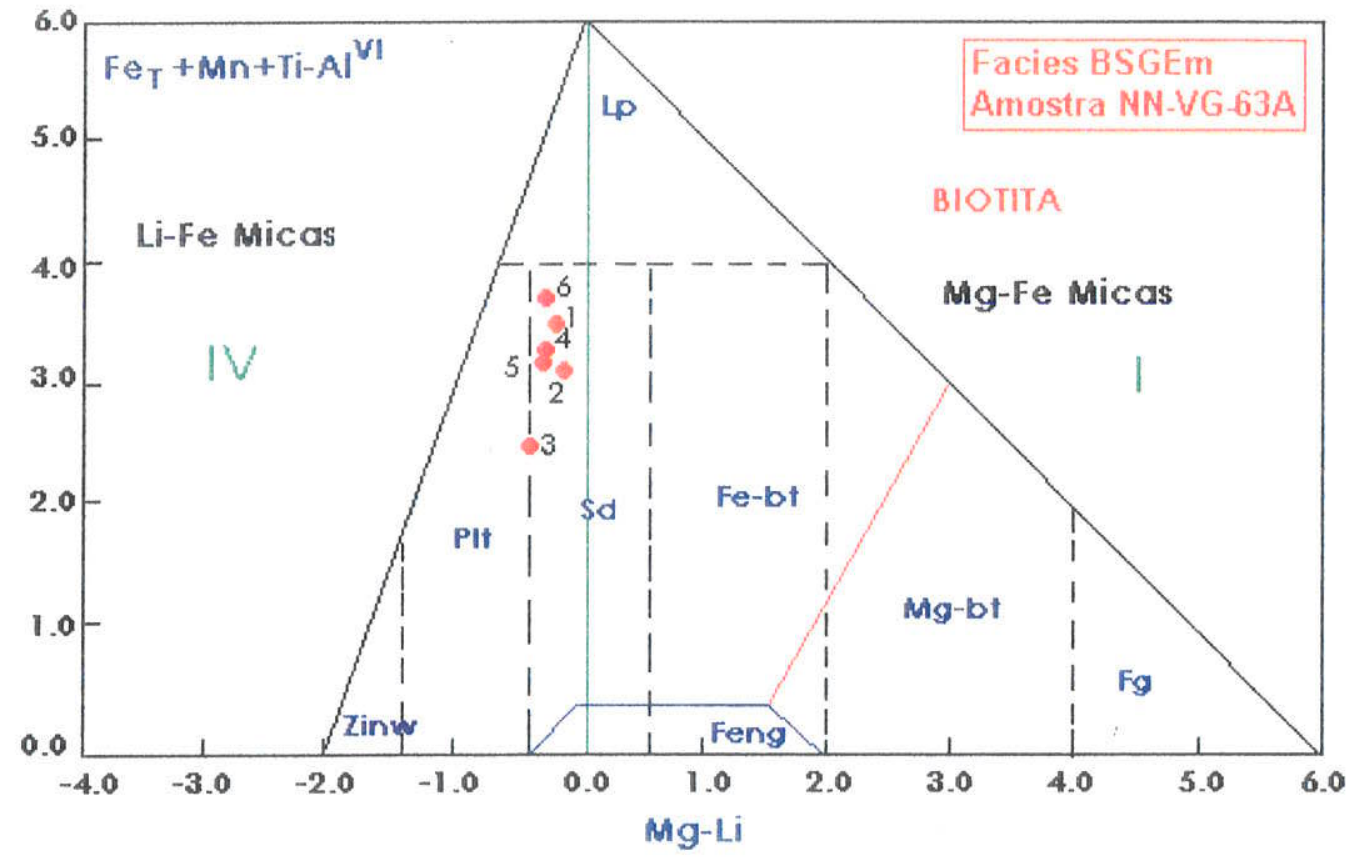

Figura 4.9.- Projeção da composição da biotita da amostra NN-VG-63A, da facies BSGEm do maciço granitóide Velho Guilherme, no diagrama (Mg-Li) vs. $\left(\mathrm{Fe}_{\mathrm{T}}+\mathrm{Mn}+\mathrm{Ti}-\mathrm{Al}^{\mathrm{VI}}\right)$, de Tischendorf et al.(1997). Lp=lepidomelana; Febt=ferro-biotita; Mgbt=magnésio biotita; Sd=siderofilita; $\quad F g=$ flogopita; Plt=protolitionita.

\subsubsection{3- Condições de Cristalização}

Os dados químicos obtidos para a biotita estudada foram tratados de modo a se determinar a temperatura de cristalização da mesma, bem como o $\log \mathrm{fO}_{2}$. Para tal foi utilizado o trabalho experimental desenvolvido por Wones \& Eugster(1965). É importante ressaltar que a aplicação do quimismo da biotita, aqui estudada, ao trabalho experimental de Wones \& Eugster(1965), deve ser vista com reserva, visto que os conteúdos de $\mathrm{Fe}^{2+}$ e $\mathrm{Fe}^{3+}$ não foram determinados diretamente na microssonda eletrônica. Em vista disso, os cálculos da temperatura de cristalização, bem como aqueles do Log da $\mathrm{fO}_{2}$, devem ser provisoriamente considerados apenas como estimativas comparativas.

No diagrama $\mathrm{Fe}^{2+}-\mathrm{Fe}^{3+}-\mathrm{Mg}$ (Wones \& Eugster, 1965; Figura 4.10 deste trabalho) nota-se que uma análise situa-se um pouco abaixo da curva "buffer" (tampão) $\mathrm{Fe}_{2} \mathrm{SiO}_{4}$ $\mathrm{SiO}_{2}-\mathrm{Fe}_{3} \mathrm{O}_{4}$ (faialita-quartzo-magnetita), duas entre esta curva e o "buffer" $\mathrm{Ni}-\mathrm{NiO}$, duas sobre essa curva tampão e uma um pouco acima da mesma. Isso evidencia que a biotita em questão cristalizou em condições de fugacidade de oxigênio relativamente baixas.

Os dados acima apresentados quando transportados para o diagrama $\mathrm{T}\left({ }^{0} \mathrm{C}\right)$ versus. Log $\mathrm{fO}_{2}$ a 2070 bar, de Wones \& Eugster(1965), Figura 4.11, indicam condições de cristalização em ambiente com $\log \mathrm{fO}_{2}$ muito baixo, variando entre $-19,2$ e - 19,8 e 
temperaturas oscilando de $658,33^{\circ} \mathrm{C}$ e $733,33^{\circ} \mathrm{C}$. Os valores obtidos para o $\log \mathrm{fO}_{2}$ são compatíveis com o esperado, sendo coerente com as observações apresentadas acima, visto que a biotita estudada mostra-se enriquecida em $\mathrm{Fe}^{2+} \mathrm{em}$ detrimento ao $\mathrm{Fe}^{3+}$, cujos teores variam entre 0,2623 e $0,0,4856$ (Anexo 16). Do mesmo modo que em relação à biotita da facies BSG do maciço granitóide Antônio Vicente, as altas razões $\mathrm{Fe}^{2+} / \mathrm{Fe}^{3+}$ e a ausência de magnetita e titanita na facies BSGEm, desse maciço, indicam que a biotita aqui estudada cristalizou-se em condições magmáticas redutoras ou em condições de fugacidade de oxigênio muito reduzidas.

Em relação à temperatura, o valor, também, parece coerente, considerando que a biotita em questão cristalizou-se tardiamente em relação aos minerais essenciais plagioclásio, quartzo e feldspato potássico, embora dentro dos limites esperados para uma biotita magmática. Além disso, conforme visto acima, trata-se de uma biotita magmática reequilibrada. Assim, a temperatura estimada é interpretada aqui como aquela de reequilíbrio da mesma com o líquido magmático.

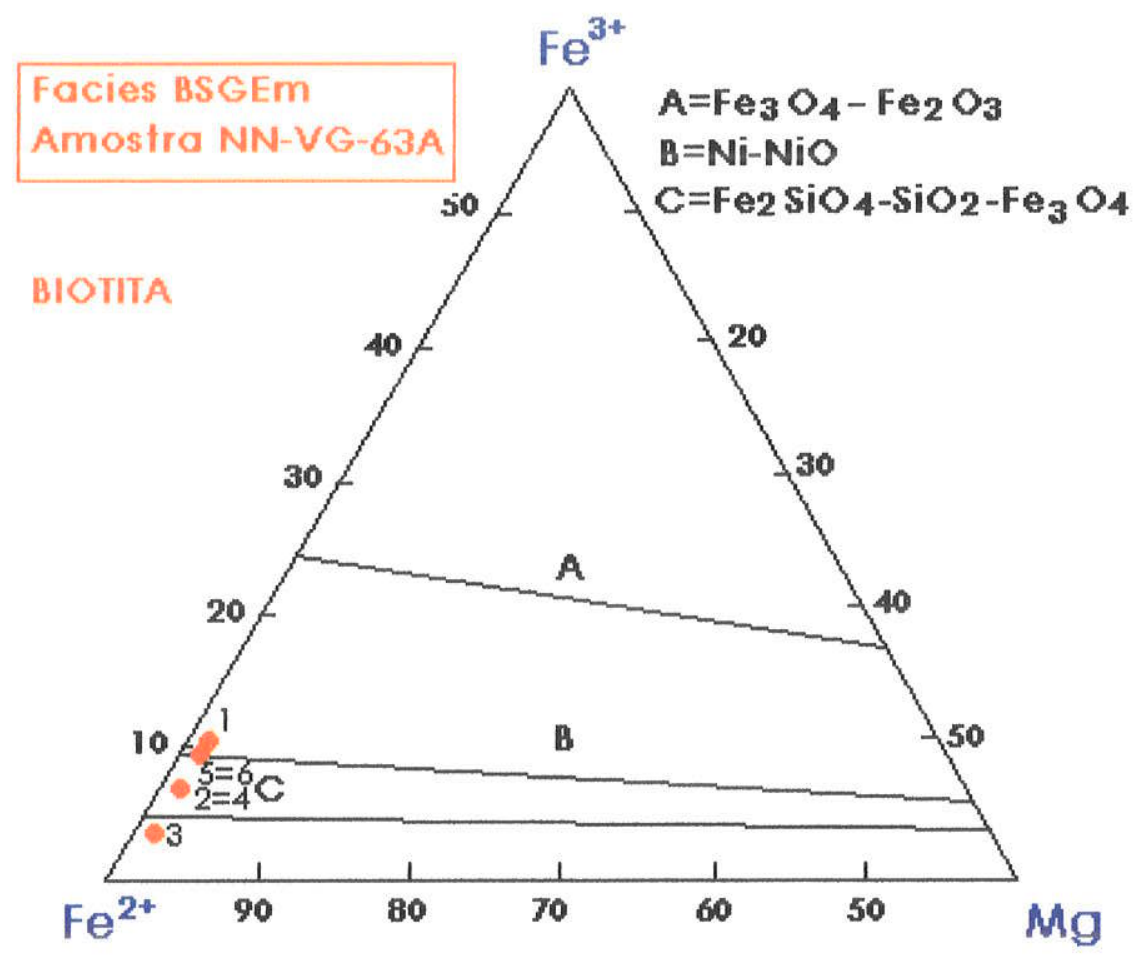

Figura 4.10 - Representação composicional da biotita da amostra NN-VG-63A, da facies BSGEm do maciço granitóide Velho Guilherme no diagrama triangular $\mathrm{Fe}^{2+}-\mathrm{Fe}^{3+}-\mathrm{Mg}$ de Wones \& Eugster(1965). 


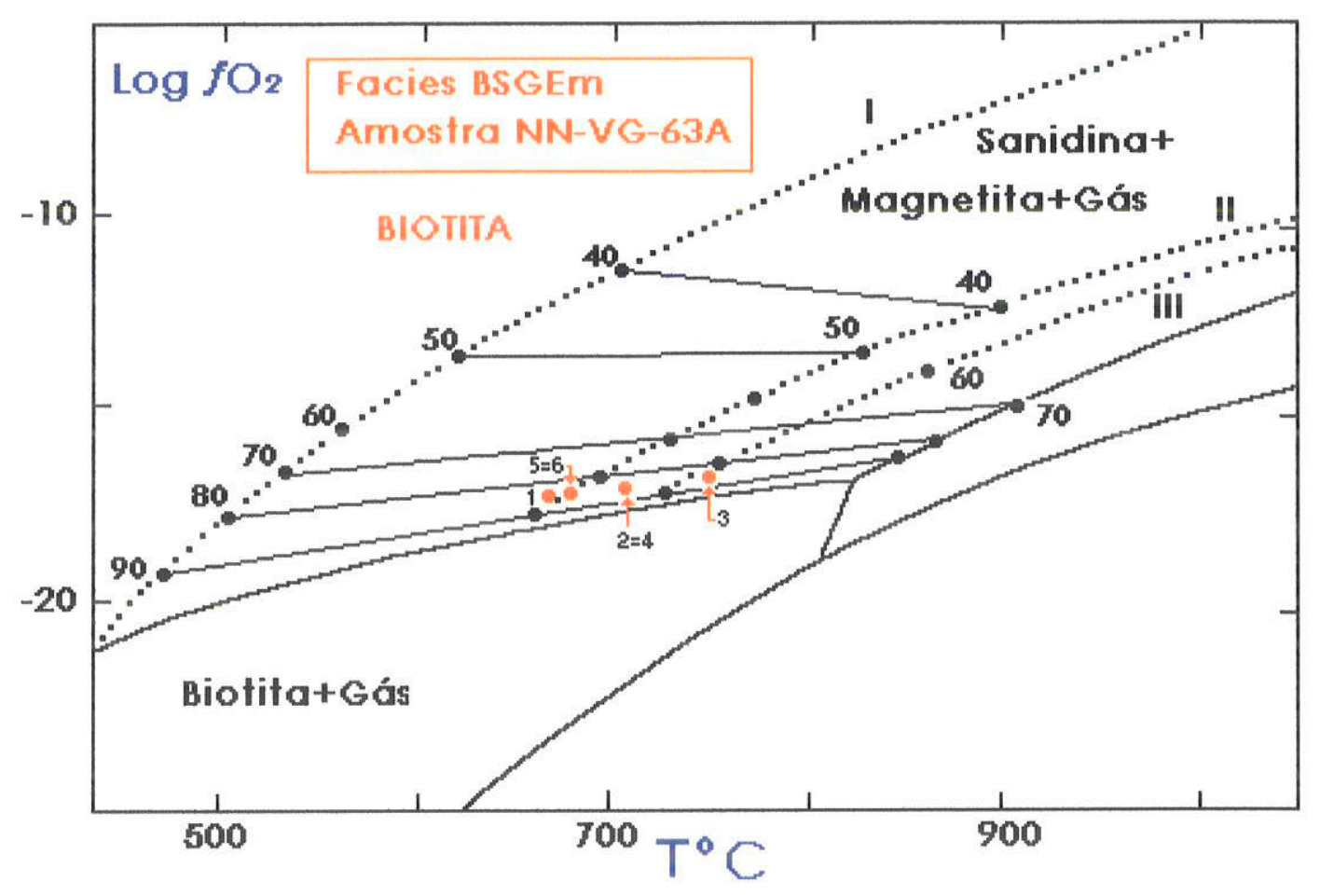

Figura 4.11- Representação composicional da biotita da amostra NN-VG-63A, da facies BSGEm do maciço granitóide Velho Guilherme no diagrama $\mathrm{T}^{0} \mathrm{C}-\log f \mathrm{O}_{2}$ para pressão total de $2070 \mathrm{~b}$ segundo Wones \& Eugster(1965). I = curva tampão $\mathrm{Fe}_{3} \mathrm{O}_{4}-\mathrm{Fe}_{2} \mathrm{O}_{3} ;$ II = curva tampão Ni-NiO; III = curva tampão $\mathrm{Fe}_{2} \mathrm{SiO}_{4}-\mathrm{SiO}_{2}-\mathrm{Fe}_{3} \mathrm{O}_{4}$. Os números pequenos do interior do diagrama representam as relações $\mathrm{Fe}^{2+}-$ $\mathrm{Fe}^{3+}-\mathrm{Mg}$ da Figura 4.10.

\subsubsection{2- Análises químicas em Plagioclásio}

O estudo de plagioclásio $\left(\mathrm{Pl}_{1}\right)$ envolveu um total de 06 análises pontuais em grãos de amostras representativas das facies granitóides BSGEm, SGH e MSG. Os resultados analíticos, as fórmulas estruturais calculadas, bem como outros dados auxiliares encontramse no Anexo 17.

\subsubsection{1- Composição química e representação gráfica}

Em termos composicionais, as análises mostram que no conjunto não existe uma variação composicional importante(Figura 4.12; Anexo 17). Entretanto, observa-se que o plagioclásio da facies SGH apresenta os mais baixos conteúdos de $\mathrm{Na}$ e os mais elevados de $\mathrm{Ca}$, enquanto que aqueles pertencentes às facies BSGEm e MSG exibem teores equivalentes desses óxidos(Figura 4.13 e 4.14). Em relação à razão $\mathrm{Na} / \mathrm{K}$ (Anexo 17), observa-se que há uma nítida tendência de crescimento da mesma no sentido do plagioclásio da facies BSGEm para o plagioclásio da facies MSG. De um modo geral as composições atuais são albíticas e variam de $A n_{2}$ a $A n_{4}$ (Figura 4.12). Entretanto, 
observações através de microscopia ótica demonstraram que se trata de plagioclásios descalcificados, visto que os mesmos encontram-se afetados por alterações tardi a pós-magmáticas. A molécula Or se faz presente em baixíssimos conteúdos, podendo, inclusive estar ausente em uma análise da facies SGH e no plagioclásio da facies MSG(Anexo 17).

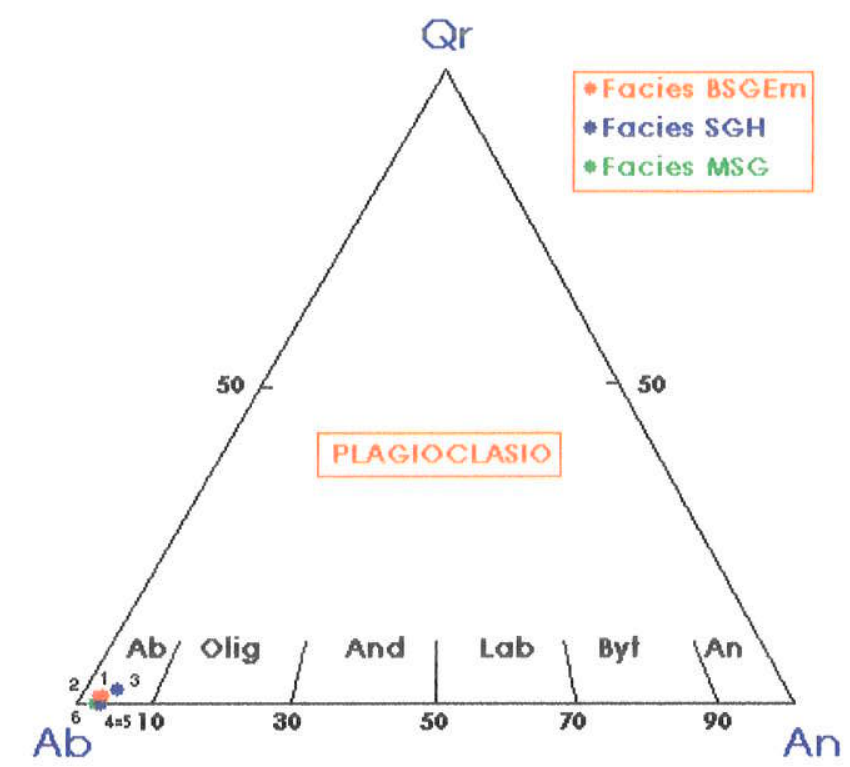

Figura 4.12. Diagrama triangular Ab-Or-An mostrando a distribuição composicional dos plagioclásio das facies BSGEm, SGH e MSG pertencentes ao maciço granitóide Velho Guiulherme.

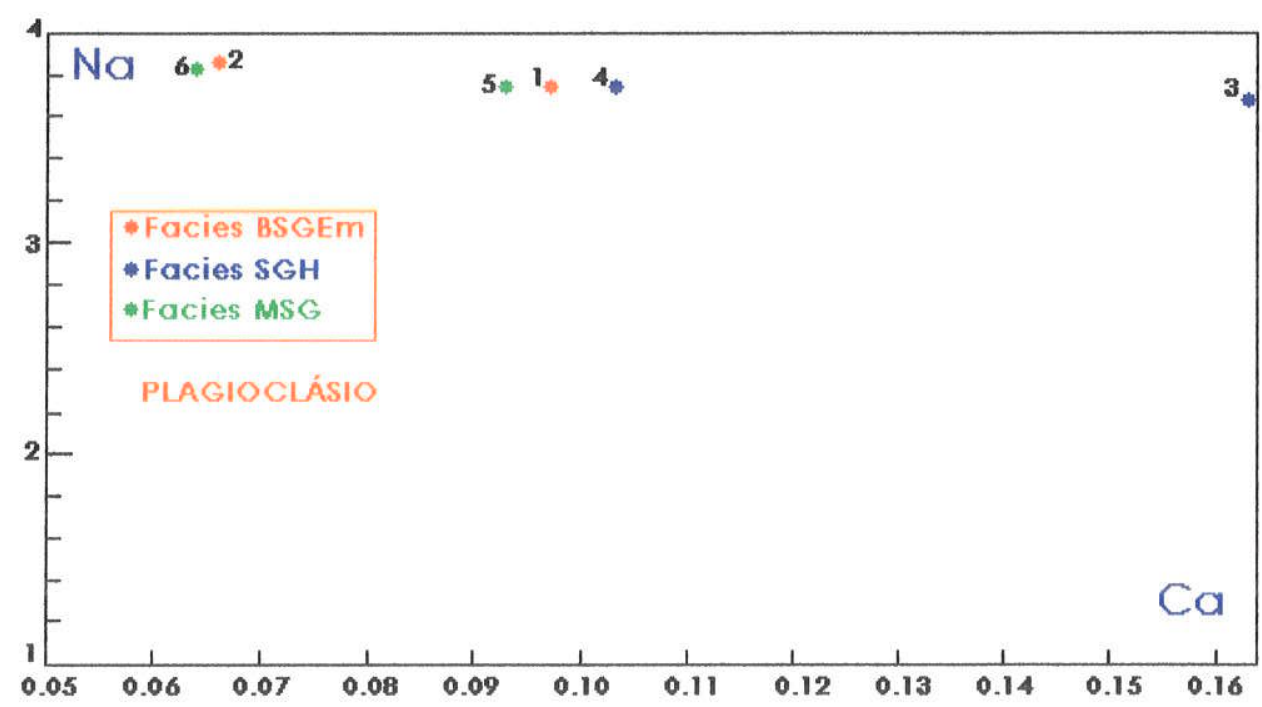

Figura 4.13. Diagrama Ca - Na mostrando a disribuição composicional dos plagioclásios estudados. 


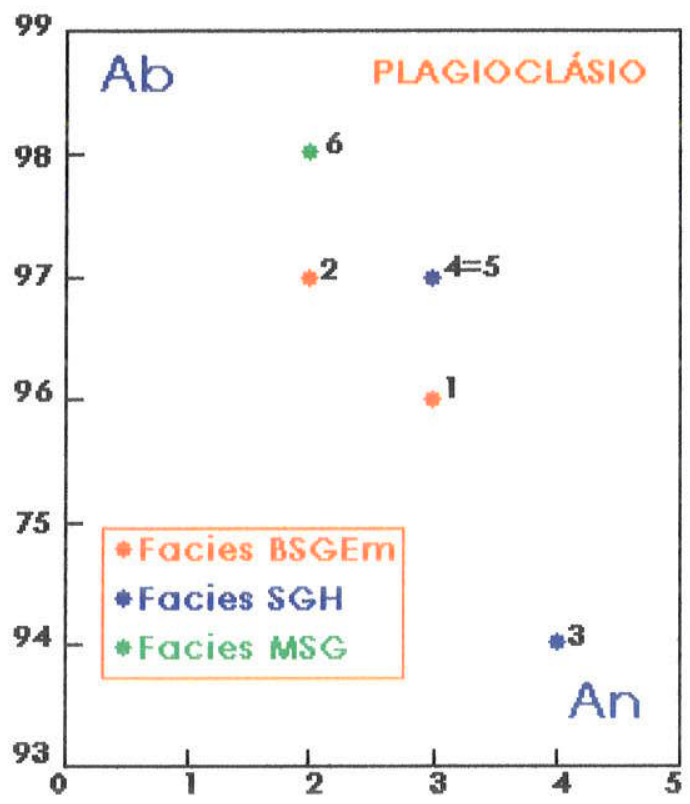

Figura 4.14. Diagrama An-Ab mostrando a participação dessas duas moléculas nos plagioclásio estudados.

\subsubsection{Análises químicas em Feldspato potássico}

Para essa fase mineral foram realizadas 07 análises assim discriminadas: facies BSGEm =02; facies $S G H=02$; facies $M S G=02$. Além disso, foram obtidas duas análises de albita pertítica da facies SGH e uma da facies MSG. As análises, as fórmulas estruturais e as proporçõpes Ab-Or-An encontram-se no Anexo 18.

\subsubsection{1- Composição química}

$\mathrm{Na}$ análise do Anexo 18 e do diagrama Ab-Or-An(Figura 4.15), observa-se que a composição da porção feldspato potássica do feldspato pertítico varia entre $\mathrm{Or}_{71}$ e $\mathrm{Or}_{98}$, enquanto que a porção albítica oscila entre $A_{2}$ e $A b_{29}$. Nota-se, ainda, que as análises referentes à facies SGH representam as composições mais potássicas(Or=98\%). As análises correspondentes à facies BSGEm ocupam uma posição intermediária, com os valores de Or variando entre $93 \%$ e $97 \%$, enquanto que aquelas da facies MSG mostram valores de Or entre $71 \%$ e $89 \%$ e representam o termo mais empobrecido na molécula potássica. No que se refere à molécula An, mostra-se ausente na totalidadede das amostras. Esse fato é discordante daquilo que é apresentado por Deer et al.(1966). Ou seja, o aumento de sódio, especialmente, nas análises da facies MSG não é acompanhado por um aumento das quantidades da fração anortita.

No que se refere às análises de albita pertítica(Anexo 18 ; Figura 4.16), obseva-se que aquelas correspondentes à facies SGH variam amplamente em termos da razão $\mathrm{Na} / \mathrm{K}(2,61$ a 165,96). Essas diferentes razões evidenciam, ao que tudo indica, relações de 
troca entre $\mathrm{Na}$ e $\mathrm{K}$ em função dos processos de substituição, que culminaram com a formação das pertitas de substituição(tais como "film", "'vein" e "band perthites"),ocorridos durante o estágio de alterações tardi a pós-magmáticas. Em relação à albita pertítica da facies MSG, a análise revela uma albita quase pura, com uma quantidades das frações $A b$ e An iguais a $98 \%$ e $2 \%$, respectivamente. $\mathrm{O} \mathrm{K}_{2} \mathrm{O}$ foi detectado apenas em conteúdos vestigiais(Anexo 18).

As condições de cristalização, não foram determinadas, visto que a ampla maioria dos cristais encontra-se invariavelmente alterada(albitizados e/ou argilizados), não sendo, portanto recomendada a utilização dos diversos geotermômetros existentes na literatura(Haselton et al., 1983; Brown \& Parsons, 1985; Elkins \& Grove, 1990; NekvasiL, 1994; entre outros). O mesmo é válido para o plagioclásio.
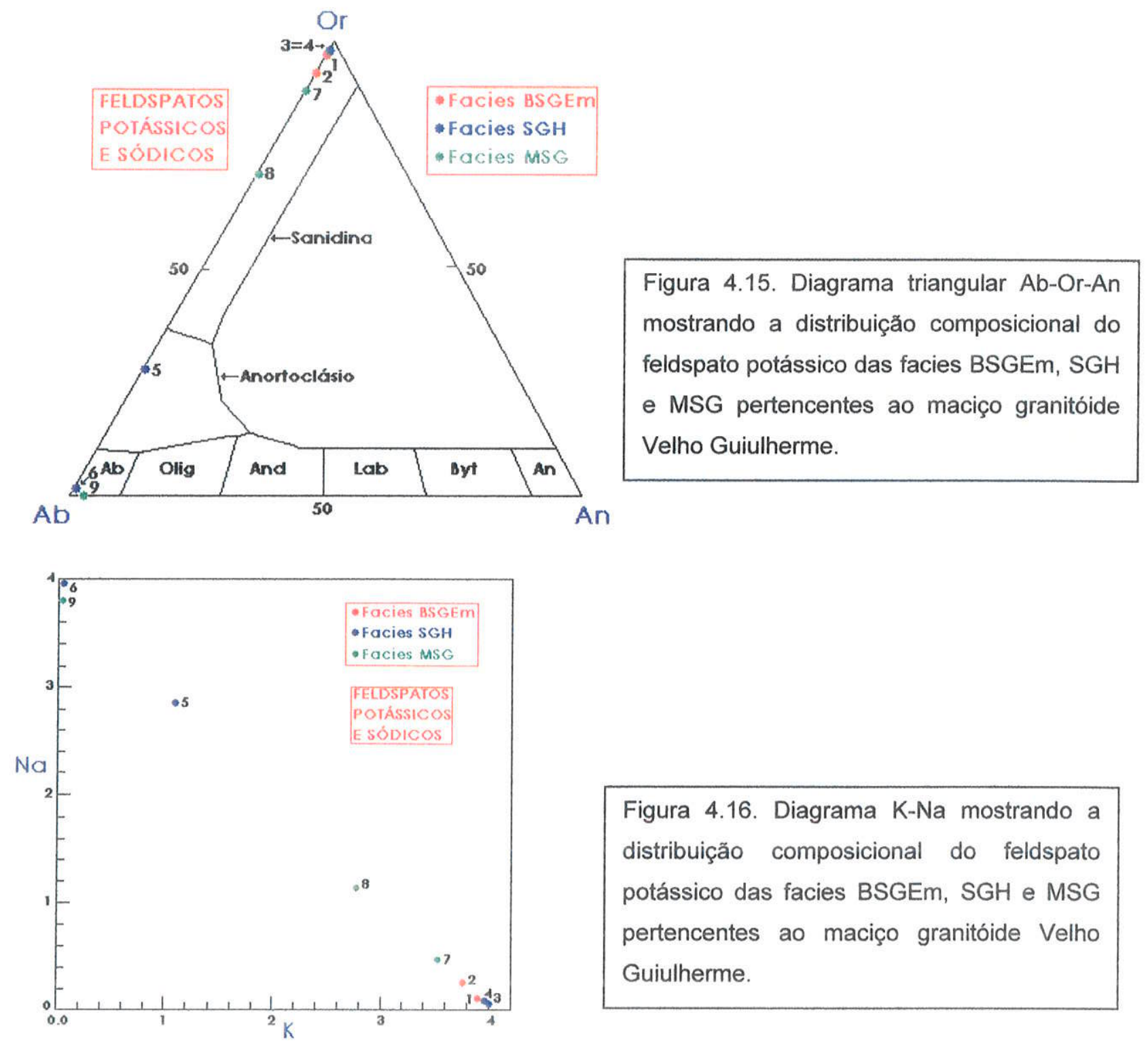

Figura 4.16. Diagrama K-Na mostrando a distribuição composicional do feldspato potássico das facies BSGEm, SGH e MSG pertencentes ao maciço granitóide Velho Guiulherme. 


\subsubsection{4- Análises químicas em Clorita}

Uma síntese sobre as principais características químicas do grupo da clorita foi apresentada no capítulo 3 .

No âmbito deste maciço foram realizadas somente duas análises pontuais em um grão de clorita 2, a qual mostra-se relacionada ao estágio de alterações tardi a pósmagmáticas, sendo produto da alteração da biotita. O grão estudado diz respeito à facies granitóide SGH. Os resultados analíticos e as fórmulas estruturais encontram-se no Anexo 19.

\subsubsection{1- Composição química}

$\mathrm{Na}$ análise do diagrama $\mathrm{Al}^{\mathrm{IV}}$ versus $\mathrm{Al}^{\mathrm{VI}}$ (Figura 4.17; Anexo 19) observa-se que o grão analisado mostra um pequena variação composicional, onde as quantidades de $\mathrm{Al}^{\mathrm{lv}}$ variam entre 1,413 e 1,484, enquanto que as de $\mathrm{Al}^{\mathrm{V} l}$ situam-se entre 0,524 e 0,579 . Notase, ainda uma correlação negativa entre $\mathrm{Al}^{\mathrm{IV}}$ e $\mathrm{Al}^{\mathrm{VI}}$, evidenciada pelo decréscimo das quantidades do primeiro no sentido da análise 1 para a 2 e pelo aumento das quantidades do segundo no mesmo sentido.

A Figura 4.18 revela uma correlação claramente negativa entre o $\mathrm{Al}^{\mathrm{VI}}$ e os cátions bivalentes $\left(\mathrm{Fe}^{2+}+\mathrm{Mg}^{2+}\right)$, caracterizada pelo crescimento de $\mathrm{Al}^{\mathrm{VI}}$ no sentido da análise 1 para a análise 2, ocorrendo o inverso com a soma dos cátion bivalente. Essa correlação se mantem no diagrama $\mathrm{Al}^{\mathrm{VI}}$ vs. $\mathrm{Fe}^{2+}$ (Figura 4.19).

As observações apresentadas acima, em relação aos três diagramas, evidenciam que paralelamente ao decréscimo de $\mathrm{Al}^{\mathrm{IV}}$ no sítio tetraedral(Figura 4.17), ocorreu um decréscimo nas quantidades dos cátions bivalentes $\left(\mathrm{Fe}^{2+}\right.$ e $\left.\mathrm{Mg}\right)$ no sítio octaedral(principalmente o $\mathrm{Fe}^{2+}$; Figuras 4.18 e 4.19) e um aumento no conteúdo de $\mathrm{Al}^{\mathrm{Vl}}$ no sítio octaédrico.

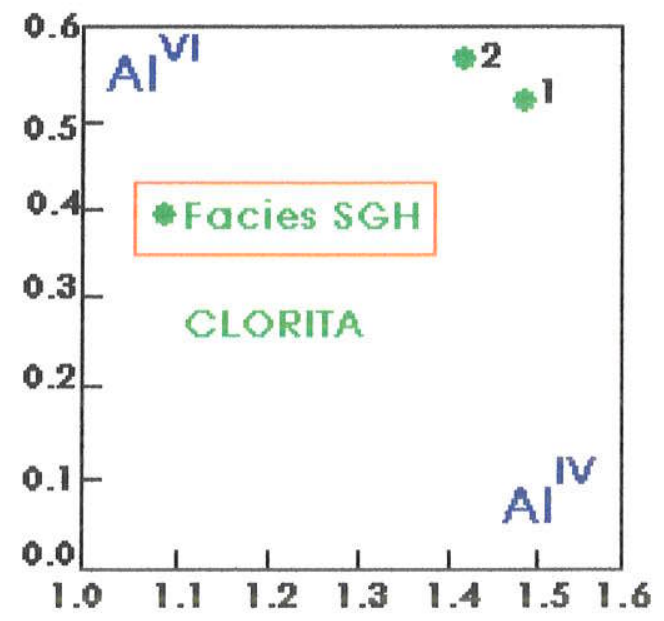

Figura 4.17- Diagrama $\mathrm{Al}^{\mathrm{Vl}}$ versus $\mathrm{Al}^{\mathrm{IV}}$ mostrando a distribuição composicional da clorita da facies SGH do maciço granitóide Velho Guilherme. 


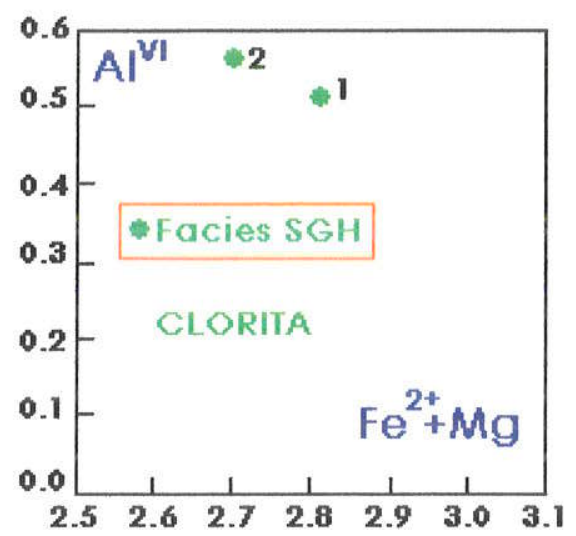

Figura 4.18.- Diagrama $\mathrm{Al}^{\mathrm{VI}}$ versus os cátions bivalentes $\left(\mathrm{Fe}^{2+}+\mathrm{Mg}^{2+}\right)$ mostrando a distribuição composicional da clorita pertencente à facies granitóide $\mathrm{SGH}$ do maciço granitóide Velho Guilherme.

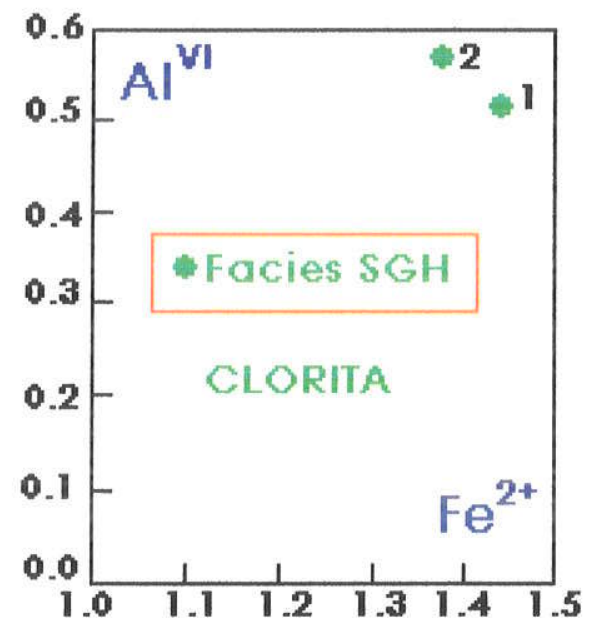

Figura 4.19- Diagrama $\mathrm{Al}^{\mathrm{VI}}$ versus $\mathrm{Fe}^{2+}$ mostrando a distribuição composicional da clorita pertencente à facies granitóide SGH do maciço Velho Guilherme.

A Figura 4.20 mostra que a diminuição nas quantidades de $\mathrm{Al}^{\mathrm{IV}}$ no sentido da análise 1 para 2 é acompanhada por um decréscimo nas quantidades dos cátions bivalente $\left(\mathrm{Fe}^{2+}+\right.$ $\mathrm{Mg}$ ), confirmando o que foi observado acima.

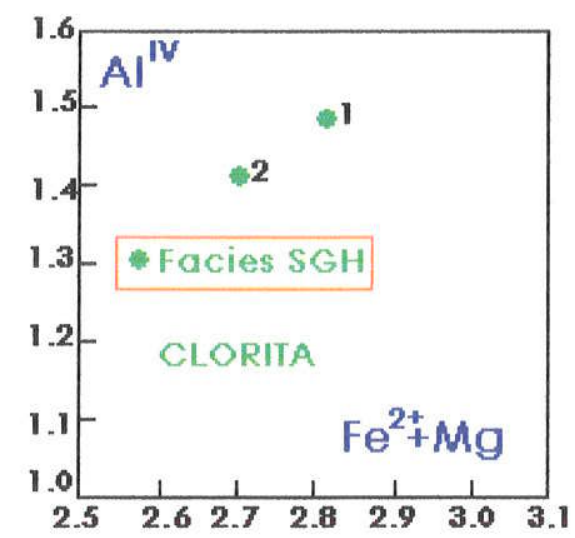

Figura 4.20- Diagrama $\mathrm{Al}^{\mathrm{IV}}$ versus os cátions bivalentes $\left(\mathrm{Fe}^{2+}+\mathrm{Mg}^{2+}\right)$ mostrando a distribuição composicional da clorita pertencente à facies granitóide SGH do maciço granitóide Velho Guilherme.

No diagrama $\mathrm{Al}^{\mathrm{IV}}$ versus $\mathrm{Fe}^{2+} /\left(\mathrm{Fe}^{2+}+\mathrm{Mg}\right)$, Figura 4.21, nota-se que enquanto o $\mathrm{Al}^{\mathrm{IV}}$ apresenta uma pequena variação, a razão $\mathrm{Fe} / \mathrm{Fe}+\mathrm{Mg}$ permanece praticamente constante. Esse comportamento químico destoa daquele apresentado pelas cloritas estudadas por diversos autores tais como Hey(1954), Foster(1962), Cathelineau \& Nieva(1985), Kranidiotis 
\& MacLean(1987), Cathelineau(1987) e Zang \& Fyfe(1995). Por outro lado, assemelha-se muito às características das cloritas estudadas por Borges(1997), bem como com as da cloritas estudadas, neste trabalho, nos outros maciços da suite.

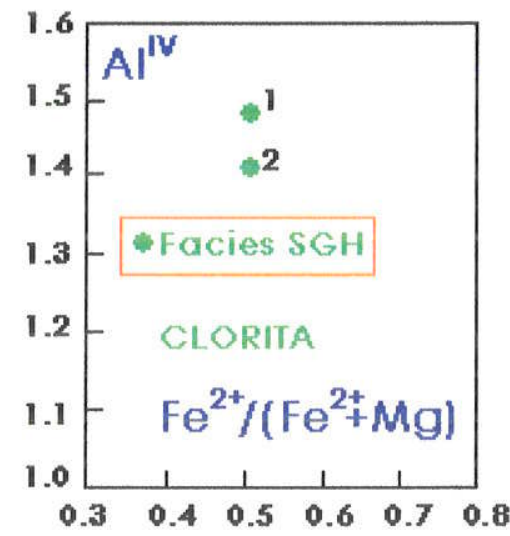

Figura 4.21- Diagrama $\mathrm{Al}^{\mathrm{IV}}$ versus a razão $\mathrm{Fe}^{2+} /\left(\mathrm{Fe}^{2+}+\mathrm{Mg}\right)$ mostrando a distribuição composicional da clorita pertencente às facies granitóide SGH do maciço granitóide Velho Guilherme.

$\mathrm{Na}$ Figura 4.22, do mesmo modo que na Figura 4.21, observa-se que a razão $\mathrm{Fe}^{2+} /\left(\mathrm{Fe}^{2+}+\mathrm{Mg}\right)$ é praticamente contante, enquanto que as quantidades de $\mathrm{Al}^{\mathrm{Vl}}$ mostram uma pequena variação.

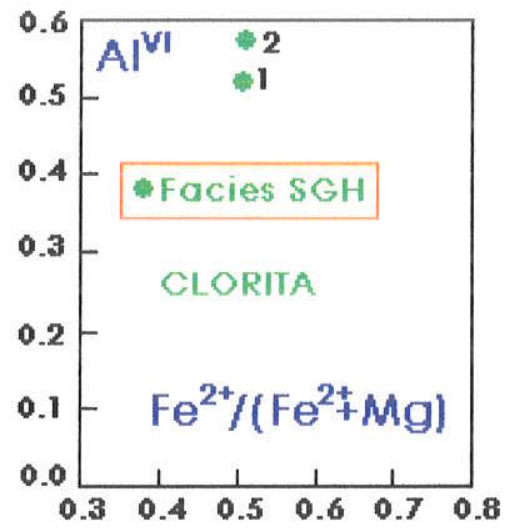

Figura 4.22- Diagrama $\mathrm{Al}^{\mathrm{VI}}$ versus a razão $\mathrm{Fe}^{2+} /\left(\mathrm{Fe}^{2+}+\mathrm{Mg}\right)$ mostrando a distribuição composicional da clorita pertencente às facies granitóide SGH do maciço granitóide Velho Guilherme.

Na Figura 4.23 observa-se uma nítida correlação negativa entre $\mathrm{Si}+\mathrm{Al}{ }^{\mathrm{VI}}$ e os cátions bivalentes $\left(\mathrm{Fe}^{2+}+\mathrm{Mg}^{2+}\right)$, caracterizada pelo aumento de $\mathrm{Si}+\mathrm{Al}^{\mathrm{VI}}$ e decréscimo de $\left(\mathrm{Fe}^{2+}+\right.$ $\mathrm{Mg}^{2+}$ ), no sentido da análise 1 para a análise 2. Isso reforça, mais uma vez, que a diminuição do $\mathrm{Al}^{\mathrm{IV}}$ foi acompanhado por um decréscimo nos cátions bivalentes $\left(\mathrm{Fe}^{2+} \mathrm{e} \mathrm{Mg}^{2+}\right)$ e por um aumento do $\mathrm{Al}^{\mathrm{VI}}$ no sítio octaédrico(conforme visto anteriormente). Assim, as Figuras 4.24 e 4.25 tornam clara a razão da correlação negativa observada acima(Figura 4.23). Na Figura 4.26, nota-se uma correlação positiva entre $\mathrm{Si}$ e $\mathrm{Al}^{\mathrm{VI}}$. Isso demonstra que a substituição de $2 \mathrm{R}^{2+}$ por $1 \mathrm{Al}^{3+}$ gerou uma carga negativa no sítio octaédrico, a qual foi neutralizada pela substituição de $1 \mathrm{Al}^{3+}$ por $1 \mathrm{Si}^{4+}$ na camada tetraédrica. Essa substituição não pode ser explicada através das equações apresentadas por Cathelineau(1988). 

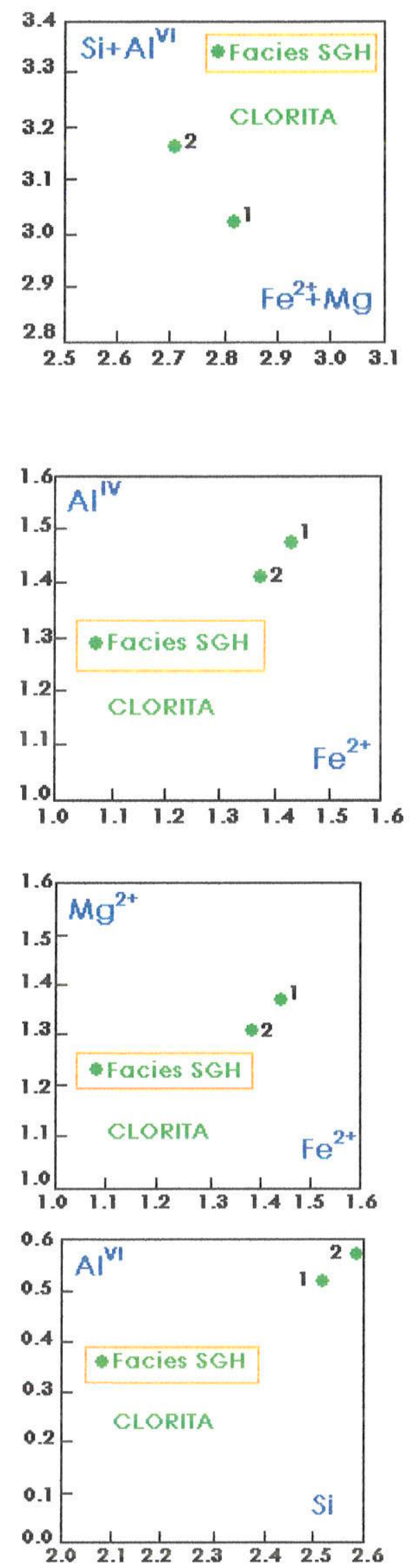

Figura 4.23.- Diagrama $\mathrm{Si}+\mathrm{Al}^{\mathrm{VI}}$ versus os cátions bivalentes $\left(\mathrm{Fe}^{2+}+\mathrm{Mg}^{2+}\right)$ mostrando a distribuição composicional da clorita pertencente à facies granitóide SGH, do maciço granitóide Velho Guilherme.
Figura 4.24 - Diagrama $\mathrm{Al}^{\mathrm{IV}}$ vs. $\mathrm{Fe}_{2+}$ mostrando a distribuição composicional da clorita da facies granitóide SGH, do maciço granitóide Velho Guilherme.
Figura 4.25 - Diagrama $\mathrm{Fe}^{2+}$ vs. $\mathrm{Mg}^{2+}$ mostrando a distribuição composicional da clorita da facies granitóide SGH, do maciço granitóide Velho Guilherme.
Figura 4.26.- Diagrama $\mathrm{Si}$ versus $\mathrm{Al}^{\mathrm{VI}}$ mostrando a distribuição composicional da clorita pertencente à facies granitóide $\mathrm{SGH}$, do maciço granitóide Velho Guilherme. 
Conforme pode ser visto no Anexo 19, as quantidades de ferro férrico, da clorita estudada(não medidas através da microssonda), devem ser muito reduzidas. Na fórmula estrutural calculada através do Minpet 2.02, os valores de $\mathrm{Fe}^{3+}$ são invariavelmente iguais a 0,00 . Entretanto, sabe-se, de antemão, que o referido software (cópia utilizada neste trabalho) arredonda os conteúdos de diversas variáveis envolvidas e, dentre elas, o ferro férrico. Assim, os supostos baixos valores de $\mathrm{Fe}^{3+}$ aliados à muito provável ausência de magnetita na facies BAFG, deste maciço, indicam baixas condições de $\mathfrak{f O}_{2}$ para a cristalização da clorita estudada, à semelhança do que foi observado em relação as cloritas dos granitóides e greisen do maciço Antônio Vicente, e, ao que tudo indica, abaixo do buffer quartzo-fayalita-magnetita(QFM).

\subsubsection{2-Classificação e representação gráfica}

O método aqui empregado(Hey, 1954) para classificação e representação gráfica da clorita estudada é o mesmo aplicado às cloritas dos granitóides e greisen do maciço granitóide Antônio Vicente. Assim, a clorita em questão pertence ao grupo das cloritas não oxidadas, visto que seus conteúdos de $\mathrm{Fe}_{2} \mathrm{O}_{3}$ são inferiores a $4 \%$. Os dados analíticos quando lançados no diagrama de Hey(1954), Figura 4.27, incidem no campo da ripidolita, muito próximos à linha divisória entre este campo composicional e aquele da corundophilita.

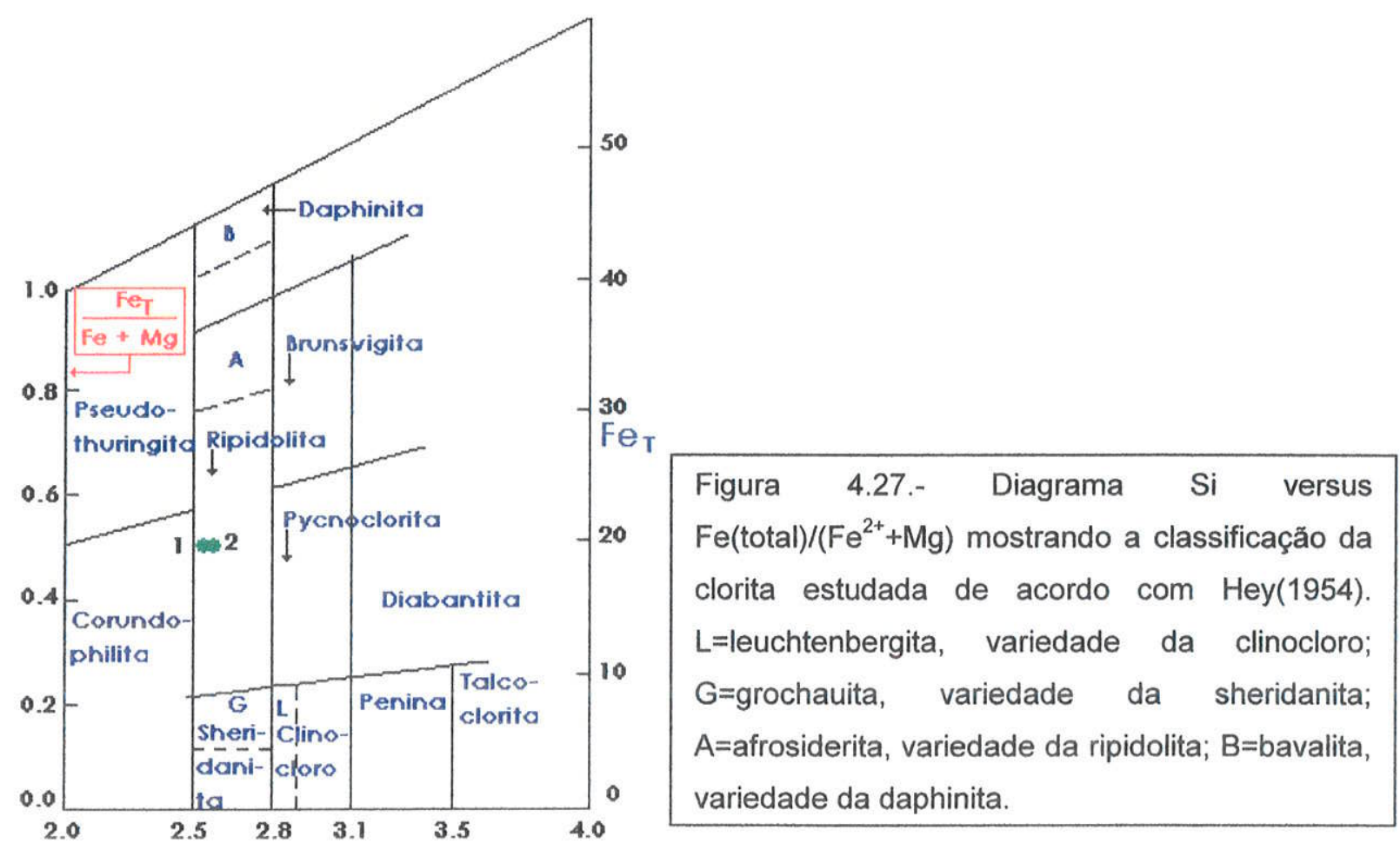




\subsubsection{3- Condições de Cristalização}

Considerando-se, a exemplo das cloritas dos granitóides do maciço Antônio Vicente, que variações nas quantidades de $\mathrm{Al}^{\mathrm{IV}} \mathrm{com}$ a temperatura a razões $\mathrm{Fe} /(\mathrm{Fe}+\mathrm{Mg})$ constantes, podem propiciar um bom geotermômetro(Cathelineau \& Nieva, 1985; Zang \& Fyfe ,1995), reconheceu-se essas características na clorita em questão, conforme é observado na Figura 4.21. De fato, ela mostra uma pequena variação nos valores de $\mathrm{Al}^{\mathrm{IV}}$ e apresenta, por outro lado, razões $\mathrm{Fe} /(\mathrm{Fe}+\mathrm{Mg})$, praticamente constantes.

Devido essa condição, estimou-se, por meio da equação de Cathelineau(1988), o intervalo de temperatura no qual a clorita estudada cristalizou. Ele situa-se entre 393 e $416^{\circ} \mathrm{C}$ e deve ser considerado como sendo aquele intervalo mínimo em que ocorreu a cristalização da clorita $\left(\mathrm{Cl}_{2}\right)$.

\subsubsection{5- Análises químicas em Muscovita}

No que se refere a essa fase mineral, foram realizadas quatro análises pontuais em um único grão de muscovita $2\left(\mathrm{Mv}_{2}\right)$ da amostra NN-VG-77N, da facies SGHm.

Uma discussão sobre as principais características químicas do grupo da muscovita foi apresentada no capítulo 3.

\subsubsection{1- Composição química}

Os resultados analíticos obtidos para essa mica, bem como suas respectivas fórmulas estruturais encontram-se no Anexo 20.

Com base nele e na Figura 4.28 verifica-se que a mesma apresenta conteúdos extremamente baixos de $\mathrm{Ti}, \mathrm{Na}$, e $\mathrm{Li}$ e possui teores, relativamente, elevados de $\mathrm{Si}, \mathrm{Al}_{\mathrm{T}}$, $\mathrm{Fe}$ (total), Mg e K. Os valores de XFe variam entre 0,64 e 078.
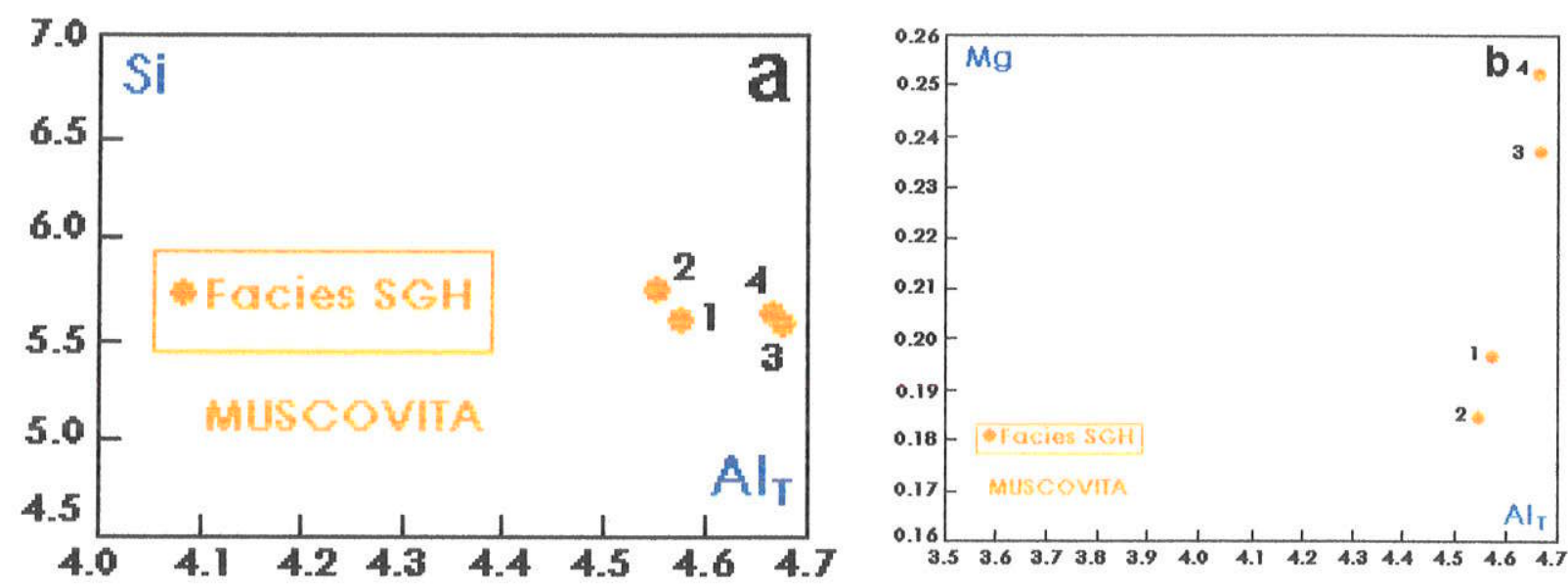

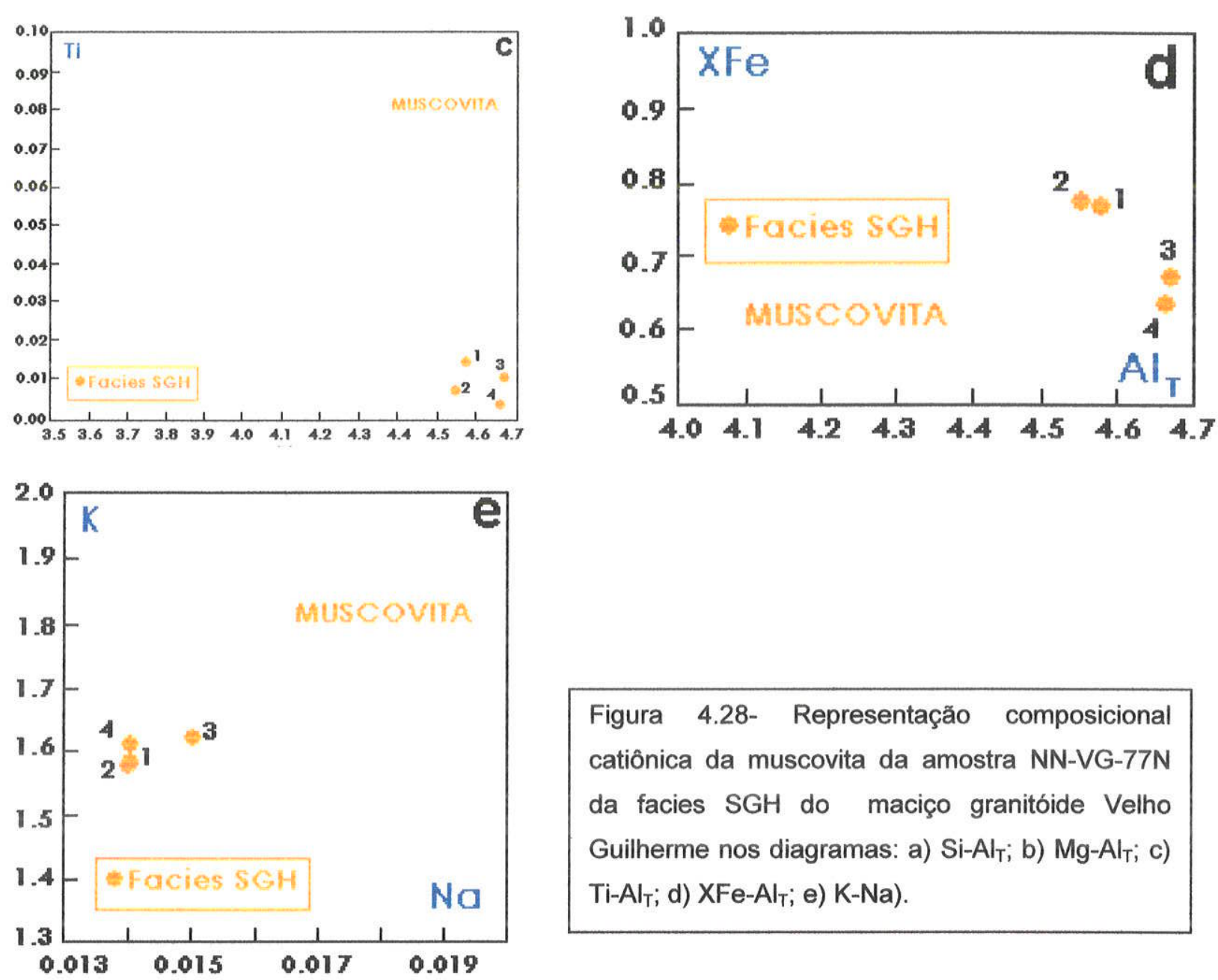

Figura 4.28- Representação composicional catiônica da muscovita da amostra NN-VG-77N da facies SGH do maciço granitóide Velho Guilherme nos diagramas: a) $\mathrm{Si}-\mathrm{Al}_{T} ;$ b) $\mathrm{Mg}-\mathrm{Al}_{\mathrm{T}}$; c) $\mathrm{Ti}_{-} \mathrm{Al}_{\mathrm{T}}$; d) XFe-Al $;$ e) $\mathrm{K}-\mathrm{Na}$ ).

\subsubsection{2- Substituições}

As Figuras 4.29(Cathelineau, 1982, modificada de Dias, 1987. In: Simões, 1992) e 4.30(modificada de Dias, 1987. In: Simões, 1992), apresentam a substituição fengítica e permitem avaliar as proporções de $\mathrm{Fe}^{3+}$ e $\mathrm{Fe}^{2+}$ presentes nas muscovitas. De acordo com Simões(1992), o diagrama retangular [(Al $\left.\left.\mathrm{I}^{\mathrm{V}}-2\right)+2 \mathrm{Ti}\right]$ vs. $\mathrm{Al}^{\mathrm{IV}}$ evidencia a correlação entre $\mathrm{Al}^{\mathrm{IV}}$ e $\mathrm{Al}^{\mathrm{VI}}$, esperada em uma substituição fengítica e indica a proporção de $\mathrm{Fe}^{3+}$ presente em função da substituição $\mathrm{Al}^{3+} \rightarrow \mathrm{Fe}^{3+}\left(\mathrm{Fe}^{3+} \rightarrow \mathrm{Al}^{3+}\right)$ inerente à própria substituição fengítica(fengita que se afasta da correlação). Ainda segundo esse autor, o diagrama (Si$6+\mathrm{Ti})$ vs. Mg tem o propósito de avaliar a proporção de $\mathrm{Fe}^{2+}$ associado ao $\mathrm{Mg}$ que entra na posição octaédrica para compensar o excesso de carga provocado pela substituição fengítica(se todo o excesso de carga é compensado pelo $\mathrm{Mg}$, então $\mathrm{Fe}^{2+}=0$ e todo o ferro estará no estado trivalente).

Em relação à muscovita estudada, as Figuras 4.29 e 4.30 mostram um baixo grau de substituição fengítica. Observa-se ainda, um grau relativamente alto da substituição $\mathrm{Al}^{\mathrm{VI}}$ por $\mathrm{Fe}^{3+}\left(\mathrm{Fe}^{3+} \rightarrow \mathrm{Al}^{\mathrm{Vl}}\right)$ para a muscovita em questão. Dessa forma, o excesso de carga 
provocado pela substituição fengítica é compensado pela entrada dos íons divalentes $\mathrm{Mg}$ e $\mathrm{Fe}^{2+}$. Na muscovita estudadas, observa-se que apenas o $\mathrm{Mg}$ contribuiu, embora muito pouco, para essa substituição, visto que, de acordo com as Figuras 4.29 e 4.30, o ferro estrutural está essencialmente no estado trivalente.

Os graus de substituições fengítica e paragoníticas podem ser avaliados a partir do diagrama $\%$ da molécula celadonítica(\%mol Cel.) vs. $\%$ da molécula paragonítica(\%mol Parag.), Figura 4.31. Nele, nota-se que a substituição paragonítica é muito reduzida, enquanto que a substituição fengítica, dada pela \% molécula celadonítica, é ausente, uma vez que os valores dessa variável são todos negativos na muscovita estudada.

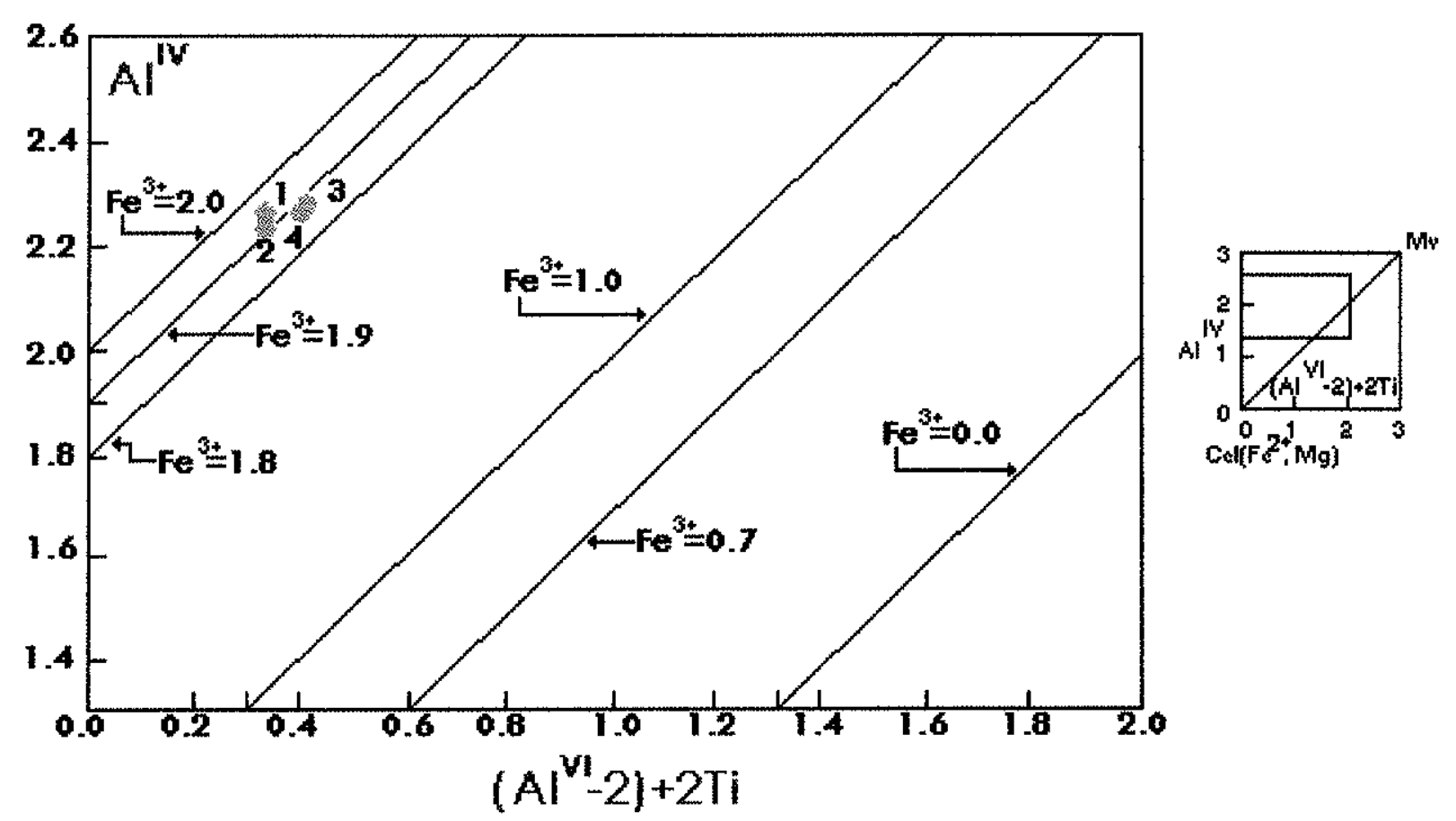

Figura 4.29- Representação composicional da muscovita da amostra NN-VG-77N da facies SGH do maciço granitóide Velho Guitherme no diagrama $A l^{\prime V}$ versus $\left[\left(A l^{V}-2\right)+2 T i\right]$ de Cathelineau(1982), modificado de Dias(1987). In: Simőes(1992). 


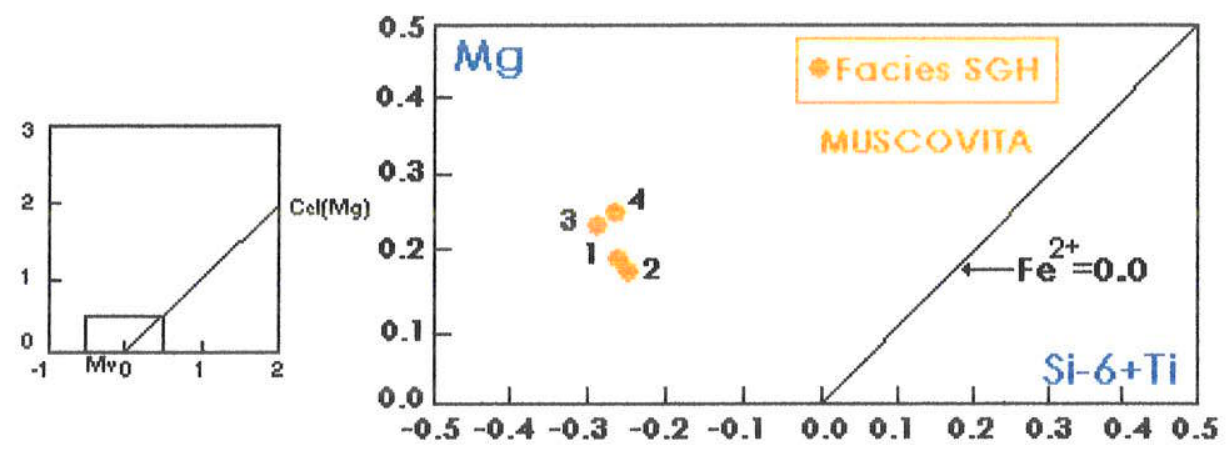

Figura 4.30- Representação composicional da muscovita da amostra NN-VG-77N da facies SGH do maciço granitóide Velho Guilherme no diagrama Mg-(Si-6+Ti), modificado de Dias(1987). In: Simões(1992).

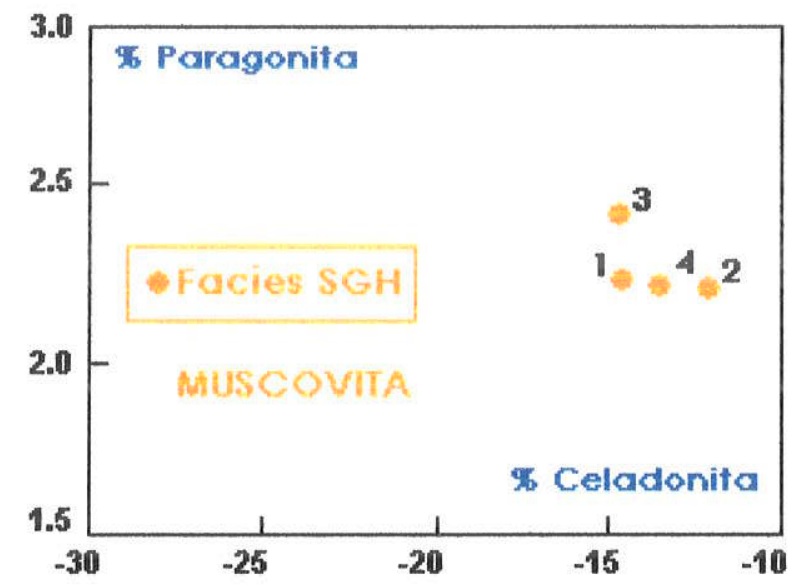

Figura 4.31- Representação gráfica das percentagens das moléculas paragoníticas e celadoníticas presentes na muscovita da amostra NN-VG-77N da facies SGH do maciço granitóide Velho Guilherme, de acordo com Simões(1992). \% mol. paragonita $=100 \times \mathrm{Na} /(\mathrm{Na}+\mathrm{K}) ; \%$ mol. celadonita= $100 \times(\mathrm{Si}-6) / 2$.

\subsubsection{3- Classificação e Representação Gráfica}

Tischendorf et al.(1997) introduziram na literatura geológica um novo diagrama bidimensional para classificação e representação gráfica de micas. O diagrama foi baseado na abundância absoluta dos cátions na camada tetraedral e propicia um meio simples para classificar as micas em termos de suas composições e da ocupância do sítio octaedral, bem como permite que seja observado, ao mesmo tempo, o relacionamento integral entre variedades de micas com ou sem lítio e entre micas trioctaédricas e dioctaédricas. 
Assim, as composições da muscovita estudada quando lançadas no diagrama $\left[\left(\mathrm{Fe}_{\mathrm{T}}+\mathrm{Mn}+\mathrm{Ti}\right)-(\mathrm{Mg}-\mathrm{Li})\right.$, Figura 4.32 deste trabalho, incidem inteiramente no campo composicional correspondente a fengita, no quadrante das Mg-Al-micas.

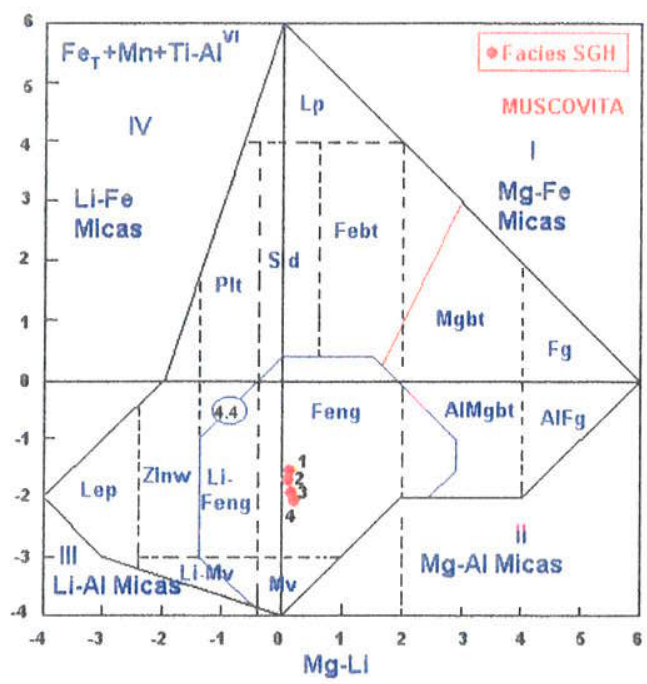

Figura 4.32. Diagrama (Mg-Li) vs. $\left(\mathrm{Fe}_{\mathrm{T}}+\mathrm{Mn}+\mathrm{Ti}-\mathrm{Al}^{\mathrm{VI}}\right)$ de Tischendorf et al.(1997) mostrando a distribuição composicional da muscovita da amostra NN-VG-77N, da facies SGH do maciço granitóide Velho Guilherme.

\subsubsection{4- Origem}

Diversos autores tem discutido a origem primária(magmática) ou secundária(tardi a pós-magmática) de muscovita em rochas granitóides(Syritso et al., 1970; Miller et al., 1981; Speer, 1984; Monier et al., 1984; Fonteilles, 1987; Monier et al., 1987; Simões, 1992, entre outros).

Os estudos petrográficos realizados em seções delgadas da amostra NN-VG-77N da facies SGH mostraram que, texturalmente, trata-se de micas brancas secundárias $\left(\mathrm{Mv}_{2}\right)$ formadas, às expensas da clorita $\left(\mathrm{Cl}_{2}\right)$ e dos feldspatos, no estágio de alterações tardi a pósmagmáticas.

Os dados químicos quando lançados no diagrama triangular $\mathrm{Mg}-\mathrm{Ti}-\mathrm{Na}$ de Miller et al.(1981), Figura 4.33 deste trabalho, mostram que a composição da muscovita aqui estudada incide, preferencialmente, no campo da muscovita secundária. Comparativamente à muscovita estudada por Miller et al.(1981), Monier et al.(1984) e Simões(1992), essa muscovita, em termos do seu quimismo, apresenta grandes afinidades com a muscovita secundária, visto que possui conteúdos muito reduzidos de $\mathrm{Ti}$ e $\mathrm{Na}$, bem como seus teores de $\mathrm{Al}, \mathrm{Mg}$ e Si são compatíveis com as mesmas. 


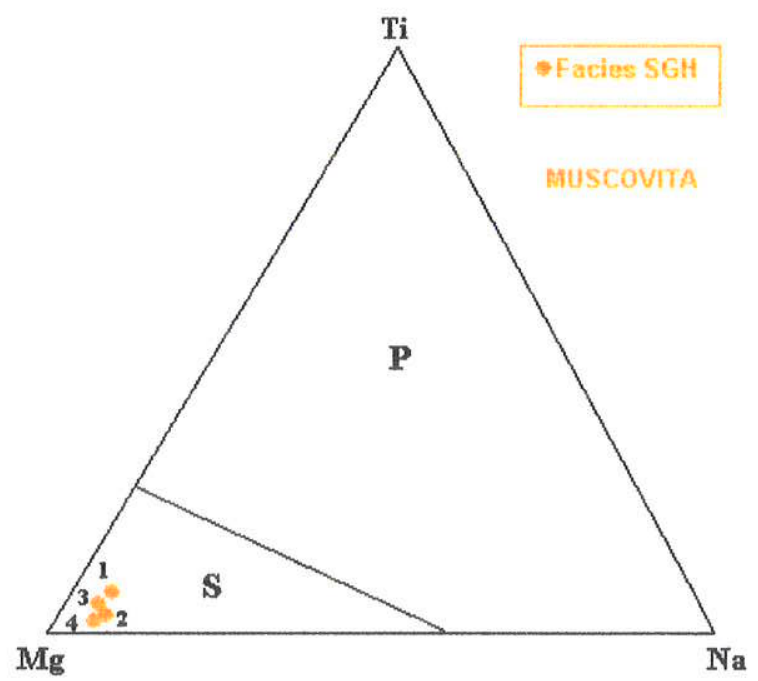

Figura 4.33- Distribuição composicional da muscovita da amostra NN-VG-77N, da facies SGH do maciço granitóide Velho Guilherme no diagrama triangular Mg-Ti-Na de Miller et al.(1981). P=campo composicional da muscovita primária; $\mathrm{S}=$ campo composicional da muscovita secundária.

\subsection{2-Análises através de Microscopia Eletrônica}

No âmbito deste maciço foram realizadas 27 análises semi-quantitativas(EDS), com o intúito de caracterizar fases minerais acessórias difíceis de serem caracterizadas com precisão através de microscopia ótica ou mesmo através de microssonda eletrônica face às suas reduzidas dimensões. Do mesmo modo que para o maciço granitóide Antônio Vicente, são análises complementares.

As análises envolveram as amostras NN-VG-77N e NN-VG-35A, ambas pertencentes à facies SGH. Na amostra NN-VG-77N foram caracterizadas as fases cálciosilicato de Zr[armstrongita(?)/cálcio-catapleita(?)], epidoto, óxido de $\mathrm{Nb}, \mathrm{Y}, \mathrm{Ca}$ e ETR[ceriopirocloro(?)/fergusonita-beta- $(\mathrm{Y})(?) /$ fergusonita- $(\mathrm{Y})(?)$ e allanita. Na amostra NNVG-35A, foram identificadas as fases esfalerita, zircão, fluocerita-(Ce), fluorita com ETR, fluorita e uma fase à base de $\mathrm{Ce}$, $\mathrm{La}$ e $\mathrm{Nd}$.

É importante ressaltar que devido não se dispor de informações sobre estrutura cristalina das fases acima apresentadas, as designações a elas atribuídas foram baseadas na comparação entre o quimismo das mesmas a a química de fases minerais constantes na literatura, especialmente, em Ewing \& Chakoumakos(1982) e Jones et al.(1996).

\section{a) Cálcio-silicato de $\mathrm{Zr}$}

Foi realizada uma única análise nessa fase mineral. Sobre ela não se dispõem de imagens através de MEV, bem como, pelas suas diminutas dimensões, não foi possível 
descrevê-la através de microscopia ótica. Assim, serão abordados aqui apenas suas características químicas(análise 12; Anexo 21). Essa fase foi, também, detectada na amostra IG-SN-11 da facies BASAFG. Comparativamente à mesma, ele apresenta em termos dos elementos maiores, conteúdos mais elevados de $\mathrm{Al}, \mathrm{O}$ e $\mathrm{Ca}$ e mais reduzidos de Si. Em relação aos elementos menores e traços mostra-se, relativamente, mais enriquecida em $\mathrm{Yb}, \mathrm{Ce}$, La e $\mathrm{Y}$ e mais empobrecida em $\mathrm{Nd}$ e $\mathrm{Zr}$.

No que se refere à sua designação e origem, são válidas as discussões apresentadas para o cálcio-silicato de Zr ocorrente na amostra IG-SN-11 da facies BASAFG do maciço granitóide Antônio Vicente, visto no capitulo anterior, sendo desnecessário repetílas aqui.

\section{b) Epidoto}

Sobre esta fase, foram realizadas duas análises. Assim como o cálcio-silicato de $\mathrm{Zr}$, não foram feitas imagens dessa fase. Entretanto, sabe-se que se trata de epidoto 2, formado às expensas da biotita(ver descrição no ítem Aspectos Petrográficos deste capitulo).

A análise do Anexo 21, revela que as duas análises( 1 e 2) não mostram variações importantes, bem como os grãos estudados não hospedam elementos raros. Comparativamente, a análise 4(Deer et al., 1966; pg. 80), apresenta teores eqüivalentes de $\mathrm{Si}$, mostra-se levemente mais enriquecida em $\mathrm{Ca}$ e contém teores relativamente mais elevados de $\mathrm{Fe} \mathrm{e} \mathrm{Al.}$

\section{c) Óxido de Nb, Y, Ca e ETR}

Foram realizadas cinco análises em dois grãos dessa fase mineral. A Figura 4.34a mostra que se trata de grãos anédricos, com bordas irregulares $\theta$, por vezes corroídas. Internamente, apresentam zonas irregulares de tonalidades branco, cinza e negro. Em relação à sua orígem, ocorre como minúsculas grãos intimamente associados à cloritização da biotita e, ao que tudo indica, representa uma fase secundária.

A análise do Anexo 21 revela um óxido com teores variáveis, porém elevados de $\mathrm{Nb}(27,60 \%$ a $33,76 \%)$, independentemente, da zona analisada, conteúdos moderados de $Y$, os quais se tornam mais elevados nas zonas de tonalidades branca e negra(análises 3,4 e 7 ) , e, em algumas amostras, de Fe(análises 5 e 6) e Ca(análises 5, 6 e 7). Além disso, exibe teores, relativamente mais modestos, de Si, Dy, Ce e $\mathrm{Nd}$.

Comparativamente ao quimismo de fases minerais semelhantes apresentadas na literatura especializada, pode corresponder tanto a ceriopirocloro-( $\mathrm{Ce})$, quanto a fergusonitabeta- $(Y)$ ou a fergusonita- $(Y)$, de acordo com as fases minerais apresentadas por Jones et al(1996; pg. 350). Esses minerais podem ser metamiticos(Ewing \& Chakoumakos, 1982). 


\section{d) Allanita}

Foram realizadas quatro análises dessa fase. Na Figura 4.34b observa-se que o grão analisado apresenta-se sob a forma anédrica a subédrica e mostra-se fracamente zonado. Observações realizadas através de microscopia ótica indicam uma orígem secundária para a allanita(ver ítem Aspectos Petrográficos, deste capitulo).

No Anexo 21 verifica-se que, dentre as quatro análises, três são muito semelhantes(análises 8,9 e 10), enquanto que a análise de número 11 mostra conteúdos mais elevados de $\mathrm{Si}, \mathrm{Al}, \mathrm{Fe}, \mathrm{Mn}, \mathrm{Ca}, \mathrm{Nd}$, Ce e La e teores mais reduzidos de Ta e $\mathrm{Y}$.

\section{e) Esfalerita}

Foram realizadas duas análises em dois grão distintos de esfalerita. Não se dispoem de imagem dos grãos estudados, embora seja sabido que se trata de uma fase claramente secundária, intimamente associada à cloritização da biotita, durante o estágio de alterações tardi a pós-magmáticas.

O Anexo 22 mostra que a análises de número 13 possui conteúdos relativamente mais elevados de $\mathrm{Fe}, \mathrm{S}$ e $\mathrm{Pb}$ e mais baixo de $\mathrm{Zn}$ em relação à análise de número 14 .

\section{f) Zircão}

Quatro análises foram realizadas em dois cristais distintos de zircão. Embora não tenham sido realizadas imagens dos cristais estudados, sabe-se que o zircão é uma fase acessória primária.

A análise do Anexo 22 mostra que os cristais estudados apresentam tanto pequenas variações composicionais internas, quanto em um grão em relação ao outro. A variação observada internamente em cada grão, evidencia, ao que tudo indica, zoneamentos nos cristais. No cristal 1(análises 20 e 21), observa-se que a porcão correspondente à análise 20 apresenta conteúdos relativamente mais elevados de $\mathrm{Si}, \mathrm{Zr}, \mathrm{Y}, \mathrm{Sn}, \mathrm{Pb}$ e $\mathrm{Th}$ e mais reduzidos de $\mathrm{O}, \mathrm{Nb}, \mathrm{Yb}, \mathrm{Dy}, \mathrm{Ce}, \mathrm{La}, \mathrm{Ca}$ e U, em relação à porção do cristal correspondente à análise 21. No grão 2(análises 22 e 23), nota-se que a zona do cristal representada pela análise 22 apresenta quantidades relativamente mais elevadas de $\mathrm{O}, \mathrm{Y}, \mathrm{Sn}, \mathrm{Yb}, \mathrm{Ce}, \mathrm{La}, \mathrm{Nb}$, $\mathrm{Pb}$, Th e $\mathrm{U}$ e mais baixas de $\mathrm{Si}, \mathrm{Zr}, \mathrm{Nb}, \mathrm{Dy}$ e $\mathrm{Ca}$, comparativamente a zona do cristal representada pela análise 23 . Considerando as composiçóes médias de cada grăo, observase que o grão 1 , em relação ao grão 2 , apresenta teores relativamente mais elevados de $\mathrm{Si}$, $\mathrm{Zr}, \mathrm{Sn}, \mathrm{Nb}, \mathrm{Yb}, \mathrm{Dy}, \mathrm{Pb}$ e $\mathrm{U}$ e mais baixos de $\mathrm{Al}, \mathrm{O}, \mathrm{Y}, \mathrm{Ce}, \mathrm{La}, \mathrm{Nd}, \mathrm{Ca}$ e Th. Deve-se ressaltar, entretanto, que em ambos os grão as concentrações médias de $\mathrm{Al}, \mathrm{Sn}, \mathrm{Nb}, \mathrm{Yb}$, $\mathrm{Dy}, \mathrm{Ce}, \mathrm{La}, \mathrm{Nd}, \mathrm{Ca}, \mathrm{Pb}$ e Th são inferiores a $1 \%$, enquanto que as de $\mathrm{U}$ situam-se entre 1,24 (grão 2) e 1,65(grão 1) e as de $Y$ oscilam entre 2,30(grão 1) e 2,94(grão 2). 

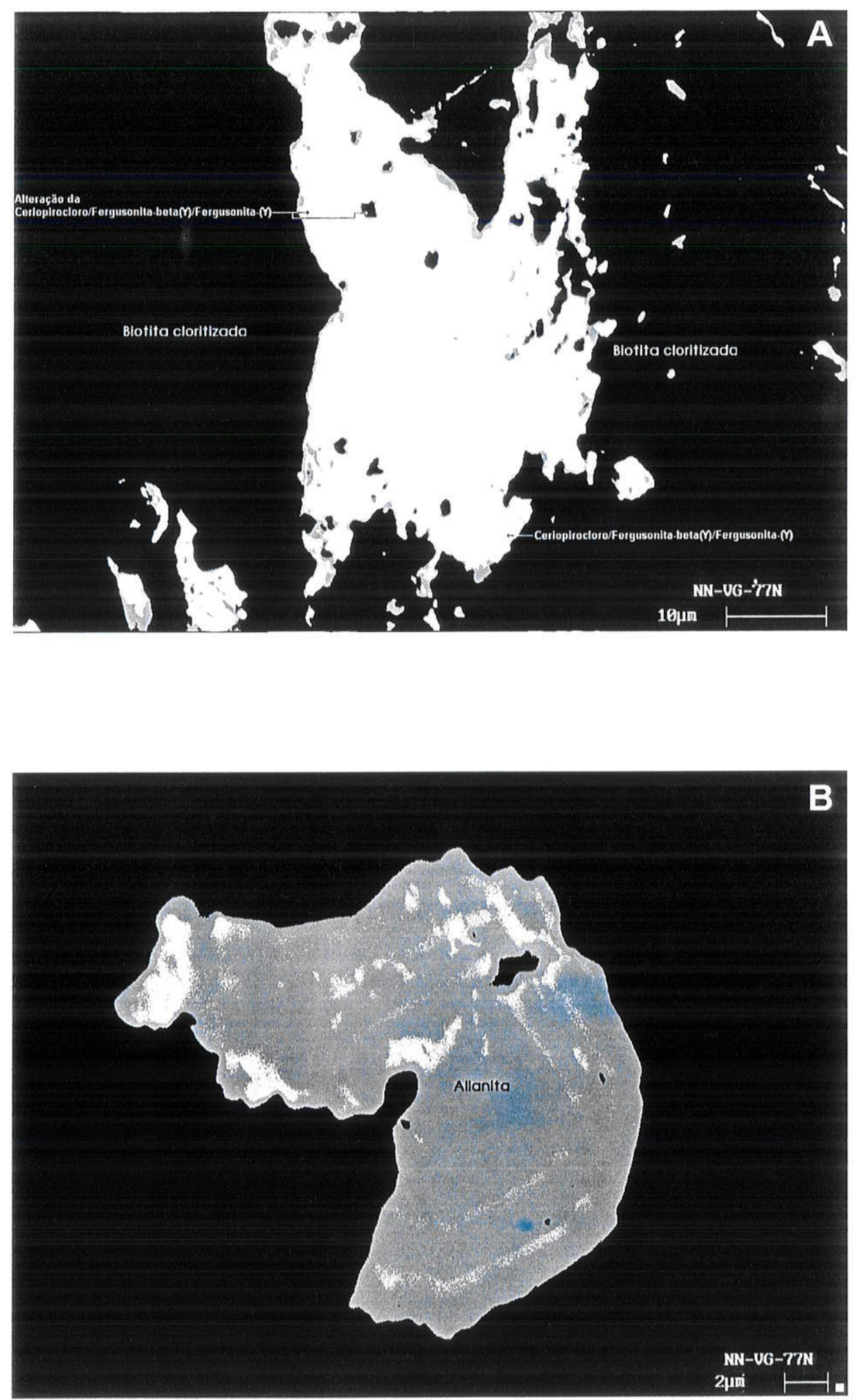

Figura 4.34. (a) aspecto microtextural do óxido de Nb-Y-Ce-ETR[ceriopirocloro-(Ce)/fergusonitabeta(Y)/Fergusonita(Y); (b) aspecto microtextural da allanita. Amostra NN-VG-77N, da facies SGH. Maciço granitóide Velho Guilherme. 


\section{g) Fluorcerita-( $\mathrm{Ce}$ )}

Duas análises dessa fase foram realizadas(análises 15 e 16 do Anexo 22). A Figura 4.35 mostra um grão anédrico a subédrico, que exibe, internamente diversas zonas irregulares, evidenciadas pelas tonalidades branca, cinza e negra. As porções de tonalidade branca correspondem a fluocerita-(Ce). No que se refere à origem, representa, ao que tudo indica, uma fase secundária, uma vez que ocorre intimamente associada à cloritização da biotita, juntamente com fluorita $\left(\mathrm{Fl}_{2}\right)$ e outras fases secundárias, conforme visto no ítem Aspectos Petrográficos.

Quimicamente, corresponde a uma fase enriquecida em $\mathrm{Ce}(35,60 \%$ a $36,24 \%)$, $\mathrm{La}(20,30 \%$ a $22,26 \%)$ e $\mathrm{F}(35,68$ a $36,00 \%)$, com quantidades mais modestas de $\mathrm{Nd}(5,29 \%$ a $7,57 \%$ ) e ínfimos teores de Y, Ca, Sm e Ta.

Essa designação foi atribuída a partir da comparação composicional entre o quimismo da fase aqui estudada e da fluorcerita-(Ce) apresentada por Jones et al.(1996; pg. 351).

\section{h) Fluorita}

Foram realizadas duas análises referentes a essa fase(análises 17 e 18; Anexo 22). $\mathrm{Na}$ Figura 4.35, as porçōes de tonalidade negra representam essas duas análises. A fluorita é uma fase claramente secundária(ver ítem Aspectos Petrográficos, deste capítulo). As duas análises correspondem à fluorita 2 .

No Anexo 22 observa-se que a análise 17, comparativamente à análise 18 , apresenta conteúdos muito mais elevados de $\mathrm{Ce}$, La e $\mathrm{Nd}$ e mais reduzidos de $\mathrm{Ca}$ e $\mathrm{F}$. Y e Sm estão presentes na análise 21 , em baixissimos teores, enquanto que na análise 22 estão presentes infimas quantidades de Dy, Sm e Ta.

A análise 18 corresponde a uma composição de fluorita pura, enquanto que a análise 17 , ao que tudo indica, representa uma composição transicional entre a fluorita pura e aquela da fluorcerita apresentada anteriormente.

\section{i) Fase mineral à base de $\mathrm{Ce}, \mathrm{La}, \mathrm{Nd}(\mathrm{Ca})$}

Este mineral corresponde, também, a um produto da cloritizaçăo da biotita e ocorre associado à fluorita $\left(\mathrm{FI}_{2}\right)$ e às demais fases secundárias, relacionadas a essa alteração, sendo, portanto, de natureza secundária. Na Figura 4.35, corresponde às zonas de tonalidades cinza.

Quimicamente, representa uma fase enriquecida em $\mathrm{Ce}, \mathrm{La}$ e $\mathrm{Nd}$, que possui conteúdos mais modestos de Ca e teores reduzidíssimos de $Y$ e $\mathrm{Sm}$ (Anexo 22; análise 19). Se não fosse pela ausência de $F$, poderia ser enquadrada no grupo de uma das duas fases 
minerais ricas nesse elemento(itens $g$ e $h$ ) apresentadas anteriormente. Fases minerais com composições semelhante a essas não foram encontradas na literatura.

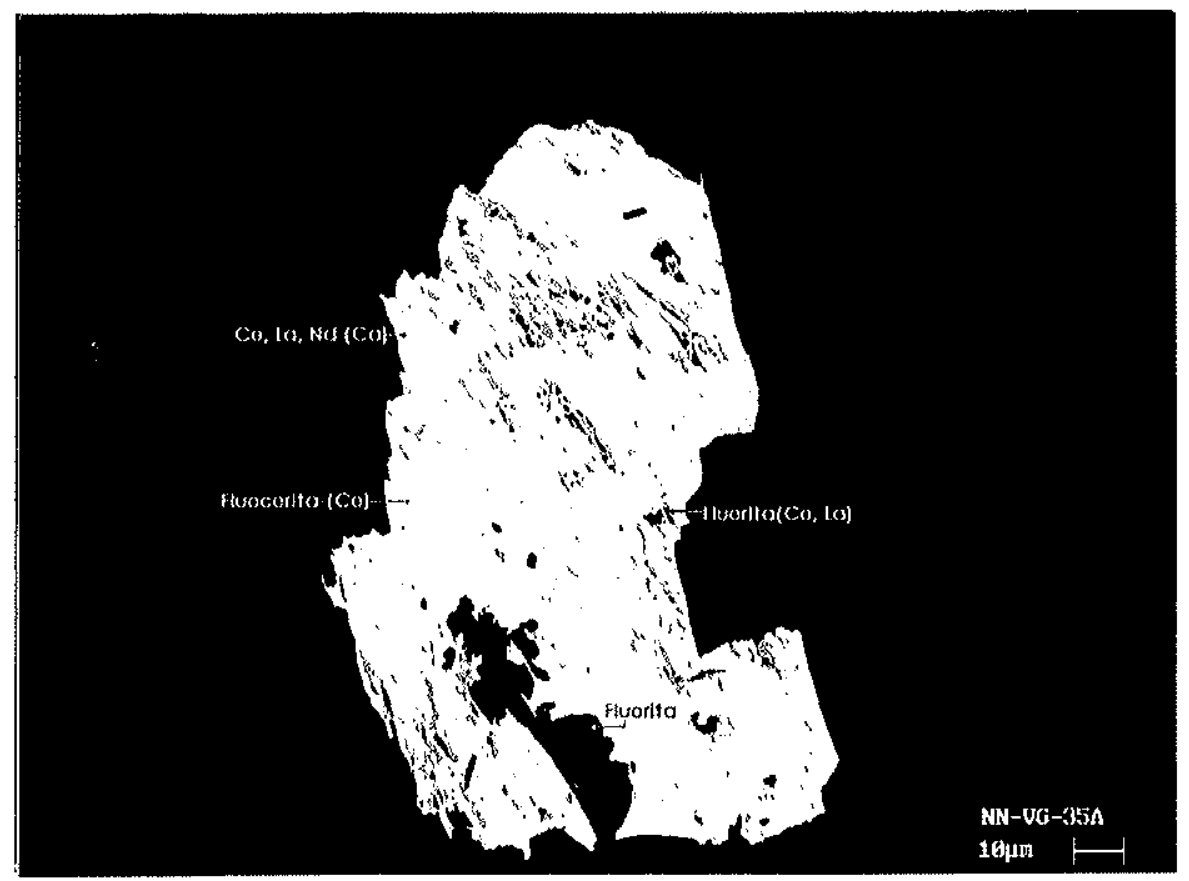

Figura 4.35- Aspecto microtextal de um cristal irregularmente zonado mostrando porç̃̃es correspondentes à fluorcerita, fluorcerita alterada, Fluorita com ETR e fluorita pura.

\section{j) Thorita}

Foram realizadas duas análises sobre essa fase mineral e não foram obtidas imagens através de MEV. Observações através de microscopia ótica mostraram, entretanto, que a mesma ocorre como minúsculos grãos, subédricos a euédricos, os quais apresentam uma estreita relação com a cloritização da biotita. Apesar disso, suas relações microtexturais, não permitem concluir claramente sobre a sua origem primária ou secundária, visto que pode representar uma inclusăo na biotita primária que resistiu aos processos de alteração da mesma.

No Anexo 22, nota-se uma pequena variação composicional entre as duas análises(24 e 25). A análise 24 corresponde corresponde a uma área da thorita, relativamente mais enriquecida em Th e $Y$, em relação a análise 25 . Em ambas as análises, observa-se a presença de pequenas quantidades de $\mathrm{Al}, \mathrm{Mg}, \mathrm{Ca}, \mathrm{Dy}, \mathrm{Ta}, \mathrm{Yb}, \mathrm{Sm}$ e $\mathrm{Nd}$.

Comparativamente a thorita das amostras NE-B-75(facies BSGIA) e NN-AV-TOP4(clorita-siderofilita-muscovita-quartzo greisen fino), do maciço granitóide Antônio Vicente, observa-se que a thorita, aqui estudada, exibe, em relação à mesma, teores mais baixos de $\mathrm{Si}, \mathrm{Al}, \mathrm{O}$ e $\mathrm{Dy}$, mais elevados de The teores equaivalentes de $\mathrm{Y}$ e $\mathrm{Yb}$. 


\section{k) Óxidos de $\mathrm{Y}$ e Zr}

Duas análises foram realizadas sobre essa fase mineral. A Figura 4.36, mostra que o grão analisado representa um cristal anédrico e zonado. Observa-se que porções branca correspondem à análise 26 , enquanto que as areas cinza estão representadas pela análise 27(Anexo 22). Face às suas diminutas dimensões não foi possivel estabelecer a natureza de sua origem.

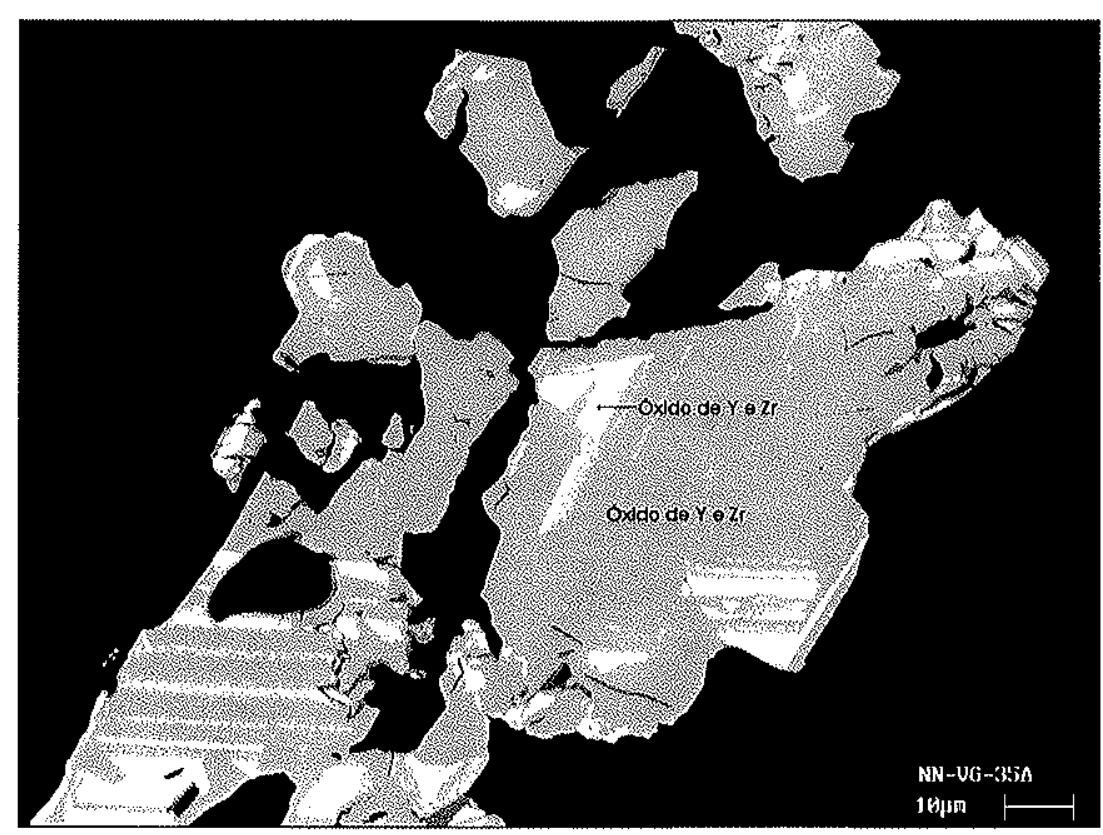

Figura 4.36. Aspecto microtextural de uma fase mineral óxido à base de $\mathrm{Y}$ e $\mathrm{Zr}$, presente na amostra NN-VG-35A, da facies SGH do maciço granitóide Velho Guilherme.

Quimicamente, representa uma fase mineral óxido portador de quantidades apreciáveis de $Y(33,22 \%$ a $44,03 \%)$ e moderadas de $\mathrm{Zr}(13,14 \%$ a $13,60 \%)$, bem como conteúdos mais modestos de Dy e $\mathrm{Yb}$ e ínfimos teores de $\mathrm{Al}, \mathrm{Ca}, \mathrm{Sn}, \mathrm{Nd}, \mathrm{La}, \mathrm{Pb}, \mathrm{Th}$ e U(Anexo 22).

\section{6- Geoquímica}

Os dados químicos apresentados na Tabela 4.3(Anexo 23) referem-se às principais facies petrográficas caracterizadas no interior do maciço e a um corpo de veio hidrotermal, à base de quartzo e epidoto, a ele associado.

\subsection{1- Características Gerais}

No âmbito deste maciço observa-se que a facies granitóide são extremamente diferenciadas, mostram-se afetadas, em diferentes graus, por alterações tardi a pós- 
magmáticas e possuem teores de $\mathrm{SiO}_{2}$, invariavelmente superiores a $75 \%$. No que se refere aos principais óxidos maiores, os granitóides possuem, de um modo geral, conteúdos de $\mathrm{TiO}_{2}, \mathrm{Al}_{2} \mathrm{O}_{3}, \mathrm{MgO}, \mathrm{CaO}$ e $\mathrm{P}_{2} \mathrm{O}_{5}$ sempre muito baixos e inferiores àqueles da média dos granitos(Le Maitre, 1976), as quantidades de $\mathrm{K}_{2} \mathrm{O}$ são ligeiramente mais elevadas e as de $\mathrm{Na}_{2} \mathrm{O}$ são equivalentes. Em relação aos elementos menores e traços, contem altos teores de $\mathrm{Rb}, \mathrm{Zr}, \mathrm{F}$ e Cl, conteúdos moderados de $\mathrm{Nb}, \mathrm{Y}, \mathrm{Ga}, \mathrm{W}$ e Th e baixas concentrações de $\mathrm{Ta}, \mathrm{Hf}, \mathrm{U}, \mathrm{Sn}, \mathrm{Mo}$ e $\mathrm{Zn}$. O Sr e o Ba apresentam teores moderados a relativamente altos na maioria das amostras das facies SGH e MSG e muito baixos na facies BSGEm. Os elementos terras raras ocorrem em conteúdos sempre baixos, embora aqueles de ETRL sejam , em geral, mais elevados do que aqueles de ETRP. O veio hidrotermal, por sua vez é rico em sílica e exibe teores elevados de $\mathrm{Fe}_{2} \mathrm{O}_{3}$ e de $\mathrm{CaO}$. Esses dois últimos em decorrência dos conteúdos algo expressivos de epidoto na amostra analisada(ver aspectos petrográficos deste capítulo). As razões $\mathrm{Rb} / \mathrm{Sr}, \mathrm{Rb} / \mathrm{Ba}$, e Th/U são altas, especialmente na facies granitóides BSGEm, enquanto as razões $\mathrm{K} / \mathrm{Rb}$ são muito baixas se comparadas com aquelas dos granitos considerados normais(Shaw, 1968).

\subsection{2- Saturação em Alumina(ISA)}

Embora as rochas do maciço possuam conteúdos de $\mathrm{Al}_{2} \mathrm{O}_{3}$ inferiores aqueles da média dos granitos(Le Maitre, 1976), em termos da aluminosidade, as rochas do maciço são essencilamente peraluminosas, com as razões dos conteúdos moleculares NKIA variando entre 0,64 e 0,69 e as razões A/CNK sendo superiores a 1 e inferiores a 1,5(exceto em uma amostra da facies BASEm, cuja razão é superior a 1,5; Figura 4.37).

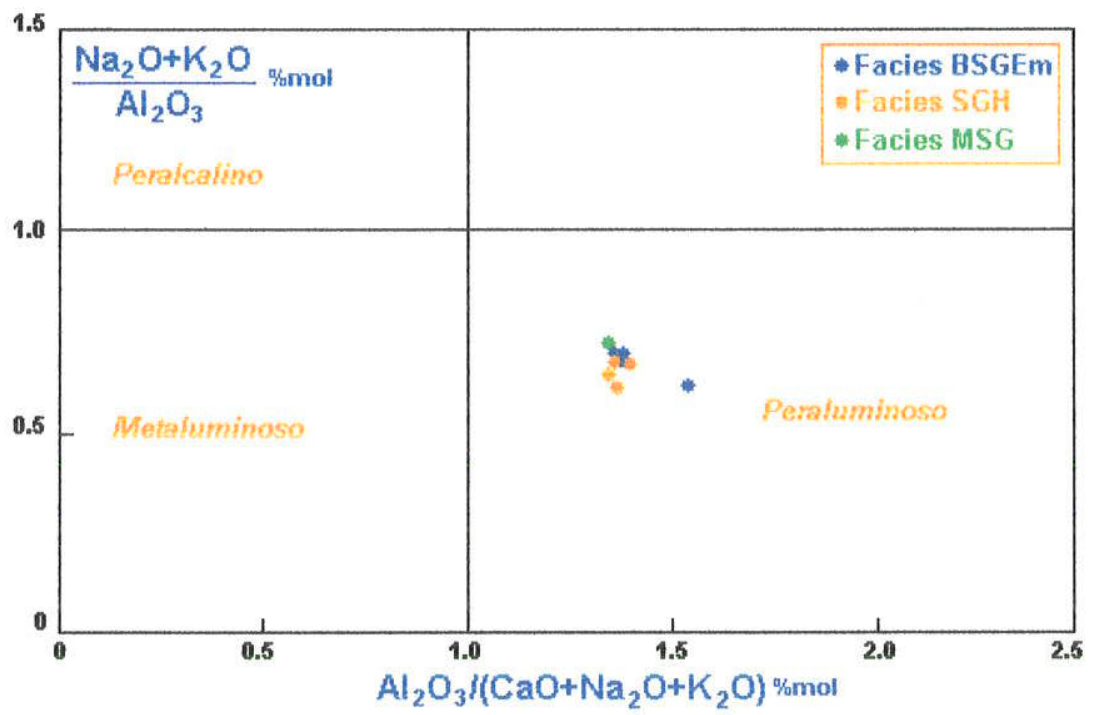

Figura 4.37. Diagrama binário A/CNK versus NK/A(Maniar\& Piccoli, 1989) mostrando a distribuição das facies granitóides do MGVG, com base nos índices de Shand(ISA). 


\subsection{3 - Afinidade Tectonomagmática e Tipologia}

Baseando-se em dados químicos referentes a elementos maiores e traços, diversos autores tem apresentado sugestões para caracterizar a tipologia de granitóides e suas relações com o ambiente tectônico onde os mesmos foram colocados(Chappell \& White, 1974; Loiselle \& Wones, 1979, Collins et al., 1982; Pitcher, 1983; Pearce et al., 1984; Whalen et al., 1987; Cobbing, 1990; Eby, 1990 e 1992; Förster at al., 1997; entre outros).

Nos Diagramas clássicos $\mathrm{Y}-\mathrm{Nb},(\mathrm{y}+\mathrm{Nb})-\mathrm{Rb}$ e Ta-Yb de Pearce et al.(1984), Figura 4.38(a, b, c) observa-se que os granitóides analisados situam-se, em sua ampla maioria, no campo dos granitóides intra-placas. Entretanto, no diagrama $\mathrm{Rb}-\mathrm{Y}+\mathrm{Nb}$, uma amostra da facies BSGEm incidem fora desse campo, mas muito próximo ao limite entre o mesmo e o campo composicional correspondente aos granitóides sin-colisionais.
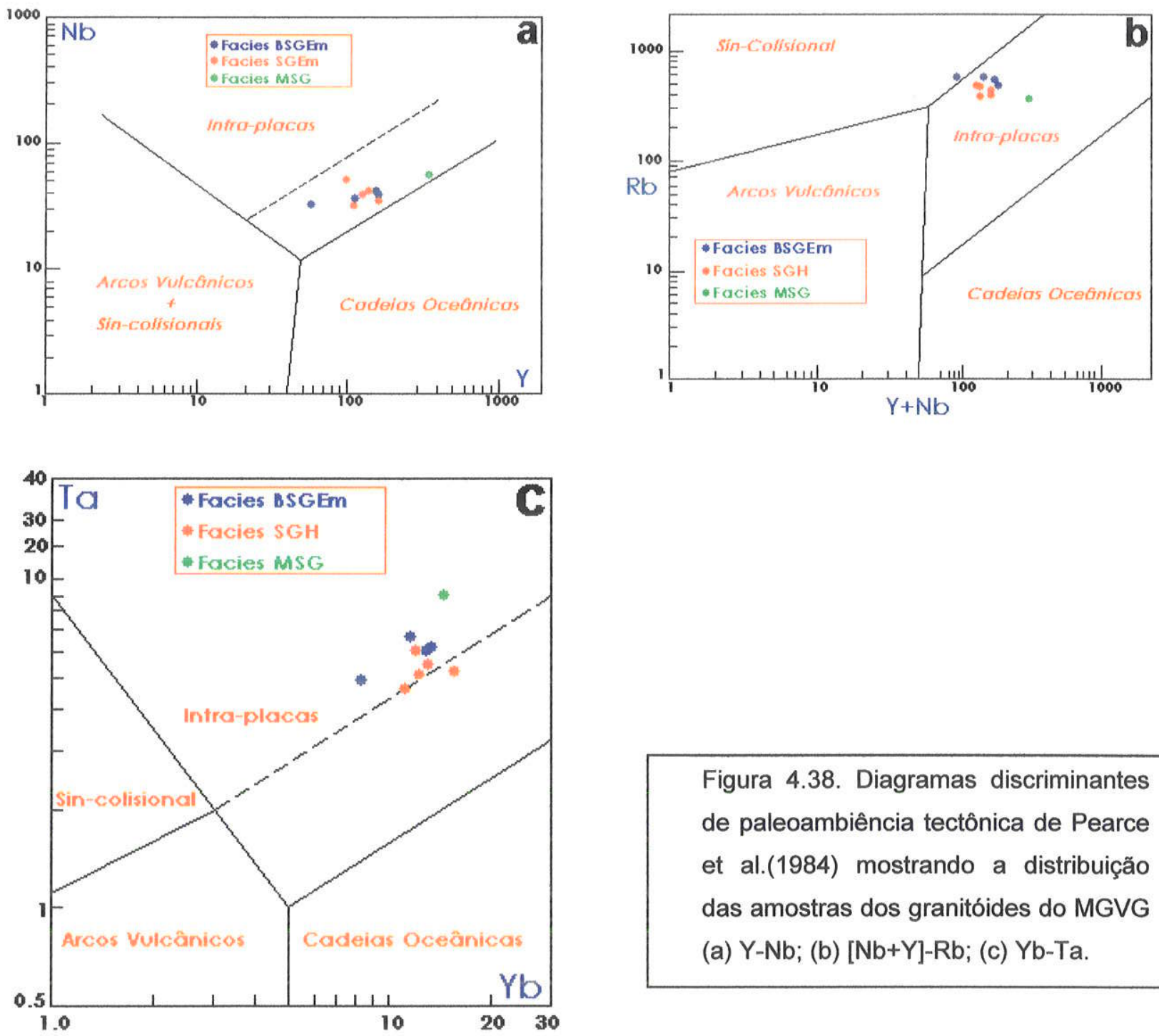

Figura 4.38. Diagramas discriminantes de paleoambiência tectônica de Pearce et al.(1984) mostrando a distribuição das amostras dos granitóides do MGVG (a) $\mathrm{Y}-\mathrm{Nb}$; (b) [Nb+Y]-Rb; (c) $\mathrm{Yb}-\mathrm{Ta}$. 
Conforme visto em relação aos granitóides do maciço Antônio Vicente, granitóides tipo-I, altamente fracionados, podem ser distinguidos de granitóides tipo-A utilizando-se para tal o parâmetro de discriminação $\mathrm{Zr}+\mathrm{Nb}+\mathrm{Ce}+\mathrm{Y}($ Whalen et al.,1987a).

Assim, no que diz respeito aos granitóides em estudo, os dados químicos referentes a esses elementos foram lançados no diagrama $\mathrm{Zr}+\mathrm{Nb}+\mathrm{Ce}+\mathrm{Y}$ vs. $\left(\mathrm{K}_{2} \mathrm{O}+\mathrm{Na}_{2} \mathrm{O}\right) / \mathrm{CaO}$, de Whalen et al.(1987a), Figura 4.39. Observa-se que duas amostras da facies SGH incidem sobre a linha limítrofe entre o campo composicional correspondente aos granitos tipo-A e aquele dos granitos tipo-I, M, S, não fracionados, duas amostra dessa mesma facies e uma da facies BSGEm caem inteiramente no campo dos granitos fracionados, uma da facies SGH e uma da facies BSGEm incidem na linha divisória ente este campo e aquele dos granitóides tipo-A e duas amostras da facies BSGEm e uma da facies MSG situam-se no campo dos granitos tipo-A. Em todos os casos, as amostras situadas fora do campo dos granitos tipo-A ocupam posição marginal ao mesmo. Isso é especialmente devido ao fato de posuíremconteúdos moderados de $\mathrm{Nb}$ e $\mathrm{Ce}$.

No diagrama $\mathrm{Zr}+\mathrm{Nb}+\mathrm{Ce}+\mathrm{Y}$ vs. $\left(\mathrm{Fe} \mathrm{e}_{\mathrm{T}} / \mathrm{MgO}\right)$, dos mesmos autores, Figura 4.40 deste trabalho, que expressa o grau de fracionamento, nota-se que a ampla maioria das amostras ocupa no campo dos granitóides tipo-A. Excetuam-se a isso duas amostras da facies SGH, que incidem no campo dos granitos félsicos fracionados, em razão dos dados referidos acima.

$\mathrm{O}$ diagrama $10.000 \mathrm{Ga} / \mathrm{Al}$ vs. $\left(\mathrm{K}_{2} \mathrm{O}+\mathrm{Na}_{2} \mathrm{O}\right) / \mathrm{Al}_{2} \mathrm{O}_{3}$ de Whalen et al.(1987), modificado por Rämö \& Haapala(1995), que exprime o grau de alcalinidade ou índice agpaítico, Figura 4.41 , mostra que a quase totalidade das amostras dos granitóides estudados incide na área composicional correspondente aos granitos tipo-A, de natureza subalcalina.

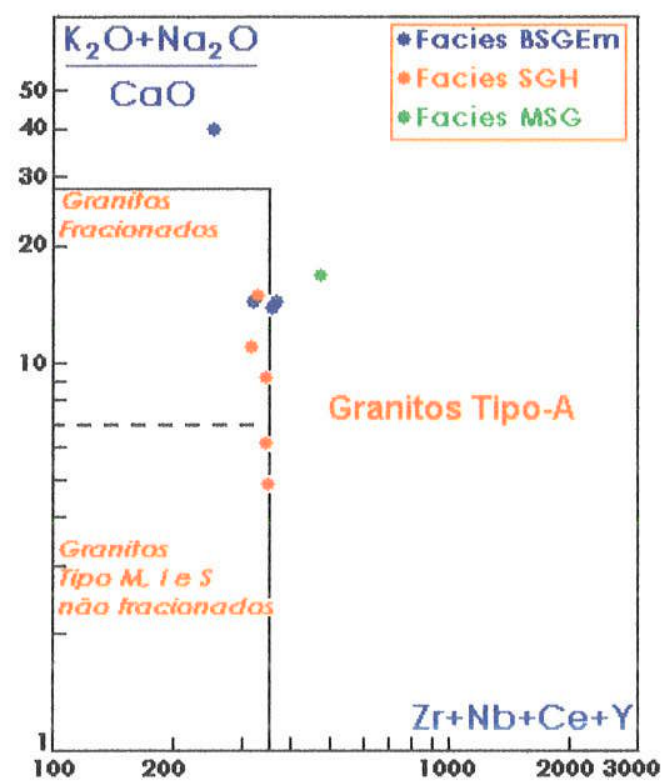

Figura 4.39- Diagrama $\mathrm{Zr}+\mathrm{Nb}+\mathrm{Ce}+\mathrm{Y} \quad$ vs. $\left(\mathrm{K}_{2} \mathrm{O}+\mathrm{Na}_{2} \mathrm{O}\right) / \mathrm{CaO}$ de Whalen et al.(1987) mostrando a distribuição composicional das amostras das principais facies granitóides do maciço granitóide Velho Guilherme. 


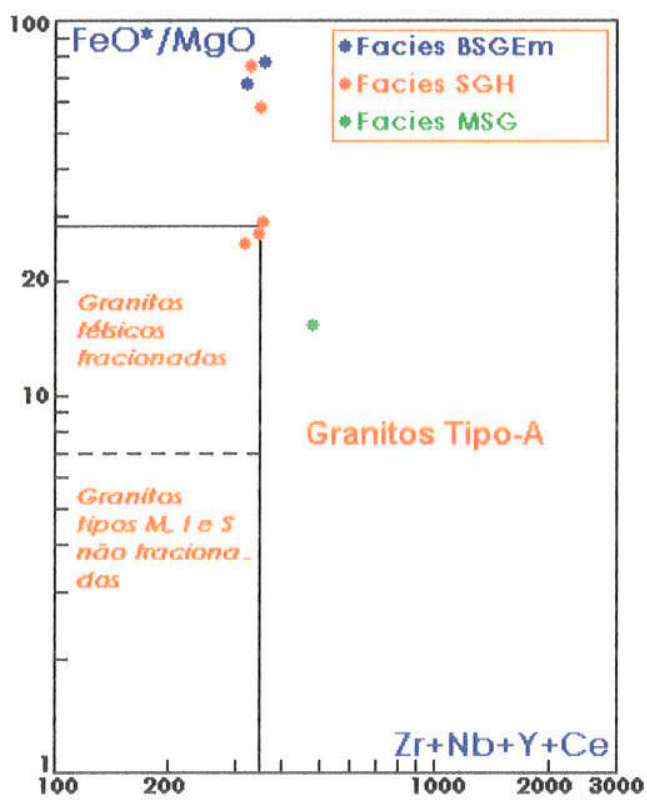

Figura 4.40- Diagrama $\mathrm{Zr}+\mathrm{Nb}+\mathrm{Ce}+\mathrm{Y}$ vs. (FeOT/MgO) de Whalen et al.(1987) exibindo as análises das principais facies granitóides do maciço granitóide Velho Guilherme.

Figura 4.41- Diagrama $10000 \mathrm{Ga} / \mathrm{Al}$ v.s. $\left(\mathrm{K}_{2} \mathrm{O}+\mathrm{Na}_{2} \mathrm{O}\right) / \mathrm{Al}_{2} \mathrm{O}_{3}$ de Whalen et al.(1987) mostrando a tipologia e o grau de alcalinidade/índice agpaítico das principais facies granitóides do maciço Velho Guilherme.

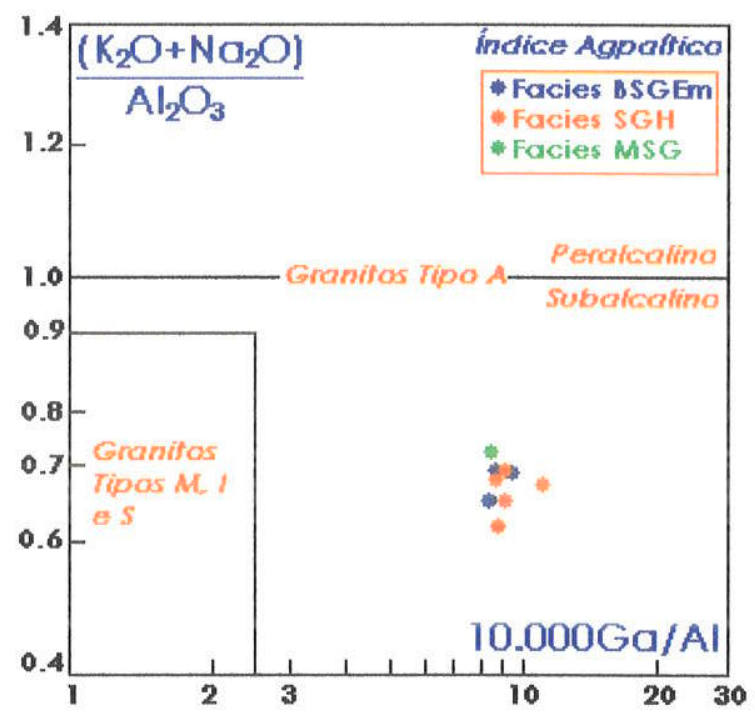

Com base na subdivisão apresentada por Eby(1992), os dados químicos dos granitóides aqui estudados foram lançados nos diagramas triangulares discriminantes $\mathrm{Y}$-Nb$\mathrm{Ce}$ e $\mathrm{Y}-\mathrm{Nb}-3 \mathrm{Ga}$, Figura 4.42(a, b). Em ambos os diagramas as amostras incidem preferencialmente no campo correspondente aos granitóides tipo- $\mathrm{A}_{2}$.
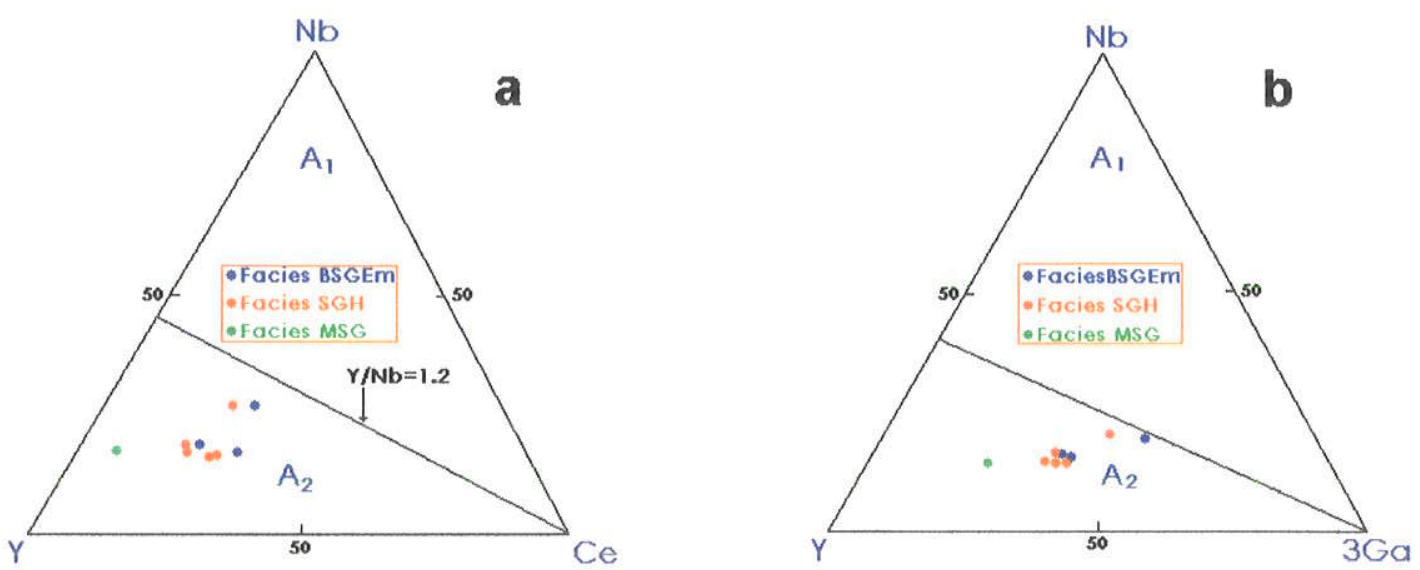

Figura 4.42 Diagramas triangulares Y-Nb-Ce(a) e Y-Nb-3Ga(b) de Eby(1992) mostrando a distribuição composicional das principais facies granitóides do maciço granitóide Velho Guilherme. 


\subsection{4- Outras Feições Geoquímicas}

A análise do diagrama $\mathrm{SiO}_{2}$ vs. $\mathrm{FeO}^{*} /\left(\mathrm{FeO}^{*}+\mathrm{MgO}\right)$, Figura 4.43a, revela uma correlação negativa entre essas duas variáveis, que mostra-se caracterizada pelo aumento de $\mathrm{SiO}_{2}$ e decréscimo da razão $\mathrm{FeO}^{*} /\left(\mathrm{FeO}^{*}+\mathrm{MgO}\right)$ no sentido da facies $\mathrm{BSGEm}$ para a facies MSG. A facies SGH representa o termo intermediário desse "trend". Esse comportamento das duas variáveis em questão é semelhante aquele observado no âmbito do maciço granitóide Antônio Vicente, em relação as variedades granitóides do estágio de alterações tardi a pós-magmáticas e dos greisens a elas associados(ver capítulo 3 deste trabalho).

A Figura 4.43b mostra uma discreta correlação positiva ente $\mathrm{CaO}$ e $\mathrm{Na}_{2} \mathrm{O}$, caracterizada por um pequeno aumento do conteúdo de $\mathrm{Na}_{2} \mathrm{O}$ e por um aumento mais evidente de $\mathrm{CaO}$ no sentido da facies MSG para a SGH, com a facies BSGEm ocupando uma posição intermediária. Os conteúdos claramente mais elevados de $\mathrm{CaO}$ na facies SGH deve-se, ao que tudo indica, as mais elevadas quantidades de epidoto e de allanita na mesma.
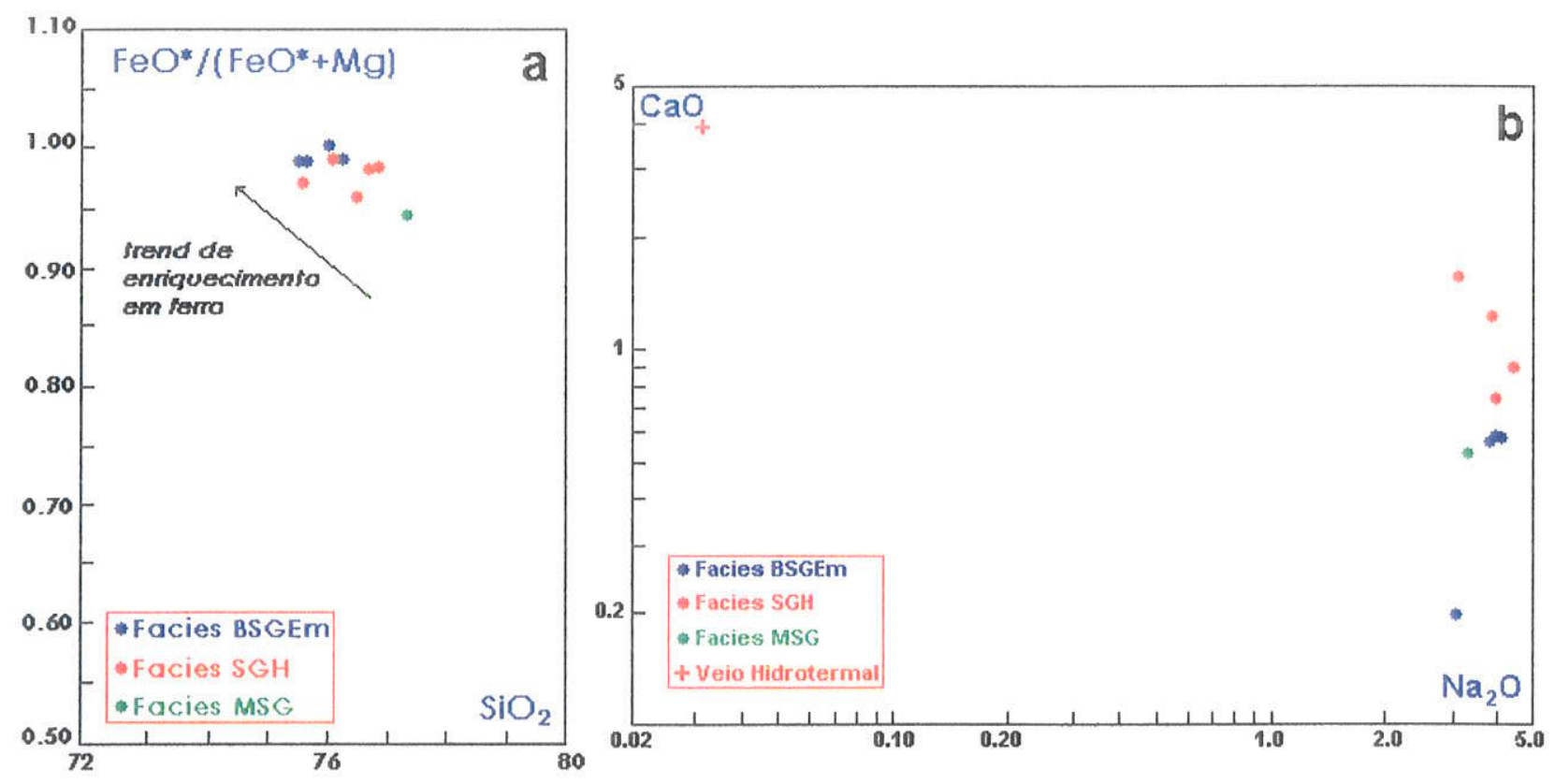

Figura 4.43. Diagramas retangulares $\mathrm{SiO}_{2}$ vs. $\mathrm{FeO}^{*} /(\mathrm{FeO}+\mathrm{MgO})$ (a) e $\mathrm{CaO}$ vs. $\mathrm{Na}_{2} \mathrm{O}$ (b) mostrando a distribuição composicional das principais facies granitóides do maciço granitóide Velho Guilherme.

A Figura 4.44, ilustra a correlação levemente positiva entre os conteúdos de $\mathrm{Sr}$ e os de $\mathrm{Na}_{2} \mathrm{O}$ no âmbito dos granitóides. Nota-se que os teores médios de $\mathrm{Sr}$ e $\mathrm{Na}_{2} \mathrm{O}$ crescem no sentido da facies BSGEm para a facies SGH. A análise da facies MSG se ajusta 
preferencialmente ao grupo de análises da facies SGH, especialmente no que se refere aos contúdos de $\mathrm{Sr}$, visto que os de $\mathrm{Na}_{2} \mathrm{O}$ são pouco variáveis.

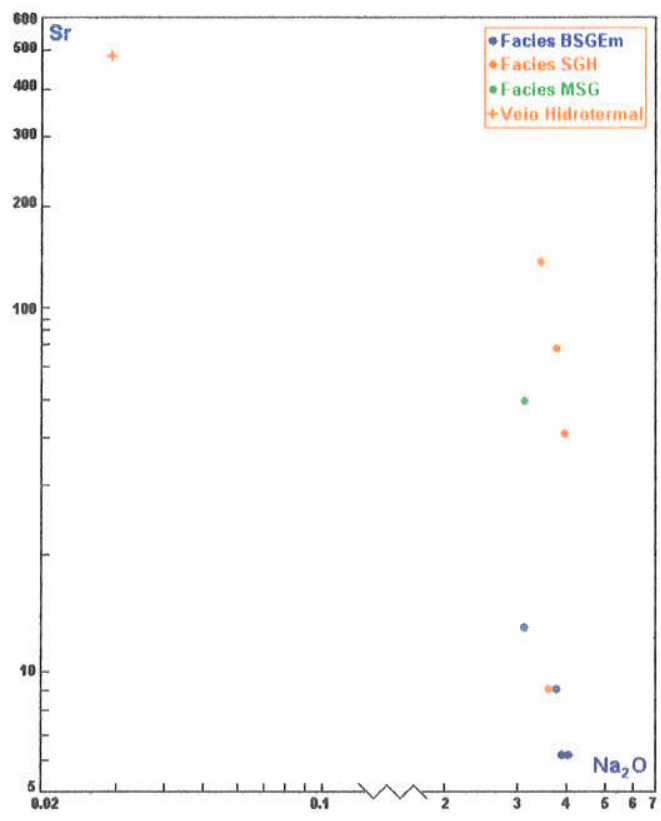

Figura 4.44-. Diagrama Sr-Na2O mostrando a distribuição composicional das amostras das principais facies granitóides do maciço granitóide Velho Guilherme.

As razões $\mathrm{K} / \mathrm{Rb}$ variáveis entre de 300 a 150 são consideradas normais para granitos (Shaw, 1968). Entretanto, em muitos dos complexos granitóides, os termos mais evoluídos apresentam razões K/Rb mais baixas do que 150(Dall'Anol et al., 1993b; Teixeira et al., 1994). Do mesmo modo que em relação aos granitóides do maciço granitóide Antônio Vicente, nestes, as razões $\mathrm{K} / \mathrm{Rb}$ da grande maioria das amostras situa-se abaixo de $100 \mathrm{e}$ acima de 20. Os conteúdos de $\mathrm{K}$ das amostras das facies BSGEm e SGH, variam muito pouco, independentemente, da intensidade das alterações tardi a pós-magmáticas e são mais elevados na amostra da facies MSG. Os teores de $\mathrm{Rb}$ aumentam claramente no sentido da facies SGH para a BSGEm(correlação positiva com o K), mas decrescem no sentido dessa última facies para a facies MSG. O veio hidrotermal encontra-se exaurido em $\mathrm{K}$ e apresenta os mais baixos conteúdos de $\mathrm{Rb}$ (Figura $4.45 \mathrm{a}$ ).

Nas Figuras 4.45(b, c) observa-se que $\mathrm{Sr}$ e $\mathrm{Ba}$ comportaram-se como elementos compatíveis durante a evolução magmática dos granitóides que correspondem a facies BSGEm, visto que mostram-se empobrecidos nos mesmos. Entretanto, nos granitóides representados pelas facies SGH e MSG, seus conteúdos são relativamente mais expressivos, principalmente os de $\mathrm{Ba}$. No veio hidrotermal são encontrados os mais elevados teores de $\mathrm{Sr}$ e os mais reduzidos de $\mathrm{Rb}$. As razões $\mathrm{Rb} / \mathrm{Srsão}$ muito variáveis, oscilando entre 2,0 a 20,0 nas facies SGH e MSG e entre 40,0 e 100,0 na facies BSGEm. No veio hidrotermal essa é muitíssimo baixa e de cerca de 0,25. 
$\mathrm{Na} 4.45 \mathrm{c}$ verifica-se que grande parte das amostras dos granitóides do maciço situam-se no campo dos granitóides diferenciados (El Bouseily \& El Sokkary, 1975). Entretanto, duas amostras da facies SGH e uma de veio hidrotermal incidem fora desse campo em razão dos seus mais elevados conteúdos de Sr. A hipótese mais provável a ser considerada reside no fato delas possuírem concentrações expressivas de allanita(Tabela 4.2 , Anexo 23) em relação às demais amostras analisadas.

$\mathrm{O} \mathrm{Zr}$ apresente-se em concentrações geralmente altas nos granitóides estudados(Tabela 4.3), comportando-se, por conseguinte, como elemento incompativel durante a diferenciação magmática. No diagrama $\mathrm{Rb}-\mathrm{Zr}$ (Figura 4.45d) nota-se que seus teores são eqüivalentes nas facies granitóides BSGEm e SGH e tendem a aumentar no sentido da facies MSG, estabelecendo-se, então, uma leve correlação negativa entre $\mathrm{Zr}$ e $\mathrm{Rb}$ nesses ganitóides, visto que esse último deresce no sentido da facies BSGEm para a facies MSG . No veio hidrotermal são encontrados as mais baixas concentrações desses elementos. As razões $\mathrm{Zr} / \mathrm{Rb}$ são sempre baixas e oscilam entre 0,2 e 0,5

No diagrama U-Th(Figura 4.45e), nota-se que o Th é mais ou menos constante nos granitóides, variando entre 41,85 ppm e 50,17 ppm. O U varia mais claramente, elevando-se de cerca de $8,11 \mathrm{ppm}$ na facies SGH até em torno de 20,10ppm na facies MSG. Na facies BSGEm possui valores intermediários, enquanto que no veio hidrotermal, tanto Th, quanto $U$ mostram conteúdos muito reduzidos, especialmente o Th. As razões U/Th são invariavelmente baixas variando entre 0,2 e 0,5. Apenas duas amostras da facies SGH possuem razões inferiores a 0,2.
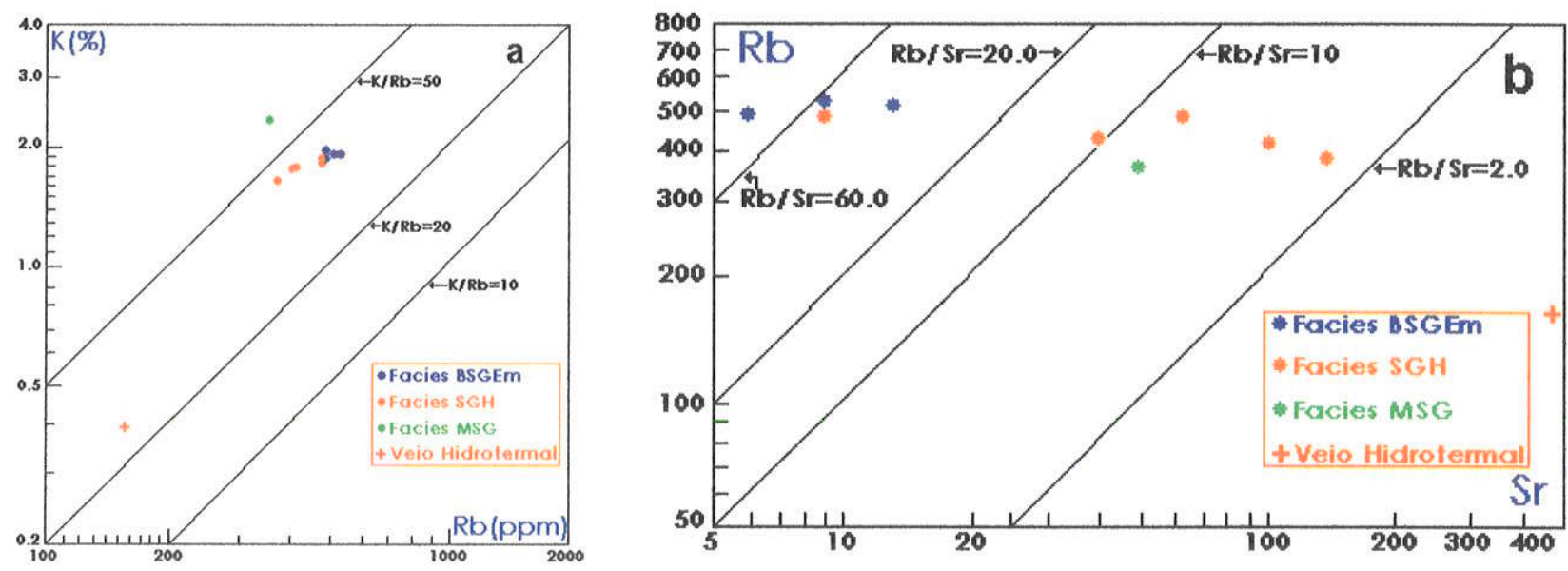

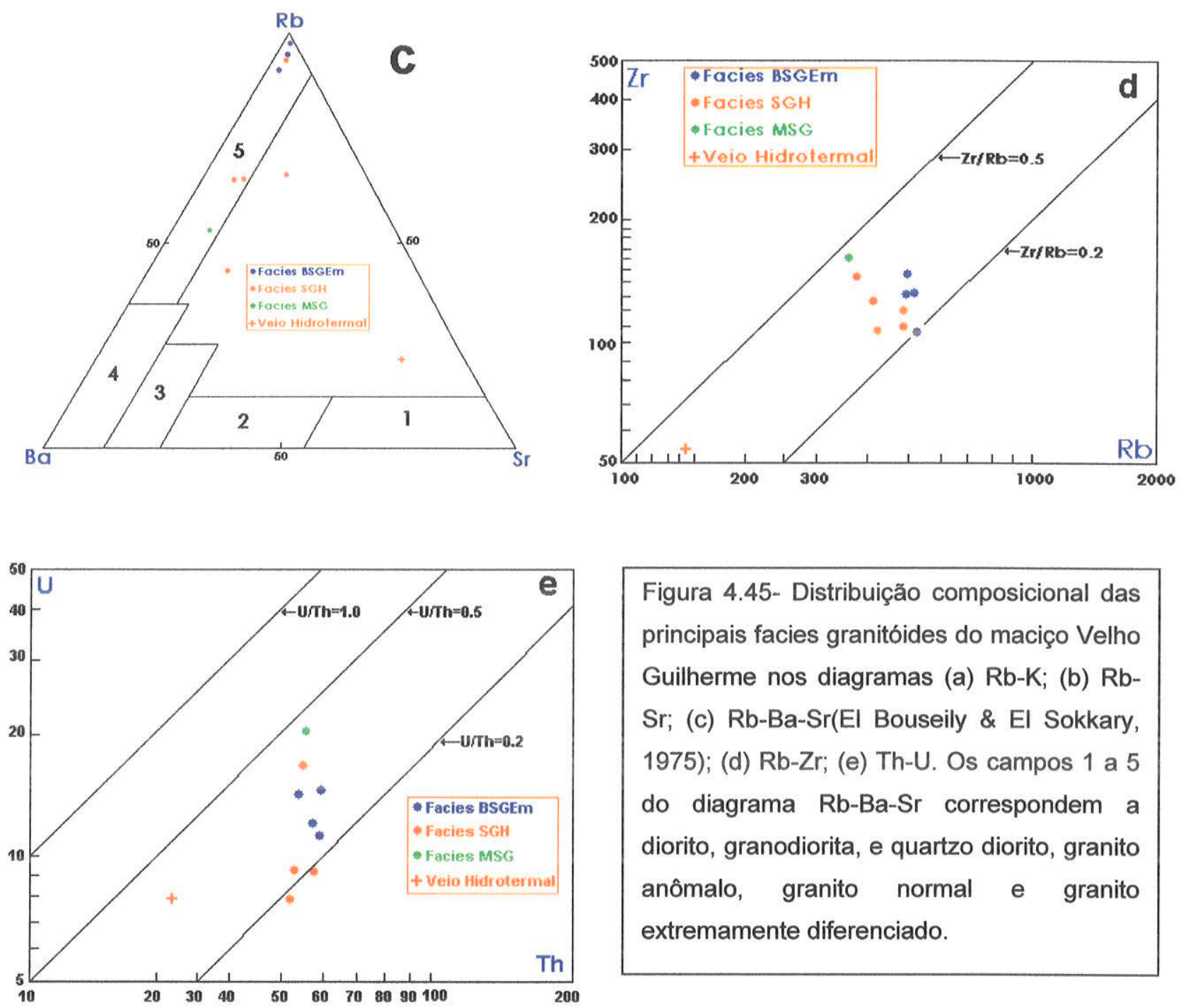

Figura 4.45- Distribuição composicional das principais facies granitóides do maciço Velho Guilherme nos diagramas (a) Rb-K; (b) RbSr; (c) Rb-Ba-Sr(El Bouseily \& El Sokkary, 1975); (d) Rb-Zr; (e) Th-U. Os campos 1 a 5 do diagrama $\mathrm{Rb}-\mathrm{Ba}-\mathrm{Sr}$ correspondem a diorito, granodiorita, e quartzo diorito, granito anômalo, granito normal e granito extremamente diferenciado.

Partido-se do fato de que os granitóides desse maciço encontram-se afetados em diferentes graus por processos de alterações tardi a pós-magmáticas, tal qual algumas facies granitóides do maciço Antônio Vicente(ver Capítulo 3) e considerando a importância dos fluidos tardios nesses processos, torna-se relevante, também, analisar o papel do $\mathrm{F} e$ do $\mathrm{Cl}$ nestes granitóides, bem como o comportamento de outros elementos relacionados aos mesmos.

A Tabela 4.3(Anexo 23) e a Figura 4.46a mostram, para o conjunto das amostras uma correlação errática entre $\mathrm{F}$ e $\mathrm{Cl}$. Entretanto, quando considerados seus conteúdos médios(Tabela 4.3; Anexo 23), nota-se que o F aumenta no sentido da facies BSGEm para a facies SGH e do veio hidrotermal, mas decresce em relação à facies MSG. O Cl, por sua vez, mostra, em termos dos seus teores médio, uma distribuição aleatória. As razões $\mathrm{F} / \mathrm{Cl}$ tendem a aumentar no sentido da facies SGH para a facies BSGEm e do veio hidrotermal. Observa-se, ainda, que essas razões oscilam entre 1,0 e 5,0(Figura 4.46a). 
A Figura 4.46b mostra, para o conjunto das amostras, que $F$ e $\mathrm{Sn}$ tendem a desenvolver uma leve correlação positiva, caracterizada pelo crescimento dos conteúdos de ambos no sentido da facies BSGEm para a facies SGH. Quando são considerados apenas seus conteúdos médios(Tabela 4.3; Anexo 23), nota-se que o F aumenta no sentido da facies BSGEm para a facies SGH e do veio hidrotermal, mas decresce em relação à facies MSG(como visto acima). O Sn tem comportamento semelhante. É importante notar que as amostras com os teores mais elevados de flúor não correspondem necessariamente àquelas com teores mais elevados de Sn, embora, na facies SGH, a amostra com maior conteúdo de $F$ (análise número 8 ) possua, também, a maior concentração relativa de $S n(F=4.300 p p m$ e $S n=16,40 p p m)$. Além disso, a amostra com o mais elevado teor de $F$, dentre todas aquelas analisadas apresentadas na Tabela 4.3(Anexo 23), corresponde ao veio hidrotermal $(F=2900$ ppm e $S n=86,50 p p m)$ e o teor de $F$ é bem mais baixo do que aquele encontrado na amostra de número 8 , da facies SGH. Afora tudo isso, durante os estudos petrográficos não foi detectada a presença de cassiterita em amostras desse maciço.

$\mathrm{Na}$ Figura 4.46c observa-se uma discreta correlação negativa entre $\mathrm{Sn}$ e $\mathrm{Cl}$, traduzida pelo aumento relativo dos conteúdos de Sn no sentido da facies BSGEm para a facies SGH e dessa para o veio hidrotermal, ocorrendo o inverso com as concentrações de $\mathrm{Cl}$. As razões $\mathrm{Sn} / \mathrm{Cl}$ são sempre muito baixas e nos granitóides alcançam no máxino 0,02 , enquanto que no veio hidrotermal é igual a 0.10 .

$\mathrm{Na}$ Figura 4.46d, correspondente ao diagrama $\mathrm{Na}_{2} \mathrm{O}-\mathrm{F}$, nota-se uma distribuição errática dos conteúdos de $F$, independentemente dos conteúdos de $\mathrm{Na}_{2} \mathrm{O}$. Este, por sua vez, apresenta conteúdos muito pouco variáveis(Tabela 4.3; Anexo 23).

No diagrama $\mathrm{Na}_{2} \mathrm{O}-\mathrm{Sn}$ (Figura 4.46e) observa-se que entre os granitóides não existe uma distribuição regular das amostras que possa caracterizar uma correlação entre os conteúdos de $\mathrm{Sn}$. Entretanto, nota-se que existe uma correlação negativa entre $\mathrm{Sn}$ e $\mathrm{Na}_{2} \mathrm{O}$, caracterizada pelo aumento nos teores de $\mathrm{Sn}$ e decréscimo das quantidades de $\mathrm{Na}_{2} \mathrm{O}$ no sentido dos granitóides para o veio hidrotermal.

$\mathrm{Na}$ Figura $4.46 f$ nota-se que o $\mathrm{Sn}$ e a razão $\mathrm{Rb} / \mathrm{Sr}$ (indice de diferenciação) desenvolvem uma correlação negativa, caracterizada, principalmente pelo crescimento dos conteúdos de $\mathrm{Sn}$ e pelo decréscimo das razões $\mathrm{Rb} / \mathrm{Sr}$ no sentido da BSGEm para a facies SGH e dessa para os veio hidrotermal. Verifica-se, ainda, que uma boa parte das análises situa-se no campo das rochas que interagiram com fluidos(Lehmann \& Mahawat, 1989), especialmente as amostras correspondentes as facies BSGEm e MSG, confirmando as observaçōes petrográficas.

No diagrama $\mathrm{Sn}-\mathrm{TiO}_{2}$ (Figura 4.46g) verifica-se uma muito discreta correlação positiva definida pele crescimento, especialmente, de Sn no sentido da facies BSGEm para a facies SGH, uma vez que as concentrações de $\mathrm{TiO}_{2}$ são pouco variáveis. Nota-se, também, que 
todas as amostras de granitóides posicionam-se no campo das rochas que interagiram com fluidos(Lehmann, 1990), reafirmado o que foi observado na Figura 4.46f.

Comparativamente aos granitóides e greisens especializados a estanho e, por conseguinte, portadores de cassiterita, ocorrentes no âmbito dos maciços granitóides Antônio Vicente e Mocambo, os granitóides do maciço granitóide Velho Guilherme mostram conteúdos muito mais elevados de $\mathrm{Cl}$, embora seus conteúdos de $\mathrm{F}$ sejam semelhantes àqueles de algumas amostras portadoras de cassiterita pertencentes ao maciço granitóide Antônio Vicente.

Assim, os dados químicos aliados aos dados petrográficos permitem concluir que granitóides com teores significativos de $\mathrm{F}$ e/ou de $\mathrm{Cl}$ não necessariamente são portadores de de estanho e, em particular, de cassiterita. Sabe-se porém, que na região de ocorrência desse maciço, houve no passado pequenos garimpos de cassiterita, sob a forma aluvionar, ao que tudo indica, associados ao mesmo. É possível, então, se imaginar que os mesmos foram originados a partir do desmonte de porções de cúpolas mineralizadas, as quais não existem mais. Dessa forma, a amostragem executa deve representar porções internas do maciço, localizadas abaixo das zonas apicais intensamente alteradas/greisenizadas, onde as mineralizações preferencialmente costumam ocorrer(Scherba; 1970, Pollard, 1983; Taylor \& Pollard, 1988; entre outros).
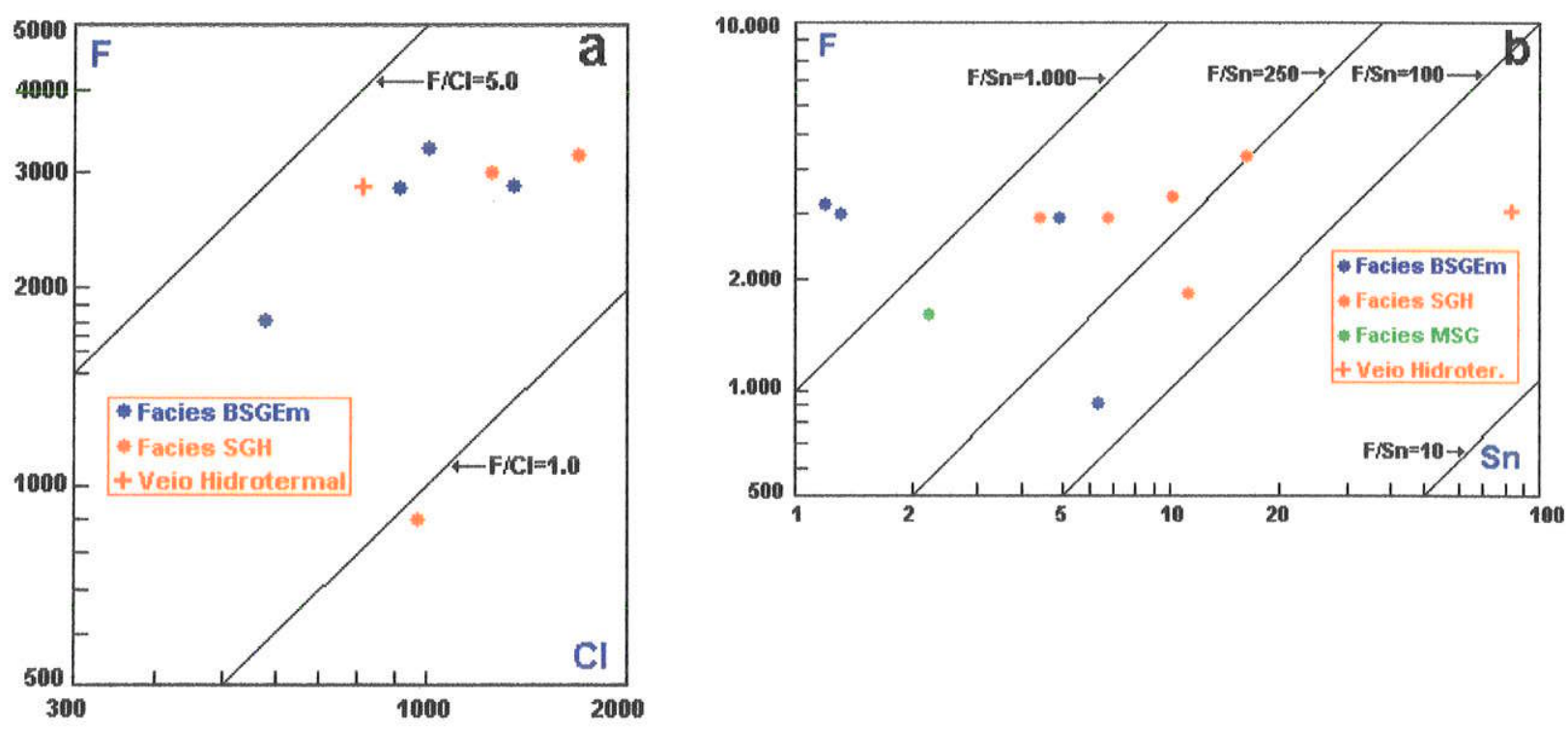

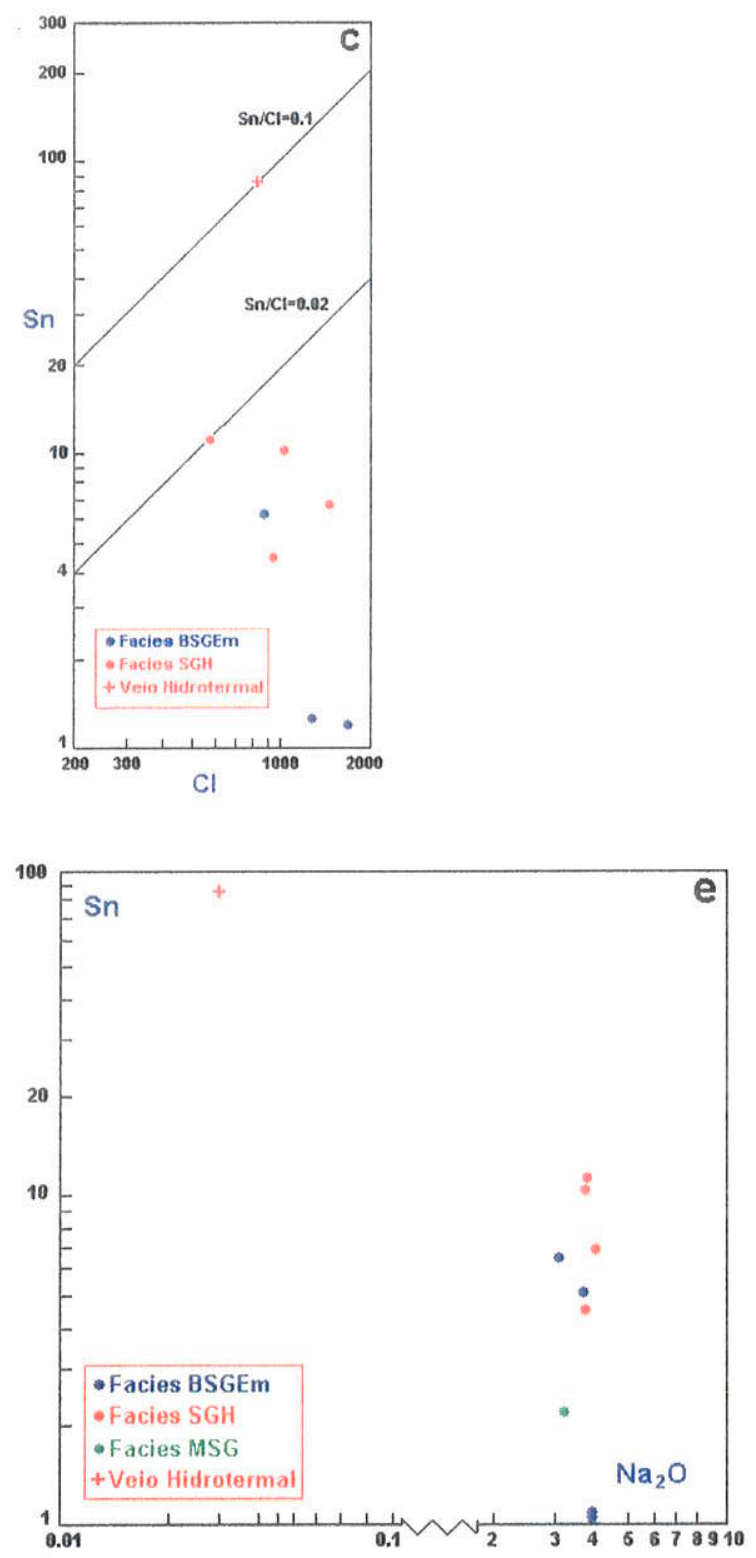

Figura 4.46. Distribuição composicional das amostras das principais facies granitóides do maciço granitóide Velho Guilherme e do veio hidrotermal a ele associados nos diagramas (a) $\mathrm{F}-\mathrm{Cl}$; (b) $\mathrm{F}-\mathrm{Sn}$; (c) $\mathrm{Cl}-\mathrm{Sn}$; (d) $\mathrm{Na}_{2} \mathrm{O}-\mathrm{F}$; (e) $\mathrm{Na}_{2} \mathrm{O}-\mathrm{Sn}$; (f) $\mathrm{Sn}-\mathrm{Rb} / \mathrm{Sr}$; (g) $\mathrm{Sn}-\mathrm{TiO}_{2}$. O losango indica a composição média da crosta conforme Taylor \& McLennan (1985).
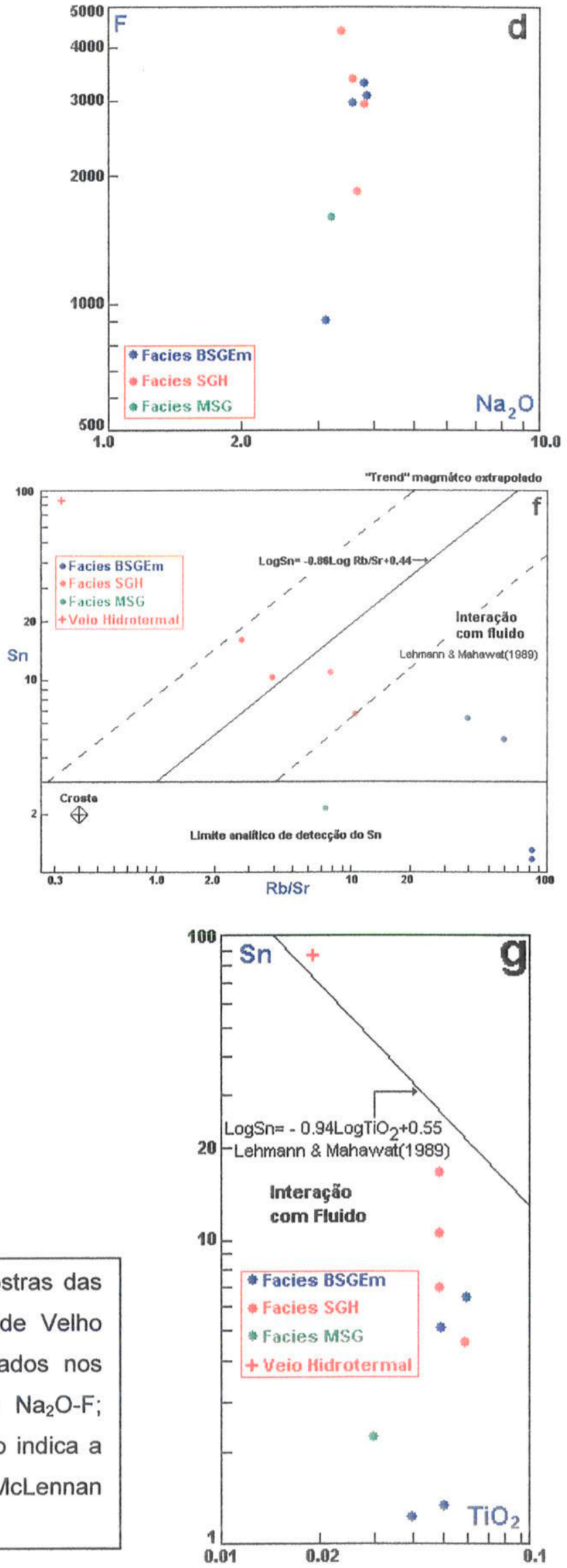
O comportamento geoquímico dos ETR tem sido objeto de muitos estudos há várias décadas(Taylor \& McLennan, 1985; Shaw et al., 1986; Condie, 1993; Henderson, 1996; entre outros). $O$ interesse das investigações tem se voltado tanto para os elementos em si, quanto para a elucidação de diversos problemas minerałógicos e petrológicos(Henderson, 1996). De acordo com esse autor, o estudo sobre a partição dos ETR é particularmente apropriado para trabalhos petrogenéticos. Suas imobilidades relativas durante certos tipos de alterações de rochas tem sido usadas para ajudar a estabelecer a proveniência ou a natureza de rochas primárias(Henderson, 1996).

Diante disso, os conteúdos dos ETR foram dosados em amostras representativas dos granitóides do maciço em questão, bem como de veio hidrotermal a ele associado. Os resultados analíticos obtidos encontram-se na Tabela 4.3(Anexo 23).

A análise da referida tabela revela que os granitóides estudados mostram-se empobrecidos em ETRL e enriquecidos em ETRP, em relação à abundância desses elementos na crosta continental(Shaw et al., 1986; Condie, 1993).

A somatória dos conteúdos médios dos ETR nas facies granitóides BSGEm, SGH e MSG e no veio hidrotermal são respectivamente 157,32, 172,21, 150,03 e 193,29ppm.

$\mathrm{Na}$ Figura 4.47 observa-se que a composição média dos ETR nos granitóides e no veio hidrotermal, normalizada para condritos(Sun, 1982), desenvolvem um padrão tipo "gaivota", a semelhança daquele que foi observado em relação ao maciço granitóide Antônio Vicente, embora no MAGAV as concentrações médias dos ETR normalizados sejam nitidamente mais elevadas. Além disso, nos granitóides e veio hidrotermal estudados, notase que os mais baixos conteúdos médios de ETRL encontram-se na facies $M S G(\Sigma E T R L=61,70)$, enquanto que nas facies granitóides BSGEm e SGH e no veio hidrotermal os teores médios desses elementos são mais ou menos eqüivalentes( $\Sigma E T R L$ são respectivamente 102,91, 109,00 e 98,59; Tabela 4.4). Uma explicação para essas diferenças pode ser atribuída à presença de quantidades relativamente mais elevadas de fases minerais acessórias hospedeiras de ETRL nas facies BSGEm, SGH e no veio hidrotermal, em relação à facies MSG.

Análises EDS através de microscopia eletrônica de varredura(MEV) realizadas em duas amostras representativas da facies SGH(Anexos 21 e 22), aliadas aos estudos petrográficos realizados através de microscopia ótica(MO), revelaram a existência de uma série de fases minerais subordinadas, quase sempre, de origem secundária, portadoras de quantidades apreciáveis de ETRL. Essas fases mostram-se representadas por allanita, fluorcerita-(Ce), fluorita contendo(Ce, $\mathrm{La}, \mathrm{Nd})$, armstrongita/cálcio-catapleiita contendo( $\mathrm{Yb}$, $\mathrm{Ce}, \mathrm{La} \pm \mathrm{Y} \pm \mathrm{Nd} \pm \mathrm{Zr}$ ) e ceriopirocloro/fergusonita-beta(Y)/fergusonita-(Y), bem como por fases minerais ricas em Ce, La e Nd sem designação formal.(ver item Quimica Mineral deste capítulo). Dentre todas essas fases, a allanita e a fluorita são as mais abundantes e foram 
caracterizadas através de MEV e de MO. As demais fases formam grãos muito reduzidos, ocorrem em baixissimas concentrações e foram caracterizadas através de MEV.

Embora os dados químicos de elementos maiores e traços, apresentados acima, não tenham demonstrado nitidamente a existência de um "trend" de diferenciação/fracionamento magmático que permitisse relacionar geneticamente e posicionar temporalmente os granitóides deste maciço devido, ao que tudo indica, ao grau de alteraçőes tardi a pósmagmáticas em que os mesmos se encontram afetados, sabe-se, a partir dos dados de campo, que a facies BSGEm é seccionada pela facies SGH e que esta, por sua vez, é cortado pela facies MSG e pelo veio hidrotermal, sendo, portanto, essa a ordem, pelo menos aparente, de injeção dos granitóides durante a edificação do maciço.

Assim, as concentrações relativamente mais baixas de ETRL na facies MSG, apesar de conter até cerca de $2,00 \%$ de allanita(Tabela 4..2), parecem estar relacionadas ao comportamento compativel desses elementos durante a cristalização da facies SGH, tornando o liquido residual que formou a facies MSG empobrecido em ETRL. A allanita presente na facies SGH é do tipo allanita-Ce(ver item Química Mineral deste capítulo) e representa, juntamente, com a fluorita $e$ as outras fases acessórias portadoras de ETR(especialmente ETRL) a principal fonte de ETRL dessa facies. Embora não se disponha de análises obtidas através de MEV de fases minerais subordinadas de amostras da facies MSG, especialmente de allanita, observa-se na Tabela 4.3(Anexo 23), que essa facies possui os mais elevados conteúdos de $Y$ e os mais baixos de Ce entre os granitóides do maciço (237ppm e 21ppm, respectivamente). Sendo a allanita a principal fase acessória da facies MSG, acredita-se que se trate de uma allanita tipo allanita-Y(Jones et al., 1996), que, por sua vez, seria a principal fonte de $Y$ dessa facies. Em relação à facies BSGEm, embora não se disponha de análises, de fases minerais acessórios, fornecidas através de MEV, os estudos petrográficos realizados por MO acusaram a presença de allanita e de fluorita nas amostras da mesma(Tabela 4.1). Pela sua semelhança mineralógica e textural com a facies SGH, pensa-se que essas duas fases são as principais fontes de ETRL da facies BSGEm. O veio hidrotermal, por sua vez, apresenta conteúdos de ETRL muito semelhantes aqueles encontrados nas facies BSGEm e SGH. Do mesmo modo que facies BSGEm, não se dispõem de análises de fases minerais através de MEV em amostras desse veio. Os estudos petrográficos mostraram que o mesmo é constituido essencialmente de quartzo e epidoto, Assim, é muito provável que se trate de um epidoto de composição particular, portador de ETRL(Ewing \& Chakoumakos, 1982). De qualquer modo, necessita-se de um aprofundamento dessas análises com vistas a esclarecer essas pendências.

$\mathrm{Na}$ Figura 4.47. Nota-se, ainda, uma acentuada anomalia negativa do Eu, que, entre os granitóides, cresce no sentido da facies SGH para a facies MSG, com a facies BSGEm ocupando uma posição intermediária, embora muito próxima da facies MSG. Esse "trend" 
não tem uma razão muito clara, haja visto que o principal componente mineral desses granitóides a influir no comportamento do Eu, no sistema magmático, é o plagioclásio. Nos granitóides estudados, o mesmo se encontra, via de regra, descalcificado, em diferentes graus, e suas composições atuais são semelhantes e albiticas. Entretanto, os dados de química mineral obtidos através de microssonda eletrônica(ME) mostraram que, embora se trate de plagioclásios sódicos, o plagioclásio da facies SGH é relativamente menos sódico do que aquele da facies BSGEm e o dessa facies é apenas um pouquinho menos sódico do que aquele da facies MSG(ver ítem Química Mineral dessse capítulo). Assim, as quantidades de Eu estariam diretamente associadas as concentrações de Ca nas amostras estudadas. Talvez essa seja a principal razão para justificar o pequeno "trend" observado na anomalia de Eu nos granitóides em questão.

As razões Eu/Eu*, nos granitóides estudados são, respectivamente 13,71(BSGEm), 13,69(SGH), 13,60(MSG) e 13,71(V.H), Tabela 4.4.

No que se refere ao veio hidrotermal, a auséncia de plagioclásio e a presença amplamente dominante de quartzo, e epidoto(principal mineral portador de $\mathrm{Ca}$ ) mostram que a fase mineral controladora de Eu parace ser o epidoto, Isso explica, em parte, a posição intermediária da anomalia negativa do Eu dessa rocha em relação às facies granitóides BSGEm e MSG. De qualquer modo são necessários estudos mais aprofundados a esse respeito, no futuro.

Em relação aos ETRP, a análise da Figura 4.47 e da Tabela 4.4 revela que os mais baixos conteúdos médios desses elementos encontram-se na facies BSGEm( $\left.\sum E T R P=54,34\right)$. Eles aumentam gradativamente no sentido das facies $\operatorname{SGH}(\Sigma E T R P=62,65)$ e $M S G(\Sigma E T R P=88,25)$, atingem as mais elevadas concentrações relativas no veio hidrotermal $\left(\sum E T R P=94,79\right)$. Dentre os granitóides esse "trend" é ilustrado pelas razões $(\mathrm{La} / \mathrm{Yb})_{\mathrm{N}}$, cujos valores são 1,03(na facies BSGEm), 0,93(na facies $S G H$ ) e 0,27 (na facies MSG).

As análises realizadas através de MEV não acusaram a existência de fases minerais particulares portadoras de importantes concentrações de ETRP. Entretanto, fases menores, ao que tudo indica, de origem primária, foram identificadas e mostraram possuir quantidades algo expressivas de ETRP, especialmente de Dy e Yb. Elas estão representadas principalmente por zircão thorita, cálcio-silicato de $\mathrm{Zr}$ e óxido de $\mathrm{Zr}$ e Y(Anexos 21 e 22). Essas fases são reconhecidas aqui como as principais fontes fornecedoras de ETRP, mas devido às suas diminutas dimensões e suas baixas concentrações nos granitóides estudados, não foi possível quantificá-las com maior precisão durante as análises modais, visto que ocorrem como traços. Assim, sem uma quantificação rigorosa dos conteúdos dessas fases nos granitóides estudados, bem como a ausência de análises químicas 
quantitativas ou semi-quantitativas sistemáticas das mesmas, nos granitóides em questão, não é possível aprofundar essa discussão, no momento.

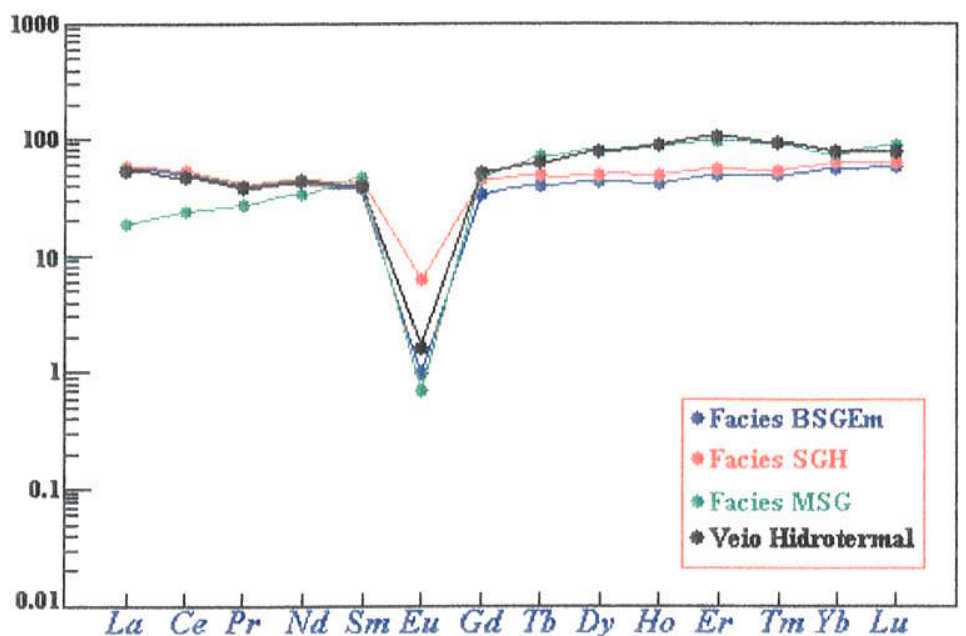

Figura 4.47. Padrão de distribuição dos ETR para os granitóides do maciço Velho Guilherme.

Tabela 4.4. Dados de ETR referentes às principais facies granitóides e veio hidrotermal associados ao maciço granitóide Velho Guilherme.

\begin{tabular}{|l|c|c|c|c|}
\hline $\begin{array}{l}\text { FACIES } \\
\text { GRANITÓIDES }\end{array}$ & BSGEm & SGH & MSG & VH \\
\hline (La/Yb) & & & & \\
\hline EuN $_{N} /$ Eu* & 1,03 & 0,93 & 0,27 & 0,71 \\
\hline$\sum$ ETRL & 13,71 & 13,69 & 13,60 & 13,71 \\
\hline$\sum$ ETRP & 102,91 & 109,00 & 61,70 & 98,59 \\
\hline$\Sigma$ ETR & 54,34 & 62,75 & 88,25 & 94,79 \\
\hline
\end{tabular}

\subsection{5- Análises Normativas CIPW}

As análises normativas CIPW correspondentes aos granitóides e veio hidrotermal desse maciço encontram-se na Tabela 4.5(Anexo 24). Elas foram calculadas através do software Minpet versão 2.02(Richard, 1988-1995), a partir de análises químicas de rocha total. A análise conjunta de todas as facies granitóides do maciço e do veio hidrotermal mostra que:

1) os granitóides são, na sua maioria, subsaturados em alumina, embora algumas amostras possam apresentar valor baixo de córindon normativo.

2) o diopsídio está presente em quase todas as amostras da facies SGH, porém, sempre em baixos teores( $0,02 \%$ a $0,22 \%)$. 
3) os conteúdos de albita tendem a decrescer no sentido da facies BSGEm para a facies MSG e, desta, para o veio hidrotermal, enquanto que os de An tendem a crescer no sentido da facies BSGEm para a facies SGH, decrescem em direção à facies MSG e voltam a crescer no sentido do veio hidrotermal, onde atingem seus mais altos teores $(15,11 \%)$. Como conseqüência, a razão Ab/An tende a decrescer no sentido da facies BSGEm para a facies SGH, sobe levemente em direção a facies MSG e cai drasticamente no veio hidrotermal( $(0,02)$. O Hy ocorre em quantidades sempre muito baixas $(0,03$ a $0,09 \%)$ e se faz presente apenas em algumas amostras. A hematita, magnetita e a ilmenita estão presentes em todas as amostras, sempre em quantidades reduzidas, embora a hematita apresente-se em conteúdos relativamente mais elevados, enquanto que a ilmenita, dentre os três óxidos, comparace com os mais baixos valores.

No diagrama Q-Ab-Or(Figura 4.489a) observa-se que as composições normativas dos granitóides incidem dentro do campo de $86 \%$ de freqüência das razões normativas QAb-Or de 1190 rochas graníticas de Winkler e Von Platen(1961), embora levemente afastadas do campo de máxima frequeencia(ponto $M$ ), deslocando-se em direção ao vértice do quartzo(silicificação). A amostra de veio hidrotermal foge totalmente para a aresta Q-Or e se posiciona próximo ao vértice do quartzo(intensa silicificação).

A exemplo do maciço Antőnio Vicente, esses granitóides mostram-se afetados por albitização, em diferentes graus. Entretanto, o efeito dessa alteração não se reflete nas suas composições normativas globais. Isso reforça a hipótese de que essa alteração se deu segundo um sistema fechado, fato que não possibilitou a entrada de $\mathrm{Na}$ no mesmo. Além disso, percebe-se nesse diagrama, que o magma gerador dos granitóides deste maciço era pobre em $F$, uma vez que as composiçōes dos mesmos situam-se abaixo da posição de temperatura do ponto de minimo correspondente a $1 \%$ de $F$ adiconado(Manning, 1981) e em torno do ponto de mínimo sem adição de $F($ Tuttle \& Bowen, 1958), o que demonstra que - F foi realmente remobilizado e enriquecido no estágio de alterações tardi a pósmagmáticas. Isso é evidenciado pela presença de quantidades um pouco expressivas desse elemento nos granitóides desse maciço, bem como pelos conteúdos um tanto elevados de fluorita, às vezes de topázio, e, subordinadamente, de outras fases menores portadoras de F nos mesmos.

Ademais, nota-se nesse diagrama, que a totalidade das composições situa-se entre as projeções das linhas cotéticas isobáricas de $P_{\mathrm{H} 2 \mathrm{O}}$ de $2 \mathrm{kbar}$ e de $5 \mathrm{kbar}$ de Winkler(1977), tal qual as amostras das variedades mais evoluídas e mais fortemente alteradas do maciço granitóide Antônio Vicente. 
No diagrama Ab-An-Or(Figura 4.48b) todas as amostras de granitóides incidem junto à aresta $A b-O r$, em posição intermediária entre esses dois vértices. $A$ razão normativa $A b$ An-Or do veio hidrotermal incide sobre a aresta An-Or, próximo ao vértice An.

\section{7- Condiçōes de Cristalização}

\subsection{1- Posicionamento Crustal}

Diferentemente do que foi apresentado em relação ao maciço granitóide Antônio Vicente, na região de exposição desse maciço não foram registradas, até o momento, quaisquer ocorrências de rochas vulcânicas intermediárias ou félsicas, não metamorfisadas, correlacionáveis ao Grupo Uatumã.

Conforme visto anteriormente os granitóides desse maciço encontram-se alojado em rochas metavulcano-sedimentares do Grupo Tucumã(CPRM/DNPM, 1991; Faraco et al, 1991) e em granitóides correlacionados ao Granodiorito Rio Maria(Medeiros, 1987). Essas unidades constituem, na área, o Terreno Granito-Greenstone do Sul do Pará, cuja estruturação interna é definida por zonas de cisalhamento obliquas e transcorrentes, que foram desenvolvidas em condições de facies xisto verde(Faraco et al., 1991), que eqüivale ao grau fraco(Winkler, 1977, pg. 48).

De acordo com Winkler(op. cit., Figura 7.2 , pg. 52) rochas metamórficas de grau fraco são portadoras de paragêneses minerais estáveis em condições de temperatura situadas entre aproximadamente $310^{\circ} \mathrm{C}$ e $520^{\circ} \mathrm{C}$ e pressões entre $1 \mathrm{~kb}$ e $\pm 4 \mathrm{~kb}$ e podem ocorrer em até aproximadamente $15 \mathrm{~km}$ de profundidade.

Estudos petrográficos realizados por Dall'Agnol(1980) em amostras de hornfels ocorrentes próximas ao contato do maciço revelaram a presença das seguintes associações minerais:

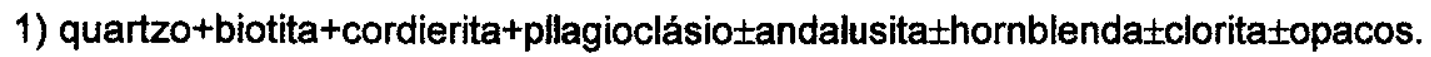

2) quartzo + cordierita + plagioclásio + cummingtonita + biotita + andalusita \pm opacos \pm muscovita \pm zircão.

3) quartzo + plagioclásio + biotita + clorita + opacos \pm feldspato potássico \pm sericita \pm muscovita \pm hornblenda \pm andalusita \pm cordierita(?).

Essas associações caracterizam a existência de uma auréola de contato entre os granitóides do maciço e suas encaixantes imediatas e foram interpretadas, com base em Turner(1968), como transicionais entre as facies albita-epidoto-horfels(associação 1) e hornblenda hornfels(associações 2 e 3). Além disso, foram consideradas, na época, como 
produtos de efeitos térmicos causados pela intrusão dos granitóides desse maciço em rochas metassedimentares do Grupo Grão Pará(associação 1), vulcânicas andesíticas ou daciticas das Formações Sobreiro-Iriri(associação 2) e vulcânicas antigas de composição dacítica(associação 3).

Neste trabalho, há um concordância com aquele desenvolvido por Dall'Agnol(1980) em relação à transição faciológia(facies albita-epidoto hornfels para hornblenda hornfels). Entretanto, com o objetivo de atualizar os dados, devido a um refinamento do mapeamento geológico regional da folha de ocorrência desse maciço, realizado por CPRM/DNPM, 1991), sabe-se que: 1) na área circunvizinha ao maciço não existe qualquer registro da presença de rochas pertencentes às Formaçōes Iriri e Sobreiro(Grupo Uatumã); 2) os metassedimentos, juntamente com rochas metavulcânicas, que no passado foram considerados como pertencentes ao Grupo Grão Pará, passaram a ser reconhecidos como do Grupo Tucumã

Em razão disso, as rochas encaixantes do maciço que foram diretamente afetadas termicamente correspondem a uma misturação tectônica da seqüência metavulcanosedimentar tipo " greenstone belts" designada de Grupo Tucumä(CPRM/DNPM, 1991). Isso é evidenciado pelas associações minerais caracterizadas por Dall'Agnol(1980), especialmente as de números 2 e 3, que guardam tanto caracteristicas de pelitos, quanto de rochas máficas a intermediárias(Turner, 1981; pgs. 245, 247 e 268).

A existência de uma auréola de contato em torno desses granitóides é indicativa de condiçōes de colocação em nivel crustal alto(Winkler, 1977). Dentre as diversas paragéneses de metamorfismo de contato apresentadas por Turner(1981), muitas, que se supõem semelhantes às definidas por Dall'Agnol(1980), foram extraidas a partir de auréolas de contato de granitos alojadas em níveis crustais altos(granitos pós-tectônicos) e caracterizam um regime metamórfico geral de baixa pressão, comumente entre 2 e $3 \mathrm{kbar}$.

Igualmente ao que foi apresentado em relação aos granitóides do maciço Antônio Vicente, a presença da paragênese fluorita + topázio + muscovita + clorita, bem como a sua relação com conteúdos importantes de $F$, nos granitóides desse maciço reforça a hipótese de que os mesmos foram colocados em nivel crustal raso, entre $1 \mathrm{Km}$ e $5 \mathrm{Km}$ (Bailey(1977).

Além disso, as observaçōes petrográficas através de microscopia ótica efetuadas por Dall'Agnol(1980; facies granófiros, pg. 211) e aquelas realizadas neste trabalho(facies SGH) mostraram a existência de texturas do tipo intercrescimentos granofíricos. À semelhança do que foi apresentado em relaçāo aos granitóides de ocorrência localizada no âmbito do maciço granitóide António Vicente, esses intercrescimentos são comuns em rochas ígneas félsicas colocadas próximo à superfície do crosta(Moorhouse, 1959, pg. 270; Smith, 1974, pg. 582; Bard, 1986, p.111; Pitcher, 1987'pg. 65) e, por conseguinte, em condições de baixas pressões, a partir de uma cristalização rápida de um granito eutético ternário, com 
quantidades semelhantes de quartzo, feldspato potássico e plagioclásio(Smith, 1974, pg. $582)$.

\subsection{2- Condições de $\mathrm{fO}_{2}, \mathrm{~T}$ e $\mathrm{P}$}

Análises químicas em grãos de biotita de composição annítica-aluminosa ocorrentes na facies BSGEm indicaram, mesmo que de modo provisório, a partir da aplicação do termômetro de Wones \& Eugster(1965), condições de reequilibrio com o líquido magmático em ambiente com $\mathrm{fO}_{2}$ muito baixa, variando de $10^{-19,2}$ a $10^{-19,8}$ e temperaturas oscilando entre $658^{\circ} \mathrm{C}$ e $733^{\circ} \mathrm{C}$. Essa temperatura é mais ou menos eqüivalente àquela estimada para a cristalização da biotita da facies BSG do maciço granitóide Antônio Vicente.

No que se refere à estimativa das condições de pressão, assim como em relação à biotita da facies BSG do maciço granitóide Antônio Vicente, utilizou-se o diagrama P-T do trabalho experimental de Brown \& Fyfe(1970), não apresentado aqui. Nele observou-se que o limite mais baixo $\left(T=658^{\circ} \mathrm{C}\right)$ não tem qualquer correspondência de pressão, enquanto que o limite superior $\left(T=733^{\circ} \mathrm{C}\right)$ corresponde a uma pressão igual a $3,2 \mathrm{kbar}$. Esse valor parece muito elevado e não deve ser considerado, uma vez que se tratra de uma mica reequilibrada e que, conseqüentemente, teve sua composição magmática original modificada.

Em razão disso, devido a grande semelhança textural e química com as facies mais evoluídas do maciço granitóide Antônio Vicente, pode-se dizer apenas que esse granitóide cristalizou em condições de baixa fugacidade de oxigênio, em temperaturas em torno dos $700^{\circ} \mathrm{C}$ e baixas pressões( $\left.\pm 1 \mathrm{kbar}\right)$, já que o mesmo foi colocado claramente em nível crustal alto conforme visto ateriormente.

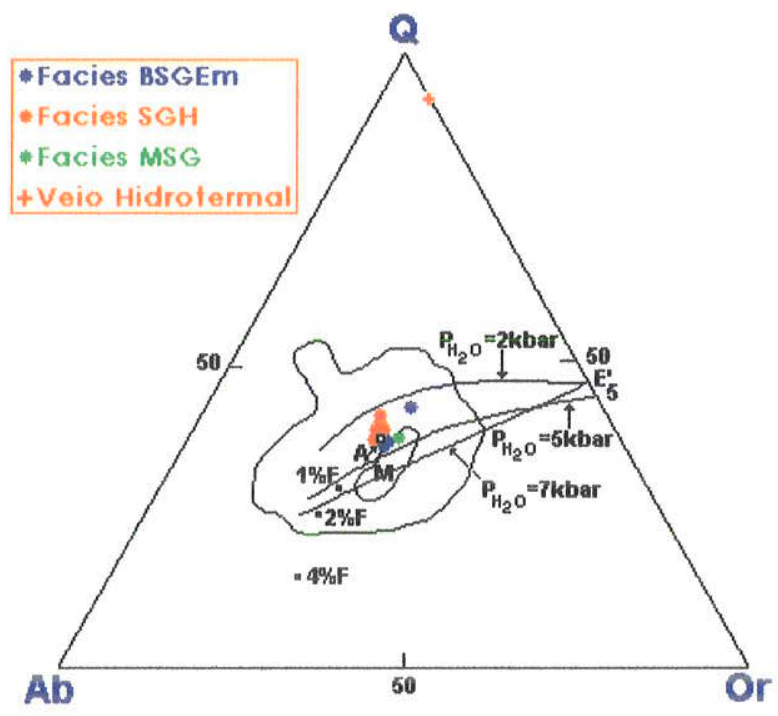

Figura 4.48a -Diagrama normativo Q-Ab-Or mostrando a distribuição composicional das principais facies granitóides do maciço granitóide Velho Guilherme. A curva envoltório de todos os pontos corresponde ao campo de freqüência das razões Q-Ab-Or de 1190 rochas graníticas de Winkler \& Von Plaren(1961). As projeções das linhas cotéticas isobáricas P-E'5 de 2,5 e $7 \mathrm{kbar}$ foram compiladas de Winkler(1977). M é o máximo de freqüência , A representa a posição e temperatura do ponto de mínimo sem $F($ Tuttle \& Bowen, 1958). 1\%F, $2 \% \mathrm{~F}$ e $4 \% \mathrm{~F}$ representam as posições e temperaturas dos pontos de mínimo com $\mathrm{F}$ adicionado e excesse de água a $1 \mathrm{kbar}($ Manning, 1981). 


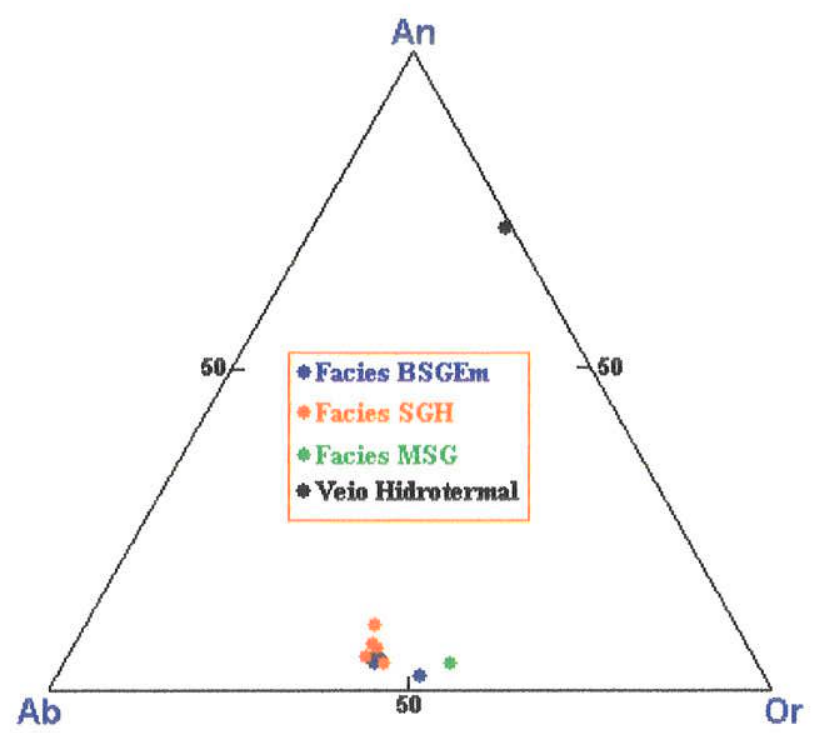

Figura 4.48b- Diagrama normativo Ab-AnOr mostrando a distibuição composicional das principais facies petrográficas do maciço granitóide Velho Guilherme.

\section{8- Conclusões e Considerações Finais}

Os dados petrográficos, juntamente com os dados de química mineral e de litogeoquímica apresentados e discutidos neste capítulo permitiram sequenciar as seguintes conclusões à respeito dos granitóides estudados:

1) foram caracterizados neste maciço, pelo menos, três variedades de granitóides a saber: 1) biotita sienogranito equigranular médio(BSGEm); 2) sienogranito heterogranular(SGH); 3) micro-sienogranito(MSG). Além, dos granitóides foram identificados veios hidrotermais, à base de quartzo e epidoto, seccionando a facies MSG.

2) essencialmente constituem sienogranito, caracteristicamente subsolvus que possuem M' sempre inferiores a $5 \%$, embora o BSGEm seja mais enriquecido em máficos do que as outras duas variedades. Essas características demonstram que: são de natureza hololeucocrática e que se originaram a partir de líquidos muito diferenciados e evoluídos, extremamente silicosos. Denotam, ainda, uma semelhança muito grande com aqueles constitutivos do maciço granitóide Antônio Vicente, em especial, a facies BSG e suas variações(BSGA e BSGIA).

3) de modo geral, encontram-se afetados, de forma intensa, por alterações tardi a pósmagmáticas, as quais decorreram de um evento metassomático inicial, de natureza potássica(microclinização), seguido de um outro sódico(albitização), que por sua vez, foi superposto por um terceiro, preferencialmente, potássico(argilização), seguido de silicificação. 
4) mineralizações importantes de cassiterita năo são noticiadas, nem tampouco foram observadas no âmbito desse maciço. Entretanto, pequenas ocorrências de cassiterita e topázio, esplotadas por garimpeiros, são registradas, sem contudo representarem um atrativo oconômico, tal como ocorreu nas áreas dos maciços granitóides Antônio Vicente e Mocambo.

5) análises de biotita realizadas através de microssonda eletrônica revelaram tratar-se de uma biotita magmática reequilibrada, de natureza subalcalina e composição variável entre annita aluminosa a siderofilita, tendendo a uma composição mais annitica aluminosa(Guidotti, 1984). Considerando a classificação proposta por Tischendorf et al.(1997), ela apresenta uma composição correspondente à siderofilita e, subordinadamente, à protolitionita. Em termos globais, ela se enquadra no grupo das Li-Fe micas.

6) no que se refere às condições de cristalização, concluiu-se que a mesma cristalizou em condições de baixa fugacidade, um pouco abaixo da curva "buffer" (tampão) $\mathrm{Fe}_{2} \mathrm{SiO}_{4}-\mathrm{SiO}_{2}$ $\mathrm{Fe}_{3} \mathrm{O}_{4}$ (faialita - quartzo - magnetita) e um pouco acima da curva tampão $\mathrm{Ni}$ - $\mathrm{NiO}$, com o $\log \mathrm{fO}_{2}$ situando-se entre $-19,2$ e $-19,8$, com as temperaturas de reequilíbrio com o liquido magmático variando entre $658^{\circ} \mathrm{C}$ e $733^{\circ} \mathrm{C}$.

7) as análises de grãos de clorita da facies granitóide $\mathrm{SGH}$, realizadas através de microssonda eletrônica, indicaram tratar-se de uma clorita não oxidada, com uma correspondência composicional com a ripidolita. A aplicação do termômetro de Cathelineau(1988) forneceu temperaturas de cristalização para a a mesma entre $393^{\circ} \mathrm{C}$ e $415^{\circ} \mathrm{C}$.

8) estudos de lâminas delgadas mostraram que a clorita é uma fase mineral tardia associada ao estágio de alterações tardi a pós-magmáticas. $E$, juntamente com sericita +muscovita+fluorita e outras fases associadas, marcam o início desse estágio. Assim, 0 intervalo de temperatura estimado deve ser considerado como aquele próximo a temperatura a partir da qual o referido estágio se iniciou.

9) análises químicas realizadas através de microssonda eletrônica em cristais de muscovita $\left(\mathrm{Mv}_{2}\right)$ indicaram uma correspondência composicional com à fengita e confirmaram sua origem secundária, já diagnosticada através de microscopia ótica. 
10) dados petrográficos e de química de rocha total, referentes à elementos maiores, elementos traços e ETR, mostraram que os granitóides desse maciço são extremamente diferenciados e que possuem teores de $\mathrm{SiO}_{2}$, invariavelmente superiores a $75 \%$. No que se refere aos principais óxidos maiores, exibem conteúdos de $\mathrm{TiO}_{2}, \mathrm{Al}_{2} \mathrm{O}_{3}, \mathrm{MgO}, \mathrm{CaO}$ e $\mathrm{P}_{2} \mathrm{O}_{5}$ sempre muito baixos $e$ inferiores aos valores médios dos granitos(Le Maitre, 1976), enquanto que as quantidades de $\mathrm{K}_{2} \mathrm{O}$ são ligeiramente mais elevadas e as de $\mathrm{Na}_{2} \mathrm{O}$ são equivalentes.

11) em relação aos elementos menores e traços, contém altos teores de $\mathrm{Rb}$ (média $=365$ 510ppm), $\quad Z r($ média=130-161ppm), $Y($ média=107-237ppm), $F($ média=1594-2680ppm) e $\mathrm{Cl}$ (média=795-955ppm), conteúdos moderados de $\mathrm{Nb}$ (média=38-52ppm) Ga(média=2830ppm), $W($ média $=60-715 \mathrm{ppm})$ e Th(média=45-48ppm) e baixas concentrações de $\mathrm{Ta}$ (média=5-9ppm), Hf(média=8-12ppm), U(média=11-20ppm), Sn(média=2-10ppm), $\mathrm{Mo}$ (média=1-4ppm) e $\mathrm{Zn}$ (média=22-87ppm). O Sr e o Ba apresentam teores moderados a relativamente altos nas maioria das amostras das facies $\mathrm{SGH}$ (média=70,40 e 175,0ppm, respectivamente) e $M S G($ média=49,0 e 264,0ppm, respectivamente) e muito baixos na facies BSGEm(média=8,5 e 16,25ppm, respectivamente).

12) os ETR ocorrem em conteúdos sempre baixos(BSGEm=157,32ppm; $S G H=172,21 \mathrm{ppm}$; $M S G=150,03 p p m$ ), ressaltando-se que as concentrações de ERTL(BSGEm=102,91ppm; $\mathrm{SGH}=109,00 \mathrm{ppm}$; $\mathrm{MSG}=61,70 \mathrm{ppm}$ ) são mais elevadas do que as de ETRP(BSGEm=54,34ppm; $S G H=62,75 p p m ; M S G=88,25$ ), exceto na facies MSG. As razões $\mathrm{Rb} / \mathrm{Sr}, \mathrm{Rb} / \mathrm{Ba}$, e Th/U são, geralmente altas, especialmente na facies granitóides $\operatorname{BSGEm}(60,10,31,43$ e 3,65, respectivamente), enquanto as razões $\mathrm{K} / \mathrm{Rb}$ (médias nas facies $B S G E m=75,25 ; S G H=81,78 ; M S G=128,73$ ) são muito baixas se comparadas com aquelas dos granitos considerados normais. As altas razões $T h / U$ indicam tratar-se de granitóides HHP.

13) os granitóides são essencialmente peraluminosos, com as razões dos conteúdos moleculares NKIA variando entre 0,64 e 0,69 e as razőes ACNK sendo superiores a 1 e inferiores a 1,5. Mostram natureza subalcalina, apresentam características de granitóides Intra-placas, são semelhantes aos granitos Tipo-A e correspondem aqueles do sub-grupo $A_{2}$.

14) as razões $\mathrm{F} / \mathrm{Cl}$ variam entre 1 e 5 e tendem a aumentar no sentido da facies SGH para a facies BSGEm e do veio hidrotermal. 
15) as amostras com os teores mais elevados de $F$ não correspondem necessariamente aquelas com teores mais elevados de $\mathrm{Sn}$.

16) as razões $\mathrm{Sn} / \mathrm{Cl}$ são sempre muito baixas e nos granitóides alcançam no máxino 0,02 , enquanto que no veio hidrotermal é igual a 0.10 .

17) comparativamente aos granitóides e greisens especializados a estanho e, por conseguinte, portadores de cassiterita, ocorrentes no âmbito dos maciços granitóides Antônio Vicente e Mocambo, os granitóides desse maciço mostram conteúdos muito mais elevados de $\mathrm{Cl}$, embora seus conteúdos de $\mathrm{F}$ sejam semelhantes àqueles de algumas amostras portadoras de cassiterita pertencentes ao maciço granitóide Antônio Vicente.

18) os dados químicos aliados aos dados petrográficos permitem concluir que granitóides com teores significativos de $\mathrm{F}$ e/ou de $\mathrm{Cl}$ não são, necessariamente, portadores de estanho e, em particular, de cassiterita.

19) em relação aos ETR esses granitóides mostram-se empobrecidos em ETRL e enriquecidos em ETRP, em relação à abundância desses elementos na crosta continental(Shaw et al., 1986; Condie, 1993).

20) a somatória dos conteúdos médios dos ETR nas facies granitóides BSGEm, SGH e MSG e no veio hidrotermal são respectivamente $157,32 \mathrm{ppm}, 172,21 \mathrm{ppm}, 150,03 \mathrm{ppm}$ e $193,29 \mathrm{ppm}$.

21) a composiçăo média dos ETR nos granitóides e no veio hidrotermal desenvolvem um padrão tipo "gaivota", à semelhança daquele que foi observado no maciço granitóide Antônio Vicente, no qual as concentraçōes médias dos ETR normalizados para condritos são nitidamente mais elevadas. Além disso, nos granitóides e veio hidrotermal estudados, notase que os mais baixos conteúdos médios de ETRL encontram-se na facies $M S G\left(\sum E T R L=61,70\right)$, enquanto que nas facies granitóides $B S G E m$ e $S G H$ e no veio hidrotermal os teores médios desses elementos são mais ou menos eqüivalentes( $\Sigma E T R L$ são respectivamente $102,91,109,00$ e 98,59). Uma explicação para essas diferenças pode ser atribuída à presença de quantidades mais elevadas de fases minerais acessórias hospedeiras de ETRL nas facies BSGEm, SGH e no veio hidrotermal, em relação à facies MSG. 
22) análises EDS realizadas em duas amostras representativas da facies $S G H$, aliadas aos estudos de láminas delgadas, revelaram a existência de uma série de minerais subordinadas, quase sempre, de origem secundária, portadoras de quantidades apreciáveis de ETRL. Essas fases mostram-se representadas por allanita, fluocerita-(Ce), fluorita contendo(Ce, La, Nd), armstrongita/cálcio-catapleiita contendo(Yb, $\mathrm{Ce}, \mathrm{La} \pm \mathrm{Y} \pm \mathrm{Nd} \pm \mathrm{Zr}$ ) e ceriopirocloro/fergusonita-beta( $(Y) / f e r g u s o n i t a-(Y)$, bem como por minerais ricos em Ce, La e Nd sem designação formal. Dentre todos, a allanita e a fluorita são as mais abundantes. As demais apresentam-se com dimensões muito reduzidas, ocorrem em baixissimas concentrações. Essas fases são as principais fontes de ETR, especialmente de ETRL, nos granitóides estudados, em particular na facies SGH.

23) as concentrações mais baixas de ETRL na facies MSG, apesar de conter até cerca de $2,00 \%$ de allanita, parecem estar relacionadas ao comportamento compativel desses elementos durante a cristalização da facies SGH.

24) a allanita presente na facies SGH é do tipo allanita-Ce e representa, juntamente, com a fluorita e os outros minerais acessórios portadoras de ETR(especialmente ETRL), a principal fonte de ETRL dessa facies.

25) em relação ao Eu, percebe-se uma acentuada anomalia negativa do mesmo, que, entre os granitóides, cresce no sentido do SGH para o MSG, com o BSGEm ocupando uma posição intermediária, embora muito próxima do MSG. Esse "trend" não tem uma razão muito clara, haja visto que o principal componente mineral desses granitóides a influir no comportamento do Eu, no sistema magmático, é o plagioclásio. Nos granitóides estudados, - mesmo se encontra, via de regra, descalcificado, em diferentes graus, $e$ as suas composições atuais são semelhantes e albiticas. Entretanto, os dados de química mineral obtidos através de microssonda eletrônica, mostraram que, embora se trate de plagioclásios sódicos, aquele dd SGH é relativamente menos sódico do que aquele do BSGEm e o dessa granitóide é apenas um pouquinho menos sódico do que aquele da facies MSG. Assim, as quantidades de $\mathrm{Eu}$ estariam diretamente associadas as quantidades de $\mathrm{Ca}$ nas amostras analisadas. Talvez essa seja a principal razão para justificar o pequeno "trend" observado na anomalia de Eu nos granitóides estudados.

26) as razões $E u / E u^{*}$, nos granitóides desse maciço são, respectivamente 13,71(BSGEm), 13,69 (SGH), 13,60(MSG) e 13,71(V.H). Essas razōes são muito semelhantes àquelas encontradas nos granitóides do maciço granitóide Antônio Vicente e parece caracterizar uma feição particular dos granitóides dessa suite. 
27) em relação aos ETRP, nota-se que, de um modo geral, os mais baixos conteúdos médios desses elementos encontram-se no BSGEm( $\Sigma E T R P=54,34)$. Eles aumentam gradativamente no sentido das facies $S G H\left(\sum E T R P=62,65\right)$ e $M S G\left(\sum E T R P=88,25\right)$, atingem as mais elevadas concentraçōes relativas no veio hidrotermal( $\left.\sum E T R P=94,79\right)$. Dentre os granitóides esse "trend" é ilustrado pelas razões (La/Yb) $)_{N}$, cujos valores são 1,03(BSGEm), $0,93(\mathrm{SGH})$ e 0,27 (MSG).

28) no que se refere às condições de cristalização, concluiu-se que os granitóides desse maciço cristalizaram em condições de baixa fugacidade de oxigênio, em temperaturas em torno dos $700^{\circ} \mathrm{C}$ e baixas pressões( \pm 1kbar) e que foram colocados claramente em nivel crustal alto. 


\section{CAPÍTULO 5}

\section{5- MACIÇO GRANITÓIDE MOCAMBO(MGM)}

\section{1-Contexto Geológico}

Esse maciço aflora no contexto da interface do Cinturão de Cisalhamento Itacaiúnas e da Bacia do Médio Xingu(CPRM/DNPM, 1991), àcerca de $21 \mathrm{Km}$ a sudeste da cidade de São felix do Xingu. Está representado por um corpo principal, maior, e três "satélites" menores, desconectados fisicamente entre si(Figura 5.1). O corpo principal mostra uma forma irregular, alongada na direção NW-SE e apresenta uma área aflorante de aproximadamente $7 \mathrm{Km}^{2}$. É intrusivo, discordantemente, em rochas metassedimentares e metavulcânicas máficas do Grupo São Felix e em vulcânicas andesíticas da Formação Sobreiro. No que se refere aos três corpos menores, dois tem contornos, aproximadamente, circulares(um a NW e outro a SE do corpo principal), enquanto que o terceiro(situado a SE do corpo principal) exibe forma alongada na direção NE-SW. São intrusivos, respectivamente, em rochas metavulcânicas máficas e metassedimentares do grupo São Felix e em vulcânicas andesiticas da Formação Sobreiro, do Grupo Uatumã(Figuras 2.3 e 5.1).

\section{2- Histórico}

Foi introduzida na literatura por Abreu \& Ramos(1974) sob a designação de "Serra do Mocambo" e em seguida Silva et al.(1974) o consideram como sendo pertencente à mesma fase magmática dos granitos "tipo velho guilherme". Atualmente, faz parte da Suite Intrusiva Velho Guilherme(CPRM/DNPM, 1991).

Abreu \& Ramos(op. cit) realizaram, neste maciço, estudos petrográficos superficiais objetivando caracterizar os granitóides ocorrentes no interior do mesmo. Adicionalmente, estudaram, também, as suas encaixantes e efetuaram, ainda, estudos de minerais pesados em amostras de sedimentos aluvionares associados aos igarapés que cortam o corpo granitóide, visando identificar as mineralizações vinculadas aos granitóides do maciço, bem como estimar o seu potencial em termos de reserva de cassiterita.

Silva et al.(1974) executaram estudos voltados, quase que exclusivamente, para o posicionamento estratigráfico desse corpo granitóide.

A exemplo dos maciços granitóides Antônio Vicente e Velho Guilherme, esse maciço foi estudado pela primeira vez, de modo mais especifico, por Dall'Agnol(1980). Os estudos realizados por esse autor, voltaram-se para aspectos petrográficos e geoquímicos, 
buscando caracterizar os processos de alterações tardi a pós-magmáticas que afetaram os granitóides, em diferentes intensidades, e compreender a história petrológica e magmática dos mesmos.

Dall'Agnol(1982a, 1984), Dall'Agnol et al.(1986) e Dall'Agnol et al.(1993b), apresentaram uma série de discussões acerca de diversos maciços granitóides ocorrentes na Amazônia Oriental e, dentre eles, o maciço Mocambo. Os vários aspectos abordados por esses autores já foram apresentados, anteriormente, quando dos comentários relativos aos maciços Velho Guilherme e Antônio Vicente, sendo desnecessário repetí-los aqui.

\section{3- Aspectos de Campo e Amostragem}

A retomada dos estudos sobre esse maciço propiciou a realização de uma amostragem mais abrangente do corpo, bem como possibilitou confeccionar um mapa geológico mais atualizado do mesmo. No entanto, as mesmas limitações apresentadas em relação aos outros maciços, vistos anteriormente, são válidas para o maciço granitóide Mocambo. Ou seja, o difícil acesso à área de ocorrência desse maciço aliado à falta de infra-estrutura prejudicaram, sobremaneira, a obtenção de uma visão mais abrangente do mesmo. De qualquer modo, houve avanços e isso justifica o trabalho realizado.

Os trabalhos de campo obedeceram os mesmos princípios e técnicas utilizadas no estudo dos outros maciços. Adicionalmente, foi utilizado um mapa geológico fornecido pela Mineração São Francisco de Assis Ltda, o qual possibilitou um reconhecimento prévio àcerca da gelogia do corpo.

\section{4- Aspectos Petrográficos}

No atual nível de erosão, esse maciço granitóide representa uma cúpola intensamente afetada por processos de alterações tardi a pós-magmáticas, decorrente da interação rocha/fluidos tardios enriquecidos em voláteis.

Neste contexto, os estudos petrográficos revelaram, pelo menos, três tipos faciológicos distintos entre si, os quais mostram-se representados por: 1) sienogranito a monzogranito porfiritico(SMGP); 2) sienogranito com muscovita(SGMv); 3) aplito álcalifeldspato granítico(AAFG). Além dos granitóides, foi caracterizado um corpo de siderofilitaclorita-muscovita-quartzo greisen(SCMQGs), associado a esse maciço granitóide..

\subsection{1- Facies SMGP}

Essa variedade parece representar a facies dominante, em área de abrangência, no contexto do corpo principal, concentrando-se, preferencialmente, nas porções S e NNW e, subordinadamente, na região SE do mesmo. 
A Tabela 5.1 mostra as composições modais desse granitóide e a Figura 5.2(a, b) ilustra a distribuição dessas composições nos diagramas $Q-A-P$ e $Q-(A+P)-M$ '(Streckeisen, 1976; Le Maitre, 1989).

Tabela 5.1. Composições modais do sienogranito a monzogranito porfirítico(SMGP). Maciço granitóide Mocambo. Tr= traço; $\mathrm{Nd}=$ näo detectado; $\mathrm{Nc}=$ näo contado.

\begin{tabular}{|l|c|c|c|c|c|c|c|c|}
\hline VARIEDADE & \multicolumn{9}{|c|}{ SMGP } \\
\hline AMOSTRAS & $\begin{array}{c}\text { NN-GM- } \\
56\end{array}$ & $\begin{array}{c}\text { NN-GM- } \\
20\end{array}$ & $\begin{array}{c}\text { NN-GM- } \\
20 A\end{array}$ & $\begin{array}{c}\text { NN-GM- } \\
57\end{array}$ & $\begin{array}{c}\text { NN-GM- } \\
28 A\end{array}$ & $\begin{array}{c}\text { NN-GM- } \\
28\end{array}$ & $\begin{array}{c}\text { NN-GM- } \\
56 \text { - }\end{array}$ & $\begin{array}{c}\text { NN-GM- } \\
29 C\end{array}$ \\
\hline & 1 & 2 & 3 & 4 & 5 & 6 & 7 & 8 \\
\hline $\begin{array}{l}\text { MINERAIS } \\
\text { PRIMARIOS(\%) }\end{array}$ & & & & & & & & \\
\hline QUARTZO & 25 & 31 & 32 & 42 & 44 & 47 & 49 & 49 \\
\hline PLAGIOCLASIO & 18 & 14 & 15 & 12 & 21 & 14 & 12 & 09 \\
\hline K-FELDSPATO & 32 & 28 & 25 & 16 & 17 & 17 & 12 & 08 \\
\hline BIOTITA & $\mathrm{Nd}$ & 03 & 01 & $\mathrm{Nd}$ & $\mathrm{Nd}$ & $\mathrm{Nd}$ & $\mathrm{Nd}$ & $\mathrm{Nd}$ \\
\hline ZIRCÁO & $\mathrm{Tr}$ & $\mathrm{Tr}$ & $\mathrm{Tr}$ & $\mathrm{Tr}$ & $\mathrm{Tr}$ & $\mathrm{Tr}$ & $\mathrm{Tr}$ & $\mathrm{Tr}$ \\
\hline MINERAISOPACOS & $\mathrm{Tr}$ & $\mathrm{Tr}$ & $\mathrm{Tr}$ & $\mathrm{Tr}$ & $\mathrm{Tr}$ & $\mathrm{Tr}$ & $\mathrm{Tr}$ & $\mathrm{Tr}$ \\
\hline MINERAIS \\
SECUNDÁRIOS(\%)
\end{tabular}

No diagrama Q-A-P observa-se que predomina uma composição sienogranítica, com apenas uma amostra incidindo no campo do monzogranito. Nota-se, ainda, que trata-se de um granitóide tipicamente subsolvus(Tuttle \& Bowen, 1958). No diagrama Q-(A+P)-M' verifica-se que os valores de $\mathrm{M}^{\prime}$ de algumas amostras são menores que $5 \%$, enquanto que os de outras situam-se entre $5 \%$ e $10 \%$, indicando uma natureza holo-leucocrático a leucocrático para o mesmo. 
Figura 5.1- Mapa geológico da área de ocorrência do maciço granitóide Mocambo. 


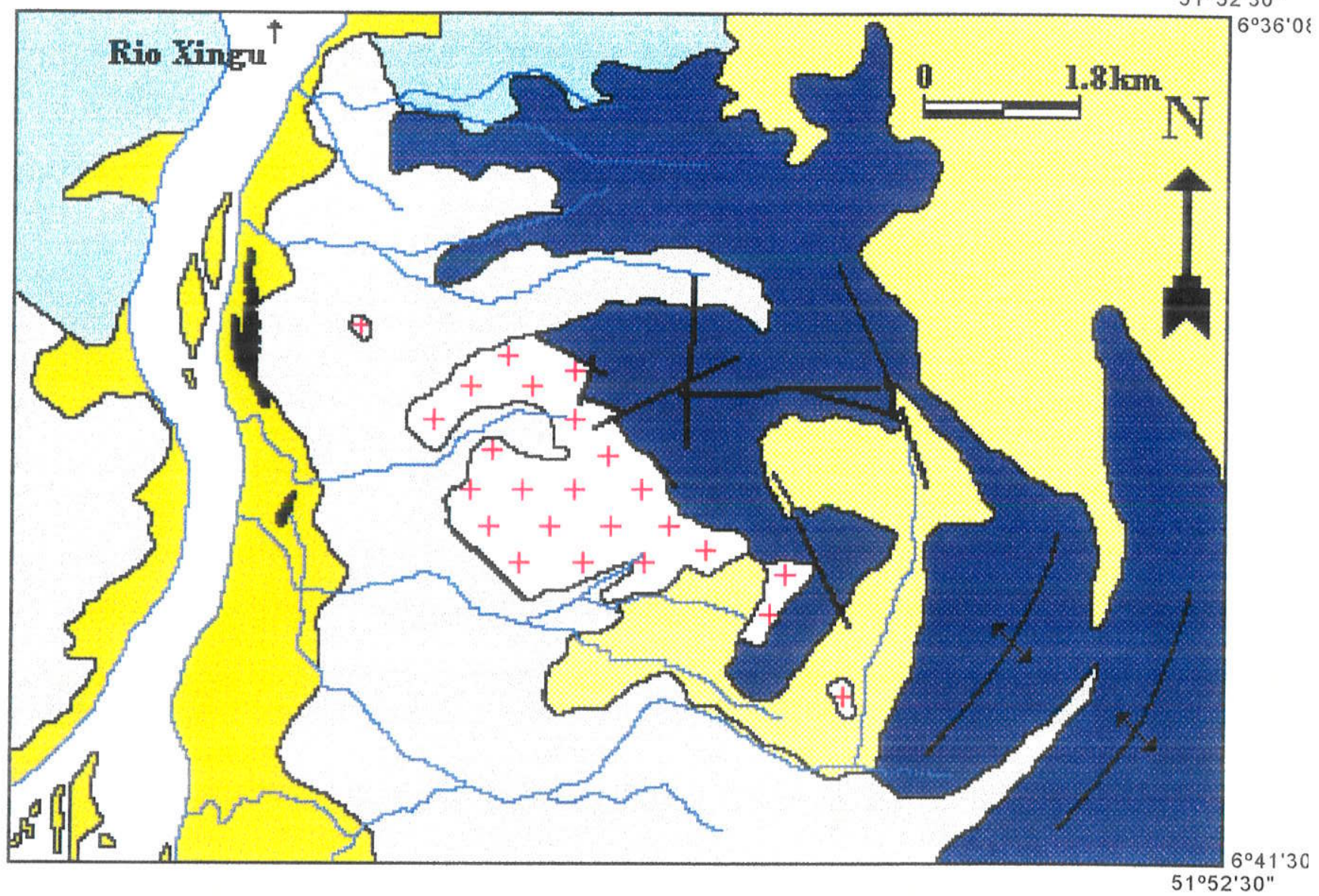

Sedimentos Aluvionares

\section{SUITE INTRUSIVA VELHO GUILHERME}

†H Maciço granitóide Mocambo: Sienogranito a monzogranito porfiritico e sienogranito com muscovita (SGMV), com siderofilita-clorita-muscovita-quartzo greisen associado.

\section{GRUPO UATUMÃ}

Formação Iriri: Riolito e tufos riolíticos com riodacitos, dacito, tufos riodaciticos e daciticos subordinados

Formaçäo Sobreiro: Rochas andesiticas com traquito e traqui-andesito subordinados e raras clastolavas.

\section{GRUPO SÃO FÉLIX}

Rochas Metassedimentares

Rochas Metavulcânicas máficas
[1) Contatos fotolitológicos

T' Traços de fraturas e/ou falhas

5. Eixos de Antiformes

तो Drenagem

Lagos 
Essas características permitem concluir que tal granitóide é uma rocha extremamente diferenciada que, ao que tudo indica, foi gerada por um líquido muito evoluído e silicoso. Além disso, esse perfil petrográfico guarda muitas semelhanças com as facies mais evoluídas e mais afetadas por alterações tardi a pós-magmáticas dos maciços granitóides Antônio Vicente e Velho Guilherme.

Deve-se ressaltar, entretanto, que assim como nos maciços Antônio Vicente e Velho Guilherme, essas composições não representam as composições magmáticas originais desse granitóide, visto que o mesmo foi afetado por alterações tardi a pós-magmáticas, as quais causaram modificações na sua composição mineralógica original e se refletiram nas análises modais, conforme já foi referido anteriormente.

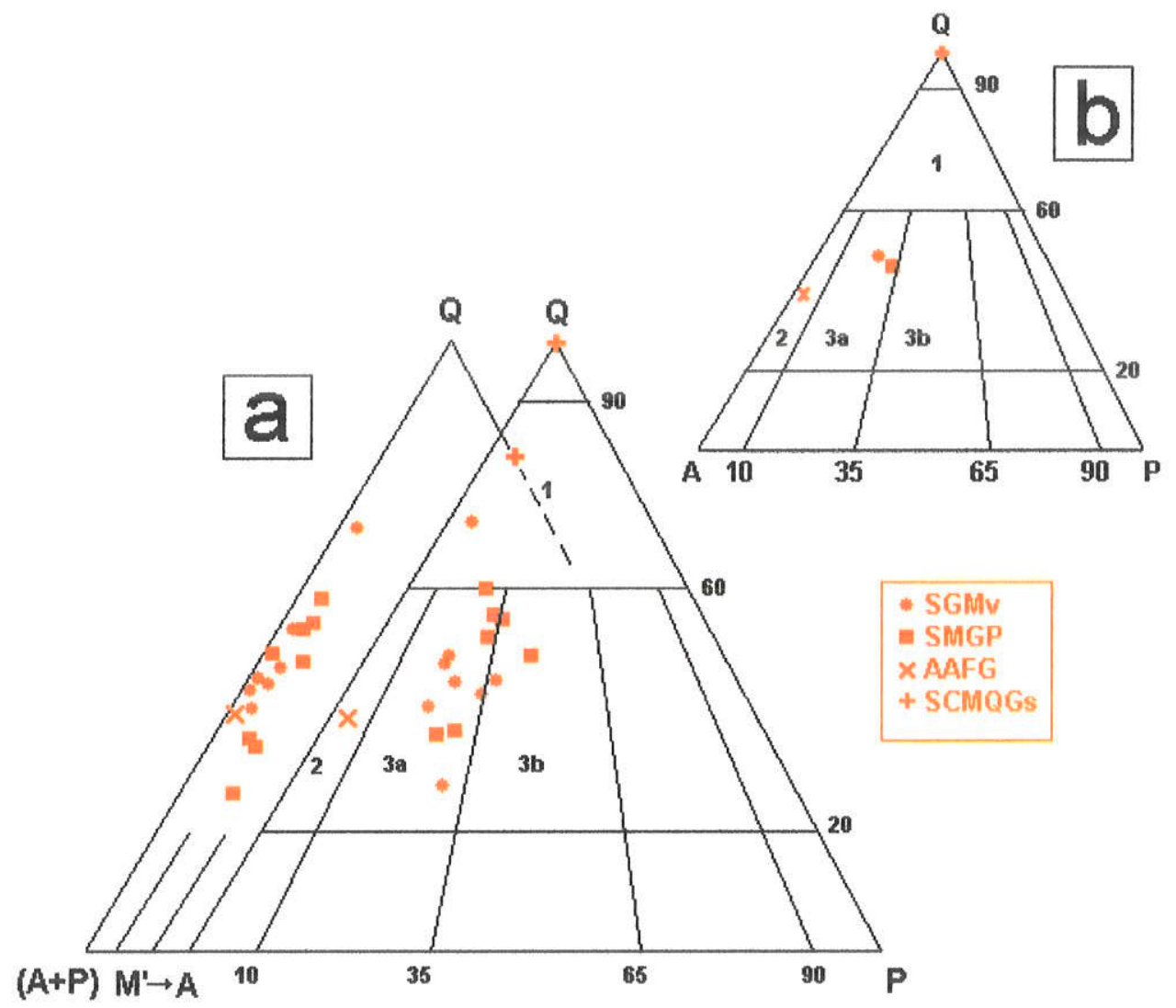

Figura 5.2. Diagramas triangulares $Q-A-P$ e $Q-(A+P) M^{\prime}$ de Streckeisen(1976) mostrando a distribuição composicional modal geral dos ganitóides e greisen do maciço granitóide Mocambo(a) e suas composições médias(b).

\subsubsection{1- Textura e Mineralogia.}

O SMGP exibe textura porfirítica, caracterizada pela presença de fenocristais gossos de quartzo e plagioclásio, imersos em uma matriz hipidiomórfica, heterogranular, média a fina e apresenta coloração cinza-esbranquiçada(Prancha 18; Fotos a, b). 
Consiste essencialmente de quartzo, feldspato potássico $\left(\mathrm{Fk}_{1}\right)$ e plagioclásio $\left(\mathrm{Pl}_{\uparrow}\right.$ e $\mathrm{PI}_{2}$ ), sendo varietal a biotita. Como minerais acessórios ocorrem zircão e minerais opacos $\left(\mathrm{MOP}_{1}\right)$.

As fases minerais atribuidas ao estágio de alteração tardi a pós-magmática estão representadas por sericita \pm muscovita $\left(\mathrm{MV}_{1}\right) \pm \operatorname{clorita}\left(\mathrm{Cl}_{1}\right) \pm$ fluorita $\left(\mathrm{Fl}_{1}\right) \pm$ epidoto $\left(\mathrm{Ep}_{1}\right) \pm$ topázio(Top 1 ) \pm carbonato e feldspato potássico $\left(F_{2}\right)$ associados à substituição parcial do plagioclásio, especialmente, do plagioclásio1, albita e argilo-minerais relacionada à alteração dos feldspatos potássicos, clorita $\left(\mathrm{Cl}_{2}\right) \pm$ fluorita $\left(\mathrm{Fl}_{2}\right) \pm$ muscovita $\left(\mathrm{Mv}_{2}\right) \pm$ allanita \pm siderofilita \pm minerais opacos $\left(M O P_{2}\right) \pm$ epidoto $\left(E p_{2}\right) \pm$ quartzo( $\left(Q t z_{3}\right)$ vinculados à desestabilização da biotita e topázio $\left(\mathrm{Top}_{2}\right)$.

O quartzo ocorre em, pelo menos, cinco variedades texturais/morfológicas a saber:

1) a variedade $1\left(Q t z_{1}\right)$ forma grãos grossos(fenocristais) subédricos, por vezes, fraturados e com forte extinção ondulante. Desenvolve contatos irregulares e suturados, entre si e com outras fases minerais, embora, muito localmente, ocorram contatos retos. Algumas vezes, hospeda minúsculas inclusões de zircão, plagioclásio $\left(\mathrm{Pl}_{1}\right)$ e de feldspato potássico( $\left.\mathrm{Fk}_{1}\right)$.

2) o tipo $2\left(\mathrm{Qtz} \mathrm{z}_{2}\right)$ difere do tipo 1 pela granulação e, às vezes, pela forma. Apresentase como grãos anédricos a subédricos, de granulação fina a média. Seus contatos são mais regulares, embora contatos retos e poligonizados possam ocorrer em menor escala. Localmente, exibe inclusões de plagioclásio $\left(P l_{1}\right)$ e feldspato potássico $\left(F k_{1}\right)$. Costuma se apresentar menos fraturado e mostra extinção ondulante moderada.

3) a variedade $3\left(Q t z_{3}\right)$ forma grãos anédricos, de granulação fina a média e mostrase uma estreita relação com a biotita, especialmente quando esta está parcialmente cloritizada, ocorrendo, juntamente, com clorita $\left(\mathrm{Cl}_{2}\right) \pm$ muscovita $\left(\mathrm{Mv}_{2}\right) \pm$ siderofilita \pm allanita \pm epidoto $\left(E p_{2}\right) \pm$ minerais opacos $\left(\mathrm{MOP}_{2}\right) \pm$ fluorita $\left(\mathrm{Fl}_{2}\right)$.

4) o quarto tipo(Qtz $)$ está representado por grãos anédricos, dispostos intersticialmente em relação ao plagioclásio $\left(\left.P\right|_{1}\right)$, feldspato potássico $\left(F k_{1}\right)$ e quartzo $\left(Q t z_{1}\right)$.

5) o quinto tipo(Qtz $)_{5}$ representa um silicificação tardia no curso da greisenização.

O plagioclásio, por sua vez, ocorre em, pelo menos, duas variedades, considerandose para isso a dimensão dos cristais, a morfologia e o modo de ocorrência.

O tipo $1\left(\mathrm{Pl}_{1}\right)$ é o mais comum, sendo amplamente dominante sobre os demais tipos. Apresenta-se como grãos anédricos a subédricos, médios a grossos(fenocristais). Seus contatos são variáveis, desde irregulares a interpenetrantes(principalmente com o feldspatos potássicos) até retos. Costuma estar mais intensamente afetado por alterações tardi a pós-magmáticas, as quais são traduzidas pela substituição parcial ou total dos cristais por sericita \pm muscovita $\left(\mathrm{Mv}_{1}\right) \pm \operatorname{clorita}\left(\mathrm{Cl}_{1}\right) \pm$ fluorita( $\left(\mathrm{Fl} \mathrm{I}_{1}\right) \pm$ topázio(Top $\left.{ }_{1}\right) \pm$ 
epidoto $\left(E p_{1}\right) \pm$ carbonato e feldspato potássico( $\left.F k_{2}\right)$, conforme pode ser observado nas Fotos c, d da Prancha 18. Há uma tendência dessa suite mineral se desenvolver, de modo mais intenso, nas porções centrais dos grãos(cristais com zoneamento normal). Esse fato evidencia uma descalcificação dos cristais zonados nessas regiōes, ao que tudo indica, mais cálcicas(Smith, 1974; Haapala, 1977; Dall'Agnol, 1980; Borges, 1997). As maclas nem sempre são muito nítidas, visto que, por vezes, mostram-se mascaradas por essas alterações. De qualquer forma, quando perceptíveis, são regidas pelas leis da albita e albitaCarisbad. Em termos composicionais, embora não tenha sido possivel determinar sua composição oticamente, pelo seu aspecto e relevo, parece tratar-se de albita-oligoclásio.

A variedade $2\left(\mathrm{Pl}_{2}\right)$ é correlacionável àquela já descrita em granitóides de outros maciços como $\mathrm{Pl}_{2}$, particularmente, do maciço granitóide Antônio Vicente("poikilitic albite"; conforme Fisher, 1971). Tem ocorrência muito localizada e ocorre como inclusões em cristais grossos de feldspato potássico $\left(\mathrm{Fk}_{2}\right)$. Os grãos são subédricos, de aspecto límpido e exibem maclas nítidas, as quais mostram-se regidas pelas leis da albita. Em termos composicionais, pelo seu aspecto e relevo, deve corresponder a uma composição albítica.

O feldspato potássico ocorre segundo, pelo menos dois tipos. O tipo 1(Fk 1 forma grãos anédricos a subédricos, de granulação média. Subordinadamente, apresenta-se na forma intersticial. E caracteristicamente pertítico, embora seja mais empobrecido em pertitas do que o tipo $2\left(\mathrm{Fk}_{2}\right)$. As fases albíticas das pertitas mais comuns estão representadas por "film", "band" e "vein perthites"(Alling, 1932 e 1938). Esses tipos são compostos(Alling, 1938), visto que ocorrem associados, gradando de um tipo a outro em um mesmo cristal. Mostra-se afetado por alterações tardi a pós-magmáticas, cujos produtos mais comuns são albita, sericita+muscovita $\left(\mathrm{Mv}_{3}\right)$ e argilo-minerais, que em algumas amostras chegam a atingir teores significativos. As vezes, encontra-se maclado sob as leis de Carisbad. Maclas tipo albita-periclina não foram observadas, o que, em termos óticos dificulta a caracterização da sua tipologia. Além disso, não foram realizados estudos aos raios- $X$, com vistas a caracterizar seu grau de triclinicidade. Entretanto, pelo seu aspecto e semelhança com aqueles descritos em granitóides dos maciços apresentados anteriormente e na literatura(Smith, 1974), pensa-se tratar-se de microclina pertítica. O mesmo é válido para o segundo tipo.

O tipo $2\left(\mathrm{Fk}_{2}\right)$ está vinculado à substtituição parcial do plagioclásio $\left(\mathrm{Pl}_{1}\right.$ e $\left.\mathrm{Pl}_{2}\right)$. Apresenta-se como cristais, grossos, anédricos e pertíticos. Os tipos de pertitas mais comuns mostram-se representados por "string", "film", "band", "vein" e, sobordinadamente, "patch perthites"(Alling, op. cit.). Assim como em relação ao $\mathrm{Fk}_{1}$, são pertitas compostas, as quais gradam de um tipo a outro em um mesmo cristal. Costuma estar parcialmente 
alterado e os principais produtos mostram-se representados por albita, sericita+muscovita $\left(\mathrm{Mv}_{3}\right)$ e argilo-minerais.

A biotita ocorre como lamelas anédricas, finas a médias, as quais se encontram, via de regra, alteradas, em diferentes graus, para clorita $\left(\mathrm{Cl}_{2}\right) \pm$ minerais opacos $\left(\mathrm{MOP}_{2}\right) \pm$ fluorita $\left(\mathrm{Fl}_{2}\right) \pm$ epidoto $\left(\mathrm{Ep}_{2}\right) \pm$ allanita \pm muscovita $\left(\mathrm{Mv}_{2}\right) \pm$ siderofilita \pm quartzo3, que costumam estar dispostas ao longo dos planos de clivagem da mesma(Prancha 18, Foto e). Exibe pleocroismo moderado, variando de castanho escuro( $Z$ e $Y)$ a castanho claro-amarelado $(X)$. As vezes, hospeda inclusões de zircão, com o qual desenvolve nítidos halos pleocróicos.

Em relação aos minerais acessórios, o zircão é o mais freqüente. Ocorre como minúsculos cristais subédricos a euédricos relacionados às fases micáceas. Os minerais opacos, por seu turno, ocorrem tanto como restos primários, associados às fases minerais máficas, tais como biotita e zircão, quanto em estreita associação com a biotita.

No que se refere aos produtos de alterações tardi a pós-magmáticas, foram agrupados em, pelo menos, três conjuntos principais a saber:

1) $O$ conjunto 1 está corresponde a um primeiro evento autometassomático, de natureza potássica, ao qual está associada a substituição, em diferentes graus, do plagioclásio primário $\left(\mathrm{Pl}_{1}\right)$ por sericita $\pm \operatorname{muscovita}\left(\mathrm{Mv}_{1}\right) \pm$ fluorita $\left(\mathrm{Fl}_{1}\right) \pm$ topázio $\left(\mathrm{Top}_{1}\right) \pm$ clorita $\left(\mathrm{Cl}_{1}\right) \pm$ epidoto $\left(E \mathrm{p}_{1}\right) \pm$ carbonato, em uma fase inicial, prosseguindo com a substituição, do mesmo, por microclina pertítica(Fk 2$)($ Prancha 18; Fotos $\mathrm{c}, \mathrm{d}$ ).

2) O conjunto 2 é atribuído a um segundo evento, dessa feita, de natureza sódica, caracterizado pela substituição parcial do feldspatos potássicos $\left(F k_{1}\right.$ e $\left.F k_{2}\right)$ e do plagioclásio $1\left(\mathrm{Pl}_{1}\right)$, por albita(albitização). $O \mathrm{Pl}_{2}$ parece ter sido poupado por esse processo, visto que mostra-se inalterado. Paralelamente a este evento de albitização, ocorreu a substituição da biotita expressa pela associação clorita $\left(\mathrm{Cl}_{2}\right) \pm$ minerais opacos $\left(\mathrm{MOP}_{2}\right) \pm$ fluorita( $\left(\mathrm{Fl}_{2}\right) \pm$ epidoto $\left(\mathrm{Ep}_{2}\right) \pm$ allanita \pm muscovita $\left(\mathrm{Mv}_{2}\right) \pm$ siderofilita \pm quartzo3(Prancha 18; Foto $\mathrm{e}$ ).

3) O conjunto 3 está relacionado a um segundo evento autometassomático, de natureza potássica, com silicificação associada(greisenização), os quais são traduzidos pela substituição, parcial dos feldspatos(feldspatos potássicos e plagioclásios) e do topázio(Top ${ }_{2}$ ) por muscovita( $\left(\mathrm{Mv}_{2}\right.$; Prancha 18, Foto f; Prancha 19, Fotos a, b) e recristalização de quartzo(Qtz $)$, culminando com greisenização.

A alteração argílica associada aos feldspatos potássicos tem posicionamento duvidoso, visto que permeia quase todos esses eventos, uma vez que está presente em todos esses momentos, exceto na greisenização.

Essas feicões petrográficas são muito semelhantes àquelas observadas nas facies mais evoluidas e mais intensamente afetadas por alterações tardi a pós-magmáticas dos 
maciços granitóides Antônio Vicente e Velho Guilherme, embora, neste granitóide, mostremse mais intensamente desenvolvidas.

Além disso, é importante ressaltar que em algumas amostras, desse granitóide, o topázio assume conteúdos, relativamente, significativos, chegando a atingir até $5 \%$ modal. 0 mesmo ocorrendo com muscovita $\left(\mathrm{Mv}_{2}\right)$ e siderofilita que são mais expressivas nesse granitóide em relação aqueles dos maciços Antônio Vicente e Velho Guilherme.

\subsubsection{2- Ordem de Cristalização}

O exame de lâminas delgadas voltado para o entendimento da ordem de cristalização das fases minerais constituintes dessa facies granitóide permitiu estabelecer a seguinte seqüência de separação dos cristais a partir do liquido magmático que as gerou:

1) a exemplo dos granitóides dos maciços apresentados anteriormente, as fases acessórias primárias representadas por zircão e minerais opacos $\left(M O P_{1}\right)$ foram as primeiras a se separarem do liquido magmático ou representam resíduos do protólito do granitóide em questão. Isso é justificado pelo fato das mesmas ocorrerem como inclusões, especialmente, o zircão(mais freqüente) nas fases essenciais- quartzo( $\left(Q t_{1}\right)$, plagioclásio $\left(P I_{1}\right)$ e feldspato potássico( $\left.\mathrm{Fk}_{1}\right)$ - e na biotita.

2) as fases essenciais parecem ter se separado do magma dentro de um mesmo intervalo de pressão e temperatura. Entretanto, a presença de inclusões de finos cristais tabulares de plagioclásio e de feldspato potássico em grãos de quartzo, especialmente, naqueles do tipo $1\left(Q t z_{1}\right)$, sugerem que os mesmos tenham se separado um pouco antes desse mineral. Posteriormente, já em condições eutéticas, essas três fases seguiram um curso de cristalização conjunto, que parece ter se encerrado com a cristalização intersticial desses minerais.

3) quanto à biotita, é muito difícil estabelecer o momento de sua separação do magma e a sua relação cronológica com as fases assenciais. Isso decorre do fato da mesma costumar estar parcialmente alterada, o que mascara suas relações com as referidas fases. Entretanto, restos de biotita, de ocorrência intersticial, em relação ao quartzo, indicam que a mesma cristalizou um pouco depois do mesmo ou, ainda, no mesmo momento do quartzo 4(intersticial). De qualquer modo, houve dificuldade em estabelecer o momento de separação da biotita, visto que não se observou uma relação de inclusões desse mineral com as fases essenciais e vice-versa.

4) O final da seqüência de cristalização, no estágio magmático, é marcado, ao que tudo indica, por um evento de albitização, que originou o plagioclásio $2\left(\mathrm{Pl}_{2}\right)$, de composição albitica, traduzido pela "piokilitic albite"(Fisher, 1971; Smith, 1974). Posteriormente, já no 
estágio de alterações tardi a pós-magmásticas, esse plagioclásio foi englobada, como inclusão, pelo feldspato potásico2( $\left.\mathrm{Fk}_{2}\right)$.

5) As demais fases estão associadas ao estágio de alterações tardi a pósmagmáticas.

A Figura 5.3 mostra de forma resumida um fluxograma das seqüencias de cristalização das fases minerais associadas aos estágios magmático e tardi a pósmagmático.

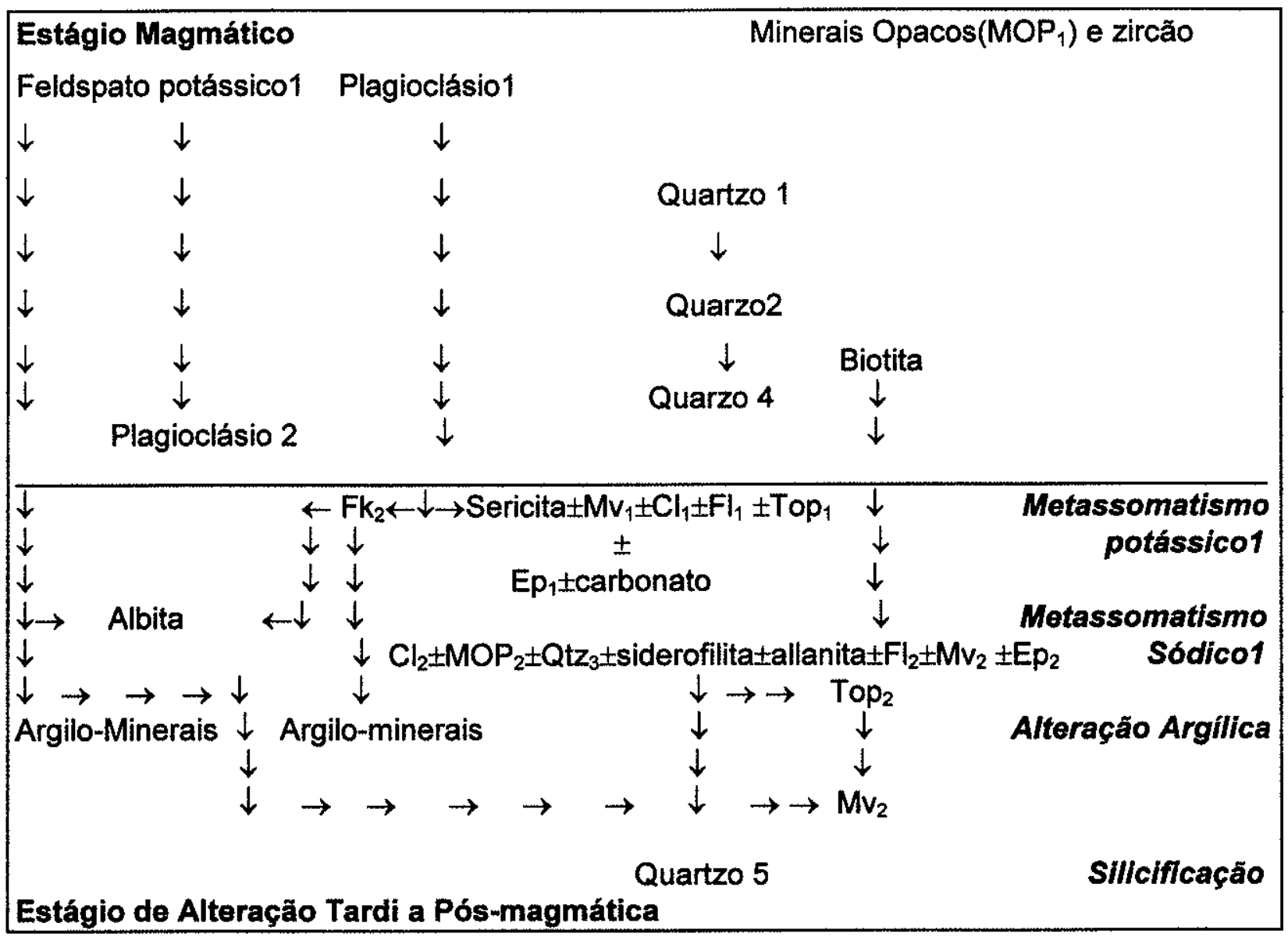

Figura 5.3- Fluxograma mostrando um esboço esquemático da seqüência de cristalização magmática e tardi a pós-magmática das fases minerais da facies SMGP do maciço granitóide Mocambo.

\subsection{2- Facies SGMv}

Essa variedade ocupa uma pequena área do corpo principal e a quase totalidade das duas apófises situadas a sudeste do mesmo(Anexo 25).

$\mathrm{Na}$ Tabela 5.2 são apresentadas as composições modais desse granitóide e na Figura 5.2 é mostrada a distribuição dessas composições nos diagramas $Q-A-P$ e $Q-(A+P)$ M'(Streckeisen, 1976). 
Tabela 5.2- Composições modais do Sienogranito com muscovita(SGMv) e rocha aplitica(AAPG). Maciço granitóide Mocambo. $\mathrm{Tr}=$ traços; $\mathrm{Nd}=$ não detectado; $\mathrm{Nc=}$ não contado.

\begin{tabular}{|c|c|c|c|c|c|c|c|c|}
\hline \multirow{2}{*}{$\begin{array}{l}\text { VARIEDADES } \\
\text { AMOSTRAS }\end{array}$} & \multicolumn{7}{|c|}{ SGMV } & \multirow{2}{*}{$\begin{array}{c}\text { AAFG } \\
\text { NN-GM- } \\
27 \mathrm{~A}\end{array}$} \\
\hline & $\begin{array}{l}\text { NN-GM- } \\
26 \\
\end{array}$ & $\begin{array}{l}\text { NN-GM- } \\
24 \\
\end{array}$ & $\begin{array}{l}\text { NN-GM- } \\
15\end{array}$ & $\begin{array}{l}\text { NN-GM- } \\
25 \\
\end{array}$ & $\begin{array}{c}\text { NN-GM- } \\
178\end{array}$ & $\begin{array}{c}\text { NN-GM- } \\
17 \mathrm{C} \\
\end{array}$ & $\begin{array}{l}\text { NN-GM- } \\
17 \mathrm{~A}\end{array}$ & \\
\hline & 9 & 10 & 11 & 12 & 13 & 14 & 15 & 16 \\
\hline \multicolumn{9}{|l|}{$\begin{array}{l}\text { MINERAIS } \\
\text { PRIMÁRIOS(\%) }\end{array}$} \\
\hline QUARTZO & 32 & 35 & 35 & 38 & 39 & 41 & 50 & 34 \\
\hline PLAGIOCLÁSIO & 10 & 10 & 15 & 17 & 09 & 09 & 02 & - \\
\hline K-FELDSPATO & 13 & 19 & 20 & 19 & 24 & 26 & 06 & 35 \\
\hline BIOTITA & Nd & $\mathrm{Nd}$ & 01 & $\mathrm{Nd}$ & $\mathrm{Nd}$ & $\mathrm{Nd}$ & $\mathrm{Nd}$ & - \\
\hline ZIRCAOO & $\mathrm{Tr}$ & $\operatorname{Tr}$ & $\mathrm{Tr}$ & $\mathrm{Tr}$ & $\mathrm{Tr}$ & $\mathrm{Tr}$ & $\mathrm{Tr}$ & $\mathrm{Tr}$ \\
\hline $\begin{array}{l}\text { MINERAIS } \\
\text { OPACOS }\end{array}$ & $\mathrm{Tr}$ & $\mathrm{Tr}$ & $\mathrm{Tr}$ & $\overline{\mathrm{Tr}}$ & $\overline{T r}$ & $\mathrm{Tr}$ & $\mathrm{Tr}$ & $\mathrm{Tr}$ \\
\hline RUTILO & $\overline{\mathrm{Nd}}$ & $\mathrm{Nd}$ & $\mathrm{Nd}$ & $\mathrm{Nd}$ & $\mathrm{Nd}$ & $\mathrm{Nd}$ & $\mathrm{Nd}$ & $\mathrm{Tr}$ \\
\hline \multicolumn{9}{|l|}{$\begin{array}{l}\text { MINERAIS } \\
\text { SECUNDÁRIOS(\%) }\end{array}$} \\
\hline $\begin{array}{l}\text { SERICITA } \pm \text { MUSCO } \\
\text { VITA }\end{array}$ & 20 & 10 & 13 & 11 & 11 & 07 & 21 & 08 \\
\hline K-FELDSPATO & Nc & Nc & Nc & Nc & Nc & Nc & Nc & Nc \\
\hline ALBITA & 16 & 21 & 11 & 10 & 09 & 08 & 12 & 18 \\
\hline SIDEROFILITA & $\mathrm{Tr}$ & $\mathrm{Tr}$ & $\mathrm{Tr}$ & $\mathrm{Tr}$ & $\operatorname{Tr}$ & $\mathrm{Tr}$ & $\mathrm{Tr}$ & \\
\hline CLORITA & 04 & 03 & 01 & 01 & 02 & 01 & 05 & Nd \\
\hline MUSCOVITA & 04 & 01 & 03 & 03 & 05 & 07 & 03 & 04 \\
\hline ALLANITA & $\mathrm{Nd}$ & $\mathrm{Nd}$ & $\mathrm{Tr}$ & $\mathrm{Tr}$ & $\mathrm{Tr}$ & $\mathrm{Tr}$ & $\mathrm{Tr}$ & $\mathrm{Nd}$ \\
\hline FLUORITA & $\mathrm{Tr}$ & 01 & 01 & 01 & 01 & 01 & 01 & $\mathrm{Nd}$ \\
\hline TOPAZZIO & $\mathrm{Tr}$ & $\overline{\mathrm{Tr}}$ & $\mathrm{Tr}$ & $\mathrm{Tr}$ & $\mathrm{Tr}$ & $\mathrm{Tr}$ & $\mathrm{Tr}$ & $\mathrm{Nd}$ \\
\hline ESFALERITA & $\mathrm{Tr}$ & $\mathrm{Tr}$ & $\mathrm{Tr}$ & $\mathrm{Tr}$ & $\mathrm{Tr}$ & $\mathrm{Tr}$ & $\mathrm{Tr}$ & $\mathrm{Nd}$ \\
\hline $\begin{array}{l}\text { MINERAIS } \\
\text { OPACOS }\end{array}$ & $\mathrm{Tr}$ & $\mathrm{Tr}$ & $\mathrm{Tr}$ & $\mathrm{Tr}$ & $\mathrm{Tr}$ & $\mathrm{Tr}$ & $\operatorname{Tr}$ & $\operatorname{Tr}$ \\
\hline CASSITERITA & $\overline{\mathrm{Tr}}$ & $T r$ & $\mathrm{Nd}$ & $\mathrm{Tr}$ & $\mathrm{Tr}$ & $\mathrm{Tr}$ & $\mathrm{Tr}$ & $\mathrm{Nd}$ \\
\hline ARGILO-MINERAIS & Nc & Nc & $\mathrm{Nc}$ & $\mathrm{Nc}$ & $\mathrm{Nc}$ & Nc & Nc & Nc \\
\hline \multicolumn{9}{|l|}{$\begin{array}{l}\text { COMPOSICAAO DO } \\
\text { PLAGIOCLÁSIO }\end{array}$} \\
\hline $\mathbf{Q}$ & 45 & 41 & 43 & 45 & 48 & 49 & 71 & 39 \\
\hline A & 41 & 47 & 38 & 35 & 41 & 40 & 26 & 61 \\
\hline$P$ & 14 & 12 & 19 & 20 & 11 & 11 & 03 & 0 \\
\hline$Q$ & 44 & 40 & 43 & 45 & 47 & 53 & 70 & 39 \\
\hline$A+P$ & 53 & 57 & 56 & 54 & 50 & 45 & 28 & 61 \\
\hline $\mathrm{M}^{\prime}$ & 03 & 03 & 01 & 01 & 03 & 02 & 02 & 0 \\
\hline $\begin{array}{l}\text { NÚMERO DE } \\
\text { PONTOS }\end{array}$ & 1500 & 1500 & 1500 & 1500 & 1500 & 1500 & 1500 & 1200 \\
\hline
\end{tabular}

No diagrama Q-A-P nota-se que a maioria das amostras incide no campo do sienogranito, com apenas uma amostra situando-se no campo dos granitóides enriquecidos em quartzo.

No diagrama $Q-(A+P)-M$ ' a totalidade das amostras ocupa uma área muito próxima à aresta $Q-(A+P)$, visto que os valores de $M$ ' são sempre inferiores a $5 \%$. 
Essas características indicam que esse granitóide é tipicamente subsolvus(Tuttle \& Bowen, 1958), tem natureza holo-leucocrática e que foi gerado a partir de líquidos muito evoluidos e silicosos, a exemplo dos granitóides dos maciços comentados anteriormente. Além disso, revelam uma estreita relação com a facies SMGP e com os granitóides do maciço granitóide Velho Guilherme(BSGEm e SGH), bem como com as facies mais evoluídas e mais alteradas do maciço granitóide Antônio Vicente(BSGA e BSGIA).

\subsubsection{1- Textura e Mineralogia}

Apresenta textura hipidiomórfica heterogranular média, com tendência a eqüigranular e exibe coloração cinza(Prancha 19, Fotos c, d).

Consiste essencialmente de quartzo( $\left(\mathrm{Qtz}_{1}\right.$ e $\left.\mathrm{Qtz} \mathrm{z}_{2}\right)$, plagioclásio e feldspato potássico. Como fases menores, acessórias, ocorrem biotita, zircão e minerais opacos $\left(\mathrm{MOP}_{1}\right)$.

Os minerais relacionadas ao estágio de alterações tardi a pós-magmáticas mostramse representadas por sericita + muscovita $\left(\mathrm{Mv}_{1}\right) \pm \operatorname{clorita}\left(\mathrm{Cl}_{1}\right) \pm$ fluorita $\left(\mathrm{Fl}_{1}\right) \pm$ Topázio $\left(\right.$ Top $\left._{1}\right)$ e microclina pertítica $\left(\mathrm{Fk}_{2}\right)$, associados à substituição do plagioclásio1, albita e argilo-minerais relacionados à alteração dos feldspatos potássicos e do plagioclásio1, clorita $\left(\mathrm{Cl}_{2}\right) \pm$ siderofilita(Sid) \pm muscovita $\left(\mathrm{Mv}_{2}\right) \pm$ Fluorita $\left(\mathrm{Fl}_{2}\right) \pm$ minerais opacos $(\mathrm{MOP}) \pm$ esfalerita \pm allanita, intimamente vinculados à cloritização da biotita, topázio2, cassiterita(ligada à oxidação da $\mathrm{Cl}_{2} \in \mathrm{Mv}_{2}$ ), ligados à alteração dos feldspatos potássicos.

O quartzo ocorre em, pelo menos três variedades a saber:

1) Quartzo1 $\left(Q t z_{1}\right)$ : ocorre sob a forma de grãos subédricos, embora ocorram, muito subordinadamente, cristais euédricos e anédricos. Ele costuma ser de dimensões médias, desenvolve contatos, quase sempre, retos e, algumas vezes, irregulares e suturados. Apresenta-se pouco deformado, raramente exibe fraturas e possui fraca extinção ondulante. As inclusões são pouco freqüentes e mostram-se representadas por zircão.

2) Quartzo 2(Qtz $)$ : apresenta-se como grãos anédricos, finos, os quais mostram-se associados à cloritização da biotita.

3) Quartzo3(Qtz $)$ : diz respeito ao quartzo vinculado à silicificação tardia no curso da greisenização.

Em relação ao feldspato potássico, face ao intenso grau de alteração dessa facies, não foi possivel caracterizar, claramente, variedades distintas, como ocorreu na facies granitóide apresentada anteriormente, bem como nas outras facies granitóides dos maciços já comentados. Apresenta-se como grãos subédricos, embora ocorram conteúdos menores de cristais anédricos e euédricos. Desenvolvem contatos entre si, bem como com outras fases minerais e, em especial, com plagioclásio e quartzo, irregulares, interpenetrantes e retos. É pertítico, sendo "band", "vein" e "patch perthites" comuns (Alling, 1932 e 1938) os 
tipos mais. Mostra-se albitizado(ver mais adiante) e muscovitizado, bem como encontra-se substituído por argilo-minerais. As maclas são pouco comuns e quando visíveis são do tipo Carisbad.

O plagioclásio, a exemplo do feldspato potássico, mostra-se bastante alterado, fato que prejudicou enormemente, qualquer distinção em variedades. Apresenta-se como cristais tabulares a semi-tabulares, anédricos a subédricos, finos a médios, os quais ocorrem ora em agregados, ora em grãos isolados, dispersos na rocha. Desenvolve contatos, entre si e com outras espécies minerais, do tipo reto(dominante), embora ocorram, subordinadamente, tipos irregulares e interpenetrantes(esse último, especialmente com o feldspato potássico). Suas maclas săo freqüentes, sendo mais comuns aquelas regidas pelas da albita e albitaCarlsbad. As alterações são expressivas e mostram-se representadas por sericita \pm muscovita $\left(\mathrm{Mv}_{1}\right) \pm \operatorname{clorita}\left(\mathrm{Cl}_{1}\right) \pm$ fluorita $\left(\mathrm{Fl}_{1}\right) \pm$ topázio(Top $\left.{ }_{1}\right)$ e microclina pertítica. Essas alterações mostram-se distribuidas amplamente sobre os cristais, não mais se concentrando em zonas preferenciais. Em termos composicionais, pelo seu aspecto e relevo, deve corresponder a uma composição em torno de albita-aligoclásio sódico. Entretanto, estudos realizados em microssonda eletrônica revelaram uma composição albítica(ver mais adiante). Apesar disso, sabe-se que essa não é a composição original desse plagioclásio, visto que os cristais apresentam-se, quase sempre, descalcificados.

A biotita é muito escassa, podendo estar ausente em diversas amostras. Quando presente ocorre como restos parcialmente oxidados e/ou cloritizados, formando lamelas anédricas de granulação fina. Exibe pleocroismo moderado, variando castanho escuroesverdeado $(Z \ominus Y)$ a castanho claro-amarelado(X). Algumas vezes hospeda inclusões de zircão e ao contato com o mesmo desenvolve nítidos halos pleocróicos. Estudos realizados através de microssonda eletrônica mostraram que tratar-se de biotita de composição entre annita aluminosa e siderofilita(ver mais adiante).

No que se refere aos minerais acessórios, o zircão é o mais freqünte é o melhor preservado. Forma grãos subédricos a euédricos, de granulação fina, os quais mostram-se zonados. Ocorre como inclusões na biotita, clorita $\left(\mathrm{Cl}_{2}\right)$ e quartzo( $\left(\mathrm{Qtz} \mathrm{z}_{1}\right)$. Os minerais opacos ocorrem tanto como fase primária associada ao zircão $\left(M O P_{1}\right)$, quanto como produto da alteração da biotita e da clorita(MOP $\left.\mathrm{P}_{2}\right)$. O primeiro tipo é pouco freqüente, forma cristais anédricos a subédricos, de granulação fina, os quais mantiveram-se preservados frente à intensa alteração que reinou sobre essa facies granitóide. O segundo tipo corresponde à cristais anédricos, que mostram-se dispostos ao longo dos planos de clivagem da biotita e clorita $\left(\mathrm{Cl}_{2}\right)$.

Em relação às fases minerais associadas ao estágio de alterações tardi a pósmagmáticas, o par sericita \pm muscovita $\left(\mathrm{Mv}_{1}\right)$ e, adicionalmente albita e muscovita2 (Prancha 
19, Fotos e, f) mostram-se mais intensamente desenvolvido, em relação às demais fases formadas nesse estágio. Sericitatmuscovita apresentam-se como lamelas anédricas, de dimensões finas a médias, as quais são atribuídas a um evento de autometassomático, de natureza potássica. Essas alterações atingiram, preferencialmente, os feldspatos primários e secundários, bem como a clorita $\left(\mathrm{Cl}_{2}\right)$ e o topázio $\left(\mathrm{Top}_{2}\right)$.

A albita, embora, algumas vezes, de difícil separação em relação ao plagioclásio primário $\left(P I_{1}\right)$, face ao intenso desenvolvimento de sericitização e muscovitização nessa facies granitóide, ocorre em teores elevados(Tabela 24; Prancha 19; Foto.f). Costuma estar desenvolvida ao longo dos contatos entre dois ou mais grãos de feldspato potássico ou entre grãos de feldspato potássico e plagioclásio e, subordinadamente, entre dois ou mais cristais de plagioclásio. Assim, em relação aos feldspatos potássicos, tem-se: 1) bordas albíticas simples("swapped rims"; Prancha 20; Foto a); 2) franjas duplas e proxidamente paralelas, com sinal ótico invertido em relação ao cristal adjacente("coroas trocadas"; Prancha 20; Foto b); 3) agrupamentos formando arranjos semelhantes a "dedos" e "mãos", os quais se dispõem como que invadindo $\circ$ cristal de feldspato potássico "hospedeiro"(Prancha 20; Fotoc); 4) "chess-board albite"(Prancha 20; Foto d). Em relação às fases albíticas desenvolvidas entre os contatos de cristais de feldspato potássico e plagioclásio, desenvolvem-se tanto "albite rims", quanto "swapped rims"(Smith, 1974). Por fim, em relação às fases albiticas ocorrentes entre dois ou mais grãos de plagioclásio(mais raras), tem-se "albite rims".

A clorita é produto de alteração do plagioclásio $\left(\mathrm{Cl}_{1}\right)$ e da biotita $\left(\mathrm{Cl}_{2}\right)$, e, muito subordinadamente, do feldspato potássico $\left(\mathrm{Cl}_{2}\right)$. Quando associada à biotita, forma lamelas anédricas, de granulação fina a média, as quais encontram-se alteradas, em diferentes graus, para muscovita $\left(\mathrm{Mv}_{2}\right)$. Exibe pleocroismo fraco, situado entre verde claro( $\mathrm{Z}$ e $\left.\mathrm{Y}\right)$ a castanho pálido-amarelada ou cor de palha ou verde claro pálido(X). Às vezes hospeda inclusões de zircão, herdado da biotita, as quais permaneceram incólumes em relação às alteracōes.

A fluorita é freqüente e chega alcançar conteúdos de até $1 \%$ modal na maioria das amostras analisadas. Apresenta-se segundo duas modalidades $\left(\mathrm{Fl}_{1}\right.$ e $\left.\mathrm{Fl}_{2}\right)$. A FI forma cristais anédricos, muito finos, intimamente associados à alteração(descalcificação) do plagioclásio. O tipo 2( $\left(\mathrm{FI}_{2}\right)$ é comumente anédrico a subédrico, fino a médio e ocorre tanto associado à biotita e à clorita $\left(\mathrm{Cl}_{2}\right)$, quanto como grãos isolados e disseminados na rocha. Ambos apresentam-se nas colorações incolor e lilás.

O topázio, por sua vez, é menos abundante nessa variedade do que na facies SMGP. Ocorre como minúsculos grãos, intimamente associados ao plagioclásio. Costuma estar presente nas porções desse mineral pouco efetadas por sericitização+muscovitização, 
visto o seu desaparecimento, ao que tudo indica, deve-se a graus elevados dessas alterações, fato que coincide, mais ou menos, com o aparecimento da cassiterita(ver adiante), neste e nos outros granitóides estudados.

A allanita é pouco freqüente e está ausente em algumas amostras. Apresenta-se como grãos anédricos, muito finos, os quais mostram-se alterados. Encontra-se, quase sempre, associada às fases filossilicáticas, em especial, à clorita $\left(\mathrm{Cl}_{2}\right)$. O rutilo é raro e, ocorre como minúsculos grãos isolados, dispresos na rocha. A esfalerita forma cristais anédricos, finos e em estreita relação com a biotita e clorita alteradas, dispondo-se, preferencialmente, ao longo dos planos de clivagens das mesmas.

A cassiterita forma cristais anédricos, finos, zonados e, às vezes, maclados. A luz natural exibe coloração castanho-avermelhada ou caramelada, enquanto que em nicóis cruzados apresenta cores de interferências altas, caracteriticas, traduzidas pela mistura de azul, verde intenso, vermelho e amarelo(Prancha 20; Fotos e, f). Ocorre tanto associada ao quartzo 3 e à muscovita $\left(\mathrm{MV}_{2}\right)$, quanto mostra-se intimamente vinculada à clorita oxidada, à semelhança do que ocorre na facies BSGIA e no clorita-siderofilita-muscovita-quartzo greisen associados ao maciço granitóide Antônio Vicente.

\subsubsection{2- Ordem de Cristalização}

O exame de seções delgadas voltado para o entendimento da ordem de separação das fases minerais primárias a partir do magma permitiu estabelecer que:

1) as fases minerais representadas por zircão e minerais opacos $\left(M O P_{1}\right)$ parecem ter sido as primeiras a cristalizar, a exemplo do que foi comentado em relação aos granitóides dos outros maciços.

2) no que se refere às fases essenciais- quartzo, feldspato potássico e plagioclásio- é muito dificil estabelecer qual a ordem exata, visto que a intensa microclinização aliada à albitização e muscovitização que afetaram essa rocha mascararam as relações entre essas fases minerais.

3) do mesmo modo, o momento de separação da biotita é difícil reconstituir, uma vez que a mesma foi, quase que inteiramente, reequilibrada e/ou substituida por clorita $\left(\mathrm{Cl}_{2}\right)$. Entretanto, a ocorrência localizada de biotita e/ou clorita intersticiais em relação às fases essenciais, indica, pelo menos em parte, uma cristalização posterior às mesmas.

\subsection{3- Aplito(AAFG)}

Essa variedade foi assim designada por apresentar, em amostra de mão, uma textura com aspecto sacaróide peculiar(conforme descrito por Bater \& Jackson,1987). Suas relações de contato não foram observadas diretamente no campo. Entretanto, presume-se 
que esteja alojado no contexto do SMGP, visto que o único afloramento observado situa-se no âmbito deste granitóide.

A Tabela 5.2 mostra a composição modal dessa rocha e a Figura 5.2 sua distribuição composicional nos diagramas Q-A-P e Q-(A+P)-M'(Streckeisen, 1976).

No diagrama Q-A-P observa-se que é uma rocha tipicamente álcali-feldspato granítica e de características hipersolvus(Tuttle \& Bowen, 1958), uma vez que o plagioclásio de composição albítica é claramente tardi a pós-magmático. No diagrama $Q-(A+P)-M$ ' notase que essa rocha "plota" muito próximo da areste $Q-(A+P)$, evidenciando o seu caráter francamente holo-leucocrático( $\left.M^{\prime}<5 \%\right)$.

Essas características demonstram que essa rocha representa a facies mais evoluída do maciço e que foi gerada a partir de um líquido muito diferenciado e extremanente silicoso.

\subsubsection{1- Textuta e Mineralogia}

Apresenta textura hipidiomórfica heterogranular fina a média, com tendência porfirítica e coloraração branca a creme esbranquiçada(Prancha 21; Fotos a, b). Consiste essencialmente de quartzo(1, 2 e 3) e feldspato potássico(1, 2 e 3), sendo ecessórios zircão minerais opacos e rutilo. Sericita \pm muscovita $\left(\mathrm{Mv}_{1}\right)$, albita e muscivita( $\left(\mathrm{Mv}_{2}\right)$ são fases tardi a pós-magmáticas.

De acordo com a morfologia e a granulação o quartzo apresenta-se em, pelo menos três variedades. $O$ primeiro tipo está representado por cristais mais grossos e subédricos, ora formando agregados, ora como grãos isolados, imersos na matriz mais fina. Mostra-se, algumas vezes, fraturado e, localmente, hospeda inclusões de feldspato potássico( $\left.F k_{1}\right)$. $O$ segundo tipo constitui a matriz. Apresenta-se como grãos subédricos, finos, embora, ocorram, em menor escala, cristais anédricos e euédricos. Localmente, alguns grãos exibem inclusões de feldspato potássico $\left(\mathrm{Fk}_{1}\right)$. O terceiro tipo, está representado por quartzo intersticial, principalmente, em relação ao tipo 2 e ao feldspato potássico1.

O feldspato potássico, do mesmo modo que o quartzo, apresenta-se segundo três variedades, as quais foram diferenciadas com base na morfologia e na granulação. $O$ tipo $1\left(F_{K_{1}}\right)$ corresponde aos cristais mais grossos(fenocristais). E invariavelmente pertitico, sendo mais comuns as pertitas tipo "band" e "patch perthites"(Alling, 1932, 1938). Mostra-se, parcialmente, substituído por sericitatmuscovita( $\left(\mathrm{Mv}_{1}\right)$, albita("chess-board albite"), muscovita $\left(\mathrm{Mv}_{2}\right)$ e por argilo-minerais. O par sericita \pm muscovita $\left(\mathrm{Mv}_{1}\right)$ se desenvolve, preferencialmente, nas zonas albíticas das pertitas e nas "chess-board albite". Não foram observados grãos maclados. O segundo tipo $\left(\mathrm{Fk}_{2}\right)$ está representado por grãos anédricos a subédricos, finos, que constituem a maior parte da matriz, juntamente com o quartzo 2 . É, 
via de regra, mais empobrecido em pertitas do que o tipo 1, sendo os tipo mais freqüentes a "patch perthite". As maclas, também, não foram observadas. O terceiro tipo( $\left.F_{k}\right)$ é anédrico e tem disposição intersticial.

Dentre as fases acessórias, o zircão é a mais comum, embora não seja abundante. Forma minúsculos cristais anédricos a subédricos, dispostos aleatoriamente na rocha. Os minerais opacos e o rutilo são escassos. Ambos ocorrem como finíssimos grãos anédricos dispersos aleatoriamente na rocha.

Quanto aos produtos de alterações tardi a pós-magmáticas, a albita é mais abundante. Ocorre ora de forma intergranular entre os contatos de dois ou mais grãos de feldspato potássico, formando agrupamentos semelhantes a "dedos" e "mãos"(dispostos como invadindo o cristal "hospedeiro) e como "coroas trocadas"(Dall'Agnol, 1980; Teixeira e Dall'Agnol, 1991; Borges, 1997), ora como albita "chess-board", substituindo o feldspato potássico(Smith, 1974) e, às vezes, como "swapped rims"(Smith 1974).

O par sericita \pm muscovita $\left(\mathrm{Mv}_{1}\right)$ e muscovita 2 ocorrem em aglomerados de lamelas anédricas(mais finas) a subédricas(cristais mais grossos), as quais encontram-se substituindo claramente a albita tardia(mais intensamente) e o feldspato potásico. Ao que tudo indica, essas alterações estão associadas a dois eventos de autometassomatismo potásico que afetaram os granitóides, os quais foram intermediados por um outro de natureza sódica, do mesmo modo que em relação aos demais granitóides desse maciço.

Os argilo-minerais mostram-se fracamente desenvolvidos. Formam finas "peliculas" semelhantes a nuvens superpostas aos cristais de feldspato potássico, atruindo-lhes um aspecto "sujo".

\subsubsection{2- Ordem de Cristalização}

O estudo petrográfico realizado com vistas à caracterização da ordem de cristalização magmática das fases minerais estudadas permitiu estabelecer o seguinte quadro:

1) Zircão, minerais opacos e rutilo certamente são fases precoces, visto que ocorrem, algumas vezes, como inclusões em cristais de quartzo e feldspato potássico.

2) O feldspato potássico deve ter se separado do magma um pouco antes do quartzo(tipos 1 e 2), uma vez que, embora, localmente, é observado como inclusões nos mesmos.

3) As demais fases estão associadas ao estágio de alterações tarơi a pósmagmáticas. 


\subsection{4- Siderofilita-Clorita-Muscovita-Quartzo Greisen(SCMQGs)}

O SCMQGs foi observado em apenas um afloramente, na zona de contato entre a facies SGMv e as rochas metassedimentares do Grupo São Felix(Anexo 25). Nesse local, o afloramento estudado consiste de blocos, não tendo sido possível deduzir a forma do corpo, nem, tampouco, as suas relações de contato. Entretanto, acredita-se que se trata de restos de uma cúpola do SGMv, greisenizada pervasivamente.

No que se refere à tipologia, pode ser considerado como mica-quartzo greisen(Scherba(1970) ou mica greisen pobre em quartzo(Figura 3.9), de acordo com a classificação de Kühne et al., 1972(In: Stemprok, 1987).

\subsubsection{1- Textura e Mineralogia}

Apresenta aspecto maciço, textura hipidiomórfica, heterogranular, granulação fina a média e coloração cinza escura a negra(Prancha 21; Fotos $c, d$ ). Consiste essencialmente de quartzo(em grande parte vinculado à intensa silicificação ocorrida durante a greisenização), muscovita, clorita e siderofilita. Como fases minerais residuais primárias ocorrem zircão e minerais opacos, sendo fases tardias, subordinadas, albita, fluorita e cassiterita(Tabela 5.3). Em relações greisens comentados no maciço granitóide Antônio Vicente, guarda muitas semslhanças com o clorita-siderofilita-muscovita-quartzo greisen associados às facies BSG e suas variedades BSGT e BSGIT, diferindo dos mesmos apenas pelo menor conteúdo de siderofilita.

O quartzo ocorre como grãos anédricos, finos médios e grossos, sendo, contudo mais comuns as dimensões médias. Desenvolvem contatos retos a irregulares e mostra-se, às vezes, deformado, cujas evidências são traduzidos pela presença de fraturas, bem como por uma moderada extinção ondulante. Essas características se assemelham muito ao quartzo tipo 1 descrito nas facies SMGP e SGMv.

A muscovita(mica branca) ocorre como lamelas anédricas e, às vezes, subédricas, desde dimensões muito finas até médias, as quais tem distribuição ampla na rocha, ultrpassando os limites outrora ocupados por plagioclásio e feldspatos potássico, chegando, mesmo, a afetarr o quartzo, clorita e siderofilita, aos quais substitui parcialmente. Exibe relevo ondulante e mostra-se oxidada. Pelas suas caracteristicas corresponde à $\mathrm{Mv}_{2}$ descrita nos granitóides deste maciço.

A clorita corresponde à $\mathrm{Cl}_{2}$ comentada nos granitóides. Apresenta-se como lamelas anédricas a subédricas, sendo porém mais comuns restos de cristais anédricos de granulação fina. Costuma estar alterada para siderofilita e muscovita e encontra-se, por vezes, oxidada. Exibe pleocroismo moderado, variando de verde abacate $(Z$ e $Y)$ a verde claro(Z). Localmente, hospeda inclusões de zircão. 
A siderofilita, pelas evidências texturais, formou-se às expensas da clorita, que por sua vez, se originou, em grande parte, às custas da biotita primária e, em menos escala, a partir do plagioclásio e do feldspato potássico(todos totalmente substituídos nesse estágio). Apresenta-se como lamelas anédricas ligadas à clorita alterada(Prancha 21; Foto e), ocorrendo, por vezes, intercrescida e/ou ao longo dos planos de clivagem da mesma. Mostra-se, também, vinculada à muscovita. Exibe pleocroísmo muito fraco, variando de castanho pálido $(Z$ e $Y)$ a incolor $(X)$.

\begin{tabular}{|lr|}
\hline $\begin{array}{l}\text { Tabela 5.3. Composição modal do "siderofilita" - clorita- } \\
\text { muscovita-quartzo greisen(SCMQGs). } \\
\text { granitóide Mocambo. Tr= traço. }\end{array}$ \\
\hline
\end{tabular}

\begin{tabular}{|l|c|}
\hline VARIEDADE & SCMQGS \\
\hline AMOSTRA & NN-GM-23 \\
\hline & 17 \\
\hline MINERAIS(\%) & \\
\hline QUARTZO & 47 \\
\hline MUSCOVITA & 35 \\
\hline CLORITA & 10 \\
\hline SIDEROFILITA & $\mathrm{Tr}$ \\
\hline ALBITA & $\mathrm{Tr}$ \\
\hline SERICITA+I- & 06 \\
MUSCOVITA & \\
\hline ZIRCÅO & $\mathrm{Tr}$ \\
\hline MINERAIS OPACOS & $\mathrm{Tr}$ \\
\hline CASITERITA & $\mathrm{Tr}$ \\
\hline Q & 100 \\
\hline A & 0 \\
\hline P & 0 \\
\hline Q & 100 \\
\hline A+P & 0 \\
\hline M' & 0 \\
\hline NUMERO DE PONTOS & 1400 \\
\hline
\end{tabular}

O zircão é um mineral acessório comum e, ao que parece, representa uma fase residual primária, precoce, que resistiu à intensa alteração que culminou com a greisenização do granitóide precursor desse greisen(SGMv). Forma minúsculos cristais subédricos a euédricos, os quais encontram-se associados às fases máficas e, às vezes, ocorre como inclusões na clorita, desenvolvendo nítidos halos pleocróicos.

Os minerais opacos apresentam-se como finos cristais, geralmente, anédricos, os quais costumam estar relacionados às fases micáceas e à cassiterita, especialmente, quando esta encontra-se um pouco alterada.

A fluorita é muito freqüente, embora nunca ultrapasse de $1 \%$ modal. Forma tanto cristais anédricos vinculados às fases filossilicáticas, quanto grãoss anédricos a subédricos, isolados e dispersos na rocha. Nesse último caso, exibe freqüentemente minúsculas 
inclusões de um mineral não identificado oticamente(Prancha 21; Foto f). Em ambos os casos, apresenta-se nas modalidades incolor e lilás.

A cassiterita é uma fase comum em todas as amostras estudadas. Forma minúsculos cristais anédricos a subédricos, os quais ocorrem em agregados reunidos com clorita, muscovita, siderofilita e fluorita. A luz natural, exibe coloração castanho avermelhada(caramelada), enquanto que a nicóis cruzados, mostra cor de interferência alta, característica, variando, em um mesmo cristal, de azul-esverdeado cintilante a rosaavermelhado e amarelo(Prancha 22; Fotos a, b).

A albita é muito escassa e ocorre como restos que foram poupadas pela intena muscovitização reinante durante a greisenização.

Essas características texturais e mineralógicas permitem deduzir que esse greisen foi formado a partir da intensa alteração pervasiva da facies SGMv. Isso é justificado pelo fato dos mesmos guardarem muitas semelhanças entre si.

\subsection{5- Discussão $\theta$ considerações finais}

Esse maciço encerra facies granitóides muito diferenciadas e bastante afetadas por alterações tardi a pós-magmáticas de natureza essencialmente pervasiva. Elas constituem, ao que tudo indica, restos de uma cúpola greisenizada que se mantém na topografia do maciço. Além dos granitóides e diques aplíticos, um corpo de greisen ocorre no contato entre a facies SGMV e rochas metassedimentares pertencentes ao Grupo São Felx. Tanto a facies SGMv, quanto o greisen hospedam mineralizações de cassiterita e fluorita, que ocorrem em pequenos agregados e disseminadas nessas rochas. Além disso, a facies SMGP abriga conteúdos relativamente expressivos de topázio(até $5 \%$ ) e teores, subordinados de fluiorita(até $1 \%$ ), sendo, entretanto desprovida de cassiterita. Esse fato é uma constante nos granitóides desse e dos outros maciços estudados. Nos granitóides onde o topázio está presente, a cassiterita é rara ou está ausente. A presença de fluorita é comum em ambos os casos.

Tabela 5.4 resume as principais características petrográficas das facies granitóides e greisen associados a esse maciço. 
Tabela 5.4-Principais caracteristicas petrográficas dos granitóides e greisen associados ao macico granitóde Mocambo.

\begin{tabular}{|c|c|c|c|c|c|}
\hline Facies & Minerais Essencials & $\begin{array}{l}\text { Minerais } \\
\text { Varietais }\end{array}$ & $\begin{array}{l}\text { Acessórios } \\
\text { Primários }\end{array}$ & Minerais Secundários & $\begin{array}{l}\text { Mineralizaçðes/Modo de } \\
\text { Ocorrência }\end{array}$ \\
\hline SMGP & $\begin{array}{l}\text { *quartzo } \\
\text { * plagioclásio } \\
\text { * feldspato potássico } \\
\text { (microctina pertítica) }\end{array}$ & "biotita" & $\begin{array}{l}\text { "Zircāo } \\
\text { * minerais opacos }\end{array}$ & $\begin{array}{l}\text { - sericita, muscovita,clorita, fluorita, epidoto, topázio, } \\
\text { feldspato potássico(microclina pertítica), albita, } \\
\text { siderofilita minerais opacos, allanita, quatzo, } \\
\text { carbonato e argilo-minerais. }\end{array}$ & $\begin{array}{l}\text { Topázio e } \quad \text { Fluorita: } \\
\text { disseminados }\end{array}$ \\
\hline SGMV & $\begin{array}{l}\text { "quartzo } \\
\text { "plagioclásio } \\
\text { ¿ feldspato potássico } \\
\text { (microclina pertitica) }\end{array}$ & "biotita" & * zircåo & $\begin{array}{l}\text { sericita, muscovita,ctorita, fluorita, topázio, } \\
\text { feldspato potássico(microclina pertlica), albita, } \\
\text { siderofilita, minerais opacos, esfalerita, allanita, } \\
\text { quatzo, cassiterita e argilo-minerais. }\end{array}$ & $\begin{array}{l}\text { "Cassiterita e Fluorita: em } \\
\text { agregados e disseminadas. }\end{array}$ \\
\hline AAFG & $\begin{array}{l}\text { "quartzo } \\
\text { " feldspato potássico } \\
\text { (microclina pertítica) }\end{array}$ & & $\begin{array}{l}\text { * zircāo } \\
\text { * minerais opacos } \\
\text { " rutito }\end{array}$ & $\begin{array}{l}\text { *sericita, muscovita, feldspato potássico(microclina } \\
\text { pertítica), albita, siderofilita minerais opacos, e } \\
\text { argilo-minerais. }\end{array}$ & Ausente \\
\hline SCMQGs & "quartzo & & $\begin{array}{l}\text { * zircăo } \\
\text { * minerais opacos }\end{array}$ & $\begin{array}{l}\text { sericita, muscovita, clorita, siderofilita, quartzo, albita } \\
\text { e cassiterita. }\end{array}$ & $\begin{array}{l}\text { "Cassiterita: disseminada } \\
\text { (predominante) }\end{array}$ \\
\hline
\end{tabular}




\section{5- Química Mineral}

No contexto deste maciço foram realizadas através de microssonda eletrônica 20 análises pontuais quantitativas(WDS) em amostras de granitóides, assim discriminadas: 04 de biotita 03 de clorita, 12 de muscovita, 07 de plagioclásio e 8 de feldspato potássico pertítico e 04 de albita pertítica. Além disso, efetuou-se 04 análises em mica branca(muscovita) e $04 \mathrm{em}$ clorita, pertencentes ao siderofilita-clorita-muscovita-quartzo greisen. Exectou-se, ainda, análises semi-quantitativas(EDS) através de microscopia eletrônica de varredura, as quais envolveram essencialmente a caracterização de fases minerais acessórias, incluindo os minerais opacos, em amostras de granitóides(22 análises) e de greisen(05 análises).

\subsection{1- Análises químicas através de Microssonda Eletrônica}

\subsubsection{Análises químicas em Biotita}

Os resultados analiticos obtidos para esta fase mineral, bem como suas fórmulas estruturais encontram-se no Anexo 26.

As análises revelam que os dois cristais estudados, pelo menos nas áreas analisadas, apresentam algumas diferenças composicionais importantes. $O$ grão 1 mostra conteúdos médios mais baixos de $\mathrm{SiO}_{2}, \mathrm{Al}_{2} \mathrm{O}_{3}, \mathrm{~K}_{2} \mathrm{O}, \mathrm{Li}_{2} \mathrm{O}$ e $\mathrm{F}$ e mais elevados de $\mathrm{TiO}_{2}$, $\mathrm{Fe}_{2} \mathrm{O}_{3}, \mathrm{FeO}, \mathrm{MnO}$ e $\mathrm{MgO}$. Entretanto, apresentam valores de XFe equivalentes, variando entre 0,97 e 0,98 .

Quando as análises dos dois grãos são lançadas no diagrama catiônico $\left(\mathrm{Al}^{\mathrm{V}}+\mathrm{Fe}^{3+}+\mathrm{Ti}^{4+}\right)-\mathrm{Mg}-\left(\mathrm{Fe}^{2+}+\mathrm{Mn}^{2+}\right)$ de $\mathrm{Foster}(1960 \mathrm{~b})$, Figura 112 deste trabalho, observa-se que as composições dos mesmos "plotam" no campo das micas trioctaédricas do tipo siderofilita e lepidomelana de pegmatitos(campo IVa).

No diagrama $\mathrm{Al}^{\mathrm{VI}}$ versus $\mathrm{Mg} / \mathrm{Mg}+\mathrm{Fe}^{2+}$ de Guidotti(1984), Figura 5.5, observa-se que as composições da biotita "plotam" na região composicional compreendida entre a composição da annita aluminosa e da siderofilita, embora com nítida tendência para essa última. Observa-se, ainda, um claro trend de variação composicional entre as análises 1 e 4, em que as quantidades de $\mathrm{Al}^{\mathrm{V}}$ aumentam sistematicamente no sentido da análise 1 para a de número 4. Isso é demonstra o importante papel desempenhado pelo $\mathrm{Al}^{\mathrm{VI}}$ no sítio octaedral em substituição ao $\mathrm{Fe}^{2+}$ e ao $\mathrm{Mg}^{2+}$.

Em relação à Figura 5.6(Nockolds, 1947), nota-se que as composições incidem no campo "l", referente à biotita associada à muscovita+topázio+fluorita, etc. Este fato é concordante com que foi observado nos estudos petrográficos, visto que a facies hospedeira dos grãos estudados(facies SGMv), é portadora de quantidades significativas de muscovita e fluorita, com quantidades subordinadas de topázio. Entretanto, conforme visto no ítem 
Aspectos Petrográficos, desse capítulo, essas fases são claramente tardias e estão vinculadas ao estágio de alterações tardi a pós-magmáticas.

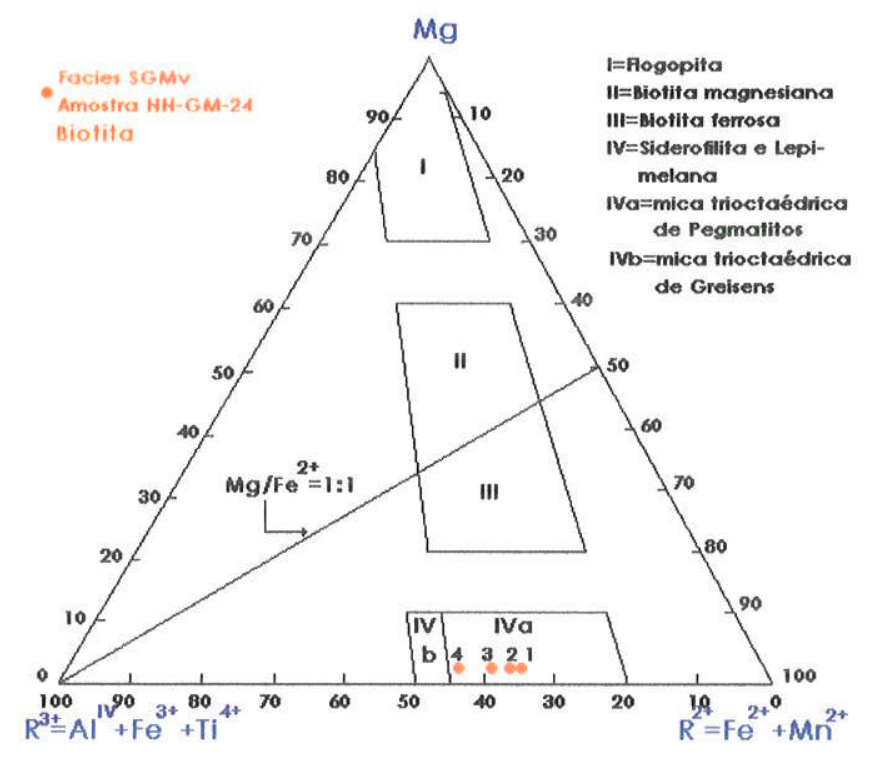

Figura 5.4.- Diagrama triangular $\mathrm{Mg}$ $\mathrm{R}^{2+}-\mathrm{R}^{3+}$ de Forster(1960b), mostrando a relação entre $\mathrm{Mg}, \mathrm{Fe}^{2+}\left(\mathrm{Mn}^{2+}\right)$ e $\left(\mathrm{Al}^{\mathrm{VI}}\right.$, $\left.\mathrm{Fe}^{3+}, \mathrm{Ti}^{4+}\right)$ em micas trioctaédricas e a posição ocupada no diagrama pelas análises de biotita da amostra NN-GM24, da facies SGMv do maciço granitóide Mocambo.

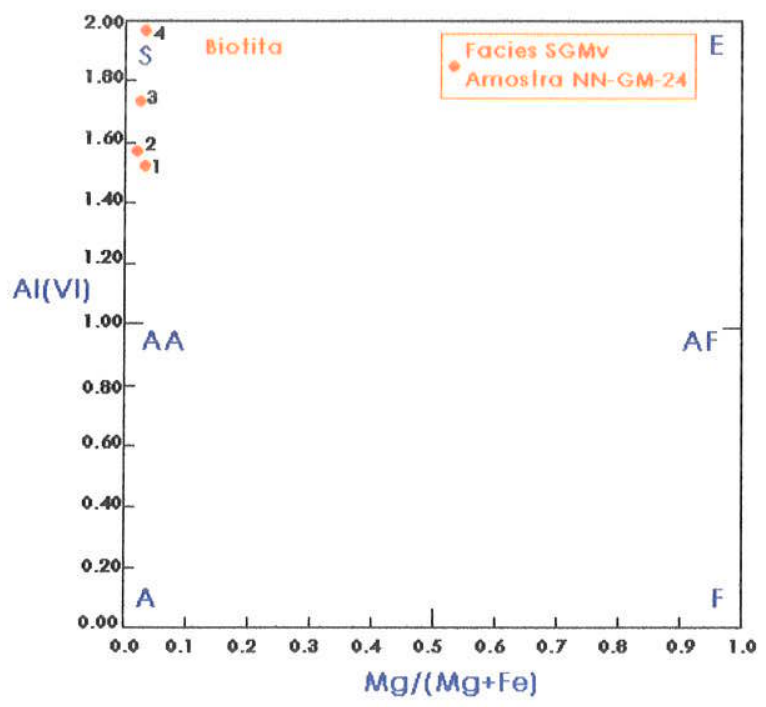

Figura 5.5.- Diagrama $\mathrm{Al}^{\mathrm{V} 1}$ versus $\mathrm{Mg} /\left(\mathrm{Mg}+\mathrm{Fe}^{2+}\right)$ de Guidotti(1984) mostrando a distribuição composicional da biotita da amostra NN-GM-24, da facies SGMv do maciço granitóide Mocambo. $A=$ annita; $B=$ flogopita; $A F=$ flogopita aluminosa; $\mathrm{AA}=$ annita aluminosa; $\mathrm{S}=$ siderofilita; $\mathrm{E}=\mathrm{K}_{2}\left(\mathrm{Mg}_{4} \mathrm{Al}_{2}\right)\left(\mathrm{Al}_{4} \mathrm{Si}_{4} \mathrm{O}_{20}(\mathrm{OH})_{4}\right.$.

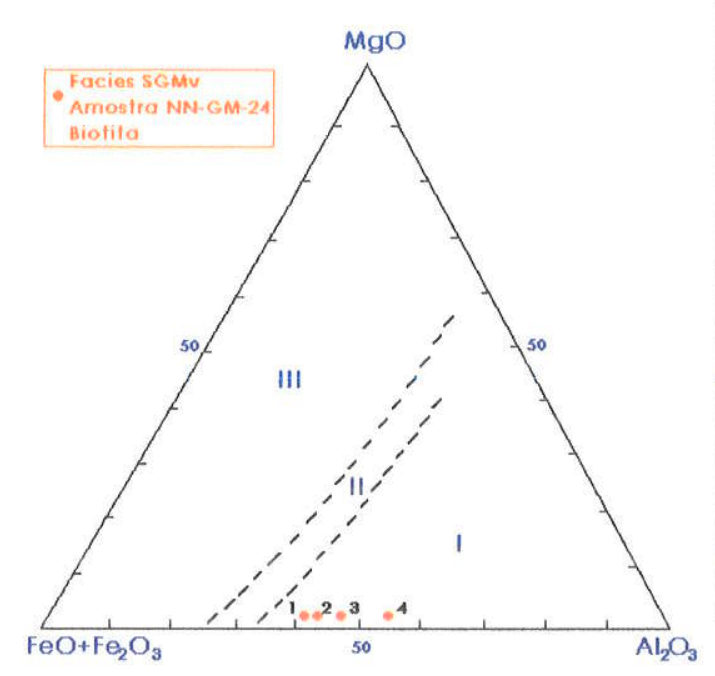

Figura 5.6.- Diagrama triangular $\mathrm{Mg}-\left(\mathrm{Feo}+\mathrm{Fe}_{2} \mathrm{O}_{3}\right)$ $\mathrm{Al}_{2} \mathrm{O}_{3}$ baseado em Nockolds(1947) mostrando as composições de biotitas em diferentes associações minerais. Campos: $1=$ biotita associada à muscovita+topázio+fluorita+etc.; II = biotita não acompanhada por outras fases máficas; III = biotita associada à hornblenda, piroxênio e/ou olivina. As análises constantes no diagrama são da amostra NN-GM-24 da facies SGMv do maciço granitóide Mocambo. 
Quando as composições dessa mica são "plotadas" no diagrama ( $\mathrm{FeO}+\mathrm{MnO}$ ) $10 \times \mathrm{TiO}_{2}-\mathrm{MgO}$ (Nachit, 1994. In: Borges, 1997), Figura 5.7, nota-se que a composição dos quatro pontos analisados incidem no campo das micas magmáticas reequilibradas(campo "B"). Isso reforça, em parte, as observações acima e indica que a mica em questão é uma fase que foi formada no estágio de alterações tardi a pós-magmáticas, a partir do reequilíbrio de uma mica precoce e secundária(clorita 2), que por sua vez, se originou às expensas de uma biotita primária.

Em relação ao diagrama $\mathrm{MgO}-\mathrm{FeO}_{\mathrm{T}}-\mathrm{Al}_{2} \mathrm{O}_{3}$ de Nockolds(1947) e Gokhale(1968), Figura 5.8, verifica-se que duas análises incidem no campo das biotitas magmáticas e duas totalmente fora dos campos composicionais definidos por Nockolds(op. cit.), embora dentro do campo das biotitas magmáticas de Gokhale(1968). Isso contraria as observação petrográficas e permite conclui-se que esse tipo de diagrama não se presta para a interpretação da natureza desse tipo de mica.

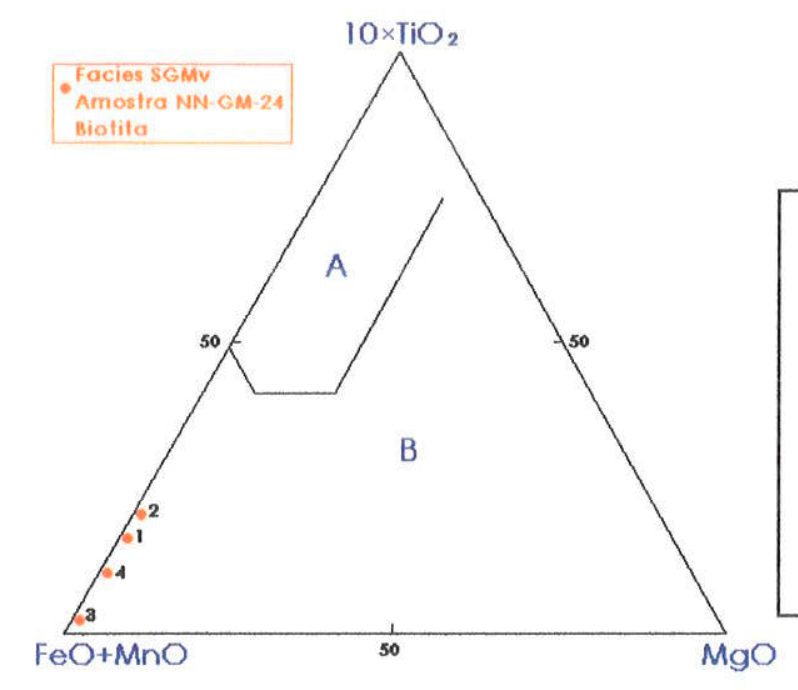

Figura 5.7.- Diagrama triangular $(\mathrm{FeO}+\mathrm{MnO})$ $\left(10 \times \mathrm{TiO}_{2}\right)$ - MgO de Nachit(1994) mostrando a distribuição composicional da biotita da amostra NN-GM-24, da facies SGMv do maciço granitóide Mocambo. $A=$ campo das micas magmáticas; $\mathbf{B}=$ campo das micas magmáticas reequilibradas.

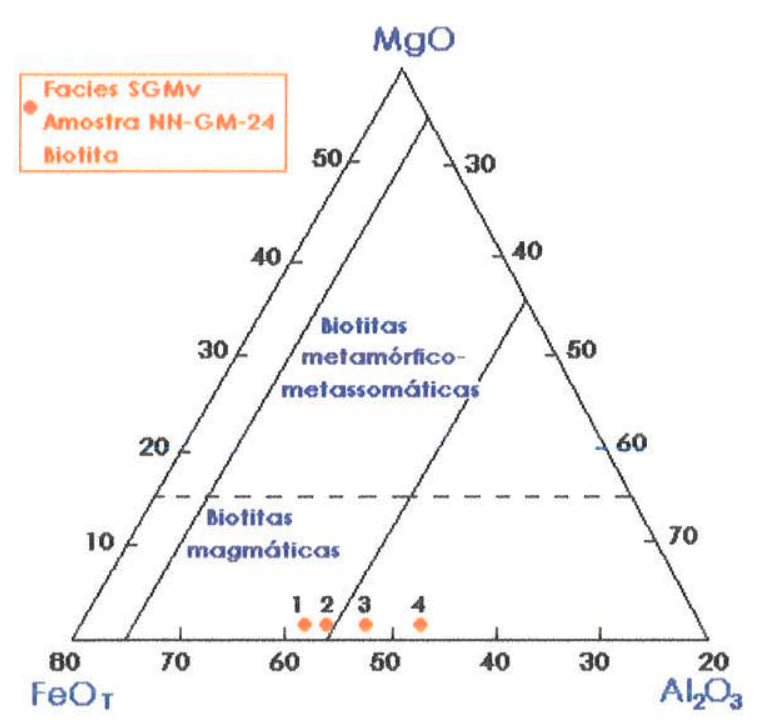

Figura 5.8.- Diagrama triangular $\mathrm{FeO}_{\mathrm{T}}-\mathrm{MgO}$ $\mathrm{Al}_{2} \mathrm{O}_{3}$ mostrando a projeção composicional da biotita da amostra NN-GM-24, da facies SGMv do maciço granitóide Mocambo. As linhas cheias delimitam o campo composicional de biotitas de rochas ígneas conforme(Nockolds, 1947) e a linha tracejada separa biotitas magmáticas de biotitas metamórficometassomáticas, conforme Gokhale(1968). 


\subsubsection{1- Classificação e Representação Gráfica}

Para a classificação e representação gráfica da mica em questão, foi utilizado o diagrama apresentado por Tischendorf et al.(1997; pg. 825), Figura 5.9. Nesse diagrama observa-se que uma análise(análise1) incide inteiramente no campo da siderofilita(análise 1 , grão 1) e uma no campo da protolitionita(análise 2, grão 2), embora muito próximo da linha limitrofe entre este campo e o da siderofilita. As outras duas restantes plotam inteiramente no campo composicional correspondente a protolitionita(análises 3 e 4, grão 2). Além disso, o conjunto de todas as análises situa-se no quadrante das Li-Fe micas(quadrante IV). Notase, ainda, um nítido trend de variação composicional no sentido da análise 1 para a análise 4, proporcionado, principalmente, pelos conteúdos de $\mathrm{Fe}^{2+} \mathrm{Fe}^{3+}$ que decrescem sistematicamente no mesmo sentido, enquanto os de de $\mathrm{Al}^{\mathrm{VI}}$ e $\mathrm{Li}$ crescem. Como ambos os grãos foram originados a partir de uma mesma fase mineral(clorita 2), esse trend de variação composicional reflete, ao que tudo indica, diferentes intensidades de alteração da clorita $\left(\mathrm{Cl}_{2}\right)$. Além disso, o sistemático aumento nos teores de $\mathrm{F}$ e Li no sentido da análise 1 para a análise 4, indica que a siderofilita(grão 1) deve representar uma fase intermediária entre a clorita 2 e a protolitionita, visto que há uma nítida tendência de crescimento dos conteúdos desses elementos, nos estágios mais avançados das alterações tardi a pósmagmáticas.

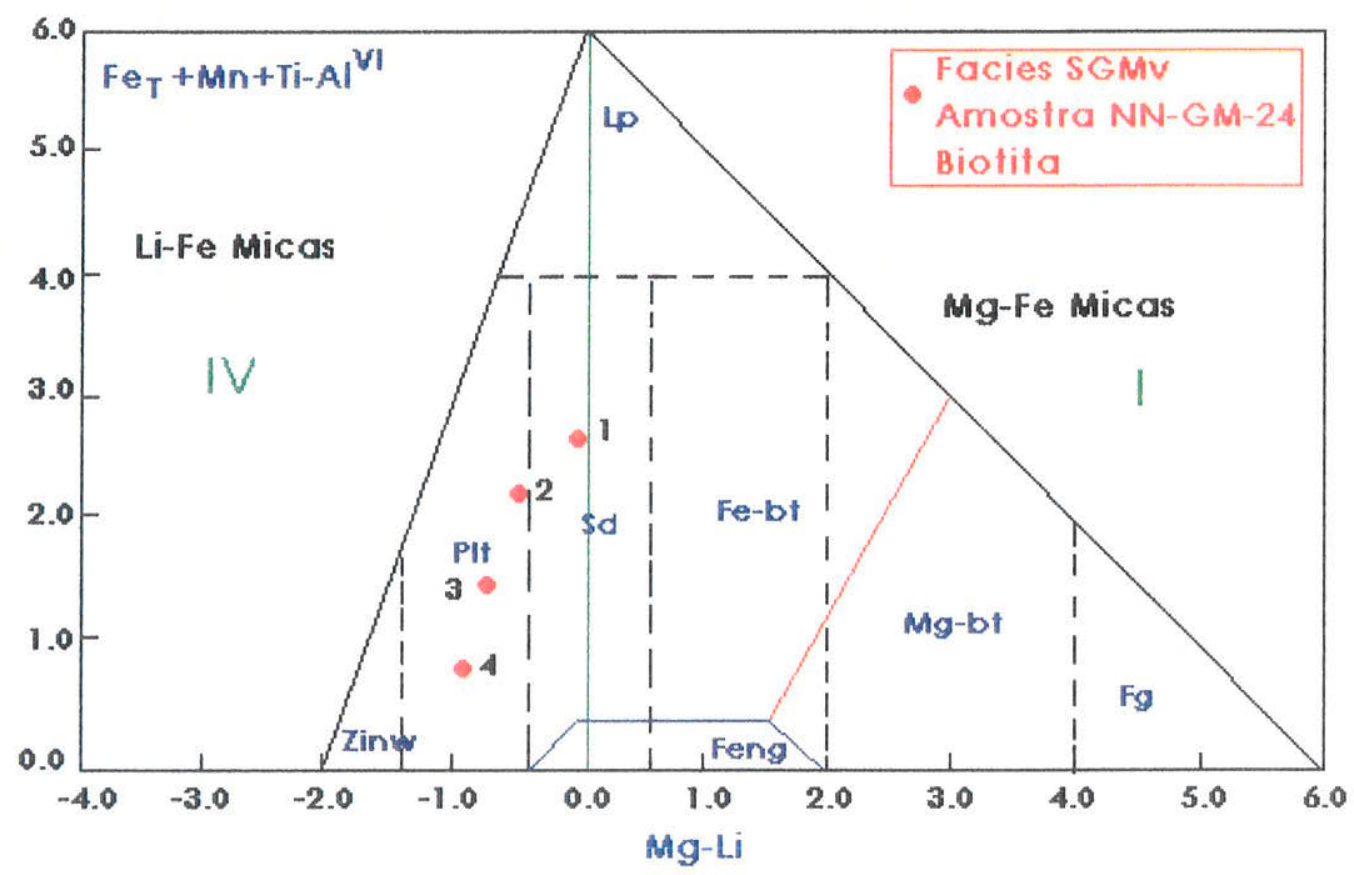

Figura 5.9. Diagrama Mg-Li vs. $\mathrm{Fe}_{\mathrm{T}}+\mathrm{Mn}+\mathrm{Ti}-\mathrm{Al}{ }^{\mathrm{v}}$ de Tischendorf et al.(1997) mostrando a distribuição composicional da biotita da amostra NN-GM-24, da facies SGMv do maciço granitóide Mocambo. 


\subsubsection{2- Análises químicas em Feldspato potássico}

Para essa fase mineral foram executadas duas análises pontuais em feldspato potássico pertítico da amostra NN-GM-56A da facies SMGP, seis em feldspato potássico pertítico e quatro em albita pertítica da amostra NN-GM-24 da facies SGMv. Deve-se ressaltar que os grãos analisados correspondem ao feldspato potássico pertítico 2(microclina pertítica 2).

\subsubsection{1- Composição química}

As análises, as fórmulas estruturais e as proporçõpes Ab-Or-An encontram-se no anexo 27.

$\mathrm{Na}$ análise do diagrama Ab-Or-An(Figura 5.10), observa-se que entre os pontos analisados há uma variação composicional mínima entre as porções correspondentes ao feldspato potássico pertítico. Nota-se que as composições são dominantemente potássicas, onde a molécula ortoclásio varia entre 95 e $99 \%$, a molécula albita entre 1 e $5 \%$ e a molécula anortita é igual a $0 \%$. Nota-se, ainda, um discreto trend composicional mostrando um empobrecimento na molécula ortoclásio no sentido das análises 1, 3, 4 e 6 para a 2. As análises 7,11 e 10 ocupam posições composicionais intermediárias. As porções correspondentes à albita pertítica, mostram composições mais variáveis, oscilando entre 65 (análise 8) e 100\%(análise 12). A molécula ortoclásio varia desde 0 até $35 \%$, enquanto que a de anortita é igual a $0 \%$. Isso é reflexo, ao que tudo indica, das relações de troca entre $\mathrm{Na}$ e $\mathrm{K}$ em decorrência dos processos de substituição, que culminaram com a formação das pertitas dos tipos "film", "vein" e "band", ocorridos durante o estágio de alterações tardi a pós-magmáticas.

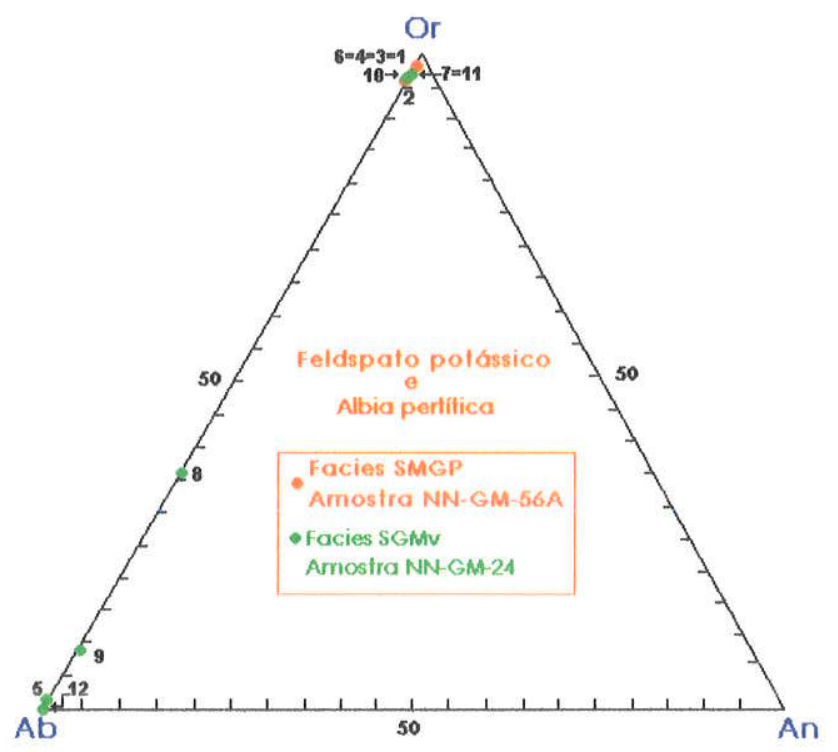

Figura 5.10- Distribuição composicional do feldspato potássico da amostra NNGM-56A do maciço granitóide Mocambo no diagrama triangular Ab-Or-An. 


\subsubsection{3.- Análises químicas em Plagioclásio}

O estudo do plagioclásio envolveu 07 análises pontuais, sendo 04 na amostra NNGM-56A, da facies SMGP e 03 na amostra NN-GM-24, da facies SGMv. Os resultados analíticos encontram-se no Anexo 28.

\subsubsection{1- Composição química}

Em termos composicionais, as análises correspondente à amostra NN-GM-56A mostram um conjunto praticamente homogêneo, onde a molécula albita varia entre $98 \mathrm{e}$ $99 \%$, a de anortita entre 0 e $1 \%$ e a de ortoclásio é igual a 1\%(Figura 5.11).As análises referentes à amostra NN-GM-24 apresentam um intervalo de variação um pouco mais amplo, onde a molécula albita oscila entre 93 e $99 \%$, a de anortita situa-se entre 0 e $7 \%$, enquanto que a ortoclásio varia de 0 a $1 \%$. Deve-se ressaltar, entretanto, que essas composições correspondem a grãos de plagioclásio $1\left(\mathrm{Pl}_{1}\right)$, que encontram-se intensamente afetados por alterações tardi a pósmagmáticas. Em outras palavras, são grãos que apresentam-se descalcificados e que, portanto, não refletem suas composições magmáticas originais.

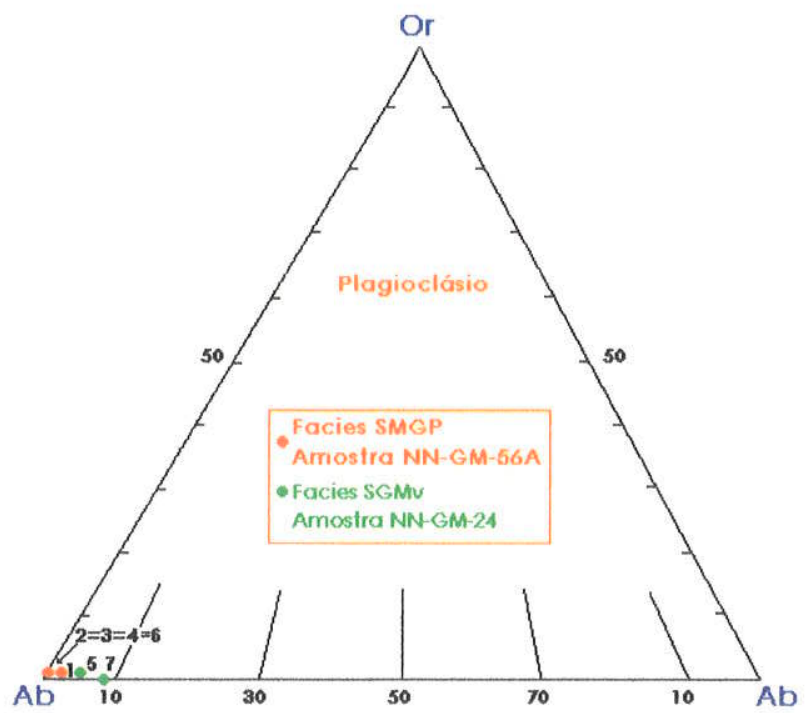

Figura 5.11- Distribuição composicional do plagioclásio da amostra NN-GM-56A do maciço granitóide Mocambo no diagrama triangular Ab-Or-An.

\subsubsection{4- Análises quimícas em Muscovita}

Em relação à muscovita foram efetuadas 16 análises pontuais, as quais foram assim discriminadas: 09 análises da amostra NN-GM-56A(SMGP), 03 análises da amostra NNGM-24(SGMv) e 04 análises do SCMQGs. Em todos os casos a muscovita analisada refere- 
se à muscovita $2\left(\mathrm{Mv}_{2}\right)$, conforme visto no ítem aspectos petrográficos. Os resultados analíticos obtidos encontram-se no Anexo 29

\subsubsection{1- Composição química}

A análise do anexo 29 e da Figura 5.12 mostra que, independentemente da facies granitóide ou do greisen estudados, a muscovita não exibe uma grande variação composicional. Na Figura 5.12 observa-se que a muscovita da facies SMGP e do SCMQGs tende a ser empobrecida em $\mathrm{Si}$, Ti e Mg em relação à muscovita da facies SGMv. Os teores de $\mathrm{FeO}$ tendem a ser mais baixos nas análises da facies SMGP relativamente às análises da facies SGMv. As quantidades de Mg são muito variáveis na facies SMGP, chegando a ser iguais a 0,00 em algumas análises, embora seu conteúdo na facies SGMv seja mais elevado do que aqueles da maior parte das análises da facies SMGP. Os conteúdos de $\mathrm{Na}$ são mais ou menos eqüivalentes para o conjunto das análises, enquanto que aqueles de $\mathrm{K}$ variam amplamente, mas tendem a ser mais elevados nas análises da facies SMGP. Os valores de XFe são semelhantes em boa parte das análises e oscilam entre 0,880 e 1,00.
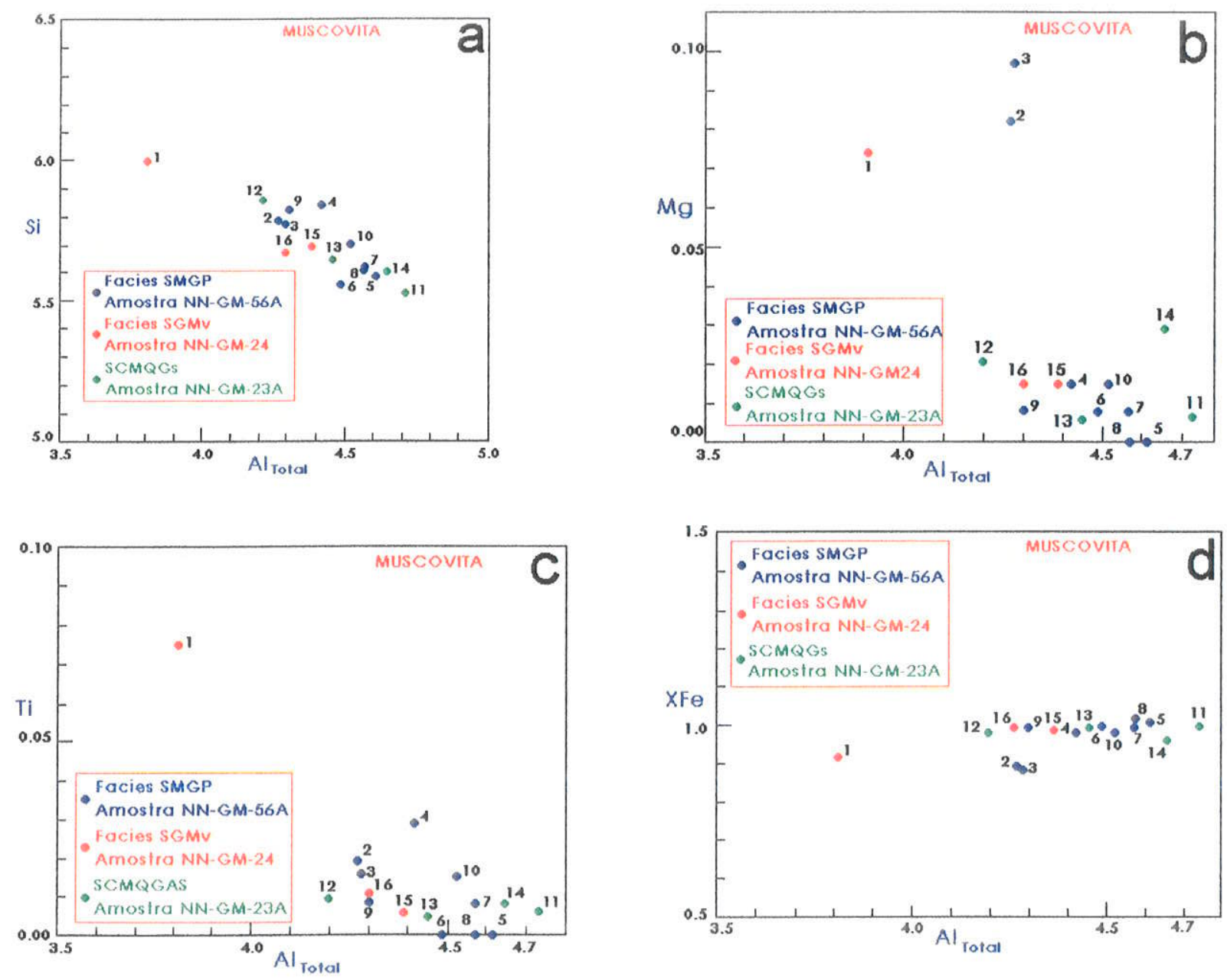


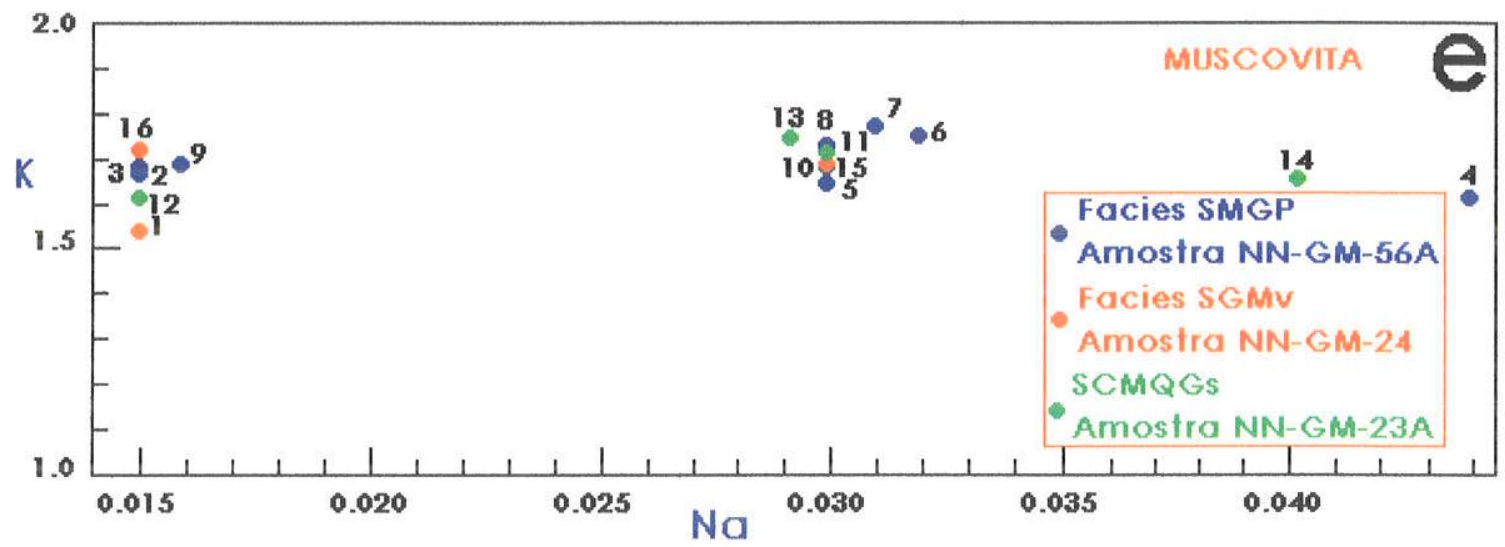

Figura 5.12- Representação composicional catiônica das muscovitas das facies SGMv e SMGP e do SCMQGs do maciço granitóide Mocambo nos diagramas $\mathrm{Si}_{-} \mathrm{Al}_{\mathrm{T}}(\mathrm{a}) ; \mathrm{Mg}-\mathrm{Al}_{\mathrm{T}}(\mathrm{b}) \mathrm{Ti}-\mathrm{Al}_{\mathrm{T}}(\mathrm{c}) ; \mathrm{XFe}-\mathrm{Al}_{\mathrm{T}}(\mathrm{d}) ; \mathrm{K}-$ $\mathrm{Na}(\mathrm{e})$.

\subsubsection{2- Substituições}

As Figuras 5.13 e 5.14 mostram um baixo grau de substituição fengítica(a análise número 1 da amostra NN-GM-24, facies SGMv, anexo 29, não foi plotada no diagrama da Figura 5.13 devido possuir valor negativo da variável $\left.\left[\left(\mathrm{Al}^{\mathrm{VI}}-2\right)+2 \mathrm{Ti}\right]\right)$. Observa-se ainda, um grau relativamente alto da substituição $\mathrm{Al}^{\mathrm{Vl}}$ por $\mathrm{Fe}^{3+}\left(\mathrm{Fe}^{3+} \rightarrow \mathrm{Al}^{\mathrm{Vl}}\right)$ para a muscovita da facies SMGP e do SCMQGs. Dessa forma, o excesso de carga provocado pela substituição fengítica é compensado pela entrada dos íons divalentes $\mathrm{Mg}$ e $\mathrm{Fe}^{2+}$. Nas muscovitas estudadas, observa-se que apenas o $\mathrm{Mg}$ contribuiu para essa substituição, visto que, de acordo com as Figuras 5.13 e 5.14, o ferro estrutural está essencialmente no estado trivalente.

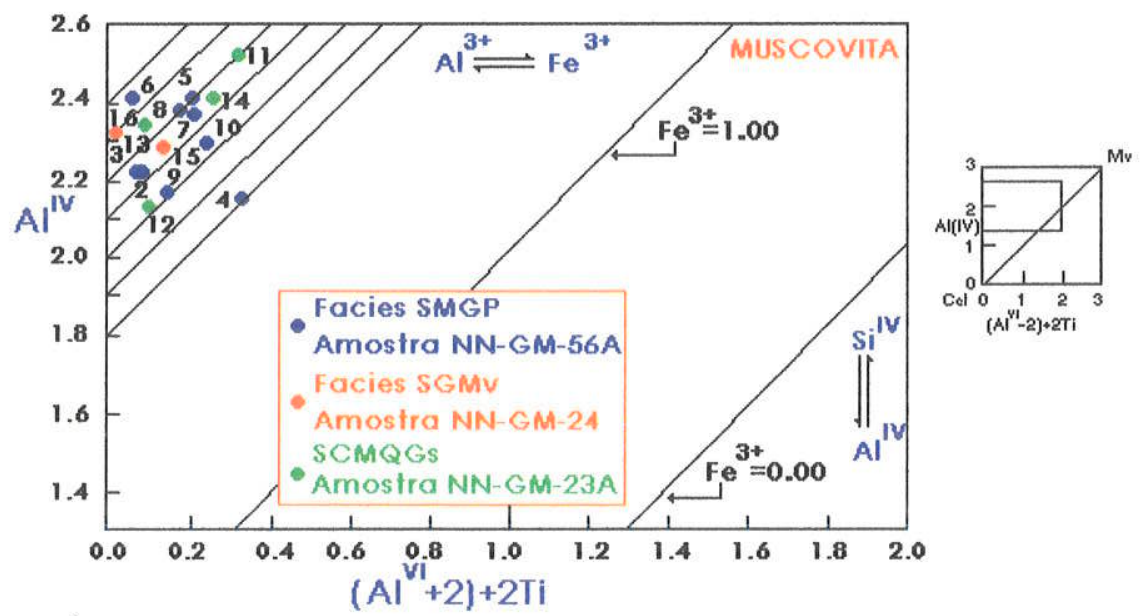

Figura 5.13- Representação composicional da muscovita das facies SMGP e SGMv e do SCMQGs do maciço granitóide Mocambo no diagrama $\mathrm{Al}^{\mathrm{IV}}$ versus $\left[\left(\mathrm{Al}^{\mathrm{V} \mathrm{l}}-2\right)+2 \mathrm{Ti}\right]$ de Cathelineau(1982), modificado de Dias(1987). In: Simões(1992). 

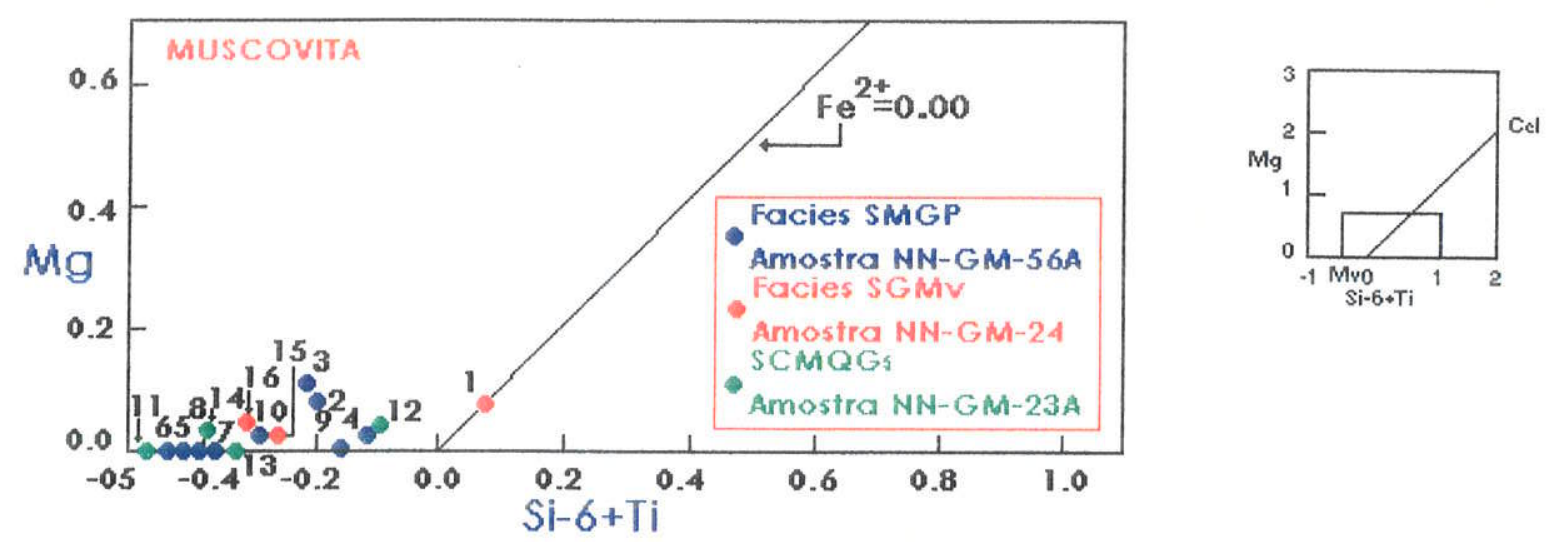

Figura 5.14- Representação composicional das muscovitas das facies SMGP e SGMv e do SCMQGs do maciço granitóide Mocambo no diagrama Mg-(Si-6+Ti), modificado de Dias(1987). In: Simões(1992).

Os graus de substituições fengítica e paragoníticas podem ser avaliados a partir do diagrama \% da molécula celadonítica versus \% da molécula paragonítica(Figura 5.15). Nele, nota-se que a substituição paragonítica é muito reduzida, enquanto que a substituição fengítica, dada pela \% molécula celadonítica, é ausente, uma vez que os valores dessa variável são todos negativos nas muscovitas estudadas.

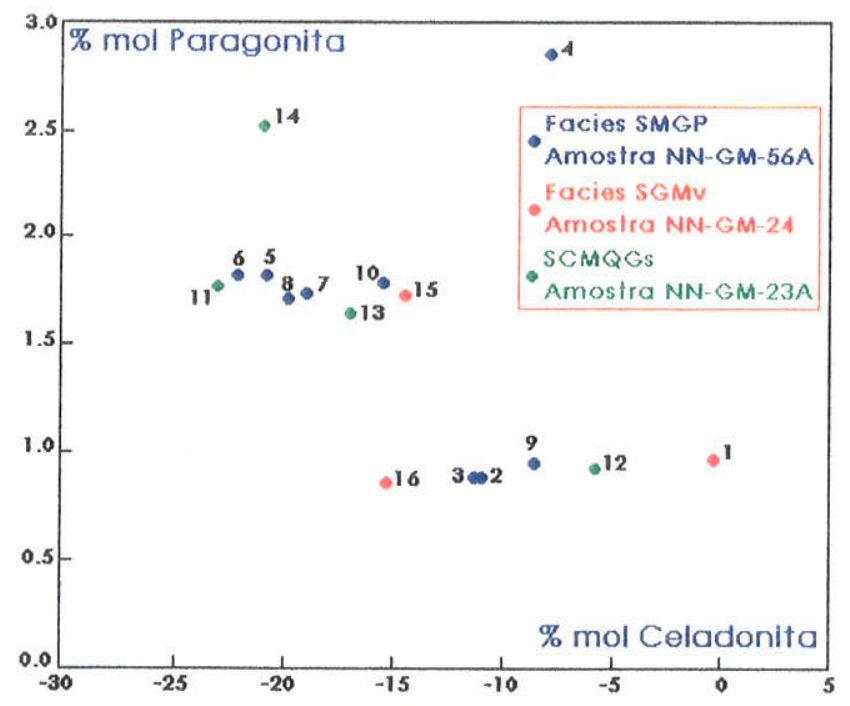

Figura 5.15- Representação gráfica das percentagens das moléculas paragoníticas e celadoníticas presentes nas muscovitas das facies SMGP e SGMv e do SCMQGs do maciço granitóide Mocambo, de acordo com Simões(1992). \% mol. paragonita= 100xNa/(Na+K); \%mol. celadonita=100x(Si-6)/2.

\subsubsection{3- Classificação e Representação Gráfica}

A exemplo das muscovitas dos granitóides e greisen do maciço Antônio Vicente, as composições das muscovitas em questão foram lançadas no diagrama [( $\left.\left.\mathrm{Fe}_{\mathrm{T}}+\mathrm{Mn}+\mathrm{Ti}\right)-\mathrm{Al}{ }^{\mathrm{V}}\right]$ versus (Mg-Li) de Tischendorf et al.(1997), Figura 5.16. Nele verifica-se que as análises 
incidem inteiramente na área composicional da fengita, embora muito próximo à linha limítrofe com a área da Li-fengita, no quadrante das Mg-Al micas.

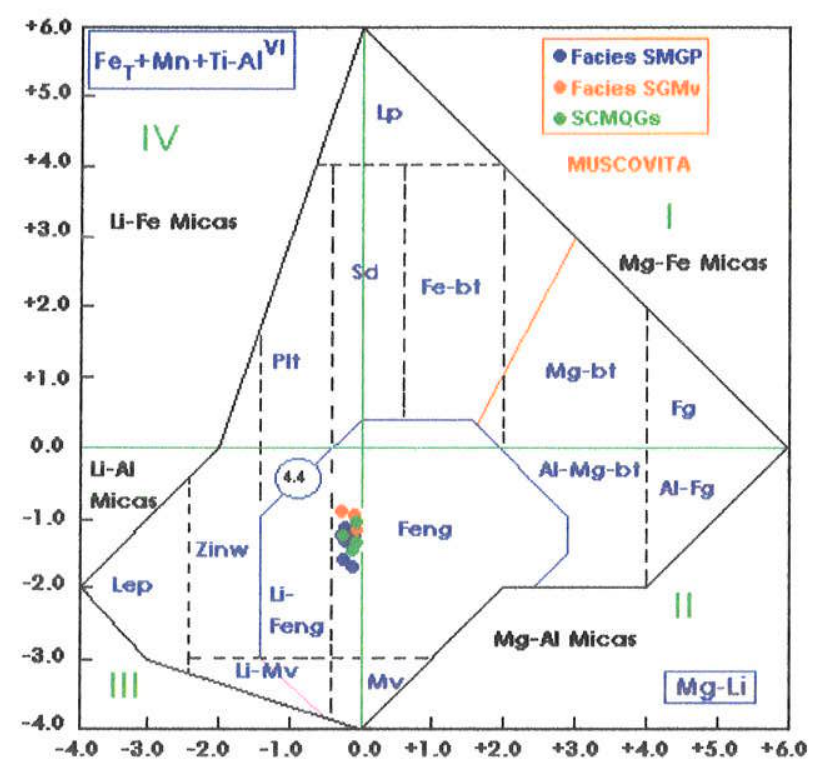

Figura 5.16- Distribuição composicional das muscovitas das facies SMGP e SGMv e do SCMQGs do maciço granitóide Mocambo no diagrama [(FeT+Mn+Ti)-(MgLi)], de classificação composicional e nomenclatura de micas trioctaédricas e dioctaédricas de Tischendorf et al.(1997).

\subsubsection{4- Origem}

Os estudos petrográficos realizados em seções delgadas de amostras das facies SGMv e SMGP e do SCMQGs mostraram que texturalmente trata-se de micas brancas, secundárias, formadas às expensas da biotita primária, no estágio de alterações tardi a pósmagmáticas.

Os dados químicos quando lançados no diagrama triangular $\mathrm{Mg}-\mathrm{Ti}-\mathrm{Na}$ de Miller et al.(1981), Figura 5.17, mostram que a composições da muscovita estudada incidem predominantemente no campo correspondente à muscovita primária, especialmente as análises da facies SGMv e do SCMQGs, embora algumas análises "plotem" no campo das muscovitas secundárias, principalmente as amostras da facies SMGP. Comparativamente às muscovitas estudadas por Miller et al.(1981), Monier et al.(1984) e Simões(1992), essa muscovita, em termos do seu quimismo, tem tanto afinidas com as muscovitas primárias(visto que apresenta conteúdos relativamente elevados de $\mathrm{Ti}$ e $\mathrm{Na}$ ), quanto com as muscovitas secundárias, uma vez que seus teores de $\mathrm{Al}, \mathrm{Mg}$ e Si são compatíveis com as mesmas. Assim, a partir do quimismo não é possível discernir claramente a origem da dessa muscovita. Entretanto, os dados petrográficos indicam uma origem inequivocamente secundária. Isso é reforçado pelo fato de certas análises de muscovitas, texturamente secundárias, apresentadas por Miller et al.(1981; Figura 2b, pg 28), incidirem no campo das muscovitas primárias.

No que se refere à muscovita da facies SMGP, quatro amostras incidem no campo das muscovitas secundárias, duas no vértice do $\mathrm{Na}$ e três na área composicional 
correspondente às muscovitas primárias. As quatro análises que incidem no campo das muscovitas primárias, embora sejam enriquecidas em $\mathrm{Na}$ são pobres em $\mathrm{Ti}$, bem como exibem baixos conteúdos de $\mathrm{Si}, \mathrm{Al}$ e $\mathrm{Mg}$, o que contraria a condição de muscovita primária, quando comparadas com aquelas estudadas por Miller et al.(1981). As análises 5 e 8(Anexo 29) possuem conteúdos de $\mathrm{Ti}$ e $\mathrm{Mg}$ iguais a 0,00 e os seus teores de Na são relativamente elevados. Isso explica o seu posicionamento no diagrama em questão. Além disso, as características texturais de todos os grãos de muscovita, aqui estudados, são tipicamente de muscovitas secundárias(ver aspectos petrográficos desse capítulo).

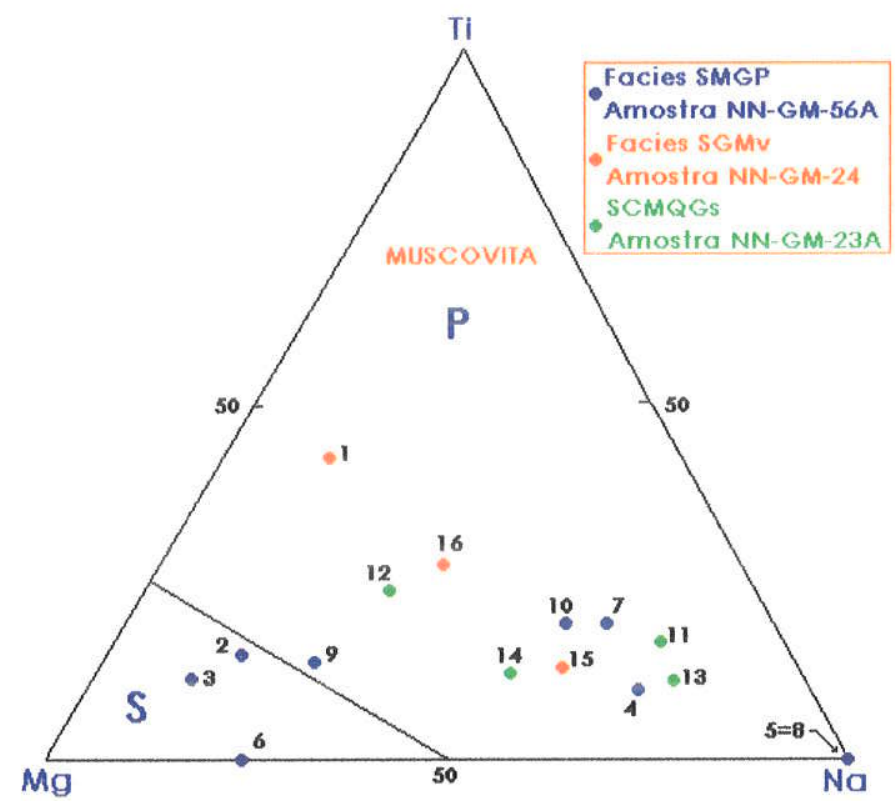

Figura 5.17- Distribuição composicional das muscovitas das facies SMGP e SGMv do maciço granitóide Mocambo no diagrama triangular Mg-Ti-Na de Miller et al.(1981). $\mathrm{P}=$ campo composicional das muscovitas primárias; $\mathrm{S}=$ campo composicional das muscovitas secundárias.

\subsubsection{5 - Análises químicas em Clorita}

Um resumo àcerca das principais características do grupo da clorita foi apresentado no capítulo 3 deste trabalho.

No âmbito deste maciço foram executadas 07 análises pontuais em grãos de clorita associada ao estágio de alterações tardi a pós-magmáticas $\left(\mathrm{Cl}_{2}\right)$. Os grãos analisados dizem respeito à facies granitóide SGMv e ao SCMQGs. Os resultados analíticos e as fórmulas estruturais encontram-se no Anexo 30.

\subsubsection{1- Composição química}

$\mathrm{Na}$ análise do diagrama $\mathrm{Al}^{\mathrm{IV}}$ versus $\mathrm{Al}^{\mathrm{VI}}$ (Figura 5.18a; Anexo 30) observa-se que, para o conjunto das análises, as quantidades catiônicas do $\mathrm{Al}^{\mathrm{IV}}$ oscilam entre 1,666 e 2,067, 
enquanto que as de $\mathrm{Al}^{\mathrm{V} l}$ variam entre 0,381 e 0,703 . No se refere a cada grão, em separado, nota-se que naquele da facies SGMv(análises 5 a 7) essas variações composicionais são muito elevadas se consideradas, de um lado, as quantidades de $\mathrm{Al}^{\mathrm{lV}}$ observadas nas análises 5 e 6 e, de outro lado, na 7.0 mesmo é válido para as quantidades de $\mathrm{Al}^{\mathrm{V}}$. Nesse caso, nota-se uma correlação negativa entre essas duas variedades, caracterizada pelo aumento do $\mathrm{Al}^{\mathrm{N}}$ e decréscimo de $\mathrm{Al}^{\mathrm{V}}$, no sentido das de números 5 e 6 para a 7. Em relação às análises do SCMQGs, verifica-se um estreito campo de variação composicional. Quando são considerados os dois grupos, nota-se que as quantidades catiônicas de $\mathrm{Al}^{\mathrm{lV}}$ e $\mathrm{Al}^{\mathrm{V}}$ do SCMQGs são semelhantes àquelas das análise 5 e 6 da facies SGMv, sendo, porém muito diferentes daquelas da de número 7.

A Figura $5.18 \mathrm{~b}$ revela que na clorita da facies $S G M v$ há uma nítida correlação negativa entre o $\mathrm{Al}^{\mathrm{V}}$ e os cátions bivalentes $\left(\mathrm{Fe}^{2+}+\mathrm{Mg}^{2+}\right)$, caracterizada pelo aumento nas quantidades catiônicas do primeiro e diminuição naquelas dos cátion bivalentes no sentido da composição 5 para a 7 , com a de número 6 ocupando uma posição intermediária no "trend". Quando consideradas as análises do SCMQGs, em separado, nota-se uma discreta correlação negativa entre as duas variáveis em questão, definida pela elevação nas quantidades de $\mathrm{Al}^{\mathrm{V}}$ e redução dos valores de $\left(\mathrm{Fe}^{2+}+\mathrm{Mg}^{2+}\right)$, no sentido das composições 2, 3 e 4(de um lado) e a análise 1(por outro lado). O mesmo é observado na Figura $5.18 \mathrm{c}\left(\mathrm{Al} \mathrm{V}^{\mathrm{V}}\right.$ versus $\mathrm{Fe}^{2+}$ ).

Para o conjunto das análises, as observações comentadas acima, em relação aos três diagramas, mostram que paralelamente ao decréscimo de $\mathrm{Al}^{\mathrm{N}}$ no sítio tetraedral(Figura 5.18a), ocorreu uma diminuição nas quantidades dos cátions bivalentes $\left(\mathrm{Fe}^{2+} \mathrm{e} \mathrm{Mg}\right)$ no sítio octaedral(principalmente o $\mathrm{Fe}^{2+}$; Figuras $5.18 \mathrm{~b}$ e 5.18c) e um aumento do conteúdo de $\mathrm{Al}^{\mathrm{V}}$ no sítio octaédral. Essa feição é, ainda, mais evidente nas análises da facies SGMv. Especialmente no que se refere as análises da clorita da facies SGMv(Anexo 30), nota-se que concomitantemente a diminuição do $\mathrm{Al}^{\mathrm{iV}}$ no sítio tetraedral ocorre um aumento nas quantidades de Si, no sentido das análises 5 e 6 para a 7, compensando a vacância, nesse sítio, deixada pela diminuição do $\mathrm{Al}^{\mathrm{lV}}$.

Em relação às composições da clorita do SCMQGs, embora não sendo tão evidente, quanto aquelas da clorita da facies SGMv, as observações acima são válidas.

A Figura 5.18d mostra uma correlação positiva entre $\mathrm{Al}^{\mathrm{lv}}$ e os cátions bivalentes(Fe $\mathrm{Fe}^{2+}$ $+\mathrm{Mg}$ ), tanto para o conjunto de todas as análises, quanto para cada grupo, em separado, caracterizada pela redução nas quantidades de $\mathrm{Al}^{\mathrm{IV}}$ e dos cátions bivalentes, confirmando que a diminuição do $\mathrm{Al}^{\dagger \vee}$ foi acompanhada por uma redução nas quantidades de ( $\mathrm{Fe}^{2+}$ $+\mathrm{Mg}^{2+}$ ), especialmente na clorita do SGMv, visto que entre as análises do SCMQGs essa correlação é muito fraca. 
No diagrama $\mathrm{Al}^{\mathrm{IV}}$ versus $\mathrm{Fe} /(\mathrm{Fe}+\mathrm{Mg})$, Figura $5.18 \mathrm{e}$, nota-se, para o conjunto das composições, que enquanto o $\mathrm{Al}^{\mathrm{IV}}$ varia, a razão $\mathrm{Fe} / \mathrm{Fe}+\mathrm{Mg}$ permanece praticamente constante. Essas características químicas são similares àquelas observadas nas cloritas dos granitóides dos maciços Antônio Vicente e Velho Gulherme e se assemelham com as características das cloritas estudadas por Borges(1997), mas destoam daquelas observadas em cloritas estudadas por Hey(1954), Foster(1962), Cathelineau \& Nieva(1985), Kranidiotis \& MacLean(1987), Cathelineau(1987) e Zang \& Fyfe(1995).

Na Figura 5.18f, do mesmo modo que na Figura 129e, observa-se que, para a totalidade das análises, a razão $\mathrm{Fe} /(\mathrm{Fe}+\mathrm{Mg})$ é praticamente contante, enquanto que as quantidades de $\mathrm{Al}^{\mathrm{VI}}$ variam amplamente, especialmente na clorita da facies SGMv.

Na Figura $5.18 \mathrm{~g}$ verifica-see uma nítida correlação negativa entre $\mathrm{Si}+\mathrm{Al} \mathrm{l}^{\mathrm{Vl}}$ e os cátion bivalentes $\left(\mathrm{Fe}^{2+}+\mathrm{Mg}^{2+}\right)$, principalmente na clorita da facies SGMv. Isso reforça, mais uma vez, o fato de que a diminuição das quantidades do $\mathrm{Al}^{\mathrm{lV}}$ no sítio tetraedral foi acompanhado por uma redução nos cátion bivalentes $\left(\mathrm{Fe}^{2+}\right.$ e $\left.\mathrm{Mg}\right)$ e por um aumento do $\mathrm{Al}^{\mathrm{VI}}$ no sítio octaédrico(conforme visto anteriormente). Assim, a Figura $5.18 \mathrm{~g}$ evidencia a razão da correlação negativa observada acima(Figuras $5.18 b$ e $5.18 d$ ).
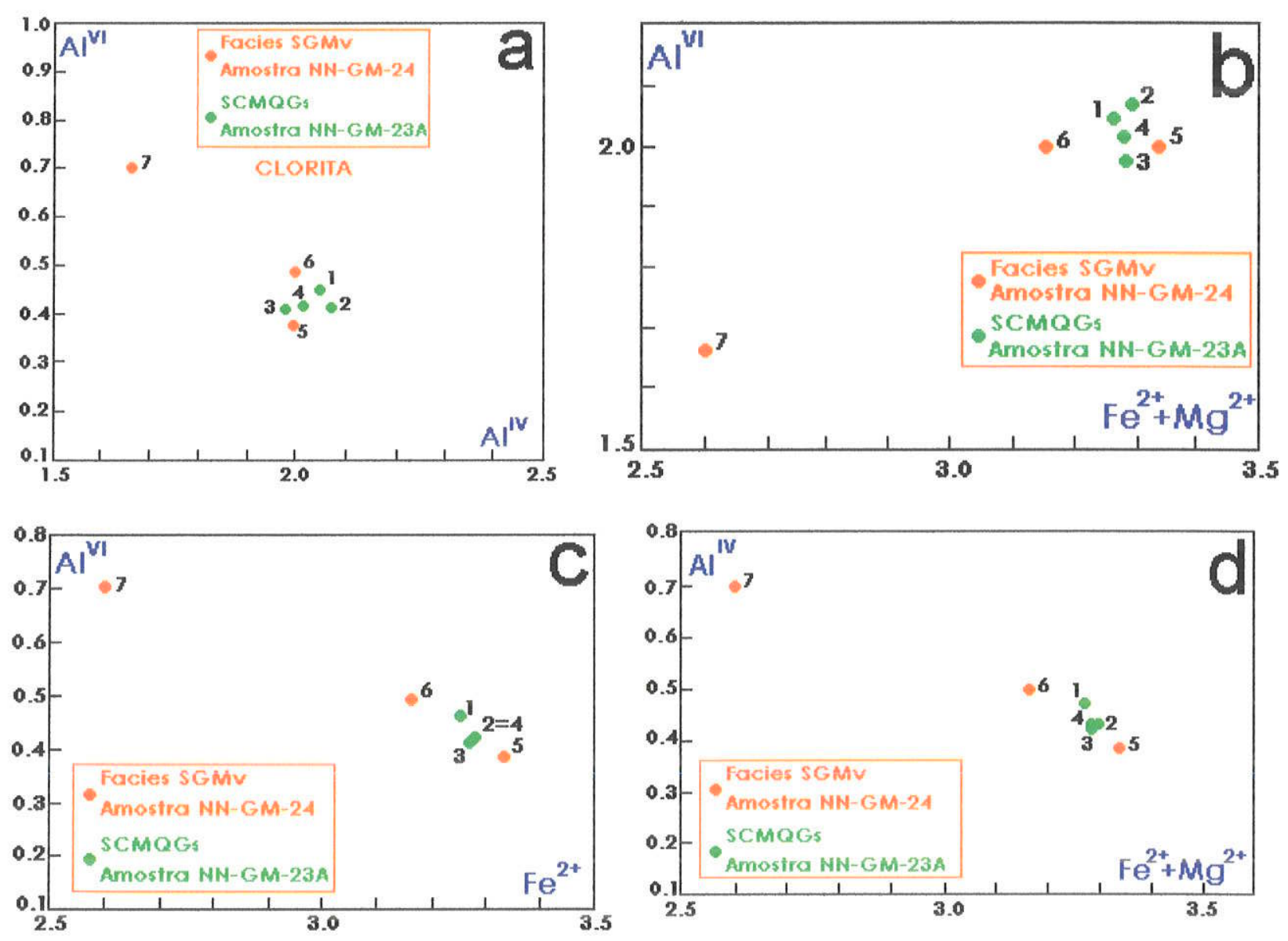

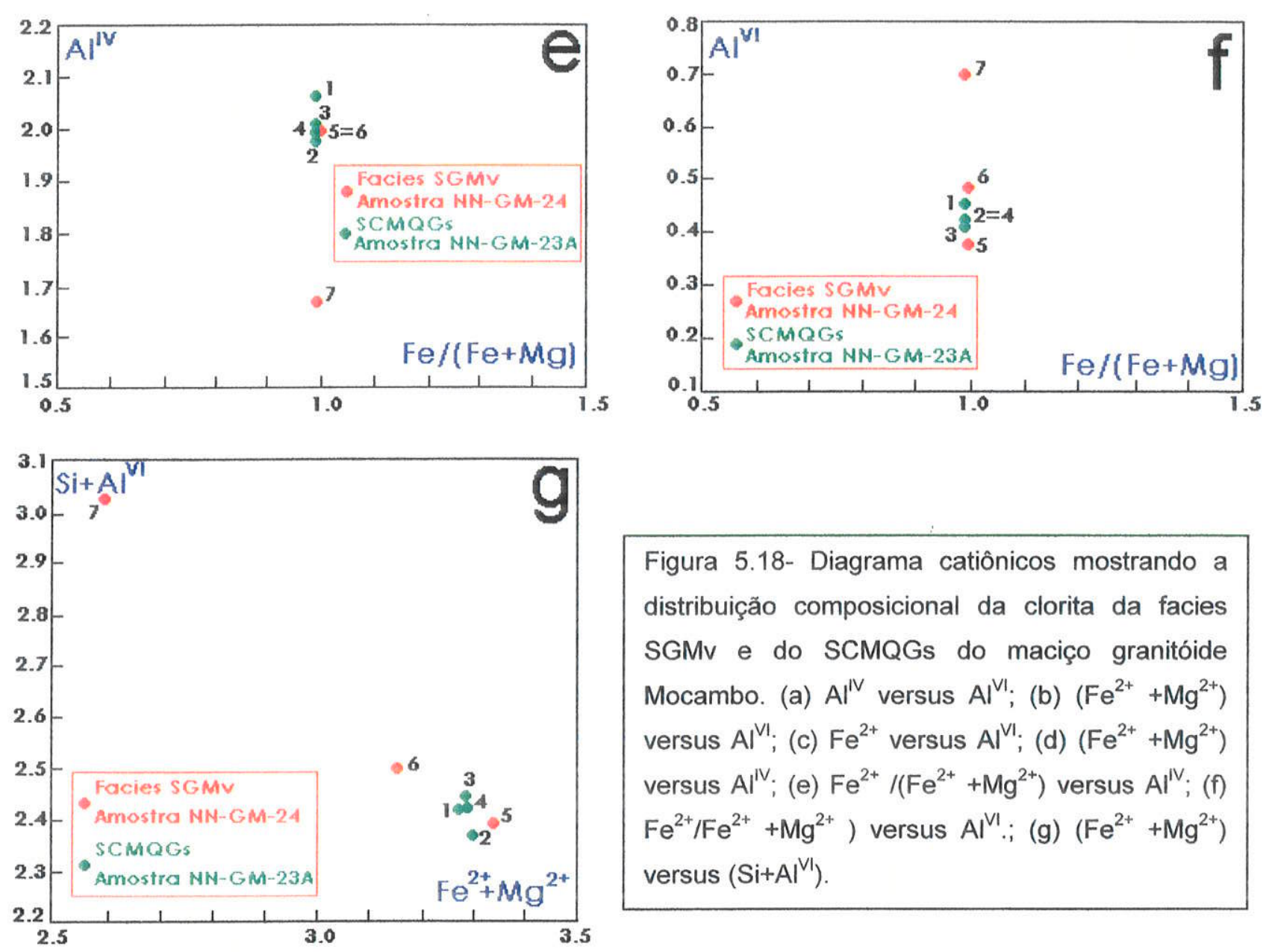

Figura 5.18- Diagrama catiônicos mostrando a distribuição composicional da clorita da facies SGMv e do SCMQGs do maciço granitóide Mocambo. (a) $\mathrm{Al}^{\mathrm{IV}}$ versus $\mathrm{Al}^{\mathrm{Vl}}$; (b) $\left(\mathrm{Fe}^{2+}+\mathrm{Mg}^{2+}\right)$ versus $\mathrm{Al}^{\mathrm{VI}}$; (c) $\mathrm{Fe}^{2+}$ versus $\mathrm{Al}^{\mathrm{VI}}$; (d) $\left(\mathrm{Fe}^{2+}+\mathrm{Mg}^{2+}\right)$ versus $\mathrm{Al}^{\mathrm{IV}}$; (e) $\mathrm{Fe}^{2+} /\left(\mathrm{Fe}^{2+}+\mathrm{Mg}^{2+}\right)$ versus $\mathrm{Al}^{\mathrm{IV}}$; (f) $\left.\mathrm{Fe}^{2+} / \mathrm{Fe}^{2+}+\mathrm{Mg}^{2+}\right)$ versus $\mathrm{Al}^{\mathrm{Vl}}$; (g) $\left(\mathrm{Fe}^{2+}+\mathrm{Mg}^{2+}\right)$ versus $\left(\mathrm{Si}+\mathrm{Al}^{\mathrm{Vl}}\right)$.

\subsubsection{2-Classificação e Representação Gráfica}

Para a classificação e representação da clorita em questão utilizou-se o método de Hey(1954), a exemplo das cloritas dos granitóides dos outros maciços. Assim, de acordo com esse autor, a clorita em tela, pelas suas características químicas, pertence ao grupo das cloritas não oxidadas, visto que seus conteúdos de $\mathrm{Fe}_{2} \mathrm{O}_{3}$ são inferiores a $4 \%$.

Quando suas composições foram lançadas no diagrama Si vs. $\mathrm{Fe}_{(\text {total) }} /\left(\mathrm{Fe}^{2+}+\mathrm{Mg}^{2+}\right)$ de Hey(op. cit.), Figura 5.19, observa-se que a da clorita da facies SGMv e apenas uma da clorita do SCMQGs incidem no campo da pseudothuringita. Três composições da clorita do SCMQGs não foram plotadas devido possuirem quantidades catiônicas de Si inferiores a 2,00 . 


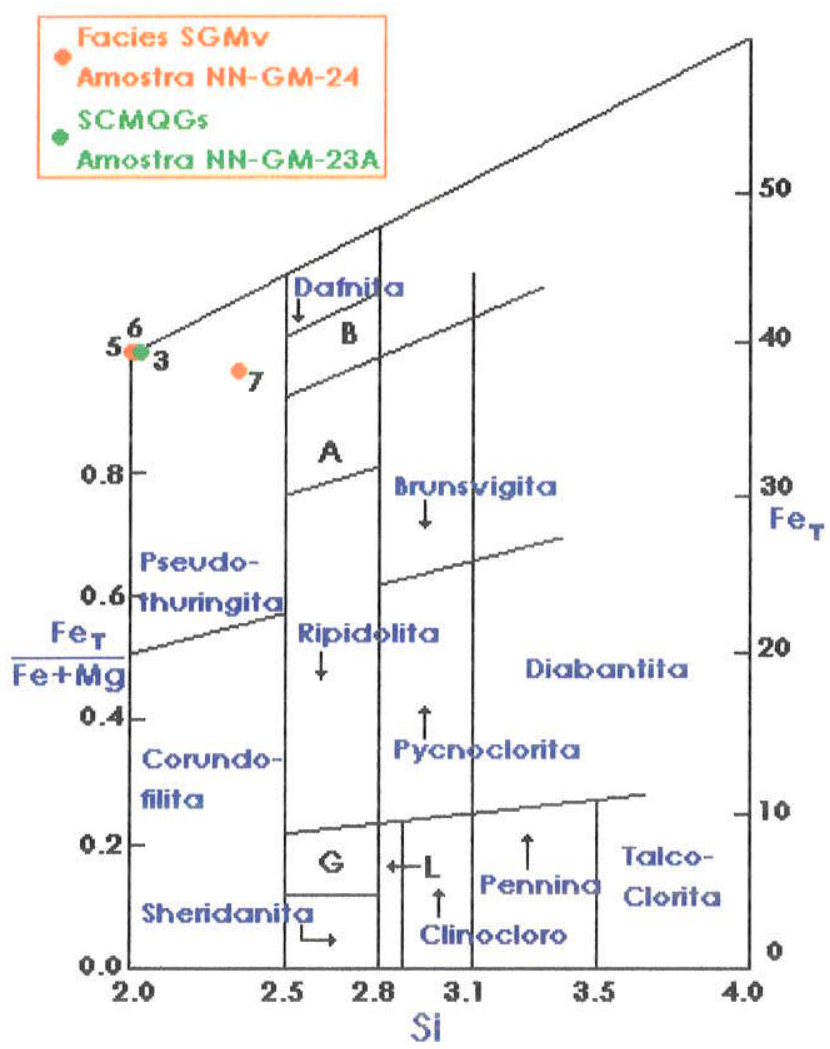

Figura 5.19- Diagrama $\mathrm{Si} \times \mathrm{Fe}_{(\text {total })} /\left(\mathrm{Fe}^{2+}\right.$ $\left.+\mathrm{Mg}^{2+}\right)$ de Hey(1954) mostrando a distribuição composicional da clorita do SGMv e SCMQGs do maciço granitóide Mocambo.

\subsubsection{3- Condições de Cristalização}

Conforme comentado em relação aos granitóides dos outros maciços, de acordo com Cathelineau \& Nieva(1985), variações nas quantidades de $\mathrm{Al}^{\mathrm{IV}}$ com a temperatura a razões $\mathrm{Fe} /(\mathrm{Fe}+\mathrm{Mg})$ constantes, podem propiciar um bom geotermômetro. De fato, os grãos de clorita analisados, mostram uma pequena variação nos valores de $\mathrm{Al}^{\mathrm{IV}}$ e apresentam, por outro lado, razões $\mathrm{Fe} /(\mathrm{Fe}+\mathrm{Mg})$, praticamente constantes. Tomando-se por base essas características composicionais, utilizou-se a equação de Cathelineau(1988) para se estimar a temperatura de cristalização da clorita estudada, obtendo-se os seguintes resultados: 1) a clorita da facies SGMv ostenta quantidades de $\mathrm{Al}^{\mathrm{IV}}$ ente 1,666 e 1,997, os quais correpondem a um intervalo de temperatura de cristalização entre $476,49^{\circ} \mathrm{C}$ e $579,46^{\circ} \mathrm{C}$; 2 ) a clorita do SCMQGs possui valores de $\mathrm{Al}^{\mathrm{lV}}$ entre 1,973 e 2,067, que equivale a um intervalo de temperatura de cristalização entre $573,34^{\circ} \mathrm{C}$ e $603,60^{\circ} \mathrm{C}$.

Essas temperaturas devem corresponder àquelas de cristalização da clorita estudada e são concordantes com as obtidas em estudos realizados por diversos autores, apartir do estudos de química mineral e de inclusões fluidas, em fases minerais de depósitos hidrotermais, associadas a rochas granitóides, pegmatitos e a corpos de greisens, bem como através da interpretação do equilíbrio de fases( Scherba, 1970; Haapala, 1977; Haapala \& Kinnnunen(1979; Durisova, 1978, charoy, 1979 e Naumov \& Ivanova, 1980, In: Stemprok, 1987; Kinnaird, 1985; Kinnaird et al., 1985a; Cathelineau, 1986; Thomas \& 
Sponer, 1985 e 1988, In: Strong, 1988; Witt, 1984, In: Taylor \& Pollard, 1988; Pollard et al.,1989; Borges, 1997) e estão dentro dos limites do campo de estabilidade da clorita de ambientes metamórficos(facies xisto verde/grau baixo) conforme Winkler(1977; pgs 49 e 52).

Elas são, também, equivalentes às temperaturas de cristalização estimadas para a clorita da facies BSG do maciço Antônio Vicente e do CSMQGs a ele associado(ver capítulo 3 , deste trabalho).

\subsection{2- Análises químicas através de Microscopia Eletrônica.}

No foram efetuadas 25 análises, envolvendo as amostras NN-GM-56A, da facies SMGP(15 análises), NN-GM-24, da facies SGMv(05 análises), e NN-GM-23A de cloritasiderofilita-muscovita-quartzo greisen(05 análises).

$\mathrm{Na}$ amostra NN-GM-56A identificou-se zircão, tveitita/yttrofluorita, fluorcerita, monazita-(Nd), pseudo-ixiolita/ferro-columbita e wolframoixiolita. Na amostra NN-GM-24 as fases investigadas foram: fluorita, tveitita/yttrofluorita e yttrocerita. E na amostra NN-GM-23A foram estudadas esfalerita e fluorcerita.

\section{a) Zircão}

As principais características óticas desse mineral, sua ordem de cristalização e origem foram comentadas no ítem Aspectos Petrográficos, deste capítulo. No estudo através de MEV foram realizadas 03 análises em dois grãos da amostra NN-GM-56A, mas não foram confeccionadas imagens. Assim, serão apresentadas apenas suas principais caracteriticas químicas.

O Anexo 31 revela que os dois grãos analisados não exibem variações significativas. O grão 1(análise 1) mostra-se mais empobrecido em $\mathrm{Zr}$ e mais enriquecido em $\mathrm{Y}, \mathrm{Yb}$ e Dy do que o grão 2(análises 2 e 3). Nele não foram analisadas as quantidades de $\mathrm{Pb}$, Th $\mathrm{U} \mathrm{U}$.

\section{b) Treitita-(Y)/Yttrofluorita}

Essa fase foi caracterizada nas amostras NN-GM-56A(análises 4, 5, 6 e 7; Anexo 31) e NN-GM-24(análises 3 e 4; Anexo 32), Figura 5.20(a ,c). Na Figura 5.20a observa-se que se trata de um grão anédrico, fraturado e de coloração cinza, que mostra-se uma estreita relação com a alteração da biotita primária para siderofilita. Nota-se, também, que esse grão abriga diversas outras fases minerais, representadas por fluorcerita-(Ce), monazita-(Nd) e epidoto, que devem corresponder à exsoluções da mesma vinculadas a alteração da fase micácea que as contém. Observações realizadas através de microscopia ótica revelaram que, no seu aspecto, essa fase lembra muito a fluorita. Na Figura 5.20c essa(s) fase(s) 
ocorre $(m)$ como zonas internas da fluorita, representando, ao que trudo indica, variações composicionais da mesma.

Nos Anexo 31 e 32, nota-se que as composições dessa fase não mostram variações importantes. Entretanto, uma comparação entre as análises das duas amostras, revela que a fase da amostra NN-GM-56A(Anexo 31) é mais enriquecida em $Y$ e mais empobrecida em $\mathrm{Ca}$ e $\mathrm{F}$ do que a fase da amostra NN-GM-24. Na realidade, a composição dessa última amostra tende mais à composição da fluorita.

É importante lembrar que por falta de dados sobre a estrutura cristalina, as designações tveititam(Y)/yttrofluorita foram extraídas da literatura, a partir da comparação entre o quimismo das fases aqui estudadas e aquelas apresentadas por Jones et al.(1996; pg 351).

\section{c) Fluorcerita-( $\left.\mathrm{Ce}_{\theta}\right)$}

Essa fase foi detectada nas amostras NN-GM-56A da facies SMGP e NN-GM-23A do SCMQGs. Conforme observado na Figura 5.20a, comentada acima, a fluorcerita da amostra NN-GM-56A, ocorre intimamente associada a tveitita-(Y)/yttrofluorita sendo, portanto, de origem secundária. Em relação àquela da amostra NN-GM-23A, não se dispõem de imagem.

As análises da amostra NN-GM-56A envolveram dois grãos(grão 1=análise 8 e grão 2=análise 9; Anexo 31), enquanto que na amostra NN-GM-23A, apenas um grão foi analisado(análise 5; Anexo 33). No Anexo 31, nota-se que o grão 1 apresenta conteúdos mais reduzidos de $\mathrm{Ce}$, La e $\mathrm{F}$ e mais elevados de $\mathrm{Nd}$ do que o grão 2. Comparativamente à composição daquela da amostra NN-GM-23A(Anexo 33), observa-se que o grão desta amostra contém quantidades menores de La e $\mathrm{F}$ em relação aos dois grãos da amostra NNGM-56A, maior teor de Ce e menor de $\mathrm{Nd}$ do que a do grão 1 e conteúdo mais elevado de Nd do que a análise do grão 2 da amostra NN-GM-56A.

Do mesmo modo que em relação às fases minerais comentadas acima, sua designação teve por base comparações com dados da literatura(Jones et al., 1996).

\section{d) Monazita-Nd}

A exemplo da fluorcerita-(Ce), a monazita ocorre intimamente associada com a tveitita-(Y)/Yttrofluorita(Figura 5.20a) e corresponde, também, a uma fase secundária. Sua presença só foi detectada na amostra NN-GM-56A.

Quimicamente, representa uma fase do tipo monazita-Nd(Jones et al., 1996), visto que contém $9,98 \%$ de $\mathrm{Nd}$, além de $\mathrm{Ce}(29,45 \%)$ e La(11,02\%). Afora esses elementos, possui cerca de $1,28 \%$ de $\mathrm{Sm}$ (Anexo 31 ). 


\section{ө) Pseudo-ixiolita/Ferro-columbita}

Essa fase foi detectada apenas na amostra NN-GM-56A(Figura 5.20b). O Anexo 31 mostra que se trata de uma fase óxido que ostenta quantidades apreciáveis de $\mathrm{Nb}(47,44 \%$ a $48,45 \%)$, conteúdos moderados de $\mathrm{Fe}(12,72 \%$ a $13,26 \%)$ e $\mathrm{Ta}(6,43 \%$ a $8,34 \%)$ e reduzidos teores de $\mathrm{Mn}$ e $\mathrm{Ti}$. Comparativamente às análises de fases minerais óxidos, ricas em $\mathrm{Nb}$, apresentadas na literatura, esta fase pode corresponder tanto à uma pseudo-ixiolita, quanto à uma ferro-columbita, ambas do grupo da columbita-tantalita(Foord, 1982; pgs. 206-210).

\section{f) Wolframoixiolita}

Do mesmo modo que a fase comentada acima, só foi detectada na amostra NN-GM56A(Figura 5.20b). Quimicamente, corresponde a um mineral com quantidades significativas de $\mathrm{Nb}(29,55 \%), \mathrm{W}(16,95 \%), \mathrm{Ta}(16,10 \%)$ e $\mathrm{Fe}(12,32 \%)$, baixos conteúdos de $\mathrm{Mn}(2,19 \%)$ e reduzidos teores de Ti(Anexo 31). Essas caracteristicas químicas, quando comparadas com aquelas apresentadas na literatura, se assemelham muito com a composição da wolframoixiolita apresentada por Foord(1982). Entretanto, de acordo com esse autor essa designação não foi aceita pela IMA, tendo sido considerada como uma provável Nbwolframita.

\section{g) Fluorita}

Dois grãos de fluorita foram analisados, ambos na amostra NN-GM-24, mas não foram obtidas imagens dos mesmos. Sabe-se, todavia, que a fluorita é uma fase claramente secundária, conforme visto no item Aspectos Petrográficos deste capítulo. Os cristais analisados correspondem a fluorita 2.

Quimicamente, as duas análises representam uma fase cuja composição é muito próxima à da fluorita pura, uma vez que incorpora apenas reduzidissimas quantidades de $Y$, Th, P, Si e Al, sendo F e Ca seus componentes essenciais(Anexo 32).

\section{h) Yttrocerita(?)}

Esta fase foi caracterizada apenas na amostra NN-GM-24 e, do mesmo modo que para a fuorita, năo foram efetuadas imagens da mesma.

O Anexo 32 indica que se trata de uma fase que contém quantidades um pouco elevadas de $\mathrm{F}(29,19 \%), \mathrm{O}(23,30 \%), \mathrm{Ca}(18,86 \%)$ e $\mathrm{Ce}(11,06 \%)$, conteúdos modestos de $Y$, $\mathrm{Nd}$ e $\mathrm{La}(6,54 \%, 6,21 \%$ e $4,47 \%$, respectivamente) e baixissimos teores de $\mathrm{Si}$, Ti e Al. Compativamente às composições químicas de fases minerais semelhantes, apresentadas na literatura, observa-se que não há uma correspondência perfeita. A composição que mais se aproximou foi a da $\left.\mathrm{Yttroceria}(\mathrm{Ca}, \mathrm{Ce}, \mathrm{Y}, \mathrm{La}) \mathrm{F}_{3}, \mathrm{nH}_{2} \mathrm{O}\right)$, apresentada por Jones et al.(1996; pg. 351). De qualquer modo, a fase aqui estudada, difere da mesma, 
principalmente, pela presença de $\mathrm{Nd}$. Com relação ao conteúdo de $\mathrm{H}_{2} \mathrm{O}$ na Yttrocerita, nada pode ser dito, visto que as análises através de MEV não fornecem esse dado.

\section{i) Esfalerita}

Sobre essa fase, foram realizadas quatro análises em cristais distintos pertencentes à amostra NN-GM-23A. No que se refere a sua origem, sabe-se que a ela ocorre intimamente associada a alteração da biotita primária, juntamente com outras fases relacionadas a essa alteração(ver Aspectos Petrográficos, deste capítulo), tendo, portanto, uma natureza secundária, relacionada ao estágio de alterações tardi a pós-magmáticas.

Quimicamente, os grãos analisados não exibem variações importantes. Mostram conteúdos elevados de $\mathrm{Zn}(62,52 \%$ a $63,61 \%)$ em relação ao $\mathrm{Fe}(5,11 \%$ a $6,50 \%)$, indicando que sua cristalização ocorreu em condições de temperatura não muito elevadas, e uma análise exibe quantidades vestiginais de Pd e $\mathrm{Al}$ (análise 2, anexo 33).
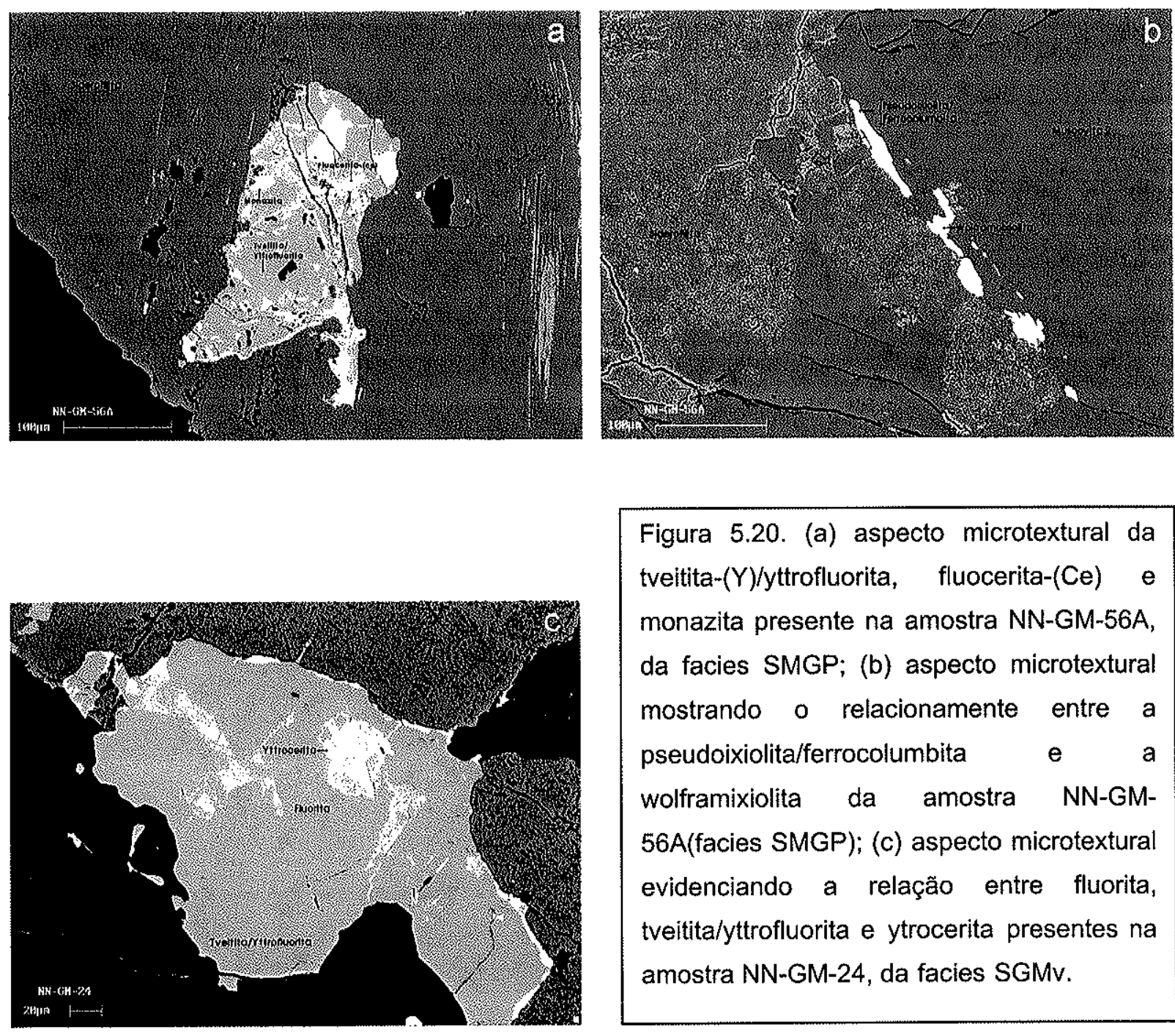

Figura 5.20. (a) aspecto microtextural da tveitita-(Y)/yttrofluorita, fluocerita-(Ce) e monazita presente na amostra NN-GM-56A, da facies SMGP; (b) aspecto microtextural mostrando o relacionamente entre a pseudoixiolita/ferrocolumbita e a wolframixiolita da amostra NN-GM56A(facies SMGP); (c) aspecto microtextural evidenciando a relação entre fluorita, tveitita/yttrofluorita e ytrocerita presentes na amostra NN-GM-24, da facies SGMv. 


\section{6- Geoquímica}

Os dados químicos de rocha total apresentados na Tabela 5.5(Anexo 34) correspondem às principais facies petrográficas identificadas no âmbito do maciço granitóide Mocambo e à um corpo de greisen a ele associado.

\subsection{1- Características Gerais}

No contexto deste maciço nota-se que os granitóides estudados correspondem à diferenciados extremamente evoluídos, os quais encontram-se afetadas, em diferentes intensidades, por alterações tardi a pós-magmáticas e possuem teores de $\mathrm{SiO}_{2}$, superiores a $75 \%$. Excetua-se a isso, o corpo de greisen que possui teores de $\mathrm{SiO}_{2}$ levemente inferior e igual a $74,94 \%$. No que diz respeito aos principais óxidos maiores, os granitóides apresentam, de um modo geral, conteúdos de $\mathrm{TiO}_{2}, \mathrm{Al}_{2} \mathrm{O}_{3}, \mathrm{MgO}$, CaO e $\mathrm{P}_{2} \mathrm{O}_{5}$ sempre muito baixos e inferiores aqueles da média dos granitos(Le Maitre, 1976), as quantidades de $\mathrm{K}_{2} \mathrm{O}$ são ligeiramente mais elevadas e as de $\mathrm{Na}_{2} \mathrm{O}$ são eqüivalentes. Em relação aos elementos menores e traços, contém altos teores de $\mathrm{Rb}$ (média entre 785,50 e 936,61ppm), $\mathrm{Zr}$ ( média entre 117,5 e 163,50ppm), Y(média de 79,0 a 218,0ppm), Zn(média entre 105,0 e 247ppm) e $F$ (média entre 1300 e $14.500 \mathrm{ppm}$ ), conteúdos moderados de $\mathrm{Nb}$ (média entre 75,83 e $125,93 \mathrm{ppm}$ ), Ga(média entre 31,50 e $36,50 \mathrm{ppm}$ ), $W$ (média entre 81,83 e 182,56ppm) e Th(média entre 51,60 e 83,24ppm) e baixas concentrações de Sr(média entre 18,0 e 21,0 ppm), Cl(não detectado nas facies SGMv, Aplitica e SCMQGs e média de 360,0ppm na facies SMGP), Ta(média entre 10,68 e 18,39ppm), Hf(média entre 6,77 e 12,28ppm), $\mathrm{U}$ (média entre 17,35 e 20,41ppm), Sn(média entre 10,5 e 69,0ppm), Mo(média entre 2,91 e $23,91 \mathrm{ppm}$ ) e Ba(média entre 27,50 e 42,0ppm, exceto na facies SMGP que esse elemento apresenta teor médio igual a $310 \mathrm{ppm}$ ). Os elementos terras raras ocorrem em conteúdos sempre baixos(exceto o $\mathrm{Ce}$ ), embora aqueles de ETRL sejam, em geral, mais elevados do que aqueles de ETRP. O greisen, por sua vez, mostra-se, relativamente aos granitóides, enriquecido em de $\mathrm{Fe}_{2} \mathrm{O}_{3}$. As razões $\mathrm{Rb} / \mathrm{Sr}$ (média entre 39,77 e 46,83), $\mathrm{Rb} / \mathrm{Ba}$ (média entre 22,30 e 28,56 , exceto na facies SMGP que é igual a 2,69) e Th/U(média entre 2,84 e 4,29) são, geralmente altas, enquanto as razões $\mathrm{K} / \mathrm{Rb}$ (média entre 33,68 e 60,83) são baixas se comparadas com aquelas dos granitos considerados normais(Shaw, 1968).

\subsection{2- Saturação em Alumina(ISA)}

Embora as rochas do maciço possuam conteúdos de $\mathrm{Al}_{2} \mathrm{O}_{3}$ inferiores aqueles da média dos granitos(Le Maitre, 1976), em termos da aluminosidade, os granitóides são essencilamente peraluminosas, com as razões dos conteúdos moleculares NKIA variando entre 0,52 e 0,67 e as razões $A / C N K$ sendo superiores a 1 e alcançam 1,78 na facies SMGP(Figura 5.21). 


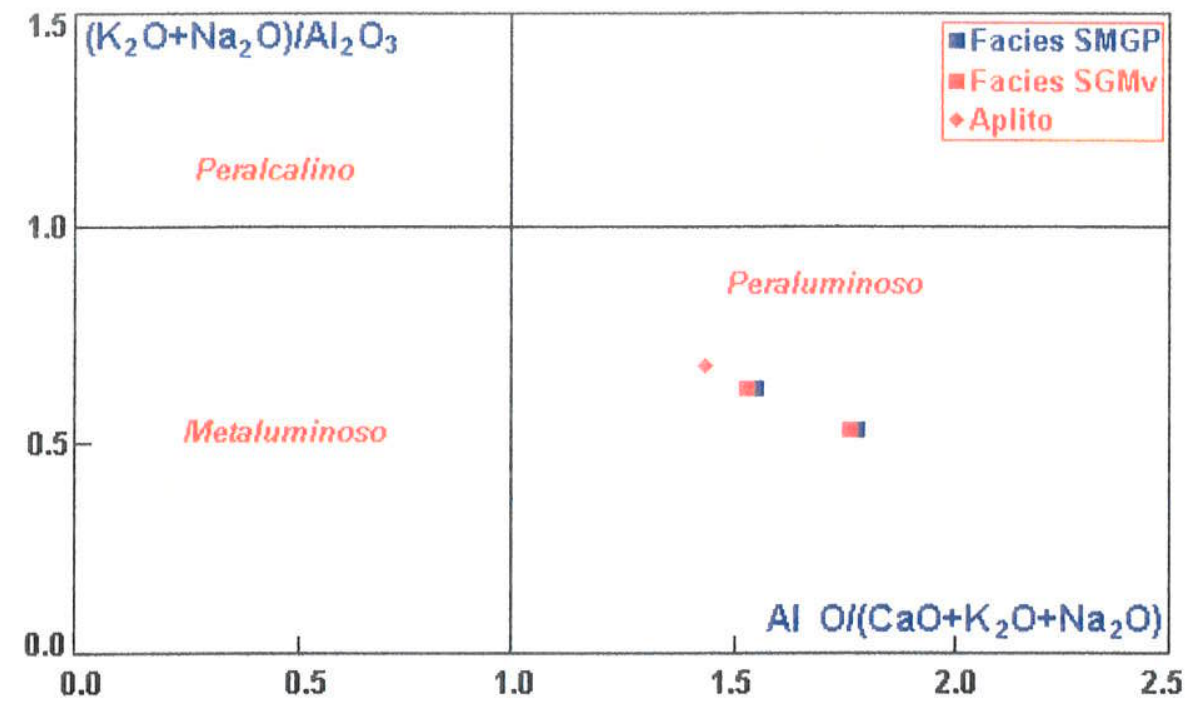

Figura 5.21- Diagrama binário A/CNK versus NK/A(Maniar\& Piccoli, 1989) mostrando a distribuição das facies granitóides do MGM, com baseado nos índices de Shand(ISA).

\subsection{3 - Afinidade Tectonomagmática e Tipologia}

Uma referência aos diversos autores que apresentaram sugestões com o intuito de caracterizar a tipologia de granitóides e a paleoambiência geológica de colocação dos mesmos foi apresentada no capítulo 3.

Nos Diagramas clássicos $\mathrm{Y}-\mathrm{Nb}$, (y+Nb)-Rb e Ta-Yb de Pearce et al.(1984), Figura 5.22(a, b e c, respectivamente), nota-se que as composições dos granitóides estudados incidem preferencialmente, nos campos correspondentes aos granitóides intra-placas. Entretanto, no diagrama $\mathrm{Rb}-\mathrm{Y}+\mathrm{Nb}$, uma amostra da facies SMGP incide fora desse campo, mas muito próximo ao limite entre o mesmo e o campo correspondente aos granitóides sincolisionais.
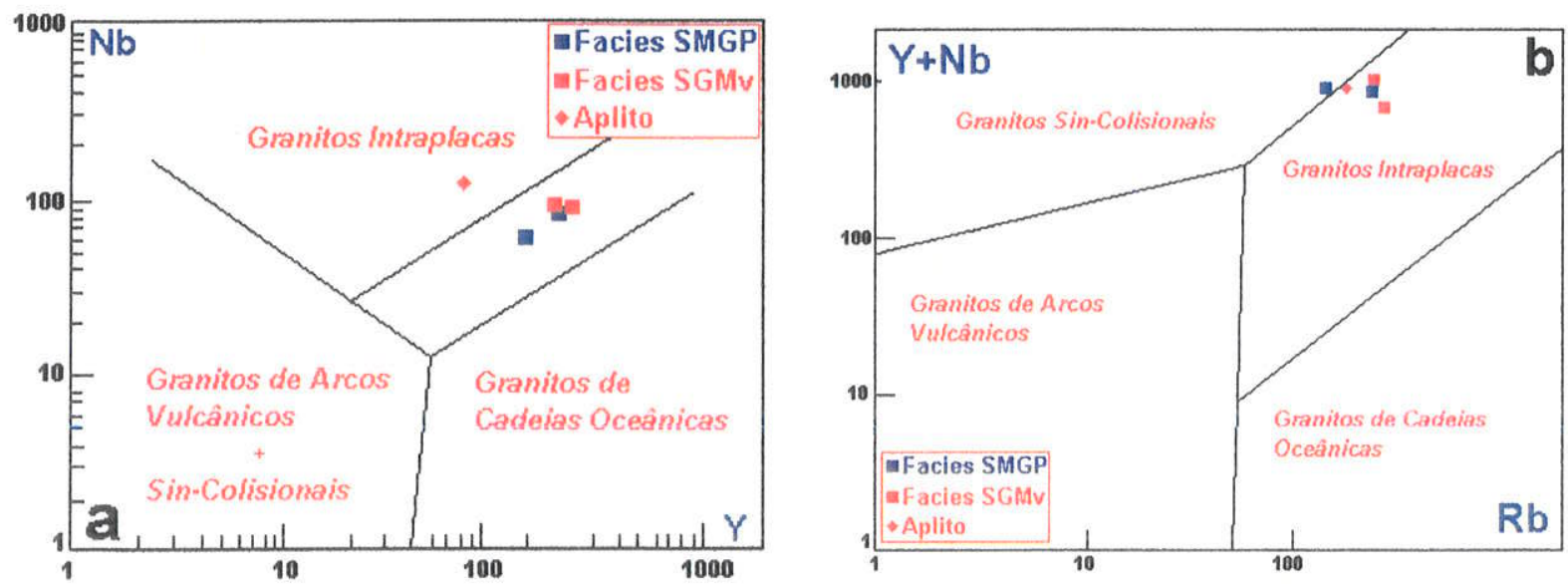


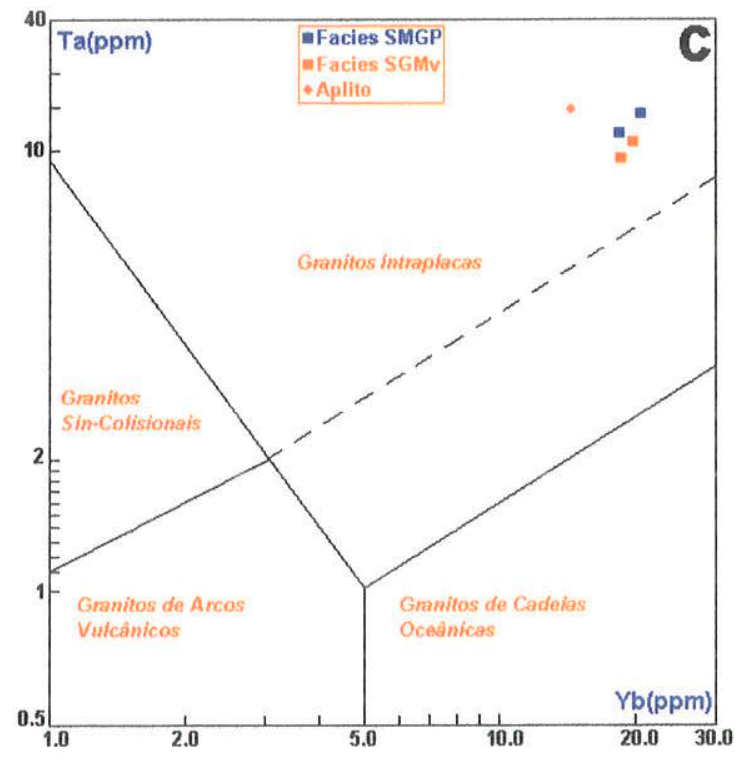

Figura 5.22- Diagramas discriminantes de paleoambiência tectônica de Pearce et al.(1984) mostrando a distribuição das amostras dos granitóides do MGM (a) Y$\mathrm{Nb}$; (b) [Nb+Y]-Rb; (c) $\mathrm{Yb}-\mathrm{Ta}$.

Como visto nos capítulos 3 e 4, os granitóides tipo-I, altamente fracionados, podem ser distiguidos de granitóides tipo-A utilizando-se o parâmetro de discriminação $\mathrm{Zr}+\mathrm{Nd}+\mathrm{Ce}+\mathrm{Y}$, uma vez que para um dado grau de fracionamento, os granitos tipo- $\mathrm{A}$ apresentam conteúdos muito mais altos desses elementos incompatíveis do que aqueles do tipo-I(Whalen et al.(1987).

Assim, no que diz respeito aos granitóides deste maciço, os dados químicos referentes a esses elementos foram lançados nos diagrama $\mathrm{Zr}+\mathrm{Nb}+\mathrm{Ce}+\mathrm{Y}$ vs. $\left(\mathrm{K}_{2} \mathrm{O}+\mathrm{Na}_{2} \mathrm{O}\right) / \mathrm{CaO}$, de Whalen et al.(op. cit.), Figura 5.23. Observa-se que a totalidade das amostras incide no campo composicional correspondente aos granitos tipo-A, confirmando as observações de Whalen et al.(1987).

No diagrama $\mathrm{Zr}+\mathrm{Nb}+\mathrm{Ce}+\mathrm{Y}$ vs. $\left(\mathrm{Fe}_{\mathrm{T}} / \mathrm{MgO}\right)$, dos mesmos autores, Figura 5.24 deste trabalho, que expressa o grau de fracionamento, nota-se que a todas as amostras "plotam" no campo dos granitóides tipo-A.

$\mathrm{O}$ diagrama $10.000 \mathrm{Ga} / \mathrm{Al}$ vs. $\left(\mathrm{K}_{2} \mathrm{O}+\mathrm{Na}_{2} \mathrm{O}\right) / \mathrm{Al}_{2} \mathrm{O}_{3}$ de Whalen et al.(op cit.), modificado por Rämö \& Haapala(1995), que exprime a tipologia e o grau de alcalinidade ou índice agpaítico, Figura 5.25, mostra que as amostras incidem inteiramente no campo correspondente aos granitos tipo-A, de natureza subalcalina.

Com base na subdivisão proposta por Eby(1992), os dados químicos referentes aos granitóides estudados foram "plotados" nos diagramas discriminantes Y-Nb-Ce e Y-Nb-3Ga, Figuras 5.26(a, b). Em ambos os casos, as amostras incidem preferencialmente no campo correspondente aos granitóides tipo- $A_{2}$. É exceção à isso a rocha aplítica que incide no campo dos granitóides tipo- $A_{1}$. Esse fato pode ser decorrente dos muito mais baixos valores de $Y$ na amostra analisada. Uma hipótese alternativa pode ser atrubuída à erros analíticos ou, ainda ao linmite entre os dois campos ter sido definido estatisticamente, possibilitando 
que certas análises de granitóides Tipo- $A_{2}$ possam cair no campo correspondente aos granitóides Tipo-A1.

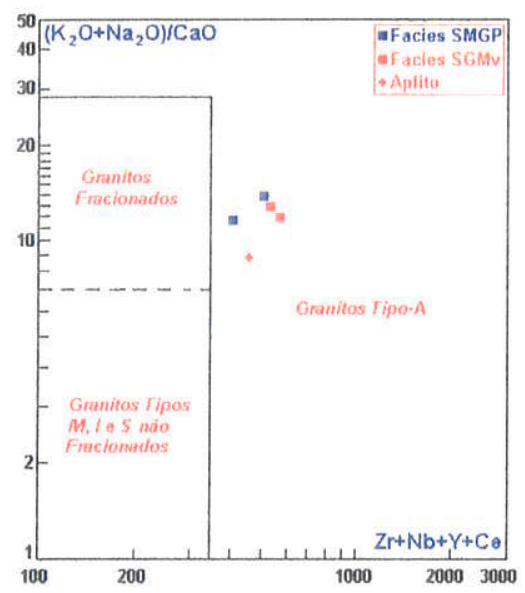

Figura 5.23- Diagrama $\mathrm{Zr}+\mathrm{Nb}+\mathrm{Ce}+\mathrm{Y}$ vs. $\left(\mathrm{K}_{2} \mathrm{O}+\mathrm{Na}_{2} \mathrm{O}\right) / \mathrm{CaO}$ de Whalen et al.(1987) mostrando a distribuição composicional das amostras das principais facies granitóides do maciço granitóide Mocambo.

Figura 5.24- Diagrama $\mathrm{Zr}+\mathrm{Nb}+\mathrm{Ce}+\mathrm{Y}$ contra ( $\mathrm{Fe}$ (total)/MgO) de Whalen et al.(1987) mostrando a distribuição composicional das amostras das principais facies granitóides do maciço Mocambo.
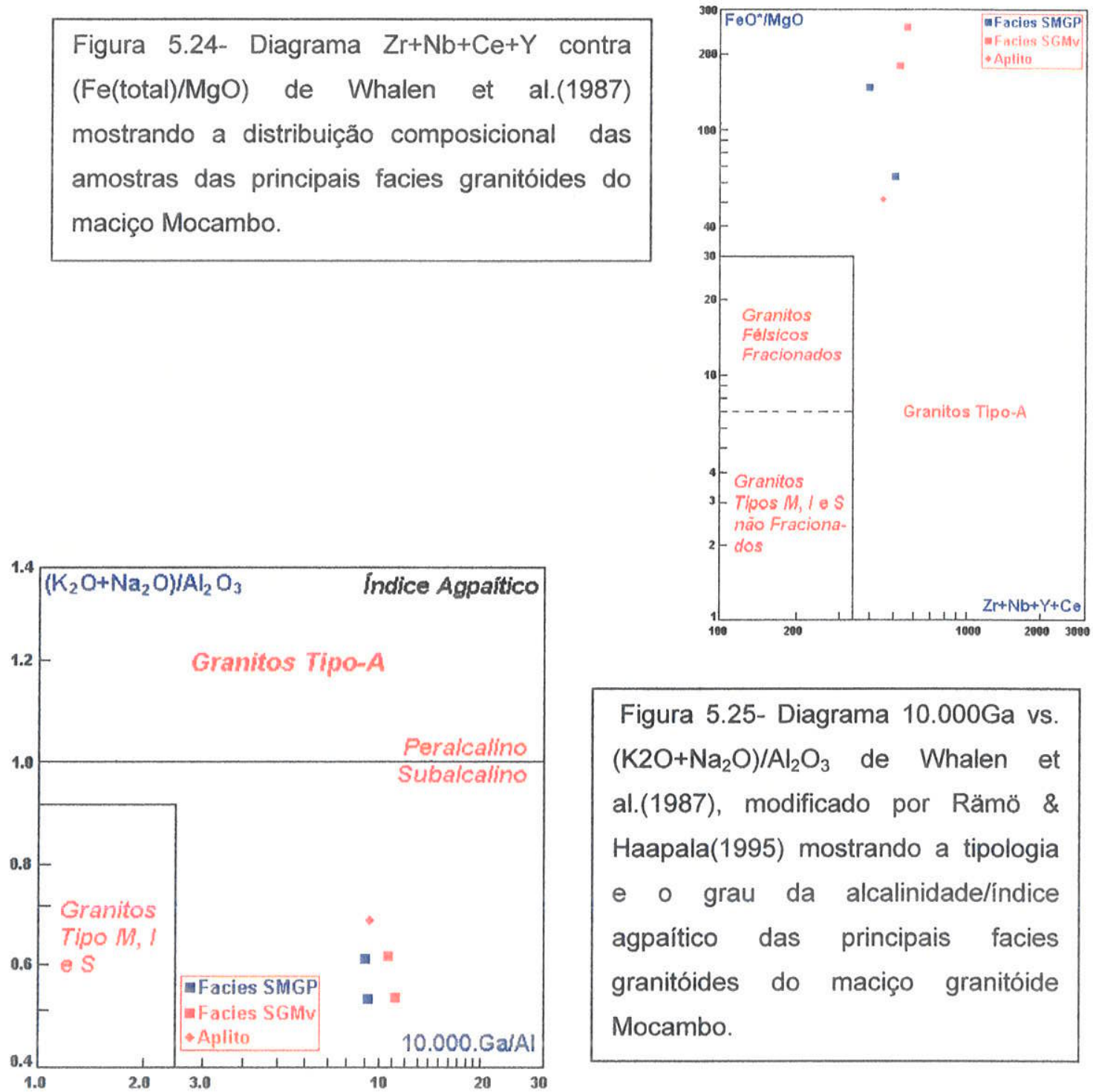

Figura 5.25- Diagrama $10.000 \mathrm{Ga}$ vs. $\left(\mathrm{K} 2 \mathrm{O}+\mathrm{Na}_{2} \mathrm{O}\right) / \mathrm{Al}_{2} \mathrm{O}_{3}$ de Whalen et al.(1987), modificado por Rämö \& Haapala(1995) mostrando a tipologia e o grau da alcalinidade/índice agpaítico das principais facies granitóides do maciço granitóide Mocambo. 

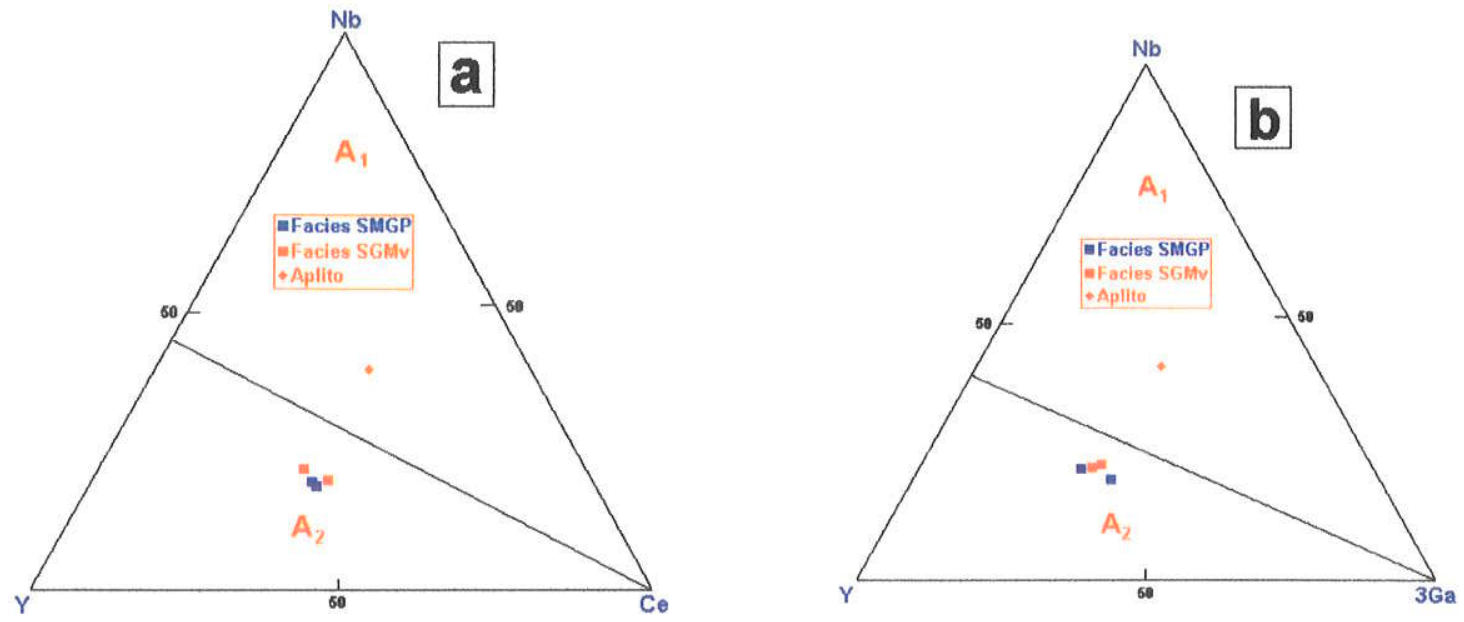

Figura 5.26 Diagramas triangulares $\mathrm{Y}-\mathrm{Nb}-\mathrm{Ce}(\mathrm{a})$ e $\mathrm{Y}-\mathrm{Nb}-3 \mathrm{Ga}(\mathrm{b})$ de $\mathrm{Eby}(1992)$ mostrando a distribuição composicional das principais facies granitóides do maciço granitóide Mocambo.

\subsection{4- Outras Feições Geoquímicas}

O diagrama $\mathrm{SiO}_{2}$ vs. $\mathrm{FeO}^{*} /\left(\mathrm{FeO}^{*}+\mathrm{MgO}\right)$, Figura 5.27a, mostra uma discreta correlação positiva entre as duas variáveis em questão, definida pelo aumento dos conteúdos de $\mathrm{SiO}_{2}$ e da razão $\mathrm{FeO}^{*} /\left(\mathrm{FeO}^{*}+\mathrm{MgO}\right)$ no sentido da facies SMGP para a facies aplítica, com a facies SGMv ocupando uma posição intermediária no "trend". Esse comportamento demonstra, ao que tudo indica, que a facies SMGP representa o termo menos evoluído no âmbito desse maciço, enquanto que a rocha aplítica corresponde ao diferenciado mais evoluído.

$\mathrm{Na}$ Figura 5.27b nota-se que as quantidades de $\mathrm{CaO}$ e de $\mathrm{Na}_{2} \mathrm{O}$ tendem a diminuir no sentido da facies SMGP para as facies SGMv e aplito(exceto no que se refere à análise número 4 da facies SGMv; Tabela 5.5, Anexo 34). Os mais reduzidos conteúdos de CaO na facies SGMv e no aplito devem-se, ao que tudo indica, ao fracionamento do plagioclásio no estágio magmático, bem como ao caráter mais hololeucocrático dessas duas facies em relação à facies SMGP. Além disso, as mais baixas taxas de plagioclásio são encontradas nessas facies(ver ítem Aspectos Petrográficos deste capítulo). No que se refere à análise de número 4 , verifica-se que as quantidadas de $\mathrm{CaO}$ e de $\mathrm{Na}_{2} \mathrm{O}$ fogem desse comportamento. Entretanto, dados de química mineral revelaram que o plagioclásio pertencente à mesma mostra composição variável, com as quantidades da molécula An variando entre $A n_{0}$ e $A n_{7}$ (ver ítem Química Mineral deste capítulo). Isso pode explicar, pelo menos em parte, o comportamento diferenciado dessa amostra em relação às demais analisadas. 

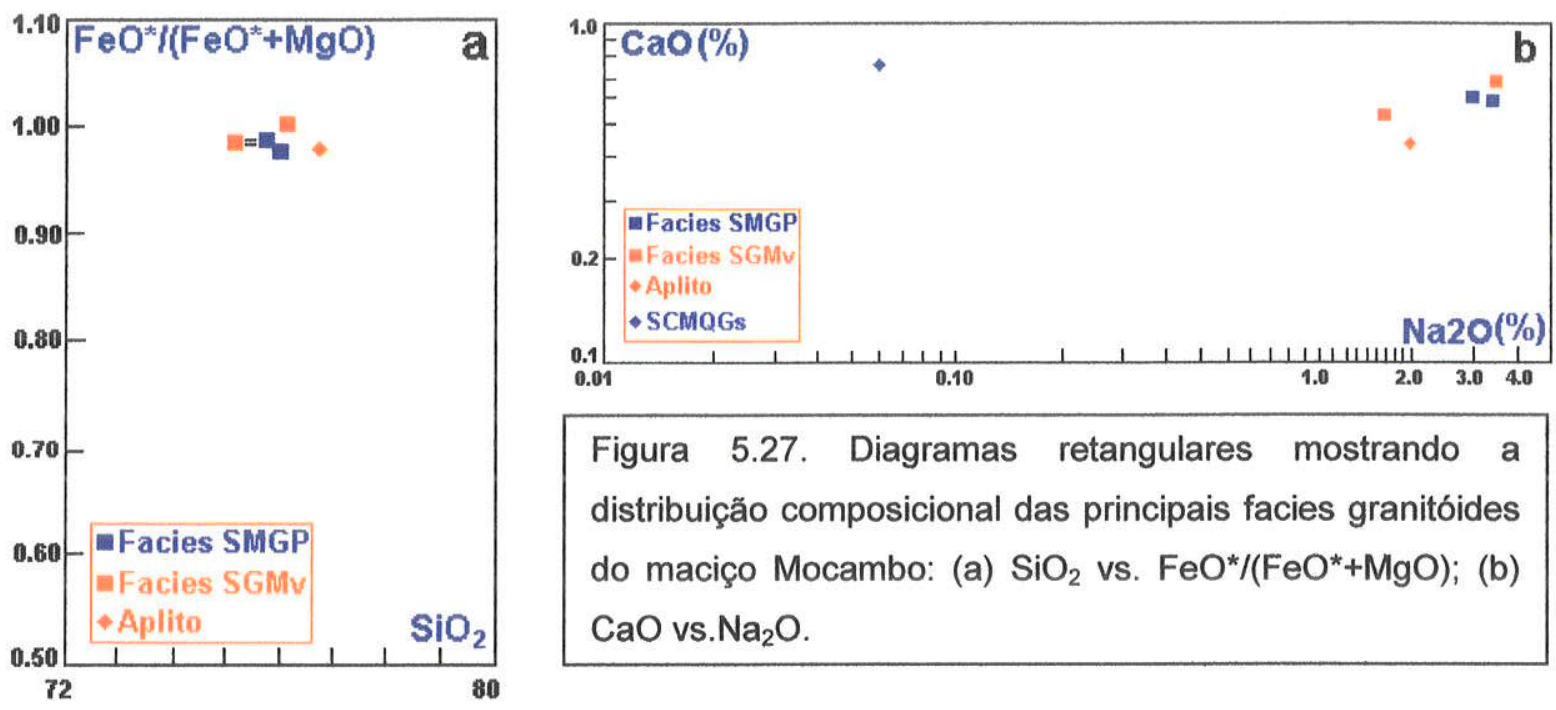

Figura 5.27. Diagramas retangulares mostrando a distribuição composicional das principais facies granitóides do maciço Mocambo: (a) $\mathrm{SiO}_{2}$ vs. $\mathrm{FeO}^{*} /\left(\mathrm{FeO}^{*}+\mathrm{MgO}\right)$; (b) $\mathrm{CaO}$ vs. $\mathrm{Na}_{2} \mathrm{O}$.

A Figura 5.28, ilustra a correlação entre os conteúdos de $\mathrm{Sr}$ e os de $\mathrm{Na}_{2} \mathrm{O}$ no âmbito das facies granitóides do maciço. Observa-se que assim como no caso da Figura 5.27b há uma tendência de diminuição nos teores de $\mathrm{Sr}$ e $\mathrm{Na}_{2} \mathrm{O}$ no sentido da facies SMGP para as facies SGMv e aplito, evidenciando que o $\mathrm{Sr}$ acompanha o $\mathrm{CaO}$ no estágio magmático, comportando-se como elemento compatível durante a diferenciação magmática. $E$ esse comportamento, assim como o do $\mathrm{Ca}$, ao que tudo indica, foi controlado pelo fracionamento do plagioclásio, bem como deve-se, adicionalmente, às menores quantidades modais dessa fase mineral nas facies granitóides SGMv e aplito. Do mesmo modo que em relação ao $\mathrm{Ca}$, a quantidade mais elevada de $\mathrm{Sr}$ na amostra de numero 4 da facies SGMv deve estar ligada a composição do plagioclásio nessa amostra, onde as quantidades da molécula An variam entre $A n_{0}$ e $A n_{7}$.

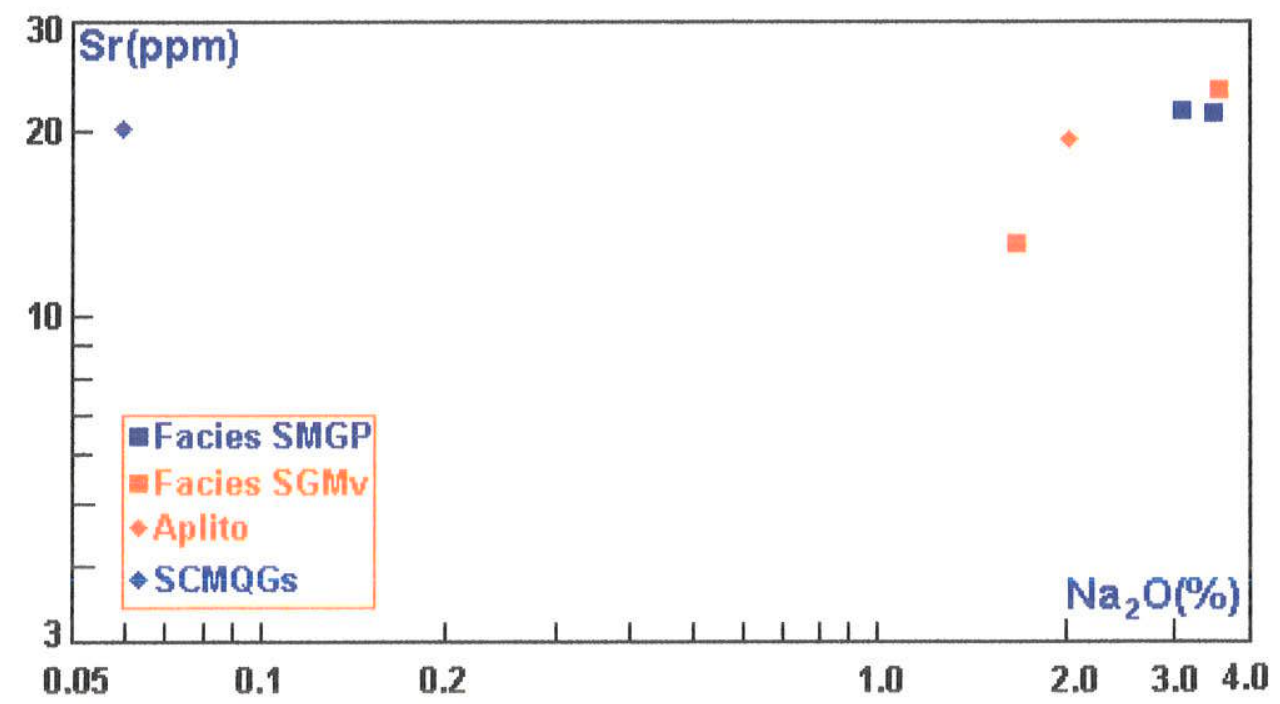

Figura 5.28- Diagrama $\mathrm{Sr}_{-} \mathrm{Na}_{2} \mathrm{O}$ mostrando a distribuição composicional das amostras das principais facies granitóides do maciço granitóide Mocambo. 
As razões $\mathrm{K} / \mathrm{Rb}$ entre de 300 a 150 são consideradas normais para granitos (Shaw, 1968). Do mesmo modo que os granitóides dos maciços granitóides Antônio Vicente e Velho Guilherme, nesses granitóides, as razões K/Rb da totalidade das amostras situa-se abaixo de 100 e acima de 20(Figura 5.29a). Os teores médios de $\mathrm{K}_{2} \mathrm{O}$ variam entre $4,03 \%$ (facies SMGP) e 6,38\%(facies aplito), com a facies SGMvc possuindo valor intermediário e igual a $4,53 \%$. Os Conteúdos de $\mathrm{Rb}$ variam aleatoriamente e a facies SGMv exibe os mais elevados e os mais baixos teores, os quais oscilam ente 628,34ppm e 942,65ppm(Tabela 5.5, Naxo 34). O greisen ostenta quantidades elevadas de $\mathrm{Rb}(936,61 \mathrm{ppm})$.

Nas Figuras $5.29 \mathrm{~b}$ observa-se que $\mathrm{Rb}$ e $\mathrm{Sr}$ variam aleatoriamente. Os mais elevados conteúdos médios de $\mathrm{Sr}$ são encontrados na facies SMGP(21ppm) e os mais baixos na facies SGMv(13ppm). Entretanto,em valores absolutos, a amostra de número 4 apresenta a maior concentração desse elemento(23ppm).

A Figura $5.29 \mathrm{c}$, mostra as composições dos granitóides do maciço situam-se no campo dos granitóides extremamente diferenciados (El Bouseily \& El Sokkary, 1975). Entretanto, as duas amostras da facies SMGP "plotam" um pouco afastadas do vértice correspondente ao $\mathrm{Rb}$ no sentido do vértice do $\mathrm{Ba}$, enquanto as demais formam um agregado localizado muito próximo do máximo de $\mathrm{Rb}$.

O $\mathrm{Zr}$ ocorre em concentrações relativamente altas nesses granitóides e greisen(Tabela 5.5, Anexo 34), comportando-se, portanto, como elemento incompatível durante a diferenciação magmática, razão pela qual mostra teores mais elevados nos diferenciados mais tardios, representados pelas facies SGMv e aplitica. No diagrama Rb$\mathrm{Zr}$ (Figura 5.29d) nota-se uma discreta correlação positiva entre o $\mathrm{Zr}$ e e Rb, caracterizada pelo aumento nos conteúdos desses dois elementos no sentido da facies granitóide evoluída(SMGP) para os diferenciados mais evoluídos(facies SGMv e aplito). É exceção a isso a amostra de número 4, que embora hospede as mais altas concentrações de $\mathrm{Zr}$, comporta os mais reduzidos teores de $\mathrm{Rb}$ como visto anteriormente. No greisen observa-se concentrações de $\mathrm{Zr}$ e de $\mathrm{Rb}$ eqüivalentes às facies granitóides mais evoluídas do maciço. As razões $\mathrm{Zr} / \mathrm{Rb}$ são invariavelmente baixas e situam-se entre 0.1 e 0.4 , embora para a maioria das análises esse intervalo seja entre 0.1 e 0.2 (Figura $5.29 \mathrm{~d}$ ).

O diagrama $\mathrm{Zr}$-Hf(Figura 5.29e) mostra uma nítida correlação positiva entre esses elementos, especialmente entre os granitóides, caracterizada pelo aumento nas concentrações de ambos no sentido da facies SMGP para a facies aplito, com a facies SGMV ocupando uma posição aproximadamente intermediária no "trend". No diagrama Zr$\mathrm{TiO}_{2}$ (não apresentado) isso não ocorre e a distribuição das análises é mais ou menos errática. 
No diagrama U-Th(Figura 5.29f), nota-se que as concentrações de Th variam mais amplamente do que àquelas de U. Observa-se, ainda, uma discreta correlação positiva entre os conteúdos ambos, cracterizada pelo aumento nas quantidades de $\mathrm{U}$ e de $T$ th no sentido da facies SMGP para as facies SGMv e aplito, atingindo a concentração máxima no greisené(Tabela 27; Figura 140e). As razões médias U/Th são sistematicamente baixas e inferiores a 0,5(SMGP=0,35; SGMv=0,23; Aplito=0,34; SCMQGs=0,25, o que indica tratar-se de granitos HHP.
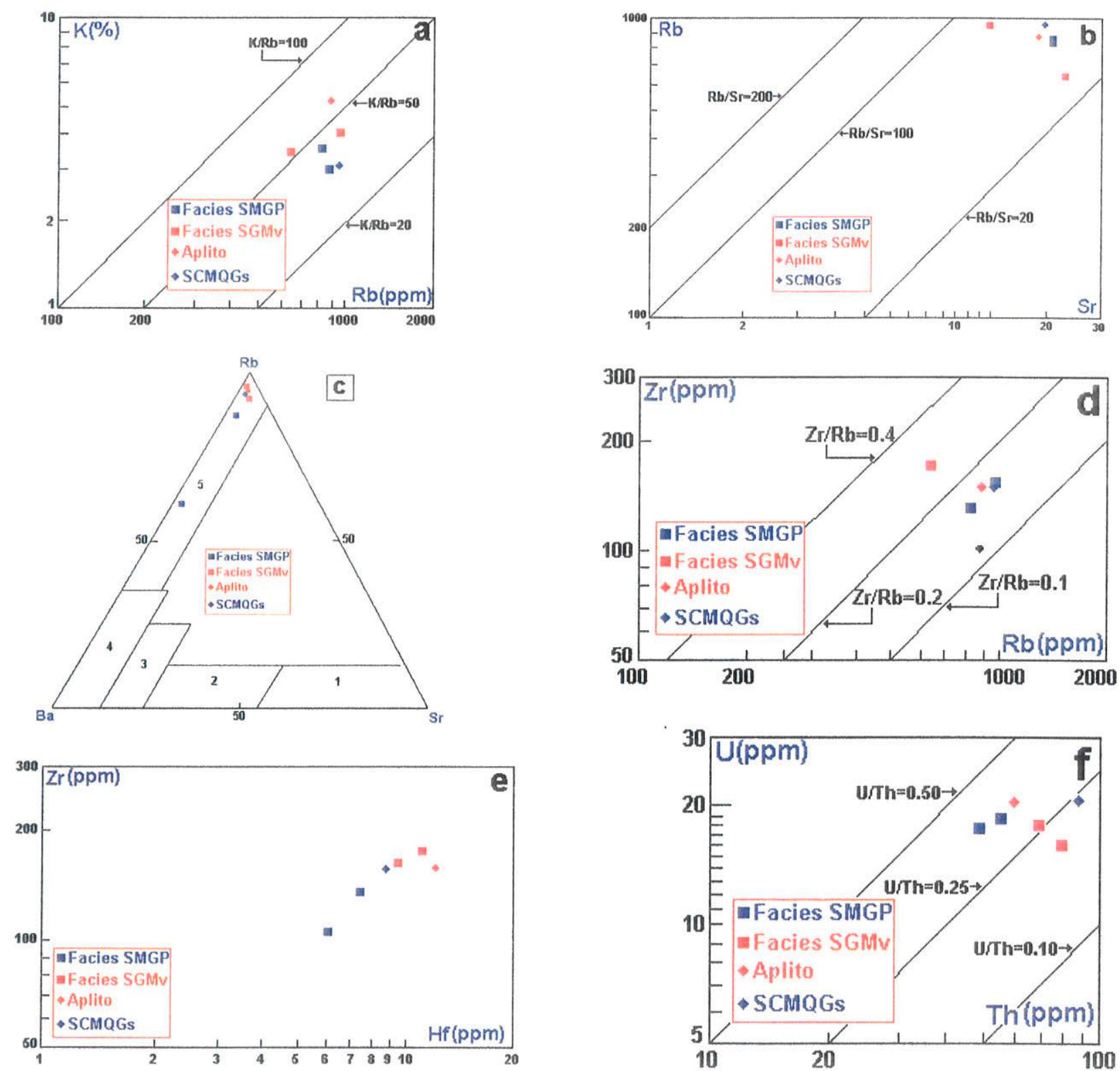

Figura 5.29- Distribuição composicional das amostras das principais facies granitóides do maciço granitóide Mocambo nos diagramas (a) Rb-K; (b) Rb-Sr; (c) Rb-Ba-Sr(El-Bouseily \& Sokkary, 1975); (d) Rb-Zr; (e) Zr-Hf; (f) Th-U. Os campos 1 a 5 do diagrama $\mathrm{Rb}-\mathrm{Ba}-\mathrm{Sr}$ correspondem a dioritos, granodioritos e quartzo dioritos, granitos anômalos, granitos normais e granitos extremamente diferenciados. 
Tomando-se por base o fato de que os granitóides desse maciço apresentam-se alterados em diferentes graus por processos tardi a pós-magmáticas, tal qual os granitóides dos maciços Antônio Vicente e Velho Guilherme, e considerando que o $\mathrm{F}$ e $0 \mathrm{Cl}$ desempenham importante papel nos fluidos residuais magmáticos e tardi a pósmagmáticos(Fuge, 1972; Bailey, 1977; entre outros) é necessário analisar o comportamento desses elementos nos granitóides em questão, bem como em relação a outros elementos a eles associados.

A Tabela 5.5(Anexo 34) mostra que o $\mathrm{Cl}$ só foi detectado na amostra de número 2 da facies SMGP, onde ocorre com 720 ppm. No restante das análises ele está ausente ou ocorre em baixíssimos conteúdos, abaixo do limite de deteç̧ão do método analítico utilizado nas análises(ver item metodologia no capitulo1 deste trabalho). O F, por sua vez, ocorre sistematicamente em quantidades variáveis e elevadas para o conjunto das análises. Possui as concentrações mais elevadas na facies SMGP(12.000ppm a 17.000ppm), sendo as mais baixas encontradas no greisen(1.300ppm). Os dados da Tabela 5.5(Anexo 34) mostram que os conteúdos de F decrescem sistematicamente no sentido do SMGP para o aplito e, desse, para o greisen. O SGMv ocupa uma posição intermediária entre o SMGP e o aplito. Esse comportamento é coerente com os dados petrográficos, visto que a facies SMGP hospeda quantidades algo expressivas de topázio(até $5 \%$ modal) e de fluorita(em torno de $1 \%$ modal), enquanto que na facies SGMv as concentrações desses minerais são menos expressivas(fluorita em torno de $1 \%$ e traços de topázio). Nas demais variedades - aplito e SCMQGs- essas fases minerais não foram detectadas. Assim, nesse maciço, as principais fontes de $F$ nos granitóides são topázio e fluorita. As fases micáceas são de fato muito probres nesse elemento(ver ítem Química Mineral deste capítulo).

A exemplo do que foi comentado no capitulo 3(item Química de Rocha Total), de acordo com Bailey(1977), às fases minerais primárias maiores de granitóides tais como biotita e, subordinadamente, hornblenda, muscovita e quartzo hospedam cerca de $30 \%$ a $90 \%$ do F, mas reconhece que ocasionalmente fases minerais menores tais como apatita, titanita, fluorita, microlita, pirocloro, topázio, turmalina, fluorita, bastnasita, ambligonita, espodumênio, criolita, etc, possam contribuir com mais de $50 \%$ de $\mathrm{F}$, notadamente quando presentes em granitos ricos em $F$ e em zonas de "roof" de origem metassomáticas(apogranitos). No caso dos granitóides estudados, os dados de campo e as características petrográficas - escassez(restos) ou ausência de fases primárias tais como biotita e hornblenda e o elevado grau de desenvolvimento de paragêneses de alterações tardi a pós-magmáticas - indicam que se trata, pelo menos em parte, de uma cúpola metassomática, a qual mostra-se melhor representada pela facies SGMv e pelo SCMQGs. Nesse caso, caberiam às fases secundárias o papel de receptores de $F$, especialmente as 
micas brancas, fluorita e topázio. Entretanto, conforme visto no item Química Mineral(deste capítulo) as fases micáceas são extremamente pobres em F. Assim, topázio e fluorita representam as principais fases portadoras de $F$ nesses granitóides. Além disso, a presença da paragênese fluorita+topázio+muscovita+clorita+siderofilita e a sua relação com conteúdos importantes de F, nessese granitóides é um bom indicativo de que os granitóides do maciço foram colocados em nivel crustal alto, entre $1 \mathrm{Km}$ e $5 \mathrm{Km}$ (Bailey(1977).

No que diz respeito ao comportamento do $\mathrm{F} \mathrm{e} \mathrm{Cl} \mathrm{durante} \mathrm{a} \mathrm{evolução} \mathrm{magmática} \mathrm{dos}$ granitóides do maciço, os dados químicos de rocha total(Tabela 5.5, Anexo 34), demonstram que enquanto o $\mathrm{F}$ é expressivo, o $\mathrm{Cl}$ é ausente na ampla maioria das amostras. De acordo com Fuge(1977), o Cl por possuir uma baixa solubilidade na fusão silicática e uma forte afinidade com as fases aquosas associadas, é concentrado nos minerais formados precocemente, enquanto que o $F$ por possuir forte afinidade com a fusão se enriquece nos minerais formados tardiamente. Esse comportamento do $\mathrm{F}$ e do $\mathrm{Cl}$ é coerente em relações aos granitóides estudados, visto que os mesmos representam diferenciados tardios, extremamente evoluídos, pobres em fases minerais máficas primárias(as quais representariam as fases precoces hospedeiras preferenciais de $\mathrm{Cl}$ ), sendo essa, portanto, a principal hipótese para explicar a quase que total ausência de cloro nesses granitóides.

A Figura 5.30a mostra, para o conjunto das amostras, que F e Sn desenvolvem uma clara correlação negativa, definida pelo decréscimo dos conteúdos de $\mathrm{F}$ e pelo aumento nas concentrações de Sn no sentido da facies SMGP(diferenciado considerado menos evoluido) para as facies SGMv e aplitica e, dessas, para o SCMQGs. É digno de nota que as amostras com os mais elevados conteúdos de $F$ não correspondem àquelas com teores mais elevados de $\mathrm{Sn}$. Esse comportamento do $\mathrm{F}$ e do $\mathrm{Sn}$ se assemelha, em parte, com o que foi observado no maciço granitóide Velho Guilherme, mas difere redondamente daquilo que foi observado no maciço granitóide Antônio Vicente. Isso signica que nem sempre é verdadeira a afirmativa de que as mineralizações de cassiterita estão condicionadas à granitóidesa com altas concentrações de F. Ademais, a presença de cassiterita não foi detectada nas amostras com os mais elevados conteúdos de F(facies SMGP), tendo sido observada, contudo, nas amostras da facies SGMv e no SCMQGs, que, embora não possuam as mais altas quantidades de $F$, hospedam os maiores teores de Sn(Tabela 5.5, Anexo 34).

$\mathrm{Na}$ Figura $5.30 \mathrm{~b}$, correspondente ao diagrama $\mathrm{Na}_{2} \mathrm{O}-\mathrm{F}$, nota-se uma nítida correlação positiva entre essas duas variáveis, caracterizada pela diminuição sistemática nas quantidades das mesmas no sentido da facies SMGP para a facies aplito(diferenciados magmáticos) e, desta, para o SCMQGs. A facies SGMv ocupa uma posição intermediária no "trend". 
Assim, os dados químicos aliados aos estudos petrográficos demonstram que granitóides com teores expressivos de $\mathrm{F}$ e/ou de $\mathrm{Cl}$ não são necessariamente enriquecidos em Sn e, como conseqüência, não são portadores de minerais de estanho e, em particular, de cassiterita. Entretanto, granitóides com conteúdos relativamente elevados de Sn são geralmente mineralizados a cassiterita, independentemente de possuírem quantidades expressivas ou não de $\mathrm{F}$ e/ou de $\mathrm{Cl}$.
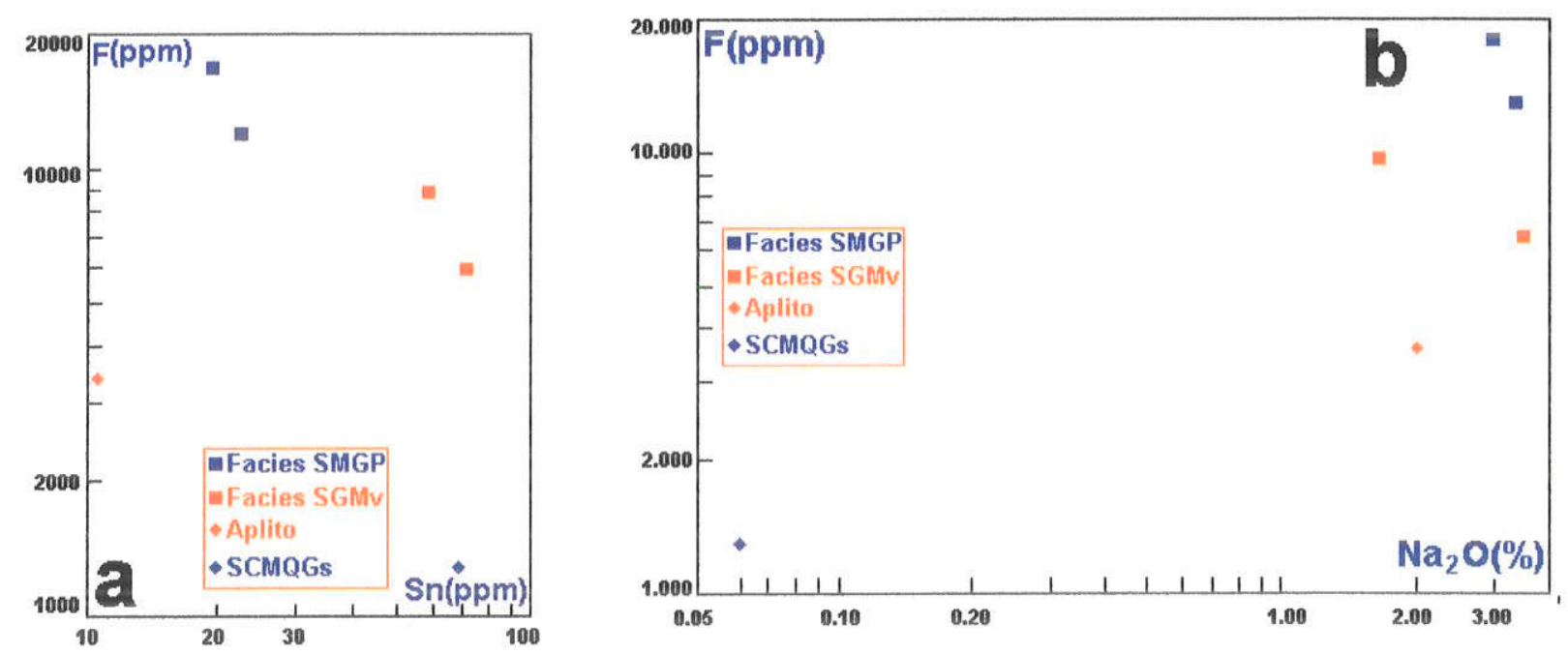

Figura 5.30- Distribuição composicional das amostras das principais facies granitóides do maciço granitóide Mocambo e de um corpo de SCMQGs a ele associado nos diagramas (a) F-Sn; (b) $\mathrm{Na}_{2} \mathrm{O}$ F.

Nas Figuras 5.31(a, b), compiladas a partir de Lehmann \& Mahawat(1989), verificase a quase totalidade das amostras de granitóides e greisen incide no campo das rochas que interagiram com fluidos, com apenas uma amostra da facies SGMv "plotando" no campo correspondente ao "trend" magmático extrapolado. Esse fato confirma as observações petrográficas e demonstra, mais uma vez, que essas rochas foram realmente afetadas por alterações tardi a pós-magmáticas decorrentes da interação fluido/rocha e indicam, também, que tais alterações parecem ser os principais agentes controladores das mineralizações, remobilizando e depositando cátions de elementos metálicos e, em especial, de Sn.

Conforme visto no capítulo anterior o estudo do comportamento dos elementos terras raras tem sido objeto de diversas investigações e tem ajudado a esclarecer uma série de problemas geológicos e, em especial, aqueles de natureza petrogenética. Em função disso, amostras representativas dos granitóides estudados e de siderofilita-cloritamuscovita-quartzo greisen foram analisadas e os resultados analíticos obtidos encontram-se na Tabela 27. 

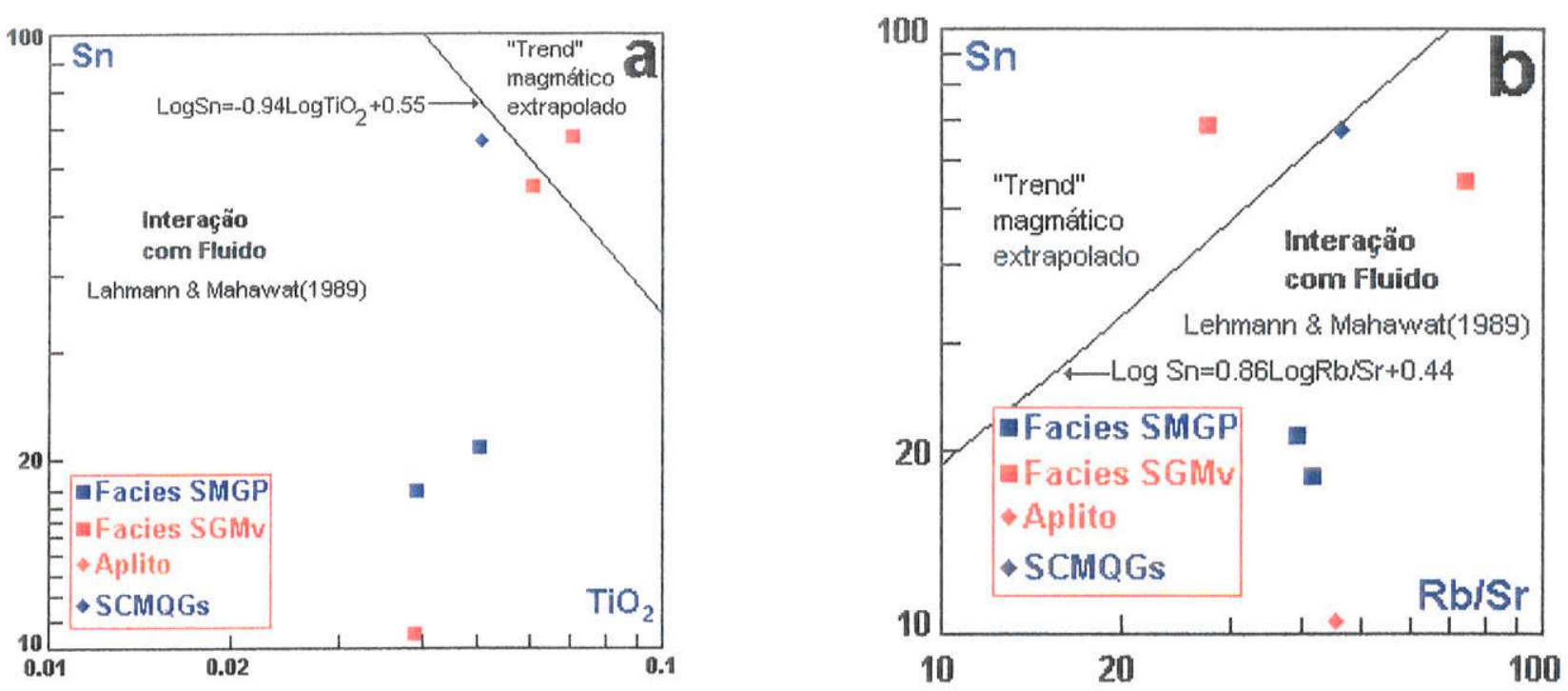

Figura 5.31- Diagramas Sn-TiO2(a) e Sn-(Rb/Sr), compilados a partir de Lehmann \& Mahawat(1989), mostrando a distribuição dos granitóides do maciço Mocambo e do SCMQGs a ele associado.

A análise da Tabela 5.5(Anexo 34) indica que os granitóides em questão mostram-se enriquecidos em ETRL e em ETRP, em relação a abundância desses elementos na crosta continental(Shaw et al., 1986; Condie, 1993).

A somatória das quantidades médias dos ETR nas facies granitóides SMGP, SGMv e aplito e no SCMQGs são respectivamente 342,91, 286,97, 214,16 e 404,08(Tabela 5.6).

Na Figura 5.32 observa-se que a composições médias dos ETR nos granitóides e no greisen, normalizada para condritos(Sun, 1982), desenvolvem um padrão tipo "gaivota" característico. Nota-se ainda, que os ETRL e ETRP mostram-se mais enriquecidos no siderofilita-clorita-muscovita-quartzo greisen, enquanto que na facies aplito são encontrados os mais reduzidos teores desses elementos. Verifica-se, também, que a maior anomalia negativa do Eu encontra-se na facies aplito e a menos acentuada é mostrada pela facies SMGP. Isso demonstra que fracionamento do plagioclásio nos líquidos magmáticos foi determinante na partição do $\mathrm{Eu}$, que nesses granitóides(diferenciados tardios) mostra-se quase que inteiramente empobrecidos.

Comparativamente aos granitóides dos maciços granitóides Antônio Vicente e Velho Guilherme, mostra um padrão de distribuição semelhante aqueles desenvolvidos pelos mesmos. Entretanto, considerando a somatória total média de todas as facies granitóides de cada maciço, observa-se que em relação ao MGAV, as concentrações de ETR do maciço granitóide Mocambo são nitidamente mais baixas, enquanto que em relação ao MGVG, são claramente mais altas.

De acordo com Clark(1984) em muitos processos formadores de rochas os ETR mostram-se dispersos, ocorrendo como constituintes menores ou traços nas fases minerais 
onde eles não são componentes essenciais. Nas rochas graniticas esses elementos encontram-se concentrados principalmente nos minerais ecessórios tais como esfeno, apatita e monazita, os quais tendem a hospedar os ETRL(Clark op. cit.). As fases minerais maiores, formadoras das rochas tais como plagioclásio, feldspato potássico e biotita(nessa ordem de abundância) atuam como hospedeiros dos ETR remanescentes(Condie \& Lu, 1971). Isso é explicado devido os ETR possuírem um pequeno coeficiente de partição entre mineral/fusão para minerais com sitios de coordenação catiônico pequeno tais como olivina, piroxênio, magnetita e feldspatos(Henderson, 1996). Durante o resfriamento de sistemas magmáticos básicos, onde esses elementos são comuns, eles tendem a residir na fusão e suas concentrações aumentam significativamente em sucessivas frações de fusões quando o fracionamento dos cristais prossegue. Devido a esse comportamento, os ETR são referidos como elementos incompativeis(Henderson, 1996).

No que se refere às quantidades de ETRL e ETRP contidas nos granitóides e no greisen do maciço granitóide Mocambo, estudos realizados através de microscopia ótica, aliados às análises EDS realizados por microscopia eletrônica de varredura, demonstraram que os mesmos são portadores de uma série de fases minerais acessorias, hospedeiras de ETRL(Anexos 31, 32 e 33) a saber: 1) allanita epidoto, zircão monazita e fluocerita(SMGP); 2) allanita, zircão e ytrocerita(SGMv); 3) zircão e fluocerita(SCMQGs); 4) zircão(aplito). Nessas última facies não foram realizados estudos através de MEV e a presença de zircão foi determinada através de microscopia ótica.

Embora as fases essenciais dos granitóides estudados não tenham sido analisadas com vistas a quantificar seus conteúdos de ETR, tomando-se por base as considerações apresentadas por Clark(1984) e Henderson(1996), pode-se assumir que os principais minerais portadores dos ETRL nos granitóides e greisen estudados são os minerais acessórios comentados acima. Entretanto, como ocorrem segundo finíssimos grãos e em baixas concentrações, não foi possível quantificá-los em termos modais. Assim, acredita-se que as pequenas variações nos conteúdos dessses elementos, apresentadas pelos granitóides e geisen sejam uma função das quantidades modais dessas fases menores identificadas nos granitóides estudados. E adicionalmente, essas variações devem ser decorrentes da ausência de uma ou mais fases em determinada facies granitóide e greisen. Como exemplo disso, nota-se que o aplito é sistematicamente mais empobrecida em ETR em relação às demais granitóides e greisen devido apresentar-se esgotado na ampla maioria das fases minerais acessórios hospedeiros desses elementos, conforme pode ser visto no ítem Aspectos Petrográficos, desse capítulo.

Em relação aos ETRP, os estudos petrogáficos e as análises através de MEV não permitiram a identificação de minerais portadores desses elementos, mas acredita-se que os 
mesmos possam estar contidos nas fases essenciais plagioclásio e feldspato potáassico, embora eventualmente possam estar hospedados nas micas.

As razões $E u / E u^{*}$, nos granitóides desse maciço são, respectivamente 13,01(SMGP), 13,01(SGMv), 13,00(aplito) e 12,98(SCMQGs). Essas razões são muito semelhantes àquelas apresentadas pelos granitóides e greisen associados ao MGAV e àquelas mostradas pelos granitóides e veio hidrotermal associado ocorrentes no âmbito do MGVG.

As razões $(\mathrm{La} / \mathrm{Yb})_{N}$ crescem sistematicamente no sentido da facies $\operatorname{SMGP}(1,99)$ para o aplito(2,86), com a facies SGMv ocupando uma posição intermediária no "trend", cujo valor é igual a 2.38 e diminui no sentido do SCMQGs(1,92;Tabela 5.6).

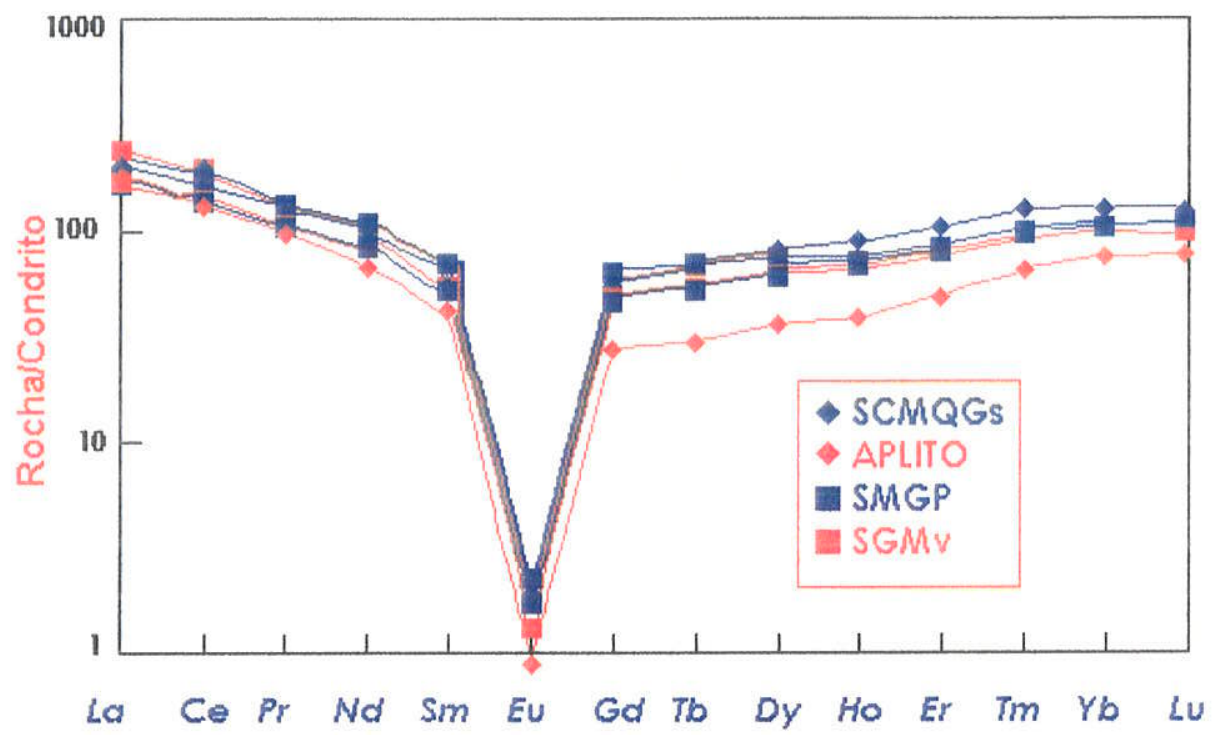

Figura 5.32- Padrão de distribuição dos elementos terras raras normalizados para condritos(Sun, 1982) do maciço granitóide Mocambo.

Tabela 5.6-. Dados de ETR referentes às principais facies granitóides e greisen associados ao maciço granitóide Mocambo.

\begin{tabular}{|l|c|c|c|c|}
\hline $\begin{array}{l}\text { Facies } \\
\text { Granitóides }\end{array}$ & SMGP & SGMv & APLITO & SCMQGs \\
\hline$\left(\right.$ La/Yb) $_{\mathbf{N}}$ & 1,99 & 2,38 & 2,86 & 1,92 \\
\hline Eu $_{N} /$ Eu $\left.^{*}\right)$ & 13,01 & 13,01 & 13,00 & 12,98 \\
\hline$\sum E T R L$ & 259,76 & 206,44 & 164,76 & 304,11 \\
\hline$\sum E T R P$ & 83,01 & 80,44 & 49,34 & 99,83 \\
\hline$\sum E T R$ & 342,91 & 286,97 & 214,16 & 404,08 \\
\hline
\end{tabular}




\subsection{5-Análises Normativas CIPW}

As análises normativas CIPW dos granitóides e greisen desse maciço(Tabela 5.7, Anexo 35) foram calculadas através do software Minpet versão 2.02(Richard, 1988-1995), a partir de análises químicas de rocha total. $A$ análise do conjunto das mesmas possibilitou as seguintes observações:

1) os granitóides desse maciço são saturados em córindon normativo(1,26\% a 3,58\%), diferentemente dos granitóides dos maciço Antônio Vicente e Velho Guilherme que são dominantemente sub-saturados, embora algumas amostras possuam córindon normativo em teores equivalentes àqueles desse maciço. Essa feição decorre do fato dos mesmos mostrarem-se invariavelmente alterados em graus elevados. Isso é evidenciado pelo SCMQGs, que representa o clímax das alterações tardi a pós-magmáticas que afetaram os granióides desse maciço, onde o conteúdo de córindon normativo ;é igual $6,56 \%$, enquanto que aqueles associados ao maciço granitóide António Vicente exibem teores entre $33 \%$ (CSMQGs) e $9,28 \%$ (CQGs).

2) os conteúdos de anortita são sempre muito baixos, não mostram variações importantes, os teores mais baixos são encontrados na facies aplítica(2,09\%) e os mais altos no SCMQGs $(3,75 \%)$.

3) os conteúdos de Hy tendem a ser mais baixos na facies $\operatorname{SGMv}(0,02 \%$ a $0,05 \%)$ e mais altos no SCMQGs $(0,13 \%)$. Os de magnetita são mais reduzidos na facies aplítica e mais elevados no SCMQGs, enquanto que os de ilmenita são mais ou menos eqüivalentes $(0,08 \%$ a $0,13 \%)$.

4) as razões $A b / A n$ tendem a ser equivalentes entre os granitóides $(8,26$ a 10,68), exceto em amostra da facies SGMv que exibe razão igual a 5,63 .

No diagrama Q-Ab-Or(Figura 5.33a) percebe-se que algumas composições normativas dos granitóides desse maciço "plotam" dentro e outras incidem fora do campo de $86 \%$ de frequiência das razões normativas Q-Ab-Or de 1190 rochas graníticas de Winkler e Von Platen(1961). Observa-se, ainda, que elas se deslocam do campo de máxima freqüência(ponto $M$ ) em direção ao vértice do quartzo(silicificação). Exceção à isso, é a amostra da facies aplítica que se desloca no sentido da aresta Q-Or(silicificação +microclinização). 
Mais intensamente do que nos granitóides dos maciços Antônio Vicente e Velho Guilherme, as alterações tardi a pós-magmáticas impostas a esses granitóides modificaram suas razões normativas originais, o que demonstra que o sistema se enriqueceu em $\mathrm{SiO}_{2}$ (mais intenso), bem em de $\mathrm{K}$ (menor escala), pelo menos em parte dos mesmos, em detrimento do $\mathrm{Na}$. Além disso, esse fato reforça a hipótese de que os granitóides dessa suite formaram-se a partir de magmas pobres em $F$. Suas composições situando-se abaixo da

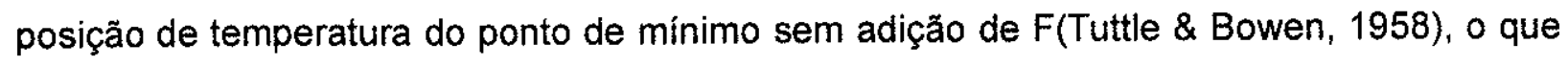
demonstra que o $\mathrm{F}$ foi remobilizado e enriquecido no estágio de alterações tardi a pósmagmáticas. Isso é traduzido pela presença de quantidades expressivas desse elemento nessas rochas e que se reflete em quantidades modais um pouco elevadas de fluorita e, às vezes de topázio, e, subordinadamente, de outras fases subordinadas, portadoras de $F$ (ver itm "química mineral" deste capitulo).

Ainda em relação à esse diagrama, verifica-se que a quase totalidade das composições situa-se entre as projeções das linhas cotéticas de $P_{\mathrm{H} 20}$ de $2 \mathrm{kbar}$ e de $5 \mathrm{kbar}$ de Winkler(1977) e abaixo da primeira, especialmente, as composições das amostras mais silicificadas..

No diagrama Ab-An-Or(Figura 5.33b), as razões normativas dos granitóides "plotam" póximo da aresta $A b-O r$, com parte das composições incidindo em posição intermedária e parte deslocando-se em direção aos vértice do Or. A composição do SCMQGs incide muito próximo da aresta An-Or, mas tendendo claramente para o vértice do Or.

\section{7- Condições de Cristalização}

\subsection{1- Posicionamento Crustal}

Guardando certas semelhanças entre o que foi comentado em relação aos granitóides dos maciços Antônio Vicente e Velho Guilherme, na região de exposição desse maciço foram registradas ocorrências de rochas vulcânicas intermediárias e félsicas, não metamorfisadas, correlacionáveis ao Grupo Uatumã. Além disso, de acordo com Dall'Agnol(1980) esse maciço desenvolve uma auréola de contato com as suas encaixantes mais imediatas.

Conforme visto anteriormente, esse maciço corresponde à um corpo principal maior, e três "satélites" menores, desconectados, fisicamente, entre si. O corpo principal é intrusivo, discordantemente, em rochas metassedimentares e metavulcânicas máficas do Grupo São Felix(metamorfisadas em facies xisto verde) e em vulcânicas andesíticas, não metamorfisadas da Formação Sobreiro. Os três corpos menores são intrusivos em, respectivamente, em: 1) rochas metavulcânicas máficas e metassedimentares do grupo São Felix; 2) rochas vulcânicas andesíticas da Formação Sobreiro do Grupo Uatumã; 3) rochas metassedimentares do Grupo são Felix. 
Conforme visto em relação ao maciço granitóide Velho Guilherme, de acordo com o que é estabelecido por Winkler(1977, Figura 7.2, pg. 52), rochas metamorfisadas em grau fraco(facies xisto verde) hospedam paragêneses minerais que são estáveis em condições de temperatura situadas entre aproximadamente $310^{\circ} \mathrm{C}$ e $520^{\circ} \mathrm{C}$ e pressões entre $1 \mathrm{~kb}$ e $\pm 4 \mathrm{~kb}$, mas podem ocorrer em profundidades de até $15 \mathrm{~km}$.

Estudos de lâminas delgadas realizados por Dall'Agnol(1980) em rochas encaixantes localizadas próximo ao contato com o maciço, indicaram a presença de hornfels de diferentes naturezas, decorrentes dos efeitos térmicos causados pela intrusão. Por analogia com o maciço Velho Guilherme, esse autor dediziu se tratar de metassedimentos pertencentes ao Grupo Grão Pará e vulcânicas das Formaçס̃es Sobreiro e Iriri do Grupo Uatumã. Assim, nas amostras de rochas metassedimentares, Dall'Agnol(op. cit.) observou a presença de uma estratificação, caracterizada pela alternância de níveis ricos em quartzo(recristalizado, contatos poligonizados e textura em mosaico), muscovita e clorita com níveis à base de andalusita, biotita e clorita. Nas rochas vulcânicas, o referido autor identificou a presença de plagioclásio(parcialmente recristalizado e largamente substituído), quartzo(neoformado) e anfibólio(neoformado e do tipo cimmingtonita semelhante àquele dos hornfels associados ao maciço granitóide Velho Guilherme), biotita e minerais opacos

Assim, como em relação às associações caracterizadas na auréola de contato do maciço granitóide Velho guilherme, essas associações evidenciam a existência de uma análoga entre os granitóides desse maciço e suas encaixantes imediatas.

Com base em Turner(1968), tais associações minerais caracterizam uma transição entre as facies albita-epidoto hornfels e a facies hornblenda hornfels.

Em relação às unidade encaixantes, há uma concordância, neste trabalho, com aquele desenvolvido por Dall'Agnol(op. cit.) no que diz respeito às rochas vulcânicas não metamorfisadas do Grupo Uatumã. Entretanto, devido a atualização dos dados geológicos da folha de ocorrência desse maciço, decorrente do mapeamento geológico regional, realizado por CPRM/DNPM(1991), as rochas que outrora foram correlacionadas ao grupo Grão Pará, passaram ser reunidas no Grupo São Félix.

A presença de uma auréola de contato em torno desse maciço, à exemplo do que foi comentado em relação ao maciço granitóide Velho Guilherme, demonstra que o mesmo foi colocado em nivel crustal raso(Winkler, 1977). Adicionalmente, a semelhança entre as associações minerais definidas por Dall'Agnol(op. cit.) e muitas daquelas extraídas a partir de auréolas de metamorfismo de contato de granitos injetados em niveis crustais altos(granitos pós-tectônicos), apresentadas por Turner(1981), caracteriza um regime metamórfico geral de baixa pressão entre 2 e $3 \mathrm{kbar}$.

Similarmente ao que foi apresentado em relação aos granitóides dos maciços Antônio Vicente e Velho Guilherme, a presença da paragênese fluorita + topázio + 
muscovita + clorita bem como a sua relação com conteúdos importantes de $F$, nos granitóides desse maciço, reforça a hipótese de que os mesmos foram colocados em nivel crustal raso, entre $1 \mathrm{Km}$ e $5 \mathrm{Km}$ (Bailey(1977).

Além disso, igualmente ao que foi apresentado em relação aos granitóides do maciço Antônio Vicente, os granitóides deste maciço ocorrem lado a lado, no mesmo nível de erosão, com rochas vulcânicas intermediárias da Formação Sobreiro, só metamorfisadas no contato(Dall'Agnol, 1980). Embora os seus contatos não tenham sido observados diretamente durante os trabalhos de campo, esse fato induz à hipótese de posicionamento no mesmo nível crustal, em condições sub-vulcânicas a vulcânicas.

Ademais, datações radiométricas em amostras de andesitos e riolitos do Grupo Uatumã(isócrona de referência), realizadas através do método $\mathrm{Pb}-\mathrm{Pb}$ em rocha total(Teixeira et al., 1998), indicaram uma idade de referência de $1.875 \pm 79 \mathrm{Ma}$ para as rochas desse grupo. Cristais de zircão analisados, através do método de evaporação de $\mathrm{Pb}$, forneceram uma $1862 \pm 32$ Ma para os granitóides do maciço, que foi interpretada como sendo aquela de cristalização dos mesmos e indicam uma contemporaneidade entre os eventos vulcânicos e plutônicos. À semelhança do que foi comentado em relação ao maciço granitóide Antônio Vicente, essa contemporaneidade e a associação entre o vulcanismo Uatumã e o plutonismo Mocambo reforça a hipótese de posicionamento em nível crustal subvulcânico dos granitóides, em razão de suas estreitas relações com as rochas vulcánicas do Grupo Uatumã, no tempo e no espaço.

\subsection{2- Condições de $f_{2}, T$ e $P$}

Devido os granitóides desse maciço apresentarem uma grande semelhança textural e química com as facies mais evoluídas do maciço granitóide Antônio Vicente, estarem estreitamente associados com rochas vulcánicas do Grupo Uatumã e desenvolverem auréolas de contato nas suas encaixantes imediatas, pode-se considerar que os mesmos cristalizaram em condições de baixa fugacidade de oxigênio, em temperaturas em torno dos $700^{\circ} \mathrm{C}$ e baixas pressões $( \pm 1 \mathrm{kbar})$. 


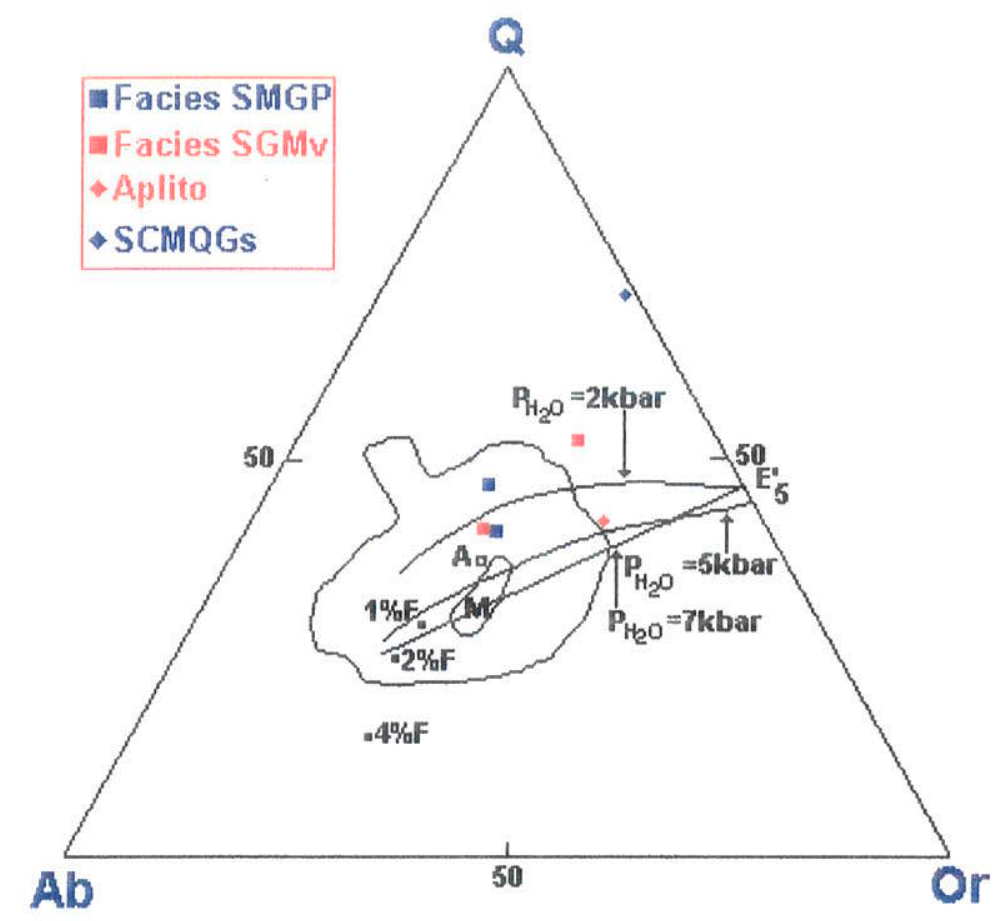

Figura 5.33a- Diagrama normativo Q-Ab-Or mostrando a distribuição composicional das principais facies granitóides do maciço granitóide Mocambo. A curva envoltório dos pontos corresponde à distribuição de freqüência das razões Q-Ab-Or de 1190 rochas graníticas de Winkler \& Von Plaren(1961). As projeções das linhas cotéticas isobáricas P-E'5 de 2, 5 e 7kbar foram compiladas de Winkler(1977). M é o máximo de freqüência , A representa a posição e temperatura do ponto de mínimo sem $\mathrm{F}$ (Tuttle \& Bowen, 1958). 1\%F, 2\%F e 4\%F representam as posições e temperaturas dos pontos de mínimo com $\mathrm{F}$ adicionado e excesse de água a $1 \mathrm{kbar}($ Manning, 1981).

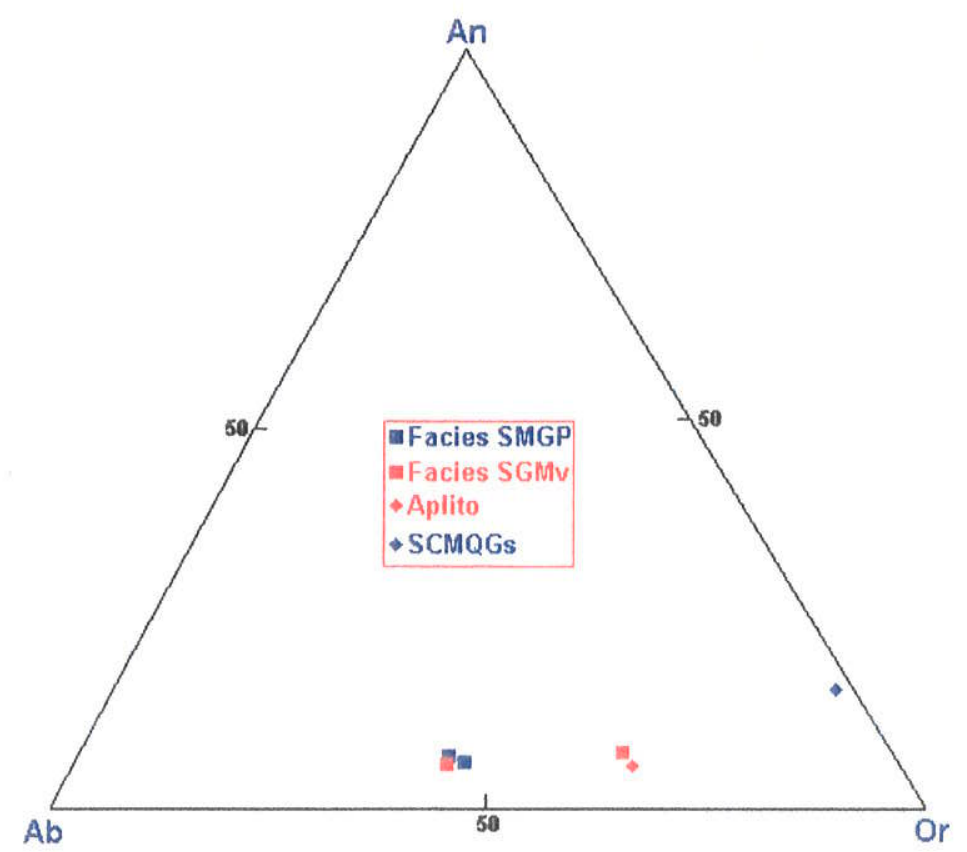

Figura 5.33b- Diagrama normativo Ab-An-Or mostrando a distibuição composicional das principais facies petrográficas do maciço granitóide Mocambo. 


\section{8- Conclusões e Considerações Finais}

Os estudos de seções delgadas, dados de química mineral e análises químicas de elementos maiores, elementos traço e ETR em amostras de rocha possibilitaram alcançar as seguintes conclusões àcerca dos granitóides ocorrentes no âmbito desse maciço:

1) os estudos petrográficos mostraram a existência de, pelo menos, três tipos faciológicos de granitóides no interior desse maciço a saber: 1) sienogranito a monzogranito porfirítico(SMGP); 2) sienogranito com muscovita(SGMv); 3) aplito álcali- feldspato granítico(AAFG). Além dos granitóides foi caracterizado, ainda, um corpo de siderofilitaclorita-muscovita-quartzo greisen(SCMQGs) associado ao SGMv.

2) as variedades SMGP e SGMv são tipicamente subsolvus. Os valores de M' de algumas amostras são menores que $5 \%$, enquanto que os de outras situam-se entre $5 \%$ e $10 \%$, indicando tratar-se de granitóides holo-leucocrático a leucocrático.

3) essas características permitem concluir que os mesmos correspondemà diferenciados extremamente evoluidos e silicosos à semelhança das facies mais evoluidas e mais afetadas por alterações tardi a pós-magmáticas dos maciços Antônio Vicente e Velho Guilherme.

4) suas composições magmáticas originais foram modificadas por alterações tardi a pósmagmáticas, as quais causaram modificações nas suas modas.

5) a variedade SGMv possui uma estreita relação com a facies SMGP, bem como mostra muitas semelhanças com os granitóides do maciço granitóide Velho Guilherme(BSGEm e SGH), diferenciando-se apenas pela presença de cassiterita que é ausente nesses últimos, e com as facies mais evoluídas e mais alteradas do maciço granitóide António Vicente, especialmente aquelas facies portadoras de cassiterita(BSGA e BSGIA). Apresenta-se intensamente afetada por alterações tardi a pós-magmáticas e hospeda mineralizações de cassiterita.

6) a facies aplítica é uma rocha tipicamente álcali-feldspato granitica e de características hipersolvus, uma vez que o plagioclásio de composição albítica é claramente tardi a pósmagmático. Mostra um caráter francamente holo-leucocrático $\left(\mathrm{M}^{\prime}<5 \%\right)$ e representa a facies mais evoluida do maciço. 
7) ○ SCMQGs guarda muitas semelhanças com o clorita-siderofilita-muscovita-quartzo greisen de granulaçăo média a grossa associados às facies BSG, BSGA e BSGIA, diferino dos mesmos apenas pelo menor conteúdo de siderofilita.

8) análises químicas em grãos de "biotita" da facies SGMv, realizadas através de microssonda eletrônica, revelaram composições compreendidas entre a annita aluminosa e da siderofilita(conforme a classificação de Guidotti, 1984). Quando considerada a classificação mais recente sugerida e recomendada por Tischendorf et al.(1997), mostra uma composição transicional entre a siderofilita e protolitionita e se enquadra no grupo das Li-Fe micas.

9) análises químicas em micas brancas secundárias pertencentes às facies SMGP e SGMV e ao SCMQGs indicaram tratar-se de muscovita fengitica, composicionalmente, correspondente ao grupo das Mg-Al micas.

10) análises químicas em grãos de clorita revelaram que a mesma é do tipo não oxidada, em razão dos seus conteúdos de $\mathrm{Fe}_{2} \mathrm{O}_{3}$ serem inferiores a $4 \%$. Em termos composicionais, ela correspondente à pseudothuringita(Hey, 1954).

11) a aplicação do geotermômetro estabelecido por Cathelineau(1988), permitiu estimar as temperaturas mínimas de cristalização da clorita em amostras do SGMv e do SCMQGs. Assim, para a clorita do granitóide estimou-se uma temperatura mínima de cristalização entre $474,49^{\circ} \mathrm{C}-581,07^{\circ} \mathrm{C}$ e para a clorita do greisen entre $573,34^{\circ} \mathrm{C}-603,60^{\circ} \mathrm{C}$.

12) análises químicas de elementos maiores, elementos traços e ETR mostraram que os granitóides desse maciço são essencialmente peraluminosos, tem natureza subalcalina, são de ambiência intraplacas, se enquadram no tipo-A e mostram muitas semelhanças com os granitóide do sub-grupo $A_{2}$.

13) eles comportam conteúdos de $\mathrm{SiO}_{2}$, superiores a $75 \%$, excetuando-se a isso o corpo de greisen que possui teores de $\mathrm{SiO}_{2}$ levemente inferior e igual a $74,94 \%$. No que diz respeito aos principais óxidos maiores, apresentam, de um modo geral, conteúdos de $\mathrm{TiO}_{2}, \mathrm{Al}_{2} \mathrm{O}_{3}$, $\mathrm{MgO}, \mathrm{CaO}$ e $\mathrm{P}_{2} \mathrm{O}_{5}$ sempre muito baixos e inferiores aqueles da média dos granitos(Le Maitre, 1976), as quantidades de $\mathrm{K}_{2} \mathrm{O}$ são ligeiramente mais elevadas e as de $\mathrm{Na}_{2} \mathrm{O}$ são eqüivalentes. 
14) em relação aos elementos menores e traços, contém altos teores de $\mathrm{Rb}$ (média entre 785,50 e $936,61 \mathrm{ppm}$ ), $\mathrm{Zr}$ ( média entre 117,5 e 163,50ppm), Y(média de 79,0 a 218,0ppm), $Z n$ (média entre 105,0 e $247 \mathrm{ppm}$ ) e $F$ (média entre 1300 e 14.500ppm), conteúdos moderados de $\mathrm{Nb}$ (média entre 75,83 e 125,93ppm), Ga(média entre 31,50 e 36,50ppm), $W$ (média entre 81,83 e 182,56ppm) e Th(média entre 51,60 e $83,24 p p m$ ) e baixas concentrações de $\mathrm{Sr}$ (média entre 18,0 e 21,0 ppm), Cl(não detectado nas facies SGMv, Aplitica e SCMQGs e média de $360,0 \mathrm{ppm}$ na facies SMGP), Ta(média entre 10,68 e $18,39 \mathrm{ppm}$ ), Hf(média entre 6,77 e 12,28ppm), U(média entre 17,35 e 20,41ppm), Sn(média entre 10,5 e 69,0ppm), Mo(média entre 2,91 e 23,91ppm) e Ba(média entre 27,50 e $42,0 \mathrm{ppm}$, exceto na facies SMGP que esse elemento apresenta teor médio igual a 310ppm).

15) os ETR ocorrem em conteúdos sempre baixos(exceto o $\mathrm{Ce}$ ), embora aqueles de ETRL sejam , em geral, mais elevados do que aqueles de ETRP. O greisen, por sua vez, mostrase, relativamente aos granitóides, enriquecido em de $\mathrm{Fe}_{2} \mathrm{O}_{3}$. As razões $\mathrm{Rb} / \mathrm{Sr}$ (média entre 39,77 e 46,83) , $\mathrm{Rb} / \mathrm{Ba}$ (média entre 22,30 e 28,56 , exceto na facies SMGP que é igual a $2,69)$ e Th/U(média entre 2,84 e 4,29) são, geralmente altas, enquanto as razões $\mathrm{K} / \mathrm{Rb}$ (média entre 33,68 e 60,83 ) são baixas se comparadas com aquelas dos granitos considerados normais(Shaw, 1968).

16) as razões U/Th são sistematicamente baixas e inferiores a 0,5 , o que indica tratar-se de granitóides HHP.

17) ० $\mathrm{Cl}$ foi detectado em apenas uma amostra da facies SMGP, onde mostra concentração de $720 \mathrm{ppm}$. No restante das análises ele está ausente ou ocorre em baixíssimos conteúdos, abaixo do limite de detecção do método analítico utilizado nas análises.

18) of ocorre em quantidades variáveis e elevadas no conjunto das amostras. Possui as concentrações mais elevadas na facies $\operatorname{SMGP}(1,2 \%$ a $1,7 \%)$, sendo as mais baixas encontradas no greisen(1.300ppm). Seus conteúdos decrescem sistematicamente no sentido da facies SMGP para a facies aplito e desse para o greisen. A facies SGMv ocupa uma posição intermediária entre as facies SMGP e o aplito. Esse comportamento é coerente com os dados petrográficos, visto que a facies SMGP hospeda quantidades algo expressivas de topázio(até $5 \%$ modal) e de fluorita(em torno de $1 \%$ modal), enquanto que na facies SGMv as concentrações desses minerais são menos expressivas(fluorita em torno de $1 \%$ e traços de topázio). Nas demais variedades - facies aplito e greisen- essas fases minerais não foram detectadas. Desse modo, nesse maciço, as principais fases portadoras de $F$ nos granitóides são topázio e fluorita, presentes, preferenciaimente na facies SMGP. 
19) conteúdos importantes de $F$, nesses granitóides é um bom indicativo de que os mesmos foram colocados em nível crustal alto, entre $1 \mathrm{Km}$ e $5 \mathrm{Km}$ (Bailey(1977).

20) no que diz respeito ao comportamento do $\mathrm{F}$ e $\mathrm{Cl}$ durante a evolução magmática dos granitóides do maciço, os dados químicos de rocha total, demonstram que enquanto o $\mathrm{F}$ é expressivo, o Clé ausente na ampla maioria das amostras. De acordo com Fuge(1977), o Cl por possuir uma baixa solubilidade na fusão silicática e uma forte afinidade com as fases aquosas associadas, é concentrado nos minerais formados precocemente, enquanto que o $F$ por possuir forte afinidade com a fusão se enriquece nos minerais formados tardiamente. Esse comportamento do $\mathrm{F}$ e do $\mathrm{Cl}$ é coerente em relações aos granitóides estudados, visto que os mesmos representam diferenciados tardios, extremamente evoluídos, pobres em fases minerais máficas primárias, as quais representariam os minerais precoces hospedeiros preferenciais de $\mathrm{Cl}$. Desse modo, acredita-se que esssa é a principal hipótese para explicar a quase que total ausência de cloro nesses granitóides.

21) no que diz respeito à relação F-Sn, percebe-se que para o conjunto das amostras, $\mathrm{F} \mathrm{e}$ Sn desenvolvem uma clara correlação negativa, definida pelo decréscimo dos conteúdos de $F$ e pelo aumento nas concentrações de $S n$ no sentido da facies SMGP(diferenciado considerado menos evoluido) para as facies SGMv e aplítica(diferenciados mais evuluidos) e dessas para o SCMQGs. E importante enfatizar que as amostras com os mais elevados conteúdos de $F$ não correspondem àquelas com teores mais elevados de $\mathrm{Sn}$. Esse comportamento do $\mathrm{F}$ e do $\mathrm{Sn}$ se assemelha, em parte, com o que foi observado no maciço granitóide Velho Guilherme, mas difere redondamente daquilo que foi comentado em relação aos granitóides do maciço Antônio Vicente. Isso signica dizer que nem sempre é verdadeira a afirmativa de que as mineralizações de cassiterita estão condicionadas a granitóides com altas concentrações de F. Ademais, a presença de cassiterita não foi detectada nas amostras com os mais elevados conteúdos de $F$ (facies SMGP), tendo sido observada, contudo, nas amostras da facies SGMV e no SCMQGs, que,embora não possuam as mais altas quantidades de $\mathrm{F}$, contém os maiores teores de $\mathrm{Sn}$.

22) Em suma, os dados químicos aliados aos estudos petrográficos demonstram que granitóides com teores expressivos de $\mathrm{F}$ e/ou de $\mathrm{Cl}$ não são necessariamente enriquecidos em Sn e, como conseqüência, não são portadores de minerais de estanho e, em particular, de cassiterita. Entretanto, granitóides com conteúdos relativamente elevados de $S n$ são geralmente mineralizados a cassiterita, independentemente de possuírem quantidades expressivas ou não de $\mathrm{F}$ e/ou de $\mathrm{Cl}$. 
23) em relação aos ETR, nesses granitóides eles mostram-se enriquecidos em ETRL e em ETRP, em relação a abundância desses elementos na crosta continental(Shaw et al., 1986; Condie, 1993). Quando normalizados para condritos(Sun, 1982), desenvolvem um padrão tipo "gaivota" característico.

24) a maior anomalia negativa do Eu encontra-se na facies aplito e a menos acentuada é encontra-se no SMGP.

25) a somatória total média de todas as facies granitóides de cada maciço revela que em relação ao MGAV, as concentrações de ETR deste maciço são nitidamente mais baixas, enquanto que em relação ao MGVG, são claramente mais altas.

26) As razões $E u / E u^{*}$, nos granitóides e greisen são, respectivamente 13,01(SMGP), 13,01(SGMv), 13,00(aplito) e 12,98(SCMQGs). Elas são muito semelhantes àquelas encontradas nos granitóides dos maciços Antônio Vicente e Velho GuilermeMGAV e MGVG, bem como no greisen e veio hidrotermal a eles associados.

27) as razões $(\mathrm{La} / \mathrm{Yb})_{N}$ crescem sistematicamente no sentido da facies $\operatorname{SMGP}(1,99)$ para o aplito(2,86), com a facies SGMv ocupando uma posição intermediária no "trend", cujo valor é igual a 2.38 e diminui no sentido do SCMQGs(1,92;Tabela 28).

28) no que se refere às quantidades de ETRL e ETRP contidas nos granitóides e no greisen desse maciço, estudos realizados através de microscopia ótica(MO) aliados às análises EDS realizados por microscopia eletrônica de varredura(MEV) demonstraram que os mesmos contém uma série de minerais acessórios portadores de ETR, especialmente de ETRL. Eles mostram-se representadas por allanita, epidoto, zircão monazita e fluorcerita(SMGP), allanita, zircão e yttrocerita(SGMv), fluorcerita e zircão(SCMQGs) e zircão(aplito).

29) devido os granitóides, desse maciço, apresentarem uma grande semelhança textural e química com as facies mais evoluídas do maciço granitóide Antônio Vicente, estarem estreitamente associados com rochas vulcânicas do Grupo Uatumã e desenvolverem auréolas de contato nas suas encaixantes imediatas, pode-se considerar que os mesmos cristalizaram em condições de baixa fugacidade de oxigênio, em temperaturas em torno dos $700^{\circ} \mathrm{C}$ e baixas pressões $( \pm 1 \mathrm{kbar})$. 


\section{CAPÍTULO 6}

\section{6- MACIÇO GRANITÓIDE BENEDITA(MGB)}

\section{1- Contexto Geológico}

O MGB aflora próximo à borda SSW do MGAV, na região sudeste do Estado do Pará, na extremidade oeste da Serra dos Carajás, a uma distância de aproximadamente 45 $\mathrm{Km}$ da cidade de São Felix do Xingu.

Faz parte da Suite Intrusiva Velho Guilherme(CPRM/DNPM, 1991), é intrusivo em rochas granitóides correlacionáveis ao "Granito Parauari"(Santos et al., 1975) e em rochas vulcânicas félsicas da Formação Iriri, pertencente ao Grupo Uatumã e encontra-se seccionado, aproximadamente ao meio, por um dique atribuído ao "Diabásio Cururu". Apresenta forma, grosseiramente, circular e possui dimensões em torno de $25 \mathrm{Km}^{2}$ (Figura 6.1).

\section{2- Histórico}

Esse maciço foi referido inicialmente na literatura por Silva et al.(1974), que o incluiram entre os granitos "tipo Velho Guilherme" sendo, psteriormente, designado, genericamente, de "Granito Benedita" por Sá(1985).

Teixeira \& Dall'Agnol(1991), durante os estudos realizados no maciço granitóide Antônio Vicente, observaram que tais corpos afloravam como maciços independentes, isolados fisicamente, entre si, e em relação ao MGAV. Em razão disso, atribuíram designaçöes específicas para cada corpo: 1) Granito Benedita; 2) Granito Ubim/sul; 3) Granito Ubim/norte.

Teixeira \& Andrade(1992) realizaram estudos petrográficos especificos nos maciços granitóides Benedita e Ubim/sul, bem como efetuaram uma análise qualitativa e quantitativa àcerca dos processos de alterações tardi a pós-magmáticas que afetaram esses granitóides, mas restringiram esses estudos aos aspectos essencialmente petrográficos.

\section{3- Aspectos de Campo e Amostragem}

A delimitação do MGB foi efetuada através de trabalhos de fotointerpretação e de campo, realizados durante os estudos voltados para MGAV(Teixeira \& Dall'Agnol, 1991). Devido esse maciço apresentar um relevo pouco pronunciado e, adicionalmente, estar localizado em uma área de difícil acesso e sem qualquer infra-estrutura, a amostragem realizada limitou-se, fundamentalmente, às porções sudeste, leste e nordeste do corpo(Anexo 36), não permitindo a obtensão de uma visão mais clara do mesmo, 
principalmente, em relação à distribuição das facies petrográficas que constituem o maciço como um todo. Também não foi possivel separar essas facies em mapa. De qualquer modo, os resultados obtidos serviram para se ter uma idéia, pelo menos parcial, a respeito dos granitóides que constituem o maciço. Assim foram distinguidos granitóides do tipo álcalifeldspato granítico(AFG), dominante na porção sudeste do corpo, os quais gradam para biotita-álcali-feldspato granítico(BAFG), este ocorrendo, preferencialmente, nas regiões leste e nordeste do mesmo(Anexo 36).

\section{4- Aspectos Petrográficos}

Os estudos petrográficos envolveram o exame de nove seções delgadas e abrangeram os mesmos aspectos envolvidos no estudo dos granitóides dos maciços vistos anteriormente, sendo, portanto, desnecessário repetí-los aqui.

Para a classificação e nomenclatura dos tipos petrográficos estudados foram utilizadas as recomendações de Streckeisen(1976). Os diagramas correspondentes são apresentados na Figura $6.2(\mathrm{a}, \mathrm{b}) \Theta$ as composições modais das amostras estudadas encontram-se na Tabela 6.1 .

O diagrama Q-A-P mostra que se trata de granitóides de composição, tipicamente, álcali-feldspato-granítica, sem plagioclásio primário na ampla maioria das amostras, com características hipersolvus(Tuttle \& Bowen, 1958), os quais diferenciam-se entre si por seus conteúdos médios de biotita. No diagrama $Q-(A+P)-M$ ' nota-se uma grande afinidade entre as duas variedades, as quais apresentam um caráter holo-leucocrático, onde os valores de M' são sempre inferiores a $5 \%$.

Isso demonstra que, assim como as facies granitóides mais evoluídas dos outros maciços estudados(vistos anteriormente), essas rochas cristalizaram-se a partir de liquidos muito evoluidos e silicosos, associados a fases magmáticas tardias, cujas evidências são traduzidas pelos seus altos conteúdos de quartzo modal(Tabela 6.1), bem como pela ausência de plagioclásio primário e pelos baixos teores de fases máficas primárias.

A separação de dois tipos granitóides deve-se exclusivamente aos conteúdos, relativamente, mais elevados de biotita na variedade $B A F G$ em relação à variedade $A F G$, visto que textural e mineralogicamente, se equivalem. $\mathrm{Na}$ realidade a variedade $B A F G$ representa uma pequena variação do tipo AFG.

\subsection{1- Textura e Mineralogia}

De modo geral, esses granitóides apresentam textura hipidiomórfica, heterogranular, fina a média, embora no BAFG predomine uma granulação média com tendência a equigranular, e coloração avermelhada a rosa esbranquiçada(Prancha 22; Foto c, d). Textura granofírica(Prancha 22; Foto e) pode ser observada localmente, destacando-se os 
Figura 6.1- Mapa geológico da área de ocorrência dos maciços granitóide Benedita e Ubim/Sul. 


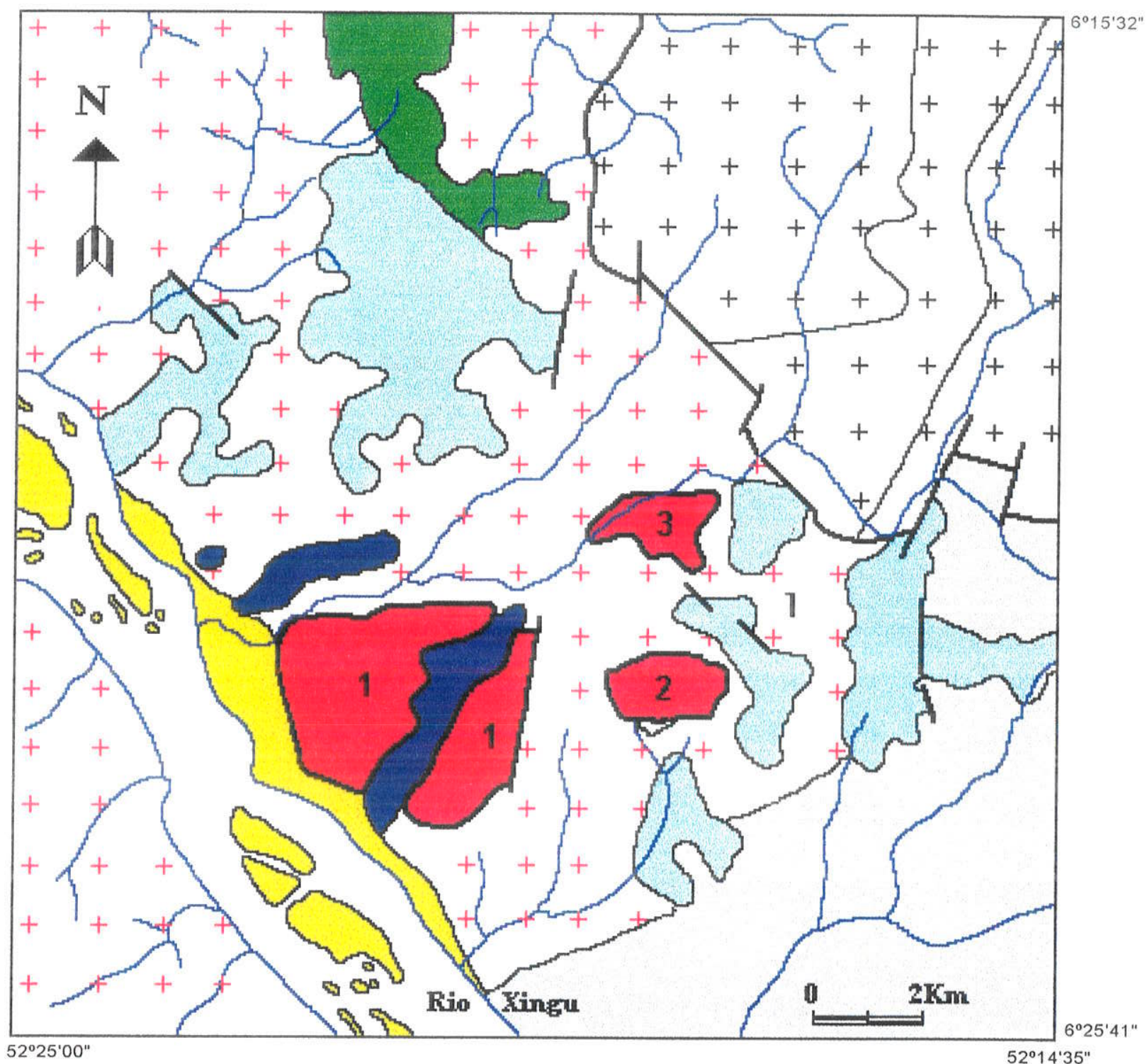

\begin{tabular}{|c|c|}
\hline \begin{tabular}{|l|} 
CENOZÓICO \\
Áreas aluvionares.
\end{tabular} & PALEO-PROTEROZÓICO (1.88-1.90 Ga) \\
\hline \begin{tabular}{|l|} 
MESOZÓICO \\
Diabásio Cururu: corpos gabróicos diversos \\
\end{tabular} & $\begin{array}{l}\text { Formaçăo Triunfo: Quartzo-arenito, arenito arco- } \\
\text { seano e conglomerado. }\end{array}$ \\
\hline $\begin{array}{l}\text { PALEO-PROTEROZÓICO (1.87-1.88 Ga.) } \\
\text { Suíte Intrusiva Velho Guliherme } \\
\text { Maciços granitóides Benedita (1), Ubim/Sul (2) e } \\
\text { Ubim/Norte(3). } \\
\text { (3) Granitóides indiferenciados. } \\
\text { (2) Biotita sienogranito com clorita e biotita monzo- } \\
\text { nogranito subordinado, médios, pouco a pouco } \\
\text { transformados. } \\
\text { (1) Biotita-álcali-feldspato granito e álcali-feldspato } \\
\text { granito, fino à médio, pouco a moderadamente } \\
\text { transformados. }\end{array}$ & $\begin{array}{l}\text { Grupo Uatumã } \\
\text { Formaçăo Iriri: Riolito e tufos riolíticos com rio- } \\
\text { dacitos, daciticos subordinados } \\
\text { Formação Sobreiro: Rochas andesiticas com } \\
\text { traquito e traqui-andesito subordinado e raras } \\
\text { clastolavas. } \\
\text { Granito Parauari } \\
++ \text { Monzogranito associado a sienogranito } \theta \\
\text { granodiorito. }\end{array}$ \\
\hline $\begin{array}{l}\text { Maciço Granitólde Antónlo Vicente } \\
\begin{array}{l}\text { B++ Biotita-anfibólio sieno a monzogranitobiotita-anfi- } \\
\text { bólio sieno a álcali feldspato granito; biotita-sieno- } \\
\text { granito com clorita; álcali feldspato granito; biotita } \\
\text { sienogranito a monzongranito, pouco a intensamen- } \\
\text { te alterados; biotita monzongranito; micromonzogra- } \\
\text { nito; sieno a monzogranito granofírico. }\end{array}\end{array}$ & $\begin{array}{l}\text { Contatos litológicos fotointerpretativos } \\
\text { Traços de foliaçöes e atitudes } \\
\text { Traços de fraturas e/ou falhas }\end{array}$ \\
\hline
\end{tabular}


tipos insular, vermicular, "radiating fringe" e, muito subordinadamente, cuneiformes(Smith, 1974). Consistem essencialmente de quartzo e feldspato potássico, sendo acessórios a biotita(que no BAFG atinge o "status" de varietal), zircão e minerais opacos(MOP 1$)$.

Em relação às fases minerais relacionadas ao estágio de alterações tardi a pósmagmáticas, elas são pouco expressivas nessas variedades de granitóides e mostram-se representadas por sericita \pm muscovita, albita(mais abundante), fluorita, clorita, minerais opacos, esfalerita, allanita e argilo-minerais.

O quartzo ocorre em, pelo menos, quatro variedades, considerando-se, para isso, sua textura e morfologia. A variedade $1\left(Q t z_{1}\right)$, corresponde aos cristais, geralmente, subédricos, de granulação média e, muito raramente, grossa. Desenvolve contatos, entre si e com as outras fases minerais, geralmente retos, embora ocorram, em menor escala, contatos retos e, até mesmo, suturados, principalmente, com o feldspato potássico. Costuma se encontrar fraturado e, por vezes, exibe forte extinção ondulante. Localmente, hospeda inclusões de zircão. O tipo $2\left(Q t z_{2}\right)$ diz respeito aos grãos anédricos, de granulação fina, que ocorrem em agregados. Desenvolve contatos irregulares e suturados, mostra-se menos fraturado que o tipo $1 \mathrm{e}$, geralmente, não apresenta extinção ondulante. $\mathrm{A}$ modalidade $3\left(Q t z_{3}\right)$ refere-se aos grãos finos, anédricos, intimamente ligados às fases filossilicáticas, especialmente, à biotita cloritizada e/ou oxidada. Por fim, o tipo 4(Qtz 4$)$, juntamente com o feldspato potássico 3 , constituem os intercrescimentos granofíricos. E muito pouco abundante, ocorrendo apenas localmente.

Assim como o quartzo, o feldspato potássico se apresenta segundo três modalidades morfo-texturais. A variedade $1\left(\mathrm{Fk}_{1}\right)$ está representada por cristais subédricos, finos, que ocorrem associados ao $\mathrm{Qtz}_{2}$. Pode ocorrer, ainda, de forma intersticial em relação ao quartzo 1. O tipo $2\left(\mathrm{FK}_{2}\right)$ forma grãos subédricos e, às vezes, anédricos, médios a grossos, os quais mostram-se, algumas vezes, maclados segundo as leis de Carlsbad e, localmente, hospedam inclusões de zircão. A variedade $3\left(\mathrm{Fk}_{3}\right)$ está relacionada aos intercrescimentos granofíricos. Os três tipos são pertíticos, sendo mais comuns as pertitas tipo "film", "band" e "patch perthites"(Alling, 1932 e 1938). Além disso, mostram-se, por vezes, afetados por alterações tardi a pós-magmáticas, traduzidas por sericita \pm muscovita( $\left(\mathrm{Mv}_{1}\right)$, albita e argilominerais. Na facies AFG, são freqüentes os agrupamentos intergranulares e intragranulares de albita("coroas trocadas"; agrupamentos semelhantes a "dedos" e a "mãos e "chessboard-albite"(Dall'Agnol, 1980; Smith, 1974; Teixeira \& Andrade, 1992). Além disso, ocorre como franjas('swapped rims").

A biotita é muito pouco frequënte, embora em algumas amostras da facies BAFG chegue a atingir $2 \%$ (Tabela 6.1). Ocorre sob a forma de lamelas anédricas dispersas na

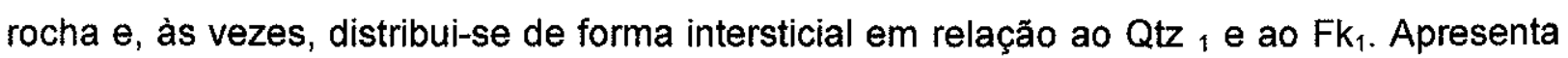
pleocroismo fraco a moderado, variando de castanho-esverdeado $(\mathrm{Z}$ e $\mathrm{Y})$ a castanho pálido- 
amarelado(X). Costuma se encontrar parciaimente cloritizada. Associados à cloritização $\left(\mathrm{Cl}_{2}\right)$, ocorrem muscovita $\left(\mathrm{Mv}_{2}\right)$, epidoto, esfalerita, allanita, quartzo3, fluorita $\left(\mathrm{Fl}_{2}\right)($ Prancha 22, Foto, $\mathrm{f}$ ) e minerais opacos, os quais mostram-se dispostos ao longo dos planos de clivagem da biotita e/ou da clorita.

Tabela 6.1- Composições modais das facies granitóides AFG e BAFG do maciço granitóide Benedita. Região Sudeste do Pará. Tr= traços; $N d=$ não detectado; $\mathrm{Nc}=$ não contado.

\begin{tabular}{|c|c|c|c|c|c|c|c|c|c|}
\hline \multirow{2}{*}{$\frac{\text { VARIEDADES }}{\text { AMOSTRAS }}$} & \multicolumn{3}{|c|}{ AFG } & \multicolumn{6}{|c|}{ BAFG } \\
\hline & $\begin{array}{c}\text { NE-B- } \\
01\end{array}$ & $\begin{array}{c}\mathrm{NE}-\mathrm{B}- \\
1\end{array}$ & $\begin{array}{c}\mathrm{NE}-\mathrm{B}- \\
4\end{array}$ & $\begin{array}{c}\text { NE-B- } \\
5\end{array}$ & $\begin{array}{c}\text { NE-B- } \\
6\end{array}$ & $\begin{array}{c}\text { NE-B- } \\
7\end{array}$ & $\begin{array}{c}\text { NE-B- } \\
8\end{array}$ & $\begin{array}{c}\text { NE-B- } \\
9\end{array}$ & $\begin{array}{c}\text { NE-B- } \\
10\end{array}$ \\
\hline & 1 & 2 & 3 & 4 & 5 & 6 & 7 & 8 & 9 \\
\hline \multicolumn{10}{|l|}{$\begin{array}{l}\text { MINERAIS } \\
\text { PRIMÁRIOS(\%) }\end{array}$} \\
\hline QUARTZO & 36 & 41 & 45 & 42 & 39 & 33 & 41 & 37 & 39 \\
\hline PLAGIOCLASIO & Nd & Nd & $\mathrm{Nd}$ & $\overline{\mathrm{Nd}}$ & $\overline{N d}$ & $\mathrm{Nd}$ & Nd & $\mathrm{Nd}$ & $T r$ \\
\hline K-FELDSPATO & 60 & 53 & 50 & 51 & 53 & 58 & 51 & 55 & 56 \\
\hline BIOTITA & 01 & $\mathrm{Tr}$ & $\mathrm{Tr}$ & $\mathrm{Nd}$ & 01 & 02 & $\mathrm{Tr}$ & $\mathrm{Tr}$ & 02 \\
\hline ZIRCĀO & $\mathrm{Tr}$ & $\mathrm{Tr}$ & $\mathrm{Tr}$ & $\mathrm{Tr}$ & $\mathrm{Tr}$ & $\mathrm{Tr}$ & $\mathrm{Tr}$ & $T r$ & $\mathrm{Tr}$ \\
\hline MINERAIS OPACOS & $\mathrm{Tr}$ & $\mathrm{Tr}$ & $\mathrm{Tr}$ & $\mathrm{Tr}$ & $\operatorname{Tr}$ & $\operatorname{Tr}$ & $\mathrm{Tr}$ & $\operatorname{Tr}$ & $\operatorname{Tr}$ \\
\hline \multicolumn{10}{|l|}{$\begin{array}{l}\text { MINERAIS } \\
\text { SECUNDÁRIOS(\%) }\end{array}$} \\
\hline SERICITA \pm MUSCOVITA & $\operatorname{Tr}$ & $\operatorname{Tr}$ & $\mathrm{Tr}$ & 01 & 01 & $\mathrm{Tr}$ & 01 & 01 & 01 \\
\hline ALBITA & 04 & 05 & 04 & 07 & 06 & 06 & 05 & 06 & 07 \\
\hline CLOI & TR & $\mathrm{Nd}$ & $\mathrm{Nd}$ & $\mathrm{Nd}$ & $\mathrm{Tr}$ & $\mathrm{Tr}$ & 03 & 01 & $\mathrm{Tr}$ \\
\hline ALLANITA & Nd & No & Nd & Nd & Nd & Nd & Nd & Nd & $\mathrm{Tr}$ \\
\hline FLUORITA & $\operatorname{Tr}$ & $\mathrm{Tr}$ & $\mathrm{Tr}$ & $\mathrm{Tr}$ & $\mathrm{Tr}$ & $\mathrm{Tr}$ & $\mathrm{Tr}$ & $\operatorname{Tr}$ & $\mathrm{Tr}$ \\
\hline MINERAIS OPACOS & $\mathrm{Tr}$ & $\mathrm{Tr}$ & $\mathrm{Tr}$ & $\mathrm{Tr}$ & $\mathrm{Tr}$ & $\mathrm{Tr}$ & $\mathrm{Tr}$ & $\mathrm{Tr}$ & $\mathrm{Tr}$ \\
\hline ESFALERITA & $\mathrm{Tr}$ & $\mathrm{Tr}$ & $\mathrm{Tr}$ & $\mathrm{Tr}$ & $\mathrm{Tr}$ & $\mathrm{Tr}$ & $\overline{\mathrm{Tr}}$ & $\mathrm{Tr}$ & $\mathrm{Tr}$ \\
\hline ARGILO-MINERAIS & Nc & $\mathrm{Nc}$ & Nc & Nc & $\mathrm{Nc}$ & Nc & Nc & Nc & $\mathrm{Nc}$ \\
\hline $\begin{array}{l}\text { COMPOSIÇÃO DO } \\
\text { PLAGIOCLÁSIO }\end{array}$ & - & - & - & - & - & - & n & - & $A n_{10}$ \\
\hline$Q$ & 36 & 41 & 45 & 42 & 40 & 34 & 42 & 38 & 35 \\
\hline $\bar{A}$ & 64 & 39 & 55 & 58 & 60 & 66 & 58 & 62 & 65 \\
\hline $\mathbf{P}$ & 0 & 0 & 0 & 0 & 0 & 0 & $\overline{0}$ & 0 & 0 \\
\hline$Q$ & 35 & 41 & 45 & 42 & 39 & 33 & 41 & 38 & 35 \\
\hline$A+P$ & 64 & 58 & 55 & 58 & 60 & 65 & 56 & 61 & 63 \\
\hline $\mathrm{M}^{\prime}$ & 01 & 01 & 0 & 0 & 01 & 02 & 03 & 01 & 02 \\
\hline NÚMERO DE & 1000 & 1300 & 1500 & 1500 & 1300 & 1200 & 1500 & 1500 & 1375 \\
\hline
\end{tabular}

Em relação aos acessórios, o zircão é o mais freqüente, especialmente na facies BAFG, embora de um modo geral, não seja abundante. Ocorre como minúsculos grãos subédricos a euédricos, ora isolados e dispersos na rocha, ora associado à biotita e, às vezes, como iclusões nessa e no quartzo 1 . Os minerais opacos tanto formam agregados de cristais subédricos, associados à biotita $\left(\mathrm{MOP}_{1}\right.$; fase primária), quanto se apresentam como grãos anédricos, vinculados à biotita cloritizada e/ou à clorita( $\mathrm{MOP}_{2}$; fase secundária).

A clorita ocorre como lamelas anédricas, finas a médias, as quais exibem um pleocroismo moderado, que varia de verde oliva $(Z$ e $Y)$ a verde pálido-amarelado $(X)$. 
A fluorita é pouco abundante, embora esteja presente em todas as amostras estudadas. Forma finos grãos anédricos, intimamente associados aos restos de biotita cloritizada e/ou oxidada(Prancha 22; Foto $f$ ) e aos minerais opacos $\left(\mathrm{MOP}_{2}\right)$. Apresenta-se nas modalidades incolor e lilás.

O par sericitat muscovita( $\left(\mathrm{Mv}_{1}\right)$ é pouco abundante e, em algumas amostras, é raro, podendo, mesmo, estar ausente. Forma finas lamelas, geralmente, associadas a uma leve alteração dos feldspatos potássicos.

A allanita é rara, tendo sido observada em uma única amostra(Tabela 6.1). Ocorre como cristais subédricos a anédricos, de granulação fina a média, por vezes, bastante, alterados, formando nódulos avermelhados, intimamente associados à biotita oxidada.

Por fim, os argilo-minerais, formam "nuvens" superpostas aos feldspatos potássicos, dando-Ihes um aspecto "sujo". São melhor observados à luz natural.
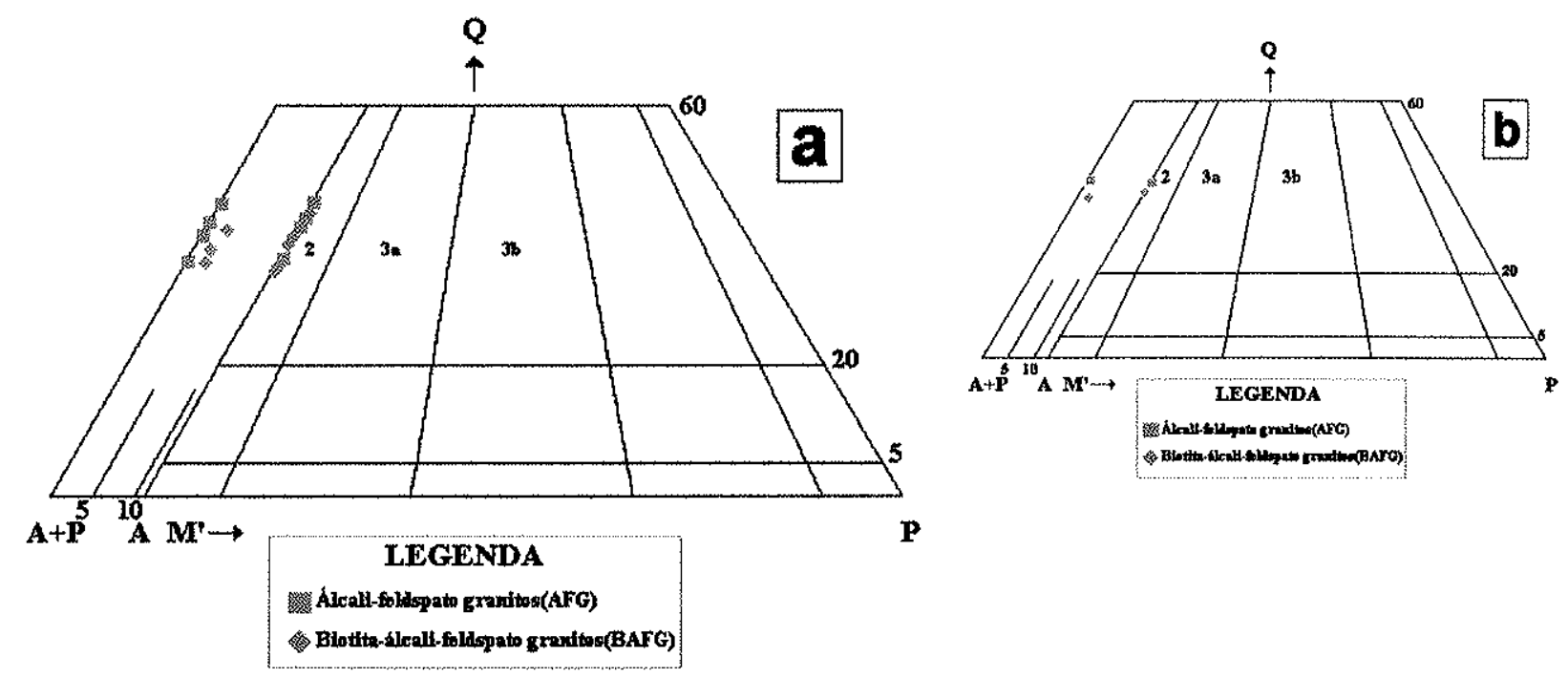

Figura 6.2- Diagramas triangularers $Q-A-P$ e $Q-(A+P)-M^{\prime}$ de Streckeisen(1976) mosttrando a distribuição composicional modal geral dos ganitóides do maciço granitóide Benedita(a) e suas composições modais médias(b).

\subsection{2- Ordem de Cristalização}

Os estudos petrográficos voltados para o estabelecimento da ordem de cristalização das fases minerais primárias constitutivas das facies granitóides desse maciço permitiram elaborar o seguinte esquema:

1) Cristalização das fases minerais acessórias primárias representadas por zircão $e$ minerais opacos $\left(M_{O P}\right)$. Isso é respaldado pela presença dessas fases, como inclusões, em grãos de quartzo1.

2) Em relação às fases essenciais- quartzo e feldspato potássico- parecem ter se separado do líquido magmático dentro de um mesmo intervalo de temperatura e pressão. 
Essas fases ocorrem lado a lado, principalmente, $Q t z_{1}, Q t z_{2}$ e $F k_{1}$. Entretanto, foi observado, localmente, finas inclusões de $F k_{1}$ em grãos de $Q t z_{1}$ e $Q t z_{2}$, indicando que o $F k_{1}$ iniciou sua separação a partir do magma um pouco antes do quartzo. No entanto, sua cristalização parece ter prosseguido além do encerramento da cristalização de quartzos 1 e 2, uma vez que o feldspato potássico pode ser observado na forma intersticial em relação aos mesmos.

3) A biotita, quase sempre, cloritizada e/ou oxidada, parece ter-se cristalizado posteriormente ao quartzo e ao feldspato potássico. Isso é justificado pela presença de inciusões de zircão, minerais opacos $\left(\mathrm{MOP}_{1}\right)$ e quartzo 1 , na biotita, bem como pela ocorrência de biotita intersticial em relação ao quartzo 1 e 2.

4) As demais fases estão associadas ao estágio de alterações tardi a pósmagmáticas.

A Figura 6.3 resume um esboço da seqüência de cristalização das fases minerais das facies granitóides desse maciço, bem como fornece a cronologia aproximada de formação das fases minerais tardi a pós-magmáticas.

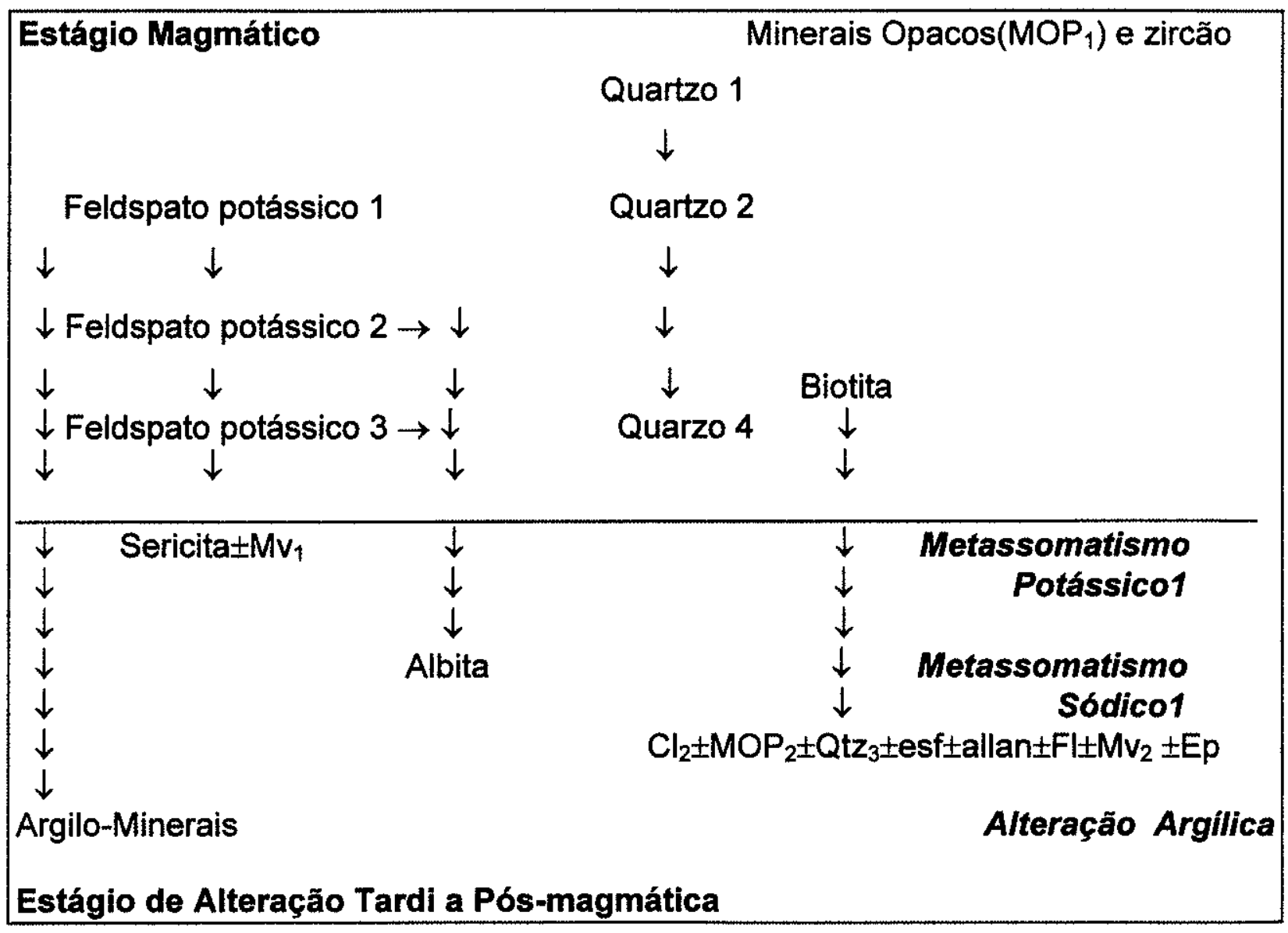

Figura 6.3- Fluxograma mostrando um esboço esquemático da seqüência de cristalização magmática e tardi a pós-magmática das fases minerais das facies BAFG e AFG do maciço granitóide Benedita. esf= esfalerita; allan= allanita. 


\subsection{3- Discussão e Considerações Finais}

Esse maciço abriga facies granitóides extremamente diferenciadas e pouco afetadas por alterações tardi a pós-magmáticas generalizadas, embora os conteúdos de albita tardia(albitização) sejam um pouco expressivos. São rochas holo-leucocráticas, de composição álcali-feldspato graníticas como teores variáveis de biotita, mas que nunca ultrapassam $2 \%$ modal, as quais apresentam uma forte afinidade com os granitos hipersolvus(Tuttle \& Bowen, 1958). A distribuição das composições modais desses granitóides é muito semelhante àquela observada para as facies granitóide mais evoluidas e diferenciadas do maciço granitóide Antônio Vicente. Em relação às mineralizações, essas não foram observadas nos granitóides desse maciço o que é justificado pelo baixos conteúdos em fases minerais associadas ao estágio de alterações tardi a pós-magmáticas. Isso reflete uma fraca interação dessas rochas com fluidos mineralizantes tardios, enriquecidos em voláteis.

Tabela 6.2 resume as principais características petrográficas das facies granitóides desse maciço.

Tabela 6.2- Principais características petrográficas das facies granitóides associadas ao maciço granitóide Benedita.

\begin{tabular}{|c|c|c|c|c|c|}
\hline \begin{tabular}{|l|} 
Facies \\
Granitoide \\
\\
\end{tabular} & Minerais Essenciais & $\begin{array}{l}\text { Minerais } \\
\text { varietais }\end{array}$ & $\begin{array}{l}\text { Acessórios } \\
\text { Primarios }\end{array}$ & Minerais Secundários & $\begin{array}{c}\text { Mineralizaçס̄es } \\
\text { Modo de } \\
\text { Ocorrencia }\end{array}$ \\
\hline AFG & $\begin{array}{l}\text { "Quartzo } \\
\text { "Feldspato potássico } \\
\text { "microclina pertítica) }\end{array}$ & ${ }^{*}$ Blotita $\leq 1 \%$ & $\begin{array}{l}\text { "Zircáo } \\
\text { " Minerais Opacos }\end{array}$ & $\begin{array}{l}\text { "Sericita+Muscovita } \\
\text { *Albita, Fluorita, Clorita, } \\
\text { Minerais Opacos, Esfalerita, } \\
\text { Allanita o Argilo-Minerais }\end{array}$ & Ausente \\
\hline BAFG & $\begin{array}{l}\text { "Quartzo } \\
\text { "Feldspato potássico } \\
\text { "microclina pertítica) } \\
\text { "Plagioclásio(traços) }\end{array}$ & "Biotita & $\begin{array}{l}\text { * Zircáo } \\
\text { * Minerais Opacos }\end{array}$ & $\begin{array}{l}\text { * Sericita+Muscovita } \\
\text { *Albita, Fluorita, Clorita, } \\
\text { Minerais Opacos, Esfalerita, } \\
\text { Allanita e Argilo-Minerais }\end{array}$ & Ausente \\
\hline
\end{tabular}

\section{5- Química Mineral}

Neste maciço foram realizadas 13 análises pontuais na amostra NE-B-09(facies BAFG), assim discriminadas: 05 de feldspato potássico pertítico, 04 de clorita e 04 em muscovita. Foram realizadas, ainda, 04 análises semi-quantitativas(EDS) através de microscopia eletrônica de varredura, as quais envolveram essencialmente a caracterização de fases minerais acessórias, incluindo os minerais opacos, da amostra referida acima. 


\subsubsection{Análises químicas através de Microssonda Eletrônica}

\subsubsection{1- Análises químicas em feldspato potássico}

Para essa fase mineral só foi possível realizar cinco análises em feldspato potássico 2(microclina pertítica 2). Os resultados obtidos, as fórmulas estruturais e as proporções $A b$ Or-An encontram-se no anexo 37.

\subsubsection{1- Composição química}

$\mathrm{Na}$ análise do diagrama Ab-Or-An(Figura 6.4), observa-se que entre os pontos analisados há uma ampla variação composicional do feldspato potássico, reflexo da tentativa de melhor representar sua composição química, visto que trata-se de um feldspato pertítico. Nota-se que nas composições dominantemente potássicas, a molécula Or varia entre $67 \%$ e $98 \%$ e a $A b$ entre $2 \%$ e $33 \%$, sendo os conteúdos de An iguais a $0 \%$. Nas composições essencialmente sódicas a Ab oscila entre $72 \%$ e $99 \%$, enquanto o Or situa-se entre $1 \%$ e $28 \%$. Considerando-se, individualmente, cada grão analisado, percebe-se que no grão 1 a composição do feldspato potássico apresenta dois extremos composicionais, sendo um mais potássico(análise 2) e um mais sódico(análise 3). A análise 1 tem composição intermedária, embora seja mais enriquecida em ortoclásio(Or=67\%). As análises 1 e 3 parecem refletir, ao que tudo indica, as relações de troca entre $\mathrm{Na}$ e $\mathrm{K}$ em decorrência dos processos de substituição sódica, que culminaram com a formação das pertitas de substituição(tais como "film", "vein" e "band perthites"),ocorridos durante o estágio de alterações tardi a pós-magmáticas. O mesmo é válido para o grão 2(análises 4 e 5).

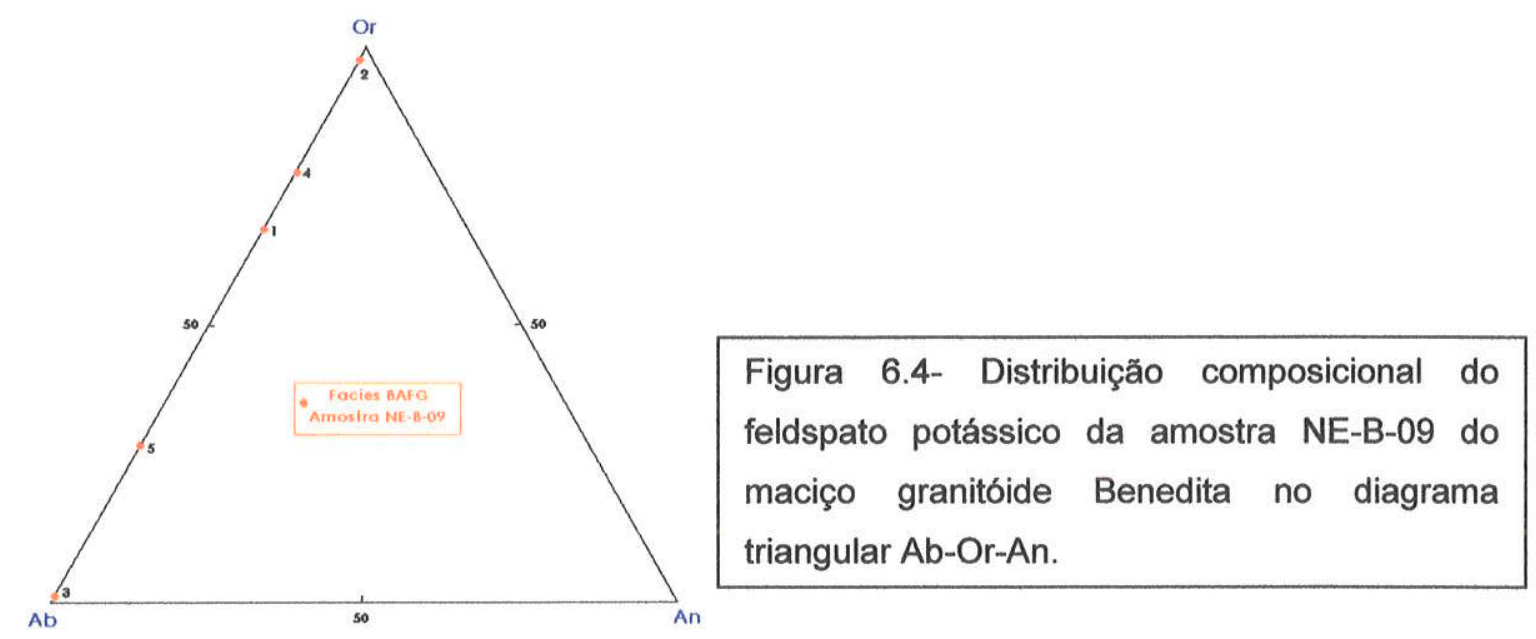

\subsubsection{2- Análises químicas em Clorita}

Uma síntese sobre as principais características do grupo da clorita foi apresentada no capítulo 3 deste trabalho, sendo, portanto, descessário repetí-la aqui. 
Os grãos de clorita analisados correspondem à clorita $2\left(\mathrm{Cl}_{2}\right)$. Os resultados analíticos e as fórmulas estruturais encontram-se no Anexo 38.

\subsubsection{1- Composição química}

No diagrama $\mathrm{Al}^{\mathrm{IV}}$ versus $\mathrm{Al}^{\mathrm{VI}}$ (Figura 6.5 a) e no Anexo 38 observa-se que, para 0 conjunto das análises, o $\mathrm{Al}^{\mathrm{N}}$ varia de 1,399 a 1,603, enquanto que o $\mathrm{Al}^{\mathrm{V}}$ situa-se entre 0,49 e 0,83. A nivel de cada grão, em separado, nota-se que no grão 1(análises 1 e 2) essas variações composicionais são muito reduzidas, embora note-se uma discreta correlação positiva entre as duas variáveis. No grão 2 as variações dessas duas variáveis são mais acentuadas e nota-se uma forte correlação negativa entre as quantidades de $\mathrm{Al}^{\mathrm{IV}}$ e $\mathrm{Al}^{\mathrm{VI}}$ (análises 3 e 4 ).

$\mathrm{A}$ análise da Figura $6.5 \mathrm{~b}$ revela uma correlação claramente negativa entre o $\mathrm{Al}^{\mathrm{V} l}$ e os cátions bivalentes $\left(\mathrm{Fe}^{2+}+\mathrm{Mg}^{2+}\right)$, quando considerado o conjunto de todas as análises. Essa correlação se mantem quando se trata das análises do grão 2 , sendo o inverso no grão 1.0 mesmo é observado na Figura $6.5 \mathrm{c}\left(\mathrm{Al}^{\mathrm{VI}}\right.$ versus $\left.\mathrm{Fe}^{2+}\right)$.

Para o conjunto das análises, as observações apresentadas acima, em relação aos três diagramas, evidenciam que paralelamente ao crescimento de $\mathrm{Al}^{\mathrm{IV}}$ no sítio tetraedral(Figura 6.5a), ocorreu um aumento nos cátions bivalentes $\left(\mathrm{Fe}^{2+} \in \mathrm{Mg}\right.$ ) no sítio octaédrico(principalmente o $\mathrm{Fe}^{2+}$; Figuras $6.5 \mathrm{~b}$ e $6.5 \mathrm{c}$ ) e uma redução no conteúdo de $\mathrm{Al}^{\mathrm{VI}}$ no sítio octaédrico. Isso é, também, válido para o grão 2. Fato semelhante a esse foi observado por Cathelineau(1988) em clorita do sistema Azufres(México) e por Borges(1997) na clorita dos greisens Gs1 e Gs2, associados ao granito Água Boa(em Pitinga, no Estado do Amazonas). Nesse caso, prevaleceram as substituições do tipo $2\left[\left(\mathrm{Al}_{+1} \mathrm{R}^{2+}{ }_{3 / 2} \square^{1 / 2}\right)_{\mathrm{VI}}\right.$ ou $(\mathrm{Al}$ ${ }_{-1} R^{2+} \square_{-1}$ ) 1 l de Cathelineau(1988; pg 478).

Em relação ao grão 1, observa-se que o aumento do $\mathrm{Al}^{\mathrm{IV}}$ foi acompanhado por um aumento nos cátions bivalentes $\mathrm{Fe}^{2+} e \mathrm{Mg}^{2+}$, mas não existem evidências de substituições do $\mathrm{Al}^{\mathrm{V}}$ pelos cátions bivalentes no sítio octaedral, visto que o ele tem correlação positiva com os mesmos.

A Figura $6.5 \mathrm{~d}$ mostra uma correlação positiva entre $\mathrm{Al}^{\mathrm{IV}}$ e os cátions bivalentes( $\mathrm{Fe}^{2+}$ $\left.+\mathrm{Mg}^{2+}\right)$, tanto para o conjunto de todas as análises, quanto para cada grão separadamente, confirmando que o aumento do $\mathrm{Al}^{\mathrm{lv}}$ foi acompanhado pou um aumento nos cátions bivalentes.

No diagrama $\mathrm{Al}^{\mathrm{lV}}$ versus $\mathrm{Fe} /(\mathrm{Fe}+\mathrm{Mg})$, Figura $6.5 \mathrm{e}$, nota-se, para o conjunto das análises, que enquanto o $\mathrm{Al}^{\mathrm{NV}}$ varia, a razão $\mathrm{Fe} / \mathrm{Fe}+\mathrm{Mg}$ permanece praticamente constante. Essa condição química destoa daquela observada em cloritas estudadas por diversos autores tais como Hey(1954), Foster(1962), Cathelineau \& Nieva(1985), Kranidiotis \& MacLean(1987), Cathelineau(1987) e Zang \& Fyfe(1995). Por outro lado, se assemelha 
muito com as características da clorita estudada por Borges(1997), bem como com a da clorita do maciço granitóide Antônio Vicente, apresentadas no capítulo 3 deste trabalho.

$\mathrm{Na}$ Figura $6.5 \mathrm{f}$, do mesmo modo que na Figura $6.5 \mathrm{e}$, observa-se que, para a totalidade das análises, a razão $\mathrm{Fe} /(\mathrm{Fe}+\mathrm{Mg})$ é praticamente constante, enquanto que as quantidades de $\mathrm{Al}^{\mathrm{VI}}$ variam amplamente no grão 2 , embora sejam muito semelhantes no grão 1. $A$ variação do $\mathrm{Al}^{\mathrm{VI}}$ apresentada pelo grão 2 deve-se à correlação positiva existente entre $\mathrm{Al}^{\mathrm{Vl}}$ e Si(conforme pode ser visto na Figura $6.5 \mathrm{~h}$ ).

$\mathrm{Na}$ Figura $6.5 \mathrm{~g}$ observa-se uma nítida correlação negativa entre $\mathrm{Si}+\mathrm{Al}{ }^{\mathrm{VI}}$ e os cátions bivalentes $\left(\mathrm{Fe}^{2+}+\mathrm{Mg}^{2+}\right)$, tanto em relação ao conjunto de todas as análises, quanto no que diz respeito ao grão 2 . Isso reforça, mais uma vez, o fato de que o aumento do $\mathrm{Al}^{\mathrm{IV}}$ foi acompanhado por um aumento nos cátions bivalentes $\left(\mathrm{Fe}^{2+} \mathrm{e} \mathrm{Mg}^{2+}\right)$ e por um decréscimo no $\mathrm{Al}^{\mathrm{Vl}}$ no sítio octaédrico(conforme visto anteriormente). Entretanto, a correlação negativa observada no grão 1 não pode ser explicada dessa forma, visto que nesse grão a correlação do $\mathrm{Al}^{\mathrm{VI}}$ com os cátions bivalentes é positiva(Figuras $156 \mathrm{~b}$ ). Assim, a Figura $6.5 \mathrm{~h}$ evidencia a razão da correlação negativa observada acima(Figura 6.5 h). Nela, nota-se uma discreta correlação negativa entre Si e $\mathrm{Al}^{\mathrm{VI}}$. Isso evidencia que a substituição de $1 \mathrm{Al}^{3+}$ por $1 \mathrm{R}^{2+}$ gerou uma carga negativa no sítio octaédrico, a qual foi neutralizada pela substituição de $\left.1 \mathrm{~A}\right|^{3+}$ por $1 \mathrm{Si}^{4+}$ na camada tetraédrica. Essa substituição pode ser explicada através da equação 1 de Cathelineau(1988). Em relação ao conjunto das amostras e ao grão 2, nota-se uma correlação positiva entre $\mathrm{Si}$ e $\mathrm{Al}^{\mathrm{V} !}$.
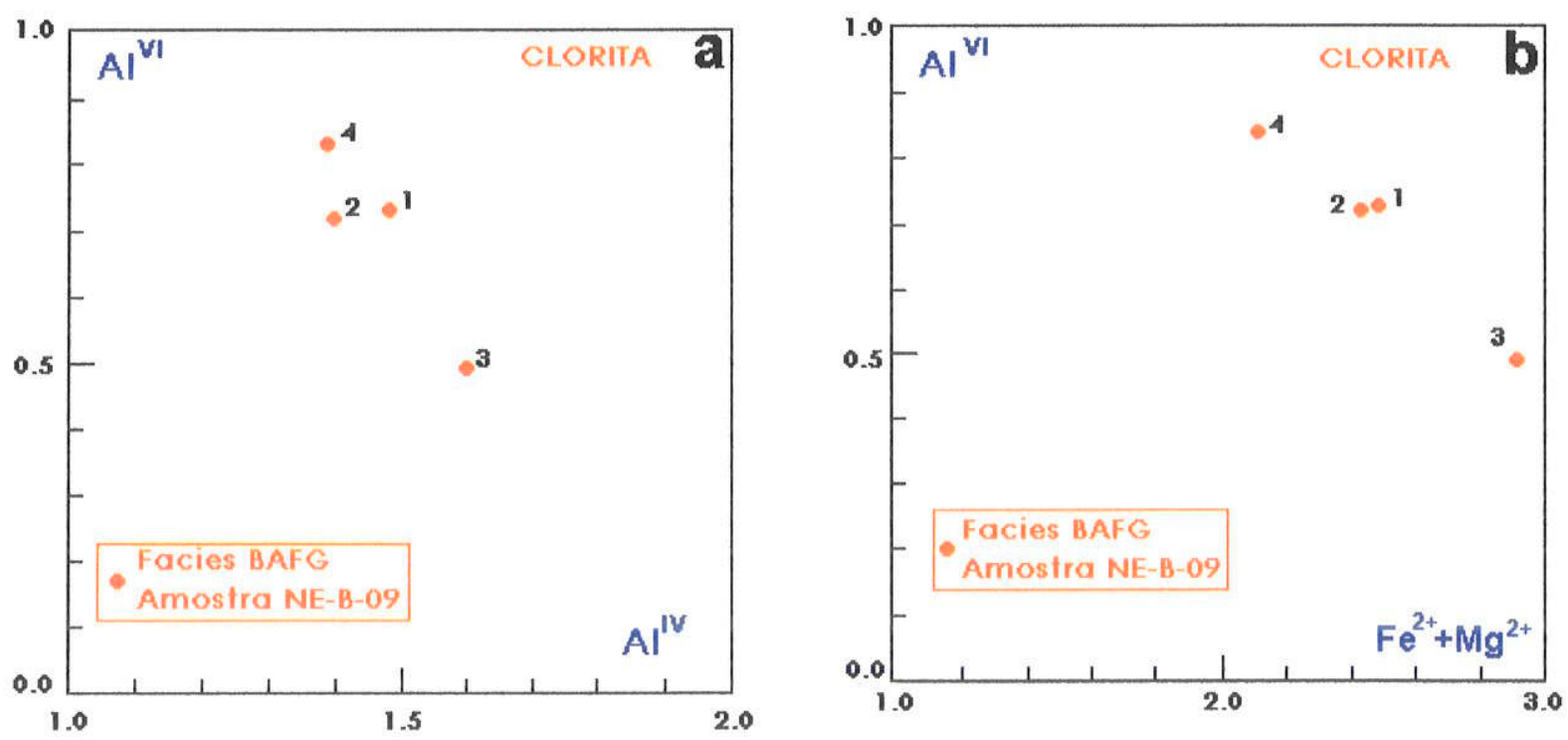

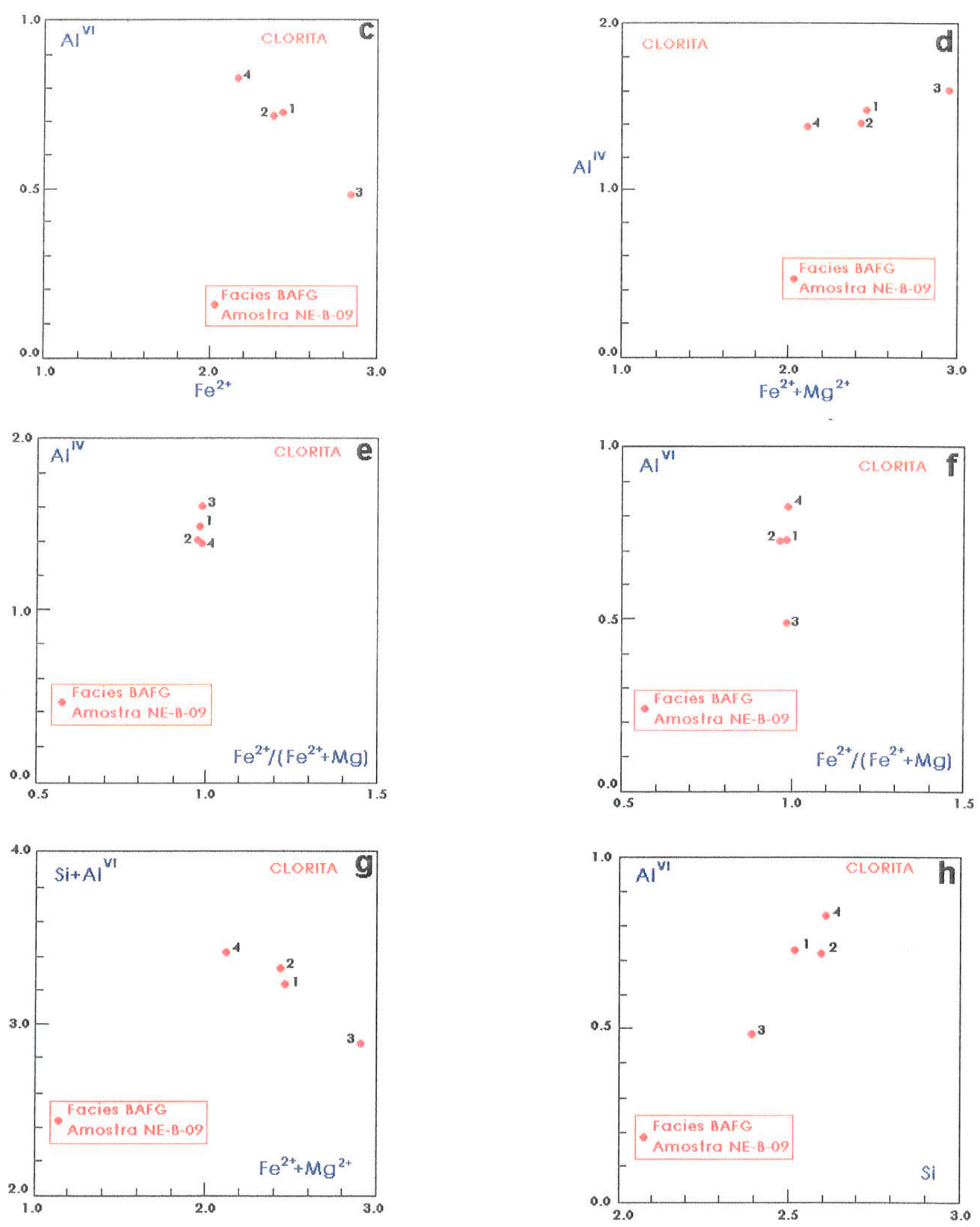

Figura 6.5- Diagramas catiônicos mostrando a distribuição composicional da clorita da facies BAFG do maciço granitóide Benedita. (a) $\mathrm{Al}^{\mathrm{Vl}}$ versus $\mathrm{Al}^{\mathrm{lV}}$; (b) $\left(\mathrm{Fe}^{2+}+\mathrm{Mg}^{2+}\right)-\mathrm{Al}^{\mathrm{Vl}}$; (c) $\mathrm{Al}^{\mathrm{VI}}-\mathrm{Fe} 2+$; (d) $\mathrm{Al}^{\mathrm{lV}}$ $\left(\mathrm{Fe}^{2+}+\mathrm{Mg}^{2+}\right) ;(\mathrm{e}) \mathrm{Al}^{\mathrm{lV}}-\mathrm{Fe} /(\mathrm{Fe}+\mathrm{Mg}) ;\left(\right.$ f) $\mathrm{AlVI}-\mathrm{Fe} /(\mathrm{Fe}+\mathrm{Mg}) ;(\mathrm{g}) \mathrm{Si}+\mathrm{Al}^{\mathrm{VI}}-\left(\mathrm{Fe}^{2+}+\mathrm{Mg}^{2+}\right) ;(\mathrm{h}) \mathrm{Si}-\mathrm{Al}^{\mathrm{V}}$. 
Por fim, na clorita estudada, em função dos dados acima apresentados, prevaleceram os mecanismos de substituições mais coerentes com aqueles estabelecidos pela equação 2 fornecida por Cathelineau(1988; pg. 478), embora tenha ocorrido, muito subordinadamente, o mecanismo de substituição da equação 1 (do mesmo autor).

Ademais, conforme visto anteriormente, as quantidades de ferro férrico, da clorita em questão(não medidas através da microssonda), devem ser muito reduzidas. Assim, do mesmo modo que a clorita do maciço granitóide Antônio Vicente, os supostos baixos valores de $\mathrm{Fe}^{3+}$ aliados à muito provável ausência de magnetita na facies BAFG, deste maciço, indicam condições de baixa $\mathrm{fO}_{2}$ durante a cristalização da clorita estudada e, ao que tudo indica, abaixo do buffer quartzo-fayalita-magnetita(QFM).

Uma hipótese semelhante à acima apresentada, foi formulada por Kranidiotis \& McLean(1987; pg. 1901), em estudo realizado em cloritas do depósito hidrotermal de sulfetos maciços, vulcanogênicos, de Phelps Dodge(Matagami, Quebec), conforme visto no capítrulo 3 deste trabalho.

\subsubsection{2-Classificação e Representação Gráfica}

A exemplo do que foi empregado em relação à clorita dos granitóidese greisen dos outros maciços, para classificação e representação gráfica da clorita desse maciço utilizou-o método de Hey(1954). Assim, a clorita em questão, pelas suas características químicas pertence ao grupo das cloritas não oxidadas, uma vez que seus conteúdos de $\mathrm{Fe}_{2} \mathrm{O}_{3}$ são inferiores a $4 \%$. Os dados analíticos quando lançados no diagrama de Hey(1954), Figura 6.6, mostram que duas análises incidem no campo da bavalita(variedade da dafnita; análises 2 e 4), uma na linha limítrofe entre este campo e o campo da pseudothuringita(análise 1) e outra neste último campo(análise 3).

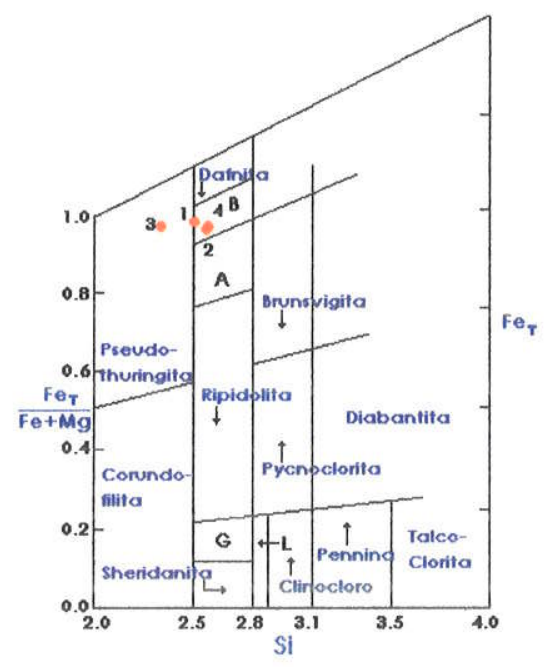

Figura 6.6- Diagrama Si versus $\mathrm{Fe}($ total $) /\left(\mathrm{Fe}^{2+}+\mathrm{Mg}^{2+}\right)$ mostrando a representação gráfica e a classificação da clorita estudada(círculos vermelhos) de acordo com Hey(1954). L=leuchtenbergita, variedade da clinocloro; $\mathrm{G}=$ grochauita, variedade da sheridanita; $A=$ afrosiderita, variedade da ripidolita; $B=$ bavalita, variedade da dafnita. 


\subsubsection{3 - Condições de Cristalização}

Tomando-se por base que a clorita estudada apresenta composição pouco variável e que suas quantidades de $\mathrm{Al}^{\mathrm{IV}}$ variam a razões $\mathrm{Fe} /(\mathrm{Fe}+\mathrm{Mg})$ constantes, utilizou-se para estimar-se a temperatura de cristalização da mesma, o geotermômetro de Cathelineau(1988), uma vez que, em casos como esses, o método desse autor pode propiciar um bom geotermômetro(Cathelineau \& Nieva, 1985).

Assim, os dados da clorita em questão foram lançados na equação de Cathelineau(1988), obtendo-se os seguintes resultados: 1) ० grão 1 possui valores de $\mathrm{Al}^{\mathrm{IV}}$ entre 1,404 e 1,484 , os quais correspondem a um intervalo de temperatura de cristalização entre $390^{\circ} \mathrm{C}$ e $415^{\circ} \mathrm{C} ; 2$ ) o grão 2 exibe valores de $\mathrm{Al}^{\mathrm{N}}$ entre 1,399 e 1,603 , que equivale a um intervalo de temperatura de cristalização entre $388^{\circ} \mathrm{C}$ e $454^{\circ} \mathrm{C}$. Essas temperaturas são equivalentes àquelas estimadas para a clorita da facies BASMG do maciço granitóide Antônio Vicente(ver capítulo 3, deste trabalho), através do mesmo método.

Os resultados apresentados acima, aliados aos estudos petrográficos demonstram que as temperaturas estimadas, embora pareçam um tanto elevadas, são coerentes, quando comparadas com os dados, dessa natureza, existentes na literatuta, a exemplo do que foi comentado em relação às cloritas dos granitóides e greisens dos outros maciços vistos anteriormente. Além disso, os intervalos de temperatura estimados estão dentro dos limites do campo de estabilidade da clorita de ambientes metamórficos(facies xisto verde/grau baixo) conforme Winkler(1977; pgs 49 e 52).

\subsubsection{3.- Análises químicas em Muscovita}

Em relação à essa fase mineral, foram executadas 04 análises pontuais referentes a um único grão da amostra NE-B-09 da facies BAFG. O grão analisado corresponde à muscovita $2\left(\mathrm{Mv}_{2}\right)$ e os resultados analíticos encontram-se no Anexo 39.

\subsubsection{1- Composição química}

O Anexo 39 mostra que o grão estudado não apresenta variações composicionais importantes. Na Figura 6.7 verifica-se que o mesmo é empobrecido em $\mathrm{Mg}, \mathrm{Ti} \mathrm{Fe}^{2+}$ e $\mathrm{Na}$ e que possui conteúdos relativamente elevados de $\mathrm{Si}, \mathrm{Al}_{\mathrm{T}}$ e $\mathrm{K}$. Internamente, observa-se uma correlação negativa entre $\mathrm{Si}$ e $\mathrm{Al}_{\mathrm{T}}$, definida pelo aumento de $\mathrm{Si}$ e decréscimo de $\mathrm{Al}_{\mathrm{T}}$ no sentido da análise 1 para o conjunto das análises 2, 3 e 4(Figura 6.7a). Na Figura 6.7b o Mg e o $\mathrm{Al}_{\mathrm{T}}$ desenvolvem, também, uma correlação negativa, caracterizada pelo aumento de $\mathrm{Mg}$ e diminuição de $A l_{T}$ no mesmo sentido observado na figura anterior. Na Figura 6.7c, nota-se uma nítida correlação positiva entre as quantidades de $\mathrm{Ti}$ e as de $\mathrm{Al}_{\mathrm{T}}$, traduzida pela diminuição do $\mathrm{Ti}$ e $\mathrm{Al}$ T no sentido da análise 1 para o conjunto das análises 2,3 e 4 . $\mathrm{Na}$ 
Figura $163 \mathrm{~d}$, enquanto as quantidades de $A \mathrm{I}_{\mathrm{T}}$ variam dentro de um pequeno intervalo $(4,510$ a 4,610$)$ os valores de XFe permanecem praticamente constantes $(0,98$ a 0,99$)$. Em relação às quantidades de $\mathrm{Na}$ e $\mathrm{K}$, nota-se uma discreta correlação negativa, caracterizada por uma diminuição do $\mathrm{K}$ e aumento de $\mathrm{Na}$ no sentido das análises 1 e 2 para as análises 4 e 3.
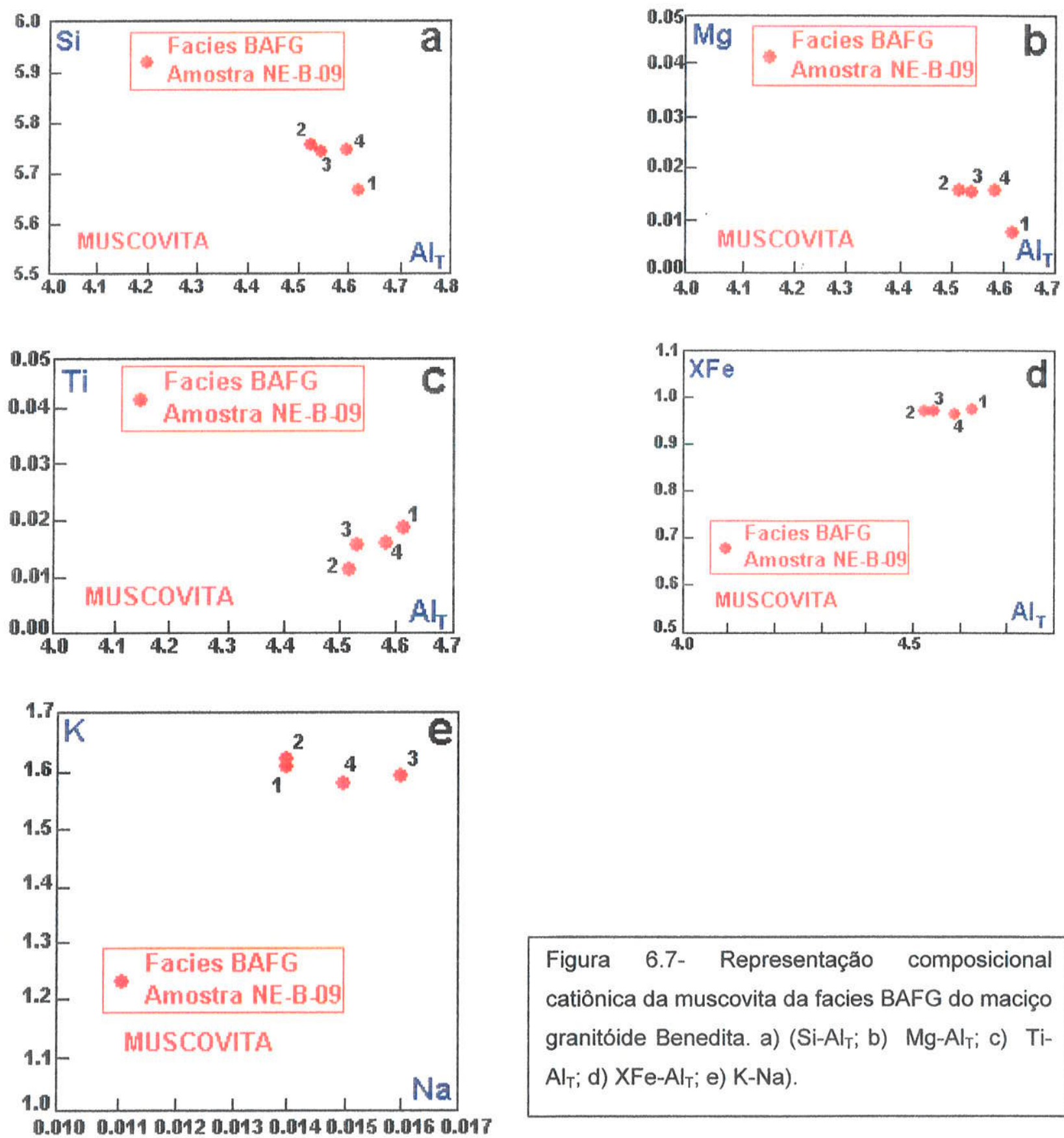

Figura 6.7- Representação composicional catiônica da muscovita da facies BAFG do maciço granitóide Benedita. a) (Si-Al $\mathrm{T}_{\mathrm{T}}$; b) Mg-Al $\mathrm{M}_{\mathrm{T}}$; c) Ti$\mathrm{Al}_{T}$; d) $\mathrm{XFe}-\mathrm{Al}_{\mathrm{T}}$; e) $\left.\mathrm{K}-\mathrm{Na}\right)$.

\subsubsection{2- Substituições}

Em relação à muscovita estudada, as Figuras 6.8 e 6.9 mostram um baixo grau de substituição fengítica e, de um modo geral, um grau baixo da substituição $\mathrm{Al}^{\mathrm{V} /}$ por $\mathrm{Fe}^{3+}\left(\mathrm{Fe}^{3+}\right.$ $\rightarrow \mathrm{Al}^{\mathrm{VI}}$ ). O excesso de carga provocado pela substituição fengítica foi compensado pela 
entrada dos íons divalentes $\mathrm{Mg}^{2+}$ e $\mathrm{Fe}^{2+}$. Entretanto, observa-se que apenas o $\mathrm{Mg}$ contribuiu para essa substituição, visto que, de acordo com as Figuras 6.8 e 6.9, o ferro estrutural está essencialmente no estado trivalente.

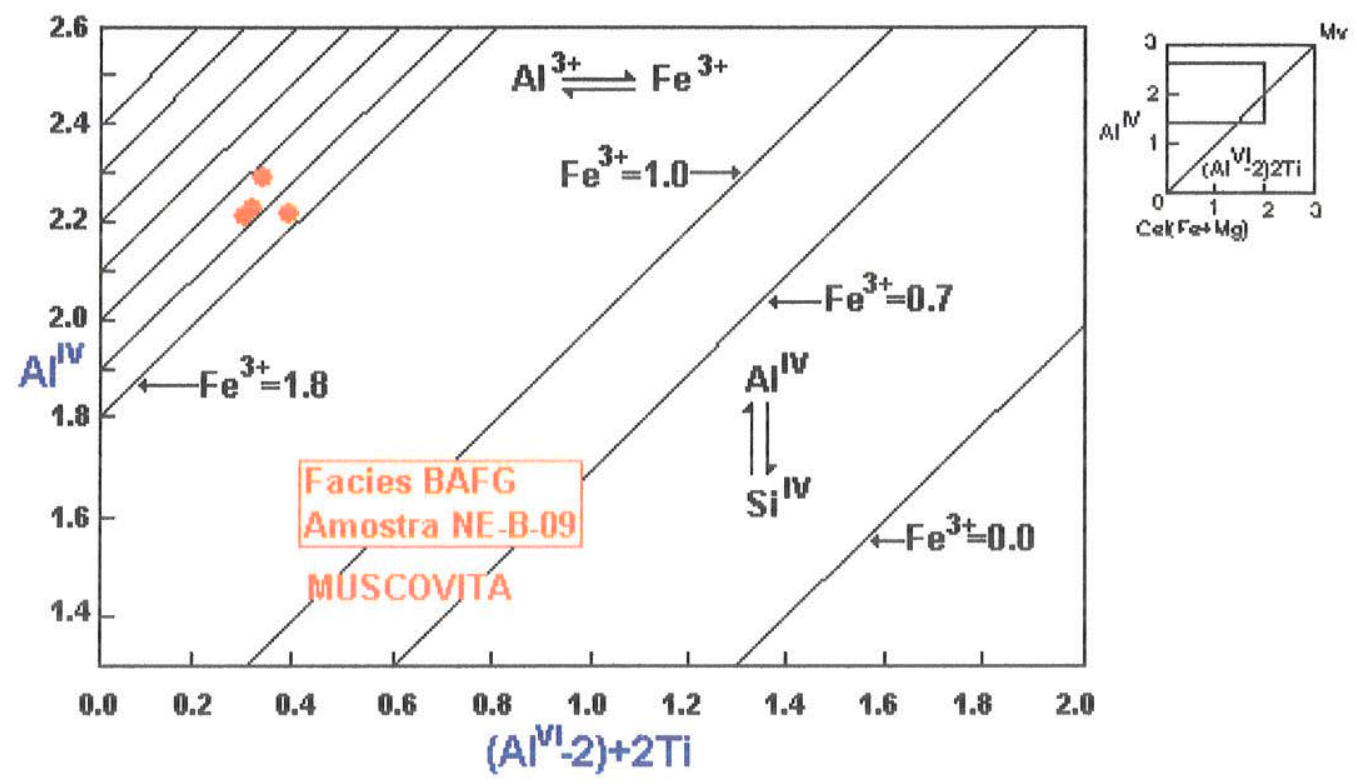

Figura 6.8- Representação composicional da muscovita da facies BAFG do maciço granitóide Benedita no diagrama $\mathrm{Al}^{\mathrm{IV}}$ versus [( $\left.\left.\mathrm{Al}^{\mathrm{VI}}-2\right)+2 \mathrm{Ti}\right]$ de Cathelineau(1982), modificado de Dias(1987). In: Simões(1992).
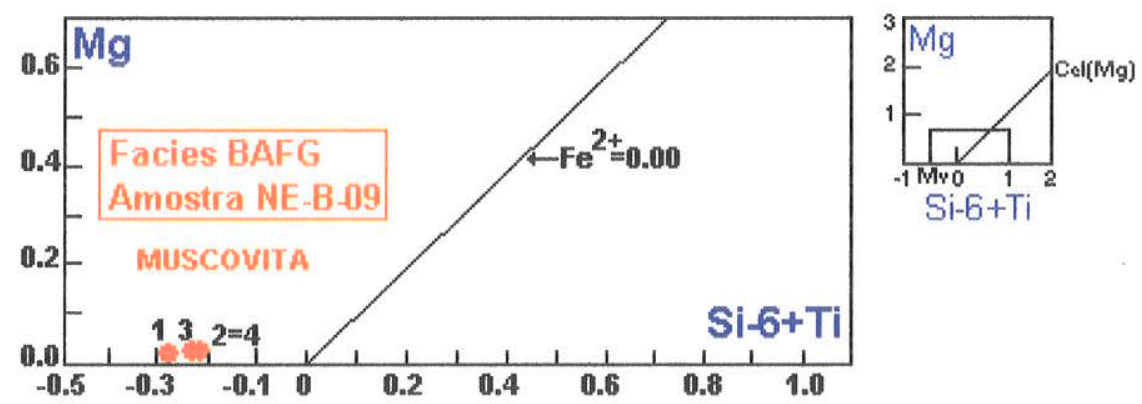

Figura 6.9- Representação composicional da muscovita da facies BAFG do maciço granitóide Benedita no diagrama Mg-(Si-6+Ti), modificado de Dias(1987). In: Simões(1992).

De acordo com Simões(1992) os graus de substituições fengítica e paragonítica podem ser avaliados a partir do diagrama \% da molécula celadonítica versus $\%$ da molécula paragonítica(Figura $6.10 a$ ). Nele, nota-se que a substituição paragonítica é muito reduzida, enquanto que a substituição fengítica, dada pela \% molécula celadonítica, é 
ausente, uma vez que os valores dessa variável são todos negativos na muscovita estudada.

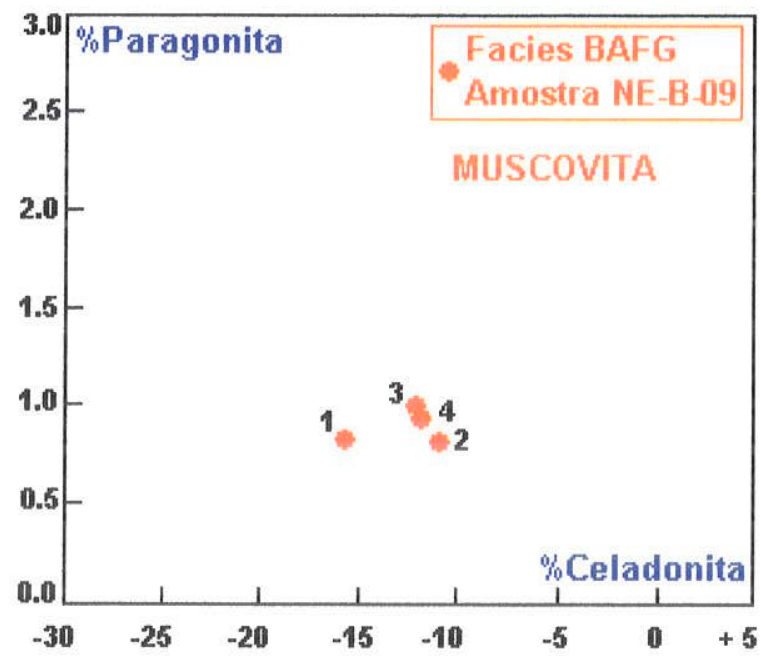

Figura 6.10a- Representação gráfica das percentagens das moléculas paragoníticas e celadoníticas presentes na muscovita da facies BAFG do maciço granitóide Benedita, de acordo com Simões(1992). \% mol. paragonita $=$ $100 \times \mathrm{Na} /(\mathrm{Na}+\mathrm{K}) ; \% \mathrm{~mol}$. celadonita $=100 \times(\mathrm{Si}-6) / 2$.

\subsubsection{3- Classificação e Representação Gráfica}

A exemplo da muscovita de granitóides e greisens dos outros maciços, utilizou-se para classificação e representação gráfica da muscovita em questão o diagrama $\left[\left(\mathrm{Fe}_{\mathrm{T}}+\mathrm{Mn}+\mathrm{Ti}\right)-\mathrm{Al}^{\mathrm{V}}{ }^{\mathrm{I}}\right]$ versus $(\mathrm{Mg}-\mathrm{Li})$ de Tischendorf et al.(1997), Figura 6.10b. Nele, verifica-se que que a composição da mesma situa-se inteiramente na área composicional correspondente à fengita, no quadrante das $\mathrm{Mg}-\mathrm{Al}$ micas.

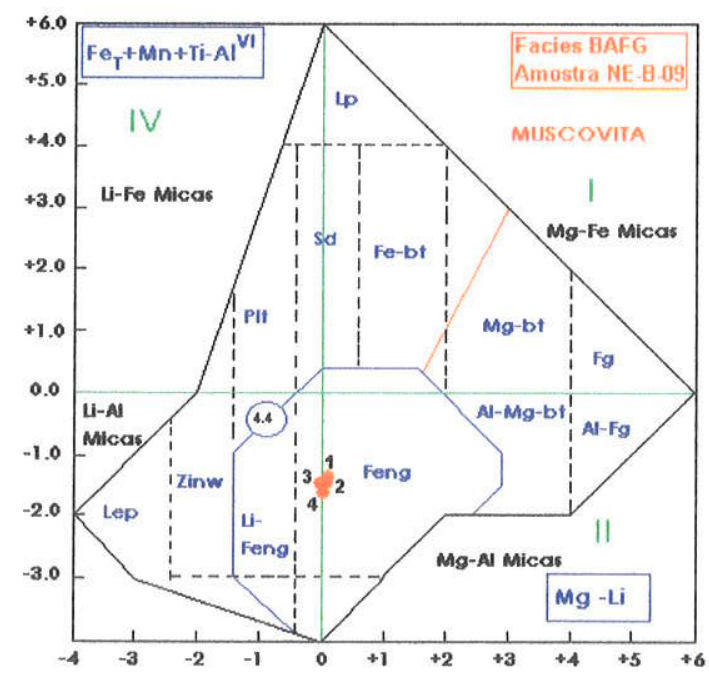

Figura 6.10b- Distribuição composicional da muscovita da facies BAFG do maciço granitóide Benedita no diagrama $\left[\left(\mathrm{Fe}_{\mathrm{T}}+\mathrm{Mn}+\mathrm{Ti}+\mathrm{Al} \mathrm{V}^{\mathrm{Vl}}\right)-(\mathrm{Mg}-\mathrm{Li})\right]$, de classificação composicional e nomenclatura de micas trioctaédrica e dioctaédrica apresentado por Tischendorf et al.(1997). 


\subsubsection{4- Origem}

As observações petrográficas realizadas em seções delgadas de amostras da facies BAFG mostraram que a mica estudada corresponde à uma variedade branca, de origem secundária, formada às custas da biotita primária, no estágio de alterações tardi a pósmagmáticas, tendo sido designada de muscovita 2.

Os dados químicos quando lançados no diagrama triangular $\mathrm{Mg}-\mathrm{Ti}-\mathrm{Na}$ de Miller et al.(1981), Figura 6.11, revelaram que a composição da muscovita em questão incide no campo da muscovita primária. Comparativamente à muscovita estudada por Miller et al.(1981), Monier et al.(1984) e Simões(1992), essa muscovita, tem tanto afinidas químicas com a muscovita primária(visto que apresenta conteúdos relativamente elevados, especialmente de Ti), quanto com a muscovita secundária, uma vez que seus teores de $\mathrm{Al}$, Mg e Si são compatíveis com as mesmas.

Nesse caso, os dados petrográficos são decisivos em relação à determinação da origem secundária da muscovita estudada. Assim, do mesmo modo como para a muscovita de outros maciços apresentados anteriormente, o quimismo nem sempre permite caracterizar a sua origem se primária ou secundária, através da relação Ti-Mg-Na. Vê-se, portanto, que muitas vezes, os estudos petrográficos cuidadosos são mais eficazes na determinação da origem de fases minerais e, em particular, de fases micáceas, do que outros métodos(químicos por exemplo). Isso é demonstrado tanto pela composição da muscovita(de origem claramente secundária), as quais fora comentadas neste trabalho, quanto por algumas composições de muscovita, texturalmente secundárias, apresentadas por Miller et al.(1981; Figura 2b, g 28), as quais incidem no campo composicional correspondente à muscovita primária.

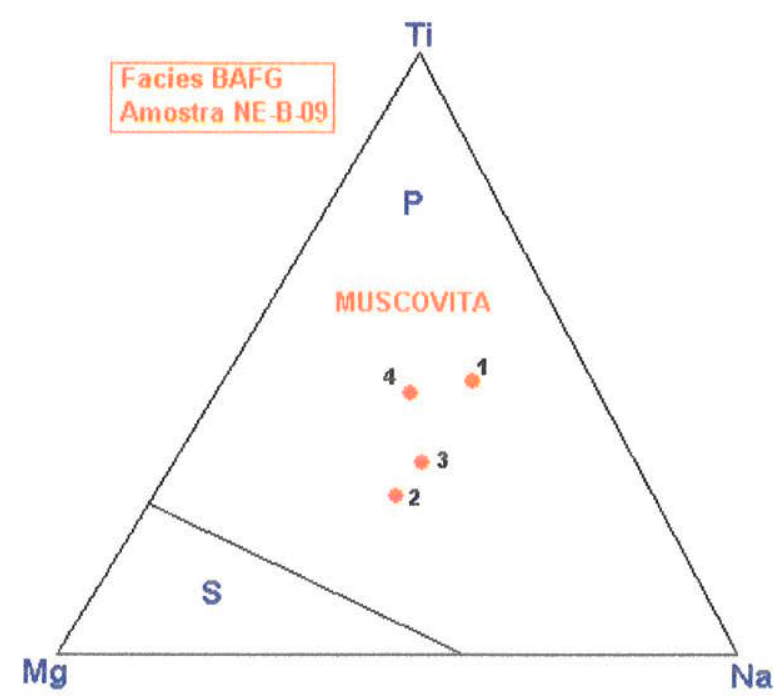

Figura 6.11- Distribuição composicional da muscovita da facies BAFG do maciço granitóide Benedita no diagrama triangular Mg-Ti-Na de Miller et al.(1981). $P=$ campo composicional da muscovita primária; $\mathrm{S}=$ campo composicional da muscovita secundária. 


\subsection{2- Análises químicas através de Microscopia Eletrônica}

Neste maciço foram realizadas oito análises na amostra NE-B-09, da facies BAFG, e envolveram as fases "óxido" de Ti com $Y$, óxido de ferro e pirita.

\section{a) Óxido de $\mathrm{Ti}$}

Apenas uma análise dessa fase foi executada e não foi obtida uma imagem da mesma. Entretanto, observações realizadas através de microscopia ótica, em luz refletida, indicaram uma origem secundária para a mesma.

Quimicamente, representa um óxido de Ti portador de concentrações significativas de $\mathrm{Y}, \mathrm{Fe}, \mathrm{U}$ e $\mathrm{Nb}$ e conteúdos mais modestos de $\mathrm{Si}, \mathrm{Dy}, \mathrm{Ce}, \mathrm{Nd}, \mathrm{Zr}$ e $\mathrm{Pb}$, bem como de quantidades vestigiais de $\mathrm{Yb}, \mathrm{Ca}$, Th e $\mathrm{Al}($ Anexo 40). Comparativamente, às fases minerais óxidos, portadoras desses elementos, apresentadas na literatura(Jones et al., 1996; pg. 350 e 353), nota-se que o mineral e questão, pela sua composição química, pode corresponder tanto à aeschynita-(Y), quanto de uma yttrocrasita-(Y). Se o Si for um componente essencial na sua estrutura cristalina, pode, ainda, tratar-se do silicato trimounsita-( $Y$ ), impregnado de impurezas. De qualquer modo, o quimismo desse mineral, não corresponde plenamente à composição química de nenhuma das fasas mencionadas acima. Em razão disso, qualquer conclusão a esse respeito é, no momento, prematura.

\section{b) Óxido de Ferro}

Estudos realizados em seções polidas através de microscopia ótica, em luz refletida, revelaram que essa fase mineral apresenta-se como grãos subédricos a euédricos, zonados, formando agregados, que exibem internamente "manchas" residuais de pirita. Eles mostram-se intimamente vinculados a cristais de feldspato potássico e de biotita, os quais apresentam-se intensamente oxidados. Suas relações microtexturais com estas duas fases indicam uma origem secundária para a mesma, que parece, representar um produto de substituição da pirita, ocorrida em condições oxidantes e, por conseguinte, em ambiente com elevada fugacidadde de oxigênio.

Duas análises em zonas distintas de um mesmo grão foram realizadas e assim como em relação ao óxido de $\mathrm{Ti}$, não se obteve imagem através de MEV.

No Anexo 40, observa-se que a composição de ambas as zonas é caracterizada por reduzidas quantidades de $\mathrm{Si}(2,23 \%-2,51)$. Nota-se, também, que a zona 1(análise 2) possui teores mais reduzidos de $\mathrm{Fe}(57,59 \%)$ e conteúdos vestigiais de $\mathrm{Yb}, \mathrm{Al}, \mathrm{Dy}, \mathrm{Pb}, \mathrm{Nd}, \mathrm{Ca}, \mathrm{Pe}$ Th(em ordem decrescente de abundância relativa), enquanto que a zona 2(análise 3 ) é mais enriquecida em $\mathrm{Fe}(61,63 \%)$ e ostenta baixissimos teores de $\mathrm{Al}, \mathrm{Pb}, \mathrm{Th}, \mathrm{U}, \mathrm{Mn}$ e $\mathrm{Ca}(\mathrm{em}$ ordem decrescente de abundância relativa). 


\section{c) Pirita e Óxido de Fe com W}

Observações efetuadas em lâmina polidas, através de microscopia ótica, em luz refletida, mostraram que o grão analisado apresenta-se intimamente associado a grãos de feldspato potássico e a finas lamelas residuais de biotita, que encontram-se fortemente oxidadas.

Estudos realizados através de MEV permitiram a obtenção de três análises em dois grãos distintos, bem como possibilitaram a confecção de uma imagem representativa dos mesmos. Na Figura 169, observa-se que se trata de um cristal de pirita que se encontra parcialmente substituido, na sua porção mais central e nas bordas, por uma fase óxido de Fe com W. Observações adicionais complementares, realizadas em lâminas polidas, através de microscopia ótica, em luz refletida, mostraram que se trata de núcleos residuais de pirita, os quais preservam, ainda, sua cor amarela típica. No interior desses núcleos amarelos podem ser observadas pintas azuladas, as quais devem corresponder a covelina(naõ detectada em MEV). De acordo com Deer et al.(1966; pg. 467), além do S e do Fe, a pirita pode hospedar elementos menores, que muitas vezes ocorrem sob a forma de impurezas. $E$ possivel que a covelina represente, também, uma fase de alteração da pirita, visto que a mesma abriga, localmente, ínfimas quantidades de Cu(análise 5; Anexo 41).

O Anexo 40 mostra que a porção piritica, dos cristais analisados, não exibe variações composicionais importantes, com o conteúdo de $\mathrm{Fe}$ variando entre $46,73 \%$ (no grăo 2) e 47,30\%(no grão 1) e o de $S$ de $51,69 \%$ (grão 2) a 51,98\%(grão 1). Observa-se, ainda, que essa porção contém quantidades ifimas de $\mathrm{Cu}, \mathrm{Pb}, \mathrm{Sn}, \mathrm{Nb}, \mathrm{Ta}, \mathrm{Mn}$ e W.

A fase óxido que, ao que tudo indica, representa uma fase de substituição da pirita. Ela exibe teores bem mais elevados de $\mathrm{Fe}$, que oscila entre $58,40 \%$ (no grão 1) e 59 , $13 \%$ (no grão 2) e quantidades de $S$ desprezíveis $(0,23 \%$ a $0,35 \%$, nos dois grãos, respectivamente). Além disso, possui baixíssimos conteúdos de Ta e Ti(Anexo 40, análises 7 e 8). Um fato relevante é que os reduzidos teores de $W$ presentes na porção pirítica, assumem, nesta fase, conteúdos, relativamente, mais elevados, chegando a atingir até $4,48 \%$.

Bastin et al.(1931), definiram substituição, ou metassomatismo, como a dissolução de um mineral ou de um grupo de minerais e a deposição simultânea de um outro mineral ou de um outro grupo de minerais em seu lugar. A solução e deposição ocorrem combinados, sem o desenvolvimento de espaços abertos de dimensões consideráveis, bem como a substituição não envolve mudanças de volume. O novo mineral, pode ser parcial ou totalmente diferente, em termos composicionais, do mineral a parir do qual ele cresceu. Esses mesmos autores denominam uma substituição mineral de metasome e quando a substituição assume as caracteríticas do arcabouço do cristal substituído é designada metacryst. 
Segundo Edwards(1954; pgs. 117-118), a substituição de borda, por metassomatose, cresce como uma estreita faixa em torno do hospedeiro e é, geralmente, distintiva, embora em algumas circunstâncias possa se assemelhar a uma textura formada por uma completa desmistura de uma solução sólida. Menos comumente, a metassomatose invade primeiro o núcleo de um mineral, abandonando a borda não substituída do mineral hospedeiro.

No que se refere a pirita, aqui estudada, as relações microtexturais observadas entre as duas porções, reforça a hipótese de que a fase óxido é fruto da substituição da pirita. Essas relações são coerentes com as definições de Bastin et al.(1931), bem como com as postulações de Edwards(op. cit.). Entretanto, observa-se na Figura 6.12, que o cristal de pirita mostra-se substituido tanto nas bordas, quanto na sua região central e que ambas as zonas mostram-se, geralmente, conectadas fisicamente. Isso indica que a substituição da pirita por óxido de Fe com $W$ pode ter-se iniciado nas bordas, que foram abandonadas, prosseguindo no núcleo do cristal. Ou, ainda, que a substituição iniciou-se nas bordas e se estendeu para o centro, sem abandonar as bordas.

No que se refere à natureza primária ou secundária, dessas fases, é difícil precisar com segurança. Todavia, como a amostra estudada encontra-se afetada por alterações tardi a pós-magmáticas, especialmente por albitização e oxidação, bem como o grão analisado, como um todo, encontra-se intimamente associado a grãos de feldspato potássico e residuos de biotita, intensamente oxidados, acredita-se que as três fases( pirita, covelina e o óxido de $\mathrm{Fe}$ ) estejam relacionadas ao estágio de alterações tardi a pós-magmáticas, pricipalmente, o óxido de $\mathrm{Fe}$. Se isso é verdade, pode-se deduzir que, durante essa alteração, as condições redutoras e/ou fracamente oxidantes, ambiente propício para a cristalização da pirita, em primeiro lugar, e covelina, em segundo, progrediram para condições, relativamente, mais oxidantes.

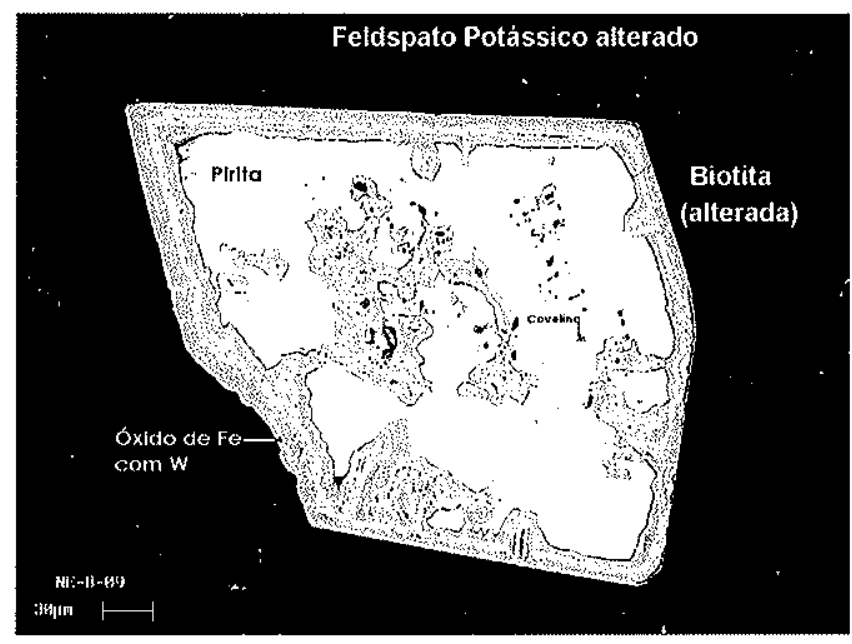

Figura 6.12- Detalhe de um cristal de pirita sendo parcialmente substituído por óxido de Fe e W, presente na amostra NE-B-09, da facies $B A F G$ do maciço granitóide Benedita. 


\section{6- Geoquímica}

Os resultados analíticos mostrados na Tabela 6.3(Anexo 41) dizem respeito às principais facies granitóides estabelecidas no âmbito desse maciço.

\subsection{1- Características Gerais}

Os granitóides desse maciço correspondem à diferenciados extremamente evoluídos, os quais encontram-se afetados, em diferentes graus, por alterações tardi a pósmagmáticas. Eles possuem teores de $\mathrm{SiO}_{2}$, superiores a $76 \%$, os conteúdos de $\mathrm{TiO}_{2}, \mathrm{Al}_{2} \mathrm{O}_{3}$, $\mathrm{MnO}, \mathrm{MgO}, \mathrm{CaO}$ e $\mathrm{P}_{2} \mathrm{O}_{5}$ são sempre muito reduzidos e inferiores àqueles da média dos granitos(Le Maitre, 1976), enquanto que os teores de $\mathrm{K}_{2} \mathrm{O}$ são eqüivalentes e os de $\mathrm{Na}_{2} \mathrm{O}$ são ligeiramente mais elevados. No que se refere aos elementos menores e traços, ostentam altos valores de $\mathrm{Rb}$ (média entre 351 e 489ppm), Zr(média entre 236 e 268ppm), $\mathrm{F}$ (média entre 903 e 1933ppm) e $\mathrm{Cl}$ (média entre 710 e 454ppm), moderados de $\mathrm{Nb}$ (média entre 62 e 75ppm), Y(média entre 68 e 89ppm), Ga(média entre 26 e 31ppm), W(média entre 45 e 68ppm), Th(média entre 65 e 70ppm) e Zn(média entre 45 e 49ppm) e baixas concentrações de $\mathrm{Sr}$ (média entre 11 e 15ppm), Ba(média entre 7 e 45ppm), Ta(média entre 7 e 8ppm), Hf(média entre 13 e 15ppm), U(média entre 17 e 19ppm, Sn(média entre 3 e $5 \mathrm{ppm}$ ) e Mo(média entre 1 e $8 \mathrm{ppm}$ ). Em relação aos ETR, apresentam teores sempre muito reduzidos( média entre 155, 51 e 186,56ppm), embora a somatória das médias dos ETRL(entre 119 e $141 \mathrm{ppm}$ ), nas duas facies granitóides, seja mais elevada do que aquela de $\operatorname{ETRP}($ entre 36 e 46ppm). As razões $\mathrm{Rb} / \mathrm{Sr}$ (média entre 23 e 46), $\mathrm{Rb} / \mathrm{Ba}$ (média entre 8 e 73 ), e Th/U(média=4) são, geralmente, altas, enquanto as razões $\mathrm{K} / \mathrm{Rb}$ (média entre 72 e 95) são baixas se comparadas com aquelas dos granitos considerados normais(Shaw, 1968).

\subsection{2- Saturação em Alumina(ISA)}

Apesar dos granitóides desse maciço possuírem teores de $\mathrm{Al}_{2} \mathrm{O}_{3}$ mais baixos do que aquele da média dos granitos fornecida por Le Maitre(1976), as rochas em questão são invariavelmente peraluminosas, com as razões dos conteúdos moleculares NKIA variando entre 0,68 e 0,71 e as razões A/CNK sendo superiores a 1 e inferiores a 1,5(Figura 6.13).

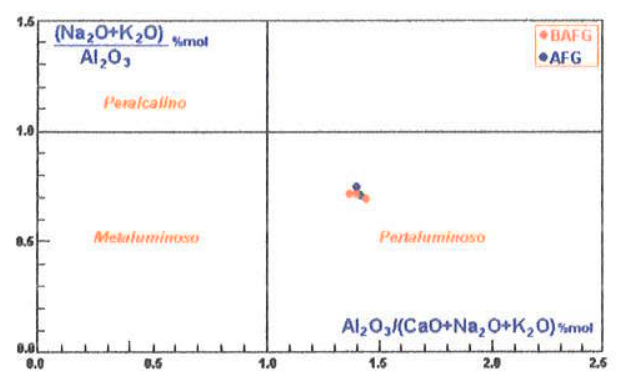

Figura 6.13- Diagrama binário A/CNK versus NK/A(Maniar\& Piccoli, 1989) mostrando a distribuição das facies granitóides do MGB, com base nos índices de Shand(ISA). 


\subsection{3 - Afinidade Tectonomagmática e Tipologia}

Nos Diagramas clássicos $\mathrm{Y}-\mathrm{Nb},(\mathrm{Y}+\mathrm{Nb})-\mathrm{Rb}$ e Ta-Yb de Pearce et al.(1984), Figura 6.14(a, b e c+), nota-se que as amostras incidem inteiramente no campo dos granitóides intraplacas.
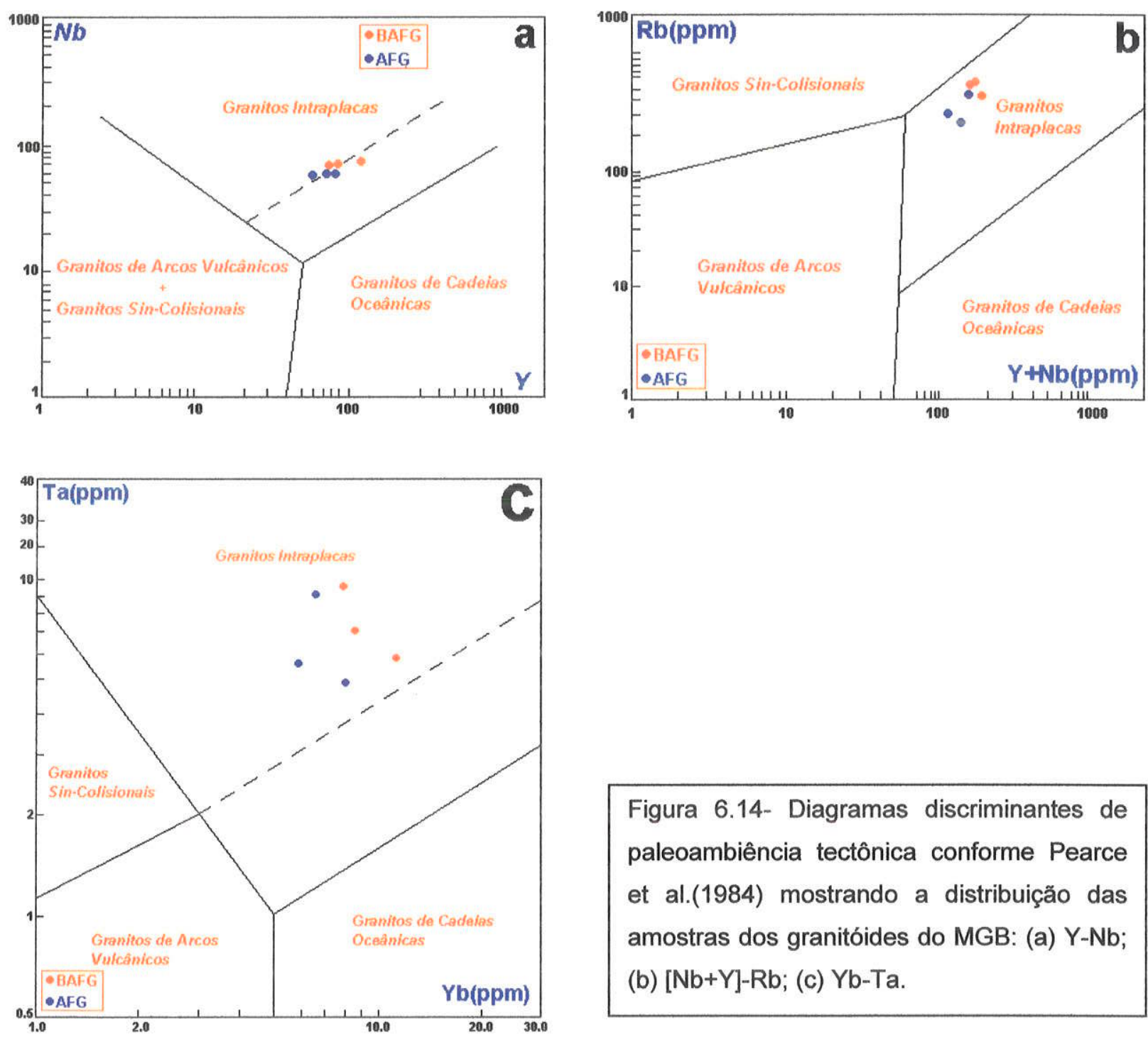

Figura 6.14- Diagramas discriminantes de paleoambiência tectônica conforme Pearce et al.(1984) mostrando a distribuição das amostras dos granitóides do MGB: (a) Y-Nb; (b) $[\mathrm{Nb}+\mathrm{Y}]-\mathrm{Rb}$; (c) $\mathrm{Yb}-\mathrm{Ta}$.

Conforme comentado no capítulo 3, Whalen et al.(1987) porpos a distinção entre granitóides tipo-I, altamente fracionados e granitóides tipo-A, baseando-se em elementos incompatíveis, utilizando para tal o parâmetro de discriminação $\mathrm{Zr}+\mathrm{Nd}+\mathrm{Ce}+\mathrm{Y}$.

Assim, em relação aos granitóides estudados, observa-se no diagrama $\mathrm{Zr}+\mathrm{Nb}+\mathrm{Ce}+\mathrm{Y}$ vs. $\left(\mathrm{K}_{2} \mathrm{O}+\mathrm{Na}_{2} \mathrm{O}\right) / \mathrm{CaO}$ (Whalen et al., op cit.), Figura 6.15 , que a totalidade das amostras incide no campo composicional correspondente aos granitos tipo-A.

No diagrama $\mathrm{Zr}+\mathrm{Nb}+\mathrm{Ce}+\mathrm{Y}$ vs. $(\mathrm{FeO} / \mathrm{MgO})$, dos mesmos autores, Figura 6.16, que expressa o grau de fracionamento dos granitóides estudados, percebe-se que as amostras situam-se inteiramente no campo dos granitóides tipo-A. Nota-se, também um nítido "trend" 
de fracionamento, caracterizado pela correlação positiva entre as quantidades de $\mathrm{Zr}+\mathrm{Nb}+\mathrm{Ce}+\mathrm{Y}$ e as razões $\mathrm{FeO} / \mathrm{MgO}$, definida pelo crescimento dessas duas variáveis no sentido da facies AFG para a facies BAFG.

No diagrama $10.000 \mathrm{Ga} / \mathrm{Al}$ vs. $\left(\mathrm{K}_{2} \mathrm{O}+\mathrm{Na}_{2} \mathrm{O}\right) / \mathrm{Al}_{2} \mathrm{O}_{3}$ de Whalen et al.(op. cit.), modificado por Rämö \& Haapala(1995), que exprime o grau de alcalinidade ou índice agpaítico, Figura 6.17, verifica-se que todas as amostras dos granitóides caem na área composicional correspondente aos granitos tipo-A, de natureza subalcalina.

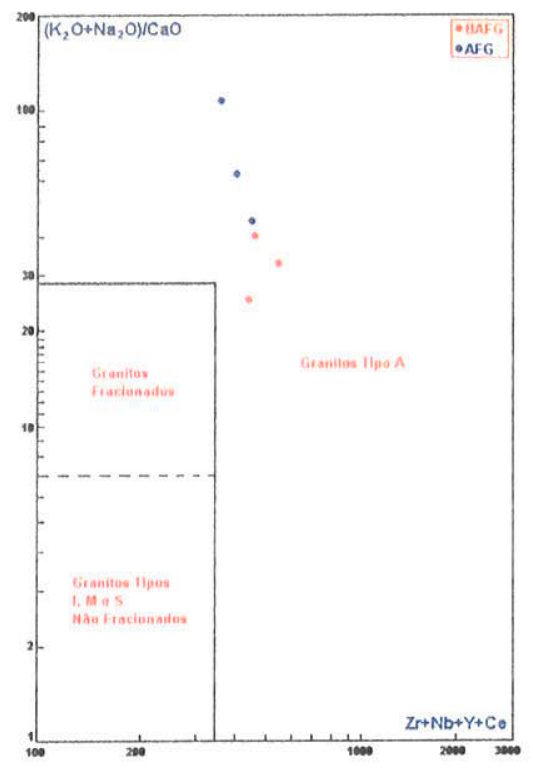

Figura 6.15- Diagrama $\mathrm{Zr}+\mathrm{Nb}+\mathrm{Ce}+\mathrm{Y}$ vs. $\left(\mathrm{K}_{2} \mathrm{O}+\mathrm{Na}_{2} \mathrm{O}\right) / \mathrm{CaO}$ de Whalen et al.(1987a) mostrando a distribuição composicional das amostras das principais facies granitóides do maciço granitóide Benedita.

Figura 6.16- Diagrama $\mathrm{Zr}+\mathrm{Nb}+\mathrm{Ce}+\mathrm{Y}$ vs. $(\mathrm{FeO} / \mathrm{MgO}) \mathrm{de}$ Whalen et al.(1987a) exibindo as análises das principais facies granitóides do maciço granitóide Benedita.
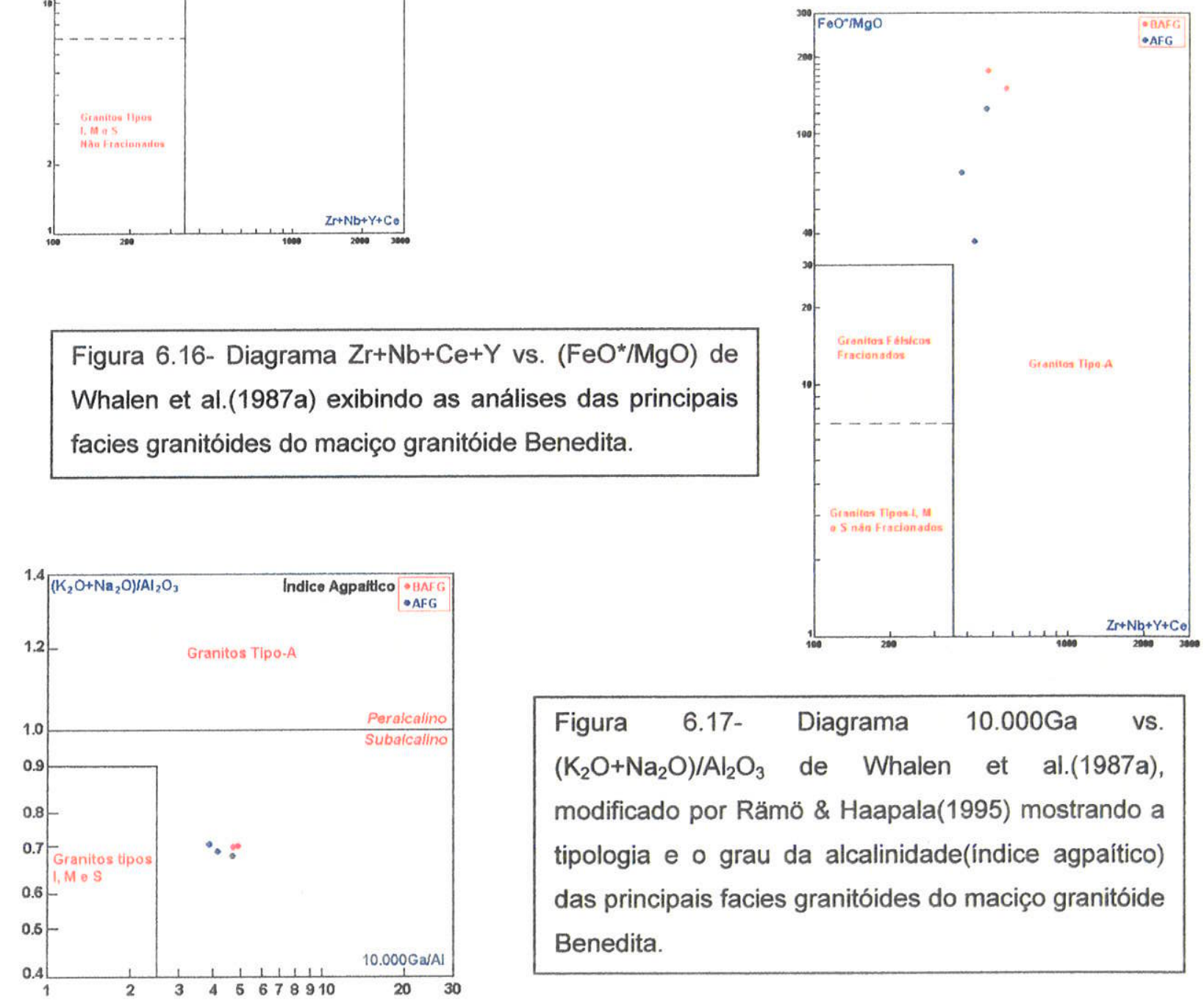

Figura 6.17- Diagrama $10.000 \mathrm{Ga}$ vs. $\left(\mathrm{K}_{2} \mathrm{O}+\mathrm{Na}_{2} \mathrm{O}\right) / \mathrm{Al}_{2} \mathrm{O}_{3}$ de Whalen et al.(1987a), modificado por Rämö \& Haapala(1995) mostrando a tipologia e o grau da alcalinidade(indice agpaítico) das principais facies granitóides do maciço granitóide Benedita. 
Tomando-se por base a subdivisão apresentada por Eby(1992), os dados químicos dos granitóides desse maciço foram lançados nos diagramas discriminantes $\mathrm{Y}-\mathrm{Nb}-\mathrm{Ce}$ e $\mathrm{Y}$ $\mathrm{Nb}-3 \mathrm{Ga}$, Figuras $6.18(\mathrm{a}, \mathrm{b})$. Nos dois diagramas as amostras incidem preferencialmente no campo correspondente aos granitóides do sub-grupo tipo- $A_{1}$, embora muito próximo a linha limitrofe entre este campo e o campo do $\mathrm{A}_{2}$.

Esse posicionamento é claramente discordante em relação à distribuição composicional, predominante, das amostras correspondentes aos granitóides do maciços Antônio Vicente, Velho Guilherme e Mocambo, uma vez que as composições dos mesmos situam-se no campo dos granitóides do sub-grupo- $A_{2}$. Uma hipótese para justificar essa diferença pode ser o fato dos granitóides deste maciço possuírem conteúdos relativamente elevados e eqüivalentes de $\mathrm{Nb}, \mathrm{Y}$ e $\mathrm{Ce}$, bem como seus teores de $\mathrm{Ga}$, quando multiplicados por três, se eqüivalem aos desses três elementos. Essas características químicas tanto podem refletir uma área fonte relativamente enriquecida nesses elementos, quanto podem indicar uma forte influência crustal sobre magma gerador dos granitóides desse maciço. $E$, de fato, tais elementos tendem a ocorrer de modo mais concentrado na crosta(Neary \& Highley, 1984; Henderson, 1986).

Alternativamente, pode-se atribuir tal distribuição aos limites de precisão das análises químicas(não fornecido pelo laboratório onde as mesmas foram executadas), visto as amostras situam-se no limite entre os dois campos composicionais, que, por sua vez, foi definido estatisticamente. Assim, qualquer pequeno erro analítico poderia deslocar os pontos composicionais de um campo para outro.
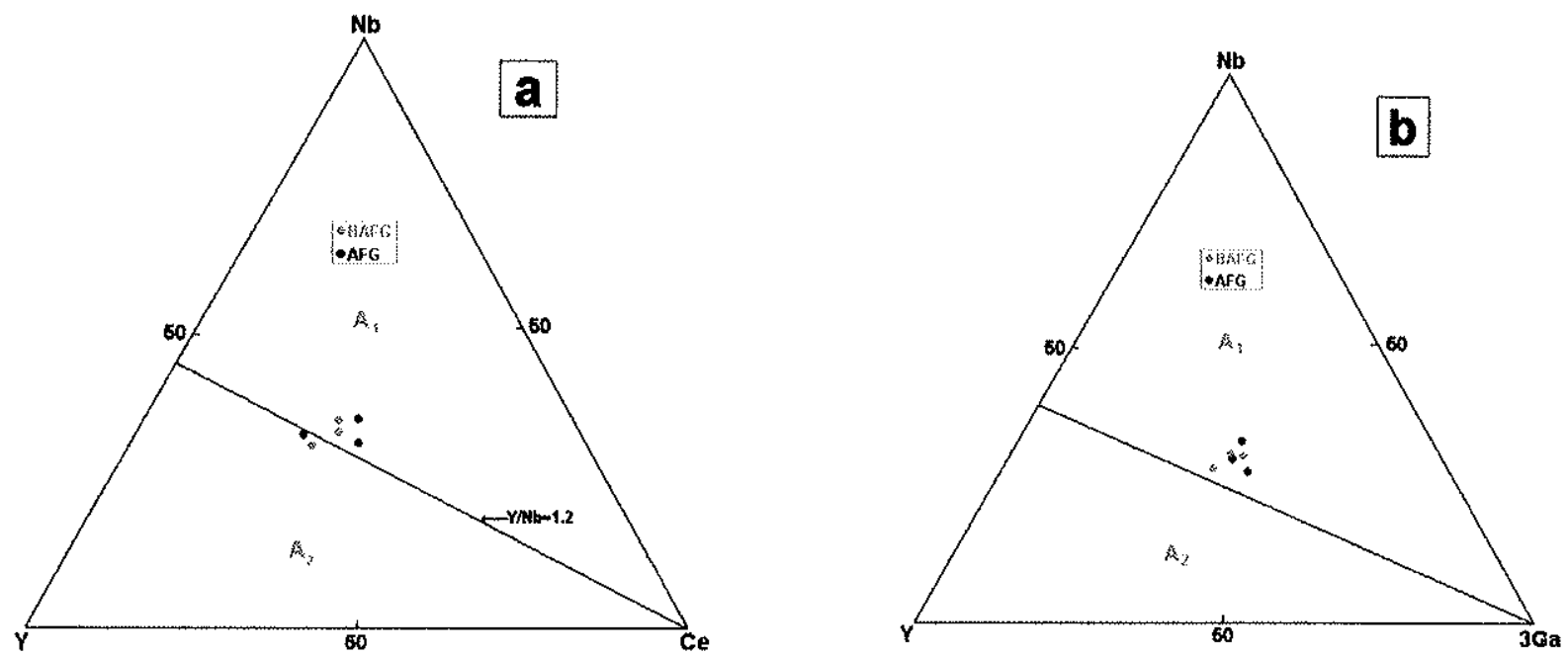

Figura 6.18- Diagramas triangulares $\mathrm{Y}-\mathrm{Nb}-\mathrm{Ce}(\mathrm{a})$ e $\mathrm{Y}-\mathrm{Nb}-3 \mathrm{Ga}(\mathrm{b})$ de $\mathrm{Eby}(1992)$ mostrando a distribuição composicional das principais facies granitóides do maciço granitoide Benedita. 


\subsection{4- Outras Feições Geoquímicas}

No diagrama $\mathrm{SiO}_{2}$ vs. $\mathrm{FeO}^{*} /\left(\mathrm{FeO}^{*}+\mathrm{MgO}\right)$, Figura 6.19a, percebe-se uma discreta correlação positiva entre essas duas variáveis, caracterizada pelo aumento de $\mathrm{SiO}_{2}$ e das razões $\mathrm{FeO}^{*} /\left(\mathrm{FeO}^{*}+\mathrm{MgO}\right)$ no sentido da facies $A F G$ para a facies BAFG. Foge a esse comportamento a amostra de número 2(Tabela 6.3, Anexo 41) devido seu elevadíssimo conteúdo de $\mathrm{SiO}_{2}(79,81 \%)$. O comportamento destas duas variáveis é semelhante àquele observado no âmbito do maciço granitóide Antônio Vicente, em relação aos diferenciados magmáticos(ver capítulo 3 deste trabalho). É digno de nota o fato do BAFG representar, no "trend" o diferenciado mais evoluído. Isso indica a biotita cristalizou tardiamente em relação às fases essenciais quartzo e feldspato potássico e caracteriza uma inversão na ordem de cristalização dessa fase micácea primária.

$\mathrm{Na}$ Figura $6.19 \mathrm{~b}$ nota-se que enquanto os conteúdos de $\mathrm{Na}_{2} \mathrm{O}$ variam muito pouco, permanecendo quase que constantes, as concentrações de $\mathrm{CaO}$ crescem sistematicamente no sentido da facies AFG para a facies BAFG, o que se deve, ao que parece, à presença de allanita, especialmente na amostra de número 9(Tabela 6.1), onde esse mineral ocorre inequivocamente. É possível que nas outras amostras dessa facies a allanita ocorra em finíssimos grãos não detectados através de microscopia ótica. Ademais, o fato do plagioclásio primário estar ausente nesses granitóides, bem como a fluorita ser uma fase comum aos mesmos, permite inferir que a presença de allanita na facies BAFG seja a principal causa, nesta, de conteúdos de $\mathrm{CaO}$ mais elevados do que na facies AFG.

A Figura 6.20 ilustra uma discreta correlação negativa entre as concentrações de $\mathrm{Sr}$ e $\mathrm{Na}_{2} \mathrm{O}$, caracterizada pela diminuição nos conteúdos de $\mathrm{Sr}$ e aumento nos teores de $\mathrm{Na}_{2} \mathrm{O}$ no sentido da facies AFG para a facies BAFG. Nesse caso o $\mathrm{Sr}$ se comportou como um elemento compativel durante a evolução magmática desses granitóides, onde a facies AFG representa o diferenciado relativamente menos evoluido, enquanto a facies BAFG representa o diferenciado mais tardio(ver aspectos petrográficos). Fogem desse comportamento as análises das amostras de números 3 e 5(Tabela 29), que ocupam uma posição invertida no "trend". Deve-se ressaltar, entretanto, que as pequenas variações nas concentrações de $\mathrm{Na}_{2} \mathrm{O}$ podem significar erros analíticos, uma vez que é possível que tais variações estejam dento dos limites de erros.

A exemplo dos granitóides do maciço granitóide António Vicente, Velho Guilherme e Mocambo, os granitóides deste maciço apresentam razóes $K / R b$, na quase totalidade das amostras, abaixo de 100. Entretanto, o limite inferior dos valores dessa razão situa-se acima de 50. Apenas a análise da amostra de número 1(Tabela 6.3, Anexo 41) possui razão K/Rb acima de 100(Figura 6.21a). O observa-se, nesta figura, uma leve correlação positiva entre $\mathrm{K}$ e $\mathrm{Rb}$, caracterizada por um discreto aumento nos conteúdos de $\mathrm{K}$ (pouco variável) e um crescimento bem mais acentuado nas quantidades de Rb, no sentido da facies AFG para a 
facies BAFG. Este fato evidencia um "trend" da evolução magmática dos granitóides em questão. As análises de números 3(facies $A F G$ ) e 4(facies BAFG) fogem desse comportamento, mas devem representar, ao que tudo indica, composições transicionais entre as duas facies granitóides, uma vez que ocupam uma posição intermediária no "trend"(Figura 6.21a).
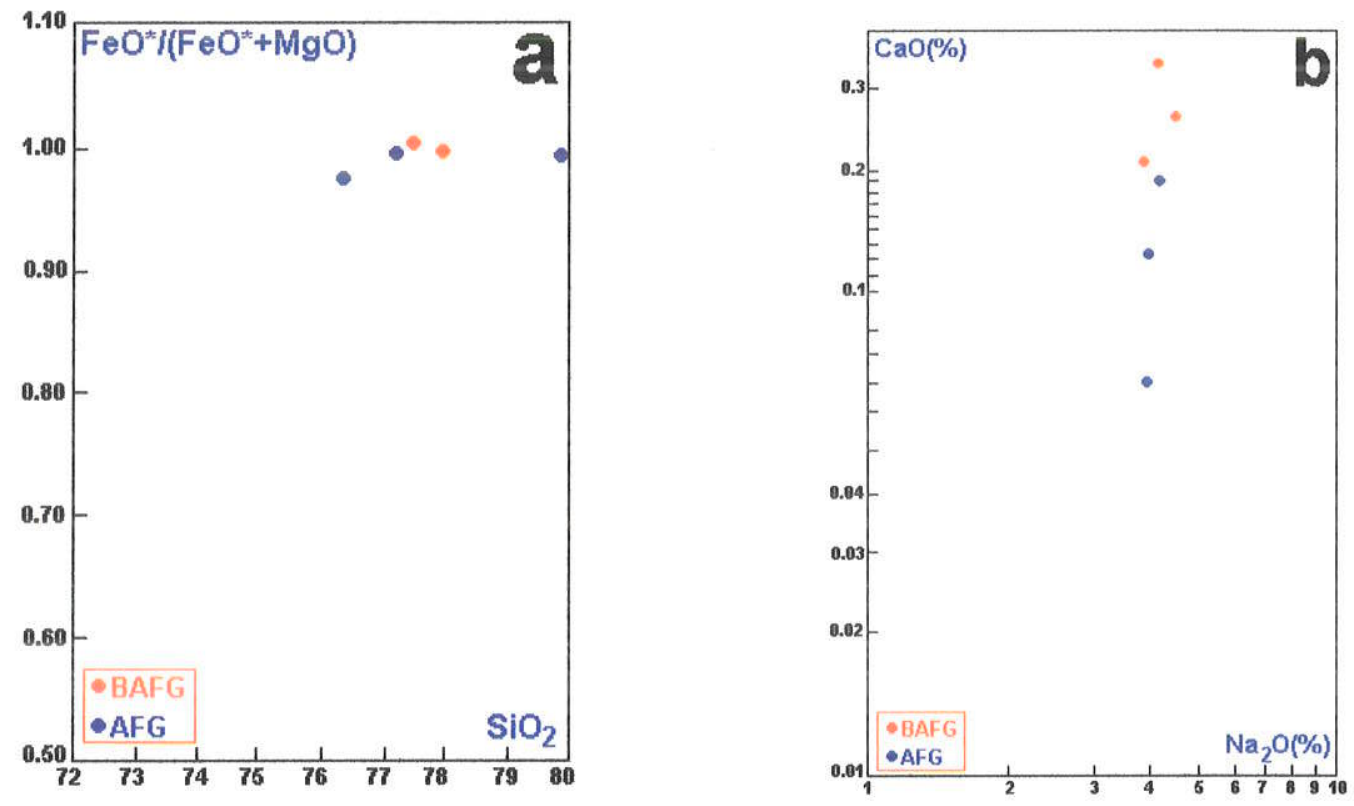

Figura 6.19- Diagramas retangulares $\mathrm{SiO}_{2}$ vs. $\mathrm{FeO}^{*} /\left(\mathrm{FeO}^{*}+\mathrm{MgO}\right)\left(\right.$ a) e $\mathrm{CaO}$ vs. $\mathrm{Na}_{2} \mathrm{O}$ (b) mostrando a distribuição composicional das principais facies granitóides do maciço granitóide Benedita.

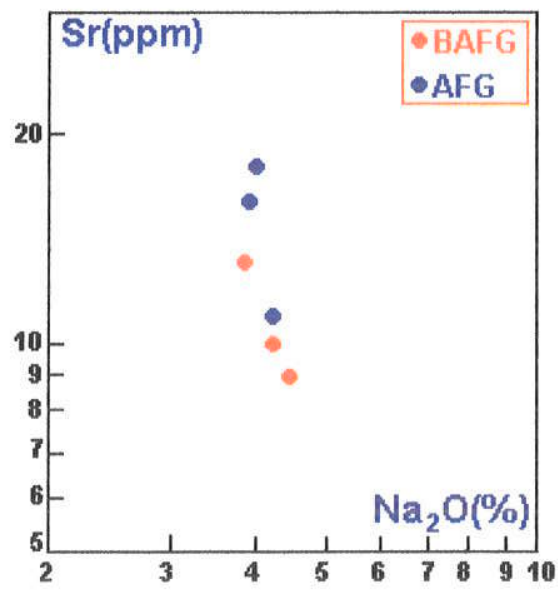

Figura 6.20- Diagrama $\mathrm{Sr}-\mathrm{Na}_{2} \mathrm{O}$ mostrando a distribuição composicional das amostras das principais facies granitóides do maciço granitóide Benedita.

Nos diagramas $\mathrm{Rb}-\mathrm{Sr}$ e $\mathrm{Rb}-\mathrm{Ba}$ (Figura $6.21 \mathrm{~b}, \mathrm{c}$ ) observa-se que $\mathrm{Sr}$ e $\mathrm{Ba}$ se comportaram como elementos compativeis durante a evolução magmática dos granitóides estudados, enquanto que o $\mathrm{Rb}$ se atuou como elemento incompatível. Nesses dois diagramas percebe-se que $\mathrm{Sr}$ e $\mathrm{Ba}$ desenvolvem correlações negativas com $\circ \mathrm{Rb}$, 
caracterizadas pelo aumento de $\mathrm{Rb}$ e decréscimo de $\mathrm{Sr}$ e Ba no sentido da facies AFG para a facies BAFG. Esse comportamento do $\mathrm{Rb}, \mathrm{Sr}$ e $\mathrm{Ba}$ evidencia mais claramente que a facies AFG, embora praticamente desprovida de biotita corresponde ao deferenciado relativamente menos evoluído, enquanto a facies BAFG representa o termo mais evoluído no âmbito desse maciço. As razões $\mathrm{Rb} / \mathrm{Sr}$ situam-se preferencialmente entre 20 e 100, sendo exceção, a isso, a razão determinada a partir da análise de número 1(Tabela 6.3, Anexo 41), cujo valor é inferior a 20(Figura $6.21 \mathrm{~b}$ ). No que se refere à razão $\mathrm{Rb} / \mathrm{Ba}$, a totalidade das amostras da facies BAFG exibe valores acima de 50 , enquanto que na facies AFG a maioria das amostras possui razão $\mathrm{Rb} / \mathrm{Ba}$ abaixo de 10 e apenas uma amostra tem essa razão acima de 50(Figura 6.21c).

No diagrama $\mathrm{Rb}-\mathrm{Ba}-\mathrm{Sr}$ (Figura 6.21d) nota-se que as análises de todas as amostras de granitóides do maciço ocupam o campo composicional correspondente aos granitos extremamente diferenciados (EI Bouseily \& El Sokkary, 1975).

O Zr apresenta-se em concentrações altas nos granitóides estudados(Tabela 6.3, Anexo 41). Isso evidencia que o mesmo se atuou como um elemento incompatível durante a diferenciação magmática. No diagrama $\mathrm{Rb}-\mathrm{Zr}$ (Figura $6.21 \mathrm{e}$ ) observa-se uma correlação positiva entre $\mathrm{Zr}$ e $\mathrm{Rb}$, definida pelo crescimento nos conteúdos desses dois elementos no sentido da facies AFG para a facies BAFG. As razões $\mathrm{Zr} / \mathrm{Rb}$ na facies AFG variam entre 0,50 e 1,00, enquanto que na facies BAFG situam-se abaixo de 0,50 e acima de 0,20. Excetua-se a isso a análise de número 4 da facies BAFG que acompanha as análises da facies AFG(Figura 6.21e).

No diagrama U-Th(Figura 6.21f), nota-se que Th e $U$ desenvolvem uma discreta correlação positiva, caracterizada pelo aumento nas concentrações dos mesmos no sentido da facies $A F G$ para a facies BAFG. A análise de número 3 correpondente à facies AFG foge desse "trend" em virtude de possuir os mais elevados conteúdo de Th e de $U$ dentre as amostras analisadas.
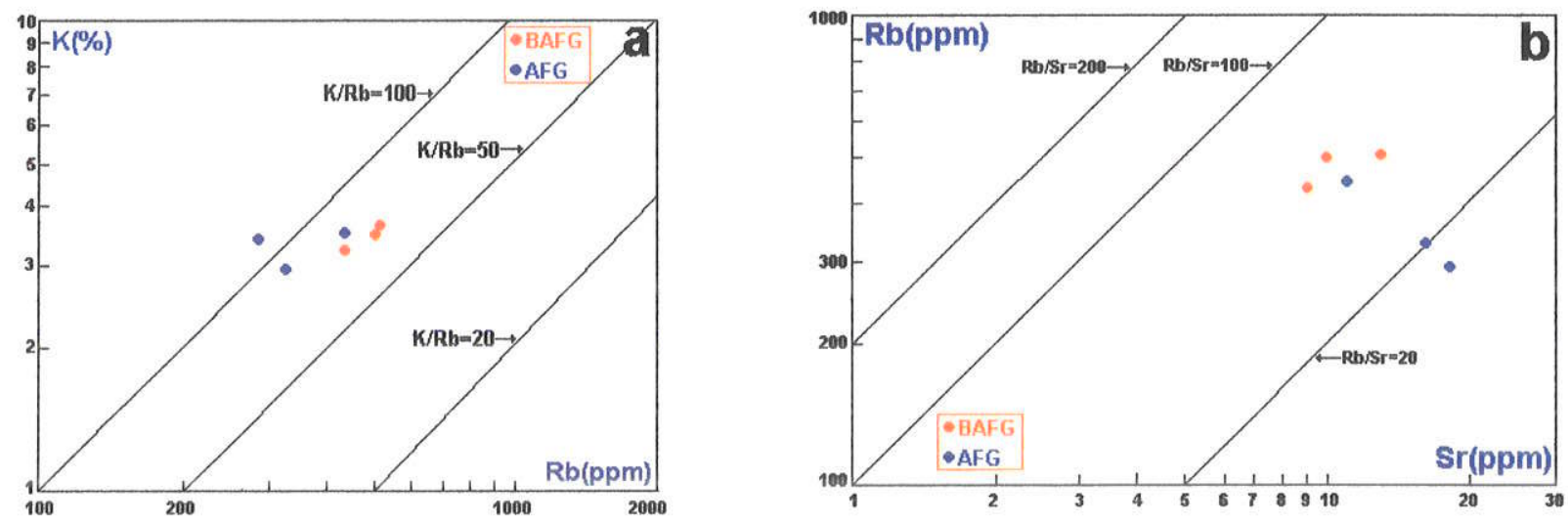

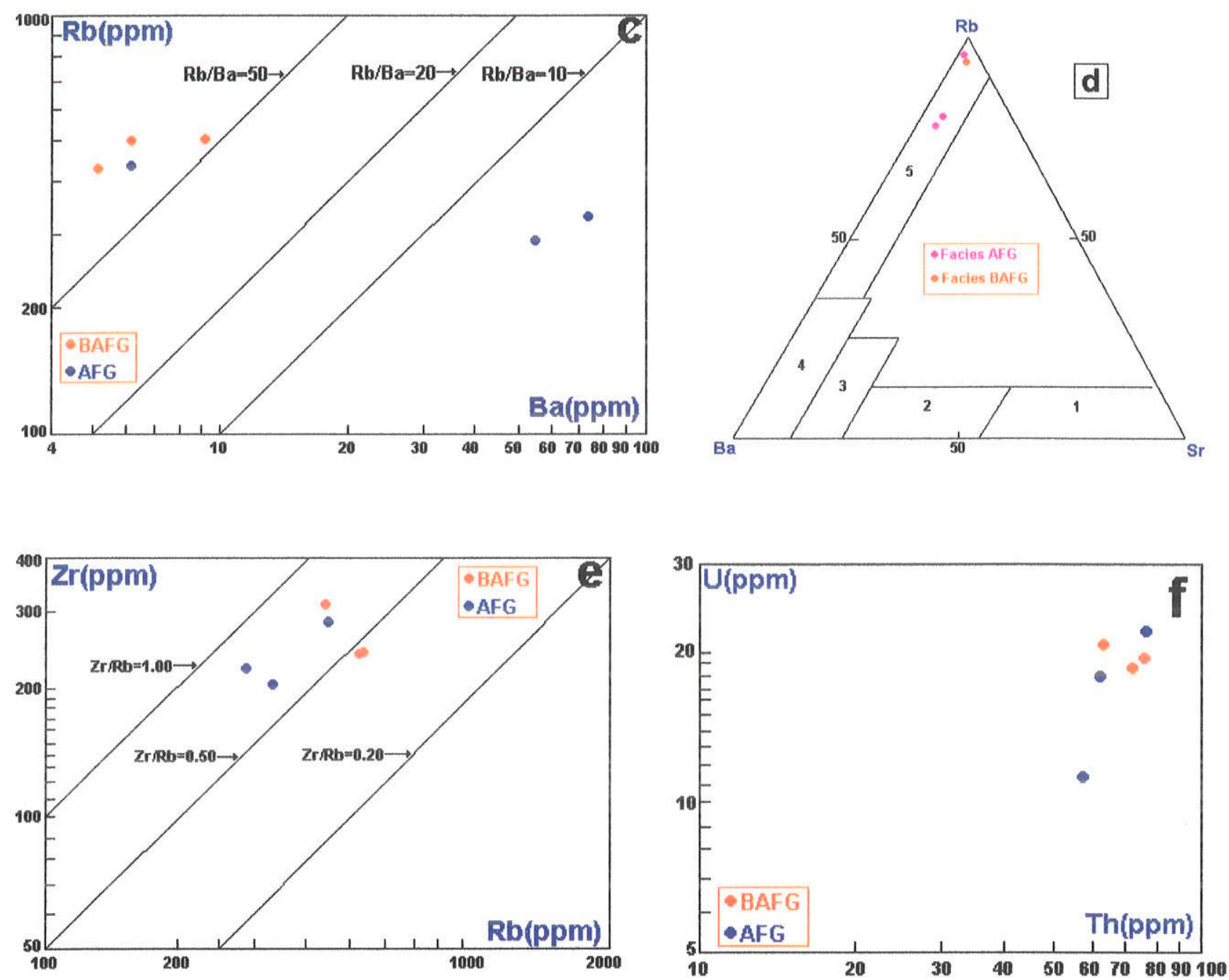

Figura 6.21- Distribuição composicional das amostras das principais facies granitóides do maciço granitóide Benedita nos diagramas (a) Rb-K; (b) Rb-Sr; c) Rb-Ba; (d) Rb-Ba-Sr(El-Bouseily \& Sokkary, 1975); (e) Rb-Zr; (f) Th-U. Os campos 1 a 5 do diagrama Rb-Ba-Sr correspondem, respectivamente, a dioritos, granodioritos e quartzo dioritos, granitos anômalos, granitos normais e granitos extremamente diferenciados.

Embora os granitóides desse maciço estejam afetados por alterações tardi a pósmagmáticas, eles não se encontram tão intensamente transformados quanto as facies granitóides alteradas e intensamente alteradas ocorrentes nos maciços granitóides Antônio Vicente, Velho Guilherme e Mocambo. Dentre as fases constitutivas da paragênese típica das alterações tardi a pós-magmáticas(conforme definida neste trabalho) a albita é a fase mais abundante, embora seus conteúdos modais não ultrapassem $7 \%$. Fluorita, sericita \pm muscovita e clorita são freqüentes, porém pouco abundantes, ocorrendo individualmente em quantidades modais inferiores a 3\%(Tabela 6.1). Ademais, assim como no maciço granitóide Velho Guilherme, não foi detectada a presença de cassiterita através 
através de microscopia ótica, nem tampouco de microscopia eletrônica de varredura. Isso é confirmado pelos baixissimos teores de Sn nas amostras analisadas. Pensa-se, contudo, que a amostragem foi realizada em porções do maciço situadas abaixo das zonas apicais, as quais são as áreas mais favoráveis à ocorrência de mineralizações, especialmente de cassiterita e outros metais raros associadas. De qualquer modo, devido esses granitóides possuírem concentrações elevadas de $\mathrm{F}$ (média entre 903 e 1933ppm) e de $\mathrm{Cl}$ (média entre 454 e 710ppm) se faz necessário analisar o papel desses voláteis e de outros elementos associados, na gênese desses granitóides.

A Tabela 6.3(Anexo 41) e a Figura 6.22a mostram, para o conjunto das amostras, uma discreta correlação negativa entre entre $\mathrm{F}$ e $\mathrm{Cl}$, caracterizada pela redução nos conteúdos de $\mathrm{Cl}$ e aumento nas concentrações de $\mathrm{F}$ no sentido da facies AFG para a facies BAFG. $\mathrm{Na}$ análise de número 5 , correspondente à facies BAFG, o conteúdo de $\mathrm{Cl}$ está abaixo do limite de deteccão do método de análise utilizado(ver item metodologia, no capítulo 1 deste trabalho). Esse comportamento dos dois voláteis é coerente com o que é apresentada na literatura(Fuge, 1977), bem como é concordante com o que é percebido nos diferenciados magmáticos do maciço granitóide António Vicente(ver capítulo 3 ).

Conforme visto anteriormente, $\circ \mathrm{Cl}$ por possuir uma baixa solubilidade na fusão silicática e apresentar uma forte afinidade com as fases aquosas associadas tende a se concentrar nos minerais formados mais precocemente, enquanto que of por apresentar forte afinidade com a fusão residual se enriquece nos minerais formados nos estágios mais tardios (Fuge, 1977). Nesse caso, a biotita, e a fluorita parecem representar as principais fontes de $F$ nesses granitóides, especialmente na facies BAFG.

As razões $\mathrm{F} / \mathrm{Cl}$ aumentam no sentido da facies AFG para a facies BAFG e situam-se entre 1,00 e 5,00, sendo excessão a análise número 2 da facies AFG, cuja razão é inferior a 1,0 .

A Figura 6.22b mostra uma nitida correlação positiva entre F e Sn, caracterizada pelo aumento nos conteúdos desses dois elementos no sentida da facies AFG para a facies BAFG. É digno de nota que as amostras portadoras das mais altas quantidades de $F$ possuem os mais elevados teores de $\mathrm{Sn}$, embora esses sejam, no geral, baixos e insuficientes para propiciar a cristalização de cassiterita, conforme visto anteriormente.

A Figura 6.22c, mostra que enquanto os conteúdos de $\mathrm{Na}_{2} \mathrm{O}$ são mais ou menos constantes os de $\mathrm{Sn}$ variam mais claramente e desenvolvem um "trend" caracterizado pelo aumento sistemático no sentido da facies AFG para a facies BAFG. Esse comportamento do Sn é indicativo de que o mesmo se comportou como elemento incompatível, se concentrando nas fases minerais mais tardias $e$, ao que tudo indica, entrou preferencialmente na biotita, visto que essa fase parece ser a principal portadora de $\mathrm{Sn}$ nesses granitóides. Uma hipótese alternativa para explicar esse "trend" enriquecimento de 
Sn em direção ao BAFG refere-se à interação dessa rocha com fluidos tardios, os quais seriam responsáveis pela elevação da sua concentração(Lehmann \& Mahawat, 1989).

$\mathrm{Na}$ Figura 6.22d, correspondente ao diagrama $\mathrm{Na}_{2} \mathrm{O}-\mathrm{F}$, nota-se uma distribuição semelhante à da Figura 179c. Enquanto o $\mathrm{Na}_{2} \mathrm{O}$ mostra-se quase que constante o $\mathrm{F}$ varia mais amplamente, definindo um "trend" de enriquecimento dos conteúdos de $F$ no sentido da facies AFG para a facies BAFG. Isso reforça a hipótese de que a biotita é uma das principais fontes de F nesses granitóides, juntamente com a fluorita(Tabelas 6.1 e 6.3-Anexo 41).

$\mathrm{Na}$ Figura 6.22e verifica-se que o $\mathrm{Sn}$ e a razão $\mathrm{Rb} / \mathrm{Sr}$ desenvolvem uma correlação positiva, caracterizada pelo crescimento dos conteúdos de $\mathrm{Sn}$ e $\mathrm{Rb} / \mathrm{Sr}$ no sentido da AFG para a facies BAFG. Isso indica que o $\mathrm{Sn}$ se enriquece nos diferenciados mais evoluídos em função da interação rocha fluido, reforçando a hipótese acima comentada. O mesmo é demonstrado no diagrama $\mathrm{Sn}-\mathrm{TiO}_{2}$ (Figura 6.22f).

Comparativamente aos granitóides e greisens especializados a estanho e portadores de mineralizações de $S$ (principalmente cassiterita), ocorrentes no contexto dos maciços granitóides Antônio Vicente e Mocambo, os granitóides desse maciço ostentam concentrações mais elevados de $\mathrm{Cl}$, embora seus conteúdos de $\mathrm{F}$ sejam, em geral, mais baixos. Em relação aos granitóides do maciço granitóide Velho Guilherme, os granitóides em questão exibem conteúdos mais ou menos equïvalentes de $F$ e de $S n$ e, geralmente, mais baixos de $\mathrm{Cl}$.

Assim, do mesmo modo que para os granitóides do maciço granitóide Velho Guilherme, os dados químicos e os estudos petrográficos permitem estabelecer que granitóides com conteúdos de $F$ variáveis entre 410 e $2500 \mathrm{ppm}$ e/ou de $\mathrm{Cl}$ entre 594 e 836 ppmm não são necessariamente hospedeiros de mineralizações de estanho $e$, em especial, de cassiterita. E noticiado(comunicação verbal), entretanto, que na região de ocorrência desse maciço e do maciço granitóide Ubim/Sul(ver mais adante no capítulo 7) foram realizados trabalhos de prospecção geoquímica para mineralizações estaníferas e outros metais associados. Embora os resultados obtidos, não tenham sido favoráveis economicamente, pequenas ocorrências aluvionares foram detectadas. Assim, do mesmo modo que em relação ao maciço granitóide Velho Guilherme, é possivel que a amostragem realizada tenha ocorrido em um nivel de erosão abaixo das zonas especializadas e hospedeiras de mineralizações de estanho e de outros metais associados(cúpolas ou zonas apicais).

A Tabela 6.3(Anexo 41) mostra que os granitóides estudados são, em geral, enriquecidos em ETRL e ETRP, em relação à abundância desses elementos na crosta continental(Shaw et al., 1986; Condie, 1993). 
A somatória dos conteúdos médios dos ETR nas facies granitóides AFG e BAFG é igual a 342,07ppm(Tabela 6.4). Esses valores são muito mais baixos do que aqueles encontrados nos granitóides dos outros maciços ora estudados.
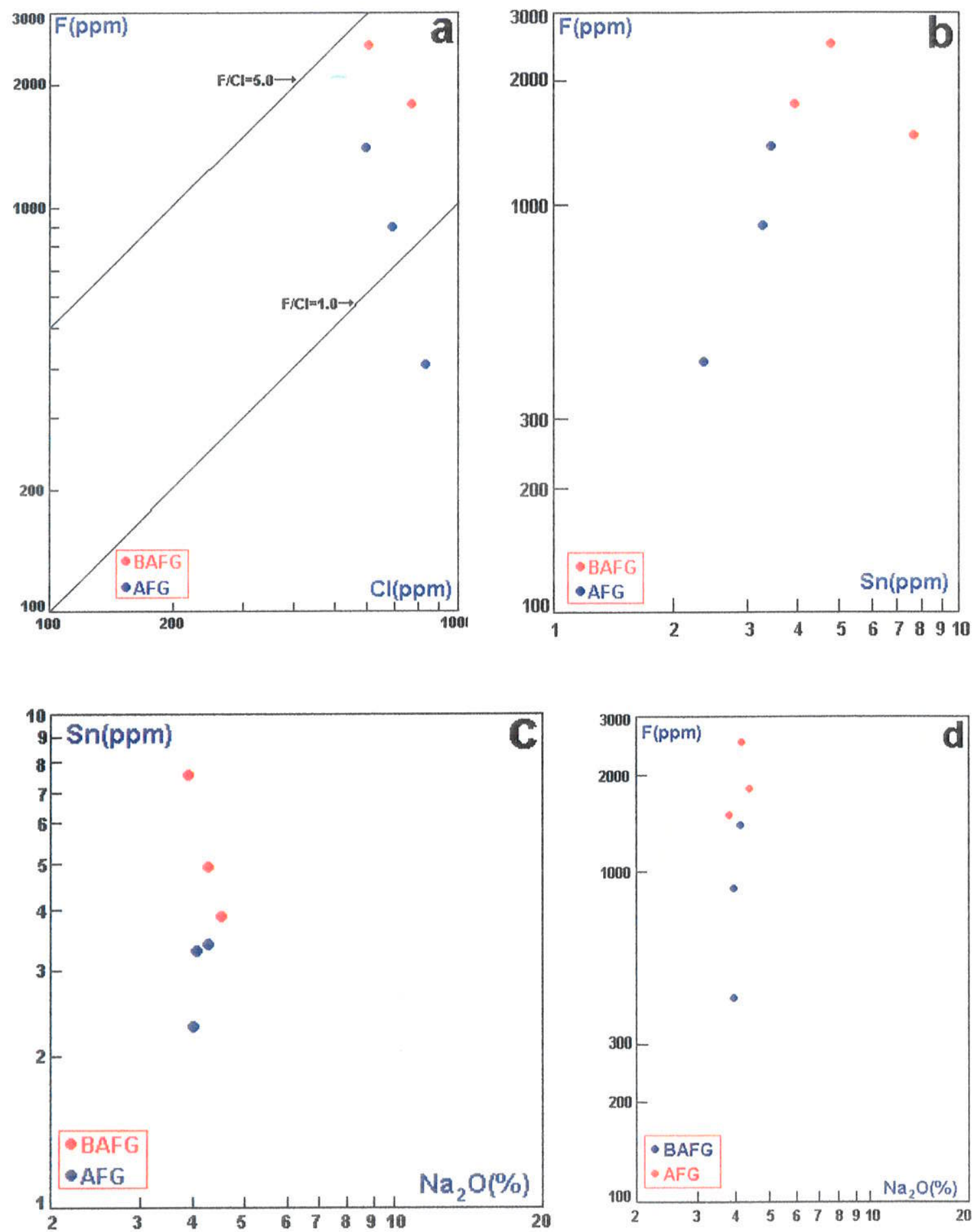

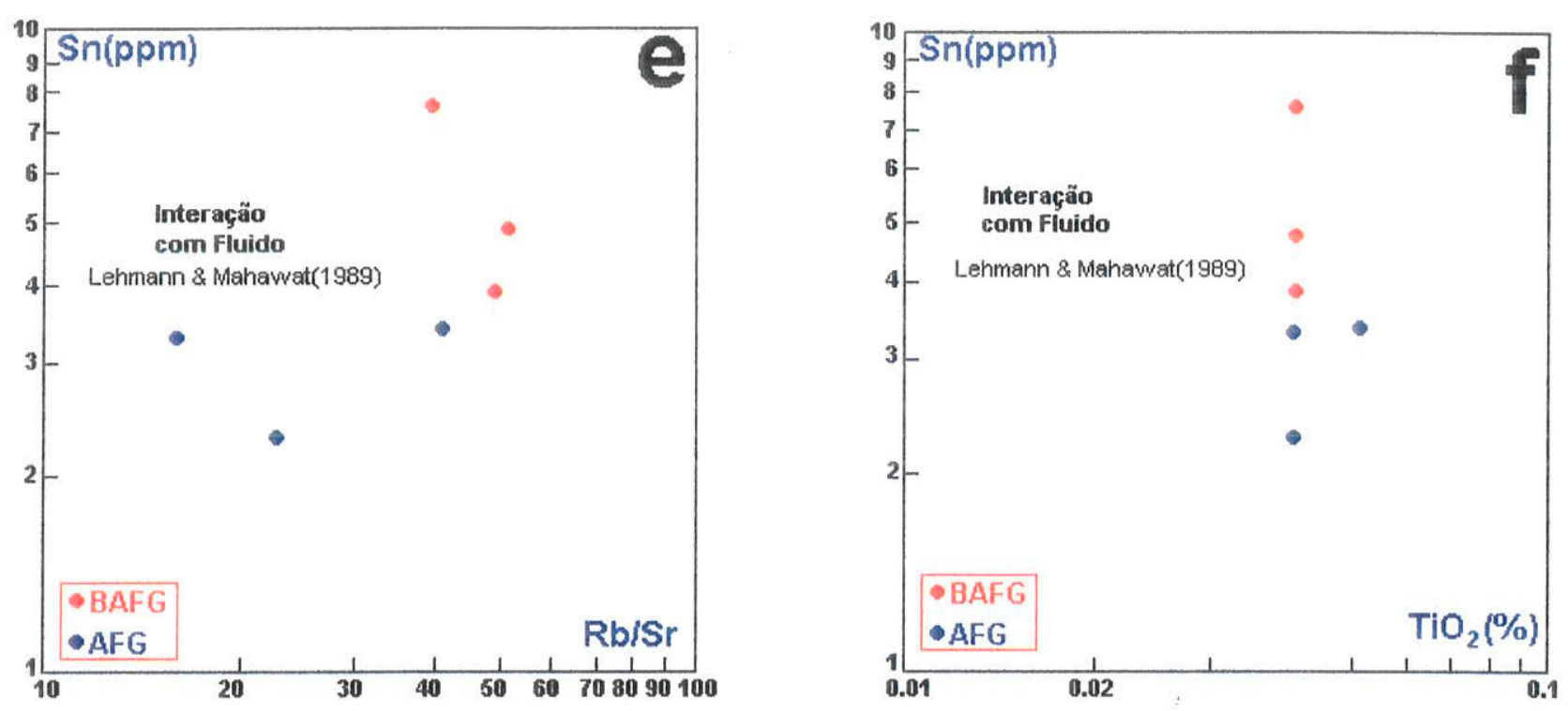

Figura 6.22- Distribuição composicional das amostras das principais facies granitóides do maciço granitóide Benedita nos diagramas (a) F-Cl; (b) F-Sn; (c) $\mathrm{Sn}_{-} \mathrm{Na}_{2} \mathrm{O}$; (d) $\mathrm{Na}_{2} \mathrm{O}-\mathrm{F}$; (e) $\mathrm{Sn}-\mathrm{Rb} / \mathrm{Sr}$; $\mathrm{Sn}-\mathrm{TiO}_{2}$.

Os conteúdos médios dos ETR nos granitóides estudados, normalizadas para condritos(Sun, 1982), desenvolvem um típico padrão "gaivota"(Figura 6.23), à semelhança daquele que foi observado nos granitóides dos maciços Antônio Vicente, Velho Guilherme e Mocambo. Observa-se também que o BAFG exibe os mais elevados conteúdos de ETRL e de ETRP em relação ao AFG. Além disso, o BAFG mostra a maior anomalia de Eu. Isso reforça a hipótese de que essa facies representa um diferenciado mais evoluído do que o AFG. Nesse caso, o plagioclásio desempenhou um papel importante na partição do Eu que se empobreceu no sentido do BAFG.

Análises EDS(MEV; Anexo 40 não revelaram a existência de fases minerais subodinadas hospedeiras de importantes concentrações de ETR. Entretanto, os estudos realizados através de microscopia ótica indicaram a presença de allanita em quantidades baixas, eqüivalentes nas duas facies granitóides identificadas no maciço(Tabela 6.1). Isso explica, em parte, as mais elevadas concentrações de ETRL e mais baixas de ETRP nos granitóides em questão, mas não explica os diferentes teores de ETRL nas duas facies granitóides. Talvez a principal razão para explicar esse comportamento dos ETRL seja o fato dos mesmos serem incompatíveis e, por conseguinte, tenderem a residir no fundido. Assim, o BAFG, aqui considerado como o diferenciado mais evoluído, hospedaria as maiores concentrações de ETRL. Nesse caso, a allanita e a biotita e, subordinadamente o zircão seriam as principais portadores de ETR nos granitóides estudados. De qualquer modo necessita-se de análises químicas nessas fases minerais para que se possa apresentar dados mais seguros a esse respeito. 
As razões $\mathrm{Eu}_{N} / \mathrm{Eu}^{*}$, nos granitóides estudados são, respectivamente 12,92(AFG) e 12,78(BAFG), enquanto que as razões (La/Yb)N são 2,20(facies AFG) e 2,06(facies BAFG). A Tabela 30 mostra as principais características a respeito dos ETR encontradas nos granitóides desse maciço.

Tabela 6.4- Principais características dos ETR nos granitóide do maciço granitóide Benedita. ! = somatória das concentrações médias.

\begin{tabular}{|l|c|c|}
\hline Facies Granitóides & AFG & BAFG \\
\hline (La/Yb)N & 2,20 & 2,06 \\
\hline (EuN/Eu*) $^{*}$ & 12,92 & 12,78 \\
\hline$\sum$ ETRL! & 119,15 & 140,72 \\
\hline$\sum E T R P !$ & 36,33 & 45,82 \\
\hline$\Sigma$ ETR! & 155,50 & 186,56 \\
\hline
\end{tabular}

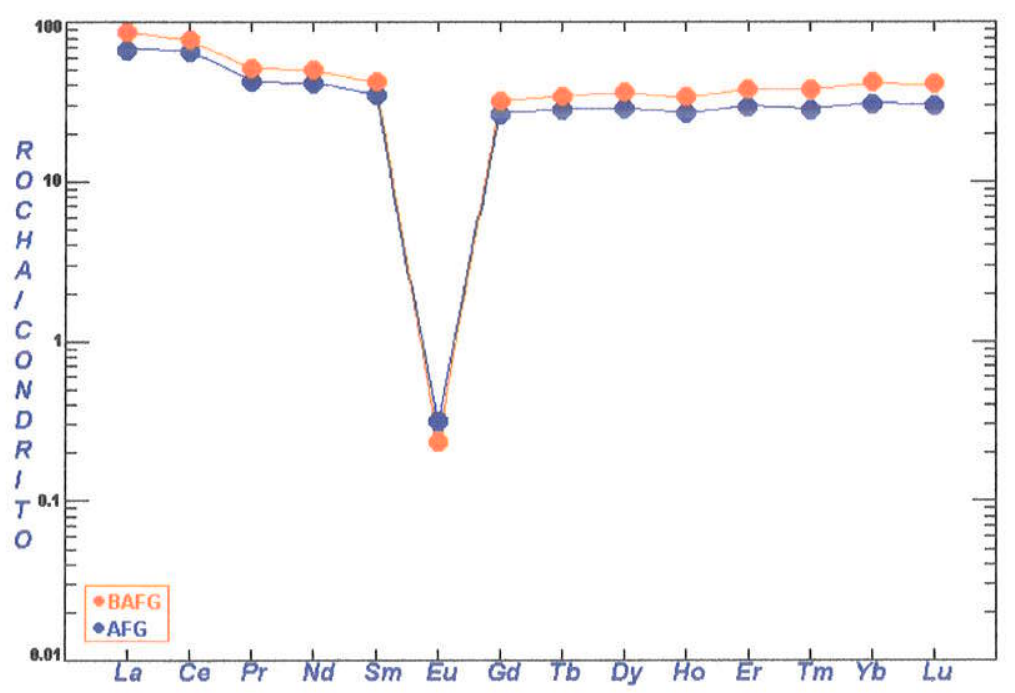

Figura 6.23- Padrão de distribuição dos ETR dos granitóides do maciço Benedita.

\subsection{5- Análises Normativas CIPW}

A análise do conjunto das composições normativas(Tabela 6.5, Anexo 42) dos granitóides estudados permitiu estabelecer as seguintes considerações:

1) os granitóides desse maciço são saturados em $\mathrm{Al}_{2} \mathrm{O}_{3}$, embora ostentem baixo córindon normativo. É exceção uma amostra da facies BAFG. 
2) os conteúdos de anortita aumentam nitidamente no sentido da facies AFG para a BAFG. Em razão disso, as razốes $A b / A n$ decrescem no mesmo sentido.

3) as quantidades de $\mathrm{Hy}$, tendem a decrescer a partir do AFG em direção ao BAFG, enquanto que os teores de magnetita e hematita tendem a crescer e os de ilmenita se mantém praticamente constantes $(0,08 \%)$, varianda em apenas uma amostra do $\operatorname{AFG}(0,10 \%)$.

No diagrama Q-Ab-Or(Figura 6.24a) nota-se que as razões normativas quartzoalbita-ortoclásio dos granitóides desse maciço incidem inteiramente no campo de $86 \%$ de freqüência das razões normativas Q-Ab-Or de 1190 rochas graniticas de Winkler e Von Platen(1961), à semelhança dos granitóides dos maciços ora estudados. Percebe-se, ainda, que as composições se afastam um pouco do campo de máxima freqüência(ponto $M$ ) em direção ao vértice do quartzo(silicificação), notadamente as amostras da facies AFG, com exceção de uma amostra, e mostram-se levemente deslocadas para a esquerda desse campo, ao que tudo indica, devido aos efeitos da albitização.

Embora esses granitóides mostrem-se afetados por albitização, em diferentes graus, seu efeito não se reflete nas suas composições normativas globais. Isso demonstra que os processos de alteração ocorrerame em um sistema fechado, fato que não permitiu um aporte de $\mathrm{Na}$ ao mesmo. Isso é reforçado pelas quantidades de $\mathrm{F}$ no magma gerador dos granitóides desse maciço, que mostram-se muito baixas. Elas situam-se abaixo da posição de temperatura do ponto de mínimo correspondente a $1 \%$ de $F$ adicionado(Manning, 1981), com as composições correspondentes à facies BAFG ocupando uma posição próxima ao ponto de mínimo sem adição de F(Tuttle \& Bowen, 1958) e as da facies AFG situando-se um pouco distantes. Isso demonstra que o magma gerador desses granitóides era empobrecido em $\mathrm{F}$ e que o mesmo foi concentrado no estágio de alterações tardi a pósmagmáticas, tal qual em relação aos granitóides dos maciços Antônio Vicente, Velho Guilherme e Mocambo. O que é evidenciado pela presença de quantidades um pouco elevadas desse elemento nos granitóides em questão, especialmente na facies BAFG(1800ppm a 2500ppm) e que se reflete na presença freqüente de fluorita nos mesmos.

Ainda em relação a esse diagrama, observa-se que as composições da facies BAFG e de uma amostra da facies AFG situam-se entre as projeções das linhas cotéticas de $P_{H 2 O}$ de $2 \mathrm{kbar}$ e de $5 \mathrm{kbar}$ de Winkler(1977). As composições das duas outras amostras da facies AFG incidem abaixo da projeção da linha cotética de $P_{\mathrm{H} 2 \mathrm{O}}=2 \mathrm{kba}$ em direção ao vértica de quartzo.

No diagrama Ab-An-Or(Figura 6.24b), todas as composições situam-se muito próximo à aresta Ab-Or, com um pequeno deslocamento em direção ao vértice da albita. 


\section{7- Condições de Cristalização}

Os granitóides desse maciço apresentam enormes semelhanças texturais e mineralógicas com as facies mais evoluídas do maciço granitóide Antônio Vicente, bem como ocorrem no mesmo contexto geológico, de modo que as considerações apresentadas em relação à facies $B S G$ daquele maciço, em termos de seu posicionamento crustal, bem como das condições de $\mathrm{fO}_{2}, \mathrm{~T}$ e $\mathrm{P}$ em que a mesma se formou, são válidas aqui. Assim, torna-se desnecessário repeti-las, evitando-se, com isso, que o texto se torne, ainda mais longo. Isso é válido também para os granitóides do maciço Ubim/Sul.

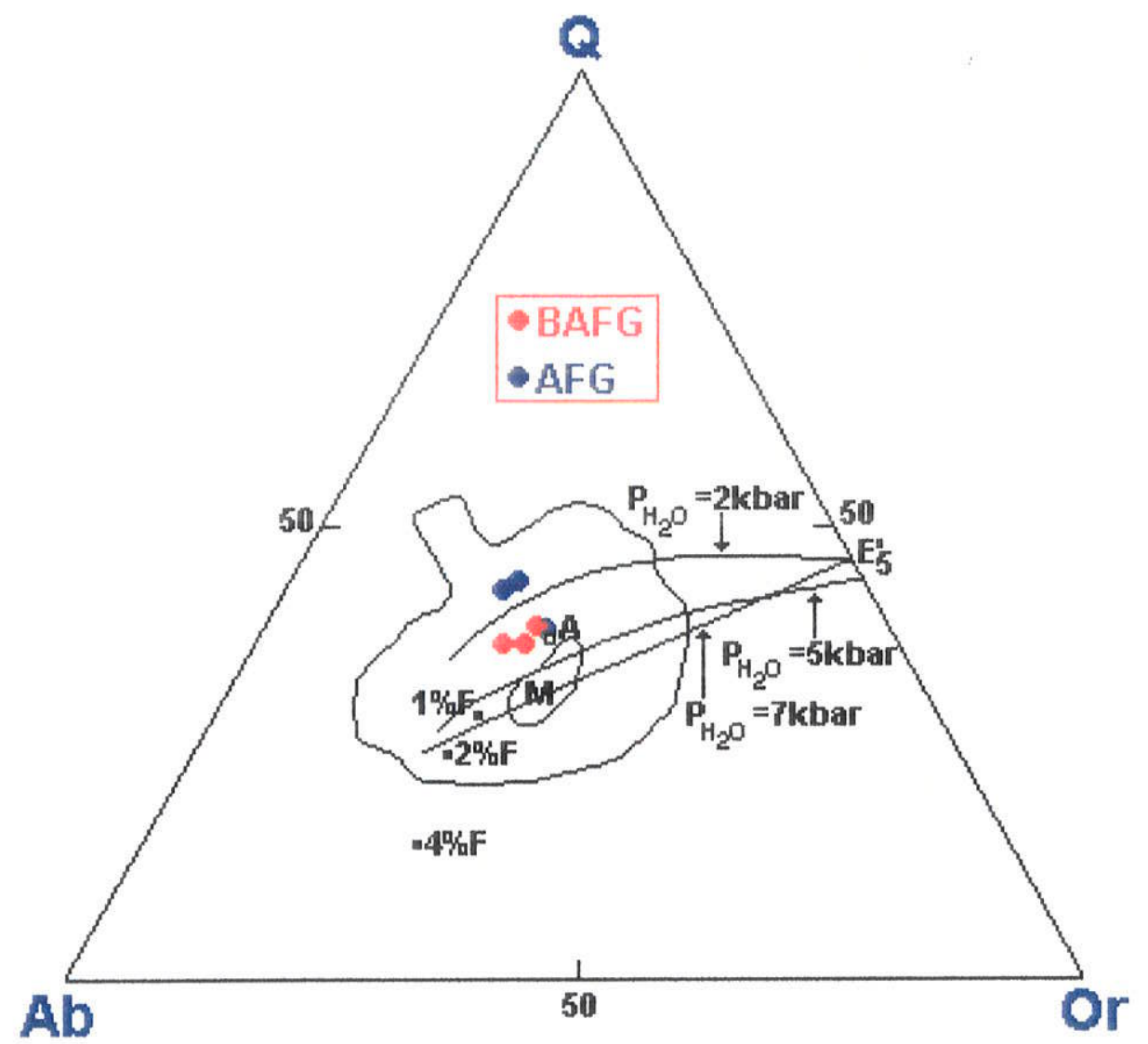

Figura 6.24a- Diagrama normativo Q-Ab-Or mostrando a distribuição composicional das principais facies granitóides do maciço granitóide Benedita. A curva envoltório dos pontos corresponde ao campo de freqüência das razões Q-Ab-Or de 1190 rochas graníticas de Winkler \& Von Plaren(1961). As projeções das linhas cotéticas isobáricas P-E'5 de 2, 5 e $7 \mathrm{kbar}$ foram compiladas de Winkler(1977). $M=$ máximo de freqüência , $A=$ a posição e temperatura do ponto de mínimo sem F(Tuttle \& Bowen, 1958). 1\%F, 2\%F e 4\%F representam as posições e temperaturas dos pontos de mínimo com $\mathrm{F}$ adicionado e excesso de água a $1 \mathrm{kbar}($ Manning, 1981). 


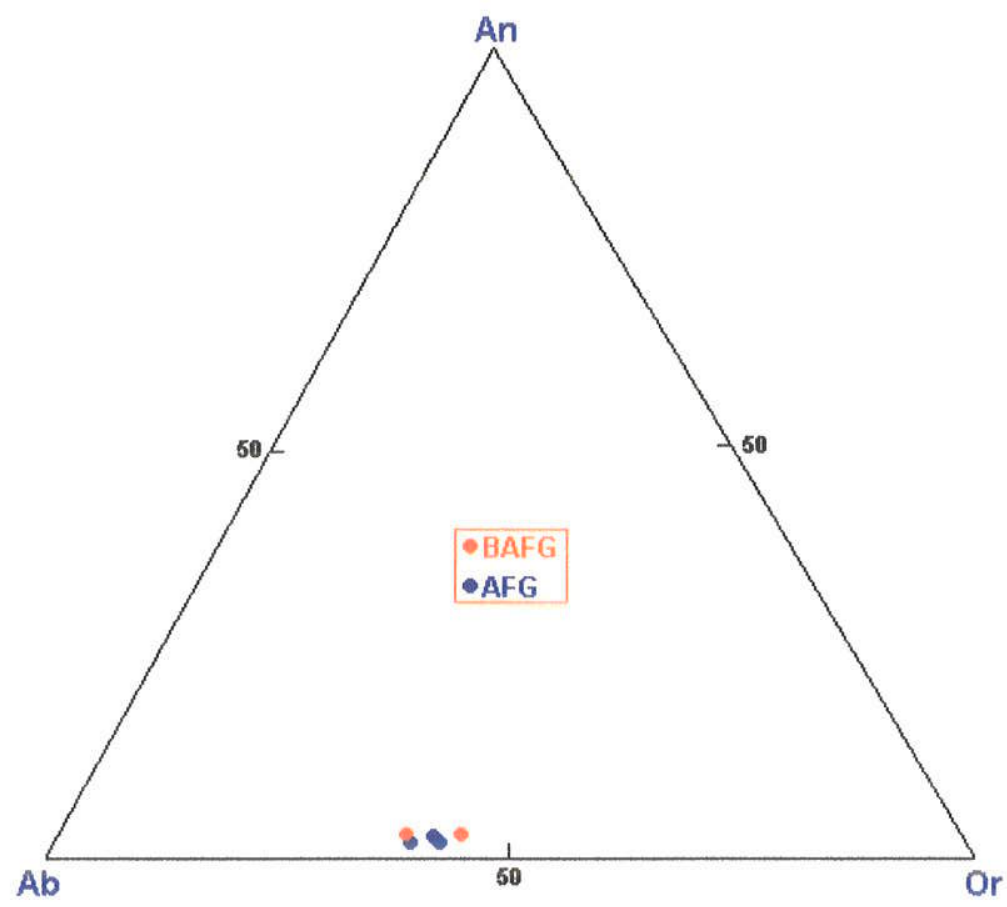

Figura 6.24b- Diagrama normativo Ab-An-Or mostrando a distibuição composicional das principais facies petrográficas do maciço granitóide Benedita.

\section{8- Conclusões e Considerações Finais}

Os estudos de lâminas delgadas, análises químicas em fases minerais, primárias e secundárias, e análises químicas de elementos maiores, elementos traço e ETR em rocha, permitiram enumerar as seguintes conclusões a respeito dos granitóides desse maciço:

1) foram caracterizadas duas variedades de granitóides, as quais mostram-se representadas por álcali-feldspato granito(AFG) e biotita-álcali-feldspato granito(BAFG). Neles, o plagioclásio primário está ausente na ampla maioria das amostras. Em razão disso, eles têm características de granitos hipersolvus e mostram, entre si, uma grande afinidade petrográfica. Possuem caráter holo-leucocrático, onde os valores de $M$ ' são sempre inferiores a $5 \%$.

2) a separação em dois tipos de granitóides deveu-se exclusivamente aos conteúdos mais elevados de biotita na variedade BAFG em relação à variedade AFG, visto que textural e mineralogicamente, se equivalem. Na realidade a variedade BAFG representa uma pequena variação do tipo AFG. 
3) de modo geral, esses granitóides apresentam textura hipidiomórfica, heterogranular, fina a média e, localizadamente, apresentam textura granofírica onde destacam-se os tipos insular, vermicular, "radiating fringe" e, muito subordinadamente, cuneiformes. Essas características são indicativas de uma colocação em nível crustal raso desses granitóides. No que se refere às alterações tardi a pós-magmáticas, elas são pouco expressivas nesses variedades de granitóides.

4) assim como as facies granitóides mais evoluidas dos outros maciços estudados, essas rochas cristalizaram-se a partir de líquidos muito evoluidos e silicosos e representam diferenciados magmáticas tardios, cujas evidências são traduzidas pelos seus altos conteúdos de quartzo modal, ausência de plagioclásio primário e pelos baixos teores de fases máficas primárias.

5) análises químicas em grãos de clorita da facies BAFG indicaram uma composição varável entre a bavalita e a pseudothuringita. Essas variações decorreram de processos de substtituições catiônicas que ocorreram na sua estrutura cristalina dos cristais, onde prevaleceram aquelas estabelecidas pela equação 2 de Cathelineau(1988), embora tenham ocorrido, muito subordinadamente, mecanismos de substituição semelhantes àqueles da equação 1 ( do mesmo autor).

6) com base no geothermômetro de Cathelineau(1988), estimou-se o intervalo entre 389 e $454^{\circ} \mathrm{C}$ como aquele correspondente à faixa de temperatura de cristalização da clorita estudada.

7) devido as quantidades de ferro férrico, presentes na fórmula estrural da clorita, serem muito reduzidas $(\equiv 0,0)$ e, adicionalmente, à muito provável ausência de magnetita na facies BAFG, estimou-se que a mesma cristalizou-se em condições de baixa $\mathrm{fO}_{2}$ e, ao que tudo indica, abaixo do buffer quartzo-fayalita-magnetita(QFM).

8) análises químicas em micas brancas da facies BAFG indicaram tratar-se de muscovita fengíca, pertencente ao grupo das Mg-Al micas e de origem secundária.

9) os granitóides desse maciço correspondem à diferenciados muito evoluídos, derivados de um magma extremamente silicoso. Eles são saturados em $\mathrm{Al}_{2} \mathrm{O}_{3}$, embora ostentem baixo córindon normativo. 
10) possuem teores de $\mathrm{SiO}_{2}$, superiores a $76 \%$, os conteúdos de $\mathrm{TiO}_{2}, \mathrm{Al}_{2} \mathrm{O}_{3}, \mathrm{MnO}, \mathrm{MgO}$, $\mathrm{CaO}$ e $\mathrm{P}_{2} \mathrm{O}_{5}$ são sempre muito reduzidos e inferiores àqueles da média dos granitos(Le Maitre, 1976), enquanto que os teores de $\mathrm{K}_{2} \mathrm{O}$ são eqüivalentes e os de $\mathrm{Na}_{2} \mathrm{O}$ são ligeiramente mais elevados.

11) quanto aos elementos menores e traços, ostentam valores elevados $\mathrm{Rb}$ (média entre 351 e 489ppm), Zr(média entre 236 e 268ppm), F(média entre 903 e 1933ppm) e Cl(média entre 710 e $454 \mathrm{ppm}$ ), moderados de $\mathrm{Nb}$ (média entre 62 e $75 \mathrm{ppm}$ ), Y(média entre 68 e 89ppm), Ga(média entre 26 e $31 \mathrm{ppm}$ ), W(média entre 45 e 68ppm), Th(média entre 65 e 70ppm) e Zn(média entre 45 e 49ppm) e baixas concentrações de Sr(média entre 11 e 15ppm), $\mathrm{Ba}$ (média entre 7 e 45ppm), Ta(média entre 7 e 8ppm), Hf(média entre 13 e 15ppm), $\mathrm{U}$ (média entre 17 e 19ppm, Sn(média entre 3 e 5ppm) e Mo(média entre 1 e $8 \mathrm{ppm}$ ).

12) em relação aos ETR, apresentam teores sempre muito reduzidos( média entre 155,51 e $186,56 \mathrm{ppm}$ ), embora a somatória das médias dos ETRL(entre 119 e 141ppm), nas duas facies granitóides, seja mais elevada do que aquela de ETRP(entre 36 e 46ppm). As razões $\mathrm{Rb} / \mathrm{Sr}$ (média entre 23 e 46), $\mathrm{Rb} / \mathrm{Ba}$ (média entre 8 e 73), e Th/U(média=4) são, geralmente, altas, enquanto as razões $\mathrm{K} / \mathrm{Rb}$ (média entre 72 e 95 ) são baixas se comparadas com aquelas dos granitos considerados normais(Shaw, 1968).

13) os granitóides são essencialmente peraluminosos, apresentam natureza subalcalina, são de ambiência intra-placas e guardam muitas semelhanças com os granitóide tipo-A, mas possuem caracteristicas do sub-grupo- $A_{1}$, diferentemente dos granitóides dos maciços Antônio Vicente, Velho Guilherme e Mocambo.

14) a principal razão para justificar essa diferença deve-se ao fato de que os granitóides desse maciço possuem conteúdos relativamente elevados e eqüivalentes de $\mathrm{Nb}, \mathrm{Y}$ e $\mathrm{Ce}$, bem como seus teores de $\mathrm{Ga}$, quando multiplicados por três, se eqüivalem aos desses três elementos. Essas características químicas tanto podem refletir uma área fonte enriquecida nesses elementos, quanto podem indicar uma influência crustal maior sobre magma gerador desses granitóides em relação aos demais maciços. Alternativamente, pode-se atribuir tal distribuição aos limites de precisão das análises químicas(não fornecido pelo laboratório onde as mesmas foram executadas), visto as amostras situam-se no limite entre os dois campos composicionais, que, por sua vez, foi definido estatisticamente. Assim, qualquer pequeno erro analítico poderia deslocar os pontos composicionais de um campo para outro. 
15) a relação $\mathrm{FeO}^{*} /\left(\mathrm{FeO}^{*}+\mathrm{MgO}\right)$ vs. $\mathrm{SiO}_{2}$ evidencia uma discreta correlação positiva entre essas duas variáveis, caracterizada pelo aumento de $\mathrm{SiO}_{2}$ e das razões $\mathrm{FeO} /(\mathrm{FeO}+\mathrm{MgO})$ no sentido da facies AFG para a facies BAFG. Foge a isso, uma amostra da facies AFG devido seu elevadissimo conteúdo de $\mathrm{SiO}_{2}(79,81 \%)$. O comportamento destas duas variáveis é semelhante àquele observado no âmbito do maciço granitóide Antônio Vicente, em relação aos diferenciados magmáticos. É digno de nota o fato do BAFG representar, no "trend", o diferenciado mais evoluído. Isso indica que a biotita cristalizou-se tardiamente em relação às fases essenciais quartzo e feldspato potássico e caracteriza uma inversão na ordem de cristalização da mesma.

16) à semelhança dos granitóides do maciço granitóide Antônio Vicente, Velho Guilherme e Mocambo, nos granitóides desse maciço as razōes $\mathrm{K} / \mathrm{Rb}$ da quase totalidade das amostras situa-se abaixo de 100. Entretanto, o limite inferior dos valores dessa razão situa-se acima de 50. Apenas uma análise da amostra da facies AFG possui razão KJRb acima de 100.

17) $\mathrm{K}$ e $\mathrm{Rb}$ desenvolvem uma leve correlação positiva, caracterizada por um discreto aumento nos conteúdos de $\mathrm{K}$ (pouco variável) e um crescimento bem mais acentuado nas concentraçóes de $\mathrm{Rb}$, no sentido da facies AFG para a facies BAFG, evidenciando um "trend" da evolução magmática dos granitóides em questão. Uma análise do AFG e e uma do BAFG fogem desse comportamento, mas devem representar, ao que tudo indica, composiçőes transicionais entre as duas facies granitóides, uma vez que ocupam uma posição intermediária no "trend".

18) Sr e Ba comportaram-se como elementos compativeis durante a evolução magmática dos granitóides, enquanto que o Rb se atuou como elemento incompatível. Em relação ao $\mathrm{Rb}$, esses dois elementos desenvolvem correlações negativas com o mesmo, caracterizadas pelo aumento de $\mathrm{Rb}$ e decréscimo de $\mathrm{Sr}$ e $\mathrm{Ba}$ no sentido do AFG para o BAFG. Esse desempenho do $\mathrm{Rb}, \mathrm{Sr}$ e $\mathrm{Ba}$ evidencia, mais claramente, que a facies AFG, embora praticamente desprovida de biotita corresponde ao deferenciado menos evoluido, enquanto a facies BAFG representa o mais evoluido no åmbito desse maciço.

19) as razões $\mathrm{Rb} / \mathrm{Sr}$ situam-se preferencialmente entre 20 e 100 , sendo exceção a isso a razão determinada em uma amostra da facies AFG, cujo valor é inferior a 20 . No que se refere à razão $\mathrm{Rb} / \mathrm{Ba}$, a totalidade das amostras do BAFG exibe valores acima de 50 , enquanto que no AFG a maioria das amostras possui razão $\mathrm{Rb} / \mathrm{Ba}$ abaixo de 10 e apenas uma amostra tem essa razão acima de 50. 
20) a relação $\mathrm{Rb}-\mathrm{Zr}$ mostra uma correlação positiva, definida pelo crescimento nos conteúdos dos dois elementos no sentido do AFG para o BAFG. As razões $\mathrm{Zr} / \mathrm{Rb}$ na facies AFG variam entre 0,50 e 1,00, enquanto que na facies $B A F G$ situam-se abaixo de $0,50 \mathrm{e}$ acima de 0,20. Excetua-se a isso a análise de número 4 da facies BAFG que acompanha as análises da facies AFG.

21) Th e U desenvolvem uma discreta correlação positiva, caracterizada pelo aumento nas concentrações dos mesmos no sentido do AFG para o BAFG. Uma análise correpondente à facies AFG foge desse "trend" em virtude de possuir os mais elevados conteúdo de Th e de $U$. As razões $T h / U$ indicam que esses granitóides são do tipo HHP.

22) $\mathrm{F}$ e de $\mathrm{Cl}$ desenvolvem uma sutil correlação negativa, caracterizada pela redução das taxas de $\mathrm{Cl}$ e aumento das de $\mathrm{F}$ no sentido do AFG para o BAFG. Esse comportamento é coerente com o que é apresentada na literatura(Fuge, 1977), bem como é concordante com - que é percebido nos diferenciados magmáticos do maciço granitóide Antônio Vicente. $\mathrm{O} \mathrm{Cl}$ por possuir uma baixa solubilidade na fusão silicática tende a se concentrar nos minerais formados mais precocemente, enquanto que o $F$ por apresentar forte afinidade com 0 fundido se enriquece nos minerais formados nos estágios mais tardios( Fuge, 1977). Nesse caso, a biotita, e a fluorita parecem representar as principais fases portadoras de $F$ nesses granitóides, especialmente na facies BAFG.

23) as razões $\mathrm{F} / \mathrm{Cl}$ aumentam no sentido da facies $A F G$ para a facies BAFG e situam-se entre 1,00 e 5,00, sendo excessão uma análise da facies AFG, cuja razão é inferior a 1,0.

24) a relação $F$ contra Sn mostra uma nítida correlação positiva, evidenciada pelo aumento nos conteúdos no sentido da facies AFG para a BAFG. É digno de nota que as amostras portadoras das mais altas quantidades de $\mathrm{F}$ possuem os mais elevados teores de $\mathrm{Sn}$, embora esses tenham sido, no geral, insuficientes para propiciar a cristalização de cassiterita, cuja formação não está vinculada simplesmente às concentrações de $\mathrm{Sn}$, mas também, a outros componentes tais como a atividade do $\mathrm{Sn}\left(\mathrm{S}^{2+}\right.$ e $\left.\mathrm{Sn}^{4+}\right)$ e dos agentes complexantes $(\mathrm{Cl}$ e $\mathrm{F}), \mathrm{fO}_{2}$ (Lehmann, 1990), entre outros.

25) comparativamente aos granitóides e greisens especializados a estanho e portadores de mineralizações de cassiterita, ocorrentes no contexto dos maciços granitóides Antônio Vicente e Mocambo, os granitóides desse maciço possuem quantidades mais elevados de $\mathrm{Cl}$, embora seus conteúdos de $\mathrm{F}$ sejam, em geral, mais baixos. Em relação ao maciço 
granitóide Velho Guilherme, as concentrações de $\mathrm{F}$ e $\mathrm{Sn}$ são mais ou menos equïvalentes, enquanto que as de $\mathrm{Cl}$ são, geralmente, mais baixas.

26) a exemplo do maciço Velho Guilherme, os dados químicos e os estudos petrográficos permitem estabelecer que granitóides com conteúdos um pouco expressivos de $F(410 \mathrm{ppm}$ a 2500ppm) e/ou de $\mathrm{Cl}(594 \mathrm{ppm}$ a $836 \mathrm{ppmm})$ não são necessariamente hospedeiros de mineralizações de estanho e, em especial, de cassiterita.

27) Em relação aos ETR, os granitóides estudados mostram-sem, em geral, enriquecidos em ETRL e em ETRP, em relação à abundância desses elementos na crosta continental(Shaw et al., 1986; Condie, 1993) e desenvolvem um padrão tipo "gaivota", à semelhança daquele que foi observado em relação aos maciços granitóides António Vicente, Velho Guilherme e Mocambo..

28) a somatória total dos seus conteúdos médios nas facies granitóides AFG e BAFG é igual a $342,07 \mathrm{ppm}$. Esses valores são muito inferiores àqueles encontrados nos granitóides dos maciços granitóides Antônio Vicente, Velho Guilherme e Mocambo.

29) a facies BAFG ostenta os mais elevados conteúdos de ETRL e de ETRP em relação a facies AFG. Além disso, a facies BAFG mostra a maior anomalia de Eu. Isso reforça a hipótese de que essa facies representa um diferenciado relativamente mais evoluído do que a facies AFG. Nesse caso, o plagioclásio desempenhou um papel importante na partição do Eu que se empobreceu no sentido da facies BAFG.

30) as razões $E U_{N} / E u^{*}$, nesses granitóides são, respectivamente 12,92 (AFG) e 12,78(BAFG), enquanto que as razões (La/Yb)N são 2,20(facies AFG) e 2,06(facies BAFG).

31) os granitóides desse maciço apresentam enormes semelhanças texturais e mineralógicas com as facies mais evoluídas do maciço granitóide Antônio Vicente, bem como ocorrem no mesmo contexto geológico, de modo que as consideraçőes apresentadas em relação à facies $B S G$, daquele maciço, em termos de seu posicionamento crustal, condições de $\mathrm{fO}_{2}, \mathrm{~T}$ e $\mathrm{P}$ em que a mesma se formou, são válidas aqui. 


\section{CAPÍTULO 7}

\section{7- MACIÇO GRANITÓIDE UBIMISUL(MGUS)}

\section{1- Contexto Geológico}

Esse maciço aflora na borda sul-sudeste do maciço granitóide Antônio Vicente e a este-nordeste do maciço granitóide Benedita(Figuras 2.3 e 6.1), na região sudeste do Pará, na extremidade oeste da Serra de Carajás, a uma distância de aproximadamente $45 \mathrm{Km}$ a nordeste da cidade de São Felix do Xingu(Figura 2.3). Apresenta forma grosseiramente circular, achatada a norte e a sul e possui dimensões em torno de 4,5 $\mathrm{Km}^{2}$.

É intrusivo em rochas granitóides atribuídas ao "Granito Parauari"(Santos et al., 1975) e faz contato com rochas vuicânicas félsicas da Formação Iriri, unidade superior do Grupo Uatumã(CPRM/DNPM, 1991), Figura 6.1

\section{2- Histórico}

A primeira referência a esse maciço é devida a Sá(1985). Entretanto, deve-se a Teixeira \& Dall'Agnol(1991) essa designação e a Teixeira \& Andrade(1992) os primeiros estudos realizados no âmbito do mesmo.

\section{3- Aspectos de Campo e Amostragem}

A delimitação desse maciço, em mapa, foi efetuada durante os estudos realizados por Teixeira \& Dall'Agnol(1991) no maciço granitóide Antônio Vicente. Devido às suas reduzidas dimensões e à inexistência de fotografias aéreas em escala de maior detalhe não foi possível distinguir domínios fotogeológicos no interior do corpo. Além disso, as dificuldades de acesso à área de ocorrência desse maciço, aliadas à falta de infraestrutura impediram a realização de uma amostragem sistemática mais abrangente dos granitóides constitutivos do mesmo, fato que impossibilitou uma separação dos seus domínios faciológicos distintos. De qualquer modo, os resultados obtidos possibilitaram caracterizar, com base na amostragem realizada(Anexo 36) e nos estudos petrográficos, duas áreas no interior do corpo, onde predominam biotita sienogranito com clorita(BSGCl) e biotita monzogranito(BMG).

\section{4- Aspectos Petrográficos}

Os estudos petrográficos realizados envolveram o exame de 13 seções delgadas que abrangeram os mesmos aspectos já abordados nos granitóides dos outros maciços. 
Para a classificação e nomenciatura dos tipos petrográficos estudados foram utilizadas as recomendações de Streckeisen(1976). Os diagramas correspondentes são apresentados na Figura 7.te as composições modais das amostras estudadas encontramse na Tabelas 7.1 e 7.2 .

No diagrama Q-A-P, nota-se que as suas composições ocupam os campos dos sienogranito e monzogranito, embora o grupo de composição monzogranítica esteja situado próximo ao limite entre essas duas composições.

No diagrama $Q-(A+P)-M^{\prime}$, o conjunto das amostras situa-se sobre ou muito próximo da aresta $Q-(A+P)$, visto que possuem valores de $M^{\prime}<5 \%$, evidenciando o caráter hololeucacrático das mesmas.

Deve-se esclarecer que a separação do plagioclásio primário(de composição albitaoligoclásio) da albita tardi a pós-magmática ocorreu de modo muito claro. $\mathrm{E}$ o conteúdo modal da albita tardia foi adicionado ao do feldspatato potássico para os cálculos dos valores "A" dos diagramas acima, conforme estabelecido por Streckeisen(1976). No caso do feldspato potássico, não foi possivel, durante a contagem de pontos, separar claramente o feldspato potássico primário daquele formado no estágio tardi a pós-magmático. Assim, os dados modais quando recalculados para $100 \%$, afim de serem lançados nos referidos diagramas, envolveram, para os cálculos dos valores de " $A$ ", a somatória dos conteúdos modais de feidspato potássico primário+feldspato potássico+albita tardi a pós-magmático tardi a pós-magmáticos. Por isso, as composições observadas nos diagramas Q-A-P e Q$(A+P)-M$ ' não representam as composições magmáticas originais dos granitóides desse maciço, mas composições modificadas pelas transformações tardi a pós-magmáticas. Além disso, não foi possível quantificar o quanto de plagioclásio primário foi substituído por feldspato potássico secundário, o que dificulta, ainda mais, recontituir a composiçăo magmática original desses granitóides.

Não obstante tais modificações nas composições magmáticas originais dos granitóides desse maciço, as características petrográficas observadas permitem estabelecer que os mesmos, a exemplo dos outros ora estudados, cristalizaram-se a partir de líquidos muito evoluídos e silicosos, cujas evidéncias são traduzidas pelos elevados conteúdos em quartzo modal(valores quase sempre superiores a $30 \%$ ), bem como pelos baixos teores de máficos(Tabelas 7.1 e 7.2 ).

A distribuição dessas amostras no diagrama $Q-A-P$, guarda muita semelhança com grande parte dos granitóides dos maciços Antônio Vicente, Velho Guilherme e Mocambo. 

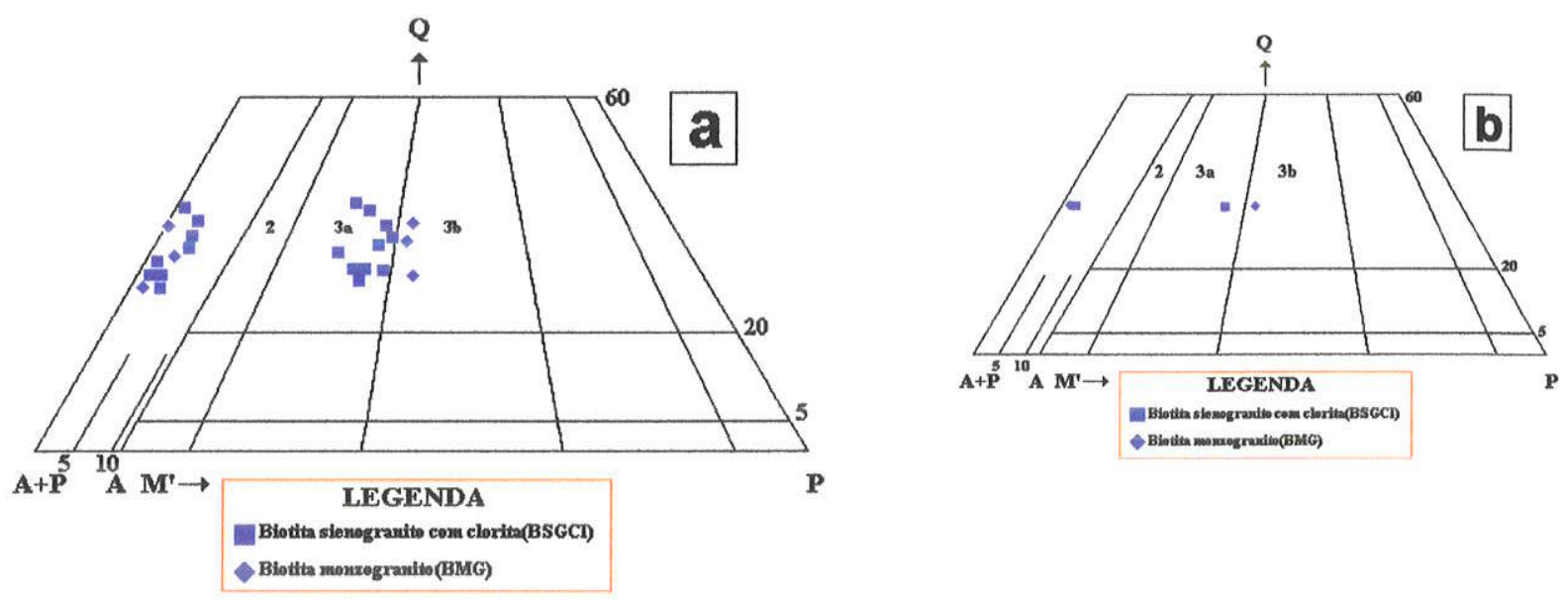

Figura 7.1- Diagramas triangulares Q-A-P e Q-(A+P)-M'(Strekeisen, 1976) mostrando a distribuição composicional modal geral(a) e valores médios(b) das facies granitóides do maciço granitóide Ubim/Sul.

Tabela 7.1- Composições modais da facies granitóide BSGCl do maciço granitóide Ubim/Sul. $\mathrm{Tr}=$ traço; $\mathrm{Nd}=$ não detectado; $\mathrm{Nc}=$ não contado.

\begin{tabular}{|c|c|c|c|c|c|c|c|c|c|c|}
\hline \multirow{2}{*}{$\begin{array}{l}\text { VARIEDADE } \\
\text { AMOSTRAS }\end{array}$} & \multicolumn{10}{|c|}{$\mathrm{BSGCI}$} \\
\hline & $\begin{array}{l}\text { NE-B- } \\
26 B\end{array}$ & $\begin{array}{l}\text { NE-B- } \\
27\end{array}$ & $\begin{array}{l}\text { NE-B- } \\
28\end{array}$ & $\begin{array}{c}\text { NE-B- } \\
29^{A}\end{array}$ & $\begin{array}{l}\text { NE-B- } \\
30\end{array}$ & $\begin{array}{c}\text { NE-B- } \\
31\end{array}$ & $\begin{array}{l}\text { NE-B- } \\
33 B\end{array}$ & $\begin{array}{c}\text { NE-B- } \\
34\end{array}$ & $\begin{array}{l}\text { NE-B- } \\
38\end{array}$ & $\begin{array}{l}\text { NE-B- } \\
39\end{array}$ \\
\hline & 1 & 2 & 3 & 4 & 5 & 6 & 7 & 8 & 9 & 10 \\
\hline \multicolumn{11}{|l|}{ MINERAIS PRIMÁRIOS(\%) } \\
\hline QUARTZO & 28 & 31 & 36 & 36 & 32 & 30 & 41 & 34 & 28 & 29 \\
\hline PLAGIOCLÁSIO & 19 & 20 & 19 & 15 & 15 & 23 & 13 & 22 & 18 & 18 \\
\hline K-FELDSPATO & 44 & 36 & 36 & 37 & 47 & 41 & 41 & 37 & 44 & 42 \\
\hline BIOTITA & $\operatorname{Tr}$ & $\operatorname{Tr}$ & $\mathrm{Tr}$ & $\mathrm{Tr}$ & 01 & 02 & 01 & 02 & 01 & 01 \\
\hline ZIRCÅO & $\mathrm{Tr}$ & $\mathrm{Tr}$ & $\mathrm{Tr}$ & $\mathrm{Tr}$ & $\mathrm{Tr}$ & $\mathrm{Tr}$ & $\mathrm{Tr}$ & $\mathrm{Tr}$ & $\mathrm{Tr}$ & $\mathrm{Tr}$ \\
\hline MINERAIS OPACOS & $\mathrm{Tr}$ & $\mathrm{Tr}$ & $\mathrm{Tr}$ & $\mathrm{Tr}$ & $\mathrm{Tr}$ & $\mathrm{Tr}$ & $\mathrm{Tr}$ & $\mathrm{Tr}$ & $\mathrm{Tr}$ & $\mathrm{Tr}$ \\
\hline \multicolumn{11}{|l|}{$\begin{array}{l}\text { MINERAIS } \\
\text { SECUNDÁRIOS(\%) }\end{array}$} \\
\hline SERICITA \pm MUSCOVITA & 02 & 07 & 03 & 04 & 01 & 01 & 01 & 03 & 05 & 05 \\
\hline K-FELDSPATO & Nc & Nc & $\mathrm{Nc}$ & $\mathrm{Nc}$ & Nc & $\mathrm{Nc}$ & $\mathrm{Nc}$ & $\mathrm{Nc}$ & $\mathrm{Nc}$ & $\mathrm{Nc}$ \\
\hline ALBITA & 05 & 04 & 03 & 03 & 03 & 04 & 03 & 03 & 04 & 04 \\
\hline CLORITA & 02 & 01 & 02 & 03 & $\mathrm{Tr}$ & $\mathrm{Tr}$ & $\operatorname{Tr}$ & $\operatorname{Tr}$ & 01 & 01 \\
\hline FLUORITA & 01 & $\mathrm{Tr}$ & $\mathrm{Tr}$ & 01 & $\mathrm{Tr}$ & $\mathrm{Tr}$ & $\mathrm{Tr}$ & $\mathrm{Tr}$ & $\mathrm{Tr}$ & $\mathrm{Tr}$ \\
\hline TOPAZIO & $\mathrm{Nd}$ & $\mathrm{Nd}$ & $\mathrm{Tr}$ & $\mathrm{Nd}$ & $\mathrm{Nd}$ & $\mathrm{Nd}$ & $\mathrm{Nd}$ & $\mathrm{Nd}$ & $\mathrm{Nd}$ & $\mathrm{Nd}$ \\
\hline MONAZITA & $\mathrm{Tr}$ & $\mathrm{Nd}$ & $\mathrm{Nd}$ & $\mathrm{Nd}$ & $\mathrm{Nd}$ & $\mathrm{Nd}$ & $\mathrm{Nd}$ & $\mathrm{Nd}$ & $\mathrm{Tr}$ & $\mathrm{Nd}$ \\
\hline MINERAIS OPACOS & $\mathrm{Tr}$ & $\mathrm{Tr}$ & $\operatorname{Tr}$ & $\mathrm{Tr}$ & $\operatorname{Tr}$ & $\mathrm{Tr}$ & $\mathrm{Tr}$ & $\operatorname{Tr}$ & $\mathrm{Tr}$ & $\operatorname{Tr}$ \\
\hline ESFALERITA & $\mathrm{Tr}$ & $\operatorname{Tr}$ & $\mathrm{Tr}$ & $\operatorname{Tr}$ & $\mathrm{Tr}$ & $\mathrm{Tr}$ & $\operatorname{Tr}$ & $\mathrm{Tr}$ & $\operatorname{Tr}$ & $\mathrm{Tr}$ \\
\hline CASSITERITA & $\mathrm{Nd}$ & $\mathrm{Nd}$ & $\mathrm{Nd}$ & $\mathrm{Nd}$ & $\mathrm{Nd}$ & $\mathrm{Nd}$ & $\mathrm{Nd}$ & $\mathrm{Nd}$ & $\operatorname{Tr}$ & $\mathrm{Nd}$ \\
\hline ARGILO-MINERAIS & $\mathrm{Nc}$ & $\mathrm{Nc}$ & $\mathrm{Nc}$ & $\mathrm{Nc}$ & $\mathrm{Nc}$ & $\mathrm{Nc}$ & $\mathrm{Nc}$ & $\mathrm{Nc}$ & $\mathrm{Ne}$ & $\mathrm{Nc}$ \\
\hline $\begin{array}{l}\text { COMPOSIÇÃO DO } \\
\text { PLAGIOCLÁSIO }\end{array}$ & $A n_{8-9}$ & - & - & - & $\mathrm{An}_{6}$ & $\mathrm{An}_{6^{-}}$ & $A n_{8-9}$ & $A n_{12}$ & $A n_{8-13}$ & $A n_{11}$ \\
\hline Q & 30 & 34 & 38 & 40 & 33 & 30 & 41 & 35 & 29 & 30 \\
\hline A & 51 & 44 & 42 & 44 & 52 & 46 & 45 & 42 & 51 & 50 \\
\hline $\mathrm{P}$ & 19 & 22 & 20 & 16 & 15 & 24 & 14 & 23 & 20 & 20 \\
\hline Q & 29 & 33 & 37 & 39 & 33 & 30 & 41 & 35 & 29 & 30 \\
\hline$A+P$ & 69 & 66 & 60 & 57 & 66 & 68 & 57 & 63 & 69 & 69 \\
\hline$M^{\prime}$ & 02 & 01 & 03 & 04 & 01 & 02 & 02 & 02 & 02 & 01 \\
\hline NÚMERO DE PONTOS & 1500 & 1500 & 1500 & 1500 & 1300 & 1300 & 1300 & 1200 & 1000 & 1300 \\
\hline
\end{tabular}


Tabela 7.2- Composiçōes modais da facies BMG. Maciço granitóide Ubim/Sul. Tr= Traço; $\mathrm{Nd}=\mathrm{Nazo}$ detectado; $\mathrm{Nc}=$ não contado.

\begin{tabular}{|l|c|c|c|}
\hline VARIEDADE & \multicolumn{3}{|c|}{ BMG } \\
\hline AMOSTRAS & NE-B-32 & NE-B-35 & NE-B36 \\
\hline MINERAIS & 20 & 21 & 22 \\
PRIMARIOS(\%) & & & \\
\hline QUARTZO & 28 & 34 & 37 \\
\hline PLAGIOCLASIO & 27 & 23 & 23 \\
\hline K-FELDSPATO & 38 & 37 & 36 \\
\hline BIOTITA & 01 & 02 & $\mathrm{Tr}$ \\
\hline ZIRCÁO & $\mathrm{Tr}$ & $\mathrm{Tr}$ & $\mathrm{Tr}$ \\
\hline MINERAIS OPACOS & $\mathrm{Tr}$ & $\mathrm{Tr}$ & $\mathrm{Tr}$ \\
\hline MINERAIS & & & \\
SECUNDARIOS(\%) & & & \\
\hline SERICITA+/ & 01 & 01 & 02 \\
MUSCOVITA & & & \\
\hline K.FELDSPATO & $\mathrm{Nc}$ & $\mathrm{Nc}$ & $\mathrm{Nc}$ \\
\hline ALBITA & 04 & 03 & 01 \\
\hline CLORITA & $\mathrm{Tr}$ & 01 & $\mathrm{Tr}$ \\
\hline MINERAIS OPACOS & $\mathrm{Tr}$ & $\mathrm{Tr}$ & $\mathrm{Tr}$ \\
\hline FLUORITA & $\mathrm{Tr}$ & $\mathrm{Tr}$ & $\mathrm{Tr}$ \\
\hline ARGILO-MINERAIS & $\mathrm{Nc}$ & $\mathrm{Nc}$ & $\mathrm{Nc}$ \\
\hline COMPOSIÇÃO DO & $\mathrm{An} 7 \cdot 9$ & $\mathrm{An} \mathrm{n}_{-12}$ & $\mathrm{An}$ \\
\hline PLAGIOCLASIO & & & \\
\hline $\mathrm{Q}$ & 29 & 35 & 38 \\
\hline A & 43 & 41 & 38 \\
\hline P & 28 & 24 & 24 \\
\hline$Q$ & 29 & 34 & 38 \\
\hline A+P & 70 & 63 & 62 \\
\hline M' & 01 & 03 & 0 \\
\hline NUMERO DE PONTOS & 1200 & 1300 & 1300 \\
\hline
\end{tabular}

\subsection{1- Facies BSGCI}

Essa variedade foi amostrada, principalmente, na porção oeste-sudoeste do corpo, onde presume-se ser a facies dominante em área de ocorrência(Anexo 36), embora se faça presente, também, na borda norte-nordeste do maciço.

\subsubsection{1- Textura e Mineralogia}

Apresenta textura hipidiomórfica, heterogranular, granulação média a grossa e coloração rosa a rosa-esbranquiçada(Prancha 23; Fotos $a, b)$. Consiste essencialmente de quartzo, feldspato potássico(microclina pertítica) e plagioclásio, sendo varietal a biotita. As fases minerais acessórias primárias estão representadas por zircão e minerais $\operatorname{opacos}\left(\mathrm{MOP}_{1}\right)$.

As fases minerais associadas ao estágio de alterações tardi a pós-magmáticas mostram-se representadas por sericita \pm muscovita( $\left(\mathrm{Mv}_{1}\right) \pm \operatorname{clorita}\left(\mathrm{Cl}_{1}\right) \pm$ fluorita $\left(\mathrm{Fl}_{1}\right)$, microclina pertítica $\left(\mathrm{Fk}_{2}\right)$, albita, clorita $\left(\mathrm{Cl}_{2}\right) \pm$ fluorita $\left(\mathrm{Fl}_{2}\right) \pm$ muscovita $\left(\mathrm{Mv}_{2}\right) \pm$ esfalerita \pm minerais opacos $\left(\mathrm{MOP}_{2}\right) \pm$ quartzo $\left(Q t z_{3}\right)$, topázio, argilo-minerais $\Theta$, muito localmente, monazita e cassiterita. 
O quartzo mostra-se representado por, pelo menos, quatro variedades, tomando-se por base a textura, morfologia e modo de ocorrência. O quartzo $1\left(Q t z_{1}\right)$ ocorre sob a forma de grãos médios a grossos, geralmente anédricos a subédricos. Desenvolve contatos retos a irregulares, embora, localmente ocorram contatos suturados entre si, também com as outras fases essenciais $e$, às vezes, com a biotita. Apresenta-se fraturado e exibe extinção ondulante. $O$ tipo 2 tem dimensões finas a médias e é subédrico. Desenvolve contatos retos, embora ocorram contatos irregulares. Mostra-se menos fraturado do que o $Q t_{1}$ e exibe extinção ondulante moderada. Às vezes, ocorre como inclusões em cristais de $\mathrm{Fk}_{2}$. $\mathrm{O}$ $\mathrm{Qtz}_{3}$ associa-se à cloritização e/ou muscovitização e/ou oxidação da biotita. Forma cristais anédricos, fusiformes, os quais costumam estar dispostos ao longo dos planos de clivagem dessas fases micáceas. Finalmente, o quartzo 4 está representado por grãos anédricos, associados à substituição do plagioclásio $\left(\mathrm{Pl}_{4}\right)$ por feldspato potássico( $\left.\mathrm{Fk}_{2}\right)$ e/ou às inclusões de feldspato potássico( $\left.F_{K_{1}}\right)$ no $\mathrm{Fk}_{2}$.

O feldspato potássico apresenta-se em, pelo menos, duas variedades. A primeira tem ocorrência localizada e representa uma fase magmática primária( $\left(\mathrm{Fk}_{1}\right)$. Ocorre como grãos subédricos, os quais são melhor caracterizados quando estão inclusos no $\mathrm{Fk}_{2}$. E pertítico e a fase sódica das pertitas apresenta granulação fina, sendo mais comuns os tipos "flim" e "patch perthites"(conforme definição de Alling, 1932, 1938; Smith, 1974). Mostra-se parcialmente alterado para argilo-minerais, os quais, à luz natural, the atribuem um aspecto "sujo". O feldspato potássico 2 corresponde aos cristais mais grossos(megacristais), os quais representam uma fase tardi a pós-magmática, decorrente da substituição do plagioclásio primário( $\mathrm{Pl}_{1}$; Prancha 23; Foto c). É pertítico e as pertitas são mais grossas do que àquelas relacionadas ao $\mathrm{Fk}_{1}$. Os tipos mais freqüentes mostramse representados por "film", "band", "vein e "patch perthites"(Alling, 1932, 1938; Smith, 1974). Elas gradam de um tipo a outro, constituindo pertitas compostas(Alling, 1938). Algumas vezes, encontra-se, parcialmente, albitizado e mostra-se alterado para argilominerais, os quais formam nuvens superpostas aos cristais, impondo-lhes, à luz natural, um aspecto "sujo. As vezes, hospeda inclusões, sendo mais comuns aquelas de quartzo 2 e de $\mathrm{Pl}_{2}$ ("poikilitic albite"; conforme Fisher, 1971). Cristais maclados, ocorrem, localmente, sendo o tipo de macla presente regido pelas leis de Carlsbad.

O plagioclásio mostra-se representado por duas variedades, as quais foram distinguidas com base na textura, no modo de ocorrência e na composição. $O$ primeiro tipo $\left(\mathrm{PI}_{1}\right)$ ostenta composição albita-oligoclásio sódico $\left(A n_{6-13} ;\right.$ Tabela 7.1 ; determinação ótica). Ele ocorre segundo cristais tabulares, de granulação fina a média, subédricos, os quais mostram-se, por vezes, parcialmente, alterados para sericita \pm muscovita $\left(\mathrm{Mv}_{1}\right) \pm$ clorita $\left(\mathrm{Cl}_{1}\right) \pm$ fluorita $\left(\mathrm{Fl}_{\uparrow}\right)$. Essa paragênese é tardi a pós-magmática e se desenvolve nas 
porções centrais dos cristais com zoneamento normal(Smith, 1974; Prancha 23, Foto c). Entretanto, algumas vezes, observa-se o desenvolvimento, dessa mesma paragênese, em zonas irregulares dos grãos("patch zones"). Isso evidencia um processo de descalcificação dos cristais nessas zonas preferenciais(Smith, 1974; Dall'Agnol, 1980; Teixeira \& Dall'Agnol, 1991; Teixeira \& Andrade, 1992). Além disso, os grãos de $\mathrm{Pl}_{1}$ costumam estar alterados, em diferentes graus, para $\mathrm{Fk}_{2}$ (microclina pertítica). Essas associações minerais de alteração estão, no seu todo, relacionadas a um evento autometassomático tardio, de natureza potássica, que afetou esse granitóide, logo após o estágio magmático, fruto de interações rocha/fluidos tardios enriquecidos em voláteis(Pollard, 1983; Pollard et al., 1983; Kinnaird, 1985; Pollard, 1986; Taylor \& Pollard, 1988, entre outros). As maclas, às vezes, mostram-se nítidas, sendo mais comuns aquelas regidas pelas leis da albita e albitaCarlsbad.

O plagioclásio tipo 2 mostra-se representado por cristais subédricos, límpidos, nitidamente maclados segundo as leis da albita, os quais, pelo relevo e aspecto, devem corresponder a uma composição albítica. Eles ocorrem, preferencialmente, como inclusões no $\mathrm{Fk}_{2}$ (Prancha 23; Foto d). Feições semelhantes a essa foram descritas por Fisher(1971), que as designou de "poikilitic albite".

A biotita ocorre sob a forma de lamelas de granulação fina a média e, às vezes, grossa, anédricas,. Apresenta pleocroismo moderado, variando de castanho escuro $(X$ e $Y$ ) a castanho claro $(X)$. Mostra-se, quase sempre, alterada, em diferentes graus, para clorita $\left(\mathrm{Cl}_{2}\right) \pm$ muscovita $\left(\mathrm{Mv}_{2}\right) \pm$ fluorita $\left(\mathrm{Fl}_{2}\right) \pm$ quartzo( $\left(\mathrm{Qtz}_{3}\right) \pm$ minerais opacos $\left(\mathrm{MOP}_{2}\right) \pm$ esfalerita(Prancha 23; Foto e). Algumas vezes, hospeda inclusões de zircão, com o qual desenvolve nítidos halos pleocróicos.

Em relação aos minerais acessórios, o zircão é o mais freqüente, embora nunca seja abundante. Ocorre como minúsculos cristais subédricos a anédricos $e$, por vezes, zonados. Os minerais opacos, como fases primárias, são raros. Ocorrem localizadamente, apresentando-se sob a forma de cristais euédricos, de granulação fina, associados à biotita.

A clorita, quando ocorre associada à alteração biotita $\left(\mathrm{Cl}_{2}\right)$, apresenta-se como lamelas finas a médias, anédricas e, subordinadamente, subédricas, com pleocroismo moderado, variando entre verde oliva( $Z$ e $Y)$ e verde claro-amarelado $(X)$. Como fase associada à alteração do plagioclásio $\left(\mathrm{Cl}_{1}\right)$, forma finissimas lamelas anédricas, fracamente pleocróicas de coloração verde claro.

A esfalerita, por sua vez, é pouco abundante e ocorre sob a forma de grãos anédricos, dispostos ao logo dos planos de clivagem da biotita cloritizada e/ou oxidada. 
O par sericita+muscovita $\left(\mathrm{Mv}_{1}\right)$ ocorre como finas lamelas, em geral, anédricas, intimamente associadas à alteração tardi a pós-magmática dos feldspatos.

A albita é a fase tardia mais abundante, podendo atingir até $5 \%$ modal(Tabela 7.1). Apresenta-se como finos cristais anédricos a subédricos, límpidos, por vezes, maclados sob as leis da albita e, subordinadamente, da albita- Carlsbad. Assume formas diversas dentre as quais destacam-se:

1) "albite rims": representa um tipo pouco freqüente e ocorre associada ao $\mathrm{Pl}_{1}$.

2) "swapped rims": mostram-se desenvolvidas mais nitidamente em relação ao $\mathrm{Fk}_{2}$.

3) "albitas inter-granulares": essa modalidade mostra-se desenvolvida segundo agrupamentos em forma de franjas duplas de cristais, ocorrentes entre dois ou mais grãos de feldspato potássico2 . Os cristais de albita apresentam sinal ótico invertido em relação ao cristal de $\mathrm{Fk}_{2}$ adjacente.

4) "albitas intra-granulares": essa designação corresponde aos agrupamentos albiticos semelhantes a "dedos "e "mãos" $e$ as "chess-board albites". Ambos os tipo mostram-se associados ao $\mathrm{Fk}_{2}$.

A fluorita apresenta-se em duas variedades, tomando-se por base a granulação e o modo de ocorrência. A fluorita $1\left(\mathrm{Fl}_{1}\right)$ forma finíssimos grãos anédricos ligados à alteração tardi a pós-magmática do plagioclásio primário(descalcificação), em especial, do $\mathrm{Pl}_{1} . \mathrm{A}$ variedade $2\left(\mathrm{Fl}_{2}\right)$, forma cristais, anédricos a subédricos, finos a médios, os quais costumam ocorrer associados à biotita e/ou à biotita cloritizada. Em ambos os casos, apresenta-se na modalidade incolor e lilás.

O topázio é muito pouco freqüente, tendo sido observado em uma única amostra(Tabela 7.1). Apresenta-se como um finissimo grão envolto, parcialmente, por lamelas de muscovita $\left(\mathrm{Mv}_{2}\right)$, em intima associação com a fluorita $\left(\mathrm{Fl}_{2}\right)$ e com restos de biotita oxidada, os quais encontram-se superpostos a um cristal de quartzo(Prancha 23; Foto f).

A muscovita 2 mostra-se desenvolvida em diferentes graus e afeta as diversas fases minerais presentes na rocha e deve representar o início da greisenização desse granitóide(Prancha 24; Foto a).

A cassiterita é muito escassa, tendo sido observada em uma única amostra(Tabela 7.1). Apresenta-se como um grão isolado, subédrico, finos e levemente maclado. A luz natural, exibe coloração castanho-avermelhada ou caramelada, característica(Prancha 24; Foto b). Apresenta cores de interferências altas, traduzidas pela mistura de cores azul, amarelo, verde e vermelho(Prancha 24; Foto c). Sua presença na amostra NE-B-38 coincide com o maior grau de oxidação dessa amostra em relação às demais de grupo. 
Os argilo-minerais mostram-se associados aos feldspatos potássicos $e$, independentemente do grau de alteração tardi a pós-magmática das rochas, estão sempre presentes. São melhor observados à luz natural, apresentando-se como nuvens superpostas aos cristais, aos quais atribuem um aspecto"sujo". O momento inicial dessa alteração é de difícil caracterização. Entretanto, nas amostras onde a $\mathrm{Mv}_{2}$ está mais intensamente desenvolvida, observou-se que em relação aos argilo-minerais, ela é posterior, visto que em amostras onde a muscovitização representada pela $\mathrm{Mv}_{2}$ é pouco expressiva ou está ausente, os argilo-minerais costumam estar presentes.

\subsubsection{2- Ordem de Cristalização}

Os estudos petrográficos mostraram que a ordem de fracionamento das fases minerais primárias, constituintes desse granitóide, a partir do liquido magmático, não difere da seqüência já estabelecida para os outros granitóides, em especial, daquelas facies mais evoluídas, mais alteradas e tipicamente "subsolvus"(Tuttle \& Bowen, 1958) dos maciços Antônio Vicente, Velho Guilherme, Mocambo.

Assim, as fases minerais precoces representadas por zircão e minerais opacos foram as primeiras a se separar do líquido magmático e a justificativa para isso é corroborada pela presença de inclusões dessas fases minerais nas fases essenciais e varietais., principalmente, no quartzo1 e na biotita.

O $\mathrm{Pl}_{1}, Q \mathrm{Qtz}_{1}$ e $\mathrm{Fk}_{1}$ parecem ter iniciado suas cristalizações durante o mesmo intervalo de temperatura e pressão, visto que ocorrem lado a lado e não são observadas, de forma inequïvoca, relações de inclusões entre as mesmas. Adicionalmente, o elevado grau de alterações tardi a pós-magmáticas, desse granitóide, dificulta a elaboração de um esquema cronológico claro àcerca da ordem de cristalização, pelo menos, em relação às principais fases minerais.

A biotita é, pelo menos em parte, posterior às fases essenciais, uma vez que que é observada, algumas vezes, na forma intersticial em relação ao $\mathrm{Qtz}, \mathrm{Qtz}, \mathrm{Pl}_{1}$ e $\mathrm{Fk}_{1}$.

Em relação ao plagioclásio 2, não foi possivel discernir um posicionamento cronológico preciso em relação às fases apresentadas acima. Ele ocorre como inclusões no $\mathrm{Fk}_{2}$, caracterizando uma "poikilitc albite", similar à que fol descrita por Fisher(1971). Assim, deve representar uma fase sódica, formada no final do estágio magmático, sendo devida a um evento de albitização ocorrido, ainda, no estágio magmático, fato, previsto nos esquemas propostos por Pollard(1983, entre outros).

As demais fases estão associadas ao estágio de alterações tardi a pósmagmáticas. 


\subsection{2- Facies BMG}

Essa variedade de granitóide tem, ao que parece, ocorrência subordinada, no interior do maciço em relação à facies $\mathrm{BSGCl}$. Representa uma variação faciológica dessa última, diferindo da mesma pelos seus maiores conteúdos modais de plagioclásio, mais baixos teores de feldspato potássico, clorita e de fluorita, pela ausência de cassiterita, topázio e monazita, bem como por encontrar-se menos afetada por alterações tardi a pósmagmáticas(Tabela 7.2). Afora essas diferenças, guarda uma grande semelhança textural e mineralógica com a $\mathrm{BSGCl}$, visto que as descrições efetuadas para a mesma, são válidas para esse granitóide. O mesmo é verdadeiro em relação à ordem de cristalização.

A Figura 7.3 resume esquematicamente um esboço da sequeencia de cristalização das fases minerais magmáticas e tardi a pós-magmáticas constituintes da facies granitóide $\mathrm{BSGCl}$.

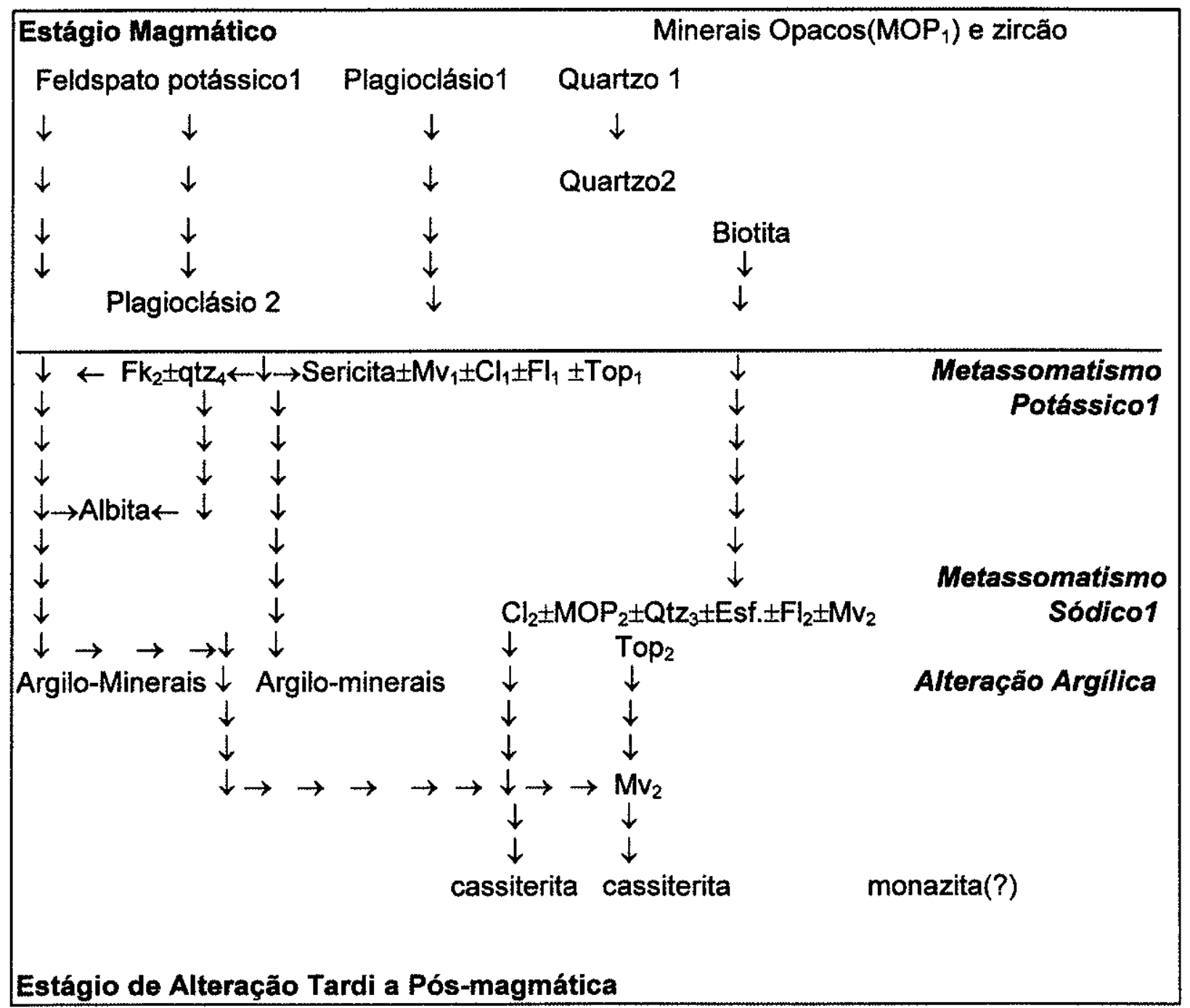

Figura 7.2- Fluxograma mostrando um esboço esquemático da sequeéncia de cristalizaçáo magmática e tardi a pós-magmática das fases minerais da facies $\mathrm{BSGCl}$ do maciço granitóideUbim/Sul. Esf= esfalerita; allan= allanita. 


\subsection{3- Discussão e Considerações Finais}

No âmbito desse maciço foram caracterizados BSGCl e BMG. Essas rochas são pobres em máficos $\left(M^{\prime}<5 \%\right)$ de composições sienogranítica(BSGCl) e monzogranítica(BMG). A separação entre os dois tipos foi baseada na diferença composicional modal entre os granitóides estudados, aliada ao fato do BSGCl estar mais afetado por alterações tardi a pós-magmáticas, traduzidas pela associação sericita \pm muscovita $\left(\mathrm{Mv}_{1}\right)$, albita e clorita $\left(\mathrm{Cl}_{2}\right)$. Deve-se ressaltar, entretanto, que a facies BSGCI pode representar uma variação da facies BMG, condicionada pelas alterações tardi a pós-magmáticas reinantes sobre porções dessa última. São rochas holo-leucocráticas, tipicamente subsolvus(Tuttle \& Bowen, 1958), originadas a partir de líquidos muito diferenciados e silicosos, as quais guardam muitas semelhanças com granitóides de outros maciços ora estudados, especialmente, com aqueles associados ao maciço granitóide Antônio Vicente(BSGCl e BMG). Fluorita(pouco abundante) e cassiterita e topázio(ausentes em várias amostras) representam os principais indícios de mineralizações nesses grantóides, particularmente, na facies BSGCl.

A Tabela 7.3 mostra as principais características petrográficas dos granitóides desse maciço.

Tabela 7.3- Principais características petrográficas dos granitóides do maciço Ubim/sul.

\begin{tabular}{|c|c|c|c|c|c|}
\hline $\begin{array}{l}\text { Facies } \\
\text { granitóides }\end{array}$ & Minerais Essenciais & $\begin{array}{l}\text { Minerais } \\
\text { Varietais }\end{array}$ & $\begin{array}{c}\text { Acessórios } \\
\text { Primários }\end{array}$ & Minerais Secundários & $\begin{array}{l}\text { Mineralizaçōes } \\
\text { Modo de } \\
\text { Ocorrência }\end{array}$ \\
\hline BSGCI & $\begin{array}{l}\text { *Quartzo } \\
\left.\text { "Plagioclásio(Ann }{ }_{6 \cdot 13}\right) \\
\text { "Feldspato Potássico } \\
\text { (Microclina pertitica) }\end{array}$ & " Biotita & $\begin{array}{l}\text { *Zircăo } \\
\text { *Minerais } \\
\text { Opacos }\end{array}$ & $\begin{array}{l}\text { Sericita, muscovita, clorita, } \\
\text { fluorita, feldspato potássico } \\
\text { (microclina pertitica), albita, } \\
\text { esfalerita, minerias opacos, } \\
\text { quartzo, topázio, monazita, } \\
\text { cassiterita e argilo-minarais. }\end{array}$ & $\begin{array}{l}\text { Indlicios: } \\
\text { "Fluorita } \\
\text { "cassiterita } \\
\text { "topázio } \\
\text { "monazita }\end{array}$ \\
\hline BMG & $\begin{array}{l}\text { "Quartzo } \\
\text { "Plagioclásio(An }(\text { An- } 12)) \\
\text { *Feldspato Potássico } \\
\text { (Microclina pertitica) }\end{array}$ & " Biotita & $\begin{array}{l}\text { *Zircło } \\
\text { *Minerais } \\
\text { Opacos }\end{array}$ & $\begin{array}{l}\text { Sericita, muscovita, clorita, } \\
\text { fluorita, feldspato potássico } \\
\text { (microclina pertítica), albita, } \\
\text { minerias opacos, quartzo e } \\
\text { argilo-minerais. }\end{array}$ & Ausente \\
\hline
\end{tabular}

\section{5- Química Mineral}

Neste maciço foram executadas através de microssonda eletrônica um total de 37 análises pontuais quantitativas(WDS), assim discriminadas: $04 \mathrm{em}$ clorita, $14 \mathrm{em}$ muscovita, 11 em feldspato potássico pertítico e 08 em plagioclásio. Realizou-se, ainda, análises semi-quantitativas(EDS) através de microscopia eletrônica de varredura, as quais envolveram a caracterização de fases minerais acessórias em uma amostra de granitóide, totalizando 02 análises. 


\subsection{1- Análises através de Microssonda Eletrônica}

\subsubsection{1- Análises químicas em Clorita}

Os grãos analisados correspondem à clorita $2\left(\mathrm{Cl}_{2}\right)$ da amostra NE-B-32, da facies BMG. As análises obtidas e as fórmulas estruturais encontram-se no Anexo 43.

\subsubsection{1.- Composição química}

A clorita estudada mostra uma composição pouco variável. Os teores de $\mathrm{SiO}_{2}$ são mais elevados na análise 1 do grão $1(23,91 \%)$, decrescendo no sentido da análise 2 desse mesmo grão(22,21\%. $\mathrm{FeO}$ (total) e $\mathrm{MnO}$ aumentam no sentido das análises 4(grão 3) e 3 (grão 2), enquanto que $\mathrm{CaO}$ e $\mathrm{TiO}_{2}$ decrescem no mesmo sentido. Os conteúdos de $\mathrm{Al}_{2} \mathrm{O}_{3}$ são um pouco mais elevados nas análises do grão 1 e os de $\mathrm{MgO}$ são mais altos nas análises 1(grão 1) e 4(grão 3). $\mathrm{F} \mathrm{e} \mathrm{Cl} \mathrm{ocorrem} \mathrm{sempre} \mathrm{em} \mathrm{teores} \mathrm{muito} \mathrm{reduzidos} \mathrm{ou} \mathrm{iguais}$ a zero.

$A$ análise do diagrama $A l^{\prime V}$ versus $A l^{V / 1}$ (Figura 7.3a; Anexo 43) mostra que, tanto para o conjunto das análises, quanto para os grãos em separado, o $\mathrm{Al}^{\mathrm{iV}}$ e $\circ \mathrm{Al}^{\mathrm{V}}$ desenvolvem uma nítida correlação negativa.

$A$ análise da Figura 7.3b revela uma correlação negativa entre $\circ \mathrm{Al}^{\mathrm{V} / \mathrm{J}}$ e os cátions bivalentes $\left(\mathrm{Fe}^{2+}+\mathrm{Mg}^{2+}\right)$, quando considerado o conjunto de todas as análises. Essa correlação se mantem quando se trata das análises de grão 1.0 mesmo é observado na Figura $7.3 \mathrm{c}\left(\mathrm{Al}^{\mathrm{VI}}\right.$ versus $\left.\mathrm{Fe}^{2+}\right)$, embora mais atenuada.

As observaçōes comentadas acima, em relação aos três diagramas, evidenciam que paralelamente ao crescimento de $\mathrm{Al}^{\mathrm{IV}}$ no sítio tetraedral(Figura 7.3a), ocorreu um aumento nos cátions bivalentes $\left(\mathrm{Fe}^{2+}\right.$ e $\left.\mathrm{Mg}^{2+}\right)$ no sítio octaedral(principalmente o $\mathrm{Fe}^{2+}$; Figuras $7.3 \mathrm{~b}$ e $7.3 \mathrm{c}$ ) e uma redução no conteúdo de $\mathrm{Al}^{\mathrm{VI}}$ no sítio octaédrico. Isso é, também, válido para o grão 1. Fato semelhante a esse foi observado na clorita das facies BAAFG e BSG do maciço granitóide Antônio Vicente e na clorita da facies BAFG do maciço granitóide Benedita, também por Cathelineau(1988) em clorita do sistema Azufres(México) e por Borges(1997) na clorita dos greisens Gs1 e Gs2, associados ao granito Água Boa(no Estado do Amazonas). Nesse caso, prevaleceram as substituições do tipo $2\left[\left(\mathrm{Al}_{+1} \mathrm{R}^{2+}{ }_{+3 / 2} \mathrm{I}_{1 / 2}\right)_{\mathrm{VI}}\right.$ ou $\left.\left(\mathrm{Si}_{-1} \mathrm{Al}_{+1}\right)_{\mathrm{IV}}\left(\mathrm{Al}_{-1} \mathrm{R}^{2+}{ }_{+2}{ }_{-1}\right)_{\mathrm{VI}}\right]$ de Cathelineau(1988; pg 478).

A Figura 7.3d mostra uma correlação positiva entre $\mathrm{Al}^{\mathrm{IV}}$ e os cátions bivalentes $\left(\mathrm{Fe}^{2+}\right.$ $\left.+\mathrm{Mg}^{2+}\right)$, tanto para o conjunto de todas as análises, quanto em relação ao grão 1 , confirmando que o aumento do $\mathrm{Al}^{\mathrm{IV}}$ foi acompanhado pou um aumento nos cátions bivalentes.

No diagrama $\mathrm{Al}^{\mathrm{N}}$ versus $\mathrm{Fe} /(\mathrm{Fe}+\mathrm{Mg})$, Figura $7.3 \mathrm{e}$, nota-se, para o conjunto das análises, que enquanto o $\mathrm{Al}^{\mathrm{iv}}$ varia, embora muito pouco, a razão $\mathrm{Fe} /(\mathrm{Fe}+\mathrm{Mg})$ permanece 
praticamente constante. Essa feição química destoa daquela observada em clorita estudada por diversos autores tais como Hey(1954), Foster(1962), Cathelineau \& Nieva(1985), Kranidiotis \& MacLean(1987), Cathelineau(1987) e Zang \& Fyfe(1995). Por outro lado, assemelha-se muito com as características da clorita estudada por Borges(1997), bem como com a da clorita dos granitóides dos maciços Antônio Vicente e Benedita, já apresentadas nos capítulos 3 e 6 .

$\mathrm{Na}$ Figura $7.3 \mathrm{f}$, do mesmo modo que na Figura $7.3 \mathrm{e}$, observa-se que, para a totalidade das análises, a razão $\mathrm{Fe} /(\mathrm{Fe}+\mathrm{Mg})$ é praticamente contante, enquanto que as quantidades de $\mathrm{Al}^{\mathrm{VI}}$ variam dentro de um limitado intervalo.

$\mathrm{Na}$ Figura $7.3 \mathrm{~g}$ observa-se uma nítida correlação negativa entre $\mathrm{Si}+\mathrm{Al}^{\mathrm{VI}}$ e os cátion bivalentes $\left(\mathrm{Fe}^{2+}+\mathrm{Mg}^{2+}\right)$, tanto em relação ao conjunto de todas as análises, quanto no que diz respeito ao grão 1. Isso reforça, mais uma vez, que o aumento do $\mathrm{Al}^{\mathrm{IV}}$ foi acompanhado por um aumento dos cátions bivalentes $\left(\mathrm{Fe}^{2+}\right.$ e $\left.\mathrm{Mg}^{2+}\right)$ e por um decréscimo no $\mathrm{Al}^{\mathrm{VI}}$ no sítio octaédrico.

$\mathrm{Na}$ Figura 7.3h observa-se uma correlação positiva entre $\mathrm{Al}^{\mathrm{Vl}}$ e o $\mathrm{Si}$, tanto em relação ao conjunto das análises quanto em relação ao grão 1. Neste essa correlação é caracterizada pela diminuição de ambas as variáveis no sentido da análise 1 para a 2 . Quando se trata do cunjunto das análises, nota-se um decréscimo de $\mathrm{Al}^{\mathrm{VI}}$ e de $\mathrm{Si}$ no sentido da análise 1 do grão 1 para as análises 4 e 3 referentes aos demais grãos. Entretanto, se considerada a análise 2 do grão 1 e as análises 3 e 4, observa-se uma correlação negativa entre o $\mathrm{Al}^{\mathrm{Vl}}$ e o $\mathrm{Si}$, definida pela redução nas quantidades do primeiro e um leve aumento do segundo no sentido do grão 1(análise 2) para os demais grãos.

Em função dos dados apresentados acima, nos grãos de clorita estudados, prevaleceram mecanismos de substituições mais compatíveis com aqueles da equação $2\left[\left(\mathrm{Al}_{+1} \mathrm{R}^{2+}{ }_{+3 / 2} \square_{1 / 2}\right)_{\mathrm{VI}}\right.$ ou $\left.\left(\mathrm{Si}_{-1} \mathrm{Al}_{+1}\right)_{\mathrm{IV}}\left(\mathrm{Al}_{-1} \mathrm{R}^{2+}{ }_{+2} \square_{-1}\right)_{\mathrm{Vl}}\right]$ de Cathelineau(1988; pg. 478).
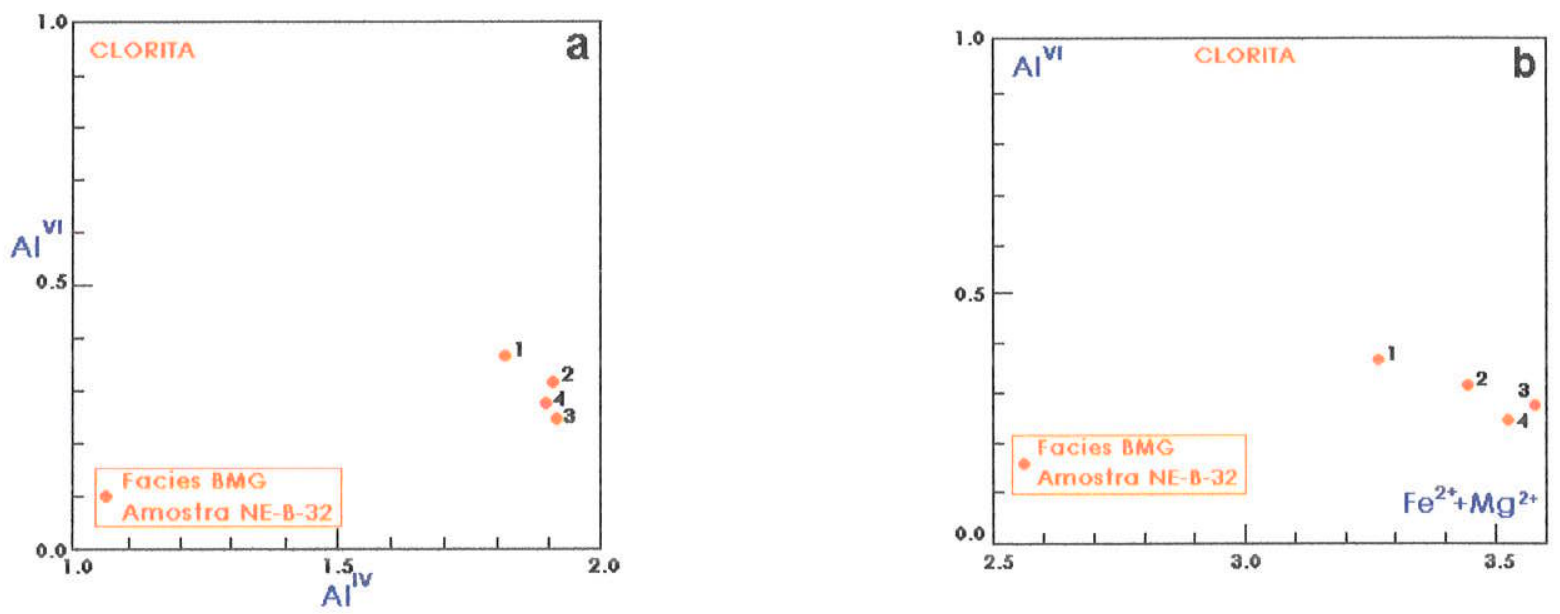

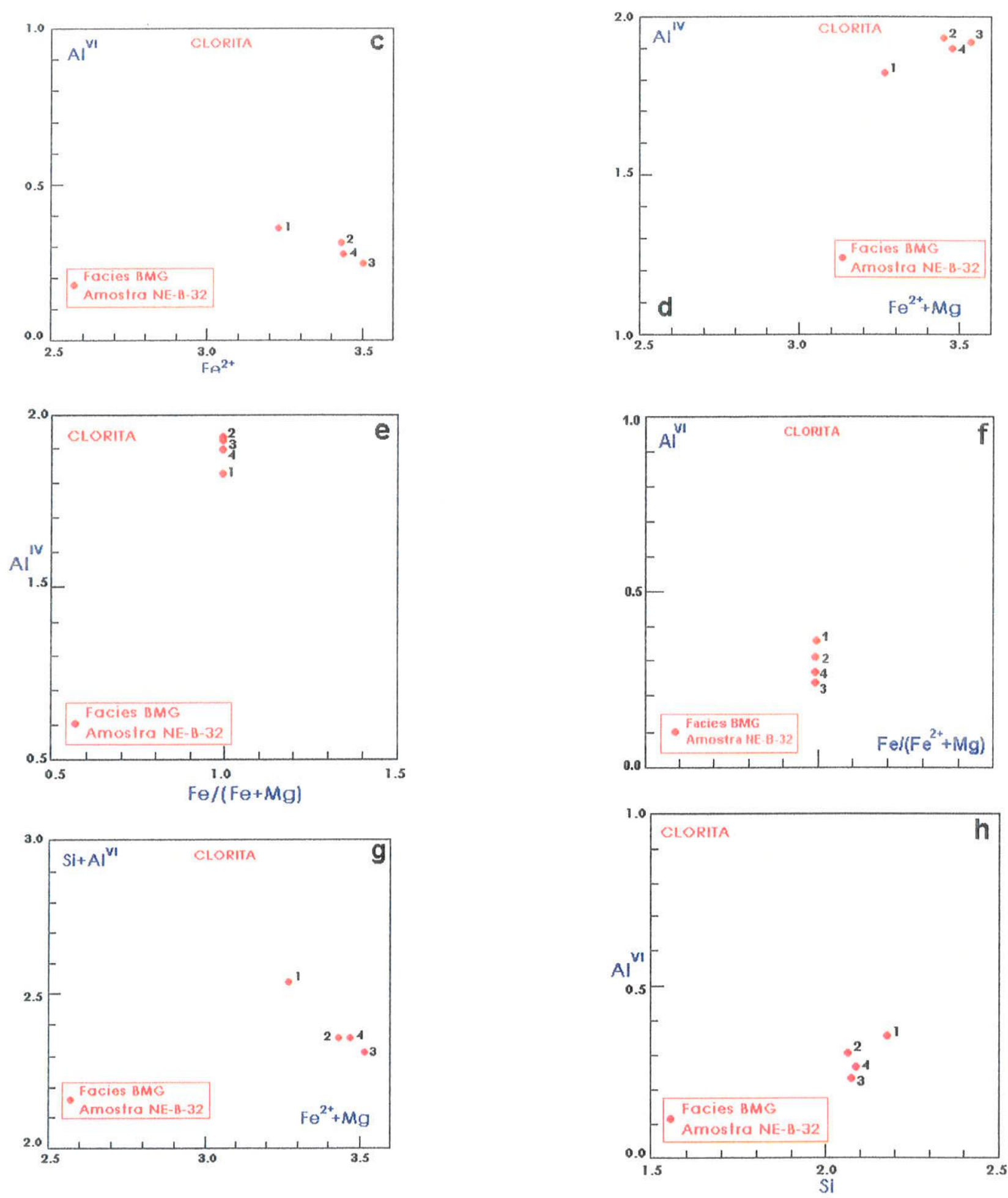

Figura 7.3 Diagramas catiônicos mostrando a distribuição composicional da clorita da facies BMG do maciço granitóide Ubim/Sul. a) $\mathrm{Al}^{\mathrm{lv}}$ vs. $\mathrm{Al}^{\mathrm{Vl}}$; b) $\mathrm{Al}^{\mathrm{Vl}}$ vs. $\left(\mathrm{Fe}^{2+}+\mathrm{Mg}^{2+}\right)$; c) $\mathrm{Al}^{\mathrm{Vl}} \mathrm{vs}^{\mathrm{F}} \mathrm{Fe}^{2+}$; d) $\mathrm{Al}^{\mathrm{lV}}$ vs. $\left(\mathrm{Fe}^{2+}+\mathrm{Mg}^{2+}\right)$; e) $A l^{\mathrm{lv}}$ vs. $\left.\mathrm{Fe} /(\mathrm{Fe}+\mathrm{Mg}) ; f\right) \mathrm{Al}^{\mathrm{Vl}}$ vs. $\left.\mathrm{Fe} /(\mathrm{Fe}+\mathrm{Mg}) ; \mathrm{g}\right) \mathrm{Si}+\mathrm{Al}^{\mathrm{Vl}}$ vs $\left.\left(\mathrm{Fe}^{2+}+\mathrm{Mg}^{2+}\right) ; \mathrm{h}\right) \mathrm{Si}$ vs. $\mathrm{Al}^{\mathrm{VI}}$. 


\subsubsection{3- Classificação e Representação Gráfica}

Para classificar e representar graficamente a clorita ora estudada utilizou-se do método de Hey(1954). A clorita em tela pertence ao grupo da clorita não oxidada, uma vez que possui conteúdos de $\mathrm{Fe}_{2} \mathrm{O}_{3}$ inferiores a $4 \%$. Em termos composicionais, corresponde a uma clorita do tipo pseudothuringita(Figura 7.4). Em relação à clorita dos outros maciços, apresenta composição semelhante à da facies BSG do maciço granitóide Antônio Vicente e, em parte, à clorita da facies BAFG do maciço granitóide Benedita.

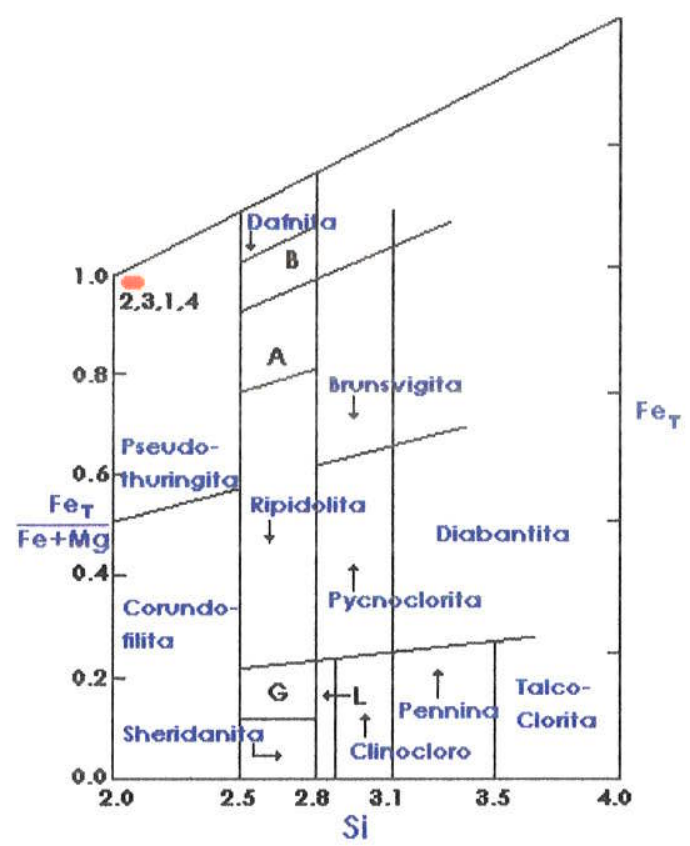

Figura 7.4.- Diagrama $\mathrm{Si}$ versus $\mathrm{Fe}($ total $) /\left(\mathrm{Fe}^{2+}+\mathrm{Mg}\right)$ mostrando a classificação da clorita estudada de acordo a proposição de Hey(1954). L=leuchtenbergita, variedade da clinocloro; $\mathrm{G}=$ grochauita, variedade da sheridanita; $A=$ afrosiderita, variedade da ripidolita; $B=$ bavalita, variedade da dafnita. Simbologia de acordo com a Figura 7.3.

\subsubsection{4- Condições de Cristalização}

A exemplo da clorita dos granitóides dos outros maciços ora estudados, utilizou-se o método de Cathelineau(1988) para estimar-se a temperatura de cristalização da clorita em questão, uma vez que o quimismo da mesma preenche os requisitos necessários para a aplicação do geotermômetro elaborado pelo referido autor. Ou seja, enquanto suas quantidades de $\mathrm{Al}^{\mathrm{IV}}$ são variáveis, as razões $\mathrm{Fe} /(\mathrm{Fe}+\mathrm{Mg})$ são praticamente constantes(Figura 7.3e). Assim, a temperatura estimada situa-se entre 525 e $561^{\circ} \mathrm{C}$.

Embora essas temperaturas pareçam um tanto elevadas, elas são equivalentes àquelas estimadas para a clorita dos granitóides e greisens do demais maciços estudados e situa-se dentro dos limites do campo de estabilidade da clorita de ambientes metamórficos(facies xisto verde/grau fraco), conforme Winkler(1977). 
Em relação às condicões de oxidação, observa-se no anexo 43 que as quantidades de $\mathrm{Fe}^{3+}$, dessa clorita, são invariavelmente iguais a 0,00 . Esse dado, aliado à muito provável ausência de magnetita na facies BMG, indicam que essa clorita cristalizou em condições de baixas fugacidade de oxigênio e, ao que tudo indica, abaixo do buffer quartzo-fayalita-magnetita(QFM), à semelhança da clorita dos demais granitóides ora estudados.

\subsubsection{2- Análises químicas em muscovita}

Foram realizadas 14 análises pontuais em cinco grãos de muscovita( $\left(\mathrm{Mv}_{2}\right)$ da facies BMG. Os resultados analíticos obtidos e as suas fórmulas estruturais encontram-se no Anexo 44

\subsubsection{1- Composição química}

Com base no Anexo 44 e na Figura 7.5 observa-se que os grãos analisados apresentam uma ampla variação composicional. O grão 4(análises 11 e 12) possui os mais elevados conteúdos de $\mathrm{Al}$ (total), enquanto que no grão 1 são encontrados os mais reduzidos teores desse cátion. Os outros grãos possuem conteúdos intermediários. Em relação ao $\mathrm{Si}^{\mathrm{lV}}$, a análise 1 ( grão 1) exibe os maiores valores e a análise 7 ( grão 2) os mais baixos. O Mg mostra uma relação invertida ao que foi observado em relação ao Al(total). Apresenta a maior concentração no grão 1(análise 1) e a menor no grão 4(análise 11). As quantidades de $\mathrm{Ti}$ são sempre muito baixas, situando-se entre 0,00 e 0,23 . As razões $\mathrm{Fe} /(\mathrm{Fe}+\mathrm{Mg})$ são pouco variáveis e muito semelhantes em todos os grão analisados. O K mostra-se mais enriquecido na análises 4(grão 2) e mais empobrecido no grão 4(análise 11). O Na mostra um amplo intervalo de variação. Apresenta teores mais elevados na análise 3(grão 2) e mais reduzidos nos grãos 3 e 5(análises 10 e 14, respectivamente).
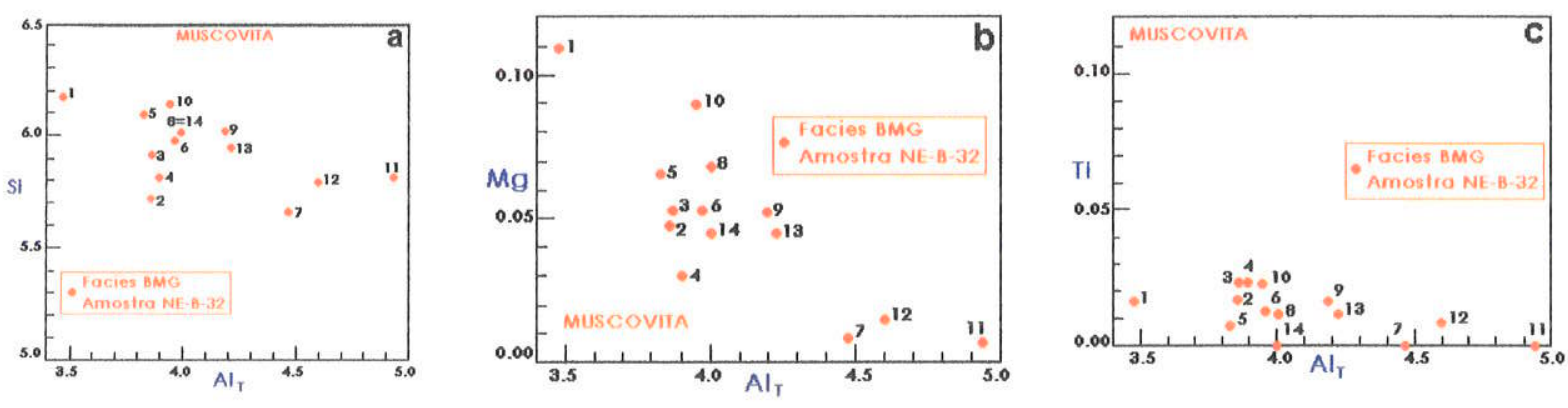

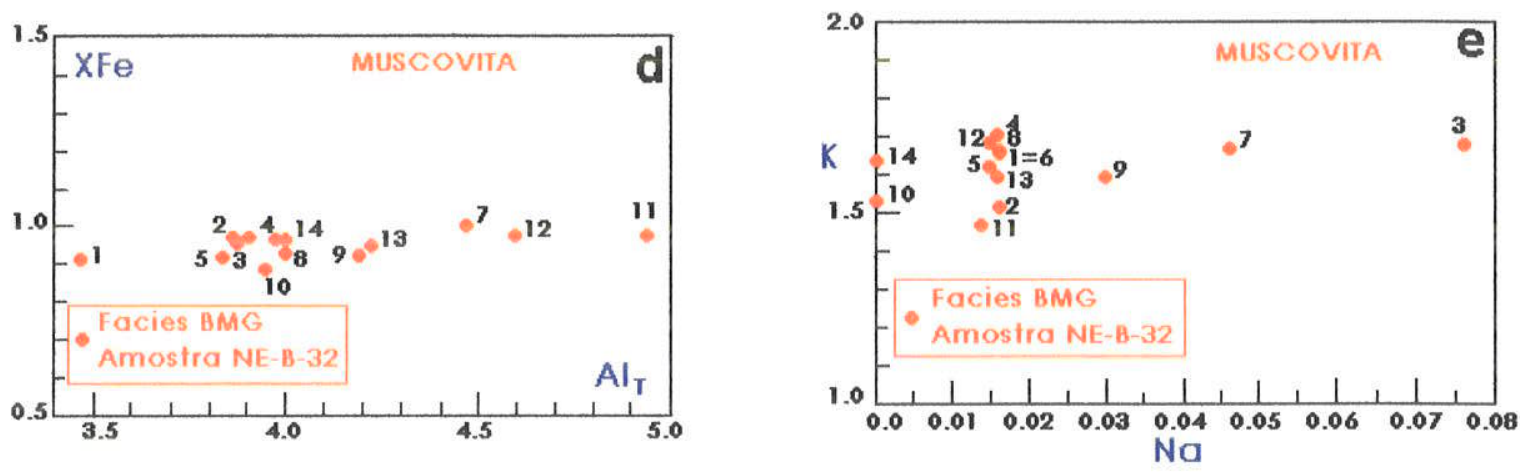

Figura 7.5- Representação composicional catiônica da muscovita da facies BMG do maciço granitóide Ubim/Sul. a) Si-AIT; b) Mg-AIT; c) Ti-AIT; d) Xfe-AIT; e) K-Na.

\subsubsection{2- Substituições}

A Figuras 7.6 e 7.7 mostram um grau baixo de substituição fengítica, muito similar para os cinco grãos analisados, uma vez que a substituição de $\mathrm{Al}^{\mathrm{lV}}$ por $\mathrm{Si}^{\mathrm{IV}}$ na camada tetraedral é muito pouco variável. Isso é traduzido pelo pequeno intervalo de variação nos teores de $\mathrm{Al}^{\mathrm{IV}}$ nos grãos estudados(entre 1,80 e 2.30). Observa-se, porém, um grau relativamente alto da substituição $\mathrm{Al}^{\mathrm{Vl}}$ por $\mathrm{Fe}^{3+}\left(\mathrm{Fe}^{3+} \rightarrow \mathrm{Al}^{\mathrm{Vl}}\right.$ ) nos grãos 2(análises $3,4,5,6$ e 7), 3(análises 8, 9 e 10), 4(análises 11 e 12) e 5(análises 13 e 14). Dessa forma, o excesso de carga provocado pela substituição fengítica é compensado pela entrada dos íons divalentes $\mathrm{Mg}^{2+}$ e $\mathrm{Fe}^{2+}$ no sítio octaedral. Na maioria dos grãos analisados, apenas o Mg contribuiu para essa substituição, visto que, de acordo com as Figuras 7.6 e 7.7, o ferro estrutural está no estado trivalente. Excetuam-se a isso as análises 5 e 10 . No grão 1 , verifica-see um grau muito baixo da substituição $\mathrm{Al}^{\mathrm{IV}}$ por $\mathrm{Fe}^{3+}$. Nesse caso, o excesso de carga provocado pela substituição fengítica foi compensado pela entrada de $\mathrm{Mg}^{2+}$ e $\mathrm{Fe}^{2+}$ no sítio octaedral, especialmente na área desse grão correspondente à análise 1 , visto que nessa análise uma pequena quantidade de ferro encontra-se no estado bivalente(Figura 7.7).

A Figura 7.8(baseada em Simões, 1992) presta-se para avaliar os graus de substituições fengítica e paragonítica. Nela, nota-se que a substituição paragonítica é muito reduzida(variando entre $0,5 \%$ e $4,5 \%$ ), enquanto que a substituição fengítica, dada pela \% da molécula celadonítica, mostra-se ausente na maioria dos grãos analisados, uma vez que os valores dessa variável são, em grande parte das análises, negativos. Entretanto, em porções de alguns grãos ela encontra-se presente, variando de $0,5 \%$ e $10 \%$. 

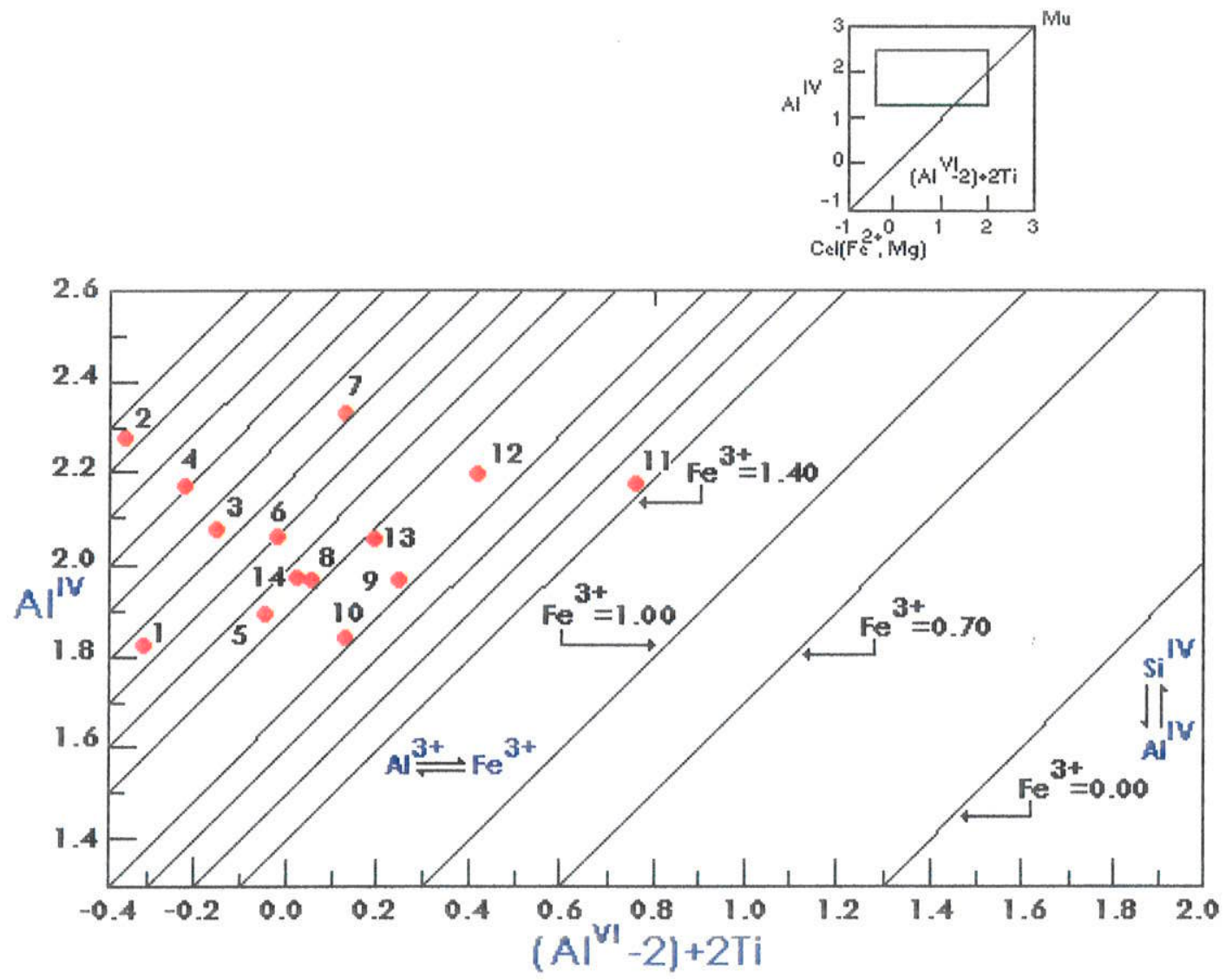

Figura 7.6- Representação composicional da muscovita da facies BMG do maciço granitóide Ubim/Sul no diagrama AlV versus [(Al $\left.\left.{ }^{\mathrm{Vl}}-2\right)+2 \mathrm{Ti}\right]$ de Cathelineau(1982), modificado de Dias(1987). In: Simões(1992).

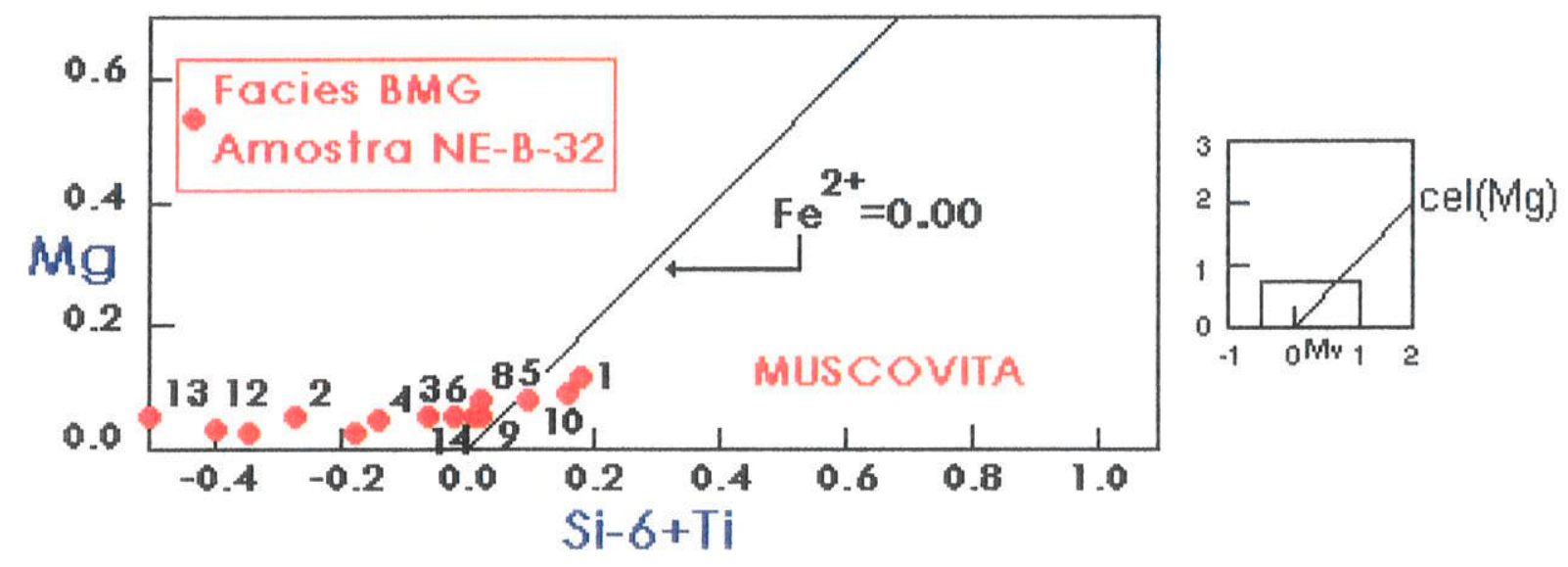

Figura 7.7- Representação composicional da muscovita da facies BMG do maciço granitóide Ubim/Sul no diagrama Mg-(Si-6+Ti), modificado de Dias(1987). In: Simões(1992). 


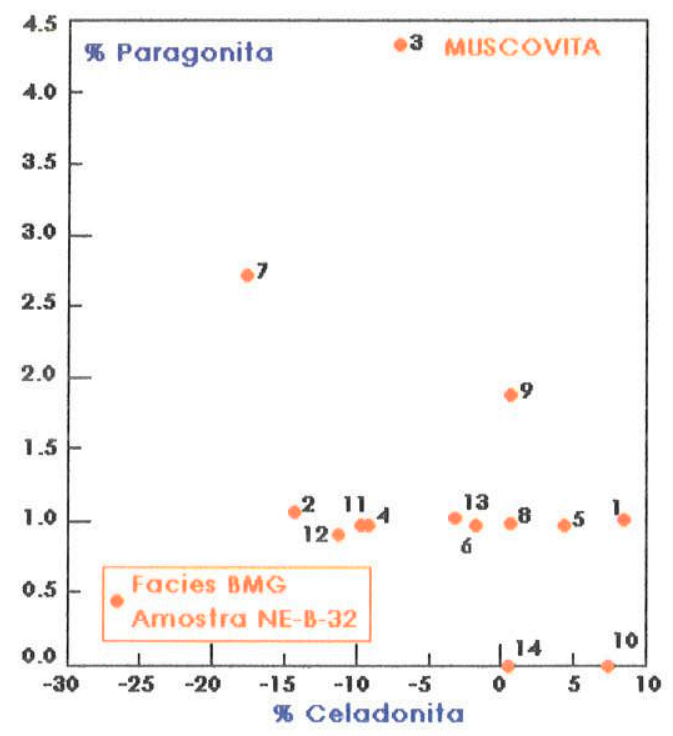

Figura 7.8- Representação gráfica das percentagens das moléculas paragoníticas e celadoníticas presentes na muscovita da facies BMG do maciço granitóide Ubim/Sul, de acordo com Simões(1992). $\%$ mol. paragonita $=100 \times \mathrm{Na} /(\mathrm{Na}+\mathrm{K}) ; \quad \%$ mol. celadonita $=100 \times(\mathrm{Si}-6) / 2$.

\subsubsection{3- Classificação e Representação Gráfica}

Para a classificação e representação gráfica da muscovita estudada utilizou-se o método de Tischendorf et al.(1997). Assim, as composições da mesma quando lançadas no diagrama $\left[\left(\mathrm{Fe}_{\mathrm{T}}+\mathrm{Mn}+\mathrm{Ti}\right)-\mathrm{Al}{ }^{\mathrm{Vl}}\right]$ versus $(\mathrm{Mg}-\mathrm{Li})$ desse autor, Figura 7.9, ocupam inteiramente o campo $d$ da fengita, embora muito próximo à linha limítrofe com a área da Li-fengita, com algumas análises situando-se no quadrante das $\mathrm{Li}$-Al micas e outras em cima da divisa entre este quadrante e aquele das $\mathrm{Mg}-\mathrm{Al}$ micas.

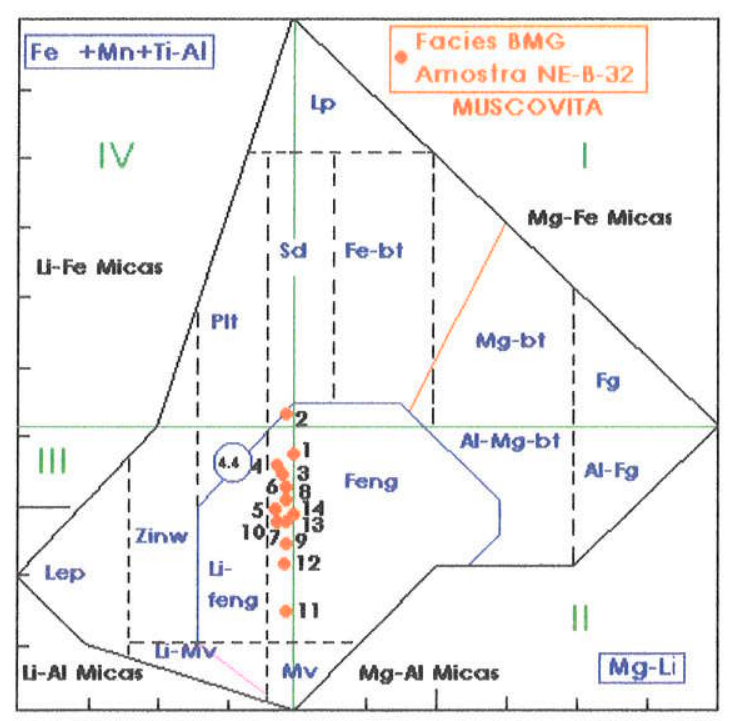

Figura 7.9- Distribuição composicional da muscovita da facies BMG do maciço granitóide Ubim/Sul no diagrama [(FeT+Mn+Ti)-(Mg-Li)], de classificação composicional e nomenclatura de micas trioctaédricas e dioctaédricas apresentado por Tischendorf et al.(1997). 


\subsubsection{4- Origem}

Os estudos de lâminas delgadas indicara trata-se de uma mica branca secundária formada, às custas da biotita primária, no estágio de alterações tardi a pós-magmáticas.

Os dados químicos quando lançados no diagrama triangular $\mathrm{Mg}-\mathrm{Ti}-\mathrm{Na}$ de Miller et al.(1981), Figura 7.10, mostram que a composição da muscovita estudada incide tanto no campo das muscovitas primárias, quanto no campo das micas secundárias. Comparativamente às muscovitas estudadas por Miller et al.(1981) e Monier et al.(1984) e Simões(1992), bem como aquelas da facies SMGP do maciço granitóide Mocambo, essa muscovita tem mais afinidades com a muscovita secundária. Ela possui baixos conteúdos de $\mathrm{Ti}, \mathrm{Na}, \mathrm{Si}, \mathrm{Al}$ e $\mathrm{Mg}$. Estas características contrariam a condição de muscovita primária se comparada com aquela estudada por Miller et al.(1981). Além disso, certas análises de muscovita, texturamente secundária (Miller et al., 1981; Figura 2b, pg 28), incidem campo da muscovita primária, o que significa dizer que nem sempre o quimismo de micas brancas serve como indicador da natureza primária ou secundária das mesmas. Conclui-se, portanto, que em muitos casos, análises microtextuturais(microscopia ótica) são mais eficazes na ceracterização da natureza dessas micas do que dados químicos, a exemplo do que tem sido comentado neste trabalho.

Uma outra alternativa, seria atribuir a distribuição composicional da muscovita estudada, a erros analíticos, já que o limite entre os dois campos( $P$ e $S)$ foi definido estatisticamente, possibilitanto que pequenos distorções nas análises desloquem a composição da mesma de um campo para o outro. Entretanto, isso parece não ter ocorrido, já que o fechamento das análises foi considerado satisfatório.

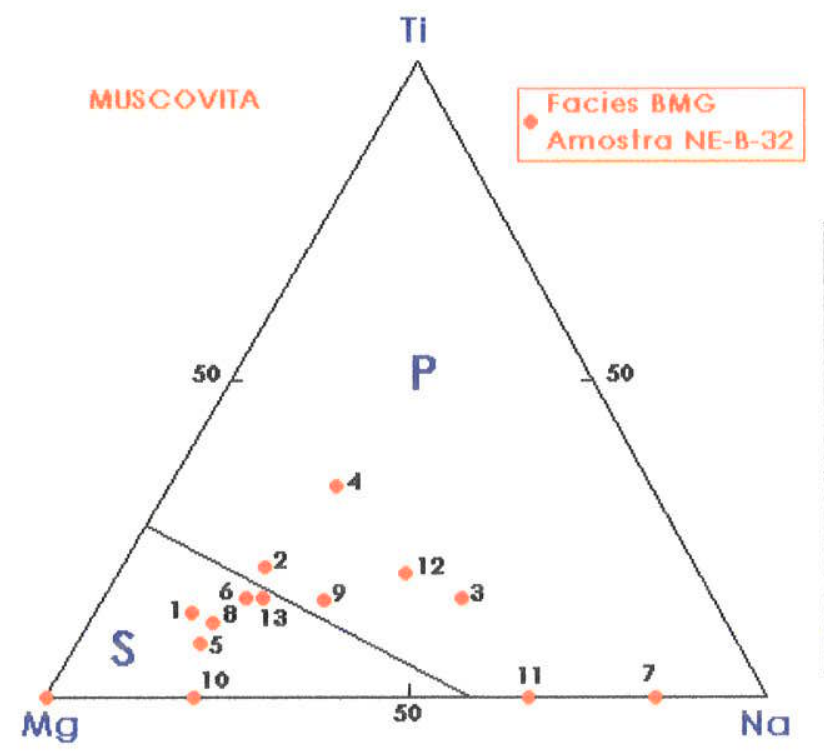

Figura 7.10- Distribuição composicional da muscovita da facies BMG do maciço granitóide Ubim/Sul no diagrama triangular Mg-Ti-Na de Miller et al.(1981). $\mathrm{P}=$ campo composicional da muscovita primária; $\mathrm{S}=$ campo composiocional da muscovita secundária. 


\subsubsection{3- Análises químicas em Feldspato potássico}

Foram executadas 11 análises pontuais em dois grãos de feldspato potássico $2\left(\mathrm{Fk}_{2}\right)$ da amostra NE-B-32 da facies BMG. Os resultados analíticos, as fórmulas estruturais e as proporçõpes Ab-Or-An encontram-se no anexo 45.

\subsubsection{1- Composição química}

O diagrama Ab-Or-An(Figura 7.11) revela os dois extremos composicionais do feldspato potássico: o termo potássico e o termo sódico(porção albítica das pertitas). A molécula Or varia de 1 a $99 \%$, a Ab oscila entre 1 e $98 \%$ e a An mostra teores extremamente baixos, alcançando no máximo $2 \%$. Uma tendência de aumento nas quantidades da fração anortita paralelamente a um aumento na molécula $A b$ não é observada, contrariando o que foi comentado em relação ao feldspato potássico dos granitóides do maciço Antônio Vicente.

De acordo com Deer et al.(1966), a molécula de anortita tem, geralmente, teores baixos de sanidina(menor do que $1 \%$ de $\mathrm{CaO}$ ). No ortoclásio, contudo, a quantidade de $\mathrm{CaO}$ tende a aumentar à medida que a razão $\mathrm{Na} / \mathrm{K}$ cresce, aproximando-se da composição da albita. No caso do feldspato estudado, isso é observado nas análises 7, 8 e 10(Anexo 45), embora isso não se verifique nas análises 4 e 6.

Em relação à temperatura de cristalização não houve condições de estimá-la em razão dos cristais de feldspato potássico apresentarem-se alterados(albitizados e/ou argilizados), não sendo, portanto recomendada a utilização de quaisquer geotermômetros existentes na literatura(Haselton et al., 1983; Brown \& Parsons, 1985; Elkins \& Grove, 1990; NekvasiL, 1994; entre outros). O mesmo é válido para o plagioclásio.

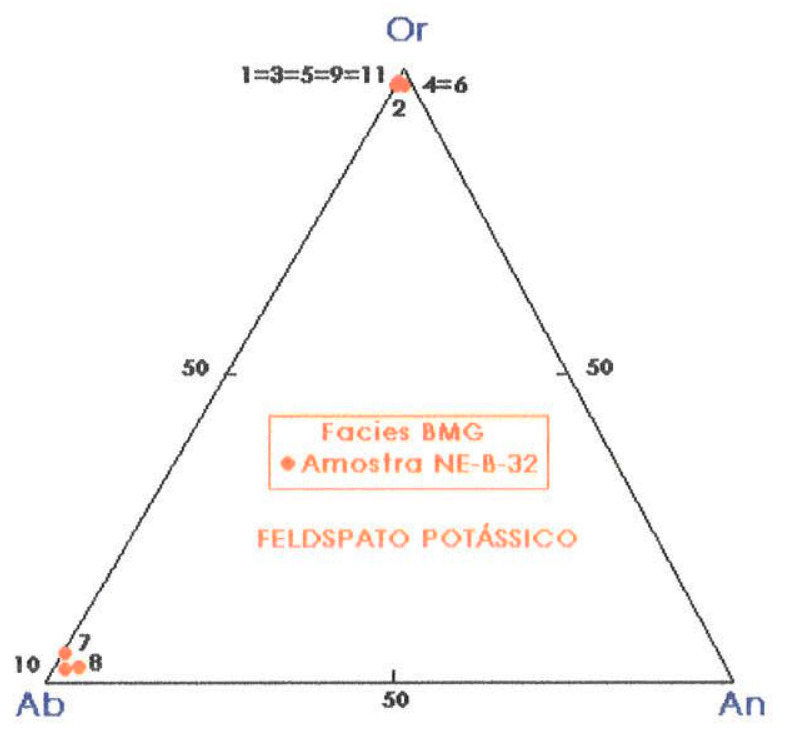

Figura 7.11- Distribuição composicional do feldspato potássico da amostra NE-B-32 do maciço granitóide Ubim/Sul no diagrama triangular A-Or-An. 


\subsubsection{4- Análises químicas em Plagioclásio}

O estudo do plagioclásio envolveu 08 análises pontuais em dois grãos de plagioclásio $1\left(\mathrm{Pl}_{1}\right)$ da amostra NE-B-32 da facies BMG. Os resultados analíticos, as fórmulas estruturais calculadas, bem como outros dados encontram-se no Anexo 46.

\subsubsection{1- Composição química}

Em termos composicionais, as análises mostram um espectro de variação da molécula $\mathrm{Ab}$ entre $96 \%$ e $99 \%$, a molécula An entre $0 \%$ e $3 \%$ e a molécula Or entre $1 \%$ e 2\%(Figura 7.13). Esse caráter fortemente albítico do plagioclásio evidencia a descalcificação do mesmo em função dos processos de alterações tardi a pós-magmáticas que imperaram sobre a facies granitóide que o hospeda, os quais são traduzidos pelo desenvolvemento, às custas do mesmo, da paragênese sericita \pm muscovita \pm clorita $1 \pm$ fluorita \pm epidoto \pm topázio. Em outras palavras, essas composições não refletem as composições magmáticas originais do plagioclásio estudado.

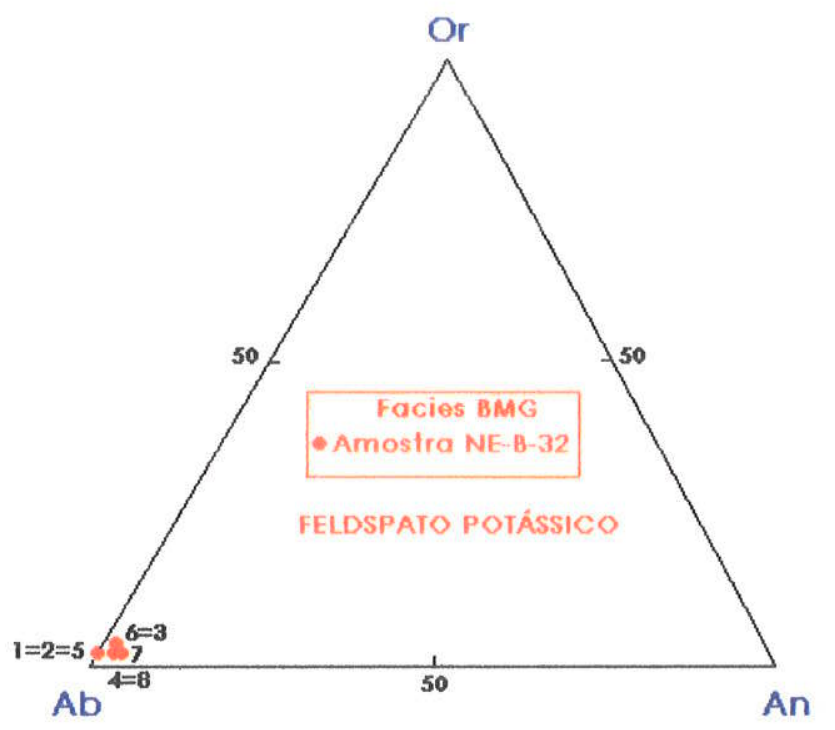

Figura 7.12- Distribuição composicional do plagioclásio da amostra NE-B-32 do maciço granitóide Ubim/Sul no diagrama triangular A-Or-An.

\subsection{2- Análises quínmicas através de Microscopia Eletrônica.}

Duas análises foram realizadas na amostra NE-B-32 da facies BMG. Elas envolveram as fases thorita e "davidita"(?). Em ambos os casos não foram confeccionadas imagens através de MEV. Entretanto, observações realizadas através de microscopia ótica revelaram que a thorita ocorre como minúsculos grãos inclusos em lamelas de biotita parcialmente cloritizada. Ao contato com a mesma desenvolve nítidos halos pleocróicos. Algumas vezes, exibe bordas de alteração que, no grão analisado, correspondem à "davinita". Suas relações microtexturais com a biotita hospedeira, indicam uma origem primária para a thorita e secundária para a "davidita". 
Quimicamente, a thorita, afora seus componentes essenciais - $\mathrm{Si}, \mathrm{O}$ e Th - abriga 5 , $64 \%$ de $\mathrm{Y}$ e $1,21 \%$ de $\mathrm{Ce}$ e concentrações muito reduzidas de $\mathrm{Ca}, \mathrm{Al}, \mathrm{Zr}, \mathrm{Nd}$, La, K, Yb, Mg e $\mathrm{Na}$ (em ordem decrescente de abundância), que ocorrem, ao que tudo indica, sob a forma de impurezas(Anexo 47).

A "davidita", por sua vez, corresponde a um silicato de Ti que hospeda quantidades um pouco elevadas de $\mathrm{U}, \mathrm{Th}, \mathrm{Y}$, e $\mathrm{Nb}$ e conteúdos bem mais modestos de $\mathrm{Ta}, \mathrm{Sn}$ e $\mathrm{Al}$. Comparativamente, à outras fases minerais com quimismo semelhante, apresentadas na literatura, observa-se que a fase estudada se aproxima, composicionalmente, da davidita(Foord, 1982; pg. 201-202). Entretanto, como não se dispõem de informações sobre a sua estrutura cristalina, não foi possivem concluir inequivocamente sobre a designação da mesma.

\section{6- Geoquímica}

Os resultados analíticos apresentados na Tabela 7.4(Anexo 48) correspondem às principais facies petrográficas identificadas no contexto do maciço granitóide Ubim/Sul.

\subsection{1- Características Gerais}

As facies granitóides $\mathrm{BSGCl}$ e BMG são diferenciados muito evoluídos e extremamente silicosos, cujos conteúdos de $\mathrm{SiO}_{2}$ são sempre superiores a $75 \%$ à semelhança dos granitóides dos demais maciços ora estudados. Em relação aos óxidos maiores, eles apresentam conteúdos de $\mathrm{TiO}_{2}, \mathrm{Al}_{2} \mathrm{O}_{3}, \mathrm{MgO}, \mathrm{CaO}, \mathrm{Na} \mathrm{O}_{2}$ e $\mathrm{P}_{2} \mathrm{O}_{5}$ muito baixos e inferiores àqueles da média dos granitos(Le Maitre, 1976), enquanto que os de $\mathrm{K}_{2} \mathrm{O}$ são ligeiramente mais altos e os de $\mathrm{Fe}_{2} \mathrm{O}_{3}$ săo eqüivalentes. Exibem altos teores de $\mathrm{Rb}$ (média entre 662 e 698ppm), Zr(média entre 67 e 119ppm), Y(média entre 121 e 177ppm), $W$ (média entre 141 e $324 \mathrm{ppm}$ ) e F(média entre 3288 e $4799 \mathrm{ppm}$ ), conteúdos moderados de $\mathrm{Nb}$ ( média entre 71 e $79 \mathrm{ppm}$ ) e Th(média entre 55 e $61 \mathrm{ppm}$ ) e baixas quantidades de $\mathrm{Sr}($ média entre 13 e $60 \mathrm{ppm}), \mathrm{Ba}$ (média entre 25 e $37 \mathrm{ppm}), \mathrm{Ta}$ (média entre 12 e $14 \mathrm{ppm}$ ), $\mathrm{Hf}$ (média em torno de $7 \mathrm{ppm}$ ), Ga(média entre 27 e $28 \mathrm{ppm}$ ), Sn(média entre 12 e 53ppm), $\mathrm{Mo}$ (média entre 7 e $23 \mathrm{ppm}$ ), Co(média entre 22 e $35 \mathrm{ppm}$ ) e $\mathrm{Zn}$ (média entre 35 e 50ppm). $\mathrm{O} \mathrm{Cl}$ exibe concentrações médias muito variáveis(385ppm no $\mathrm{BSGCl}$ e $0,01 \mathrm{ppm}$ no $\mathrm{BMG}$ ). Os teores de $U$ são baixos na facies $B S G C l($ média $=25 p p m)$ e moderados na facies BMG (média=44ppm). Quanto aos ETR, ostentam conteúdos moderados(média entre 241 e $340 \mathrm{ppm}$ ), com as quantidades de ETRL(média entre 179 e $247 \mathrm{ppm}$ ) sendo mais elevadas do que aquelas de ETRP(média entre 63 e 93ppm; Tabela 7.5). As razões $\mathrm{Rb} / \mathrm{Sr}$ (média entre 11,67 e 49,93 ) e $\mathrm{Rb} / \mathrm{Ba}$ (média entre 18,85 e 26,46) são altas, exceto na amostra de número 6 da facies BMG(Tabela 7.4, Anexo 48), onde elas apresentam valores 
anomalamente mais baixos devido aos conteúdos mais elevados de $\mathrm{Ba}$ e de $\mathrm{Sr}$ na mesma. As razões $T h / U$ (média entre 1,41 e 2,16) são maiores que 1,00 e decrescem sistematicamente no sentido da facies BMG, enquanto as razões $\mathrm{K} / \mathrm{Rb}$ (média entre 56,29 e $59,47)$ são baixas se comparadas com aquelas dos granitos considerados normais(Shaw, 1968).

\subsection{2- Saturação em Alumina(ISA)}

Apesar dos granitóides desse maciço possuirem conteúdos de $\mathrm{Al}_{2} \mathrm{O}_{3}$ mais baixos do que aqueles da média dos granitos(Le Maitre, 1976), em termos da aluminoisidade, eles são peraluminosos(Figura 7.13). As razões moleculares NKIA variam entre $0,53 \mathrm{e}$ 0,63 (facies $B M G$ ) e entre 0,58 e 0,64 (facies $B S G C l$ ), enquanto que as razões $A / C N K$ oscilam entre 1,45 e 1,69(facies BMG) e entre 1,47 e 1,60(facies BSGCl).

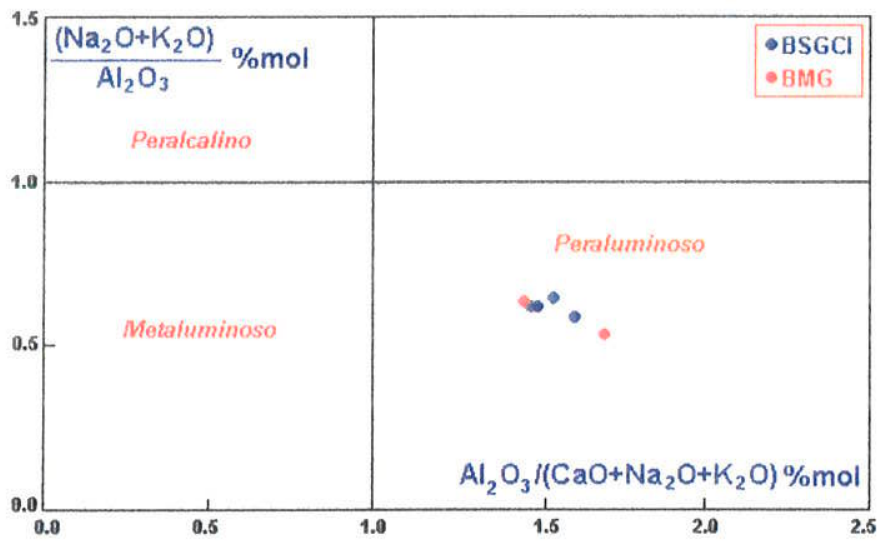

Figura 7.13- Diagrama binário A/CNK versus NK/A(Maniar\& Piccoli, 1989) mostrando a distribuição das facies granitóides do MGUS, com base nos indices de Shand(ISA).

\subsection{3 - Afinidade Tectonomagmática e Tipologia}

Nos Diagramas $\mathrm{Y}-\mathrm{Nb},(\mathrm{y}+\mathrm{Nb})-\mathrm{Rb}$ e Ta-Yb de Pearce et al.(1984) correspondentes à Figura 7.14(a, b e c, respectivamente), verifica-se que as composições dos granitóides ocupam o campo dos granitóides intra-placas à semelhança dos demais ocorrentes nos maciços ora estudados.
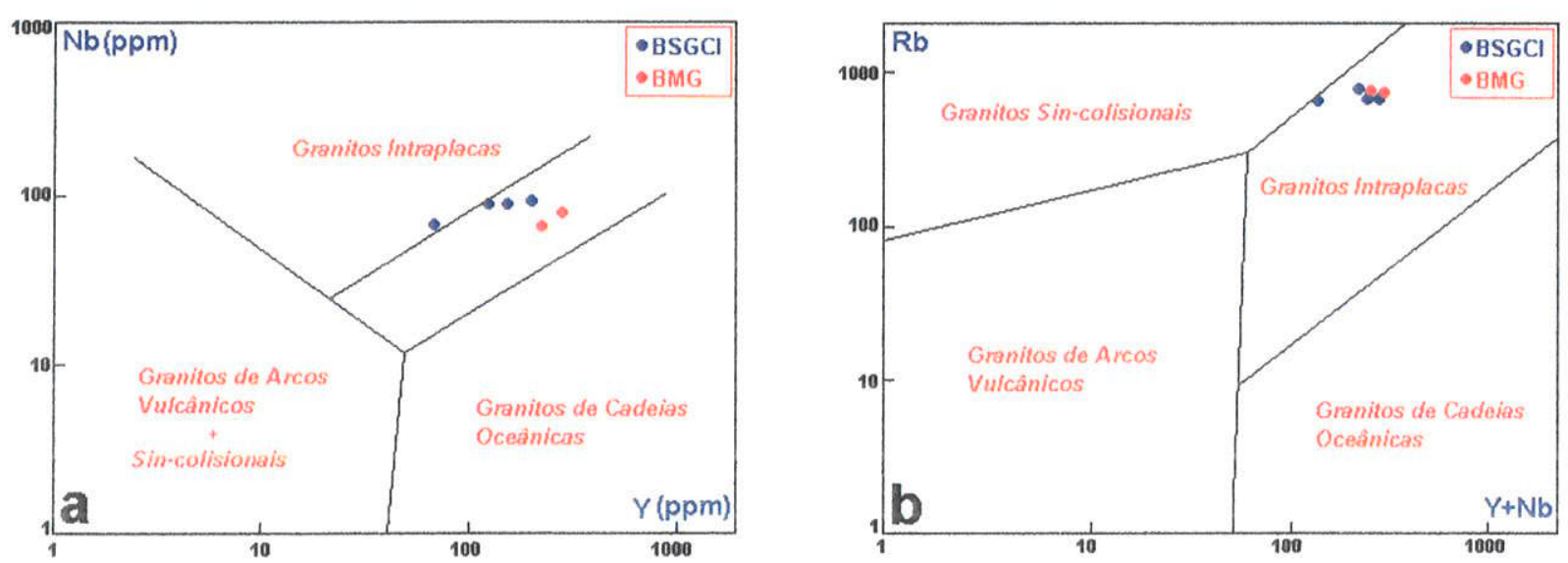


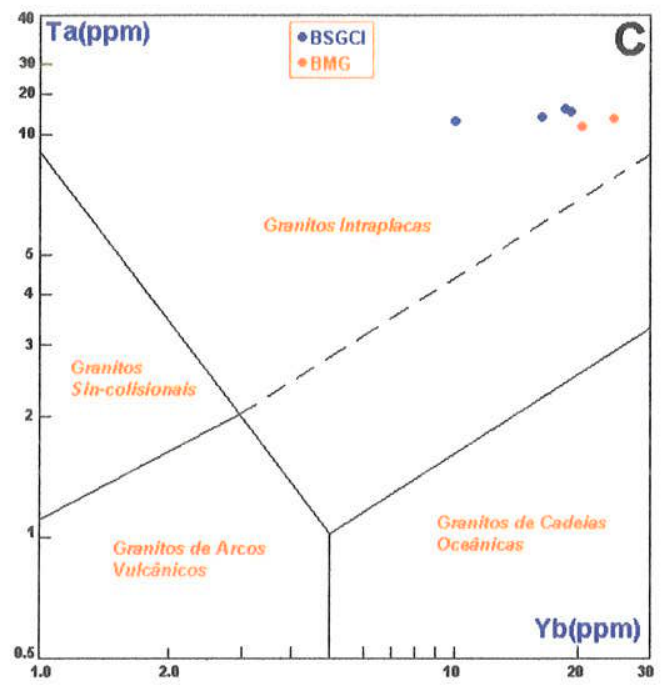

Figura 7.14- Diagramas discriminantes de paleoambiência tectônica de Pearce et al.(1984) mostrando a distribuição das amostras dos granitóides do MGUS. (a) Y-Nb; (b) [Nb+Y]-Rb; (c) Yb-Ta.

Objetivando caracterizar a tipologia dos granitóides estudados, utilizou-se os parâmetros discriminantes entre os granitos tipo-l e tipo-A de Whalen et al.(1987). No diagrama $\mathrm{Zr}+\mathrm{Nb}+\mathrm{Ce}+\mathrm{Y}$ vs. $\left(\mathrm{K}_{2} \mathrm{O}+\mathrm{Na}_{2} \mathrm{O}\right) / \mathrm{CaO}$, Figura $7.15 \mathrm{a}$, observa-se que as amostras incidem no campo correspondente aos granitos tipo-A.

No diagrama $\mathrm{Zr}+\mathrm{Nb}+\mathrm{Ce}+\mathrm{Y}$ vs. $\left(\mathrm{Fe}_{\mathrm{T}} / \mathrm{MgO}\right)$, dos mesmos autores, Figura $7.15 \mathrm{~b}$ (que expressa o grau de fracionamento) percebe-se que todas amostras ocupam o campo dos granitóides tipo-A, confirmando o que foi observado na Figura 7.15a.

No diagrama $10.000 \mathrm{Ga} / \mathrm{Al}$ vs. $\left(\mathrm{K}_{2} \mathrm{O}+\mathrm{Na}_{2} \mathrm{O}\right) / \mathrm{Al}_{2} \mathrm{O}_{3}$ de Whalen et al.(op. cit.), modificado por Rämö \& Haapala(1995), que exprime o grau de alcalinidade ou índice agpaítico, Figura $7.15 \mathrm{c}$, as amostras situam-se área composicional correspondente aos dos granitos tipo-A, de natureza subalcalina.

Adicionalmente, utilizou-se os diagramas discriminantes $\mathrm{Y}-\mathrm{Nb}-\mathrm{Ce}$ e $\mathrm{Y}-\mathrm{Nb}-3 \mathrm{Ga}$ de Eby(1992), Figura 7.16(a e b). Nesses diagramas verifica-se que a ampla maioria das amostras ocupa a área dos granitos do sub-grupo tipo- $A_{2}$. Em outras palavras, os granitóides desse maciço incidem no campo composicional que guarda certas semelhanças químicas com a média da crosta e com basaltos de arcos de llha(Eby, 1992). É exceção a isso a amostra de número 3 da facies $\mathrm{BSGCl}$, que incide no campo dos granitóides do sub-grupo $A_{1}$. Esse comportamento pode ser devido a mesma possuir conteúdos de $\mathrm{Y}$ e de $\mathrm{Ce}$ extremamente baixos em relação às demais amostras do grupo, já que os de Ga são equivalentes(Tabela 7.4, Anexo 48). Uma outra hipótese, seria atribuir esse posicionamento diferenciado, da amostra em questão, a erros analíticos, uma vez que o limite entre os dois campos foi definido estatisticamente e qualquer pequena perturbação nas análises pode levar uma composição a se deslocar de um campo para o outro. 

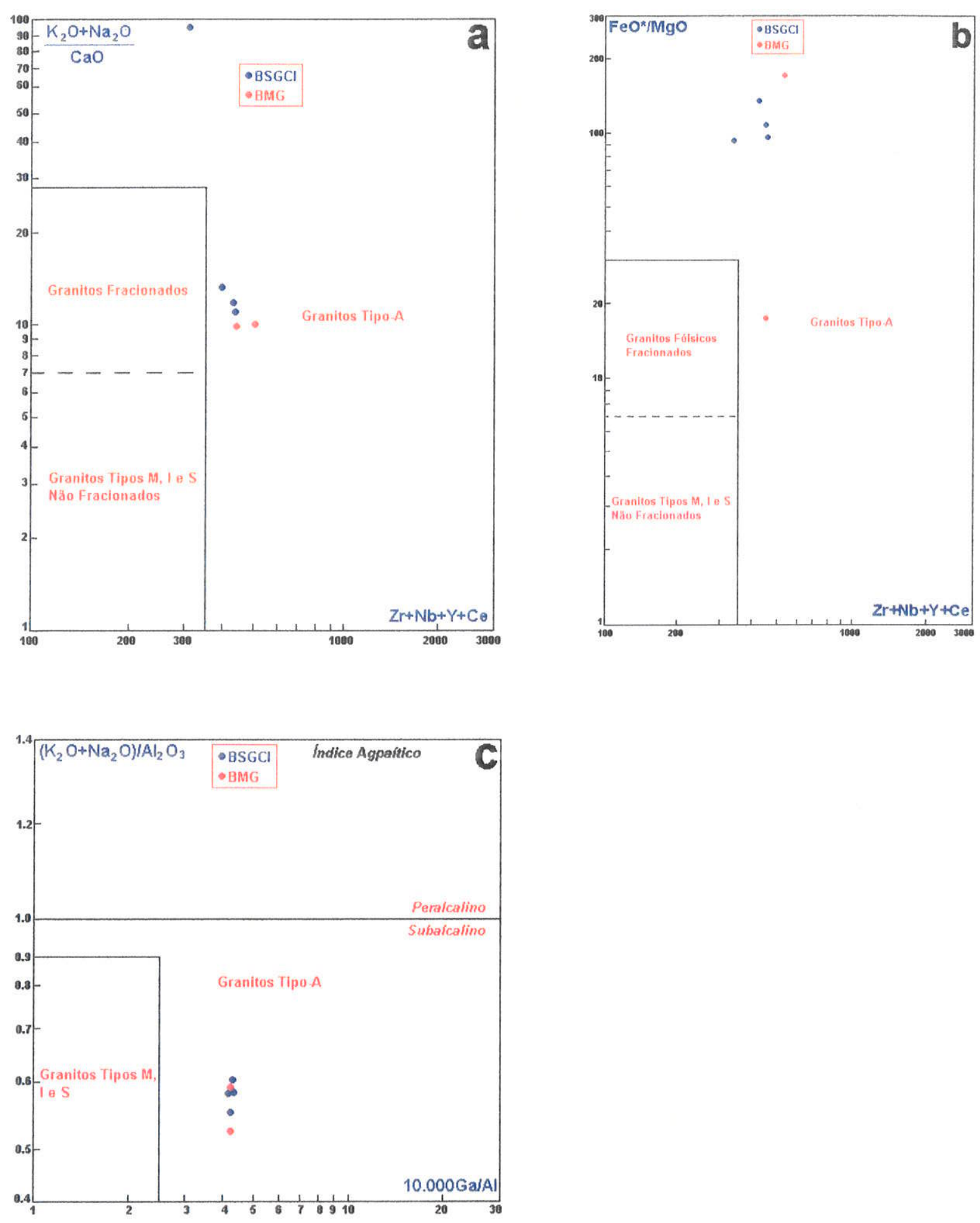

Figura 7.15- Diagramas disciminantes mostrando a tipologia e o grau da alcalinidade(ndice agpaítico) das principais facies granitóides do maciço granitóide Ubim/Sul. a) $\mathrm{Zr}+\mathrm{Nb}+\mathrm{Ce}+\mathrm{Y}$ vs. $\left(\mathrm{K}_{2} \mathrm{O}+\mathrm{Na}_{2} \mathrm{O}\right) / \mathrm{CaO}$ (Whalen et al., 1987); b) $\mathrm{Zr}+\mathrm{Nb}+\mathrm{Ce}+\mathrm{Y}$ vs. (FeOT/MgO) de Whalen et al.(1987); c) $10.000 \mathrm{Ga}$ vs. ( $\mathrm{K} 2 \mathrm{O}+\mathrm{Na2O}$ ) / Al2O3(Whalen et al., 1987; modificado por Rämö \& Haapala, 1995). 

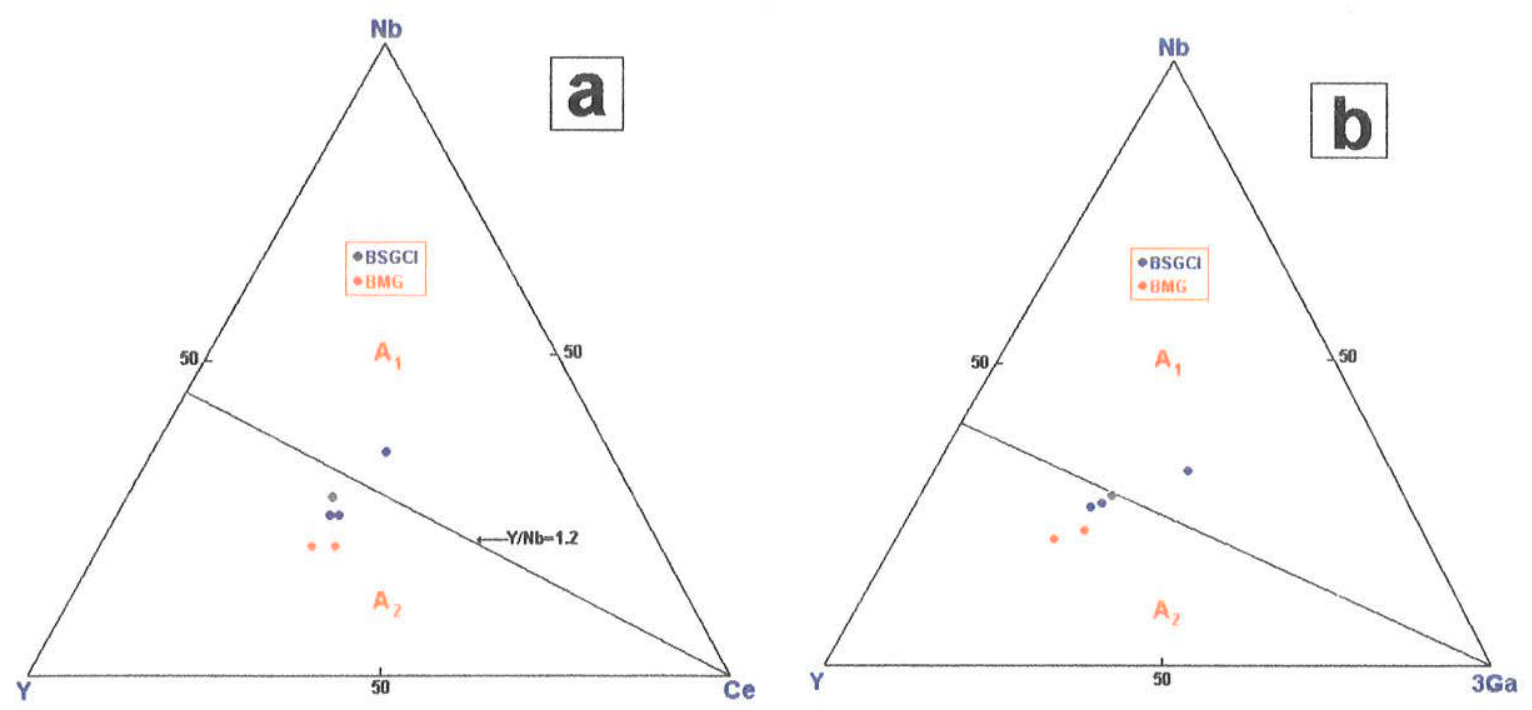

Figura 7.16- Diagramas triangulares $\mathrm{Y}-\mathrm{Nb}-\mathrm{Ce}(\mathrm{a})$ e $\mathrm{Y}-\mathrm{Nb}-3 \mathrm{Ga}(\mathrm{b})$ de Eby(1992) mostrando a distribuição composicional das principais facies granitóides do maciço granitóide Ubim/Sul.

\subsection{4- Outras Feições Geoquímicas}

$\mathrm{Na}$ Figura 7.17a observa-se que as razões K/Rb situam-se entre 50 e 100, embora mais próximas de 50 . Na facies $\mathrm{BSGCl}$ essa razão varia entre 52,01 e 62,84 , enquanto que na facies BMG ela oscila entre 50,81 e 62,03(Tabela 7.4. Anexo 48). Comparativamente aos outros maciços da suite, elas são semelhantes àquelas encontradas nos granitóides dos maciços granitóides Velho Guilherme e Benedita, são mais elevadas do que às determinadas no maciço granitóide Mocambo e se assemelham àquelas observadas nas facies BSGA e BAGIA do maciço granitóide Antônio Vicente.

$\mathrm{Na}$ Figura $7.17 \mathrm{~b}$ nota-se que as razões $\mathrm{Rb} / \mathrm{Sr}$, da ampla maioria das amostras, situam-se entre 40 e 100. Foge dessa condição, uma amostra da facies BMG, que ostenta razões entre 5 e 10. De qualquer modo, no geral, essa razão é semelhante às encontradas nos granitóides dos maciços granitóides Mocambo e Benedita, no BSGEm do maciço granitóide Velho Guilherme e nas facies BSGA e BSGIA do maciço granitóide Antônio Vicente.

No diagrama Rb-Ba(Figura 7.17c), verifica-se uma distribuição aleatória entre esses dois elementos. Percebe-se, ainda, que as razões $\mathrm{Rb} / \mathrm{Ba}$ de todas as amostras situam-se entre 10 e 40.

Na Figura 7.17d(El-Bouseily \& El-Sokkary, 1975) as amostras situam-se no campo correspondente aos granitóides extremamente diferenciados (EI Bouseily \& El Sokkary, 1975). É exceção, a esse comportamento, uma amostra da facies BMG que foge um pouco desse campo devido seu conteúdo mais elevado de $\mathrm{Sr}($ Tabela 7.4, Anexo 48). 
O $\mathrm{Zr}$ apresente-se em concentrações elevadas(Tabela 7.4, Anexo 48), o que é indicativo de que o mesmo comportou-se como elemento incompatível durante a diferenciação magmática. Foge a esse comportamento a amostra de número 5 (facies $\mathrm{BMG}$ ), cujo teor de $\mathrm{Zr}$ é igual a 12,50ppm. No diagrama $\mathrm{Rb}-\mathrm{Zr}$ (Figura 7.17e) percebe-se que as amostras amontouam-se em torno de um ponto comum, não definindo nenhum "trend" evolutivo. Nota-se, ainda, quee as razões $\mathrm{Zr} / \mathrm{Rb}$ são sempre muito baixas e variam entre 0,20 e 0,10 .

No Diagrama Th-U(Figura 7.17f) observa-se uma discreta correlação positiva entre essas duas variávais, caracterizada pela crescimento nas concentrações das mesmas no sentido da facies BSGCl para a facies BMG. Esse comportamento poderia representar um "trend" de diferenciaçã/fracionamento magmático entre os granitóides em questão, onde a facies $\mathrm{BSGCl}$ representaria o diferenciado menos evoluído e a facies BMG corresponderia ao termo mais evoluído. Entretanto, qualquer afirmação a esse respeito é prematura, visto que em outros diagramas envolvendo a distribuição de elementos incompativeis e compativeis esse comportamento não foi claramente observado. AllmanWard(1985) estudou a distribuição do Th e U no granito St. Austell(Inglaterra) e os efeitos dos processos de alteração sobre a concentração dos mesmos. Ele notou que enquanto o Th é imóvel, o $U$, altamente susceptível à lixiviação, é empobrecido durante todos os processos de alteração. No que se refere aos granitóides estudados isso parece ser coerente visto que os conteúdos de $U$ decrescem drasticamente no sentido da facies BMG(média igual a 43,60ppm) para a facies $\mathrm{BSGCl(média} \mathrm{igual} \mathrm{a} \mathrm{25,32ppm),} \mathrm{que}$ representa a facies mais afetada por alterações tardi a pós-magmáticas. Os conteúdos de Th, embora diminuam no mesmo sentido, mostram uma pequena variação( 61,40 para $54,68)$. Nesse caso o "trend" observado na Figura 7.17e representa o efeito dos processos de alterações tardi a pós-magmáticas.
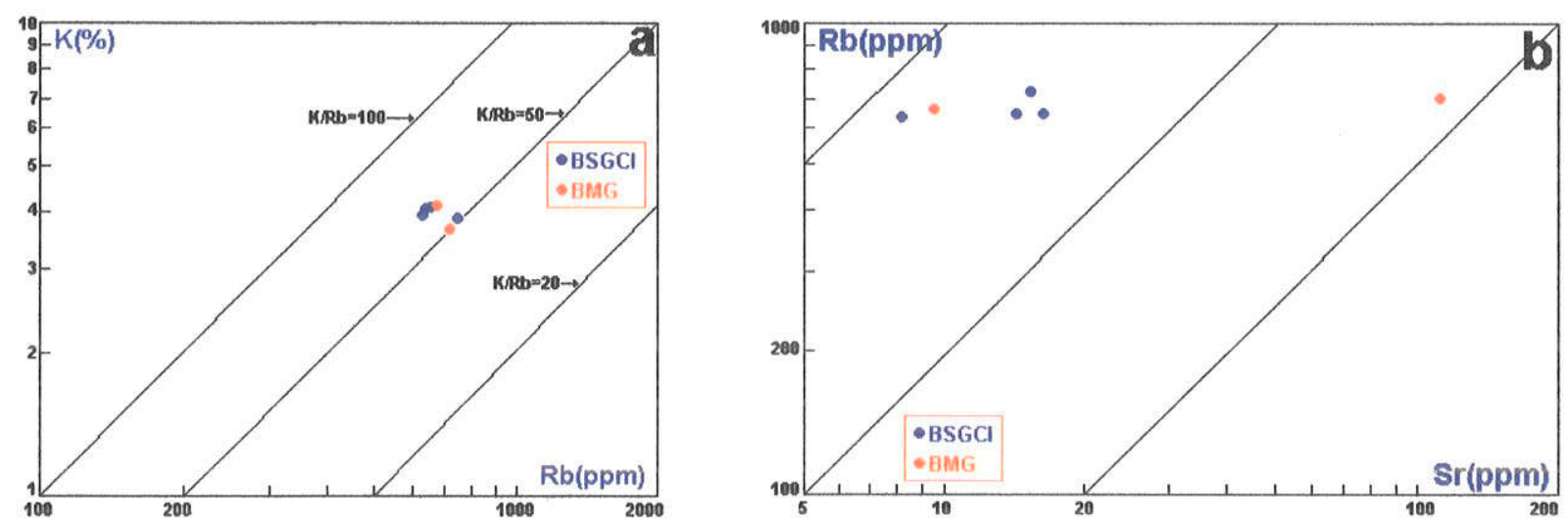

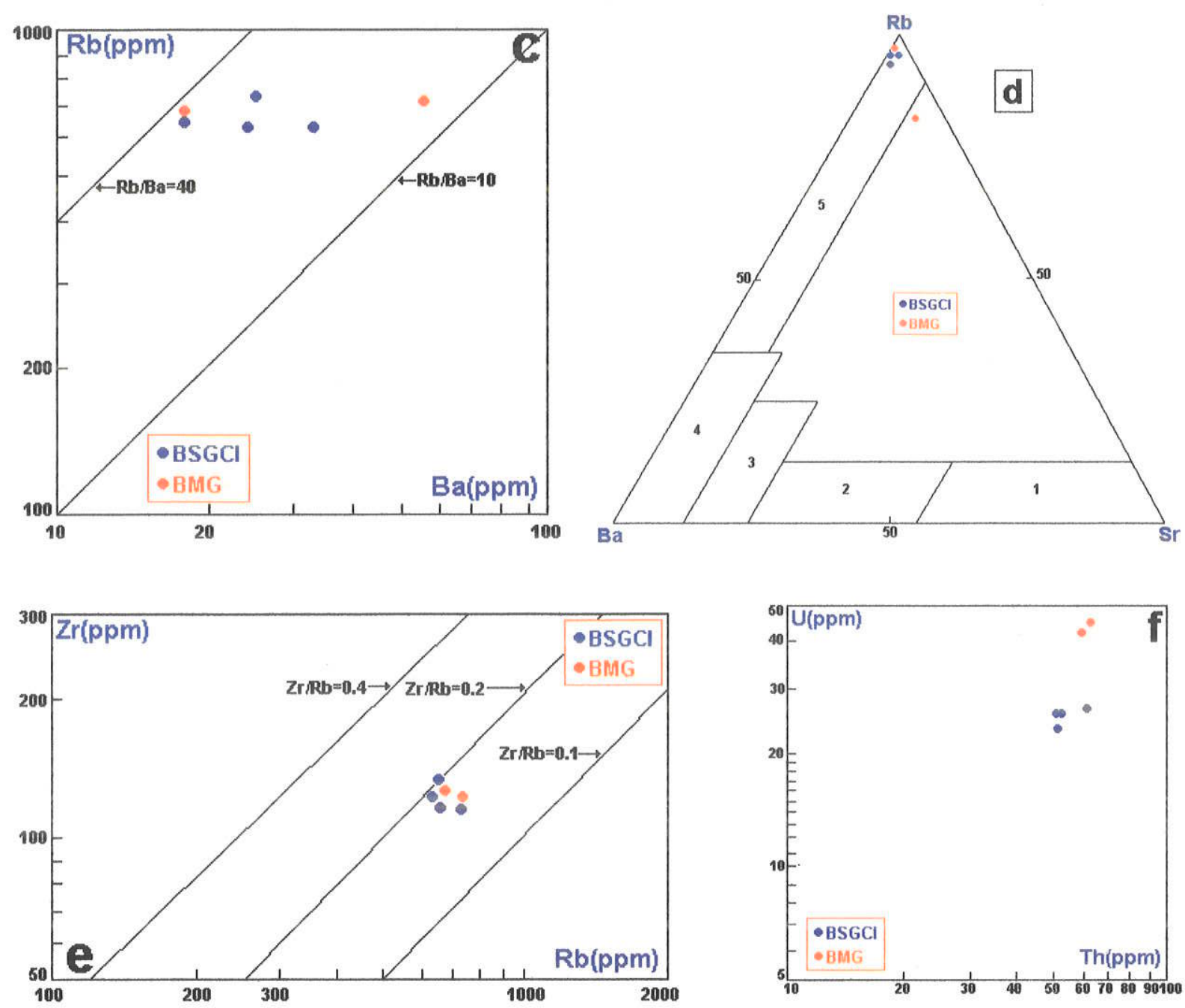

Figura 7.17- Distribuição composicional das amostras das principais facies granitóides do maciço granitóide Ubim/Sul nos diagramas (a) Rb-K; (b) Rb-Sr; (c) Rb-Ba-Sr(El-Bouseily \& Sokkary, 1975); (d) $\mathrm{Rb}-\mathrm{Zr}$; (e) Th-U. Os campos 1 a 5 do diagrama Rb-Ba-Sr correspondem, respectivamente, a dioritos, granodioritos e quartzo dioritos, granitos anômalos, granitos normais e granitos extremamente diferenciados.

Considerando que a fluorita é uma fase presente em todas as amostras desses granitóides, bem como foi detectada a presença de topázio na amostra de número 3 e de cassiterita na de número 9, ambas do BSGCI(Tabela 7.1), e que os mesmos foram formados no estágio de alterações tardi a pós-magmáticas, em decorrência de interações fluidos tardios/rocha, é importante analisar o papel do $\mathrm{F}$ e dos $\mathrm{Cl}$ nesses granitóides a exemplo do que foi realizado em relação aos granitóides dos demais maciços ora estudados.

Conforme visto nos capítulos anteriores,o conteúdo médio de F em granitóides é de cerca de 800ppm, embora os valores absolutos possam estar limitados entre dezenas de "ppm" e vários "porcentos"( Bailey(1977). 
A Tabela 7.4(Anexo 48) mostra que as concentrações de F variam entre 750ppm 5024ppm. Em termos dos seus conteúdos médios observa-se um crescimento dos seus teores no sentido da facies $\mathrm{BSGCl}(3287,50 \mathrm{ppm})$ para a facies $\mathrm{BMG}(4799 \mathrm{ppm})$. O Cl, por outro lado, não foi detectado em algumas amostras, embora ocorra em conteúdos elevados em outras. Na facies BSGCl observa-se os mais elevados conteúdos desse elemento(761 a $777 \mathrm{ppm})$, enquanto que no BMG ele é praticamente ausente( $\cong 0,02 \mathrm{ppm})$. E importante salientar que a amostra de número $3(\mathrm{BSGCl})$ apresenta a maior concentração de $\mathrm{Cl}(777 \mathrm{ppm})$, contém o menor conteúdo de $\mathrm{F}(750 \mathrm{ppm})$, possui o mais elevado teor de $S n(179,60 \mathrm{ppm})$ e corresponde a única amostra em que foi observada a presença de cassiterita. Isso demonstra que amostras com conteúdos elevados de $\mathrm{F}$ e quantidades reduzidas ou elevadas de $\mathrm{Cl}$ não hospedam necessariamente mineralizações de estanho e, em particular, de cassiterita. Fato semelhante foi verificado em granitóides dos maciços granitóides Antônio Vicente, Velho Guilherme, Mocambo e Benedita.

Assim, os dados químicos e petrográficos permitem estabelecer que rochas granitóides com teores expressivos de $\mathrm{F}$ e/ou de $\mathrm{Cl}$ ou mesmo com concentrações reduzidas desses voláteis, não são necessariamente enriquecidos em $\mathrm{Sn} e$, como consequuência, não são portadores de minerais de estaniferos tais como a cassiterita. Entretanto, granitóides com conteúdos elevados de $\mathrm{Sn}$ são, em geral, mineralizados à cassiterita, independentemente de possuírem concentrações expressivas ou não de $F$ e/ou de Cl.

No que diz respeito aos ETR(Tabela 7.4, Anexo 48), observa-se que os granitóides desse maciço apresentam-se enriquecidos em ETRL e em ETRP relativamente à abundância desses elementos na crosta continental(Shaw et al., 1986; Condie, 1993). Percebe-se, também, que as concentrações médias dos ETR são mais elevadas no BMG em relação ao $\mathrm{BSGCl}$. Considerando-se que essa última facies encontra-se mais intensamente afetada por alterações tardi a pós-magmáticas do que o BMG, é muito provável que o empobrecimento dos ETRL no BSGCl esteja ligado à essas alterações, uma vez que a presença de quantidades apreciáveis de fases de vapor, nos estágios tardi a pós-magmáticos, pode ter produzido uma redução nos conteúdos de ETRL(Miller \& Mittlefheld, 1982). No que se refere aos ETRP, seus mais baixos conteúdos no BSGCl em comparação à facies BMG não é claro. Entretanto, os ETR tendem a se empobrecer fortemente durante evolução de magmas félsicos(Miller \& Mittlefheld, 1982). Isso pode explicar, pelo menos em parte, os baixos valores de ETR nesses granitóides. Uma hipótese alternativa para interpretar essa questão é atribuir esses baixos valores à uma fonte magmática originalmente empobrecida nesses elementos. 
Suas concentrações normalizadas para condritos(Sun, 1982) desenvolvem um típico padrão "gaivota" , com uma moderada a forte anomalia negativa do Eu, a qual mostra-se um pouco mais acentuada na facies BSGCI(Figura 7.18). Isso deve decorrer da maior quantidade modal de plagioclásio na facies BMG em relaçãp à facies BSGCI(Tabelas 7.1 e 7.2), uma vez que o plagioclásio desses dois granitóides tem composições eqüivalentes.

$\mathrm{Na}$ Tabela 7.5 percebe-se que, em ambos os granitóides, a somatória dos conteúdos dos ETRL é mais elevada do que a dos ETRP, evidenciando a caráter mais incompatível dos ETRL em relação aos $\operatorname{ETRP}(\mathrm{Cox}$ et al., 1979; Figueiredo, 1985; Figueiredo, 1993). As razões médias $(\mathrm{La} / \mathrm{Yb})_{\mathrm{N}}$ decrescem no sentido do $\mathrm{BSGCl}$ para o $B M G$, enquanto que as razões $\left(E_{N} / E u^{*}\right)$ situam-se em torno de 13 à semelhança do que foi determinado nos granitóides dos maciços granitóides Antônio Vicente, Velho Guilherme, Mocambo e Benedita. Contrariamente ao que foi observado na Figura 7.17f(diagrama Th$\mathrm{U})$, as razões $(\mathrm{La} / \mathrm{Yb})_{\mathrm{N}}$ e as anomalias do $\mathrm{Eu}$ dos granitóides estudados, sugerem a existência de um discreto "trend" de diferenciação/fracionamento magmático dentre os mesmos, onde o BMG representa o diferenciado menos evoluído e o $\mathrm{BSGCl}$ corresponde ao diferenciado mais evoluído. Essa hipótese é respaldada no estudos petrográficos, visto que em termos modais, este "trend" também é observado(Figura 7.1). De qualquer modo, como o $\mathrm{BSGCl}$ foi mais fortemente afetada por alterações tardi a pós-magmáticas do que o BMG, é possível que a sua composição modal tenha sido mudada. Nessse caso, o "trend" observado na Figura 7.1 é falso. Em razão dissso, recomenda-se que, no futuro, um maior número de análises seja executado, com vistas a esclarecer em definitivo essa questõe.

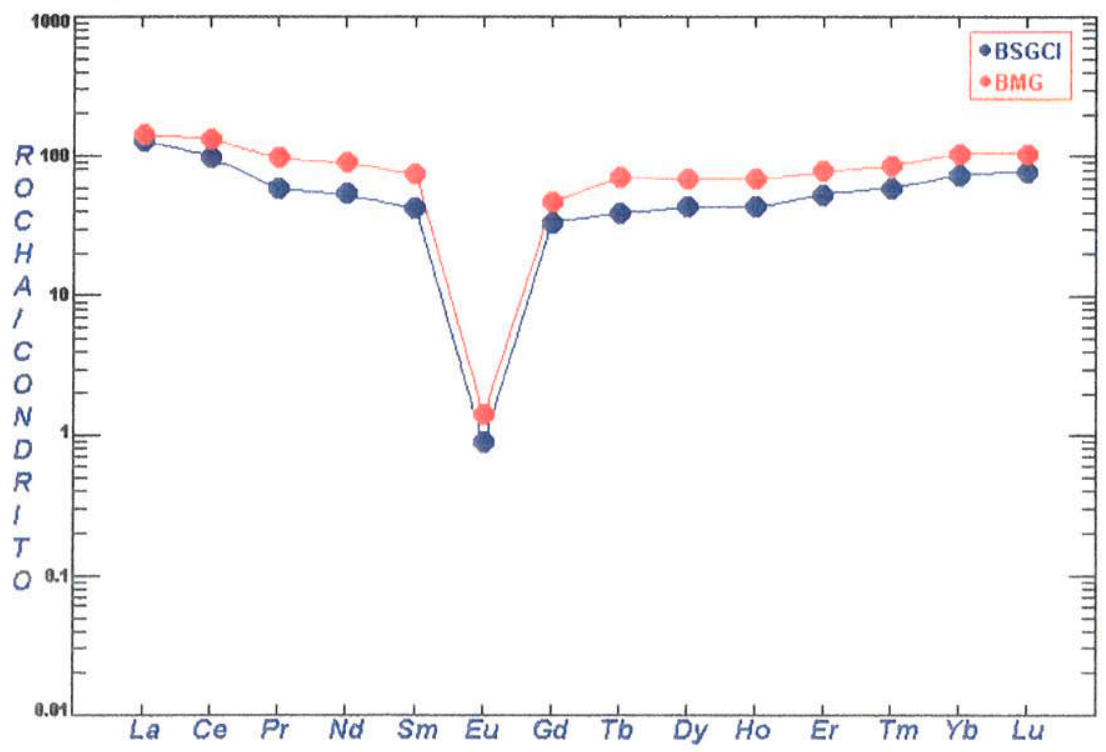

Figura 7.18-. Padrão de distribuição dos ETR para os granitóides do maciço Ubim/Sul. 
Tabela 7.5- Principais caracteristicas dos ETR nos granitóides do maciço granitóide Ubim/Sul.

\begin{tabular}{|l|c|c|}
\hline Facies Granitóides & BMG & BSGCI \\
\hline (La/Yb)N & 1,39 & 1,76 \\
\hline (EuN/Eu $)$ & 13,00 & 12,94 \\
\hline$\sum E T R L$ & 246,99 & 178,66 \\
\hline$\sum E T R P$ & 92,84 & 62,62 \\
\hline$\sum E T R$ & 339,64 & 241,35 \\
\hline
\end{tabular}

\subsection{5- Análises Normativas CIPW}

Os dados normativos CIPW foram obtidos à semelhança daqueles dos granitóides dos demais maciços ora estudados. Eles encontram-se na Tabela 7.6(Anexo 49) possibilitaram estabecer as seguintes considerações:

1) Os granitóides desse maciço são invariavelmente saturados em $\mathrm{Al}_{2} \mathrm{O}_{3}$, fato que é traduzido pele presença constante de córindon normativo nas análises dos mesmos.

2) Os conteúdos de anortita variam erraticamente e, do mesmo modo, as razões Ab/An.

3) Os teores de Hy são sempre muito baixos e constantes na facies $B S G C l(0,05 \%)$, mas são muito variáveis na facies $\mathrm{BMG}(0,03$ a 0,26$)$, embora sejam igualmente baixos.

4) As quantidades de magnetita variam aleatoriamente, enquanto que as de hematita decrescem no sentido da facies BSGCl para a facies BMG e as de ilmenita são constantes $(0,08 \%)$.

No diagrama Q-Ab-Or(Figura 7.19a) observa-se que as composições normativas dos granitóides desse maciço incidem, quase que inteiramente, no campo de $86 \%$ de freqüência das razões normativas $Q$-Ab-Or de 1190 rochas graniticas de Winkler e Von Platen(1961), já que uma amostra da facies BMG incide fora desse campo. Nota-se, ainda, que elas encontra-se afastada do campo de máxima freqüência(ponto $M$ ) em direção ao vértice do quartzo, devido aos processos de silicificação e mostra-se levemente deslocada para a direita desse campo, ao que todo indica, em decorrência dos processos de microclinização.

A exemplo dos granitóides dos outros maciços ora estudados, embora esses granitóides mostrem-se afetados por albitização, seu efeito não influenciou suas 
composições normativas globais. Isso demonstra que os processos de alteração se deram segundo um sistema fechado, fato que não permitiu um aporte de $\mathrm{Na}$ ao mesmo. Com relação ao $\mathrm{F}$, verifica-se que o magma gerador desses granitóides era pobre nesse elemento, uma vez que suas composições situam-se abaixo da posição de temperatura do ponto de mínimo sem adição de $F($ Tuttle \& Bowen, 1958). Isso demonstra que o $F$ foi remobilizado e enriquecido no estágio de alterações tardi a pós-magmáticas, tal qual foi observado nos granitóides dos demais maciços estudados. Isso é evidenciado pelas concentrações expressivas desse elemento nos granitóides desse maciço(Tabelas 7.4, Anexo 48), que se traduz pela presença das quantidades modais elevadas de fluorita, às vezes de topázio(Tabelas 7.1 e 7.2).

Ainda no que se refere a esse diagrama, nota-se que as composições do BMG e uma do $\mathrm{BSGCl}$ situam-se em torno da projeção da linha cotética de $\mathrm{P}_{\mathrm{H} 2 \mathrm{O}}$ de $2 \mathrm{kbar}$ de Winkler(1977). A outra composição d BSGCI incide abaixo da projeção dessa linha.

No diagrama Ab-An-Or(Figura 7.19b), as composições dos granitóides distruiem-se próximo à aresta $\mathrm{Ab}-\mathrm{Or}$, com um pequeno deslocamento para o vértice do Or.

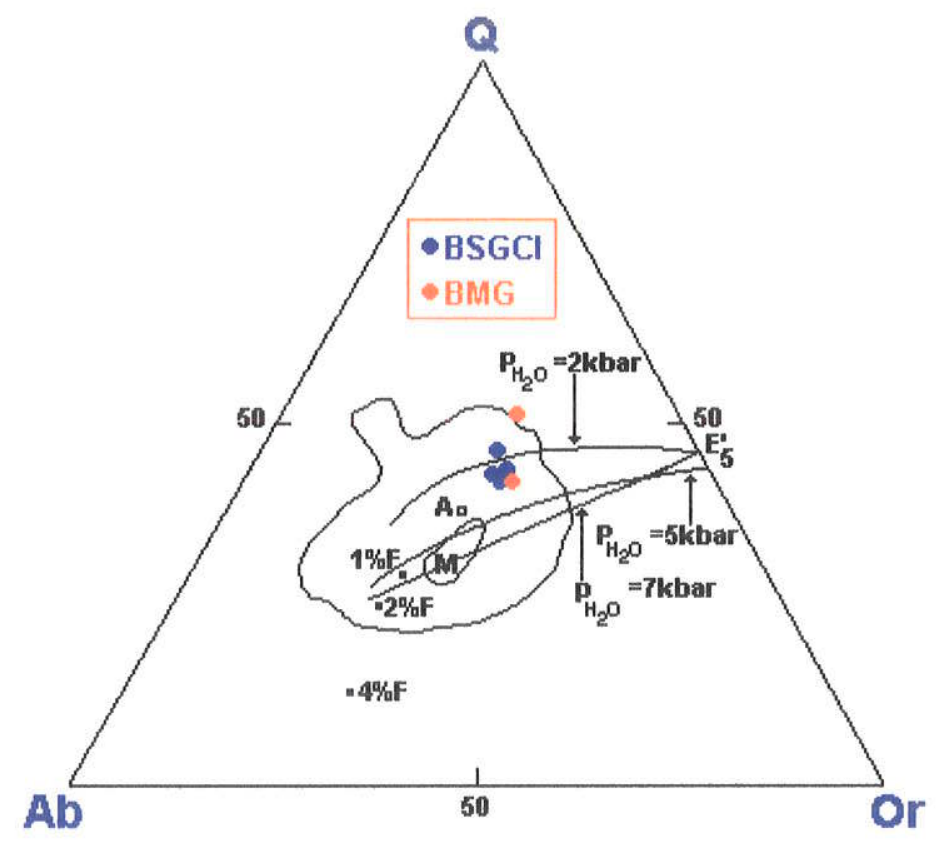

Figura 7.19a- Diagrama normativo Q-Ab-Or mostrando a distribuição composicional das principais facies granitóides do maciço granitóide Ubim/Sul. A curva envoltório dos postos composicionais corresponde ao campo de freqüência das razões Q-Ab-Or de 1190 rochas graníticas de Winkler \& Von Plaren(1961). As projeções das linhas cotéticas isobáricas P-E'5 de 2, 5 e $7 \mathrm{kbar}$ foram compiladas de Winkler(1977). $M=$ é o máximo de freqüência das rochas graníticas, $A=$ a posição e temperatura do ponto de mínimo sem $\mathrm{F}$ (Tuttle \& Bowen, 1958). 1\%F, $2 \% \mathrm{~F}$ e $4 \% \mathrm{~F}$ representam as posições e temperaturas dos pontos de mínimo com $F$ adicionado e excesse de água a $1 \mathrm{kbar}($ Manning, 1981). 


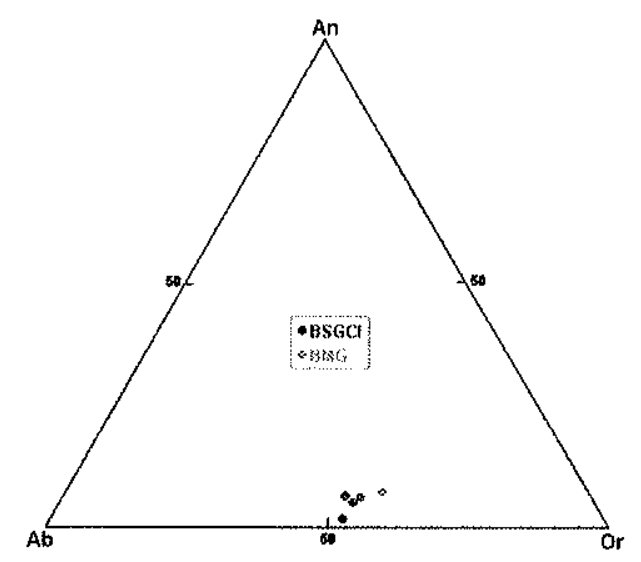

Figura $7.19 \mathrm{~b}$ - Diagrama normativo Ab-An-Or mostrando a distibuição composicional das principais facies petrográficas do maciço granitóide Ubim/Sul.

\section{7- Condições de Cristalização}

Em relação a esse aspecto, são válidas aqui as considerações feitas a esse respeito no capítulo anterior, quando da discussão das condições de cristalização dos granitóides do maciço Benedita.

\section{8- Conclusões e Considerações Finais}

Os estudos petrográficos aliados às análises químicas de fases minerais e de rocha total, envolvendo elementos maiores, elementos traços e ETR permitiram estabelecer as seguintes conclusões à respeito desse maciço granitóide:

1) nesse maciço foram caracterizadas duas variedades de granitóides, as quais mostramse representadas por biotita sienogranito com clorita e biotita monzogranito. Eles possuam caráter holo-leucocrático e mostram valores de $M^{\prime}<5 \%$.

2) as características petrográficas observadas nesses ganitóides permitem concluir que os mesmos, a exemplo dos granitóides dos demais maciços ora estudados, cristalizaram a partir de líquidos muito evoluídos e silicosos, cujas principais evidências são traduzidas pelos elevados conteúdos em quartzo modal (quase sempre superiores a $30 \%$ ), bem como pelos baixos teores de máficos.

3) análises químicas de clorita da facies BMG, indicaram que tratar-se de uma clorita não oxidada, de composição correspondente. A pequena variação composiciona observada decorreu de processos de substituições catiônicas, nas quais prevaleceram mecanismos mais compatíveis com aqueles da equação 2 de Cathelineau(1988; pg. 478).

4) os baixos valores de $\mathrm{Fe}^{3+}$, aliados a muito provável ausência de magnetita na facies BMG, desse maciço, demonstram que a clorita em questão cristalizou em condições de 
baixas $\mathrm{fO}_{2}$ e, ao que tudo indica, abaixo do buffer quartzo-fayalita-magnetita(QFM) e temperaturas situadas entre 525 e $562^{\circ} \mathrm{C}$.

5) análises quimicas de muscovita revelaram corresponder à fengita, de composiçăo muito próximo a da Li-fengita, transicionando entre o grupo das $\mathrm{Li}$-Al micas e o da Mg-Al micas.

6) os granitóides são diferenciados muito evoluídos e extremamente silicosos, cujos conteúdos de $\mathrm{SiO}_{2}$ são sempre superiores a $75 \%$ à semelhança dos granitóides dos demais maciços ora estudados. Apresentam conteúdos de $\mathrm{TiO}_{2}, \mathrm{Al}_{2} \mathrm{O}_{3}, \mathrm{MgO}, \mathrm{CaO}, \mathrm{Na}_{2} \mathrm{O}$ e $\mathrm{P}_{2} \mathrm{O}_{5}$ muito baixos e inferiores àqueles da média dos granitos(Le Maitre, 1976), enquanto que os de $\mathrm{K}_{2} \mathrm{O}$ são ligeiramente mais altos e os de $\mathrm{Fe}_{2} \mathrm{O}_{3}$ são eqüivalentes

7) eles são essencialmente peraluminosos, mostram de natureza subalcalina, correspondem aos granitos intra-placas, exibem muitas afinidades com os granitos tipo-A e são muito semelhantes àqueles do sub-grupo $A_{2}$.

8) exibem altos teores de $\mathrm{Rb}$ (média entre 662 e 698ppm), $\mathrm{Zr}$ (média entre 67 e 119ppm), $Y$ (média entre 121 e 177ppm), $W$ (média entre 141 e $324 \mathrm{ppm}$ ) e $F$ (média entre 3288 e 4799ppm), conteúdos moderados de $\mathrm{Nb}$ (média entre 71 e 79ppm) e Th(média entre 55 e $61 \mathrm{ppm}$ ) e baixas quantidades de $\mathrm{Sr}$ (média entre 13 e 60ppm), Ba(média entre 25 e 37ppm), Ta(média entre 12 e 14ppm), $\mathrm{Hf}$ (média em torno de $7 \mathrm{ppm}$ ), Ga(média entre 27 e 28ppm), Sn(média entre 12 e 53ppm), Mo(média entre 7 e 23ppm), Co(média entre 22 e $35 \mathrm{ppm})$ e $\mathrm{Zn}$ (média entre 35 e 50ppm). $\mathrm{O} \mathrm{Cl}$ exibe concentrações médias muito variáveis(385ppm no $\mathrm{BSGCl}$ e $0,01 \mathrm{ppm}$ no $\mathrm{BMG}$ ). Os teores de $U$ são baixos na facies $B S G C l$ (média $=25 \mathrm{ppm}$ ) e moderados na facies $B M G$ (média=44ppm).

9) ostentam conteúdos moderados de ETR(média entre 241 e 340ppm), com as quantidades de ETRL(média entre 179 e $247 \mathrm{ppm}$ ) sendo mais elevadas do que aquelas de ETRP(média entre 63 e 93ppm).

10) as razões $\mathrm{Rb} / \mathrm{Sr}$ (média entre 11,67 e 49,93) e $\mathrm{Rb} / \mathrm{Ba}$ (média entre 18,85 e 26,46) são altas, exceto na amostra de número 6 da facies BMG, onde elas apresentam valores anomalamente mais baixos devido aos conteúdos mais elevados de $\mathrm{Ba}$ e de $\mathrm{Sr}$ na mesma. As razões $\mathrm{K} / \mathrm{Rb}$ (média entre 56,29 e 59,47 ) são baixas se comparadas com aquelas dos granitos considerados normais(Shaw, 1968). 
11) as razões $T h / U$ (média entre 1,41 e 2,16) são maiores que 1,00 e decrescem sistematicamente no sentido da facies BMG. Esses valores classificam os granitóides desse maciço como do tipo HHP.

12) as razões $Z r / R b$ são sempre muito baixas e variam entre 0,20 e 0,10 .

13) as quantidades de $\mathrm{F}$ variam entre $750 \mathrm{ppm} 5024 \mathrm{ppm}$. O Cl, por outro lado, não foi detectado em algumas amostras, embora ocorra em conteúdos elevados em outras. No BSGCl observa-se os mais elevados teores desse elemento(761 a $777 \mathrm{ppm}$ ), enquanto que no BMG ele está praticamente ausente $(\cong 0,02 \mathrm{ppm})$.

14) é digno de nota o fato de que a amostra da facies $B S G C l$ que apresenta a maior concentração de $\mathrm{Cl}(777 \mathrm{ppm})$, contém o menor conteúdo de $\mathrm{F}(750 \mathrm{ppm})$, possui o mais elevado teor de $\operatorname{Sn}(179,60 \mathrm{ppm})$ e corresponde a única amostra na qual foi detectada a presença de cassiterita. Isso demonstra que amostras com conteúdos elevados de $\mathrm{F}$ e quantidades reduzidas ou elevadas de $\mathrm{Cl}$ não hospedam necessariamente mineralizações estaniferas.

15) os dados químicos e petrográficos permitem estabelecer que rochas granitóides com teores expressivos de $\mathrm{F}$ e/ou de $\mathrm{Cl}$ ou mesmo com reduzidos conteúdos de $\mathrm{F}$ e de $\mathrm{Cl}$ não são necessariamente enriquecidos em $\mathrm{Sn}$. Entretanto, granitóides com conteúdos elevados de Sn são, geralmente, mineralizados a cassiterita, independentemente de possuirem quantidades expressivas ou não de $\mathrm{F}$ e/ou de $\mathrm{Cl}$.

16) em relação às condições de cristalização, são válidas aqui as considerações efetuadas em relação aos demais granitóides ora estudados 


\section{CAPÍTULO 8}

\section{8- MACIÇO GRANITÓIDE RIO XINGU(MGRX)}

\section{1- Contexto Geológico}

O MGRX(Teixeira et al., 1998) ocorre como um pequeno "stock", aproximadamente circular, de cerca de $1 \mathrm{Km}^{2}$ e aflora a $3 \mathrm{Km}$ a norte da cidade de São Felix do Xingu, na margem esquerda do Rio Xingu, próximo à confluência com a desembocadura do Rio Fresco(Figura 2.3). Suas relações com as encaixantes não foram observadas diretamente no campo. Entretanto, ocorre no contexto das rochas vulcânicas andesíticas pertencentes à Formação Sobreiro, que constitui a unidade basal do Grupo Uatumã.

\section{2- Aspectos de Campo e Amostragem}

Esse corpo granitóide foi identificado por nós identificado, pela primeira vez durante o mês de Julho de 1995. Devido às suas reduzidas dimensões e à inexistência de fotografias aéreas disponíveis em escala adequada, não foi possível confeccionar um mapa especifico para representar esse maciço. Os trabalhos de campo voltaram-se exclusivamente para a amostragem do mesmo. Em razão de se tratar de um corpo muito pequeno e bastante homogêneo, foram coletadas apenas quatro amostras as mais representativas do maciço.

\section{3- Aspectos Petrográficos}

Nos estudos petrográficos, realizados através de microscopia ótica, foram utilizados os mesmos métodos e técnicas seguidos no estudo dos granitóides dos outros maciços ora estudados, não sendo, portanto, necessário repeti-los aqui. Esses estudos confirmaram as observações mesoscópicas realizadas nos trabalhos de campo, em relação a homogeneidade do corpo(ver mais adiante).

$\mathrm{Na}$ Tabela 8.1 são apresentadas as composições modais das amostras estudadas e a Figura 8.1 mostra a distribuição das mesmas nos diagramas Q-A-P e $Q-(A+P)-$ M'(Streckeisen, 1976).

No diagrama Q-A-P observa-se que esses granitóides são essencialmente sienograníticos e "subsolvus"(Tuttle \& Bowen, 1958), havendo apenas uma amostra situada no campo dos álcali-feldspato granitos.

No diagrama $Q-(A+P)-M$ ' nota-se que as quatro amostras analisadas apresentam $M^{\prime}<5 \%$, caracterizando uma natureza holo-leucocrática para esses granitóides. 
Assim, essas características demonstram, tal como em relação aos granitóides dos outros maciços vistos anteriormente, que essa rocha foi gerada a partir de um magma muito evoluido e silicoso.

Tabela 8.1. Composiçóes modais do sieno a álcali-feldspato granito
porfirítico(SAFGP). Maciço granitóide Rio Xingu. $\mathrm{Tr}=$ traços; $\mathrm{Nd}=$ não
detectado.

\begin{tabular}{|c|c|c|c|c|}
\hline \multirow{2}{*}{$\begin{array}{l}\text { VARIEDADE } \\
\text { AMOSTRAS }\end{array}$} & \multicolumn{4}{|c|}{ SAFGP } \\
\hline & NN-AV-40 & NN-AV-43 & $\mathrm{NN}-\mathrm{AV}-44$ & $N N-A V-45$ \\
\hline & 1 & 2 & 3 & 4 \\
\hline \multicolumn{5}{|l|}{ MINERAIS PRIMARIOS(\%) } \\
\hline QUARTZO & 38 & 26 & 36 & 42 \\
\hline PLAGIOCLASIO & 13 & 04 & 12 & 14 \\
\hline K-FELDSPATO & 34 & 47 & 36 & 31 \\
\hline ZIRCAO & Tr & $\mathrm{Tr}$ & $\mathrm{Tr}$ & $\mathrm{Tr}$ \\
\hline MINERAIS OPACOS & 02 & 02 & 01 & $\mathrm{Tr}$ \\
\hline APATITA & $\mathrm{Tr}$ & $\mathrm{Nd}$ & $\mathrm{Tr}$ & $\operatorname{Tr}$ \\
\hline \multicolumn{5}{|c|}{ MINERAIS SECUNDARIOS(\%) } \\
\hline SERICITA \pm MUSCOVITA & 02 & 10 & 02 & 04 \\
\hline ALBITA & 03 & 05 & 06 & 02 \\
\hline CLORITA & 04 & 02 & 02 & 02 \\
\hline FLUORITA & $\mathrm{Tr}$ & $\mathrm{Tr}$ & Tr & $\mathrm{Tr}$ \\
\hline EPIDOTO & $\mathrm{Tr}$ & 01 & $\mathrm{Tr}$ & $\mathrm{Tr}$ \\
\hline ESFALERITA & $\mathrm{Tr}$ & $\mathrm{Tr}$ & $\mathrm{Tr}$ & $\mathrm{Tr}$ \\
\hline CARBONATO & 03 & 04 & 03 & 03 \\
\hline \multicolumn{5}{|l|}{$\begin{array}{l}\text { COMPOSICAAO DO } \\
\text { PLAGIOCLASIO }\end{array}$} \\
\hline$Q$ & 43 & 32 & 40 & 47 \\
\hline $\mathrm{A}$ & 42 & 63 & 47 & 37 \\
\hline $\mathbf{P}$ & 15 & 05 & 13 & 16 \\
\hline Q & 42 & 30 & 40 & 47 \\
\hline$A+P$ & 56 & 67 & 59 & 53 \\
\hline $\mathrm{M}^{\prime}$ & 02 & 03 & 01 & 00 \\
\hline NUMERO DE PONTOS & 1578 & 1353 & 1296 & 1422 \\
\hline
\end{tabular}

Com o objetivo de uniformizar a liguagem petrográfica àcerca desse granitóide em relação aos demais estudados, ele será designado sienogranito a álcali -feldspato granito porfiritico(SAFGP).
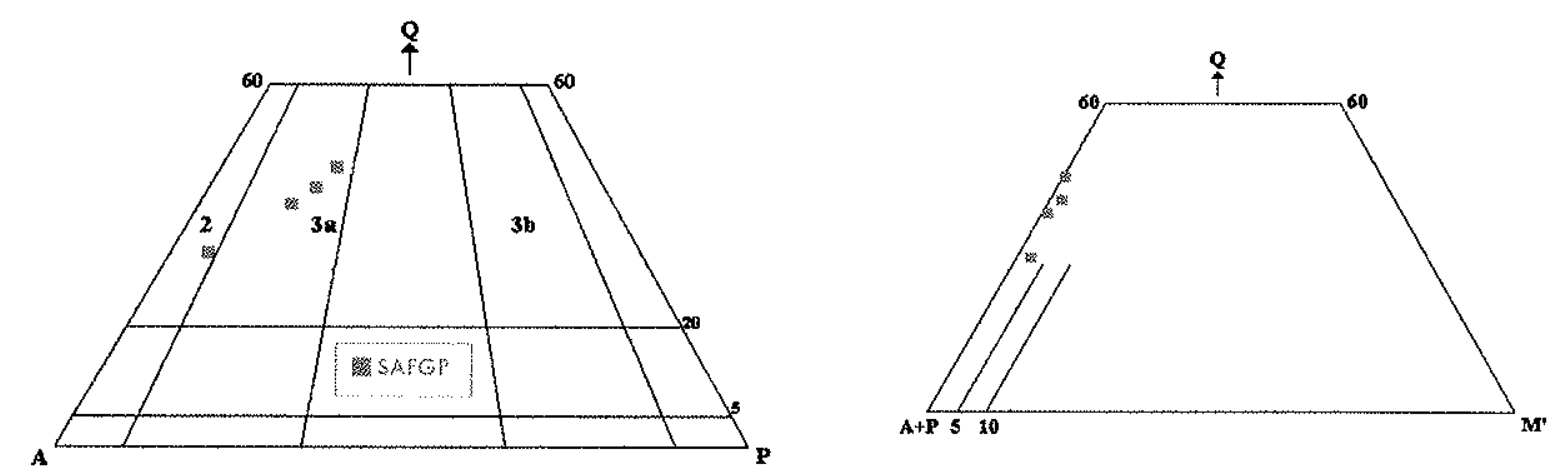

Figura 8.1 Diagramas ternários Q-A-P e Q-(A+P)-M'(Streckeisen, 1976) mostrando a distribuiçăo composicional modal do granitóide do maciço Rio Xingu. 


\subsection{1- Textura e Mineralogia}

Esse granitóide apresenta textura porfirítica peculiar(Prancha 24; Foto d), caracterizada pela presença de fenocristais grossos a médios, tabulares a semi-tabulares e, às vezes, ovoidais, de feldspato potássico, bem como de fenocristais médios a grossos, arredondados a semi-arredondados, de quartzo e fenocristais médios a grossos, ripiformes e tabulares, de plagioclásio. Os mesmos encontram-se imersos em uma matriz heterogranular fina, constituída essencialmente de feldspato potássico + quartzo (intercrescimentos granofíricos e gráficos), quartzo e feldspato potássico(em cristais independentes) e plagioclásio(Prancha 24; Foto e). Ainda, na matriz, ocorrem como fases minerais menores, primárias, zircão, minerais opacos $\left(M O P_{1}\right)$ e apatita.

Associados ao estágio de alteração tardi a pós-magmática, estão presentes sericita \pm muscovita $\left(\mathrm{Mv}_{1}\right) \pm \operatorname{clorita}\left(\mathrm{Cl}_{1}\right) \pm$ carbonato $\left(\mathrm{Cb}_{1}\right) \pm$ epidoto $\left(\mathrm{Ep}_{1}\right) \pm$ fluorita $\left(\mathrm{Fl}_{1}\right)$, clorita $\left(\mathrm{Cl}_{2}\right)$, minerais opacos $\left(\mathrm{MOP}_{2}\right)$, esfalerita $\left(\mathrm{Esf}_{1}\right)$, epidoto $\left(\mathrm{Ep}_{2}\right)$ e carbonato $\left(\mathrm{Cb}_{2}\right)$.

Texturas de preenchimento de cavidades são observadas, localmente, em algumas amostras, as quais encontram-se preenchidas, principalmente, por carbonato $\left(\mathrm{Cb}_{2}\right)$, minerais opacos $\left(M O P_{2}\right)$, muscovita $\left(\mathrm{Mv}_{2}\right)$, epidoto $\left(E p_{2}\right)$ e esfalerita( $\left(E s f_{2}\right)$.

O quartzo ocorre em, pelo menos quatro variedades, tomando-se por base a textura e a morfologia:

1) quartzo $1\left(Q t z_{1}\right)$ : mostra-se representado por fenocristais anédricos a subédricos, médios a grossos, geralmente arredondados a semi-arredondados, que, algumas vezes, apresentam-se fraturados e exibem extinção ondulante variável, desde fraca até forte, embora sejam mais freqüentes aqueles com extinção fraca. Localmente, hospedam inclusões de minerais da matriz(Prancha 24; Foto f).

2) quartzo2(Qtz $)$ : ocorre como grãos anédricos, de granulação fina, constituindio a matriz.

3) quartzo3 $\left(Q t z_{3}\right)$ : forma cristais, quase sempre, anédricos associado à alteração da clorita, juntamente, com minerais opacos $\left(\mathrm{MOP}_{2}\right)$ e muscovita $\left(\mathrm{Mv}_{2}\right)$.

4) quartzo4(Qtz $)$ : se apresenta como finissimos cristais anédricos, associados ao feldspato potássico, formando os intercrescimentos gráficos e granofíricos, os quais formam tipos diversos..

O feldspato potássico apresenta-se, de acordo com a textura e morfologia, em, pelo menos, três variedades. O tipo 1 refere-se aos fenocristais tabulares a semi-tabulares e, subordinadamente, arredondados e sub-arredondados, subédricos a euédricos e, localmente, anédricos, de granulação grossa a média, invariavelmente, pertíticos, os quais apresentam-se, parcialmente, alterados para sericita + muscovita $\left(\mathrm{Mv}_{1}\right)$, carbonato $\left(\mathrm{Cb}_{1}\right)$, e argilo-minarais. Além disso, mostram-se, por vezes, albitizados, cujas evidências são expressas por "chess-board-albite" e "swapped rims". As fases albíticas das pertítitas são, geralmente, dos tipos "films"e "patch perthites"(Alling, 1932 e 1938; Smith, 1974). Os 
cristais, geraimente, não exibem maclas ou encontram-se mascaradas pelos minerais de alteração. Localmente, hospedam inclusões de minerais da matriz. O tipo 2 ocorre na matriz. Forma cristais independentes, finos e anédricos , os quais são, às vezes, pertíticos("patch perthites"). Não exibe maclas e mostra-se, parcialmente, alterado para argilo-minerais. A variedade 3 , refere-se às finissimas fases constitutivas dos intercrescimentos granofíricos e gráficos.

O plagioclásio, por sua vez, ocorre segundo duas modalidades, as quais se diferenciam pela textura, morfologia e granulação. A variedade1 mostra-se representada por fenocristais ripiformes e tabulares, subédricos a euédricos e de granulação grossa a média. Apresenta maclas nítidas e os tipos mais comuns são regidos pelas leis da albita e da albitaCarlsbad. Costuma estar, parcialmente, alterado para sericita \pm muscovita $\left(\mathrm{Mv}_{1}\right) \pm \operatorname{clorita}\left(\mathrm{Cl}_{1}\right)$ \pm fluorita $\left(\mathrm{Fl}_{1}\right) \pm$ epidoto $\left(E \mathrm{p}_{1}\right) \pm$ carbonato $\left(\mathrm{Cb}_{1}\right)$. O tipo 2 encontra-se confinado à matriz. Apresenta-se como grãos subédricos a anédricos finos, os quais exibem maclas pouco marcantes. Mostra-ser, parcialmente, alterado para sericita + muscovita $\left(\mathrm{Mv}_{1}\right) \pm$ fluorita $\left(\mathrm{FI}_{1}\right) \pm$ epidoto $\left(E p_{1}\right) \pm$ clorita $\left(\mathrm{Cl}_{1}\right) \pm$ carbonato $\left(\mathrm{Cb}_{1}\right)$. Localmente, ocorre como inclusões em cristais médios de feldspato potássico1. Em termos composicionais, parece não diferir do tipo 1. Estudos realizados através de microssonda eletrônica indicaram uma composição albítica. Entretanto. E válido ressaltar que os cristais analisados encontram-se alterados na sua composição magmática original visto que mostram-se descalcificados.

A clorita ocorre segundo duas variedades. A primeira $\left(\mathrm{Cl}_{1}\right)$, apresenta-se como finíssimas lamelas, anédricas, associadas à alteração tardi a pós-magmática do plagioclásio. O segundo tipo $\left(\mathrm{Cl}_{2}\right)$ está representada por lamelas anédricas finas e dispersas na rocha. Apresenta pleocroismo moderado, variando de verde oliva $(Z$ e $Y)$ a verde claroamarelado $(X)$ e tem cor de interferência caracteristicamente baixa, expressa por tonalidades verde a verde-acinzentada. Mostra-se, parcialmente, alterada para muscovita( $\left.\mathrm{Mv}_{2}\right) \pm$ minerais opacos $\left(M O P_{2}\right) \pm$ esfalerita $\left(E s f_{1}\right) \pm$ quartzo $\left(Q t z_{3}\right)$ e deve representar um produto de alteração da biotita primária(agora ausente).

Os minerais opacos ocorrem tanto como fase primária(MOP 1 ), quanto como secundária $\left(\mathrm{MOP}_{2}\right)$. A modalidade 1 , é muito freqüente e chega a alcançar até $2 \%$ da moda desse granitóide(Tabela 8.1). Forma cristais euédricos a subédricos, finos, embora ocorram, subordinadamente, grãos médios. Mostram-se dispersos na rocha, embora apresentam-se, também, em menor quantidade, como inclusões nas principais fases minerais dessa rocha. O tipo 2, forma grãos, via de regra, anédricos, finos, os quais costumam ocorrer intimamente associados à clorita, dispondo-se ao longo dos planos de clivagem da mesma.

O zircão é muito pouco freqüente. Apresenta-se como finissimos cristais euédricos e, às vezes, zonados, os quais mostram-se distibuidos erraticamente na rocha. 
A apatita ocorre em teores muito reduzidos. Foma grãos euédricos muito ginos, os quais mostram-se associados ao zircão e minerais opacos $\left(M O P_{1}\right)$, embora, localmente, mostre-se inclusa no plagioclásio $\left(\mathrm{PI}_{2}\right)$.

A esfalerita(Esf $\left.f_{1}\right)$ ocorre como grãos anédricos, associados à alteração da clorita $\left(\mathrm{Cl}_{2}\right)$, dispondo-se ao longo dos planos de clivagem da mesma.

$O$ epidoto ocorre segundo duas variedades. $A$ primeira $\left(E p_{1}\right)$ apresenta-se como cristais anédricos, os quais mostram-se associados à descalcificação do plagioclásio( $\mathrm{Pl}_{1}$ e $\left.\mathrm{Pl}_{2}\right)$. A variedade 2(E $\left.\mathrm{p}_{2}\right)$ ocorre como grãos anédricos a subédricos, os quais apresentam-se, por vezes, em agregados, juntamente com $\mathrm{Mv}_{2}+\mathrm{MOP}_{2}+\mathrm{Cl}_{2} \mathrm{e}$, às vezes, com carbonato $\left(\mathrm{Cb}_{2}\right)$.

O carbonato ocorre segundo duas modalidades. O tipo $1\left(\mathrm{Cb}_{1}\right)$ forma finissimos grãos associados à descalcificação dos plagioclásios primários. A variedade $2\left(\mathrm{Cb}_{2}\right)$ ocorre como grăos anédricos a subédricos, finos a médios, os quais formam agregados, conforme visto acima.

O conjunto sericita \pm muscovita $\left(\mathrm{Mv}_{1}\right) \pm$ clorita $\left(\mathrm{Cl}_{1}\right)$, predomina, em média, sobre as demais fases tardias. Ocorrem como finas lamelas anédricas, as quais mostram-se, preferencialmente, associadas à alteracão do plagioclásio $\left(\mathrm{Pl}_{1}\right.$ e $\left.\mathrm{Pl}_{2}\right)$. Da mesma forma como nos demais granitóides dos outros maciços vistos anteriormente, está associado a um evento autometassomático, de natureza potássica que afetou esse granitóide no início do estágio de alteração terdi a pós-magmática.

A albita tardia, exceto as fases albiticas das pertitas, se apresenta como finos cristais anédricos, límpidos, às vezes, maclados sob as leis da albita. Apresenta-se substituindo, parcialmente, o feldspato potássico sob a forma de "chess-board albite"(Smith, 1974).

A fluorita $\left(\mathrm{Fl}_{1}\right)$ é pouco abundante e ocorre como finissimos cristais associadas à descalcificação do plagioclásio $\left(\mathrm{Pl}_{1} \in \mathrm{Pl}_{2}\right)$.

\subsection{2- Ordem de Cristalização}

O exame de lâminas delgadas com o objetivo de estabelecer a ordem de cristalização das fases minerais primárias que constituem esse granitóide permitiu definir o seguinte esquema:

1) As fases minerais primárias representadas por zircão, minerais opacos $\left(M O P_{1}\right)$ e apatita são claramente precoces em relação às fases essenciais-quartzo, plagioclásio e feldspato potássico- uma vez que ocorrem como inclusões nas mesmas.

2) Plagioclásio $\left(\mathrm{Pl}_{2}\right)$, quartzo2 e feldspato potássico $\left(\mathrm{Fk}_{2}\right)$, fases essenciais na matriz, são, nitidamente precedentes em relação aos seus termos mais grossos(fenocristais)- $\mathrm{Qtz}_{1}, \mathrm{Pl}_{1}$ e $\mathrm{Fk}_{1^{-}}$visto que esses últimos hospedam inclusões de matriz onde os primeiros são dominantes. Entretanto, no que se refere aos a $\mathrm{Pl}_{2}, \mathrm{Qtz}_{2}$ e $\mathrm{Fk}_{2}$, é dificil estabeler com segurança uma ordem de cristalização entre os mesmos, visto que não foram observadas 
relações de inclusões entre eles. Nas porcões de matriz, inclusas nos fenocristais, suas dimensões são muito reduzidas, bem como 0 elevado conteúdo de fases intercrescidas(intercrescimentos gráficos e granofíricos) mascaram as observações. $\mathrm{Na}$ matriz as três fases ocorrem lado a lado e, ao que parece, se separaram do líquido magmático durante o mesmo intervalo de temperatura e pressão.

3) A clorita formou-se às expensas da biotita primária, que foi totalmente substituida durante o estágio de alterações tardi a pós-magmáticas. O seu modo de ocorrência nas amostras estudadas assume, às vezes, uma forma intersticial em relação às fases essenciais da matriz. Isso é indicativo de que a biotita primária se cristalizou, pelo menos em parte, posteriormente ao $\mathrm{Qtz}_{2}, \mathrm{Pl}_{2}$ e $\mathrm{Fk}_{2}$.

4) Além da clorita, as demais fases minerais estão associadas ao estágio de alterações tardi a pós-magmáticas.

A Figura 8.2 mostra resumidamente um esboço da seqüência de cristalização das fases minerais dos granitóides desse maciço.

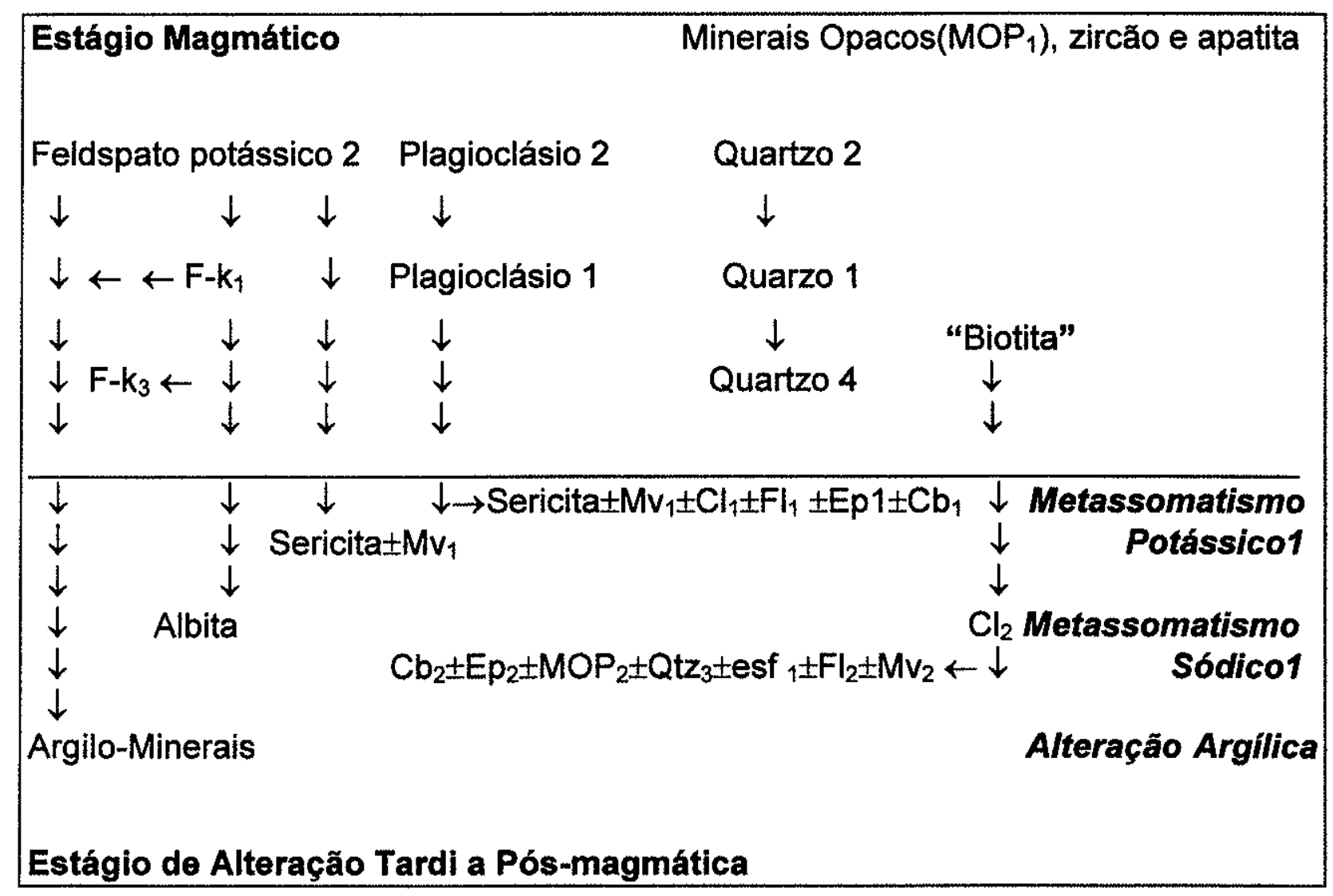

Figura 8.2 Fluxograma mostrando um esboço esquemático da sequeéncia de cristalização magmática e tardi a pós-magmática das fases minerais associadas à facies SAFGP do maciço granitóide Rio Xingu. esf=e esfalerita. 


\section{4- Discussão e Considerações Finais}

Trabalhos de campo aliados a estudos petrográficos mostraram que esse maciço é um corpo bastante homogêneo composicionalmente. Nele foi caracterizado essencialmente sieno a álcali-feldspato granito porfirítico(SAFGP), cuja principal fase máfica está representada por clorita, que, ao que tudo indica, é uma fase tardi a pós-magmática, formada às expensas da biotita primária. Texturalmente, difere muito dos outros granitóides apresentados anteriormente, embora guarde algumas semelhanças com as facies granofíricas do maciço granitóide Antônio Vicente(SMGGf). É uma rocha tipicamente subsolvus(Tuttle \& Bowen, 1958), holo-leucocrática a leucocrática, que, assim como as outras facies granitóides dos outros maciços ora estudados, evoluiu a partir de um magma muito diferenciado e silicoso, o qual foi colocado em niveis crustais rasos(Castro, 1987; Marre, 1982; Turner et al., 1992). Isso é traduzido, principalmente, pela presença de cavidades preenchidas por carbonato, epidoto, clorita, muscovita e esfalerita, bem como pela marcante textura granofírica.

A Tabela 8.2 mostra as principais caracteristicas petrográficas do granitóide desse maciço.

Tabela 8.2- Principais características da facies SAFGP do maciço granitóide Rio Xingu.

\begin{tabular}{|c|c|c|c|c|c|}
\hline $\begin{array}{l}\text { Facies } \\
\text { Granitólde }\end{array}$ & Minerals Essencials & $\begin{array}{l}\text { Minerals } \\
\text { Varietais }\end{array}$ & $\begin{array}{l}\text { Acessórios } \\
\text { Primários }\end{array}$ & Minerais Secundários & $\begin{array}{l}\text { Mineraltzacóos/Modo } \\
\text { de Ocorréncla }\end{array}$ \\
\hline SAFGP & $\begin{array}{l}\text { *Quartzo } \\
\text { "Plagioclásio(Anto-13) } \\
\text { "Feldspato } \\
\text { Potássico(Microclina } \\
\text { pertítica) }\end{array}$ & "Clorita & $\begin{array}{l}\text { * Zircåo } \\
\text { "Minerais } \\
\text { Opacos } \\
\text { " Apatita }\end{array}$ & $\begin{array}{l}\text { "Clorita "muscovita *epidoto } \\
\text { "fluorita "carbonato "esfalerita } \\
\text { "quartzo } \\
\text { "albita } \\
\text { "argilo-minerais }\end{array}$ & Ausente \\
\hline
\end{tabular}

\section{5- Química Mineral}

\subsection{1- Análises químicas através de Microssonda Eletrônica}

Neste maciço foram analisados apenas as fases minerais feldspato potássico(fenocristais/Fk2) e plagioclásio(fenocristais/PI2). As análises, as fórmulas estruturais e as proporções Ab-Or-An encontram-se no Anexo 50.

\subsubsection{1- Análises químicas em Feldspato potássico}

\subsubsection{1- Composição química}

No diagrama Ab-Or-An(Figura 8.3) nota-se que o cristal analisado não exibe variações composicionais importantes. A molécula Or varia entre $92 \%$ e $98 \%$, enquanto que a molécula $\mathrm{Ab}$ oscila entre $2 \%$ e $8 \%$. No que se refere à molécula $\mathrm{An}$, as análises, de um modo geral, não há teores. Uma tendência de aumento nas quantidades da fração anortita 
paralelamente a um aumento na molécula $\mathrm{Ab}$ não é observada. Isso é discordante com o que ocorre nos feldspato potássicos pertencente aos granitóides do maciço granitóide Antônio Vicente, bem como vai de encontro com o que é apresentado Deer et al.(1966). Conforme esses autores, a molécula de anortita tem, geralmente, teores baixos na sanidina, a qual tem, de um modo característico, menos do que $1 \%$ de $\mathrm{CaO}$. No ortoclásio, contudo, a quantidade de $\mathrm{CaO}$ tende a aumentar à medida que a razão $\mathrm{Na} / \mathrm{K}$ cresce aproximando-se da composição da albita. No caso do feldspato em questão, isso não é observado como mostrado na Figura 8.4 e no Anexo 44.

No que se refere à temperatura de cristalização não foi possível estimá-la em virtude dos cristais estarem invariavelmente alterados(albitizados e/ou argilizados), não sendo, por conseguinte, recomendada a utilização dos vários geotermômetros apresentados na literatura(Haselton et al., 1983; Brown \& Parsons, 1985; Elkins \& Grove, 1990; NekvasiL, 1994; entre outros). O mesmo é válido para o plagioclásio.

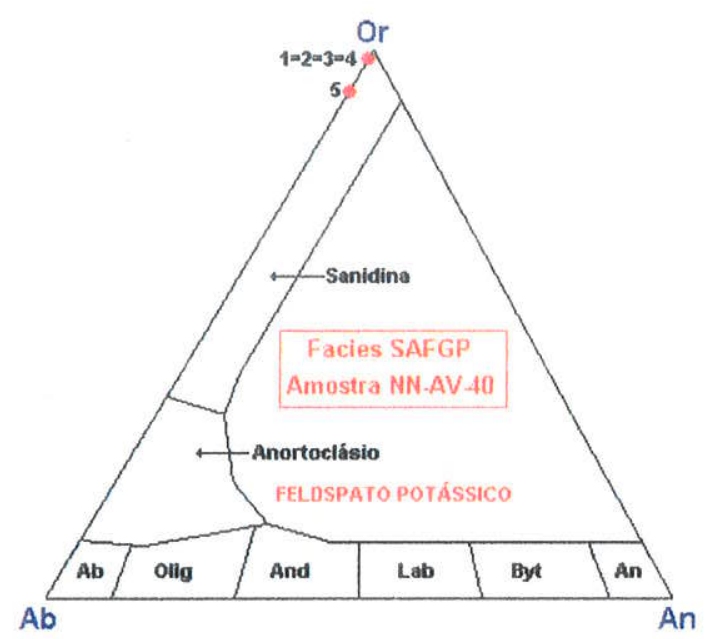

Figura 8.3- Distribuição composicional do feldspato potássico da amostra NN-AV-40 do maciço granitóide Rio Xingu no diagrama triangular A-Or-An.

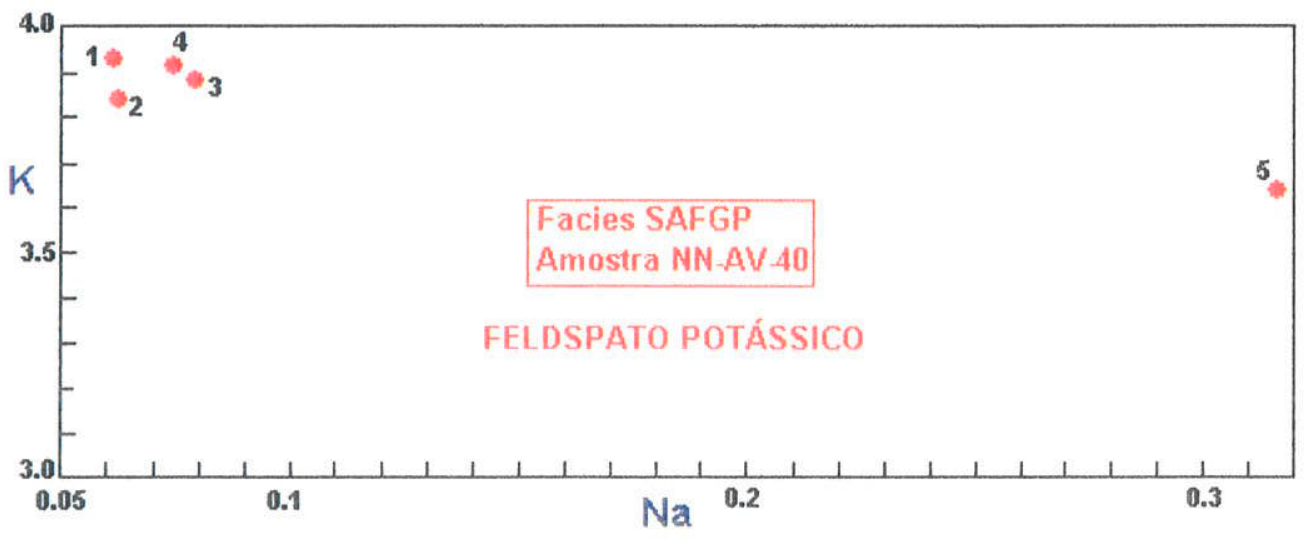

Figura 8.4- Diagrama Na-K mostrando a distribuição composicional do feldspato potássico da facies SAFGP do maciço granitóide Rio Xingu. 


\subsubsection{2- Análises químicas em plagioclásio}

O estudo do plagioclásio envolveu 06 análises pontuais em um único cristal da amostra NN-AV-40. Os resultados analíticos obtidos, bem como as fórmulas estruturais calculadas e as proporçõpes Ab-Or-An encontram-se no Anexo 50.

\subsubsection{1- Composição química}

Em termos composicionais, as análises mostram um pequeno espectro de variação da molécula $\mathrm{Ab}$ entre $92 \%$ e $99 \%$, a molécula An entre $1 \%$ e $3 \%$ e a molécula Or entre $0 \%$ e 7\%(Figura 8.5). Essa característica fortemente albítica do plagioclásio deve ser decorrente, ao que tudo indica, da descalcificação do mesmo em função dos processos de alterações tardi a pós-magmáticas que afetaram esse granitóide e são evidenciados pelo desenvolvemento da associação sericita \pm muscovita \pm clorita $1 \pm$ fluorita \pm epidoto \pm topázio, às expensas do plagioclásio. Em outras palavras, as composições do cristal estudado não correspondem às composições magmáticas originais. Em relação às quantidades de $\mathrm{CaO}$, nota-se que quanto maiores as razões $\mathrm{Na} / \mathrm{K}$ menores os conteúdos deste óxido(Figura 8.6; Anexo 50).

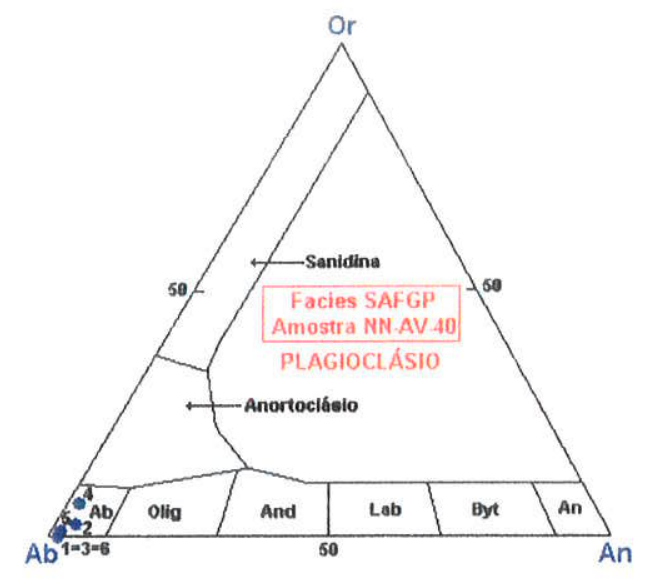

Figura 8.5- Distribuição composicional do plagioclásio da amostra NN-AV-40 do maciço granitóide Rio Xingu no diagrama triangular A-Or-An.

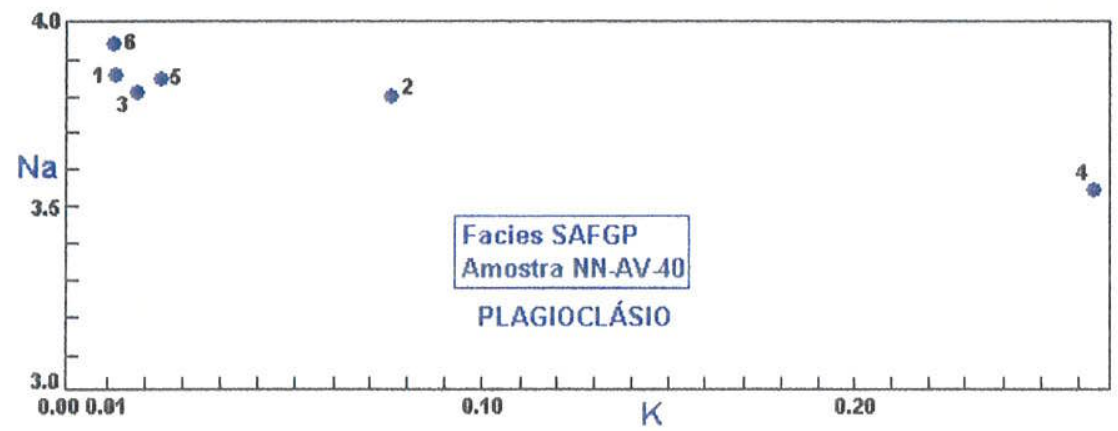

Figura 8.6- Diagrama Na-K mostrado a distrubuição composicional do plagioclásio da facies SAFGP do maciço granitóide Rio Xingu. 


\subsection{2-Análises químicas através de Microscopia Eletrônica}

Neste maciço foram executadas três análises em fases minerais subordinadas da amostra NN-AV-40, da facies SAFGP, as quais envolveram apatita(duas análises) e óxido de Fe com W. Em ambos os casos, não foram obtidas, através de MEV, imagens ilustrativas das relações microtexturais das mesmas com outras fases com as quais elas estão associadas. Entretanto, estudos realizados através de microscopia b́tica, mostraram que a apatita ocorre como diminutos cristais grosseiramente arredondados dispersos na matriz dessa facies granitóide. Suas relações microtexturais com as outras fases minerais constitutivas da matriz indicam uma origem primária. A fase óxido de Fe com W, por sua vez, apresenta-se como grãos anédricos, os quais mostra-se associados a oxidação de feldspato potássico e de biotita cloritizada. Por essa razão, deve corresponder a uma fase secundária, ligada ao estágio de alterações tardi a pós-magmáticas.

As análises de apatita revelaram que se trata de grãos quase puros, que incorporam de $1,08 \%$ a $1,58 \%$ de $\mathrm{Y}$ e infimas quantidades de $\mathrm{Al}$ e $\mathrm{Cl}$ (Anexo 51). A presença de $\mathrm{Cl}$, mesmo em quantidades reduzidas, pode indincar que os gräos analisados correspondam ao componente extremo da série isomórfica(cloroapatita).

A fase óxido de $\mathrm{Fe}$, por sua vez, afora seus componentes essenciais( $\mathrm{Fe}$ e $\mathrm{O}$ ), contém quantidades um pouco significativas de $\mathrm{W}$ e abriga reduzidas quantidades de $\mathrm{Ta} e$ Ti(Anexo 51).

\section{6- Geoquímica}

No âmbito desse maciço foram analisadas duas amostras da facies SAFGP. Deve-se ressaltar que esse número reduzido de análises decorreu do fato de se tratar de um corpo granitóide de pequena dimensão e bastante homogêneo. Os resultados analíticos obtidos encontram-se na Tabela 8.3(Anexo 52).

\subsection{1- Características Gerais}

Na Tabela 8.3 observa-se que se trata de um granitóide muito diferenciado, cujos teores de $\mathrm{SiO}_{2}$ situam-se entre $74,55 \%$ e $75,00 \%$. Em relação aos principais óxidos possui conteúdos invariavelmente baixos de $\mathrm{TiO}_{2}, \mathrm{Al}_{2} \mathrm{O}_{3}, \mathrm{MgO}, \mathrm{CaO}$ e $\mathrm{P}_{2} \mathrm{O}_{5}$, muito inferiores àqueles da média dos granitos fornecidos por Le Maitre(1976). Os teores de $\mathrm{Fe}_{2} \mathrm{O}_{3}$ e de MnO são mais elevados, os de $\mathrm{K}_{2} \mathrm{O}$ são ligeiramente mais altos e os de $\mathrm{Na}_{2} \mathrm{O}$ são bem mais reduzidos. No que se refere aos elementos menores e traços, ostenta altos teores de $B a($ média $=1378 \mathrm{ppm}), \mathrm{Zr}($ média $=350 \mathrm{ppm})$ e de $\mathrm{Zn}($ média $=266 \mathrm{ppm})$, conteúdos moderados de $\mathrm{Rb}($ média $=220 \mathrm{ppm}), \quad \mathrm{Sr}($ média $=101 \mathrm{ppm}), \quad \mathrm{Y}($ média $=83 \mathrm{ppm}), \quad F($ média $=525 \mathrm{ppm})$, $W($ média $=67 \mathrm{ppm})$ e de $T$ (média $=60 \mathrm{ppm})$ e baixas concentrações de $\mathrm{Nb}($ média $=30 \mathrm{ppm})$, 
$\mathrm{Ga}($ média $=23 \mathrm{ppm}), \mathrm{Sn}($ média $=2 \mathrm{ppm}), \mathrm{Mo}($ média $=1 \mathrm{ppm}), \mathrm{Ta}$ (média $=2 \mathrm{ppm}), \mathrm{Hf}($ média $=$ $11 \mathrm{ppm})$ e de $U($ média $=5 \mathrm{ppm})$. No que tange aos ETR(Tabela 8.2, Anexo 52), verifica-se que, de modo geral, seus conteúdos são um pouco elevados, especialmente aqueles de ETRL, que mostram-se mais altos do que as quantidades de ETRP. As razões $\mathrm{Rb} / \mathrm{Sr}(2,10$ a 2,29), $\mathrm{Zr} / \mathrm{Rb}(1,56$ a 1,61) e $\mathrm{Rb} / \mathrm{Ba}(0,16)$ são sempre muito baixas. A razão Th/U é moderada a alta(11,13 a 11,23), enquanto as razões $\mathrm{K} / \mathrm{Rb}(200,95$ a 209,26) são eqüivalentes àquelas dos granitos considerados normais(Shaw, 1968).

\subsection{2- Saturação em Alumina(ISA)}

Não obstante esse granitóide exibir quantidades de $\mathrm{Al}_{2} \mathrm{O}_{3}$ mais baixas do que aquela da média dos granitos apresentada por Le Maitre(1976), ele é uma rocha genuinamente peraluminosa, caracterizada pelas razões dos conteúdos moleculares NK/A entre 0,67 e 0,68 e pelas razões A/CNK oscilando entre 1,32 e 1,33( Figura 8.7).

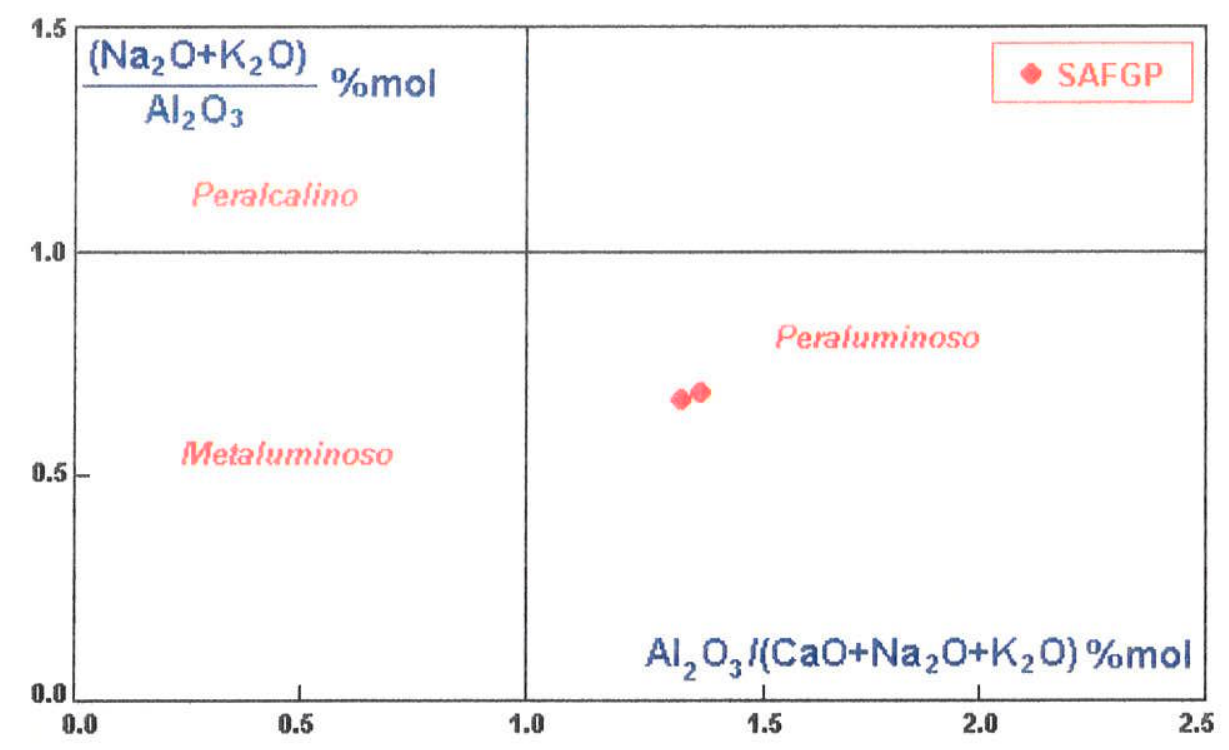

Figura 8.7. Diagrama binário A/CNK versus NKJA(Maniar\& Piccoli, 1989) mostrando a distribuição das facies granitóides do MGRX, com baseado nos indices de Shand(ISA).

\subsection{3 - Afinidade Tectonomagmática e Tipologia}

A exemplo do que foi comentado em relação aos granitóides dos outros maciços estudados, as composições desses granitóides foram lançadas diagramas $\mathrm{Y}-\mathrm{Nb},(\mathrm{y}+\mathrm{Nb})-\mathrm{Rb}$ e Ta-Yb de Pearce et al.(1984), Figura 8.8a, b e c. Observa-se que as amostras incidem plenamente no campo composicional correspondente aos granitóides intra-placas. 

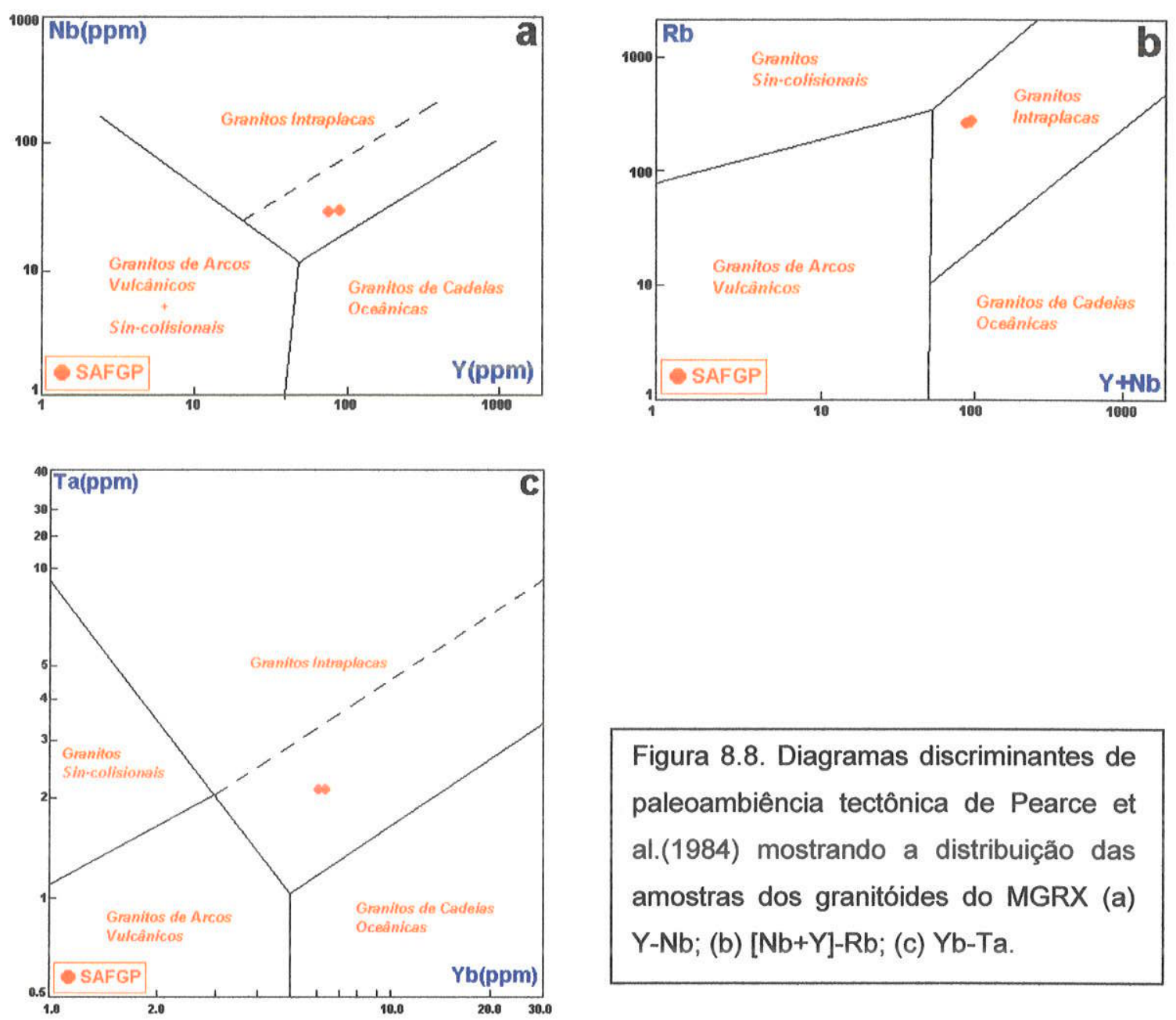

Figura 8.8. Diagramas discriminantes de paleoambiência tectônica de Pearce et al.(1984) mostrando a distribuição das amostras dos granitóides do MGRX (a) $\mathrm{Y}-\mathrm{Nb}$; (b) [Nb+Y]-Rb; (c) Yb-Ta.

Foi apresentado nos capítulos anteriores que os granitóides tipo-I, altamente fracionados, podem ser distiguidos de granitóides tipo-A utilizando-se o parâmetro de discriminação $\mathrm{Zr}+\mathrm{Nd}+\mathrm{Ce}+\mathrm{Y}$ (Whalen et al.(1987).

No que se refere aos granitóides desse maciço, os dados químicos foram lançados nos diagrama $\mathrm{Zr}+\mathrm{Nb}+\mathrm{Ce}+\mathrm{Y}$ vs. $\left(\mathrm{K}_{2} \mathrm{O}+\mathrm{Na}_{2} \mathrm{O}\right) / \mathrm{CaO}$, de Whalen et al.(1987), Figura 8.9. Percebe-se, assim, que as duas amostras incidem inteiramente no campo composicional correspondente aos granitos tipo- $\mathrm{A}$. No diagrama $\mathrm{Zr}+\mathrm{Nb}+\mathrm{Ce}+\mathrm{Y}$ vs. $\left(\mathrm{Fe}_{\mathrm{T}} / \mathrm{MgO}\right)$, dos mesmos autores, Figura 8.10, que expressa o grau de fracionamento, nota-se que as amostras ocupam no campo dos granitóides tipo-A, confirmando o que foi observado na figura anterior.

$\mathrm{O}$ diagrama $10.000 \mathrm{Ga} / \mathrm{Al}$ vs. $\left(\mathrm{K}_{2} \mathrm{O}+\mathrm{Na}_{2} \mathrm{O}\right) / \mathrm{Al}_{2} \mathrm{O}_{3}$ de Whalen et al.(1987), modificado por Rämö \& Haapala(1995), que exprime o grau de alcalinidade ou índice agpaítico, Figura 8.11, mostra que as duas amostras dos granitóides do maciço incidem na área composicional correspondente aos granitos tipo-A, de natureza subalcalina.

Considerando-se a subdivisão proposta por Eby(1992), os dados químicos dos granitóides desse maciço foram "plotados" nos diagramas triangulares discriminantes $\mathrm{Y}-\mathrm{Nb}$ - 
$\mathrm{Ce}$ e $\mathrm{Y}-\mathrm{Nb}-3 \mathrm{Ga}$, Figura $8.12 \mathrm{a}$, b. Em ambos os diagramas as amostras incidem invariavelmente no campo composicional correspondente aos granitóides tipo- $A_{2}$ enquanto que o segundo grupo, tipo- $A_{2}$, foi assim definido por guardar certas, o qual guarda, de acordo com o referido autor, certas semelhanças químicas com a composição média da crosta e com basaltos de arcos de ilha.

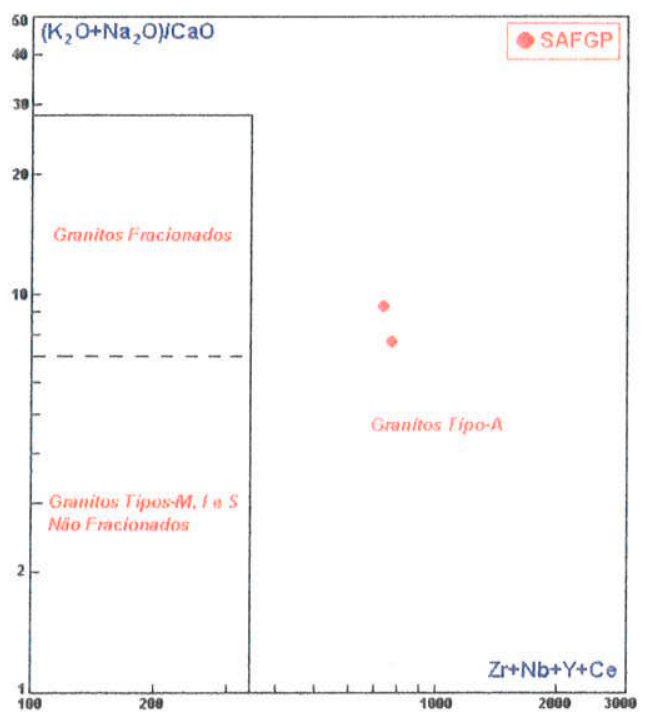

Figura 8.9- Diagrama $\mathrm{Zr}+\mathrm{Nb}+\mathrm{Ce}+\mathrm{Y} \quad$ vs. $\left(\mathrm{K}_{2} \mathrm{O}+\mathrm{Na}_{2} \mathrm{O}\right) / \mathrm{CaO}$ de Whalen et al.(1987) mostrando a distribuição composicional das amostras das principais facies granitóides do MGRX.

Figura 8.10- Diagrama $\mathrm{Zr}+\mathrm{Nb}+\mathrm{Ce}+\mathrm{Y}$ vs. $\mathrm{FeO} / \mathrm{MgO}$ de Whalen et al.(1987) mostrando a distribuiçäo composicional das amostras das principais facies granitóides do MGRX.
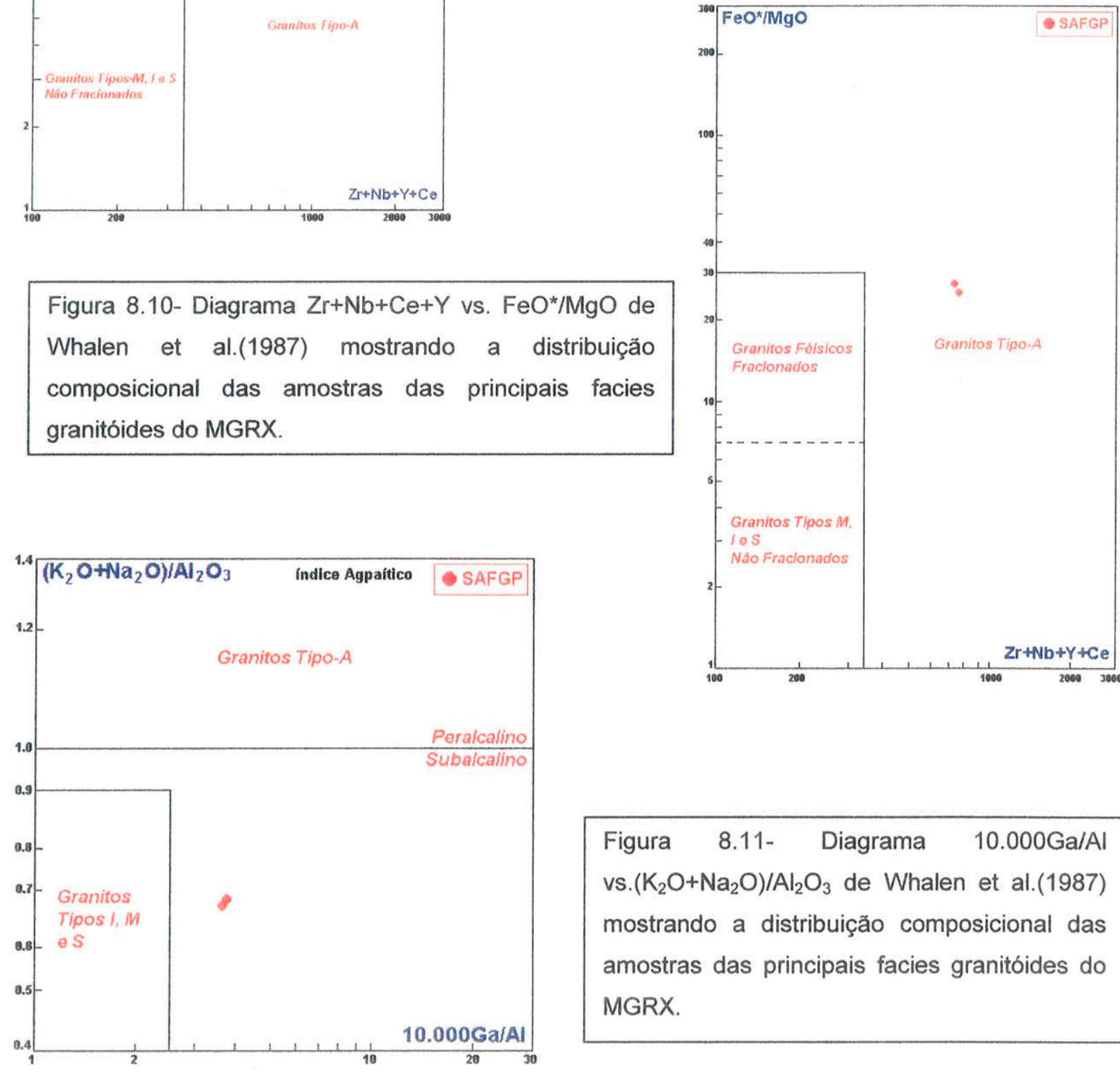

Figura 8.11- Diagrama $10.000 \mathrm{Ga} / \mathrm{Al}$ vs. $\left(\mathrm{K}_{2} \mathrm{O}+\mathrm{Na}_{2} \mathrm{O}\right) / \mathrm{Al}_{2} \mathrm{O}_{3}$ de Whalen et al.(1987) mostrando a distribuição composicional das amostras das principais facies granitóides do MGRX. 

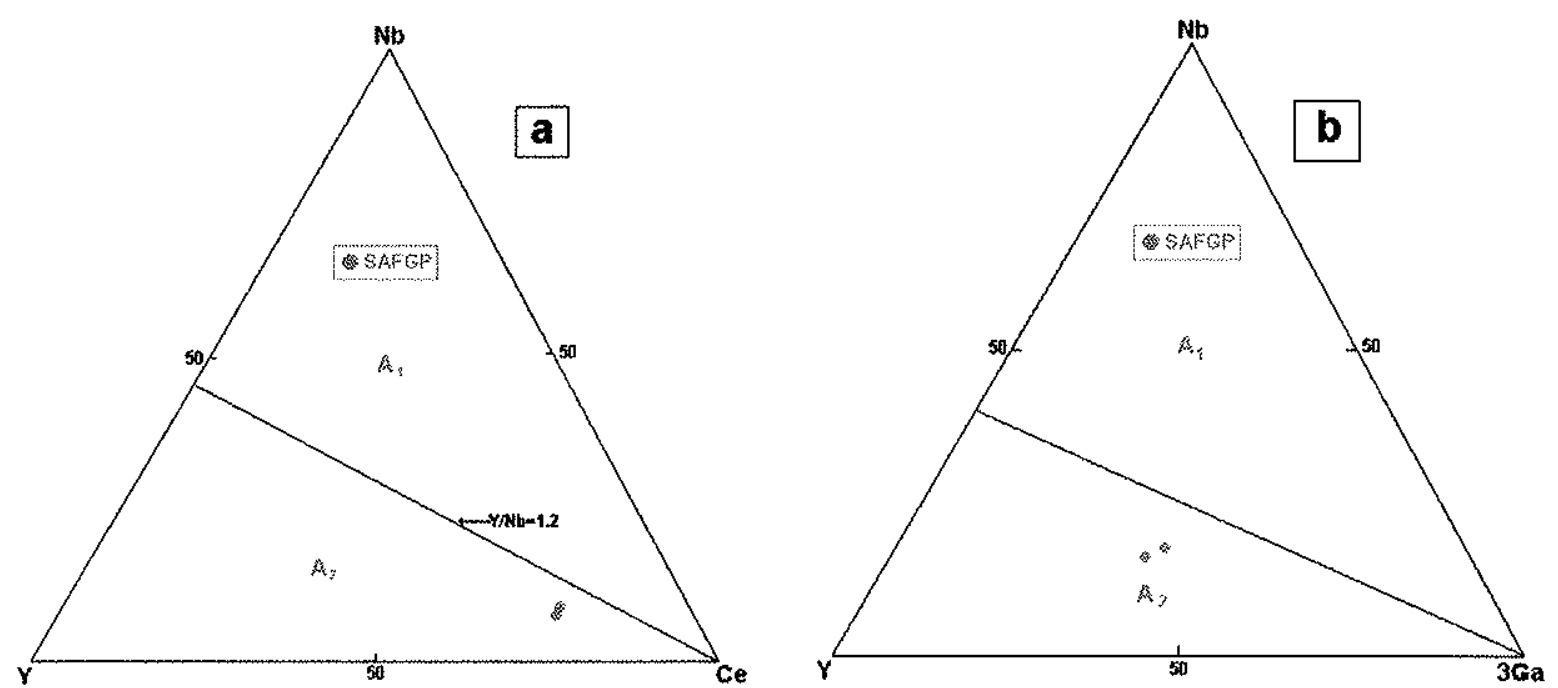

Figura 8.12- Diagramas triangulares Y-Nb-Ce(a) e Y-Nb-3Ga(b) de Eby(1992) mostrando a distribuição composicional da facies granitóides SAFGP do maciço granitóide Rio Xingu.

\subsection{4- Outras Feições Geoquímicas}

As razões K/Rb entre 150 e 300 são consideradas normais para granitóides(Taylor, 1964, Shaw, 1968). No granitóide desse maciço, diferentemente dos tipos vistos anteriormente, as razões $\mathrm{K} / \mathrm{Rb}$ das duas amostras analisadas situam-se entre $200 \mathrm{e}$ 250(Figura 8.13a). A razão disso, é devido ao fato desses granitóides possuírem quantidades um pouco elevadas de $\mathrm{K}_{2} \mathrm{O}(5,41 \%$ a $5,48 \%)$ e conteúdos baixos de $\mathrm{Rb}(214,58 \mathrm{ppm}$ a $226,34 \mathrm{ppm})$, decorrentes, principalmente, da sua composição ser rica em feldspato potássico e da ausência de biotita(Tabela 8.1).

$\mathrm{Na}$ Figura $8.13 \mathrm{~b}$ observa-se que as razões $\mathrm{Rb} / \mathrm{Sr}$ situam-se entre 1,50 e 3,00, demonstrando que tanto $\mathrm{Rb}$ quanto $\circ \mathrm{Sr}$ se comportaram como elementos compativeis durante a diferenciação/fracionamento desse granitóide. Uma outra hipótese para explicar esses teores baixos de $\mathrm{Rb}$ nesses granitóides é o fato dos mesmos terem sido derivados de uma fonte algo empobrecida de $\mathrm{Rb}$, já que os mesmos representam diferenciados muito evoluídos.

No diagrama $\mathrm{Rb}-\mathrm{Ba}$ (Figura $8.13 \mathrm{c}$ ) percebe-se que as razões $\mathrm{Rb} / \mathrm{Ba}$ situam-se entre 0,20 e 0,10 . Esses valores extremamente baixos para granitóides muito diferenciados(Taylor, 1964) são devido aos conteúdos anomalamente altos de Ba nas rochas estudadas (1375ppm a $1380 \mathrm{ppm}$ ) em contrapartida aos teores relativamente baixos de Rb(Tabela 8.3, Anexo 52). De acordo com Taylor(1965) e Ollila(1984) ० $\mathrm{Ba}^{2+}$ é capturado pelos minerais de $\mathrm{K}$ formados precocemente e conforme Nockolds \& Mitchell(1948. In: Taylor, 1965, pg 156) ele prefere mais o feldspato potássico do que a biotita em uma razão de cerca de 2:1. Segundo Smith(1974) $\circ \mathrm{Ba}^{2+}$ se concentra mais fortemente no feldspato 
potássico em relação ao plagioclásio. Nos granitóides estudados os conteúdos elevados de Ba podem ser explicados por esse modelo ou seja as quantidades elevadas de Ba podem estar diretamente atreladas ao conteúdo de feldspato potássico, visto que a biotita está ausente nessas rochas e o plagioclásio é pouco abundante e de composição albítica. Entretanto, dados de química mineral obtidos através de microssonda eletrônica(Anexos 50) mostram que tanto o feldspato potássico, quanto o plagioclásio são pobres em $\mathrm{Ba}$. Por outro lado os estudos petrográficos em lâminas delgadas revelaram que esses granitóides são portadores de carbonato( $3 \%$ a $4 \%$ modal, Tabela 8.1$)$, epidoto e fluorita, os quais foram interpretado como fases tardias, visto que ora estão intimamente associados à descalcificação do plagioclásio, ora ocorrem preenchendo cavidades, juntamente com muscovita minerais opacos e clorita, especialmente os dois primeiros(ver ítem aspectos petrográficos desse capítulo). Assim, pode-se pensar alternativamente que $0 \mathrm{Ba}$, inicialmente concentrado no feldspato potássico, no plagioclásio e na provável biotita primária( atualmente alterada para clorita) foi remobilizado durante os processos de alterações tardi a pós-magmáticas, juntamente o cálcio do plagioclásio, e se concentrou nesses fases tardias, principalmente na fase carbonática, juntamente com algumas terras raras leves(Ce e La) e outros elementos associados, como por exemplo o F(Cesbron, 1989), que também mostram-se enriquecidos nesses granitóides. De qualquer modo, essa hipótese representa, no momento, uma conjectura que necessita ser comprovada no futuro através de estudos detalhados de microssonda eletôrnica ou mesmo através de microscopia eletrônica de varredura.

$\mathrm{O} \mathrm{Zr}$ apresenta-se em quantidades elevadas nesses granitóides(346ppm a 353ppm), se comparadas com os outros granitóides da suite ora estudados(Tabela 8.3, Anexo 52), comportando-se, portanto, como elemento incompativel durante a diferenciação magmática. No diagrama $\mathrm{Rb}$ - Zr(Figura 8.13d) observa-se que as razões $\mathrm{Zr} / \mathrm{Rb}$ situam-se entre 1,00 e 2,00 , estando, por conseguinte, em niveis compativeis com as médias dos granitos apresentada em Taylor(1964). Sua principal fonte, nesse granitóide, mostra-se representada principalmente pelo zircão, embora a apatita possa ter alguma contribuição(Taylor, 1965).

$\mathrm{Na}$ Tabela 8.3(Anexo 52) nota-se que os conteúdos de Th(58,01ppm a 61,60ppm) são elevados se comparados com a média dos granitos apresentada em Taylor(1965; pg. 1281 ), enquanto que as de $U$ são levemente superiores $(5,21 \mathrm{ppm}$ a $5,48 \mathrm{ppm})$. Na Figura 8.13 e observa-se que as razões $U / T h$ situam-se entre 0,10 e 0,05 . Dentre as fases minerais presentes nesse granitóide, o zircão representa a principal fonte desses elementos.

No diagrama Rb-Ba-Sr(El-Bouseily \& El-Sokkary, 1975), Figura 8.13f percebe-se que as amostras analisadas incidem no campo composicional correspondente aos granitos normais. Isso diferencia esse granitóide daqueles da maioria dos seus correlativos dos maciços apresentados anteriormente, embora coincida com uma amostra da facies BASMG 
e uma amostra da facies BSGCl, ambas pertencentes ao maciço granitóide Antônio Vicente e correspondentes aos termos menos evoluídos e desprovidos de mineralizações de estanho, bem como de outros metais associados. Não não foi registrado, até o momento, qualquer ocorrências de mineralizações nesse maciço.
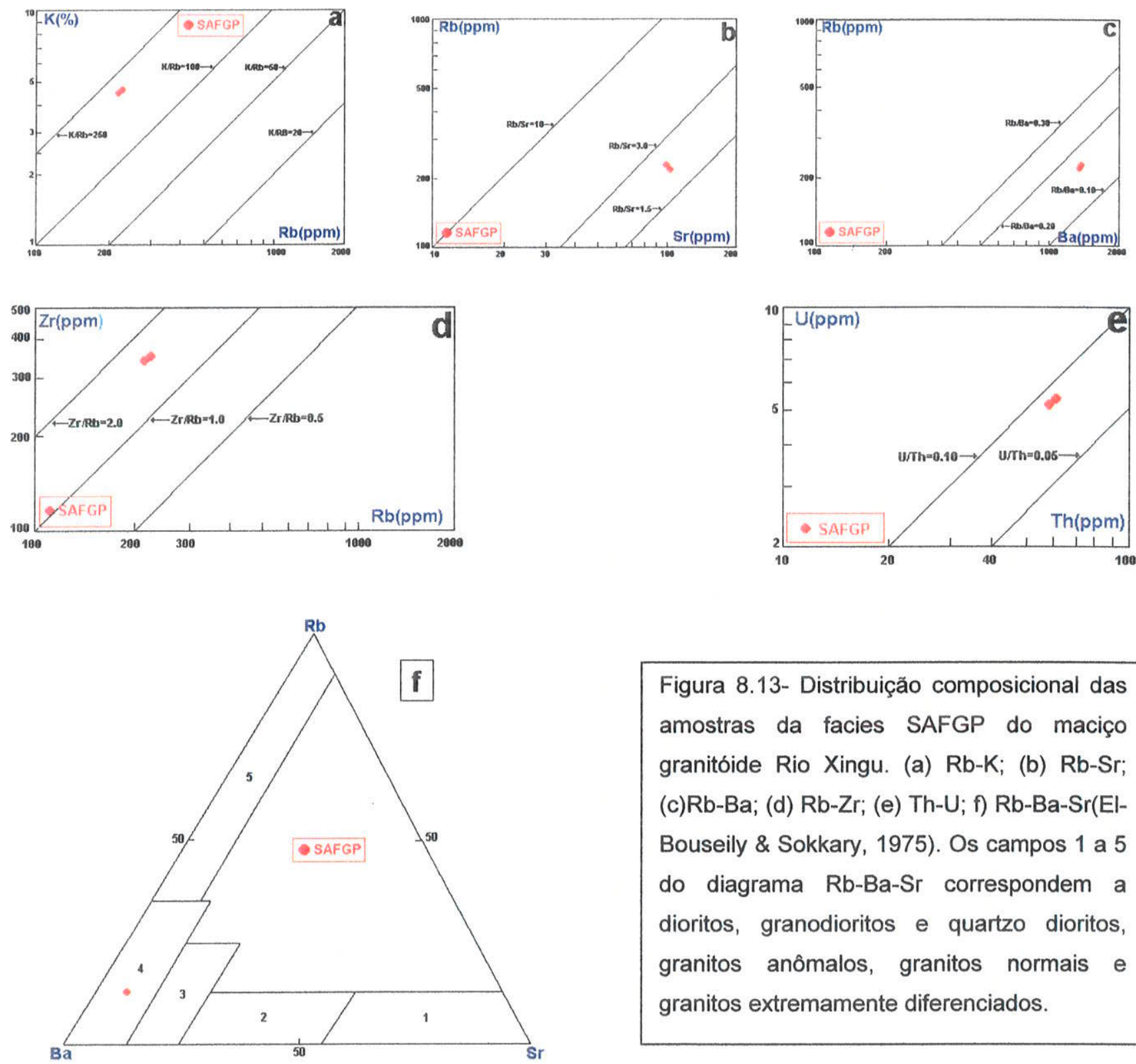

Figura 8.13- Distribuição composicional das amostras da facies SAFGP do maciço granitóide Rio Xingu. (a) Rb-K; (b) Rb-Sr; (c)Rb-Ba; (d) Rb-Zr; (e) Th-U; f) Rb-Ba-Sr(ElBouseily \& Sokkary, 1975). Os campos 1 a 5 do diagrama $\mathrm{Rb}-\mathrm{Ba}-\mathrm{Sr}$ correspondem a dioritos, granodioritos e quartzo dioritos, granitos anômalos, granitos normais e granitos extremamente diferenciados.

No que se refere aos ETR, a análise da Tabela 8.3(Anexo 52) mostra que o granitóide desse maciço é empobrecido em ETRL e enriquecidos em ETRP, em relação à abundância desses elementos na crosta continental(Shaw et al., 1986; Condie, 1993).

Em relação ao comportamento geoquímico desses elementos observa-se na Tabela 8.4 que, de um modo geral, esse granitóide é enriquecido em $\operatorname{ETRL}\left(\sum E T R L=613,85 p p m\right)$ relativamente aos $\operatorname{ETRP}\left(\sum E T R P=47,62 \mathrm{ppm}\right)$. Na Figura 8.14 nota-se que a distribuição 
desses elementos normalizada para condritos(Sun, 1982) desenvolve, um padrão "gaivota", com uma anomalia negativa de Eu, atenuada em relação à maioria dos granitóides dos outros maciços vistos anteriormente, sendo, entretanto, semelhante ao padrão de distribuição desenvolvido pelas facies granitóides BASMG e BSGCl ocorrentes no maciço granitóide Antônio Vicente(ver capítulo 3 deste trabalho).

A razão média $(L a / Y b)_{N}$ nesse granitóide é igual a 17,75, sendo a mais elevada entre todos os granitóides dos maciços estudados nesse trabalho. A razão média(EuN/Eu*) é igual a 12,99 e se assemelha muito àquelas determinadas para os demais granitóides vistos nos capitulos $3,4,5,6$ e 7 .

Estudos realizados através de microscopia ótica acusaram a existência de diversas fases minerais acessórias representadas por minerais opacos, apatita e zircão(fases primárias) e fluorita, epidoto, esfalerita e carbonatos(fases secundárias). Adicionalmente, foram realizadas análises químicas em algumas dessas fases através de microscopia eletrônica de varredura. Essas análises revelaram a presença de apatita e de óxido de $\mathrm{Fe}$ com W. A apatita corresponde a uma fase quase pura, com infimas quantidades de Y. A fase óxido, por sua vez, também, não hospeda ETR. Assim, restam como candidatos a portadores desses elementos as fases a saber: 1) o zircão, que pode conter diversos porcentos ou mais de óxidos de ETR, com o grupo do $Y$ predominando sobre o grupo do $\mathrm{Ce}$, especialmente nas variedades mais ou menos metamíticas tais como "cyrtolita" e malacon(Cesbron, 1989; pg. 11); 2) os carbonatos que podem abrigar quantidades expressivas de ETRL, $\mathrm{F}$ e de $\mathrm{Ba}$ (anomalamente concentrado nesse granitóide), tais como cebaita e cordilita(Cesbron, 1989, pg. 23; Jones et al., 1996). Entretanto, qualquer conclusão a esse respeito, no momento, é prematura, visto que essas fases não foram analisadas quimicamente através de microssonda eletrônica ou mesmo através de MEV.

Tabela 8.4. Principais caracteristicas dos ETR nos granitóide do maciço granitóide Rio Xingu.

\begin{tabular}{|l|c|}
\hline Facies Granitóide & SAFGP \\
\hline (La/Yb)N & 17,75 \\
\hline (EuN/Eu*) & 12,99 \\
\hline$\sum E T R L$ & 613,85 \\
\hline$\sum$ ETRP & 47,62 \\
\hline$\sum E T R$ & 662,99 \\
\hline
\end{tabular}




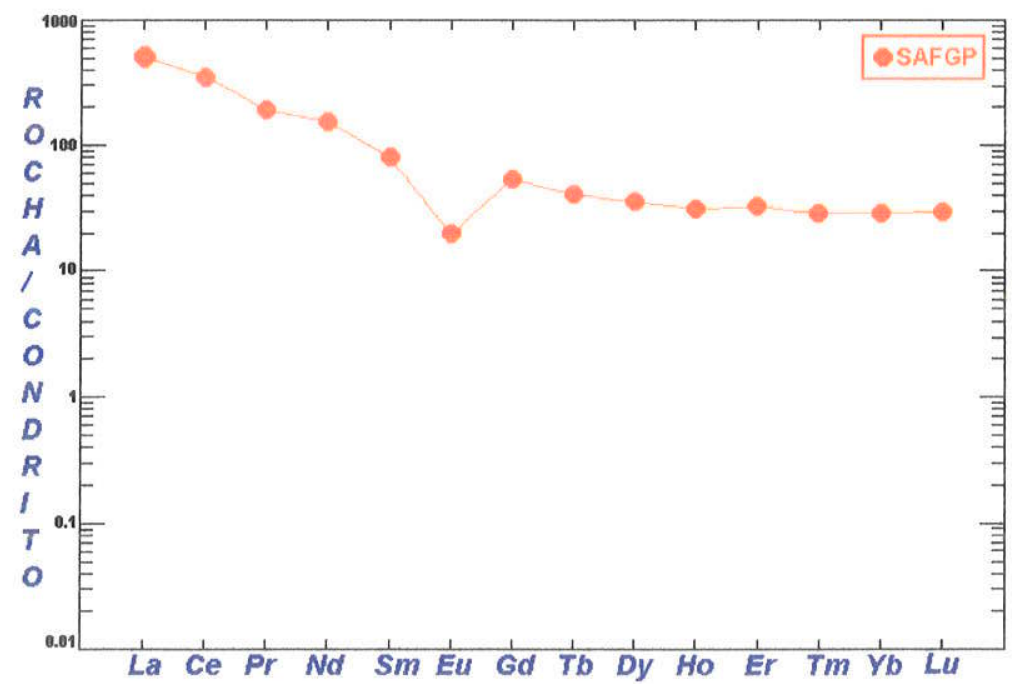

Figura 8.14. Padrão de distribuição dos ETR para os granitóides do maciço Rio Xingu.

\subsection{5- Análises Normativas CIPW}

A Tabela 8.5 permite estabelecer as seguintes considerações àcerca desse granitóide:

1) trata-se de um granitóide saturado em $\mathrm{Al}_{2} \mathrm{O}_{3}$, embora com baixo córindon normativo, tal qual a grande maioria dos granitóides dos demais maciços ora estudados, especialmente, as facies mais evoluídas.

2) as análises revelam uma grande homogeneidade dessa rocha. São excessões os conteúdosc de córindon( $0,01 \%$ a $0,17 \%)$ e de anortita(5,14\% a 4,00\%)

No diagrama Q-Ab-Or(Figura 8.15a) observa-se que as composições normativas desse granitóide incide no campo correspondente a $86 \%$ de freqüência das razões normativas Q-Ab-Or de 1190 rochas graníticas de Winkler e Von Platen(1961), porém mostram-se um pouco afastadas do campo de máxima freqüência(ponto $M$ ), deslocando-se para a direita e em direção ao vértice do $Q$ (slicificação +microclinização).

A exemplo dos demais granitóides comentados anteriormente, este mostra-se albitizado, em grau variado, embora, o efeito dessa alteração não se reflita na sua composição normativa global, confirmando o que foi observado nas rochas dos outros maciços da suite. Adicionalmente, percebe-se, nesse diagrama, que o magma gerador deste granitóide era, também, pobre em $\mathrm{F}$, uma vez que a composição do mesmo situa-se abaixo da posição de temperatura do ponto de mínimo correspondente a $1 \%$ de $F$ adiconado(Manning, 1981), bem como encontra-se distante do ponto de mínimo sem adição de F(Tuttle \& Bowen, 1958). O que demonstra que este elemento foi realmente remobilizado e enriquecido no estágio de alterações tardi a pós-magmáticas. Isso é traduzido pela presença de quantidades um pouco expressivas do mesmo nestas rochas, embora não 
sejam tão elevadas quanto nos demais granitóides dos outros maciços, especialmente naquelas facies mais evoluídas e mais intensamente alteradas. Isso é reforçado pela presença freqüente de fluorita.

Ademais, nota-se, nesse diagrama, que a totalidade das composições situa-se entre as projeções das linhas cotéticas isobáricas de $\mathrm{P}_{\mathrm{H} 2 \mathrm{O}}$ de $2 \mathrm{kbar}$ e de $5 \mathrm{kbar}$ de Winkler(1977), tal qual as amostras das variedades mais evoluídas e mais fortemente alteradas do maciço granitóide Antônio Vicente.

No diagrama Ab-An-Or(Figura $8.15 \mathrm{~b}$ ) as duas composições incidem junto à aresta $A b-O r$, mas um pouco deslocadas para o vértice do Or.
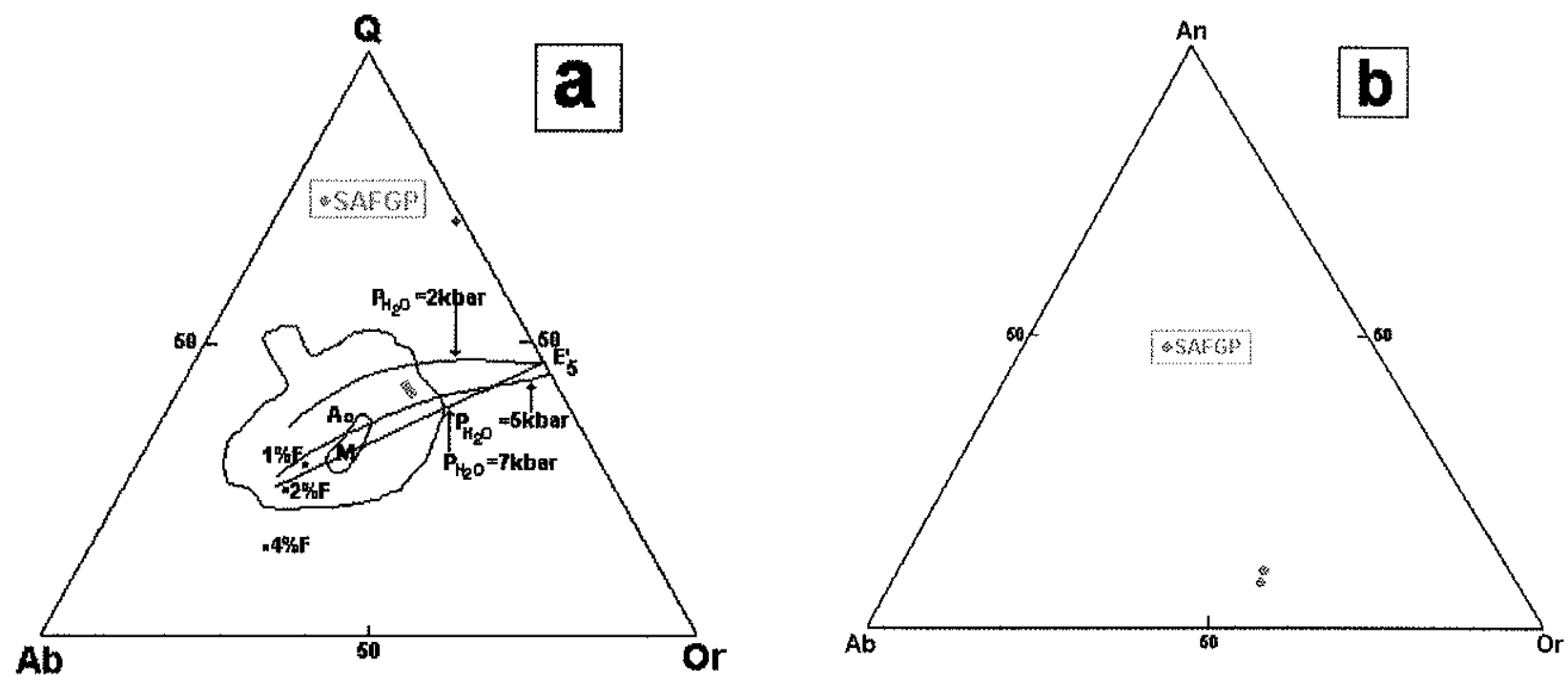

Figura 8.15- a) Diagrama normativo Q-Ab-Or mostrando a distribuição composicional das principais facies granitóides do maciço granitóide Rio Xingu. A curva envoltório dos pontos composicionais corresponde ao campo de distribuição de freqüência das razóes $Q$-Ab-Or de 1190 rochas graníticas de Winkler \& Von Plaren(1961). As projeções das linhas cotéticas isobáricas P-E'5 de 2, 5 e 7kbar foram compiladas de Winkler(1977). $M=0$ máximo de freqüéncia , $A=$ a posição e temperatura do ponto de mínimo sem $F($ Tuttle \& Bowen, 1958). 1\%F, $2 \% \mathrm{~F}$ e $4 \% \mathrm{~F}$ representam as posições e temperaturas dos pontos de mínimo com $\mathrm{F}$ adicionado e excesse de água a $1 \mathrm{kbar}($ Manning, 1981);

b) Diagrama normativo Ab-An-Or mostrando a distibuição composicional das principais facies petrográficas do maciço granitóide Rio Xingu.

\section{7- Condições de Cristalização}

\subsection{1- Posicionamento Crustal}

Similarmente aos granitóides dos macicos Antônio Vicente, Mocambo, Benedita e Ubim/Sul, essa rocha ocorre, no campo, lado a lado e no mesmo nivel de erosão, com 
rochas vulcânicas intermediárias, não metamorfisadas regionalmente, pertencentes à Formação Sobreiro do Grupo Uatumã. Entretanto, trabalhos de detalhe com vistas a caracterizar as relações de contato entre essamaciço e as vulcânicas, bem como definir auréola de metamorfismo entre as mesmas não foram, até o momento, realizados. De qualquer modo, a semelhança entre o ambiente de ocorrência dos maciços acima citados e esse granitóide permite deduzir que o mesmo foi alojado em nivel crustal alto.

Além disso, estudos petrográficos realizados através de microscopia ótica mostraram a presença de abundantes intercrescimentos granofíricos, os quais constituem a quase totalidade da matriz. Texturas de preenchimento também foram observadas. Essas microtexturais são, geralmente, desenvolvidos em rochas igneas félsicas colocadas próximo à superficie do crosta(Moorhouse, 1959, pg. 270; Smith, 1974, pg. 582; Bard, 1986, p.111; Pitcher, 1987) e, por portanto, em condições de baixas pressões, a partir de uma cristalização rápida de um granito eutético ternário, com quantidades semelhantes de quartzo, feldspato potássico e plagioclásio(Smith, 1974, pg. 582).

A presença da paragênese fluorita+sericita+muscovita nesse granitóide, bem como sua relaçăo com quantidades importantes de $F$, indicam um posicionamente do mesmo em nivel crustal raso, entre $1 \mathrm{~km}$ a $5 \mathrm{~km}$ (Bailey, 1977).

Datações radiométricas realizadas por Teixeira et al(1998) forneceram idades de $1.906 \pm 29 \mathrm{Ma}$ (rocha total) e 1.862 3 (evaporação de $\mathrm{Pb}$ em zircões) para esse granitóide. Essas idades quando comparadas com aquelas obtidas pelos mesmos autores em rochas do Grupo Uatumã, indicam contemporaneidade entre esse granitóide e as vulcãnicas $O$ fato de terem idades semelhantes e ocorrererem lado a lado no campo indica que essas rochas estão associadas no tempo e no espaço, tal qual foi observado em relação aos granitóides dos maciços Antônio Vicente, Mocambo, Benedita e Ubim/Sul.

\subsection{2- Condições de $\mathrm{fO}_{2}, \mathrm{~T}$ e $\mathrm{P}$}

Em relaçăo a esse granitóide, não foram obtidos em laboratório dados que possibilitassem uma discussão àcerca das condições de $\mathrm{fO}_{2}$, bem como permitissem estimar quantitativamente a temperatura e pressão que reinaram durante a história de cristalização desse granitóide.

Entretanto, o fato de ocorrerem am ambientes similares àqueles dos granitóides Antônio Vicente, Mocambo, Benedita e Ubim/Sul, bem como mostrarem feições texturais indicativas de nivel crustal raso, permite supor que o mesmo cristalizou em condições semelhantes àquelas estimadas para os granitóides dos maciços referidos acima. Assim, pode ser estabelecido que esse granitóide cristalizou em condições de baixa fugacidade de oxigênio, em temperaturas em torno dos $700^{\circ} \mathrm{C}$ e baixas pressões( $( \pm 1 \mathrm{kbar}$ ). 


\section{8- Conclusões a Considerações Finais}

Os estudos petrográficos, análises quimicas de fases minerais e de rocha total permitiram estabelecer as seguintes conclusões a respeito desse maciço granitóide:

1) o granitóide desse maciço é essencialmente sienogranítico e "subsolvus", havendo apenas uma amostra cuja composição corresponde ao álcali-feldspato granito. Tem natureza holo-leucocrática e apresenta $M^{\prime}<5 \%$. Essas características demonstram que o mesmo se formou a partir de um fundido muito evoluído e félsico, do mesmo modo que os granitóides dos demais maciços, embora, texturalmente seja muito diferente dos mesmos. Ele apresenta textura porfiritica peculiar, caracterizada pela presença de fenocristais grossos a médios, tabulares a semi-tabulares e, às vezes, ovoidais, de feldspato potássico, arredondados a semi-arredondados de quartzo e ripiformes e tabulares, de plagioclásio. Esses fenocristais encontram-se imersos em uma matriz heterogranular fina, constituida essencialmente de feldspato potássico + quartzo (intercrescimentos granofíricos e gráficos), quartzo e feldspato potássico(em cristais independentes) e plagioclásio. Mostra-se afetado por alterações tardi a pós-magmáticas.

2) a presença da associação fluorita + muscovita + clorita, etc., sugere que o mesmo foi colocados em nível crustal raso, entre $1 \mathrm{Km}$ e $5 \mathrm{Km}$ (Bailey(1977). Isso é reforçado pela ocorrência de abundantes intercrescimentos gráficos e granofíricos e pela existência de cavidades, as quais mostram-se preenchidas, principalmente, por carbonato $\left(\mathrm{Cb}_{2}\right)$, minerais $\operatorname{opacos}\left(M O P_{2}\right)$, muscovita( $\left(\mathrm{Mv}_{2}\right)$, epidoto $\left(E \mathrm{p}_{2}\right)$ e esfalerita(Esf $\left.\mathrm{f}_{2}\right)$.

3) análises quimicas de rocha total demonstram que se trata de um granitóide muito diferenciado, cujos teores de $\mathrm{SiO}_{2}$ situam-se em torno de $75,00 \%$, confirmando o que fora estabelecido através dos dados petrográficos. Em relação aos principais óxidos possui conteúdos sempre reduzidos de $\mathrm{TiO}_{2}, \mathrm{Al}_{2} \mathrm{O}_{3}, \mathrm{MgO}, \mathrm{CaO}$ e $\mathrm{P}_{2} \mathrm{O}_{5}$ e muito inferiores àqueles da média dos granitos fornecidos por Le Maitre(1976). Os teores de $\mathrm{Fe}_{2} \mathrm{O}_{3}$ e de $\mathrm{MnO}$ são mais elevados, os de $\mathrm{K}_{2} \mathrm{O}$ são ligeiramente mais altos e os de $\mathrm{Na}_{2} \mathrm{O}$ são bem mais reduzidos.

4) é essencialmente peraluminoso, de natureza subalcalina, apresenta características de granitóides intra-placas, mostra semelhanças químicas com os granitos tipo-A, sub-grupo $\mathrm{A}_{2}$. ). Trata-se de um granitóide saturado em $\mathrm{Al}_{2} \mathrm{O}_{3}$, embora com baixo córindon normativo, tal qual a grande maioria dos granitóides dos demais maciços ora estudados, especialmente, as facies mais evoluidas. 
5) no que se refere aos elementos menores e traços, ostenta altos teores de $\mathrm{Ba}($ média $=1378 \mathrm{ppm}), \mathrm{Zr}($ média $=350 \mathrm{ppm})$ e de $\mathrm{Zn}$ (média=266ppm), conteúdos moderados de $R b($ média $=220 \mathrm{ppm}), \quad \mathrm{Sr}($ média $=101 \mathrm{ppm}), \quad \mathrm{Y}($ média $=83 \mathrm{ppm}), \quad F($ média $=525 \mathrm{ppm})$, $W($ média $=67 \mathrm{ppm})$ e de $T h($ média $=60 \mathrm{ppm}$ ) e baixas concentrações de $\mathrm{Nb}$ (média=30ppm), $\mathrm{Ga}($ média $=23 \mathrm{ppm}), \mathrm{Sn}($ média $=2 \mathrm{ppm}), \mathrm{Mo}($ média $=1 \mathrm{ppm}), \mathrm{Ta}($ média $=2 \mathrm{ppm}), \mathrm{Hf}($ média $=$ $11 \mathrm{ppm})$ e de $U($ média $=5 \mathrm{ppm})$.

6) em relação aos ETR, esse granitóide mostra-se empobrecido em ETRL e enriquecido em ETRP, em relação a abundância desses elementos na crosta continental(Shaw et al., 1986; Condie, 1993). Entretanto, verifica-se que as concentrações de ETRL(média=613,85ppm) mostram-se mais altos do que as quantidades de $\operatorname{ETRP}(47,62 \mathrm{ppm})$. O padrão de distribuição desses elementos normalizado para condritos(Sun, 1982) é também do tipo "gaivota", com uma anomalia negativa de Eu atenuada em relação à maioria dos granitóides dos outros maciços ora estudados, sendo, porém, semelhante ao padrão de distribuição desses elementos apresentado pelas facies granitóides BASMG e BSGCl, ocorrentes no maciço granitóide Antônio Vicente. Uma pequena anomalia de Eu pode decorrer, também, da presença de pequenas quantidades no resíduo do fundido.

A razão média (La/Yb) $)_{N}$ nesse granitóide é igual a 17,75, sendo a mais elevada entre todos os granitóides dos maciços estudados. A razão média(Eu $\left.u_{N} / E u^{*}\right)$ é igual a 12,99 e se assemelha muito àquelas determinadas para os demais granitóides da suite.

7) as razões $\mathrm{Rb} / \mathrm{Sr}$ ( em torno de 2), $\mathrm{Zr} / \mathrm{Rb}$ ( em torno de 1,5) e $\mathrm{Rb} / \mathrm{Ba}(0,16)$ são sempre muito baixas. A razão $\mathrm{Th} / \mathrm{U}$ é moderada a alta( em torno de 11), enquanto as razões $K / R b(201$ a 209) são eqüivalentes àquelas dos granitos considerados normais(Shaw, 1968).

8) as razões $\mathrm{K} / \mathrm{Rb}$ das amostras analisadas situa-se entre 200 e 250. A razão disso reside no fato desses granitóides possuírem quantidades elevadas de $\mathrm{K}_{2} \mathrm{O}(5,41 \%$ a $5,48 \%)$ e conteúdos baixos de $\mathrm{Rb}(214,58 \mathrm{ppm}$ a $226,34 \mathrm{ppm})$, decorrentes, principalmente da sua composição rica em feldspato potássico e da ausência de biotita.

9) as razões $\mathrm{Rb} / \mathrm{Sr}$ situam-se entre 1,50 e 3,00, demonstrando que tanto $\mathrm{Rb}$ quanto o $\mathrm{Sr}$ se comportaram como elementos compativeis durante a diferenciação/fracionamento desse granitóide. Uma outra hipótese para explicar esses teores relativamente baixos de $\mathrm{Rb}$ nesses granitóides é o fato dos mesmos terem sido derivados de uma fonte algo empobrecida de $\mathrm{Rb}$, já que os mesmos representam diferenciados muito evoluldos. 
10) as baixas razões $\mathrm{Rb} / \mathrm{Ba}$ devem-se aos conteúdos anomalamente altos de $\mathrm{Ba}$ nas rochas estudadas (1375ppm a $1380 \mathrm{ppm}$ ) em contrapartida aos teores relativamente baixos de Rb. De acordo com Taylor(1965) e Ollila(1984) $\circ \mathrm{Ba}^{2+}$ é capturado pelos minerais de $\mathrm{K}$ formados precocemente e conforme Nockolds \& Mitchell(1948. In: Taylor, 1965, pg 156) ele prefere mais o feldspato potássico do que a biotita em uma razão de cerca de 2:1. Segundo Smith(1974) ele se concentra mais fortemente no feldspato potássico em relação ao plagioclásio. Nos granitóides estudados os conteúdos elevados de Ba podem ser explicados por esse modelo ou seja as quantidades elevadas de Ba podem estar diretamente atreladas ao conteúdo de feldspato potássico, visto que a biotita está ausente nessas rochas e o plagioclásio é pouco abundante e de composição albítica. Entretanto, dados de química mineral obtidos através de microssonda eletrônica mostram que tanto o feldspato potássico, quanto o plagioclásio são pobres em Ba. Por outro lado os estudos petrográficos em lâminas delgadas revelaram que esses granitóides são portadores de carbonato( $3 \%$ a $4 \%$ modal), epidoto e fluorita, os quais foram interpretado como fases tardias, visto que ora estão vinculados à descalcificação do plagioclásio, ora ocorrem preenchendo cavidades, junto com muscovita minerais opacos e clorita, especialmente os dois primeiros. Assim, pode-se pensar em uma hipótese alternativa em que o $\mathrm{Ba}$, inicialmente concentrado no feldspato potássico, no plagioclásio e na provável biotita primária( atualmente alterada para clorita) foi remobilizado durante os processos de alterações tardi a pós-magmáticas, juntamente com o cálcio do plagioclásio, e se concentrou nesses fases tardias, principalmente na carbonática, em companhia com algumas terras raras leves(Ce e $\mathrm{La}$ ) e outros elementos associados, como por exemplo o $F(C e s b r o n, 1989)$, que também mostram-se enriquecidos nesses granitóides. De qualquer modo, essa hipótese representa, no momento, uma conjectura que necessita ser comprovada no futuro através de estudos detalhados de microssonda eletôrnica ou mesmo através de microscopia eletrônica.

11) os conteúdos de Th(58,01ppm a $61,60 \mathrm{ppm})$ são elevados se comparados com a média dos granitos apresentada em Taylor(1965; pg. 1281), enquanto que as de $U$ são levemente superiores $(5,21 \mathrm{ppm}$ a $5,48 \mathrm{ppm})$. As razões $U / T h$ situam-se entre 0,10 e 0,05 . Granitos peraluminosos afetados por microclinização são, quase sempre, empobrecidos em $U$, enquanto que a taxa de Th mantem-se inalterada, refletindo razões $\mathrm{Th} / \mathrm{U}$ crescentes. Esse fato é coerente em relação aos granitos estudados já que os mesmos mostram-se afetados por alterações tardi a pós-magmáticas.

12) estudos realizados através de microscopia ótica acusaram a existência de diversas fases minerais acessórias representadas por minerais opacos, apatita e zircão(fases primárias) e fluorita, epidoto, esfalerita e carbonatos(fases secundárias). Adicionalmente, 
foram realizadas análises químicas em algumas dessas fases através de microscopia eletrônica de varredura. Essas análises revelaram a presença de apatita e de óxido de $\mathrm{Fe}$ com W. A apatita corresponde a uma fase quase pura, com ínfimas quantidades de $Y$. A fase óxido, por sua vez, também, não hospeda ETR. Assim, restam como candidatos a portadores desses elementos as fases a saber: 1) o zircão, que pode conter diversos porcentos ou mais de óxidos de ETR, com o grupo do $Y$ predominando sobre o grupo do $\mathrm{Ce}$, especialmente nas variedades mais ou menos metamiticas tais como "cyrtolita" e malacon(Cesbron, 1989; pg. 11); 2) os carbonatos que podem abrigar quantidades expressivas de ETRL, $\mathrm{F}$ e de Ba(anomalamente concentrado nesse granitóide), tais como cebaita e cordilita(Cesbron, 1989, pg. 23; Jones et al., 1996). Entretanto, qualquer conclusão a esse respeito, no momento, é prematura, visto que essas fases não foram analisadas quimicamente através de microssonda eletrônica ou mesmo através de MEV.

13) similarmente aos granitóides dos macicos Antônio Vicente, Mocambo, Benedita e Ubim/Sul, essa rocha ocorre, no campo, lado a lado e no mesmo nivel de erosão, com rochas vulcânicas intermediárias, não metamorfisadas regionalmente, pertencentes à Formação Sobreiro do Grupo Uatumã. A semelhança entre o ambiente de ocorrência dos maciços acima citados e esse granitóide permite deduzir que o mesmo foi alojado em nível crustal alto.

14) em relação a esse granitóide, não foram obtidos em laboratório dados que possibilitassem uma discussão àcerca das condições de $\mathrm{fO}_{2}$, bem permitissem como estimar quantitativamente a temperatura e pressão que reinaram durante a história de cristalização do mesmo. Entretanto, o fato de ocorrerem am ambientes similares àqueles dos granitóides António Vicente, Mocambo, Benedita e Ubim/Sul, bem como mostrarem feições texturais indicativas de nível crustal raso, permite supor que o mesmo cristalizou em condições semelhantes àquelas estimadas para os granitóides dos maciços referidos acima. Assim, pode ser estabelecido que esse granitóide cristalizou em condições de baixa fugacidade de oxigênio, em temperaturas em torno dos $700^{\circ} \mathrm{C}$ e baixas pressões $( \pm 1 \mathrm{kbar})$. 


\section{CAPITULO 9}

\section{9 - ESTUDO DE ISÓTOPOS DE OXIGÊNIO}

Nas últimas décadas um número elevado de análises de isótopos de oxigênio tem sido realizado em granitóides, tanto em rocha total, quanto em minerais separados(Clayton et al., 1972; Bottinga \& Javoy, 1973; O'Neil et al., 1977; Ferester \& Taylor Jr., 1980; Möller et al., 1985; Cheang et al., 1986; Kerrich \& Beckinsale, 1988; Taylor Jr., 1988; Rios, 1995, entre outros). Esses trabalhos tem fornecido importantes informaçóes sobre a origem e evolução de granitóides, tipos de protólitos e condições de formação, bem como àcerca dos processos que afetaram os corpos granitóides durante e após as suas colocações.

Neste trabalho, o estudo de isótopos de oxigênio tem caráter preliminar e representa um dos primeiros estudos dessa natureza em granitóides da Amazônia Oriental, só tendo sido antecipado pelos estudos realizados por Rios(1995) em granitóides e veios hidrotermais, ocorrentes no âmbito dos maciços Musa e Serra dos Carajás. Foi realizado em grãos de quartzo, correspondentes ao tipo 1, extraídos dos maciços granitóides Antônio Vicente, Velho Guilherme e Mocambo e as análises foram assim discriminadas:

1) Maciço granitóide Antônio Vicente: foram analisados grãos de quartzo oriundos das facies BASMG, BASAFG e BSG e do CSMQGs. Os granitóides encontram-se pouco afetados por alterações tardi a pós-magmáticas, enquanto que o CSMQGs representa um extremo dessas alterações.

2) Maciço granitóide Velho Guilherme: foram estudados gãos de quartzo 1 pertencentes à facies SGH, cujo grau de alteração é mais alevado do que aqueles dos granitóides do MGAV.

3) Maciço granitóide Mocambo: foram analisados grãos de quartzo 1 em três amostras distintas da facies SMGP, as quais encontram-se um pouco mais alteradas do que aquela do MGVG.

Em todos os casos foram estudados gãos de quartzo puros. A limpeza de impurezas odsorvidas nas superfícies dos mesmos foi realizada através de banhos em soluções de $\mathrm{HCl}$ com diluição 1:1. 
A Tabela 9.1 mostra a somatória das quantidades modais das principais fases minerais de alteração dos granitóides estudado e do greisen, bem como os valores de $\delta^{18} \mathrm{O}(\% 0)$ obtidos nos mesmos.

Os cáculos de $\delta^{18} \mathrm{O}(\%$ ) obedeceram a seguinte condição:

$$
\begin{aligned}
& \delta^{18} \mathrm{O}_{\text {amostra }}\left({ }^{\%} / 00\right)=\left[\left({ }^{18} \mathrm{O} /{ }^{16} \mathrm{O}_{\text {amostra }} \div{ }^{18} \mathrm{O} /{ }^{16} \mathrm{O}_{\text {padrăo }}\right)-1\right] \times 1000 \\
& \text { onde: }{ }^{18} \mathrm{O} /{ }^{16} \mathrm{O}_{\text {padráa é SMOW e }}{ }^{18} \mathrm{O} /{ }^{16} \mathrm{O}_{\text {padråoo }}=0,0039948
\end{aligned}
$$

O caráter preliminar desse estudo decorre do fato de não se dispor, no momento, de análises de isótopos de $H(\delta D)$, bem como de não ter sido analisado, pelo menos, um par de minerais em equlibrio ou mesmo, amostras de rocha total.

Assim, de posse tão somente dos valores de $\delta^{18} \mathrm{O}$, esse estudo fica limitado à discussão do significado da assinatura isotópica dos granitóides estudados e do geisen.

\section{1- Discussão dos Resultados}

De acordo com Clayton et al.(1972) o fracionamento isotópico de oxigênio entre o quartzo e a água é grande e depende fortemente da temperatura. Como resultado, a composição isotópica do quartzo formado ou recristalizado em sistemas aquosos é governada mais pela temperatura de formação do que pela composição isotópica da água.

Sabe-se, entretanto, que o quartzo é altamente resistente à troca isotópica de oxigênio com fluidos hidrotermais a temperaturas menores ou iguais a $300^{\circ} \mathrm{C}$ (Clayton, op. cit., pg. 3058; Forester \& Taylor, 1980, pg. 357; Kerrich \& Beckinsale, 1988, pg. 117), enquanto que os feldspatos são susceptiveis a trocas até cerca de $150^{\circ} \mathrm{C}$. De acordo com esses autores, essa diferença na cinética das reações de troca de isótopos ocorre devido a uniformidade dos valores de $\delta^{18} \mathrm{O}$ do quartzo em contraste com a grande dispersão dos valores de $\delta^{18} \mathrm{O}$ do feldspato.

Em relação aos granitóides estudados, conforme visto acima, não foi analisada qualquer outra fase mineral a não ser o quartzo. Por isso, não é possível estabelecer uma comparação entre os dados aqui apresentados e aqueles apresentados pelos estudos acima mencionados.

Na Tabela 9.1 e na Figura 9.1, verifica-se que os valores de $\delta^{18} \mathrm{O}$ referentes maciços granitóides Antônio Vicente e Velho Guilherme são muito semelhantes e pouco variáveis, estando compreendidos entre $+8,0 \%$ (facies BSG) e $+8,5 \%$ (facies BASAFG). Em relação ao maciço granitóide Mocambo, os valores de $\delta^{18} \mathrm{O}$ tornam-se um pouco mais elevados e situam-se ente $+8.8 \%$ e $9,0 \%$, o que é sugestivo de uma fonte provavelmente distinta daquela dos granitóides dos dois outros maciços ora comentados. 
Essas observações reforçam, em parte, as considerações apresentadas pelos autores supracitados, de que o quartzo é resistente à troca isotópica de oxigênio com fluidos hidrotermais coexistentes, uma vez que os granitóides estudados mostram-se afetados por fluidos tardios, em diferentes intensidades, e os valores de $\delta^{18} \mathrm{O}$ mostram-se muito pouco variáveis internamente a cada maiço.

Dados de química mineral obtidos através de microssonda eletrônica em grãos de clorita, inequivocamente formados no estágio de alterações tardi a pós-magmáticas, hospedadas nos granitóides estudados e no greisen, indicaram os seguintes intervalos de temperaturas mínimas de cristalização para a mesma:

1)Facies BASMG(MGAV) $=395,93^{\circ} \mathrm{C}-439,40^{\circ} \mathrm{C}$
2)Facies BASAFG(MGAV) $=267,46^{\circ} \mathrm{C}-418,15^{\circ} \mathrm{C}$
3)Facies BSG(MGAV) $=493,17^{\circ} \mathrm{C}-507,98^{\circ} \mathrm{C}$
4)CSMQGs(MGAV) $=458,17^{\circ} \mathrm{C}-592,66^{\circ} \mathrm{C}$
5)facies SGH(MGVG) $=393,03^{\circ} \mathrm{C}-415,89^{\circ} \mathrm{C}$
6)Facies SGMV(MGM) $=474,49^{\circ} \mathrm{C}-581,07^{\circ} \mathrm{C}$
7)SCMQGs(MGM) $=573,34^{\circ} \mathrm{C}-603,60^{\circ} \mathrm{C}$

Embora não se tenha analisado grãos de clorita correspondente à facies SMGP do maciço granitóide Mocambo, considera-se que sua temperatura mínima de cristalização não foge muito dos intervalos estimados para os grão de clorita da facies SGMV e SCMQGs daquele maciço.

Diante disso, percebe-se que os fluidos tardios que interagiram e alteraram as rochas em questão atingiram temperaturas mínimas em torno destas estimadas para a clorita, visto que esta fase mineral representa uma das primeiras a se formar no estágio de alterações tardi a pós-magmáticas. Nesse caso, como o quartzo é mais susceptível a trocas isotópicas de oxigênio em condições de temperatura acima de $300^{\circ} \mathrm{C}$ (conforme visto acima), pode-se concluir que durante os processos de alteração houve trocas isotópicas de oxigênio entre os fluidos tardios aquosos(ver estudo de inclusões fluidas, capítulo 10) e os grãos de quartzo estudados, sem, no entanto, causar modificações importantes nas assinaturas isotópicas 
originais de oxigênio dos mesmos. Esse fato se torna mais claro em relação ao CSMQGs que embora represente um extremo de alteração pervasiva da facies $B S G$, mostra um valor de $\delta^{18} \mathrm{O}$ semelhante ao deste granitóide $(+8,4 \%$ ), embora um pouco mais elevado(Tabela 9.1).

Além disso, os valores de $\delta^{18} \mathrm{O}$ do quartzo 1 das rochas dos maciços Antônio Vicente e Velho Guilherme sugerem que as mesmas derivaram de fontes com características isotópicas de oxigênio muito semelhantes, as quais não foram modificadas de modo significante. $O$ granitóide do maciço Mocambo devido exibir valor de $\delta^{18} \mathrm{O}$ um pouco mais elevado, deve ter sido derivado de uma fonte diferente ou teve seu valor original de $\delta^{18} \mathrm{O}$ modificado devido aos processos de alterações tardi a pós-magmáticas. Este último caso não parece ser verdadeiro, visto que não explica o fato do CSMQGs, associado ao maciço granitóide Antônio Vicente, mostrar valor muito semelhante àquele do granitóide do qual foi originado(facies BSG, Tabela 9.1), conforme comentado acima.

Adicionalmente, os valores relativamente mais elevados de $\delta^{18} \mathrm{O}$ encontrados na facies SMGP do MGM $(+8,8 \%$ a $9,0 \%$ ), superam o mais reduzido $(+8,0 \%$ encontrado na facies BSG do MGAV $12,5 \%$, o que se supõe ser uma diferença muito expressiva, visto que tratam-se de dados obtidos através de um método analítico convencional de análises, os quais admitem apenas pequenas oscilações nos resultados.

De acordo com Taylor(1978), as rochas graníticas podem ser classificadas, arbitrariamente, em três categorias a saber: 1) granitos com baixos $\delta^{18} \mathrm{O}\left(\delta^{18} \mathrm{O}<+6\right)$; 2) granitos com $\delta^{18} \mathrm{O}$ normais $\left(+6 \%<\delta^{18} \mathrm{O}<+10 \%\right)$; 3) granitos com $\delta^{18} \mathrm{O}$ altos $\left(\delta^{18} \mathrm{O}>\right.$ $+10 \%$ ). Considerando-se esta classificação, os granitóides ora estudados enquadram-se no grupo dos granitos normais $\left(\delta^{18} \mathrm{O}\right.$ entre +8 e $+9 \%$ ).

As composições isotópicas de oxigênio mais favoráveis à interpretação encontram-se fora do intervalo da granitos normais(Anderson \& Morrison, 1992). Entretanto, a ampla maioria dos granitóides anorogênicos possui valores de $\delta^{18} \mathrm{O}$ correspondentes aos granitos normais(Anderson \& Morrison, op. cit.). Assim, a interpretação dos valores de $\delta^{18} O$ referentes aos granitos normais geralmente incorrem em ambiguidades, as quais podem estar vinculadas à múltiplos processos envolvendo os valores de $\delta^{180}$ a saber: 1) mistura variável entre basalto derivados do manto e grabros $\left(\delta^{18} \mathrm{O} \cong+6 \%\right)$ e rochas crustais $\left(\delta^{18} \mathrm{O} \cong+\right.$ 8 a $+10 \%$ pode explicar alguns valores normais. Alternativamente, a fusão de rochas crustais meta-ígneas com valores de $\delta^{18} \mathrm{O}$ variáveis entre $+6 \mathrm{e}+10 \%$, pode, também, gerar granitos normais(Anderson \& Morrison, op. cit.).

De acordo com Taylor(1988) valores incomunmente altos de $\delta^{18} \mathrm{O}\left(>+8^{0} \% 0\right)$, em magmas, requerem o envolvimento com material parental precursor que em algum tempo no 
passado residiu próximo à superfície, ou com rochas sedimentares ou, ainda, com rochas alteradas imtempericamente ou hidrotermalmente.

No que se refere aos granitos estudados, os valores de $\delta^{18} \mathrm{O}$ aliados aos dados de isótopos radiogênicos( $\mathrm{Pb}-\mathrm{Pb}$ e $\mathrm{Sm}-\mathrm{Nd}$; ver mais adiante) indicam que os magmas parentais dos granitóides estudado evoluíram a partir de uma fonte com importante contribuição crustal(niveis rasos), predominantemente Arqueana, com provável contaminação com sedimentos.

Deve-se ressaltar, entretanto, que devido o valor de $\delta^{18} \mathrm{O}(+8,8$ a $9,0 \%$, correspondente ao granitóide do maciço Mocambo, ser um pouco diferente e mais elevado do que aqueles relativos aos maciços António Vicente e Velho Guilherme, pode-se inferir que o protólito do mesmo tinha características isotópicas distintas daquele(s) gerador(es) dos granitóides destes maciços. Isso é muito evidente na Figura 9.2.

De qualquer modo, essas considerações devem ser vistas como preliminares em função dos dados disponiveis serem, no momento, insuficientes para se concluir de forma mais consistente a esse respeito, bem como para se obter outras informações adicionais àcerca dos granitóides dos maciços em questão.

Comparativamente às assinaturas isotópicas obtidas através da análise de grãos de quartzo extraídos dos granitos Musa e Serra Carajás, ocorrentes, também, no Craton Amazônico, na Amazônio Oriental(Rios, 1995), os valores de $\delta^{18} \mathrm{O}$ obtidos em grãos de quartzo dos granitóides ora estudados, mostram-se mais elevados, enquanto que em relação àqueles fornecidos por grãos de quartzo oriundos de veios hidrotermais associados aos granitos supracitados, são eqüivalentes, especialmente, em relação ao veio hidrotermal associado ao granito Serra dos Carajás

Tabela 9.1- Características isotópicas de granitóides e greisen dos maciços Antônio Vicente, Velho Guilherme e Mocambo, em termos de $\delta^{18} \mathrm{O}(\% 0)$. ${ }^{\star \star}$ Valor médio. Alb=albita; Ep=epidoto; $\mathrm{Cl}=$ =lorita; Ser=sericita; Mv=muscovita; $\mathrm{Fl=fluorita;} \mathrm{Top=topázio;} \mathrm{Cass=cassiterita;} \mathrm{Sid=siderofilita.}$

\begin{tabular}{|c|c|c|c|}
\hline MACIÇOS GRANITÓIDES & $\begin{array}{l}\text { VARIEDADES } \\
\text { LITOLOGICAS }\end{array}$ & $\begin{array}{l}\Sigma \text { das quantidades modais das principais fases } \\
\text { minerais de alteraçăo }\end{array}$ & $\delta^{18} \mathrm{O}(\%)$ \\
\hline ANTÓNIO VICENTE & $\begin{array}{l}\text { BASMG } \\
\text { BASAFG } \\
\text { BSG } \\
\text { CSMQGs } \\
\end{array}$ & 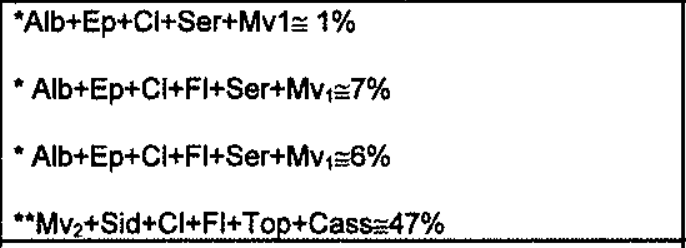 & $\begin{array}{r}+8,3 \\
+8,5 \\
+8,0 \\
+8,4 \\
\end{array}$ \\
\hline VELHO GUILHERME & SGH & ${ }^{*} \mathrm{Alb}+\mathrm{Cl}+\mathrm{Fi}+\mathrm{Mv}_{2}+\mathrm{Ser}+\mathrm{M} v_{1} \approx 20 \%$ & $+8,2$ \\
\hline MOCAMBO & $\begin{array}{l}\text { SMGP(anátise 1) } \\
\text { SMGP(análise 2) } \\
\text { SMGP(análise 3) }\end{array}$ & 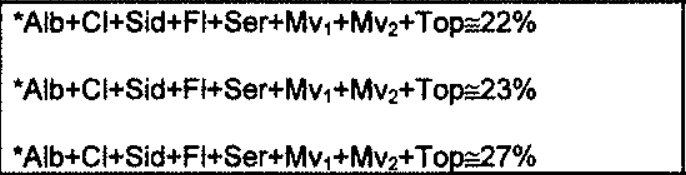 & $\begin{array}{c}+8,8 \\
+8,8-+9,0 \\
+9,0\end{array}$ \\
\hline
\end{tabular}




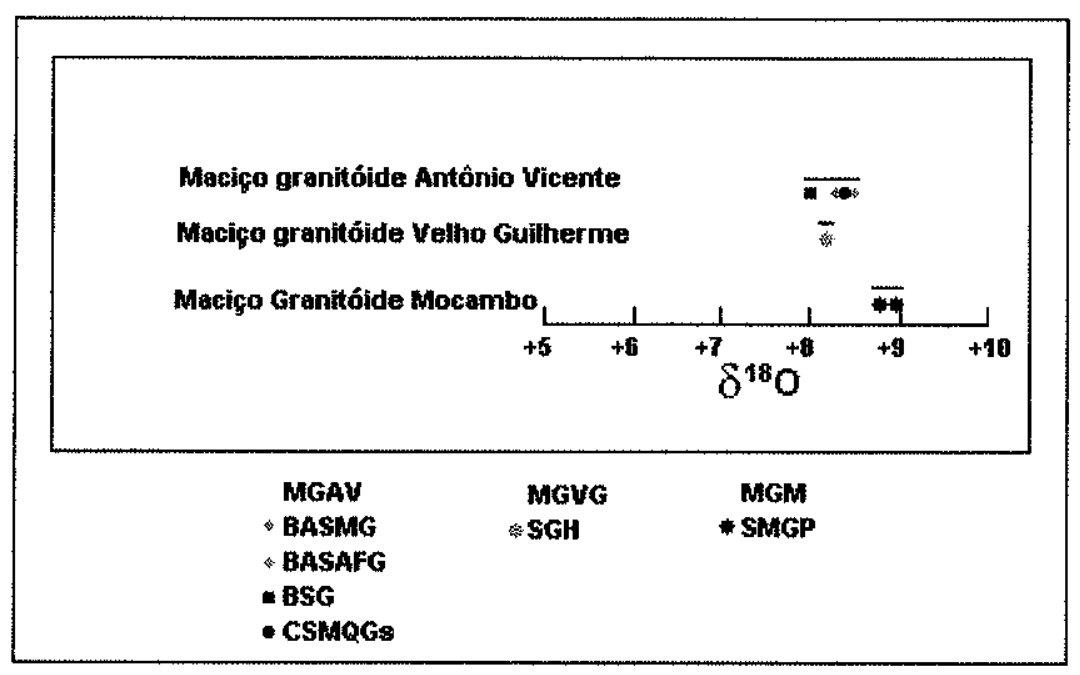

Figura 9.1- Esquema comparativo mostrando as características isotópicas em termos de $\delta^{18} \mathrm{O}$ obtidos em grãos de quartzo de granitóides e de greisen dos maciço Antônio Vicente, Velho Guilherme e Mocambo.

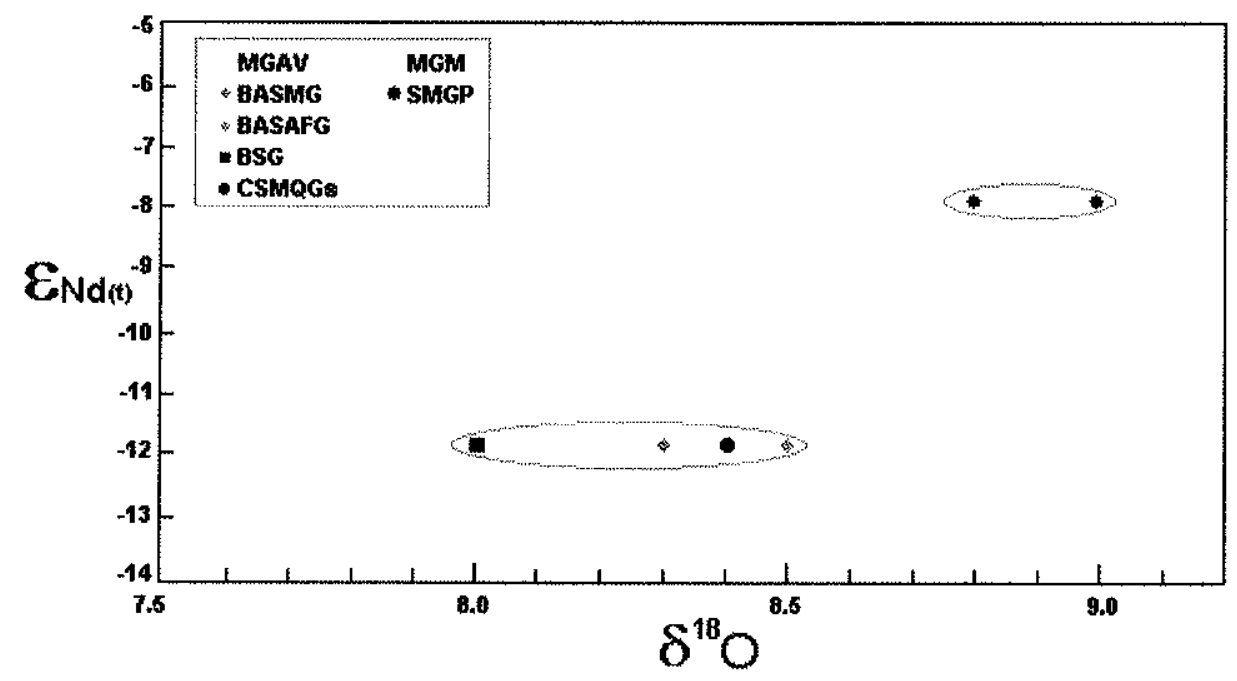

Figura 9.2- Diagrama retangular $\delta^{18} \mathrm{O}$ v.s $\varepsilon \mathrm{Nd}$ mostrando as assinaturas isotópicas dos granitóides dos maciços Antônio Vicente e Mocambo. 


\section{CAPÍTULO 10}

\section{0- ESTUDO DE INCLUSÕES FLUIDAS(IFs)}

Os fluidos e suas interações com as rochas desempenham papel importante na maioria dos processos geológicos e, por isso, seu estudo, integrado aos dados petrológicos, pode fornecer uma interpretação mais precisa das condições físico-químicas reinantes durante a cristalização e/ou recristalização dos minerais.

Dada essa importância, observa-se que um número cada vez mais expressivo de trabalhos sobre o estudo dessas inclusões tem sido publicado envolvendo aspectos diversos(Borizenko, 1978; Eadington \& Nashar, 1978; Haapala \& Kinnunen, 1979; Crawford, 1981; Eadington, 1983; Roedder, 1984; Shepherd et al., 1985; Kwak et al., 1986; Davis et al., 1990; Rios, 1991; Bennet \& Barker, 1992; Bello et al., 1994; Gandini, 1994, Rios 1995; Fuzikawa \& Alves, 1995; Luiz-Silva et al., 1997; Molnár et al., 1999; entre muitos outros).

Esses trabalhos mostram, de modo geral, que esses estudos revestem-se de grande importância pois podem permitir o estabelecimento das salinidades, composições e densidades dos fluidos envolvidos nos processos formadores das rochas e minerais de minério $e$, em muitos casos, auxiliar na determinação das condições de $P$ e $T$ atuantes durante a cristalização das associações minerais minerais hospedeiros $e$, algumas vezes, no estabelecimento da evolução das soluções aprisionadas.

Neste trabalho, a análise de IFs tem caráter preliminar e representa um dos primeiros estudos dessa natureza efetuado em granitóides e em fases minerais de sistemas mineralizados da Amazônia Oriental, tendo sido antecipado apenas por Pinho(inédito) e Rios(1991, 1995). O enfoque dado aqui corresponde à caracterização dos sistemas salinos envolvidos( composições, salinidades e densidades), bem como ao estabelecimento preliminar da história evolutiva dos mesmos. A Tabela 10.1 mostra resumidamente as principais características petrográficas dos granitóides e greisen envolvidos neste estudo.

\section{1- Descrições das IFs}

As análises microtermométricas envolveram um total de 257 IFs, contidas em grãos de quartzo 1(ver ítem Aspectos Petrográficos do capítulo 3), presentes em granitóides(facies BASMG, BSG e BSGIA) do maciço granitóide Antônio Vicente, bem como em greisen(CSMQGs) a ele associado. Neste último caso, a fase analisada corresponde ao quartzo 1 herdado a partir do granitóide do qual o greisen foi originado através de intensa alteração pervasiva(facies BSG). 
As inclusões investigadas foram principalmente aquelas de distribuição aleatória(não alinhadas), que ocorrem em agrupamentos ou isoladamente, possuindo, portanto, feições indicativas de inclusões primárias, de acordo com os princípios estabelecidos por Roedder(1984).

De um modo geral, são inclusões bifásicas $(L+V$; Fotomicrografia 10.1) e trifásicas a muitifásicas( $S+L+V$; Fotomicrografia 10.2), sendo constituídas por soluções aquosas salinas. Inclusões monofásicas foram observadas, mas não foram estudadas. Em relação à morfologia ocorrem desde inclusões prismáticas(cristais negativos) até de contornos bastante irregulares, com dimensöes variando desde inferiores a $10 \mu \mathrm{m}$ até superiores a $30 \mu \mathrm{m}$ (Fotomicrografias $10.3 \mathrm{a}, \mathrm{b}$ ). Fases sólidas mostram-se presentes e exibem coloração dominantemente clara e esbranquiçada e podem apresentar forma cúbica(dominantes) a alongadas. Subordinadamente foram observados cristais de coloração escura. Aqueles claros, de forma cúbica, foram interpretados como sendo cristais de saturação eqüivalentes à halita ou silvita(Borizenco, 1978), conforme os princípios apresentados por Roedder(op. cit.). Os tipos alongados, de coloração clara, e os escuros não foram devidamente identificados.

Os dados microtermométricos obtidos revelaram a existência de, pelo menos, oito grupos distintos de inclusões aquossalinas(Tabela 10.2) a saber:

\section{Grupo 1:}

As inclusões desse grupo são muito pouco freqüentes e foram observadas nas amostras IE-02( facies BASMG; cinco exemplos), SL-7C-DT( facies BSG; dois exemplos) e NN-AV-IN-5(CSMQGs; dois exemplos). Elas mostram temperaturas do eutético(TE) variando entre $-95,8$ e $-88,5^{\circ} \mathrm{C}$ (Figura 10.1a), temperatura de fusão do gelo(Tfg) entre $-57,0$ e $-27,3^{\circ} \mathrm{C}$ (Figura $10.1 \mathrm{~b}$ ), indicativas de salinidades bastante elevadas(Tabela 10.2) e temperatura de homogeneização(Th), para o líquido, entre 116,3 e $147,0^{\circ} \mathrm{C}$ (Figura $10.1 \mathrm{c}$ ).

De acordo com os dados experimentais apresentados por Borizenko(1978; pg. 12), Anexo 54, valores de TE acentuadamente negativos $\left(-78,0\right.$ e $\left.-74,8^{\circ} \mathrm{C}\right)$ são indicativos dos sistemas salinos $\mathrm{LiCl}-\mathrm{KCl}-\mathrm{H}_{2} \mathrm{O}$, $\mathrm{LiCl}-\mathrm{MgCl}_{2}-\mathrm{H}_{2} \mathrm{O}$, $\mathrm{LiCl}-\mathrm{CaCl}_{2}-\mathrm{H}_{2} \mathrm{O}$ e $\mathrm{LiCl}-\mathrm{H}_{2} \mathrm{O}$. Os valores fortemente negativos obtidos que caracterizam esse grupo de IFs, inferiores a $-78,0^{\circ} \mathrm{C}$, evidenciam, que a composição da fase aquosa estudada pode permitir seu enquadramento em qualquer um desses sistemas salinos, especialmente nos três primeiros, embora acompanhados de outros cátions que propiciaram um grande rebaixamento nos valores de TE.

Alternativamente, outras hipóteses podem ser aventadas para explicar baixos valores de TE. Segundo Bakker(1997), valores muito baixos de TE podem indicar a presença de Li 
na fase aquosa ou o fluido pode apresentar um estranho fenômeno de metaestabilidade(Bakker, 1997) ou, ainda, os fluidos parecem requerer uma composição exótica(Burruss, 1997). Entretanto, tais composições não estão bem documentadas experimentalmente(Burruss, op. cit.).

De cordo com Burrus $(1997,1998)$ e Bodnar(1998) existe uma suspeita muito grande de que muitos dos baixos valores de TE obtidos decorrem de erros cometidos durante o monitoramento visual do processo, ao microscópio, em que se confunde o fenômeno de crescimento de cristais de gelo a partir do seu pleno estado de congelamento, que, por sua vez, apresenta um aspecto vítreo(liso/homogêneo). Em outras palavras, após o resfriamento completo da fase aquosa, ao se deixar a temperatura retomar as condições ambientais, cristais de gelo recristalizam-se e crescem dando a impressão que se trata do inicio da fusão(TE). Na realidade, o fenômeno observado pode representar somente um rearranjo dos cristais de gelo em crescimento. Nesse caso, o ponto eutético situa-se em temperaturas um pouco mais elevadas.

Bodnar(1998) mostrou que a quantidade de liquido gerado nas temperaturas do eutético está diretamente relacionada à salinidade. Ou seja, quanto mais próximo a salinidade está da composição do eutético, mais claramente será observada a explosão da fusão. Por outro lado, se a salinidade é muito baixa, pouco líquido será formado no ínicio da fusão, o que dificultará o observação da TE, especialmente em inclusões muito pequenas.

Segundo Oakes(1997) é possivel que valores de TE muito baixos sejam, na verdade, uma metaestabilidade da primeira fusão do gelo em um sistema do tipo $\mathrm{NaCl}-\mathrm{CaCl}_{2}-\mathrm{H}_{2} \mathrm{O}$ de alta salinidade. Nesses casos, essa fusão ocorre, geralmente, em temperaturas mais baixas do que aquelas dos verdadeiras TE. Entretanto, esse comportamento não é comumente observado na natureza.

Roedder(1997) baseado na presença de minerais de saturação obscuros, tal como a avogadrita(borofluoreto de $\mathrm{K}$ e $\mathrm{Cs}$ ) em pegmatitos, considerou que sendo a composição das inclusões fluidas um extremo final de diferenciação, não existe uma razão para excluir a ocorrência de qualquer elemento nas inclusões fluidas.

Em relação às inclusões deste grupo, verifica-se na Tabela 10.2 que se trata de inclusões de salinidades elevadas cujos valores são superiores a 23,02 eqüivalentes em \% em peso de $\mathrm{NaCl}$. Além disso, suas dimensões apropriadas à investigação do fenômeno propiciaram uma clara observação da primeira fusão(TE). Esses dados ratificam as considerações apresentadas por Bodnar(1998) e contemplam as observações de Roedder(1997).

Ademais estudos experimentais apresentando valores de TE semelhantes aos identificados nesse grupo de inclusões não foram encontrados, até o momento, na literatura. 
De qualquer modo, dúvidas àcerca da verdadeira composição salina das inclusões desse grupo permanecem e essa discussão fica em aberto.

Conforme visto nos ítens "Aspectos Petrográficos" e "Química mineral"(Capítulo 3) e na Tabela 10.1, a paragênese mineral principal presente nas amostras de granitóides estudados, especialmente naquela da facies BASMG(IE-02), onde esse grupo de inclusões é relativamente mais abundante, indica uma maior tendência para o sistema salino LiCl$\mathrm{CaCl}_{2}-\mathrm{KCl}-\mathrm{NaCl}-\mathrm{H}_{2} \mathrm{O}$ uma vez que esses cátions maiores podem ter sido lixiviados da mesma, a partir dos processos de alterações tardi a pós-magmáticas, passando a ser incorporados à fase aquosa. Assim, as principais fontes dos cátions de $\mathrm{Li}^{+}$seriam anfibólio e biotita; de $\mathrm{K}^{+}$, o feldspato potássico e biotita; de $\mathrm{Ca}^{2+}$, principalmente, anfibólio e plagioclásio e de $\mathrm{Na}^{+}$, preferencialmente, plagioclásio. Isso explicaria a presença conjunta desses cátions na fase aquosa, que por sua vez, foi aprisionada como inclusões em grãos de quartzo 1. No caso do greisen, essas inclusões podem ser interpretadas como herdadas(reliquiares), visto que as mesmas não foram observadas na variedade BSGIA, que representa um estágio intermediário de alteração entre a facies BSG e o CSMQG. Entende-se, assim, que essa hipótese é a que melhor se ajusta, no momento, para explicar o tipo de sistema salino caracterizado nesse grupo de inclusões.

\section{Grupo 2:}

As inclusões desse grupo são muito freqüentes e foram observadas nas amostras IE02( facies BASMG) e SL-7C-DT( facies BSG). Elas mostram temperaturas do eutético(TE) oscilando entre $-84,2$ e $-71,1^{\circ} \mathrm{C}$ (Figura $10.2 \mathrm{a}$ ), temperatura de fusão do gelo( $\mathrm{Tfg}$ ) entre $-46,0$ e $-13,2^{\circ} \mathrm{C}$ (Figura $10.2 \mathrm{~b}$ ), evidenciando salinidades intermediárias a elevadas(Tabela 10.2) e temperatura de homogeneização(Th), para o liquido, entre 119,0 e $192,1^{\circ} \mathrm{C}$ (Figura 10.2c).

Os valores de TE obtidos nas inclusões desse grupo são mais elevados do que aqueles apresentados em relação às inclusões do Grupo 1 e mostram um amplo intervalo de valores coincidentes com aqueles estabelecidos por Borizenko(op. cit), para os sistemas salinos $\mathrm{LiCl}-\mathrm{KCl}-\mathrm{H}_{2} \mathrm{O}$, LiCl-MgCl $2-\mathrm{H}_{2} \mathrm{O}$, LiCl-CaCl $2-\mathrm{H}_{2} \mathrm{O}$ e $\mathrm{LiCl}-\mathrm{H}_{2} \mathrm{O}$. Embora os valores obtidos tendam mais fortemente para esses sistemas do que aqueles obtidos nas inclusões do grupo 1, é difícil precisar exatamente qual dentre eles é o que melhor representa a composição catiônica da fase aquosa das inclusões desse grupo. Entretanto, pelas considerações apresentadas em relação às inclusões do Grupo 1, acredita-se que se trata de um sistema salino do tipo $\mathrm{LiCl}-\mathrm{CaCl}_{2}-\mathrm{NaCl}-\mathrm{H}_{2} \mathrm{O}$ e que representa uma variação do sistema $\mathrm{LiCl}-\mathrm{H}_{2} \mathrm{O}$ (puro), causadas pela presença dos cátions de $\mathrm{Ca}^{2+}, \mathrm{K}^{+}$e $\mathrm{Na}^{+}$, especialmente aqueles valores inferiores a $-78,0^{\circ} \mathrm{C}$, visto que de acordo com a tabela de TE 
apresentada por Borizenko(op. cit.), a presença desses cátions tende a baixar a temperatura do eutético da fase aquosa.

A mesma hipótese apresentada para explicar a presença desses cátions na fase aquosa das inclusões do grupo 1 é válida para as inclusões deste grupo, com a ressalva de que, neste último, a fase aquosa parece estar relativamente mais pura em $\mathrm{Li}^{+}$.

As inclusões desse grupo devem representar, portanto, uma variação composicional das inclusões do grupo 1 em direção aos sistema salino $\mathrm{LiCl}-\mathrm{H}_{2} \mathrm{O}($ puro) .

\section{Grupo 3:}

As inclusões desse grupo são muito pouco freqüentes e foram visualizadas nas amostras IE-02( facies BASMG; quatro exemplos) e SL-7C-DT( facies BSG; três exemplos). Suas TE variam entre $-69,9$ e $-66,1^{\circ} \mathrm{C}$ (Figura $10.3 \mathrm{a}$ ), as de fusão do gelo(Tfg) entre $-26,7 \Theta$ $-16,5^{\circ} \mathrm{C}$ (Figura $\left.10.3 \mathrm{~b}\right)$, as quais são indicativas de salinidades intermediárias a um pouco elevadas(Tabela 10.2) e as de homogeneização(Th), para o líquido, entre $123,8^{\circ} \mathrm{C}$ e $126,6^{\circ} \mathrm{C}$ (Figura 10.3c).

Considerando os resultados experimentais apresentados por Linke(1958. In: Roedder, 1984) e por Borizenko(1978), os valores de TE obtidos aqui indicam a presença dos sistemas salinos a saber: 1) $\mathrm{AlCl}_{3}-\mathrm{H}_{2} \mathrm{O}$ (Linke, 1958; $\mathrm{TE}=-55,0^{\circ} \mathrm{C}$ ) acompanhado de outros cátions tais como $\mathrm{Ca}^{2+}, \mathrm{Na}^{+}$e $\mathrm{K}^{+}$já que os mesmos tendem a reduzir as TE quando presentes na fase aquosa; 2 ) $\mathrm{CaCl}_{2}-\mathrm{NaCl}-\mathrm{H}_{2} \mathrm{O}$ (Borizenko, $1978 ; \mathrm{TE}=-55,0^{\circ} \mathrm{C}$ ) acompanhado de outros cátions tais como $\circ \mathrm{Li}^{+}$e, possivelmente $\mathrm{Al}^{3+}$, que também como $\mathrm{Ca}^{2+}$ e $\mathrm{Na}^{+}$ tendem a diminuir as TE da fase aquosa; 3) $\mathrm{CaCl}_{2}-\mathrm{KCl}-\mathrm{NaCl}-\mathrm{H}_{2} \mathrm{O}$ (Yanatieva, 1946; TE=-

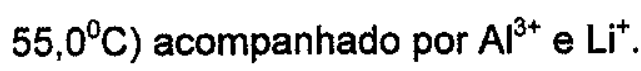

Considerando que anfibólio, biotita e feldspatos são as principais fases minerais presentes nas amostras estudadas, acredita-se que um sistema salino transicional híbrido do tipo $\mathrm{AlCl}_{3}-\mathrm{CaCl}_{2}-\mathrm{KCl}-\mathrm{NaCl}-\mathrm{LiCl}-\mathrm{H}_{2} \mathrm{O}$ é o que melhor se adeqüa a este grupo de inclusões, visto que a paragênese apresentada acima pode perfeitamente fornecer todos esses cátions para a solução aquosa aprisionada, a partir da lixiviação dos mesmos, em decorrência dos processos de alterações tardi a pós-magmáticas que afetaram as rochas estudadas.

\section{Grupo 4:}

As inclusões desse grupo são bastante freqüentes e ocorrem principalmente nas amostras IE-02(facies BASMG) e SL-2A-DT(variedade BSGIA), embora tenham sido observadas localmente na amostra SL-7C-DT(facies BSG) e SL-7C-DT( facies BSG; três exemplos). As análises microtermométricas acusaram TE variando entre $-65,7^{\circ} \mathrm{C}$ e $54,7^{\circ} \mathrm{C}$ (Figura $\left.10.4 \mathrm{a}\right)$, as de fusão do gelo(Tfg) oscilando entre $-43,2^{\circ} \mathrm{C}$ e $-2,9^{\circ} \mathrm{C}$ (Figura 
10.4b), que representa uma faixa bem ampla de variação, indicando soluções com salinidades desde muito baixas até bastante elevadas(Tabela 10.2) e as de homogeneização(Th), para o líquido, entre 98,6 e $250,0^{\circ} \mathrm{C}$ (Figura 10.4c).

Tomando-se por base os dados experimentais obtidos por Yanatieva(1946), Luzhnaja \& Vereshtchetina(1946), Linke(1958. In: Roedder, 1984), Borizenko(1978) e por Crawford(1981), as TE obtidas para as IFs desse grupo indicam a presença dos sistemas salinos $\mathrm{AlCl}_{3}-\mathrm{H}_{2} \mathrm{O}$ (Linke, $1958 ; \mathrm{TE}=-55,0^{\circ} \mathrm{C}$ ), $\mathrm{CaCl}_{2}-\mathrm{NaCl}-\mathrm{H}_{2} \mathrm{O}$ (Luzhnaja \& Vereshtchetina, 1946; TE $=-52,0^{\circ} \mathrm{C}$; Borizenko, 1978; $\mathrm{TE}=-55,0^{\circ} \mathrm{C}$; Crawford, $\left.1981 ; \mathrm{TE}=-52,0^{\circ} \mathrm{C}\right)$ e $\mathrm{CaCl}_{2}-$ $\mathrm{KCl}-\mathrm{NaCl}-\mathrm{H}_{2} \mathrm{O}$ (Yanatieva, $1946 ; \mathrm{TE}=-55,0^{\circ} \mathrm{C}$ ). Os valores em torno de $-55,0^{\circ} \mathrm{C}$ correspondem a esses três sistemas no estado puro. Por outro lado, as TE mais baixas podem corresponder aos mesmos sistemas, porém acompanhados de outros cátions à semelhança das IFs do Grupo 3 . Nesse caso, a composição mais aproximada do conjunto dessas inclusões deve corresponder a um sistema salino do tipo $\mathrm{AlCl}_{3}-\mathrm{CaCl}_{2}-\mathrm{KCl}-\mathrm{NaCl}-\mathrm{H}_{2} \mathrm{O}$.

As fontes dos cátions presentes nas fases aquosas aprisionadas estão representadas principalmente pelo plagioclásio, feldspato potássico e biotita, que mostramse, nas amostras estudadas, afetados pelas soluções tardi a pós-magmáticas, em diferentes graus, liberando, por lixiviação, esses cátions e tornando a fase aquosa presente enriquecida nos mesmos.

\section{Grupo 5:}

As inclusões desse grupo são frequientes(15 exemplos) e estão restritas à amostra SL-2A-DT(variedade BSGIA). As análises microtermométricas mostraram TE variando entre $-52,8^{\circ} \mathrm{C}$ e $-47,0^{\circ} \mathrm{C}$ (Figura 10.5a), de fusão do gelo(Tfg) entre $-21,9^{\circ} \mathrm{C}$ e $-6,9^{\circ} \mathrm{C}$ (Figura $10.5 \mathrm{~b}$ ), representando salinidades baixas a levemente elevadas(Tabela 10.2), e as de homogeneização(Th), para o llquido, entre 98,6 e $244,1^{\circ} \mathrm{C}$ (Figura 10.5c).

Por analogia aos dados experimentais obtidos por Linke(1958. In: Roedder, 1984) e por Borizenko(1978), as TE obtidos para as IFs desse grupo indicam a presença dos sistemas salinos $\mathrm{CaCl}_{2}-\mathrm{H}_{2} \mathrm{O}$ (Borizenko, 1978; Crawford, $1981 ; \mathrm{TE}=-49,80^{\circ} \mathrm{C}$ ), $\mathrm{CaCl}_{2}-\mathrm{KCl}-$ $\mathrm{H}_{2} \mathrm{O}$ (Borizenko, $1978 ; \mathrm{TE}=-50,5^{\circ} \mathrm{C}$ ), $\mathrm{CaCl}_{2}-\mathrm{NaCl}-\mathrm{H}_{2} \mathrm{O}$ (Crawford, $1981 ; \mathrm{TE}=-52,0^{\circ} \mathrm{C}$ ). Valores de TE iguais a $-47,0^{\circ} \mathrm{C}$ não tem correspondência na literatura. Entretanto, uma boa parte das medidas de TE determinadas para essas inclusões situa-se entre $-52,00 \mathrm{C}$ e $-48,00 \mathrm{C}$. Assim, os sistemas correspondentes são aqui interpretados como uma mistura salina do tipo $\mathrm{CaCl}_{2}-\mathrm{KCl}-\mathrm{NaCl}-\mathrm{H}_{2} \mathrm{O}$.

A presença desses cátions na fase aquosa decorre das mesmas razões apresentadas em relação às inclusões do Grupo 4. Ou seja, eles foram lixiviados através da interação de fluidos tardi a pós-magmáticos com a rocha granitóide, que se encontra 
intensamente alterada, demonstrando que grande parte desses cátions entraram na fase aquosa a partir da atuação desses processos de alteração.

\section{Grupo 6:}

Em relação às inclusões desse grupo, elas são freqüentes, mas só foram observadas na amostra SL-2A-DT(variedade BSGIA). Os dados obtidos revelaram valores de TE variáveis desde $-46,4^{\circ} \mathrm{C}$ até $-39,1^{\circ} \mathrm{C}$ (Figura 10.6a), com a Tfg estando compreendida entre $18,9^{\circ} \mathrm{C}$ e $-2,2^{\circ} \mathrm{C}$ (Figura $10.6 \mathrm{~b}$ ), demonstando salinidades baixas a intermediárias(Tabela 10.2) e a Th, para o líquido, entre 95,7 e $139,1^{\circ} \mathrm{C}$ (Figura 10.6c).

Valores de TE semelhantes aos apresentados acima não tem correspondência na literatura. Assim, por aproximação com os dados experimentais fornecidos por Borizenko(1978), acredita-se que a fase aquosa aprisionada encontra-se constituída por um sistema salino do tipo $\mathrm{NaCl}-\mathrm{FeCl}_{2}-\mathrm{H}_{2} \mathrm{O}\left(\mathrm{TE}=-37,0^{\circ} \mathrm{C}\right)$, acompanhado de outros cátions tais como $\mathrm{Ca}^{2+}$ e $\mathrm{K}^{+}$que são considerados como redutores de TE(Borizenko, 1978). Nesse caso, a associação biotita, plagioclásio e feldspato potássico seria a principal fonte desses solutos, que foram lixiviados da mesma pelos processos de alterações tardi a pós-magmáticas, os quais são muito intensos na amostra estudada.

\section{Grupo 7:}

As IFs em questão são pouco freqüentes e mostram-se restritas à amostra SL-2A$\mathrm{DT}$ (variedade $\mathrm{BSGIA}$ ). Elas mostram TE variável desde $-37,60^{\circ} \mathrm{C}$ até $-34,10^{\circ} \mathrm{C}$ (Figura 10.7a), Tfg entre $-21,20^{\circ} \mathrm{C}$ e $-15,80^{\circ} \mathrm{C}$ (Figura $10.7 \mathrm{~b}$ ), o que significa salinidades intermediárias a levemente elevadas(Tabela 10.2) e Th compreendido entre $126,40^{\circ} \mathrm{C}$ e $181,30^{\circ} \mathrm{C}$ (Figura 10.7c).

Os valores de TE quando comparados com aqueles de natureza experimental fornecidos por Borizenko(1978; Anexo 54) são compativeis com aqueles dos sitemas salinos $\mathrm{NaCl}-\mathrm{FeCl}_{2}-\mathrm{H}_{2} \mathrm{O}\left(\mathrm{TE}=-37,0^{\circ} \mathrm{C}\right), \quad \mathrm{FeCl}_{2}-\mathrm{H}_{2} \mathrm{O}\left(\mathrm{TE}=-35,0^{\circ} \mathrm{C}\right)$ e $\mathrm{FeCl}_{3}-\mathrm{H}_{2} \mathrm{O}\left(\mathrm{TE}=-36,50^{\circ} \mathrm{C}\right.$ ), especialmente aqueles compreendidos entre $-37,0^{\circ} \mathrm{C}$ e $-35,0^{\circ} \mathrm{C}$, visto que valores iguais a $34,10^{\circ} \mathrm{C}$ não tem correspondência na literatura.

Assim, tomando-se por base os estudos petrográficos, verifica-se que em termos composicionais a solução aquosa aprisionada deve corresponder a um sistema salino do tipo $\mathrm{NaCl}-\mathrm{FeCl}_{2}-\mathrm{FeCl}_{3}-\mathrm{H}_{2} \mathrm{O}$. O sistema salino $\mathrm{FeCl}_{3}-\mathrm{H}_{2} \mathrm{O}$ está sendo aqui considerado devido estarem presentes nessa amostra fases minerais onde o ferro férrico está presente(biotita e clorita, principalmente), embora em reduzidas quantidades. Dessa forma, é razó́vel admitir a presença desse cátion na fase aquosa. 


\section{Grupo 8:}

As inclusões desse grupo tem ocorréncia freqüente e foram observadas apenas na amostra NN-AV-IN-5(CSMQGs). Elas possuem TE variável entre $-31,0^{\circ} \mathrm{C}$ e $-27,0^{\circ} \mathrm{C}$ (Figura 10.8a), Tfg entre $-23,6^{\circ} \mathrm{C}$ e $-11,3^{\circ} \mathrm{C}$ (Figura 10.8b), correspondendo a salinidades intermedárias a levemente elevadas(Tabela 10.2) e os valores de $T h$, para o líquido, situando-se entre $179,8^{\circ} \mathrm{C}$ e $396,6^{\circ} \mathrm{C}$ (Figura 10.8c).

Os valores de TE apresentados acima não tem correspondência na literatura. Em razão disso, esta questão fica, no momento, em aberto, embora se possa supor que cátions tipo $\mathrm{Sn}^{2+}$ ou mesmo $\mathrm{Sn}^{4+}$ possam estar presentes na fase aquosa, interferindo nos valores das TE, uma vez que a cassiterita é mais abundante nessa rocha, que também exibe os mais elevados conteúdos de Sn. Isso é reforçado pelo que é observado na Figura 3.55f(ver ítem Química de rocha total do Capítulo 3).

E digno de nota o fato de que, em quase todos os casos, os valores de salinidade obtidos foram calculados até o limite de $\mathrm{Tfg}=-21^{\circ} \mathrm{C}$, uma vez que o programa FLINCOR(Brown, 1989) utilizado, calcula esse parâmetro em eqüivalentes a \% em peso do $\mathrm{NaCl}$, no sistema puro $\mathrm{NaCl}-\mathrm{H}_{2} \mathrm{O}$, cuja $\mathrm{Tfg}=-20,8$.

Além disso, devido aos baixos valores de Th obtidos para todos os grupos de inclusões, mesmo representando as temperaturas mínimas de aprisionamento, interpretouse as mesmas como expressões do estágio de alterações tardi a pós-magmáticas, uma vez que as inclusões relacionadas ao estágio magmático deveriam apresentar temperaturas de homogeneização mais elevadas e, ao que tudo indica, acima de $600^{\circ} \mathrm{C}$. Isso é condicionado pelas temperaturas de cristalização da clorita, presente nos granitóides e greisen(ver ftem Química Mineral do Capítulo 3), estimadas a partir da aplicação geotermômetro de Cathelineau(1988) a saber: 1) 393,93 a $439,40^{\circ} \mathrm{C}$ (facies BASMG); 2) 493,17 a $507,78^{\circ} \mathrm{C}$ (facies BSG); 3) 458,71 a $592,66^{\circ} \mathrm{C}$ (CSMQGs). Assim, como clorita representa uma fase cuja cristalização se deu inequivocamente no estágio da alterações tardi a pósmagmáticas, estas temperaturas foram consideradas como de referência para o mesmo.

\section{2- Evoluçăo dos Fluidos}

A análise das Tabelas 10.2 e 10.3 indica uma gradativa variação composicional catiônica da fase aquosa das inclusões estudadas, a qual é traduzida pelo aumento sequencial dos valores de TE $\left(-95,8\right.$ A $\left.-27,0^{\circ} \mathrm{C}\right)$ obtidos através das análises microtermométricas.

As inclusões do grupo 1 foram interpretadas como as mais precoces pelas seguintes razões: 
1) apresentarem os mais baixos valores de TE e representarem um extremo composicional;

2) foram melhor observadas nos grãos de quartzo 1 das amostras IE-02(facies BASMG) e SL-7C-DT(facies BSG), que representam os granitóides menos afetados por alterações tardi a pós-magmáticas;

3) Embora tenham sido reconhecidas na amostra NN-AV-IN-05, do CSMQGs, foram consideradas reliquiares, uma vez que não foram detectadas em grãos de quartzo 1 da amostra SL-2A-DT(facies BSGIA), que representa um estágio intermediária entre o BSG e o CSMQGs.

Assim, a fase aquosa inicialmente constituida de $\mathrm{LiCl}+\mathrm{KCl}+\mathrm{CaCl}_{2}+\mathrm{NaCl}+\mathrm{H}_{2} \mathrm{O}$, bem como de outros solutos não identificados, foi sistematicamente modificada, numa evolução quase contínua, no sentido da grupo 1 para o grupo 8, ao que tudo indica, em decorrência dos diversos eventos de alteração mineral, ocorridos no estágio de alterações tardi a pósmagmáticas.

Essas alterações afetaram, em diferentes graus, as rochas estudadas desestabilizando as fases minerais maiores anfibólio(cloritização), feldspato potássico (albitização,biotitização,argilização), plagioclásio(sericitização + muscovitização, microclinização, albitização, etc) e biotita(cloritização, muscovitização, etc) e lixiviando, das mesmas, $\mathrm{Ca}^{2+}, \mathrm{Na}^{+}, \mathrm{K}^{+}, \mathrm{Al}^{3+}, \mathrm{Fe}^{2+}$ e, possivelmente, $\mathrm{Sn}^{2+}$ e $\mathrm{Sn}^{4+}$, entre outros cátions.

Esses cátions incorporaram-se à fase aquosa e foram mais ou menos concentrados na mesma, em diferentes momentos, no curso das alterações, que culminaram com a greisenização. Essas modificações foram acompanhadas por variações na salinidade e na densidade da mesma.

Nas Figuras 104c, 105c, 107c e 108c verifica-se que os grupos de IFs exibem um espalhamento considerável dos valores de Th(total). Tais espalhamentos podem ser, em parte, decorrentes de modificações das IFs, causadas por processos de deformação intracristalinos(Kerrich, 1976; Wilkins \& Barkas, 1978; Hollister, 1990; Bakker \& Jansen, 1990; Bakker, 1992, entre outros), uma vez que os grãos de quatzo 1 estudados mostramse, por vezes, deformados, exibindo extinção ondulante moderada a forte, bem como podem desenvoiver, algumas vezes, subgrãos de deformação(ver ítem Aspectos Petrográficos do Capítulo 3).

Além disso, os diagramas Th(total) contra Tfg(Figura 109 a, b, c, d, e, f, g, h) não mostram nenhuma tendência indicativa de mistura de fluidos, confirmando o que foi observado em relação aos valores de $\delta \mathrm{O}^{18}$ obtidos nos granitóides estudados, nem tampouco de evolução normal(Roedder, 1984), sugerindo, uma vez mais, que as 
modificações nas IFs, posteriores ao aprisionamento, podem ter desempenhado um papel importante.

Localmente, tais modificações podem, também, ser evidenciadas pela presença de algumas variações nas relações entre o volume da fase gasosa e 0 da fase líquida(Fotomicrografia 10.4).

\section{3- Controle dos fluidos sobre as mineralizações de Sn}

Conforme visto anteriormente, a mineralização mais expressiva associada ao maciço granitóide Antônio Vicente está vinculada às facies granitóides mais evoluídas e mais intensamente afetadas por alterações tardi a pós-magmáticas e aos greisens. De acordo com os estudos petrográficos a cassiterita é de natureza secundária e sua presença, no material primário(rocha), foi observada em amostras da facies BSGIA, do muscovita-quartzo greisen(MQGs) e do clorita-siderofilita-muscovita-quartzo greisen(CSMQGs), sendo que nesse último, ela é mais abundante. Em razão disso, considera-se que os fluidos residuais ricos em voláteis, que interagiram com as rochas do maciço e propiciaram a formação de variedades granitóides intensamente alteradas e greisens, lixiviaram e incorporaram às soluções tardias diversos tipos de cátions e, dentre eles, os de $\mathrm{Sn}^{2+}$ e $\mathrm{Sn}^{4+}$, já que sem os mesmos não haveria a possibilidade da formação de cassiterita.

Esses dados aliados ao estudo de IFs sugerem que a lixiviação e a precipitação do Sn tenha sido iniciada, mesmo que de modo incipiente, a partir de uma composição da fase aquosa correspondente às inclusões do grupo 6 e se tornou sistematicamente mais intensa em direção à composição das inclusões do grupo 7, atingindo o clímax nas soluções de composição das inclusões do grupo 8. Essa hipótese é baseada nos seguintes argumentos: 1) a presença de cassiterita é restrita à facies BSGIA e ao CSMQGs; 2) as inclusões dos grupos 5, 6 e 7 só foram reconhecidas na amostra SL-2A-DT da facies BSGIA e a do grupo 8 na NN-AV-IN-5 do CSMQGs. Considerando-se a presença de cassiterita e que as composições das inclusões dos grupos 7 e 8 são muito próximas, é razoável se imaginar que a formação da mesma esteja vinculada, em grande parte, a esses sistemas salinos.

Como nas demais amostras estudadas não foi identificada a presença de cassiterita, acredita-se que as fases aquosas correspondentes aos grupos 1, 2, 3 e 4 não continham Sn em solução

Nesse caso, as principais fontes de Sn seriam as fases micáceas, principalmente biotita e clorita, visto que as mesmas representam, ao que tudo indica, a principal fonte de Sn nas rochas estudadas. 


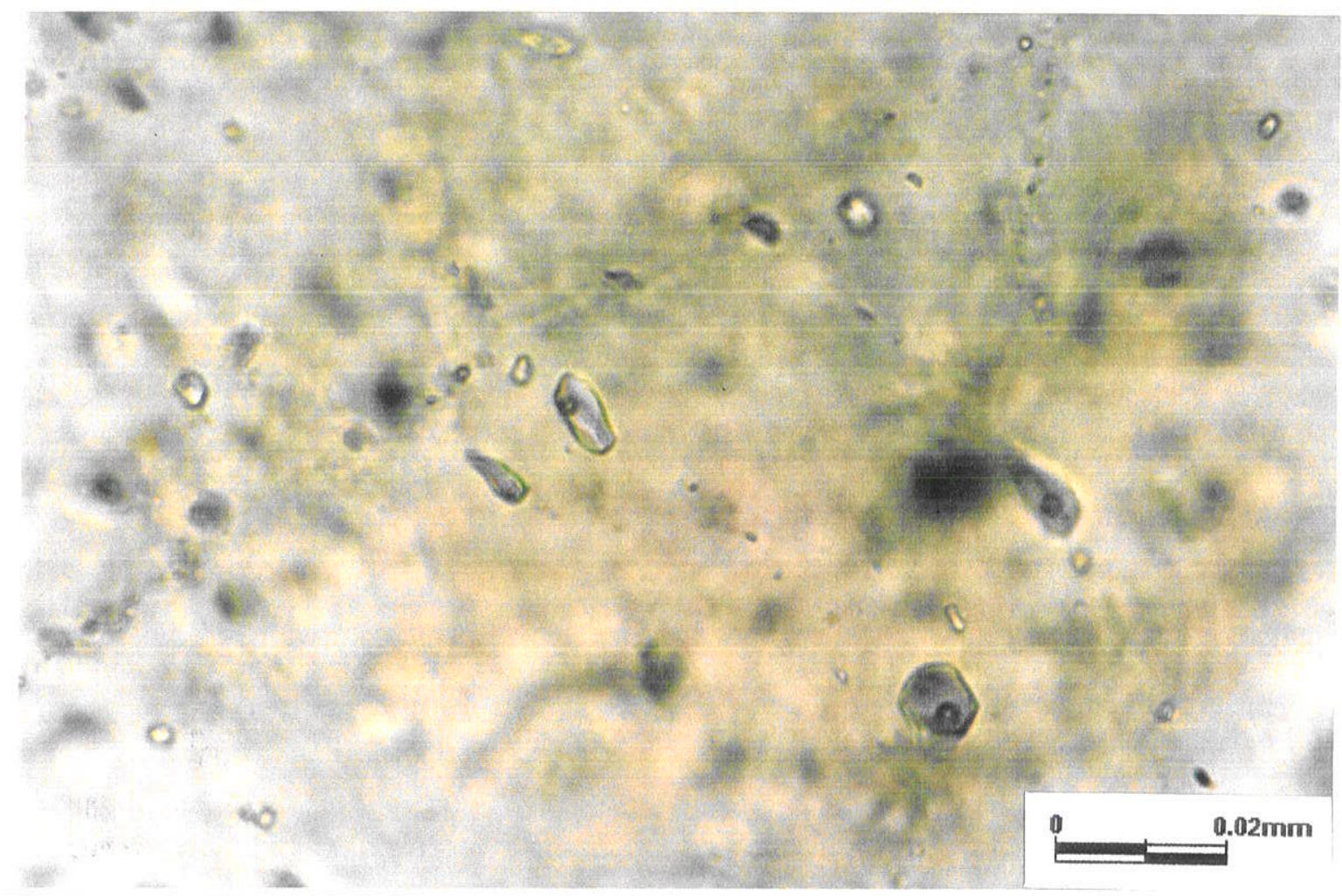

Fotomicrografia 10.1- Aspecto das IFs bifásicas observadas em grãos de quartzo 1 da amostra SL-7C-DT(BSG). LN(1000X).

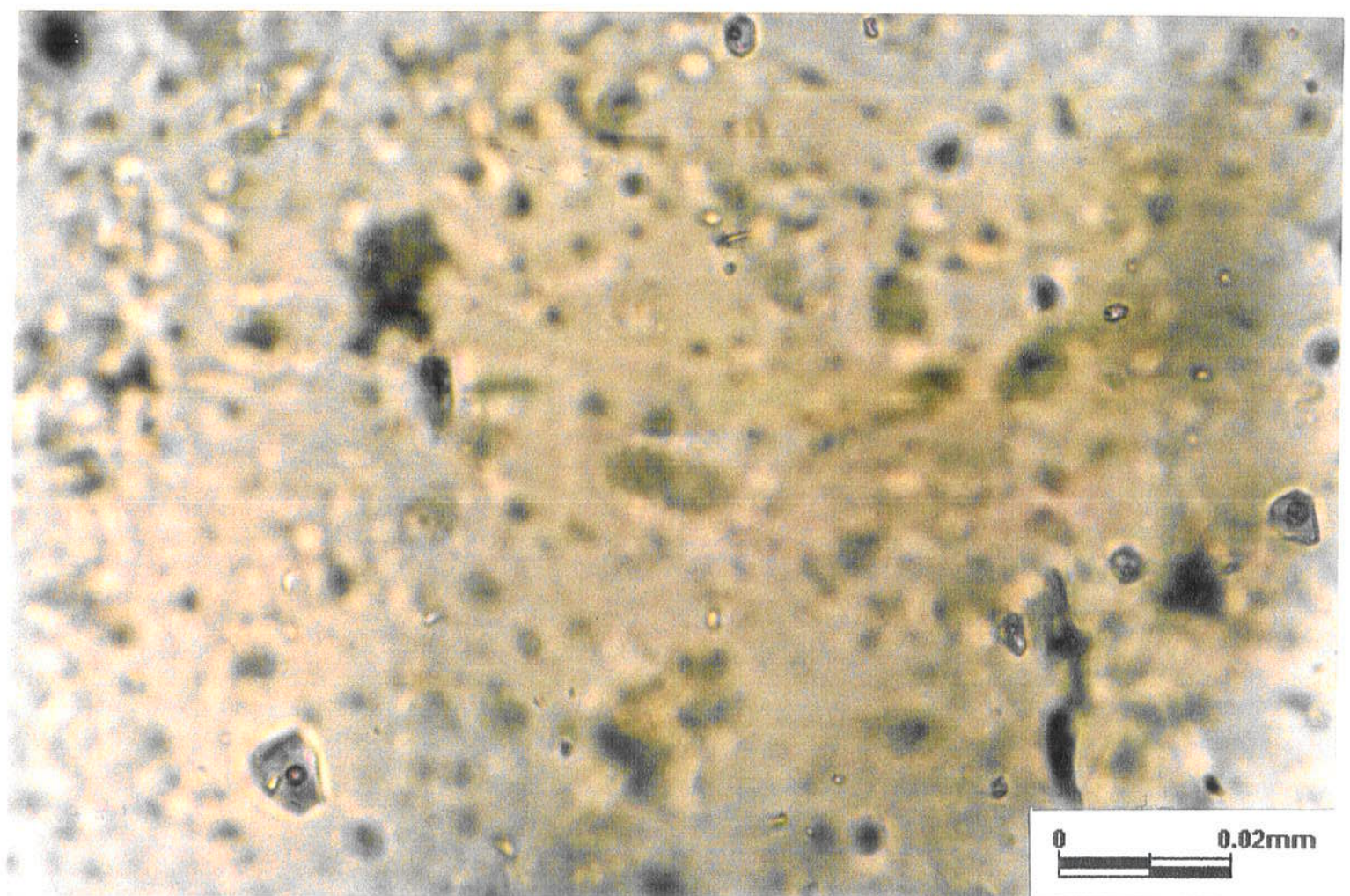

Fotomicrografia 10.2- Aspecto das IFs trifásicas(em baixo à esquerda) presentes na amostra SL-7C-DT(BSG), LN(1000X). 

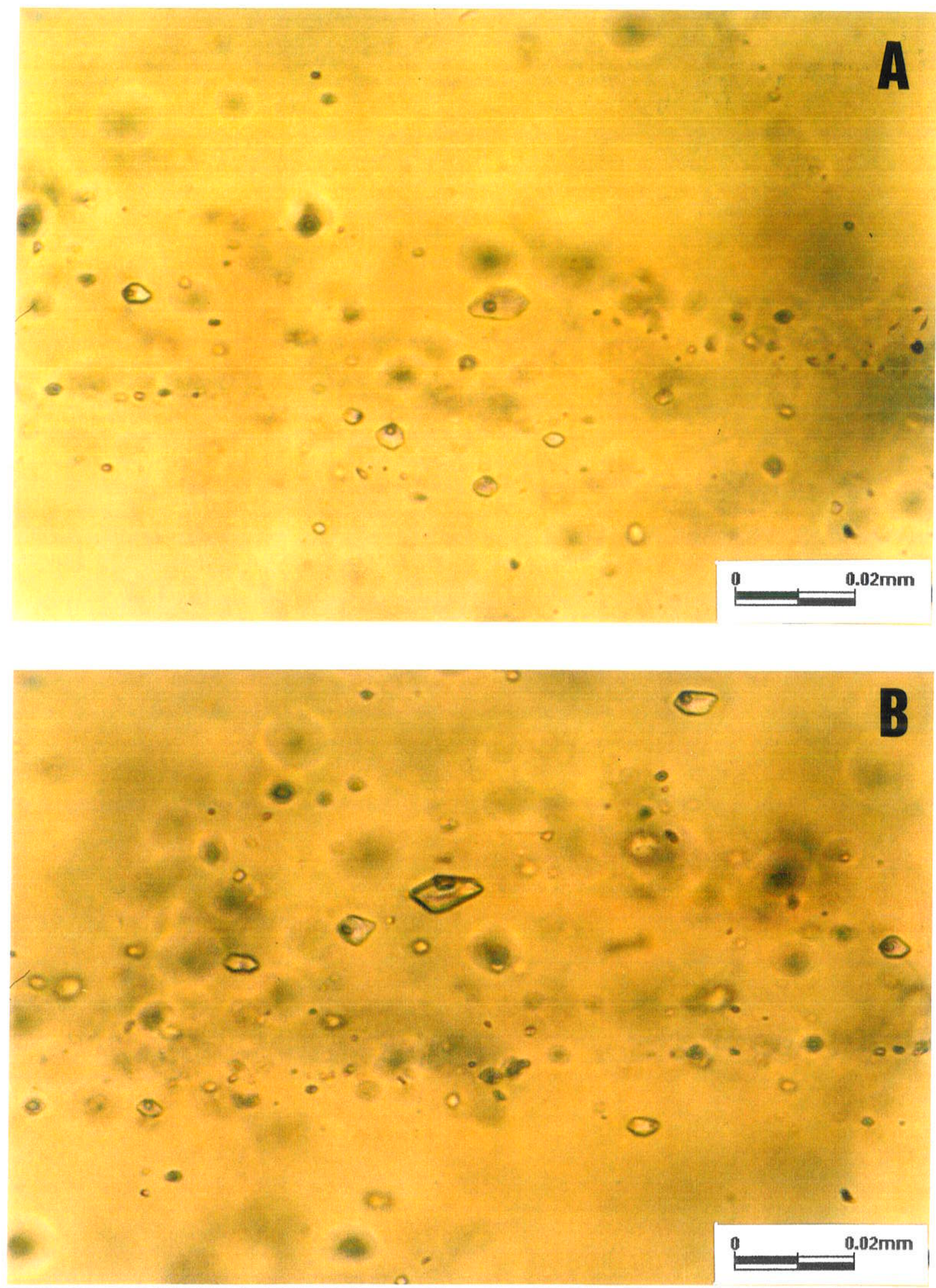

Fotomicrografia 10.3(a, b)- Aspecto geral das dimensões das IFs estudadas. Amostra SL-2A-DT(BSGIA). LN(1000X). 
Tabela 10.1- Principais caracteristicas petrográficas das facies granitóides e de greisens do maciço granitóide Antônio Vicente estudados através de microtermometria.

\begin{tabular}{|c|c|c|c|c|c|c|}
\hline $\begin{array}{l}\text { Facies } \\
\text { Granitóide }\end{array}$ & Minerais Essenciais & Minerais Varietais & $\begin{array}{l}\text { Minerais Acessórios } \\
\text { Primários }\end{array}$ & Minerais Secundários & $\begin{array}{c}\text { Estilo de } \\
\text { Mineralizaçắo }\end{array}$ & $\begin{array}{c}\text { Associaçăo } \\
\text { Mineral Correlata }\end{array}$ \\
\hline BASMG & $\begin{array}{l}\text { "quartzo, "plagioclásio(Ab-Olg a } \\
\text { And), "feldspato } \\
\text { potássico(microclina pertítica) }\end{array}$ & $\begin{array}{l}\text { "aluminiohastingsitica } \\
\text { a ferro-edenita } \\
\text { " biotita }\end{array}$ & $\begin{array}{l}\text { "minerais opacos } \\
\text { "Apatita } \\
\text { " titanita } \\
\text { "zircão } \\
\text { "allanita }\end{array}$ & $\begin{array}{l}\text { sericita, muscovita, clorita, epidoto, } \\
\text { fluorita, carbonato, fetdspato } \\
\text { potássico(microclina pertítica), albita, } \\
\text { minerais opacos, quartzo, argilo- } \\
\text { minerais }\end{array}$ & Ausentes & Ausentes \\
\hline BSG & $\begin{array}{l}\text { "quartzo, "plagioclásio(Ab-Olig), } \\
\text { "feldspato potássico(microclina } \\
\text { pertítica) }\end{array}$ & * biotita & $\begin{array}{l}\text { "minerais opacos } \\
\text { "Apatita } \\
\text { "zircão }\end{array}$ & $\begin{array}{l}\text { sericita, muscovita, clorita, epidoto, } \\
\text { fluorita, feldspato } \\
\text { potássico(microclina pertítica), albita, } \\
\text { topázio, allanita, monazita, minerais } \\
\text { opacos, quartzo, argilo-minerais }\end{array}$ & Ausentes & Ausentes \\
\hline BSGIA & $\begin{array}{l}\text { "quartzo, "plagioclásio(Ab-Olig), } \\
\text { "feldspato potássico(microclina } \\
\text { pertítica) }\end{array}$ & " biotita & $\begin{array}{l}\text { "minerais opacos } \\
\text { "Apatita } \\
\text { "zircão }\end{array}$ & $\begin{array}{l}\text { sericita, muscovita, clorita, epidoto, } \\
\text { fluorita, feldspato } \\
\text { potássico(microclina pertítica), albita, } \\
\text { topázio, cassiterita, minerais opacos, } \\
\text { quartzo, argilo-minerais }\end{array}$ & $\begin{array}{l}\text { disseminada } \\
\text { veios }\end{array}$ & $\begin{array}{l}\text { Cassiterita, } \\
\text { Fluorita e Topázio } \\
\text { Fluorita }\end{array}$ \\
\hline CSMQGS & $\begin{array}{l}\text { quarzo, muscovita, siderofilita e } \\
\text { ciorita }\end{array}$ & & $\begin{array}{l}\text { biotita, zircão, minerais } \\
\text { opacos }\end{array}$ & monazita, fluorita, topázio, cassiterita & disseminada & $\begin{array}{l}\text { Cassiterita, } \\
\text { fluorita e topázio }\end{array}$ \\
\hline
\end{tabular}


Tabela 10.2- Resultados microtermométricos obtidos através do estudo de inclusōes fluidas em granitóides e greisen do maciço granitóide Antônio Vicente. ${ }^{\star}$ Linke(1958); ${ }^{*}$ Davis et al. $(1990) ;{ }^{\star \star \star}$ Borisenko(1978. $\Delta \mathrm{TE}\left({ }^{\circ} \mathrm{C}\right)=$ variaçāo das temperaturas dos eutéticos; $\Delta \mathrm{Tfg}\left({ }^{0} \mathrm{C}\right)=$ variaçäo das temperaturas de fusāo do gelo; $\Delta \mathrm{Tht}_{\mathrm{otal}}\left({ }^{0} \mathrm{C}\right)=$ variação das temperaturas de homogeneização total.

\begin{tabular}{|c|c|c|c|c|c|c|c|c|}
\hline Amostras & $\begin{array}{l}\text { Facies } \\
\text { Granitóides }\end{array}$ & $\begin{array}{l}\text { Grupos de } \\
\text { Inclusöes } \\
\text { Fluidas }\end{array}$ & $\begin{array}{l}\text { Sistemas } \\
\text { Salinos }\end{array}$ & $\triangle \mathrm{TE}\left({ }^{\circ} \mathrm{C}\right)$ & $\Delta \mathrm{Tfg}\left({ }^{\circ} \mathrm{C}\right)$ & $\Delta T h_{(\text {total })}\left({ }^{0} \mathbf{C}\right)$ & $\begin{array}{c}\text { Salinidade } \\
\text { (eqüivalência } \\
\text { em\% em peso } \\
\mathrm{NaCl} \text { ) }\end{array}$ & $\begin{array}{c}\text { Densidade } \\
\left(\mathrm{g} / \mathrm{cm}^{3}\right)\end{array}$ \\
\hline $\begin{array}{c}\text { IE-02/SL7C- } \\
\text { DT }\end{array}$ & $\overline{B A S M G / B S G}$ & 2 & $\begin{array}{l}* * \mathrm{LiCl}-\mathrm{KCl}- \\
\mathrm{CaCl}_{2}-\mathrm{NaCl}- \\
\mathrm{H}_{2} \mathrm{O}\end{array}$ & $\begin{array}{l}-84,2 \\
-71,1\end{array}$ & $\begin{array}{l}-46,7 \\
-13,2\end{array}$ & $\begin{array}{l}119,0 \\
192,1\end{array}$ & $\begin{array}{c}>23,02-17,08 \\
23,02-17,08\end{array}$ & $\begin{array}{c}>1,11-1,067 \\
1,05-1,01\end{array}$ \\
\hline $\begin{array}{c}\mathrm{IE}-02 / \mathrm{SL}-7 \mathrm{C}- \\
\mathrm{DT}\end{array}$ & BASMG/BSG & 3 & $\begin{array}{l}{ }^{\star A l C l}{ }_{3}-\mathrm{CaCl}_{2-} \\
\mathrm{KCl}-\mathrm{NaCl}-\mathrm{LiCl}- \\
\mathrm{H}_{2} \mathrm{O}\end{array}$ & $\begin{array}{l}-69,9 \\
-66,1\end{array}$ & $\begin{array}{l}-26,7 \\
-16,5\end{array}$ & $\begin{array}{l}123,8 \\
126,6\end{array}$ & $\begin{array}{c}>23,02-19,82 \\
23,02-19,82\end{array}$ & $\begin{array}{c}>1,11-1,09 \\
1,11-1,08\end{array}$ \\
\hline $\begin{array}{l}\text { IE-02/SL-7C- } \\
\text { DT/ SL-2A-DT }\end{array}$ & $\begin{array}{c}\text { BASMG/BSGI } \\
\text { BSGIA }\end{array}$ & 4 & $\begin{array}{l}{ }^{*} \mathrm{AlCl}_{3}-\mathrm{CaCl}_{2-} \\
\mathrm{KCl}-\mathrm{NaCl}-\mathrm{H}_{2} \mathrm{O}\end{array}$ & $\begin{array}{l}-65,7 \\
-54,7 \\
\end{array}$ & $\begin{array}{l}-43,2 \\
-2,9 \\
\end{array}$ & $\begin{array}{l}98,6 \\
250\end{array}$ & $\begin{array}{c}>23,02-4,70 \\
23,02-4,70\end{array}$ & $\begin{array}{c}>1,13-0,99 \\
1,00-0,84\end{array}$ \\
\hline SL-2A-DT & BSGIA & 5 & $\begin{array}{l}{ }^{\star \star} \mathrm{CaCl}_{2}-\mathrm{KCl}- \\
\mathrm{NaCl}-\mathrm{H}_{2} \mathrm{O}\end{array}$ & $\begin{array}{l}-52,8 \\
-47,0 \\
\end{array}$ & $\begin{array}{c}-21,9 \\
-6,9 \\
\end{array}$ & $\begin{array}{c}98,6 \\
220,3 \\
\end{array}$ & $\begin{array}{c}>23,02-9,45 \\
23,02-9,45 \\
\end{array}$ & $\begin{array}{c}>1,13-1,03 \\
1,01-0,90\end{array}$ \\
\hline SL-2A-DT & BSGIA & 6 & $\begin{array}{l}* * \mathrm{FeCl}_{2}-\mathrm{NaCl} \\
\mathrm{CaCl}_{2}-\mathrm{H}_{2} \mathrm{O}\end{array}$ & $\begin{array}{r}-46,4 \\
-39,1 \\
\end{array}$ & $\begin{array}{l}-18,9 \\
-2,2 \\
\end{array}$ & $\begin{array}{r}95,7 \\
139,1 \\
\end{array}$ & $\begin{array}{l}21,59-3,60 \\
21,59-3,60 \\
\end{array}$ & $\begin{array}{r}1,12-0,99 \\
1,09-0,96 \\
\end{array}$ \\
\hline$\overline{I S L-2 A-D T}$ & BSGIA & 7 & $\begin{array}{l}\star \star \mathrm{FeCl}_{2}-\mathrm{NaCl}- \\
\mathrm{H}_{2} \mathrm{O}\end{array}$ & $\begin{array}{l}-37,6 \\
-34,1 \\
\end{array}$ & $\begin{array}{l}-21,2 \\
-15,8\end{array}$ & $\begin{array}{l}126,4 \\
181,3\end{array}$ & $\begin{array}{c}>23,02-19,27 \\
23,02-19,27 \\
\end{array}$ & $\begin{array}{c}>1,09-1,08 \\
1,06-1,03\end{array}$ \\
\hline NN-AV-IN-5 & CSMQGs & 8 & $\begin{array}{l}\star \star \mathrm{FeCl}_{2}-(\mathrm{NaCl}- \\
\left.\mathrm{KCl}-\mathrm{H}_{2} \mathrm{O}\right)\end{array}$ & $\begin{array}{l}-31,0 \\
-27,0\end{array}$ & $\begin{array}{l}-23,6 \\
-11,3\end{array}$ & $\begin{array}{l}179,8 \\
396,6\end{array}$ & $\begin{array}{c}>23,02-15,28 \\
23,02-15,28\end{array}$ & $\begin{array}{c}>1,07-1,00 \\
0,84-0,75\end{array}$ \\
\hline
\end{tabular}


Tabela 10.3 -Evolução dos sistemas salinos segundo o "trend" BASMG(facies menos evoluida) ao CSMQGs(greisen) do maciço granitóide Antônio Vicente. $x x x x x=$ muito freqüentes; $x x x=$ freqüentes; $x=$ pouco freqüentes.

\begin{tabular}{|c|c|c|c|c|c|c|c|c|}
\hline $\begin{array}{l}\text { Sistemas } \\
\text { Salinos }\end{array}$ & $\begin{array}{c}\mathrm{LiCl}-\mathrm{KCl}- \\
\mathrm{CaCl}_{2}-\mathrm{NaCl}- \\
? ?-\mathrm{H}_{2} \mathrm{O} \\
\end{array}$ & $\begin{array}{c}\mathrm{LiCl}-\mathrm{KCl}-\mathrm{CaCl}_{2-} \\
\mathrm{NaCl}-\mathrm{H}_{2} \mathrm{O}\end{array}$ & $\begin{array}{c}\mathrm{AlCl}_{3}-\mathrm{CaCl}_{2} \\
\mathrm{KCINaCl}-\mathrm{LiCl}- \\
\mathrm{H}_{2} \mathrm{O} \\
\end{array}$ & $\begin{array}{c}\mathrm{AlCl}_{3}-\mathrm{CaCl}_{2-} \\
\mathrm{KCl}-\mathrm{NaCl}- \\
\mathrm{H}_{2} \mathrm{O} \\
\end{array}$ & $\begin{array}{l}\mathrm{CaCl}_{2}-\mathrm{KCl}- \\
\mathrm{NaCl}-\mathrm{H}_{2} \mathrm{O}\end{array}$ & $\begin{array}{c}\mathrm{FeCl}_{2}-\mathrm{NaCl} \\
\mathrm{CaCl}_{2}-\mathrm{H}_{2} \mathrm{O}\end{array}$ & $\begin{array}{c}\mathrm{FeCl}_{2}-\mathrm{NaCl}- \\
\mathrm{H}_{2} \mathrm{O}\end{array}$ & $\begin{array}{c}\mathrm{FeCl}_{2}-(\mathrm{NaCl}- \\
\left.\mathrm{KCl}^{-} \mathrm{H}_{2} \mathrm{O}\right)\end{array}$ \\
\hline$\Delta \mathrm{TE}$ & $\begin{array}{c}-95,8 \mathrm{a}- \\
88,5 \\
\end{array}$ & $-84,2$ a $-71,1$ & $-69,9$ a $-66,1$ & $-65,7 a-54,7$ & $-52,8 \mathrm{a}-47,0$ & $\begin{array}{c}-46,4 \mathrm{a}- \\
39,1 \\
\end{array}$ & $-37,6 a-34,1$ & $-31,0$ a $-27,0$ \\
\hline \multicolumn{9}{|l|}{ Amostras/Facies } \\
\hline IE-02/BASMG & $\bar{x}$ & $x x x x x$ & $x$ & $x x x x x$ & & & & \\
\hline SL-7C-DT/BSG & $x$ & $x x x x x$ & $x$ & $x$ & & & & \\
\hline SL-2A-DT/BSGIA & & & & $x x x x x$ & $x x x$ & $x x x$ & $x$ & \\
\hline $\begin{array}{l}\text { NN-AV-IN-5I } \\
\text { CSMQGs }\end{array}$ & $\bar{x}$ & & & & & & & $x x x$ \\
\hline
\end{tabular}



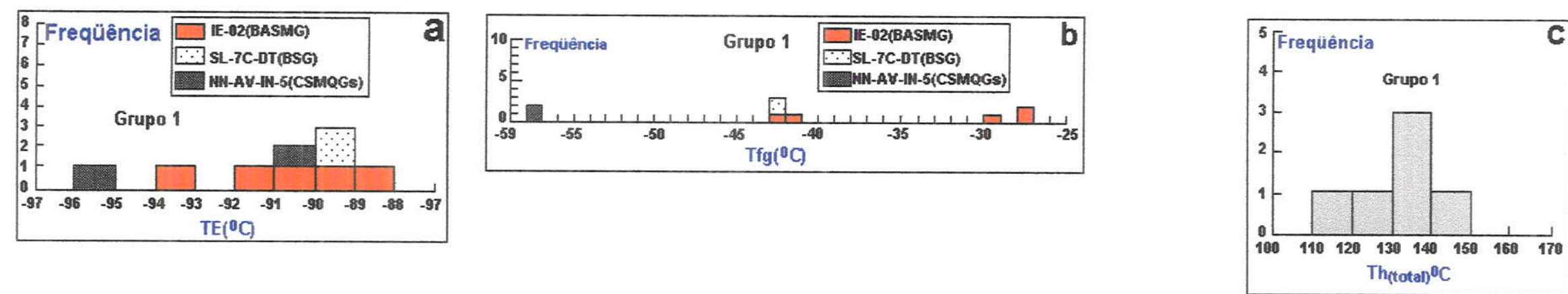

Figura 10.1- Histogramas de frequêencia mostrando os intervalos de variação das $T E(a), \operatorname{Tfg}(b)$ e Th(total)(c) das lfs do Grupo 1 presentes em grão de quartzo 1 das amostras IE-02(BASMG), SL-7C-DT(BSG) e NN-AV-IN-5(CSMQGs) do maciço granitóide Antônio Vicente.
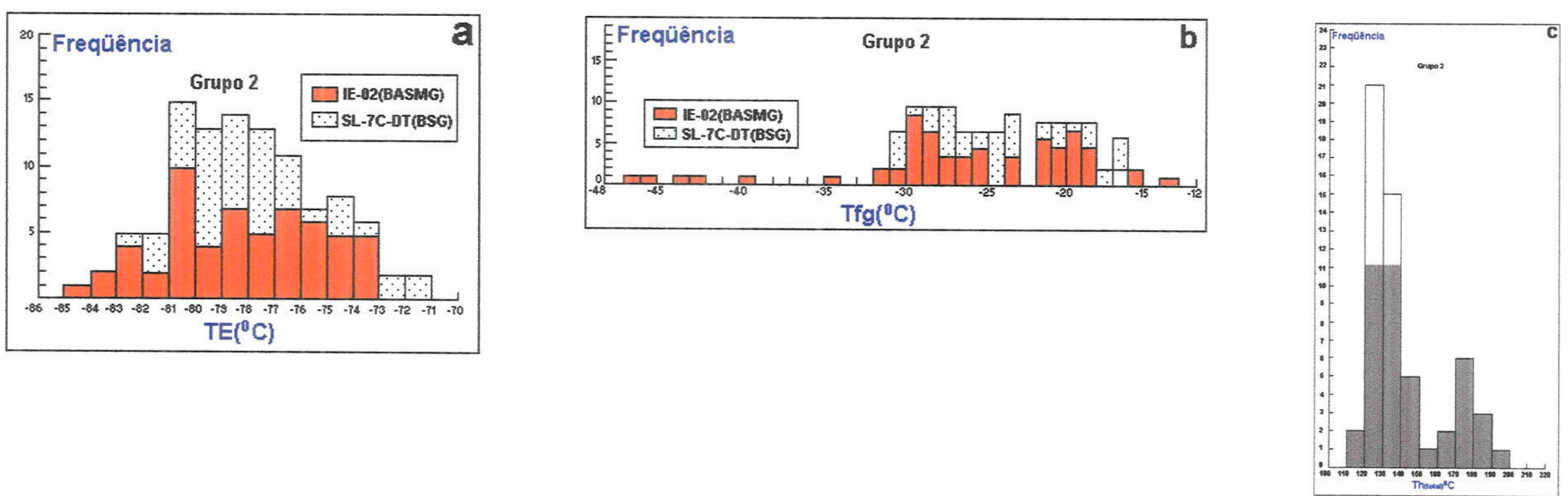

Figura 10.2- Histogramas de freqüência mostrando os intervalos de variação das TE(a), Tfg(b) e Th(total)(c) das IFs do Grupo 2 presentes em grãos de quartzo1 das amostras IE-02(BASMG) e SL-7C-DT(BSG) do maciço granitóíde Antônio Vicente. 

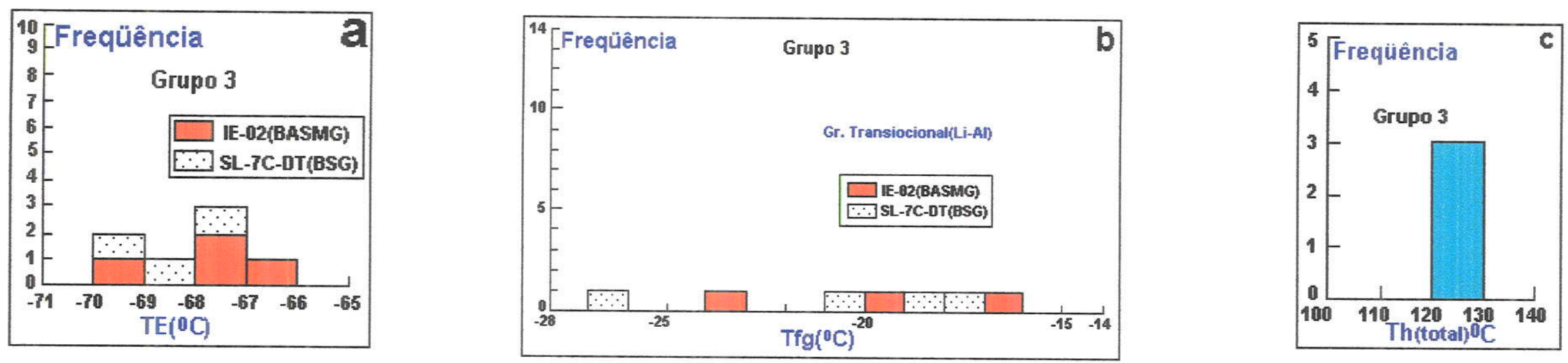

Figura 10.3- Histogramas de freqüência mostrando os intervalos de variação das TE(a), Tfg(b) e Th(total)(c) das Ifs do Grupo 3 presentes em grão de quartzo 1 das amostras IE-02(BASMG) e SL-7C-DT(BSG) do maciço granitóide Antônio Vicente.
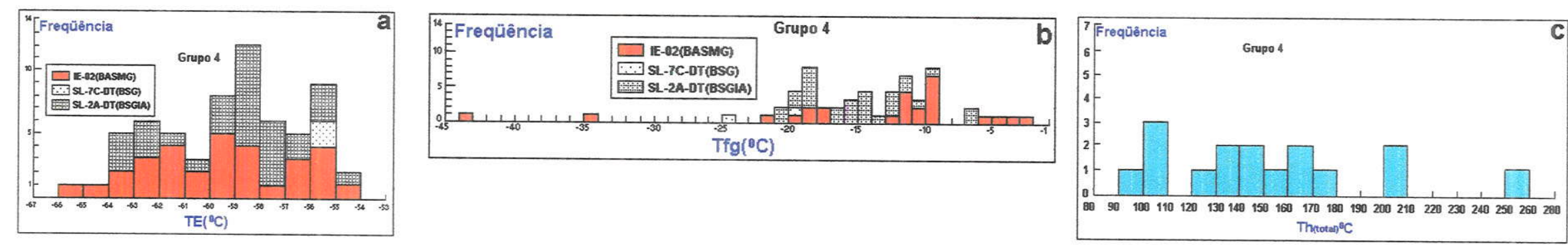

Figura 10.4- Histogramas de freqüência mostrando os intervalos de variação das TE(a), Tfg(b) e Th(total)(c) das Ifs do Grupo 4 presentes em grão de quartzo 1 das amostras IE-02(BASMG), SL-7C-DT(BSG) e SL-2A-DT(BSGIA) do maciço granitóide Antônio Vicente. 

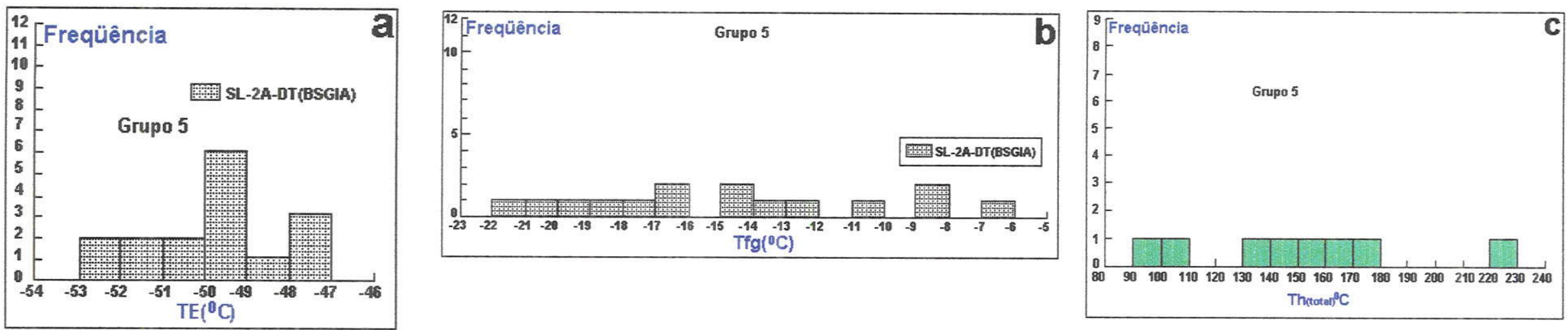

Figura 10.5- Histogramas de freqüência mostrando os intervalos de variação das $\mathrm{TE}(\mathrm{a}), \mathrm{Tfg}(\mathrm{b})$ e Th(total)(c) das lfs do Grupo 5 presentes em grão de quartzo 1 da amostra SL-2A-DT(BSGIA) do maciço granitóide Antônio Vicente.
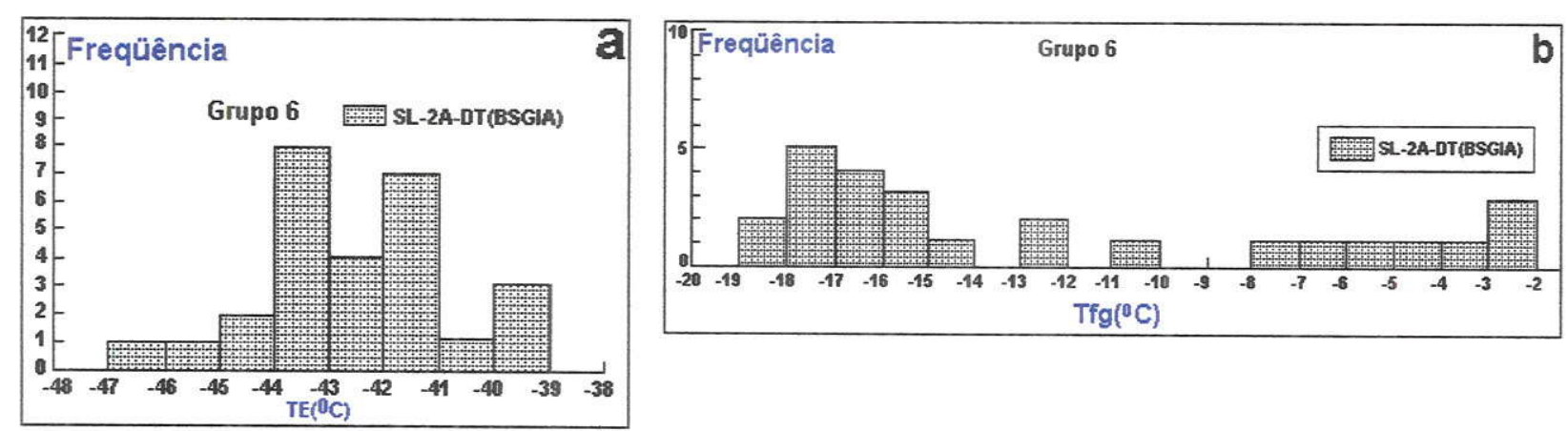

.

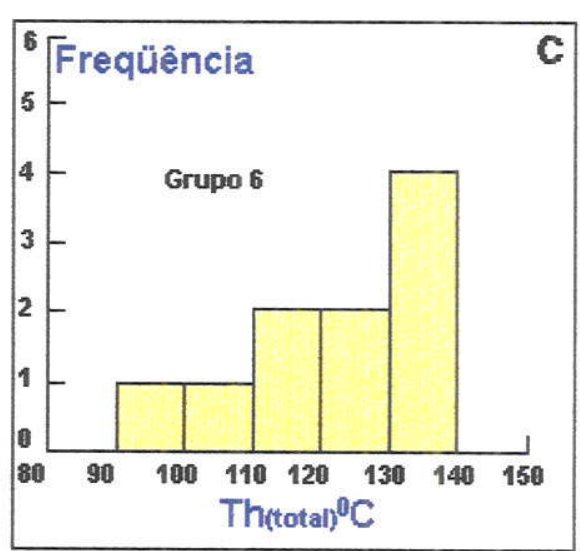

Figura 10.6- Histogramas de freqüência mostrando os intervalos de variação das TE(a), Tfg(b) e Th(total)(c) das lfs do Grupo 6 presentes em grão de quartzo 1 da amostra SL-2A-DT(BSGIA) do maciço granitóide Antônio Vicente. 

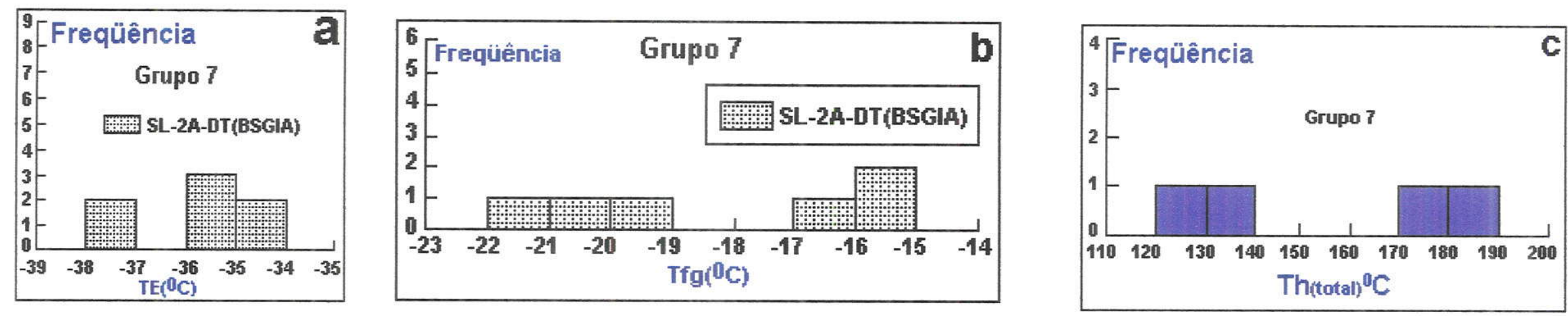

Figura 10.7- Histogramas de freqüência mostrando os intervalos de variação das TE(a), Tfg(b) e Th(total)(c) das Ifs do Grupo 7 presentes em grão de quartzo 1 da amostra SL-2A-DT(BSGIA) do maciço granitóide Antônio Vicente.
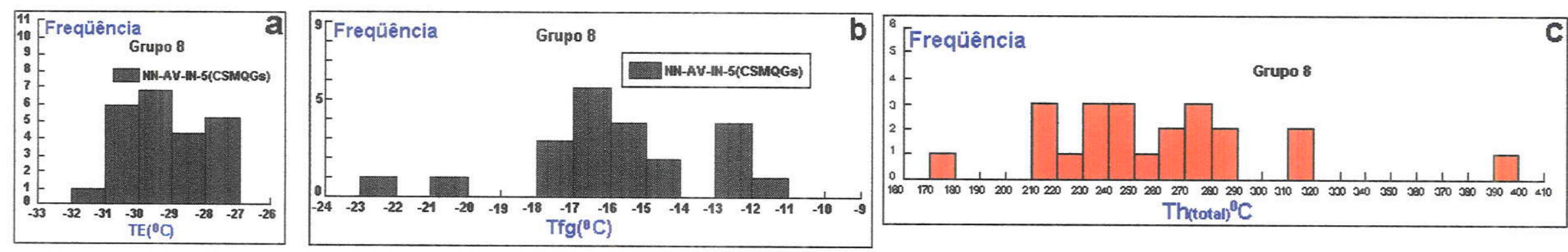

Figura 10.8- Histogramas de freqüência mostrando os intervalos de variação das TE(a), Tfg(b) e Th(total)(c) das lfs do Grupo 8 presentes em grão de quartzo 1 da amostra NN-AV-IN-5(CSMQGs) do maciço granitóide Antônio Vicente. 

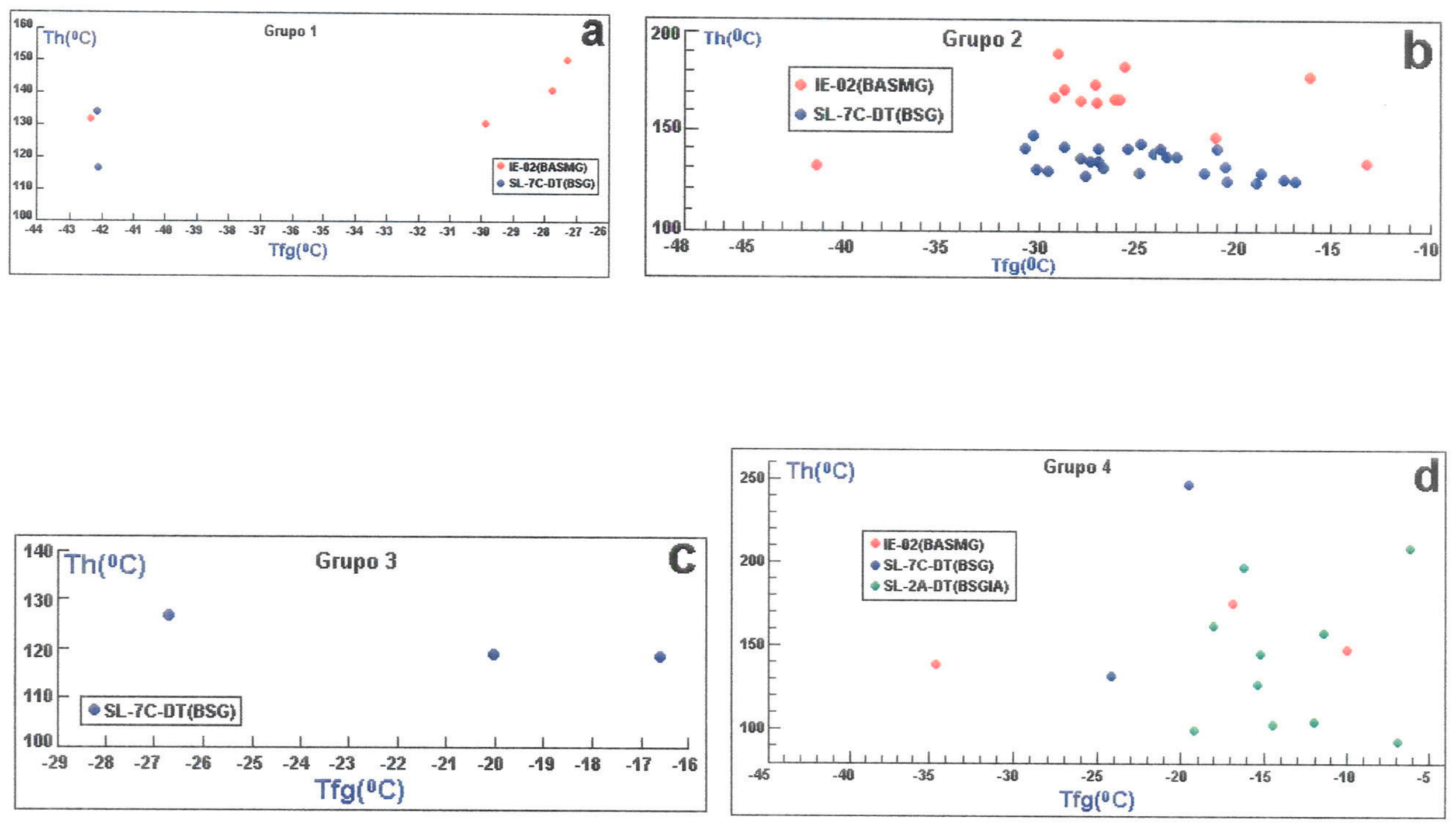

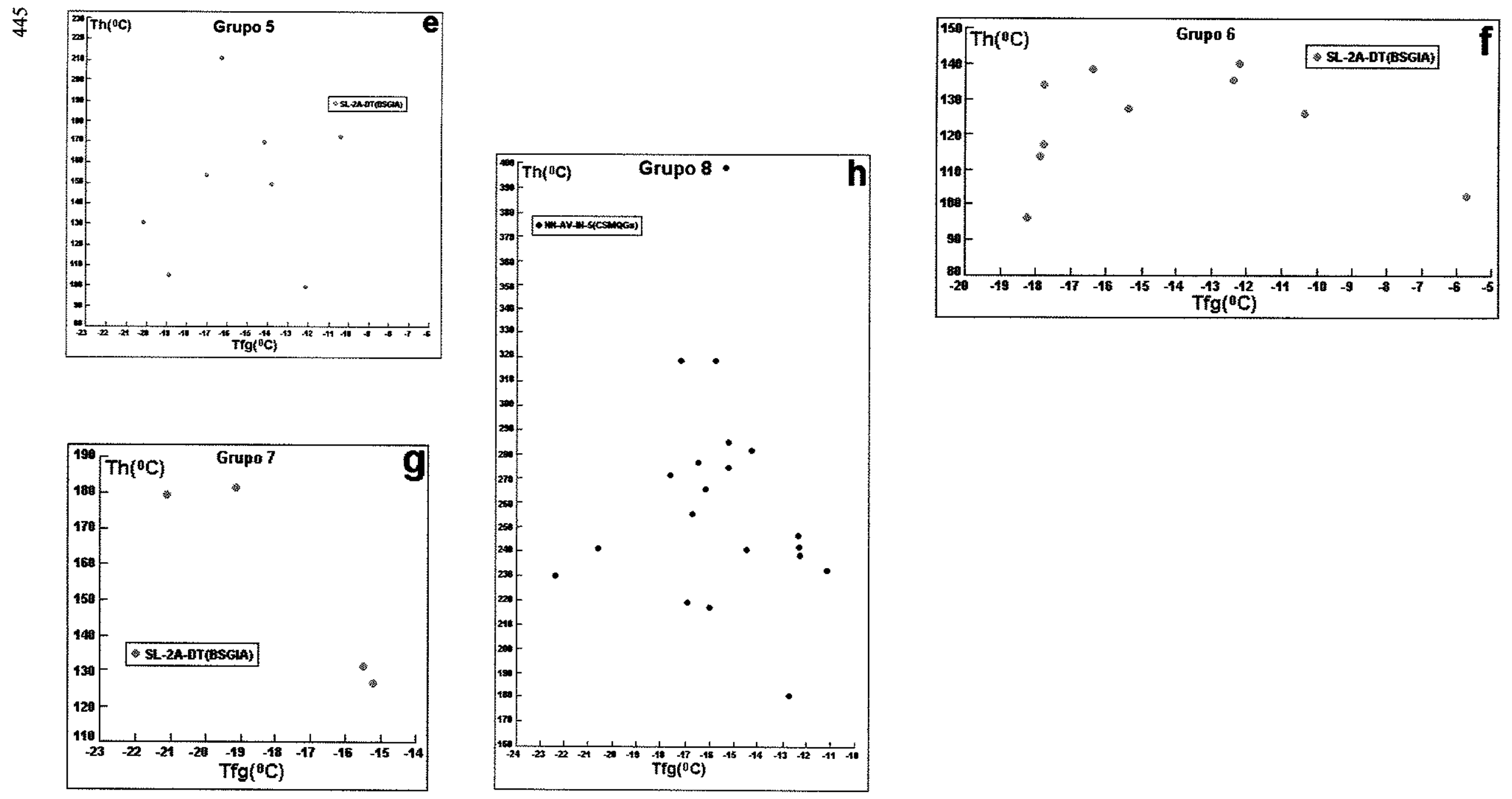

Figura 10.9- Diagramas Th contra Tfg mostrando a distribuição de todos os grupos de IFs caracterizados . (a) Grupo 1;(b) Grupo 2; c) Grupo 3; d) Grupo
4; e) Grupo 5; f) Grupo 6; g) Grupo 7; h) Grupo 8c). 


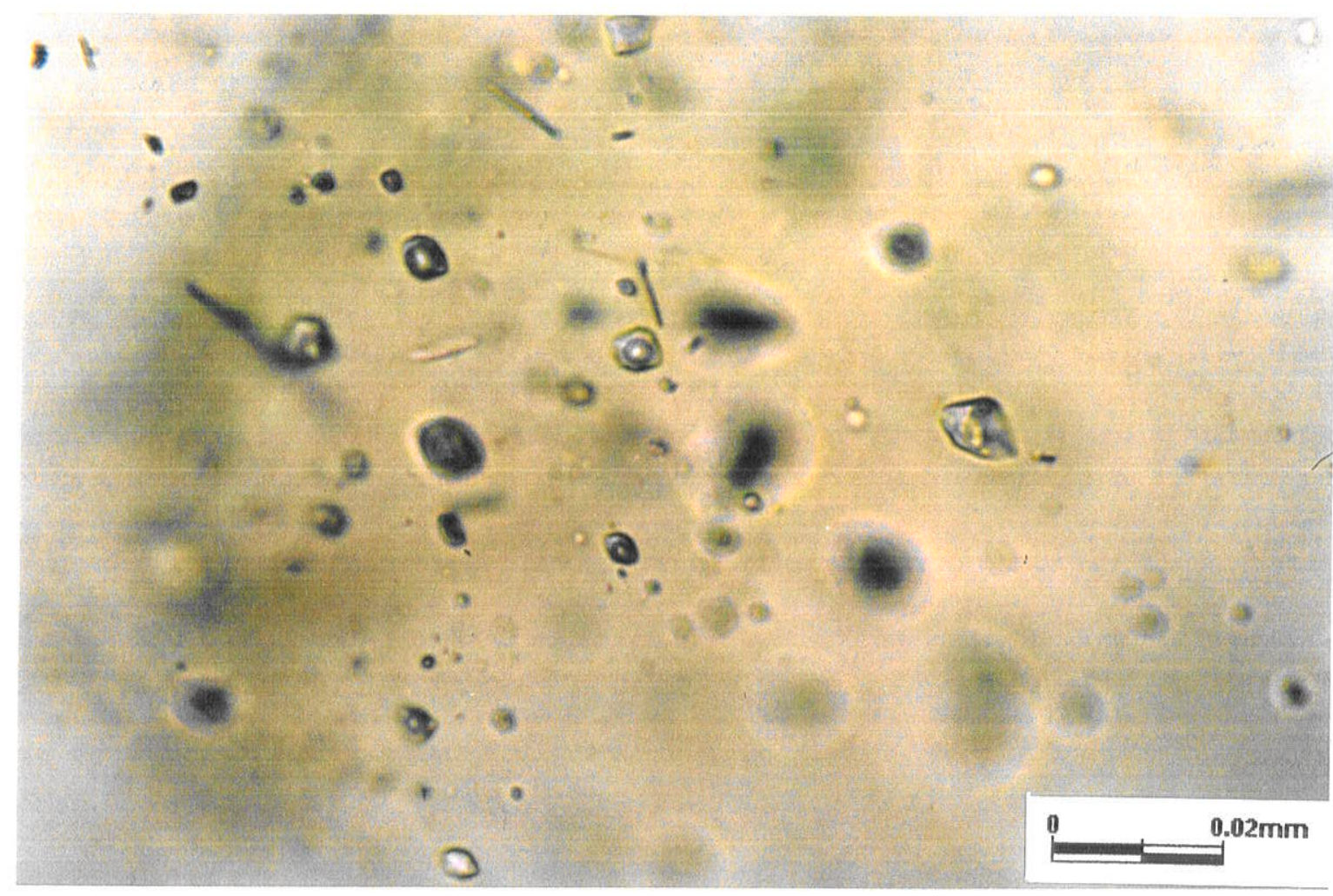

Fotomicrografia 10.4- Aspecto das inclusões estudadas mostrando a relação de volume entre a fase de vapor(gás) e a líquida. Amostra IE-02(BASMG). LN. 


\section{CAPÍTULO 11}

\section{1- GEOCRONOLOGIA E GEOQUIMICA ISOTÓPICA}

Wirth et al.(1986) realizaram datações radiométricas, pelo método $U-\mathrm{Pb}$ em zircões(monozircão), em riolitos decompostos da seqüência inferior do Grupo Grão Pará e em amostras do Granito da Serra dos Carajás e obtiveram, respectivamente, idades de $2758 \pm 39 \mathrm{Ma}$. e $1820 \pm 49 \mathrm{Ma}$. para as duas unidades.

Baseando-se nas propriedades físicas $e$ isotópicas dos zircões estudados, os autores supracitados, interpretaram a idade de $2758 \pm 39 \mathrm{Ma}$ como sendo a idade do vulcanismo riolítico na região, que, por sua vez, caracterizava uma idade mais antiga do que se suspeitava previamente para o Grupo Grão Pará e demonstrava a existência de uma crosta Arqueana na região da Serra de Carajás. Esse fato trouxe diversas implicações para a evolução crustal Pré-Cambriana no Craton Amazônico.

Considerando a similaridade entre os basaltos do Grupo Grão Pará e os basaltos continentais modernos apresentada por Gibbs et al.(1986), os referidos autores sugeriram que os mesmos foram extravasados sobre um embasamento mais velho, o qual poderia, em parte, estar representado pelas rochas do Complexo Xingu e dos greenstone belts de baixo grau, ocorrentes nos arredores, os quais foram considerados mais velhos do que o Grupo Grão Pará.

Posteriomente, Machado et al.(1988) realizaram uma série da datações geocronológicas, pelo método U-Pb em zircões(monozircão), em unidades litoestratigráficas da região da Serra dos Carajás. Os resultados obtidos, pelos referidos autores, revelaram a existência de, pelo menos, quatro periodos de atividades geológicas na região a saber:

1) o mais antigo, de idade $2851+1-4$ a $2859+/-2 \mathrm{Ma}$., está registrado no Complexo Xingu e é caracterizado por múltiplos episódios de deformação, metamorfismo e migmatização;

2) um periodo seguinte, de idade $2759+/-2$ a $2.763+/-6 \mathrm{Ma}$., que corresponde a um evento envolvendo vulcanismo máfico e félsico, plutonismo ultramáfico e deposição de Formações Ferriferas, representado pela Intrusões Luanga e pelo Grupo Grão Pará;

3) um terceiro, de idade $2.555+4 /-3 \mathrm{Ma}$, ocorrido já em crosta rígida, gerador de metamorfismo localizado em zonas de cisalhamento, exemplificado pela Seqüência Salobo; 
4) por último, um periodo cuja idade corresponde à colocação dos granitóides anorogênicos a exemplo dos Granitos Cigano(1883+/-2 Ma), Musa(1883+5/-2 Ma), Carajás(1880+/-2 Ma) e Pojuca(1874+/-2 Ma)

Além disso, os autores referidos acima, obtiveram, no Granito Musa, uma idade média do $\mathrm{Pb}$ herdado igual a 3.2+/-0.2 Ga. Essa idade foi interpretada como sugestiva da existência de uma crosta mais antiga, com essa idade, bem como sugere que o magma granítico é derivado(ou incorporou) material crustal desta idade.

Macambira \& Lafon(1995) elaboraram uma síntese dos dados geocronológicos existentes àcerca da Província Mineral de Carajás, o que Ihes permitiu definir uma evolução geológica baseada em uma seqüência de eventos magmáticos, metamórficos e sedimentares, predominantemente arqueana, a saber:

a) formação de de uma crosta siálica mais antiga, de idade entre 3,0 e 2,87 Ga, representada pelos granulitos do Complexo Pium da área do Cateté(3050 $\pm 114 \mathrm{Ma}, \mathrm{Pb}-\mathrm{Pb}$ em rocha total; Rodrigues et al., 1992), pelo Metatonalito Arco Verde da região de Rio Maria(2957+25/-21 Ma, U-Pb em zircões; Macambira \& Lancelot, 1991a, Macambira 1992), granitóides arqueanos tais como Granodiorito Rio Maria(2874+9/-10 Ma, U-Pb em zircões; Macambira \& Lancelot, 1991a, Macambira 1992; 2872 5 Ma, U-Pb em zircões; Pimentel \& Machado, 1994) e o Granito Mata Surrão(2872 $10 \mathrm{Ma}, \mathrm{Pb}-\mathrm{Pb}$ em rocha total; Rodrigues et al., 1992; Lafon et al., 1994) Ga); 4) Complexo Xingu(sem idade determinada).

b) formação de seqüências supracrustais de natureza vulcano-sedimentar representadas pelas das regiōes de Rio Maria-Gradaús(2.98-2.90 Ga ou mais velhas), tais como as rochas metavulcânicas do Grupo Lagoa Seca do Supergrupo Andorinhas(2904+29/-22 Ma, U-Pb em zircões; Macambira \& Lancelot, 1992) e da Serra dos Carajás, correspondente ao Grupo Grão Pará(2758 $\pm 78 \mathrm{Ma}$, U.Pb em zircões; Wirth et al., 1986; $2759 \pm 2 \mathrm{Ma}, \mathrm{U}-\mathrm{Pb}$ em zircões; Machado et al., 1991)

c) colocação de complexos básicos-ultrabásicos, de idade entre 2.97-2.76 Ga, como os complexos Luanga(2763 $\pm 6 \mathrm{Ma}$, U-Pb em zircões; Machado et al., 1991) e Serra Azul(2970 \pm Ma, U-Pb; Pimentel \& Machado, 1994), que encontram-se associados ou são intrusivos nas seqüências referidas acima.

d) magmatismo anorogênico do Proterozóico representado pelos Granitos Cigano(1883+/-2 $\mathrm{Ma})$, Musa(1883+5/-2 Ma), Carajás(1880+/-2 Ma) e Pojuca(1874+/-2 Ma), Machado et al.(1991), Velho Guilherme(1874 $\pm 30 \mathrm{Ma}, \mathrm{Pb}-\mathrm{Pb}$ em rocha total; Lafon et al., 1995), 
Redenção(1893 $178 \mathrm{Ma}, \mathrm{Pb}-\mathrm{Pb}$ em rocha total; Barbosa et al., 1994) e Seringa(1892 \pm 30 $\mathrm{Ma}, \mathrm{Pb}-\mathrm{Pb}$ em zircões por evaporação; Avelar et al., 1994).

\section{1- Geocronologia}

\subsection{1-Grupo São Félix}

Conforme visto no capitulo 2(Geologia Regional), Costa et al.(1995) admitiram ter havido um diacronismo no desenvolvimento dos Grupos Aquiri, São Sebastião e São Félix e assumiram a hipótese dos mesmos estarem ligados a um mesmo evento tectono-termal regional, apesar de estarem relacionadas a sistemas transcorrentes independentes.

Tendo como objetivo mais imediato melhor posicionar essa unidade no arranjo litoestratigráfico da região, foram realizadas datações radiométricas em zircões(por evaporação de $\mathrm{Pb}$ ) em amostras de rochas metavulcânicas máficas deste grupo.

Assim, foram analisados 8 cristais de zircão, sendo que em apenas seis deles foi possivel realizar datações e obter idades aparentes 207Pb/206 Pb(ver ítem Metodologia do capítulo 1).

A análise do cristal 1 envolveu duas etapas de evaporação. Uma a $1480^{\circ} \mathrm{C}$ e outra a $1550^{\circ} \mathrm{C}$. Na primeira etapa foi obtida uma idade de $2729 \pm 12 \mathrm{Ma}\left(18\right.$ razões ${ }^{207} \mathrm{~Pb} /{ }^{206} \mathrm{~Pb}$ ), enquanto que a segunda fase forneceu uma idade de $2732 \pm 10 \mathrm{Ma}\left(68\right.$ razões $\left.{ }^{207} \mathrm{~Pb} /{ }^{206} \mathrm{~Pb}\right)$. No cristal 2 também foram obtidas duas etapas de evaporação. Uma a $1500^{\circ} \mathrm{C}$ que forneceu uma idade de $2832 \pm 12 \mathrm{Ma}\left(36\right.$ razões $\left.{ }^{207} \mathrm{~Pb} /{ }^{206} \mathrm{~Pb}\right)$ e a outra a $1550^{\circ} \mathrm{C}$ cuja idade obtida foi $2809 \pm 56 \mathrm{Ma}\left(18\right.$ razóes $\left.{ }^{207} \mathrm{~Pb} /{ }^{206} \mathrm{~Pb}\right)$. A análise do cristal 3 envolveu três etapas de evaporação. Na primeira, à temperatura de $1450^{\circ} \mathrm{C}$, foi obtida uma idade de $2571 \pm 30 \mathrm{Ma}$ (84 razões ${ }^{207} \mathrm{~Pb} /{ }^{206} \mathrm{~Pb}$ ). Na Segunda, à temperatura de $1500^{\circ} \mathrm{C}$, a idade fornecida foi de $2687 \pm 18 \mathrm{Ma}\left(88\right.$ razões $\left.{ }^{207} \mathrm{~Pb} /{ }^{206} \mathrm{~Pb}\right)$, enquanto que a terceira, a $1550^{\circ} \mathrm{C}$, indicou uma idade de $2811 \pm 10 \mathrm{Ma}\left(36\right.$ razões $\left.{ }^{207} \mathrm{~Pb} /{ }^{206} \mathrm{~Pb}\right)$.

As idades aparentes ${ }^{207} \mathrm{~Pb} /{ }^{206} \mathrm{~Pb}$ fornecidas pelos cristais 6 e 7 não foram consideradas em razão dos valores das razões ${ }^{206} \mathrm{~Pb} /{ }^{204} \mathrm{~Pb}$, obtidas nas diferentes etapas de evaporação, terem sido inferiores ao limite de 2500 , aceito no laboratório. 0 cristal 8 forneceu idades ${ }^{207} \mathrm{~Pb} /{ }^{206} \mathrm{~Pb}$ de $3024 \pm 6 \mathrm{Ma}\left(90\right.$ razões $\left.{ }^{207} \mathrm{~Pb} /{ }^{206} \mathrm{~Pb}\right)$ e de $3030 \pm 16 \mathrm{Ma}(70$ razões ${ }^{207} \mathrm{~Pb} /{ }^{206} \mathrm{~Pb}$ ) nas etapas de evaporação de $1450^{\circ} \mathrm{C}$ e $1500^{\circ} \mathrm{C}$, respectivamente.

O zircão 8 possui uma idade aparente de $3024 \pm 4 \mathrm{Ma}$, calculada a partir da média das idades obtidas nas duas etapas de evaporação. As duas etapas de evaporação do zircão 2 forneceram idades similares, as quais são eqüivalentes à idade obtida na última etapa de evaporação do zircão 3. Assim, foi possível calcular a idade média aparente para esses dois cristais equivalente a $2820 \pm 14 \mathrm{Ma}$. As duas etapas de evaporação do cristal 1 indicaram uma idade média aparente ${ }^{207} \mathrm{~Pb} /{ }^{206} \mathrm{~Pb}$ de $2727 \pm 4 \mathrm{Ma}$. 
Considerando que a idade do zircão 8 é mais velha do que aquelas obtidas nos demais zircões, sua idade pode ser interpretada como a de um cristal herdado a partir da rocha fonte do seu magma ou então o mesmo deve representar uma contaminação por assimilação a partir das rochas encaixantes da câmara magmática, ou mesmo do conduto magmático, pelo qual o magma fluiu. Em relação às duas idades mais jovens, é tarefa difícil de interpretar se as mesmas representam a idade das rochas vulcânicas originais dessa unidade metavulcano-sedimentar. A idade de $2727 \pm 4$ Ma verificada no zircão 1 certamente indica uma idade mínima para esse evento vulcânico. Entretanto, o fato de existirem dois cristais fornecendo idades ${ }^{207} \mathrm{~Pb} /{ }^{206} \mathrm{~Pb}$ de $2820 \pm 14$ Ma sugere que esse episódio magmático possa ser em torno de $100 \mathrm{Ma}$ mais velho. Uma hipótese alternativa é que essa idade mais jovem represente a idade de formação metamórfica dessas rochas. Assim o zircão 1 corresponderia a uma fase menor recristalizada durante o metamorfismo regional dessa unidade, bem como das outras unidades correlacionadas, representadas, na área, pelos Grupos Aquiri e São Sebastião.

\subsection{2- Suite Intrusiva Velho Guillherme}

Teixeira et al.(1998) apresentaram uma sintese sobre dados geocronológicos inéditos àcerca dos granitóides Antônio Vicente, Mocambo e Rio Xingu pertencentes a essa suite. Neste trabalho, os dados apresentados pelos referidos autores serâo tratados em detalhe, bem como novos dados adicionais serão acrescentados à discussão:

\section{a) Maciço granitóide Antônio Vicente:}

Nesse maciço foram analisadas inicialmente através do método $\mathrm{Pb}-\mathrm{Pb}$ (em rocha total) sete amostras de rochas e duas de feldspato potássico. O diagrama isocrônico obtido revelou o desalinhamento de uma amostra correspondente à variedade BSGIA. Essa amostra foi retirada do cálculo isocrónico, visto que se trata de um granitóide intensamente afetado por alterações tardi a pós-magmáticas. A idade obtida é de $1.895 \pm 19 \mathrm{Ma}$ com MSWD igual a 18,9. Este alto valor de MSWD indicou desalinhamento dos pontos analíticos, em especial, de uma amostra da facies BASAFG e uma amostra da facies BMG. Apesar dessas amostras não sugerirem nenhum problema geológico(alterações), um novo diagrama foi construído sem as mesmas. Esse diagrama forneceu uma idade de $1896 \pm 9$ e MSWD de 4,47, indicando um maior alinhamento dos pontos experimentais(Figura 11.1). Percebe-se que a idade não se alterou, fato que permite interpretar a idade de $1,89 \mathrm{Ga}$ como a aquela de colocação dos granitóides do maciço Antônio Vicente

Adicionalmente, foram realizadas datações radiométricas $\mathrm{Pb}-\mathrm{Pb}$ em zircões(por evaporação de $\mathrm{Pb}$ ). Entretanto, dos 10 zircões analisados não foi conseguido sinal de $\mathrm{Pb}$ 
suficiente em grande parte deles. Apenas dois cristais forneceram dados que possibilitaram calcular uma idade média de $1867 \pm 4 \mathrm{Ma}$, comparável àquela fornecida pelo método $\mathrm{Pb}-\mathrm{Pb}$ em rocha total. A coerência dos dois métodos sugere tratar-se da idade de cristalização dos granitóides desse maciço.

\section{b) Maciço granitóide Mocambo}

Em relação a esse maciço, foram realizadas datações radiométricas $\mathrm{Pb}-\mathrm{Pb} \mathrm{em}$ zircões(por evaporação de $\mathrm{Pb}$ ). A análise envolveu um total de seis zircões, que em geral apresentavam aspecto metamítico e coloração acinzentada. Embora não fossem os mais adequados, foram analisados por falta de opções de escolha. Dentre os seis grãos analisados, quatro forneceram idade variando entre 1832 e $1921 \mathrm{Ma}$ e o valor médio, considerando todos os cristais, foi estabelecido em $1862 \pm 32 \mathrm{Ma}$. Um cristal indicou a idade de $1865 \pm 2 \mathrm{Ma}$. Esses valores são similares àqueles obtidos para o granitóide Antônio Vicente e, parece mais razoável, admitir a idade de $1865 \pm 2 \mathrm{Ma}$, obtida em um dos cristais, como sendo a idade mínima mais provável dos granitóides desse maciço.

\section{c) Maciço granitóide Rio Xingu}

Nesse maciço foram datadas quatro amostras pelo método $\mathrm{Pb}-\mathrm{Pb}$ em rocha total. $\mathrm{O}$ diagrama isocrônico construído com base nos dados obtidos forneceu um valor de $1906 \pm 29 \mathrm{Ma}$ com MSWD de 0,06, indicando um excelente alinhamento dos pontos experimentais(Figura 11.2).

Adicionalmente, foram datados seis cristais de zircóes, sendo que todos foram aproveitados para o cálculo da idade média, cujo valor é $1866 \pm 3 \mathrm{Ma}$. O zircão mais novo forneceu uma idade de $1860 \pm 7 \mathrm{Ma}$ e o mais antigo de $1870 \pm 3 \mathrm{Ma}$.

$\mathrm{A}$ idade média obtida é inferior àquela de $1906 \pm 29 \mathrm{Ma}$ fornecida pelo método $\mathrm{Pb}-\mathrm{Pb}$ em rocha total e feldspato potássico. Entretanto, se for considerada a incerteza dessa idade em $2 \delta$, ela se superpõe, nos limites dos erros, com a idade de zircão.

Assim, as idades obtidas através do método $\mathrm{Pb}-\mathrm{Pb}(\mathrm{em}$ rocha total) e aquelas aparentes ${ }^{207} \mathrm{~Pb} /{ }^{206} \mathrm{~Pb}$ fornecidas por zircões de $1867 \pm 4 \mathrm{Ma}$ para o maciço granitóide António Vicente, de $1865 \pm 2 \mathrm{Ma}$ para o maciço granitóide Mocambo e de $1866 \pm 3 \mathrm{Ma}$ para o maciço granitóide Rio Xingu(Teixeira et el., 1998 e neste trabalho), bem como aquela de $1874 \pm 30 \mathrm{Ma}$ obtida através do método $\mathrm{Pb}-\mathrm{Pb}$ em rocha total(La Fon et al., 1995) para o maciço granitóide Velho Guilherme, podem ser interpretadas como as idades de cristalização desses corpos granitóides e confirmam uma contemporaneidade dos eventos magmáticos que os geraram. 
Os diagramas correspondentes às Figuras 11.1 e 11.2 indicam também os valores de $\mu$, que expressam a razão ${ }^{238} \mathrm{U} /{ }^{204} \mathrm{~Pb}$ hoje do reservatório a partir do qual um magma foi extraído no passado(Köppel \& Grünenfelder,.1979)

$O$ valor de $\mu$ pode ser calculado a partir de modelo simples de evolução em estágio único(conhecido como o modelo de Holmes-Houtermans; Köppel \& Grünenfelder, 1979, pg.138) e do modelo de evolução em dois estágios(modelo de Stacey \& Kramers, 1975). Com base no modelo simples de evolução em estágio único do $\mathrm{Pb}$ os valores de $\mu$ situamse em torno de 9, considerando: 1) maciço granitóide Antônio Vicente igual a 9,2 $\pm 0,60 ; 2$ )

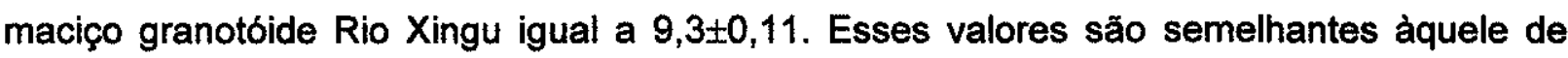
$8,9 \pm 0,14$ obtidos por Lafon et al.(1995) para o maciço granitóide Velho Guilherme e indicam uma importante contribuição crustal(niveis rasos), com provável contaminação com sedimentos, na geração dos granitóides da suite, visto que os valores de $\mu$ para uma fonte matélica situam-se hoje entre 8,0 e 7,5(conforme Dupre \& Arndt, 1990).

Os valores de $\mu$ calculados a partir de Stacey \& Kramers(1975) revelam que o modelo em dois estágios não pode ser aplicado às rochas estudadas, uma vez que o valor adotado para o modelo dos referidos autores é 9,74.

Em razão disso, os valores de $\mu$ invariavelmente superiores a 12 , nos granitóides estudados, reforçam a interpretação de que houve uma marcante contribuição crustal aos magmas que geraram os granitóides dos maciços Antônio Vicente e Rio Xingu.

Datações radiométricas pelo método $\mathrm{Rb}-\mathrm{Sr}$ sempre foram muito problemáticas em granitóides dessa suite devido os mesmos se encontrarem, via de regra, alterados metassomaticamente, em diferentes graus. Entretanto, Lafon et al.(1991) dataram através desse métrodo ganitóides do maciço Velho Guilherme e obtiveram uma idade de $1653 \pm 28 \mathrm{Ma}((2 \delta)$, com razão inicial de $0,708 \pm 0,048(2 \delta)$ e MSWD=1,71. Embora essa idade tenha sido considerada, pelos referidos autores, como sendo um distúrbio, nota-se que o valor da razão inicial obtido corresponde a assinaturas tipicamente crustais. Isso reforça, ainda mais, as consideraçōes acima comentadas.

Adicionalmente, os elevados conteúdos de elementos litófilos de raio iônico grande(LILE) tais como $\mathrm{Rb}, \mathrm{K}$ e Th, bem como aqueles de ETRL e de elementos de alto campo de força(HFSE), estes representados por $\mathrm{Zr}$, Nb e $\mathrm{Y}$, observados nos granitóides estudados ratificam a interpretação da existência de uma importante participação crustal durante a gênese e evolução dos granitóides dessa suite. 


\subsection{3- Grupo Uatumã}

Desse grupo, foram datadas pelo método $\mathrm{Pb}-\mathrm{Pb}(\mathrm{em}$ rocha total) seis amostras pertencentes à Formação Sobreiro(rochas andesiticas) e duas à Formação Iriri(rochas rioliticas).

A partir dos resultados analíticos obtidos para a Formação Sobreiro, foi tentativamente construido um diagrama isocrônico que forneceu um valor de $2239 \pm 241 \mathrm{Ma}$ e MSWD $=22,80$. Objetivando melhorar os resultados, adicionou-se duas amostras da Formação Iriri. Percebeu-se, então, que o desalinhamento dos pontos experimentais persistiu, sendo a indicação dada por $M S W D=19,11$. Em razão disso, a idade obtida de $2023 \pm 107 \mathrm{Ma}$ não possibilitou definir com confiabilidade a idade do vulcanismo que gerou as rochas do Grupo Uatumá. Assim, mais uma tentativa para melhorar os resultados foi levada a efeito. Eliminou-se do diagrama duas amostras pertencentes à Formação Sobreiro, cujos pontos experimentais mostravam-se mais desalinhados e construiu-se um outro diagrama isocrônico integrado envolvendo três amostras da Formação Sobreiro e três da Formação Iriri(isócrona de referência). Nesse diagrama, o valor de MSWD é de 5,56 e a idade correspondente obtida foi de $1875 \pm 79 \mathrm{Ma}$, Figura 11.3. Esse valor foi interpretada por Teixeira et al.(1998) como sendo uma idade de referéncia do vulcanismo do Grupo Uatumã.

O fato dessa idade de referência se superpor, nos limites de erros, com àquelas obtidas para os granitóides da Suite Intrusiva Velho Guilherme(ver adiante), bem como o fato das rochas desse grupo ocorrerem lado a lado no campo com os granitóides dessa suite e no mesmo nível de erosão, sugerem uma contemporaneidade entre os eventos de plutonismo e de vulcanismo, na região.

A Figura 11.3 mostra os valores de $\mu$, da isócrona obtida para essas rochas. Do mesmo modo que em relação aos granitóides da suite intrusiva Velho Guilherme, tomandose por base o modelo simples de evolução em estágio único, observa-se um valor de $\mu$ igual a 9,0 0,27 à semelhança daqueles que foram obtidos para os granitóides, sendo, também, indicativos de uma importante contribuição crustal na geração das vulcânicas desse grupo.

O valor de $\mu$ quando calculado a partir do modelo de dois estágios(Stacey \& Kramers, 1975) demonstra que tal modelo não pode ser aplicado às rochas estudadas, por razão idêntica àquela considerada em relação aos granitóides da Suite Intrusiva Velho Guilherme, já que o valor de $\mu$ encontrado é igual a $12,0 \pm 0,81$.

Em razão disso, o valor de $\mu$ superior a 12, reforça a interpretação de que houve realmente uma nítida contribuição crustal aos magmas que geraram as rochas vulcânicas reunidas no Grupo Uatumã.

Essa condição, vem confirmar os dados obtidos por Basei(1978). Datações radiométricas $\mathrm{Rb}-\mathrm{Sr}$ realizados por este autor em riolito e andesito ocorrentes a leste da 
Cidade de Marabá e em riolito dos rios Cupari e Iriri forneceram uma idade de referencia $1756 \pm 72 \mathrm{Ma}$ e razão inicial igual a 0,7058 , o que sugere assinatura crustal para as rochas analisadas.

\section{2- Análises dos isotopos de Sm $\theta \mathrm{Nd}$}

Teixeira et al.(1998) apresentaram uma breve discusão sobre dados de Sm e Nd obtidos em rochas granitóides dos maciços António Vicente e Rio Xingu e em rochas vulcânicas andesíticas da Formação Sobreiro do Grupo Uatumã.

Neste trabalho estendeu-se as análises para unidades encaixantes mais imediatas do maciço granitóide Velho Guilherme, corrrespondentes ao granodiorito Rio Maria e às rochas metavulcánicas máficas do Grupo Tucumã, devido representarem uma das unidades mais antigas da região, bem como, foi ampliado o número de análises em vulcánicas do Grupo Uatumã.

\subsection{1- Discussão e Interpretação dos Resultados}

As análises apresentadas na Tabela 11.1 revelam que os protólitos dos granitóides da Suite Intrusiva Velho Guilherme e das rochas vulcânicas do Grupo Uatumă foram diferenciados diretamente do manto superior entre $3,2 \mathrm{Ga}$ e 2,9Ga conforme é indicado pelos seus valores de $T_{D M}$ a saber: 1) 3,2Ga(AMGAV); 2) 3,0Ga(MGRX); 3) 3,0Ga(MSM); 4) 2,9 a $3,1 \mathrm{Ga}$ ( riolitos da FI); 5) 3,1 Ga(andesitos da FS). As idades modelo( $\mathrm{T}_{\mathrm{DM}}$ ) dos granitóides e vulcânicas representam as idades de formação de protólitos Arqueanos com base no fracionamento das razões $\mathrm{Sm} / \mathrm{Nd}$ durante a formação de uma nova crosta continental a partir de um manto "depletado"(DePaolo, 1981).

Percebe-se, ainda, que tanto os granitóides, quanto as rochas vulcânicas exibem valores de $\varepsilon \mathrm{Nd}(\mathrm{t}=\mathrm{idade}$ de cristalização das rochas estudadas) fortemente negativos, respectivamente, -11,939(rocha total)/-12,20(zircão), MGAV; -8,08(zircão), MGM; 11,87(rocha total)/-12,36(zircão), MGRX; $-10,16$ (rocha total/andesito + riolito)/-11,61(rocha total/riolito/-9,78(rocha total/riolito), os quais podem ser interpretados mais consistentemente como envolvendo uma crosta predominantemente Arqueana, ou mesmo uma provável mistura de uma fonte matélica com componentes de crosta Arqueana em 3,2 Ga(maciço granitóide Antônio Vicente), 3.1(vulcánicas andesíticas e rioliticas do Grupo Uatumã), 3,0 Ga(maciços granitóides Rio Xingu e Mocambo) e 2.9(riolito da Formação Iriri do Grupo Uatumã).

Deve-se ressaltar, entretanto, que devido o valor de $\varepsilon N d(t=1862 \pm 32 \mathrm{Ma})$ igual a $-8,08$, correspondente aos granitóides do maciço Mocambo, ser diferente daqueles relativos aos maciços Antônio Vicente e Rio Xingu, pode-se conjecturar que o protólito do mesmo tinha caracteristicas geoquímicas $e$ isotópicas distintas daquele, de mesma idade modelo $\left(T_{D M}=3.0\right.$ 
Ga), referente ao maciço Rio Xingu. Nesse caso, a hipótese de cogeneticidade entre os mesmos fica descartada. O mesmo é válido para o valor de $\varepsilon \mathrm{Nd}(\mathrm{t}=1875 \pm 79)$ correspondentes $a-10,16$ e $-9,78$ referentes às rochas vulcânicas do Grupo Uatumã. Nesse último caso, verifica-se que, também, entre as vulcânicas do Grupo Uatumã existem fontes distintas. Uma caracterizada pela idade modelo $\left(T_{D M}\right)=3,1 \mathrm{Ga}$ e $\varepsilon \mathrm{Nd}(\mathrm{t})=-11,61$ e outra de idade modelo $\left(T_{D M}\right)=2.9 \mathrm{Ga}$ e $\varepsilon N d(t)=-9,78$.

Pode-se concluir, portanto, que tanto em relação às rochas granitóides da Suite Intrusiva Velho Guilherme, quanto no que se refere às vulcânicas do Grupo Uatumã, protólitos com diferentes características geoquímicas e isotópicas foram envolvidos como fontes das mesmas.

Esses dados ( $T_{D M}$ e $\varepsilon N d(t)$ ) são indicativos, também, de que, embora os protólitos dos granitóides e vulcânicas tenham sido extraídos diretamente do manto superior entre $3,2 \mathrm{Ga}$ e $2,9 \mathrm{Ga}$, passando a compor, ao que tudo indica, um arco magmático arqueano juvenil, eles tiveram um longo tempo de residência na crosta(Figura 11.4a e b), visto que a fusão dessa crosta Arqueana, por eles formada, só gerou os granitóides e as vulcânicas em torno de $1.88 \mathrm{Ga}$. Adicionalmente, os valores de $\mathrm{f}_{\mathrm{Sm} / \mathrm{Nd}}($ entre $-0,48$ e $-0,35$ ), apresentados na Tabela 11.1, indicam que a evolução do protólito dos granitóides estudados e vulcânicas se deu em estágio único confirmando o que foi comentado em relação aos valores de $\mu$ obtidos nas datações $\mathrm{Pb}-\mathrm{Pb}$ em rocha total.

Em relação aos dados $\mathrm{Sm}-\mathrm{Nd}$ referentes ao granodiorito Rio Maria e à metavulcânica máfica do Grupo Tucumã, nota-se na Tabela 11.1 que os protólitos dessas duas unidades tem idades muito semelhantes: 1) $3,15 \mathrm{Ga}$ (GDRM); 2) 3,17(GTUC). Essas idades são similares àquelas de alguns dos protólitos dos granitóides da Suite intrusiva Velho Guilherme e das vulcânicas do Grupo Uatumã e confirmam a existência de um segmento de crosta Arqueana muito antigo, ao que tudo indica, relacionado a um arco, magmático juvenil.

Os baixos e negativos valores de $\varepsilon N d(t)$ determinados para as rochas dessas unidades(GDRM=-2,15; GTUC=-0,60) são indicativos de que seus protólitos diferenciaramse diretamente do manto superior(Figura 11.4 b), um pouco antes das mesmas cristalizarem, e reforçam o caráter.juvenil dos mesmos (Sato,1998).

No que se refere à evolução dos protólitos das mesmas, os valores de $\mathrm{f}_{\mathrm{Sm} / \mathrm{Nd}}$ obtidos no Granodiorito Rio Maria(,-0,55) e na metavulcânica máfica do Grupo Tucumã(-0,44), Tabela 11.1, indicam que o mesmo evoluiu em estágio único, já que esses valores são considerados normais para rochas desse tipo. 


\section{3- Contexto Regional}

Em termos regionais, as rochas mais antigas reconhecidas na região sul-sudeste do Pará correspondem a granulitos félsicos e máficos pertencentes ao Complexo Pium(Rodrigues et al., 1991). De acordo com Costa et al.(1995) esse complexo representa frações de crosta inferior que foram lançadas ao nivel de crusta superior através da componente de cavalgamento de zonas de cisalhamento obliquas. Essas lascas alternamse com faixas de gnaisses do Complexo Xingu. Datações radiométricas pelo método $\mathrm{Pb}-\mathrm{Pb}$ em rocha total, realizadas por Rodrigues et al.(1992), indicaram uma idade de $3.050 \pm 114$ $\mathrm{Ma}\left(\mathrm{MSWD}=72 ; \mu_{1}=9,2\right)$, que foi interprtetada como a idade do protólito ígneo dos granulitos. Tassinari(1996) baseando-se no elevado valor de $\mu_{1}$ obtido pelos autores supracitados, considerou essa idade suspeita, uma vez que o valor de $\mu_{1}=9,2$ indicaria uma origem a partir de fontes com altas razões $U / \mathrm{Pb}$, fato muito improvável em rochas com baixas razões $\mathrm{Rb} / \mathrm{Sr}$ da crosta inferior. Entretanto, essa idade é muito similar às dos protólitos dos granitóides e vulcânicas aqui estudados.

Os granulitos do Complexo Pium, especialmente os termos máficos, podem ser apontados como os principais candidatos a protólitos dos granitóides da Suite Velho Guilherme e da vulcânicas do Gupo Uatumã, desde que a idade de $3.050 \pm 114 \mathrm{Ma}$ seja interpretada como a idade de formação das rochas granulíticas. Aliás, 0 valor de $\mu_{1}$ encontrado nos granulitos do complexo Pium são muito semelhantes àqueles encontrados nos granitóides da Suite Intrusiva Velho Guilherme e nas vulcânicas do Grupo Uatumã.

\section{4- Considerações Finais}

Os dados apresentados acima permitem caracterizar à existência de, pelo menos, três períodos de atividades geológicos envolvendo formação de crosta no setor norte da Província Mineral de Carajás(região da Serra dos Carajás, aba oeste) a saber:

1) formação de uma crosta Arqueana mais antiga ocorrida entre 3.2 e $3.0 \mathrm{Ga}$ evidenciada pelas idades $\left(T_{D M}\right)$ dos protólitos dos granitóides dos maciços Antônio Vicente, Rio Xingu e Mocambo, das vulcânicas do Grupo Uatumã, do granodiorito Rio Maria e da metavulcânica máfica do Grupo Tucumă, bem como pelos granulitos do Complexo Pium;

2) segue-se um episódio de idade entre 2.8 e $2.7 \mathrm{Ga}$ representado pelas supracrustais metavulcânicas máficas do Grupo São Felix;

3) e finalmente um terceiro e último período, de idade entre 1,88 e 1,87, representado pelos granitóides da Suite Intrusiva Velho Guilherme e das vulcânicas do Grupo Uatumã. 
A integração desses dados com aqueles obtidos por Machado et al.(1991) permite estabelecer, entre o Arqueano e o Mesoproterozóico, o seguinte quadro evolutivo para a ragião da Serra dos Carajás(setor norte da Província Mineral Carajás):

1) formação de uma crosta Arqueana mais antiga ocorrida entre 3.2 e $3.0 \mathrm{Ga}$ evidenciada pelas idades $\left(\mathrm{T}_{\mathrm{DM}}\right)$ dos protólitos dos granitóides dos maciços Antônio Vicente, Rio Xingu e Mocambo , das vulcânicas do Grupo Uatumã, do granodiorito Rio Maria e da metavulcânica máfica do Grupo Tucumã, bem como pelos granulitos do Complexo Pium;

2) segue-se um período de multiplos episódios de deformação, metamorfismo com migmatização associada registrado no Complexo Xingu e encerrado em $2.85 \mathrm{Ga}$;

3) segue-se a este um episódio de vulcanismo máfico e félsico, com intrusão de magma ultramáfico e deposição de formações ferríferas, com idades entre 2.8 e $2.7 \mathrm{Ga}$ representado pelo Grupo Grão, intrusão de Luanga, Grupo São Felix e, possivelmente, pelos Grupos Aquiri e São Sebastião;

4) no Arqueano Superior, há $2.56 \mathrm{Ga}$, a crosta rígida é falhada e sujeita à intensa percolação de fluidos em zonas de cisalhamento localizadas, a exemplo do que mostra-se registrado na Seqüência Salobo;

5) e finalmente um terceiro e último período, de idade entre 1,88 e 1,87, representado pelos granitos anarogênicos e vulcânicas do Grupo Uatumã.

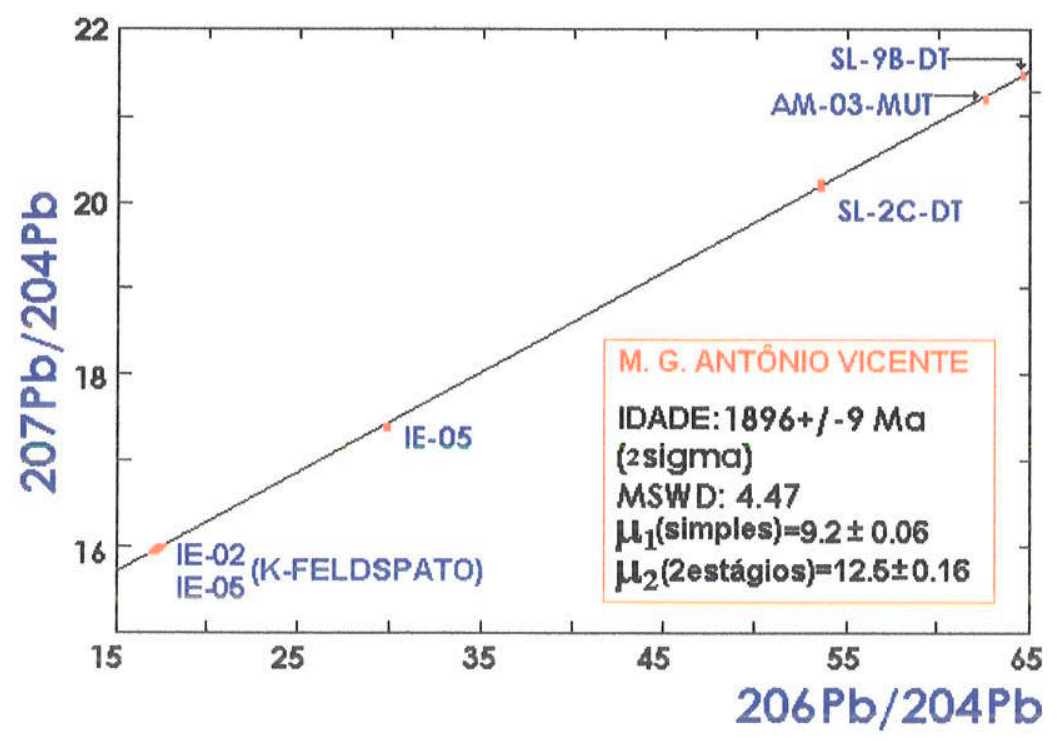

Figura 11.1- Diagrama isocrônico $206 \mathrm{~Pb} / 204 \mathrm{~Pb}$ vs. $207 \mathrm{~Pb} / 204 \mathrm{~Pb}$ mostrando a distribuição dos pontos experimentais e a idade de cristalização dos granitóide do maciço Antônio Vicente. 


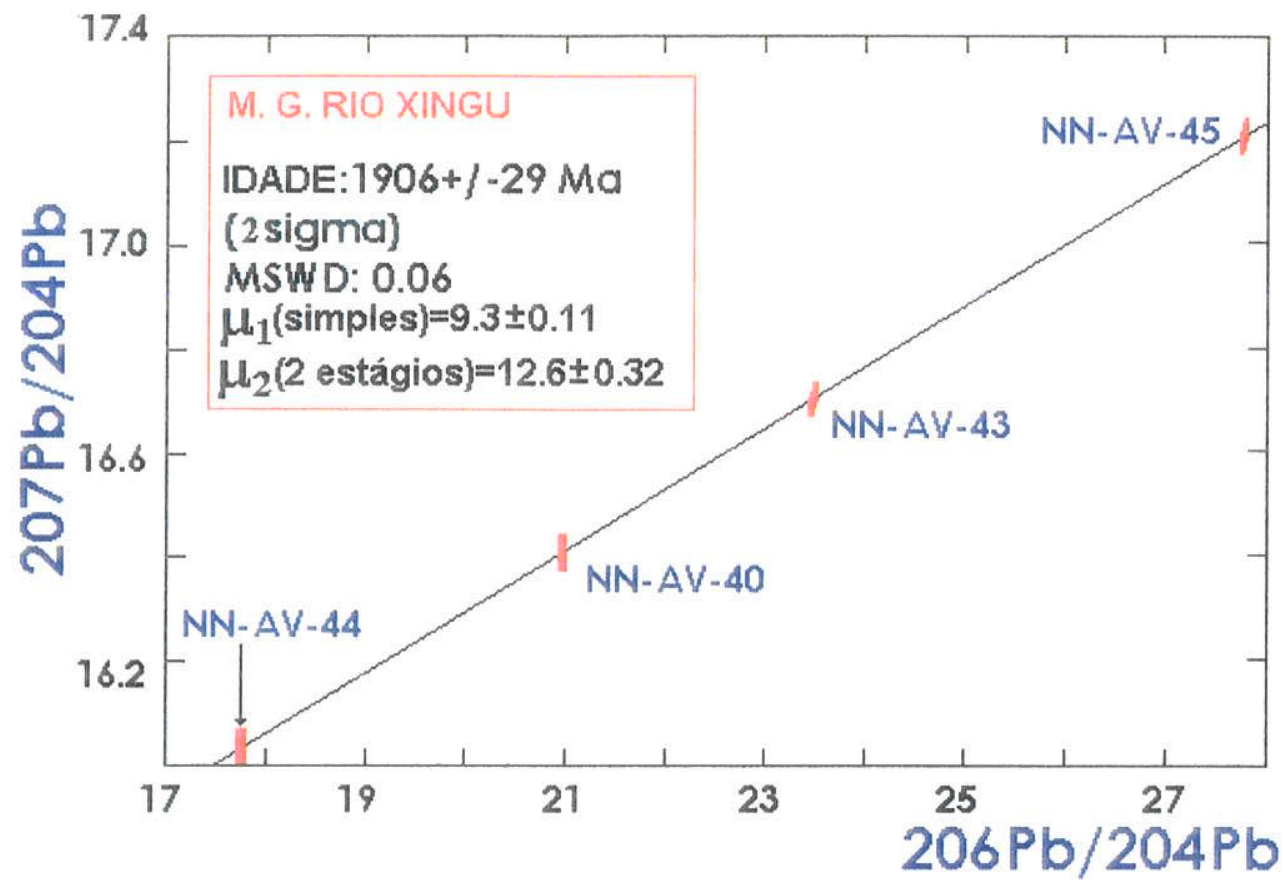

Figura 11.2- Diagrama isocrônico 206Pb/204Pb vs. $207 \mathrm{~Pb} / 204 \mathrm{~Pb}$ mostrando a distribuição dos pontos experimentais e a idade de cristalização dos granitóides do maciço Rio Xingu.

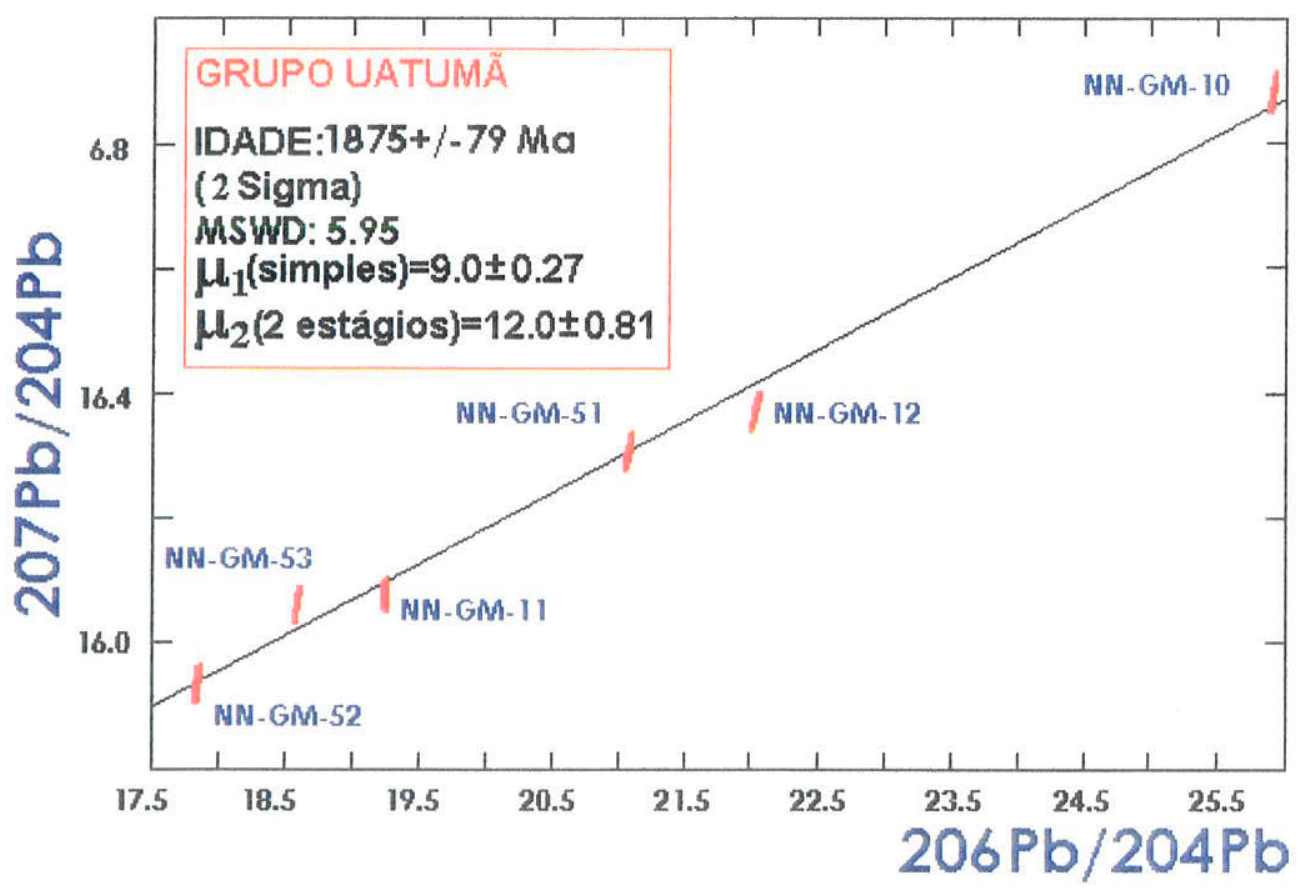

Figura 11.3- Diagrama isocrônico $206 \mathrm{~Pb} / 204 \mathrm{~Pb}$ vs. $207 \mathrm{~Pb} / 204 \mathrm{~Pb}$ mostrando a distribuição dos pontos experimentais e a idade de cristalização das rochas vulcânicas do Grupo Uatumã. 

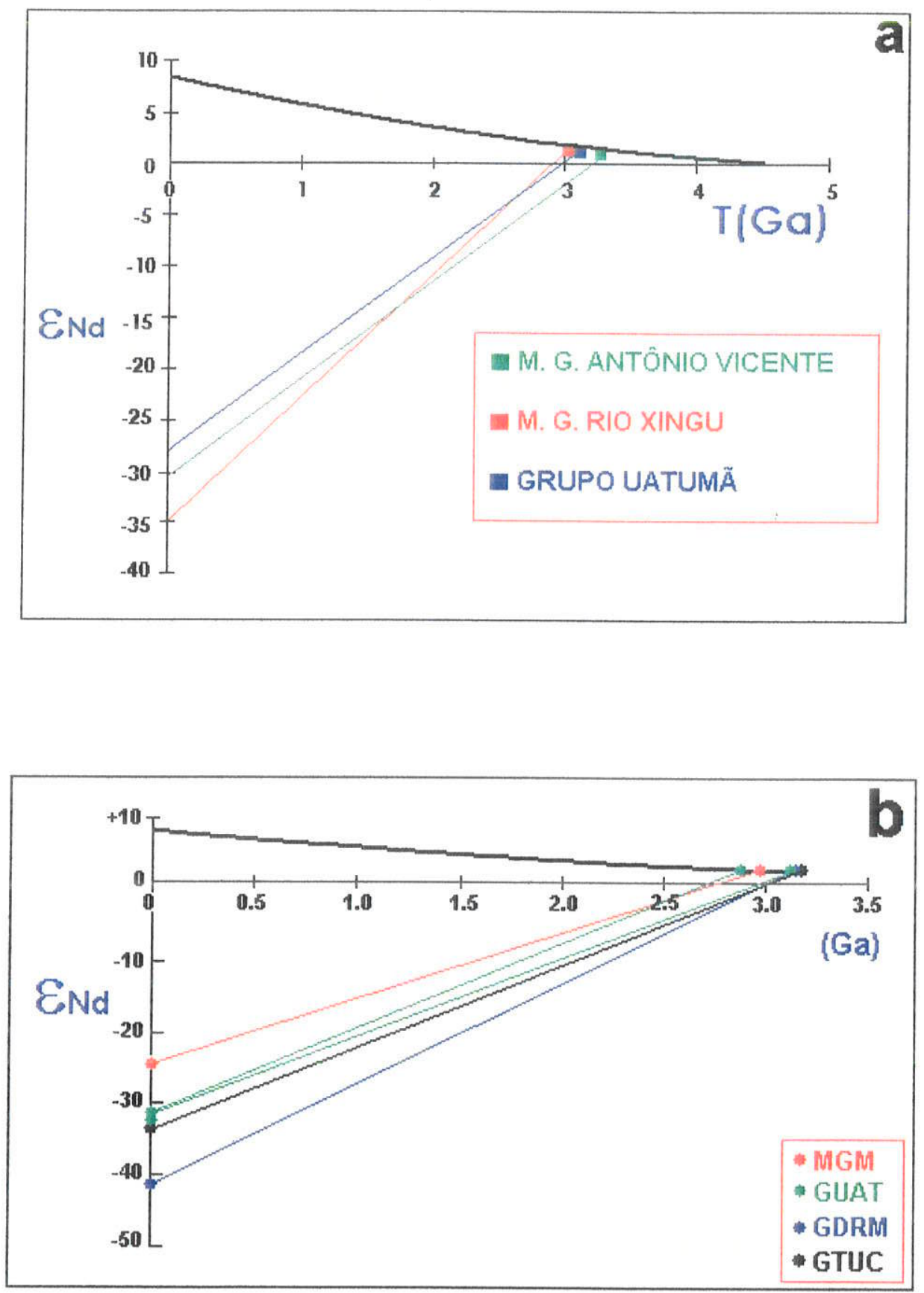

Figura 11.4- Diagrama de variação do \&Nd em função do tempo geológico, mostrando os intervalos de tempo de diferenciação manto-crosta dos protólitos crustais dos granitóides dos maciços Antônio Vicente e Rio Xingu e da vulcânica andesíticas do Grupo Uatumã(a). (b) dos granitóides do maciço Mocambo, das vulcânicas riolíticas do Grupo Uatumã, do granodiorito Rio Maria e da metavulcânica máfica do grupo Tucumã. 
Tabela 11.1- Idades radiométricas $\mathrm{Pb}-\mathrm{Pb}$ (em rocha total), $\mathrm{Pb}-\mathrm{Pb}$ (em zircões por evaporação de $\mathrm{Pb}$ ) e U-Pb(em ziçōes) e características isotópicas $\mathrm{Sm}-\mathrm{Nd}$ de rochas granitbides da Suite Intrusiva Velho Guilherme, Grupo Uatumã, Grupo São Félix, Granodiorita Rio Maria e Grupo Tucumã, ocorrentes na Folha São Féelix do Xingu SB-22-Y-B. SIVG=Suite Intrusiva Velho Guilherme; GUTM=Grupo Uatumã; GSF=Grupo São Félix; GDRM=Granodiorito Rio Maria; GTUC=Grupo Tucumã; MGAV=maciço granitóide Antônio Vicente; MGVG=maciço granitóide Velho Guilherme; MGM=maciço granitóide Mocambo; MGRX=maciço granitóide Rio Xingu; FS=Formação Sobreiro; FI=Formação Iriri; FIC=Formação Igarapé do Cuca; BASMG=biotita-anfibólio sieno a

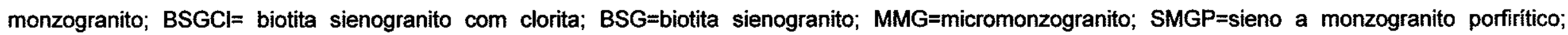

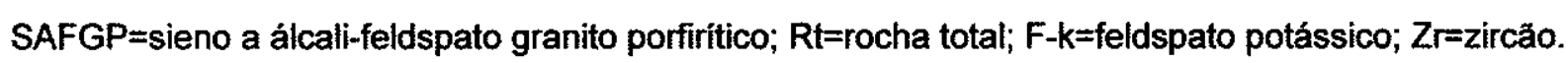

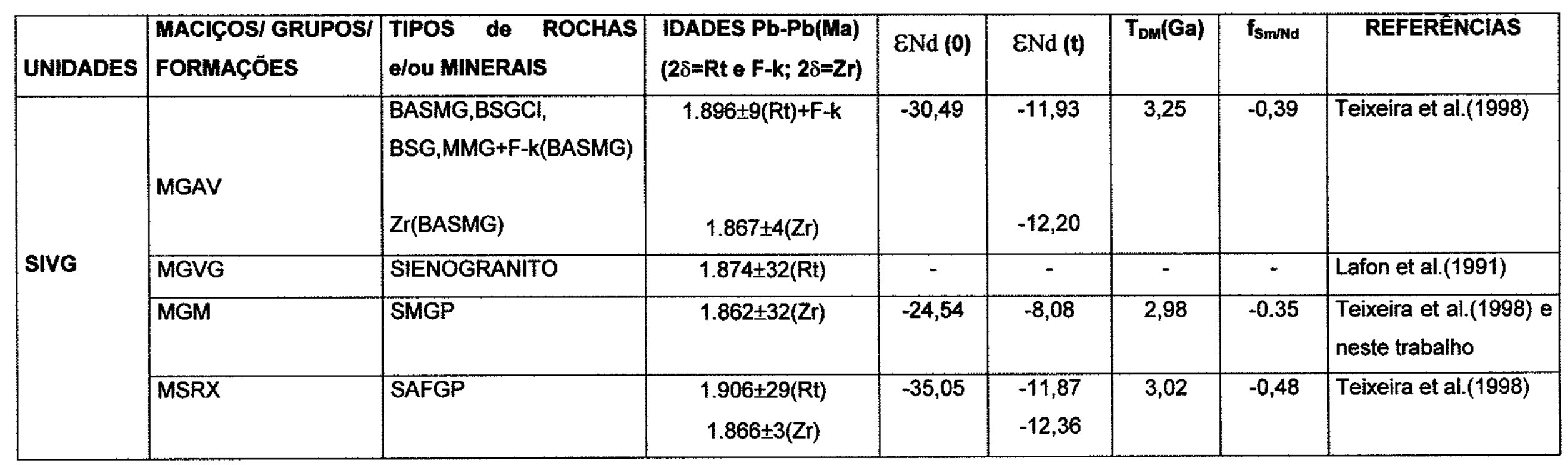




\begin{tabular}{|c|c|c|c|c|c|c|c|c|}
\hline GUTM & $\begin{array}{l}\mathrm{FS}+\mathrm{FI} \\
\mathrm{FI}\end{array}$ & $\begin{array}{l}\text { Andesito+Riolito } \\
\text { Andesito } \\
\text { Riolito }\end{array}$ & $(.875 \pm 79) \mathrm{Rt})^{*}$ & $\begin{array}{l}-28,05^{\star} \\
-31,27^{\star \star} \\
-31,66^{\star \star}\end{array}$ & $\begin{array}{l}-10,16^{\star} \\
-11,61^{* \star} \\
-9,78^{* *}\end{array}$ & $\begin{array}{l}3,10^{\star} \\
3,13^{\star \star} \\
2,88^{\star \star}\end{array}$ & $\begin{array}{l}-0,38 \\
-0,42 \\
-0,47\end{array}$ & $\begin{array}{l}\text { "Teixeira et al.(1998) } \\
{ }^{* *} \text { Neste trabalho }\end{array}$ \\
\hline GSF & & metavulcânicas máficas & $\begin{array}{l}2.727 \pm 4(\mathrm{Zr}) \quad \text { idade } \\
\text { mínima } \\
2.820 \pm 14(\mathrm{Zr}) \quad \text { idade } \\
\text { média aparente }\end{array}$ & - & - & - & - & Neste trabalho \\
\hline GDRM & GDRM & granodiorito & $\begin{array}{l}2.876+13 /+11^{*} \\
\text { (U-Pb em zircōes })\end{array}$ & $-41,55^{\star \star}$ & $-2,15^{\star \star}$ & $3,15^{\star \star}$ & $-0,55$ & $\begin{array}{l}\text { *Macambira } \\
\text { Lancelot(1991a) } \\
{ }^{\star} \text { Neste trabalho }\end{array}$ \\
\hline GTUC & FIC & Metavulcânicas máficas & $\begin{array}{l}2.979 \pm 5^{\star} \\
\text { (U-Pb em zircōes) }\end{array}$ & $-33,20^{\star \star}$ & $-0,60^{\star \star}$ & $3,17^{\star \star}$ & $-0,44$ & $\begin{array}{l}\text { "Machado(1994) } \\
{ }^{*} \text { Neste trabalho }\end{array}$ \\
\hline
\end{tabular}




\section{CAPÍTULO 12}

\section{2-QUADRO COMPARATIVO ENTRE OS GRANITÓIDES DOS MACIÇOS DA SUITE}

O Quadro 12.1 mostra as principais características dos granitóides dos maciços da Suite Intrusiva Velho Guilherme, pertencente à Província Estanífera do Sul do Pará(PESP), ora estudados.

Observa-se que existe uma grande similaridade entre os granitóides dos maciços ora estudados, especialmente em relação aos maciços Antônio Vicente, Velho Guilherme, Benedita e Ubim. Os granitóides dos maciços Mocambo e Rio Xingu, embora guardem muitas semelhanças com os mesmos, mostram algumas diferenças marcantes. a saber:

1) Maciço granitóide Mocambo: as diferenças mais evidentes correspondem aos seus valores de $\delta^{18} \mathrm{O}\left(\mathrm{em}\right.$ quartzo 1), $\varepsilon \mathrm{Nd}(\mathrm{t})$ e $\mathrm{T}_{\mathrm{DM}}$, quando comparados com aqueles obtidos em granitóides dos maciços António Vicente $\left(\delta^{180}, \varepsilon N d(t)\right.$ e $\left.T_{D M}\right)$, Velho Guilherme $\left(\left(\delta^{18} \mathrm{O}\right)\right.$ e Rio $X i n g u[\varepsilon N d(t)]$. Esses dados indicam que: a) os granitóides do maciço Mocambo evoluíram a partir de um protólito de idade $\left(T_{D M}\right)$ mais jovem do que aquele dos granitóides do maciço Antônio Vicente; b) o protólito dos granitóides do maciço Mocambo tinha características isotópicas $\left[\left(\delta^{18} \mathrm{O}\right.\right.$ e $\left.\varepsilon \mathrm{Nd}(\mathrm{t})\right]$ distintas daquela(s) gerador(as) dos granitóides dos maciços Antônio Vicente, Velho Guilherme e Rio Xingu.

2) Maciço granitóide Rio Xingu:

a) apresenta razão $\mathrm{Rb} / \mathrm{Sr}$ muito mais baixa(entre 2,10 e 2,29) do que os granitóides dos outros maciços. Isso pode indicar que o $\mathrm{Rb}$ e $0 \mathrm{Sr}$ se comportaram como elementos compativeis durante a diferenciação/fracionamento desse granitóide, ou ainda, que os baixos teores de $\mathrm{Rb}$ devem-se ao fato deste granitóide ter sido derivado de uma fonte empobrecida neste elemento, já que representa um diferenciado muito evoluido.

b) possui razão $\mathrm{Rb} / \mathrm{Ba}$ muito baixa, embora a mesma aproxime-se um pouco daquela da facies BASMG do maciço Antônio Vicente. Esses valores extremamente reduzidos para granitóides muito diferenciados(Taylor, 1964) são devido aos seus conteúdos anomalamente altos de $\mathrm{Ba}$ em contraste com aos baixos teores de $\mathrm{Rb}$ (Tabela 8.3, Anexo 52). De acordo com Taylor(1965) e Ollila(1984) o $\mathrm{Ba}^{2+}$ é capturado pelos minerais de $\mathrm{K}$ formados precocemente. Conforme Nockolds \& Mitchell(1948. In: Taylor, 1965, pg 156) ele tem preferência pelo feldspato potássico em relação à biotita em uma razão de cerca de 2:1 
e se concentra preferencialmente no feldspato potássico em detrimento do plagiociásio(Smith, 1974).

Neste granitóide, os conteúdos elevados de $\mathrm{Ba}$ podem ser explicados por esse modelo ou seja as quantidades elevadas de Ba podem estar diretamente vinculadas ao conteúdo de feldspato potássico, visto que a biotita está ausente nessa rocha e o plagioclásio é pouco abundante e tem composição albítica. Entretanto, dados de química mineral obtidos através de microssonda eletrônica(Anexos 50) mostram que tanto o feldspato potássico, quanto o plagioclásio são pobres em Ba. Por outro lado os estudos petrográficos revelaram que esse granitóide hospeda carbonato( $3 \%$ a $4 \%$ modal), epidoto e fluorita(Tabela 8.1), os quais foram interpretados como fases tardias, uma vez que: a) ora estão intimamente associados à descalcificação do plagioclásio; b) ora ocorrem preenchendo cavidades em companhia de muscovita, minerais opacos e clorita(ver ítem aspectos petrográficos do capítulo 8). Assim, pode-se pensar, alternativamente, que o $\mathrm{Ba}$, inicialmente concentrado no feldspato potássico, no plagioclásio e na provável biotita primária(atualmente alterada para clorita), foi extraido e remobilizado durante os processos de alterações tardi a pós-magmáticas, acompanhando o cálcio(do plagioclásio), e se concentrou nesses fases minerais tardias, principalmente, no carbonato, juntamente com algumas terras raras leves(Ce e La) e outros elementos associados, como por exemplo o $F(C e s b r o n, 1989$ ), que também mostram-se enriquecidos nesse granitóide. Uma outra hipótese para explicar os elevados conteúdos de Ba nessa rocha seria atribuir a uma possivel mistura do magma gerador deste granitóide com material máfico ou mesmo à assimilação de rocha máfica. De qualquer modo, essas hipóteses representam, no momento, uma conjectura que necessita ser comprovada no futuro. 


\begin{tabular}{|c|c|c|c|c|c|c|c|}
\hline $\begin{array}{l}\text { MACICCOS } \\
\text { GRANITOIDES }\end{array}$ & & ANTÓNIO VICENTE & VELHO GUILHERME & MOCAMBO & BENEDITA & UBIMISU: & RIO XINGU \\
\hline \multirow{7}{*}{$\begin{array}{l}\text { CRITERIOS DE } \\
\text { CAMPO }\end{array}$} & $\begin{array}{l}\text { TIPODE } \\
\text { TERRENO }\end{array}$ & \begin{tabular}{|l|} 
Embasamento arqueano retrabalhado \\
|Cinturăo de cisalhamento Itacaiúnas e \\
Bacia vulcano-sedimentar do Medio \\
Xingu)
\end{tabular} & Terreno granito-greenstone & $\begin{array}{l}\text { Embasamento arqueano retraballhado } \\
\text { (Cinturamo de cisalthamento } \\
\text { Bacia vacaiunas e } \\
\text { Xingu) }\end{array}$ & 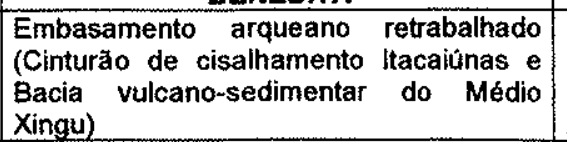 & $\begin{array}{l}\text { Embasamento arqueano retrabalhado } \\
\text { (Cinturăo de cisalhamento Itacaiaunas e } \\
\text { Bacia vulcano-sedimentar do Médio } \\
\text { Xingu) }\end{array}$ & $\begin{array}{l}\text { Bacia vulcano-sedimentar do Médio } \\
\text { Xingu }\end{array}$ \\
\hline & $\begin{array}{l}\text { TIPODE } \\
\text { PLUTON }\end{array}$ & $\begin{array}{l}\text { Complexo distinguido pela textura e } \\
\text { composiçao }\end{array}$ & $\begin{array}{l}\text { Complexo distinguido pela textura e } \\
\text { composiçăo }\end{array}$ & $\begin{array}{l}\text { Complexo distinguido pela textura e } \\
\text { composiçăo }\end{array}$ & $\begin{array}{l}\text { Complexo distinguido pela textura e } \\
\text { composicăo }\end{array}$ & $\begin{array}{l}\text { Complexo distinguido pela textura e } \\
\text { composição }\end{array}$ & Simples \\
\hline & $\begin{array}{l}\text { TAMANHO DA } \\
\text { INTRUSÃO }\end{array}$ & Batoflito & Batblito & stock & & & stock \\
\hline & COMPOSIÇÃO & $\begin{array}{l}\text { Sienogranito a monzogranito, monzogra- } \\
\text { nito e álcali-feldspato granito subordinado }\end{array}$ & Sienogranito & $\begin{array}{l}\text { Sienogranito a monzogranito, sienogra- } \\
\text { nito e alcaliffeldspato granito }\end{array}$ & Alcali-feldspato granito & Sienogranito e monzogranito & Sienogranito a álcali-feldspato granito \\
\hline & $\begin{array}{l}\text { RELACAODDE } \\
\text { CONTATO }\end{array}$ & \begin{tabular}{|l|l|} 
Discordante \\
\end{tabular} & Discordante & Discordante & Discordante & Discordante & Discordante \\
\hline & $\begin{array}{l}\text { NATUREZA } \\
\text { TECTONICA }\end{array}$ & \begin{tabular}{|l|} 
Anorogènica \\
\end{tabular} & Anorogênica & Anorogênicia & Anorogênica & Anorogênica & Anorogênica \\
\hline & $\begin{array}{l}\text { DIQUES } \\
\text { INTERNOS }\end{array}$ & Năo observado & Năo observado & Aplito & Diabásio & Não observado & Năo observado \\
\hline \multirow[b]{2}{*}{$\begin{array}{l}\text { CRITÉRIOS } \\
\text { PETROGRAFICOS }\end{array}$} & $\frac{\text { ESTRUTURA }}{\text { TEXTURA }}$ & \begin{tabular}{|l|} 
sotrópica \\
Hipidiomórica heterogranutar, com ter- \\
mos equigranulares porfirfticos e granoff- \\
ricos
\end{tabular} & $\begin{array}{l}\text { sotropica } \\
\text { Hipidiomórfica equigranular e heterogra- } \\
\text { nular, com termos granofiricos subordina- } \\
\text { dos }\end{array}$ & $\begin{array}{l}\text { Isotropica } \\
\text { Hipidiomórfica heterogranular e porfirfi- } \\
\text { ca, com termos granofiricos subordina- } \\
\text { dos }\end{array}$ & \begin{tabular}{|l|} 
sotrópica \\
$\begin{array}{l}\text { Hipídiomórfica heterogranular e equigra- } \\
\text { nular, com termos granoffricos subordina- } \\
\text { dos }\end{array}$
\end{tabular} & \begin{tabular}{|l|} 
Isotropica \\
Hipidiomórfica heterogranular e equigra- \\
nular, com termos granoíiricos subordina- \\
dos
\end{tabular} & \begin{tabular}{|l|} 
Isotrópica \\
$\begin{array}{l}\text { Hipidiomórfica porfirtica, granofirica e } \\
\text { gráfica }\end{array}$
\end{tabular} \\
\hline & MINERALOGIA & 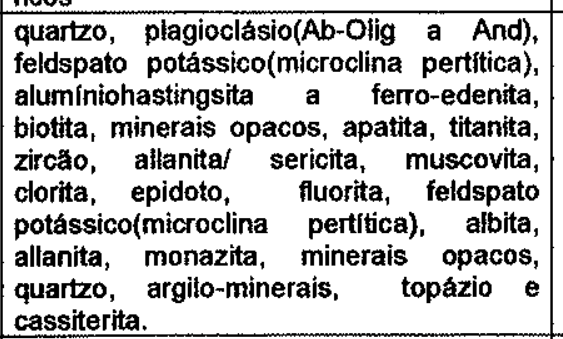 & 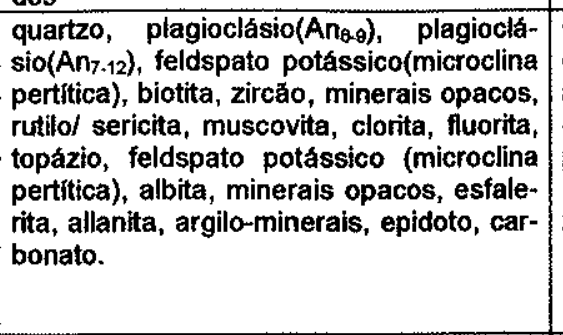 & 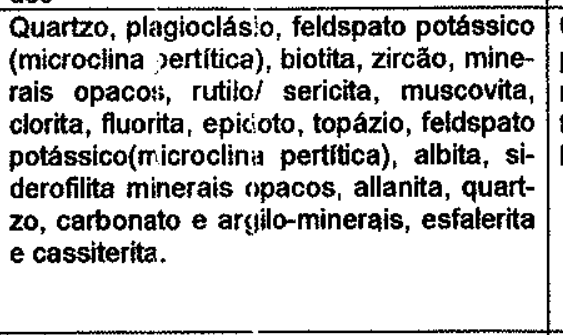 & $\begin{array}{l}\text { Quartzo, feldspato potássico (microclina } \\
\text { pertitica), plagiociásio(traços), zircăo, mi- } \\
\text { nerais opacos/ sericita } \pm \text { muscovita, albi- } \\
\text { ta, fluorita, clorita, minerais opacos, esfa- } \\
\text { lerita, allanita e argilo-minerais. }\end{array}$ & 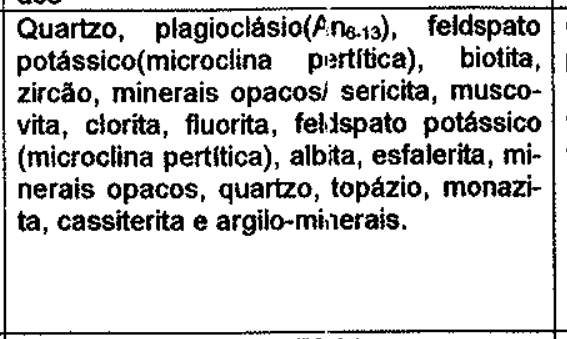 & 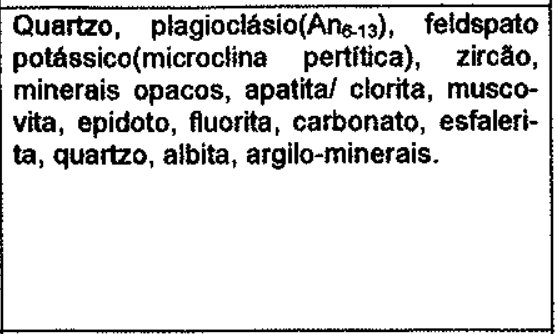 \\
\hline \multirow{9}{*}{ GEOQUIMICA } & $\frac{\mathrm{SiO}_{2}(\% \text { MEDIA })}{\mathrm{ISA}}$ & $\begin{array}{c}68,38-77,12 \\
\text { Peraluminoso a metaluminoso }\end{array}$ & \begin{tabular}{|l|}
\multicolumn{1}{|c}{$75,90-77,41$} \\
Peraluminoso
\end{tabular} & $\begin{array}{r}75,9 !-76,76 \\
\text { Peraluminoso }\end{array}$ & 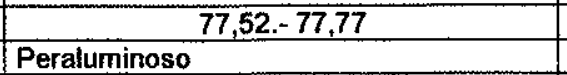 & 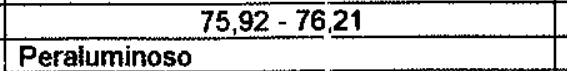 & 74,77 \\
\hline & ALCALINIDADE & $\begin{array}{l}\text { Subalcalino } \\
\end{array}$ & Subalcalino & Subalcalino & \begin{tabular}{|l} 
Subalcalino \\
\end{tabular} & Subalcalino & Subalcalino \\
\hline & $\mathrm{Rb} / \mathrm{Sr}$ & $\frac{1,68-47,53}{0,21-18,68}$ & $\frac{6,16-60,09}{1,38-1,43}$ & $\frac{39,7 /-46,83}{269-28,56}$ & $\frac{23,0-46,0}{8.0-73,0}$ & $\frac{11,67-49,93}{18,85-26,46}$ & $\frac{2,10-2,29}{0,16}$ \\
\hline & $\begin{array}{ll}\text { Kol/Ra } \\
\text { K/Rb }\end{array}$ & $72,75-143,69$ & $\frac{1,00-31,45}{75,23-128,71}$ & $33,63-60,83$ & $\frac{0,0<0,0}{72,0<95,0}$ & $56,29-59,47$ & $200,95-209,26$ \\
\hline & $\frac{R b / 2 r}{T T / U}$ & $\begin{array}{l}0,75-4,56 \\
144.471\end{array}$ & $\frac{2,27-3,93}{2,24-4.07}$ & $\frac{4,80 \cdot-7,11}{2,8 \cdot-4,29}$ & $0,99-1,82$ & $\frac{5,56-10,37}{1,41-2: 6}$ & $\frac{0,63}{11,123}$ \\
\hline & $\frac{\ln (\mathrm{L} / \mathrm{Nb})_{N}}{4}$ & $\frac{1,14-4,71}{1,26-16,71}$ & $\frac{2,4-4,01}{0,27-1,03}$ & $\frac{2,8,-4,29}{1,9 ! 3-2,86}$ & $\frac{4,0}{2,06-2,20}$ & $\begin{array}{l}\frac{1,41-2,6}{1,39-1,6} \\
\end{array}$ & $\frac{11,13-11,23}{17,75}$ \\
\hline & $\left(E U_{N} E_{E *}^{*}\right)$ & & & $\cong 13$ & & $\cong 13$ & $\cong 13$ \\
\hline & $\begin{array}{l}\Sigma E T R L \\
E T P D\end{array}$ & $170,55-777,55 \mathrm{ppm}$ & $61,70-109,0 \mathrm{ppm}$ & $64,76-259,76 \mathrm{ppm}$ & $119,15-140,72 \mathrm{ppm}$ & $178,66-246,39 \mathrm{ppm}$ & 613,86 \\
\hline & $\begin{array}{l}\sum E T R P \\
\Sigma E T R\end{array}$ & $\frac{30,42-74,80 \mathrm{ppm}}{245,37-870,03 \mathrm{ppm}}$ & $\frac{54,34-88,25 \mathrm{ppm}}{150,03-172,21 \mathrm{pmm}}$ & $49,34-83,01 \mathrm{ppm}$ & $36,33-45,82 \mathrm{ppm}$ & $62,62-92,84 \mathrm{ppm}$ & $\begin{array}{ll}47,62 \mathrm{ppm} \\
662000 m\end{array}$ \\
\hline \multirow{8}{*}{ ISÓTOPOS } & $\mathrm{Rb} / \mathrm{Sr}$ & $245,3 f-80,030 \mathrm{ppm}$ & $\begin{array}{l}150,03-172,21 \mathrm{ppm} \\
1653 \pm 28 \mathrm{Ma} \\
\operatorname{Ri}=0,708 \pm 0,048 \\
M S W D=1,71\end{array}$ & $214,16-342,91 \mathrm{ppm}$ & $\frac{155,50-186,56 \mathrm{ppm}}{-}$ & $\frac{241,35-339,54 \mathrm{ppm}}{-}$ & $\frac{662,99 \mathrm{ppm}}{-}$ \\
\hline & $\begin{array}{c}\begin{array}{c}\text { Pb-Pb(Zircão por } \\
\text { evaporaçáa de } \\
\text { Pb) }\end{array} \\
\end{array}$ & $1867 \pm 4 \mathrm{Ma}$ & - & $1862 \pm 32 \mathrm{Ma}$ & - & - & $1866 \pm 3 \mathrm{Ma}$ \\
\hline & $\begin{array}{c}\text { Pb-Pb(Rocha } \\
\text { total e feldspato } \\
\text { potássico) }\end{array}$ & $\begin{array}{c}1896 \pm 9 \mathrm{Ma} \\
\mu_{1}=9,9 \pm 0,60\end{array}$ & - & - & - & & \\
\hline & $\begin{array}{c}\mathrm{Pb}-\mathrm{Pb}(\mathrm{Roch} a \\
\text { total) }\end{array}$ & & $\begin{array}{c}1874 \pm 30 \mathrm{Ma} \\
\mu_{1}=8,9 \pm 0,14\end{array}$ & - & - & - & $\begin{array}{c}1906 \pm 29 \mathrm{Ma} \\
\mu_{1}=9,3 \pm 0,11 \\
\end{array}$ \\
\hline & $\varepsilon N d(0)$ & $-30,49$ & - & $-24,54$ & . & - & $-35,05$ \\
\hline & $\varepsilon N d(t)$ & $\begin{array}{l}-11,93 \\
-12,20\end{array}$ & - & $-8,08$ & - & - & $\begin{array}{l}-11,87 \\
-12,36\end{array}$ \\
\hline & $T_{\text {OM }}$ & $3,2 \mathrm{Ga}$ & & $2,98 \mathrm{Ga}$ & $=$ & - & $3,02 \mathrm{Ga}$ \\
\hline & $\delta^{18} \mathrm{O}_{\text {(quatrof }}$ & $+8,0 \mathrm{a}+8,5 \%$ & $+8,2 \%$ & $-8,8$ a $9,0 \%$ & - & & - \\
\hline \multicolumn{2}{|c|}{ TIPOLOGIA } & Tipo-A/Subgrupo $A_{2}$ & Tipo-ANSubgrupo $A_{2}$ & Tipo-A/subgrupo $A_{2}$ & Tipo-A/Subgrupo $A_{2} / A_{1}(?)$ & Tipo-A/Subgripo $A_{2}$ & Tipo-A Subgrupo $A_{2}$ \\
\hline \multicolumn{2}{|c|}{ PALEOAMBIĖNCIA TECTÓNICA } & Intra-placas & Intra-placas & Intra-placas & Intra-placas & Intra-placias & Intra-placas \\
\hline \multicolumn{2}{|c|}{ FONTE MAGMÁTICA } & $\begin{array}{l}\text { Provável mistura de uma componente de } \\
\text { material derivado do manto com } \\
\text { componente de material crustal em } 3,2 \\
\text { Ga }\end{array}$ & $\begin{array}{l}\text { Provável mistura de uma componente de } \\
\text { material derivado do manto comm } \\
\text { componente de material crustal em } 3,2 \\
\text { Ga (?) }\end{array}$ & $\begin{array}{l}\text { Provável mistura de uma componente de } \\
\text { material derivado do manto com } \\
\text { componente de material crustal em } 3,0 \\
\text { Ga }\end{array}$ & $\begin{array}{l}\text { Provável mistura de uma componente de } \\
\text { material derivado do manto com } \\
\text { componente de material crustal em } 3,2 \\
\text { Ga (?) }\end{array}$ & $\begin{array}{l}\text { Provável mistura de uma componente de } \\
\text { material derivado do manto com } \\
\text { componente de material crustal em } 3,2 \\
\text { Ga (?) }\end{array}$ & $\begin{array}{l}\text { Provável mistura de uma componente de } \\
\text { material derivado do manto com } \\
\text { componente de material crustal em } 3,0 \\
\text { Ga }\end{array}$ \\
\hline \multicolumn{2}{|c|}{ MINERALZZAÇŌES ASSOCIADAS } & 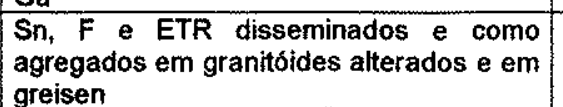 & sali] & $\begin{array}{l}\text { Sn e } F \text { disseminados em granitoide alte- } \\
\text { rado e em greisen }\end{array}$ & - & $\begin{array}{l}\text { Sn e f disseminados em granitoide alte- } \\
\text { rado }\end{array}$ & $\cdot$ \\
\hline
\end{tabular}




\section{CAPITULO 13}

\section{3- DISCUSSÃO E CONCLUSÕES FINAIS}

A cristalização fracionada é, ao que tudo indica, o principal processo petrogenético que controlou a evolução dos granitóides da Suite Intrusiva Velho Guilherme. Os diferenciados mais evoluidos e hospedeiros de mineralizações de Sn mostram um grau extremo de diferenciação $\left(\mathrm{SiO}_{2}>75 \%\right)$ e são produtos de fracionamento magmático e da interação com fluidos tardi a pós-magmáticos(diagramas $\mathrm{Sn}-\mathrm{TiO}_{2}$ e $\mathrm{Sn}-\mathrm{Rb} / \mathrm{Sr}$ de Lehman \& Mahawat, 1989), Figura 13.1(a, b). Isso é indicado pela ausência de mineralizações de Sn nos diferenciados menos evoluidos e pouco afetados por alterações tardi a pós-magmáticas decorrentes da interação rocha fluidos tardios ricos em voláteis $(\mathrm{F}, \mathrm{Cl})$. Assim, esses fluidos foram responsáveis pela extração de $\mathrm{Sn}^{+2}$, a partir das fases minerais primárias, especialmente, da biotita, incorporando-o às soluções residuais onde, ao que tudo indica, oxidou-se, passando para a forma $\mathrm{Sn}^{+4}$ e depositando-se como cassiterita(t kersterita/estanita), sendo difícil precisar o momento exato da deposição dessas fases minerais.

Os resultados de química mineral (biotita e clorita), ora obtidos, demonstraram que os granitóides dessa suite evoluíram sob condições magmáticas de baixa $\mathrm{fO}_{2}\left(10^{-18}\right.$ a $\left.10^{-16}\right)$, as quais estenderam-se para o estágio de alterações tardi a pós-magmáticas. É exceção a isso a facies BASMG, do maciço Antônio Vicente, que iniciou sua cristalização em condições de fugacidade de oxigênio intermediárias, as quais gradaram para baixas $\mathrm{fO}_{2}$ na facies BASAFG, conforme atestam os dados químicos obtidos a partir de anfibólio.

Estudos petrográficos, por outro lado, revelaram que a deposição da cassiterita ocorreu muito próximo ao tempo de desestabilização e transformação do topázio(devido muscovitização). Além disso, observou-se que sempre que a cassiterita está presente, as fases micáceas tardias(clorita, muscovita, siderofilita) encontram-se, via de regra, oxidadas. A análises coletiva dos dados petrográficos e de química mineral sugere que as condições de baixa $\mathrm{fO}_{2}$, sob as quais os granitóides evoluíram, deixaram de existir, ao tempo da transformação total do topázio, passando a imperar no sistema condições oxidantes na fase fluidal(estágio de alterações tardi a pós-magmáticas), as quais favoreceram a deposição de cassiterita.

A interpretação conjunta dos dados apresentados indica uma fonte crustal para os magmas geradores dos granitóides estudados, bem como demonstra que os protólitos dos mesmos evoluíram em estágio único, o que é reforçado pelos valores de $\mathrm{fSm} / \mathrm{Nd}$ (Tabela 11.1). 
Adicionalmente, os dados apresentados demonstram que os protólitos dos granitóides dessa suite foram diferenciados diretamente do manto entre $3,2 \mathrm{Ga}$ e $3,0 \mathrm{Ga}$, conforme é indicado pelas suas idades modelo( $T_{D M}$ ) a saber: 1) 3,2 Ga-maciço granitóide Antônio Vicente; 2) 3,0 Ga- maciço granitóide Rio Xingu; 3) 3.0 Ga-maciço granitóide Mocambo. Os valores fortemente negativos de $\varepsilon \mathrm{Nd}(\mathrm{t}=$ idade de cristalização dos granitóides estudados), respectivamente, $-11,939$ (rocha total)/-12,20(zircão); $-8,08$ (zircão) ;-11,87(rocha total)/-12,36(zircão), podem ser interpretados mais consistentemente como envolvendo uma crosta predominantemente Arqueana, ou mesmo uma provável mistura de uma componente de material derivado do manto com componentes de material crustal Arqueano em 3,2 $\mathrm{Ga}$ (maciço granitóide Antônio Vicente) e 3,0 Ga(maciços granitóides Rio Xingu e Mocambo).

Deve-se ressaltar, entretanto, que devido os valores de $\varepsilon N d(t=1862 \pm 32 \mathrm{Ma})$ igual a $-8,08$, idade modelo( $\left.T_{D M}\right)$ de $3,0 \mathrm{Ga}$ e $\delta^{18} \mathrm{O}=+8,8$ a $+9,0 \%$ correspondentes aos granitóides do maciço Mocambo, serem diferentes daqueles relativos aos maciços Antônio Vicente, Velho Guilherme e Rio Xingu, pode-se conjeturar que: a) os granitóides do maciço Mocambo evoluíram a partir de um protólito de idade $\left(T_{D M}\right)$ mais jovem do que aquele dos granitóides do maciço Antônio Vicente; b) o protólito dos granitóides do maciço Mocambo tinha características isotópicas $\left[\left(\delta^{18} \mathrm{O}\right.\right.$ e $\left.\quad \varepsilon N d(t)\right]$ distintas daquela(s) gerador(as) dos granitóides dos maciços Antônio Vicente, Velho Guilherme e Rio Xingu.

Além disso, as elevadas concentrações de elementos litófilos de raio iônico grande(LILE) tais como $\mathrm{Rb}, \mathrm{K}$ e Th, de ETRL e elementos de alto campo de força(HFSE), $\mathrm{Zr}, \mathrm{Nb}$ e $\mathrm{Y}$, observada nos granitóides estudados ratificam a interpretação de que, pelo menos uma parte, das rochas fonte dos mesmos era francamente crustal. A Figura 13.2 ilustra essa condição e indica que os granitóides estudados foram formados a partir de diferentes fontes crustais, com contribuição do manto.

A relação $\mathrm{Th} / \mathrm{Ta}$ (Figura 13.2) referente aos granitóides dos maciços Velho Guilherme, Benedita e Rio Xingu sugere uma fonte dominantemente de crosta continental superior. Adicionalmente, a razão inicial ${ }^{87} \mathrm{Sr} /{ }^{86} \mathrm{Sr}=0,708$ obtida em granitóides do maciço Velho Gulherme(Lafon et al., 1991) indica um baixo grau de contaminação por crosta mais antiga. Em relação aos granitóides do maciço Ubim, a fonte magmática indicada por esses elementos, corresponde a uma segmento crustal um pouco mais profundo, visto suas composições situam-se totalmente entre o limite composicional da crosta continental superior e o limite estimado da crosta continental como um todo(Hofman, 1988). Já o material fonte dos granitóides do maciço Mocambo, parece corresponder a uma mistura de material de crosta profunda e crosta continental superior. O amplo espalhmento composicional observado em relação aos granitóides dos maciço Antônio Vicente(Figura 13.2) parece representar uma mistura de material do manto com componentes de crosta 
profunda e crosta continental e talvez, até, incorpore uma contribuição de sedimentos. Uma hipótese alternativa seria atribuir essa ampla variação nas razões $\mathrm{Th} / \mathrm{Ta}$ às alterações tardi a pós-magmáticas. Entretanto, nos demais granitóides dos maciços ora estudados, onde as tais alterações também ocorrerem em diferentes graus, essa feição não é observada.

Apesar disso, os granitóides estudados não desenvolveram concentrações econômicas de metais(classe mundial). Mesmo os depósitos de cassiterita, explotados, eram fracos e tornaram-se inviáveis economicamente. Em razão disso, e, principalmente, em relação à assinatura geoquimica da crosta profunda arqueana(baixo $U$, Th, $R b, K / R b$ e HREE e empobrecida em W, Sn, F, Be e Mo nos materiais da fonte), considera-se que os protólitos arqueanos dos granitóides estudados eram empobrecidos nesses elementos. Embora reconheça-se que os granitóides sejam diferenciados extremamente silicosos e evoluidos, os processos de diferenciação magmática, estado de oxidação, a cristalização fracionada e outros fatores, não foram suficientes para gerar concentrações económicas de elementos litófilos, como era de se esperar. Do mesmo modo, na liberação de voláteis, o fracionamento líquido-líquido ou, enfim, a carga fluidal atuante no estágio de alterações tardi a pós-magmáticas não propiciou a formação de depósitos importantes. A Figura 13.3(Lehmann \& Mahawat, 1989) ilustra claramente essa condição, especialmente, em relação aos granitóides dos maciços Antônio Vicente, Velho Guilherme e Ubim sul, uma vez que a distribuição composicional dos mesmos ocupa ao mesmo tempo os campos correspondentes aos granitóides com e sem estanho.

Em razão do que foi comentado acima, acredita-se que granitóides da Suite Intrusiva Velho Guilherme evoluiram a partir da fusão de diferentes segmentos crustais, ora com mistura de material mantélico, de composição particular e empobrecidos em elementos produtores de calor $(\mathrm{U}, \mathrm{Th}, \mathrm{Rb} \in \mathrm{K})$. Talvez a mistura de uma fonte mantélica depletada em elementos litófilos com componentes crustais de crosta inferior e de crosta continental superior, também, empobrecida, tenha sido o fator determinante para gerar granitóides com essas características geoquímicas.

Os resultados obtidos enfatizam a importância da concentração metálica multi-cíclica nos terrenos estudados, processos esses dependentes de orogenias superpostas ou de magmatismo anorogênico. Os granitóides dos maciços Mesoproterozóicos do Craton Amazônico, especialmente aqueles ocorrentes na área da abrangência da Província Amazônia Central(Tassinari, 1996) são, em geral, estéries(Jamon, Redenção, etc) ou fracamente mineralizados(Suite Intrusiva Velho Guilherme, Musa, Carajás, etc). São exceções a isso, os granitos mineralizados da região de Pitinga(Amazonas), que hospedam importantes mineralizações de $\mathrm{Sn}$ e de outros metais raros associados(Horbe et al., 1991). Por outro lado, os granitos jovens de Rondônia(ex: Caritanas, Santa Bárbara, Polangueta, etc.) são fortemente mineralizados a metais raros importantes( Bettencourt et al., 1997). 
Essas concentrações anômalas de metais nos granitos jovens de Rondônia contrastantes com aquelas ausentes ou muito fracas nos grantóides Mesoproterozóicos da Província Amazônia Central, devem-se, pelo menos em parte, a processos de retrabalhamento crustal e fracionamento magmático progressivo na Província Estanifera de Rodônia, os, os quais propiciaram enriquecimento de metais naquele segmento crustal do craton.

A ausência de atividades orogênicas superpostas e de magmtismo sucessivos mais jovens do que 1,8 Ga na porção leste-nordeste do craton Amazônico, foi, talvez, o fator determinante para a ausência de depósitos de classe mundial relacionados a granitóides nesta porção do craton. Presume-se, portanto, que a crosta Arqueana mais antiga era, por natureza, empobrecida em elementos litófilos e mesmo os processos de fracionamente magmático aliados à intensa interação fluido rochas não propiciaram a formação de grandes depósitos desses elementos.

Para melhor entendimento dos processosmineralizantes é de suma importancia a análise dos dados obtidos através da sistemática $\mathrm{U}-\mathrm{Pb}, \mathrm{Sm}-\mathrm{Nd}$ e $\mathrm{Pb}-\mathrm{Pb}$ que nos possibilita saber o momento de separação do material constitutivo da crosta, a partir do manto, e entender a história subsequente que leva à concentração metálica.

"Underplating" de magma básico tem sido sugerido, hipoteticamente, como sendo a fonte para a fusão parcial de rochas granulíticas máficas na base da crosta inferior(Teixeira et al., 1998; Dall'Agnol et al., 1999). Neste trabalho não se descarta as hipóteses do papel dos hot-spots como fonte de calor para a fusão parcial dos protólitos dos granitóides estudados nem tampouco o modelo de plumas mantélicas. O magmatismo anarogênico em pauta pode ainda estar relacionado a atividade magmática distal associada tanto à orogenia Maroni-Itacaiúnas, quanto à orogenia Tapajós-Ventuári.

Em termos regionais, as rochas mais antigas reconhecidas na região sul-sudeste do Pará correspondem a granulitos félsicos e máficos pertencentes ao Complexo Pium(Rodrigues et al., 1991). De acordo com Costa et al.(1995) esse complexo representa frações de crosta inferior que foram carreadas, por cavalgamento, à crusta superior, provavelmente, ao longo de zonas de cisalhamento com componente oblíqua. Essas lascas granulíticas alternam-se com faixas de gnaisses do Complexo Xingu. Datações radiométricas pelo método $\mathrm{Pb}-\mathrm{Pb}$ em rocha total, realizadas por Rodrigues et al.(1992), indicaram uma idade de $3.050 \pm 114 \mathrm{Ma}\left(\mathrm{MSWD}=72 ; \mu_{1}=9,2\right)$, que foi interprtetada como a idade do protólito ígneo dos granulitos. Tassinari(1996) baseando-se no elevado valor de $\mu_{1}$ obtido pelos autores supracitados, considerou essa idade suspeita, uma vez que o valor de $\mu_{1}=9,2$ indicaria uma origem a partir de fontes com altas razões $U / P b$, fato muito improvável em rochas com baixas razões $\mathrm{Rb} / \mathrm{Sr}$, indicativas de assinaturas crustal inferior. Entretanto, a idade obtida é muito similar às idades modelo dos protólitos dos granitóides dos maciços 
Mocambo e Rio Xingu e vulcânicas do Grupo Uatumã, mas difere da idade modelo obtida nos granitóides do maciço Antônio Vicente.

Assim, é possivel que os granulitos do Complexo Pium, especialmente os termos máficos, pudessem ser apontados como um dos principais candidatos a protólitos dos granitóides dos maciços Mocambo e Rio Xingu e do riolito da Formação Iriri do Grupo Uatumã, desde que a idade de 3.050 $1114 \mathrm{Ma}$ fosse interpretada como sendo a idade de formação das rochas granulíticas. No que se refere aos granitóides do maciço Antônio Vicente, essa hipótese está descartada e, até o momento, não é possivel estabelecer qualquer relação, a esse respeito, visto que não foram identificadas regionalmente rochas com idade em torno de 3,2 Ga.

Em relação aos granitóides dos maciços Velho Guilherme, Benedita e Ubim/Sul, nada pode ser comentado a esse respeito, uma vez que não se dispõe de dados que permitam analisar essa questão.

De qualquer modo, as hipóteses aventadas requerem dados adicionais e comprovação futura.

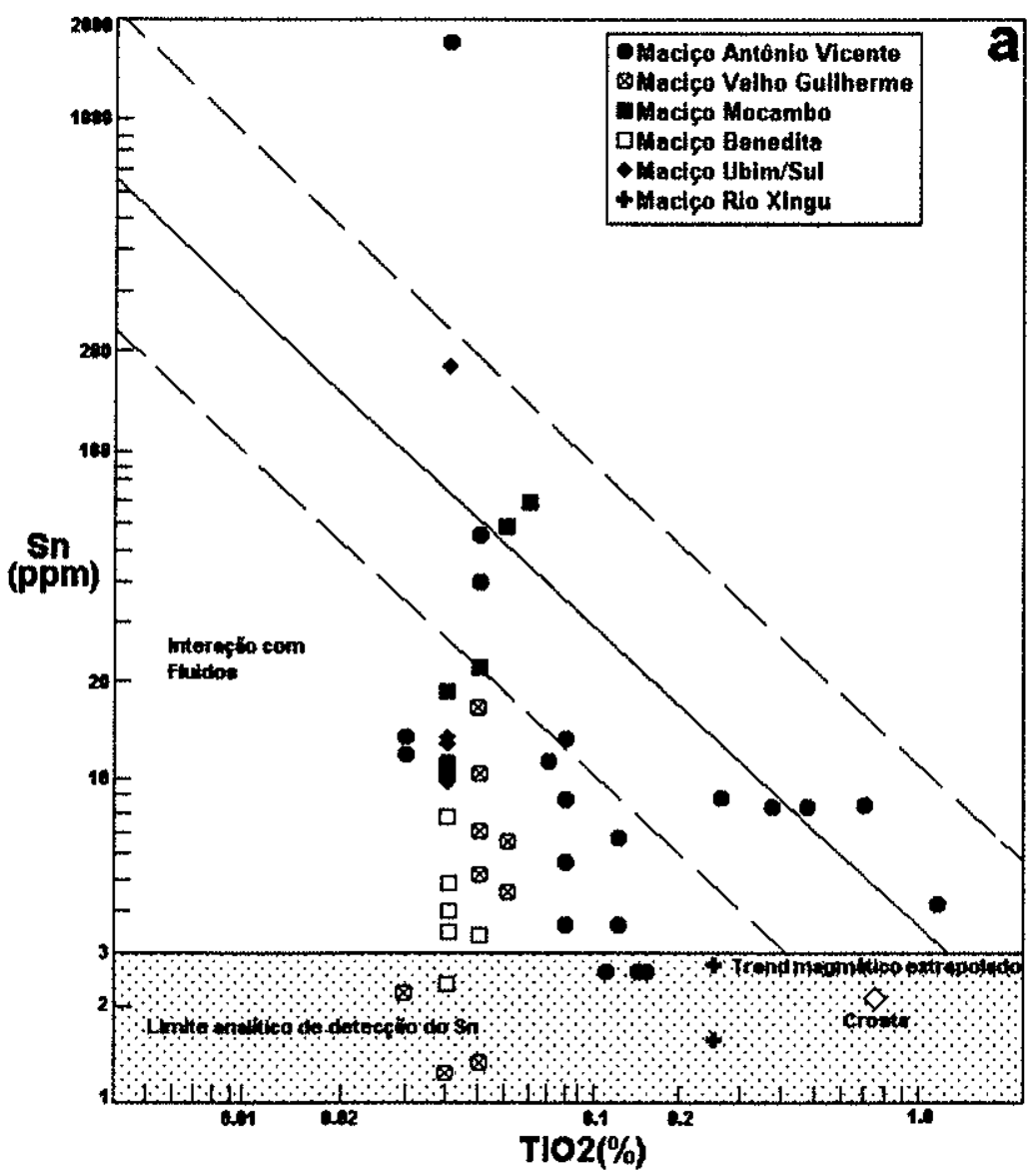




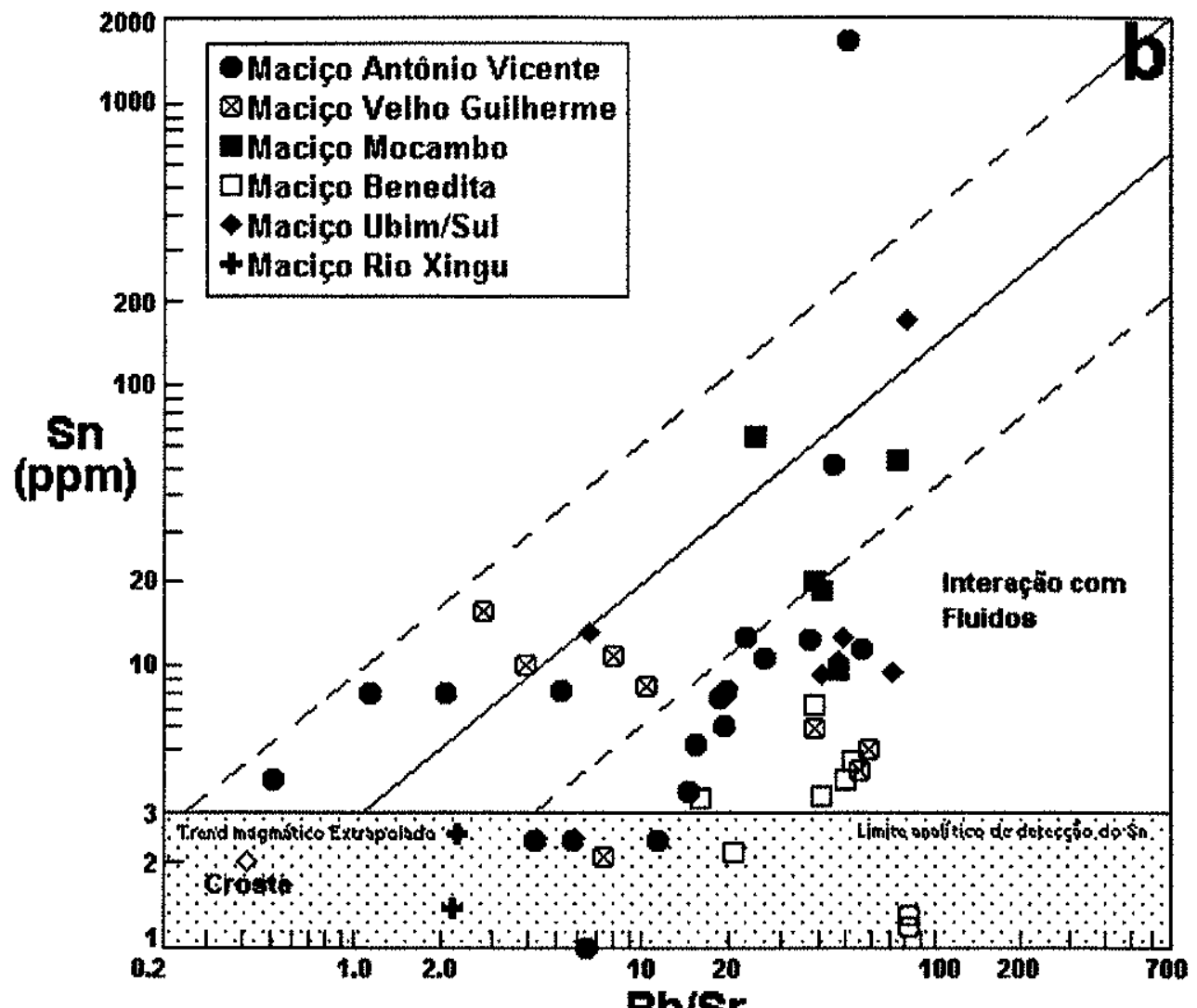

$\mathrm{Rb} / \mathrm{Sr}$

Figura 13.1- Diagramas $\mathrm{Sn}_{-1 \mathrm{TiO}}$ (a) e $\mathrm{Sn}-\mathrm{Rb} / \mathrm{Sr}$ (b) compilado a partir de Lehmann \& Mahawat(1989) mostrando a distribuiçăo composicional dos granitóides dos maciços da Suite Intrusiva Velho Guilherme, Província Estanifera do Sul do Pará.

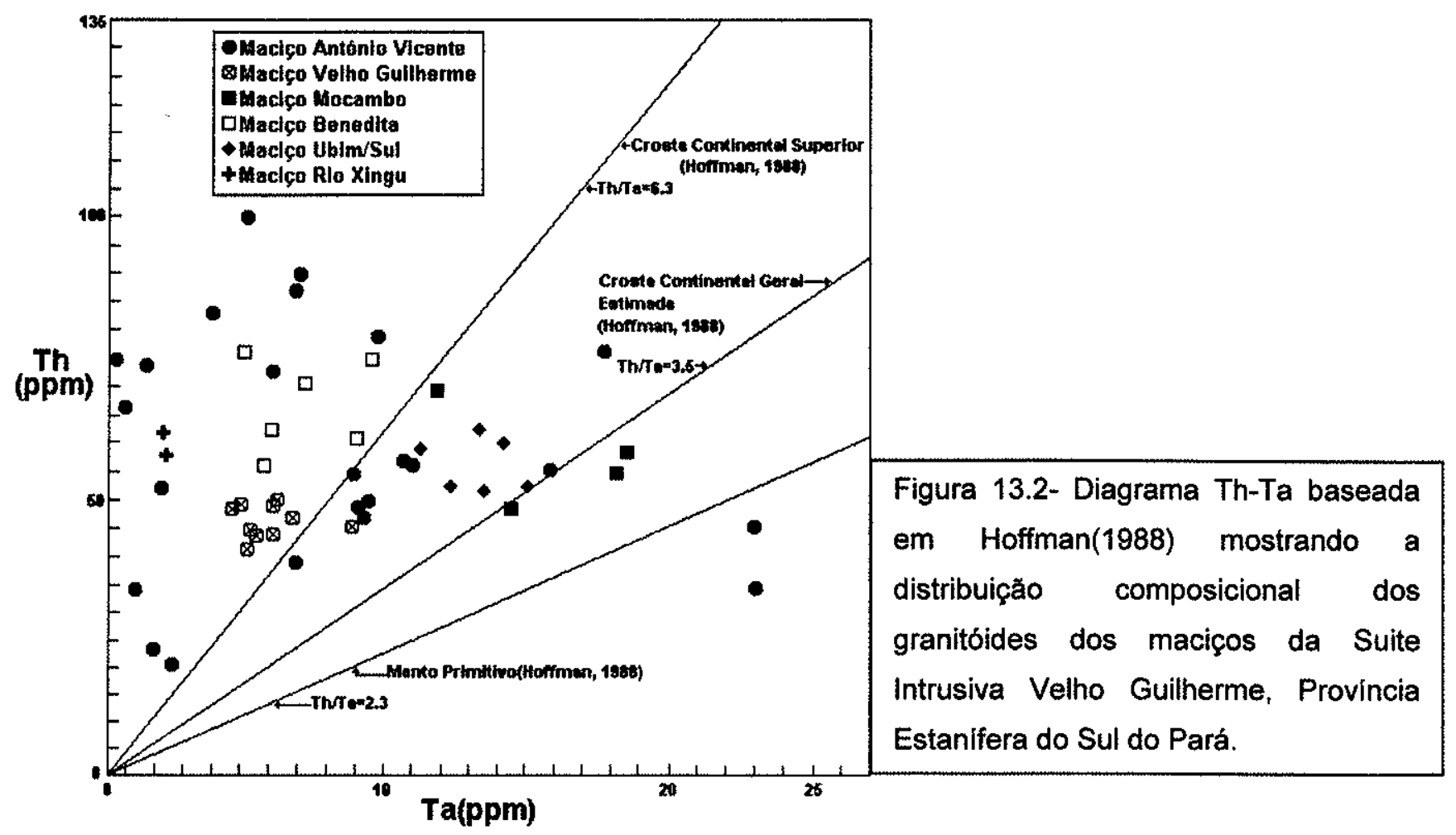




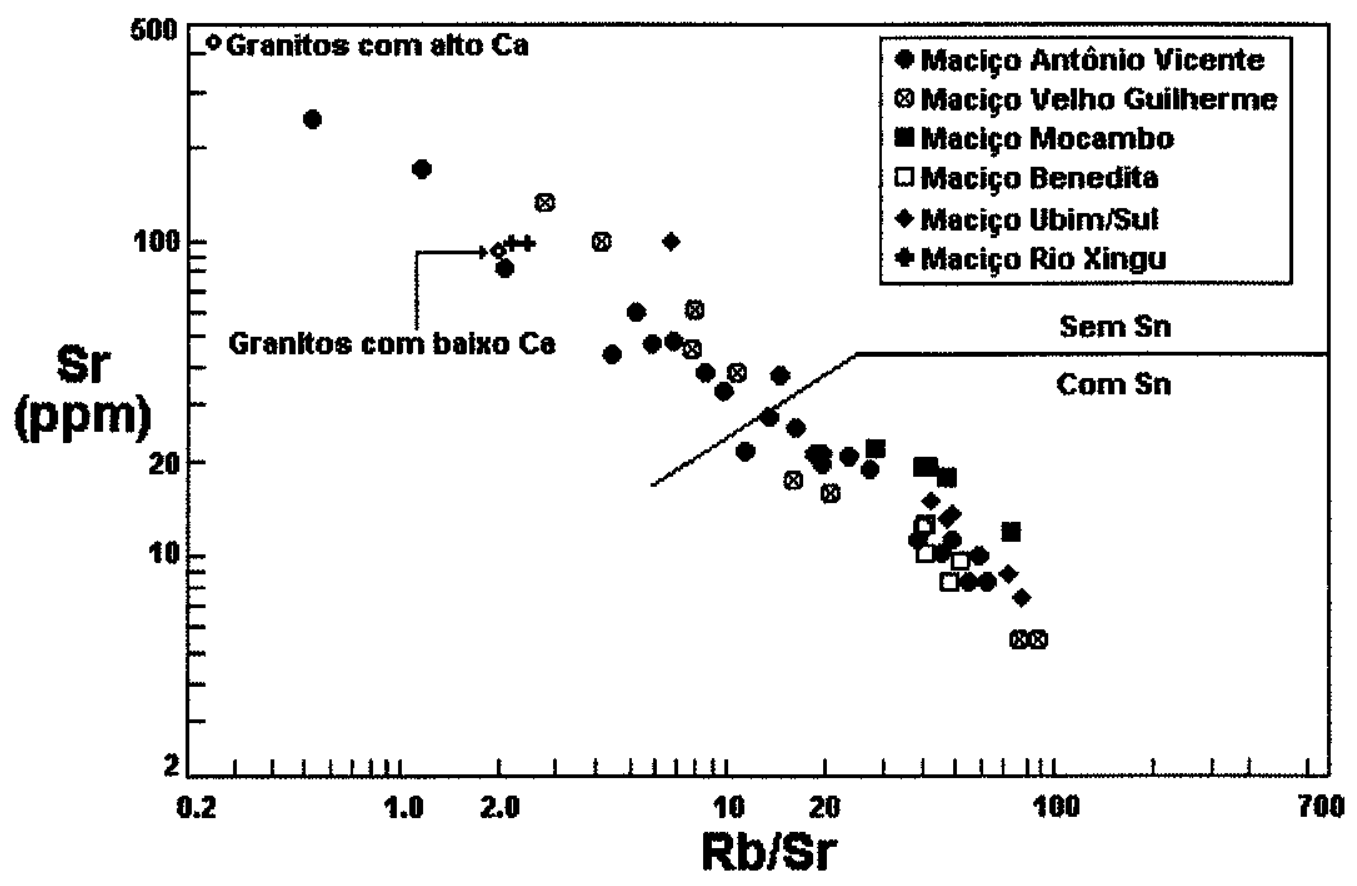

Figura 13.3- Diagrama $\mathrm{Sr}-\mathrm{Rb} / \mathrm{Sr}$ compilado a partir de Lehmann \& Mahawat(1989) mostrando a distribuição composicional dos granitóides dos maciços da Suite Intrusiva Velho Guilherme, Província Estanífera do Sul do Pará. 


\section{REFERÊNCIAS BIBLIOGRÁFICAS}

ABDEL-RAHMAN, A.-F. M. - 1994 - Nature of biotites from alkaline, calc-alkaline, and peraluminous magmas. Jour. Petrol., v. 35., Part 2, p. 525-541.

ABREU, F. A. M.; RAMOS, C. R.-1974- Estanho do Sul do Pará. In: Anais do 28 Congr. Bras. Geol., Porto Alegre, SBG, V.5, P.11-23.

ALLING, H.L. - 1932 - Perthites. Amer.Mineral., v.17, n.2, p. 43-65.

ALLING, H. L. - 1938 - Plutonic Perthites. Journal of Geology, v.46, n. 1-3, p.143-165.

ALLMAN-WARD, P. - 1985 - Distribuition of uranium and thorium in the western lobe of the St. Austell granite and the effects of alteration processes. High heath production(HHP) granites, hydrothermal circulation and ore genesis. Inst. Min. Metal. p. 437-456.

ALMEIDA, F. F. M.-1978- Evolução dos Cratons Amazônico e do São Francisco comparada com a de seus homólogos do hemisfério norte. In: Anais do 30 Congr. Bras. Geol., Recife, SBG, v.6, p.2393-2407.

ALMEIDA , F. F. M.; BRITO NEVES, B. B. de; FUCK, R. A. - 1981 - Brazilian Structural Provinces: an introduction. Earth Sci. Rev., 17(1-2): p.1-29.

AMARAL. G. - 1974 - Geologia Pré-cambriana da Região Amazônica. Tese de Livre Docência(Instituto de Geociências da Universidade de São Paulo), São Paulo. 212p.

ANDERSON, J. L.; BRENDER, E. E. - 1989 - Nature and origin of Proterozoic A-type granitic magmatism in the southwestern United States of Amarica. Lithos, vol. 23, p. 19-52.

ANDERSON, J. L.; MORRISON, J. - 1992 - The role of Anorogenic Granites in the Proterozoic Crustal Development of North America. In: CONDIE, K. C.(Ed.) - 1992 Proterozoic Crustal Evolution, p.263-299.

ANDERSON, J. L.; SMITH, D. R. - 1995 - The effects of temperature and $\mathrm{fO}_{2}$ on the Alhorblende barometer. Amer. Mineral., v. 80, p.549-559.

ARAÚJO, O. J. B.; MAIA , R. G. N. - 1991 - Serra dos Carajás - Folha SB-22-Z-A, Estado do 
Pará. Texto explicativo. Brasília, DNPM/CPRM, 164p. (Programa de levantamentos geológicos básicos da Brasil).

ARAÚJO, O.J.B.; MAIA, R.G.N.; JORGE JOÃO, X.S.; COSTA, J.B.S. - 1988 - A megaestruturação da Serra dos Carajás. In: Congr. Latinoam. Geol., Belém, 1988. Anais... Belém, S BG, V.1, p.324-338.

ARAÚJO, O. J. B.; COSTA, J. B. S.; PINHEIRO, R. V. L.; MAIA, R. G N.,; MACAMBIRA, E. M. B.; VALE, A. G.; SIQUEIRA, J. B.-1992- Arcabouço Estrutural do Complexo de Bacias Transcorrentes Arqueanas da Região da Serra dos Carajás. In: 37 Congr. Bras. Geol., São Paulo, Resumos Expandidos, v.1, p. 547-549.

ARAÚJO, O. J B.; MACAMBIRA, E. M. .; VALE, E. G.; OLIVEIRA, J. R.; SILVA NETO, C. S.; COSTA, E. J. S.; SANTOS, A.; PENA FILHO, J. I. C.; NEVES, A. P.; JORGE JOÃO, X. S.; CoSTA, J. B. S. - 1994 - Primeira integração das investigações geológicas do Programa Grande Carajás na região SSE do Pará. Simp. Geol. Amaz., 4, Resumos, Belém, SBG, P. 299-301.

AVELAR, V. G.; LAFON, J. M.; SCHELLER, T.; ARAÚJO, O. J. B.; MACAMBIRA, E. M. B.m 1994- Geocronologia $\mathrm{Pb}-\mathrm{Pb}$ por evaporação de zircões e $\mathrm{Rb}-\mathrm{Sr}$ em rocha total do Granito Seringa, Provincia Mineral de Carajás. In: 38 Congr. Bras. Geol., Boletim de Resumos, v. 2, p.387-388.

BAILEY, J. C. - 1977 - Fluorine in granitic rocks and melts: a review. Chemical Geology, 19, p.1-42.

BAKER, D. R.; VAILLANCOURT, J.-1995- The low viscisities of $F+H 2 O$-bearing granitic melts and implications for melt extraction and transport. Earth and Planetary Sciences Letters, 132:199-211.

BAKKER, R. J. - 1992 - On modification of fluid inclusions in quartz. Geológica Ultraiectina, 94:1-85.

BAKKER, R. J. - 1997 - Short discussion of apparent low eutetic temperature observations that was held during June 1997. http://www.geology. wisc. edu/ pbrown/loweutec. html. BAKKER, R. J.; JANSEN, J. B. H. - 1990 - Preferencial ater leakage from fluid inclusions by 
means of mobile dislocations. Nature, 345(6270): 58-60.

BARBOSA, A. A.; LAFON, J. M.; NEVES, A.; VALE, a G. - 1994 - O Granito Redenção(Sul do Pará): Novos dados geocronológicos Rb-Sr e Pb-Pb. $4^{Q}$ Simp. Geol. Amaz., Resumos. Belém, SBG, p.302-306.

BARD, J. P.-1980- Microtextures des roches magmatiques et metamorphiques. Paris, Mason, 192p.

BARD, J. P. - 1986 - Microtextures of igneous and metamorphic rocks. D. Reidel Publishing company. Dordrecht. 264p.

BASEI, M. A. S. - 1978 - O vulcanismo ácido-intermediário na Região Amazônica. Anais do 30 Congr. Bras. Geol., v. 5, p.2408-2422.

BATCHELOR, R. A.; BOWDEN, P.-1985- Petrogenetic interpretation of granitoid rock series using multicationic parameters. Chemical Geology, 48:35-43.

BELLO, R. M. da S.; SVISERO, D. P.; GANDINI, A. L.; FUSIKAWA, K. - 1994 - Estudo microtermométrico das inclusões fluidas do topázio imperial da jazida de Boa Vista, Ouro Preto, MG. In: 38 Congr. Bras. Geol. Boletim de Resumos expandidos. Cambouriú, v. 1, p.636-637.

BELOLIPETSKII, A. P.; VOLOSHIN, A. V. - 1996 - Yttrium and rare earth element minerals of the Kola Península, Russia, p.311-326. In: JONES, A. P.; WALL, F; WILLIAMS, C. T.(Eds.) - 1996 - Rare Earth Minerals. Chemistry, origin and ore deposits. Chapman \& Hall, London. 372p.

BENNET, D. G.; BAKER, A. J. - 1992 - High salinity fluids: The result of retrograde metamorphism in thrust zones. Geoch. Cosmoch. Acta, v.56, p.81-95.

BETER, R. L.; JACKSON, J. A.-1987- Glossary of Geology, 788p.

BETTENCOURT, J. S.; DALL'AGNOL, R. - 1987 - The Rondonian tin-bearing anorogenic granites and associated mineralization. In: Inter. Symp. Granites Associated Mineralizations, Salvador, 1987. Excurssion Guides... Salvador, SGRM, P.49-87.

BETTENCOURT, J. S.; DAMASCENO, E. C.; FONTANELLI, W. S.; FRANCO, J. R. M.; PEREIRA, N. M.-1981- Brasilian tin deposits and potencial. In: Wond Conference on tin, 
5, Kuala Lumper. Ministry of Primary Industries \& Int. Tin Counc., 69p.

BETTENCOURT. J. S.; LEITE JR., U. B.; PAYOLLA, B. L.; DALL'AGNOL, R. - 1991 - The rapakivi granites of the south-southwestern sector of the Guapore Shield(western margin of the Amazonian Craton), Brazil. In: Rapakivi Granites and Related Rocks. Helsink, IGCP-Geol. Surv. Finland, Abstract vol., p.19.

BETTENCOURT, J. S.; TOSDAL, R. M.; LEITE JR., W. B.; PAYOLLA, B. L. - 1995 Overview of the rapakivi granites of the Rondônia Tin Province(RTP). in: BETTENCOURT, J. S.; DALL'AGNOL, R.(Eds.) - 1995 - Excursion Guide: The rapakivi granites of the Rondônia Tin Province and associated mineralization. IGCP PROJECT 315. Belém, Pará, Brasil. 48p.

BETTENCOURT, J. S.; LEITE, W. B.; PAYOLLA, B. L.; SCANDOLARA, J. E.; MUZZOLON, R,; VIAN, J. A. J - 1997 - The rapakivi granites of the Rondônia Tin Province, northern Brazil. In: International Symposiumon Granites and Associated Mineralizations, Salvador, Bahia, Brazil, 24-29 August, 1997, Excursion Guide. Companhia Baiana de Pesquisa Mineral and Superintendência de Geologia e Recursos Minerais do Estado da Bahia, Brasil, pp.3-31.

BEUS, A. A.-1964- Wall rock alterations of hydrotermal-pneumatolytic deposits of rare elements. Inter. Geol. Review, v.4, n.10, p.1144-1153.

BEUS, A. A.; ZALASHKOVA, N. Ye.-1964- Pot-magmatic high temperature metasomatic processes in granitic rocks. Inter. Geol. Review, n.4, p.668-681.

BEUS, A. A.; SITNIN, A. A.-1968- Geochemical Specialization of magmatic Complexes as Criteria for the Exploration of Hidden Deposits. Inter. Geol. Congr. Report of Twentythird session Czechoslovakia. Proceedings of Section 6. Geochemistry. Prague, p.101105.

BLASI, A.; BLASI, C. P. - 1994 - Aspects of alkali feldspar characterization: prospects and relevance to problems outstanding. p. 51-101. In: PARSON, I.(Ed.) - 1994 - Feldspars and their reactions. Series C: Mathematical and physical sciences, v.421,650p.

BLEVIN, P. L.; CHAPPELL, B. W.-1995- Chemical, origin, and evolution of mineralized 
granites in the Lachlan Fold Belt, Australia: The metallogeny of 1 - and S- type granites. Economic Geology, v. 90, p.1604-1619.

BODNAR, R. - 1998 - Additional discussion of apparent low temperature observations that was held in February 1998. http://www.geology.wisc.edu/ pbrown/loweutec2.html.

BORGES, R. M. K. - 1997 - Petrografia e química mineral dos greisens associados ao Granito Água Boa - Mina Pitinga(AM): um estudo dos processos de formação de greisens. Tese de Mestrado(Curso de Pós-graduação em Geologia e GeoquímicaCentro de Geociências-Universidade Federal do Pará), Belém, 190p.

BORGES, R. M. K.; DALL'AGNOL, R.; COSTI, H. T.-1996- Petrografia dos greisens associados ao Granito Água Boa-Mina Pitinga(AM). In: 39 Congr. Bras. Geol. Salvador. Anais., SBG, v.6, p.436-438.

BORIZENKO, A. S. - 1978 - Study of the salt composition of solutions of gas-liquid inclusions in minerals by the cryometric method. Soviet Gelogy and Geophysics, v.18, 11-19.

BOTELHO, N.F. - 1984 - "O granito Pedra Branca (Goiás) e as mineralizações de estanho associadas". Tese de mestrado(tE-Depto. de Geoc./UnB). Brasilia. 259p.

BOTELHO, N. F. - 1992 - Les ensembles granitiques subalcalins a peralumineux mineralises en Sn et In de la Sous.-Province Parana, Etat de Goias, Brasil. Tese de Doutorado(L' Universite Paris VI/Laboratoire de Geologie Apliquee). Paris. 344p.

BOTELHO, N. F.; MARINI, O. J. 1984. Petrografia, petroquímica e transformações tardi/pós-magmáticas do granito Estanifero de Pedra Branca, In: 33 Congr. Bras. Geol., Rio de Janeiro, 1984. Anais,.. Rio de Janeiro, SBG, v.6, p. 2935-2949.

BOTELHO, N. F.; BILAL, E.; MOUTTE, J.; FONTEILLES, M.-1993- Precambrian A-Type tinbearing granites in the Goiás. Tin Province, Central Brazil: a review. In: Worshop MAGMA. Resumos Expandidos. Acad. Bras. Cienc., Rio de Janeiro, p.5-8.

BOTTINGA, Y.; JAVOY, M. 1973 - Commments on oxygen isotope geothermometry. Earth Plan. Sci. Let., , 20:250-265.

BOWDEN, P'; KINNAIRD, J. A.-1984- The Petrology and Geochemistry of alkaline granites 
from Nigeria. Physics of Earth and Plannetary Interiors, 35:199-211.

BOWDEN, P.; KINNAIRD, J.A.; ABAA, S.L.; IKE, E.C.; TURAKI, U.M. 1984. Geology and mineralization of the Nigerian anorogenic ring complexes. Geol. JB., B56, p. 3-65.

BRASIL-1972- Superintendência de Desenvolvimento da Amazônia(SUDAM). Pesquisa Mineral do Iriri/Curuá. Relatório Preliminar(Divisão de Recursos Naturais), Belém, 62p.

BROWN, G. C.; FYFE, W. S. - 1970 - The Production of Granitic Melts during Ultrametamorphism. Contr. Mineral. Petrol., v.28, p.310-318.

BROWN, P. E. - 1989 - FLINCOR. A fluid inclusion data reduction and exploration program(abstr.). In: Secound biennial Pan-American Conference on Researcc on Fluid Inclusions. Program with Abstracts. P.14.

BROWN , W. L'.; PARSON, I. - 1994 - Feldspars in igneous rocks. p.449-499. In: PARSON, I.(Ed.). - 1994 - Feldspars and their reactions. Series C: Mathematical and Physics Sciences. Kluwer Academic Publishers, Notherlands, v. 421, 650p.

BROWN, W. L.; PARSONS, I. - 1985 - Calorimetric and phase-diagram approaches to twofeldspar geothermometry: a critique. Amer. Mineral., v.70, p.356-361.

BUDDINGTON, A. F.; LINDSLEY, D. H. - 1964 - Iron-Titanium Oxide Minerals and Syntetic Equivalents. Jour. Petrol., v. 5, Part 2,p.310-357.

BURNHAM, C. W.; OHMOTO, H.-1980- Late-stage processes in felsic magmatism. Mining Geology Special /ssue, v.8, p.1-11.

BURRUSS. R. - 1997 - Short discussion of apparent low eutetic temperature observations that was held during June 1997. http://www.geology. wisc.edu/ pbrown/loweutec. htm/.

BURRUSS, R. - 1998 - Additional discussion of apparent low temperature observations that was held in February 1998. http://www.geology.wisc.edu/ pbrown/loweutec2.html.

CANDELA, P. A.-1989a- Magmatic ore-forming fluids: thermodynamic and mass-transfer calculations of metal concentrations. Reviews in Economic Geology, v.4. p.203-221.

CANDELA, P. A.-1989b- Felsic magmas volatiles and metallogenesis. Reviews in Economic Geology, v.4, p.223-233.

CANDELA, P. A.-1992- Controls on ore metal ratios in granite-related ore systems: an 
experimental approach. Transactions of the Royal Society of Edinurgh: Earth Sci., v.83, p.317-326.

CAPUTO, M. V.; RODRIGUES, R.; VASCOCELOS, D. N. N.-1972- Nomenclstura Estritigráfica da Bacia do Amazonas: História e Atualização. In: Anais do 26 Congr. Bras. Geol., Belém, p.35-46.

CASTRO, A. 1987. On granitoid emplacement and related structures: a review. Geol. Rund. $76 / 1: 101-124$.

CATHELINEAU, M. - 1986 - The hydrothermal alkali metasomatism effects on granitic rocks: quartz dissolution and related subsolidus changes. Jour. Petrol., v. 27, Part 4, p.945965.

CATHELINEAU, M. - 1987 - Les interactions entre fluids et minéraux: thermométrie et modèlisation. L'exemplo d'un système géothermique actif(Los Azufres, Mexique) et d'altèration fossils dans la Chaine Varisque. Doct. Thesis(I.NP.I), Nancy, France.

CATHELINEAU, M. - 1988 - Cation site occupancy in chiorites and illites as a function of temperature. Clay Minerals, v.23, p. 471-485.

CATHELINEAU, M.; NIEVA, D. - 1985 - A chlorite solid solution geothermometer. The Los Azufres(Mexico) geothermal system. Contr. Min. Petrol., v.95, p.235-244.

CERNY, P.; MEINTZER, R. E.-1988- Fertile granites in the Archean and Proterozoic Fields of rare-element pegmatites: crustal environment, geochemistry and petrogenetic relationships. Recent Advances in the geology of granite. Related Mineral Deposits, p.170-207.

CESBRON, F. P. - 1989 - Mineralogy of the Rare-Earth Elements. Lanthanides, Tantalum and Niobium. In: MÖLLER, P; CERNÝ, P.; SAUPÉ, F.(Eds.).Springer-Verlag, Berlin Heidelberg. P.3-26.

CHAPPELLL, B. W.; WHITE, A. J. R.-1974-Two Contrasting Granite Type. Pacific Geology, v.8, p.173-174.

CHAPPELL, B. W.; WHITE, A. J. R.-1982- Geology of granites and their metallogenetic relations. Proceedings of the international symposium, Held at Nanjing University, 
China, p.87-101.

CHAROY, B. - 1979 - Définition et i portance des phénomènes deutériques et des flurides associés dnas les granites: conséquence metallogénique. Sciences de la Terre, ném., $n$ 37. In:

CHAROY, B.; POLLARD, P. J. -1989 - Albite-Rich, Silic-Depleted metasomatic rocks at Emufort Northeast Queensland: Mineralogical, Geochemical, and fluid inclusion constraints on hydrothermal evolution and tin mineralization. Economic Geology, v.84, p.1850-1874.

CHAROY, B.; CHAUSSIDON, M.; NORANHA, F. - 1995 - Lithium zonation in white micas from the Argemela microgranite(Central Portugal): na in-situ ion-, electron-microprobe and spectroscopic investigation. Eur. Journ. Min., 7, p.335-352.

CHAYES, F. - 1956 - Petrografic modal analysis. New York, John Willey \& Sons. 113p.

CHEANG, K. K.; WENNER, D. B.; STUCLESS, J. S.-1986- Oxygen isotopic constrainst on the origin of the Precambrian Granites from the Southern Wind River range and the Granite Mountains, Central Wyoming. U. S. Geological Survey Bulletin, p.109-129.

CLARK, A. M. - 1984 - Mineralogy of the rare earth elements. In: Rare Earth Element Geochemistry, (Ed. P. Herderson), Development in Geochemistry, 2, Elsevier, p.33-61.

CLAYTON, R. N.; O'NEIL, J. R.; MAYEDA, T. K. 1972 - Oxygen isotope exchange between quartz and water. Jour. Geophys. Research., v. 77, n 17, p.3057-3067.

COBBING, E. J.-1990-A comparison of granites and their tectonics settings from the South American Andes tin belt. Geol. Soc. Am., Special Paper, 241:193-204.

COLLINS, W.J.; BEAMS, S.D.; WHITE, A.J. \& CHAPELL, B.W. - 1982 - Nature and origin of A. type Granites with particular reference to Southeastern Australia. Contr. Mineral. Petrol., 80:189-200.

CONDIE, K. C. - 1993 - Chemical composition and evolution of the upper continental crust contrasting results from surface samples and shales. Chem. Geol., 104, p.1-37.

CORDANI, U. G. ; BRITO NEVES, B. B. de - 1982 - The geological evolution of South America during the Archean and Early Proterozoic. Rev. Bras. Geoc., 12(1/2/3): 78-88. 
COSTA. J. B. S.; MACAMBIRA, E. M. B.; VALE, E. G.; ARAÚJO, O. J. B.; PINHEIRO, R. V.

L. -1992 - Geologia estrutural da Folha São Felix do Xingu(SB-22-Y-B), Serra dos Carajás. 37 Congr. Bras. Geol., Boletim de Resumos Expandidos, São Paulo, 1, 332333.

COSTA, J. B. S.; MACAMBIRA, E. M. B.; VALE, A. G.; ARAÚJO, O. J. B.; PINHEIRO, R. V. L.; JORGE JOÃO, X. S.-1993- Evolução lito-estrutural da região de São Felix do XinguSerra dos Carajás. Rev. Geoc., 12(2): 315-332.

COSTA, J. B. S,; ARAÚJO, O. J. B.; JORGE JOÃO, X. S,; MAIA, R. G. N.; MACAMBIRA, E. M. B.; VALE, A. G.; SANTOS, A.; PENA FILHO, J. I. C.; NEVES, A. P.-1994- Panorama tectono-estrutural da região sudeste do Pará. 4 Simp. Geol. Amaz., Belém, Resumos Expandidos, v. 1, p. 314-317.

COSTA, J. B. S.; ARAÚJO, O. J. B.; SANTOS, A.; JORGE JOÃO, X. S.; MACAMBIRA, M. J. B.; LAFON, J. M.- 1995 - A Província Mineral de Carajás: Aspectos Tectono-Estruturais, Estratigráficos e Geocronológicos. Bol. Mus. Para. Emílio Goeldi, Sér. Cienc. da Terra COSTI, H. T.; DAL'AGNOL, R.; TEIXEIRA, J. T.; POPINI, M. V.-1995- The albite granite of Pitinga mine: petrography, geochemistry and mineralizations. In: INTERNATIONAL SYMPOSIUM RAPAKIVI GRANITES AND RELATED ROCKS, IGCP-315, Abstract volume. Belém, University of Para, p.20-21.

COSTI, H. T.; DAL'AGNOL, R.; MINUZZI, O. R. R.; TEIXEIRA, J. T.-1996-Tin bearing sodic metasomatic episyenites associated with the Agua Boa granite, Pitinga, Amazonian Craton, Brazil. In: INTERNATIONAL SIMPOSYUM RAPAKIVI GRANITES AND RELATED ROCKCS, 7, Helsinki, 1996. Abstract volume. Helsinki, International Geological Correlation Programme Project 315, p.16.

COTTSMANN, B.; TISCHENDORF, G.; FÖRSTER, H.-J. - 1994 - Trioctahedral micas as indicators of the compositional evolution of $\mathrm{Sn}-\mathrm{Li}-\mathrm{Rb}-\mathrm{Cs}-\mathrm{F}$ granites, na example: The Eibenstock Pluton(western Erzgebirge/Germany). $16^{\text {th }}$ General IMA Meeting, Pisa, Abstracts, p.152.

COX, K. G.; BELL. J. D.; PANKHURST, R. J. -1979- The Interpretation of Igneous Rocks. 
London. George Allen \& Unwin, 450p.

CPRM/DNPM -1991- Projeto Especial Mapas de Recursos Minerais, de Solo e de Vegetação para a Área do Projeto Grande Carajás- Sub-Programa Mapas metalogenéticos e de Previsão de Rcursos Minerais. Folha São Felix do Xingu-SB-22Y-B. CPRM, Superintendência Regional de Belém(Relatório Final).

CRAWFORD, M. L. - 1981 - Phase equilibria in aqueous fluid. In: HOLLISTER, L. S.; CRAWFORD, M. L.(Eds.) - 1981 - Fluids Inclusions: applications to petrology. Calgary, Mineralogy Association of Canada, 75-100(short Course, handbook, v,6)

CREASER, R. B.; PRICE, R. C.; WORMALD, R. J.-1991- A -Type granites revised: assessment of a residual-source model. Geology, v.19, p. 163-166.

CUNEY, M.; RAIMBAULT, L.-1991- Variscan rare metal granites and associated mineralization from the north French Massif Central: Field guide book of the 25 years SGA anniversary meeting, Nancy, France, 30th August- 3rd September. 75p.

CUNHA, B. C. C.; POTIGUAR, L. A. T.; IANHEZ, A. C.; BEZERRA, P. E. L.; PITTHAN, J. H. L.; SOUZA JR., J. J. ; MONTALVÃO, R. M. G. de; SOUZA, A. M. S.; HILDRED, P. R.; TASSINARI, C. C. G. - 1981 - Levantamento de Recursos Naturais, v. 22, Folha SC-22 Tocantins, Gelogia I, 196. NME/SG.

CZAMANSKE, G. K.; WONES, D. R. - 1973 - Oxidation during magmatic differentiotion, Finnmarka Complex, Oslo Area, Norwey: Part 2, The mafic silicates. Jour. Petrol., v.14, Part 3, p.349-380.

DALL'AGNOL, R. - 1980 - Etudes sur des granites du type "Rondonian" en Amazonie Orientale et leurs transformations tardi-magmatiques. Tese de Doutorado(Labor. Geol. Petrol./Univ. Paul Sabatier), Tolouse, 348p.

DALL'AGNOL, R. - 1982a - Estudos comparativo de alguns maciços graníticos pósTransamazônicos da Amazônia Oriental. In: Anais 32 Congr. Bras. Geol., Salvador, SBG. v.2, p.500-513.

DALL'AGNOL, R.; SCHUKMANN, W.K., BASEI, M.A.S.; SCHELLER, T. - 1984 - Novos dados geocronológicos e estudo de elementos traços de maciços graníticos 
anorogênicos da Amazônia Oriental, Estado do Pará (Brasil). In: 2 Symp. Amaz., Manaus, Atas. MMC-DNPM, p.59-74.

DALL'AGNOL, R.; VIEIRA, E.A.P.; SA, C.A.S.; MEDEIROS, H.; GASTAL, M.C.P.; TEIXEIRA N.P. - 1986 - Estado atual do conhecimento sobre as rochas granitóides da porção sul da Amazônia Oriental. Rev. Bras. Geoc., v. 16, n.1, p.11-23.

DALL'AGNOL, R.; BETTENCOURT, J.S.; JORGE JOÃO, X.; MEDEIROS, H.; COSTI, T.H.; MACAMBIRA, M.J.B. - 1987 - Granitogeneses in the northern Brazilian region: a review. Rev. Bras. Geoc., V.17, n.4, p.382-403.

DALL'AGNOL, R.; SAUCK, W.A.; GONÇALEZ, M. G. B.-1988- Susceptibilidade magnética em granitóides da Amazônia: Um estudo preliminar. In: Anais do 35 Congr. Bras. Geol., Belém,v.3, p.1164-1173.

DALL'AGNOL, R.; TEIXEIRA, N. P.; MAGALHÃES, M. S.-1993b- Diagnostic features of the Tin-specialized anorogenic granites of the Eastern Amazonian Region. In: Anais Acad. Bras. Cienc., v.65, sup.1, p.33-50.

DALL'AGNOL, R.; TEIXEIRA, N. P.; MAGALHÃES, M. S. - 1994 - The anorogenic leucogranites of the eastern Amazonian region: an example of tin-mineralized granites of the rapakivi series. In: Anortosites, Rapakivi Granites and Related Rocks, International Geological Correlation Programme, Joint meeting IGCP Nos 290 and 315, Program and Abstracts. McGill University, Montreal, p.2.

DALL'AGNOL, R.; LAFON, J. M.; MACAMBIRA, M. J. B.-1995- Proterozoic Anorogenic Magmatism in the Central Amazonian Province, Amazonic Craton: Geochonological, Petrological and Geochemical Aspects. Min. Petrol., 46: 1-26.

DALL'AGNOL, R.; COSTI, H. T.; LEITE, A. A. da; MAGALHÃES, M. S. de; TEIXEIRA N. P.1999 - Rapakivi granites from Brazil and adjacent areas. Precambrian Research, 95: 939.

DAOUD, W. K. - 1988 - Granitos estaníferos de Pitinga. Contexto Geológico e depósitos minerais associados. Dissertação de Mestrado(Depto. de Geoc./UNB). Brasilia. 194p.

DAVIS, D. W.; LOWESTEIN, T. K.; SPENCER, R. J. - 1990 - Melting behavoir of fluid 
inclusions in laboratory-grown halite crystals in the systems $\mathrm{NaCl}-\mathrm{H}_{2} \mathrm{O}, \mathrm{NaCl}-\mathrm{KCl}-\mathrm{H}_{2} \mathrm{O}$, $\mathrm{NaCl}-\mathrm{Mg}-\mathrm{Cl}_{2}-\mathrm{H}_{2} \mathrm{O}$ and $\mathrm{NaCl}-\mathrm{CaCl}_{2}-\mathrm{H}_{2}$. Geochem. Cosmochem. Acta, v. 54, p.591-601.

DEER, W. A.; HOWIE, R. A.; ZUSSMAN, J. - 1966 - Minerais constituintes das rochas. Fundação Calouste Gulbenkian, Lisboa, 556p.

DE PAOLO, D. J. - 1981 - A Neodymium and Strontium isotopic study of the Mesozoic calcalkaline granitic batholiths of the Sierra Nevada and Penninsular Ranges. California. Journ. Geophys. Research, 86(B11), p.10470-10488.

DE PAOLO, D. J.-1988 - Neodymium isotope geochemistry. An introduction. Spring-Verlag, Berlin, 187p.

DIDIER, J.-1991- Enclaves and Granite Petrology. Elsivier, New York, 625p.

DOCEGEO - 1988 - Provínia Mineral de Carajás. Litoestratigrafia e principais depósitos minerais. In: Anais do 35 Congr. Bras. Geol., 35, Belém, SBG, Anexo, 165p.

DUPRÉ, B.; ARNDT, N.T. - 1990 - Pb isotopic compositions of Archean Komatiites and sulfides. Chem. Geol., 85, p.35-56.

DURISOVA, J. - 1978 - Geothermometry in the minerals from the tin deposits of the eastern Krusne hory Mts.(Czechoslovakia). Metallization Associated with Acid Magmatism, v.3, p.325-335.

EADINGTON, P. J. - 1983 - A fluid inclusion investigation of ore formation in a tinmineralized granite, New South Vales. Econ. Geol., v. 78, p.1204-1221.

EADINGTON, P. J.; NASHAR, B. - 1978 - Evidence of the magmatic origin of quartz-topaz. rocks from the New England batholith, Australia. Contr. Mineral. Petrol., v.67, p.433438.

EBY, G. N. - 1990 - The A-tipe granitoids: review of their occurrence and chemical characteristics and speculations on their petrogenesis. Lithos, 26, p.115-134.

EBY, G. N. - 1992 - Chemical subdivision of the A-tipe granitoids: petrogeneses and tectonic implications. Geology, 20, p.641-644.

EDWARDS, A. B. - 1954 - Textures of the ore minerals and their significance. Australasian Institute of Mining and Mettalurgy. 242p. 
EL-BOUSEILY, A. M.; EL-SOKKARY, A. A-1975- The relation between $\mathrm{Rb}, \mathrm{Ba}$ and $\mathrm{Sr}$ in granitic rocks. Chemical Geology, 16:207-219.

ELKINS, L. T.; GROVE, T. L. - 1990 - Ternary feldspar experiments and thermodynamic models. Amer. Mineral., v. 75, p.544-559.

EMSLIE, R. F. - 1991 - Granitoids of rapakivi granite-anorthosite and related associations. Precambrian. Research., 51: 173-192.

ERNST, W. G - 1976 - Petrologlc phase equiulibria. W. H. Freeman and company. San Francisco, 33P.

EWING, R. C.; CHAKOUMAKOS, B.C. - 1982 - Lanthanide, Y, Th, U, Zr and Hf minerals: seleted structure descriptions. In: CERNÝ, P.(Ed.) - 1982 - MAC. Short course in Granitic Pegmatitic in Science and Industry, v. 8, p.239-265.

FARACO, M. T.; MACAMBIRA, E. M. B.; VALE, A. G.-1991- Potencial mineral da Folha São Felix do Xingu(SB-22-Y-B). Estado do Pará. In: Anais do 3 Simp. Geol. Amaz., Belém, p. 275-290.

FIGUEIREDO, M. C. H. - 1985 - Introdução à geoquímica dos elementos terras raras. Bol. IG-USP, Sér. Cient., 16, p.15-31.

FIGUEIREDO, M. C. H. - 1993 - Geoquimica da Sequências Vulcanossedimentares. Apostila de apoio para um curso ministrado aos geólogos da Superintedência Regional(SUREG) de Belo Horizonte(Junho de 1993). 47p.

FISHER, D. J. -1971- Poikilitic albite in the microcline of granitic pegmatites. Amer. Mineral., v.56, p.1769-1787.

FLEISCHER, M. - 1974 - New Mineral Names. Amer. Mineral., v.59, p.208-212.

FONTEILLES, M. - 1987 - La composition chimique des micas lithiniféres(et autres minéraux) des granites d'Echassières comme image de leur évolution magmatique. Géologie de la France, n. 2-3, p.149-178.

FOORD, E. E.- 1982 - Minerals of tin, titanium, niobium and tantalum in granitic pegmatites. In: CERNÝ, P.(Ed.) - 1982 - MAC. Short course in Granitic Pegmatitic in Science and Industry, v. 8, p. 187-238. 
FORESTER, R. W.; TAYLOR Jr.; H. P. - 1980 - Oxygen, hydrogen, and carbon isotope studies of the Stony Mountain Complex, western San Juan Mountains, Colorado. Econ. Geol., v. 75, p. $362-383$.

FÖRSTER, H. J.; TISCHENDORF. G.; TRUMBULL, R. B. - 1997 - An evaluation of the Rb vs. $(\mathrm{Y}+\mathrm{Nb})$ discrimination diagram to infer tectonic setting of silicic igneous rocks. Lithos, v.40, p. $261-293$.

FOSTER, M. D. - 1960a - Layer charge relations in the dioctahedral and trioctahedral micas. v. 45, p.383-398.

FOSTER, M. D.-1960b - Interpretation of the composition of trioctahedral micas. $U . S$. Survey Prof. Paper, 354 A-K, p. 11-48.

FOSTER, M. D. - 1962 - Interpretation of the composition and classification of the chlorites. Geological Survey Professional Paper 414-A, A-33.

FRANK, R. E.-1990- Geologia, Petrologia e Mineralizações Estaniferas do Complexo Granítico Santa Bárbara, Rondônia. Tese de Mestrado(IG-UFRJ), Brasil. 244P.

FUGE, R. - 1977 - On the behaviour of fluorine and chlorine during magmatic differentiation. Contr. Mineral. Petrol. v.61, $\mathrm{n}^{\ell} 3$, p.245-249.

FUZIKAWA, K.; ALVES, J. V. - 1995 - Interpretações sobre o comportamento e as mudanças de fase de uma inclusão aquo-carbônica durante a criometria. Rev. Esc. Minas, 42(2), p.123-126.

GANDINI, A. L. - 1994 - Mineralogia, inclusões fluidas e aspectos genéticos do topázio imperial de Ouro Preto, Minas Gerais. Dissertação de Mestrado(Instituto de Geocências/USP), São Paulo. 212p.

GANGULY, J.; SAXENA, S. K. - 1984 - Mixing properties of aluminosilicate garnets: Constraints from natural and experimental data, and applications to geothermobarometry. Amer. Mineral., 69, p.88-97.

GARLICK, G. D.-1966- Oxygen isotope fractionation in igneous rocks. Earth Plan. Lett., $1: 361-368$.

GASTAL, M.C.P. - 1987 - Maciço Granitico Musa: Mapeamento, Petrologia e Petroquímica, 
Rio Maria, SE do Pará. Tese de Mestrado(CG/UFPA). Belém. 327p.

GASTAL, M. C. P.; MACAMBIRA, M. J. B.; MEDEIROS, H.; DALL'AGNOL, R.-1987-Idades e geoquímica isotópica Rb-Sr do Granito Musa e do Granodiorito Rio Maria. Amazônia Oriental. Geoch. Bras., 1(2): 247-259.

GIBBS, A. K.; WIRTH, K. R.; HIRATA, W. K. ; OLSZEWSKI JR., W. J. - 1986 - Age and composition of the Grão Pará Group volcanics, Serra dos Carajás. Rev. Bras. Geoc. 16(2): 201-211.

GINZBURG, A. I. - 1970 - Peculiarities of the postmagmatic deposits associated with intrusions of various alkalinity., p.12-15. In: POUBA, Z; STEMPROK, M.(Eds.) - 1970 Problems of hydrothermal ore deposition. Internat. Union Geol. Sci. A., n.2.

GHENT, E. D.; STOUT, M. Z. - 1981 - Geobarometry and Geothermometry of plagioclasebiotite-garnet-muscovite assemblages. Contr. Mineral. Petrol., 76, p.92-97.

GOKHALE, N. W. - 1968 - Chemical composition of biotites as a guide to acertain the origin of granites. Bull. Geol. Finland, 40:107-112.

GONÇALEZ, M.G.B.; VIEIRA, E.A.T.; DALL'AGNOL, R.; MACAMBIRA, M.J.B.; ANGELIM, E.P.V.; SENTA, N.D. - 1988 - Geologia do Maciço Anorogênico Cigano. Vale do Rio Parauapebas-PA. In: Congr. Bras. Geol., 35, Belém, 1988. Anais... Belém, SBG, v.3, p.1132-1146.

GUIDOTTI, C. V. - 1984 - Micas in metamorphic rocks. In: BAILEY, S. W.(Ed.) - 1084 Micas. Reviews in Mineralogy, p. 357-467.

HAAPALA, 1.-1977-Petrogrphy and geochemistry of the Eurajoki stock. A rapakivi-granite complex with greisen-type mineralization in southwestern Finland. Geol. Surv. Finland Bull., 286, 128p.

HAAPALA, I.-1995- Metallogeny of the Rapakivi. Granites. Mineralogy and Petrology, $54: 149-160$.

HAAPALA, I.; KINNUNEN, K. 1979 - Fluid inclusions in cassiterite and beryl in greisen veins in the Eurajoki Stock, Southwesthern Finland. Econ. Geol., v.74, p.1231-1238.

HAAPALA, I.; RÄMÖ, O. T. - 1990 - Petrogenesis of the proterozoic rapakivi granites of 
Finland. Geol. Soc. Am., 246: 275-286.

HAAPALA, I.; RÄMÖ, O. T.-1992- Tectonic setting and origin of the Proterozoic rapakivi granites of southeasthern Fennoscandia. Trans. R. Soc. Edinburgh, Earth Sci., 83:165171.

HAGGERTY, S. E.- 1991- Oxide texture- A Mini Atlas. In: LINDSLEY(ED.)-1991- Oxide Minerals Petrologic and Magnetic Significance. Min. Soc. Am. Rev. in Mineralogy, v.25, p.129-219.

HAMMARSTROM, J. M.; ZEN, E-NA. - 1986 - Aluminium in hornblende: An empirical igneous geobarometer. Amer. Mineral., 71, p.1297-1313.

HARRISON, T. N. - 1990 - Chemical variation in micas from the Cairngorm pluton, Scotant. Mineral. Magaz. v. 54 , n. 376 , p. 355-366.

HASELTON JR., H. T.; HOVIS, G. L.; HEMINGWAY, B. S.; ROBIE, R. A. - 1983 Calorimetric investigation of the excess entropy of mixing in analbite-sanidine solid solutions: lack of evidence for $\mathrm{Na}, \mathrm{K}$ short-range order and implications for two-feldspar thermometry. Amer. Miineral., v.68, p.398-413.

HASUI, Y.; HARALYI, N. I. E.; SCHOBBENHAUS, C.-1984 - Elementos geofísicos e geológicos da Região Amazônica: Subsídios para o modelo geotectônico. In: Anais do 2 Symp. Amaz.. Manaus, v.1, p.129-148.

HAWTHORNE, F. C.-1981- Crystalchemistry of the Amphiboles. Reviews in Mineralogy, v.9B, p.1-102.

HAWTHORNE, F. C.; CERNY, P. - 1982 - The mica group. Mac short course handbook. In: CERNÝ, P.(Ed.) - 1982 - MAC. Short course in Granitic Pegmatitic in Science and Industry, v. 8, p. 63-98.

HENDERSON, P. - 1996 - The rare earth elements: introdução and review. p.1-19. In: JONES, A. P.; WALL, F.; WILLIAMS, C. T.(Eds.) - 1996 - Rare Earth Minerals. Chemistry, origin and ore deposits. Chapman \& Hall, London. 372p.

HEWITT, D. A.; WONES, D. R. - 1975 - Physical properties of some synthetic Fe-Mg-Al triocthedral biotites. Amer. Mineral., v.60, p. 854-862. 
HEY, M. H. - 1954 - A reviews of the chlorites. Mineral. Magazine, n.224, vol. xxx, p.277292.

HIRATA, W.K.; RIGON, J.C.; KADEKARU, K.; CORDEIRO, A.C.; MEIRELES, E.M. 1982. Geologia Regional da Província Mineral de Carajás. In: Anais do $1 \mathrm{Simp.} \mathrm{Geol.} \mathrm{Amaz.,}$ Belém, 1982. Anais..., SBG, V.1, p.100-110.

HOEFS, J.-1980- Stable isotope geochemistry. Spring-Verlag, Beriin. 208p.

HOFMAN, A. W. - 1988 - Chemical differentiation of the Earth: the relationship between mantle, continental crust, and oceanic crust. Earth and Planetary Science Letters, 90, p.297-314.

HOLLAND, H. D.-1972- Granites, solutions and base metal deposits. Econ. Geol., p.281300.

HOLLISTER, L. S. - 1990 - Enrichment of $\mathrm{CO}_{2}$ in fluid inclusions in quartz by removal of $\mathrm{H}_{2} \mathrm{O}$ during crystal-plastic deformation. Journal of structural Geology, 12(7): 895-901.

HOLLISTER, L.S.; GRISSOM, G. C.; PETERS, E. K.; STOWELL, H. H.; SISSON, V. B. 1987 - Confirmation of the empirical correlation of Al in hornblende with pressure of solidification of calc-alkaline plutons. Amer. Mineral., 72, p.231-239.

HORBE, M. A.; HORBE, A. C.; COSTI, H. T.; TEIXEIRA, J. T.-1991- Geochemical characteristics of cryolite-tin-bearing granites from Pitinga Mine, northwestern Brazil - a review. In: ROSE, A. W.; TAUFEN, P.(Eds) - 1981 - Geochemical Exploration, 40:227249.

HORBE, M. A.; HORBE, A. C.; TEIXEIRA, J. T.; COSTI, H. T. - 1985 - Granito Madeira: petrologia, petroquímica e mineralizações. In: Anais do 2 Simp. Geol. Amaz., Belém. SBG, P.284-320.

HUTCHINSON, R. W.; CHAKRABORTY, K. R.-1979- Tin: a mantle or crustal source? Bull. Geol, Soc. Malaysia, 11: 71-79.

IDESP-1970- Programa de Pesquisa de Carvão Mineral na Bacia do Rio Fresco, afluente do Rio Xingu, Estado do Pará. Instituto de desenvolvimento Econômico-Social do Pará(IDESP). Relatório de Pesquisa II, Fase 2. Belém. 
ISHIHARA, S.-1977- The Magnatite- Series and IImenite- Series Granite Rocks. Mining Geology, v. 27, p.293-305.

ISHIHARA, S.-1981- The granitoid series and mineralization. Economic Geology, 75 th Anniversary volume, p.458-484.

ISSLER, R. S.-1974- Esboço Geológico Tectônico do Craton do Guaporé. Rev Bras. Geoc., 3:177-211.

ISSLER, R. S.; LIMA, M. I. C. - 1987 - Amazonic Craton(Brazil) granitogenesis and its relation to geotectonic units. Rev. Bras. Geoc., 17(4): 426-441.

JANASI, V. A - 1992 - Rochas sieníticas e mangeriticomcharnoquíticas Neoproterozóicas da região entre Caldas e Capestre, MG: Aspectos Petrológicos. Tese de Doutorado(Instituto de Geociências-USP). São Paulo. 298p.

JOHNSON, M. C.; RUTHERFORD, M. J. - 1988 - Experimental calibration of an aluminiumin-hornblende geobarometer applicable to calc-alkaline rocks. EOS, V.69, n. 44, p.1511. JOHNSON, C. M.; RUTHERFORD, M. J. - 1989a - Experimental calibration of the aluminium-in-hornblende geobarometer with application to Long Valley caldera(California) volcanic rocks. Geology, v. 17, p. 837-841.

JONES, A. P.; WALL, F.; WILLIAMS, C. T.(Eds.) - 1996 - Glossary of rare earth minerals, Appendix A. , p. 349-356. In: JONES, A. P.; WALL, F.; WILLIAMS, C. T.(Eds.) - 1996 Rare Earth Minerals. Chemistry, origin and ore deposits. Chapman \& Hall, London. $372 p$.

JUNG, J.; BROUSSE, R.-1959- Classification modale des roches eruptives utilizant les donnees fournier par le compteur de points. Paris, Mason, 129p.

KERRICH, R. - 1976 - Some effects of tectonic recrystallization on fluid inclusions in vein quartz. Contr. Mineral. Petrol., 59(2): 195-202.

KERRICH, R; BECKINSALE, R. D.; - 1988 - Oxygen and strontium isotopic evidence for the origin of granites in the tin belt of southeast Asia. Recent Advances in the Geology of Granite-Related Mineral Deposits. P. 114-123.

KINNAIRD, J. A.-1985- Hydrothermal alteration of the alcaline anaragenic complexes of 
Nigeria. Journal of African Earth Sciences, v.3, p.229-251.

KINNAIRD, J. A.; BOWDEN, P.; IXER, R. A.; ODLING, N. W. A.- 1985a - Mineralogy, geochemistry and mineralization of the Ririwai complex, northern Nigeria. Jour. Afr. Earth Sci., v.3, n. 1/2, p.185-222.

KINNAIRD, J. A.; BATCHELOR, R. A.; WHITLEY, J. E; MACKENZIE, A. B. - 1985b Geochemistry, mineralization and hydrothermal alteration of the Nigeria high heat producing granites. High heat prodution(HHP) granites, hydrothermal circulation and ore genesis the Instituition of Minning and Metallurgy, p.169-195.

KOVALENKO, V. I.-1978-The genisis of metal granitoids and related ore deposits. Metallization Associated with Acid Magmatism. Inter. Corr. Progr., v.3, p.235-247.

KOVALENKO, V. I.; KUZ'MIN, M. I.; LEINIKOV, F. A.-1970- Magmatic origin of lithium- and fluorine-bearing rare metal granite. Doklady Academy of Scieces USSR Earth Science Section, v.190, p.189-192.

KOVALENKO, V. I.; KOVALENKO, N. 1.-1984- Problems of the origin ore-bearing and evolution of rare-metal granitoids. Physics of the Earth and Planetary Interiors, 35(1/3): 51-62.

KRANIDIOTIS, P.; MACLEAN, W. H. - 1987 - Systematics of chlorite alteration at the Phelps Dodge Massive Sulfide Deposit, Matagami Quebec. Econ. Geol., v. 82, p.1898-1911.

KROBER, B. - 1986 - Whole grain evaporation for 207Pb/206Pb age investigations on single zircons using a double filament source. Contr. Mineral. Petrol., 93, p.482-490.

KROBER, B. -1987 - Single grain evaporation conbined with $\mathrm{Pb}+$ emitter bedding for $207 \mathrm{~Pb} / 206 \mathrm{~Pb}$ investigations using thermal ion mass spectrometry, ans implications for zirconology. Contr. Mineral. Petrol. 96, p.63-71.

KWAK, T. P.; BROWN, W. M.; ABEYSINGHE, P. B.; TAN, T. H. -1986 - Fe solubilities in very saline hydrothermal fluids: Their relation to zoning in some ore deposits. Econ. Geol., v.81, p.447-465.

LAFON, J. M.; MACAMBIRA, M. J. B.-1990- Datation Rb-Sr de la Granodiorite Cumaru, Serra dos Gradaús, PABR. C. R. Acad. Sci. Paris, 310(II): 1635-1641. 
LAFON, J. M.; PEREIRA, E. D.; MACAMBIRA, E. M. B.; VALE, A. G.; BARRADAS, J. A. S.1991-"Geocronologia Rb-Sr da região de São Felix do Xingu. Resultados preliminares". In: Anais do 3 Simp. Geol. Amaz., Belém, v.1, p. 21-35.

LAFON, J. M.; RODRIGUES, E.; DUARTE, K. D.-1994- Le granite Mata Surrão: un magmatisme monzogranitique contemporain des associations tonalitiquestrondhjémitiques-granodioritiques Archéennes de la région de Rio Maria(Amazonie Orientale, Brésil). C. R. Acad. Sci. Paris, 318: 643-648.

LAFON, J. M.; RODRIGUES, E.; MACAMBIRA, E M. B.; PEREIRA, E. D.-1995m Magmatisme anarogénique du Protérozoique Inférieur dans la région de São Felix do Xingu-Tucumã(Amazonie Orientale, Brésil). Nouvelles données geochronologiques. $C$. R. Acad. Sci. Panis, 320: 937-944.

LAMEYRE, J.; BOWDEN, P. - 1982 O Plutonic rock types series and related rocks. Journ. Voicanol. Geothermal. Research., 14:169-186.

LEAKE, B. E.-1978- Nomenclature of Amphiboles. Amer. Mineral., v. 63, p.1023-1052.

LEAKE, B. E; WOOLEY, A. R.; ARPS, C. E. S; BIRCH; GILBERT, M. C.; GRICE, J. D.; HAWTHORNE, F. C.; KATO, A.; KISCH, H. J.; KRIVOVICHEV, V. G.; LINTHOUT, K.; LAIRD, J.; MANDARINO, J. A.; MARESCH, W. V; NICKEL, E. H.; SCHUMACHER, J.; SMITH, J. C.; STEPHENSON, N. C. N.; UNGARETTI, L.; WHITTAKER, E. J. W.; YOUZHI, G. - 1997 - Nomenclature of amphiboles: report of the subcpmmittee on amphiboles of the international mineralogical association, commmission on new minerals and mineral names. Canad. Mineral., v.35, p. 219-246.

LEITE JR., W. B.-1992- O Maciço Oriente Novo(RO) e Mineralizaçào estano-tungstífera associada. Tese de Mestrado(IG/USP), 173p.

LE MAITRE, R. W.- 1976 - The chemical variability of some common igneous rocks. Jour. Petrol., v.17, Part 4, p.589-637.

LE MAITRE, R. W.-1989- A Classification of Rocks and Glossary of Terms. Blackwell Scientific Publication. 193p.

LEHMANN, B.-1987- Tin granites, geochemical heritage, magmatic differenciation. Geol. 
Rund., 76/1:177-185.

LEHMANN, B.; MAHAWAT, C. - 1989 - Metallogeny of tin in central Thailand: A genetic concept. Geology, V. 17, P.426-429.

LEHMANN, B. - 1990 - Metallogeny of Tin. Springer-Verlag, New York, 32211p.

LENHARO, S. L. R. - 1998 - Evolução magmática e modelo metalogenético dos granitos mineralizados da região de Pitinga, Amazonas, Brasil. Tese de Doutorado(Escola Politécnica da USP. Departamento de Engenharia de Minas). São Paulo, 290p.

LINNEN, R. L.; PICHAVANT, M.; HOLTZ, F.; BURGESS, S.-1995- The effect of $\mathrm{fO}_{2}$ on the solubility, diffusion, and spaciation of tin in haplogranite melt at $850^{\circ} \mathrm{C}$ and $2 \mathrm{kbar}$. Geochm. Cosmochm. Acta, v. 59, n. 8, p.1579-1588.

LINNEN, R. L.; PICHAVANT, M.; HOLTZ, F.-1996- The combined effects of $\mathrm{FO}_{2}$ and melt composition on $\mathrm{SnO}_{2}$ solubility and Tin diffusivity in haplogranitic melts. Geochm. Cosmochm. Acta, v. 60, n. 24, p.4965-4976.

LOISELLE, M. C.; WONES, D. R.-1979- Characteristics and origin of anarogenic granites. Geol. Soc. Am. Abst. Prog., v.11, p.468.

LUIZ-SILVA, W.; LEGRAND, J. M.; XAVIER, R. P. - 1997 - Natureza dos fluidos em diferentes gerações de veios de quartzo no depósito aurifero São Francisco, Nordeste do Brasil. Rev. Esc. Minas, Ouro Preto, 50(2): 45-50.

LUZHNAJA, N. P.; VERESHTCHETINA, I. P. - 1946 - Sodium, calcium, magnesium chlorides in aqueous solutions at -57 to $+25^{\circ} \mathrm{C}$ (polythermic solubility). Zhurnl. Prike. Khimii, 19, 723-733.

MACAMBIRA, E. M. B.; VALE, A. G.-no prelo- Programa levantamentos geológicos básicos do Brasil. Programa Grande Carajás. São Felix do Xingu. Folha SB-22-Y-B. Estado do Pará. Texto(Belém). DNPM/CPRM.

MACAMBIRA, E. M. B.; JORGE JOÃO, X. S.; LAFON, J. M.; PEREIRA, E. D. - 1992 Aspectos geológicos e geomorfológicos do Granito Parauari no Domínio da Folha São Felix do Xingu(SB-22-Y-B)- Sul do Pará. Anais do 37 Congr. Bras. Geol., São Paulo, Boletim de Resumos Expandidos, v.2, p.171-172. 
MACAMBIRA, E. M. B.; VALE, A. G.; JORGE JOÃO, X. S.; COSTA, J. B. S. - $1994-0$ quadro geológico da Folha São Felix do Xingu(SB-22-Y-B), SE do Estado do Pará. Anais do 38 Congr. Bras. Geol., Balneário de Cambouriú. Boletim de Resumos Expandidos, p.111-112.

MACAMBIRA, M. J. B. - 1992 - Chronologie U-Pb, Rb-Sr, K-Ar et croissance de la croûte continentale dans l' Amazonie du Sud-Est; exemple de la région de Rio Maria, Province de Carajás, Brésil. Tese de Doutorado(Univ. Montpellier II). Montpellier, France. 212p.

MACAMBIRA, M. J. B.; LAFON, J. M.; DALL'AGNOL, R.; JORGE JOÃO, X. S.; COSTI, H. T.-1990- Geocronologia da granitogênese da Província Amazônia Central Brasileira: uma revisão. Rev. Bras. Geoc., 20:258-266.

MACAMBIRA, M. J. B.; LANCELOT, J.-1991a- Em busca do embasamento Arqueano da região de Rio Maria, sudeste do Esrado do Pará. In: Anais do 3 Simp. Geol. Amaz., v.1, p. 49-58.

MACAMBIRA, M. J. B.; LANCELOT, J.-1991b- História Arqueana da Região de Rio Maria, SE do Estado do Pará., registrada em zircões detríticos de greenstone belts e de cobertura plataformal. In: Anais do 3 Simp. Geol. Amaz., Belém, v.1, p. 59-69.

MACAMBIRA, M. J. B.; LAFON, J. M.; BARRADAS, J. A S.-1991- Le granite de Xinguara, témoin d'un magmatisme monzogranitique dans l'Archéen de l'Amazonie Orientale, Brésil. C. R. Acad. Sci. Paris, 313(II):781-785.

MACAMBIRA, M, J. B.; LANCELOT, J.-1992- Idade U-Pb em zircões de metavulcânicas do greenstone do Supergrupo Andorinhas; delimitante da estratigrafia Arqueana de Carajás, Estado do Pará. In: 37 Congr. Bras. Geol., São Paulo, Resumos Expandidos, v.2, p. $188-189$.

MACAMBIRA, M. J. B.; BARBOSA, A. A.; LAFON, J. M.-1993- Uma história geológica complexa a partir de estudos de sistemas geocronológicos abertos $\mathrm{Rb}-\mathrm{Sr}$ e U-Pb em zircões. In: Anais do 4 Congr. Bras. Geoq., Brasília, v.1, p. 238-249.

MACAMBIRA, M. J. B.; LAFON, J. M.-1994- Geocronologia da Província Mineral de Carajás:

Sintese dos dados e novos desafios. In: 4 Simp. Geol. Amaz., Belém, Resumos 
Expandidos, v.1, p. 339-342.

MACAMBIRA, M. J. B.; LAFON, J. M.-1994- Geocronologia da Província Mineral de Carajás:

Síntese dos dados e novos desafios. Bol. Mus. Para. Emílio Goeldi, Sér. Ciênc. Da Terra, 7, p.263-287.

MACHADO, N.; LINDENMAYER, Z.; LINDENMAYER, D. - 1988 - Geologia U-Pb da Província Mineral de Carajás, Pará: resultados preliminares. Anais do 7 Congr. Latinoam. Geol., Belém, 1988, Belém, SBG: 339-347.

MACHADO, N.; LINDENMAYER, Z.; KROGH, T. E.; LINDENMAYER, D.-1991- U Pb geochronology of Archean magmatism and basement reactivation in the Carajás área, Amazon Shield, Brazil. Precabrian. Research., 49:329-354.

MAGALHÃES, M. S.-1991- Minerais opacos e susceptibilidade magnética de granitóides da Amazônia Oriental: Implicações Petrológicas. Tese de Mestrado(Centro de Geociências/UFPA). Belém, 247p.

MACKENZIE, W. S.; DONALDSON, C. H.; GUILFORD, C. - 1982 - Atlas of igneous rocks and their textures. Longman Scientific \& Technical. John Wiley \& Sons, New York, $148 \mathrm{p}$.

MANIAR, P. D.; PICCOLI, P. M. - 1989 - Tectonic Discrimination of granitoids. Geol. Soc. Amer. Bull., v.101, p.635-643.

MANNING, D. A. C.-1981- The effect of fluorine on liquidus phase relationships in the system Qz-Ab-Or with excess water at $1 \mathrm{Kg}$. Contr. Mineral. Petrol., v.76, p.206-215.

MANNING, D. A. C.-1982- An experimental study of the fluorine on the cristalization of granitic rocks melts. In: EVANS, A. M.(Ed.). Metallization Associated with Acid Magmatic. John Wiley \& Sons., p.191-203.

MANNING, D. A. C.; HILL, P. 1.-1990- The petrogenetic and metallogenetic significance of topaz granite from the southwest England orefield. In: STEIN, H. J.; HANNAH, J. L.(Eds). Ore-bearing granite systems. Petrogenesis and mineralizing processes. Geological Society of America Special Paper, 246, p.51-69.

MANNING, D. A. C.; HENDERSON, P.-1984- The behavoir of tungsten in granitic melt- 
vapor systems. Contr. Mineral. Petrol., v.86, p.286-292.

MARINI, O. J.; BOTELHO, N. F.; ROSSI, P.-1992- Elementos terras raras em granitóides da Província Estanifera de Goiás. Rev Bras. Geoc., 22(1): 61-72.

MARRE, J. 1982. Methodes D'analyses Structurale des granitoides. Manuels et méthodes, $n^{\circ}$ 3. Orléans, BRGM. 128p.

MEDEIROS, H.-1987- Petrologia da porção leste do batólito granodiorítico Rio Maria, sudeste do Pará. Tese de Mestrado(Centro de Geociências/UFPA). Belém, 166p.

MELO, I. S. C.-1995- Geologia e estudo metalogenético do Maciço Itaoca, Vale do Rio Ribeira, SP e PR. Tese de Doutorado(Instituto de Geociências/USP). São Paulo, 168P. MIDDELAAR, W. T.: KEITH, J. D.-1990- Mica chemistry as an indicator of Oxygen and Halogen fugacities in the Can Tung and other W-related granitoids in the North America Cordillera. Geological Society of America Special Paper, 246:205-220.

MILLER, C. F.; MITTLEFEHLDT, D.W. - 1982 - Depletion of light rare-earth elements in felsic magmas. Geology, v.10, p.129-133.

MILLER, C. F.; STODDARD, E. F.; BRADFISH, L. J.; DOLLASE, W. A. - 1981 - Composition of plutonic muscovite. Can. Min., v. 19. p.25-34.

MÖLLER, P.; MORTEANI, G.; HOEFS, J. - 1985 - REE and ${ }^{18} \mathrm{O} /{ }^{16} \mathrm{O}$ distribuitions in altered Variscan granites of the Western Harz, Germany, and southern Sardinia, Italy. High heat production(HHP) granites, hydrothermal circulation and ore genesis. The Instituition of Mining and metallurgy. p. 213-220.

MOLNÁR, F.; WATKINSON, D. H.; EVEREST, J. O. - 1999 - Fluid-inclusions characteristics of hydrothermal Cu-Ni-PGE veins in granitic and metavolcanic rocks at the contact of the Little Stobia deposit, Sudbury, Canada. Chemical Geology, 154, p.279-301.

MONIER, G.; ROBERT, J.-L. - 1986b - Evolution of the miscibility gap between muscovita and biotite solid solutions with increasing lithium content: an experimental study in the system $\mathrm{K}_{2} \mathrm{O}-\mathrm{Li}{ }_{2} \mathrm{O}-\mathrm{MgO}-\mathrm{FeO}-\mathrm{Al}_{2} \mathrm{O}_{3}-\mathrm{SiO}_{2}-\mathrm{H}_{2} \mathrm{O}-\mathrm{HF}$ at $600^{\circ} \mathrm{C}$, $2 \mathrm{Kbar} \mathrm{PH}_{2} \mathrm{O}$ : comparison with natural lithium micas. Mineral. Magaz., v. 50, 0.641-651.

MONIER, G.; MERGOIL-DANIEL; LABERNARDIĖRE, H. - 1984 - Générations sucessives 
de muscovites et feldspaths potassiques dans les leucogranites du massif de Millevaches(Massif Central Français). Bull. Minèral., 107, p.55-68.

MONIER, G.; CHAROY, B.; CUNEY, M.; OHNENSTETTER, D.; ROBERT, J. L. - 1987 Evolution spatiale et temporelle de la composition des micas du granite albitique à topaze-lépidolite de Beauvoir. Géologie de la France, n² 2-3, p. 179-188.

MOOEHOUSE, W. W - 1959 - The study of rocks in thin section. Harper \& Brothers. New York, 514p.

NACHIT, H. - 1994 - Contribuition à la typologie des granitoïdes, Petrogenèse et Petrologie structurale du Batholite Panafricain du Cercle de Tafraoute(Boutonniére de Kerdous, Anti-Atlas Occidental, Maroc). Thése d'état( Université Ibhou Zohor). Agadir, 465p

NACHIT, H.; RAZAFIMAHEFA, N.; STRUSSI, J. M.; CARRON, J. P. - 1985 - Composition chimique des biotites et typologie magmatique des granitoïdes. C. R. Acad. Sc. Paris, t. 301 , Série II, n. 11.

NEARY, C. R.; HIGHLEY, D. E. - 1984 - The economic importance of the rare earth elementes. In: HENDERSON, P.(Ed.) - 1984 - Rare Earth Element Geochemistry. Elsevier, New York, p.423-466.

NEIVA, A. M. R.-1982- Geochemistry of muscovite and some physical-chemical conditions of the formation of some tin-tungsten deposits. Metallization Associated whit Acid Magmatism. John Wiley \& Sons Ltd., p.243-259.

NEKVASIL, H. - 1994 - Ternary feldspar/melt equilibria: a review. In: PARSON, I.(Ed.) - 1994 - Feldspars and their reactions. Kluwer Academic Publishers. Printed in the Netherlands., 195-219.

NIMER, E. - 1989 - Climatologia do Brasil. Secretaria de Planejamento e Coordenação da Presidência da República. Fundação Instituto Brasileiro de Geografia e Estatística(IBGE). Departamento de Recursos Naturais e Estudos Ambientais-DERNA. $421 \mathrm{p}$.

NOCKOLDS, S. R. -1947 - The relation between chemical composition and paragenesis in the biotite micas of igneous rocks. Am. Jour. Sci., v. 245, n. 7, p.401-420. 
OAKES, C. - 1997 - Short discussion of apparent low eutetic temperature observations that was held during June 1997. http://www.geology.wisc.edu/ pbrown/loweutec.html.

OLADE, M. A.-1980- Ceochemical characteristics of tin-bearing and tin-barren granites, Northern Nigeria. Econ. Geol., v. 75, p.71-82.

OLIVEIRA, A. I.-1928- Reconhecimento Geológico do Rio Xingu, Estado do Pará. Boletim de Serviço Geológico e Mineralógico. Rio de Janeiro, 29: 2-22.

OLLILA, , J. T. - 1984 - Partitioning of barium between coexisting k-feldspars ans plagioclases in the Bushveld Granites from the Zaaiplaats Area, South Africa. Bull. Gool. Soc. Finland, 56, Part 1-2, p.53-57.

OLSZEWSKI, W. J.; WIRTH, K. R.; GIBBS, A. K.; GAUDETTE, H. E.-1989- The age, origin and tectonics of the Grão Pará Group and associated rocks, Serra dos Carajás, Brésil. Archean continental volcanism and rifting. Precabrian. Research., 42: 229-254.

O'NEIL, J. R.; SHAW, S. E.; FLOOD, R. H.-1977- Oxygen and Hydrogen Isotope compositions as indicators of granite genesis in the New England Batholith, Australia. Contr. Mineral. Petrol., 62:313-328.

PEARCE, J. A.; HARRIS, N. B. W; TINDLE, A. C.-1984- Trace Elements discrimination diagrams for the tectonic interpretation of granitic rocks. Jour. Petrol., v.25, p. 956-983.

PETERS, E. K.; GRISSOM, G. C.; HOLLISTER, L. S.; SISSON, V. B.; STOWELL, H. H. 1985 - Pressure of crystallization of Calcalkaline Plutons besed Aluminium content of hornblende. EOS, V.66, V52A-13.

PHILLIPS, E. R. - 1974 - Myrmekite- one hundred years later. Lithos, v.7, p. 181-194.

PICHAVANT, M.-1981- An experimental study of the effect of boran on a water satured haplogranite a 1 kbar vapour presure. Contr. Min. Petrol., v.76, p.430-439.

PICHAVANT, M. - 1987 - Effects of $\mathrm{B}$ and $\mathrm{H} 2 \mathrm{O}$ on liquidus phase relations in the haplogranite system at $1 \mathrm{kbar}$. Amer. Mineral., 72, p.1056-1070.

PIMENTEL, M. M.; MACHADO, N.-1994- Geocronologia U-Pb dos terrenos granitogreenstone de Rio Maria, Pará. In: 38 Congr. Bras. Geol., Resumos Expandidos, v.2, p.390-391. 
PINHEIRO, R. V. L. - 1997 - Reactivation history of the Carajás and Cinzento Strik-Slipe System, Amazon, Brazil. Thesis PhD(Department of Geological Sciences/University of Durham). Durham, 407p.

PINHO, O. - inédito -Geologia e Mineralizções de Sn no maciço Caritianas, Rondônia. texto preliminar de Dissertação de Mestrado(linstituto de Geociências/USP). São Paulo, $248 p$.

PITCHER, W.S. - 1979 - The nature, ascent and empacement of granitic magmas. Jour. Geol. Soc London, v. 136:627-662.

PITCHER, W. S.-1983- Granite type and tectonic environment. In: HUS, K. - 1983 Mountain Building process. London, Academic Oress, p.19-40.

PITCHER, W. S. - 1987 - Granites and yet more granites forty years on. Geol. Runds. 76/1, p.51-79.

PITCHER, W. S.- 1995- The Nature and Origin of Granite. Blackie Academic \& Professional, New York, 321p.

PLIMER, I. R.; KLEEMAN, J. D.-1991- Geology, geochemistry and genesis of the Sn-W deposits associated with the Mole Granite, Australia. In: PAGEL \& LEROY(Eds.) - 1991

-. Source, Transport and Deposition of metals, p.785-788.

POLLARD, P. J.-1983- Magmatic and Postmagmatic processes in the formation of rocks, associated whith rare-element deposits. Trans. Inst.. Min. Metall.(Sect. B ), 92: B1-B9.

POLLARD, P.J. - 1988 - Petrogenesis of tin-bearing granites of the Emuford district, Heberton tinfield, Australia. Austr. Earth Sci., 35:39-57.

POLLARD, P. J.-1989a- Geochemistry of granites associated with Tantalum and Niobium mineralization. In: MÖLLER, P.; CERNY, P.; SAUPÉ, F.(Eds.)- 1989 - Lanthanides, Tantalum and Niobium. Spring-Verlag, Berlin, p.145-168.

POLLARD, P. J.-1989b- Geologic characteristics and genetic problems associated with the development of granite-hosted deposits of Tantalum and Niobium. In: MÖLLER, P.; CERNY, P.; SAUPE, F.(Eds.)- 1989 - Lanthanides, Tantalum and Niobium. SpringVerlag, Berlin, p.240-260. 
POLLARD, P. J.-1995a- Geology of rare metals deposits: An introduction and overview. Econ. Geol, v.90, n. 3, p.489-494.

POLLARD, P. J. - 1995b - Granites and Related Mineralization. Notes to accompany a short course presented at the Universidade Federal do Pará, Belém, Brasil, 22-24 August.

POLLARD, P. J.; TAYLOR, R. G.-1986- Progressive evolution of alteration and tin mineralization: Controls by intersticial permeability and fractured-related tapping of magmatic fluid reservoirs in tin granites. Econ. Geol., v.81, p.1795-1800.

POLLARD, P.J.; MILBURA, D.; TAYLOR, R.G.; GUFF, C. - 1983 - Examination of textural features of a series of granites of the Herberton Mt-Gernet tin field-Queenslandm Australia. In: Press. Permian Conf. Geol. Soc. Australia (brisbane). 27p.

POLLARD, P. J.; TAYLOR, R. G.; TATE, N. M. - 1989 - Textural evidence for quartz and feldspar dissolution as a mechanism of formation for Maggs Pipe, Zaaiplaats tin mine, South Africa. Mineral. Deposita, v. 24: 210-218.

POLLARD, P. J.; NAKAPADUNGRAF, S.; TAYLOR, R. G.-1995- The Phuket Supersuite, Southwest Thailand: Fractionated 1-Type granites associated with tin-Tantalum mineralization. Econ. Geol., v.90, n.3, p.586-602.

POTY, B.; LEROY, J.; JACHIMOWICZ, L. - 1976 - Un nouvel appareil pour la mesure des températures sous le microscope: L'instaliation de microthermométrie Chaimeca. Beelletin de la Société Française de Minéralogie et de Cristallographie, 99:182-186.

POWELL, R.; EVANS, J. A. - 1983 - A new geobarometer for the assemblage biotitemuscovite-chlorite-quartz. Journal of Metamorphic Geology, v.1, p.331-336

RAGLAND, P. C. - 1989 - Basic Analytical Petrology. Oxford University Press, Oxford. ?p.

RAMDHOR, P.-1980 - The ore minerals and their intergrowths. Int. Ser. in Earth Sci., v.25, Pergamon Press, Frankfurt, 1205p.

RÄMÖ, O. T.; HAAPALA. 1.-1995- One hundred years of Rapakivi Granite. Mineralogy and Petrology, 52:129-185.

RICHARD, L. R. - 1995 - Minpet Software. Mineralogical and Petrological Data Processing System. Versão 2.02. Copyright(1988-1995). 
RICHARD, L. R.; CLARK, D. B. - 1990 - Amphibol: A program for calculating structural formulae and for classifying and plotting chemical analyses of amphiboles. Amer. Mineral. , v.75, p.421-423.

RICHARDSON, J. M. - 1988 - Field and textural relationships of alteration and greisenhosted mineralization at the East Kemptvile tin deposit, Davis Lake Complex, Southwest Nova Scotia. Recent Advances in the Geology of Granites- Related Mineral Deposits. Can. Inst. Min. Metal., Special Volume, 39, p.265-279.

RIOS, F. J. -1991- O Granito Central da Serra dos Carajás: Facies petrográficas e alteração hidrotermal do setor norte. Tese de Mestrado/Curso de Pós-graduação em Geociências-UFPA), Belém, 124p.

RIOS, F. J. - 1995 - A jazida de wolframita de Pedra Preta, Granito Musa, Amazônia Oriental(PA): Estudo dos fluidos mineralizantes e Isótopos Estáveis de Oxigênio em veios hidrotermais. Tese de Doutorado(Curso de Pós-graduação em Geociências UFPA), Belém, 215p.

RODRIGUES, E. S.; LAFON, J. M.; SCHELLER, T.-1992- Geocronologis Pb-Pb da Província Mineral de Carajás: Primeiros resultados. In: 37 Congr. Bras. Geol., São Paulo. Boletim de Resumos, v.2, p.183-184.

ROEDDER, E. W.-1984- Fluid Inclusions. Reviews in Mineralogy. Min. Soc. Am., v.12, 641p. ROEDDER, E. W. - 1997 - Short discussion of apparent low eutetic temperature

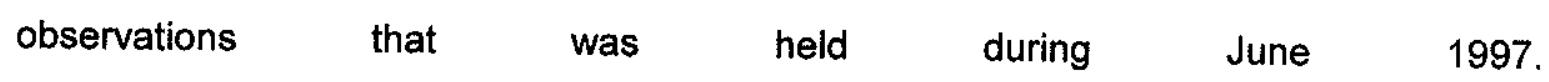

http://www.geology.wisc.edu/ pbrown/loweutec.html.

ROLLINSON, H.-1993- Using geochemical data: evaluation, presentation, interpretation. Longman Group UK Ltd., 351p.

ROSSI, PH.; COCHERIE, A; MEYER, G.; FOUILLAC, A. M.; AUTRAN, A.-1988Metallogenetic $W$ and $S n$ Granites: Genesis and main distinguishing features. In: BOISSONNAS, J; OMENETTO, P.(Eds)- 1988 - Mineral deposits within the European Community. Spring-Verlag, Berin, p.3-28.

ROUBAUT, M. -1963 - Détermination des Minéraux des Rochas au microscope Palarisant. 
Éditions Lamarre-Poinat, Paris, 365p.

RUTHERFORD, M. J. - 1973 - The fase relations of aluminous iron biotitas in the system $\mathrm{KAISi}_{3} \mathrm{O}_{8^{-}} \mathrm{KAISiO}_{4^{-}} \mathrm{Al}_{2} \mathrm{O}_{3}-\mathrm{Fe}-\mathrm{O}-\mathrm{H}$. Jour. Petrol., v.14, part 1, p.159-180.

RUTTER, M. J.; LAAN, S. R. van der; WYLLIE, P. J. - 1989 - Experimental data for a proposed empirical igneous geobarometer: Aluminium in hornblende at 10kbar pressure. Geology, v.17, p.897-900.

SA, C.A.S. - 1985 - Esboço da geologia da área do Granito Antônio Vicente, S. Félix do Xingu (PA). In: Anais do 2 Simp. Geol. Amaz., Belém, SBG, v.1, p.182-193.

SALONSAARI, P. T. - 1995 - Hybridization in the subvolcanic Jaala-litti Complex and its petrogenetic relation to rapakivi granites and associated mafic rocks of southeastern Finland. Academic Dissertation. Bull. Geol. Soc. Finland, n. 67, Part 1b, 104p.

SAMSON, S. D. ; COLER, D. G.; SPEER, J. A.-1995- Geochemical and Nd-Sr-Pb isotopic composition of Alleghanian granites of the southern Appalachians: origin, tectinic setting, and source characterization. Earth and Planet. Scien. Lett., 134:359-376.

SANTOS, D. B.; FERNANDES, P. E. C. A.; DREHER, A. M.; CUNHA, F. M. B.; BASEI, M. A. S.; TEIXEIRA, J. B. G. - 1975 - Geologia da Folha SB-21, Tapajós. Projeto Radam. Levantamento de Recursos Naturais. Vol. 7, p.15-116.

SANTOS, M. D. - 1996 - O papel dos granitóides na gênese dos depósitos de ouro tipo lode Arqueano: caso da jazida do Cumaru-PA. Tese de Doutorado(Instituto de GeociênciasUniversidade de Brasilia). Brasília, 157p.

SATO, K.; TASSINARI, C. C. G.; KAWASHITA, K.; PETRONILHO, L.- 1995 - O método geocronológico Sm-Nd no IG-USP e suas aplicações. Anais Acad. Bras. Cienc., 67(3),p.313-336.

SATO, K. - 1997 - The double stage Sm-Nd model age and aplications to Brazilian Platform rocks. In: South-American Symposium on Isotope Geology. Extended Abstracts. Campos do Jordão, São Paulo, p.286-288.

SATO, K. - 1998 - Evolução crustal da Plataforma Sul-Americana, com base na geoquímica isotópica Sm-Nd. Tese de Doutorado(Instituto de Geociências-USP), São Paulo. 299p. 
SCHERBA, G. N.-1970- Greisens. Int. Geol. Rev., v.12, p114-150 and 239-255.

SCHMIDT, M. W. - 1992 - Amphibole composition in tonalite as a function of pressure: An experimental calibration of the Al-in-hornblende barometer. Contr. Mineral. Petrol., 110, p.304-310.

SCHOBBENHAUS, C; CAMPOS, D. A; DERZE, G. R.; ASMUS, H. E. - 1981 - Mapa geológico do Brasil e da área Oceânica adjacente, incluindo os depósitos minerais. Brasília, Ministério das Minas e Energia/DNPM.

SCHWARTZ, G. M. -1931 - Textures due to unmixing of solid solution. Econ. Geol., 26, p.730-763.

SCHWARTZ, M. O.-1992- Geochemical criteria for distinguishing magmatic and metasomatic albite-enrichment in granitoids-examples from the Ta-Li granite Yichun(China) and the Sn-W deposit Tiku(Indonesia). Mineral Deposita, 27: 101-108.

SEREBRYAKOVA, V. A.-1961- Autometasomatic alteration of granitoids and association of tin mineralization whit the zone of sodium-potassium metasomatism. Inter. Geol Review, n.2, p.100-113.

SHAND, S. J.-1922- The Problem of the Alcaline Rocks. Proc. Geol. Soc. S. Afr., 25, XIXXXXIII.

SHAW, D. M. - 1968 - A review of K-Rb fractionation trends by covariance analysis. Geochm. Cosmochm. Acta, v. 32, p. 573-601.

SHAW, D. M.; CRAMER, J. J.; HIGGINES, M. D.; TRUSCOTT, M. G. - 1986 - Composition of the Canadian Precambrian shield and the continental crust of the earth. Geol. Soc. Spec. Publ., 24, Blackwell, p.275-282.

SHEPHERD, T. J.; RANKIN, A. H.; ALDERTON, D. H. H. - 1985 - A pratical guide to fluid inclusions estudies. Blackie and Son Ltda, New York, 239p.

SILLITOE, R. H.-1974- Tin mineralization above mantle hot spot. Nature, 248:497-499.

SILVA, G.G.; LIMA, J.J.C.; ANDRADE, A.R.F.; ISSLER, R.S.; GUIMARÃES, G. - 1974 Geologia da Folha SC. 22/Tocantins. In: Projeto Radam Brasil. rio de Janeiro, DNPM, v.4, p.1-143. 
SILVERMAN, R. S.-1951- The isotope geology of Oxygen. Geochm. Cosmochm. Acta, 2:2642.

SIMÕES, P. M. M. P. - 1992 - Caracterização petrográfica, mineralógica e geoquímica de granitos de duas micas da região de Viana do Castelo- Vila Praia de Âncora(NW de Portugal). Tese de Mestrado(Departamente de Ciências da Terra/Universidade do Minho), Minho-Portugal, 157p.

SMITH, J.V. - 1974 - Feldspar minerals: Chemical and textural properties. Berlim. SpringVerlag., v.2, p.206-247.

SMITH, J. V. ; BROWN, W. L. -1988 - Feldspar minerals. 2ªEd., Spring-Verlag/Berlin, 828p.

SOARES, P.C.; FIORI, A.P. 1976. Lógica e sistemática na análise e interpretação de fotografias aéreas. Notícias Geomorfológicas. Campinas, 16(3):71.

SOARES, A. D. V.; BERNARDELLI, A. L.; MEDEIROS FILHO, C. A.; BASTOS, J. M. E.; MARTINS, L. P. B. LOURENÇO, R. S.-1988 - Geologia regional das cabeceirasa do igarapé Aquiri, extremo oeste da Província Carajás(PA). In: Anais do 35 Congr. Bras. Geol., Belém, v.5, p.2704-2712.

SOUZA, E. C.; MARQUES, M. T. G. -1994 - Aspectos litogeoquímicos e metalogenéticos do granito Velho Guilherme, na região São Félix da Xingu, centro-sul do Pará, Brasil. In: Anais do IV Simp. Geol. Amaz., SBG, Belém. P.383-386

SPEER, A. J. - 1984 - Micas in igneous rocks. In: Bailey, S. W.(Ed.) - 1984 - Micas. Reviews in Mineralogy, p. 299-356.

STACEY, J. S.; KRAMER, J. D. - 1975 - Approximation of terrestrial lead isotope evolution by a two-stage model. Earth Planet. Sci. Lett., 26, p.207-221.

STEMPROK, M.-1978a - Classification criteria of tin, tungsten and molybdenum deposits. Metallizatiom Associated with Acid Magmatism. St. Geol., special issue, 14: 119-143. STEMPROK, M.-1978 b- Differentiation of same elements by ore-bearing granites. Metallization Assiciated with Acid Magmatism. Inter. Geol. Corr. Progr., v.3, p.393-403. STEMPROK, M. - 1987 - Greisenization(a review). Geol. Runds., v.76, n.1, p.169-175. STRECKEISEN, A. - 1976 - To each plutonic rocks its proper name. Earth Sci. Rev., 12, 
1:33.

STRONG, D. F.-1988- A review and model for granite-related mineral deposits. Recent Advances in the Geology of Granite Related Mineral Deposits., p.425-445.

SUN. S. S. - 1982 - Chemical composition and origin of the Earth's primitive mantle. Geochm. Cosmochm. Acta, v. 46, p.179-197.

SUWIMONPRECHA, P.; CERNY, P.; FRIEDRICH, G.-1995-Rare metal mineralization related to granites and pegmatites, Phuket, Thailand. Econ. Geol., v.90, p.603-615.

SYRITSO, L. F.; ZALASHKOVA, N. Ye.; ZORINA, M. L.; SOKOLOVA, Ye. P.-1970- Micas metassomatically altered granites of the acid series. Inter. Geol. Rev, v. 3, n.5, p.717729.

TAKAHASHI, M.; ARAMAKI, S.; ISHIHARA, S.-1980- Magnetite-Series/limenite-Series v.s. IType/S-Type granitoids. Mining Geology Special /ssue, n. 8, p. 13-28.

TASSINARI, C. C. G. -1996 - O mapa geocronológico do Craton Amazônico no Brasil: Revisão dos dados Isotópicos. Tese de Livre Docência(Instituto de Geociências/ USP). $139 \mathrm{P}$.

TAUSON, L. V.; KOZLOV, V. D.; KUZ'MIN, M. I.-1968- Geochemical criteria of potencial orebearing in granite intrusions. In: XXIII Inter. Geol. Congr., v.6, p.123-129.

TAYLOR, S. R. - 1964 - Abundance of chemical elements in the continental crust: a new table. Geochm. Cosmochm. Acta, v. 28, p.1273-1285.

TAYLOR, S. R. - 1965 - The application of trace element data to problems in Petrology. p. 133-213. In: AHRENS, L. H.; PRESS, F. RUNCORN, S. K.; UREY, H. C.(Eds.) - 1965 Physics and chemistry of the earth. Pergamon Press, New York, v.6, 510p.

TAYLOR JR., H. P.-1968- The Oxygen isotope Geochemistry of igneous rocks. Contr. Mineral. Petrol., 19:1-71.

TAYLOR JR., H. P.-1978- Oxygen and Hydrogen isotope studies of plutonic granitic rocks. Earth Plan. Lett., 38:177-210.

TAYLOR JR., H. P.-1988 - Oxygen, hydrogen, and strontium isotope constrainsts on the origin of granites. Transactions of the Royal Society of Edinburg: Earth Sciences, 79, p 
317-338.

TAYLOR, R. G. - 1979 - Gelogy of tin deposits. Amsterdam, Elsevier, 543p.

TAYLOR, R. G.; POLLAR, P. J. - 1988 - Pervasive hydrothermal alteration in tin-bearing granites and implications for the evolution of ore-bearing magmatic fluids. Recent Advances in the Geology of Granite-Related Mineral Deposits. Can. Inst. Min. Metal., Special Volume, 39, p. 86-95.

TAYLOR, R. G.; WALL, V. J.-1992- The behavoir of tin in granitoid magmas. Econ. Geol., v.87: 403-420.

TAYLOR, S. R.; MCLENNAN, S. M - 1985 - The continental crust: its composition and evolution. Blackwell. 312p.

TEIXEIRA, N.P.; DALL'AGNOL, R. - 1990 - Geologia a petrografia do maciço granítico Antonio Vicente, Região de São Félix do Xingu - PA. In: 36 Congr. Bras. Geol. Boletim de Resumos. Natal, SBG. Breves Comunicações, p.218-219.

TEIXEIRA, N.P.; DALL'AGNOL, R. - 1991- Geologia e petrografia do Maciço Granítico Antônio Vicente. Região de São Félix do Xingu/PA. Boletim do Museu Paraense Emíli Goeldi. Série Ciências da Terra, CNPq, v.3, p.45-73.

TEIXEIRA, N. P.; ANDRADE, W. L. G.-1992- Cracterização Petrográfica dos "stocks" graníticos Benedita e Ubim/Sul. Região de São Felix do Xingu/PA. Boletim do Museu Paraense Emilio Goeldi, Série Ciências da Terra, CNPq, v.4, 3-33.

TEIXEIRA, N. P.; DALL'AGNOL, R.; MAGALHÃES, M. S.- 1994- Complexo granítico Antônio Vicente: Feições características de um granito especializado a estanho. In: IV Simp. Geol. Amaz., Belém,SBG, Boletim de Resumos, 391-393.

TEIXEIRA, N. P.; BETTENCOURT, J. S.; MOURA, C. A. V.; DALL'AGNOL, R. - 1998 - Pb$\mathrm{Pb}$ and $\mathrm{Sm}-\mathrm{Nd}$ constraints of the Velho Guilherme Intrusive Suite and volcanic rocks of the Uatumã Group. South-Southeast Pará-Brasil. Inter. Geol. Corr. Project 426: Granite Systems and Proterozoic Lithospheric Processes. Wisconsin(EUA), Part III, p. 178-180. TEIXEIRA, W.; TASSINARI, C. C. G.; CORDANI, U. G.; KAWASHITA, K.-1989 A review of the geochronology of the Amazonian Craton: tectonic implication. Precambrian. 
Research., 42: 213-227.

THOMAS. A. V.; SPOONER, E. T. C. - 1985 - Occurence, petrology and fluid inclusions characteristics of tantalum mineralization in the Tanco granitic pegmatite, S.E. Manitoba. In: Taylor, R. P.; STRONG, D. F.(Eds.) - 1985 - Granite-related Mineral Deposits Geology, petrogenesis and tectonic setting, CIM Conference on Graniterelated Mineral Deposits. p. 274-279.

THOMPSON, J. B.; LAIRD, J.; THOMPSON, a B. - 1982 - Reactions in amphibole, greenschist and blueschist. Journ. Petrol., 23. p.1-27.

TINDLE, A. G.; WEBB, P. C. -1990 - Estimation of litium contents in trioctahedral micas using microprobe data: application to micas from granitic rocks. Eur. J. Mineral, v.2., p. 595-610.

TISCHENDORF, G.-1977- Geochemical an Petrographics characteristics of silic magmatic rocks associated with rare-elements mineralization. In: SPEMPROK, M. S.; BURNOL, L.; TISCHENDORF, G.(EDs.). Metallization associated with acid magmatism. Inter. Geol. Corr. Program., Prague, 2: 41-96.

TISCHENDORF, G.; GOTTESMANN, B.; FORSTER, H-J.; TRUMBULL, R. B. - 1997 - On Li-bearing micas: estimating $\mathrm{Li}$ from electron microprobe analyses and na improved diagram for graphical representation. Mineral. Magaz., v.6, p.809-834.

TURNER, F. J. - 1968 - Metamorphic Petrology. McGraw-Hill Book Company, New Yok, $403 p$.

TURNER, F. J. - 1981 - Metamorphic Petrology. McGraw-Hill Book Company, New York, $524 p$.

TURNER, S. P.; FODEN, J. D.; MORRISON, R. S. - 1992 - Derivation of some A-Type magmas by fractionation of basaltic magma: An example from the Padthaway Ridge, South Australia. Lithos, 28, p.151-179.

TUTTLE, O. F.; BOWEN, N. L. -1958 - Origin of granite in the light of experimental studies in the system $\mathrm{NaAlSi}_{3} \mathrm{O}_{8}-\mathrm{SiO}_{2}-\mathrm{H}_{2} \mathrm{O}$. Geol. Soc. Amer, Memoir, 74, 153p.

VANCE, J.A. 1969. On syenneusis. Contr. Mineral. Petrol, 24:7-29. 
VARLAMOFF, N.-1978- Classification spatio-temporal distribuition of tin and associated mineral deposits. Metallization Associated with Acid Magmatism. Inter. Corr. Geol. Progr., v. 3, p.139-156.

VELOSO, M. P.; JAPIASSU, M. S.; GÓES FILHO, L.; LEITE, P. F. - 1974 - Vegetação das Folhas SB-22 Araguaia e parte da SC-22 Tocantins. Geologia, Geomorfologia, Solos, Vegetação e Uso Potencial da Terra. Rio de Janeiro, v.4.

VLADYKIN, N. V.; KOVALENKO, V. I.; KASHAEV, A. A.; SAPOZHNIKOV, . A. N.; PISARKAYA, V. A. - 1974 - A new silicate of calcium and zirconium, armstrongite. Dokl. Akad. Nauk. SSSR, 209, 1185-1188(In Russian).

VORMA, A.-1976- On the Petrochemistry of Rapakivi Granites with special reference to the Laitila Massif, Southwestern Finland. Geol. Surv. Finland Bull., 285, 98p.

VORONINA, L. B.; GAYDUKOVA, V. S.; DOBROVOL'SKAYA, N. V.; KOROVUSHKIN, V. V. - 1978 - Forms of occurrence of iron in cassiterite. Geokhimiya, 10, 1474-1490.(in Russian).

WHALEN, J. B.; CURRIE, K. L.; CHAPPELL, B. W.-1987- A-Type granite: geochemical characteristics, discrimination and petrogenesis. Contr. Mineral. Petrol., v.95, p. 407419.

WHITE, A. J. R-1992- Granite Handbook: description, genesis, some associated ore deposits. Short Course. In: Anais do 37 Congr. Bras. Geol., São Paulo, 109p.

WILKINS, R. W. T; BARKAS, J. P. - 1978 - Fluid inclusions, deformation and recrystallization in granite tectonites. Cont $r$. Mineral. Petrol., 65:293-299.

WILLIAMS, H.; TURNER, F. J.; GILBERT, C. H.- 1982 - Petrography. A introduction to the study of rocks in thin section. Second Edition, W. H. Freeman and Company. San Francisco, 406p.

WINKLER, H. G. F. - 1977 - Petrogênese das Rochas Metamórficas. Editora Edgar Blücher Ltda. 254p.

WINKLER, H. G. F.; VON PLATEN, H. - 1961 - Geochem. Cosmochem. Acta, 24: 48-69.

WIRTH, K. R.; GIBBS, A. K.; OLSZEWSKI JR, W. J. - 1986 - U-Pb ages of zircões from the 
Grão Pará Group and Serra dos Carajás Granite, Pará, Brazil. Rev. Bras. Geoc., 16(2): 195-200.

WITT, W. K. - 1988 - Evolution of high-temperature hydrothermal fluids associated with greisenization and feldspathic alteration of a tin-mineralized granite, Northeast Queensland. Econ. Geol., v.83, p.310-334.

WONES, D. R.; EUGSTER, H. P. - 1965 - Stability of biotite: experiment, theory, and application. Amer. Mineral., v. 50, p. 1228-1272.

WONES, D. R.; GILBERT, M. C.-1981- Amphiboles in the igneous anvironment. Reviews in Mineralogy, v.9A, p.355-390.

YANATIEVA, O. K. - 1946 - Solubility polytherms in the systems $\mathrm{CaCl} 2-\mathrm{MgCl} 2-\mathrm{H} 2 \mathrm{O}$ and $\mathrm{CaCl} 2-\mathrm{NaCl}-\mathrm{H} 2 \mathrm{O}$. Zh. Prikl. Khin., 19, 709-722.(in Russian).

YIN, L.; POLLARD, P. J.; SHOUXI, H.; TAYLOR, R. G.-1995- Geologic and Geochemical characteristics of the Yichum Ta-Nb-Li Deposit, Jiangxi Province, South China. Econ. Geol., v.90, p.577-585.

ZANG, W.; FYFE, W. S. - 1995 - Chloritization of the hydrothermally altered bedrock at the Igarapé Bahia gold deposit, Carajás, Brazil. Mineral Deposita, v. 30, p. 30-38.

ZHANG, L.; LIU, J.; CHEN, Z.; ZHOU, H.-1994- Experimental investigation of oxygen isotope fractionation in cassiterite and wolframite. Econ. Geol., v. 89:150-157. 